\title{
National Briefing Summaries: Nuclear Fuel Cycle and Waste Management
}
K. J. Schneider, Coordinator
L. T. Lakey
D. J. Bradley
S. J. Mitchell
J. F. Fletcher
P. M. Molton
C. J. Konzek
R. E. Nightingale

April 1991

Prepared for the U.S. Department of Energy under Contract DE-AC06-76RLO 1830

Pacific Northwest Laboratory Operated for the U.S. Department of Energy by Battelle Memorial Institute 


\title{
DISCLAIMER
}

This report was prepared as an account of work sponsored by an agency of the United States Government. Neither the United States Government nor any agency thereof, nor Battelle Memorial Institute, nor any of their employees, makes any warranty, expressed or implied, or assumes any legal liability or responsibility for the accuracy, completeness, or usefulness of any information, apparatus, product, or process disclosed, or represents that its use would not infringe privately owned rights. Reference herein to any specific commercial product, process, or service by trade name, trademark, manufacturer, or otherwise does not necessarily constitute or imply its endorsement, recommendation, or favoring by the United States Government or any agency thereof, or Battelle Memorial institute. The views and opinions of authors expressed herein do not necessarily state or reflect those of the United States Government or any agency thereof.

\author{
PACIFIC NORTHWEST LABORATORY \\ operated by \\ BATTELLE MEMORIAL INSTITUTE \\ for the \\ UNITED STATES DEPARTMENT OF ENERGY \\ under Contract DE-AC06-76RLO 1830
}

Printed in the United States of America

Available to DOE and DOE contractors from the

Ofilce of Scientific and Technical Information, P.O. Box 62, Oak Ridge, TN 37831; prices available from (615) 576-8401. FTS 626-8401.

Available to the public from the National Technical Information Service, U.S. Department of Commerce, 5285 Port Royal Rd., Springfield, VA 22161.

All references cited in this document are public information, but may not be available from public sources (e.g., some foreign travel reports). These references may be made available to interested readers from the author of the specific reference or from:

International Program Support Office

Waste Technology Center

Pacific Northwest Laboratory P.O. Box 999

Richland, WA 99352

(509) 376-0933 or

(509) 376-5059 
NATIONAL BRIEFING SUMMARIES:

NUCLEAR FUEL CYCLE AND

WASTE MANAGEMENT
K. J. Schneider, Coordinator
D. J. Bradley
J. F. Fletcher
G. J. Konzek
L. T. Lakey
S. J. Mitchell
P. M. Molton
R. E. Nightingale

April 1991

Prepared for the U.S. Department of Energy

under Contract DE-AC06-76RLO 1830

Cosponsored by

Office of Civilian Radioactive

Waste Management

Office of Environmental Restoration and Waste Management

Pacific Northwest Laboratory

Richland, Washington 99352 



\section{FOREWORD}

Since 1976, the International Program Support Oltice (IPSO) at the Pacific Northwest Laboratory (PNL) has collected and compiled publicly available information concerning foreign and international radioactive waste management programs. In fuffilling this assignment, IPSO has issued a variety of publications, including:

- PNL-3594, International Nuclear Fuel Cycle Fact Book, a directory of waste management agencies, facilities, key personnel, and research and development programs--revised annually. The latest issue is Revision 10, issued in the spring of 1990.

- PNL-2478, International Source Book: Nuclear Fuel Cycle Research and Development, a compilation of country-by-country summaries of national fuel cycle activities--revised as IPSO staft time has permitted. The last full issue was Revision 2 (October 1982). Copies of this document are no longer available from IPSO.

This National Briefing Summaries is a printout of an electronic database that has been compiled and is maintained by the IPSO staff. The database contains current information concerning the radioactive waste management programs (with supporting information on nuclear power and the nuclear fuel cycle) of most of the nations (except eastern European countries) that now have or are contemplating nuciear power, and of the multinational agencies that are active in radioactive waste management. Information in this document is included for three additional countries (China, Mexico, and USSP) compared to the prior issue. The database and this document were developed in response to needs of the U.S. Department of Energy. This document is formatted so that information may be found under consistent headings. Dates on the pages identify the month and year that the latest updated information was entered for that country in this document. Periodic updates of the information are planned as the needs arise and resources permit.

The information given is intended to be as factual and accurate as practicable. The accuracy of the information may be limited to that of the sources and its interpretation by the authors.

The authors would appreciate having their attention called to new or revised information that should be entered. Updates on the various countries will be issued as appropriate new or revised information becomes available. Such information can be transmitted to:

Pacific Northwest Laboratory International Program Support Office

P. O. Box 999, Mailstop K6-24

Richland, Washington 99352

Telephone: (509) 376-5372/444-5372 (commercial/FTS) or (509) 376-0933/444-0933 (commercial/FTS)

Telefacsimile/Telex: (509) 376-1101/15-2874

Verification: (509) 376-5059 



\section{CONTENTS}

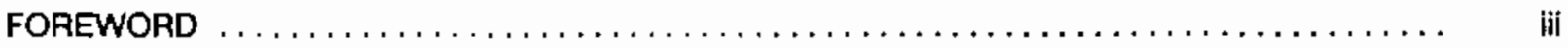

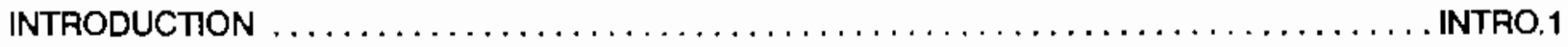

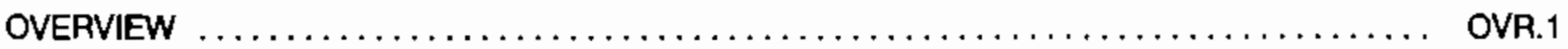

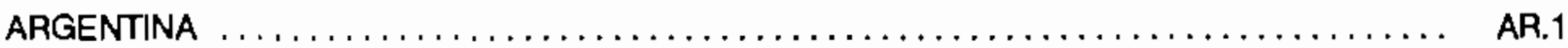

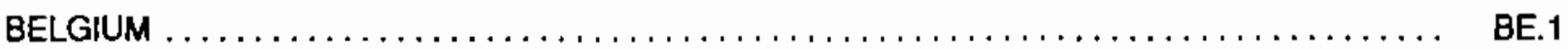

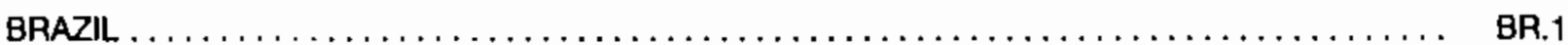

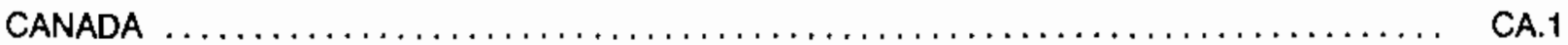

CHINA (PEOPLES REPUBLIC OF) $\ldots \ldots \ldots \ldots \ldots \ldots \ldots \ldots \ldots \ldots \ldots \ldots \ldots \ldots \ldots \ldots \ldots \ldots \ldots \ldots \ldots$

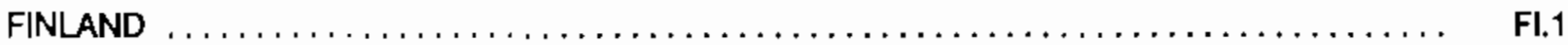

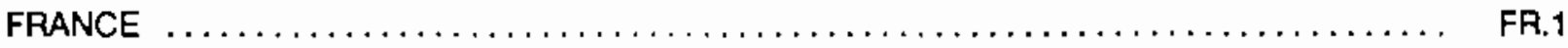

GERMANY (FEDERAL REPUBLIC OF) $\ldots \ldots \ldots \ldots \ldots \ldots \ldots \ldots \ldots \ldots \ldots \ldots \ldots \ldots \ldots \ldots \ldots \ldots$

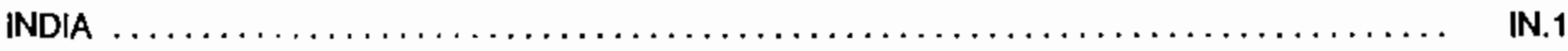

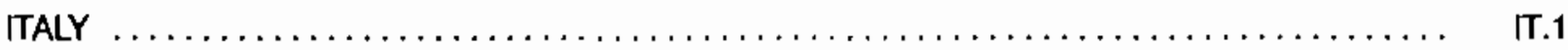

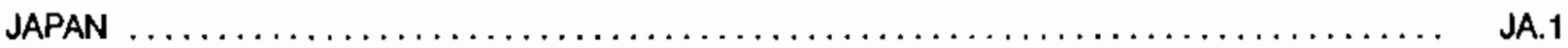

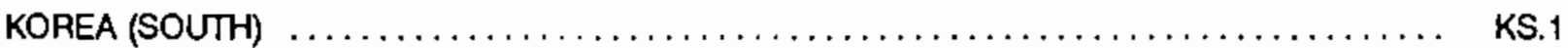

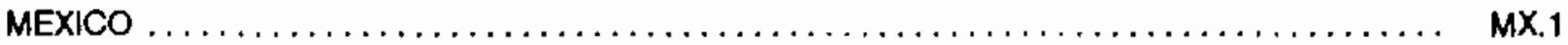

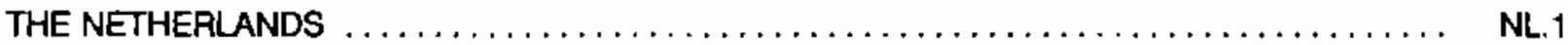

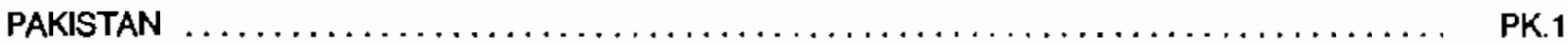

REPUBLIC OF SOUTH AFRICA $\ldots \ldots \ldots \ldots \ldots \ldots \ldots \ldots \ldots \ldots \ldots \ldots \ldots \ldots \ldots \ldots \ldots \ldots \ldots \ldots$

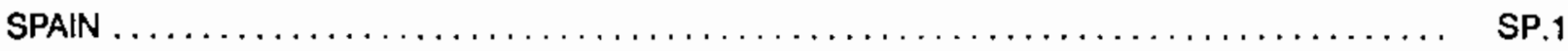

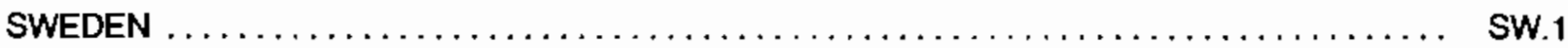

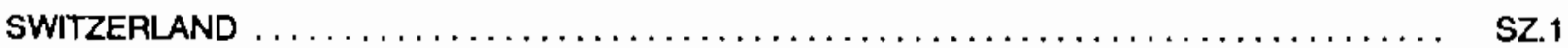

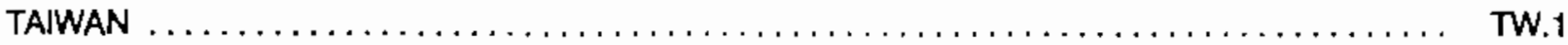

UNION OF SOVIET SOCIALIST REPUBLICS $\ldots \ldots \ldots \ldots \ldots \ldots \ldots \ldots \ldots \ldots \ldots \ldots \ldots \ldots \ldots$ UR.

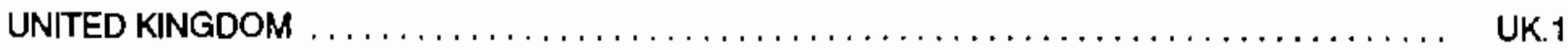




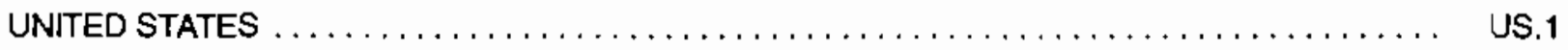

COMMISSION OF EUROPEAN COMMUNITIES (CEC) $\ldots \ldots \ldots \ldots \ldots \ldots \ldots \ldots \ldots \ldots \ldots \ldots \ldots \ldots \ldots$

INTERNATIONAL ATOMIC ENERGY AGENCY (IAEA $\ldots \ldots \ldots \ldots \ldots \ldots \ldots \ldots \ldots \ldots$ IAEA.1

OECD NUCLEAR ENERGY AGENCY (NEA) $\ldots \ldots \ldots \ldots \ldots \ldots \ldots \ldots \ldots \ldots \ldots \ldots \ldots \ldots \ldots \ldots \ldots \ldots$

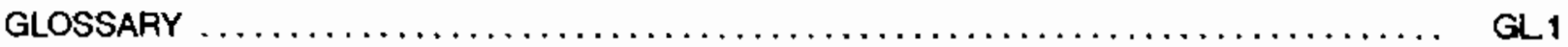




\section{INTRODUCTION}




\section{INTRODUCTION}

The National Briefing Summaries is a compilation of publicly available information concerning the nuclear fuel cycle and radioactive waste management strategies and programs of 23 nations, including the United States, and three international agencies that have made public their activities in this field. It presents available highlight information with references that may be used by the reader for additional information.

The information in this document is compiled primarily for use by the U.S. Department of Energy and other U.S. federal agencies and their contractors. It provides summary information on activities in the U.S. and other countries. This document provides managers and technical staff with an awareness of what is occurring in other countries with regard to strategies, activities, and facilities. The information may be useful in program planning to improve and benefit the U.S.'s programs through foreign information exchange. Benefits may be derived through a number of foreign exchange activities, including:

- specific and general technical exchanges with peers in related fields

- cooperative studies and projects with experts in other countries

- cooperative development of scientific data

- early access to use or trial of experimental methods

- shared use of unique foreign or U.S. sites or capabilities for technical investigations

- shared use of foreign facilities that are less expensive or are not available in the U.S.

- exchange of technical staff with other countries.

Information for each country or multinational agency is presented using the same subject outline. The generic outlines for each country and multinational agency are given in the Detailed Subject Outline that follows. At the first-heading level in the country discussions (e.g., 1.0 NUCLEAR POWER), the authors of this document followed the outline exactly as shown to collect information. At the second level (e.g., 1.1 Reactor Mix), however, information was not always available on all of the subject categories. In this case, subjects were omitted and the next topic with information was discussed in turn, in order of appearance in the outline (the numbering system was then adjusted accordingly). For this reason, the number of second-level subjects varies in the country discussions. For the multinational agencies, first- and second-level subjects are followed exactly as shown in the outline. 
$m$ 
OVERVIEW 


\section{OVERVIEW}

This section presents an overview of general activities and future trends in radioactive waste management and related fuel cycle activities within countries covered by this document. The countries included in this report are generally those with active nuclear fuel cycle and/or nuclear electric power activities, and those for whom the information is publicly avalable.

\section{SOURCES OF RADIOACTIVE WASTES}

Most of the radioactive wastes of interest in this report originate from the following major activities with nuclear materials (IAEA 1986):

- operation of nuclear power stations

- operation of nuclear fuel cycle facilities (uranium purification and conversion, enrichment, fuel fabrication, spent fuel reprocessing)

- operation of uranium and thorium mining and milling facilities

- decontamination and decommissioning of nuclear facilities

- production and use of radicactive isotopes in activities other than nuclear power (e.g., medicine, research, irradiation).

\section{RADIOACTIVE WASTE CATEGORIES}

Although definitions and ciassifications of radioactive wastes differ in various countries, the generally accepted categorization of radioactive wastes has been developed by the International Atomic Energy Agency (IAEA) as follows (IAEA 1986):

Spent Fuel: The nuclear fuel that has been irradiated to the extent of its useful life in a nuclear reactor. Spent fuel has a mixture of all the radionuclides (high-and low-heat-generating; long-lived, short-lived; fission products, actinides, activation products). Spent nuclear fuel is considered a waste by some, and a resource to be recycled through reprocessing by others.

High-Level Wastes: The waste stream resulting from the first cycle of fuel reprocessing. The wastes contain almost all the heat-generating and long-lived radionuclides (except for most of the uranium and plutonium which were recovered) that were in spent nuclear fuel. They require long-term isolation from the biosphere.

Intermediate-Level Wastes: This category is used in some but not all countries to describe wastes with significant beta/gamma radioactivity levels and generally low alpha radioactivity levels. Some countries include wastes with significant alpha radioactivity levels. Isolation requirements may approach those for high-level or low-level wastes depending on the toxicity and longevity of the contained radionuclides.

Low-Level Wastes: These wastes contain negligible amounts of long-lived radionuclides. The wastes generally require isolation from the biosphere for relatively shon time periods (typically one to a few centuries), and generally can be disposed of near the earth's surface. 
Transuranic (or Alpha) Wastes: These are non-high-level wastes that contain significant amounts of long-lived, alpha-emitting radionuclides. The wastes require long-term isolation from the biosphere.

Other groupings of wastes include:

Gaseous Wastes: These wastes include gaseous radionuclides and/or radionuclides as aerosols that are removed from gaseous waste streams. They generally fall into the low-level waste category, but some can be categorized as intermediate-level wastes. The wastes arise primarily from fuel reprocessing and from reactor operations and waste processing facilities. Typical radionuclides include hydrogen-3, carbon-14, iodine- 129 .

Uranium or Thorium Mine and. Mill Tailings: These wastes consist of large volumes of ore materials that result from mining (untreated rock) or milling (treated rock) of ores. The wastes contain only naturally occurring radionuclides (e.g., uranium isotopes and uranium decay chain isotopes).

Decommissioning Wastes: These wastes result from decommissioning of nuclear reactors and nuclear fuel cycle facilities. These wastes are generally large in volume, and most of them are low-level or intermediate-level, although a small amount are contaminated with transuranic radionuclides.

\section{NUCLEAR POWER}

At the end of 1990 , there were 420 nuclear power reactors in operation in 25 countries around the world (including countries with centrally planned economies), with a total net capacity of about $323 \mathrm{GWe}$ (NW 3/14/9i). In the countries with nuclear power that are discussed in this document, nuclear power supplied as littie as $0.2 \%$ of the total electricity consumed in 1989 in Pakistan to as much as $74.6 \%$ in France. And because all of Italy's reactors have been shut down, nuclear power supplied $0 \%$ of its total electricity. Most of the nuclear power reactors in the world are lightt water reactors (LWRs), with the majority of these being pressurized water reactors (PWRs), and a significant fraction being boiling water reactors (BWRs). Other significant power reactor types are gas-cooled reactors and pressurized heavy water reactors. Nine small fast-breeder reactors are also producing power (NEl 6/90).

A summary of projections of net nuclear power plant capacity in the world, including countries that currently do not have nuclear power but are planning for it, is given in Table 1. By 1995, nucleargenerated electricity is projected to increase by about $10 \%$; by 2000 , by about $20 \%$, and by 2005 , by about $28 \%$ (relative to 1990 capacity) (NUKEM 2/91; NEl 6/90). The worldwide growth rate of nuclear power has slowed down significantly in the past five years. Nuclear power is projected to grow at a slower rate in the near future, but it is expected to continue to grow at a steady rate in the early 2000 s. The amount of nuclear power in the United States and in a few other western countries is currently projected to decline at about the time period of 2000 to 2005, but will continue to rise in many other countries, particularly in the Far East and in countries with centrally planned economies. 
Table 1. Nuclear Power Plant Capacity in the World (GWe net $)^{(a, b)}$

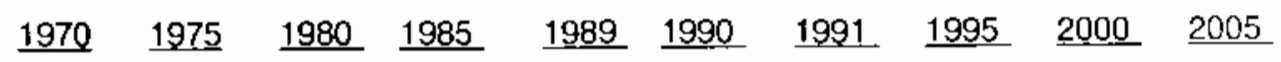

\begin{tabular}{|c|c|c|c|c|c|c|c|c|c|c|}
\hline Argentia & --- & 0.3 & 0.3 & 0.9 & 0.9 & 0.9 & 0.9 & 1.6 & 1.6 & 2.3 \\
\hline Belgium & --- & 1.7 & 1.7 & 4.5 & 5.5 & 5.5 & 5.5 & 5.5 & 5.5 & 6.5 \\
\hline Brazil & $\ldots$ & -- & --- & 0.6 & 0.6 & 0.6 & 0.6 & 1.9 & 1.9 & 1.9 \\
\hline Bulgaria $^{(c)}$ & --- & 0.8 & 0.8 & 1.6 & 2.6 & 2.6 & 2.6 & 3.7 & 4.6 & 4.6 \\
\hline Canada & 0.2 & 2.5 & 5.5 & 9.5 & 11.7 & 12.7 & 14.5 & 15.4 & 15.4 & 15.4 \\
\hline China & $\cdots$ & --- & $\ldots$ & --- & --- & -- & 0.3 & 2.1 & 2.1 & 2.1 \\
\hline Cuba $^{(c)}$ & --- & $\cdots$ & --- & $\cdots$ & --- & --- & $\cdots$ & 0.4 & 0.9 & 0.9 \\
\hline Czechoslovakia $^{(c)}$ & --- & --- & 0.4 & 1.6 & 3.3 & 3.3 & 3.3 & 4.6 & 6.0 & 6.0 \\
\hline Finland & --- & --- & 1.1 & 2.3 & 2.3 & 2.3 & 2.3 & 2.3 & 3.3 & 3.3 \\
\hline France & 1.5 & 2.8 & 12.7 & 33.9 & 52.7 & 55.7 & 56.7 & 61.3 & 64.2 & 66.9 \\
\hline Germany ${ }^{(0)}$ & 0.8 & 3.2 & 8.5 & 16.1 & 24.4 & 22.5 & 22.8 & 24.3 & 22.8 & 28.7 \\
\hline Hungary ${ }^{(c)}$ & -- & --- & -- & 0.8 & 1.7 & 1.7 & 1.7 & 1.7 & 1.7 & 1.7 \\
\hline India & 0.4 & 0.6 & 0.6 & 1.0 & 1.3 & 1.5 & 1.7 & 2.2 & 4.2 & 8.2 \\
\hline Japan & 0.8 & 5.0 & 14.5 & 23.7 & 28.3 & 30.4 & 32.1 & 38.5 & 50.9 & 61.2 \\
\hline Mexico & -- & $\cdots$ & $\cdots$ & -- & -- & 0.7 & 0.7 & 1.3 & 1.3 & 1.3 \\
\hline Netherlands & 0.1 & 0.5 & 0.5 & 0.5 & 0.5 & 0.5 & 0.5 & 0.5 & 0.4 & 2.4 \\
\hline Pakistan & -- & 0.1 & 0.1 & 0.1 & 0.1 & 0.1 & 0.1 & 0.1 & 0.1 & 0.6 \\
\hline Romania $^{(c)}$ & -- & -- & --- & -- & -- & --- & $\cdots$ & 0.6 & 1.2 & 1.2 \\
\hline South Africa & -- & -- & --- & 1.8 & 1.8 & 1.8 & 1.8 & 1.8 & 1.8 & 1.8 \\
\hline South Korea & --- & --- & 0.6 & 2.7 & 7.2 & 7.2 & 7.2 & 7.2 & 10.7 & 11.6 \\
\hline Spain & 0.2 & 1.1 & 1.1 & 4.7 & 7.5 & 7.0 & 7.0 & 7.0 & 8.7 & 10.7 \\
\hline Sweden & -- & 3.1 & 4.6 & 9.5 & 9.9 & 9.9 & 9.9 & 9.9 & 9.9 & 9.1 \\
\hline Switzerland & 0.3 & 1.0 & 1.9 & 2.9 & 2.9 & 2.9 & 2.9 & 2.9 & 2.9 & 2.6 \\
\hline Taiwan & $\cdots$ & $m$ & 1.2 & 4.9 & 4.9 & 4.9 & 4.9 & 4.9 & 7.7 & 10.7 \\
\hline UK & 3.3 & 4.4 & 6.8 & 7.2 & 12.4 & 11.9 & 11.9 & 11.6 & 10.5 & 8.2 \\
\hline USA & 5.6 & 37.0 & 51.9 & 75.6 & 99.0 & 102.1 & 102.1 & 104.4 & 103.0 & 96.5 \\
\hline USSR & 1.5 & 2.7 & 12.5 & 26.3 & 35.7 & 32.2 & 32.9 & 37.8 & 44.4 & 45.5 \\
\hline Yugoslavia ${ }^{(c)}$ & $\cdots$ & $\cdots$ & --- & 0.6 & 0.6 & 0.6 & 0.6 & 0.6 & 0.6 & 0.6 \\
\hline TOTALS & 15.1 & 66.8 & 127.1 & 234.2 & 317.8 & 321.5 & 327.5 & 353.4 & 386.7 & 412.2 \\
\hline \multicolumn{11}{|l|}{ Subtotals } \\
\hline Western Europe & 6.8 & 18.4 & 39.3 & 83.5 & 118.7 & 118.8 & 120.1 & 124.4 & 127.2 & 139.0 \\
\hline $\begin{array}{l}\text { Far East } \\
\text { Centrally Planned }\end{array}$ & 0.8 & 5.0 & 16.3 & 31.3 & 40.4 & 42.5 & 44.2 & 50.6 & 69.3 & 83.5 \\
\hline Economies $^{(\theta)}$ & 1.5 & 3.5 & 13.7 & 30.3 & 43.3 & 39.8 & 40.8 & 50.9 & 60.9 & 62.0 \\
\hline USA & 5.6 & 37.0 & 51.9 & 75.6 & 99.0 & 102.1 & 102.1 & 104.4 & 103.0 & 96.5 \\
\hline Other Countries ${ }^{(i)}$ & 0.4 & 2.9 & 5.9 & 13.5 & 16.4 & 18.3 & 20.3 & 24.3 & 26.3 & 31.2 \\
\hline
\end{tabular}
(a) NUKEM Market Report on the Nuclear Fuel Cycle. July 1988. NUKEM GmBH, Hanau, Federal Republic of Germany, pp. 20-21.
(b) NUKEM Market Report. February 1991. World Nuclear Power Plant Capacity, 1988-1989, and 2000- 2005." NUKEM GmbH, Hanau, Federal Republic of Germany, pp. 28-30.
(c) Not covered in this document.
(d) For former West Germany only through 1990.
(e) Includes: Bulgaria, China, Cuba, Czechoslovakia, Hungary, Romania, and the USSR.
(f) Includes: Argentina, Brazil, Canada, India, Mexico, Pakistan, and South Africa. 


\section{FUEL CYCLE AND WASTE MANAGEMENT}

Many countries with nuclear power have essentially no natural ores for nuclear fuel, and they impon the uranium or thorium fuel materials from the countries where they are mined and milled. Similarly, the industrial-scale capability for conversion and purification of uranium, as well as for enrichment of uranium, does not exist in most of the countries, and this requires purchase of those services from foreign sources. Most countries with nuclear power have some capability for fuel fabrication, although a considerable amount of fuel fabrication is purchased from other countries.

Some countries consider spent nuclear fuel to be a (high-level) waste, and plan to dispose of it directly. Other countries consider spent fuel to be a resource for recycle. Therefore, they plan to reprocess it for recovery of fissile and fertile materials for future use, and plan to dispose of the resultant high-levei wastes from reprocessing. Only five countries currently have industrial-scale fuel reprocessing capabilities, so that the other countries that use reprocessing purchase that senvice from those five countries, with plans to receive the resultant solidified high-level wastes (and in many cases, the other reprocessing wastes) for management in the country of origin. Almost all countries with nuclear power plan to dispose of their spent fuels/high-level wastes in their own countries. An exception to this is the spent fuel from reactors supplied by the Soviet Union, which is being returned to the Soviet Union for management. However, there are indications that this Soviet policy may change in the future.

Low-level, intermediate-level, and transuranic (or alpha) wastes from the nuclear fuel cycle are all managed within the respective countries. Low-level wastes and some intermediate-level wastes are frequently disposed of in surface or near-surface burial facilities, although there is a trend to use more engineered barriers and/or geologic disposal for these wastes. Transuranic wastes are generally planned to be disposed of in deep geologic repositories.

\section{INSTITUTIONAL CONSIDEAATIONS/ORGANIZATIONS}

Many countries have a "stipulation law" that requires a solution to the disposal (or at least long-term storage) of spent fuels or high-level wastes before nuclear power can be implemented or new nuclear reactors can be operated.

In some countries, the responsibility for ultimate management of spent fuels and high-level wastes is in the hands of the nuclear power industry. In most countries, however, the responsibility rests with the federal government. In essentially all cases, the cost of management of these wastes is borne by the current consumers of the nuclear electric power through some sort of fee imposed upon the power generator.

In all countries covered in this document, overall licensing criteria for waste management is the responsibility of the federal agencies. Actual licensing of waste management facilities and their operations is usually the responsibility of federal government agencies, but state agencies have licensing authority in some countries.

Public participation in nuclear power and waste management issues exists in all the countries covered in this document, with degrees and levels of impact varying from very little to major. The general trend, however, is for increased public involvement, whether or not the public involvement has been legislated into the overall decision process. 


\section{SPENT FUEL STORAGE AND TRANSPORTATION}

All countries have interim storage of spent fuel following discharge from the reactor for time periods ranging from about one year to the order of 50 years. All the initial storage is in water-filled basins at the respective reactors. Some spent fuel storage following that in water basins is in dry storage at the reactors or in dry or wet storage at central, away-from-reactor storage facilities. Countries planning to dispose of spent fuel without reprocessing are generally increasing the amount of dry storage (primarily in vaults or in storage casks) that is planned for tens of years until a repository is available. Countries that are employing reprocessing are generally storing spent fuel at the reactors for one to 10 years before shipping to a reprocessing facility.

Transportation of spent fuel has been relatively routine for more than 20 years. Spent fuel transportation occurs regularly within countrles, and there is an increasing amount of such transportation between countries. Most spent fuel transportation is by rail or truck, but there has been a significant amount transported by ships on the open seas between countries (and some belween sites in the same country).

\section{WASTE CONDITIONING, STORAGE AND TRANSPORT}

Countries that are employing reprocessing are generally storing the resultant high-level liquid wastes for one to several tens of years in underground storage tanks. After this storage, the wastes will be (or are being) immobilized at the reprocessing facility site into a canistered, monolithic solid in preparation for transportation and ultimate disposal. Vitrification of the wastes into borosilicate glasses is the unanimous current choice (with one exception of some phosphate glass in the Soviet Union), although some R\&D continues to be on "improved" waste forms, such as ceramics. Vitrification is well-developed and demonstrated in several countries, Including several years of production in France. Transport of vitrified high-level wastes has been done with R\&D canisters, but not on a routine production basis. Such transport will use technology and hardware basically the same as for spent fuel. Existing vitrified high-level wastes are being stored in air-cooled facilities at the respective vitrification plant until a repository is available for transport and disposal.

In Sweden and Finland where spent fuels are planned to be disposed of directly, the reference waste package currently involves embedding spent fuel in a matrix of lead or copper, which is surrounded by a long-lived canister. Canada's reference package for spent fuel disposal includes a backfill of sand or glass beads in the canister. Other spent fuel packages for final disposal include canisterizing the spent fuel or consolidated spent fuel rods without the use of a matrix or solid backfill.

Low-level radioactive wastes are generally treated to reduce the free liquid content to zero or near zero, to reduce volumes (such as by mechanical compaction or supercompaction, or by incineration of combustibles), and/or to immobilize the waste content (incorporation into bitumen, cement, or plastic matrices). The wastes are placed in canisters (typically metal, concrete or plastic, but some are wood) with a wide variety of sizes and shapes. Low-level wastes are typically stored for short time periods (usually a few months to a few years) onsite in engineered structures or in outside areas before transport to the final disposal site. However, a number of countries do not yet have disposal facilities for their low-level wastes, and their wastes are stored in engineered facilities for up to 50 to 100 years. Transport is frequently accomplished with conventional covered truck or rail vehicles, but some low-level wastes are transported by ship.

Intermediate-level wastes are generally handled similarly to low-level wastes, except that the former usually are sufficiently radioactive to require remote handling, and extended storage (frequently in a large, central facility) awaiting future disposal in a special repository is frequently employed. Transportation of 
these wastes is routinely accomplished by truck, rail, or barge in commercially available transport packagings that provide shielding and containment. Transuranic (or alpha) wastes are typically stored at the generation site, awalting requirements to be speclfied for ultimate disposition. Treatment consists of those processes used for low-and intermediate-level wastes, although some countries are considering vitrification.

\section{DISPOSAL OF NON-HIGH-LFVEL WASTES}

Surface and near-surface disposal for low-level and some intermediate-level wastes has been practiced by most countrles for tens of years. (Before the moratorium in 1982, some countries were disposing of low-level wastes into the oceans.) Each country has developed general and detailed criteria for safe surface and near-surface disposal of low-level wastes. Disposal concepts include burial in open pits followed by backfill (typically 5 to $20 \mathrm{~m}$ deep), burlal in engineered trenches just below the earth's surface, disposal in engineered structures that are on top of the earth's surfacer, disposal in engineered berms or tumuli, disposal in shallow dry wells or caissons, and disposal in shallow rock caverns (man-made or natural). There is a trend to use concepts with increasing levels of engineered containment and/or concepts that use deeper disposal ( $50 \mathrm{~m}$ or more deep).

In several countries in western Europe, all wastes, including low-level wastes, are planned to be disposed of in deep geologic reposttories. Sweden initiated emplacement of low-and intermediate-level wastes in 1987 in an engineered facility in bedrock about $60 \mathrm{~m}$ below the Baltic Sea, and Finland is constructing a similar facility at a similar depth below the land surface.

In essentially all countries, intermediate-fevel and transuranic wastes are planned to be disposed of in deep geological formations. These wastes are being stored until a repository is available. Currently, Sweden is the only country disposing of intermediate-level wastes. Two other countries (the Federal Republic of Germany and the United States) have deep geological disposal facilities for intermediate-level and/or transuranic wastes nearly ready for demonstration operations.

\section{DISPOSAL OF HIGH-LEVEL WASTES}

Disposal of high-level wastes, spent fuel, and other wastes with long-ived radioactivity into deep geological repositories ( 300 to $1200 \mathrm{~m}$ below the earth's surface) is planned by all countries covered in this document. Most countries have developed general criteria for this type of disposal, but detailed criteria are generally still under development in many countries. Several countries have major activities underway to site, design and implement a national deep geologic repository within their country. Two countries West Germany and the U.S.) have selected their proposed final disposal site for determination of its suitability, and final approval of the sites depends on results of site characterization. Other countries are identifying and evaluating potential repository sites and developing repository and waste disposal package concepts. Several countries have done relatively little toward repository development and are waiting for up to tens of years before proceeding. An overall summary of the status of national strategies for managing spent fuels and high-level wastes is given in Table 2.

All countries' siting plans involve a sequence of screening potential areas from existing geologic information, through measurements from the surface and small boreholes. All countries plan on extensive confirmation of potential site surtability through measurements and tests made from shafts and down-hole facilities in the geologic horizon planned for the repository. This work is being done in concert with significant efforts on development of methods and computerized modes s for assessing the safety 
Table 2. National Strategies for Managing Spent Fuel/High-Level Wastes ${ }^{(a)}$

\begin{tabular}{|c|c|c|c|c|c|}
\hline Country & $\begin{array}{l}\text { Spent Fuel } \\
\text { Storage Mode }\end{array}$ & $\begin{array}{l}\text { Waste Form } \\
\text { For Dispossal }\end{array}$ & $\begin{array}{l}\text { Repository } \\
\text { Host Rock }\end{array}$ & $\begin{array}{l}\text { Underground } \\
\text { Research }\end{array}$ & $\begin{array}{l}\text { Approximate } \\
\text { Target Year } \\
\text { to Open } \\
\text { Repository }\end{array}$ \\
\hline Argentina & $\begin{array}{l}\text { AR in pools \& } \\
\text { AFR (if needed) }\end{array}$ & HLW glass & Granite & $\ldots(c)$ & $>2010$ \\
\hline Belgium & AR pools & $\begin{array}{l}\text { HLW glass, } \\
\propto \text { wastes }\end{array}$ & Clay & URL at $\mathrm{Mol}^{(\mathrm{b})}$ & 2030 \\
\hline Brazil & AR pools & $\begin{array}{l}\text { Spent fuel (or } \\
\text { HLW glass) }\end{array}$ & -- & -- & $>2020$ \\
\hline Canada & $\begin{array}{l}\text { AR pools; then AR or } \\
\text { AFR wet or dry stor- } \\
\text { age in concrete } \\
\text { casks }\end{array}$ & $\begin{array}{l}\text { Spent fuel (or } \\
\text { HLW glass) }\end{array}$ & Crystalline rock & $\begin{array}{l}\text { Whiteshell URL } \\
\text { studies }\end{array}$ & $>2015$ \\
\hline China & AR pools; then AFR & HLW glass & $\begin{array}{l}\text { Granite, tulf, basalt, } \\
\text { salt }\end{array}$ & --- & 2030 \\
\hline Finland & AR pools & $\begin{array}{l}\text { Spent fuel (or } \\
\text { HLW glass) }\end{array}$ & Granite, gneiss & --- & 2020 \\
\hline France & $\begin{array}{l}\text { AR pools \& pools at } \\
\text { reprocessing } \\
\text { plants }\end{array}$ & $\begin{array}{l}\text { HLW glass, } \\
\propto \text { wastes }\end{array}$ & $\begin{array}{l}\text { Granite, salt, clay } \\
\text { or schist }\end{array}$ & $\begin{array}{l}\text { U'ground studies } \\
\text { in granite. Test } \\
\text { facilities plan- } \\
\text { ned. }\end{array}$ & $2010+$ \\
\hline $\begin{array}{l}\text { Federal } \\
\text { Republic } \\
\text { of Germany }\end{array}$ & $\begin{array}{l}\text { AR pools; AFR dry } \\
\text { casks }\end{array}$ & $\begin{array}{l}\text { HLW glass; some } \\
\text { spent fuel }\end{array}$ & $\begin{array}{l}\text { Salt; } \propto \text { wastes in } \\
\text { clay-marlstone }\end{array}$ & $\begin{array}{l}\text { Asse mine studies; } \\
\text { Gorleben studies }\end{array}$ & $2008+$ \\
\hline India & $\begin{array}{l}\text { AR \& AFR pools; } \\
\text { some dry casks }\end{array}$ & HLW glass & $\begin{array}{l}\text { Granite or gneiss } \\
\text { (basalt, amphibolite) }\end{array}$ & URL in gold mines & $>2010$ \\
\hline Italy & AR pools & HLW glass & Clay (salt) & URL in Sicily & 2040 \\
\hline Japan & $\begin{array}{l}\text { AR \& reprocessing } \\
\text { pools; cask \& vault } \\
\text { studies }\end{array}$ & HLW glass & $\begin{array}{l}\text { Diabase, granite, } \\
\text { tuff, or sedimentary } \\
\text { rock }\end{array}$ & URL planned & 2030 \\
\hline Mexico & $\begin{array}{l}\text { AR pools, possible } \\
\text { future dry storage }\end{array}$ & Spent fuel & $\cdots$ & --- & -- \\
\hline Netherlands & $\begin{array}{l}\text { AR pools; dry AFR } \\
\text { vault }\end{array}$ & $\begin{array}{l}\text { HLW glass or } \\
\text { spent fuel }\end{array}$ & $\begin{array}{l}\text { Salt (clay, meta- } \\
\text { morphic rock) }\end{array}$ & Use foreign URLs & $>2020$ \\
\hline
\end{tabular}


Table 2. (contd)

\begin{tabular}{|c|c|c|c|c|c|}
\hline Country & $\begin{array}{l}\text { Spent Fuel } \\
\text { Storage Mode }\end{array}$ & $\begin{array}{l}\text { Waste Form } \\
\text { For Disposal }\end{array}$ & $\begin{array}{l}\text { Repositcry } \\
\text { Host Rock }\end{array}$ & $\begin{array}{c}\text { Underground } \\
\text { Research }\end{array}$ & $\begin{array}{l}\text { Approximate } \\
\text { Target Year } \\
\text { to Open } \\
\text { Repository }\end{array}$ \\
\hline Pakistan & AR pool &.- & $\cdots$ & $\cdots$ & --- \\
\hline $\begin{array}{l}\text { Republic } \\
\text { of South } \\
\text { Africa }\end{array}$ & AR pod, dry casks & -- & - & --- & $\cdots$ \\
\hline $\begin{array}{l}\text { South } \\
\text { Korea }\end{array}$ & AR pools, wet AFR & $\begin{array}{l}\text { HLW glass or } \\
\text { spent fued }\end{array}$ & Granite & --- & $>\mathbf{2 0 1 0}$ \\
\hline Spain & $\begin{array}{l}\text { AR pools then AFR } \\
\text { dry cask storage }\end{array}$ & $\begin{array}{l}\text { Spemt fuel (or } \\
\text { HLW glass) }\end{array}$ & Granite, salt, or clay & Use foreign URLs & 2020 \\
\hline Sweden & AR and AFR pool & Spert fuel & Crystalline rock & $\begin{array}{l}\text { Stripa mine } \\
\text { studies; HRL } \\
\text { started }\end{array}$ & 2020 \\
\hline Switzerland & $\begin{array}{l}\text { AR pools and AFR } \\
\text { dry casks }\end{array}$ & $\begin{array}{l}\text { HLW glass; some } \\
\text { spent fuel }\end{array}$ & $\begin{array}{l}\text { Granite or sedi- } \\
\text { mentary rocks }\end{array}$ & $\begin{array}{l}\text { URL at Grimsel } \\
\text { Pass }\end{array}$ & 2025 \\
\hline Taiwan & $\begin{array}{l}\text { AR pools; AR or AFR } \\
\text { dry casks planned }\end{array}$ & Spent fuel & $\begin{array}{l}\text { Granite, shale or } \\
\text { mudstone }\end{array}$ & $\ldots$ & --- \\
\hline UK & $\begin{array}{l}\text { AR pool \& dry vaults; } \\
\text { AFR pool at repro- } \\
\text { cessing plant }\end{array}$ & HLW glass & $\begin{array}{l}\text { Crystalline, argit- } \\
\text { laceous, or evaporite } \\
\text { rocks }\end{array}$ & --- & $>2040$ \\
\hline USA & $\begin{array}{l}\text { AR pools; AR casks } \\
\& \text { vaults; AFR cask } \\
\text { storage in planning }\end{array}$ & $\begin{array}{l}\text { Spent fuel; some } \\
\text { HLW glass }\end{array}$ & $\begin{array}{l}\text { Tuff (salt, basalt, } \\
\text { crystalline rock: } \\
\text { are backup) }\end{array}$ & $\begin{array}{l}\text { Planned at candi- } \\
\text { date site }\end{array}$ & 2010 \\
\hline USSR & AR \& AFR pools & HLW glass & $\begin{array}{l}\text { Salt, granite, clay, } \\
\text { gneiss }\end{array}$ & --- & $\cdots$ \\
\hline $\begin{array}{l}\text { (a) Inform } \\
\text { (b) AFR - } \\
\text { AR - A } \\
\text { URL - } \\
\text { (c) Dash n }\end{array}$ & $\begin{array}{l}\text { In in parentheses indic } \\
\text { ay-from-reactor (or cer } \\
\text { actor storage. } \\
\text { derground research lak } \\
\text { ans information not ava }\end{array}$ & $\begin{array}{l}\text { es second choices. } \\
\text { alized) storage. } \\
\text { ratory. } \\
\text { ble. }\end{array}$ & & & \\
\hline
\end{tabular}


performance of their future respective repository. Most countries have generally identified their likely areas and host rock types for a repository. Potential rock types are salt, granite or other crystalline rock, tuff, or clay, depending on the availability in the respective country.

Engineering of the repository and the supporting waste management system concepts is in the early stages in most of the countries. In most cases, the repository concept involves 1) a surface facility for receiving, handling and final preparation of the wastes; 2) two or more large shafts for moving wastes, personnel, ventilation and other utilities, and materials between the surface facility and the disposal horizon (including excavated and backfill materials); 3) an underground receiving station and a series of tunnels for routing wastes to the final disposal locations; and 4) a system for placing waste canisters in horizontal or vertical boreholes from the below-grade tunnels. Some concepts involve placing the waste packages directly in tunnels. Some concepts utilize one or more engineered barriers against migration of the waste materials out of the emplacement hole. After emplacement, the emplacement holes are typically backfilled. Finally, all excavations for the repository are backfilled, either soon after filling the repository to capacity or after a period of years of monitoring to assure appropriate performance of the repository. Allowance for future retrievability is not being universally considered. Considerable research and development efforts are underway or planned through the use of underground research laboratories in many countries. These laboratories are either in the geologic horizon planned for disposal, or are in a geologic formation with characteristics similar to those expected in the final repository. Numerous down-hole measurements and tests are planned to confirm the physical and chemical characteristics of the repository system. This information, in turn, is to be used in the detailed assessments of the expected performance of the repositories. Significant research and development efforts are underway in defining the waste package and evaluating its performance as part of the engineered barriers to waste migration. All waste package concepts include at least one metal canister. Some include matrix materials with the waste form, or packing (or buffer) materials or additional containers surrounding the primary waste canisters.

\section{URANIUM MINING AND MILLING WASTES}

Most countries with uranium mining and milling activities are using conventional techniques for impounding the tailings and leached ores. Activities to improve the longer-term isolation of the materials from the environment are planned and/or underway in some countries. These plans generally include drying out the ponds and covering the tailings surfaces with clay, rip-rap, and/or impermeable membranes to minimize inward water and plant/animal penetration and external leakage of radon and its daughter products.

\section{DECOMMISSIONING}

In the countries considered in this document, decommissioning of nuclear facilities varies from temporary, safe storage to prevent radionuclides from entering the biosphere, to entombment, to complete decontamination, dismantlement and removal of radioactivity to disposal facilities. Final decontamination and dismantlement can be done immediately after facility shutdown or after a period of time in safe storage. The primary need for decommissioning in the future is for nuclear power reactors and, to a lesser extent, fuel reprocessing plants. Decommissioning of surplus nuclear fuel cycle facilities has been carried out in many of the countries. In particular, numerous small tacilities have been or are being decommissioned in a number of countries. As a result of this activity and a significant amount of supporting R\&D in a number of countries, technology is generally considered to be available and has been demonstrated to be applicable to complete decommissioning of large facilities in the future. However, no large power reactor or reprocessing plant has yet been decommissioned to unrestricted 
use of the facility and site in any country. R\&D continues in many countries to improve decommıssioning by improving the effectiveness of decommissioning techniques, by reducing costs, radiation doses to workers, and waste volumes.

As part of the growing worldwide concern about protectirig the environment and cleaning up past industrial insults to the environment, a significant trend is starting in a number of countries to restore sites or facilities at nuclear installations to conditions that reduce their detrimental effects on the environment. This restoration is not only associated with decommissioning of inactive sites, but is also being applied to portions of active sites with past environmental problems. The restoration at nuclear facilities can involve removing materials that have been deposited in the environment that are radioactive, nonradicactive but otherwise hazardous materials, or mixed (radicactive and nonradioactive hazardous) wastes. The removed hazardous materials are treated for disposal in ways that assure continued protection of the environment.

\section{REFERENCES}

International Atomic Energy Agency (IAEA). 1986. World Status of Radioactive Waste Management," and "Long-Term Storage and Disposal of Spent Fuel." IAEA Bulletin, Volume 28, No. 1, Spring 1986.

Nuclear Engineering International (NEI). 6/90. World Survey, New Emphasis on Safety," p. 20.

NUKEM Market Report on the Nuclear Fuel Cycle (NUKEM). 7/88. "Nuclear Power Plant Capacity of the Western World." NUKEM GmbH, Hanau, Federal Republic of Germany, pp. 20-21.

NUKEM Market Report (NUKEM). 2/91. Word Nuclear Power Plant Capacity" (for 1988 through 2005. NUKEM GmbH, Hanau, Federal Republic of Germany, pp. 28-30.

Nucleonics Week (NW). 3/14/91. "IAEA Says World Added 9,000 MW of Nuclear Capacity Last Year," pp. 5-6. 
ARGENTINA 


\section{ARGENTINA}

\section{CONTENTS}

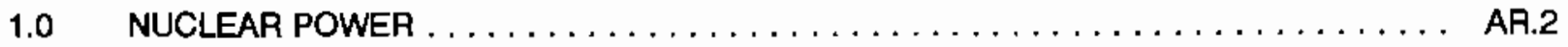

2.0 NUCLEAR FUEL CYCLE AND RADIOACTIVE WASTE MANAGEMENT

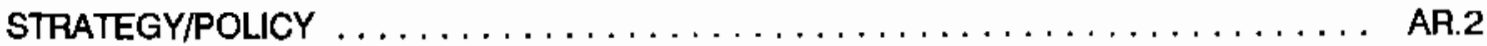

3.0 HIGHLIGHTS AND MAJOR MILESTONES $\ldots \ldots \ldots \ldots \ldots \ldots \ldots \ldots \ldots \ldots$

4.0 INSTITUTIONAL CONSIDERATIONS/ORGANIZATIONS $\ldots \ldots \ldots \ldots \ldots \ldots \ldots$ AR.3

$5.0 \quad$ NUCLEAR FUEL PRODUCTION $\ldots \ldots \ldots \ldots \ldots \ldots \ldots \ldots \ldots \ldots \ldots \ldots \ldots \ldots$

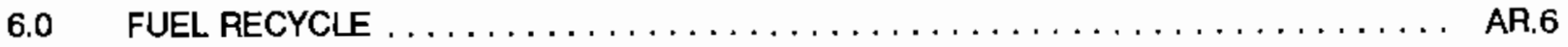

7.0 SPENT FUEL STORAGE AND TRANSPORT $\ldots \ldots \ldots \ldots \ldots \ldots \ldots \ldots \ldots \ldots$ AR.7

8.0 WASTE CONDITIONING, STORAGE AND TRANSPORT $\ldots \ldots \ldots \ldots \ldots \ldots \ldots$ AR.8

9.0 DISPOSAL OF NON-HIGH-LEVEL WASTES $\ldots \ldots \ldots \ldots \ldots \ldots \ldots \ldots \ldots \ldots$

10.0 DISPOSAL OF HIGH-LEVEL WASTES $\ldots \ldots \ldots \ldots \ldots \ldots \ldots \ldots \ldots \ldots \ldots$

11.0 MANAGEMENT OF URANIUM MINE AND MILL WASTES $\ldots \ldots \ldots \ldots \ldots \ldots \ldots$ AR.12

12.0 DECOMMISSIONING AND ENVIRONMENTAL RESTORATION $\ldots \ldots \ldots \ldots \ldots \ldots$ AR.13

13.0 INTERNATIONAL ACTIVITIES $\ldots \ldots \ldots \ldots \ldots \ldots \ldots \ldots \ldots \ldots \ldots \ldots \ldots \ldots \ldots$

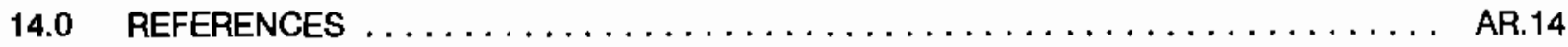




\subsection{NUCLEAR POWER}

1.1 REACTOR MIX: 2 PHWRS

\subsection{ELECTRIC POWER PRODUCTION}

1987-48.1 TWh (41\% oil/gas/coal; $45 \%$ hydro; $13 \%$ nuclear) (NEI 2/89)

2000--108.0 TWh total

New construction in Argentina will concentrate on medium-sized units, with incremental new capacity of 2.8 GWe coming on line in 1985-1990, 4.1 GWe in 1991-1995, and 6.4 GWe in $1996-2000$ (NEI 11/86)

\subsection{NUCLEAR POWER CAPACITY PROJECTIONS}

$1987-0.9 \mathrm{GWe}$

1994--1.6 GWe

2000--1.6 GWe (NUKEM 12/87)

2020--14.0 GWe (NEI 2/89)

A. A total of six reactors are expected eventually in Argentina (NF 11/3/86); two new 350 MWe units are planned for about the year 2000 (NEI 6/87)

B. Argentina has developed the Argos PHWR-380 with enhanced safety features for a possible fourth domestic power reactor and for export (NEI 5/87)

1.4 NUCLEAR ENERGY POLICY: Argentina's general policy places high priority on a CANDUbased nuclear power industry with an indigenous fuel cycle, government ownership and operation of all nuclear power plants, and development of a nuclear plant and export serv:ces capability (Leigh and Mitchell 1990)

\subsection{NUCLEAR FUEL CYCLE AND RADIOACTIVE WASTE MANAGEMENT STRATEGY/POLICY (NF 11/3/86)}

2.1 OVERALL NUCLEAR FUEL CYCLE POLICY: Argentina's strategy is to achieve complete selfsufficiency in the fuel cycle (CANDU-type PHWR)

2.2 POLICY ON THE FRONT END OF THE NUCLEAR FUEL CYCLE: Argentina plans to achieve self-sufficiency on the front end of the nuclear fuel cycle, including enrichment and heavy water production capabilities

\subsection{POLICY ON THE BACK END OF THE NUCLEAR FUEL CYCLE}

A. Argentina plans to develop a reprocessing capability and to recycle plutonium to its PHWR system or to countries with breeder reactors

B. Argentina will store spent fuels AA and possibly in AFR facilities, pending reprocessing

C. Argentina plans to vitrity and dispose of $\mathrm{HLW}$ in a deep geologic repository and to use surface disposal for LLW 


\subsection{HIGHLIGHTS AND MAJOR MILESTONES}

1974 Startup of Atucha I (357-MWe PHWR) nuclear power plant (NEI 1990)

1980 Startup of uranium conversion pilot-scale plant (not under IAEA safeguards) (NF 12/29/86)

1982 Startup of commercial-scale uranium conversion and PHWR fuel assembly plants

1984 Startup of Embalase (648-MWe Candu) nuclear power plant (NEI 1990)

1984 Completed initial characterization of proposed repository site in Chubut province

1987 Startup of uranium enrichment plant at Pilcaniyeu

1987 Startup of heavy water plant at Atucha (NEI 6/87)

1987 Enlargement of uranium oxide plant at Cordoba to $150 \mathrm{MT} / \mathrm{yr}$ (NEI 6/87)

1987-88 Design and engineering studies conducted for HLW repository

1988 Startup of 15-MW Ra-9 isotope production reactor (NW 12/4/86)

1990 Startup of heavy water production plant at Arroyito (NEI 6/87)

$1990 \quad$ Industrial production attained at zirconium sponge plant (NEI 6/87)

1992 Startup of uranium production at Sierra Pintada mili

after $1994 \quad$ Startup of pilot reprocessing plant at Ezeiza (NN 3/90)

1994 Startup of Atucha-2 745-MW PHWR (NEI 2/89)

1995-2000 Startup of fuel reprocessing at commercial plant at Ezeiza nuclear complex (NF 11/3/86)

1997 Startup of third PHWR, 325-350 MW capacity (NEI 11/86)

2000 Startup of fourth PHWR, 325-350 MW capacity (NEl 11/86)

2010 Begin receiving waste at HLW repository in Patagonia from Atucha-1 (NF 11/3/86; Cooley 1987)

\subsection{INSTITUTIONAL CONSIDERATIONS/ORGANIZATIONS}

\subsection{KEY AGENCIES AND FUEL CYCLE CENTERS}

A. In Argentina, the CNEA (National Atomic Energy Commission) owns and operates all nuclear facilities and is responsible for all aspects of nuclear power development, including the fuel cycle 
1) The Advisory Committee for the Licensing of Nuclear Facilities, part of the CNEA, is responsible for reactor licensing and operation (NEI 2/89)

2) The Directorate of Radiation Protection and Nuclear Safety, the Advisory Committee on the Application of Radioisotopes (CAAR), and a Safeguards Committee are also part of the CNEA (NEJ 2/89)

B. Ezeiza Atomic Centre, near Buenos Aires, develops and tests reactor fuels, fuel cycle processes, and equipment; its facilities include:

1) A reprocessing pilot plant with a planned capacity of $20 \mathrm{~kg} / \mathrm{d}$ feed, $10-15 \mathrm{~kg} \mathrm{Pu} / \mathrm{yr}$ product; non-radioactive runs are to be made in 1990 for a hot startup date of 1994; the pilot plant may be expanded into the commercial facility

2) A full-scale reprocessing plant is planned, either by expansion of the pilot plant or by construction of a new plant with $160 \mathrm{~kg} / \mathrm{d}$ (40 MTU/yr) capacity, to be operational by the late 1990 s

3) A commercial fuel fabrication plant that is operational

C. Arroyito, a heavy water plant in Neyquen province, will be run by a private firm (NF 1/12/87)

D. ENACE (Empresa Nuclear Argentina de Centrales Electricas) is the main contractor and architectural engineer for the nuclear power plants in Argentina; it is owned by Siemens/KWU of the FRG (25\%), with the remainder owned by CNEA; it developed the Argos (Argentine Offer of a Safer Pressurized Heavy Water Reactor) PHWR-380 reactor (NEI 2/89)

E. INVAP, formed by the CNEA and the Rio Negro province, is a high-tech company that is involved with international marketing of Argentine nuclear technology (NEI 10/88)

\subsection{PRINCIPAL RESEARCH, DEVELOPMENT, AND DEMONSTRATION FACILITIES/PROGRAMS}

A. The Constituyentes Atomic Centre near Buenos Aires performs R\&D of fuels and materials and fabricates MOX and enriched uranium fuel; its facilities include a heavy ion accelerator (20 million volts) which was started up in 1986 (NW 10/30/86)

B. The Ezeiza Atomic Centre near Buenos Aires develops and tests reactor fuels, fuel cycle processes, and equipment; its facilities include:

1) The reprocessing pilot plant discussed above in item 4.1.B

2) Research reactors that are in operation at the Ezeiza site

C. The University of San Juan's Institute of Geologic Investigations performs geologic repository site characterization (NF 11/3/86) 
4.3 KEY PERSONNEL (Leigh and Mitchell 1990)

Manuel A. Mondino, President of CNEA

Dr. Jaime Pahissa Campa, Radioactive Waste Management at Ezeiza Atomic Center

4.4 LICENSING: In Argentina, licensing is performed by the Advisory Committee for the Licensing of Nuclear Facilities (part of the CNEA) (NEI 2/89)

\title{
5.0 NUCLEAR FUEL PRODUCTION (IAEA 10/88)
}

5.1 URANIUM RESOURCES: Reasonably assured resources of uranium, recoverable at costs below $\$ 130 / \mathrm{kg}$, have been estimated at $12,000 \mathrm{MT}$ as of $1 / 1 / 87$ (NEI 2/89; OECD 1988)

\subsection{URANIUM PRODUCTION}

\author{
1984--129 MTU \\ 1985--126 MTU \\ 1986--173 MTU \\ 1987--150 MTU (OECD 1988) \\ 1988--134 MTU (NEI 2/90)
}

A. There are two mills presently operating in Argentina (San Rafael and La Estela); primary production is at the San Rafael deposit, $1100 \mathrm{~km}$ west of Buenos Aires (NF 12/25/89); the capacity of its heap-leaching plant is planned to be expanded from 120 to $300 \mathrm{MT} / \mathrm{yr}$ of $\mathrm{U}_{3} \mathrm{O}_{8}$, at a cost of about $\$ 24$ million (U.S.) (NF 10/19/87)

B. The mill at Los Gigantes, with a capacity of $150 \mathrm{MT} / \mathrm{yr}$, was shut down in late 1989 because of badly overestimated proven recoverable yellowcake reserves in the deposit (NF 12/25/89)

C. A mill at Sierra Pintada, with a capacity of $700 \mathrm{MTU} / \mathrm{yr}$, is planned for operation in 1992; Sierra Pintada is Argentina's largest uranium deposit (NEI 2/90; NF 12/25/89)

\subsection{URANIUM CONVERSION}

A. Argentina is constructing a $150 \mathrm{MT} / \mathrm{yr}$ conversion plant at Cordoba City (under IAEA safeguards) using German technology

B. A plant also exists at Cordoba City that is not under IAEA safeguards, and which produces up to about $150 \mathrm{MT} / \mathrm{yr}$ using Argentine technology; it produced about $80 \mathrm{MT}$ between 1980 and 1982

C. A possible additional pilot plant (not under IAEA safeguards) is at Cordoba City for undefined "special projects"; its 1986 production was estimated at $8 \mathrm{MTU}$, and production was projected in 1987 for about $15 \mathrm{MTU}$ in this or the above-mentioned plant (NF 12/29/86)

D. A conversion plant is planned at Ezeiza with a capacity of $150 \mathrm{MTU} / \mathrm{yr}(\mathrm{NEl} 2 / 90)$ 


\subsection{URANIUM ENRICHMENT}

A. There is a small "commercial" plant at Pilcaniyeu in the Rio Negro province with a production of $500 \mathrm{~kg} / \mathrm{yr}$ of $20 \%$ enriched uranium using gaseous diffusion; the plant was started up in 1987; construction is under way to expand the capacity of the plant from $20,000 \mathrm{SWU} / \mathrm{yr}$ to $100,000 \mathrm{SWU} / \mathrm{yr}$ (NEI 2/90)

B. Production of $\mathrm{UF}_{6}$ feed for gaseous diffusion enrichment also takes place at the Pilcaniyeu facility in Argentina (NF 5/30/88)

\subsection{FUEL FABRICATION}

A. A commercial-scale fuel assembly plant at Ezeiza produces uranium dioxide pellets, assembly parts, and zircalloy tubing; it also performs assembly operations and fabrication of natural uranium PHWR fuels; the plant has a capacity of $300 \mathrm{MTHM} / \mathrm{yr}$ and produces 240 elements/yr for Atucha 1 and 5360 elements/yr for Embalse (NEl 2/90; NEI 2/89)

B. MOX fuels are produced at the Constituyentes Atomic Center for PHWR tests

\subsection{HEAVY WATER PRODUCTION}

A. Heavy water will be produced in a 250-MT/yr plant at Arroyito by the monothermal ammonia-hydrogen exchange process (NW 10/22/87); the plant is due to start up in 1990 (NEl 2/89); the plant was $93 \%$ complete in 1989 , but financing must be located for its completion (NW 7/13/89)

B. The Zarate pilot plant (70 km northwest of Buenos Aires) is to start up in 1988; this $\$ 100$-million plant will have a capacity of 2-8 MT/yr; the plant uses a water-hydrogen sulfide exchange (GS) process; Argentina plans for scale-up and export of the GS technology (NW 10/22/87)

\subsection{FUEL RECYCLE}

\subsection{FUEL REPROCESSING}

A. A $20 \mathrm{kgU} / \mathrm{d}$ (30 Atucha-1 assemblies/yr) pilot reprocessing facility is under construction at the Ezeiza complex; the plant is designed to separate $15 \mathrm{~kg}$ of plutonium per year (NW 11/24/88); the plant was $80 \%$ complete by mid-1986; it was $95 \%$ complete in 1989 (Pahissa 10/89); hot startup was planned for 1990 at a rate of $5 \mathrm{MTU} / \mathrm{yr}$; the facility will use chop-leach and PUREX-type processes (Mellinger 1984; Masters 1986; Cooley 1987)

B. Construction of Argentina's first reprocessing plant has been put on indefinite hold; the last announced completion target date of 1994 is going to be delayed; the country has already spent between $\$ 150-\$ 160$ miltion on the plant (NN 3/90)

C. A commercial-size plant is to be buith after 1995 at the same site, the Ezeiza nuclear complex, with a capacity of $40 \mathrm{MTU} / \mathrm{yr}$; the facility will use chop-leach and PUREX-type processes (IAEA 1984; NW 8/27/87) 
6.2 PROGRAM/FACILITES COSTS: Argentina has already spent $\$ 150$ - $\$ 160$ million on the reprocessing plant (NN 3/90)

\subsection{SPENT FUEL STORAGE AND TRANSPORT}

\subsection{SPENT FUEL ARISINGS}

1987-1,070 MTU cumulative, stored in AR pools (IAEA 1988)

\subsection{FUEL ASSEMBLY CHARACTERISTICS (Sametband 1987)}

A. Atucha reactor fuel characteristics are: natural uranium dioxide in zircalloy rods; 36 rods per assembly connected by an upper plate and 15 spacers; active length is $5.3 \mathrm{~m}$ and total length is $6.0 \mathrm{~m}$; $173 \mathrm{~kg} \mathrm{UO}$ are in each assembly; average burnup is $6500 \mathrm{MWd} / \mathrm{MTU}$

B. Embalse reactor fuel characteristics are: natural uranium dioxide in $\mathbf{3 7}$ zircalloy rods; active fuel length is $0.48 \mathrm{~m} ; 21.3 \mathrm{~kg} \mathrm{UO} \mathrm{O}_{2}$ are in each assembły

7.3 SPENT FUEL STRATEGIES: Spent fuel will be stored in reactor pools and (if needed) AFR facilities until it can be reprocessed in an Argentine plant; the first reactor has enough storage capacity for the operating life of the reactor (Sametband 1987)

\subsection{WET STORAGE (Sametband 1987, 1988)}

A. At Atucha, the spent fuel storage capacity is enough for the life of the reactor; fuel is stored in two reactor basins and in four basins next to the reactor at Atucha; the basins are $16 \mathrm{~m}$ deep by $8 \mathrm{~m}$ by $5.5 \mathrm{~m}$; capacity exists for storage of $1580 \mathrm{MTU}$

B. At Embalse, the storage capacity is enough for 10 years of spent fuel discharge, to be stored in one pool; a separate pool is used for defective fuel bundles; the total capacity is $830 \mathrm{MTU}$; the pool depth is $7.6 \mathrm{~m}$

C. AFR pool storage is under construction at Ezeiza (NEI 2/90)

D. Research reactor fuel elements are stored in a concrete building $85 \mathrm{~m}$ long $\times 12 \mathrm{~m}$ wide $\times 4 \mathrm{~m}$ high, with 198 pits containing stainless steel tubes capable of storing 2 fuel elements each; the pits are interconnected by piping to allow the circulation of cooling water (Pahissa 10/89)

\subsection{DFY STORAGE}

A. Dry storage in silos was once considered for an expansion of Atucha storage capabilities

B. AFR dry storage at the Gastre (Sierra del Medio) repository site was also under consideration (Kessler 1986) 


\subsection{TRANSPORT}

A. Transport of spent fuel from the Atucha reactor over $150 \mathrm{~km}$ to the pilot reprocessing plant is to be carried out using a $36 \mathrm{MT}$ stainless steel/lead truck cask which holds seven assemblies; the cask is $7.2 \mathrm{~m}$ long and $1 \mathrm{~m}$ in outside diameter; it has no fins; a prototype cask was available for testing in 1987; the cask is to conform to IAEA standards (NF 10/20/86; Sametband 1987)

\subsection{WASTE CONDITIONING, STORAGE AND TRANSPORT}

\subsection{WASTE ARISINGS}
A. LLW: $70 \mathrm{~m}^{3} / \mathrm{yr}$ (solid); $200 \mathrm{~m}^{3} / \mathrm{yr}$ (liquid) (Lakey 1985)
B. HLW: initially 3,000 canisters after vitrification in borosilicate glass (NF 11/3/86)

\subsection{STRATEGY}

A. Formaldehyde-denitrated HLLW will be stored in acid form in stainless steel tanks until treatment facilities are built after 1995 (IAEA 1984)

B. Some ILW is to be combined with HLW; alkaline ILLW and solid wastes are to be embedded in concrete, with ultimate disposition to be determined

C. It is planned to reduce the volume of LLW and dispose of it in shallow-ground facilities

\subsection{HLW IMMOBILIZATION}

A. The CNEA is planning to build facilities (by France using the French AVM process) for borosilicate vitritication of HLW

B. The HLW package is planned to be borosilicate glass in a stainless steel canister with a $10-\mathrm{cm}$-1 hick lead overpack (package life of $t, 000-10,000$ years claimed) (NF 11/3/86); wastes are to be aged 20 years after reactor discharge before disposal

\subsection{LLW/ILW CONDITIONING}

A. Reactor and research wastes are collected at Ezeiza, where storage, incineration, compaction and bituminization facilities are available; impregnating wastes in polyester resins is being considered

B. ILLW are to be dried and combined with HLW (NF 10/20/86); alkaline liquid and solid wastes are to be embedded in concrete in steel drums; liquid alpha wastes are to be treated by acid digestion (IAEA 1984)

C. LW are placed in steel drums; incinerator ash is bituminized

D. The CNEA is planning to build facilities for embedding compacted fuel hulls in lead alloy, acid digestion of alpha-bearing wastes, and cementation (Lakey 1985; NF 11/3/86; Cooley 1987) 


\subsection{TRANSPORT OF WASTES}

A. HLW will be vitrified and shipped by rail to a depot $150 \mathrm{~km}$ from the deep geological disposal facility, then by truck on the final leg to the repository; Argentina is also investigating shipments by truck only; transport casks will conform to IAEA regulations

(NF 10/20/86; NF 11/3/86)

B. In Argentina, LLW is shipped by truck to the disposal site

\subsection{DISPOSAL OF NON-HIGH-LEVEL WASTES (Palacios 1983; NF 11/3/86)}

9.1 STRATEGY: Argentina has designed and constructed shallow-land trenches for LLW disposal and is studying the feasibility of a monolithic repository for ILW (Pahissa 10/89)

9.2 WASTE DISPOSAL CRITERIA: The radiological safety criteria adopted by the Argentine authorities for the release of radioactive wastes conform with ICRP recommendations; the upper bound for the maximum dose received by an individual from a single installation is set at $0.1 \mathrm{~m} \mathrm{~Sv} / \mathrm{yr}$ (Palacios 10/86)

\section{$9.3 \quad$ ILW DISPOSAL}

A. Some ILW streams are to be combined (vitrified) in the HLW package and disposed of in a deep geologic repository; disposition of cemented ILW in drums is to be determined (IAEA 1984)

B. ILW (requiring an isolation time of more than 20 years but not longer than the useful life of engineered barrier materials such as cement) are incorporated into a stable matrix (e.g., cement, bitumen, or plastic); they are presently stored, but are planned to be emplaced in concrete compartments designed to retain their integrity for periods of 100 200 years; the compartments will be filled and sealed with cement; a geological barrier will be used to ensure confinement for a period exceeding 200 years; this may be achieved by constructing the concrete compartments in clayish soil with a high ion exchange capacity (Palacios 10/86)

C. The monolithic-type concrete repository described above for ILW is planned to have a capacity for 10,000 drums (200 l) and will probably be located near Atucha at Lima (Pahissa 10/89)

D. For ILW containing alpha emitters or resulting from reprocessing, the geological barrier is planned to be an unused mine located in a rocky formation at a depth of several tens of meters (Palacios 10/86)

E. ILW (immobilized in cement) are presently placed in intermediate storage, awaiting development of a ILW repository (Pahissa 10/89)

\subsection{LLW DISPOSAL (Lakey 1985)}

A. Low-activity liquids are discharged into trenches in clay formations; the trenches are $10 \mathrm{~m}$ wide $\times 20 \mathrm{~m}$ long $\times 3 \mathrm{~m}$ deep (Pahissa 10/89) 
B. Solids are disposed by shallow-land burial in trenches; the trench for LLW is $120 \mathrm{~m}$ ing $\times 20 \mathrm{~m}$ wide $\times 1.2 \mathrm{~m}$ deep and can accommodate up to 5600 drums (200 liters); the trench is filled in sections under a movable shed; after filling a section, it is covered with $30 \mathrm{~cm}$ of clayish soil, a polyethylene sheet, and $10 \mathrm{~cm}$ of topsoil (Pahissa 10/89)

C. LLW are conditioned, put into plastic bags, placed into metal drums, then placed in shallow trenches and covered with about one meter of soil (Palacios 10/86)

D. A physical barrier prevents public access to the LLW disposal zone for an isolation period of $10-20$ years (Palacios $10 / 86$ )

\subsection{DISPOSAL OF HIGH-LEVEL WASTES (Palacios 1983; NF 11/3/86)}

\subsection{SPECIFICATIONS AND CRITERIA (for HLW and combined HLW/ILW)}

A. For radiological protection, waste must remain stationary for 1000 years

B. The arrival of radionuclides in the biosphere must be delayed for about 100,000 years

C. Areas to be avoided during site selection are: high-seismicity zones, unstable geologic formations, areas of potential mineral interest, densely populated or tourist areas, areas with difficult access, and those known to have unfavorable hydrogeologic sonditions

D. The criteria for the waste package and repository include (Beninson $3 / 86$ ):

1) The maximum thermal power of each package is $500 \mathrm{~W}$, and the maximum thermal density at the repository level is $5 \mathrm{~W} / \mathrm{m}^{2}$

2) The maximum design temperature of the host rock is $60^{\circ} \mathrm{C}$

3) The hydraulic conductivity of the rock in the repository zone is not greater than $1 \mathrm{E}-9 \mathrm{~m} / \mathrm{second}$

\subsection{REPOSITORY DEPLOYMENT STRATEGY (NF 11/3/86)}

A. Argentina's strategy is to screen sites in granite and reduce those to the few most suitable; select one site for detailed characterization; if satisfactory, develop the repository. there

B. In late 1989, Argentine President Carlos Menem ruled out installation of a proposed medium- and high-ievel nuclear waste repository in Chubut province at Gastre (Sierra del Medio region); he cited unresolved scientific questions and safety concerns and said, "There is no chance a nuclear waste repository will be built at Gastre" (NF 11/27/89)

\subsection{SITE SELECTION AND CHARACTERIZATION (Beninson 3/86)}

A. The selection of the site (see Section 10.1 for some siting-related criteria) was scheduled in five steps:
1) Preliminary survey of granitic outcrops
2) Preselection of granitic formations 
3) Selection of the most appropriate sites for detailed studies

4) Detailed studies in a selected site

5) Validation of the selected site

B. Four potential sites were identified (at Calcatapul and Sierra del Medio in the Chubut province and at La Esperanza and Chasico in the Rio Negro province) from about 200 geologic granite formations throughout Argentina

C. Work has included characterization of a deep repository site in a granite massif in the Sierra del Medio region in northwest Chubut province and preparation of an engineering proposal; deep borehole coring was performed during 1987-1988

D. Characterization of the Sierra del Medio site included:

1) Photointerpretation

2) Statistical analysis of alignments

3) Geologic and geophysical reconnaissance of the massif

4) Regional geomorphologic and hydrologic analysis

5) Construction of ten wells, 200-280 $\mathrm{m}$ deep, around borders of the selected area for petrographic and structural investigation and to study anomalies observed at the surface

6) Construction of four wells $600-800 \mathrm{~m}$ deep

E. If the site and concept are acceptable, Argentina plans to construct a repository to be operable around $2000-2010$

\subsection{REFERENCE HLW/SPENT FUEL DISPOSAL CONCEPT (IAEA 1984)}

A. The reference HLW disposal concept includes the following:

1) The repository area will be about $1 \mathrm{~km}^{2}$ (Cooley 1987)

2) Galleries will be mined out of granite at a depth of $500 \mathrm{~m}$

3) One waste container will be placed in each hole in gallery floors; the holes are to be $1 \mathrm{~m}$ in diameter, $4.5 \mathrm{~m}$ deep and $5 \mathrm{~m}$ apart in tunnels located $20 \mathrm{~m}$ apart

4) Access to the repository will be by both a vertical shaft and a ramp

5) Packing/buffers and seals of bentonite/quartz sand are planned

6) The capacity of the repository is planned for 3000 containers $(0.6 \mathrm{~m}$ in diameter by $1.6 \mathrm{~m}$ high); it will be sized for HLW from six nuclear power plants (IAEA 12/83; Palacios 1988) 
B. The HLW package concept is:

1) HLW borosilicate glass will be the waste form and will contain 10 wt\% fissionproduct and actinide oxides; it will have a leach rate less than $4 \mathrm{E}-4 \mathrm{~g} / \mathrm{cm}^{2}$ (Beninson 3/86)

2) Waste will be aged for at least 20 years after reactor discharge

3) A stainless steel canister $0.6 \mathrm{~m}$ in diameter and $1.6 \mathrm{~m}$ in length will be used; a lead overpack $10 \mathrm{~cm}$ thick will also be used, protected on the outside by a metal sheath (IAEA 12/83; Pahissa 10/89)

\subsection{WASTE PACKAGE R\&D}

A. Waste package R\&D includes investigation of:

1) Corrosion of container materials

2) Properties of barriers

\subsection{GEOSCIENCES R\&D}

A. Geosciences R\&D includes investigation of:

i) Rock mechanics

2) Thermal effects in granite

10.7 PERFORMANCE ASSESSMENT: An analysis of the radiological impact of geologic disposal in Argentina's proposed repository has been performed (de Beninson 1983; Palacios 1988)

10.8 PROGRAM/FACILITIES COSTS: The total cost to develop the Gastre HLW disposal site may reach $\$ 500$ million (U.S.) (Kessler 1986; NF 11/3/86)

\subsection{MANAGEMENT OF URANIUM MINE AND MILL WASTES}

11.1 WASTE ARISINGS: Argentina's solid wastes total 3.5E6 tons from mining and milling operations through March 1987 (Pahissa 1989)

\subsection{STRATEGY/POLICY}

A. Two alternatives are under study in Argentina for management of uranium mining and milling wastes (Pahissa 1989):

1) Refilling of exhausted mines (considered to be expensive)

2) Immobilization of tailings by use of a soil covering of about $2 \mathrm{~m}$ thickness to reduce the radon emanation rate 


\subsection{DECOMMISSIONING AND ENVIRONMENTAL RESTORATION (no information)}

\subsection{INTERNATIONAL ACTIVITIES}

\subsection{MEMBERSHIP: IAEA}

\subsection{COOPERATION WITH OTHER COUNTRIES}

A. Argentina has a cooperative pact with Cuba on nuclear activities; it was signed in November 1986 by CNEA and the Cuban Atomic Energy Commission; its scope includes nuclear plant safety and operations, nuclear security, radiological protection, and food irradiation (NN 1/87); Argentina has signed contracts with Cuba for the construction of a radioisotope production plant ( $\mathrm{NEI} 5 / 89)$

B. Argentina cooperates with Algeria on sales of nuclear services, a possible radioisotope complex, research reactors, $\mathrm{UO}_{2}$, a possible uranium treatment plant, and a possible power reactor (NW 10/16/86; NEl 6/87; NW 1/4/90; NEI 5/89); Argentina exported a 1-MW thermal tank-type research reactor to Algeria (NW 3/16/89)

C. Argentina has a working agreement with Uruguay, signed in May 1987, on nuclear R\&D; it involves training Uruguayans and possibly supplying them with a research reactor complex and a hot cell complex for radioisotope production (NW 6/4/87)

D. Argentine cooperation with Brazil includes building a small (100 MW or smaller) FBR within the next 20 years; Argentina will provide the plutonium from its Ezeiza reprocessing plant and Brazil the sodium moderator (NEJ 6/87; NW 4/6/89); Argentina also has an agreement with Brazil (as of August 1987) to jointly carry out R\&D on separation, transport, and disposal of LLW, ILW, and HLW (NW 8/27/87)

E. Argentina has an agreement with Iran (May 1987) for export of a new core for a research reactor ( $\mathrm{NEI} \mathrm{7/87);} \mathrm{Argentina} \mathrm{has} \mathrm{also} \mathrm{proposed} \mathrm{to} \mathrm{repair} \mathrm{the} \mathrm{Bushehr} \mathrm{plant} \mathrm{working}$ together with Spain and the FRG (NEI 5/89)

F. Argentina has had discussions with Morocco and Indonesia on nuclear export (NEI 7/87)

G. Argentina will construct and supply equipment for the Atomic Research Center in Peru (NEI 2/89); Argentina sold a 10-MW (thermal) isotope production reactor and support facifities to Peru. the largest nuclear export project to date between two developing countries (NW 1/4/90)

H. Argentina and Egy'pt signed a 15-year nuclear fuel cycle cooperation agreement during 1988; the agreement includes fuel fabrication and waste disposal, cooperation in building research reactors, and production of radiojsotopes (NW 12/15/88); Argentina plans to bid on supplying a research reactor and related support facilities for Egypt (NW 11/9/89)

I. Argentina has cooperative agreements signed with 12 countries, including Brazil, Cuba, Turkey, Nigeria, and Algeria (NEI 2/89)

J. Argentina plans to supply a modular 25-MW Carem-15 LWR to Turkey for baseload power production; several developing nations are reportedly interested in buying the Argentine reactor, including Indonesia, Saudi Arabia, Algeria, and Iran (NW 5/11/89) 
$\mathrm{K}$ The focus of Argentina's export strategy to the Middle East is on research reactor sales and technology cooperation accords for uranium exploration, mining and milling, fuel fabrication, nuclear regulation, and nuclear waste treatment and disposal; the Argentine government is discussing nuclear exchanges with Egypt, Iran, Saudi Arabia, Syria, and other unnamed Middle East countries (NW 4/27/89)

M. Mexico has made inquiries about obtaining frontend fuel cycle information and services from Argentina, particularly fuel fabrication technology (NW 6/25/87)

\subsection{REFERENCES}

$-1983-$

de Beninson, A. M., and D. Cancio. 1983. "Impacto Radiologico de la Gestion de Residuos Radiactivos del Programa Nuclear Argentino.' In proceedings of IAEA intemational conference on Radioactive Waste Management, Vol. 1, pp. 331-344. IAEA-CN-43/118, May 1983, Seattle, Washington.

International Atomic Energy Agency (IAEA). December 1983. IAEA Bulletin, Vol. 25, No. 4.

Palacios, E., J. Mattar, C. Perucca, and G.E. Preisz. 1983. 'Bases Conceptuales Para la Construccion de Un Repositorio en la Argentina." In proceedings of IAEA intemational conference on Radioactive Waste Management, Vol. 3, p. 179. IAEA-CN-43/439, May 1983, Seattle, Washington (English translation available from PNLAPSO).

$-1984$

Intemational Atomic Energy Agency (IAEA). 1984. "Spent Fuel Management, Existing Experience." Paper presented by Argentine Representative at IAEA Advisory Group Meeting on Spent Fuel Management, March 27-30, 1984, Vienna.

Mellinger, P. J., K. M. Harmon, and L. T. Lakey. 1984. A Summary of Nuclear Fuel Reprocessing Activities Around the World. PNL-4981, Pacific Northwest Laboratory, Richland, Washington.

Nuclear Fuel (NF). 3/12/84. 'Argentina Produces 203 MT . . . p. 15.

$-1985-$

Lakey, L. T., K. M. Harmon, and P. Colombo. 1985. Management of Low-Level Radioactive Wastes

Around the World, p. 9. PNL-5173, Pacific Northwest Laboratory, Richland, Washington.

$-1986-$

Beninson, D. J., A. J. Gonzalez, E. Palacios, and N. R. Ciallella. 1986. 'The Argentine Radioactive Waste Repository,' Proceedings of the Intemational Symposium on Siting. Design and Construction of Underground Repositories for Radioactive Wastes. IAEA-SM-239/3, March 3-7, 1986, Hannover, FRG.

Kessler, A. 1986. "Argentina Has No Plans to Export Heavy Water." Nuclear Fuel. April 22, 1986, p. 7.

Masters, R. 1986. 'World Survey: Still Working through the Backlog.' Nuclear Engineering International. June 1986, p. 49. 
Nuclear Engineering International (NEI). 11/86. "Argentina Looks to Medium-Sized Unils," p. 3.

Nuclear Fuel (NF). 10/20/86. 'Argentina's Affonsin Said to Endorse Reprocessing Over Once-Through Cycle,' pp. 5-6.

Nuclear Fuel (NF). 11/3/86. Argentine Official Outlines Strategy for Disposal of High-Lovel Nuclear Waste,' pp. 9-10.

Nuclear Fuel (NF). 12/29/86. "CNEA Steps Up Production at $\mathrm{UO}_{2}$ Plant Not Under IAEA Safeguards," p. 9.

Nucleonics Week (NW). 10/16/86. 'Argentina and Algeria Will Expand Nuclear Cooperation," p. 8.

Nucleonics Week (NW). 10/30/86. 'Argentina: Heavy lon Accelerator Opened," p. 11.

Palacios, E. 1986. 'Argentina's Radioactive Waste Disposal Policy.' Seminar on Management

Options for Low- and Intermediate-Level Wastes in Latin America. IAEA-SR-110, October 13-17, 1986, Rio de Janeiro, Brazil.

$-1987-$

Cooley, C. R., and J. D. Saltzman. 1987. 'Foreign Trip Report to IAEA, Vienna." January 26-28, 1987.

Nuclear Engineering International (NEI). 5/87. "Argentina Offers a $380 \mathrm{MWe}$ PHWR with Enhanced Safety Features," pp. 24-34.

Nuclear Engineering International (NE). 6/87, "Country-by-Country Programs, Argentina," p. 29.

Nuclear Engineering Imternational (NEI). 7/87. "Argentina Strikes a Deal with Iran," p. 4.

Nuclear Fuel (NF). 1/12/87. 'Argentina: CNEA Seeking Private Firm to Run Arroyito," p. 10.

Nuclear Fuel (NF). 10/19/87. "Argentina Looks for Some Short-Term U, But Moves to Cover All Its Own Needs," p. 9.

Nuclear News (NN). 1/87. 'Argentina and Cuba Signed a Cooperative Pact," p. 66.

Nucleonics Week (NW). 2/5/87. "Nuclear Electricity Generation for December 1986," p. 18.

Nucleonics Week (NW). 6/4/87. The Presidents of Argentina and Uruguay Signed a Working Agreement," p. 6.

Nucleonics Week (NW). 6/25/87. "Mexico Quietly Seeking Fuel Cycle Technology from Argentina," pp. 2-3.

Nucleonics Week (NW). 8/27/87. "Argentina and Brazil to Develop Waste Technology Jointly," p. 6.

Nucleonics Week (NW). 10/22/87. 'Argentina to Export Heawy Water Process Know-How to Next Decade," p. 13. 
NUKEM Market Report on the Nuclear Fuel Cycle (NUKEM), 12/87. NUKEM GmbH, Hanau, Federal Republic of Germany.

Sametband, M. J. 1987. 'The Wet Spent Fuet Surveillance Program in Argentina." Paper presented at IAEA Technical Committee Meeting, October 27-30, 1987, Vienna.

$-1988-$

International Atomic Energy Agency (IAEA). October 1988. The Nuclear Fuel Cycle Information System, A Directory of Nuclear Fuel Cycle Facilities, Vienna.

Nuclear Engineering International (NEI). 1/88. "CNEA Re-structuring may Ease Problems," p. 8.

Nuclear Engineering International (NEI). 10/88. "Argentina to go private?" pp. 4-5.

Nuclear Fuel (NF). "CNEA Officials Provide More Details about Pilcaniyeu Enrichment Plant," pp. 4-5.

Nucleonics Week (NW). 11/24/88. "Brazil's Sarney to Visit Last Closed Argentine Plant," pp. 10-11.

Nucleonics Week (NW). 12/15/88. 'Argentina/Egypt Nuclear Pact Signed,' p. 14.

OECD Nuclear Energy Agency and International Atomic Energy Agency. March 1988. Uranium Pesources, Production and Demand.

Palacios, E., A. A. Oliveira, A. Curti, G. Siraky, and C. E. Nollmann. 1988. 'Padiological Impact of Disposing of High-Level Waste In Granitic Repository in Argentina." Proceedings of 7 th International Congress of the International Radiation Protection Association. April 10, 1988, Sydney, Australia.

Sametband, M. J. 1988. "The Wet Spent Fuel Surveillance Program in Argentina." Spent Fuel Surveillance And Monitoring Methods. IAEA-TECDOC-461, International Atomic Energy Agency, Vienna Austria.

$-1989-$

Pahissa, M. H., C. J. Pahissa, and T. Ramallo. 1989. "Radioactive Waste Management Strategy in Argentina.' Proceedings of the 1989 Joint International Waste Management Conference. October 22 28, 1989, Kyoto, Japan.

Nuclear Engineering International (NEI). 2/89. 'Datafile: Argentina,' pp. 52-54.

Nuclear Engineering Intemational (NEl). 5/89. "Argentina Seeks to Extend its Exports," p. 4.

Nuclear Fuel (NF). 11/27/89. 'Argentine President Aules Out Proposed Nuclear Waste Repository,' p. 8.

Nuclear Fuel (NF). 12/25/89. "Argentine Atomic Energy Commission Shuts Down Uranium Mill Operation,' pp. 14-†5.

Nucleonics Week (NW). 3/16/89. Argentina to Start Algerian Research Reactor in Late March," p. 4.

Nucleonics Week (NW). 4/6/89. 'Brazilian/Argentine Observer to Attend IAEA Breeder Meeting,' p. 10. 
Nucleonics Week (NW). 4/27/89. 'Argentina to Continue Seeking Nuclear Sales to Middle East," p. 11.

Nucleonics Week (NW). 5/11/89. "Argentina Said Near to Deal with Turkey for 25-MW LWR," p. 5.

Nucleonics Week (NW). 7/13/89. "New President Demands Pespect for Argentine Nuclear Technology," p. 4.

Nucleonics Week (NW). 11/9/89. 'Argentina will Bid on Sale to Egypt of Small Research Reactor,' pp. 7-8.

\section{$-1990$}

Fuel Cycle Review. 1990. 'Special Nuclear Engineering International Publications," pp. 2, 10, 11, 13, $14,15$.

Leigh, I. W., and S. J. Mitchell. 1990. International Nuclear Fuel Cycle Fact Book. PNL-3594 Rev. 10, Pacific Northwest Laboratory, Richland, Washington.

Nuclear Engineering International (NEI). 1990. "World Nuclear Industry Handbook 1990."

Nuclear News. 3/90. 'Argentina Announces Delay of Controversial Plant," 33(3):70.

Nucleonics Week (NW). 1/4/90. 'Menem Government Eyes isotope Production Reactor for Algeria," p. 11. 



\section{BELGIUM}




\section{BELGIUM}

\section{CONIENTS}

1.0 NUCLEAR POWER $\ldots \ldots \ldots \ldots \ldots \ldots \ldots \ldots \ldots \ldots \ldots \ldots \ldots \ldots \ldots \ldots \ldots$, BE. 2

2.0 NUCLEAR FUEL CYCLE AND WASTE MANAGEMENT

STRATEGY/POUCY $\ldots \ldots \ldots \ldots \ldots \ldots \ldots \ldots \ldots \ldots \ldots \ldots \ldots \ldots, \ldots \ldots \ldots, 2$

3.0 HIGHUGHTS AND MAJOR MILESTONES $\ldots \ldots \ldots \ldots \ldots \ldots \ldots \ldots \ldots \ldots$, BE.4

4.0 INSTITUTIONAL CONSIDERATIONS/ORGANIZATIONS $\ldots \ldots \ldots \ldots \ldots \ldots \ldots$ BE.5

$5.0 \quad$ NUCLEAR FUEL PRODUCTION $\ldots \ldots \ldots \ldots \ldots \ldots \ldots \ldots \ldots \ldots \ldots \ldots \ldots \ldots \ldots \ldots \ldots \ldots .7$

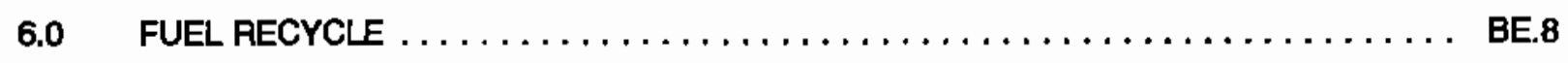

7.0 SPENT FUEL STORAGE AND TRANSPORT $\ldots \ldots \ldots \ldots \ldots \ldots \ldots \ldots \ldots \ldots$ BE.8

8.0 WASTE CONDMONING, STORAGE AND TRANSPORT $\ldots \ldots \ldots \ldots \ldots \ldots$ BE.9

9.0 DISPOSAL OF NON-HIGH-LEVEL WASTES $\ldots \ldots \ldots \ldots \ldots \ldots \ldots \ldots \ldots \ldots \ldots . .13$

10.0 DISPOSAL OF HIGH-LEVEL WASTE $\ldots \ldots \ldots \ldots \ldots \ldots \ldots \ldots \ldots \ldots \ldots \ldots \ldots \ldots \ldots \ldots \ldots \ldots$

11.0 MANAGEMENT OF URANIUM MINE AND MIL WASTES $\ldots \ldots \ldots \ldots \ldots \ldots$ BE.15

12.0 DECOMMISSIONING AND ENVIRONMENTAL RESTORATION $\ldots \ldots \ldots \ldots \ldots \ldots$ BE.15

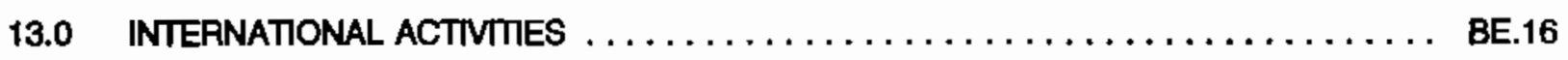

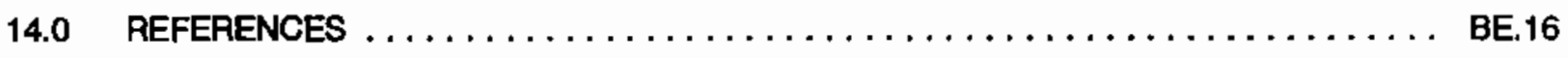




\title{
1.0 NUCLEAR POWER
}

1.1 REACTOR MIX: 7 PWRs; 2 Test Reactors (NUKEM 5/89)

\subsection{ELECTRIC POWER PRODUCTION}

1988-61.9 TWh; 65.5\% nuclear, $26.7 \%$ coal; $7.8 \%$ other (NUKEM $3 / 89$ )

1989-Nuclear share reduced to $60.7 \%$ (NW 1/11/90)

\subsection{NUCLEAP POWER CAPACITY PROJECTIONS (NUKEM 5/89)}

\author{
1980-1.7 GWe \\ 1989-5.5 GWe \\ 2000-5.5 GWe
}

1.4 NUCLEAB PLANT AVAILABIUTY (NEI 4/90)

Year ending $12 / 89-80.4 \%$

Lifetime through $12 / 89-80.2 \%$

\subsection{NUCLEAR ENERGY POLICY}

A. Belgium relies on private industry for electric power generation and the necessary supporting activities except for management and regulation of radioactive wastes (Schneider et al. 1990; IEAL 1987)

B. Belgium's policy on nuclear power generation is to produce base load electricity by nuclear and coal power plants; in December 1988, the Belgian cabinet decided made against the addition of an eighth (1300 MWe) nuclear unit in favor of non-nuclear sources to cover the country's expanding power needs through the 1990s (NUKEM 5/89)

C. Regulation of nuclear activities is spread across several government and private bodies, but Belgium is considering a single regulatory agency (NW 5/25/89)

D. Belgium's high-level and medium-level (TRU) radioactive wastes are to be disposed in a deep geologic repository; low-level radioactive wastes are to be disposed in a shallowland burial facility (NUKEM 2/90)

1.6 NUCLEAR R\&D BUDGET: Costs associated with waste management R\&D for the period 19881992 are estimated at 7.5 billion BF (about U.S. $\$ 200$ million) (NEA 8/88)

1.7 ELECTRICITY PRODUCTION COSTS: Costs for generating electricity from nuclear and coal power plants in 1989 are estimated at 30.8 and 53.1 U.S. mills/kWh (NEA 1989a)

\subsection{NUCLEAR FUEL CYCLE AND WASTE MANAGEMENT STRATEGY/POLICY}

2.1 OVERALL NUCLEAR FUEL CYCLE POLICY: Belgium's policy on support of the nuclear fuel cycle is one of flexibility, allowing conformance with economic and political pressures; Belgium imports uranium and purchases conversion/enrichment services from others; fabrication services are provided for both LWR and MOX fuels; interim wet storage of spent fuel is provided at the nuclear power stations; reprocessing is contracted to others; radioactive wastes are managed by a firm wholly owned by the government (NEA 1986; IAEA 1988; Detilleux 1989) 


\subsection{POLICY ON THE FRONT END OF THE NUCLEAR FUEL CYCLE}

A. All uranium is imported; Belgium obtains $44 \mathrm{MTU} / \mathrm{yr}$ by processing imported phosphate ores Nanhellemont 1985; NEA 1986; IAEA 1988)

B. The utilities decide whether or not to reprocess and recycle uranium and plutonium. At present, spent fuel is being reprocessed in foreign facilities and MOX fuel is being used in Belgian power reactors (Detilleux 1987; Haas 1989)

C. Enrichment services are obtained from foreign suppliars and through an $11 \%$ share of Eurodif (European Enrichment Facility) (Vanhellemont 1985)

D. LWR fuel is fabricated at Dessel by the French-owned FBFC (Franco-Belge de Fabrication de Combustibles); MOX fuel is also fabricated at Dessel, but by Belgonucleaire; Belgium is involved in pan-European negotiations to produce mixed oxide fuels (Vanhellemont 1985; NF 6/26/89)

\subsection{POLICY ON THE BACK END OF THE NUCLEAR FUEL CYCLE}

A. Belgium is storing spent fuel in water pools at the nuclear power stations (Detilleux 1987; Shelor 1988)

B. The decision between reprocessing in foreign facilities or increasing spent fuel storage capacity remains with the utilities; by the end of $1986,50 \%$ had been sent to the reprocessors; the other $50 \%$ remained in pool storage (Detilleux 1987)

C. Research and demonstration programs are under way to obtain data necessary to evaluate use of MOX fuels in the LWR cycle (Haas 1987; Haas 1989)

D. Responsibility for waste management, other than that at the producer's site, which includes transportation, interim storage, treatment and disposal, belongs to the National Agency for Radioactive Waste and Fissile Materials (ONDRAF/NIRAS) ${ }^{(a)}$; the agency may conduct its own operations or subcontract to others (Detilleux 1989)

E. All radioactive wastes, high-level, intermediate-level, and low-level, are to placed in interim storage facilities, existing or to be built at the Mol site; the facilities will be expanded as needed (Detilleux 1989)

F. The waste generator is free to select a waste transport system, provided that relevant national and international regulations are met and ONDRAF concurs; as a result, wastes are shipped by truck, by rail, and by ship (NEA 8/88)

G. Treatment of radioactive wastes other than that performed by the generator is centralized at the Mol-Dessel site where the National Nuclear Research Center and the former Eurochemic reprocessing plant are located (Detilleux 1989)

(a) ONDRAF and NIRAS are abbreviations for the same organization, in French and Flemish, respectively. 
H. Four altematives (engineered surface structures, shallow-land burial, coal mines, and geologic repository) are being examined for disposal of low- and intermediate-level wastes (Detilleux 1989)

I. Disposal in a deep clay fomation on the Mol-Dessel site is planned for high-level and alpha-bearing wastes (Detilleux 1989)

J. Belgium has developed an R\&D plan for the 1988-1992 period covering treatment, storage and disposal of all categoric s of radioactive wastes (NEA 2/88)

K Belgium cooperates extensively with other countries through participation in the CEC, the OECD/NEA and the IAEA and through bilateral agreements (Leigh and Mitchell 1990)

\subsection{HIGHLIGHTS AND MAJOR MILESTONES}

1962 BR3, the first PWR buit in Europe, started operation

1963 Belgium was the first coumtry to insert a MOX fuel assembly in an LWR

1966-74 Operation of Eurochemic fuel reprocessing plant

1972-74 Construction of bitumenization plant for Eurochemic ILW

$1974 \quad$ Belgian waste disposal program concept was developed

1975 Reconnaissance drilling at Mol site was completed

1975-79 Clay repository concept and design were developed; risk assessment methodology was selected for geologic disposal; seismic campaign was completed

1980 The National Agency for Radioactive Waste and Fissile Materials (ONDRAF/NIRAS) was created to manage radioactive wastes

1980-84 URL was installed and made operational; risk assessment exercises were completed; regional hydrologic network was installed

1982 Dumping of low-level waste at sea was discontinued

1985 Belgoprocess was unable to enlist foreign partners in project to refurbish and operate Eurochemic reprocessing plant

1985 Startup of HLW vitrification pilot plant (PAMELA) at Mol

1985-87 Design and construction of new experimental drift in Mol URL

1986 Decision was made to decommission the Eurochemic reprocessing plant

1988-95 Tests were cartied out in new experimental drift in URL 
1987-88 Preparation was completed of clay-repository safety assessment and feasibility interim report

1987 Construction of a $63 \cdot m-$ long test drift in the URL at Mol was completed

1990-94 Carry out site selection and characterization of a site for disposal of LIW

1992 A supercompaction unit for $L L W$ is to be installed to replace the existing units at Mol

1993 Storage facilities are to be constructed for conditioned wastes arising from reprocessing abroad of spent fuel

995 The medium-temperature $\left(900^{\circ} \mathrm{C}\right)$ incinerator for LLW will be replaced with a hightemperature incinerator $\left(1600^{\circ} \mathrm{C}\right)$ that can also handle alpha wastes

1995 Prepare a safety assessment and feasibility report for demonstration operations in the proposed clay repository

2025 Begin construction of a repository for HLW

2030 Begin disposal of HLW

\subsection{INSTITUTIONAL CONSIDERATIONS/ORGANIZATIONS}

4.1 LEGAL REQUIREMENTS: In Belgium, there is no stipulation law that links the employment of nuclear power to availability of waste disposal; the central government has preemptive rights in local siting matters but so far has not had to use them; investment plans must be approved by the Ministry of Economic Affairs; there is no land use veto (Paige 1985; NEI 2/87; Numark 1989)

4.2 RADIATION PROTECTION PRINCIPLES: Belgium's radiation protection principles are established by the 1963 Royal Order and subsequent amendments; these lay down the basic safety standards for the health protection of the general public and workers against the dangers of ionizing radiation; any activity implying exposure to ionizing radiation should be justified in advance, and all exposures should be kept as low as reasonably achievable (ALARA principle; NEA 1987)

4.3 LICENSING: The Federal Ministries of Labor, Employment and Public Heahth are jointly responsible for licensing of nuclear plants (they are advised by a special commission on ionizing radiation); safety reviews are made by foreign experts coordinated by the CEC and by a Belgian non-profit organization that authorizes power operation and oversees operational safety; U.S. NRC rules are generally used as guides; final construction license is issued at the provincial level; provincial decisions may be appealed to the central government; serious consideration is being give to establishing a single national nuclear regulatory agency (Paige 1985; NEI 2/87; Numark 1989)

4.4 PUBLIC INVOLVEMENT: Public review and hearings are conducted but with a short-time allotment; an extensive information campaign is conducted; close contact with the media is maintained (NEI 2/87; Numark 1989) 
4.5 WASTE FUND: Synatom collects and banks a $\mathrm{kWh}$ fee from the utilities for spent fuel management; the power producers set aside funds for waste management and decommissioning; negotiations are under way to increase the utilities' payments to cover the costs of managing Belgium's untreated waste at the Mol site (Detilleux 1984; NW 9/7/89)

\subsection{KEY AGENCIES AND FUEL CYCLE CENTERS}

A. The Ministry of Economic Affairs oversees energy-rolated matters, including nuclear power development; the Ministry of Employment oversees nuclear safety; the Ministry of Public Health oversees radiation protection (NW 5/25/89; Leigh and Mitchell 1990)

B. Nuclear power stations in Belgium are operated by three utilities, Ebes, Intercom and Unerg, which provide the supply of electricity and natural gas for Belgium; in 1990, the three utilities agreed to merge to make takeovers by European utilities more difficult after the borderless energy market is formed within the European Community in 1992. (NW 2/15/90)

C. Synatom, a firm owned by the utilities and half by the federal government, purchases nuclear fuel and support services for the utilities (Vanhellemont 1985)

D. In 1980, a government agency, the National Agency for Radioactive Waste and Fissile Materiais (ONDRAF/NIRAS) was formed to define and implement a waste management policy in Belgium; the responsibilities of ONDRAF range from transport to final disposal, including conditioning and interim surface storage of conditioned or non-conditioned waste for those producers who do not have adequate installations on their own site; implementation can be conducted by ONDRAF's departments, by subsidiary companies, or through subcontracts to others; funding is provided by the waste producers (ONDRAF 1987; Detilleux 1989)

E. The Belgian Nuclear Research Center (CEN/SCK) was the lead organization in radioactive waste management within Belgium until the formation of ONDRAF; CEN/SCK is a state-owned agency established to conduct research in the nuclear field, which covered fast reactors, gas-cooled reactors, light-water reactors, materials, radiation effects, and waste treatment; the latter activities led to the centralization of radioactive waste storage and treatment activities for Belgium at the Mol site and which have now been assumed by ONDRAF (ONDRAF 1987; NW 3/16/89)

F. The French-owned company, Societe Franco-Belge de Fabrication de Combustibles (FBFC), operates a $400 \mathrm{MT} / \mathrm{yr}$ fabrication plant for PWR fuels at the Dessel site (IAEA 1988)

G. The Belgian firm, Belgonucleaire, $50 \%$ owned by CEN/SCK and $50 \%$ by the utilities, operates a $35 \mathrm{MT} / \mathrm{yr}$ fabrication plant for plutonium-based fuels (MOX and FBR) at the Dessel site (IAEA 1988)

H. Belgoprocess was formed in 1976 by Synatom and the Ministry of Economic Affairs as a study organization and in 1978 was assigned the responsibility for re-commissioning and operating the Eurochemic reprocessing plant, located at the Mol site; this responsibility included managing the wastes created by the reprocessing operations which led to the construction and operation of the Eurobitum bitumenization plant and storage hall near the Eurochemic facility; Belgoprocess also shared responsibility with WAK in Germany for operation of the PAMELA high-level waste vitrification facility installed as a demonstration 
at the Mol site; Belgoprocess has also installed a low-level waste storage facility on the Mol site; Belgoprocess is now a subsidiary of ONDRAF/NIRAS (ONDRAF 1987; Detilleux 1989)

I. The firm, Belgian Wastes Technology (BWT), was established by Belgonucleaire and $\mathrm{CEC} / \mathrm{SCK}$ to market expertise in the areas of treatment and storage of radioactive wastes (NN 1/87)

J. Transportation of radioactive materials in Belgium is performed by Transnubel, a firm jointly owned by Belgonucleaire and Transnucleaire of France; Transnubel also represents Britain's Nuclear Transport, Ltd., in Belgium (Schneider et al. 1990)

4.7 PRINCIPAL RESEARCH, DEVELOPMENT AND DEMONSTRATION FACIUTIES/PROGRAMS: Except for a small amount of R\&D that might be performed by the off-site waste generators, all R\&D on radioactive waste management is conducted at the Mol-Dessel site by various contractors under contract to ONDRAF; the major research/demonstration programs include:
A. The High-Temperature Slagging Pyrolysis Incinerator (van de Voorde 1986)
B. The PAMELA vitrification facility for high-level wastes (Hoehlein 1986; Ewest 1987)
C. The underground research laboratory, HADES, for research on geologic disposal of wastes in clay (Baetsle 1986; NEA 8/88)

4.8 KEY PERSONNEL (Leigh and Mitchell 1990)

J. van Dievoet, General Manager, Belgonucleaire

J. Claes, Operations Manager, Belgoprocess

P. Goldschmidt, General Manager, Synatom

E. Detilleux, General Manager, ONDRAF/NIPAS

C. M. Malbrain, Managing Director, CEN/SCK

A. A. Bonne, Geological Disposal Research, CEN/SCK

M. Huberlant, Plant Manager, FBPC

\subsection{NUCLEAR FUEL PRODUCTION}

5.1 URANIUM RESOURCES: There are no economically workable uranium-bearing deposits in Belgium; however, since the end of 1980, a Belgian company has operated the first European plant extracting uranium contained in imported phosphates at a rate of about 35 MTU per year; hence, Belgium is heavily dependent upon imports and, through Synatom, imports uranium in approximately equal proportions from Australia, Canada, Central Africa and South Africa; a twoyear reserve is maintained (Vanhellemont 1985; IAEA 1988)

5.2 ENRICHMENT: As with the uranium supply, Synatom obtains enrichment services from multiple sources; Synatom, through Soben, a Belgian company, has taken a 11.1\% stake in the Eurodif enrichment firm and has signed contracts with the U.S. DOE and the USSR's 
5.3 FUEL FABRICATION: Two fuel fabrication plants are operating in Belgium, both on the Mol/Dessel site:

A. A plutonium fuel fabrication plant, now operated by Belgonucleaire, has been operating since 1973; fuels have been fabricated for several breeder demonstration programs in the past; more recently, the facility is increasing its capacity for MOX fuels to $35 \mathrm{MT} / \mathrm{yr}$ to maintain a competitive position in Europe's mixed oxide fuel market Nanhellemont 1985; IAEA 1988)

B. Belgium began fabricating nuclear fuels at the Mol site in 1958, first for test reactors and then for PWAs; in 1973, the operation was taken over by the French firm, FBFC, and is now part of the largest PWA fuel supply company in the world; the Dessel facility has a capacity to produce 400 MTU/yr of nuclear fuel Nanhellemont 1985; IAEA 1988)

\subsection{FUEL RECYCLE}

\subsection{FUEL REPROCESSING}

A. The Eurochemic reprocessing plant on the Mol site was initiated in 1957 as a joint undertaking of the 13 OECD/NEA member countries; it operated between 1966 and 1974 , processing $181.5 \mathrm{MT}$ of natural and slightly enriched uranium fuels along with $30 \mathrm{MT}$ of high-enriched fuels; this was followed by decontamination of the plant and transfer to Belgian ownership in 1983; Belgoprocess was created by Belgium in 1984 to reactivate the plant, however, a search for foreign financial backing did not succeed and the project was abandoned in 1986, leaving Belgoprocess with the assignment of decommissioning the facilities Nanhellemont 1985; Goldschmidt 1986; Claes 1989)

B. Simultaneously with the abandonment of the Eurochemic program, reprocessing A\&D being conducted by CEN/SCK and as joint cooperative programs with the CEC at Mol were curtailed; these included programs on mixed oxide fuel dissolution, krypton recovery from off-gases, and tritium separation from process streams (Geens 1985; Bruggeman 1985; De Regge 1985)

C. At the end of 1986 , about $700 \mathrm{MTU}$ of spent fuel had been discharged from Belgian nuclear power plants; $20 \%$ have been reprocessed at La Hague, France; another $30 \%$ have been sent to La Hague to be reprocessed between 1989 and 1998 in the new UP3A reprocessing plant; $50 \%$ were still stored in pools of the Belgian nuclear power plants (Detilleux 1987)

6.2 PLUTONIUM AND URANIUM RECYCLE: Belgium has pursued a policy of recycling plutonium in PWRs and FBRs since 1958 and made the first loading of a mixed oxide fuel assembly in a PWA in 1963; the Belgonucleaire plant is Dessel is one of three mixed oxide fabrication plants in the world; successful demonstrations of mixed oxide fuels have been conducted in several countries; present capacity is $35 \mathrm{MT} / \mathrm{yr}$ and is projected to go to $70 \mathrm{MT} / \mathrm{yr}$ by 1995 (Bariot 1985; NF 5/1/89; NEA 1989b)

\subsection{SPENT FUEL STORAGE AND TRANSPORT}

\subsection{SPENT FUEL ARISINGS}

A. Through 1986, about 700 MTU of spent fuel have been generated (Detilleux 1987) 
B. The total amount of spent fuel to be discharged from the seven power reactors now operating in Belgium will over their lifetime of thirty years amount to $3,800 \mathrm{MTU}$ (Goldschmict 1986)

7.2 FUEL ASSEMBLY CHARACTERISTICS: All of Belgium's power reactors are PWRs; the Belgian power reactors use typical PWR assemblies; DOEL 1 and 2 assemblies use a $14 \times 14$ geometry; Tihange 1 uses a $15 \times 15$ geometry; Doel 3 and 4 and Thange 2 and 3 use the later $17 \times 17$ geometry; Belgium also has two test reactors, BR2 and BR3; the BR2 reactor uses aluminum alloy fuels for FBR studies; the BR3 reactor is a PWR with small assemblies, 28 pins per assembly and may contain plutonium (IAEA 1989; NEI 11/89)

7.3 SPENT FUEL STRATEGIES: The Belgian utilities have, to date, opted for reprocessing spent fuel in favor of the once-through cycle; the timing of reprocessing contracts and addition of spent fuel storage capacity is decided largely upon reprocessing charges and economic analyses by the utilities (Detilleux 1987)

7.4 WET STORAGE: The spent fuel storage capacity using water pools at reactors has been progressively increased from 1979 to reach about $1350 \mathrm{MTU}$ in 1988 (Detilleux 1987)

7.5 TRANSPORT: Spent fuel has been transported for almost twenty years (from various nuclear installations to the Eurochemic reprocessing plant and from Belgian nuclear installations to reprocessing plants in other countries); various types of containers are used for the shipments using truck, rail and ship transport; the transportation is handled by Transnubel (NEI 2/87; NEA 8/88)

\subsection{WASTE CONDITIONING, STORAGE AND TRANSPORT}

8.1 WASTE DEFINITIONS: Belgium classifies radioactive waste into three categories: (ONDRAF 1987; Decamps 1990)

A. Category A wastes are material contaminated with low- and intermediate-levels of betaand gamma-emitting radionuclides with half-lives that do not exceed thirty years; these wastes originate primarily with nuclear power stations and installations that use or produce radioelements

B. Category $B$ wastes are material contaminated with long-life alpha-emitting radionuclides; these wastes originate mainly from installations that produce nuclear fuel or reprocess spent fuel

C. Category $\mathrm{C}$ wastes are material contaminated with large quantities of long-life beta-, gamma- and/or alpha-emitting radionuclides; these wastes originate mainly from the reprocessing of spent fuel

\subsection{WASTE ARISINGS}

A. Operation of the Eurochemic reprocessing plant between 1966 and 1974 produced the following quantities of radioactive waste (Claes 1989):

1) $60 \mathrm{~m}^{3}$ of high-level liquid wastes from lowenriched fuels and $775 \mathrm{~m}^{3}$ of high-level liquid wastes from high-enriched fuels 


\subsection{UW/LW STORAGE}

A Prior to 1982, drums of low-level wastes containing less than $10 \mathrm{~g}$ of Pu per package were dumped at sea; a prefabricated concrete building $(60 \mathrm{~m}$ long, $19 \mathrm{~m}$ wide, $7.5 \mathrm{~m}$ high) with a wall $0.25 \mathrm{~m}$ thick was erected at Mol to provide $2,000 \mathrm{~m}^{3}$ of storage capacity following interruption of sea dumping in 1983; another interim storage facility (72 $\mathrm{m}$ long, $39 \mathrm{~m}$ wide, $13.5 \mathrm{~m}$ high) with $0.25 \mathrm{~m}$ thick walls was placed in operation at $\mathrm{Mol}$ in 1988; the newer facility is served by remotely operated bridge cranes and has a capacity of $6,300 \mathrm{~m}^{3}$ which can be expanded to $14,000 \mathrm{~m}^{3}$ (NEA 8/88; Claes 1989)

B. In 1976, the engineered storage facility at Mol, Eurostorage, was placed in operation to accommodate the bitumenized ILW from Eurochemic; the initial facility included two bunkers, each $64 \mathrm{~m}$ long, $12 \mathrm{~m}$ wide, $8.2 \mathrm{~m}$ high with a capacity of 5,000 drums; in 1983 two additional bunkers were added; one of the bunkers is being used for conditione waste from Belgian power stations (Claes 1989; Detilleux 1989)

C. ONDRAF is considering several former coal mines as potential interim storage sites for intermediate-level waste which is currently being stored at Mol (NUKEM 1/88)

8.8 HLW STORAGE: Vitrified HLW from the PAMELA vitrification plant are stored in a separate building near the vitrification plant. The waste canisters are cooled by forced-air circulation to keep the waste temperatures below $450^{\circ} \mathrm{C}$ and the building concrete temperatures below $90^{\circ} \mathrm{C}$; the total storage capacity of the initial facility is 1,512 canisters of $0.063 \mathrm{~m}^{3}$ each; a second storage cell was completed in 1988 with a capacity of 1,060 canisters of $0.15 \mathrm{~m}^{3}$ each (Claes 1989)

8.9 TRANSPORT OF WASTES (Detilleux 1986; ONDAAF 1987; NEA 8/88)

A. Industry is free to select the methods of transportation provided relevant national and intemational regulations are met

B. Belgian regulations for transportation of radioactive wastes are based upon the IAEA standards but may include special requirements, i.e., escorts for selected shipments

C. The transport of low-level wastes with surface radiation levels up to $0.5 \mathrm{mr} / \mathrm{hr}$ is done only by truck

D. Special transport containers have been developed for transport of waste packages with higher surface radiation levels; packages with surface radiation levels between 1 and $5 \mathrm{r} / \mathrm{hr}$ are transported in a specially designed shielded container placed on a truck trailer; each container has a capacity of 14 drums and weighs 14 tons; packages with surface radiation levels above $5 \mathrm{r} / \mathrm{hr}$ will be transported in individual shielded containers having a wall thickness of $14 \mathrm{~cm}$ and weighing 5 tons

8.10 RESEARCH AND DEVELOPMENT: The Belgian R\&D organization, CEN/SCK, was created in 1952 and has an extensive history of R\&D programs related to the nuclear fuel cycle and waste management, particularly in connection with Eurochemic reprocessing operations; with the shutdown and decommissioning of the Eurochemic reprocessing plant and the transfer of waste treatment operations to Belgoprocess, fuel-cycle R\&D has been curtailed; major R\&D activities currently under way include: 
A. Evaluation, selection and design studies are under way on modernization of the waste treatment facilities at Mol. These include planning for a supercompactor installation, a high-temperature incinerator, and additional intenim waste storage (Detilleux 1989)

B. Evaluation, selection and testing of methods for decontaminating and decommissioning the Eurochemic reprocessing plant and associated facilities at Mol (Claes 1989)

\subsection{DISPOSAL OF NON-HIGH-LEVEL WASTES}

\subsection{STRATEGY}

A. Belgium practiced sea disposal of low-level wastes until a moratorium was agreed to at the London Dumping Convention in 1983; low-level wastes have been collected at Mol since that date (Dejonghe 1986; NEI 2/87)

B. Belgium is planning to begin disposal of low-level wastes in a shallow-land burial facility in the middle of the 1990s and is examining five possible sites; the facility will be sized to accommodate 150,000 $\mathrm{m}^{3}$ of low-level waste expected about 2050 (NUKEM 8/89; NUKEM 2/89)

C. Belgium will dispose of alpha-contaminated (TRU) wastes in a geologic repository along with high-level wastes (see Section 10.0)

\subsection{PROGRAM/FACILITIES COSTS (NEA 8/88)}

A. The cost of the R\&D program associated with development and site selection for a lowlevel disposal system is estimated at 75 million BF between 1983 and 1987 and 211 million BF (U.S. \$2 million) in the period 1988 to 1990

B. Site confirmation, site characterization, conceptual design and safety analyses will cost 0.7 billion BF (U.S. $\$ 20$ million) in the 1990 to 1994 time period

C. The cost of the constructing a facility for disposal of approximately $150,000 \mathrm{~m}^{3}$ of conditioned low-level wastes is estimated at ten billion BF (U.S. \$28 million)

\subsection{DISPOSAL OF HIGH-LEVEL WASTE}

\subsection{SPECIFICATIONS AND CRITERIA}

A. No specific legal regulations have been issued so far concerning the disposal of radioactive waste; ONDRAF is responsible for the development of waste repositories (Detilleux 1989; NEA 8/88)

B. The generad licensing procedures for nuclear installations are applicable to waste repositories (NEA 8/88)

C. Belgium classifies radioactive waste into three categories; transuranic wastes are classified as Class B; high-level wastes are Class C wastes (see Section 8.1) 
10.2 REPOSITORY DEPLOYMENT STRATEGY: High-level and transuranic wastes will dispose $\rightarrow$ in the same geologic facility which is planned to be at the Mol site; assuming results of underground research and performance assessments are favorable, start of repository construction is expected in 2025 and repository operation in 2030 (NEA 8/88)

\subsection{SITE SELECTION AND CHARACTERIZATION}

A. Based upon selection factors established in agreement with the Belgian National Geologic Service and considering those suggested by working groups of the $\mathrm{CEC}$ and IAEA, the CEN/SCK selected a site in 1975 in a tertiary clay formation (called Boom clay) in the Mol region for a geologic repository (NEA 8/88; Detilleux 1989)

B. An underground laboratory has been established at the site where R\&D is under way and will continue for several years to develop design features and to characterize the clay media; since 1985, extensive in situ experiments have been performed with regard to geomechanics, corrosion, migration, and heat transfer (Bonne 1986; Detilleux 1989; NEA 8/88)

\subsection{REFERENCE HLW/SPENT FUEL DISPOSAL CONCEPT}

A. Design studies for a repository in the clay formation at a depth of between 100 and 230 meters have led to two concepts using parallel disposal dritts in the midplane of the formation; in one concept, the bottom half of the disposal drift would be filled with canisters of alpha-bearing waste fixed in cement; after backfilling around the ILW, HLW canisters would be placed upon the ILW and then covered with backtilling; in the other concept, the HLW would be placed in holes drilled at 45 degrees from the horizontal in the drift floor; the wastes in the latter concept are considered "retrievable;" three of the disposal drifts would be dedicated to alpha wastes fixed in bitumen and one would be dedicated to cladding waste (Schneider et al. 1990)

B. The overall area required for the repository is governed by the amount of heat generating waste (about $850 \mathrm{~m}^{3}$ of vitrified high-level wastes) and the maximum thermal loading that can be accepted for the site; present assessments indicate thermal loadings up to 2.5 watts per $\mathrm{m}^{2}$ are acceptable; the maximum temperature of the host rock and the rock/canister interface is set at $100^{\circ} \mathrm{C}$ to prevent degradation of the clay (Schneider et al. 1989)

C. No retrievabjlity requirements have been established for the repository (Schneider et al. 1989)

D. The waste package design under consideration for high-level waste is conceptual only and includes the vitrified high-level wastes in a French-type stainless steel canister, with no buffer material other than a clay backfill in the drifts; drums up to 1600 liter capacity' are being considered for alpha-bearing waste (NEA 8/88; Schneider et al. 1990)

10.5 WASTE PACKAGE R\&D: Research and development on waste packages has been under way for several years and is continuing; studies not requiring in situ conditions are under way in surface laboratories to characterize the waste forms and to evaluate materials; in the Underground Research Laboratory at Mol, an ambitious study program is being carried out on clay-related phenomena such as corrosion as well as on methods for placement and handling the waste package in the repository (Schneider et al. 1989; NEA 1989c) 
10.6 GEOSCIENCES R\&D: As in the waste package area, research and development in the geosciences area has been under way for years and is continuing; studies directed at characterizing the clay medium are under way in surface laboratories; in the underground laboratory, studies are under way on migration, heat dissipation, local hydrology, etc., as well as on methods for construction, handling, backfilling and sealing (NEA 1989c; Schneider et al. 1990)

10.7 PERFORMANCE ASSESSMENT (Marivoet 1989; NEA 1989c; Schneider et al. 1990)

A. A preliminary and generic total system pertormance assessment pertormed early in the repository program suggested that a repository in undisturbed clay was very likely to be safe for very long periods of time

B. Another performance assessment was completed more recently as part of the Performance Assessment of Geologic Isolation System (PAGIS) exercise of the CEC; calculations were carried out for time periods of millions of years and included perturbing scenarios selected by expert opinion; the drought scenario proved to be the worst in terms of dose increases, but those were on the order of four times that calculated for an undisturbed scenario

C. In a new pertormance assessment to be conducted by the Belgians, more attention will be paid to human intrusion scenarios and to scenarios in which the engineered barriers maffunction

\subsection{PROGRAM/FACILITIES COSTS (NEA 8/88)}

A. The costs of the R\&D program including site selection and confirmation, laboratory and field investigations, construction of the underground laboratory and associated experiments are estimated at:

1974-1988 1.5 billion BF (U.S. $\$ 42$ million)

1989-1999 1.2 billion BF (U.S. \$34 million); demonstration not included

2000- not yet defined

B. The cost of an industrial facility for the disposal of approximately $20,000 \mathrm{~m}^{3}$ of conditioned high-level and alpha-bearing wastes is estimated at 30 billion BF (US $\$ 850,000,000$ )

11.0 MANAGEMENT OF URANIUM MINE AND MILL WASTES: Belgium imports all uranium; as such it has no uranium mine and mill wastes (IAEA 1988)

12.0 DECOMMISSIONING AND ENVIRONMENTAL RESTORATION: Following shutdown of the Eurochemic fuel reprocessing plant in 1974, a large effort was undertaken to decontaminate the facility and to condition the reprocessing and decontamination wastes; started in 1987, a program is now under way to dismantle the facilities; more recently, a decision has been made to decommission the BR 3 test reactor at Mol and negotiations are under way between the government and industry on the responsibility for decommissioning costs; all decommissioning and waste management activities are directed by ONDRAF (Claes 1989; NUKEM 2/89; NW 3/16/89; NW 9/7/89) 


\subsection{INTERNATIONAL ACTIVITIES}

13.1 MEMBERSHIPS: Belgium is a member of the CEC, IAEA and NEA

\subsection{COOPERATION WITH MULTINATIONAL AGENCIES}

A. Belgium participates in cost-shaning R\&D programs with the CEC, including development of the PAGIS performance assessment code with its application to clay systems and in part of the R\&D work under way in Belgium's underground research laboratory (ECF - 8/88)

B. CEN/SCK is part of the European co-operative R\&D effort on fast reactors, concentrating on fuel development (Haas 1987)

C. Belgium is a party to the 1984 European FBR agreement (Haas 1987)

D. Belgium actively participates in the waste management programs of the NEA and IAEA

13.3 COOPERATION WITH THE UNITED STATES: The U.S. DOE and Belgium's CEN/SCK have a bilateral agreement for exchange of technology in the area of radioactive waste management; the current agreement is in effect until 1/19/94 and covers the topics of: 1) terminal storage in geologic formations; 2) technology of retrievable storage; 3) waste processing technology; and 4) environmental effects

\subsection{COOPERATION WITH OTHER COUNTRIES}

A. Belgian utilities have a $15 \%$ interest in the German $300 \mathrm{MW}$ SNR 300 fast breeder project (NEI 2/87)

B. Belgium has a technology exchange agreement with France on development of FBR fuel (NEI 2/87)

C. CEN/SCK at Mol and Japan's PNC have an agreement to study the suitability of a clay formation as host rock for disposal of conditioned nuclear waste; joint research will be performed at the URL near Mol (AlJ 7/87- NE 10/87)

D. Belgium shares ownership of the Eurodif enrichment enterprise with France, Iran, Italy and Spain (Leclercq 1986)

\subsection{REFERENCES}

$-1984-$

Detilleux, E. J., and P. Tonon. 1984. "Management of Nuclear Spent Fuel and Radioactive Waste in Belgium." In Proceedings of ANS Topical Meeting on Fuel Reprocessing and Waste Management, Vol. 1, pp. 1-3 to 1-13. August 26-29, 1984, Jackson, Wyoming.

Swennen, R. et al. 1984. The Treatment of Combustible Alpha-Wastes at EUROCHEMIC Using Acid Digestion and a Plutonium Recovery Process.' In Proceedings of the ANS Topical Meeting on Fuel Reprocessing and Waste Management, pp. 549-563. August 26-29, 1984, Jackson, Wyoming.

-1985 - 
Bairot, H., and G. Lebastard. 1985. "Commox: a European Joint Venture," Nuclear Europe, Journal of the European Nuclear Society, Berne, Switzerland, No. 12, December 1985, pp. 27-28.

Bruggeman, A., L Meynendonckx, and C. Parmentier et al. 1985. "Development of the ELEX Process for Tritium Separation at Reprocessing Plants.' Radioactive Waste Management and the Fuel Cycle, Hawwood Academic Publishers, New York, Vol. 6, pp. 237-254.

de Regge et al. 1985. 'The Solubility of Plutonium Based Fuels at the Reprocessing Stage," Radioactive Waste Management and the Nuclear Fuel Cycle, Harwood Academic Publishers, New York, Vol. 6, pp. 207-218.

Geens, L. P., G. E. R. Collard, W. R. A. Goossens, and L. H. Baetsle. 1985. 'Krypton Recovery from Reprocessing Off-Gases by Cryogenic Distillation." Radioactive Waste Management and the Nuclear Fuel Cycle, Harwood Academic Publishers, New York, Vol. 6, pp. 219-235.

Paige, H.W., and N. J. Numark. 1985. Assessment of National Systems for Obtaining Local Siting Acceptance of Nuclear Waste Management Facilities. IEAL-R/B6-16, Vol. 1, pp. 3-1 to 3-6 and Vol. 2, pp. 5-1 to 5-5, October 1985, International Energy Associates, Limited, Washington, D.C.

Vanhellemont, G. 1985. "The Nuclear Fuel Cycle in Belgium," Nuclear Europe, Journal of the European Nuclear Society, Bern, Switzerland, December 1985, pp. 21-24.

-1986-

Baetsle, L. H., A. Bonne, and P. Dejonghe. 1986. "The Hades Demonstration Projector for Radwaste Disposal in Deep Clay.' In Proceedings of the Canadian Nuclear Society 2nd International Conference on Waste Management, Vol. 4, p. 591. Winnipeg, Manitoba, Canada.

Bonne, A., and B. Neerdael. 1986. "Disposal of Radwaste in Clay: The Experience Gained in Belgium." In Proceedings of ENC Foratom IX, Vol. 4, p. 591. June 1986, Geneva.

Dejonghe, P. 1986. "Status of the Radioactive Waste Management Program in Belgium." Waste Management ' 86 , Vol. 1, pp. 85-88. March 1986, Tucson, Arizona.

Detilleux, E., and F. Decamps. 1986. "Belgium's Radioactive Waste Management Policy.' In Proceedings of the ANS Topical Meeting on Waste Management and Decontamination and Decommissioning, pp. 1-11. September 14-18, 1986, Niagara Falls, New York.

Goldschmidt, P., and J. Danguy. 1986. 'Reprocessing and Waste Management: The National Experience," ENC '86 Transactions. In Proceedings of the Fourth International ENS/ANS Conference, Vol. 5, pp. 121-136. June 1-6, 1986, Geneva.

Hoehlein, G., E. Tittmann, S. Weisenburger, and H. Wiese. 1986. "Vitrification of High Level Radioactive Waste - Operating Experience with the Pamela Plant." Waste Management '86, Vol. 2, pp. 413-420. March 1986, Tucson, Arizona.

Leclercq. J. 1986. The Nuclear Age, Sodel Publishing, 94 Rungis, France, p. 302.

Nuclear Energy Agency (NEA). 1986. Uranium Resources, Production and Demand, OECD/Nuclear Energy Agency, Paris. 
van de Voorde, N., Vanbrabant, A. de Coninck, and J. Verraver. 1986. High-Temperature Slagging Incinerator." In Proceedings of ENC Foratom IX, Vol. 4, p. 691. June 1-6, Geneva.

$-1887-$

Atoms in Japan (AlJ). 7/87. "PNC Signs contract with CEN for Geological Disposal Research of HLW," p. 24.

Detilleux E., and J. Danguy. 1987. 'Spent Fuel Reprocessing and Waste Management in Belgium.' in Proceedings of RECOD 87, International Conference on Nuclear Fuel Reprocessing and Waste Management, Vol. 4, p. 1387-1394. August 23-27, 1987, Paris.

Ewest, E., and H. Weise. 1987. "High-Level Liquid Waste Vitrification with the PAMELA Plant in Belgium." In Proceedings of the IAEA International Conference on Nuclear Power Performance and Safety. IAEA-CN-48/177, September 28 - October 2, 1987, Vienna.

Haas, D. 1987. "Building a Data Base on MOX Performance in LWRs." Nuclear Engineering Intemational, February 1987, pp. 35-36.

International Energy Associates, Ltd. (IEAL). 12/87. Regulatory Strategies for High-Level Radioactive Waste Management in Nine Countries. IEAL-R/87-93, International Energy Associates, Limited, Fairfax, Virginia

Nuclear Engineering International (NEI). 2/87. "Datafile: Belgium," p. 24-25.

Nuclear Europe (NE). 10/87. "Beigians Agree to Japan Joining Part of Their Radwaste Research," p. 56.

Nuclear Energy Agency (NEA) 1987. Nuclear Law Bulletin, No. 39, OECD/NEA, Paris, June 1987.

Nuclear News (NN). 1/87. 'A Joint Association," p. 59.

ONDRAF/NIRAS Annual Report. 1987. Brussels.

$.1988-$

Decamps, F., and P. Manfroy. 1988. "HLW Management Policies in Belgium," Nuclear Europe, Journal of the European Nuclear Society, n. 8/9, September 1988, p. 22.

ECF. 8/88. Radioactive Waste, Commission of the European Communities, Brussels, No.. 9, August 1988.

International Atomic Energy Agency (IAEA). 1988. The Nuclear Fuel Cycle Information System: A Directory of Nuclear Fuel Cycle Facilities, Intemational Atomic Energy Agency, Vienna.

Nuclear Energy Agency (NEA). 2/88. "Belgium." Nuclear Waste Bulletin: Update on Waste Management Policies and Programmes, No. 2, OECD/Nuclear Energy Agency, February 1988, pp. 9-13.

Nuclear Energy Agency (NEA). 8/88. "Radjoactive Waste Management in Belgium." Status report provided to the OECD/NEA's Radioactive Waste Management Committee in response to a request made at the March 29-31, 1989 meeting of the RWMC in Paris, dated August 1988. 
NUKEM Market Report on the Nuclear Fuel Cycle (NUKEM). 1/88. NUKEM GmbH, Hanau, Federal Republic of Germany, p. 11.

NUKEM Market Report on the Nuclear Fuel Cycle (NUKEM). 2/88. NUKEM GmbH, Hanau, Federal Republic of Germany, p. 22.

NUKEM Market Report on the Nuclear Fuel Cycle (NUKEM). 6/88. NUKEM GmbH, Hanau, Federal Republic of Germany, p. 20.

Nucleonics Week (NW). 1/14/88. "According to an Expert at the Karlsruhe...' p. 9.

Schelor, D. W., and W. Whittington. April 1988. 'Summary of International Activities in Spent Fuel Storage," Journal of the Institute of Nuclear Materials (JNMM), XVI(3):38-40.

$-1989-$

Claes, J., and H. Meyers. 1989. 'The Radioactive Waste Management Programme Associated with the Decommissioning of the Former Eurochemic Reprocessing Plant.' In Proceedings of the 1989 Joint International Waste Management Conference, pp.441 - 459. October 22-28, 1989, Kyoto, Japan.

Detilleux, E., F. Decamps, and R. Heremans. 1989. "Radioactive Waste Management Activities and Related Research in Belgium." In Waste Management '89, February 26 - March 2, 1989, Tucson, Arizona.

Haas, D., M. Lippens, and A. Charlier. 1989. 'MOX Fuel In-Pile Behavior up to 60,000 MWd/t,' Nuclear Europe, Journal of the European Nuclear Society, Berne, Switzerland, January-February, 1989, pp. 14-16.

International Atomic Energy Agency (IAEA). 1989. Nuclear Research Reactors in the World, International Atomic Energy Agency Reference Data Series No. 3, May 1989.

Marivoet, J. L., G. Volckaert, and A. A. Bonne. 1989. 'Performance Assessment of a High-Level Waste Repository in Clay." In Proceedings of the Materials Research Society Symposium, Scientific Basis for Nuclear Waste Management Xll, Vol. 127, pp. 563-570. October 10-13, 1988, Berlin.

Nuclear Energy Agency (NEA). 1989a. Projected Costs of Generated Electricity from Power Stations for Commissioning in the Period 1995-2000. OECD/Nuclear Energy Agency, Paris.

Nuclear Energy Agency (NEA). 1989b. Plutonium Fuel; An Assessment, OECDINuclear Energy Agency, Paris, p. 83.

Nuclear Energy Agency (NEA). 1989c. "Nuclear Waste Management in Belgium." Status report provided to the OECD/NEA's Radioactive Waste Management Committee at the January 23-24, 1990, meeting of the RWMC in Paris, dated 1988-1989.

Nuclear Engineering International (NEl). 11/89. "World Nuclear Industry Handbook: 1990," pp. 72-125.

Nuclear Fuel (NF). 6/26/89. "Europe said heading toward umbrella agreement on MOX fuel," pp. 5-6.

Nuclear Fuel (NF). 5/1/89. "Near-Term Market for MOX Fuel Seen Exceeding Supply Capacity," pp. 9-10. 


\section{BELGIUM}

Nucleonics Week (NW). 3/16/89. "Belgium's CEN/SCK to Build Future Around BR-2 Test Reactor,' pp. 5-6.

Nucleonics Week (NW). 5/11/89. 'Belgian Government, Industry Dispute Payment for Waste Cleanup," pp. 9-10.

Nucleonics Week (NW). 5/25/89. 'Belgium Heading for a Single Nuclear Regulatory Agency,' p. 10.

NUKEM Market Report on the Nuclear Fuel Cycle (NUKEM). 2/89. NUKEM GmbH, Hanau, Federal Republic of Germany, p. 7.

NUKEM Market Report on the Nuclear Fuel Cycle (NUKEM). 3/89. NUKEM GmbH, Hanau, Federal Republic of Germany, pp. 10-11.

NUKEM Market Report on the Nuclear Fuel Cycle (NUKEM). 8/89. NUKEM GmbH, Hanau, Federal Republic of Germany, p. 5.

NUKEM Special Report: The Nuclear Power Plant Capacity of the Westem World (NUKEM). 5/89. NUKEM GmbH, Hanau, Federal Republic of Germany, pp. 12-26.

Numark, N. J., H. W. Paige, and E. F. Wonder. 1989. Public Perception and Acceptance of the Siting of Nuclear Waste Facilities in Seven Countries, Environmental and Energy Services Company (ERC), Fairfax, Virginia, ERCE-R/89-42.

Schneider, K. J., L. T. Lakey, and D. J. Silviera. 1989. Survey of Waste Package Designs for Disposal of High-Level Waste/Spent Fuel in Selected Foreign Countries. PNL-6981, Pacific Northwest Laboratory, Richland, Washington.

\section{$.1990-$}

ATW. 5/90. "Production Progress in PAMELA," pp. 6-7.

Decamps, F., and E. Biesemans. 1990. "Radwaste Disposal in Belgium," Nuclear Europe, European Nuclear Society, Berne, Switzerland, March-April 1990, p. 44.

Leigh, I. W., and S. J. Mitchell. 1990. International Nuclear Fuel Cycle Fact Book, PNL-3594, Rev. 10, Pacific Northwest Laboratory, Richland, Washington.

Nuclear Engineering International (NEl). 4/90. Annual Review of Load Factor Trends," p.18.

Nucleonics Week (NW). 1/11/90. 'Belgium: Nuclear Share Drops in 1989," p. 12.

Nucleonics Week (NW). 2/15/90. "Belgian Utilities Merging Now to Avoid Post-1992 Takeovers," p. 9.

NUKEM Market Report on the Nuclear Fuel Cycle (NUKEM). 2/90. 'Reprocessing and Waste Management: Review 1989," NUKEM GmbH, Hanau, Federal Republic of Germany, p. 14.

Schneider, K. J., L. T. Lakey, and A. B. Johnson, Jr., R. F. Hazetton, and D. J. Bradley. 1990. Comparison of Selected Foreign Plans and Practices for Spent Fuel and High-Level Waste Management. PNL-7293, Pacific Northwest Laboratory, Richland, Washington. 
BRAZIL 
BRAZIL

\section{BRAZIL}

\section{CONTENTS}

1.0 NUCLEAR POWER $\ldots \ldots \ldots \ldots \ldots \ldots \ldots \ldots \ldots \ldots \ldots \ldots \ldots \ldots \ldots \ldots \ldots \ldots$

2.0 NUCLEAR FUEL CYCLE AND RADIOACTIVE WASTE MANAGEMENT

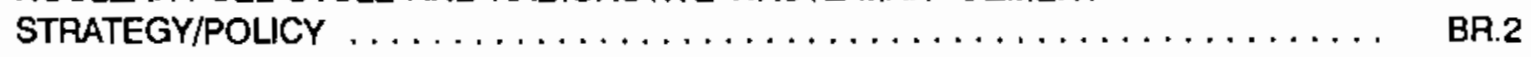

3.0 HIGHUGHTS AND MAJOR MILESTONES $\ldots \ldots \ldots \ldots \ldots \ldots \ldots \ldots \ldots \ldots \ldots$

4.0 INSTITUTIONAL CONSIDERATIONS/ORGANIZATIONS $\ldots \ldots \ldots \ldots \ldots \ldots \ldots$ BR.4

5.0 NUCLEAR FUEL PRODUCTION $\ldots \ldots \ldots \ldots \ldots \ldots \ldots \ldots \ldots \ldots \ldots \ldots$

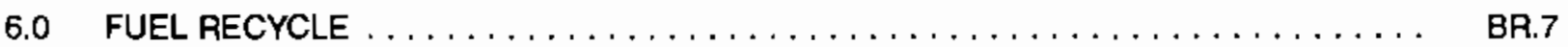

7.0 SPENT FUEL STORAGE AND TRANSPORT $\ldots \ldots \ldots \ldots \ldots \ldots \ldots \ldots \ldots \ldots$ BR.7

8.0 WASTE CONDITIONING, STORAGE AND TRANSPORT $\ldots \ldots \ldots \ldots \ldots \ldots \ldots$ BR.8

9.0 DISPOSAL OF NON-HIGH-LEVEL WASTES $\ldots \ldots \ldots \ldots \ldots \ldots \ldots \ldots \ldots \ldots$

10.0 DISPOSAL OF HIGH-LEVEL WASTES $\ldots \ldots \ldots \ldots \ldots \ldots \ldots \ldots \ldots \ldots \ldots \ldots$

11.0 MANAGEMENT OF URANIUM MINE AND MILL WASTES (no information) $\ldots \ldots \ldots$ BR,10

12.0 DECOMMISSIONING (no information) $\ldots \ldots \ldots \ldots \ldots \ldots \ldots \ldots \ldots \ldots \ldots \ldots \ldots$ BR.10

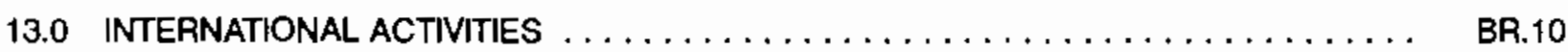

14.0 REFERENCES $\ldots \ldots \ldots \ldots \ldots \ldots \ldots \ldots \ldots \ldots \ldots \ldots \ldots \ldots \ldots \ldots \ldots$ BR.11 


\subsection{NUCLEAR POWER}

\subsection{REACTOR MIX}

1 PWR (626 MWe net)

\subsection{ELECTRIC POWER PRODUCTION}

A. The total electric power produced in Brazil in 1989 was about $200 \mathrm{TWh}$, of which about $90 \%$ was hydro, $4 \%$ was oil, $0.7 \%$ was nuclear, and the rest was other thermal (NEI 6/89; NEI 4/90)

B. About 1.6 TWh of nuclear power was produced in Brazil in 1989; the capacity factor was about 31\% (IAEA 1990)

\subsection{NUCLEAR POWER CAPACITY PROJECTIONS}

1985--0.6 GWe

1990--0.6 GWe

1995--1.9 GWe

2000--3.1 GWe (NUKEM 4/90)

\subsection{NUCLEAR FUEL CYCLE AND RADIOACTIVE WASTE MANAGEMENT STRATEGY/POLICY}

\subsection{OVERALL NUCLEAR FUEL CYCLE POLICY}

A. Brazil plans to work toward domestic capability for a completely closed fued cycle that includes uranium mining, milling, and enrichment; fuel fabrication; reprocessing; waste treatment; and disposal

B. Brazil plans to develop a 50-MW reactor to propel submarines by the mid-1990s ‘ $N W$ 4/14/88)

C. Brazil plans to develop, jointly with Argentina, a fast-breeder reactor within 20 years (NEI 2/89)

D. Brazil plans to store spent fuel at the reactors until at domestic reprocessing plant is ready to operate

\subsection{HIGHLIGHTS AND MAJOR MILESTONES}

1956 The government created the Comissao Nacional de Energia Nuclear (CNEN) to define Brazil's nuclear energy policy (NEI $4 / 90$ )

1956-1966 Brazil established three research centers, each with its own research reactor; these were IPEN (Navy) at Sao Paulo, CDTN (civilian) at Belo Horizonte, and IEN (Army) in Rio de Janiero (NEI 4/90)

A 657-MWe PWR was ordered from Westinghouse for the Angra dos Reis site (NEI 4/90) 
1975

1975

1979

1980

1982

1984

1985

1986

1986

1987

1987

1988

1988-1989

1989

1990

1990

1992

1992

Brazil's military launched a secret nuclear weapons program (NF 10/29/90)

An agreement was signed with the Federal Republic of Germany to build eight 1300-MWe PWRs over 15 years with supporting enrichment and reprocessing facilities

The CNEN started a parallel program of R\&D in the nuclear fuel cycle (NEI 4/90)

A reactor-component production factory at haguaj was opened (NEI 4/90)

A fuel-fabrication plant, with a capacity of $100 \mathrm{MT}$ (heavy metal)/yr, bogan operation in 1982 at the Resende complex in the state of Rio de Janeiro

Angra-1, the first nuclear power reactor, was started up

Commissioning tests were pertormed on the first cascade (of 24 stages) at the Resende pilot-scale jet-nozzle uranium enrichment plant (NEI 11/85)

The first reload of 40 fuel elements for Angra-1 was delivered from the Resende fuel-fabrication plant (ATW 7/86)

The government ordered severe cut-backs in the nuclear program, including having Nuclebras sell its reactor site at Iguape (NEI 4/90)

Experimental centrifuge uranium enrichment was demonstrated to $1.2 \%$ uranium-235 (NF 10/19/87)

A radiological accident near Goiania contaminated a large number of individuals and several urban areas with cesium-137 (Mezrahi 1989)

The Aramar Experimental Center uranium-ennichment facility (gas centrifuge) at Ipero was inaugurated on April 8, 1988, for development of nuclear-powered submarines (NEI 6/88).

The nuclear industry was reorganized and partially privatized (NEI 5/89,6/89, NUKEM 5/89)

The second research reactor at IPEN was commissioned (NEI 4/90)

The pilot jet-nozzle enrichment plant for "testing and operational evaluation" began operation at Resende, to 0.7-0.8\% U-235 (NF 9/89; NEI 4/90)

Operational capacity of 3,000 SWU enrichment is expected from gas centrifuges (NF 9/89)

Operation of a prototype reactor for the first nuclear submanine is expected at the Aramar experimental center (NEI 9/89)

A decision is expected on domestic uranium enrichment for power reactors if nuclear capacity is to expand beyond the three Angra reactors (NF 9/89) 


\subsection{INSTITUTIONAL CONSIDERATIONS/ORGANIZATIONS}

\subsection{LEGAL REQUIREMENTS}

The CNEN has based regulatory requirements on national standards and codes as well as from the IAEA, the U.S. NRC, and the Federal Republic of Germany (NEI 4/90)

\subsection{KEY AGENCIES AND FUEL CYCLE CENTERS}

President Jose Sarney reorganized Brazil's entire nuclear industry on August 31, 1988, by a decree entitled "The National Nuclear Energy Program" (NW 9/88); the primary reasons appear to be to lower costs, to transfer debt incurred by the government-owned organization to the Brazilian treasury, and to attract private capital (NEI 4/90); two nuclear programs were eliminated, one under IAEA safeguards and the other run by the military (NEI 12/88); the government is a Federative Republic consisting of the President (executive branch), Bicameral National Congress (legislative branch), and Supreme Federal Tribunal (judiciary branch); the key agencies are as follows:

A. The Federal Ministry of Mines and Energy plans, executes, and controls Brazil's nuclear power program

B. The Superior Council for Nuclear Policy (CSPN) sets guidelines for Brazil's nuclear industry and controls the CNEN through a non-military board composed of representatives from 19 ministries, the CNEN, INB, and three private citizens (NUKEM 5/89; NW 9/88)

C. In Brazil, the Comissao Nacional de Energia Nuclear (CNEN), commonly called the National Nuclear Energy Commission, performs nuclear research and development, implements enrichment projects, evaluates safety, and controls four research institutes: CDTN, IPEN, IEN, and IRD; CNEN also owns 51\% of INB (NEI 6/89) and controls research reactors at CDTN, IPEN, and IEN (NW 9/88; NEI 4/90)

D. The Industrias Nucleares de Brasil (INB) replaced the former Nuclebras organization and its subsidiaries; it is responsible for commercially viable segments of the nuclear fuel cycle, currently uranium mining and processing and fued fabrication; these operations are managed by a subsidiary cailed Uranio do Brazil, S.A., which is open to $49 \%$ private shareholdings; the former Nuclebras subsidiaries Nuclep and Nuclemon were transferred to INB and are to be sold; Nuclei and Nustep (enrichment by the jet-nozzle process) and Nuclam (uranium prospecting) were dissolved (NUKEM 5/89; NEI 4/90)

E. The Federal Environmental Protection Agency is involved in site approval, installation, and issuing operating licenses for nuclear facilities (NEI 4/90)

F. Electrobas is responsible for construction and operation of nuclear power plants in Brazil (NEl 6/89) 
G. Nuclen is responsible for nuclear-power-plant engineering under Electrobas; Siemens/Kraftwerk Union retains a 25\% holding in Nuclen (NEI 4/90)

\subsection{PRINCIPAL RESEARCH, DEVELOPMENT AND DEMONSTRATON FACILITIES/PROGRAMS}

A. The CDTN (Center for Development of Nuclear Technology) in Bolo Horizonte carries out applied research and industrial development of uses for atomic energy for Nuclebras, operates a Triga reactor for research and isotope production, and carries out laboratory-scale development of the nozzle process for uranium enrichment (Leigh and Mitchell 1990)

B. The IPEN (Nuclear and Energy Research Institute) in Sao Paulo is a nuclear fuel cycle R\&D institute at the University of Sao Paulo; it is active in the Brazilian military nuclear program (Spector 1985); it carries out R\&D on nuclear and high-energy physics, nuclear medicine, radiobiology, radiation health and safety, materials in the nuclear industry, isotope applications, radioactive waste disposal, nuclear metallurgy, radiochemistry, laboratory-scale spent fuel reprocessing R\&D, small-scale development of gas centrifuge for uranium enrichment, and a 10-MW swimming-pool reactor for isotope production; a 100-kWt research reactor became operational on November 9, 1988 (NEI 2/89; Leigh and Mitchell 1990)

C. The IEN (Nuclear Engineering Institute) in Rio de Janeiro conducts R\&D in nuclear and reactor physics, cyclotron radioisotope production, reactor engineering, research reactor operation (10-kW Argonaut type), metallurgy, nuclear and applied chemistry, nuclear instrumentation (development and production), health physics, mathematics and computations, sodium technology, reactor development for isotope production and fast breeders (Leigh and Mitchell 1990)

D. The IRD (Heakh Physics and Dosimetry Institute) carries out personnel-dosimetry control. calibration of radiation detectors, reactor environmental control, nuclear medicine and $x$-ray equipment control, radiobiology, determination of background radiation level, dosimetry research, and operation of a Brazilian secondary-standards dosimetry laboratory (Leigh and Mitchell 1990)

\subsection{KEY PERSONNEL (Leigh and Mitchell 1990)}
A. Aureliano Chaves, Minister of Federal Mines and Energy Ministry (NW 9/88)
B. Jose Goldemberg, Minister for Science and Technology (NF 10/29/90)
C. Rex Nazare Alves, President, CNEN
D. H. R. Franzen, Head, Waste Disposal, CNEN (NW 11/13/86)
E. John Albuquerque Forman, President, INB (NW 9/88)
F. Claudio Rodrigues, Superintendent, IPEN
G. Alcyr Mauricio, Director, IEN
H. Anamelia Habib de Mendonca, Director, IRD 
I. V. Mattos Andrade Silva, Director, CDTN

\subsection{NUCLEAR FUEL PRODUCTION}

\subsection{URANIUM RESOURCES}

A. In 1990, according to the INB, Brazil had 301,490 MT of $\mathrm{U}_{3} \mathrm{O}_{B}$ equivalent in ore, with $192,540 \mathrm{MT}$ as reasonably assured

B. The main ore deposits are at Itataia, Lagoa Real, and Pocas de Caldas; others are at Rio Cristalino and Gandarela (NEI 4/90)

\subsection{URANIUM PRODUCTION}

A. The INB announced that yellowcake $\left(\mathrm{U}_{3} \mathrm{O}_{\mathrm{B}}\right)$ production would start by the end of 1989 at Pocas de Caldas, with an output of $500 \mathrm{MT} / \mathrm{yr}$ (NE1 8,89)

B. The Pocas de Caldas site has an estimated 8,000 MT in deposits (NEI 8/89)

C. Pocas de Caldas is the only producing mine (NEI 4/90)

\subsection{URANIUM CONVERSION (NF 11/26/84; NEI 4/90)}

A. In 1984, the domestic conversion plant was commissioned by IPEN at Ipero with a capacity of $90 \mathrm{MT} / \mathrm{yr}$ uranium (as uranium hexafluoricle)

B. Construction of the Resende industrial conversion plant with a capacity of $2000 \mathrm{MT} / \mathrm{yr}$ (Pechiney equipment and technology) has been delayed indefinitely

\subsection{URANIUM ENRICHMENT}

A. In 1980, a laboratory-scale Becker nozzle enrichment plant was moved from the Federal Republic of Germany to Belo Horizonte for R\&D by Nuclebras (NF 4/26/82)

B. In 1985, testing started on a uranium enrichment plant $(6,000 \mathrm{SWU} / \mathrm{yr}$ capacity) at Resende using jet-nozzle technology; the first cascade of 24 stages was installed and can produce up to $0.85 \%$ U-235 (Becker 1983; NW 7/30/87)

C. In 1988, operation of a second cascade $(64,000 \mathrm{SWIJ} / \mathrm{yr})$ was scheduled; expansion to match Angra-1 reactor needs are to be determined in 1990 or later (NF 1/31/83; NW $7 / 30 / 87$ )

D. The IPEN has been developing gas-centrifuge enricrment technology since 1979 for military uses; it began experimental operations in late 1985 and achieved enrichments to $1.2 \%$ uranium-235 in 1987 (NN 11/85; NF 10/19/87)

E. A uranium-enrichment process using the centrifuge technique was inaugurated in April 1988 at the Aramar Experimental Center at Ipero in the state of San Paulo; the facility is enriching to $4 \%$ and was expected to reach $20 \%$ by November 1989 when the second enrichment module was to be operational (NEI 3/89) 
F. Laser enrichment was under development in 1987 at the Aerospace Technology Center at Sao Jose dos Compos (NW 7/23/87)

G. Interim enrichment services for Brazil are contracted with Argentina (NW 7/30/87); enrichment services for Angra-1 have been supplied by Urenco (NEl 4/90)

H. In 1990, a plan by the military to expand its unsafeguarded nuclear program was at issue; the military proposed to expand the hitherto secret Ipero enrichment facility from the present capacity of under 1,000 SWU/yr to 100,000 SWU/yr by 1996 (NF 10/29/90)

A. The fuel-fabrication plant (Fábrica de Elementos Combustiveis), with a capacity of $100 \mathrm{MT}$ (heavy metal)/yr, began operation in 1982 at the Resende complex in the state of Pio de Janeiro

B. The Resende plant is now absorbed in the new fuel-cycle company, Indústrias Nucleáres de Brasil (INB)

C. The plan is to add further 100-MT modules up to a final capacity of $400 \mathrm{MT} / \mathrm{yr}$; the facility was built by KWU (FRG) (NEI 4/90)

\subsection{PROGRAM/FACILITIES COSTS}

The centrifuge enrichment program is estimated to have cost $\$ 85$ million (U.S.) since its inception in 1979 (NW 4/14/88)

\subsection{FUEL RECYCLE}

\subsection{FUEL REPROCESSING}

A. A $10-\mathrm{kg} / \mathrm{d}$ reprocessing pilot plant has been under construction at Resende; startup, scheduled for 1986, has been delayed; the facility may be a forerunner of a $300 \mathrm{MT} / \mathrm{yr}$ industrial plant (Spector 1984)

B. Brazil has no intention to reprocess spent fuel for 20 years (Franzen 1986)

\subsection{RESEARCH AND DEVELOPMENT}

As of 1986 IPEN had non-radioactive laboratory-scale reprocessing studies under way, and reportedly has reprocessing technology for plutonium recycle (NF 12/29/86; NEI 3/87; NW $7 / 23 / 87)$

\subsection{SPENT FUEL STORAGE AND TRANSPORT}

7.1 SPENT FUEL ARISINGS (Leigh and Mitchell 1990)

198932 MTU cumulative

199048 MTU cumulative 
1995162 MTU cumulative

2000412 MTU cumulative

\subsection{SPENT FUEL STRATEGIES}

Brazil will use at-reactor spent-fuel storage in water pools until a domestic reprocessing plant can be built and commissioned; it has a nominal 10-year storage capacity at reactors

\subsection{WASTE CONDITIONING, STORAGE AND TRANSPORT}

\subsection{WASTE ARISINGS}

A. IPEN was expected to generate 60200 -liter drums/yr of $\amalg W$ as of 1986; the Angra-1 nuclear power plant was expected to generate 2500200 -liter drums/yr of $\amalg W$ (NW 11/13/86)

B. Cleanup from the September 1987 radiological accident near Goiania contaminated a large number of individuals and several urban areas; with cesium-137 and created $3340 \mathrm{~m}^{3}$ of wastes

1. 300 drums of radioactive waste resulted from the initial cleanup; the waste was stored at Abadia de Goias (NWN 1/7/88)

2. The radioactive wastes arising from the $50.9 \mathrm{TBq}(1376 \mathrm{Ci})$ cesium-137 source have been classified as follows (Mezrahi 1989):
a. Non-radioactive $(<0.002 \mu \mathrm{Ci} / \mathrm{g}): 918 \mathrm{~m}^{3}, 0.7 \mathrm{Ci}$
b. Low-level solid waste $(\leq 200 \mathrm{mrem} / \mathrm{h}): 1971 \mathrm{~m}^{3}, 186 \mathrm{Ci}$
c. Intermediate-level solid waste $(\leq 2,000 \mathrm{mrem} / \mathrm{h},>200 \mathrm{mrem} / \mathrm{h}): 105 \mathrm{~m}^{3}$, $412 \mathrm{Ci}$
d. High-level solid waste $(>2,000 \mathrm{mrem} / \mathrm{h}): 24 \mathrm{~m}^{3}, 573 \mathrm{Ci}$
e. Not yet classified: $320 \mathrm{~m}^{3}$

\subsection{STRATEGY}

Brazil plans to dispose HLW from reprocessed spent fuel in a geologic nuclear-waste repository; ILW and $\amalg W$ would be buried in shallow-land facilities with engineered barriers

\subsection{ULW/LW CONDITIONING}

ILW and LLW will be immobilized using ordinary Portland cement as a binder (Rzyski 1989)

\subsection{HLW STORAGE}

A. Spent fuel will be stored in water pools at the reactor until a domestic reprocessing plant is ready to operate 
B. The governor of Brazil's Golas state signed a preliminary contract with Italy's Casa Grande Group to build a temporary storage facility for the wastes accumulated from the 1987 Goiania accident, where a radiotherapy device containing cesium-137 was inadvertently opened (NWN 3/89)

C. The HLW and all other wastes collected from the cesium-137 accident are being stored temporarily in the open air on concrete pads in a sparsely populated area about $2.5 \mathrm{~km}$ from the city of Abadia de Goias (Mezrahi 1989)

\subsection{TRANSPOAT OF WASTES}

Transport of wastes from the cesium-137 accident at Goiania was by trucks, in accordance with Brazilian regulations (Mezrahi 1989)

\subsection{RESEARCH AND DEVELOPMENT}

A. IPEN conducts research on treatment of low- and intermediate-level liquid wastes; this includes cementation, bituminization, evaporation, and precipitation (NW 11/13/86; Vicente 1986; Filho 1986)

B. IPEN conducts research on treatment of low- and intermediate-leved solid wastes; this includes compaction and incineration (NW 11/13/86; Vicente 1986; Filho 1986)

\subsection{DISPOSAL OF NON-HIGH-LEVEL WASTES}

\subsection{STRATEGY}

นW in Brazil is to be disposed of in shallow-land facilities (NN 1/88)

\subsection{WASTE DISPOSAL CRITERIA}

ILW and LLW in Brazil will be buried in shallow land; engineered barriers will be provided to guarantee long life; safety will be emphasized during transport and emplacement (Rzyski 1989)

\subsection{ILW DISPOSAL}

As of 1987, CNEN had identified 24 feasible sites in Brazil for low- and intermediate-level radioactive waste disposal; 18 are inland, three are in an abyssal ocean region, and one is on an island (NW 12/10/87)

\subsection{LLW DISPOSAL}

A. CNEN has been screening sites for disposal of UW since 1978 (NW 11/13/86); as of 1987. CNEN had identified 24 feasible sites in Brazil for low- and intermediate-level radioactive waste disposal; 18 are inland, three are in an abyssal ocean region, and one is on an island (NW 12/10/87)

B. The governor of the state of Rio de Janeiro has sanctioned a ban against disposal of radioactive waste in that state ( $\mathrm{NN} \mathrm{1/88)}$ 
9.5 UW/ILW DISPOSAL R\&D (NW 11/13/86; Vicente 1986; Filho 1986)
A. IPEN is developing methodology for performance assessment of shallow-land disposal sites
B. Leaching tests for various waste forms are in progress
C. Storage and disposal designs are in progress
D. A seven-phase LLW repository safety-analysis project (1985-1987) was sponsored by CNEN (Santos 1985)
E. R\&D has shown that the immobilization of nitric-acid waste streams with ordinary Portland cement can be improved by use of some admixtures (Rzyski 1989)

\subsection{DISPOSAL OF HIGH-LEVEL WASTES}

\subsection{SITE SELECTION AND CHARACTERIZATION}

Extensive drilling, seismic testing, and geologic mapping have been done for a possible geologic nuclear waste repository at Cachimbo in the Amazon jungle (NW 8/27/87)

\subsection{MANAGEMENT OF URANIUM MINE AND MILL WASTES (no information)}

\subsection{DECOMMISSIONING (no information)}

\subsection{INTERNATIONAL ACTIVITIES}

\subsection{MEMBERSHIPS}

IAEA; as of 10/90 Brazil had not signed the non-proliferation treaty, but Jose Goldemberg, Minister for Science and Technology, stated that Brazil is moving toward the goal of making a full-scope safeguards agreement with the IAEA (NF 10/29/90)

\subsection{COOPERATION WITH USA}

A. Joint natural-analog studies on migration of radionuclides from thorium ore deposits were carried out at Morro do Ferro, in Pocos de Caldas with Sweden, Switzerland, U.K. and U.S. (Penna-Franca 1984; Franca 1986)

B. As of 1986, Furnas Centrais Electricas planned a contract with the U.S. corporation NUS to upgrade the Angra-1 reactor waste treatment and packaging (NW 11/13/86)

C. The Angra-1 PWR was built by Westinghouse (ATW $7 / 86$ )

D. In 1990, Richard Kennedy, U.S. representative to the IAEA, said that exchange of technology will not continue if Brazil does not ratify the Nuclear Non-Proliferation Treaty (Bonàlume 1990) 


\subsection{COOPERATION WITH OTHER COUNTRIES}

A. A nuclear-transter agreement between Brazil and the FRG provides tor the FRG to supply Brazil with power reactors, enrichment technology, and a pilot reprocessing plant (Spector 1985; ATW 7/86; NW 1/15/87); the agreement was extended for another 5 years in 1989 (NEl 2/90)

B. In 1990 , West German officials stated they were ready to amend Germany's 1975 bilateral agreement to supply technology only if Brazil safeguards all of its nuclear activities (NF 10/29/90)

C. China and Brazil have a general nuclear-cooperation agreement with emphasis on $R \& D$ on fast reactors fueled by thorium (NW 1/88)

D. Brazil and Argentina are collaborating on a small FBR (NEI 3/87); they have reached agreement on seven other areas; these are: Detectors, safeguards, research-reactor fuels, fusion, conversion, security, and waste disposal (NW 9/10/87)

E. Brazil has signed a nuclear-cooperation agreements with several countries; Brazil would like to become a major exporter of enriched uranium and equipment; projected reductions in nuclear-power growth and slowdown in Brazil's enrichment program will limit this development (Spector 1985)

F. The USSR and Brazil signed an agreement on 11/24/89 on reactor safety, technology transfer on small reactors and fast reactors, isotope utilization, emergency planning and ervironmental monitoring (NEI 2/90;)

G. Brazil cooperates with Sweden, Switzerland, the U.K., and the U.S., on natural-analog studies (Pocos de Caldas Project)

\subsection{REFERENCES}

$-1982$.

Nuclear Fuei (NF). 1/4/82. "Brazil's First Production of Yellowcake Puts It on the Road to Fuel Cycle Independence."

Nuclear Fuel (NF). 4/26/82. "Critics See Brazil as Taken for a Ride on Its 'Last Train' to SWU Technotogy," p. 7.

$-1983-$

Becker, E.W. 1983. "Developing Double Deflection Systems for Advanced Nozzle Enrichment." Nuclear Engineering Intemational, November 1983, pp. 33-37.

Nuclear Fuel (NF). 1/31/83. 'Cals Says Resende SWU Plant Will Run in This Decade Despite Big Budget Cuts," p. 2. 
$-1984$

Nuclear Fuel (NF). 11/26/84. "Brazil's First Enrichment Cascade to Begin Operation in February."

Penna-Franca, E., et al. 1984. "Radium Mobilization and Transport at a Large Thorium Ore Deposit in Brazil." In IAEA Waste Management Research Abstracts No. 15, International Atomic Energy Agency, Vienna, p. 101.

Spector, L S. 1984. Nuclear Proliferation Today. A Carnegie Endowment Book, Vintage Books, New York.

$-1985-$

Nuclear Engineering Imternational (NEI), 11/85. 'Brazil Enriches by Jet Nozzle,' p. 25.

Nuclear News (NN). 11/85. "Brazil," p. 142.

Santos, J.M.E., et al. 1985. "Low Level Waste Repository Safety Analysis." In IAEA Waste Management Research Abstracts No. 16, International Atomic Energy Agency, Vienna, p. 118.

Spector, L. S. 1985. The New Nuclear Nations. A Carnegie Endowment Book, Vintage Books, New York.

$-1986-$

ATW News (ATW) 7/86. "KWU Participation in Reload Fuel for the Angra-1 Brazilian Nuclear Power Station," p. 6.

Filho, C.E.G., and U. Chandra. 1986. 'Bituminization of Simulated Waste, Spent Resins, Evaporator Concentrates and Animal Ashes by Extrusion Process." Paper presented at IAEA seminar Management Options for Low- and Intermediate-Level Wastes in Latin America, IAEA-SR-110, Rio de Janeiro, Brazil, October 13-17, 1986, International Atomic Energy Agency, Vienna.

Franca E.P., et al. 1986. "Thorium Report of Morro do Ferro in Pocos de Caldas, Brazil; An Analog of a Radioactive Waste Repository." New York University, New York, N.Y. (available through NTIS, Springfield, Virginia)

Franzen, H.R. 1986. "Management for Low- and intermediate-Level Wastes in Brazil." Paper presented at IAEA seminar Management Options for Low- and Intermediate-Level Wastes in Latin America, IAEA-SR-110, Rio de Janeiro, Brazil, October 13-17, 1986, International Atomic Energy Agency, Vienna.

Nuclear Fuel (NF). 12/29/86. "Brazil Denies Report of Reprocessing, Plutonium Production at IPEN," p. 9.

Nucleonics Week (NW). 11/13/86. 'Brazil's Furnas Will Tap NUS for Radwaste Disposal Services,' p. 3.

Vicente, R. 1986. 'Development and Design of a Cementation Process.' Paper presented at IAEA seminar Management Options for Low- and Intermediate-Level Wastes in Latin America, IAEA-SR-110, Rio de Janeiro, Brazil, October 13-17, 1986, International Atomic Energy Agency, Vienna. 
$-1987-$

Nuclear Engineering IIttemational (NEI). 3/87. "More Collaboration for Brazil and Argentina," p. 17. Nuclear Engineering International (NEI). 12/87. The World's Nuclear Fuel Cycle Facilities," p. 47. Nuclear Fuel (NF). 10/19/87. "Brazil's Parallel Program Publicized by Sarney's Centrifuge Announcement,' pp. 3-4.

Nucleonics Week (NW). 1/15/87. "Argentine-Brazilian Firms to Pool Nuclear Design Know How,' p. 11. Nucleonics Week (NW). 7/23/87. "Samey Visit to Pilcaniyeu Was Key to Reciprocal Inspections," p. 11.

Nucleonics Week (NW). 7/30/87. "Brazil's Nuclebras Wants to Sell Slightly Enriched U to Argentina," p. 1.

Nucleonics Week (NW). 8/27/87. 'Argentina and Brazil to Develop Waste Technology Jointly,' p. 6.

Nucleonics Week (NW). 9/10/87. "Brazil and Argentina Reach Agreements in Research, Other Areas," pp. 3-4.

Nucleonics Week (NW). 12/10/87. "Five Indictments Asked in Brazil's Fatal Cs-137 Incident," pp. 7-8.

-1988-

Nuclear Engineering International (NEI). 6/88. "Brazil Inaugurates Research Centre," p. 5.

Nuclear Engineering International (NEl). 12/88. "Major Changes for Brazilian Industry." p. 5.

Nuclear News (NN). 1/28/88. "Nuclear Waste Disposal Has Been Banned," p. 61.

Nuclear Waste News (NWN). 1/7/88. 'Debris from Brazilian Mishap Awaits Disposal,' p. 3.

Nucleonics Week (NW). 1/88. "Brazil Takes Final Steps in Nuclear Accord with China," p. 15

Nucleonics Week (NW). 4/14/88. "Sarney and Altonsin Inaugurate Brazilian Enrichment Facility," p. 6.

Nucleonics Week (NW). 9/8/88. "Brazil's Nuclear Reorganization Limits Dual Program Development," pp. 1-2.

$-1989$

Mezrahi, A., and A. Xavier. 1989. 'Management of the Radioactive Wastes Arising from the Accident in Goiania, Brazil," in Proceedings of the 1989 Joint Intemational Waste Management Conference on Low and Intermediate Lovel Radioactive Waste Management, Kyoto, Japan, October 22-28, 1989, vol. 1, p. 281.

Nuclear Engineering International (NEI). 2/89. 'South American FRG Deal Signed,' p. 5.

Nuclear Engineering Intemational (NEI). 3/89. "Brazil Anticipates 20 Percent Enrichment," p. 5. 
Nuclear Engineering International (NEl). 5/89. 'Nuclear Program to be Privatized,' p. 4.

Nuclear Engineering International (NEI). 6/89. "Brazil-Major Reorganization," p. 21.

Nuclear Engineering Intemational (NEl). 8/89. 'Uranium Production Restarts in Brazil,' p. 5.

Nuclear Engineering International (NEl). 9/89. "Brazil Plans 1992 Prototype," p. 3.

Nuclear Fuel (NF) 9/18/89. 'Brazil will Develop Domestic Fuel Cycle if its Nuclear Power Capacity Warrants,' p. 6.

Nuclear Waste News (NWN) 3/23/89, 'Brazil, Italian Casa Grande Group Sign Agreement for Goiania Waste Facility," p. 97.

NUKEM 5/89. 'Special Report--Brazill," p. 13.

Rzyski, B. M., and A. A. Suarez. 1989. "Characteristics of Waste Forms Improved by Using Admixtures," in Proceedings of the 1989 Joint International Waste Management Conference on Low and Intermediate Level Radioactive Waste Management, Kyoto, Japan, October 22-28, 1989, Vol. 1, p. 317.

$-1990-$

Leigh, I. W., and S. J. Mitchell. 1990. International Nuclear Fuel Cycle Fact Book. PNL-3594, Rev. 10, Pacific Northwest Laboratory, Richland, Washington.

Bonàlume, R. 1990. "Brazilian Atomic Bomb Now a Possibility." Nature, Vol. 345, p. 469.

International Atomic Energy Agency (IAEA). 1990. Operating Experience With Nuclear Power Stations in Member States in 1989. Vienna.

Nuclear Engineering International (NEI). 2/90. "World News--Brazil," p. 10.

Nuclear Engineering International (NEI). 4/90. "Datafile: Brazil," pp. 47-50.

Nuclear Fuel (NF). 10/29/90. "Policy Shitt to Full-Scope Safeguards Could Happen Soon, Goldemberg Says," p. 6.

NUKEM Market Report (NUKEM 4/90). "Nuclear Power Plant Capacity in the Western World," NUKEM $\mathrm{GmbH}$, Hanau, Federal Republic of Gemany, p. 26. 
CANADA 


\section{CANADA}

\section{CONTENTS}

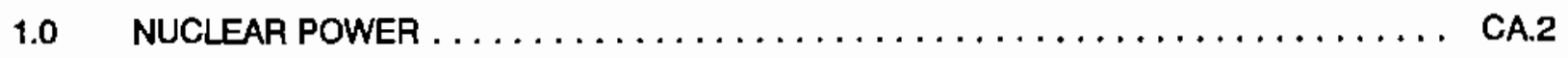

2.0 NUCLEAR FUEL CYCLE AND RADIOACTIVE WASTE MANAGEMENT

STRATEGY/POUCY $\ldots \ldots \ldots \ldots \ldots \ldots \ldots \ldots \ldots \ldots \ldots \ldots \ldots \ldots \ldots \ldots \ldots \ldots \ldots$

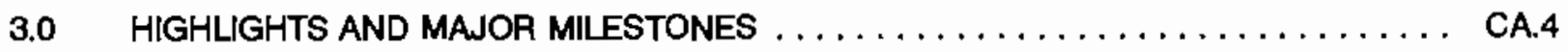

4.0 INSTITUTIONAL CONSIDERATIONS/ORGANIZATIONS $\ldots \ldots \ldots \ldots \ldots \ldots \ldots$ CA.5

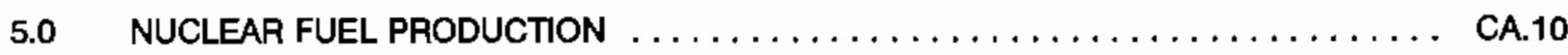

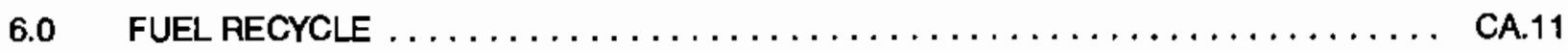

7.0 SPENT FUEL STORAGE AND TRANSPORT $\ldots \ldots \ldots \ldots \ldots \ldots \ldots \ldots \ldots \ldots \ldots \ldots \ldots \ldots \ldots \ldots$

8.0 WASTE CONDITONING, STORAGE AND TRANSPORT $\ldots \ldots \ldots \ldots \ldots \ldots \ldots$ CA.14

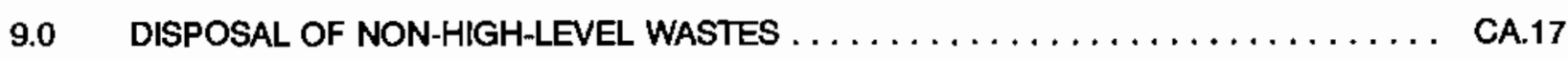

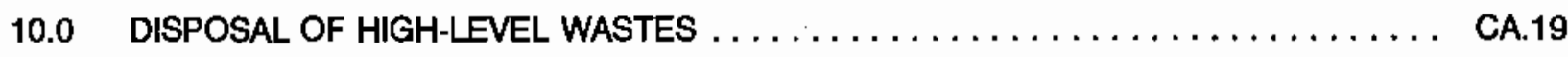

11.0 MANAGEMENT OF URANIUM MINE AND MILL WASTES $\ldots \ldots \ldots \ldots \ldots \ldots$ CA.30

12.0 DECOMMISSIONING AND ENVIRONMENTAL RESTORATION $\ldots \ldots \ldots \ldots \ldots \ldots$ CA.31

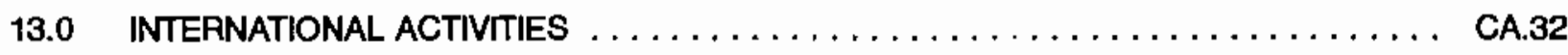

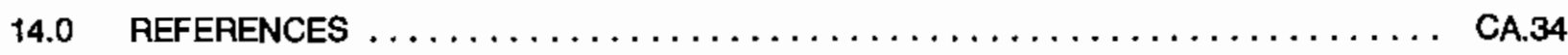




\subsection{NUCLEAR POWER}

1.1 REACTOR MIX (Leigh and Mitchell 1990)

PHWR (CANDU): 18 (1968-87)

$4(1990-93)$

\subsection{ELECTRIC POWEA PRODUCTION}

A Past and expected future electric power production is (Leigh and Mitchell 1990):

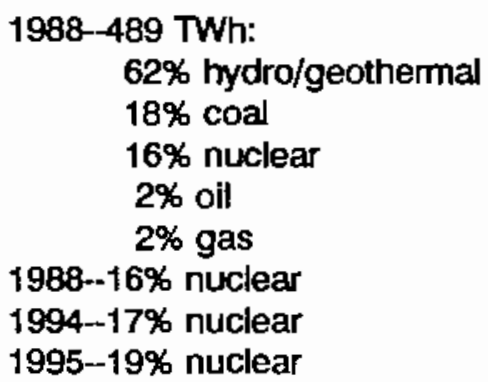

B. In 1989, Canadian nuclear plants generated 93.7 TWh, compared with 95.3 TWh in 1988 (NPJ 5-6/90); the projection for 1990 is 100 TWh (AECL 1989)

\subsection{NUCLEAR POWER CAPACITY PROJECTIONS}

A. Nuclear capacity:

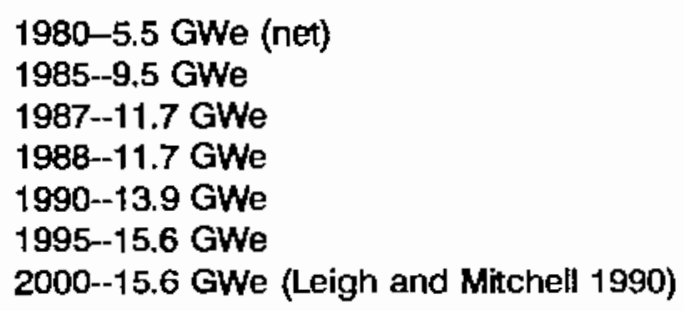

B. Ontario Hydro's "preferred choice" in its 25-year energy plan calls for ten additional 883-MWe CANDU generating units; the plan now goes through an environmental assessment committee and extensive public hearings before being voted on by the Ontario provincial government (NEI 2/90; NN 2/90)

\subsection{NUCLEAR ENERGY POLICY}

A. The reactor technology developed for domestic use and for export is the CANDU (CANada Deuterium Urranium) reactor system

B. The supply of electricity and construction of additional nuclear plants is the responsibility of the provincial public utilities; Ontario Hydro plans additional CANDU units (see Section 1.3) 


\subsection{NUCLEAR R\&D BUDGET}

A. Federal funding to the Atomic Energy Control Bureau (AECL) for R\&D, which had been cut from $\$ 200$ million/yr (Canadian) to $\$ 100$ million/yr (Canadian) in the 1985-1990. period, was reestablished at $\$ 224 \mathrm{million} / \mathrm{yr}$ (Canadian), indexed against inflation and guaranteed for 7 years (NW 4/6/90)

B. The Canadian government will make the Atomic Energy Control Board (AECB) self-sustaining by implementing a license fee schedule that will produce $\$ 27$ million (Canadian)/yr (NN 1/25/90)

\subsection{NUCLEAR FUEL CYCLE AND RADIOACTIVE WASTE MANAGEMENT STRATEGY/POLICY}

\subsection{OVERALL NUCLEAR FUEL CYCLE POLICY}

Canada's overall policy is to maintain high flexibility; maintain active mining, milling, fuel fabrication for independent national nuclear power program using CANDU reactors; and to export CANDU reactor and fuel cycle services (NEI 12/87)

\subsection{POLICY ON FRONT END OF THE NUCLEAR FUEL CYCLE}

A. Canada's policy is to market its extensive uranium resources and milling/conversion services in the world market; private Canadian companies produce and sell the uranium (see also Section 5)

B. Private Canadian companies produce HWR fuel pellets and fuel assemblies for the CANDU reactors

C. Canada stores spent fuel at reactor sites, while developing technology for land-based geological disposal; no decision on reprocessing has been made, and disposal technology will include options of disposing of both spent fuel and vitrified reprocessing waste

\subsection{POLICY ON THE BACK END OF THE NUCLEAR FUEL CYCLE}

A. Canada's policy is to not reprocess spent fuel; current estimates are that fuel reprocessing will not be economic with the once-through CANDU fuel cycle until there is a three-fold increase in uranium prices; this is not likely to occur for at least several decades (Dormuth 1989)

B. Policies on the management of $\amalg W$ are (Charlesworth and Howieson 1988):

1) $\amalg W$ will be managed such that human health and the environment will be protected now and in the future; social and environmental factors will be taken into account

2) The primary responsibility for management of $U W$, including disposal, rests with the producers of the wastes

3) The federal government has residual responsibility for managing $U W$ when no person or company can be held responsible for the wastes 
C. Canada stores spent fuel at reactor sites, while developing technology for land-based geological disposal; no decision on reprocessing has been made; disposal technology will include options for disposing of both spent fuel and vitrified reprocessing wastes

3.0 HIGHLIGHTS AND MAJOR MILESTONES (Rummery and Rosinger 1984; NEA 1986; AECL 1989)

1978 Started exploration for promising sites in Ontario for HLW disposal (NF $2 / 8 / 88$ )

1986 Commenced operation of the Underground Research Laboratory (URL) for spent fuel/HLW disposal studies at Whiteshell

1987 Commenced federal study of UW disposal plans

1988 Completed URL shaft construction to $420 \mathrm{~m}$ depth

1988 Designed, built, and licensed full-size cask for large-scale transport of spent fuel (Ontario Hydro) (Carter et. al. 1987)

1989 Appointed Environmental Assessment and Review Panel with responsibility for reviewing the geologic disposal plan (Leigh and Mitchell 1990)

1989 Completed geotechnical characterization at URL at $440 \mathrm{~m}$ depth

1990 Prepare report by Environmental Assessment and Review Panel on issue-identification phase of the geologic disposal concept (Leigh and Mitchell 1990)

1991 Issue Concept Assessment Documentation (CAD) for disposal of spent fuel/HLW for review by AECB (Atomic Energy Control Board), special review panel, and public (NF 2/8/88)

1991 Submit environmental impact statement on geological disposal concept (Leigh and Mitchell 1990)

1991 Evaluate Canadian disposal concept by the Environmental Assessment and Review Panel appointed by the federal government (Torgerson 1990a)

1991 Begin public hearings on spent fuel/HLW repository concept

1992 Open the first Intrusion Resistant Underground Structure (IRUS) at CRNL for LLW disposal (NN 4/90)

1993 Receive recommendations from review panel on acceptability of spent fuel/HLW repository concept

1993 Receive AECB statement on compliance of spent fuel/HLW repository concept with regulations

1993 Receive decision by governments of Canada and Ontario concerning the spent fuel waste disposal concept (NF 2/8/88)

2000 Complete evaluations in deep geologic URL 
$>2015$ Commission spent fuel/HLW repository

\subsection{INSTITUTIONAL CONSIDERATIONS/ORGANIZATIONS}

\subsection{LEGAL REQUIREMENTS (IEAL 1987)}

A. No stipulation law or land-use veto regulation exists in Canada that links deployment of nuclear power with the availability of a radioactive waste repository

B. The 1946 act gives the national government responsibility over nuclear affairs, with preemptive rights (Paige and Numark 1985)

C. In Canada, producers have primary responsibility for disposal of their wastes (Charlesworth and Howieson 1988)

D. The federal government accepts residual responsibility Yor cleanup and disposal of historic wastes' and for post-operational management of disposal sites

E. Manitoba Province passed a law that prohibits disposal of HLW in that province (NWN $8 / 6 / 87)$

\subsection{RADIATION PROTECTION PRINCIPLES}

A. Canada's dose limits are $50 \mathrm{mSv} / \mathrm{yr}(5 \mathrm{rem} / \mathrm{yr})$ for nuclear workers and $5 \mathrm{mSv} / \mathrm{yr}(0.5$ $\mathrm{rem} / \mathrm{yr}$ ) for the general public; these will not be changed even though the International Commission on Radiological Protection has called for a general reduction in dose limits (TS $3 / 9 / 90)$

B. Requirements for nuclear fuel disposal (per AECB document R-104, proposed in 1986, finalized in 1987) (NEA 1986; Wasywich et al. 1986; NEA 7/87):

1) General provisions are broadly applicable to disposal of $U W$ and mill tailings

2) Predicted risk shall not exceed $10^{-6}$ serious health effects per year

3) Period for demonstrating compliance using mathematical models need not exceed 10,000 years

4) The calculated individual risk is based on 0.0002 serious health effects per rem, and the probability of the exposure scenario with annual individual doses calculated using either 1) a deterministic pathway analysis or 2) mean individual doses per year calculated using probabilistic pathway analysis

5) Following closure of the HLW disposal vault, no individual should receive an annual dose greater than $0.05 \mathrm{mSv} / \mathrm{yr}$ or $5 \mathrm{mrem} / \mathrm{yr}$ (compared with $1 \mathrm{mSv} / \mathrm{yr}$ or $100 \mathrm{mrem} / \mathrm{yr}$ from natural sources); this criterion must be satisfied for 10,000 years (Torgerson 1990a) 


\subsection{LICENSING}

A. In Canada, the licensing of a $\amalg W$ disposal facility is a three-step sequential process (Chamney 1986)

1) Licensing is initiated by application for siting and construction to the AECB by the responsible waste generator; the AECB awards a license following an extensive review by AECB staff, outside experts, provincial and local government staff, and public reviews

2) An operating license is issued after 1) final information is provided on questions arising from the application, and 2) operating procedures and limits are developed

3) Prior to closure of an LLW disposal site, the operator must submit a final package, updating all information relative to closure, including the need for institutional controls

B. For high-level wastes the process by which the federal government and the Ontario provincial government will accept or reject the waste-management system is (TAC 1989):

1) A disposal concept assessment is performed by AECL, Ontario Hydro (the principal nuclear utility), and other organizations over the period 1981-1990; the result is a Concept Assessment Documentation (CAD), a set of nine documents submitted by AECL

2) The disposal concept-assessment submission must meet the regulatory requirements set out by the Atomic Energy Control Board (AECB)

a. Requirements applying to the concept include a radiological criterion for post-closure radiation exposure from a waste vault set at a level for individuals that is a small fraction of natural background radiation

b. The AECB has also issued a Regulatory Guide that describes the geological criteria of an acceptable site for $\mathrm{HLW}$

3) The AECL has examined plans for the CAD and concluded that the plans conform to the requirements for an EIS (the normal document for assessment of any proposed action)

4) In accordance with the federal Environmental Assessment and Review Process (EARP), an Environmental Assessment and Review Panel would be established under the Federal Environment Assessment Review Office (FEARO) to examine the $\mathrm{CAD}$ and to ensure an opportunity for full public discussion

a. No site selection will take place until the disposal concept has been deemed safe

b Such other issues as federal and provincial energy policies would also be excluded from review at this stage

5) The Panel would report its findings to the Minister of Environment and the Minister of Energy, Mines and Resources, who would make them public (also see Section 10.4) 
6) The federal and Ontario governments will accept, conditionally accept, or reject the disposal concept presented in the EIS

C. FEARO plans to issue final guidelines for its public environmental review of AECL's deep-rock spent fuel disposal concept by March 1991; on the basis of these guidelines, AECL will then prepare an EIS on its disposal concept (NF 9/17/90)

D. A seven-member Environmental Assessment and Review Panel was established in October 1989 to review plans for a permanent geologic repository; the panel will also look at Ontario Hydro's proposal to transport spent fuel to the repository (MEO 7/24/90)

E. AECL has agreed to provide up to $\$ 750,000$ (Canadian) to public participants in the federal review of Canada's spent nuclear fuel management and disposal concept the CAD and EIS); funding will be provided for public participation in both the socio-economic and technical areas (NWN 9/13/90)

\subsection{PUBLIC INVOLVEMENT}

A. Although Canadian regulations do not require public approval of nuclear issues, the responsible agencies have recognized the need for public support, and public reviews/hearings are held; this is particularly true on siting questions (Greber 1990)

B. Public opposition to the siting of new LLW disposal facilities has led to a community-oriented, cooperative siting process that provides a method for addressing social concerns (Charlesworth and Howieson 1988)

C. A national opinion survey in 1989 found that (Greber 1990):

1) There is a limited degree of public support for deep geological disposal of nuclear fuel waste; this support is based on belief that Canada has the technological capability to develop a permanent method to safely manage nuclear fuel wastes; there is a fair amount of trust and confidence in the agencies involved and in the review process by which the concept will be evaluated

2) The public desires more information related to 1) health and safety; 2) the nature, volume, and hazard of nuclear wastes; 3) the effectiveness of geological disposal; and 4) commitments to long-term environmental monitoring

\subsection{WASTE FUND}

A. Disposal R\&D is funded jointly by the federal government and Ontario Hydro

B. Nuclear power producers pay a kWh fee based on estimated costs to cover 1) spent fuel and waste management and 2) decommissioning

4.6 KEY AGENCIES AND FUEL CYCLE CENTERS (Leigh and Mitchell 1990)

A. AECB (Atomic Energy Control Bureau) regulates all stages of the nuclear fuel cycle

B. CAMECO (Canadian Mining and Energy Corporation) is responsible for uranium mining and refining (privatized from the former government corporation, Eldorado Nuclear Limited) 
C. AECL (Atomic Energy of Canada Limited) is the federal agency responsible for reactor design, isotope production, marketing, R\&D; $A E C L$ is responsible for research on immobilization and disposal of spent fuel and operates facilities for processing and storage of LWW and ILW (Torgerson 1990b)

D. CRNL (AECL/Chalk River Nuclear Laboratory) conducts R\&D on LW management

E. WNRE (AECLWhiteshell Nuclear Research Establishment) directs and coordinates the R\&D program on immobilization and safe disposal of nuclear fuel waste

F. EMR (Ministry of Energy, Mines, and Resources) is the federal government ministry to which $A E C B$ and $A E C L$ report

G. LRWMO (Low-Level Radioactive Waste Management Office) is the agent of the federal government for management of $\amalg W$

H. Ontario Hydro (a provincial public utility) operates 10,000 MWe of CANDU nuclear power plants, manages reactor wastes, and develops technology for intenim storage and transportation of spent fuel

I. Hydro-Quebec (a provincial public utility) operates the Gentilly-2 CANDU nuclear power station and manages reactor wastes

J. New Brunswick Electric Power Corporation (a provincial public utility) operates Lepreau CANDU nuclear generating station and manages reactor wastes

\subsection{PRINCIPAL RESEARCH, DEVELOPMENT AND DEMONSTRATION FACIUTIES/PROGRAMS (Leigh and Mitche!l 1990)}

A. CRNL has the following facilities:

1) A cemer for development of LLW and ILW treatment (incineration, compaction, ultrafittration/reverse osmosis, evaporation, ion exchange, pyrohydrolysis, and solidification in bitumen); HLLW solidification using in-can meiting

2) A project has been established to site, construct, and operate an Intrusion Resistant Underground Structure (IRUS) engineered disposal facility for LLW (Torgerson 1990b)

B. WNRE has the following facilities:

1) The URL (20 km from WNRE) for studies related to disposal in deep granite formations (started underground operations in 1986); it has a horizontal tunnel at $200 \mathrm{~m}$ depth in the Lac du Bonnet granite batholith; it started shaft extension to $465 \mathrm{~m}$ depth and horizontal tunnels at $\mathbf{4 4 0} \mathrm{m}$ depth in July 1987 (extension was completed in 1989); it will use licensed radioactive sources and tracers, but no radioactive wastes will be emplaced

2) The Hydrostatic Test Facility (HTF) to test the performance of waste container materials in underground disposal conditions; it includes a carbon-steel pressure-chamber cavity $1.5 \mathrm{~m}$ in diameter and $3 \mathrm{~m}$ tall; it started up in 1984 
3) The Immobilized Fuel Test Facility (IFTF) to test effects of water, heat and pressure on spent fuel and HLW forms; containers, buffer and rock in radiation fields; utilizes high-level radiation source in concrete canisters; tests started in 1984

4) A non-radioactive pilot plant (WIPE) for developing a HLLW conditioning process for CANDU-based thorium fuel cycle; $10 \mathrm{~kg} / \mathrm{hr}$ glass rate using rotospray calciner and joule-heated ceramic melter; started up in 1983

5) The Large Block Radionuclide Migration Facility (LBRMF)

6) The Borehole Instrumentation Test Facility (BतF)

7) A radioactive reprocessing pilot plant to develop CANDU - thorium fuel cycle technology and provide HLLW for waste studies; $0.3 \mathrm{~kg} / \mathrm{d}$ using Thorex process in mixer-settlers; it operated 1980-1985

8) The capital investments in WNAE and its URL are $\$ 121$ million (Canadian) and operating costs are nearly $\$ 40$ million/yr (NF 5/18/87)

C. ONTARIO HYDRO has the following facilities:

RWVR, pyrolysis incinerator; engineered storage for ILW; and tritium extraction plant from CANDU operations at the Darlington site (NEI 6/87)

D. AECL's Spent Fuel Storage Facilities Centre has contracted with the Korean Electric Power Corp. to provide engineering, technical services, tooling and equipment for a spent fuel dry storage facility at the Korean Wosong-1 nuclear power plant

(NWN 3/22/90b)

4.8 KEY PERSONNEL (Leigh and Mitchell 1990)
A. J. Epp, Minister, Energy, Mines, and Resources
B. P. Brown, Director, Radioactive Waste Management, EMR
C. S. R. Hatcher, Acting President and CEO, AECL
D. M. G. Wright, General Manager, AECLWNRE
E. S. McDowall, Manager, Waste Management, AECLMNRE
F. W. T. Hancox, V.P., Technology and Planning, AECL
G. D. F. Torgerson, V.P., Waste Management and Environmental Research, AECLWNRE
H. P. J. Harvey, General Manager, CANL
I. D. H. Charlesworth, Waste Management Technology, CRNL
J. W. D. Smythe, Fuel Cycle/Materials Regulations, AECB
K G. C. Jack, Waste Management, AECB 
L R. Pollock, UW Management, AECM

M. R. W. Morrison, Director General, Uranium/Nuclear Technology, EMR

N. R. Franklin, Chairman, Ontario Hydro

O. H. N. Isaac, Nuclear Materials Management, Ontario Hydro

\subsection{NUCLEAR FUEL PRODUCTION}

\subsection{URANIUM RESOURCES}

A. 210,000 MTU are reasonably assured; 200,000 MTU estimated additional uranium (NEA 1988); Canadian estimate at the end of 1986 was 567,000 MTU measured, indicated, and inferred (NN 11/87)

B. The Cigar Lake deposit is the world's richest uranium ore deposit at 4.7 to $14 \% \mathrm{U}_{3} \mathrm{O}_{8}$ (NF 5/18/87)

\subsection{URANIUM PRODUCTION}

A. Canadian $\mathrm{U}_{3} \mathrm{O}_{8}$ production in 1990 was $10,050 \mathrm{MT}$, about one-third of the total world production (NUKEM 3/90)

B. The uranium supply companies, Eldorado Nuclear and Saskatchewan Mining Development Corp., were merged in 1988 to create Cameco; the first phase of a planned privatization of Cameco has been deferred due to a weak uranium market (NF 9/17/90)

\subsection{URANIUM CONVERSION (NEI 12/87)}

A. The Blind River facility corverts yellowcake to $\mathrm{UO}_{3}$, with a capacity of $18,000 \mathrm{MTU} / \mathrm{yr}$

B. The Port Hope facility converts $\mathrm{UO}_{3}$ to $\mathrm{UF}_{6}$, with a capacity of $9,000 \mathrm{MTU} / \mathrm{yr}$; the Port Hope facility also converts $\mathrm{UO}_{3}$ to $\mathrm{UO}_{2}$, with a capacity of $2,800 \mathrm{MTU} / \mathrm{yr}$

5.4 FUEL FABRICATION (NEJ 12/87)

A. The Canada G-E Toronto facility produces Heavy Water Reactor (HWR) fuel pellets with a capacity of $1,050 \mathrm{MTU} / \mathrm{yr}$

B. The Canada G-E Peterborough facility produces HWR fuel assemblies with a capacity of $1,000 \mathrm{MTU} / \mathrm{yr}$

C. The Westinghouse Port Hope facility produces HWR fuel assemblies with a capacity of $900 \mathrm{MTU} / \mathrm{yr}$

5.5 HEAVY WATER PRODUCTION (NEI 6/87)

A. Ontario Hydro has a $\$ 30$ million (Canadian) tritium extraction plant at the Darlington site (for CANDU operations) 
B. The AECL is building a pilot plant at CRNL to demonstrate new tritium removal technology

\subsection{FUEL RECYCLE}

\subsection{FUEL REPROCESSING}

A. At present in Canada, there are no plans to reprocess spent fuel, but the final decision on reprocessing has not been made; current estimates are that fuel reprocessing will not be economic with the once-through CANDU fuel cycle until there is a three-fold increase in uranium prices; this is not likely to occur for at least several decades (Dormuth 1989)

B. Several fuel-recycle options are being studied in the Canflex development program; these include: low enrichment, recycle of uranium from PWR and CANDU fuel, recycle of both uranium and plutonium, and use of thorium (NN 6/89)

C. If fuel recycle were adopted in the future, it would involve separating the plutonium and probably uranium, and refabricating fuel from a mixture of the recovered plutonium and natural uranium or thorium; the composition and quantity of the waste stream from reprocessing has been calculated (Dormuth 1989)

\subsection{SPENT FUEL STORAGE AND TRANSPORT}

\subsection{SPENT FUEL ARISINGS}

A. The past and future expected spent fuel arisings in Canada are Wuschke et al. 1985; Numark et al. 1986; NF 1/25/88):

9,000 MTU through 1985
12,400 MTU through 1987
33,900 MTU through 2000
100,000 MTU through 2025
191,000 MTU through 2035 (Crosthwaite and Chadha 1989)
334,000 MTU through 2050 if no reprocessirig
270,000 MTU (equivalent of HLW) through 2050 with reprocessing

B. As of 1990 in Canada, all fuel was stored underwater in nine pools at the reactor sites; the combined capacity of these pools is about 32,000 MTU (Grande 1990)

\subsection{SPENT FUEL ASSEMBLY CHARACTERISTICS}

The spent fuel from CANDU reactors is naturad uranium as uranium dioxide pellets in tubes; about $20 \mathrm{~kg}$ uranium are in each assembly; the assembly length is up to $0.5 \mathrm{~m}$; burnup averages $7500 \mathrm{MWd} / \mathrm{MT}$ (Wuschke et al. 1985)

\subsection{SPENT FUEL STRATEGY}

A. Canada plans to store spent fuel initially in water pools at power stations; the required capacity is available until the early to mid 1990s; capacity will then be expanded as needed; it is considered safe to store spent fuel for at least 50 years (NEI 12/87)

B. Use retrievable storage pending decision on reprocessing and availability of repository 
C. Use expanded AR or centralized storage, either wet or dry; a vault and a concrete canister are under consideration

\subsection{WET STORAGE (Frost 1989)}

A. Ontario Hydro's fuel-storage pools are of two types: primary bays store and provide cooling for the freshly discharged fuel; auxiliary bays store fuel after its initial cooling in the primary bays; with on-power fueling, a typical 4-unit station discharges $40-50$ spent fuel bundles per full-power day

B. The integrity of spent fuel in storage is monitored; some of the fuel has been in wet storage since 1962; evidence from the monitoring program indicates there will be no significant change in the spent fuel integrity and retrievability for at least 50 years

C. Fuel bundles are stored horizontally in stainless-steel trays that are stacked to improve space utilization; there is no criticality problem because of the use of natural uranium fuel (Patterson 1986)

\subsection{DRY STORAGE (Patterson and Hoye 1986; Smith and Zarecki 1987)}

A. Four dry-storage systerns have been studied by Ontario Hydro and AECL in a joint program for developing concrete casks for storage, transportation and disposal; these are 1) convection vaults; 2) concrete casks; 3 ) concrete integrated casks (fo; storage, transportation and disposal; and 4) metal casks (Lisle and Wright 1986; NEI 12/87)

B. WNRE stores WR-1 fuel in cylindrical concrete "canisters" or casks (2.5 m diameter, $5.5 \mathrm{~m}$ high, with inner steel and metallic lead liners); the fuel is in six steel sealed "baskets" backfilled with helium; casks are loaded dry in a hot cell; the casks are licensed for the maximum thermal rating of $4.4 \mathrm{~kW}$, up to $6000 \mathrm{~kg}$ uranium (IAEA 1984; Smith and Zarecki 1987)

C. Gentily-1 fuel (3213 assemblies, 64 MTU) is stored in seven WNRE-type concrete casks since 1985 inside a building; each cask has eight sealed stainless-steel canisters with an air atmosphere; each silo is $2.6 \mathrm{~m}$ outside diameter and $6 \mathrm{~m}$ high, with the steel-lined cavity $0.78 \mathrm{~m}$ diameter and $4.6 \mathrm{~m}$ high, and holds 459 assemblies (9 MTU); each Gentilly concrete storage cask and its pad costs $\$ 64,000$ (Canadian); the transfer cask for loading costs $\$ 111,000$ (Canadian)

D. Douglas Point fuel (23,000 assemblies, $300 \mathrm{MTU})$ is stored in about 50 above-ground steel-lined concrete casks; each cask holds spent fuel in eight sealed stainless-steel canisters in an air atmosphere; casks are $6 \mathrm{~m}$ high and $2.5 \mathrm{~m}$ outside diameter (NWN $11 / 26 / 87 ; \mathrm{NN} 1 / 88$ )

E. A prototype Concrete integrated Container $(\mathrm{CIC})$ was built and tested for dry storage and transportaion of spent fuel; it is $8 \mathrm{ft}$ in diameter $\times 12 \mathrm{ft}$ high, weighs about 80 tons, and holds 384 CANDU fuel bundles containing 7.7 MTU (also see Section 7.6) (Grande 1990)

\subsection{TRANSPORT}

A. Small amounts of spent fuel have been shipped using three small casks; the largest is a French Pegase cask that holds 72 fuel bundles (1.6 MTU) (Carter et al. 1987) 
B. A transportation assessment document will be completed in 1991 on environmental effects of transporting Ontario Hydro's irradiated fuel to the future disposal site; the system must transport 180,000 fuel bundles/yr; the three disposal sites under consideration are located from 400 to $1900 \mathrm{~km}$ from the generating stations; transportation may be by road, rail, water, or a combination of these; any mode must meet the AECB/IAEA regulations for Type B(U) packages (Ribbans 1989)

1) Road transportation is the most developed; to ship 180,000 bundles/yr, it would operate 275 days/yr, 7 days/wk, 24 hr/day; travel would be on Class A roads

2) A rail transportation system would carry 10 casks on unit trains dedicated to spert fuel; each rail cask would carry up to 576 fuel bundles; the system would operate 275 days/yr

3) Water transportation of spent fuel on the Great Lakes is feasible and practical because all of Ontario Hydro's nuclear stations are on navigable water; water transportation does not impose arry additional cask requirements; conventional ship or tug/barge combinations are possible; a portion of the distance must be by rail or road, requiring intermodal transfer

4) A cask has been designed, licensed, and manufactured for road transportation (Ribbans 1988)

a. The cask is constructed of monolithic 304 stainless steel

b. The cask is licensed to carry 192 fuel bundles of 10-yr-cooled fuel

c. The cask weighs $2.97 \mathrm{MT}$ empty, $34.7 \mathrm{MT}$ loaded, and 59 MT loaded with trailer

d. The cask's computer-simulated behavior in accidents was verified by a series of drop tests (Gavin et al. 1990)

C. A Concrete Integrated Container (CIC) concept is being developed by Ontario Hydro; the same container would be used for both dry storage and transportation (after 6 years cooling) without any rehandling of spent fuel; the cortainers, fitted with an impactabsorbing overpack, would be licensable as type $\mathrm{B}(U)$ transportation packages

1) A prototype $\mathrm{ClC}$ was built and tested; it is $8 \mathrm{ft}$ in diameter $\times 12 \mathrm{ft}$ high, weighs about 80 tons, and holds 384 CANDU fuel bundles containing 7.7 MTU; analytical modeling and scale-model drop tests are being conducted to confirm that the $\mathrm{ClC}$ will survive the accidents postulated by the LAEA transport regulations (Grande 1990)

2) The containers will be loaded underwater in the storage bay; the concrete would be clad inside and out with steel to facilitate drying/decontamination (Tulk and Sumar 1989)

3) Tests have shown that wet loading is feasible; the container can be successfully sealed, drained, and dried; scale-model tests (2:1) have shown the container to be very robust (Tulk and Sumar 1989) 
4) A second full-scale CIC will be loaded with 6-yr-old spent fuel for long-term monitoring of temperature, radiation, and iission-gas concentrations; quarter- and half-scale drop and fire tests are planned (Tulk and Sumar 1989)

D. The radiological impact of spent fuel transportation was assessed for normal and accident conditions; the annual collective risk (product of collective dose and probability, summed over all scenarios) was conservatively estimated to be less than $10^{-6}$ to $10^{-5}$ person-Sv/yr (equal to $10^{-4}$ to $10^{-3}$ person-rem/yr) (Kempe and Grondin 1989)

\subsection{RESEARCH AND DEVELOPMENT (Dormuth 1989)}

A. Under a 1987 agreement beween the federal and provincial governments, Ontario Hydro is reponsible for R\&D on interim storage and transportation of spent fuel

B. R\&D activilies include:

1) Development of high-strength concretes for "concrete integrated casks" for storage/transport/disposal of irradiated fuel

2) Design, fabrication and testing (heat dissipation, drop tests, performance in fire) of half-scale models of prototype canisters

3) Behavior of intact and defected irradiated CANDU fuel bundles during storage in dry and moist air in canisters (Wasywich et al. 1986)

\subsection{PROGRAM/FACIUTIES COSTS}

A. As of 1988 cumulative estimated costs for Ontario Hydro's research on spent fuel storage and transportation were $\$ 40$ million (Canadian) (NF 2/8/88)

B. AECL has been spending $\$ 60$ million (Canadian)/yr on R\&D on waste management; total estimated costs for AECL and Ontario Hydro A\&D through 1991 average $\$ 25$ million/yr (Canadian)

C. Costs (lifetime capital and operating) per $\mathrm{kg}$ uranium stored are $\$ 29$ (Canadian) for WNRE casks, \$26 (Canadian) for gentilly casks, and about $\$ 18$ (Canadian) for Douglas Point casks (Smith and Zarecki 1987)

D. Each Gentilly concrete storage cask and its pad costs $\$ 64,000$ (Canadian); the transfer cask for loading costs $\$ 111,000$ (Canadian)

\subsection{WASTE CONDITIONING, STORAGE AND TRANSPORT}

\subsection{WASTE DEFINITIONS}

A. In Canada, low-level wastes are defined as all radioactive wastes except spent fuel and uranium mine tailings (Charlesworth and Howieson 1988)

B. Three LLW/LW categories, classified according to their hazardous lifetime, are used in Canada; the categories and appropriate disposal concepts are:

1) Low radionuclide concentrations with short half-lives (landfills may be appropriate) 
2) Wastes that remain hazardous for several hundred years (engineered facilities at shallow depth are considered)

3) Long-lived radionuclides, or intermediate-level wastes (deep geologic disposal facilities are considered) (Hancox et al. 1986)

\subsection{WASTE ARISINGS}

A. Canada's $\amalg W$ arisings are:

1) The total volume of current $\amalg W$ wastes, including contaminated soils, is about $1,200,000 \mathrm{~m}^{3}$; all are temporarily stored; in addition, there are also very large volumes of LLW from uranium mining and milling (see Section 11)

2) The projected LLW arisings in Canada for the period 1985-2025 are about 370,000 $\mathrm{m}^{3}$, including decommissioning wastes, assuming a compaction ratio of $4: 1$ for the compactable solid wastes (Cameron 1987)

3) The Canadian nuclear industry and radioisotope users produce about $13,000 \mathrm{~m}^{3}$ of low-level reactor waste per year (Charlesworth 1989); an additional $5,000 \mathrm{~m}^{3}$ of uranium refining and conversion wastes are produced each year

B. HLW (spent fuel) is produced at the rate of $1800 \mathrm{MTU} / \mathrm{yr}$; about $14,000 \mathrm{MTU}$ are currently being stored at reactor sites (Torgerson 1990a)

\subsection{HLW IMMOBIUZATION}

A. Under a 1987 agreement, AECL is reponsible for research on immobilization and disposal (Dormuth 1989)

B. Past development of the vitrification process includes: hot-cell and engineering-scaie tests; design of an industrial-scale facility; evaluation of glass and mineral waste forms; evaluation of waste forms, butfer materials, container materials and host rock under repository conditions (at WNRE); vitrification using in-can melting at CRNL (Wikjord 1984; Sridhar 1984, 1985); as of 1988, these programs were complete

\subsection{LLW/LW CONDITIONING}

A. The Bruce Nuclear Power Development site processes and stores all the LLW/LW from Ontario Hydro reactors (Ontario Hydro operates 20 of Canada's 22 nuclear power plamts); waste production and management practices are (Krasznai et al. 1990):

1) Treatment of solid wastes depends on content and radioactivity; solid wastes with contact dose rates $<60 \mathrm{mR} / \mathrm{h}$ that do not contain large quantities of halogenated material are incinerated; a low-force compactor/baler is used for solid wastes that cannot be combusted; the remaining wastes are stored

2) Liquids (mostly hydraulic and lubricating oils from fueling machines) are currently stored pending immobilization

3) Tritium-contaminated heavy water is treated at the tritium extraction plant; solids contaminated with low levels of tritium will be processed like other low-level wastes; highly tritiated wastes are packaged to retain the tritium 
B. The CRNL, WNRE, and CAMECO's Port Hope sites operate collection and storage facilities for their $\amalg W$ (Torgerson 1990a)

C. Ontario Hydro's $2.5-\mathrm{kg} / \mathrm{yr}$ tritium extraction plant (to remove tritium from heavy water used in the CANDU reactors) has restarted after a two-year shutdown for repairs (NW $10 / 18 / 90)$

1) The heavy water is first removed by vapor-phase catalytic exchange, followed by cryogenic distillation (Sood and Li 1987)

2) To date (October 1990), about a kilogram of tritium has been extracted from heavy-water coolant to reduce occupational exposure at Ontario Hydro's power reactors

3) About $350 \mathrm{~kg}$ of heavy water are processed per hour; tritium of $98-99 \%$ purity is recovered and immobilized by reaction with titanium to form titanium tritide; $600 \mathrm{~g}$ of tritium immobilized in September - October 1990 occupy two containers, each the size of a conventional fire extinguisher

4) Ontario Hydro is looking for markets for the tritium; the estimated value is about $\$ 30$ million (Canadian)/kg

\subsection{UW/LW STORAGE}

Retrievable storage of all LLW and ILW is carried out at seven collection centers (major reactor sites, CRNL and WNRE) (Lakey 1985; Cameron et al. 1986; Hancox et al. 1986)

A. Containers of $\amalg W$ typically are stacked in covered buildings; liquid $\amalg W$ is typically stored in tanks

B. Reactor sites used tile- and concrete-lined caissons about $30 \mathrm{in}$. in diameter and $12 \mathrm{ft}$ deep for ILW storage (Armstrong 1987)

C. Reactor sites use concrete and steel-lined caissons for ILW storage; two sizes are used: 24-in. inside diam. $\times 25 \mathrm{ft}$ long, and 68-in. inside diam. $\times 25 \mathrm{ft}$ long (Amstrong 1987)

D. Some reactor sites use concrete "quadricells," which are large concrete boxes separated into four compartments

E. LLW and ILW production in Canada, before processing, is about $11,000 \mathrm{~m}^{3} / \mathrm{yr}$; it comes from nuclear generating stations, universities, hospitals, R\&D institutions, and the nuclear-tuel industry (Torgerson 1990b)

F. Centralized $\amalg W / L W$ processing and storage facilities are operated at the following sites:

1) The Bruce Nuclear Power Development site processes and stores all the solid and liquid LLW/LW from Ontario Hydro reactors; storage methods are shallow, in-ground reinforced-concrete trenches, vertical concrete tile holes backfilled with concrete, above-ground concrete 'quadricells', and low-level waste storage buildings (Torgerson 1990b; Krasznai et al. 1990) 
2) The AECL Chalk River Nuclear Laboratories operates facilities for processing and storage similar to those at the Bruce site; before waste is sent to the IRUS for disposal, it will be characterized and processed at the Chalk River Waste Treatment Center (Torgerson 1990b)

\subsection{TRANSPORT OF WASTES}

In Canada, $\amalg W$ is transported mainly by truck from sources to the central collection locations; transportation packages are categorized according to the IAEA transportation regulations and as licensed for use by the AECB (Carter 1982)

\subsection{RESEARCH AND DEVELOPMENT}

A. The LLW/LW waste treatment R\&D is centered at CRNL for development and testing of a wide variety of treatment processes; an incinerator is used for combustibles and a compactor/baler for solids; ultrafiltration and reverse osmosis facilities for liquid LLW/LW wastes was commissioned in 1987; ash and concentrates are bituminized (Devgun and Charlesworth 1987)

B. Exploratory experiments indicate that silicon carbide is a potential waste form for fixing carbon-14 in LLW (Torok et al. 1990)

1) Molten silica is reacted with $\mathrm{CO}_{2}$ that has been stripped from spent ion-exchange resins containing carbon-14; $43 \%$ of the silicon was converted to silicon carbide with carbon-14, which is expected to be a very stable waste form

2) Additional work is needed to access the feasibility of this concept for treatment/ disposal of wastes containing carbon-14; this includes improvement in reaction rate, increase in carbon content of the waste form, reduction in reaction temperature, waste-form stability, and leach properties

\subsection{DISPOSAL OF NON-HIGH-LEVEL. WASTES}

\subsection{STRATEGY}

A. The primary responsibility for management of LLW in Canada, including disposal, rests with the producers of the wastes (also see Section 2.3) (Charlesworth and Howieson 1988)

B. LLW will be stored at the sites of the three major LLW producers until a permanent disposal method has been developed; a development and demonstration program on permanent disposal will be conducted

C. UW will be sorted into broad categories based on the duration of their hazard; each category will be matched to an appropriate disposal technology (Hardy et al. 1988)

D. The small quantity of long-lived low-level reactor wastes will continue to be managed by interim storage; disposal in a rock cavity is preferred, but development of such a repository will be postponed until an economic scale of operation is needed (Charlesworth 1989) 
E. A separate disposal program is being developed to handle the large existing inventory of LLW from uranium refinery operations

\subsection{WASTE DISPOSAL. CRITERIA}

To be acceptable under Canadian regulations, a $\amalg W$ disposal system must ensure that the serious health risk to individuals from escape to the environment and from inadvertent intrusion is less than $10^{-6}$ per year (Charlesworth 1989)

9.3 LLW DISPOSAL (Charlesworth 1989)

A. There are no permanent LLW disposal sites in Canada; wastes are being stored by the major waste generators; the use of non-engineered, shallow-land burial is being phased out

B. There is a large existing inventory of about $1,200,000 \mathrm{~m}^{3}$ of LLW stored at several locations, most coming from uranium refinery operations; a separate disposal program is being developed specifically for these wastes (see Section 11)

C. An Intrusion Resistant Underground Structure (IRUS) is being developed for LLW disposal (see Section 9.4)

D. Disposal of short-half-life wastes is expected to be available in 1992; disposal of longer-lived wastes is expected about the year 2000 (Hoye and Arseneault 1989)

\subsection{LLW/ILW DISPOSAL, R\&D}

A. The developmem/demonstration program is designed to deal with three categories of LLW according to the radiological decay properties of the wastes (Charlesworth 1989)

1) Wastes containing radionuclides with short halt-lives: radiopharmaceuticals comaining iodine-125, activated corrosion products such as zinc-65 and cobalt-60, and tritium; for these wastes the residual hazard is small after 150 years; disposal of these wastes is expected to be available in 1992

2) Wastes comaining fission products and other isotopes that must be isolated for up to 500 years

3) Long-lived radionuclides such as uranium, thorium, and carbon-14

B. A disposal concept called Improved Sand Trench (IST) is being developed by the Canadians to contain LW with a hazardous lifetime of less than 150 years (Charlesworth 1989)

1) The concept uses a water-shedding membrane cap supported on a panel structure of lean concrete

2) Infiltrating water is intercepted by the cap and drains laterally to channels at the boundaries of each panel

3) A free-flowing unconfined aquifer in a sand layer well below the waste dilutes any escaping nonreactive radionuclides, but provides a reasonable retardation for most other nuclides 
4) A prototype IST at CRNL is planned to be available in 1992

C. An Intrusion-Resistant Underground Structure (IRUS) is being developed at Chalk River Nuclear Laboratories; it relies on the durability of concrete for a minimum of 500 years of service life; the IRUS will consist of (Torgerson 1990b):

1) Three reinforced concrete vaults, each $30 \mathrm{~m}$ long, $20 \mathrm{~m}$ wide, and $9 \mathrm{~m}$ deep; the capacity of one vault will be $2,000 \mathrm{~m}^{3}$ of packaged waste in the form of compacted bales, 200-liter steel drums, or boxes of unprocessed wastes; spaces between packages will be filled with sand; the vault floor will be a compacted layer of clay and sand to retard radionuclide migration; startup is planned in 1992 (NN 4/90)

2) While operating, the vaults will be covered by an unheated, weather-resistant metal-frame building equipped with an overhead crane

3) When filled, the vault will be covered by a concrete cap and $1.5 \mathrm{~m}$ of sand and soil; vegetation will prevent erosion; the crane, building, and other equipment will then be moved to another IRUS unit

D. The four design requirements applied to the IRUS concept are: minimize entry of water into the vault; avoid the "bathtub" effect; discourage inadvertant intrusion; and restrict loss of radionuclides from the vault (Hardy et al. 1988)

E. A program to design a durable concrete for the IRUS repository is focused on (Philipose 1988):

1) Identification of major concrete degradation agents

2) Assessment of rate of diffusion of corrosive ions

3) Determination of the rate of advancement of the corrosion front into the concrete

4) Use of accelerated test methods and extrapolation procedures to predict long-term durability

F. A methodology to assess the durability of a variely of concretes subjected to different exposure conditions has been developed to (Philipose et al. 1990a):

1. Design a concrete formulation for a service life of 500 years in a repository site environment

2. Determine the durability of concrete systems under appropriate exposure conditions and predict the life of concrete types

10.0 DISPOSAL OF HIGH-LEVEL WASTES (NEA 1986; Hancox 1986; Torgerson 1990a)

10.1 SPECIFICATIONS AND CRITERIA (Dunford 1985; AECB 1985, 1987a, 1987b; NEA 1986; Wagstaff 1986)

A. For pre-closure: contingency measures for retrieval during the pre-closure period are required 
B. For post-closure:

1) The probability must be small that radiation doses to the public attributable to the repository will exceed a small fraction of natural background radiation doses; proposed specific regulations are (NEA 1986):

a. The predicted risk to individuals should not exceed $10^{-6}$ serious health effects/yr (using $2 \times 10^{-4}$ health effects/rem)

b. The period for demonstrating compliance using mathematical models need not exceed 10,000 years

2) Vauh design shall be such that maintenance or intervention by future generations shall not be required; however, this may be required to gain public acceptance

C. Public-interest groups in Canada believe post-closure monitoring is necessary, but proof of long-term safety of the repository cannot be based on long-term monitoring

D. Quality Assurance is required by Canadian regulations governing nuclear fuel waste management (Dormuth et al. 1989)

\subsection{REPOSITORY DEPLOYMENT STRATEGY}

A. Canada began investigating deep geologic disposal in 1978

B. Concept assessment and generic R\&D on spent fuel disposal were conducted in 1981-1991; the concept was submitted for public and regulatory review in 1988; provincial and federal response on acceptability will be obtained in 1993 (NEl 12/87); the overall objectives of the program are (NEA 11/87):

1) Assess environmental and safety aspects of deep underground disposal of immobilized spent fuel in plutonic rock

2) Develop technology for storage, transportation, immobilization and disposal; provide data for concept assessment and demonstrate that practical technology is available

3) Establish requirements, equipment and procedures for site characterization and selection

4) Develop basis for public support through review and interactions

C. After the concept is accepted, site selection and construction of demonstration facilities may be considered

D. Public acceptance of HLW disposal may be contingent on providing information to the public on safety and on physically demonstrating the safe disposal of nuclear fuel waste (see Section 4.4) (Greber 1990)

E. S. R. Hatcher, acting president and CEO of $\mathrm{AECL}$, stated that under the right set of circumstances Canada might accept commercial spent fuel for disposal from the U.S. (NN 1/90) 


\subsection{SITE SELECTION AND CHARACTERIZATION}

A. Site selection

1) Priority col isideration is given to the Canadian shield in Ontario Province, where $\sim 1400$ plutons were identified; three areas in the Canadian shield were extensively characterized as of early 1988 (NEI 12/87)

2) The final site selection will be deferred until the concept-assessment report is completed and acted upon by the government

3) Manitoba Province passed a law prohibiting disposal of HLW in the province (NWN $8 / 6 / 87)$

B. Site characterization

1) Characterization of potential repository sites awaits government approval of the disposal concept; technology for site characterization is being developed and tested at field research areas

2) Factors considered important for site characterization include: tectonic and structural setting; major lithologies and contacts; properties and history of sealed fracture, fluid-filled fracture, and rock alteration; chemistry ano mobility of fluids; fluid pressure field; rock stress and thermal fields; nature of local topography; nature and distribution of soils; local meteorology; surface-water hydrology; and terestrial and aquatic biology (Dormuth 1989)

10.4 REFERENCE HLW/SPENT FUEL DISPOSAL CONCEPT (Wuschke et al. 1985; Baumgartner and Simmons 1987; Dormuth and Nuttall 1987)

A. The reference waste is CANDU spent fuel bundles in canisters; concepts for immobilizing reprocessing wastes have also been studied, including sodium alumino-silicate glasses and glass-ceramics

B. Waste-package concept (Truss 1984; Crosthwaite 1985, 1989; Hancox 1986; Teper and Reid 1989)

1) The reference concept for spent fuel is a thin-walled container; a low-carbon steel basket assembly (capacity 72 intact CANDU assemblies, or about $1400 \mathrm{~kg}$ uranium) holds the fuel bundles inside a cylindrical titanium canister; the canister is $0.63 \mathrm{~m}$ diam. $\times 2.3 \mathrm{~m}$ long; the canister is filled with granular material (glass or sand) to provide structural support for the canister walls

2) Alternative designs for the spent fuet package are (or have been):

a. The same as the reference concept container but with the empty space filled with metallic lead to form a structural matrix

b. An iron-based, stressed-shell container, a thick-walled steel cask with titanium-shell overpack (Teper 1986)

c. Copper and Hastelloy are also being considered as canister material 
d. A steel-lined integrated concrete cask (for storage, transportation and disposal) also is being developed (Lisle and Wright 1986)

3) HLW from fuel recycle would be borosilicate glass; ceramics and other glasses have been studied as the waste form

C. Reference repository concept

1) A repository in mined galleries in plutonic (crystalline) rock, at a depth of $500-1000 \mathrm{~m}$; potential alternatives are salt or sedimentary rocks (including clays or shales)

2) Handling and sealing of spent fuel would be at the repository (Wuschke et al. 1985; Nathwani 1986)

a. Bundles would be loaded into canisters in a facility at the disposal site

b. Containers are to be placed vertically in boreholes in the floor of repository rooms and surrounded by compacted buffer material $0.25 \mathrm{~m}$ thick; containers are to be spaced to limit the container skin temperature to $<100^{\circ} \mathrm{C}$

c. An alternative is to place canisters vertically on a 1-m-thick bed of buffer/ packing material in 7.5-m-wide tunnels; canisters would be spaced on 1.5-m centers; 300 canisters would be placed in each of 52 rooms for each of 18 panels; as individual canisters are emplaced, canisters would be covered with crushed buffer/packing material; later, the top of the room would be backtilled using a sand mixture, crushed rock, and clay

d. The completed underground facility would be $3600 \mathrm{~m}$ long $\times 1700 \mathrm{~m}$ wide, and would accommodate $18,000,000$ assemblies containing about $334,000 \mathrm{MTU}$; a 1000-m exclusion zone to the site boundary would be included

e. The reference buffer/packing material around the waste container is $50 \%-50 \%$ sodium bentonite/quartz (Gray and Cheung 1985; Wuschke 1985; Johnson et al. 1987)

f. The reference backfill material for the tunnels would be $20-30 \%$ clay, $75-80 \%$ filler (e.g., sand and crushed rock)

g. The borehole sealing materials would be cement-based grouts, admixed with bentonite, silica or fly ash

3) Handling and sealing of solidified HLW at the repository would include (Wuschke 1985):

a. Waste containers placed in boreholes in the floor of repository tunnels; one container, packed in buffer/packing material, would be placed in each borehole

b. Borehole sealing materials would be cement-based grouts, admixed with bentonite, silica, or fly ash 
c. The gallery would be backfilled with the same material as is used for spent fuel

d. The complete underground facility would be $3600 \mathrm{~m}$ long $\times 900 \mathrm{~m}$ wide (plus a 1000-m exclusion zone around the tacility), and would accommodate $\mathrm{HLW}$ from about $13,000,000$ assemblies containing about $270,000 \mathrm{MTU}$

D. An atternative to the reference concept is disposal beneath a thick sedimentary blanket in crystalline rock (Heystee and Freire-Canosa 1988)

1) This concept would take advantage of the superior strength of crystalline rocks and the unique hydrogeologic and geomechanical properties of a sedimentary sequence

2) Preliminary investigations have been conducted in the Great Lakes and Hudson Bay lowlands of Ontario

3) The concept appears viable and further work is currently proposed

E. An independent Technical Advisory Committee (TAC) was appointed in 1979 to advise AECL on the Nuclear Fuel Waste Management Program; its purpose was to (Shemilt and Sheng 1989):

1) Advise the AECL on content of proposed research projects

2) Review scientific methods used

3) Review program results and recommend specific areas of needed work

4) Report results of the TAC activities in publicly available documents

F. The schedule for completion of a spent tuel repository is as follows (NUKEM 2/90):

1989 Environmental Assessment Review Panel formed and terms of reference established; panel holds intemational meetings to identify and rank the issues for inclusion in review guidelines

1989/1990 Panel issues guidelines for preparation of the Concept Assessment Documentation (CAD)

1991 AECL submits CAD for formal review

1992 Interested federal and provincial government departments and the public submit comments

1992/1993 Panel organizes public hearings on the disposal concept; AECL and the public testity at these hearings

1994 Panel submits report to the Minister of Energy, Mines and Resources and to the Minister of Environment; government issues statement on acceptabilitity of the concept 


\subsection{WASTE PACKAGE RED}

A. Under a 1987 agreement between the federal govemment of Canada and the provincial goverment of Ontario, AECL is reponsible for research on immobilization and disposal (Dormuth 1989)

B. Fuel-container research has focused on titanium alloys and copper, which are particularty resistant to the chloride-rich groundwaters found deep in the Canadian Shield (Torgerson 1990a,b)

1) An extremely low corrosion rate of $<0.001 \mu \mathrm{m} / \mathrm{yr}$ was found for titanium under disposal conditions

2) For copper, only uniform corrosion is expected in chloride solutions in the presence of bentonite; the corrosion rate is limited by the rate that dissolved metal is transported away from the corroding surface

C. Fuel-behavior tests have shown there are three principal mechanisms for release of radionuclides from CANDU fuel; these are (Torgerson 1990a,b):

1) Rapid release of about $2 \%$ of the cesium and iodine when the fuel sheath fails

2) Slow release of radionuclides, particularly iodine and cesium, by dissoiution at the grain boundaries

3) Extremely slow release of the remaining fission products and actinides trapped within the $\mathrm{UO}_{2}$ grains

D. Sodium aluminosilicate glasses are superior to borosilicate glasses for calcined reprocessing wastes (Rosinger and Hancox 1988)

1) Leach rates are low in saline groundwaters characteristic of the Canadian Precambrian Shield

2) Glass ceramics, based on the natural mineral sphene, give further improvements in leach resistance

E. Two container concepts are being developed for disposal of spent fuel; based on tests conducted to date, both provide a satistactory container (Crosthwaite and Chadha 1989; Teper and Reid 1989)

1) The design selected for a reference engineering study is a thin-walled titanium container holding 19 steel baskets; each basket can contain up to 72 fuel bundles in 4 levels of 18; the outer shell is supported by a granular material such as glass beads packed in the voids;

2) An iron-based stressed-shell container is aiso being tested; a thick steel wall provides structural support; it is overpacked with a titanium shell for corrosion protection

\subsection{GEOSCIENCES RED}

A. Geosciences R\&D has three major goals (Torgerson 1990a): 
1) Develop and demonstrate the technology to site, design, build and operate a disposal facility in plutonic rock that will satisfy regulatory safety criteria

2) Develop and demonstrate a methodology to evaluate the performance of a disposal system against the safety criteria

3) Show that suitable sites in plutonic rock are likely to exist that, when combined with a suitably designed facility, would meet the safety criteria

B. R\&D on sealing and backfilling materials has shown (Torgerson 1990a):

1) Radionuclide movement in compacted bentonite - sand mixtures is limited by diffusion; layer thicknesses of only $25 \mathrm{~cm}$ can delay movement of dissolved and suspended radionuclides for thousands of years

2) Bentonite clay is expected to remain stable for long periods of time under the geochemical conditions in the Canadian Shield

3) Natural bentonite deposits in southern Saskatchewan have nuaintained an acceptably high swelling potential and low permeability millions of years after deposition

C. Geology and geophysics (Brown and Ray 1985; Dormuth and Whitaker 1985; Everitt and Brown 1985):

1) Geological, geophysical and geochemical investigations have been carried out at the surface and in cored boreholes at field research areas (granitic and gabbroic plutons and gneisses)

2) Subsurface geologic data were collected during URL construction

D. Geohydrology (Pearson 1984; Davison 1985; Hancox 1986):

1) Hydrogeologic testing and long-term hydrogeologic monitoring were carried out at field research areas using multiple-interval casing systems

2) Open-borehole hydrogeologic testing has been carried out at field research areas

3) A tracer-testing program has been performed at field research areas

4) A hydrogeologic testing program at the URL was carried out before and after excavation

5) A regional flow-system study was performed to depths of $1000 \mathrm{~m}$ at the Whiteshell research area

6) Development of a mathematical model of groundwater flow was performed at the URL, with extensive validation using experimental data

E. Studies of rock mechanics have been performed at WNRE, EMR, and Ontario Hydro to (Simmons 1984; Lang and Thompson 1985; Hancox 1986):

1) Develop and test techniques and equipment for assessing plutonic rock properties 
2) Understand and measure changes in plutonic rock caused by excavation, heat from wastes, and by operation of a repository

3) Develop computer codes simulating response of rock to mechanical and thermal stresses

F. Geochemistry studies of groundwater-rock and waste-rock interactions include the following: thermodynamics; fission product and actinide chemistry; sorption effects; radjonuclide transport in buffer materials; radjonuclide transport in natural fractures; interactions of groundwater with minerals; and colloid phenomena Nandergraaf 1984; 1985; Vikis et al. 1985; NEA 1986)

G. A model has been developed of radionuclide solubility under geochemical conditions in a spent fuel repository (NWN 3/22/90a)

1) The model has been incorporated into the Systems Variability Analysis Code (SWAC) (see Section 10.8)

2) Major radionuclides included are $\mathrm{U}, \mathrm{Np}, \mathrm{Pu}, \mathrm{Th}$, and $\mathrm{Tc}$

H. Natural analogs are being used; the stability of uranium oxide in groundwater has been confirmed by studjes at the Cigar Lake uranium deposit; grains of $\mathrm{UO}_{2}$ with local concentrations up to $60 \%$ have remained stable since the ore body was formed about 1.3 billion years ago (Dormuth 1989)

10.7 FIELD TESTS (Rummery and Rosinger 1984; TAC 1985; Hancox 1986; NEA 11/87)

A. The Underground Research Laboratory (URL) was constructed in a previously undisturbed granite pluton near the WNRE

1) The project schedule is:
a. Site evaluation and monitoring, $1980-2000$
b. Facilities development and characterization, 1982-1989
c. Operating-phase experiments, 1989-2000

2) The lease for the URL land calls for return of land to Ontario Province by year 2000

3) Manitoba provincial law prohibits permanent disposal of radioactive wastes in the URL (NWN 8/6/87)

B. The overall objectives of URL studies are to (Torgerson 1990b):

1) Provide realistic environment and boundary conditions for understanding integrated processes

2) Examine scaling effects

3) Conduct long-term experiments on a scale that is impracticable in the laboratory 
4) Provide a database for model development and validation

C. Principle design features of the URL are (Torgerson 1990b):

1) A 443-m shaft with shaft stations at $130 \mathrm{~m}, 300 \mathrm{~m}$, and $420 \mathrm{~m}$

2) A working level at $240 \mathrm{~m}$ with about $330 \mathrm{~m}$ of tunnels

3) U.S.-approved quality assurance implemented during the extension of the shaft to the 443 m depth (Baker 1989)

D. The following major experiments are planned for the URL (Torgerson 1990a, b):

1) Solute transport in highly and moderately fractured rock

2) Engineering tests on the buffer/container system

3) Grouting

4) Shaft sealing

5) Multicomponent test in a back-filled room

6) Impact of excavation on surrounding rock

7) Vault characterization and monitoring

8) Biosphere studies

E. The methodology developed to characterize plutonic rock masses is being applied to tne Whiteshell Research Area on the Lac du Bonnet Batholith, a large granite pluton located in southeastern Manitoba (Torgerson 1990a)

\subsection{PERFORMANCE ASSESSMENT}

A. Natural analogs studies at Cigar Lake in northern Saskatchewan are in unweathered sandstone-hosted uranium deposits; a study of trace-element mobilities in a system similar to that expected in a repository is being carried out (Cramer 1986)

B. An integrated approach to modeling system behavior has been adopted (Dormuth 1989; Shemilt and Sheng 1989)

1) A systems approach leads to assessment of impact in terms of overall risk (in contrast to performance criteria for individual components)

2) The uncertainty and variability of the system is modeled, as opposed to calculating 'worst credible' or 'worst reasonable' cases

3) A computer program, SWAC, has been developed for long-term assessment of the disposal system 
a. Probability distributions for parameter values are input; a distribution of estimates of consequence is calculated that reflects the distributions of the parameter values

b. Calculations are made for three subsystems: the vault, the geosphere, and the biosphere

C. The in situ heat and moisture transport of a bentonite-sand buffer has been modeled for a fuel disposal site (Radhakrishna and Lau 1989)

1) Calculations show that the thermal vapor diffusivity has the most significant effect on thermal drying

2) Laboratory experiments are in progress to define the moisture diffusivity parameters

3) A full-scale buffer/container experiment is planned in the URL to assess the effects of scale and in situ boundary conditions on buffer performance

D. The effects of cracks in the buffer (due to cementation, moisture depletion, etc.) on mass transport through a clay barrier have been calculated (Garisto and Garisto 1989)

1) For unfractured rock, the flux of dissolved uranium is similar to the flux through an uncracked butfer

2) For fractured rock, the flux of uranium through the cracked buffer system is greater than through an uncracked buffer

E. Electrochemical techniques were used to study $\mathrm{UO}_{2}$ fuel-dissolution mechanisms and container corrosion processes (Shoesmith et al. 1988)

1) For chemically reducing conditions, a solubility-limited dissolution model for $\mathrm{UO}_{2}$ is appropriate; for more oxidizing conditions, the specific dissolution process must be considered and a kinetic model developed

2) The most likely failure mechanism for titanium is crevice corrosion; it is dependent on the grade of titanium used

3) Copper corrosion appears to be controlled by transport of dissolved copper species in the surrounding buffer material

F. The Vault Model (Garisto and LeNeveu 1989b) has been used to assess the masstransport performance of engineered barriers following failure of a spent fuel container; analytical estimates generally support the Vault Model calculations (Garisto and Garisto 1989)

G. A team of Canadian and Japanese scientists has begun a study of 25 vitrified glass blocks buried 30 years ago near Chalk River (NWN 9/6/90)

t) The nepheline-syente glass blocks contain a total of about $5.5 \times 10^{11} \mathrm{~Bq}(15 \mathrm{Ci})$ of mixed fission products

2) The leaching rate (primarily strontium-90) will be measured 
3) The chemical reactions among radionuclides, groundwater, and solids within the underground flow system will be measured

4) The experiment will continue through 1992; the existing stack of blocks in five vertical columns will be left in place for future analysis

10.9 ENVIRONMENTAL RESEARCH (Iverson 1984; Amiro and Davis 1985; Killey 1985; Sheppard et al. 1985; Zach 1985; NEA 1986)

Assessment of the possible transport of radionuclides from an underground disposal vault through the biosphere to man has been studied; a generic biosphere model for environmental and safety assessment has been developed, along with supporting research, at WNRE

10.10 PROGRAM/FACIUTIES COSTS (Rummery and Rosinger 1984; Wuschke et al. 1985; NEA 1986)

A. A 10-year concept assessment/R\&D program established in 1981 was funded at $\$ 29$ million/yr (Canadian); projected fiscal year (FY) (April to March) expenditures in 1986 Canadian dollars were:

$\$ 47$ million for $\mathrm{FY} 86 / 87$

$\$ 47$ million for FY $87 / 88$

$\$ 45$ million for FY $88 / 89$

$\$ 39$ million for FY 89/90

$\$ 39$ million for FY $90 / 91$

B. Additional costs were estimated at about $\$ 60$ million (Canadian) annually by $A E C L$; also $\$ 40$ million (Canadian) were spent as of 1988 by Ontario Hydro for researching onsite storage and transport of spent fuel (NF 2/8/88)

C. The total nuclear waste management development costs funded by the federal EMR was $\$ 300$ million (Canadian) through 1987 (NF 1/25/88)

D. Estimated costs for the conceptual spent fuel disposal system as of 1985 were $\$ 540$ $\$ 670$ million (capital) and \$135-\$235 million (annual operating), in 1979 Canadian doliars (Wuschke et al. 1985)

E. As of 1986, the estimated total capital and operating costs for a concept to use the integrated casks (for storage, transportation and disposal) were $\$ 750-\$ 950$ million (1982 Canadian dollars) for disposing of t0-year-old spent fuel (Lisle and Wright 1986)

F. In May 1985, the federal government decided on five-year phased reduction of the budget for waste management, with industry picking up a share of the costs; in 1987, the industry share was $\$ 13$ million (Canadian) (Personal Communication, C. R. Cooley with W. Hancox and $K$. Dormuth, 10/7/87)

G. The capital investrnents in WNRE and its URL are $\$ 121$ million (Canadian) and operating costs are nearly $\$ 40$ million/yr (NF 5/18/87) 


\subsection{MANAGEMENT OF URANIUM MINE AND MILL WASTES}

\subsection{WASTE ARISINGS}
A. Six to eight million tons are generated per year in Canada
B. Total to 1982 was 130 million tons, covering $10 \mathrm{~km}^{2}$
C. Eldorado Resources had $880,000 \mathrm{~m}^{3}$ of uranium refining wastes and contaminated soil from its three sites in 1987 (NWN 11/12/87)

\subsection{CRITERIA}

No regulations exist with specific criteria for management of these uranium mine and mill wastes; the AECB has issued broad guidelines and reviews plans on a case-by-case basis; the NUTP (National Uranium Tailings Program) assumes structures to be stable for 100-200 years, and has selected $1000-2000$ years as the period for evaluating the stability (Caldwell and Robertson 1987)

\subsection{STRATEGY/POLICY}

Canada has a National Uranium Tailings Program (NUTP); the preferred concept is to put dewatered material in deep pit with engineered drainage, and cover it with backfill (Caldwell and Robertson 1987; NEI 12/87)

\subsection{REMEDIAL ACTIONS}

A. Treatment of acid seepage from tailings piles at Elliot Lake consisted of reduction in acidity and removal of radium

B. Three uranium mining/milling facilities have been decommissioned: 1) Agnew Lake Ltd. facility near Espanola, Ontario; 2) Madawaska Mines Ltd. facility near Bancroft, Ontario; and 3) Eldorado Nuclear Ltd. Beaverlodge facility near Uranium City, Saskatchewan (Whitehead 1986)

1) Stabilization of mill tailings is done by rock/till cover or by vegetation

2) Post-decommissioning monitoring will be carried out for a few years before abandonment

C. Several options are being studied for the stabilization and in situ management of radioactively contaminated sediments of the Port Hope Harbour facility in Ontario (Underdown and Moffitt 1989; Philipose 1990b)

11.5 R\&D (John 1986)

A. Canada's National Uranium Tailings Program includes modeling, field measurements and disposal technology

B. Dry placement at Elliot Lake by coning or stacking of tailings is being studied to provide a contour that will shed water and reduce infiltration 
C. Dry placement by sub-aerial discharge or layering at Key Lake is being studied

D. Disposal in a mined-out pit, with hydraulic barriers to minimize interaction with groundwater, is being studied

E. Deep lake disposal was studied at Quirke Lake in the Elliot Lake region

F. Radium removal from effluents has been studied

G. Evaluations of environmental effects have been carried out

H. Environment Canada's wastewater technology center at Burlington, Ontario, carried out a study from 1974-1987 on leaching of radionuclides and other chemical constituents from mine/mill tailings and settling-pond sludges (NWN 6/18/87)

I. Small amounts of uranium in some soils have been found to have an adverse effect on plant yields (NWN 8/2/90)

\subsection{DECOMMISSIONING AND ENVIRONMENTAL RESTORATION}

\subsection{R\&D}

The Can-decon process (dilute chemical decontamination process for reactor piping systems) was developed by AECL and Ontario Hydro (Knox 1987)

\subsection{MAJOR PROJECTS}

A. Gentilly-1 decommissioning project (was included in an NEA project) (Gupta 1987; Hoye and Arseneault 1989)

1) Gentilly-1 is a 296-MWe CANDU, moderated with heaw water and cooled with boiling light water; it has been mothballed since 1979

2) The strategy is to place the facility in "static state," monitor it for 50-80 years, then dismantle the facility

3) A "static state" was achieved by sealing the reactor building and consolidating the contaminated wastes (including spent fuel) in the turbine building; work was completed in the spring of 1986 (also see Section 12.3)

4) Extensive use was made of an electrically driven water blaster (hydrolaser) for decontamination of fuel bundles, equipment, and spent fuel pool surfaces

B. Douglas Point decommissioning project (NN 1/88; NWN 11/26/87)

1) The 218 (MW gross) CANDU pressurized HWR was operated from 1967 to 1984 and permanently shut down in 1984

2) All 23,000 spent fuel assemblies ( $300 \mathrm{MTU}$ ) were moved into 47 above-ground concrete canisters (completed 1987) for storage until a permanent repository is available 
3) The reactor facility was sealed and kept intact in "static state," pending decision on possible other tuture use

4) The radionuclide inventory and distribution in the high- and nomal-density concrete was measured; at the end of the 30-year Phase I of decommissioning, the activity will be dominated by tritium (Krasznai et al. 1990)

C. The NPD (Nuclear Power Demonstration) reactor is an underground installation, offering special options for ultimate disposal (Hoye and Arseneault 1989)

1) All spent fuel was removed in 1987 for shipment to CRNL and temporarily stored in the spent fuel bay; spent fuel is to be placed in dry storage in canisters similar to that for Douglas Point fuel (NWN 12/3/87)

2) Components that were highly radioactive or that contained long-Iived radioactive materials were identified

3) At the end of the 'static-state' period, it may be possible to permanently dispose of all remaining wastes without dismantling

D. The WR-1, a heavy-water-moderated, organic-cooled demonstration reactor at WNRE, was scheduled to be decommissioned starting in late 1989 (NN 10/89)

\section{3 costs}

Decommissioning of the Gentilly-1 CANDU reactor to the "static state" was completed in 1986 at a cost of $\$ 13$ million (Canadian) (Hoye and Arseneault 1989); surveillance costs are about $\$ 1$ million (Canadian) per year

\subsection{INTERNATIONAL ACTIVITIES}

\subsection{MEMBERSHIPS}

IAEA and OECD/NEA

\subsection{COOPERATION WITH MULTINATIONAL AGENCIES}

A. Information is exchanged with the CEC through published reports, annual meetings, visits, and temporary assignment of exchange staft (NEA 1986)

1) An agreement for joint R\&D on nuclear fusion was signed in 1986 (NW 8/13/87)

2) An agreement for joint $R \& D$ on health and environmental effects of radiation was implemented in 1987 (NW 8/13/87)

B. Canada participates in the NEA-coordinated Stripa URL project in Sweden (NEA 1986)

C. NEAVECD/CEC working and study groups of 8-20 members focus on particular technical areas to discuss and resolve common issues (Shemitt and Sheng 1989) 


\subsection{COOPERATION WITH USA}

A. The AECB and USNRC concluded a five-year Administrative Arrangement on cooperation and exchange of technical information relating to the regulation of health, safety, security, safeguards, and environmental protection; informal arrangements on exchange of this information had already existed (NLB 12/89)

B. A DOE/AECL umbrella agreement is in place

1) Term: 1976-1992

2) Scope: waste treatment, packaging, storage and geologic disposal; transportation; environment and safety; public acceptance

C. A DOE/AECL agreement for cooperative research in radioactive waste management was in place until about 1989; total estimated cost to the U.S. was estimated to be $\$ 62$ million U.S.; the work included (Dormuth 1988):

1) Extension and characterization of the URL shaft

2) Planning and design of experiments in the URL

3) Field testing investigations

4) Performance assessment studies

D. The DOE/AECL agreement was canceled when U.S. policy on a HLW repository changed to a single site in basalt; the scope of the agreement is being renegotiated

\subsection{COOPERATION WITH OTHER COUNTRIES}

A. Switzerland ratified a nuclear cooperation agreement with Canada in March 1989; a previous agreement was suspended by Canada in 1977; the new accord will make it possible for Swiss utilities to resume normal uranium trade with Canadian suppliers (NF $4 / 17 / 89$ )

B. The Soviet Union and Canada signed a comprehensive cooperative agreement in November 1989; it provides for bilateral nonproliferation assurances (NW 11/30/89)

C. Japan (PNC) and Canada (AECL-WNRE) cooperation on geologic tests began in 1986; in August 1987, Japan (JAERI) engaged AECL to conduct a series of radionuclide diffusion and migration experiments (ASC 1988)

D. Germany (BMFT) has an exchange agreement with Canada on waste management

E. Ontario Hydro will begin a study in September 1989 to determine the potential for selling CANDU-generated power in Hungary (NW 8/24/89)

F. AECL's Spent Fuel Storage Facilities Centre has contracted with the Korean Electric Power Corp. to provide engineering, technical services, tooling and equipment for a spent fuel dry storage facility at Korea's Wosong-l nuclear power plant (NWN 3/22/90) 


\subsection{REFERENCES}

$-1982-$

Carter, T. J. 1982. 'Radioactive Waste Management Practices at a Large Canadian Electrical Utility.' Radioactive Waste Management, 2(4):381-412. Harwood Academic Publishers, New York.

$-1984-$

International Atomic Energy Agency (IAEA). 1984. Guidebook on Spent Fuel Storage. Technical Reports Series No. 240, pp. 24, 38-40. Intemational Atomic Energy Agency, Vienna.

Iverson, S. L 1984. "The Biosphere Model and Emvironmental Research." In Proceedings of the Eighteenth Information Meeting of the Nuclear Fuel Waste Management Program (1984 General Meeting), pp. 221-230. TR-320, September 26-27, 1984, Atomic Energy of Canada Limited, Ontario, Canada.

Pearson, R., compiler. 1984. "Hydrogeological Research for the Canadian Nuclear Fuel Waste Management Program: September 1983 to August 1984." In Proceedings of the Eighteenth Information Meeting of the Nuclear Fuel Waste Management Program (1984 General Meeting), pp. 52-64. TR-320, September 26-27, Atomic Energy of Canada Limited, Ontario, Canada.

Rummery, T. E., and E. L. J. Rosinger. 1984. The Canadian Nuclear Fuel Waste Management Program." In proceedings of ANS topical meeting on Fuel Reprocessing and Waste Management, Vol. 1, pp. 14-32. August 26-29, 1984, Jackson, Wyoming.

Simmons, G. R., compiler. 1984. The Geomechanics Program - A Review." In Proceedings of the Eighteenth Information Meeting of the Nuclear Fuel Waste Management Program (1984 General Meeting), pp. 23-34. TR-320, September 26-27, 1984, Atomic Energy of Canada Limited, Ontario, Canada.

Sridhar, T. S. 1984. 'Waste Immobilization Process Experiment (WIPE).' In Proceedings of the Eighteenth Information Meeting of the Nuclear Fuel Waste Management Program (1984 General Meeting), pp. 206-217. TR-320, September 26-27, 1984, Atomic Energy of Canada Limited, Ontario, Canada.

Truss, K. J. 1984. "Container Development and Testing." In Proceedings of the Eighteenth Information Meeting of the Nuclear Fuel Waste Management Program (1984 General Meeting), pp. 121-130. TR-320, September 26-27, 1984, Atomic Energy of Canada Limited, Ontario, Canada.

Vandergraaf, T. T. 1984. "Geochemistry and Applied Chemistry Research." In Proceedings of the Eighteenth Information Meeting of the Nuclear Fuel Waste Management Program (1984 General Meeting), pp. 45-51. TR-320, September 26-27, 1984, Atomic Energy of Canada Limited, Ontario, Canada.

Wikjord, A. G. 1984. Waste Immobilization Studies for Concept Assessment." In Proceedings of the Eighteenth Information Meeting of the Nuclear Fuel Waste Management Program (1984 General Meeting), pp. 192-205. TR-320, September 26-27, 1984, Atomic Energy of Canada Limited, Ontario, Canada. 
$-1885-$

Amiro, B. D., and P. A. Davis. 1985. 'Atmospheric Suspension Processes in the Nuclear Fuel Waste Management Program.' In Proceedings of the Twentieth Information Meeting of the Canadian Nuclear Fuel Waste Management Program (1985 General Meeting), Vol. 2, pp. 312-317. TR-375, Atomic Energy of Canada Limited, Ontario, Canada.

Atomic Energy Control Board (AECB). 1985. "Deep Geological Disposal of Nuclear Fuel Waste: Background Information and Regulatory Requirements Regarding the Concept Assessment Phase." Atomic Energy Control Board Regulatory Document. AECB R-71, Regulatory Policy Statement, Atomic Energy Control Board, Ottawa, Ontario, Canada.

Brown, P. A., and W. A. C. Rey. 1985. 'Investigation of Geological Extrapolations at the Atikokan Research Area.' In Proceedings of the Twentieth Information Meeting of the Canadian Nuclear Fuel Waste Management Program (1985 General Meeting), Vol. 1-2, pp. 182-205. TR-375, Atomic Energy of Canada Limited, Ontario, Canada.

Crosthwaite, J. L. 1985. "Container Design and Development." In Proceedings of the Twentieth Information Meeting of the Canadian Nuclear Fuel Waste Management Program (1985 Genera! Meetingl, Vol. 2, pp. 213-226. TR-375, Atomic Energy of Canada Limited, Ontario, Canada.

Davison, C. C. 1985. "URL Drawdown Experiment and Comparisons with Model Predictions." In Proceedings of the Twentieth Information Meeting of the Canadian Nuclear Fuel Waste Management Program (1985 General Meeting), Voi. 1, pp. 103-124. TR-375, Atomic Energy of Canada Limited, Ontario, Canada.

Dormuth, K. W., and S. H. Whitaker. 1985. "Geotechnical Projects." In Proceedings of the Twentieth Information Meeting of the Canadian Nuclear Fuel Waste Management Program (1985 General Meetingl, Vol. 1, pp. 3-3b. TR-375, Atomic Energy of Canada Limited, Ontario, Canada.

Dunford, W. E. 1985. 'A Comparison of the Second Interim Concept Assessment with Regulatory Requirements." In Proceedings of the Twentieth Information Meeting of the Canadian Nuclear Fuel Waste Management Program (1985 General Meeting), Vol. 2, pp. 378-383. TR-375, Atomic Energy of Canada Limited, Ontario, Canada.

Everitt, R., and A. Brown. 1985. "Subsurface Geology of the Underground Research Laboratory: An Overview of Recent Developments." In Proceedings of the Twentieth Information Meeting of the Canadian Nuclear Fuel Waste Management Program (1985 General Meeting), Vol. 1, pp. 146-181. TR-375, Atomic Energy of Canada Limited, Ontario, Canada.

Frech, E. R. 1985. "Public Interaction and Social Aspects." In Proceedings of the Twentieth Information Meeting of the Canadian Nuclear Fuel Waste Management Program (1985 General Meetingl, Vol. 1, pp. 84-90. TR-375, Atomic Energy of Canada Limited, Ontario, Canada. 84-90.

Gray, M. N., and S. Cheung. 1985. 'Disposal Vaut Sealing." In Proceedings of the Twentieth Information Meeting of the Canadian Nuclear Fuel Waste Management Program (1985 General Meetingl, Vol. 2, pp. 252-263. TR-375, Atomic Energy of Canada Limited, Ontario, Canada. 252-263.

Killey, R. D. W. 1985. "Concept Assessment of Overburden Contaminant Transport for the Nuclear Fuel Waste Disposal Program - Post-closure Phase.' In Proceedings of the Twentieth Information Meeting of the Canadian Nuclear Fuel Waste Management Program (1985 General Meeting), Vol. 2, pp. 318-329. TR-375, Atomic Energy of Canada Limited, Ontario, Canada. 
Lakey, L. T., K. M. Harmon, and P. Colombo. 1985. Management of Law Level Radioactive Wastes Around the World. PNL-5173, Pacific Northwest Laboratory, Richland, Washington.

Lang, P. A., and P. M. Thompson. 1985. "Geomechanics Experiments During Excavation of the URL Shaft." In Proceedings of the Twentieth Information Meeting of the Canadian Nuclear Fuel Waste Management Program (1985 General Meeting), Vol. 1, pp. 125-145. TR-375, Atomic Energy of Canada Limited, Ontario, Canada.

Nucleonics Week (NW) 10/17/85.

Paige, H. W., and N. J. Numark. 1985. Assessment of National Systems for Obtaining Local Siting Acceptance of Nuclear Waste Management Facilities. IEAL-R/86-16, International Energy Associates Limited, Washington, D.C., Vol. 1, pp. 4-1 to 4-6 and Vol, 2, pp. 6-1 to 6-3.

Sheppard, M. I., D. H. Thibault, and J. H. Mitchell. 1985. "Nuclide Redistribution in Soil." In Proceedings of the Twentieth Information Meeting of the Canadian Nuclear Fuel Waste Management Program (1985 General Meeting), pp. 294-311. TR-375, Atomic Energy of Canada Limited, Ontario, Canada.

Sridhar, T. S. 1985. "Waste Immobilization Engineering Studies." In Proceedings of the Twentieth Information Meeting of the Canadian Nuclear Fuel Waste Management Program (1985 General Meeting), Vol. 2, pp. 264-273. TR-375, Atomic Energy of Canada Limited, Ontario, Canada.

Technical Advisory Committee (TAC). 1985. Technical Advisory Committee on the Nuclear Fuel Waste Management Program: Sixth Annual Report. TAC-6, Dr. L. W. Shemilt, Chairman, McMaster University, Hamilton, Ontario, Canada.

Tait, J. C. 1985. 'Performance Assessment of Fuel Recycle Waste Forms.' In Proceedings of the Twentieth Information Meeting of the Canadian Nuclear Fuel Waste Management Program (1985 General Meetingl. Vol. 2, pp. 274-283. TR-375, Atomic Energy of Canada Limited, Ontario, Canada.

Vikis, A. C., et al. 1985. "Chemistry Research for the Canadian Nuclear Fuel Waste Management Program." In Proceedings of the Twentieth Information Meeting of the Canadian Nuclear Fuel Waste Management Program (1985 General Meeting), Vol. 1, pp. 30-67. TR-375, Atomic Energy of Canada Limited, Ontario, Canada.

Vandergraaf, T. T. 1985. "Geochemistry Research Program." In Proceedings of the Twentieth Information Meeting of the Canadian Nuclear Fuel Waste Management Program 11985 General Meetingl, Vol. 2, pp. 284-311. TR-375, Atomic Energy of Canada Limited, Ontario, Canada.

Wuschke, D. M., P. A. Gillespie, and D. E. Main. 1985. Second Interim Assessment of the Canadian Concept for Nuclear Fuel Waste Disposal. Volume 1: Summary. AECL-8373-1, Atomic Energy of Canada Limited-Whiteshell Nuclear Research Establishment, Pinawa, Manitoba, Canada.

Zach, R. 1985. "Environmental Research." In Proceedings of the Twentieth Information Meeting of the Canadian Nuclear Fuel Waste Management Program (1985 General Meeting), Vol. 1, pp. 4-20. TR-375, Atomic Energy of Canada Limited, Ontario, Canada. 
Cameron, D. J., et al. 1986. "An Analysis of the Need for Low-Level Radioactive Waste Disposal in Canada and the Alternatives for Establishing Disposal Facilities." In proceedings of The Canadian Nuclear Society 2nd international Conference on Radioactive Waste Management. September 7-11, 1986, Winnipeg, Manitoba, Canada.

Charnney, L. G. 1986. "Licensing of Uranium Mine and Mill Waste Management Systems." In the Proceedir.gs of The Canadian Nuclear Society's 2nd International Conference on Radioactive Waste Management, pp. 432-438. September 7-11, 1986, Winnipeg, Manitoba, Canada

Cramer, J. J. 1986. "Cigar Lake Project: a U-Deposit Natural Analog." In Report of the First Meeting of the NEA Perfo:mance Assessment Advisory Group (PAAG). May 12-14, 1986, OECD/Nuclear Energy Agency, Paris.

Hancox, W. T. 1986. "Progress in the Canadian Nuclear Fuel Waste Management Program." In proceedings of The Canadian Nuclear Society 2nd International Conference on Radioactive Waste Management. September 7-11, 1986, Winnipeg, Manitoba, Canada

Hancox, W. T., H. N. Isaac, and J. Howieson. 1986. "Radioactive Waste Management in Canada." In proceedings of IAEA Symposium, Siting, Design and Construction of Underground Repositories for Radioactive Wastes, p. 19. March 3-7, 1986, Hanover, Federal Republic of Germany.

Hardy, D. G., et al. 1986. "Safety and Cost Assessments for Disposal in a Prototype Shallow Land Burial Facility." In proceedings of The Canadian Nuclear Society 2nd International Conference on Radioactive Waste Management. September 7-11, 1986, Winnipeg, Manitoba, Canada.

Jarvis, R. G., et at. 1986. The COSMOS-S/D Assessment Code Complex for a SLB Repository at CRNL. AECL-9350, Atomic Energy of Canada Limited, Ontario, Canada.

John, R. D. 1986. "Research Into the Long-Term Environmental Effects of Uranium Tailings." in proceedings of The Canadian Nuclear Society 2nd Intemational Conference on Radioactive Waste Management. September 7-11, 1986, Winnipeg, Manitoba, Canada.

Lisle, P. D. R., and E. D. Wright, compilers. 1986. The Canadian Nuclear Fuel Waste Management Program 1985 Annual Report." TR-400, Atomic Energy of Canada Limited, Ontario, Canada.

Nathwani, J. S. 1986. 'Safety Assessment of a Conceptual Design of a Facility for Geologic Disposal of Used CANDU Nuclear Fuel in the Canadian Shield." In proceedings of LAEA Symposium, Siting. Design and Construction of Underground Repositories for Radioactive Wastes, p. 575. March 3-7, 1986, Hanover, Federal Republic of Germany.

Nuclear Energy Agency (NEA). 1986. "Summary Record of Ad Hoc Meeting of the Directors of Crystalline Rock Projects." Nuclear Energy Agency, November 3, 1986, París.

Numark, N. J., R. J. Mattson, and J. Gaunt. 1986. "Comparison of National Programs and Regulations for the Management of Spent Fuel and Disposal of High-Level Waste in Seven Countries.' Waste Management ' 86 , Vol. 2, pp. 535-541. March 2-6, 1986, Tucson, Arizona.

Nuclear Waste News (NWN). 5/15/86. "Canada Releases General Policy Statement on $\amalg W$ Management," p. 124. 
Patterson, D. W., and D. S. Hoye. 1986. "Canadian Experience Storing Irradiated CANDU Fuel in Concrete Canisters.' In proceedings of the Third International Spent Fuel Storage Technology Symposium Workshop, pp. S-136 to S-155. CONF-860417, April 8-10, 1986, Seattle, Washington.

Russell, S. 1986. "Preliminary Assessment of Ontario Hydro's Low Level Waste Disposal Concepts." Waste Management '86, Vol. 3, pp. 175-180. March 2-6, 1986, Tucson, Arizona.

Statistics Canada (Stat Can). 1986. Statistics Canada 1986. Catalogue 57-OD1, December 1986.

Teper, B. 1986. "Evaluation of Iron-Based, Stressed-Shell Container." Waste Management '86, Vol. 2, pp. 291-296. March 2-6, 1986, Tucson, Arizona.

Wagstaff, K P. 1986. 'Regulatory Criteria for the Disposal of Radioactive Wastes.' In proceedings of The Canadian Nuclear Society 2nd Intemational Conference on Radioactive Waste Management.

September 7-11, 1986, Winnipeg, Manitoba, Canada.

Wasywich, K. M., et al. 1986. "Examination of Intact and Defected Irradiated CANDU Fuel Bundles Stored Up To $\approx 30$ Months in Moist Air at $150^{\circ} \mathrm{C}$.' In proceedings of the Third International Spent Fuel Storage Technology Symposium/Workshop, pp. S-231 to S-252. CONF-860417, April 8-10, 1986, Seattle, Washington.

Whitehead, W. 1986. "Decommissioning of Nuclear Facilities in Canada - A Summary." Atomic Energy Control Board, Ottawa, Ontario, Canada.

\section{$-1987-$}

Armstrong, P. J. 1987. 'Ontario Hydro's Experience with Augered Borehole Storage." Waste Management '87, Vol. 1, pp. 501-504. March 1-5, Tucson, Arizona.

Atomic Energy Control Board (AECB). 1987a. "Geological Considerations in Siting a Repository for Underground Disposal of High-Level Radioactive Waste.' Atomic Energy Control Board Regulatory Document. AECB R-72, Regulatory Guide. Atomic Energy Control Board, Ottawa, Ontario, Canada.

Atomic Energy Control Board (AECB). 1987b. "Regulatory Objectives, Requirements and Guidelines for the Disposal of Radioactive Wastes - Long-Term Aspects." AECB R-104, Regulatory Policy Statement. Atomic Energy Control Board, Ottawa, Ontario, Canada.

Baumgartner, P., and G. R. Simmons. 1987. "Disposal Centre Engineering for the Canadian Nuclear Fuel Waste Management Program." Radioactive Waste Management and the Nuclear Fuel Cycle. Harwood Academic Publishers GmbH, New York, 8 (2-3):219-239.

Caldwell, J. A., and A. M. Robertson. 1987. "An Evaluation of Geotechnical and Hydrologic Aspects of Uranium Mill Tailings Reclamation in the USA and Canada.' Waste Management ' 87 , Vol. 3, pp. 145150. March 1-5, 1987, Tucson, Arizona.

Cameron, D. J. 1987. "A Comparative Economic Analysis of Low-Level Radioactive Waste Disposal in Canada." Waste Management '87, Vol. 1, pp. 455-464. March 1-5, 1987, Tucson, Arizona.

Carter, T. J., J. F. Tanaska, and P. K. M. Rao. 1987. "Development of Systems for Transporting Irradiated CANDU Fuel in Ontario." In proceedings of RECOD 87, International Conference on Nuclear Fuel Reprocessing and Waste Management, Vol. 1, p. 361-368. August 23-27, 1987, Paris. 
Devgun, J. S., and D. H. Charlesworth. 1987. "Impact of Past Experiences on Engineering a Shallow Land Burial Facility." Waste Management '87, Vol. 3, pp. 205-212. March 1-5, 1987, Tucson, Arizona.

Dormuth, K W., and K Nuttall. 1987. "The Canadian Nuclear Fuel Waste Management Program." Radioactive Waste Management and the Nuclear Fuel Cycle. Harwood Academic Publishers GmbH, New York, 8 (2-3):93-104.

Goodwin, B. W. et al. 1987. "Post-Closure Ervironmental Assessment for the Canadian Nuclear Fuel Waste Management Program.' Radioactive Waste Management and the Nuclear Fuel Cycle. Harwood Academic Publishers GmbH, New York, 8 (2-3):241-272.

Gupta, B. 1987. "Decommissioning of Gentily-1 - Canada.' In proceedings of 1987 International Decommissioning Symposium, Vol. 2, p. IV-1. October 48, 1987, Pittsburgh, Pennsylvania.

Interr: ational Energy Agency (IEA). 1987. Energy Balances of OECD Countries, 1970-1985. International Energy Agency of the Organization for Economic Cooperation and Development, Paris, $p$. 181.

International Energy Associates Limited (IEAL). 1987. Regulatory Strategies for High-Level Radioactive Waste Management in Nine Countries. IEAL-R/87-93, Intemational Energy Associates Limited, Fairfax, Virginia.

Johnson, L H., J. L Crosthwaite, N. N. Gray, B. M. Ikeda, and J. C. Tait. 1987. "Engineered Barrier Research for the Canadian Nuclear Fuel Waste Management Program." In Radioactive Waste Management and the Nuclear Fuel Cycle. Harwood Academic Publishers GmbH, New York, $8(2-3): 105-143$.

Knox, R. 1987. "How Independent Tests Have Eliminated Can-Decon Corrosion Concerns." Nuclear Engineering International, March 1987, p. 48.

Nuclear Energy Agency (NEA). 7/87. Nuclear Waste Bulletin (No. 1). OECD/Nuclear Energy Agency, Paris, p. 5.

Nuclear Energy Agency (NEA). 11/87. In-Situ Research and Investigations in OECD Countries. OECD/Nuclear Energy Agency Advisory Group on In-Situ Research and Imvestigations for Geologic Disposal, Paris.

Nuclear Engineering International (NEI). 6/87. "Canada: Working on Smaller Units," p. 29.

Nuclear Engineering International (NEl). 12/87. "Canada Maintains Maximum Flexibility," pp. 47, 50.

Nuclear Fuel (NF). 5/18/87. "Manitoba Govemment Proposes Ban on High-Level Waste Disposal," p. 13.

Nuclear Fuel (NF). 11/30/87. "Swiss, Canadians Prepare for New Accord," p. 11.

Nuclear Newrs (NN). 11/87. "Canada Reserves Increase; Facility Planned in NWT," p. 55.

Nucleonics Week (NW). 8/13/87. "Canada: Utilities to Bear CANDU R\&D Costs," p. 18.

Nuclear Waste News (NWN). 4/16/87. 'AECL Studies Natural Uranium Deposit as Natural Analog to HLW Repository;' p. 96. 
Nuclear Waste News (NWN). 6/18/87. "Environment Canada Completes Study on Leachates from Uranium Wastes," p. 168.

Nuclear Waste News (NWN). 8/6/87. 'Manitoba's Radwaste Disposal Ban Enacted Despite Industry Concerns," p. 220.

Nuclear Waste News (NWN). 11/12/87. 'Ontario ШW Disposal Report Will Go to Federal Governmient Next Month,' p. 325.

Nuclear Waste News (NWN). 11/26/87. "AECL Completes Transfer of SF to Dry Storage at Decommissioned Douglas Point Reactor,' p. 341.

Nuclear Waste News (NWN). 12/3/87. 'Last of SF Removed from Canada's NPD Reactor," p. 348.

Smith, R., and C. W. Zarecki. 1987. "Above-Ground Dry Storage of Used Nuclear Fuel in Concrete Canisters." Joumal of Nuclear Materials Management, April 1987, p. 36.

Sood, S., and J. S. Li. 1987. "Tritium Experience at Ontario Hydro." Proceedings of 1987 International Waste Management Conference, p. 331-337. November 29 - December 5, 1987, Kowloon, Hong Kong.

$-1988-$

Ascent (ASC). 1988. "AECL Works with Japan to Manage Nuclear Waste." Vol. 7, No. 1.

Charlesworth, D. H., and J. Howieson. 1988. "Overview of Management of Low Level Radioactive Wastes in Canada." Management of Low and intermediate Level Radioactive Waste - 1988, Vol. 1, p. 25. May 16-20, 1988, Stockholm, Sweden.

Dormuth, K. W., and S. A. Mann. 1988. "An Agreement between the United States Department of Energy and Atomic Energy of Canada Limited for Cooperative Research in Radioactive Waste Management." Waste Management ' 88 , Vol. Il, p. 259. February 28 - March 3, 1988, Tuscon, Arizına.

Hardy, D. G., D. E. Philipose, and R. G. Jarvis. 1988. "Design, Development and Safety Assessment of the IRUS Repository for Disposal of Low-Level Radioactive Waste." in Proceedings of the International Topical Meeting on Nuclear and Hazardous Waste Managernent - Spectrum '88, p. 396. September 11-15, 1988, Pasco, Washington.

Heystee, R. J., and J. Freire-Canosa. 1988. "Disposal Beneath a Thick Sedimentary Sequence in Crystalline Rock.' Waste Management '88, Vol. II, p. 753. February 28 - March 3, 1988, Tuscon, Arizona.

Nuclear Energy Agency (NEA). 1988. Uranium: Resources, Production and Demand. Joint report by the OECD Nuclear Energy Agency and the IAEA, OECD/Nuclear Energy Agency, Paris.

Nuclear Fuel (NF). 2/8/88. 'Further Slippage Seen in Schedule for Canada's Nuclear Waste Study," p. 7.

Nuclear News (NN). 1/88. 'All Douglas Point Spent Fuel is Now in Dry Storage," p. 61.

NUKEM Market Report on the Nuclear Fuel Cycle (NUKEM). 1/88. NUKEM GmbH, Hanau, Federal Republic of Germany, p. 22. 
Nucleonics Week (NW). 1/21/88. "Uranium Mining Town Volunteers to Take Canada's Nuclear Waste," p. 2.

Philipose, K. E. 1988. "500 Year Concrete for a Radioactive Waste Repository." Waste Management 'B8, Vol. 1, p. 995 . February 28 - March 3, 1988, Tuscon, Arizona.

Ribbans, D. J. 1988. 'Road Cask for the Transportation of CANDU Irradiated Fuel." In Transportation for the Nuclear Industry. J.G. Walton and S.M Blackburn, eds., Plenum Press, New York.

Rossinger, E. L. J., and W. T. Hancox. 1988. "Recent Developments in Radioactive Waste Management in Canada.' Waste Management '88, Vol. II, p. 249. Febnuary 28 - March 3, 1988, Tuscon, Arizona.

Shoesmith, D. W., S. Sunder, B. M. Ideda, and F. King. 1988. 'The Development of a Mechanistic Basis for Modelling Fuel Dissolution and Container Failures under Waste Vault Conditions." Symposium on Scientific Basis for Nuclear Waste Management XII, p. 279. October 10-13, 1988, Berlin.

$-1989-$

Atomic Energy of Canada, Ltd. (AECL). 1989. "Managing Canada's Nuclear Fuel Wastes." Brochure WWM-89-05-01, Ottawa, Ontario, Canada.

Baker, R. C. 1989. "How Quality Results Were Achieved During Construction and Testing in Atomic Energy of Canada's Underground Research Laboratory." International Waste Management Conference. April 2-5, 1989, Las Vegas, Nevada.

Charlesworth, D. H. 1989. "Progress Toward Disposal of LLRW in Canada," in Proceedings of the 1989 Joint International Waste Conference on High Level Radioactive Waste and Spent Fuel Management, v. 1, p. 629. October 22-28, 1989, Kyoto, Japan.

Crosthwaite, J. L., and J. A. Chadha. 1989. "Nuclear Fuel Waste Container Performance Evaluation and Fabrication Development Studies in the Canadian Program.' In Proceedings of the 1989 Joint International Waste Conference on High Level Radioactive Waste and Spent Fuel Management, Vol. 2, p. 489. October 22-28, 1989, Kyoto, Japan.

Dormuth, K. W. 1989. 'The Canadian Nuclear Fuel Waste Management Program.' Symposium on the Final Disposal of Radioactive Waste. October 17, 1989, The Hague, Netherlands.

Dormuth, K. W., R. B. Cooper, G. R. Sherman, and K. J. Truss. 1989. "Development and Status of Quality Assurance for Research and Development in the Canadian Nuclear Fuel Waste Management Program." International Waste Management Conference. April 2-5, 1989, Las Vegas, Nevada.

Frost, C. R. 1989. "Design Considerations, Operation and Maintainance Experience with Wet Storage of Ontario Hydro's Used Fuel." In Proceedings of the 1989 Joint International Waste Conference on High Level Radioactive Waste and Spent Fuel Management, Vol. 2, p. 447. October 22-28, 1989, Kyoto, Japan.

Garisto, N. C., and F. Garisto. 1989. 'The Effect of Cracks on Diffusive Mass Transport through a Clay Barrier." In Scientific Basis for Nuclear Waste Management XIII, p. 733. November 27-30, 1989, Materials Research Society, Pittsburgh, Pennsylvania. 
Garisto, N. C., and D. M. LeNeveu. 1989a. "Analysis of Mass Transport in an Engineered Barriers System for the Disposal of Used Nuclear Fuel." In Scientific Basis for Nuclear Waste Management XIII, p. 775. November 27-30, 1989, Materials Research Society, Pittsburgh, Pennsylvania

Garisto, N. C., and D. M. LeNeveu. 1989b. The Vault Model for the Disposal of Used CANDU Fuel: Documentaion and Analysis of Scoping Calculations. AECL-9578, Atomic Energy of Canada Limited, Ontario, Canada.

Hoye, D. S., and J. L. Arseneault. 1989. 'Decommissioning Waste Management in Canada. In Proceedings of the 1989 Joint International Waste Conference on High Level Radioactive Waste and Spent Fuel Management, Vol. 1, p. 193. October 22-28, 1989, Kyoto, Japan.

Kempe, T. F., and L Grondin. 1989. 'Radiological Impact on the Public of Transportaion for the Canadian Nuclear Fuel Waste Management Program." in Proceedings of the 9th International Symposium on the Packaging and Transportation of Radioactive Materials, Vol. II, p. 1058. June 11-16, 1989, Washington D.C.

Nuclear Fuel (NF). 4/17/89. 'Switzerland Pact with Canada Ratified,' p. 11.

Nuclear News (NN). 6/89. "New CANDU Fuel Bundle May Use Old LWR Fuel," p. 60.

Nuclear News (NN). 10/89. "Decommissioning of WR-1 in Canada is Getting Started," p. 116.

Nucleonics Week (NW). 8/24/89. "Canadian - Hungarian Study Set on Electricity Export Reactor," p. 5.

Nucleonics Week (NW). 11/30/89. 'Nuclear Agreement Clears Canadian - Soviet Trade Path," p. 12.

Nuclear Law Bulletin (NL). 12/89. "Administrative Arrangement for Cooperation and the Exchange of Information in Nuclear Regulatory Matters (1989)," p. 59.

Radhakrishna, A. S., and K. C. Lau. 1989. "Modelling the In-Situ Performance of Bentonite - Sand Buffer.' In Scientific Basis for Nuclear Waste Management XIII, p. 725. November 27-30, 1989, Materials Research Society, Pittsburgh, Pennsylvania.

Ribbans, D. J. 1989. "Systems for the Transportation of CANDU Irradiated Fuel by Road, Rail, and Water.' In Proceedings of the 1989 Joint International Waste Conference on High Level Radioactive Waste and Spent Fuel Management, Vol. 2, p. 67. October 22-28, 1989, Kyoto, Japan.

Shemilt, L. W., and G. Sheng. 1989. "Evaluation of the Canadian High-Level Waste Research Program in an International Context." In Proceedings of the 1989 Joint International Waste Conference on High Level Radioactive Waste and Spent Fuel Management, Vol. 2, p. 403. October 22-28, 1989 , Kyoto, Japan.

Technical Advisory Committee on the Nuclear Fuel Waste Management Program (TAC). 1989. Technical Advisory Committee Tenth Annual Report. TAC-10, July 1989.

Teper, B., and S. A. Reid. 1989. "Recent Developments in Design of Containers for Disposal of High Level Waste from CANDU Reactors.' Waste Management '89, vol. 1, p. 623. February 26 - March 2, 1989, Tuscon, Arizona. 
Tulk, J. D., and R. N. Sumar. 1989. "Development of a Concrete Container for Irradiated Fuel Storage and Transport." In Proceedings of the 9th International Symposium on the Packaging and Transportation of Radioactive Materials, Vol. H, p. 995. June 11-16, 1989, Washington D.C.

Underdown, G., and D. Moffett. 1989. 'Low Level Radioactive Waste Disposal in the Absence of a Disposal Site." Waste Management '89, Vol. II, p. 215. February 26 - March 2, 1989, Tuscon, Arizona.

$-1990-$

Gavin, M., R. Sauve, and J.D. Tulk. 1990. "Radioactive Waste Transportation Package Development by a Public Utility." American Nuclear Society Winter Meeting. November 11-14, 1990, Washington, D.C.

Grande, L. 1990. "Irradiated Fuel Storage Program - Concrete Integrated Container Demonstration." In Proceedings of the Spent Fuel Management Seminar VII, Institute of Nuclear Materials Management. January 17-19, 1990, Washington, D.C.

Greber, M. A. 1990 . 'Sociological Research for the Canadian Nuclear Fuel Waste Management Program,' Waste Management '90, Vol. 1, p. 629. February 25 - March 1, 1990, Tuscon, Arizona.

Krasznai, J. P., S. B. Vaughan, and A. S. Williamson. 1990. 'Current Issues in the Management of Low and Intermediate Level Radioactive Wastes from Ontario Hydro's CANDU Reactors." American Nuclear Society Winter Meeting. November 11-14, 1990, Washington, D.C.

Leigh, I. W. and S. J. Mitchell. 1990. International Nuclear Fuel Cycle Fact Book. PNL-3594, Rev. 10, Pacific Northwest Laboratory, Richland, Washington.

Multinational Environmental Outlook (MEO). 7/24/90. "Panel Examines Canada's Spent Nuclear Fuel Disposal Plans,' p. 115.

Nuclear Engineering International (NEl). 2/90. "Ontario Hydro Unveils Plan for Ten More CANDUs," p. 2.

Nuclear Fuel (NF). $7 / 17 / 90$. “Cameco Defers Public Stock Offering; U Market, Waste Issues Key in Canada," p. 12.

Nuclear News (NN). 1/90. 'Upbeat \& Eclectic - And: Will Canada Take U.S. Spent Fuel?' p. 93.

Nuclear News (NN). 2/90. 'Ontario Hydro's 25-Year Plan Calls for New Nuclear Units,' p. 41.

Nuclear News (NN). 4/90. p. 93.

Nuclear Plant Journal (NPJ). 5-6/90. "Utility News - Canada Update," p. 6.

Nuclear Waste News (NWN). 3/22/90a. "Canadian Researchers Study Radionuclide Solubility in a Repository Environment,' p. 119.

Nuclear Waste News (NWN). 3/22/90b. "Korean Electric Power Company Contracts for Canadian Dry Storage Technology," p. 113.

Nuclear Waste News (NWN). 8/2/90. 'Uranium Soil Study Could Affect Canadian Waste Cleanup Policy,' p. 305. 
Nuclear Waste News (NWN). 9/6/90. 'Long-Buried Glass Blocks Studied by Researchers," p. 346.

Nuclear Waste News (NWN). 9/13/90. "Review of Canada's Spent Nuclear Fuel Management," p. 359.

Nucleonics Week (NN). 1/25/90. 'Canada Proposes Funding AECB Fully through License Fees," p. 11.

Nucleonics Week (NW). 4/6/90. "Ontario, Canada Agree to Fund AECL for Next Seven Years," p. 3.

Nucleonics Week (NW). 10/18/90. "Hydro Tritium Plant Is Finally Working But Buyers Remain Scarce," p. 12.

NUKEM Market Report (NUKEM). 2/90. "Reprocessing and Waste Management Review 1989."

NUKEM GmbH, Hanau, Federal Republic of Germany, p. 14.

NUKEM Market Report (NUKEM). 3/90. "Uranium Production of the Western World." NUKEM GmbH, Hanau, Federal Republic of Germany, p. 3.

Philipose, K. E., R. F. Feldman, and J. J. Beaudoin. 1990. "Qualifying Concrete for a Low-Level Waste Repository." Waste Management '90, Vol. 1, p. 473. February 25 - March 1, 1990, Tuscon, Arizona.

Philipose, K. E., R. W. D. Killey, and G. M. Dolinar. 1990a. "Stabilization and In-Situ Management of Radioactive Contaminated Sediments of the Port Hope Harbour, Ontario, Canada." In Second International Symposium on Stabilization/Solidification of Hazardous, Radioactive, and Mixed Wastes,

p. 111. May 29 - June 1, 1990, Williamsburg, Virginia.

Torgerson, D. F. 1990a. 'The Canadian Nuclear Fuel Waste Management Program." ENC '90 ENS/ANS - Foratom Conference Transactions, Vol. IV, p. 2315.

Torgerson, D. F. 1990b. 'The Canadian Waste Management Research Program.' Waste Management '90, Vol. 2, p. 27. February 25 - March 1, 1990, Tuscon, Arizona.

Torok, J., Z. Lovasic, and M. K. Haas. 1990. "Silicon Carbide Waste Form for Carbon-14." In Proceedings of the International Topical Meeting on Nuclear and Hazardous Waste Management Spectrum ' 90 , p. 70 . September 30 - October 4, 1990, Knoxville, Tennessee.

Toronto Star (TS). 4/9/90. "Canada Won't Slash Radiation Exposure Levels, Official Says." 
CHINA 


\title{
CHINA (PEOPLE'S REPUBLIC OF)
}

\author{
CONTENTS
}

1.0 NUCLEAR POWER $\ldots \ldots \ldots \ldots \ldots \ldots \ldots \ldots \ldots \ldots \ldots \ldots \ldots \ldots \ldots$

NUCLEAR FUEL CYCLE AND RADIOACTIVE WASTE MANAGEMENT
STRATEGY/POLICY $\ldots \ldots \ldots \ldots \ldots \ldots \ldots \ldots \ldots \ldots \ldots \ldots \ldots \ldots \ldots \ldots \ldots \ldots \ldots, \ldots \ldots .2$

3.0 HIGHLIGHTS AND MAJOR MILESTONES $\ldots \ldots \ldots \ldots \ldots \ldots \ldots \ldots \ldots \ldots \ldots$

4.0 INSTITUTIONAL CONSIDERATIONS/ORGANIZATIONS $\ldots \ldots \ldots \ldots \ldots \ldots \ldots . .4$

5.0 NUCLEAR FUEL PRODUCTION $\ldots \ldots \ldots \ldots \ldots \ldots \ldots \ldots \ldots \ldots \ldots$

6.0 FUEL RECYCLE $\ldots \ldots \ldots \ldots \ldots \ldots \ldots \ldots \ldots \ldots \ldots \ldots \ldots \ldots$

7.0 SPENT FUEL STORAGE AND TRANSPORT $\ldots \ldots \ldots \ldots \ldots \ldots \ldots \ldots \ldots$

8.0 WASTE CONDITIONING, STORAGE AND TRANSPOAT $\ldots \ldots \ldots \ldots \ldots \ldots \ldots$ CH.8

9.0 DISPOSAL OF NON-HIGH-LEVEL WASTES $\ldots \ldots \ldots \ldots \ldots \ldots \ldots \ldots \ldots \ldots \ldots \ldots$

10.0 DISPOSAL OF HIGH-LEVEL WASTES $\ldots \ldots \ldots \ldots \ldots \ldots \ldots \ldots \ldots \ldots \ldots \ldots$

11.0 MANAGEMENT OF URANIUM MINE AND MIU WASTES $\ldots \ldots \ldots \ldots \ldots \ldots \ldots$ CH.14

12.0 DECOMMISSIONING AND ENVIRONMENTAL FESTORATION $\ldots \ldots \ldots \ldots \ldots \ldots$ CH.15

13.0 INTERNATIONAL ACTIVITIES $\ldots \ldots \ldots \ldots \ldots \ldots \ldots \ldots \ldots \ldots \ldots \ldots \ldots \ldots \ldots$

14.0 REFERENCES $\ldots \ldots \ldots \ldots \ldots \ldots \ldots \ldots \ldots \ldots \ldots \ldots \ldots \ldots \ldots \ldots$ 


\subsection{NUCLEAR POWER}

1.1 REACTOR MIX: One 300-MWe PWF (indigenous) under construction at Qinsan (near Shanghai) is scheduled to start up in 1990-1991; two 900-MWe foreign-built PWRs are under construction at Guangdong (Daya Bay) and are scheduled to start up about 1993; two indigenous 600-MWe PWRs are under construction at Qinshan and are scheduled to start up in 1995-1996 (this type of 600-MWe unit is expected to be the mainstay of the future China nuclear industry); other units are under consideration, including HTGRs; R\&D is also under way for future breeders and fusion reactors (Peng 1988; NF 11/13/89; EIA 1989)

1.2 ELECTRIC POWER PRODUCTION (NEI 10/87; EIA 1989)

1986--445 TWh total production 1987-496 TWh total production

91 GWe total capacity (approx. $70 \%$ coal; 30\% hydro)

12 MWe geothermal

3 MWe tidal

2 MWe wind

2000-230 GWe total projected, including $140 \mathrm{GWe}$ coal (Qian 1989)

\subsection{NUCLEAR POWER CAPACITY PROJECTIONS}

1989--0.0 GWe

1991--0.3 GWe

1995-1.5 GWe

2000--6.0 GWe (NF 9/27/87; NF 11/13/89)

2015--30 GWe (NF 10/3/88)

\subsection{NUCLEAR ENERGY POLICY}

A. Coal and hydroelectric stations will continue to provide the great majority of power needs in China, with many additional new sites and facilities being planned and constructed; nuclear power could provide a significant fraction of new capacity

B. China considers nuclear energy important to energy security (U.S. House of Representatives 1985)

\subsection{NUCLEAR FUEL CYCLE AND RADIOACTIVE WASTE MANAGEMENT STRATEGY/POLICY}

2.1 OVERAL NUCLEAR FUEL CYCLE POUCY: China plans to acquire foreign technology and become self-sufficient with respect to all parts of the fuel cycle (U.S. House of Representatives 1985)

2.2 POLICY ON THE FRONT END OF THE NUCLEAR FUEL CYCLE: China plans to become selfsufficient in mining, milling, enrichment, fuel fabrication and uranium dioxide conversion to uranium hexafluoride (U.S. Congress 1985)

A. China plans to export an average of 1,000 MTU/yr uranium over the next decade, either as $\mathrm{U}_{3} \mathrm{O}_{8}$ or $\mathrm{UF}_{6}$, enriched or natural, at market prices (NF 2/9/87; NF 12/25/89)

B. China is marketing its 300-MWe PWR to ther countries (NN 1/90) 


\subsection{POLCY ON THE BACK END OF THE NUCLEAR FUEL CYCLE}

A. In China, spent fuel will be reprocessed to conserve resources; HLW will be vitrified and placed in engineered storage for 30-50 years and finally disposed of into a geological formation (LuO 1987; NE] 12/87; Yang 1987)

B. Low- and intermediate-level wastes from nuclear facilities will be stored onsite for one to two years, then transported to regional shallow-ground disposal facilities; intermediatelevel liquid waste from reprocessing is planned to be disposed of by hydrotracturing (Pan 1989; Xian De 1989)

\subsection{HIGHLIGHTS AND MAJOR MILESTONES (NEI 6/86; Yang 1987)}

1949 Founded People's Republic of China

1958 Commissioned first research reactor, HWR-1

1960 Passed first national atomic energy law

1962 Started up first uranium mine

1964 Started enrichment by gaseous diffusion

1970 Started industrial-scale reprocessing of defense fuels

1978 Announced start of civil nuclear power program, including 300-MWe PWR and two 900-MWe PWRs

1979 Decided on PWR for Daya Bay

1984 Offered to store spent nuclear fuel for other countries; suspended offer in 1989

1985 Started R\&D on deep geologic disposal and on continuous vitrification of HLLW

1986 Announced new nuclear power program based on indigenous designs; launched nuclear export drive

1987 Started production of fuel for PWRs

1990 Identify candidate geologic HLW repository site and begin feasibility study

1991 Start up first nuclear power reactor at Qinsan

1996 Start up pilot scale reprocessing plant for power reactor fuel

2010 Decide on site for geologic repository for HLW disposal

2020 Begin construction of HLW repository 
2030 Begin trial disposal of HLW

2040 Begin full-scale operation of HLW repository

\subsection{INSTITUTIONAL CONSIDERATIONS/ORGANIZATIONS}

\subsection{LEGAL REQUIREMENTS}

A. China's national Environmental Protection Law of 1979 is now undergoing revisions (Cooley 1988)

B. Under development in China are: a revision of the national atomic energy law (originally passed in 1960 and revised in 1974); nuclear pollution control act which will regulate the management principles for radioactive wastes; and guidance for radioactive waste management for nuclear power stations (Cooley 1988; Pan 1989)

c. In 1989 , standards and techuical regulations including classification of radioactive wastes and disposal of low- and intermediate-level wastes were issued (Pan 1989)

\subsection{RADIATION PROTECTION PRINCIPLES}

A. These principles were established in the radiation protection regulations (1960, revised in 1974) and in the national Environmental Protection Law of 1979, but are undergoing revisions; radiation dose to the public is being changed from $500 \mathrm{mrem} / \mathrm{yr}$ to $100 \mathrm{mrem} / \mathrm{yr}$ (Cooley 1988; Pan 1989)

B. In China, implementation of ALARA principle is encouraged (Pan 1989)

\subsection{KEY AGENCIES AND FUEL CYCLE CENTERS (Leigh and Mitchell 1990)}

A. The Ministry of Energy (formed in March 1988) reports to the state (federal) council which resolves all issues; some key organizations in the ministry are as follows (Jiang 1987; NN 5/88; Cooley 1988; EIA 1989):

1) CNNI, the China National Nuclear Industry Corporation, is responsible for promotion of all aspects of nuclear power including fuel cycle development; it comprises about 200 companies, associations and institutes

a. DSPEH, the Department of Safety Protection, Environment and Health, is responsible for controlling the activities of $\mathrm{CNNI}$ operations; it coordinates waste management activities in China

b. Development and operating organizations (including management of their respective wastes) are the following:

- Nuclear Power Bureau

- Mining and Milling Department

- Nuclear Fuel Cycle Department (responsibilities include management of spent fuel, including fuel reprocessing)

- Department of Science and Technology Development 
8. National Environment Protection Bureau, which reports to State Council; it issues licenses for ervironmental protection; the Environment Protection Agency of each province or city reports to this bureau

C. National Nuclear Safety Bureau reports to the State Council; it is responsible for safety regulations and assessments, and licenses relative to nuclear safety

D. Committee on Science and Technology advises the State Council and the National Nuclear Safety Bureau

E. Supporting organizations are:

1) Institute of Atomic Energy, which develops waste treatment and conditioning and fuel reprocessing

2) Institute for Radiation Protection

3) Beijing Nuclear Engineering Institute, which designs and engineers facilities for fuel reprocessing and waste treatment and conditioning

4) Institute of Uranium Geology, whose work includes prospecting for uranium, R\&D on mining and milling, siting of disposal facilities and barrier materials

5) Qinhua University near Beijing, which carries out R\&D on cement solidification

F. Most front-end nuclear facilities are in the southeast part of China (Cooley 1988)

\subsection{PRINCIPAL RESEARCH, DEVELOPMENT AND DEMONSTRATION FACILITIES/PROGRAMS}

A. Atomic and Nuclear Energy Research Institute of the Academy of Sciences (Beijing area and southwest China) carries out nuclear R\&D

8. IAE (Institute of Atomic Energy) leads R\&D for nuclear energy and development of waste vitrification technology including investigation of glass formulation, characterization and evaluation of glass products, as well as chemistry of final disposal; it also carries out R\&D on cementation, bitumenization, incineration, and incorporation of wastes into polymers (Cooley 1988)

1) The twin screw bitumenizer-extruder has the capacity to evaporate 200 liters/day; product is $25 \%$ waste solids

2) The pilot incinerator has the capacity for 10 liters/hour of organic liquids

\subsection{KEY PERSONNEL}
A. Pan Zi Qiang, Deputy Director, DSPEH
B. Jiang Xinxiong, President, CNNI
C. Jiang Yunqing, Senior Engineer, CNNI Department of Nuclear Fuel 

D. Wang Deming, Director, CNNI Department of Science and Technology
E. Ma Xinli, Senior Engineer, CNNI Department of Foreign Affairs
F. Zhao Fengmin, Director, Beijing Institute of Uranium Geology
G. Luo Shangeng, Deputy Director, Radiochemistry Division, LAE

\subsection{NUCLEAR FUEL PRODUCTION}

5.1 URANIUM RESOURCES: China has many ore deposits, of which about $60 \%$ are classed as low-to-medium grade; uranium has been discovered in nearly every province; available resources in 1987 were 100,000 MTU (260 million lb $\left.\mathrm{U}_{3} \mathrm{O}_{8}\right)$ (NF 2/9/87; NF 10/3/87; NF $11 / 13 / 89$ )

\subsection{URANIUM PRODUCTION}

A. Uranium mining and milling is carried out at a number of sites (NF 11/13/89)

B. China's first three uranium mines (Chen-Xian in Hengshan Province, Shangrao in Hunan Province, and Shangrao in Jianqxi Province), and its first mill (Heng Yang in Hunan Province) all were developed in 1956-1958 and went into service in 1962-1963; further mines in Xinjiang, Zhejiang, and Liaoning Provinces were developed in the second stage of development; one mill is at Heng Yang can produce $1100 \mathrm{MT} /$ year of uranium (NF 10/3/87; IAEA 1988; Cooley 1988)

C. China can process 2 million tons of uranium ore (roughly equivalent to 5.2-7.8 million lbs of $\mathrm{U}_{3} \mathrm{O}_{8}$ ) annually (NF $3 / 6 / 89$ )

D. China employs open-pit and underground mining methods; acid extraction is used in most cases and most milis produce pure $\mathrm{UO}_{2}$, although $\mathrm{U}_{3} \mathrm{O}_{8}$ is available for export (NF 2/9/87)

E. China planned to supply $600 \mathrm{MT}$ of uranium concentrates to Finland during 1988-95 (NE 10/87)

F. R\&D in China is aimed at improving extraction efficiency and reducing production costs; some heap leaching tests have been carried out (NF 10/3/87)

\subsection{URANIUM CONVERSION}

A. One facility is located in south-central China (Cooley 1988)

B. China can process 2 million tons of uranium ore, or $2-3$ thousand tons of uranium metal (roughly equivalent to 5.2-7.8 million Ibs of $\mathrm{U}_{3} \mathrm{O}_{8}$ ) annually (NF $3 / 6 / 89$ )

\subsection{URANIUM ENRICHMENT}

A. China has been developing centrifuge enrichment since the late 1950 s and laser enrichment since the late 1970s; it is currently working on the CRISLA process (chemical reaction by isotope laser activation) (NW 10/23/86; NE 12/86; NF 10/3/87; NF 6/26/89) 
B. Gaseous diffusion enrichment has been conducted in China since 1964 in the Lanzhou plant (NEI 6/86; NF 10/3/87)

C. China has two gaseous diftusion facilities with a total capacity estimated at about 300,000 SWU/yr at Lanzhou in Gansu Province in central China; another facility has a capacity of about 400,000 SWU/yr (NF 11/13/89)

D. China has been selling enriched uranium abroad since 1981 (NF 10/3/88)

\subsection{FUEL FABRICATION}

A. R\&D on fabricating fuel for power reactors was started at Yibin in Sichuan Province in 1975 , with the first trial assembly produced in 1984 (NF 10/3/87)

B. As of 1987, PWR fuel-manufacturing facilities were completed at Yibin in Sichuan Province and trial production began; by 1995, expected capacity is $150 \mathrm{MTU} / \mathrm{yr}$; the Sichuan Yibin fuel components factory, the only such factory in China, plans to upgrade the facility to include fuel for 600- and 900-MWe reactors (NF 10/3/87; NEI 11/87; NW 12/21/89)

\subsection{FUEL RECYCLE}

\subsection{FUEL REPROCESSING}

A. Reprocessing in China uses the PUREX solvent extraction process, using mixer-seltlers; R\&D on various types of pulse columns is in progress Nang 1987; Jiang 1987; De-Xi 1988)

B. R\&D on reprocessing started in the late 1950s for defense purposes; a trial reprocessing workshop was built for military purposes in 1968, and a military reprocessing plant was set up in 1970 in northwestern China (Jiang 1987; NF 10/3/87)

C. A $100-\mathrm{kg} / \mathrm{d}$ reprocessing pilot plant (in the Gobi Desert in the Quinshai Province in northcentral China) for commercial fuel is scheduled to begin service in 1996 (NF $9 / 27 / 87$; NEI 2/89); also planned to be included in the pilot plant is recovery of noble metals, neptunium, americium and curium from the HLLW stream; the goal is to extract a few thousand $\mathrm{kg} / \mathrm{yr}$ of noble metals for China's petrochemical industry (NF 5/18/87; De-Xi 1988)

D. A non-radioactive reprocessing test facility in north-central China is scheduled for operation in the 1990s; it will test processes, equipment, and instrumentation for use in a pilot plant (Cooley 1988)

E. A larger-scale reprocessing plant is planned to be under construction by about 2000-2010 at the same $20,000-\mathrm{km}^{2}$ site in the Gobi Desert as the pilot-scale reprocessing plant; the plant will also recover noble metals, neptunium, americium and curium from the HLLW stream; the first stage will be completed by 1995; the complex will include a solidification plant and a permanent burial site for solid radioactive waste (De-Xi 1988; NEI $2 / 89$; NWN 5/4/89)

F. A plant was built to remove cesium from defense HLW but has not operated because no current industrial applications are available for the cesium (Slate 1988) 
G. $R \& D$ is in progress for managing the liquid wastes generated in reprocessing; R\&D also includes no-inorganic-salt chemical reductants in reprocessing (NEI 12/87; De-Xi 1988)

H. The existing reprocessing plant in the Gobi Desert in Gansu Province uses chemical decladding of aluminum-clad fuels and neutralizes the rafinates from the second uranium and plutonium solvent extraction cycles for storage; the resultant wastes are ILWW (Feng-Ting 1989)

\subsection{SPENT FUEL STORAGE AND TRANSPORT}

7.1 SPENT FUEL ARISINGS: By the year 2000 there will be 1600 MTU cumulative for 10,000 years of nuclear power (Yang 1987)

7.2 WET STORAGE: All spent fuel discharged in the 1990s will be temporarily stored at reactor site pools, planned for 3 to 10 years before reprocessing; pools at Qinshan will have design capacity of 15 years; pools at the 900-MWe PWRs at Guangdong will have storage space for 2.33 reactor cores; interim storage at the reprocessing plant is also in storage pools (Jiang 1987; Cooley 1988)

7.3 SPENT FUEL STRATEGIES: China plans to store spent fuel at reactor sites for about 10 years, then move the fuel to a central interim storage facility (Cooley 1988)

\subsection{WASTE CONDITIONING, STORAGE AND TRANSPORT}

8.1 WASTE DEFINITIONS (Based on the Standard for Classification of Radioactive Wastes, GB9133) (Xian De 1989)

A. Low-level wastes:

liquid: $\quad 1 \times 10^{8}$ to $1 \times 10^{5} \mathrm{Ci} / \mathrm{L}$

gaseous: dac ${ }^{\star}$ to $1 \times 10^{4} \mathrm{dac}^{\star} \mathrm{Ci} / \mathrm{m}^{3}$

gaseous: $2 \times 10^{-6}$ to $1 \times 10^{-3} \mathrm{Ci} / \mathrm{kg}$

B. Intermediate-level wastes:

liquid: $\quad 1 \times 10^{-5}$ to $1 \times 10^{-1} \mathrm{Ci} / \mathrm{L}$ gaseous: $1 \times 10^{4}$ dac to $1 \times 10^{8} \mathrm{Ci} / \mathrm{m}^{3}$

gaseous: $1 \times 10^{4}$ to $10 \mathrm{Ci} / \mathrm{kg}$

"dac= icrp derived air concentration limit that would yield the lifetime allowable dose received in each year

C. Composition of liquid wastes (ILLW) from chemical decladding of aluminum-clad fuel: sodium nitrate $280 \mathrm{~g} / \mathrm{L}$, sodium carbonate $40 \mathrm{~g} / \mathrm{L}$, sodium hydroxide $80 \mathrm{~g} / \mathrm{L}$, sodium aluminate $100 \mathrm{~g} / \mathrm{L}$, aluminum $14 \mathrm{~g} / \mathrm{L}$, total salt $311 \mathrm{~g} / \mathrm{L}$, uranium $3.8 \times 10^{-4} \mathrm{~g} / \mathrm{L}$, plutonium $9.4 \times 10^{-6} \mathrm{~g} / \mathrm{L}, 0.02$ to $0.05 \mathrm{Ci} / \mathrm{L}$ beta (Xian De 1989; Feng-Ting 1989)

D. Composition of intermediate-level liquid wastes as neutralized raffinate from second uranium and plutonium solvent extraction: sodium nitrate $330 \mathrm{~g} / \mathrm{L}$, sodium carbonate $50 \mathrm{~g} / \mathrm{L}$, sodium hydroxide $20 \mathrm{~g} / \mathrm{L}$, total salt $330 \mathrm{~g} / \mathrm{L}$, uranium $2.8 \times 10^{-4} \mathrm{~g} / \mathrm{L}$, plutonium $2.6 \times 10^{-5} \mathrm{~g} / \mathrm{L}$, 0.05 to $0.12 \mathrm{Ci} / \mathrm{L}$ beta (Xian De 1989; Feng-Ting 1989) 
E. Composition of typical low-level liquid wastes: total salt $>300$ to $<500 \mathrm{~g} / \mathrm{L}$ (consisting of sodium nitrate, sodium carbonate, sodium sulfate and sodium oxalate), ammonia ion $<0.5 \mathrm{~g} / \mathrm{L}, \mathrm{pH} 10-13$, and beta activity $4 \times 10^{-4} \mathrm{Ci} / \mathrm{L}$ (Feng-Ting 1989)

F. Typical low-level liquid wastes from the future Quinshan nuclear power station are (Wang 1988):

1) Borated wastes: $15.7 \mathrm{Wt} \% \mathrm{NaBo}_{2} ; 0.0006 \mathrm{Ci} /$

2) Low-level wastes: 30 wt\% $\mathrm{NaNo}_{3}$, with small amounts of $\mathrm{CaCo}_{3}$ and $\mathrm{MgCo}_{3}$; $0.00006 \mathrm{Ci} / \mathrm{L}$

3) Sludges: silt; $1 \times 10^{7} \mathrm{Cin}$

4) Chemical wastes: boron +3 ion $1500 \mathrm{ppm}$, lithium +1 ion $2 \mathrm{ppm} ; 2.2 \times 10^{-7} \mathrm{Ci} / \mathrm{L}$

\subsection{WASTE ARISINGS}

A. In 1988, China accumulated $3700 \mathrm{~m}^{3}$ solid $\amalg W$ from the two research reactors, $2000 \mathrm{~m}^{3}$ of LLW from fuel reprocessing, $50 \mathrm{~m}^{3}$ of LW from use of isotopes, and $1000 \mathrm{MT}$ of wastes from enrichment (NW 5/26/88; Cooley 1988)

B. China expects $160 \mathrm{~m}^{3}$ of HLW glass from $1600 \mathrm{MT}$ of spent fuel from nuclear power reactors and $1650 \mathrm{~m}^{3}$ of transuranic waste from 10,000 MWe-years of nuclear power; it expects $20,000 \mathrm{~m}^{3}$ of all radioactive wastes by year 2000 from the nuclear power reactors (Yang 1987; Cooley 1988)

C. The volume of solid and concentrates of $L W$ and ILW accumulated over the past 30 years in China was 'dozens of thousands of cubic meters' (Shi 1987); in another estimate, the volume of detense UW as of earty 1986 was several hundred cubic meters; by the year 2000, the volume of defense HUW, which is now stored in stainless steel tanks, will be more than $1000 \mathrm{~m}^{3}$; China's commercial HLW glass volume will be $160 \mathrm{~m}^{3}$ and TRU waste volume will be $1650 \mathrm{~m}^{3}$ (Yang 1987)

\subsection{STRATEGY}

A. Low- and intermediate-level wastes: control the amount produced, collect and classify, treat to reduce volumes, immobilize, package in good containers, interim-store onsite, and transport to regional disposal facilities; liquid ILW from reprocessing is planned to be disposed of by hydrofracture (Cooley 1988; Pan 1989)

B. China's high-level wastes will be vitriified for deep geologic disposal; vitrification of defense HLW can start as early as year 2000 (Yang 1987; Cooley 1988)

\subsection{HLW IMMOBILIZATION}

A. The HLLW contains about $4.5 \mathrm{~g} / \mathrm{L}$ aluminum, $30 \mathrm{~g} / \mathrm{L}$ sodium, $13 \mathrm{~g} / \mathrm{L}$ iron, $18 \mathrm{~g} / \mathrm{L}$ uranium, and $4.8 \mathrm{~g} / \mathrm{L}$ sulfate $(\mathrm{Wang} 1989$ )

B. HLW will be vitrified into canisters (Yang 1987); a borosilicate glass vitrification plant is being developed with help from the FAG; the HLW has sufficient sulfate content to require special flowsheets to prevent separation of a sulfate phase in the glass melt; a joule-heated melter system has been selected as the vitrification process (Bradley 1989) 
C. An industrial-scale mock-up vitrification facility will be built in the mid-1990s; it is not clear whether this will later become a radioactive unit (Liu 1989)

D. China is considering conversion of $\mathrm{H} \amalg W$ to SYNROC; a study is being undertaken with Australia on the feasibility of an active SYNAOC demonstration plant in China, including investigation of possible disposal sites (NEI 12/88)

\subsection{LLW/LW CONDITIONING}

A. In China, LLW and ILW are solidified by incorporation into cement or bitumen (Ren 1987); the nuclear power station at Quinshan will have a cementation facility for conditioning liquid LLW; there is also a pilot bitumenization facility and a compaction facility at one station; wastes are placed in bags and barrels (Wang 1988; Cooley 1988)

B. The Institute of Atomic Energy and other institutions pre-treat high-salt, low-level liquid wastes first by flocculation/precipitation with an alkaline $\mathrm{pH}$ using sodium hydroxide, sodium phosphate, ferric sulfate and potassium permanganate; after settling, the sludges are dewatered by centrifuging, then placed in drums for storage; the trend is away from this treatment because of its low decontamination factor of about 10 (Cooley 1988; Xian De 1989)

C. A bitumenization facility at a reprocessing plant will start trial tests soon after 1989; the facility can concentrate ILLW up to $12 \mathrm{~m} / \mathrm{d}$ using a rotary-scraping film evaporator; the leach rate of the bitumen is about $1 \times 10^{-5} \mathrm{~cm} / \mathrm{d}$ (Xian De 1989)

D. At the Quinshan reactor, in-drum cementing of several kinds of waste will be carried out; the facility will have the capacity of $550 \mathrm{drums} / \mathrm{yr}$; the carbon steel drums are $560 \mathrm{~mm}$ in diameter and $900 \mathrm{~mm}$ high; $190-200 \mathrm{~kg}$ of cement and 90-100 liters of waste are mixed in each drum (Xian De 1989)

E. The Institute of Atomic Energy treats liquid wastes by evaporation, then by ion exchange; denigration during evaporation is sometimes carried out by addition of formaldehyde (Cooley 1988; Xian De 1989)

F. In general, ion exchange is used to treat low-salt liquid wastes including evaporator distilletes; fittration is used to treat liquid wastes with very low radioactivity levels (Xian De 1989)

G. Solid wastes are collected and sorted onsite and are then incinerated or mechanically compacted; some incinerators with a capacity of $50 \mathrm{~kg} / \mathrm{hr}$ are under construction; mechanical compaction using a pressure of 7 to 9 atmospheres yields volume reduction for compatible wastes by factors of 4.9-5.3 (Xian De 1989)

H. The Institute of Atomic Energy uses a batch, horizontal, three-axis compactor with a pressure of $100 \mathrm{MT}$ for compatible solid LWW (paper, plastics, rags) with radioactivity levels less than $1 \times 10^{-4} \mathrm{Ci} / \mathrm{kg} ; 2 \mathrm{~m}^{3} / \mathrm{hr}$ of wastes in plastic bags (a total of $0.6 \mathrm{~m}^{3}$ ) can be fed to the machine, yielding an average volume reduction factor of about 7; compacted briquettes are put into 80 -liter drums that are then capped and sealed; surface dose rates of the filled drums are less than $200 \mathrm{mrem} / \mathrm{hr}$; another similar unit will be installed in Shanghai in late 1989 (Zongzhou 1989)

I. Plutonium-contaminated wastes will be solidified in cement (Cooley 1988) 
J. Some LIW and ILW are decomposed in a pilot-scale pyrolysis incinerator (Cooley 1988; Pan 1989)

$K \quad$ In situ cementing of ILLW is planned at the existing reprocessing plant (see Section 9 below)

L. China has a plant to remove radiocesium from defense $\mathrm{HLW}$, but as of 1987 had not operated it because of lack of firm applications for use of the cesium (Slate 1987)

\subsection{AIRBORNE WASTES TREATMENT AND IMMOBIUZATION}

A. Radioiodine is removed from reprocessing off-gases using silver-coated silica gel (Di-Xi 1988)

B. Filtration and electrostatic precipitation are used for cleaning off-gases from reprocessing plants; polymer fibers (operating temperatures below $60^{\circ} \mathrm{C}$ ) and glass fibers are used in filters; decontamination factors are 100 to 1000 for single fithers and about 10,000 for two filters in series; a pipe-type electrostatic precipitator ( $3500 \mathrm{~mm}$ long by $273 \mathrm{~mm}$ in diameter) is used to give decontamination factors of 330 to 1000 (Xian De 1989)

\subsection{LLW/LW STORAGE}

A. Interim storage is typically onsite (in 200-liter steel drums for solid wastes); in the longrun, China expects to have central storage located at disposal facilities; each province will have its own interim storage facility for spent radiation sources; as of 1989, twelve storage facilities had been built at a cost of more than 42 million yuan ( $\$ 11$ million U.S.), and 10 more were to be built in 1989 in Anhui, Sichuan, Tlanjin and other places; another waste storage facility will be built at a fuel reprocessing complex and permanent burial site in the Gobi Desert in about 1995 (Cooley 1988; NWN 5/4/89; Zongzhou 1989)

B. Interim storage of ILLW from reprocessing is onsite in mild steel tanks (12 $\mathrm{m}$ diameter by $6 \mathrm{~m}$ high) in individual concrete cells with steel-lined floors, located underground; the inside and outside tank walls and the floor of the cells are coated with asphalt; storage of the oldest ILLW has lasted 20 years as of 1989 (Feng-Ting 1989)

8.8 HLW STORAGE: Interim storage is onsite; in the long-run, China expects to have central storage located at disposal facilities; a surface facility will be buit at a fuel reprocessing complex in the Gobi Desert by 1995 to store vitrified HLW (Yang 1987; Cooley 1988; NWN 5/4/90)

\subsection{TRANSPORT OF WASTES}

A. Annual freight volume of radioactive material and $\amalg W / \mathrm{LW}$ is approximately 100,000 packages; radioisotopes are mainly iodine-131, phosphorus-32, and gold-198 (Fan 1986)

B. Transport of HLW is expected to be by rail (Cooley 1988)

\subsection{RESEARCH AND DEVELOPMENT}

A. $\amalg W / L W$

1) Research is being done in the areas of bitumenization, cementation, solidification with plastics, incineration, compaction, migration of radionuclides in soils, electrodialysis, and reverse osmosis separations (Cooley 1988; Wang 1988) 
2) Engineering-scale testing has been carried out in two parallel bitumenization units with a capacity of $250 \mathrm{~L} / \mathrm{hr}$ of ILLW each; after modifications of the evaporator to eliminate scale formation (adding more scraper blades and larger motor), screening the asphalt, and adding a surfactant, satisfactory performance was obtained using highway asphalt; the facility is expected to be commissioned soon for radioactive operation (Feng-Ting 1989)

B. HLW (Wang 1989; Liu 1989)

1) Vitrification studies started in 1977 in China; a pot vitrification process similar to the PIVER process, using induction-heated furnace at $1100-1150^{\circ} \mathrm{C}$, was tested in a non-radjoactive unit up to 1985; pots/canisters were austenitic stainless steel and $120-137 \mathrm{~mm}$ in diameter by $739-920 \mathrm{~mm}$ long; work was abandoned because of the low capacity of the pot system

2) Borosilicate glass with $16-20 \%$ waste oxides is currently being studied in a twostage continuous process similar to the German/Belgian PAMELA or French AVM process; sulfate concentration in the final glass is $0.48 \%$; a non-radioactive full mock-up facility is being developed for startup in the mid-1990s, with a calciner throughput capacity of $50-55 \mathrm{l} / \mathrm{hr}$, producing glass at $40-45 \mathrm{~kg} / \mathrm{hr}$; the glass canister is $430 \mathrm{~mm}$ in diameter and $1335 \mathrm{~mm}$ in height

3) Glass formulation efforts have been directed to glasses with low leach rates and the capability to incorporate sulfate in the waste with no resulting separate sulfate yellow phase; a borosilicate glass (designated No. 704) is the best, with a melting temperature of $1300^{\circ} \mathrm{C}$ and a leach rate of $1.7 \mathrm{~g} / \mathrm{cm}^{2} / \mathrm{d}$; glass formulations are still under study

4) China is also interested in converting HLW to SYNROC; performance evaluations of waste forms are also carried out (NEI 12/88)

5) Control of ruthenium volatilization during waste evaporation and vitrification has been studied; denitration during evaporation before vitrification using formic acid is preferred

\subsection{DISPOSAL OF NON-HIGH-LEVEL WASTES}

9.1 STAATEGY: China plans to dispose of solid LLW-ILW in two or three regional shallow-ground facilities by the year 2000; one will be sited in northeast China where the nuclear power plants are located, and one in the northwest to support defense activities; liquid ILW from reprocessing are planned to be disposed of by hydrofracturing; transuranic wastes are likely to be disposed of in a deep geologic repository (Yang 1987; NW 5/26/88; Cooley 1988; NN 4/89; Xiang De 1989)

\subsection{LLW/ILW DISPOSAL}

A. Most LLW is currently disposed of in shallow-land trenches (NE 12/86)

B. Investigations are completed for the norhwest disposal site (a dry region in the Gobi Desert in the Taishon district; disposal at the reprocessing plant site is preferred); investigations are underway for the northeastern site in Zhejiang province near Shanghai (a 
wet region); wastes in steel containers are reportedly to be disposed of between 5 and 30 meters underground (Cooley 1988; NEI 2/89; NUKEM 8/89)

C. In situ immobilization is planned for use where the disposal site is near the waste generation site; one such facility is planned and has been designed for ILW at the Lanzhou reprocessing facility in the Gobi Desert area where non-radioactive tests were carried out in 1986; ten concrete trenches or "silos" $(8 \times 8 \times 6 \mathrm{~m})$ will be built underground; radioactive waste, dehydrating additives, and cement (at a ratio of waste:cement of 0.5 and salt:cement about 0.3 ) will be fed to a mixer and fed to a silo (pouring time is about 26 hours); after the silo is full, a 1-m cover of clay will be added, a concrete cap will be poured into the silo, and the cap will be covered with $7 \mathrm{~m}$ of soil; groundwater at the site is about $40 \mathrm{~m}$ deep (Xian De 1989; Feng-Ting 1989)

\subsection{LLW/ILW DISPOSAL R\&D}

A. In 1988, China was planning on selecting a site and developing a large facility for radionuclide migration testing (Cooley 1988)

B. Since the early 1980 s, a hydrofracture process has been under development for final disposal of ILLW onsite at the reprocessing plant; twelve survey wells were drilled in 500-mdeep shale ( $150 \mathrm{~m}$ below the water table) at a candidate site; two experimental injections, one with water and the second with concrete, were successfully carried out in 1983 with favorable results; an environmental impact statement has been prepared; approval by the regulatory authorities is pending (NE 12/86; Xian De 1989)

C. Investigations are underway for rock cavity disposal of LLW/LW (Pan 1989)

\subsection{DISPOSAL OF HIGH-LEVEL WASTES}

\subsection{REPOSITORY DEPLOYMENT STRATEGY}

A. China's civilian solidified high-level wastes are to be stored for about 30 to 50 years as HLW, then disposed of in a deep geologic formation about the year 2030; transuranic wastes are likely to be disposed of in a deep geologic repository (Yang 1987; Cooley 1988)

B. China's HLW program is divided into four phases: technical preparation and site screening, geologic study, field test in underground laboratories, and repository construction (Yang 1987)

\subsection{SITE SELECTION AND CHARACTERIZATION}

A. Five or six sites will be selected for preliminary characterization before the final site is selected; the north-central region is preferred because of proximity to defense facilities; the repository will dispose of civilian and defense wastes; the Gobi Desert is not a prime location for a repository because of the transportation problem (NW 5/26/88; Cooley 1988)

B. The schedule is (Yang 1987; NW 5/26/88; Cooley 1988):

1) Selection of region (1985-1988) 
2) Selection of area (1988-1991)

3) Exploration and characterization (1991-2000)

4) Decision on first site (2010)

5) Detailed site characterization by field tests that include an underground research laboratory (timing to be determined)

6) Construction (2020 to 2030) and trial repository operation in retrievable mode (2030-2040) followed by repository operation about 2040

\subsection{REFERENCE HLW/SPENT FUEL DISPOSAL CONCEPT}

A. Granite is the first choice for host rock for a repository in China (Yang 1987); also under consideration are tuff (about $1000 \mathrm{~m}$ thick), basalt (300-400 $\mathrm{m}$ thick at $1200 \mathrm{~m}$ depth), and possibly bedded salt (considered as a future resource) and clay (Cooley 1988)

B. Multiple barriers to waste dispersion are planned; disposal concepts are under study, including canister designs, and backfill materials such as montmorillonite (De-Xi 1988; Cooley 1988)

C. Borosilicate glass in stainless steel canisters is the first generation waste for.n (Luo 1987)

10.4 GEOSCIENCES R\&D: R\&D on deep geologic disposal started in 1985 in China; collection of scientific and technical information for siting and site evaluations and migration of radionuclides in a repository environment have been emphasized (Yang 1987; Cooley 1988)

\subsection{MANAGEMENT OF URANIUM MINE AND MILL WASTES}

11.1 WASTE ARISINGS: In 1988, China was processing about 1 million MT ore/yr at Heng Yang uranium mill center (about half the total uranium production in China); about 3,000 MT/d of sludge was going to ponds; 5.6 million MT of mining wastes and 14 million MT of milling wastes had accumulated (Cooley 1988)

11.2 STRATEGY/POLICY: China backfills the mine slag into excavated pits to the extent possible, and stabilizes for the long term the slag piles and tailings; some tailings dams are up to $40 \mathrm{~m}$ high (Cooley 1988)

\subsection{MANAgemENT PRACTICES}

A. Mill waters with uranium above $2 \mathrm{mg} / \mathrm{L}$ are treated by ion-exchange, then by precipitation using barium chloride, barium carbonate and manganese dioxide; ammonia and acids are recovered (Cooley 1988)

B. Tailings and ore piles are being stabilized (Pan 1989)

11.4 COSTS: About $10,000,000$ yuan (about $\$ 2,700,000$ U.S.) have been spent on the Heng Yang uranium mill (Cooley 1988) 


\subsection{DECOMMISSIONING AND ENVIRONMENTAL RESTORATION}

A. The HWRR-1, a 10-MW heavy water research reactor in Beifing, was shut down in 1978 after 20 years of operation; the reactor vessel was replaced with a new one; two heat exchangers and other equipment were replaced; total time for the work was about 1.5 years (Zunqi 1985)

B Some waste steel has been decontaminated and recycled, and some contaminated facilities are undergoing remediation (Pan 1989)

\subsection{INTERNATIONAL ACTIVITIES}

13.1 MEMBERSHIPS: China has been a member of the IAEA since 1984

13.2 COOPERATION WITH MULTI-NATIONAL AGENCIES (Cooley 1988)

A. China participates in IAEA-coordinated research program on performance of waste forms

B. China cooperates technically with IAEA on solidification of spent ion-exchange resins and organic polymers

\subsection{COOPERATION WITH USA}

A. China has an agreement with the U.S. on cooperation concerning peaceful uses of nuclear energy; the term is from 1985-2015

B. China is interested in increasing exchanges with U.S. DOE and with U.S. companies in several areas of radioactive waste management (Slate 1988)

C. Some natural uranium is exported from China to the U.S. (NF 6/12/89)

\subsection{COOPERATION WITH OTHER COUNTRIES}

A. China has reached bilateral agreements with France, Finland, Germany (FRG), U.K., Argentina, Pakistan, Switzerland, and Brazil since joining the IAEA in 1984 (NEI 11/86; NW 11/27/86; NW 7/30/87)

B. China has an agreement with Finland to supply 600 tons of uranium concentrate from 1988-1995 (NE 10/87)

C. China renewed its accord with ENEA (Italian Energy R\&D Agency) for cooperation on fusion, PWRs, and fast breeder reactors; a separate accord was signed for exchange of information on safety and emergency measures (NW 6/4/87)

D. Chinese officials have had several meetings with France and Germany (FRG) on the possibility of using AVM or PAMELA vitrification technology; a HLW vitrification plant is being developed with help from the FRG (Slate 1988; Bradley 1989)

E. China signed an agreement with Nuclear Waste Management of Australia for a feasibility study into an active SYNROC demonstration (NEI 6/90) 
F. China signed an agreement with Chile in March 1989 on uranium prospecting, mining, processing and extractive metallurgy in Chile (NEI 5/89)

G. An agreement was approved by the Japanese Diet for cooperation with China on research and application of radioactive isotopes; on design, construction and operation of nuclear reactors; and on disposal of radioactive waste (Kyodo News Service 1986)

H. China signed an agreement with the FRG to design a 10-MWe pebble-bed HTR at the Chinese Institute of Nuciear Techno'rgy in Beijing (NE] 4/89)

1. China signed an agreement with Switzerland on advanced reactor concepts (including reactors for district heating), production and application of radioisotopes, waste management, and environmental studies (NE 11/12/87)

\subsection{REFERENCES}

$-1985-$

U.S. House of Representatives. 1985, Nuclear Energy Cooperation with China. A hearing before the Special Subcommittee on U.S.-Pacific Rim Trade of the Committee on Energy and Commerce, September 12, 1985.

Zunqui, L. 1985. 'Overhaul and Reconstruction of the HWR-1 Reactor, A Decommissioning Project of Nuclear Reactors in China" Beijing Institute of Atomic Energy, April 15, 1985.

$-1986-$

Fan, S., et al. 1986. "Survey of Radioactive Material Transport in China." In Proceedings of Packaging and Transportation of Radioactive Materials, PATRAM '86. June 16-20, Davos, Switzerland.

Kyodo News Service. 1986. "Japan-China N-Power Pact Passed by Diet," May 21, 1986.

Nuclear Europe (NE). 12/86. 'Beijing Scientist Highlights China's R\&D in Fuel Cycle,' p. 32.

Nuclear Engineering International (NEI). 6/86. 'China's Nuclear Industry Comes of Age,' p. 23.

Nuclear Engineering International (NEI). 11/86. "Pakistan Signs Pact with China," p. 9.

Nucleonics Week (NW). 10/23/86. "Chinese Nuclear Development Efforts Said to Involve 200,000," p. 11.

Nucleonics Week (NW). 11/27/86. "China: Nuclear Cooperation Agreement Signed with Swiss," p. 12.

$-1987$.

Jiang, Y. Q., et al. 1987. "Preparing for Reprocessing of Spent Fuel from Nuclear Power Plants in China." IAEA-CN-48/291, presented at IAEA International Conference on Nuclear Power Performance and Safety, September 28 - October 2, 1987, Vienna. 
Nuclear Energy Joumal of the British Nuclear Energy Society (NEJ). 10/87. 'Power in China,' 26(5):272.

Nuclear Engineering Intemational (NEI). 11/87. "China Lays Foundations for the 21st Century," p. 11.

Nuclear Engineering International (NEI). 12/87. "China Goes for Reprocessing:" p. 51.

Nuclear Europe (NE). 10/87. "China to Supply Uranium to Finland," p. 56.

Nuclear Europe (NE). October-November 1987. "Swiss-Chinese Cooperation in Developing a Small Integral Heating Reactor System," p. 28.

Nuclear Fuel (NF). 2/9/87. "China Looking to Export 1,000 MTU/yr of Uranium in Next Decade, More Later," p. 1.

Nuclear Fuel (NF). 5/18/87. "Chinese Announce Plans for Rare Metals Recovery at Pilot Reprocessing Plant,' p. 7.

Nuclear Fuel (NF). 9/27/87. "Chinese Outline Plans for LWR Fuel Reprocessing Plants," p. 4.

Nuclear Fuel (NF). 10/3/87. "China Has Been Selling Enriched Uranium Commercially Since 1981, Official Says," p. 11.

Nucleonics Week (NW). 6/4/87. 'China: Italian Nuclear Agreements Reached,' p. 10.

Nucleonics Week (NW). 7/30/87. "China/Finland: Nuclear Cooperation Pact Signed," p. 15.

Ren, W., and S. Ming-Sheng. 1987. 'Cement Solidification of Radioactive Wastes and improvements." In Proceedings of 1987 international Waste Management Conference. November 29 - December 5, 1987, Hong Kong.

Luo, S., et al. 1987. "Evaluation of Solidified High-Level Waste Forms.' Presented at the IAEA Second Research Coordination Meeting on the Performance of Solidified High-Level Waste Forms and Engineered Barriers under Repository Conditions. April 6-10, 1987, Sydney, Australia.

Shi, C., L Xuequn, Y. Liji, Y. Kazhi, and W. Zhixiang. 1987. "An Overview and Status of Low and Intermediate Level Solid Radioactive Waste Management in China.' In Proceedings of 1987 International Waste Management Conference. November 29 - December 5, 1987, Hong Kong.

Yang, L. 1987. "High Level Waste Disposal in China." In Proceedings of 1987 International Waste Management Conference. November 29 - December 5, 1987, Hong Kong.

$-1988-$

Cooley, C. R. 1988. Summary of IAEA Sponsored WAMAP Mission to the Republic of Korea and the People's Republic of China. U.S. Department of Energy, Washington, D.C.

De-Xi, W. 1988. "Back End Status of the Nuclear Fuel Cycle in China." Nuclear Technology International, p. 80.

International Atomic Energy Agency (IAEA). 1988. The Nuclear Fuel Cycle Information System (a directory of nuclear fuel cycle facilities). International Atomic Energy Agency, Vienna, p. 56. 
Nuclear Engineering International (NEl). December 1988. "China Considers SYNROC Plant," p. 15. Nuclear News (NN). 5/88. "Energy Ministry Created to Cover MNI, MWREP,' p. 72.

Nucleonics Week (NW). May 26, 1988. "Chinese Plan to Have Several LLW Sites in Operation by Year $2000, "$ p. 11.

Peng, S. 1988. 'The Prospects for Nuclear Power in China.' Nuclear Technology International, p. 19.

Slate, S. C. 1988. Foreign Trip Report. International Waste Management Conference, November 26December 4, 1988, Hong Kong. Pacific Northwest Laboratory, Richland, Washington.

Wang, X. 1988. "Research and Development on Management of Radwastes from Nuclear Power Plants in China." IAEA-SM-303/37, IAEA Intemational Symposium on Management of Low and Intermediate Level Radioactive Wastes 1988. May 16-20, 1988, Stockholm, Sweden. International Atomic Agency, Vienna.

$-1989-$

Bradley, D. J. 1989. "Information from the IAEA Coordinated Research Program." Letter to Distribution. Pacific Northwest Laboratory, Richland, Washington.

Energy Information Administration of U.S. Department of Energy (E|A), 1989. "Commercial Nuclear Power 1989, Prospects for the United States and the World.' U.S. Department of Energy, Washington, D.C.

Feng-Ting, Y., W. Shi-Sheng, and J. YunQing. 1989. 'A Review on the Development of Two Immobilization Processes for ULW and ILLW in China: Paper in Proceedings of the 1989 Joint international Waste Management Conference. October 22-28, 1989, Kyoto, Japan. American Society of Mechanical Engineers, New York.

Liu, G. M., and W. Xian De. 1989. 'An Overview of Vitrification for High-Level Radioactive Waste in China. Paper in Proceedings of the 1989 Joint International Waste Management Conference. October 22-28, 1989, Kyoto, Japan. American Society of Mechanical Engineers, New York.

Nuclear Engineering International (NEI). February 1989. "Reprocessing Plant for Gobi Desert?' p. 14.

Nuclear Engineering Intemational (NEI). April 1989. "Interatom to Build HTR in China," p. 8.

Nuclear Engineering International (NEl). May 1989. "China to Aid Chile in Uranium Prospecting," p. 4.

Nuclear Fuel Special Report (NF). 6/26/89. "Looking Ahead to the Enrichment Marketplace of the 1990 s,' p. 1.

Nuclear Fuel (NF), 6/12/89. "U.S. First Quarter Figures on Soviet, Chinese U Imports Reported," p.18. Nuclear Fuel (NF). 11/13/89. "China Stops Production of Military HEU; All SWU Capacity Now for Civil Use," p. 5.

Nuclear News (NN). April 1989. "China: More Reactors Planned; Specifics Not Clear," p. 83.

Nuclear Waste News (NWN). 5/4/89. "China to Construct to Nuclear Waste Storage Sites This Year," p. 156. 
Nucleonics Week (NW). 12/21/89. "China Claims Big Profit Gains in 1989 Nuclear Sales, Exports," p. 8.

NUKEM Market Report on the Nuclear Fuel Cycle (NUKEM). 8/89. "Reprocessing and Waste Management, First Seven Months of 1989,' p. 5. NUKEM GmbH, Hanan, Federal Republic of Germany.

Pan, Z, M. Huanzhang, L. Xuequn, and C. Shi. 1989. "Management of Radioactive Waste in Chinese Nuclear Industry.' Paper in Proceedings of the 1989 Joint Imternational Waste Management Conference. October 22-28, 1989, Kyoto, Japan. American Society of Mechanical Engineers, New York.

Quian, J. 1989. 'Advanced Reactors in Developing Coumtries: A View from China.' IAEA Bulletin, p. 43. International Atomic Energy Agency, Vienna.

Wang, X. 1989. 'The Chinese Situation of Vitrification of High-Level Radioactive Waste." Paper submitted at IAEA Consultant Meeting on Design and Operation of High-Level Waste Vitrification Facilities. Intemational Atomic Energy Agency, Vienna.

Xian De, W., and S. M. Sheng. 1989. "Status and Development on Treatment of Low- and Intermediate-Level Radioactive Wastes in China.' Paper in Proceedings of the 1989 Joint International Waste Management Conference. October 22-28, 1989, Kyoto, Japan. American Society of Mechanical Engineers, New York.

Zongzhou, G., and J. Huimin. 1989. Development of Baling Machine for Compressing and Packing Radioactive Solid Wastes." Paper in Proceedings of the 1989 Joim Imternational Waste Management Conference. October 22-28, 1989, Kyoto, Japan. American Society of Mechanical Engineers, New York.

$-1990$

Leigh, I. W., and S. J. Mitchell. 1990. International Nuclear Fuel Cycle Fact Book. PNL-3594, Rev. 10, Pacific Northwest Laboratory, Richland, Washington.

Nuclear Engineering International (NEl). June 1989. "China, Major Restructuring," p. 21.

Nuclear Fuel (NF). 3/6/89. "China Offers to Undercut Competitors in Uranium Bids to Japanese Utilities,' p. 2.

Nuclear Fuel (NF). 12/25/89. 'Market Pauses While Chevron Eyes Deal for Mt. Taylor, DOE Restates Feed Policy,' p. 2.

Nuclear News (NN). 1/90. 'China to Supply PWR in 300-MWe Range,' p. 73. 

FINLAND 


\section{FINLAND}

\section{CONTENTS}

$1.0 \quad$ NUCLEAR POWER $\ldots \ldots \ldots \ldots \ldots \ldots \ldots \ldots \ldots \ldots \ldots \ldots \ldots \ldots \ldots \ldots \ldots$

2.0 NUCLEAR FUEL CYCLE AND RADIOACTIVE WASTE MANAGEMENT

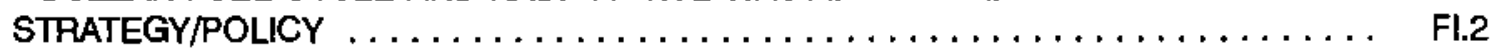

3.0 HIGHLIGHTS AND MAJOR MILESTONES $\ldots \ldots \ldots \ldots \ldots \ldots \ldots \ldots \ldots \ldots$

4.0 INSTITUTIONAL CONSIDERATIONS/ORGANIZATIONS $\ldots \ldots \ldots \ldots \ldots \ldots \ldots \ldots$

$5.0 \quad$ NUCLEAR FUEL PRODUCTION $\ldots \ldots \ldots \ldots \ldots \ldots \ldots \ldots \ldots \ldots \ldots \ldots \ldots \ldots$

6.0 FUEL RECYCLE $\ldots \ldots \ldots \ldots \ldots \ldots \ldots \ldots \ldots \ldots \ldots \ldots \ldots \ldots \ldots$

7.0 SPENT FUEL STORAGE AND TRANSPORT $\ldots \ldots \ldots \ldots \ldots \ldots \ldots \ldots \ldots \ldots \ldots$

8.0 WASTE CONDITIONING, STORAGE AND TRANSPORT $\ldots \ldots \ldots \ldots \ldots \ldots \ldots \ldots$ Fl.11

9.0 DISPOSAL OF NON-HIGH-LEVEL WASTES $\ldots \ldots \ldots \ldots \ldots \ldots \ldots \ldots \ldots \ldots$

10.0 DISPOSAL OF HIGH-LEVEL WASTES $\ldots \ldots \ldots \ldots \ldots \ldots \ldots \ldots \ldots \ldots \ldots \ldots$

11.0 MANAGEMENT OF URANIUM MINE AND MILL WASTES $\ldots \ldots \ldots \ldots \ldots \ldots \ldots$

12.0 DECOMMISSIONING AND ENVIRONMENTAL RESTORATION $\ldots \ldots \ldots \ldots \ldots \ldots$ FI.20

13.0 INTERNATIONAL ACTIVITIES $\ldots \ldots \ldots \ldots \ldots \ldots \ldots \ldots \ldots \ldots \ldots \ldots \ldots \ldots \ldots \ldots \ldots \ldots \ldots .21$

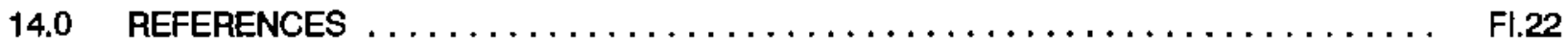




\subsection{NUCLEAR POWER}

1.1 REACTOR MIX: Two 445-MWe Soviet WERs (PWRs); two 710-MWe Swedish BWRs

\subsection{ELECTRIC POWER PRODUCTION}

$1988--58,700$ GWh (36\% nuclear, $26 \%$ hydro, $18 \%$ coal, $12 \%$ peat $/$ wood, $5 \%$ gas, $3 \%$ oil); additional imports amount to $13 \%$ of total electrical usage (NEI 1/90);

1990--60,700 GWh projected (30\% nuclear)

2000--79,700 GWh projected demand (NEI 1/90)

1.3 NUCLEAR POWER CAPACITY PROJECTIONS (NUKEM 5/90)

1989--2.3 GWe net

1995-2.3 GWe net

2000-3.3 GWe net

In March 1986, before the Chernobyl accident, PEVO had applied to the government to construct a fitth reactor ( $1000 \mathrm{MWe}$ ); a governmental decision on building the plant has been delayed until alter 1991; an agreement was signed with ABB Atom (Sweden) to work on an advanced BWR (NE 1987; NEI 1/90)

\subsection{NUCLEAR FUEL CYCLE AND RADIOACTIVE WASTE MANAGEMENT STRATEGY/POLICY (NEA 11/86; Leigh and Mitchell 1990; NE! 1/90)}

2.1 OVERALL NUCLEAR FUEL CYCLE POLICY: Finland's energy goal to reduce dependency on foreign oil makes a strong case for using nuclear power; Finland does not plan to reprocess its spent fuel, except that spent fuel from its Soviet-built reactors will be shipped to the USSR for reprocessing

\subsection{POLICY ON THE FRONT END OF THE NUCLEAR FUEL CYCLE:}

A. Finland plans on the foreign supply of uranium and its conversion, enrichment ar,d fabrication services

B. Small domestic deposits of uranium (1500 MTU) are to be held as reserves

2.3 POLICY ON THE BACK END OF THE NUCLEAR FUEL CYCLE: The national policy is based on storing spent fuel and other nuclear wastes at the power plant sites until they are transferred abroad or disposed of in Finland

A. The Finnish nuclear utilities have the financial and operational responsibility for nuclear waste management; annually the authorities give specific orders in connection with the review of annual waste research programs or reports; the principles of the waste management policy are set in the Finnish governments's policy decision of November 1983; the decision also set a target schedule which the utilities should follow in their preparations for the final disposal of wastes; a national program has been compiled for the different activities relating to waste management in Finland 
B. For spent fuel management, the utility companies are required to seek the use of international waste management services, including final disposal; in case this solution is not possible, the utilities must prepare themselves for the final disposal of spent fuel in the Finnish bedrock

C. Finland plans on storing spent fuel from two Soviet-supplied PWRs at the Loviisa power station for up to five years and then retuming the fuel to the Soviet Union for reprocessing; there will be no return of reprocessing wastes from the USSR back to Finland (NEA 1/90)

D. Spent fuel from non-Soviet nuclear power plants will be stored at the station site for about $\mathbf{4 0}$ years, then placed in granitic, deep bedrock repository in Finland (or, if available and attractive, utilize foreign fuel management services)

E. The planned long interim storage of spent fuel keeps both the direct disposal and reprocessing options open; thus, the decision against reprocessing has not been made, but direct disposal of spent fuel is favored on the basis of economics

F. Finland plans on storing immobilized LLW/LW at individual reactor sites until disposal facilities are available; the LLW/ILW from reactors will be disposed of in bedrock facilities beneath the nuclear power station sites

G. Reactor operating licenses require utilities to build funding reserves for spent fuel and waste management and for decommissioning; the funds are collected and governed by the Federal Ministry of Trade and Industry (KTM)

3.0 HIGHLIGHTS AND MAJOR MILESTONES (Raumolin 1985; NEA 11/86; Tusa 1986; NEAYJT 1989; Leigh and Mitchell 1990)

1982 A feasibility study was completed for the final disposal of spent fuel in Finland

1982 Preliminary assessments were completed for the suitability of the reactor sites for LLW/ILW disposal

1983-86 The deep borehole (1001 m deep) investigation was completed for a HLW repository

1984 Plans were completed for the interim storage of spent fuel

1985 The preliminary selection of the areas for the site investigations for the spent fuel repository was completed

1986 The preliminary safety analysis was completed for the LLW/LW repositories at the two nuclear power station sites

1987 Five final candidate sites were selected for detailed evaluation as a spent fuel repository

1987 Drilling studies were begun at two of the five final candidate spent fuel repository sites (NW 7/16/87) 
The operation of the first stage of the KPA Store (interim storage of spent fuel) was begun at Olkiluoto Nuclear Power Station (BWRs)

1988 Drilling studies were started at the last three of the five final candidate spent fuel repository sites (NUKEM 1/88)

1988 The process of revising the nuclear energy legislation was completed and the Nuclear Energy Act and Decree came into force on March 1 (NEA 1/90)

1989 Excavation works for the LLW/LW repository at Olkiluoto were completed (NWB 6/1990a)

1990 A set of nuclear safety regulations, including a regulation concerning the safety of LLW/ILW disposal, will be issued by the government (NWB 6/1990a)

1992 The LLW solidification plant at the Loviisa power station will be commissioned

1992 The at-reactor repository for reactor $\mathrm{LLW} / \mathrm{LW}$ at the Olkiluoto BWR power station will be commissioned

1992 Preliminary site investigations will be completed for the five candidate spent fuel repository sites-final sites will be chosen for detailed studies

1997 The at-reactor repository for reactor LLW/LW at the Lovilsa PWR power station will be commissioned

1993-2000 Detailed site investigations will be carried out at two or three of the candidate deep geologic repository sites for spent fuel

2000 The repository site for the spent fuel will be selected and the supplementary investigations will start at the selected site

2010 The design of the deep geologic repository and spent fuel encapsulation station will be completed, and the license application for its construction will be submitted

2010 Decommissioning will start at Olkiluoto-1, a BWR

2020 Construction will be completed and the deep geologic repository and encapsulation station for spent fuel will be commissioned

2040 Dismantling of the Olkiluoto BWRs will begin (NF 11/12/90)

2050 The disposal operations of the deep geologic repository will be completed

2060 The repository sealing operation of the deep geologic repository will be completed 


\subsection{INSTITUTIONAL CONSIDERATIONS/ORGANIZATIONS}

\subsection{LEGAL REQUIREMENTS}

A. A governmental decision in principle (1983) requires utilities to transter and irrevocably dispose of their spent fuel outside Finnish territory, if possible; if this cannot be done, utilities must provide capability to carry out safe final disposal in Finland; the decision also requires utilities to manage their own LLW/LW (Paige 1985; NEA 11/86)

B. Radioactive waste producers (e.g., nuclear utilities) are responsible for management of the wastes, including disposal (Tusa 1986; OECD/NEA 1/90)

C. The Nuclear Energy Bill of 1985 requires an acceptable waste management plan be made a criterion for any future reactor license; it also gives local municipalities veto rights over siting of any future nuclear facility

D. The 1988 Nuclear Energy Act and Decree gives the national parliament the authority to decide on building major new nuclear installations (NEA 1/90)

E. The federal government will assume responsibility for repositories after closure and proof of safety (Heinonen 1986)

4.2 LICENSING: Construction and operating licenses are granted by the central government, with approval from parliament (Paige 1985); the Nuclear Energy Act $(3 / 88)$ renewed the operating licenses for all nuclear power plants and their waste storage facilities for 10 years

(NW 12/22/88; NEJ 1/90)

\subsection{PUBLIC INVOLVEMENT}

A. Adverse public opinion after the Chernobyl accident has gradually moved back towards acceptance of nuclear facilities; public comment was invited on proposals for new nuclear facilities (Paige 1985; NEI 1/90)

B. According to the Nuclear Energy Act, the Federal Ministry of Trade and Industry (KTM) is required to ask for the statements from STUK (Finnish Center for Radiation and Nuclear Safety) and the Ministry of the Environment on matters that concem the construction or use of significant nuclear facilities; all nuclear waste repositories and the facilities for conditioning and storage of radioactive wastes and spent nuclear fuel belong in this category; in addition, statements are required from the municipal councils of the facility host community as well as the neighboring communities; the local community has a vetoright for a facility in its jurisdiction and its positive statement is an unconditional prerequisite for the government's decision to allow the construction of the planned facility (NEA 1/90)

4.4 WASTE FUND: Reactor operating licenses require utilities to build financial reserves for spent fuel and waste management and for facility decommissioning; funds are collected and governed by KTM; the State Nuclear Waste Management Fund has been established under KTM for the supervision and handling of financial liability issues (NEA 1/90)

A. According to the presently applied Finnish practice to ensure that the financial liability not be underestimated, it is required that each year the utilities present cost estimates for the future management of their nuclear waste, on the assumption that nuclear power 
production would have to be stopped at the end of the year considered; for 1989, the pertinent estimates for the cost of future nuclear waste management operations - spent fuel management, reactor waste management, decommissioning, and research and administration - are about $\mathbf{4 0 0 0}$ million Finnish markka (FIM) for TVO, equal to about $\$ 1$ billion, and about 1000 million FIM for IVO, equal to about $\$ 250$ million

B. At the end of 1989 , the fund totalled 1750 million FIM, equal to about $\$ 440$ million for TVO, and 500 million FIM, or about $\$ 125$ million for IVO (NEA 1/90)

4.5 KEY AGENCIES AND FUEL CYCLE CENTERS (NO 1990; Leigh and Mitchell 1990; NEI 1/90; OECD/NEA 1/90)

A. Ministry of Trade and Industry (KTM): KTM is the main responsible authority on nuclear power; it makes sure that the planning and implementation of any measures belonging to nuclear waste management are carried out in a timely and proper manner; the State Nuclear Waste Management Fund has been established under KTM for the supervision and handling of financial liability issues

B. Nuclear Energy Commission: This commission is an advisory body that gives support to $\mathrm{KTM}$ in preparation of matters related to nuclear power production

C. STUK (Finnish Center for Radiation and Nuclear Safety): This center, located at Helsinki, has the responsibility for the control of nuclear safety, including waste management; it enforces regulations, including transportation, and inspects nuclear facilities; the center also performs research on transport of radionuclides in the biosphere; the center obtains advice from an Advisory Committee on Nuclear Safety created under the Nuclear Energy Act (March 1988)

D. Advisory Committee on Nuclear Safety Commission: This committee acts as an advisory body to STUK on major safety issues

E. TVO (Teollisuuden Voima Oy, Industrial Power Company, $43 \%$ government and $57 \%$ privately-owned): TVO operates the two nuclear power plants (Swedish BWRs) at Olkiluoto in Eurajoki, southwestern Finland; it also operates the KPA storage facility for spent fuel (KPA-Store) at Olkiluoto

1) The KPA-Store, an interim wet storage facility for spent fuel at the power station site, was commissioned in 1987

2) The VLJ repository for $\amalg W / L W$ will be located at Olkiluoto; construction started at the reactor site in April 1988

F. IVO (Imatran Voima Oy, National Power Company, 95.6\% government-owned and $4.4 \%$ owned by the Social Insurance Institution): NO operates two nuclear power plants (Soviet-built PWRs) at Loviisa, southeastern Finland

1) IVO stores spent fuel at the Loviisa plant for about five years before shipment to the USSR for reprocessing

2) The repository for $\amalg W / L W$, located at Loviisa, has been accepted in principle, but completion is postponed until the late 1990 s (NEAYJT 1989) 
G. YJT (Nuclear Waste Commission of Finnish Power Companies): YJT was formed by TVO and IVO to coordinate their waste management program planning and analysis; each year the YJT compiles a program on the nuclear waste management of the power companies and submits it to the Ministry of Trade and industry for approval

H. PEVO (Perusvoima Oy, Nuclear Company; owned $50 \%-50 \%$ by IVO and TVO) was established in February 1986; in March 1986, before the Chernobyl accident, PEVO had applied to the government to construct a fitth reactor $(1000 \mathrm{MWe})$; a governmental decision on building the plant has been delayed until atter 1991; an agreement was signed with ABB Atom (Sweden) to work on an advanced BWR (NE 1987; NEI 1/90)

\subsection{PRINCIPAL RESEARCH, DEVELOPMENT AND DEMONSTRATION FACILITIES/PROGRAMS} (Leigh and Mitchell 1990)

d. STUK, at Helsinki, enforces regulations, including transportation, and inspects nuclear facilities; it performs research on transport of radionuclides in the biosphere

B. The Geologic Survey of Finland, located at Espoo, carries out bedrock-related research and waste repository site identification and characterization; in addition, it maintains minimum levels of activity and expertise in uranium exploration, mainly for interpretation and follow-up studies of Finland's ongoing radiometric survey activities (OECD//AEA 1989)

C. The VTT (Technical Research Center of Finland, located at Helsinki and Espoo) performs radioactive waste management $R \& D$, including safety analysis and performance assessment; R\&D on leaching and dissolution of spent fuel and HLW glass, properties of barrier materials, corrosion of encapsulation materials, near-field chemistry in repositories, longterm stability of ILW forms, decommissioning of nuclear power plants; VTT also performs other nuclear R\&D

D. The University of Helsinki performs basic research on radiochemistry, soliditication of nuclear waste solutions, and radionuclide sorption

\subsection{KEY PERSONNEL}

A. J. Routti, Chairman, Nuclear Energy Commission

B. J. Forsten, Chairman, Advisory Committee on Nuclear Safety

C. L. Mattila, Director, Nuclear Waste, VTT Nuclear Engineering Laboratory

D. S. Vuori, Nuclear Waste Management, VTT Nuclear Engineering Laboratory

E. A. Muurinen, Nuclear Waste Management, VTT Reactor Laboratory

F. P. Hiismaki, Director, Nuclear Waste Management, VTT Reactor Laboratory

G. K. Saari, Rock Mechanics, VTT Geotechnical Laboratory

H. H. Koponen, Nuclear Fuel Cycle, STUK

I. E. Ruokola, Nuclear Waste, STUK

J. V. Ryhanen, Nuclear Waste, TVO 
K J. Palmu, Nuclear Waste, IVo

L P. Vuorela, Nuclear Waste Disposal, Geological Survey of Finland

M. T. Jaakkola, Director, Department of Radiochemistry, University of Helsinki

\subsection{NUCLEAR FUEL PRODUCTION (NE 10/87; NF 10/19/87; NEI 1/90)}

5.1 STRATEGY: All uranium and fuel assemblies are purchased from outside Finland; possible interruptions in supply are guarded against by stockpiles (at least one reload per reactor is always held in reserve) and by diversification of suppliers (NEI 1/90)

\subsection{URANIUM RESOURCES}

A. Finland has reasonably ensured uranium resources of 1500 to $2900 \mathrm{MTU}$, depending on the cost of recovery (NEA 1989)

B. Uranium for Soviet PWRs is purchased from the USSR; uranium for the Swedish BWRs is currently purchased from Canada and Australia; through a 1987 agreement, China will supply $30 \%$ of Finland's future requirements (NEA 1/90)

C. Since 1983, Finland's uranium exploration activities have considerably slowed; for the year 1989 no new uranium exploration projects were planned (OECD/AEA 1989)

5.3 URANIUM ENRICHMENT: The procurement of enriched fuel for the Loviisa nuclear power plant is based on a long-term contract with a Soviet supplier; the TVO Power Company has chosen a policy to purchase the uranium, conversion, enrichment, and fuel fabrication services from several supplier countries (OECD/AEA 1989); in 1989, enrichment services were purchased from the Soviet Union, the Federal Republic of Germany, and the Netherlands (TVO 1990)

5.4 FUEL FABRICATION: Finland has no domestic fuel cycle industry and all the uranium for its nuclear power stations is imported as fuel assemblies (NEI 1/90)

A. Fuel assemblies for Finland's PWRs are supplied by the USSR

B. Fuel assemblies for Olkiluoto 1 are supplied by Siemens (FRG); they are supplied for Olkiluoto 2 by ABB Atom (Sweden)

\subsection{FUEL RECYCLE}

\subsection{FUEL REPROCESSING}

A. Finland leans toward direct disposal of its spent fuel from its Swedish-built BWRs, but could eventually opt for foreign reprocessing; no reprocessing contracts have been signed as of June 1990

B. Spent fuel from its Soviet-built PWAs is returned to the Soviet Union where it is reprocessed (NEI 1/90) 


\subsection{SPENT FUEL STORAGE AND TRANSPORT}

7.1 SPENT FUEL ARISINGS (Raumolin 1985; NEA 11/86; NN 3/88; Leigh and Mitchell 1990; OECD/NEA 1/90; YJT 1990)

1980

$198565 \mathrm{MTU} / \mathrm{yr} ; 45 \mathrm{MTU} / \mathrm{yr}$ from BWRs

1989

1990

2000

\author{
68 MTU cumulative \\ 368 MTU cumulative \\ 530 MTU cumulative \\ 590 MTU cumulative \\ 1040 MTU cumulative
}

A. The total amount of spent fuel expected from the Loviisa plant during its lifetime is about 850 MTU; after about five years of storage the spent fuel is transported from Loviisa to the USSR; thus, a storage capacity of at least $170 \mathrm{MTU}$ is needed

B. The total amount of spent fuel arising at the Olkiluoto plant is estimated to be about $1840 \mathrm{MTU}$, based on 40 years' operation; the interim store at the site will have an estimated operating life of 60 years, and the estimated maximum storage time for an individual fuel assembly is 40 years

\subsection{FUEL ASSEMBLY CHARACTERISTICS}

A. Soviet PWR fuel assemblies at Loviisa have hexagonal cross-section; they are $144 \mathrm{~mm}$ across and $3.2 \mathrm{~m}$ long; each assembly contains 126 fuel rods with $0.120 \mathrm{MTU}$ per assembly; 120 assemblies are discharged for each refueling; one fuel assembly irradiated to $32,000 \mathrm{MWD} / \mathrm{MTU}$ and five years out-of-reactor contains 500 curies and generates $200 \mathrm{~W}$ (NEI 2/88)

B. Swedish BWR fuel assemblies have about $0.18 \mathrm{MTU} /$ assembly; Swedish fuel has 64 rods/assembly (8x8); German KWU fuel has 80 rods/assembly $(9 \times 9)$; assemblies are $4 \mathrm{~m}$ long (NF 8/10/87; TVO 1987a)

\subsection{SPENT FUEL STRATEGIES}

A. Finland plans on storing spent fuel trom the two Soviet-supplied Loviisa PWRs at the reactor site for up to about five years and then returning the fuel to the Soviet Union for reprocessing

B. Spent fuel from the non-Soviet nuclear power plants will be stored at the station site for about 40 years, then placed in a granitic, deep bedrock repository (or, if available and attractive, foreign fuel management services will be utilized)

7.4 Wet Storage (NEA 11/86; Ryhanen 1986; TVO 1987c; NEl 1/90; NEA 1/90)

A. IVO (Loviisa power station with two Soviet-built PWRs): The power station has two reactor-hall pools, also two separate (wet) storage facilities; storage capacity is about 300 MTU (equivalent to 10 years' operation or 12.5 reactor discharges); the total amount of spent fuel in the storage pools averages $140 \mathrm{MTU}$; spent fuel is normally stored about five years before transport to the Soviet Union 
B. TVO (Olkiluoto power station with two Swedish-built BWRs): The spent fuel is initially cooled for a few years in the water pools in the reactor buildings; the combined storage capacity of these pools is about $370 \mathrm{MTU}$; subsequently, the spent fuel is transferred to a separate facility (KPA-Store) on the site for long-term storage; at the end of 1989, the amount of spent fuel in the pools at Olkiluoto was $412 \mathrm{MTU}$

1) The KPA-Store is an onsite spent fuel interim storage facility that provides wet storage in compact racks in three pools, not including a reserve pool, with a capacity of $400 \mathrm{MTU}$ each--initial capacity is $600-900 \mathrm{MTU}$-the facility was completed in late 1987; the total planned capacity is 1600 MTU; the estimated life of the KPA-Store is 60 years (NN 1/89)

a. The minimum age of fuel to be received is one year out-of-reactor

b. The storage building is on bedrock, with pools (12.5 m water depth) below grade

c. Cooling of fuel pool water is with sea water through heat exchangers; cooling capacity is $23 \mathrm{MW}$

d. The KPA-Store can be made independent after decommissioning of the power plant units (Raumolin 1985)

\subsection{TRANSPORT}

A. IVO spent fuel is transported to the Soviet Union by train, using Soviet casks and transport vehicles leased from the Soviet Union (NEI 2/88; OECD/NEA 1/90)

1) Transport is by special train with up to eight casks (one per vehicle), with Finnish rail transport to Vyborg ( $30 \mathrm{~km}$ inside Soviet border); it is $255 \mathrm{~km}$ from Loviisa

2) Casks are transferred to special highway trailers at the Loviisa railway station for subsequent transport $15 \mathrm{~km}$ to/from the power station

3) Turnaround time for eight casks at the power station is about 10 days

4) Each of the Soviet-built TK-6 casks holds about 30 spent fuel assemblies, or about 3.6 MTU; a loaded cask weighs about $90 \mathrm{MT}$

a. Overall cask dimensions are $4.375 \mathrm{~m}$ high by $2.8 \mathrm{~m}$ diameter, including the fins

b. The cask body is forged steel with a stainless steer liner and lid

c. Heat capacity is $8 \mathrm{~kW}$ with a gas-filled cavity and $15 \mathrm{~kW}$ with a water-filled cavity

5) In the period 1981-1989, a total of nine shipments (about 180 MTU of spent fuel) were made from Loviisa to the USSR; in the future, it is estimated that about $28 \mathrm{MTU} / \mathrm{yr}$ will be transported

6) In 1989, a total of $56 \mathrm{MTU}$ of spent nuclear fuel from the Loviisa Power Plant was returned to the USSR in two consignments (IVO 1990) 
B. At Olkiluoto, 40-60 MTU of spent fuel is transferred annually from the storage pools inside the reactor units to a separate storage facility at the site; the transfer cask is of the German CASTOR-type, specially designed according to the specifications of TVO spent fuel (NEA 1/90)

\subsection{PROGRAM/FACILITIES COSTS}

A. The interim spent fuel storage facility (KPA-Store) cost 183 million Finnish markka (\$45 million U.S.) (NN 1/89).

B. The estimated investment cost of the interim storage of spent fuel at Olkiluoto is about $200 \mathrm{FIM} / \mathrm{kgU}$ (about $\$ 50$ per $\mathrm{kgU}$ ) (NEA 1/90)

\subsection{WASTE CONDITIONING, STORAGE AND TRANSPORT}

\subsection{WASTE ARISINGS}

A. The total $\amalg W / I L W$ waste arisings from the four reactors are approximately $300 \mathrm{~m}^{3} / \mathrm{yr}_{\text {, not }}$ including decornmissioning wastes (NEAYJT 1989)

B. Loviisa: By the year 2010 ( 30 years of reactor operations), cumulative wastes are estimated to be $10,000 \mathrm{~m}^{3}$ with about 160 curies (Heinonen 1986; Harkonen 1987b); R\&D on volume reduction methods is expected to reduce this volume to less than $1000 \mathrm{~m}^{3}$ (Tusa 1988)

1) Volumes of evaporator concentrates in storage tanks have been reduced substantially over the past several years by releases of low-level liquids into the sea (Tusa 1989); by the end of 1989 , the accumulated reactor wastes amounted to about $1400 \mathrm{~m}^{3}$ (NEA 1/90)

2) Packaged decommissioning wastes are expected to be about $18,800 \mathrm{~m}^{3}$ (NEA 1/90)

C. Olkiluoto: Waste arisings are $150-200 \mathrm{~m}^{3} / \mathrm{yr}$; cumulative (packaged) arisings will be about $8700 \mathrm{~m}^{3}$ (Heinonen 1986; Harkonen 1987b; TVO 1987d; NN 3/88)

1) As of the end of 1989 , total arisings were $1700 \mathrm{~m}^{3}$ of reactor wastes and about $800 \mathrm{~m}^{3}$ of slightly contaminated metal components (unpackaged) (NEA 1/90)

2) The lifetime accumulation is expected to be 15,000 drums and 1000 boxes

8.2 STRATEGY: The national policy is to store spent fuel and other nuclear wastes at the nuclear power plant sites or other waste generator sites until they are transferred to disposal facilities

\subsection{LLW/LW WASTE CONDITIONING}

A. Loviisa: The LLW/LW is stored pending a contract with the Soviet Union for disposal and construction of a cementation plant; the liquid wastes are concentrated and stored in four tanks (1200 $\mathrm{m}^{3}$ capacity total); spent resins are stored in three tanks $\left(900 \mathrm{~m}^{3}\right.$ capacity total); a cementation plant has been designed and licensed (Finland 1987; Harkonen 1987b) 
1) The waste packages are 200-liter steel drums for compacted, dry solid wastes; 1000-liter concrete drums, with $10 \mathrm{~cm}$ wall thickness are used for other wastes

B. Olkiluoto: The solid LLWALW trash is compacted when possible; spent resins are dried, then mixed with equal volumes of bitumen; these wastes are interim stored onsite (Finland 1987; TVO 1987d; Harkonen 1987b)

1) The waste packages are 200-liter steel drums for compacted wastes and bituminized wastes; 1300 -liter steel boxes are used for other wastes

C. Decommissioning wastes with high radioactivity content will be encapsulated in a concrete matrix in thick-walled concrete containers (Finland 1987)

8.4 LLW/ILW STORAGE: LLW/LW from the two nuclear power stations is stored at station sites

A. At Olkiluoto, $\amalg W$ is stored in the MAJ-Store facility (one building for compacted trash with capacity of 5,000 drums, and two buildings for other LLW with capacity of 1500 drums each); ILW is stored in the KAJ-Store facility (large shielded warehouse with capacity for 6,000 drums of bituminized waste); capacity is enough to last to the mid. 1990s (TVO 1987a; Harkonen 1987b); in the VLJ repository, the design capacity is 24,800 drums (200 liter/drum) for the MAJ-SILO and 17,360 drums (200 liter/drum) for the KAJ-SILO NLJ 1989)

B. At Loviisa, concentrated liquid wastes are stored in four tanks (1200 $\mathrm{m}^{3}$ capacity total); spent resins are stored in three tanks $\left(900 \mathrm{~m}^{3}\right.$ capacity total); a fourth $300-\mathrm{m}^{3}$ tank is a spare; compacted dry trash is stored in 200-liter drums in different areas depending on radioactivity, content, combustibility, and compactability; activated metal components are stored in special storage "holes" inside the reactor building and in spent fuel pools (Tusa 1987; Harkonen 1987b)

\subsection{RESEARCH AND DEVELOPMENT}

A. A pilot plant has demonstrated a microbiological waste reduction process (IVO-mictreat) for organic trash; wastes containing paper, board, wood, cloth, rubber, and plastics decompose almost completely in 2-10 days, resulting in volume reductions by a factor of 10 to 20; testing decomposition of spent resins was to be completed in late 1989; a fullscale, 30-cubic-m bioreactor was to be constructed at Loviisa in the spring of 1989 and commissioned in the fall of 1989; supercompaction was rejected because it did not relieve gas production; incineration was rejected because of high temperature and release of vaporized radionuclides (Tusa 1989)

B. In 1987, separation of cesium from LLW by cobalt hexacyanoferrate ion exchange was undergoing pilot-scale tests (Harkonen 1987b)

C. Waste package tests in 1986 included leaching properties of waste forms and the behavior of bituminized wastes under repository conditions (Snellman 1986)

8.6 PROGRAM/FACILITIES COSTS: The storage facility at Olkiluoto for bituminized LLW cost $\$ 1.2$ million (U.S.); the storage facility at Olkiluoto for LLW trash cost $\$ 330,000$ (U.S.) (Harkonen 1987b) 


\subsection{DISPOSAL OF NON-HIGH-LEVEL WASTES (Tusa 1986; Harkonen 1987a)}

\subsection{STRATEGY:}

A. The conditioning, storage and final disposal of $\amalg W / L W$ from reactor operation, as well as waste from the decommissioning of nuclear facilities, will take place in Finland; the nuclear power plant sites in Finland are planned to be the locations of repositories for disposal of LLW/LW (NEA 1/90)

B. The federal government will assume responsibility for repositories after closure and proof of safety (Heinonen 1986)

\subsection{WASTE DISPOSAL CRITERIA}

A. The risk limit to individuals in the critical group of members of the public is 1E-5 deaths/ year; the estimated risk taken is calculated as the sum of the risks from the expected scenarios, from the probabilistic disruptive events (natural and man-caused), and from the low-probability natural distumances (TVO 1985)

B. Multiple barriers are required for disposal; bemiers include waste forms, containers, backfill, concrete structures, geosphere, biosphere; extra concrete barriers are required for the higher activity wastes (Finland 1987)

C. The radioactivity of the $\amalg W / L W$ wastes will decay within 300 years after repository closure to less than that in background levels in a $100 \mathrm{~m} \times 100 \mathrm{~m} \times 100 \mathrm{~m}$ area of surrounding bedrock (Finland 1987)

D. Very LLW are being disposed of at dumping areas on the power station sites (Harkonen 1987b)

\subsection{ILW DISPOSAL}

A. $\quad \mathrm{LW}$ repositories are to be constructed in pre-Cambrian bedrock at the two nuclear power station sites (both sites are on islands), and to eventually be enlarged to include reactor decommissioning wastes

1) Wastes with higher radioactivity content (such as some reactor materials from decommissioning and some core components) will also be backfilled with concrete in the repository disposal room (Finland 1987)

B. Olkiluoto (1 $\mathrm{km}$ north of the power plant on a peninsula at Eurajoki): The VLJ repository will be in a $100 \mathrm{~m}$ wide by $170 \mathrm{~m}$ deep tonalite massif (waste silos rather than tunnels are appropriate to the dimensions of the massif) surrounded by fractured mica gneiss; there will be a vault at $60 \mathrm{~m}$ depth for irradiated reactor metal parts, with a silo extending upward from the $90 \mathrm{~m}$ depth to the $60 \mathrm{~m}$ depth for the remaining ILW and LLW; the total activity for disposal will be less than 2700 curies (NW 3/17/88; Finland 1987; TVO 1987d; IAEA 1989) 
1) The VLJ repository will have a large underground waste operating hall that overlies two large cylindrical silos (one for ILW, one for LLW) that are subdivided vertically into smaller compartments; each compartment will have an individual cover block in the floor of the overlying hall; in both silo types, the waste drums will be emplaced within concrete boxes, each containing 16 drums

2) Backfill above the silos will be concrete using crushed excavated rock as aggregate; vent holes will be provided for each silo

a. One silo will have a $0.5-\mathrm{m}$ concrete wall tiner for bituminized ILW; the silo net volume is $6,800 \mathrm{~m}^{3}$ (19 m diameter $\times 24 \mathrm{~m}$ high); the silo will have a 1.0-m space between it and the excavated hole that will be backfilled with suitable material at the time of repository closure

b. Waste will be emplaced in the ILW silo using an overhead crane located in the overlying hall and operated remotely from the receiving and handling building on the surface

c. From the surface, access to the repository will be by truck through a winding 700-m-long inclined tunnel $(5 \mathrm{~m} \times 6 \mathrm{~m})$

d. Backfill will be with crushed rock and concrete seal plugs

e. The construction permit was obtained in early 1988; the facility is expected to be commissioned in 1992 (NW 3/17/88)

C. Loviisa (on the island of Hastholmen): The repository will be constructed at a depth of 110 to $120 \mathrm{~m}$ in rapavivi granite between two almost horizontal fracture zones (disposal in tunnels is thus more appropriate than in silos) under the island (Fintand 1987; Harkonen 1987b; IAEA 1989)

1) The repository will have two main disposal areas, connected by an access tunnel

a. One set of disposal tunnels $(5.5 \mathrm{~m} \times 5.5 \mathrm{~m}$ cross-section, and 46 to $100 \mathrm{~m}$ long) will be for combustible and (separate from) noncombustible wastes, including decommissioning wastes; the wastes will be emplaced with a forklift; the backill material will be crushed rock

b. One set of large concrete-lined caverns (14 m wide $\times 14 \mathrm{~m}$ high and $100 \mathrm{~m}$ long) will be for solidified ILW and LLW, and for future decommissioning wastes; the wastes will be in concrete canisters and emplaced using the remotely operated bridge crane; the spaces between waste containers will be filled with flowing concrete and the space between the concrete liner and the bedrock will be backfilled with crushed rock

c. Waste access to the repository will be by truck through a winding transport tunnel $1 \mathrm{~km}$ long

d. Access to the underground disposal tunnels will be via smaller tunnels connected to the transport tunnel

e. Backfill will be with crushed rock and concrete seal plugs 
f. Upon reactor decommissioning, each reactor vessel (weighing about 215 MT) will be transferred in one piece into the ILW and $\amalg W$ repository; reactor vessel internals will be placed inside the vessels; steam generators and pressurizers will also be disposed of unsectioned; other decommissioning wastes will be cut into small pieces and emplaced in wood or concrete containers (IAEA 1988)

2) The plans for the repository at the Lovisa plant have been accepted by the federal safety authorities but the decision to start the construction has been deferred due to the low amount of waste arisings so far (NEA 1/90)

\subsection{LLW DISPOSAL}

A. LLW repositories are to be constructed along with the ILW repository in pre-Cambrian bedrock at the two nuclear power station sites (both sites are on islands), and to eventually be enlarged to include reactor decommissioning wastes

B. More than $60 \%$ of the LLW trash (with low specific activity) is to be disposed of at the power station sites (Harkonen 1987b)

C. Olkiluoto ( $1 \mathrm{~km}$ north of the power plant on a peninsula at Eurajoki): the silos at the VLJ repository will be used for LLW and ILW (see Section 9.3.B) (NW 3/17/88; Finland 1987; TVO 1987d; (AEA 1989)

1) One silo will be for dry LLW (20 m diameter $\times 33 \mathrm{~m}$ high; volume is $10,400 \mathrm{~m}^{3}$ ) and additional silos will be constructed later for reactor decommissioning wastes

2) Waste will be emplaced in the LLW silo using an overhead crane located in the overlying hall and operated remotely from the receiving and handling building on the surface

3) From the surface, access will be by truck through a winding 700-m-long inclined tunnel $(5 \mathrm{~m} \times 6 \mathrm{~m})$

4) Backfill above the silos, including seal plugs, will be concrete, using crushed excavated rock as aggregate; vent holes will be provided for each silo

5) The construction permit was obtained in early 1988; the facility is expected to be commissioned in 1992 (NW 3/17/88)

D. Loviisa (on the island of Hastholmen): The repository will be used for LLW and ILW (see Section 9.3.C); the plans for the repository at the Loviisa plant have been accepted by the federal safety authorities, but the decision to start the construction has been deferred until 1997 due to the low amount of waste arisings so far (NEA 1/90)

9.5 LLW/LW DISPOSAL R\&D: Results from laboratory tests in Finland suggest bitumen is a potential candidate for turnel-sealing or shaft-plugging materials in repositories for low- and high-level wastes; in addition, it has been found that impregnation with bitumen effectively reduces microbial decomposition of easily destructible waste components; the time scales involved in the degradation processes of bitumen, as observed in natural occurrences, exceed the time scales dictated by the half-lives of most important fission products in low- and mediumlevel waste by orders of magnitude (Helirnuth 1989) 
FINLAND

\subsection{PROGRAM/FACIUTIES COSTS}

A. In 1988, the construction costs for the Lovisa repository were estimated at \$25 million (NW 10/20/88)

B. The construction cost of the Olkiluoto VLJ bedrock repository is expected to be $\$ 17$ million (NW 8/31/89)

C. For 1989, the Loviisa LLW/LW repository R\&D costs were $\$ 1.15$ million (U.S.) (YJT 1990)

D. For 1989 , the Olkiluoto LLW/LW repository R\&D costs were \$1.34 million (U.S.) (YJT 1990)

E. See also Section 10.9

10.0 DISPOSAL OF HIGH-LEVEL WASTES (Paige 1985; Raumolin 1985; NEA 11/86; Peftonen 1986; Ryhanen 1986)

\subsection{SPECIFICATIONS AND CRITERIA}

A. Finland has referenced the maximum individual risk from a repository proposed by NEA of $1 \mathrm{E}-5$ deaths/year from all scenarios (TVO 1985)

B. Use of multiple barriers is required

C. The repository is to be several hundred meters deep (NEI 12/87)

\subsection{REPOSITORY DEPLOYMENT STRATEGY (NEA 11/86)}

A. Finland plans to return all spent fuel from the Soviet reactors to the Soviet Union for disposal after approximately a five-year cooling period (NF 5/4/87; NEI 2/88;

OECD/NEA 1/90)

B. The preference for its BWR spent fuel is to buy foreign or international disposal service, but to prepare TVO spent fuel in Finland for disposal

C. Interim storage of TVO spent fuel is planned for 40 years

D. Starting about 2020 , spent fuel will be disposed of in a deep geologic repository in Finland

E. Using applicable foreign technology to the maximum extent, Finland is conducting preliminary site investigations, and performance assessments

\subsection{SITE SELECTION AND CHARACTERIZATION}

A. Alter initial screening, 162 possible sites were identified by review of geologic maps and consideration of population density, land-use planning, water resources, and recreational use; some borehole and core tests, etc., were done during 1983-1985 (NEA 11/86;

Ryhanen 1986; Aikas 1986; TVO 1987b) 
B. The preliminary investigation of five sites is to be completed by 1992: the first stage will consist of geological mapping and surtace-based geophysics; the second stage will include borehole studies 500-1000 $\mathrm{m}$ deep (NW 7/16/87)

1) Test drilling staned at the first two sites (at Hyrynsalmi in granite and at Kuhmo in gneiss) in 1987; test drilling in the remaining three sites (in granodiorite, granite and migmatite) started in 1988 (NUKEM 1/88; TVO 1987a)

2) Preliminary site investigations studies and status as of early 1990 (NWB 1990b):

a. Eurajoki Site: Drilling of two deep boreholes and borehole investigations are planned for 1990; hydrological monitoring and testing is also planned for 1990

b. Hyrynsalmi Site: Geological and geophysical investigations have been completed, and groundwater sampling has continued; hydrological monitoring and testing are in progress; geological and hydrological modeling in is progress

c. Konginkangas Site: Geological and geophysical investigations have been completed and groundwater sampling has continued; hydrological monitoring and testing is planned for 1990; preliminary geological and hydrological modeling is planned for 1990

d. Kuhmo Site: Geological and geophysical investigations have been completed, and groundwater sampling has continued; hydrological monitoring and testing is in progress; preliminary geological and hydrological modeling has been completed; more detailed modeling is in progress

e. Sievi Site: Geological and geophysical investigations are completed, and groundwater sampling has continued; hydrological monitoring and testing is planned for 1990; preliminary geological and hydrological modeling is planned for 1990

C. Detailed field studies on two to three sites will occur during the 1993-2000 time frame; one site will be selected in the year 2000 (NEA 11/86; Ryhanen 1986; Aikas 1986; TVO 1987b)

D. Supplementary detailed investigations will be conducted on the proposed site between 200 and 2010 (NEA 11/86; Ryhanen 1986; Ajkas 1986; TVO 1987b)

\subsection{REFERENCE HLW/SPENT FUEL DISPOSAL CONCEPT}

A. Reference waste: Spent fuel (or vitrified HLW, if Finland obtains foreign reprocessing)

8. Waste package: Spent fuel is planned to be encapsulated in thick-walled copper canisters, each containing 8-9 BWR fuel assemblies; the spaces in the canisters are to be firled with either molten lead, lead shot, or other suitable material; studies on other canister designs are underway (NEA 1/90); TVO is giving strong consideration to a waste package, developed in cooperation with Sweden, in which spent fuel would be encapsulated in thick steel containers covered with a thin layer of copper for corrosion protection; the spaces between the spent fuel rods are to be filled with either a lead-gravel, quartzgravel, or glass packing material (NF 11/12/90) 
1) About 1000 canisters are required for the expected spent fuel arisings

2) A canister is $60 \mathrm{~cm}$ inside diameter, $80 \mathrm{~cm}$ outside diameter, $450 \mathrm{~cm}$ long

C. The current reference repository and waste package concept is patterned after the Swedish KBS-3 concept, with the encapsulation plant located above the repository (TVO 1985; NEA 1/90)

1) At the repository site, the encapsulation facility activities will include:

a. dry unloading of incoming spent fuel from a transfer cask

b. removing and placing fuel channels in concrete molds as ILW

2) Tunnels will be mined out of crystalline bedrock of battic shield (granite or gneiss) at about $500 \mathrm{~m}$ depth

a. the total underground area will be about $400 \mathrm{~m} \times 600 \mathrm{~m}$, with a series of tunnels about $25 \mathrm{~m}$ apart

b. individual canisters will be emplaced in individual boreholes in tunnel floors (boreholes abour $1.5 \mathrm{~m}$ In diameter $\times 7.5 \mathrm{~m}$ deep, and about $6 \mathrm{~m}$ apart)

c. due to the small number of canisters, one level of disposal tunnels will probably be sufficient

d. fuel channel waste will be stacked in a separate room

D. TVO has proposed a variant of a new repository and waste package concept, developed in cooperation with Sweden, to its regulatory authorities; the concept involves horizontal emplacement of thick-walled steel containers containing spent fuel in drilled tunnels (NF 11/12/90)

E. Buffers and seals: There will be compacted bentonite blocks below, around, and above the canister in the hole in the reference concept (TVO 1985)

F. Tunnel backfill: Sand and bentonite mixture will be used (also used for shaft backfill) in the reference concept (TVO 1985)

10.5 WASTE PACKAGE R\&D: The R\&D work carried out by VTT includes measuring the solubility of unirradiated fuel in granitic groundwater, characterization of HLW glass, canister corrosion, and the behavior of backfill materials (Nykyri 1985)

10.6 GEOSCIENCES R\&D (Ryhanen 1986; TVO 1987b)

A. R\&D is carried out by the VTT Geotechnical Laboratory and the Geologic Survey of Finland

B. A 1000-m-deep test hole was drilled at Lavia and used for hydraulic tests, geophysical logging, and groundwater sampling; VTT plans to develop test methods and gain experience in site characterization; studies of groundwater flow patterns and level fluctuations will be conducted as well as sorption capacity determination for rocks and minerals; radionuclide migration will be measured in rocks and bentonite 
C. In 1989, site investigations concentrated on the Konginkangas, Sievi, and Olkiluoto sites, where several cored boreholes were drilled and investigations based on the program were made; at Kuhmo and Hyrynsalmi, the last phase of the field imvestigations was started; interpretation of the results and the modeling of the irvestigation sites increased considerably (YJT 1990)

D. The field investigations, the equipment development work, and the studies at the Underground Research Laboratory at Stripa, Sweden, progressed according to the research program plans (Y.JT 1990)

\subsection{PERFORMANCE ASSESSMENT (Vieno 1986; Peltonen 1986)}

A. R\&D is carried out at the VTT Nuclear Engineering Laboratory and at the VTT Reactor Laboratory

B. Radionuclide release analyses performed during 1984-85 were aimed at identifying pathways and evaluating the timescale of radionuclide releases to the biosphere in condjtions characteristic of Finnish bedrock

C. Comprehensive generic safety analyses, using the Olkiluoto area as the reference site, showed clear safety margins using conservative assumptions; analyses were conducted for three types of scenarios:

1) Expected conditions

2) Scenarios with disturbances for each barrier

3) Scenarios with disruptive events (dealt with probabilistically) from natural and man-caused events

D. Site-specific safety analyses will be conducted for final candidate sites

E. In 1989, interpretation of the results of site investigations and the modeling of the sites increased considerably (YJT 1990)

10.8 ENVIRONMENTAL RESEARCH: The research work is carried out by STUK

10.9 PROGRAM/FACILITIES COSTS

A. Waste management R\&D costs (NEA 11/86; NF $3 / 9 / 87$ )

1) Annual R\&D costs (in the past): $\$ 2-4$ million (U.S.) plus a lesser amount from the government

2) Costs through 1987: $\$ 6$ million (U.S.) plus a lesser amount from the government

3) For 1989 , the R\&D costs for management of spent luel and high-level wastes was $\$ 7.4$ million (U.S.) (YJT 1990)

B. As of 1989, the pertinent estimates for the cost of future nuclear waste management operations for Olkiluoto are about $\$ 1.0$ billion (U.S.), consisting of the following shares (NEA 1/90): 
1) $\$ 0.549$ billion for spent fuel management

2) \$0.017 billion for reactor waste management

3) $\$ 0.228$ billion for decommissioning

4) \$0.212 billion for research and administration

C. The cost of disposal of the spent nuclear fuel from the two Olkiluoto BWRs, using the thick carbon steel packages emplaced in horizontal tunnels, is estimated at $\$ 350$ million, including a $15 \%$ contingency margin (NF 11/12/90)

D. As of 1989 , the pertinent estimates for the cost of future nuclear waste management operations for Loviisa are about $\$ 0.26$ billion (U.S.), consisting of the following shares (NEA 1/90):

1) $\$ 0.006$ billion for spent fuel management

2) \$0.218 billion for reactor waste management and decommissioning

3) \$0.032 billion for research and administration

11.0 MANAGEMENT OF URANIUM MINE AND MILL WASTES (no uranium is mined or milled in Finland)

\subsection{DECOMMISSIONING AND ENVIRONMENTAL RESTORATION}

12.1 WASTE ARISINGS (NEA 1/90; YJT 1990)

A. According to the safety analyses, the expected total amounts of decommissioning wastes (as packaged) are:

1) At Loviisa--3,900 $\mathrm{m}^{3}$ of activated waste and $16,500 \mathrm{~m}^{3}$ of contaminated waste

2) At Olkiluoto-- $4,500 \mathrm{~m}^{3}$ of activated waste and $14,300 \mathrm{~m}^{3}$ of contaminated waste; packaged decommissioning wastes are expected to be $20,400 \mathrm{~m}^{3}$

\subsection{STRATEGY/POLICY (Finland 1987)}

A. Current operating licenses for Finnish nuclear power plants require that updated plans for decommissioning be presented to federal authorities every ive years; at the end of 1987, reports dealing with technical plans for the decommissioning of nuclear power plants and the safety aspects of the management of the arising wastes were finished (IAEA 1988; NEA 1/90)

B. At Loviisa, the PWRs will be dismantled within 5-10 years after shutdown in the 2010s

1) Each reactor vessel $(\sim 215 \mathrm{MT})$ will be transferred in one piece into a LLW/LW repository to be constructed at about $100 \mathrm{~m}$ deep in bedrock at the power plant site; reactor vessel internals will be placed inside the vessels; steam generators 
and pressurizers will aiso be disposed of unsectioned; other decommissioning wastes will be cut into small pieces and emplaced in wood or concrete containers; decommissioning is expected to be complete in 2016 Harkonen 1987b; IAEA 1988)

C. At Olkiluoto, the two BWRs will be placed in a mothball condition for 30-50 years until spent fuel is removed from storage, then they will be dismantled; the dismantling plans and the cost estimates for the Olkiluoto units were to be updated by the end of March 1990; the interim wet storage facility at the site, KPA-Store, can be made independent after decommissioning of the power plant units, if desired

D. Current plans call for the interim stores inside the power plants to be decommissioned at the same time as the plants themselves; the KPA-Store for spent fuel at Olkiluoto is planned to be decommissioned by the year 2055 (NEA 1/90)

E. Because the reactor and decommissioning wastes are stored and most likely also disposed of onsite, there is no need for very specialized transportation systems for these wastes

12.3 A\&D: The work is being carried out at the VTT Reactor Laboratory at Espoo

12.4 COSTS: Reactor operating licenses require utilities to build reserves (a waste fund) for spent fuel and waste management and for decommissioning; the funds are collected and governed by the Federal Ministry of Trade and Industry (KTM) (NEA 1/90)

A. At the end of 1989, the fund totalled 1750 million Finnish markka (FIM), equal to about $\$ 438$ million for TVO and $\$ 500$ million FIM, or about $\$ 125$ million for NO

B. In 1989, R\&D costs were $\$ 0.5$ million (U.S.) (YJT 1990)

\subsection{INTERNATIONAL ACTIVITIES}

\subsection{MEMBERSHIPS: IAEA, OECD/NEA}

\subsection{COOPERATION WITH MULTINATIONAL AGENCIES}

A. Finland participates in the NEA-coordinated Stripa Underground Research Project in Sweden

B. Finland participates in most NEA waste management activities

C. Finland participates in Nordic projects coordinated by the Nordic Liaison Committee for Atomic Energy

D. A cooperation agreement with the CEC was signed in 1989 (NE 3-4 1990)

\subsection{COOPERATION WITH USA}

A. Finland's Center for Radiation and Nuclear Safety and the U.S. Nuclear Regulatory Commission have renewed their cooperative agreement on information exchange in nuclear regulation, which was first signed in 1980 and renewed in 1985 (NN 9/90) 


\subsection{COOPERATION WITH OTHER COUNTRIES}

A. Finland has purchase agreements for fuel fabrication with German and Swedish firms (NF 8/10/87); in 1989, enrichment senvices were purchased from the Soviet Union, the Federal Republic of Germany, and the Netherlands (TVO 1990)

B. Finland has agreements with the Soviet Union for fuel cycle services, including the supply of fresh fuel and Soviet acceptance of spent fuel and some reactor wastes from the Soviet-supplied reactors

C. Finland purchases uranium concentrates from Canada, Australia, and central Africa; it has an agreement with China for purchase of about $30 \%$ of its lifetime uranium needs for its two Swedish-built BWRs (NE 10/87; NF 10/19/87; Mikkola 1988)

D. The Finnish utilities (TVO and IVO) have formal bilateral cooperation agreements with the SKB (Sweden), NAGRA (Switzerland), and AECL (Canada)

E. In 1990, Finnish and Swedish spent fuel management companies have been cooperating in developing spent fuel disposal schemes for spent fuel packaging and repository design which should improve the economics of spent fuel disposal (NF 11/12/90).

F. IVO is concentrating on PWR technology in collaboration with Atomenergoexport of Moscow and Nuclear Power International (Siemens/Framatome) (NE 3-4 1990)

\subsection{REFERENCES}

$-1985-$

Industrial Power Company Ltd. (TVO). 1985. Final Disposal of Spent Fuel: Technical Plans, Summary Report. Industrial Power Company, Ltd., Helsinki, Finland.

Lakey, L. T., K. M. Harmon, and P. Colombo. 1985. Management of Low-Level Radioactive Wastes Around the World. PNL-5173, Pacific Northwest Laboratory, Richland, Washington, pp. 21-23.

Nykyri M., and K Ollila. 1985. 'Solubility of Unirradiated Fuel in Granitic Groundwater.' Waste Management '85, March 24-28, Tucson, Arizona, p. 489.

Paige, H. W., and N.J. Numark. 1985. Assessment of National Systems for Obtaining Local Siting Acceptance of Nuclear Waste Management Facilities. IEAL-R/86-16, International Energy Associates Limited, Washington, D.C.

Raumolin, H., and V-P. Toermaelae. 1985. "Spent Fuel Storage and Disposal in Finland." Nuclear Europe, February 1985, p. 18.

$-1986-$

Aikas, T., et al. 1986. Testing of Methods and Equipment for Deep Borehole Studies. In Canadian Nuclear Society proceedings of 2nd International Conference on Radioactive Waste Management. September 7-11, Winnipeg, Canada 
Heinonen, J, and U. Vuorinen. 1986. "Management of Low- and Intermediate-Level Radioactive Waste in Finland." In ANS proceedings SPECTRUM-86, p. 1878. September 14-18, Niagara Falls, New York.

Nuclear Energy Agency (NEA). 11/86. "Summary Record of Ad Hoc Meeting of the Directors of Crystalline Rock Projects.' Meeting held November 3-4, 1986, Paris.

Nucleonics Week (NW). 10/16/86. 'Finland's Imatran Voima Oy (IVO) and the USSR's Atomenergoexport Have Signed a New Radwaste Disposal Agreement," p. 11.

Peltonen, E.K., et al. 1986. "Concept and Safety Assessment for Final Disposal of Spent Nuclear Fuel in Finland.' In proceedings of IAEA Symposium on Siting, Design and Construction of Underground Repositories for Radioactive Wastes, p. 611. March 3-7, 1986, Hannover, Federal Republic of Germany.

Ryhanen V., T. Aikas, and P. Vuorela. 1986. 'Site Investigations for Final Disposal of Spent Nuclear Fuel in Finland.' In proceedings of IAEA Symposium on Siting, Design and Construction of Underground Repositories for Radioactive Wastes, p. 329. March 3-7, Hannover, Federal Republic of Germany.

Snellman, N. 1986. 'Long-Term Behavior of Bituminized Waste.' Waste Management ' 86 , Vol. 3, p. 501. March 2-6, 1986. Tucson, Arizona,

Tikkanen, T. 1986. "Finnish Utilities Are Counting on Bacteria to Halve Volumes of Organic Waste." Nucleonics Week, February 13, 1986, p. 10.

Tusa E.H., et al. 1986. "Final Disposal of Low- and Intermediate-Level Wastes from Nuclear Power Plants in Finland." In proceedings of IAEA Symposium on Siting, Design and Construction of Underground Repositories for Radioactive Wastes, p. 231. March 3-7, Hannover, Federal Republic of Germany.

Vieno T. 1986. Paper presented at OECD Nuclear Energy Agency PAAG Meeting, May 1986, Paris.

-1987 .

Finland. 1987. Generation of Nuclear Energy in Finland (Brochure)

Harkonen H. T., and E. H. Tusa. 1987a. "Final Disposal of Low and Medium Waste in Finland." Nuclear Europe, March-April 1987, p. 41.

Harkonen, H. T., and E. H. Tusa. 1987b. "LLW Management by Finnish Power Companies." Waste Management ' 87 , Vol. 3, p. 33. March 1-5, 1989, Tucson, Arizona.

Industrial Power Company Ltd. (TVO). 1987a. Nuclear Waste Facts, (Brochure).

Industrial Power Company Ltd. (TVO). 1987b. TVO Site Selection Program, (Brochure).

Industrial Power Company Ltd. (TVO). 1987c. TVO-KPA-Store, (Brochure).

Industrial Power Company Ltd. (TVO). 1987d. Summary of the Preliminary Safety Analysis Report : Disposal of Reactor Wastes from the Olkiluoto Power Plant. 
International Atomic Energy Agency (IAEA). 1987. 'Nuclear Share of Electricity Production in 1986." Nuclear Safety Review For 1986, p. 23. August 1987, Vienna.

Nuclear Europe (NE). 10/87. 'China to Supply Uranium to Finland,' p. 56.

Nuclear Engineering International (NEI). 12/87. 'Finland to Build Deep Repositories," p. 51.

Nuclear Fuel (NF). 3/9/87. 'Finnish Utilities Moving Forward With Search for Disposal Sites,' p. 4.

Nuclear Fuel (NF). 5/4/87. "Finland, Spent Fuel Returns," p. 14.

Nuclear Fuel (NF). 8/10/87. 'TVO Takes Two Reloads from ASEA-Atom,' p. 12.

Nuclear Fuel (NF). 10/19/87. TVO Says Direct Storage of Spent Fuel Is Cheaper Than Other Options," p. 4.

Nucleonics Week (NW. 7/16/87. 'Finland: TVO Seeks Repository Site,' p. 14.

Tusa, E. H., and B. G. Walstrom. 1987. 'Practice to Minimize Nuclear Waste Amounts in Loviisa NPS." Waste Management ' 87 , Vol. 3, p. 23. March 1-5, Tucson, Arizona.

$-1988-$

International Atomic Energy Agency (IAEA). 1988. "Overvtew of the Finnish Radioactive Waste Management Activities." Ninth Meeting of the Technical Review Committee on Underground Disposal of Radioactive Waste (TRCUD) of the International Atomic Energy Agency, February 15-19, 1988, Vienna.

Nuclear Engineering International (NEI). 2/88. 'Sending Loviisa's Fuel to Russia,' p. 46.

Nuclear News (NN). 3/88. 'Waste Strategy in Finland,' p. 81.

Nucleonics Week (NW). 1/14/88. "Finns Keep Fifth Reactor Plans But Polls Show Public Nervous,' p. 12.

Nucleonics Week (NW). 2/4/88. "Nuclear Electricity Generation for December 1987," p. 18.

Nucleonics Week (NW). 3/17/88. 'FINLAND: Olkiluoto LLW Permits Approved,' p. 12.

Nucleonics Week (NW). 10/20/88. "Waste Site Permit Issued by STUK to Loviisa Owner," p. 8.

Nucleonics Week (NW). 12/22/88. 'Finnish Government Awards 10-Year Reactor Licenses,' p.11.

NUKEM Market Report on the Nuclear Fuel Cycle (NUKEM). 1/88. "Finland," p. 12.

Tusa, E. H. 1988. "Options of LLW Volume Reduction in Loviisa NPP," Proceedings of Nuclear and Hazardous Waste Management - International Topical Meeting (ANS), p. 189. September I988, Pasco, Washington.

Mikkola, I. "Stockpiling of Uranium and Diversification of Supplies," Proceedings of the International Conference on Nuclear Energy - World Nuclear Fuel Market - Fifteenth Annual Meeting, p. 195.

October 16, 1988, Seville, Spain. 
Hellmuth, K-H. 1989. "Natural Analogues of Bitumen and Bituminized Radioactive Waste." STUK-BVALO 58, Finish Centre for Radiation and Nuclear Safety, Helsinki, Finland.

Nuclear Energy Agency (NEA). 1989. Uranium: Resources, Production and Demand. Joint report by OECD/NEA and IAEA, Nuclear Energy Agency, Paris, p. 170.

Nuclear News (NN). January 1989. "TVO uses spent-fuel interim storage facility," p. 40.

Nuclear Waste Commission of Finnish Power Companies (YJT). 1989. "Nuclear Waste Management Finland." Brochure published by OECD/NEA-1989.

Nucleonics Week (NW). 8/31/89. "FINLAND: Olkiluoto Repository Progress,' p. 13.

Proceedings of Management of Low and Intermediate Level Radioactive Wastes 1988, IAEA. 1989. "Disposal of Low and intermediate Level Wastes in Finland," Vol. 2, p. 171.

Tusa, E. H. 1989. "Microbial Treatment of Radioactive Waste at the Loviisa NPP. In Proceedings of Waste Management 89, Vol. 2. February 26 - March 2, 1989. Tuscon, Arizona, p. 485.

VLJ-Repository. 1989. Final Repository for Operating Waste at Olkiluoto. (Pamphlet) published by Teollisuuden Vaimasy, Helsinki, Finland.

$-1990-$

Industrial Power Company Ltd. (TVO). 1990. Annual Report 1989 (brochure).

Leigh, I. W., and S. J. Mitchell. 1990. International Nuclear Fuel Cycle Fact Book. PNL-3594 Rev. 10, Pacific Northwest Laboratory, Richland, Washington.

National Power Company Ltd. (IVO). 1990. Annual Report 1989 (brochure).

Nuclear Energy Agency (NEA). 1/90. "Radioactive Waste Management in Finland - Status Overview January 1990.' Presented at the Meeting of the NEA's Radioactive Waste Management Committee.

Nuclear Engineering International (NEI). January 1990. "Datafile: Finland."

Nuclear Europe Worldscan (NE). 3-4/1990. "Finns and Soviets Agree on Optimizing the WER-1000," p. 54.

Nuclear Fuel (NF). 11/12/90. 'TVO Submits Cheaper Spent Fuel Plan Thanks to New SwedishFinnish Concept," p. 11.

Nuclear News (NN). 9/90. "International Briefs," p. 82.

Nuclear Waste Bulletin (NWB). June 1990a. "New Regulation for L/LW Disposal to be Issued,' p. 14. Bulletin No. 5. Nuclear Energy Agency (NEA) of the Organization for Economic Cooperation and Development (OECD), Paris.

Nuclear Waste Bulletin (NWB). June 1990b. "Siting Investigations Undenway for Spent Fuel Repository," p. 12. Bulletin No. 5. Nuclear Energy Agency (NEA) of the Organization for Economic eooperation and Development (OECD), Paris. 
Nuclear Waste Commission of Finnish Power Companies (YJT). 1990. Annual Report 1989 (brochure).

NUKEM Market Report on the Nuclear Fuel Cycle (NUKEM). 5/90. "Nuclear Power Plant Capacity of the Westem World." NUKEM Gmbh, Hanau, Federal Republic of Germany, p. 22. 
FRANCE 


\section{FRANCE}

\section{CONTENTS}

$1.0 \quad$ NUCLEAR POWER $\ldots \ldots \ldots \ldots \ldots \ldots \ldots \ldots \ldots \ldots \ldots \ldots \ldots \ldots \ldots \ldots .2$

2.0 NUCLEAR FUEL CYCLE AND RADIOACTIVE WASTE MANAGEMENT

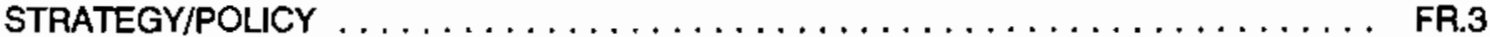

3.0 HIGHLIGH ITS AND MAJOR MILESTONES $\ldots \ldots \ldots \ldots \ldots \ldots \ldots \ldots \ldots \ldots \ldots$

4.0 INSTITUTIONAL CONSIDERATIONS/ORGANIZATIONS $\ldots \ldots \ldots \ldots \ldots \ldots \ldots \ldots$ FR.7

5.0 NUCLEAR FUEL PRODUCTION $\ldots \ldots \ldots \ldots \ldots \ldots \ldots \ldots \ldots \ldots \ldots \ldots \ldots$

6.0 FUEL RECYCLE $\ldots \ldots \ldots \ldots \ldots \ldots \ldots \ldots \ldots \ldots \ldots \ldots \ldots \ldots \ldots \ldots \ldots$

7.0 SPENT FUEL STORAGE AND TRANSPORT $\ldots \ldots \ldots \ldots \ldots \ldots \ldots \ldots \ldots \ldots \ldots$ FR.22

8.0 WASTE CONDITIONING, STORAGE AND TRANSPORT $\ldots \ldots \ldots \ldots \ldots \ldots \ldots \ldots$ FR.24

9.0 DISPOSAL OF NON-HIGH-LEVEL WASTES $\ldots \ldots \ldots \ldots \ldots \ldots \ldots \ldots \ldots \ldots \ldots$

10.0 DISPOSAL OF HIGH-LEVEL WASTES $\ldots \ldots \ldots \ldots \ldots \ldots \ldots \ldots \ldots \ldots \ldots \ldots \ldots \ldots \ldots$

11.0 MANAGEMENT OF URANIUM MINE AND MILL WASTES $\ldots \ldots \ldots \ldots \ldots \ldots \ldots$ FR.39

12.0 DECOMMISSIONING AND ENVIRONMENTAL RESTORATION $\ldots \ldots \ldots \ldots \ldots \ldots \ldots$ FR.39

13.0 INTERNATIONAL ACTIVITIES $\ldots \ldots \ldots \ldots \ldots \ldots \ldots \ldots \ldots \ldots \ldots \ldots \ldots \ldots$ FR.42

14.0 REFERENCES $\ldots \ldots \ldots \ldots \ldots \ldots \ldots \ldots \ldots \ldots \ldots \ldots \ldots \ldots \ldots \ldots \ldots$ FR.44 


\subsection{NUCLEAR POWER}

1.1 REACTOR MIX: 49 PWAs; 4 GCAs; 2 FBPs (NEI 1990)

\subsection{ELECTRIC POWER PRODUCTION (NUKEM 4/90)}

1989--387.5 TWh net (74\% nuclear, $12.5 \%$ fossil, $13.5 \%$ mydro and geothermal)

\subsection{NUCLEAR POWER CAPACITY PROJECT,ONS (NUKEM 4/90)}

1990-55.7 GWe

1995-61.2 GWe

2000-64.1 GWe

\subsection{NUCLEAR PLANT AVALABIUTY (Howles 1990)}

Year ending $12 / 89-61.8 \%$

Lifetime through $12 / 89-60.8 \%$

\subsection{NUCLEAR ENEAGY POLICY:}

In 1946, the coal, gas and electricity industries were nationalized; France, therefore, has a highly centralized state-control system over the energy agencies and companies; federal agencies reporting to the Ministry of Industry are responsible for development of nuclear energy for both military and civilian applications and for electricity production and distribution (de Carmoy 1982)

In the economic expansion following World War II, French demand for primary sources of energy increased dramatically; because of limitations on domestic energy supplies and hydroelectric sites, most of the increased demand was met through imported coal, oil and gas, with imports providing $75 \%$ of energy needs at the time of the energy crisis in 1973 (de Carmoy 1982; Carle 1983)

France's entry into commercial production of electricity using nuclear energy began in 1956 when the Marcoule G1, a 2-MWe natural uranium, gas-cooled graphite reactor, was connected to an electrical grid; based upon strong support by the nationalized electric utility, the gascooled graphite reactor design was discontinued in the late 1960 s in favor of the Westinghouse PWA design; with the advent of the 1973 oil crisis, the government's energy planning was revised to include a substantial number of nuclear reactors using a standardized design, thereby starting a nuclear program leading to the present system of PWAs, GCAs and FBAs which produce 74\% of the nation's electricity (Goldschmict 1982; NEI 1990; NE 1-2/90)

Fuel cycle support (i.e., uranium supply, conversion, enrichment, fuel fabrication and reprocessing) is provided largely through Cogema, established in 1976 as an industrial firm whollyowned by the CEA; the first five-year plan adopted by the government in 1952 established the Marcoule nuclear site, including a reprocessing plant for gas-reactor fuels; a second reprocessing complex was started by the CEA in 1959 near Cherbourg, France, for LWA oxide fuels, both domestic and foreign (Cogema 1986; Cogema 1989; Cogema 1990)

Strong support for continued growth of France's nuclear prograin is still voiced by the government; however, political and public pressure to re-evaluate the program is growing; also, the 
French Atornic Energy Commission's operating divisions were reorganized to encourage a "customer-oriented" approach in the R\&D programs; priorities for the CEA's research programs in 1990 include reactors of the future, laser isotope separation, and studies of decontamination, waste conditioning, and the geologic behavior of candidate nuclear waste disposal sites (NN 12/89; NW 3/1/90; NW 3/15/90; NW 11/30/89)

1.6 NUCLEAR R\&D BUDGET: Research and development related to nuclear programs is conducted by several entities in France

A. Reactor R\&D: Framatome, EDF and the CEA are the main parties conducting R\&D on nuclear reactor development; the program costs the parties roughly 1.5 billion French Francs (FF) per year (\$300 million U.S.) (Schwartz, J-P. 1989)

1. Fuel Cycle R\&D: R\&D on the nuclear fuel cycle, other than waste management, is conducted mainly by Cogema and its subcontractors; costs of this R\&D were approximately 3.1 billion FF (\$600 million U.S.) in 1988 (Cogema 1989)

C. Waste Management R\&D: R\&D on general management systems and safety is conducted and funded by the CEA; technology R\&D is also mainly carried out and funded by the CEA, with some contribution from the European Community and from waste producers such as Cogema; the CEA waste R\&D budget was about 345 million FF ( $\$ 70$ million U.S.) in 1990 (NEA 3/90)

In France, waste management operations downstream of the waste producer's facilities (i.e., transportation and disposal) are the responsibility of ANDRA, a federal agency created in 1979; ANDRA, in turn, recovers the costs from the waste producers, mainly the CEA and Cogema; in 1989, R\&D costs of 300 million FF ( $\$ 60$ million U.S.) were incurred mainly for development of a geologic disposal system for long-lived wastes (NEA 3/90)

1.7 ELECTRICITY PRODUCTION COSTS: In France, costs for generating electricity are estimated at $\$ 0.0286 / \mathrm{kWh}$ for nuclear stations and $\$ 0.040 / \mathrm{kWh}$ for coa!-fired stations (NEA 1989)

\subsection{NUCLEAR FUEL CYCLE AND RADIOACTIVE WASTE MANAGEMENT} STRATEGY/POLICY

2.1 OVERALL NUCLEAR FUEL CYCLE POLICY: France's strategy/policy on supponing its strong nuclear power program has been one of developing a domestic capability in all aspects of the nuclear fuel cycle except the supply of uranium, for which foreign sources must be relied upon; implementation of this policy is left to industrial firms heavily subsidized by the federal government to provide fuel cycle support for its nuclear power program but encouraged to develop other funding sources, either domestic or foreign; the federal government provides regulatory oversight, including licensing, of all nuclear activities and conducts the waste disposal programs; France cooperates with other countries and participates in international nuclear organizations on activities leading to improvements in radioactive waste management and environmental protection; France's heavy reliance on nuclear power was reaffirmed by the government in late 1989 but stronger emphasis on public information/participation is likely (de Carmoy 1982; FNN 1/89; NN 12/89)

2.2 POLICY ON THE FRONT END OF THE FUEL CYCLE: France's policy on the front end of the nuclear fuel cycle is to develop and maintain domestic capability for providing the services required by its strong nuclear program utilizing light-water, gas-cooled and fast-breeder 
reactors; out of necessity, about half of France's uranium needs are imported from foreign sources with a stockpile of three-years' consumption being maintained to avoid possible supply interruptions; both private and federally-supported industrial firms are used to provide the services with costs being borne by the user (de Carmoy 1982; FNN 1/89; IAEA 1988; NEA 1990a; NEI 1990)

2.3 POLICY ON THE BACK END OF THE NUCLEAR FUEL CYCLE: France's policy on the back end of the nuclear fuel cycle is to develop complete domestic capabilities and to rely on industrial firms for conduct of fuel cycle operations as well as bear the associated costs; reprocessing with recycle of uranium and plutonium is accepted as a necessary step in managing spent nuclear fuel; near-surface engineered facilities are considered adequate for disposal of short-lived (i.e., with half-lives less than 30 years) radioactive wastes; geologic disposal is considered necessary for longer-lived radioactive wastes but only after adequate technology has been developed; in the interim, extended dry storage of these wastes is acceptable; the policy also includes (de Carmoy 1982; NEA 3/90):

A. the requirement that the waste generator condition, package and store radioactive waste prior to collection and disposal as well as pay the associated costs; high-level wastes from reprocessing are vitrified in glass; low- and intermediate-level wastes are immobilized in cement or plastic (FNN 10/88);

B. assigning responsibility for transportation of waste to a disposal site and disposal of radioactive waste to a federal agency (ANDRA); ANDRA, in turn, subcontracts transportation and disposal activities to industrial firms and charges costs to the waste producers (NEA 3/90);

C. relying on water basins for interim storage of spent nuclear fuel but is evaluating dry storage as an alternative (NEA 3/90);

D. reprocessing of spent nuclear fuel to obtain plutonium and uranium for recycle in power reactors; plutonium and uranium are being recycled to a limited extent in both lightwater reactors and breeder reactors; uranium is being recycled to a small extent in lightwater reactors (Quinaux 1989; NEI 1990);

E. co-mingling radioactive wastes from commercial and defense activities for disposal (ANDRA 1988):

F. evolving plans in regard to decommissioning of nuclear facilities; decommissioning performed to date has been performed by the owner/operator adhering to regulations applicable to nuclear facilities (Cregut 1986; IAEA 1986; NEA 1986)

\subsection{HIGHLIGHTS AND MAJOR MILESTONES}

1946 Coal, gas and electricity industries were nationalized; nuclear energy development was assigned to the CEA; electricity production was assigned to the EDF (de Carmoy 1982)

$1956 \quad$ First electricity was supplied by nuclear power (Marcoule G1, a 2-MWe natural uranium, gas-graphite reactor) (Cogema 1990; NEI 1990) 
1958 Reprocessing plant (UP1) at Marcoule began operation on gas-cooled reactor fuels (NUKEM 3/88)

1962 CFCa fuel fabrication facility for FBR fuels began operations at Cadarache (Lebastard 1987)

1966 Reprocessing plant (UP2) at La Hague began operation on gas-cooled reactor fuels (NUKEM 3/88)

1969 Near-surface disposal site for short-lived wastes was started up at La Manche, adjacent to La Hague reprocessing center (ANDRA 1987)

1969 AT1 fuel reprocessing facility for FBR fuels began operating at La Hague (NUKEM 3/88)

1969 PIVER pilot HLW vitrification facility started operation at Marcoule (NUKEM 4/88)

$1970 \quad$ First PWR was ordered (Goldschmidt 1982)

1973 EDF announced an "all-nuclear" policy with an annual rate of increase in nuclear generating capacity of 5,000 MWe using LWRs (Goldschmidt 1982)

1973 250-MWe prototype breeder reactor 'Phenix' began operation at Marcoule (Goldschmidt 1982)

1974 TOP pilot fuel reprocessing plant for FBR fuels began operations at Marcoule (NUKEM 3/88)

1976 Cogema established under the CEA to provide nuclear fuel cycle services, i.e., uranium supply and conversion, enrichment, fuel fabrication, transportation, fuel reprocessing and waste treatment (Cogema 1989)

1976 UP2 reprocessing plant, with a new head-end and called UP2-400, began processing LWR oxide fuel at La Hague (Cogema 1990)

1977 UP3 reprocessing plant launched for La Hague site, primarily for reprocessing LWR fuels from Belgium, Japan, the Netherlands, Sweden, Switzerland and West Germany (Cogema 1990)

1978 AVM vitrification facility at Marcoule began radioactive operations (NUKEM 4/88)

1978 The engineered tumulus" facility design for disposal of low-level wastes was instituted at La Manche (FNN 10/88)

1979 ANDRA was created as a government, non-profit agency to conduct radioactive waste management operations downstream of the producer; this includes establishing policy, waste packaging and disposal criteria and disposal centers (ANDRA 1988)

1984 Castaing Commission released results of review supporting French reprocessing/ waste management program (NUKEM 3/88) 
l'Aube site for new LLW/LW near-surface disposal facility was approved by French government (NUKEM 1/88)

1987 Goguel report on the selection criteria for high-level waste disposal sites was released (NUKEM 4/88)

ANDRA selected four sites for investigation on suitability for disposal of HLW (NUKEM 4/88)

TOR pilot FBR fuel reprocessing plant began operation at Marcoule (NUKEM 1/87)

1987 Expanded CFCa FBR/MOX fuel fabrication facility began operation at Cadarache (IAEA 1988)

1988 APM pilot reprocessing plant began operation at Marcoule on FBR and MOX fuels (NUKEM 3/88)

1989 New UP3-800 reprocessing plant at La Hague began operation on LWR fuels, replacing the TOP facility (NUKEM $3 / 88$; NUKEM $2 / 90$ )

1989 Vitrification of $\mathrm{HLW}$ began in R.7 facility associated with UP2 reprocessing plant at La Hague (NUKEM 2/90)

1989 Construction license was issued to ANDRA for LLW/LW near-surface facility at l'Aube (NUKEM 2/90)

$1990 \quad$ French Prime Minister personally placed a moratorium of at least a year on field studies to evaluate four candidate HLW disposal sites (NN 3/90)

1990 Construction license was issued for Melox fuel fabrication plant at Marcoule for MOX fuels (NF 5/28/90)

1991 Begin operation of new LW disposal facility at l'Aube (NEA 3/90)

1991 Begin vitrification of HLW in T-7 facility associated with UP3-800 reprocessing plant at La Hague (NN 1/90)

1992 Select site for underground in situ validation laboratory (ISVL) for HLW disposal (NN 3/90)

1993 Begin operation of Cogema's expanded UP2 reprocessing plant (UP2-800) at La Hague (NUKEM 2/90)

1994 Begin operation of Cogema/Framatome's MELOX fabrication facilities for MOX fuels at Marcoule (NF 5/28/90)

2000 Reach decision on construction of a HLW/TRU repository (NEA 3/90)

2010 Begin operation of a HLW/TRU repository (NEA 3/90) 
4.0 INSTITUTIONAL CONSIDERATIONS/ORGANIZATIONS: Nuclear legislation in France has developed in successive stages in line with technological advances and growth in the nuclear energy field; the Atomic Energy Commission (CEA) was established in 1945 to control nuclear matters, reporting directly to the head of the government; in 1946, the energysupply industries were nationalized with nuclear development being made the responsibility of the CEA and electricity production and distribution being made the responsibility of a new federal agency, EDF; the Decree of 1970 permitted the CEA to extend its activities, particularly fuel cycle support, to subsidiary companies; licensing of major nuclear facilities, left to local departments (equivalent to states in the U.S.) until 1963, now requires approval of the federal government (de Carmoy 1982; NEA 1983; IEAL 1987; Burholt 1988)

\subsection{LEGAL REQUIREMENTS}

A. In France, major nuclear facilities (i.e., those where the radioactivity levels of the nuclear materials used exceed specified limits) must be licensed by application to the appropriate Ministry; other nuclear activities are licensed by application to the local Department Commissioner (NEA 1983)

B. The legal requirements to be satisfied by any possessor or user of nuclear materials are embodied in the numerous statutes passed as part of general legislation on environmental protection, water supply, atmospheric pollution, public health and labor (NEA 1983)

C. France does not have a stipulation law making the licensing of nuclear facilities dependent upon existence or proof of adequate means of waste disposal (Numark 1989)

D. The federal Parliament has preemptive rights in siting decisions; local veto of land use can be overruled by the federal government (Numark 1989)

4.2 RADIATION PROTECTION PRINCIPLES: French regulations for the control of ionizing radiation are contained in the Decree of June 20,1966, as amended, and are consistent with Euratom and ICRP recommendations; the principal recommendations include limiting the exposure of radiation workers to $5 \mathrm{rem} / \mathrm{yr}$ and members of the public to $0.5 \mathrm{rem} / \mathrm{yr}$ (Leclercq 1986; NEA 1988a; NEA 3/90)

4.3 LICENSING (NEA 1983; EDF 1986; IEAL 1987; Burholt 1988; Numark 1989; NEA 6/90a)

A. In France, licenses are required for construction and operation of major nuclear installations, which include reprocessing plants, storage systems and disposal repositories; major nuclear installations classified as secret by the Prime Minister are not subject to licensing; the major licensing requirement, initiated in 1963, is a Licensing Decree signed by the Prime Minister; separate licenses are also required for construction and for release of gaseous and liquid radioactive effluents

B. The application for a Licensing Decree is submitted to the Central Service for the Safety of Nuclear Installations (SCSIN), which solicits reviews from appropriate groups, at both the federal level and the local level; the review at the federal level is conducted by the Permanent Group, which is assisted by the Institute for Protection and Nuclear Safety (IPSN), a part of the CEA; the review at the local level is conducted by the Department Commissioner and includes announcements with discussions of opposing viewpoints and may result in the formation of local information committees 
C. Once the reports by the Permanent Group and local Departments have been received along with comments from appropriate Ministers, the SCSIN prepares a draft Licensing Decree that is sent to the Interministerial Committee for Major Nuclear Installations and to the Secretary for Heatth for approval before going to the Prime Minister for signing; if approval is not given by the Secretary for Health within three months, the Decree may be approved by the Council of Ministers

D. The Licensing Decree fixes the perimeter of the installation, the conditions imposed upon the operator and details of the commissioning procedure; final commissioning is contingent upon approval by the Minister of Industry of the final safety report and general operating rules; a 1990 amendment to the 1963 Decree statute extends the provisions of the licensing decree to include plans and schedule for decommissioning the facility

E. Allowable releases of gaseous or liquid radioactive effluents from nuclear installations are the subject of separate licensing procedures; the license application covering effluent releases is filed at the same time as the license application for the nuclear installation and is granted jointly by the Minister of Industry, Minister of Environment and Minister of Health after considering the opinions of the Central Service for Protection Against lonizing Radiation (SCPRI); if the release is to be made to the sea, the approval of the Mirister of Transport is also required

F. Nuclear installations also require a construction license, which is issued by the Department Commissioner

\subsection{PUBLIC INVOLVEMENT (NEA 12/88; Numark 1989)}

A. Statutes enacted in 1985 expanded the role of the public in the licensing of nuclear installations; construction authorization is subject to a "Public Inquiry," which entails making available to the public all necessary information concerning the proposed project, including the environmental impact statement

B. Proceedings at the local level begin with the appointment of a Commissioner of inquiry to interact with the public; that individual is responsible for alerting the public within $10 \mathrm{~km}$ of the site of a "Public Inquiry' using newspaper announcements, official public notices, etc.; the "Public Inquiry' is a process whereby all interested parties can examine the project application and record, in writing, their observations, comments, objections and suggested alternatives in an official register maintained near the proposed site; however, only comments related to safety or to the environment are considered germane; comments on overall nuclear policy are ruled out-of-order

C. An Inquiry Commission is appointed by the local administrative court; the Commission evaluates the comments and prepares a report that is circulated to the administrative court, the license applicant, the regulatory authorities and each of the local town councils in the area of inquiry

D. Communities within a 5-km radius of the proposed project now have the opportunity to vote for or against the project; a negative vote can be overruled by the national Parliament

E. At the beginning of 1987, investigations were started at four potential sites for an underground research laboratory for long-lived wastes; lively opposition to borehole drilling at 
three of the sites led the Prime Minister to place a one-year moratorium on further drilling on these sites, beginning in February 1990 (NF 1/22/90; NEA 6/90b)

F. A decision to construct a second facility for near-surface disposal of low-level wastes was made in 1984; a license for construction was awarded in 1989; the licensing process included the public participation described earlier and met no objections; construction is underway (NEA 1/90)

4.5 WASTE FUND: Costs for managing radioactive wastes up to the point of disposal are the responsibility of the waste generator; the costs of low-level waste disposal at La Manche and l'Aube are charged to the generator by ANDRA as they are incurred; the cost of constructing the new disposal site at l'Aube is also charged to the generators by ANDRA according to the disposal volume they have reserved; ANDRA also charges the costs of developing a geologic disposal system for long-lived wastes to the prospective generators according to the disposal volume they have reserved (NEA 3/90)

\subsection{KEY AGENCIES AND FUEL CYCLE CENTERS}

A. The Ministry of Industry has primary jurisdiction over all nuclear activities, including their regulation; a special department of this Ministry, the Central Service for Safety of Nuclear Installations (SCSIN), develops and enforces safely regulations, issues construction permits and operating licenses

B. The Ministry of Health has primary jurisdiction over protection of public health, including the effects of radioactivity in the environment; a special department of this Ministry, the Central Protection Service against lonizing Radiation (SCPRI), monitors radioactivity in the environment, monitors and controls radioactive effluents and issues permits for radioactive releases

C. The French Atomic Energy Commission or Commissariat a l'Energie Atomique (CEA) has the responsibility for the development of nuclear energy for production of both electricity and weapons; this is accomplished through numierous operating directorates, research centers and wholly or partially owned industrial concerns, e.g., Cogema (de Carmoy 1982)

1) The CEA's operating directorates include (CEA 1989a; NW 3/1/90):

a) The Directorate of Military Applications (DAM) directs production and development activities related to nuclear weaponry, including strategic warheads, nuclear testing, nuclear physics, and nuclear propulsion

b) The Institute for Protection and Nuclear Safety (IPSN) directs research related to safery for reactors, nuclear facilities and fuel cycle installations

c) The Directorate for the Nuclear Fued Cycle directs the technical development activities related to the nuclear fuel cycle, i.e., enrichment, reprocessing, waste disposal, decontamination and decommissioning, etc.

d) The Directorate of Nuclear Reactors directs the technical support for development of reactor systems, current and future 
e) The Directorate of Material Sciences directs the technical development of advanced materials such as superconductors, semiconductors, etc.

f) The Directorate of Life Sciences directs basic research on biomolecular mechanisms, on biomedicine and on plant physiology

g) The Directorate of Advanced Technologies directs development related to advanced technologies such as microelectronics, instrumentation, robotics, automation, etc.

h) The National Radioactive Waste Management Agency (ANDRA) has responsibility for creating and operating systems for disposal of radioactive wastes

i) The National Institute for Nuclear Sciences and Technology (INSTN) has the responsibility for international exchanges and cooperation, nuclear education, and industrial property/technology transfer

2) The CEA's research centers are described in Section 4.7

3) Over the years the CEA has found it necessary to establish a number of subsidiaries in charge of handling the industrial activities stemming from its research; in addition, the CEA research entity has acquired interests in previously founded companies like Framatome; the principal CEA industrial subsidiaries involved in the nuclear arena include (RGN 1986; CEA 1989a; CEA 1989b; Cogema 1989):

a) The Compagnie Générale des Matiéres Nucléaires (Cogema Group), a wholly-owned subsidiary of the CEA eștablished in 1976, supports the entire nuclear fuel cycle including uranium prospecting and mining, uranium components, uranium enrichment, fuel assembly, spent fuel reprocessing and associated services; Cogema operates the reprocessing/waste management facilities at La Hague and Marcoule; other services are performed in France and internationally through numerous wholly-owned and partiallyowned subsidiaries such as:

- $\quad$ Compagnie Francaise de Mokta (CFM), wholly-owned by Cogema, operates uranium mines in France; several subsidiaries of Cogema prospect for uranium and operate uranium mines around the world

- GIE Cogema/Belgonucléaire pour la Commercialisation de Combustibles è l'oxyde Mixte (COMMOX), $60 \%$ owned by Cogema, manufactures MOX fuel

- Société pour la Conversion de l'Uranium en Metal et Héxafluorure (COMURHEX), 49\% owned by Cogema, processes uranium concentrate into hexafluoride or metal at Pierrelatte and Malvési

- Société Européenne de Diffusion Gazeuse (EURODIF), 51.5\% owned by Cogema, enriches uranium by gaseous diffusion at the Pierrelatte site

- GIE Framatome et Cogéma (FRAGEMA), jointly owned by Framatome and Cogerna, designs and markets nuclear fuel 
- Franco-Belge de Fabrication de Combustibles (FBFC), $25 \%$ owned by Cogema, manufactures LWR fuel

- Melox, S.A., jointly owned by Cogema and Framatome, will manufacture MOX fuel at a new facility being built at the Marcoule site (NW $5 / 24 / 90$ )

- $\quad$ Numatec, inc., owned by Cogema and SGN, provides engineering services and technology to the U.S. industry

- Société Générale pour les Techniques Nouvelles (SGN), 66\% owned by Cogema, provides engineering design services for the nuclear industry

- $\quad$ Société Industrielle de Combustible Nucléaire SICN), wholly-owned by Cogema, produces metallic fuel for French gas-cooled reactors

- Société Industrielle des Minerais de l'Quest (SIMO), wholly-owned by Cogema, produces uranium concentrate or "yellow cake' in France

- $\quad$ Transnucléaire (TN), 32.9\% owned by Cogema, provides transportation services for the nuclear industry

- USSI Ingénierie, $38 \%$ owned by Cogema and $27 \%$ by SGN, provides engineering services for the construction and maintenance of nuclear facilities

b) Framatome, $35 \%$ owned by the CEA, conducts preliminary studies, sells, builds and maintains nuclear power plants, develops and sells nuclear fuels internationally

c) Technicatome, $90 \%$ owned by the CEA, provides engineering services in the nuclear sector, including low- and medium-level power reactors, nuclear research facilities, reprocessing plants, computerized services, construction and maintenance of nuclear reactors for sea-going vessels

d) Intercontrôle, 61.3\% owned by the CEA, conducts preliminary studies and provides engineering services in the area of non-destructive control and maintenance

e) The Société des Techniques en Milieu lonisant (STMI), 40\% owned by the CEA, provides services related to decontamination, dismantling, radio-protection, waste disposal, and management of effluent and waste treatment plants; STMl operates the low-level disposal site at La Manche for ANDRA

f) The Compagnie internationale de Services en Informatique (CISI Group), $64 \%$ owned by the CEA, provides technical, industrial and management computer services

g) The ORIS-Industrie Group, wholly-owned by the CEA, is engaged in the development, production and sale of radiotherapeutic, ionization and in vitro and in vivo diagnostic techniques 
D. Electricité de France (EDF), the French national utility, is responsible for production ai id distribution of all electricity within France, including electricity produced by nuclear power; EDF has a Research and Development Division that concentrates on new technologies applicable to improvements in its generating units and distribution systems; nuclear-related R\&D areas include robots for maintenance, cameras for remote viewing, specialized instrumentation, leak-testing equipment, etc.; EDF also has a International Division that markets EDF services worddwide (EDF 1989; EDF 1990; NE 1-2/90)

E. Bureau of Geological and Mineral Research (BGMR): The BGRM conducts geological research and safety studies for ANDRA (ANDFA 1987; Leigh and Mitchell 1990)

F. Paris School of Mines performs fluid flow, heat transport and mass transport studies related to geologic waste isolation, including sub-seabed disposal for ANDRA (ANDRA 1987; Leigh and Mitchell 1990)

G. Althsom is an international-scale French firm that produces the turbine generators for nuclear power plants (TR 1990)

H. Pechiney is a large French metals company with interests in numerous nuclear applications such as ceramics, coatings, control rods, uranium, Zircaloy, neutron adsorbers, fuel storage racks, etc.; a subsidiary of Pechiney, called Cezus, has the capab'lity to supply $45 \%$ of the world's zirconium market or 2,000 MT/yr (RGN 1986; NF 11/13/89)

\section{Major Fuel Cycle Operations/Centers}

1) The Centre de Stockage l'Aube (CSA) is being constructed by ANDRA for disposal of low-level radioactive wastes; the facility is located at Soulaines-Dhuys, $150 \mathrm{~km}$ east of Paris; operation is expected to begin in 1991 (NEA 3/90)

2) Cadarache, located $38 \mathrm{~km}$ northeast of Aix-en-Provence, is a major CEA research center (see Section 4.7) and is the site of the CFCa facility operated by Cogema for fabrication of MOX and FBR fuel elements (CEN 1980; NEI 1990; NF 10/1/90)

3) La Haque is France's principal site for the reprocessing of LWR fuels; created in 1959 by the CEA, the facility is located on the northern coast of France on the peninsula of La Hague $20 \mathrm{~km}$ east of Cherbourg; it began operations in 1966 on gas-cooled reactor fuels; Cogema assumed management in 1976 and the site is now dedicated strictly to reprocessing of LWR fuels; major facilities/operations on the site include (LH 1987; LH 1989; Cogema 1989; Singer 1991):

a) the UP2 800 and UP3 800 reprocessing plants, each with a capacity of 800 MTU/yr of LWR fuels

b) high-level liquid wastes from the UP2 and UP3 reprocessing plants are placed in tanks for interim storage prior to being vitrified in the $R 7$ and $T 7$ vitrification plants, respectively; each facility is accompanied by a dry storage area for the canisters of vitrified high-level wastes

c) In addition to the high-level waste vitrification facilities, extensive facilities are provided for collection, treatment and storage of low- and intermediate-level wastes 
d) Supporting facilities at the La Hague site inciude storage areas for solid wastes, analytical laboratories, maintenance shops, chemical makeup/ storage area and power plant; dock facilities are maintained at Cherbourg for loading/unloading ship-borne spent fuet casks and a rail loading/ unloading station is maintained at Valognes, near La Hague, for rail-borne spent fuel casks

e) The CEA operates marine radioecology and wet corrosion laboratories at the La Hague site

4) The Centre de la Manche is the site of a near-surface disposal area for short-lived radioactive wastes; it is adjacent to and east of the La Hague reprocessing site and is operated by STMI for Andra (Andra 1987)

5) The Marcoule Nuclear Industrial Center was created by the CEA in 1952 and has developed into a major nuclear center for both research and development and nuclear operations; the R\&D activities, directed by the CEA, are summarized in Section $4.7 A$; the operating activities, managed largely by Cogema, include (Marcoule 1988; Cogema 1989; NF 5/28/90):

a) The MAR 400 facility provides interim storage in water basins for metallic fuels from gas-cooled reactors (GCR)

b) The UPI reprocessing plant has a capacity of $600 \mathrm{MTU} / \mathrm{yr}$ for GCR fuels

c) The Marcoule Vitrification Facility (AVM) converts the high-level liquid wastes from reprocessing activities into a borosilicate glass which is packaged in stainless steel canisters and stored in an air-cooled storage facility adjacent to the AVM plant

d) The Liquid Waste Treatment Station (STEL) purifies all liquid wastes before discharge into the Rhone River

e) The Solid Waste Conditioning Station (CDS) encapsulates low- and intermediate-level wastes into large concrete blocks which are shipped to the disposal site at La Manche

f) The Celestin Industrial Research Reactors provide irradiation services for defense and industrial users

g) The Melox facility, scheduled to begin operation in 1994, will fabricate MOX fuel elements for use in pressurized water reactors

6) The Tricastin Site, near Pierrelatte in the Rhone Valley in southern France, offers services for the nuclear industry including uranium conversion, enrichment, fuel fabrication, uranium defluorination, uranium container management and reprocessed uranium recycling; these are in addition to the R\&D conducted by the CEA on the site (see Section 4.7A); the various firms involved in providing these services include (Cogema 1989; TRI 1990): 
a) Comurhex, a subsidiary of Cogema and Pechiney, converts $\mathrm{UF}_{4}$ received from Malvesi into $\mathrm{UF}_{6}$ to be used as feed material for enrichment (Com 1990)

b) Eurodif, a subsidiary of Cogema (51.5\%) and commercial firms in Belgium, Italy and Spain, operates the Georges Besse diffusion enrichment plant with a throughput of $26,500 \mathrm{MT} / \mathrm{yr}$ of natural uranium; Cogema operates a section of the enrichment plant in which high-enriched uranium is produced for France's national defense requirements (NEI 12/89; Petit 1989; Eurodif 1990; Pierrelatte 1990)

c) Cogema Uranium Management Facility (UMF) acts as the interface between the nuclear utilities and the service companies located at Tricastin; services include provision and maintenance of $\mathrm{UF}_{6}$ shipping containers and isotopic sampling and assay (Tri 1990)

d) Cogema's Deflcorination Plant $(W)$ converts the depleted uranium from enrichment operations in the form of $\mathrm{UF}_{6}$ into the oxide form; the hydrofluoric acid (HF) produced as a byproduct makes Cogema one of Europe's producers of HF; Cogema expects to double the present capacity of 6,0007,000 MTU/yr by 1993 (NF 9/3/90; Pichat 1990; Tri 1990)

e) Franco-Belge de Fabrication de Combustibles (FBFC), a subsidiary of Cogema, Pechiney and Framatome, converts the enriched uranium from the enrichment plant into uranium dioxide $\left(\mathrm{UO}_{2}\right)$ in the form of pellets and uses these in the production of fuel assemblies for light water reactors (Tri 1990)

f) Comurhex and Cogema are collaborating on the development of capability to recycle the uranium returned from fuel reprocessing operations; Comurhex is operating a fluorination plant to convert $350 \mathrm{MT} / \mathrm{yr}$ of uranyl nitrate from reprocessing into $\mathrm{UF}_{6}$ for reenrichment; Cogema is operating a facility (TU 5) for converting the uranyl nitrate from reprocessing into oxides for storage or incorporation into $\mathrm{UO}_{2} / \mathrm{PuO}_{2}$ (MOX) fuels; In 1989, Comurhex received a license to build a new facility, $A C 25$, that is designed to convert up to $2,000 \mathrm{MTU} / \mathrm{yr}$ of recycled uranium into uranium oxides, uranium hexafluoride, or uranium tetrafluoride; these plans are now on hold pending development of the reprocessed uranium (REPU) market (NF 10/2/89; NF 11/13/89; Tri 1990)

g) EDF, the French electrical utility, operates four 915-MWe PWRs at the Tricastin site primarily for producing the power required by the diffusion enrichment plant (Tri 1990)

7) The Malvesi Plant, located near Narbonne in southern France, is the site of Comurhex's facilities for converting uranium ore (domestic and foreign) into $\mathrm{UF}_{4}$ for shipment to the enrichment plant at Tricastin or into uranium metal for France's gas-cooled reactor program; it has a capacity of 25,000 MTU/yr; $A \& D$ is underway on preparing a product suitable for laser enrichment of uranium (Com 1990)

8) Miramas, located about $30 \mathrm{~km}$ northwest of Marseille, is the site for production of jithium-6, lithium-7 and boron-10 for the French government; Cogema, the operator, has stored depleted uranium defluorinated at Tricastin on the Miramas site 
since 1983 and is seeking approval to increase the quantity of depleted uranium to be stored there (Cogema 1989; NF 10/30/89; NF 9/3/90)

9) Annecy, located about $100 \mathrm{~km}$ east of Lyon, is the site of a 500-MTU/yr fuel fabrication facility for GCR fuels operated by the Cogema subsidiary, SICN (NEI 1990)

10) Romans-Sur-lsere, located about $100 \mathrm{~km}$ south of Lyon, is the site of a 750 MTU/yr fuel fabrication facility for LWR fuels operated by the Cogema subsidiary, FBFC; an expansion, planned to open near the end of 1990, consists of a 200MTU/yr fabrication line for producing fuel pellets from uranium recycled from reprocessing operations (NF 11/13/89; NEI 1990)

11) Superphenix is the world's first commercial-scale fast-breeder reactor; a 1250MWe LMFR, it is located at Creys-Malville, about $50 \mathrm{~km}$ east of Lyon, and began operation in 1986; an international group called NERVA, representing French, Italian, German and Swedish utilities, operates the facility (NEI 5/88; NEI 1990)

\subsection{PRINCIPAL RESEARCH, DEVELOPMENT, AND DEMONSTRATION FACILITIES/PROGRAMS}

The principal CEA-Sponsored R\&D facilities and programs involved in waste management in France include (CEA 1989a):

A. Bruyeres-le-Chatel: alpha waste assay and transportation

B. Cadarache: development and production of MOX and FBR fuel elements (including conversion of $\mathrm{UF}_{6}$ to uranium oxjde and metal); operation of the CASCAD dry storage facility for spent fuels; facilities and laboratories for the development of fast-breeder reactors; prototype nuclear propulsion reactor (PAT); experimental breeder reactor RAPSODIE; operation of research reactors; development of treatment processes for fuel fabrication wastes; treatment and packaging of radioactive wastes generated onsite; waste assay; reactor safety research; Tore Supra tokamak facility; radioecology and radioagronomy studies (CEN 1980)

C. Cesta: simulated testing of environmental conditions; mechanical/structural tests; climatic tests; reliability and safety tests

D. Fontenay-aux-Roses: studies (including radioactive testing) of actinide chemistry and radionuclide migration in soils and barrier materials; evaluation of barrier materials for waste containment; waste storage studies; modeling of release of radionuclides at disposal facilities

E. Grenoble: heawy water purification; management of tritium-bearing wastes; global climate studies; operation of research reactors; European Synchrotron Radiation Facility (ESRF)

F. Rhone Valley (Pierrelatte): R\&D on uranium enrichment, including laser enrichment (NE 3/4/90; Tri 1990)

G. Rhone Valley (Marcoule): 250-MWe Phenix demonstration FBR (1973-present); reprocessing (APM pilot plant) and waste treatment development studies; waste form evaluations; waste assay evaluations; pilot plant waste treatment facilities; tritium production; support for MELOX fabrication facility for MOX fuels; FBR spent fuel examination in the Irradiated Sub-Assembly Monitoring Laboratory (LASI) 
H. Saclay: evaluation/testing of waste forms (including large-scale leach testing); treatment and packaging of liquid and solid radioactive wastes generated onsite and in nearby facilities; operation of the NEA Data Bank for nuclear physics, nuclear safety and waste management data; Saturne synchrotron; Orphée research reactor; Saclay Linear Accelerator (ALS); Superconducting HF Cavity Electron Accelerator (MACSE); OSIRIS research reactor

I. Valduc: treatment and packaging of low-level wastes; management of tritium-bearing wastes; dismantling/decontamination of solid wastes

4.8 KEY PERSONNEL (Leigh and Mitchell 1990)

A. Ministry of Industry

- Jean-Daniel Levi, Director General, Energy and Raw Materials

B. BGRM

- Gerard Renon, Director

- H. Astie, Managing Director, Geology

- P.F.R. Peaudecerf, Managing Director, Waste Storage

- J. J. Collin, Managing Director, Hydrogeology

- Ph. Masure, Managing Director, Geotechnology

C. CEA

- Phillippe Rouvillois, Administrator General

- Guy Paillotin, Deputy Administrator General

- Jean Teillac, High Commissioner

D. ANDRA

- Francois Chevenier, Director

- Denis Alexandre, Deputy Director

- Yves Marque, Deputy Director

E. IPSN

- Francois Cogne, Inspector General for Nuclear Safety

- Anne-Marie Chapuis, Waste Protection Research

- Christian Devilliers, Safety Analysis Services

- Michael Montjoie, Decommissioning

F. Cadarache Nuclear Research Center (CEN-CA)

- Jean Megy, Director

G. Fountenay-Aux-Roses Nuclear Research Center (CEN-FaR)

- Yves Martin, Director

- Jean Lefevre, Director, Waste Research

- Annie Sugier, Director, Decommissioning

H. Grenoble Nuclear Research Center (CEN-G)

- Francis DeCool, Director

1. Marcoule Nuclear Research Center (CEN.VALRHO)

- Albert Teboul, Director

- Roger Bonniaud, Manager HLW, R\&D 
- Claude Sombret, Deputy Manager, HLW R\&D

- André Cregut, Decontamination and Decommissioning

J. Saclay Nuclear Research Center (CEN-S)

- Paul Delpeyroux, Director

$K$ Valduc (DAM)

- Marcel de La Graviére, Director

- Jean Ohmann, Director, Quality/Security

L. Cogema, Headquarters

- Jean Syrota, President

- Christian Gobert, Executive Vice-President

- Yves Coupin, Vice-President, Mining

- André Schneider Maunoury, Vice-President, Enrichment

- Jean-Pierre Mustelier, Vice-President, Fuel Fabrication

- Maurice Delange, Vice-President, Reprocessing and Engineering

M. Cogema, USA

- Michael McMurphy, Prosident

- Frank A. Shallo, Vice-President

- William Gallagher, President, Numatec

N. Cogema, La Hague

- Hugue Delaunay, Director

O. Cogema, Marcoule

- Jean Charlade, Director

- Maurice Chotin, Reprocessing

- Pierre Hugony, HLW Vitrification

P. Cogema, Pierrelatte

- Michel Michallet, Director

Q. FBFC, Pierrelatte

- J. Henckes, Deputy Plant Manager

R. Paris School of Mines

- Ghislain de Marsily, Director, Math/Geology Center

- G. E. Ledoux, Deputy Director

S. SGN

- Claude Aycoberry, President

- Jean Louis Ricaud, Vice-President

- Claude Bernard, Technical Director

T. TN

- Bernard Savornin, General Manager

- Paul Blum, Technical Manager 


\subsection{NUCLEAR FUEL PRODUCTION}

5.1 STRATEGY: France's strategy on nuclear fuel production is to provide domestic support services for its gas-cooled, light-water and fast-breeder reactor programs and to market those services to other countries; this strategy has led to (IAEA 1988; NEI 1990):

A. reliance on foreign sources for most of its uranium but uses a domestic firm (Cogema) for procurement

B. development of self-sufficiency in uranium conversion and enrichment with additional capability for marketing enriched uranium to foreign buyers

C. seff-sufficiency in fuel fabrication with additional capability for marketing nuclear fuel to foreign buyers

D. creation of a major reactor supplier (Framatome) for domestic needs and foreign buyers

5.2 URANIUM RESOURCES: France has an estimated 46,657 MT of uranium recoverable at costs up to $\$ 80 / \mathrm{kg}$ and an estimated $12,239 \mathrm{MT}$ recoverable at costs up to $\$ 120 / \mathrm{kg}$ (NEA 1990a)

5.3 URANIUM PRODUCTION: Uranium is mined domestically at six sites which produced 3,920 MTU in 1988; however, most uranium is imported by Cogema or its subsidiaries; foreign mining companies in which Cogema has an interest have a production capability of $8,500 \mathrm{MTU} / \mathrm{yr}$; a stockpile equivalent to three years' consumption is required in case of a supply interruption (Cogema 10/89; NEA 1990a)

5.4 URANIUM CONVERSION: Comurhex is operating three uranium conversion facilities in France: 1) a $14,000-M T U / y r$ facility at Malvesi to produce uranium metal and $U_{4}$ from uranium ore; 2 ) a $14,000-\mathrm{MTU} / \mathrm{yr}$ facility at Tricastin to produce $\mathrm{UF}_{6}$ from $\mathrm{UF}_{4}$; and 3) a 350-MTU/yr facility at Tricastin to produce $U_{6}$ from uranyl nitrate recovered in fuel reprocessing; a new Comurhex facility is under construction at Tricastin that will have the capacity to convert 2,000 MTU/yr of recycled uranium to $\mathrm{UF}_{4}, \mathrm{UF}_{6}$ or $\mathrm{UO}_{2}$ (see Section $4.6 \mathrm{I}$ )

5.5 URANIUM ENRICHMENT: France's uranium enrichment facilities are located at Tricastin, near Pierrelatte; the gaseous-diffusion facility, commissioned in 1979, is operated by Eurodif, a subsidiary of Cogema and industrial firms in Belgium, Italy and Spain; the capacity is $\mathbf{1 0 . 8}$ MSWU/yr; the initial cascade, buit by the CEA in 1958, is used by Cogema to produce highenriched uranium for the French government (Eurodif 1990; NEI 1990; Pierrelatte 1990; Tri 1990)

5.6 FUEL FABRICATION: France has the capability to produce nuclear fuel assemblies for lightwater, gas-cooled and fast-breeder reactors through four facilities operated by industrial firms; additional facilities are being built for MOX and REPU fuels

A. Fabrication of GCR Fuels: a 500-MTU/yr plant for GCR fuels is operated by SICN at Annecy (NEI 1990)

B. Fabrication of LWR Fuels: a 500-MTU/yr facility for LWR fuels is operated by FBFC at Tricastin and a 750-MTU/yr plant for LWR fuels is operated by FBFC at Romans-SurIsere; an expansion is underway at the latter plant to permit fabrication of $200 \mathrm{MTU} / \mathrm{yr}$ of 
LWR fuels containing uranium recycled from reprocessing operations (REPU) (NEI 9/89; NF 11/13/89; NEI 1S90; Tri 1990)

C. Fabrication of MOX and FBR Fuels: a 25-MTU/yr plant (CFCa) for MOX and FBR fuels is operated by Cogema at Cadarache; a new plant, Melox, is scheduled to be operating by Cogema and Framatome at Marcoule in 1994 with capacity for $120 \mathrm{MTU} / \mathrm{yr}$ of MOX fuels (Lebastard 1987; Cogema 1989; NEA 1989; NE 3-4/90; NEI 1990; NF 5/28/90; NF 10/1/90)

\subsection{PROGRAM/FACILITIES COSTS}

A. The initial 1975 investment in the Georges Besse diffusion-enrichment plant at Tricastin was 25 billion FF, roughly equivalent to 62 billion FF ( $\$ 10$ billion U.S.) in 1988 currency (NF 7/11/88)

B. Cogema estimates the cost of expanding the conversion complex at Tricastin as being between 250 and 300 million FF (\$45 and \$54 million U.S.); the expansion, projected to be completed in 1993, will double the capacity of the $W$ defluorination plant to 14,000 $\mathrm{MTU} / \mathrm{yr}$ and provide 2,000 MTU/yr capacity to convert uranyl nitrate recovered from reprocessing (REPU) into $\mathrm{UF}_{4}$, UF 6 , or uranium oxides (NE 5-6/90)

6.0 FUEL RECYCLE: France's policy is to reprocess spent nuclear fuel and recycle the recovered uranium and plutonium in power reactors; both are now being recycled to a limited extent in light-water and breeder reactors, and facilities for fabricating fuels using the recovered uranium and plutonium are being expanded

\subsection{FUEL REPROCESSING}

A. Gas-Cooled Reactor Fuels: Cogema reprocesses metal fuels from France's gas-cooled reactors, both domestic and foreign, in the $600 \mathrm{MTU} / \mathrm{yr}$ UP1 reprocessing plant located at the Marcoule Nuclear Industrial Center; the plant includes the MAR $\mathbf{4 0 0}$ facility installed in 1983 for receiving and storing fuels and for decladding the metal fuels; solvent extraction with tri-butyl phosphate (TBP Purex process) is used to recover the plutonium and uranium; high-level wastes are immmobilized in borosilicate glass in the nearby AVM vitrification facility (Lallement 1988; Marcoule 1988; Cogema 6/89; Cogema 1989)

By 1986, 16,500 MTU of GCR fuel had been reprocessed in France (Numark 1986)

B. Light-Water Reactor Fuels: Cogema reprocesses oxide fuels from both domestic and foreign reactors at the La Hague site on the northern coast of France; two reprocessing facilities, UP2 and UP3, each with a capacity of $800 \mathrm{MTU} / \mathrm{yr}$ are located at the site; the plants include cask-unloading facilities, spent fuel storage pools, and head-end and extraction cells for the TBP Purex extraction process, along with purification processing for the products to be recycled--uranyl nitrate and plutonium oxide; UP2 has been operating since 1976; UP3 started operations in late 1990; both use a chop-leach head-end and the TBP solvent extraction process; foreign spent fuels destined for La Hague are unloaded from ships at nearby Cherbourg; spent fuels from the continent are received by rail at La Hague; five water-filled basins with a capacity of 10,000 MTU are used for interim storage of the fuel prior to reprocessing; high-level wastes are immobilized in the R7 and T7 AVM-type vitrification plants located on the site (Chenevier 1987; Lallement 1988; Cogema 1/89; Cogema 6/89; Cogema 1989; NN 10/90) 
Prior to transfer of all GCA fuel reprocessing to Marcoule, the UP2 plant at La Hague had processed about 4,900 MT of GCR fuel; by October 1990 , the UP2 plant had processed more than 3,150 MT of oxide fuel; the UP3 plant, started in late 1990, is expected to process $250 \mathrm{MT}$ by the end of 1990 and is expected to reach design capacity of $800 \mathrm{MT} / \mathrm{yr}$ in 1991 (Cogema 1989; Robinson 1989; NN 10/90)

C. LWR MOX Fuels: Loading of MOX fuel into LWRs in France began in 1987 at the St. Laurent reactor and has expanded to other LWR reactors but little has been reprocessed; during the recent improvements made to the UP2 reprocessing plant at La Hague, capability was added for reprocessing MOX fuels; Cogema's initial plans for reprocessing MOX fuels in the UP2 plant include MOX fuel from the German 340-MWe PWR at Obrigheim, probably in 1992; a 2-MT batch of MOX fuel was reprocessed in the APM/TOR facility at Marcoule in late 1990 (Lenail 1988; NF 11/28/88; NUKEM 1/88; NN 10/90)

D. FBR Fuels: Reprocessing of FBR fuel from the Rapsodie FBR began on a laboratory scale at Fontenay-aux-Roses and continued in the one $\mathrm{kg}$ /day ATt pilot reprocessing facility at La Hague until 1979 atter processing more than one MT of Rapsodie fuel; reprocessing of Rapsodie and Phenix F8R fuels began at Marcoule in 1975 using the 10$30 \mathrm{~kg} /$ day SAP/TOP pilot reprocessing plant; through 1987, 10.7 MT of FBR fuels had been processed in the facility and 9.9 MT of FBR fuel had been processed at La Hague, diluted with GCR fuel; in 1985, a new pilot reprocessing facitity (APM) with a capacity of 5-7 MTHM/yr began radioactive operations at Marcoule on FBR fuels from Phenix; German SNR-300 FBR fuels are also scheduled to be processed through APM (Lefevre 1980; Patarin 1987; Lallement 1988; NUKEM 3/88)

\subsection{PLUTONIUM/URANIUM RECYCLE}

A. Plutonium Recycle in FBRs: France began the recycle of plutonium in 1967 for its fastbreeder program with the startup of the 40-MWt Rapsodie FBR at Cadarache using plutonium recovered from reprocessing of GCR fuels; use of plutonium recovered from reprocessing continued in the 250 -MWe Phenix FBR that began operating at Marcoule in 1974 and in the 1250-MWe Superphenix FBA that began operating at Creys-Maiville in 1986; the fuels used in these programs were manufactured in the CFCa facility operated by Cogema at Cadarache; the plutonium used in the Phenix fuels has included some recycled from reprocessing at least twice (CEN 1980; Vendryés 1984; Bairiot 1985; NEI 1990)

8. Plutonium Recycle in LWRs: For economic reasons, France has decided to slow development of the fast-breeder reactor; early studies showed that recycle of the plutoniurn accumulating from spent fuel reprocessing was competitive with the use of uranium oxide fuel, and the French embarked upon a program of plutonium recycle in LWRs in the middie 1980s; MOX fuels have been and are being used in five reactors; the MOX fuels are being supplied by both Cogema at Cadarche and Belgonucléaire at Dessei, Belgium, and in the future by a new MOX fabrication (Melox) facility being built at Marcoule (NEI 10/87; NEA 1989b; Gloaguen 1989; Vanden Bemden 1990; Vincent 1990)

C. Uranium Recycle in LWRs: France is not recycling uranium recovered during reprocessing (REPU) except in experimental quantities because of marginal economics; uranium recycle in significant quantities is not expected until after the year 2000; some uranium recovered from Cogema's reprocessing operations is being converted into $\mathrm{UF}_{6}$ by 
Comurhex at Tricastin and then shipped to the USSR for re-enrichment as part of an existing contract; the remainder is being converted to $\mathrm{UO}_{2}$ and $\mathrm{U}_{3} \mathrm{O}_{8}$ in Cogema's TU2 facility at Tricastin, with the $\mathrm{UO}_{2}$ destined for MOX fuels and the $\mathrm{U}_{3} \mathrm{O}_{8}$ going to storage; France considers the REPU material as good feed material for its laser-enrichment process now under development (Rougeau 1988; Gobert 1990; Mollard 1990; NUKEM 9/90; NUKEM 10/90)

6.3 RESEARCH AND DEVELOPMENT: To support its active program of reprocessing and recycling of uranium and plutonium in light-water and fast-breeder reactors, France has had a large R\&D program underway; reprocessing R\&D is concentrated at Marcoule where pilot reprocessing facilities exist; MOX and FBR fuel R\&D is concentrated at Cadarache; basic studies are conducted at many of the research centers and in universities; applied R\&D is conducted at the La Hague reprocessing site; a recent review of the CEA's R\&D program recommended longterm changes in the program; the recommendations included (CEA 1989; NW 2/15/90; NW 3/1/90):

A. reducing the R\&D support for operating reprocessing and waste management facilities

B. examining more flexible solutions to the back end of the fuel cycle such as long-term storage before reprocessing and direct spent fuel disposal

C. developing improved reprocessing methods that would reduce releases and allow recycling of actinides

\subsection{PROGRAM/FACIUTIES COSTS}

A. The R\&D program conducted from 1960 to 1975 on reprocessing for the La Hague repro. cessing plant and the startup of the breeder reprocessing program cost 100 million $\mathrm{FF}$ (\$17 million U.S.) and involved 150 technical staff (Lallement 1988)

B. The R\&D program conducted since 1975 on reprocessing in support of the La Hague expansion and development of the fast-breeder reactor cost 900 million FF ( $\$ 150$ million U.S.) and involved 900 technical staff (Lallement 1988); the Rouvillois report issued in May 1989 provides a higher estimate of 600 million FF per year $(\$ 100$ million U.S. per year) over the past 10 years for the reprocessing R\&D conducted by the CEA (NF $3 / 19 / 90)$

C. The cost of the FBFC 200-MTU/yr facility at its Romans-Sur-Isere complex for fabricating fuels using uranium recovered from reprocessing is estimated at 20 million FF (\$3.2 million U.S.) (NF 11/13/89)

D. The Melox plant under construction at Marcoule is designed to produce $120 \mathrm{MTU} / \mathrm{yr}$ of MOX fuels and is expected to cost 1.5 billion FF (\$270 million U.S.) (NN 8/90)

E. Cogema estimates the cost of expanding its uranium conversion complex at Tricastin at between 250 and 300 million FF ( $\$ 40$ to $\$ 50$ million U.S.); the expansion would double the capacity for converting depleted $U F_{6}$ into uranium oxide and would convert uranium recovered during reprocessing into $\mathrm{UF}_{4}$ for re-enrichment. (NE 5-6/90)

F. Cogema estimates the total construction cost of the $800 \mathrm{MT} / \mathrm{yr}$ UP3 reprocessing plant at La Hague will reach 27.6 billion FF (\$4.8 billion U.S.) (NUKEM 2/90) 
7.0 SPENT FUEL STORAGE AND TRANSPORT: France stores spent fuel in water basins at the reactors or at a reprocessing site until reprocessed; an exception is the spent fuel from the Phenix and Superphenix breeder reactors, which is stored dry; transport of spent fuel is done primarily by rail, with trucks being used for short hauts and ships for spent fuel received from foreign countries not on the continent (NEA 3/90)

7.1 SPENT FUEL ARISINGS: In France, spent fuel arises from operation of its four gas-cooled reactors, 49 light-water reactors, and two fast-breeder reactors; alt of these fuels are subject to reprocessing; thus, the inventory of spent fuet at any one moment is dependent upon the reprocessing that has taken place; also, the inventory includes foreign spent fuel that has been shipped to La Hague and is in storage awaiting reprocessing; by August 1990, about 7,000 MT of oxide fuel were in the La Hague spent fuel basins; the annual spent fuel arisings from French reactors as projected for 1990 and in the future are (NEA 1989d; NN 10/90):

1990: 1,000 MTU

1995: 1,050 MTU

2000: $1,100 \mathrm{MTU}$

Reprocessing contracts in place at the end of 1989 for spent fuel to be reprocessed in the 1990 to 2002 time-frame cover 9,000 MTU of light-water reactor fuel (NUKEM 9/90)

7.2 FUEL ASSEMBLY CHARACTERISTICS: Spent fuel arisings in France originate from its GCRs, PWRs and the FBRs

A. GCR Fuel: France is operating four gas-cooled, graphite reactors varying in output from 375 to 555 MWe each; a fuel assembly consists of one hollow rod fabricated of natural uranium metal that is clad with a magnesium-zirconium alloy; fuel assemblies are inserted 15 to a channel in the core; except for Bugey-1 with 12,780 assemblies, each reactor contains about 44,000 assemblies representing 350 to $450 \mathrm{MTU}$; average burnup achieved is about $3500 \mathrm{MWd} / \mathrm{MTU}$ (Fujii 1985; NEI 1990)

B. PWR Fuel: France is operating 49 PWRs of two sizes-900 MWe and $1300 \mathrm{MWe}$; the fuel is $\mathrm{UO}_{2}$ clad in Zircaloy-4; each fuel assembly contains $2649.5-\mathrm{mm}$ outside-diameter rods on a $17 \times 17$ matrix; the 900-MWe units contain 157 assemblies representing 72.5 MTU; the 1300-MWe units use an enrichment of $3.16 \%$ and contain 193 assemblies representing $103.9 \mathrm{MTU}$; to extend fuel life for the $900-\mathrm{MWe}$ units, enrichment has been increased from 3.25 to $3.70 \%$, and burnup has been increased from 33,000 to $42,00 \mathrm{MWd} / \mathrm{MTU}$; by 1995, enrichments are expected to reach $4.5 \%$ and burnups 55,000 MWd/MTU (Fujii 1985; Gobert 1990; NEI 1990)

C. FBR Fuel: France is operating two fast-breeder reactors--the 250-MWe Phenix at Marcoule and the 1250-MWe Superphenix at Creys-Malville

1) Phenix fuel contains mixed plutonium and uranium oxides with an equivalent enrichment of 27.1\%; the fuel is contained in 103 hexagonal assemblies, each having 217 pins with an outside diameter of $6.6 \mathrm{~mm}$ and height of $17.93 \mathrm{~mm}$; the cladding is Type 316 stainless steel; the Phenix core contains 4.3 MTHM (Fujii 1985; NEI 1990)

2) Superphenix fuel contains mixed plutonium and uranium oxides with an equivalent enrichment of $16.6 \%$; the fuel is contained in 364 assemblies, each having 271 
pins with an outside diameter of $8.5 \mathrm{~mm}$ and a height of $2700 \mathrm{~mm}$; the cladding is Type 316 stainless steel; the Superphenix core contains 31.5 MTHM (NEI 6/78; Fujii 1985; NEl 1990)

7.3 SPENT FUEL STRATEGIES: France's strategy for interim storage and transport of spent fuel is dictated heavily by its policies of reprocessing and recycling uranium and plutonium and heav reliance on industry; most spent fuels from France's GCR and LWR programs are stored for a short time in water basins at the reactor and then transported to a water basin at the reprocessing plant; a dry storage facility has been constructed at Cadarache for miscellaneous spent fuels

7.4 WET STORAGE: In addition to the wet storage provided at each reactor, France has water basin storage for $10,000 \mathrm{MT}$ of spent fuel at La Hague and for $800 \mathrm{MT}$ of spent fuel at Marcoule; spent fuels of domestic origin are stored for about 1 year in the reactor storage basin and 2-3 years in the reprocessing plant storage basin; both wet and dry unloading facilities are provided at La Hague (Harmon 1984; Bailli 1987; Blomeke 1987; NEI 12/87; Bonnet 1989; Dabat 1989; NEA 3/90; NEI 1990)

7.5 DRY STORAGE: France is using dry storage of spent fuel in two instances: 1) FBR fuels slated for reprocessing in the APM/TOR pilot-reprocessing facility at Marcoule are stored in air-cooled wells in the floor of a vautt, and 2) a 180-MTHM dry storage facility, CASCAD, recently went into operation at Cadarache for GCHWR fuel from the shutdown Monts d'Aree reactor and other miscellaneous fuels; in the CASCAD facility, spent fuel contained in a sealed canister is placed in a vault through which cooling air flows by natural convection (Blomeke 1987; Patarin 1987; Geoffrey 1989; Baillif 1990; Bonnet 1990; NEI 1990)

7.6 TRANSPORT OF SPENT FUELS: In France, the nuclear industry is free to select the means of transportation and packaging as long as relevant regulations are satisfied; using casks and transport equipment provided by industrial firms, spent fuels are transported by truck (short haul), rail (long hauls on the European continent) and ship (from Japan) (Lenail 1987; NEA 3/90)

A. Firms Involved in Transport of Spent Fuel: All transport of spent fuel in France is managed by Cogema working through transportation companies; Transnucléaire $(\mathrm{TN}), 33 \%$ owned by Cogema, develops transportation systems, including casks; Nuclear Transport Limited (NTL), 33\% owned by Transnucleaire, handles transport of spent fuel within Europe; Pacific Nuclear Transport Limited (PNTL), 12.5\% owned by Cogema, handles the transport of spent fuel between Europe and Japan (FNN 6/89; Lazarevitch 1990)

B. Casks Used to Transport Spent Fuel: Cogema certifies that all casks meet applicable French regulations and those relating to international shipments by rail and ship; in addition, casks must meet the IAEA transportation standards for nuciear materials; by 1983 , Cogema had licensed the casks of two designers, Ets Lemer et Cie (LKh) and Transnucléaire (TN) for transport of PWR fuels; the TN casks are fabricated of carbon steel forgings; the LK casks are lead shielded and include a neutron shield of borated water; the 'cask" fleet consists of two general designs-1) older casks weighing about 72 MT loaded and capable of holding 17 BWR or 6 PWR assemblies, and 2) newer casks weighing about $110 \mathrm{MT}$ loaded and capable of holding 32 BWR or 12 PWR assemblies; GCR fuels are transported in cube-shaped casks fabricated of lead shielding between two stainless steel liners and weighing about $50 \mathrm{MT}$, about haff the weight of a PWR cask (Lenail 1985; Blomeke 1988) 
More than 90 casks are used for transport of spent fuel; of these, more than $50 \%$ are dedicated to transocean movement of Japanese fuels to Europe; 40 are used for the European market, including domestic use in France; of the 40 , only six are used for truck transport, the rest being used for rail shipments (Lazarevilch 1990)

C. Transport Modes Used: EDF ships spent fuels from its reactors mainly by rail to the reprocessing facilities at La Hague and Marcoule using specially-designed rail cars; at La Hague, Cogema uses specially-designed heary-haul trucks to move the casks between a nearty rail station and the reprocessing fuel storage facilities; truck transport is also used for lighter-weight casks and shorter-haul distances; five specially-designed, doublehulled ships are used by PNTL to provide spent fuel transport between Japan and Europe and serve Cogema's La Hague plant and BNFL's Sellafield plant; in 1989, the number of spent fuel cask shipments were 50 by sea, 40 by truck and 250 by rail (FNN 6/89; Gouin 1989; Lazarevitch 1990)

D. Special Transports of Spent Fuel: Special shipments of spent fuel include transfers of fast-breeder and research reactor fuels to a reprocessing site or to a "hot-cell" fuel examination laboratory at the Chinon reactor site; these are accommodated on a case-bycase basis; for transport of PWR fuels for examination, EDF has had Robotel design a special cask capable of holding one irradiated fuel assembly (Gouin 1989)

E. Cask Maintenance: Ccgema has a special cask maintenance facility (referred to as the AMEC facility) located at the La Hague reprocessing plant; there is also a remote maintenance facility at La Hague where remote maintenance and decontamination are carried out as part of the cask maintenance cycle; all French and most British casks are maintained at this facility (Lazarevitch 1990)

\subsection{WASTE CONDITIONING, STORAGE AND TRANSPORT}

8.1 WASTE DEFINITIONS: On the basis of their characteristics, radioactive wastes in France are classified into three categories (Barthoux 1986; Lefévre 1986a; ANDRA 1987; FNN 10/88):

A. Category A includes short-lived wastes of low- and intermediate-level radioactivity; these wastes contain almost exclusively radionuclides with half-lives less than 30 years; the major sources of this class of waste include nuclear power reactors, fuel cycle facilities and users of radioisotopes; this is the only category considered suitable for near-surface disposal; the limits on alpha content allowed are $0.10 \mathrm{Ci}$ in a single container and an average of $0.01 \mathrm{Ci} / \mathrm{MT}$ in the repository; these wastes are further classified as contacthandled $(<200 \mathrm{mrem}$ at the package surface) or remote-handled $(>200 \mathrm{mrem}$ at the package surface)

B. Category $B$ includes wastes naving radionuclide contents greater than those allowed in Category $A$; the major sources of these wastes include the reprocessing plants, fabrication plants for MOX and FBR fuels, defense and R\&D facilities; non-high-level, alpha-contaminated wastes fall into this category; deep geologic disposal is planned for these wastes following conditioning and interim storage

C. Category $\mathrm{C}$ includes the high-level wastes generated in the reprocessing of spent nuclear fuels; these wastes will be disposed in a deep geologic repository following conditioning and interim storage 
1) Canister: Each canister is fabricated of $Z 15$ CN 24-13 stainless steet; a canister for glasses produced at La Hague has an overall length of $1.335 \mathrm{~m}$ and an outside diameter of $0.43 \mathrm{~m}$; the empty weight is $80 \mathrm{~kg}$ and internal volurne is $170 \mathrm{~L}$; the glass in a canister has a volume of $150 \mathrm{~L}$ and weighs $400 \mathrm{~kg}$; canisters for glasses produced at Marcoule are similar but have an overall length of $1.0 \mathrm{~m}$ and an outside diameter of $0.5 \mathrm{~m}$ (Sombret 1985a; Lung 1988b)

2) Glass: The vitrified high-level wastes consist primarily of a vitreous combination of elemental oxides; major elem?nts include silica, sodium, boron and aluminum; minor elements include iron, chromium, nickel, magnesium and calcium; fission product oxides make up 1.3 to $13.0 \mathrm{wt}$.\% of the glass, depending on the type of fuel from which the high-level wastes were derived; control of operating parameters is relied upon to produce a consistent and satisfactory glass quality (Lung 1988b; Maillet 1988; Alexandre 1989a)

8.5 SPENT FUEL CONDITIONING: Little or no conditioning of spent fuel is performed in France because the fuel is reprocessed atter a fow years of interim storage; there are no current plans for extended interim storage or direct disposal of spent fuel

8.6 LLWILW CONDITIONING: Of the total LLW/LW (Category A wastes) produced in France, 90\% come from nuclear reactor operations and only $10 \%$ from all other sources; government policy on these wastes is the storage time is to be a minimum; before acceptance at the LLW storage facility, an inspection is performed to confirm that the LLW/LW has been treated and conditioned to meet ANDRA requirements; it must pass inspection by IPSN and be accepted by ANDRA; also, the LLW/LW must be in one of 15 waste containers accepted by ANDRA, including steel $110-\mathrm{L}$ drums, metal boxes, and high-integrity concrete drums (2 $\mathrm{m}^{3}$ capacity); others may be accepted in special cases, atter prior agreement with ANDRA specialists.

The major producers of LLW/ILW from the reactor sites and reprocessing plants at least compact their dry, solid LLW, and most perform further treatment up to and including final packaging, onsite. The LLW/ILW generated by the hundreds of smaller generators are usually compacted and transported to the CEA's facilities at La Hague, Cadarache or Marcoule for further processing, which the generator pays for (Lakey 1985; Barthoux 1986; Lefévre 1986a; Lefévre 1986b; ANDRA 1987; Ducos 1987; Alexandre 1989b; NEA 3/90)

A. Low- and Intermediate-Level Liquid Wastes: Category A liquid wastes must be converted to solids and placed in one of 15 Andra-approved waste containers (mostly 110-L or 225-L drums) before disposal; low-level liquid wastes are collected, in most cases at the generator's site, where volume reduction is performed through a sequence of operations (filtration, ion-exchange, re-filtration, evaporation) to concentrate radionuclides; some liquid wastes are treated chemically to precipitate a sludge, which is then encapsulated into bitumen; some radioactive spent resins are immobilized in polymer; organic liquids are incinerated atter phase separation from aqueous layers, and the radioactive solid residues further treated by encapsulation into concrete, bitumen, or polymer

B. Low- and Intermediate-Level Solid Wastes: Category A solid wastes undergo volume reduction by compaction or incineration; compacted LLW are placed directly into ANDRA-approved containers, while incinerator solids are encapsulated into concrete or bitumen

C. Alpha-Contaminated Wastes: Category B wastes undergo sorting and separation and various treatments, including recycling along with incineration, and crushing or leaching. 
8.2 WASTE ARISINGS: The volumes of radioactive westes expected to be accumulated through the year 2000 by category are (ANDRA 1987 ):

$$
\begin{aligned}
& -800,000 \mathrm{~m}^{3} \text { Category A wastes } \\
& -47,000 \mathrm{~m}^{3} \text { Category B wastes } \\
& \text { - 3,000 } \mathrm{m}^{3} \text { Category C wastes }
\end{aligned}
$$

8.3 STRATEGY: In France, responsibility (including costs) for conditioning, interim storage and transportation (other than to a disposal site) of radioactive wastes resides with the waste generator; the generators are free to choose the method of processing of their wastes (from ANDRA-approved methods such as incineration, bitumenization, cementation, resins, etc.); short-term interim storage is generally performed at the generator's site (except for spent fuel for which large fuel storage pools are available at La Hague and Marcoule); truck, rail and ship transportation are employed using commercially-available equipment and carriers; all operations are subject to licensing approval (NEA 3/90)

8.4 HLW IMMOBILIZATION: R\&D on HLW vitrification, underway at Marcoule since 1957, has led to the development and commercial application of the French AVM process for vitritying the highlevel liquid waste solutions produced in the reprocessing of spent fuels

A. Process Description: After analysis and chemical adjustments, the high-level liquid waste solutions from reprocessing are fed to a heated, rotating kiln or calciner where they are evaporated to a dry powder; the powder, consisting mainly of oxides of the chemicals and radionuclides in the waste, is mixed with a borosilicate glass frit in a metal pot heated to $1,150^{\circ} \mathrm{C}$ in an induction furnace; intermittently, the pot is drained into a stainless steel canister where the mohen glass is allowed to harden; after a canister is filled, a lid is welded on using a plasma torch; the canister is then decontaminated and placed in interim storage; gaseous effluents from the vitrification operations are treated by condensation, absorption, washing and filtration before release; secondary liquid wastes are recycled to the waste feed stream or transferred to the reprocessing plant for treatment (Jouan 1986; Lung 1988a)

B. Major Facilities and Experience: Four major facilities using the French AVM vitrification process are operating or under construction

1) The AVM facility at Marcoule began operating in 1978; equipped with one vitrification line, the facility has, by 1990 , operated 46,000 hours and converted $1,362 \mathrm{~m}^{3}$ of liquid wastes into $603 \mathrm{MT}$ of borosilicate glass; the vitrified waste is contained in 1,730 metal canisters (Alexandre 1990)

2) Two AVM-type vitrification facilities are located at the La Hague reprocessing site in northwestern France; each facility employs three processing lines and will convert $180 \mathrm{~L} / \mathrm{hr}$ of liquid wastes into $60 \mathrm{~kg} / \mathrm{hr}$ of borosilicate glass; the R-7 facility began operation in 1989; the T-7 facility will begin operation in 1991 (Jouan 1986; Lung 1988a; NN 1/90; NUKEM 2/90)

3) One AVM-type vitrification facility is located at the Sellafield reprocessing site in the United Kingdom (Lung 1988b; Heafield 1989; OT 8/15/90)

C. Waste Form Characteristics: The vitrified high-level wastes consist of borosilicate glass contained in a metal canister 
followed by fixation in cement, bitumen or polymers

D. Low-Level Mixed and Biological Wastes: These are incinerated, and the solid residues are converted into one of the ANDRA-approved waste forms (concrete, bitumen, or polymers)

8.7 AIRBORNE WASTES TREATMENT AND IMMOBILIZATION: The French use conventional gascleaning technology (i.e., scrubbing, adsorption, filtration) for removing radionuclides from gaseous wastes emanating from their nuclear facilities; the waste materials containing the recovered radionuclides are conditioned as discussed above (Thiry 1983; IAEA 1988a; Lallement 1988; IAEA 1989)

8.8 LLW/ILW STORAGE: The government policy is to minimize interim storage of LLW/ILW beyond the time required for the short-lived radioisotopes to decay; LLW/LW are usually conditioned within 70 days after generation; LLW/ILW in the Category $B$ category are being heid in longterm interim storage pending development of a geologic repository (ANDRA 1985; Lefévre 1986a)

8.9 HLW STORAGE: In France, the high-level liquid wastes produced in the reprocessing of spent fuels are collected in stainless steel tanks within the reprocessing facility until vitrified; the canisters of vitritied wastes are placed in a dry-storage facility adjacent to the vitrification facility pending availability of a disposal system

A. Storage of High-Level Liquid Wastes: At Marcoule and La Hague, the high-level liquid wastes produced in reprocessing spent fuels are stored in specially-designed stainless steel tanks placed in concrete vaults inside the reprocessing facility structure; the liquid wastes are stored in the acid condition (unneutralized) and are cooled by circulating water through coils inside the tanks; the tanks are agitated and purged, and vented to the atmosphere through an off-gas cleanup system to prevont the buildup of radiolytically-produced hydrogen (IAEA 1979; Cogema 1983; Mellinger 1984; Cogema $7 / 87)$

B. Storage of Vitrified High-Level Wastes at Marcoule: The interim storage facility at Marcoule is a concrete structure consisting of three underground engineered vaults fitted with 220 vertical, 0.6 -m-diameter metal sleeves, each capabie of hoiding ten of the AVM canisters; each canister of vitrified waste is carried from the vitrification cell to the storage area in specially-designed carrier from which the canister can be lowered into the storage sleeve; cooling is provided by air circulation (either forced or natural) around the sleeves; the cooling system is designed for a maximum glass heating rate of $50 \mathrm{~W} / \mathrm{L}$ (Cogema 1983; IAEA 1983)

C. Storage of Vitrified High-Level Wastes at La Hague: The R-7 and T-7 vitrification facilities at La Hague are provided with interim storage facilities patterned after the Marcoule installation; each facility includes an adjoining interim storage unit comprised of five modules, each containing 100 metal sleeves capable of holding nine canisters each; removal of fission produce heat is accomplished by circulating cooling air (either forced or natural) past the sleeves (Alexandre 1990)

8.10 TRANSPORT OF WASTES: As in the case of transport of spent fuel, industry is free to undertake transport of low- and intermediate-level wastes provided that the relevant regulations are satisfied and the necessany formalities are fulfilled; in practice, transportation of LLW and ILW is conducted largely by the major producers, the CEA and Cogema; transport to a disposal facility 
is carried out by ANDRA; these agencies may pertorm the transport themselves or subcontract to a licensed industrial firm; regulatory oversight is provide by the CEA's Protection and Nuclear Safety Institute (IPSN); regulations closely follow the IAEA's regulations; the variations in transportation practices stem mainly from the type of wastes being transported (IAEA 1985; Lefévre 1986a; FNN 6/89; Lecoq 1990; NEA 3/90)

A. Industrial Waste: Fifteen types of industrial waste containers are used for the transport of very low specific activity wastes (e.g., $<7 \mathrm{mCi}$ Co-60 per package) such as uranium ores and concentrates; regulations for transport containers for this type of waste include proof of integrity following a drop onto a concrete surface from a height of $1.2 \mathrm{~m}$; no special transportation packagings are used for these wastes (FNN 6/89)

B. Category A Solid Low-Level Wastes: Waste packages for Category A solid LLW are designed for wastes of low-specific activity (e.g., $>7 \mathrm{mCi}$ and $<7 \mathrm{Ci} \mathrm{Co}-60$ per package); transport is performed by road and by rail in the same 15 general types of containers used for industrial wastes; these containers can be used for Category A solid wastes if the containers maintain integrity after spraying with $5 \mathrm{~cm}$ of water for one hour, after compression by a force equal to five times the package weight, and after the impact of a $1-\mathrm{kg}$ bar dropped from a height of $1 \mathrm{~m}$; no other special transportation packagings are generally used for these wastes (FNN 6/89)

C. Category B Solid Wastes: Transportation packagings for Category B wastes are designed for higher-activity wastes (e.g., $>7 \mathrm{Ci} \mathrm{Co-60} \mathrm{per} \mathrm{package);} \mathrm{tests} \mathrm{which} \mathrm{this} \mathrm{type}$ of packaging must withstand include a 9-m drop onto an unyielding surface, a $1-\mathrm{m}$ drop onto a penetrating object, crushing by a $500-\mathrm{kg}$ plate falling from a height of $9 \mathrm{~m}$, a 30-minute exposure to fire at $800^{\circ} \mathrm{C}$, and an 8-hour immersion under $15 \mathrm{~m}$ of water; alpha-contaminated and vitrified high-level wastes fall into this category Nerdier 1987; FNN 6/89; Lazarevitch 1990)

D. Liguid Wastes: Liquid wastes cannot be disposed in France but may be transported between facisities if applicable regulations are satisfied; the CEA has developed, through the industrial firm ATEA, 16 Cendrillion transportation cask models with load capacities ranging from 3 to $250 \mathrm{~L}$ and lead shielding 5 to $30 \mathrm{~cm}$ thick; they weigh from 0.7 to $6 \mathrm{MT}$ and are fabricated of various grades of stainless steel selected to be compatible with the liquid being transported; the packagings are used to transpon all categories of liquid wastes ranging from industrial wastes to high-level radioactive wastes (IAEA 1985; FNN $6 / 89)$

8.11 MIXED WASTE CONDITIONING, STORAGE AND TRANSPORT: France apparently has not considered mixed waste as a category deserving separate handling

8.12 RESEARCH AND DEVELOPMENT: As part of its large nuclear program, France has conducted and is continuing to conduct extensive R\&D programs on radioactive waste management; this includes R\&D on LLW/LW conditioning, storage and transport; with the "maturing" of the nuclear power program in France, the burden of conducting R\&D on waste conditioning, storage and transport for the nuclear power cycle is being shifted from the CEA research establishments to the waste generators; the research establishments are currently concentrating on wastes from defense operations and advanced fuel cycles (Lefévre 1986a; NW 3/1/90)

A. Waste Conditioning: Recent R\&D on waste conditioning in France has been directed at minimization of wastes and costs, improved fixation of wastes, and conditoning of alphacontaminated wastes; typical R\&D activities include: 
1) EDF is studying the economics of various scenarios for conditioning and siting treatment facilities for nuclear power station wastes destined for one of the shallow-land disposal sites (Celeri 1989)

2) The Cadarache Nuclear Research Center is evaluating various embedding matrices for incinerator ashes resulting from the treatment of low- and intermediate-level wastes and the ultrafithration treatment of laundry wastes (Kertesz 1989; Barnier 1989; Kertesz 1990; Kertesz 1991)

3) Cementation and size reduction of large objects are being evaluated at the Centre de Valduc (Mangin 1988a; Mangin 1988b)

4) Technicatome is evaluating the use of a thermosetting resin as an embedding medium for low- and intermediate-level wastes (Gauthey 1989)

5) The CEA is evaluating use of leaching with continuous electrolyte regeneration for cleanup of solid alpha-contaminated wastes at Fontenay-aux-roses and Marcoule (Madic 1990)

6) SGN is studying the cementation of ion-exchange resins in an effort to understand and improve the waste form (Jaouen 1988)

7) SGN, CEA and Cogema have cooperated on a study to improve the postcombustion in incineration of hazardous and radioactive wastes (Carpentier 1988)

8) Melting of nuclear fuel cladding from reprocessing operations is being evaluated by the CEA at Marcoule (Jouan 1987)

9) SGN is building mobile cementation and bituminization systems for use in France and the United States (Tchemitcheff 1990)

10) EDF is testing portable waste treatment equipment, i.e., tanks, filters, piping, for use at nuclear power reactors (Glorennec 1988)

B. Waste Storage and Transport: These operations are well-developed for low- and intermediate-level wastes in France; R\&D underway is generally directed at improving waste packages and the extension of existing technology for the introduction of MOX fuel reprocessing and high-level waste vitrification (Lazarevitch 1990; Boudry 1991)

8.13 PROGRAM/FACILITIES COSTS: Costs of waste conditioning, storage and transport facilities in France are not readily availabie for two reasons: 1) such facilities are generally part of a larger facility or operation, and 2) the operators are generally commercial firms who consider such information proprietary

\subsection{DISPOSAL OF NON-HIGH-LEVEL WASTES}

9.1 STRATEGY: Beginning in 1967, France, along with several other European countries, disposed of LLW by dumping in the north Atlantic ocean; this practice was discontinued in favor of the lower-cost shallow-land disposal initiated at La Manche; France's present strategy for disposal of LLW/ILW depends upon the level and type of radioactivity contained in the waste package; 
Category A wastes are disposed in engineered, near-surface facilities; Category B wastes (which include alpha-contaminated wastes) will be disposed in a deep, geologic formation along with vitrified high-level (Category C) wastes (IAEA 1980; Holcomb 1982; Lefévre 1986b; FNN 10/68; Hoxie 1988; Alexandre 1989b; Nouguier 1989)

\subsection{CRITERIA FOR NEAR-SURFACE DISPOSAL.}

A. Waste Package: Before acceptance at a near-surface disposal facility, low-level wastes must satisfy four criteria (Barthoux 1986; Lefévre 1986b):

1) The maximum half-life for any isotope must be less than 30 years

2) The alpha-radionuclide content must not exceed $0.1 \mathrm{Ci} / \mathrm{MT}$ of waste for each waste package and $0.01 \mathrm{Ci} / \mathrm{MT}$ when averaged over the entire site

3) At the Centre de la Manche, the concentrations of specific radionuclides are limited as follows $-1,200 \mathrm{Ci} / \mathrm{MT}$ of waste for $\mathrm{Co}-60,20 \mathrm{Ci} / \mathrm{MT}$ for $\mathrm{Sr}-90$ and 130 $\mathrm{Ci} / \mathrm{MT}$ for $\mathrm{Cs}-137$

4) The waste package must be qualified by ANDRA prior to shipment

B. Disposal Facility (Barthoux 1986; Lefévre 1986b):

1) Radionuclides must be kept isolated from the biosphere until they have decayed sufficiently and the residual potential risk can be considered negligible whatever may occur; for low-lovel (Category A) wastes, an isolation period of 300 years is considered adequate

2) A multi-barrier system coupled with a drainage collection and treatinent system will be relied upon to prevent release of radionuclides into the biosphere by infiltrating waters

3) Control by ANDRA, a government organization, will be relied upon to prevent release of radionuclides into the biosphere through human intrusion for 300 years

\subsection{ILW DISPOSAL (See Section 10)}

\subsection{LLW DISPOSAL.}

A. General Status of Near-Surface Disposal: The La Manche disposal facility near Cherbourg has been in operation since 1969; initially, packages of LLW/LW were buried directly in two shallow trenches; these were of plain earth with a layer of gravel at the bottom; the LLW were solid but not necessarily embedded in a matrix, and were contained in metal drums or boxes and some plastic bags; these trenches were backfilled with soil, covered with a plastic sheet, and topped with another layer of soil; some 700 $\mathrm{m}^{3}$ were disposed of in this way; for intermediate-level wastes, the trenches were modified by the addition of concrete vaults made of prefabricated slabs joined in place, backfilled with sand or concrete and covered with a concrete cap; four trenches of this type were filled at La Manche (Marque 1987)

In 1976, regional monitoring revealed leaching of radionuclides from the La Manche site to a nearby stream; with current annual deliveries of $30,000 \mathrm{~m}^{3}$, much more stringent 
safety criteria have been applied since 1978 and more extensive and thorough disposal practices have been implemented; since this facility is expected to become full in 1991, a new site was sought by ANDRA, beginning in 1984; the selection process was completed and a site at Soulaines-Dhuys in the l'Aube region was chosen, with development beginning in 1987; the l'Aube site will commence acceptance of LLW/LWW as soon as the La Manche site is full, anticipated to occur in 1991; the l'Aube facility will also be a shallow-ground facility that incorporates multiple engineered barriers; the l'Aube site will have a capacity of 1 million $\mathrm{m}^{3}$, or about 30 years lifetime at current LLW/LW production rates (Marque 1987; FNN 10/88; Cruickshank 1989)

B. Site Selection: ANDRA is responsible for finding and evaluating potential disposal sites; the Ministry of Industry is responsible for choosing a site from the list, and the selection is approved by the Prime Minister (Marque 1988; Numark 1989; McCabe 1990)

1) La Manche: The initial site at La Manche was developed largely for reasons of convenience, since it is close to the La Hague reprocessing plant; the geology of the site is complex and not ideal (Kemp 1989)

2) l'Aube: Geological and hydrogeological requirements for the chosen second site include (Barthoux 1986):

a) well-known system hydraulic limits unchanging with time

b) lithologically homogeneous medium, easy to characterize and model, with good radionuclide retention capacity

c) medium to low regional seismicity

d) site protected against landslides, rockfalls, subsidence, erosion

e) good topography, with limited water flowing across the site, water runoff downhill, protected from floods, and near a river or the sea or other water source with a high dilution capacity

\section{Description of Disposal Sites}

1) La Manche: The La Manche disposal site is located at the tip of a peninsula in Normandy, $25 \mathrm{~km}$ west of Cherbourg near the English channel and east of the La Hague reprocessing plant owned by Cogema; the Centre de La Manche is in a thinly populated region with only 1500 inhabitants within a radius of $10 \mathrm{~km}$; it covers an area of 12 hectares; primary local industries are fishing, agriculture, and caltle; the climate is temperate, with annual rainfall light but steady at approximately $100 \mathrm{~cm} / \mathrm{yr}$ (Hoxie 1988)

2) l'Aube: The l'Aube site is situated among three small villages in a rural area with a declining and aging population structure; the general area is forested and slightly elevated, but the site itselt is overlaid with a permeable layer of sand and mud; beneath the top layer is a layer of impermeable clay (Kemp 1989)

D. Design of Disposal Facilities: The origiral disposal concept at La Manche when the site was opened in 1969 was to dispose of LLW/LW in shaliow unlined trenches backfilled 
with soil and covered with plastic and soil; in 1978, the facility was redesigned to employ engineered structures

At La Manche, short-lived wastes with relatively high external radiation levels are disposed of in rectangular concrete pits buried a few meters underground; to prepare the pit foundation, a large trench is excavated and lined with concrete at the bottom, and provided with a drainage channel; successive layers of waste packages are placed on the concrete, with the more radioactive wastes towards the bottom and middle; these wastes are then completely encapsulated by backfilling with concrete to form the monolith, which is completed by pouring a concrete slab on the upper layer of the trench; additional LLW waste packages are placed on top of the monoliths, on platforms provided with drainage channels; stacks of LLW containers are $6 \mathrm{~m}$ high above the monolith and all spaces are filled with gravel; the disposal tumulus is then covered with a layer of impervious clay and topsoil and seeded with grass; the final result is a grassy mound about $10 \mathrm{~m}$ high, commonly referred to as the "tumulus" concept (FNN 10/88; Hoxie 1988; Cruickshank 1989)

A similar concept to that described above for the La Manche facility is also planned for the l'Aube facility. The primary difference between the new concept and the former concept (at La Manche) is that at l'Aube there will be no burial of LLW drums (i.e., no tumulus) on top of the concrete vault. Instead, all wastes will be emplaced in vaults. Vaults full of lower-activity wastes will be backfilled with gravel to fill the spaces between containers; vaults with higher-activity wastes will be backfilled with concrete to fill the voids, and will have a layer of concrete over each layer of waste packages. When filled, each vault will be sealed with a concrete roof (ANDRA 1989).

The structure of the monoliths at l'Aube is that of a series of separate and independent vaults that are each about half below the original grade level and half above grade. The vaults are $25 \mathrm{~m}$ square and about $8.5 \mathrm{~m}$ high, with walls and floors of 30 -cm-thick reinforced concrete. Each vault rests on another, thick reinforced pad that is above the groundwater level. Waste packages are stacked remotely by crane in a movable building that has a covered truck receiving area and a cover for the vault being filled. After a vault is full, it will be sealed with a concrete roof and the entire vault will be sprayed with a waterproof plastic coating. After a number of vaults are filled and sealed, the space: between vaults and above them will be backtilled with ridge-tike earth mounds. These earthen ridges are then covered with successive layers of bituminous material, sand, clay and finaliy topsoil planted with grass and shrubs (ANDRA 1989). At l'Aube, rain water is routed from the mounded ridges to surface drains where it is routed toward a storm basin. A special water collection system beneath the disposai structures collects any water from around or inside the vaults for monitoring (ANDRA 1989).

E. Engineered Barriers: Near-surface disposal facilities in France are based on the triple barrier disposal concept, comprised of: 1) grout + waste + container (first barrier), 2) the engineered waste disposal facility (second barrier), and 3 ) the site itself (third barrier) (Hoxie 1988)

F. Marking, Retrievability, and Monitoring Provisions: For LLW/LW disposal at La Manche and i'Aube, each waste container is checked individually for appearance, radioactivity, and identification; all containers carry an identification number allowing determination of their initial content and traceability to the original waste composition and source; numbers are entered on a chart, allowing for the exact pinpointing of each container in the 
disposal matrix; individual mounds are not externally marked but their locations are recorded (Barthoux 1986; FNN 10/88; Marque 1988)

G. Retrievability Plans: Retrievability of LLW/ILW containers is not planned; retrievability from a tumulus is theoretically possible, although time-consuming; retrieval from the lower monolith part of a disposal trench would involve destroying the integrity of the monolith after completely removing the overlying tumulus (Nouguier 1989)

H. Surveillance Plans: Surveillance of the $\amalg W / L W$ is to be performed in three phases: the operational period, during which wastes are accepted at the site; the survey period during which the wastes decay to low levels of activity ( 300 years); and the unrestricted access period following, when no surveillance or service is required (Barthoux 1985; Barthoux 1986)

Groundwater monitoring and personnel dosimetry at the near-surface disposal sites is carried out continuously while the site is in operation; continuation of groundwater monitoring is planned for 300 years to ensure safety, after which time all outbuildings and surface structures will be removed, the site will be allowed to return to normal use, and monitoring will be discontinued (Barthoux 1985; Marque 1987)

I. $\quad$ Closure Plans: The La Manche site will close as soon as it is full, expected to be in 1991; La Manche will then enter Phase 2, or surveillance for $\mathbf{3 0 0}$ years to ensure no leakage of radioactivity into the environment; this will include groundwater and surface monitoring for radioactivity and physical inspection to ensure cap integrity; after 300 years, all surface structures will be removed and the land returned to 'normal use' (undefined, but probably will not include farming); the l'Aube site, due to open in 1991, will have capacity for another 30-50 years (Barthoux 1985; Marque 1987)

J. Approach to Proving Safety of Repositories: France, like all countries developing waste repositories for isolation of radioactive wastes for periods well into the future, must rely on modeling of release scenarios to demonstrate safely over the required future time periods; effort has been and is continuing on modeling the source terms, hydrology, various release scenarios, migration through the geosphere, distribution in the environment and potential radiation doses to man; probabilities of the events are also being estimated; much of the modeling is being done as part of the development of a deep, geologic repository for alpha and high-level wastes but is applicabie to a near-surface repository; French agencies are also participating in performance assessment activities sponsored by the IAEA, CEC and NEA (Chapuis 1986; CEC 1988; Foult 1988; Lovera 1988; Lewi 1989; Mangin 1989; Cacas 1990; Izabel 1990; Lewi 1990; Peaudecerf 1990; Robeau 1990)

9.5 LLW/ILW DISPOSAL RESEARCH AND DEVELOPMENT: With the new near-surface disposal facility at l'Aube about to begin operations, R\&D on near-surface disposal is essentially complete with continuing R\&D emphasizing improvement of waste forms (see Section 8.12), modeling of radioisotope movement through clay, safety assessments and site monitoring; recent $R \& D$ activities include:

A. Radioisotope Movement in Clay: Safety-related R\&D is being performed to determine techniques for measurement of radioisotope movement in clays; a Laboratory for the Study of Methodology and Instrumentation is planned for operation under IPSN in 1990-91 (IAEA 1990b) 
B. Performance Assessment: (See Section 9.3., 'Approach to Proving Safety of the Repository')

9.6 PROGAAM/FACIUTIES COSTS: The cost of construction of the l'Aube near-surface facility is estimated as 1.2 billion FF (\$200 million U.S.) (NEA 3/90)

10.0 DISPOSAL OF HIGH-LEVEL AND LONG-LIVED WASTES: (This applies to Categories $\mathrm{C}$ and $\mathrm{B}$, respectively); disposal of long-lived (Category $\mathrm{B}$ ) and high-level (Category $\mathrm{C}$ ) radioactive wastes was generally not considered until 1979 when ANDFA was created and given the responsibility for the long-term management of all radioactive wastes; deep geologic disposal was selected for these categories of wastes, and a program was implemented to site and create a geologic waste repository; in developing the program, France has periodically undertaken independent reviews of its disposal plans (Goguel Review and Castaing exercises), and is participating in the numerous CEC, IAEA and the NEA development programs on deep geologic disposal (ANDFA 1987; Goguel 1987; Schapira 1987; FNN 10/88; NEA 1990b)

In February 1990, the French Prime Minister placed a 1-year moratorium on the siting program because of local opposition at three of the sites; later in 1990, a parliamentary group released a report calling for major changes in the disposal program, including: 1) separation of ANDRA from the CEA organization; 2) development of at least two underground research laboratories; 3) implementation of financial incentives to affected communities; and 4) an increase in the R\&D effort on actinide removal and transmutation as a way of diminishing the hazard of wastes to be disposed underground (NUKEM 4/88; NN 3/90; NW 12/20/90)

10.1 SPECIFICATIONS AND CRITERIA: France is in the pre-conceptual stage in regard to deep geologic disposal of radioactive wastes; firm specifications and criteria are yet to be established

10.2 REPOSITORY DEPLOYMENT STRATEGY: ANDRA plans to establish the In-situ Site Validation Laboratory (ISVL) at one or more of the candidate sites; assuming a site is confirmed, a geologic repository for high-level and long-lived wastes will be constructed there; the general characteristics of the French repository system (as based upon types of wastes being generated, waste production, R\&D in progress, and disposal media under consideration) appear to be as follows (Schneider et al. 1990):

A. Waste Characteristics: The radioactive wastes to be disposed in a deep geologic repository consist of 1) the canisters filled with borosilicate glass (Category C) produced by the French high-level waste vitrification plants at La Hague and Marcoule, and 2) the long-lived wastes (Category B) produced mainly in reprocessing but also at defense and R\&D facilities; the latter wastes will be embedded in bitumen, cement or polymers (Jaouen 1985; ANDRA 1987; NUKEM 4/88)

B. Number, Capacity and Nature of Repositon: Only one repository is being planned presently, with the capacity being set by the medium and site eventually selected; the repository would a system of shafts and caverns in which the wastes are emplaced at a depth of 400 to $1,000 \mathrm{~m}$ (NEA 1990b; NEA 3/90)

C. Performance Requirements: Specific performance requirements have yet to be mandated; however, the Goguel report provides the following recommendations in regard to performance and safety (NEA 1988): 
Time Period of Concern: The repository must provide containment for long-lived radionuclides in the wastes for a geological period of time $(100,000$ years or more)

2) Hydrology: There should be zero or very low water flow in the vicinity of the repository

3) Geology: The geologic structure housing the repository should be stable (i.e., unaffected by construction, resistant to natural events such as earthquakes, glaciation, flooding, and accepting of the thermal load imposed by the waste)

4) Human Intrusion: the repository should be located at a depth (at least 150-200 m) that is sufficient to discourage common types of human intrusion

5) Post-Closure Monitoring: The repository should be kept under administrative control for several centuries following closure

D. Siting: By 1987, ANDRA had selected four sites for study as a deep geological repository location, and characterization activities were started with plans to start construction of one or two underground research laboratories (ISVL) by 1992 and open a repository by 2000; the four sites represent different geologic host rocks (e.g., clay, granite, salt, and schist); from these, one or two will be selected as the site of the underground research laboratory; if found suitable, one site will be converted to an operating repository (NEA 3/90)

E. Proposed Schedule: Selection of the four candidate sites was made in 1987; characterization activities, now under a temporary restraining order, were to lead to start of an underground research laboratory in 1992; operation of a repository was planned to begin in 2010; these schedules are likely to be delayed by the 1990 moratorium placed on site characterization (NUKEM 4/88; NN 3/90; NEA 3/90)

10.3 SITE SELECTION AND CHARACTERIZATION: By 1983, ANDRA had assembled an inventory of 30 zones covering the four main geologic seltings in France (clay, granite, salt and schist); in 1987, four candidate sites representing the four geologic media were selected for further evaluation; a 3-year program of surface investigations and selected borehole drilling was then initiated; the surface investigations included seismic soundings, airborne radiometric surveys, and helicopter resistivity surveys; deep boreholes (one to $1,100 \mathrm{~m}$ ) had been completed at the clay site by the end of 1988; because of local opposition at the other sites, the French Prime Minister placed a 1-year moratorium on further site characterization and requested an independent review of the program in February of 1990; this review led to a parliamentary recommen. dations described in Section 10.0 (Barthoux 1985; Payrus 1986; NEA 7/87; NEA 6/90)

10.4 REFERENCE HLW/SPENT FUEL (CATEGORY C) DISPOSAL CONCEPT: ANDRA has been evaluating various concepts, but because a specific site and host rock have not been chosen, a reference disposal concept has yet to be developed; however, a study concept has been developed for the granite site at Auriet, France, as part of the comprehensive PAGIS study by the CEC; the concept defined for that study has the following characteristics (Jaoven 1985; ANDRA 1987; CEC 1988; Schneider ot al. 1988; Potier 1989):

A. Geology: The Auriet site is located in a 300-million-year-old granite outcropping in the Limousin region $30 \mathrm{~km}$ east northeast of Limoges, France; the outcropping has a surface area of $90 \mathrm{~km}^{2}$ and is at least $1,000 \mathrm{~m}$ thick; the surface is heavity fractured with the fractures being filled with calcite and feldspsar; studies indicate the fractures are closed at 
the deeper locations; the region exhibits low seismicity and shows no evidence of re ent volcanism; based upon two borehole drillings, the bulk hydraulic conductivity is low, below $\mathbf{5 0 0} \mathrm{m}$

B. Waste Capacity: The capacity of the repository was assumed to be adequate for 30 years production of vitrified high-level wastes or equivalent to the reprocessing of 48,000 MTHM of spent fuel from the power production of $1,800 \mathrm{GWe}-\mathrm{yr}$; the HLW was assumed to have a volume of $5,400 \mathrm{~m}^{3}$ and is contained in 36,000 French-type canisters

C. Repository Design: Vitrified waste canisters were assumed to be stacked 20 high in vertical boreholes drilled in the floors of horizontal galleries and backfilled with compacted bentonite; the repository was assumed to have $\mathbf{4 2}$ horizontal galleries, each containing 43 boreholes spaced $35 \mathrm{~m}$ apart; the repository, located at a depth between 500 and $1,000 \mathrm{~m}$, was expected to cover an area of $2.2 \mathrm{~km}^{2}$

10.5 REFERENCE CATEGORY B WASTE DISPOSAL CONCEPT: Three concepts are being considered for Category B wastes (TRU wastes); one is an underground vault, either an open structure or divided into vertical pits, and covered with a concrete roof; the second is a vertical silo in which the waste packages are stacked and then covered with a concrete roof; the third concept consists of vertical boreholes similar to that considered for high-level wastes; the disposal facility for Category $B$ wastes would be adjacent to the HLW disposal facility (Potier 1989)

10.6 WASTE PACKAGE R\&D: The characteristics of the vitrified high-level wastes and the design of the waste canisters have been fixed by the on-going vitrification operations at La Hague and Marcoule; still to be determined and the subject of R\&D are glass durability in repository environments, the possible use of overpack containers, the assay of the radioactivity content in TRU waste packages and selection of barrier/backfill materials; R\&D underway on these topics includes (Schneider et al. 1989):

A. Waste Product Durability: To obtain data for the source term modeling of the wastes in a repository, France is carrying out considerable R\&D directed at the dissolution of waste glass in groundwater containing dissolved minerals likely to be found in the geologic environment; the effects of variations in glass composition are also being examined; the behavior of natural basaltic glasses in contact with groundwater is also being examined as a possible analogue to waste glass dissolution; the effect of alpha disintegration damage on glass is also being examined; the leaching of cement in a repository is also being examined (Crovisier 1989a; Crovisier 1989b; Godon 1989; Nomine 1989; Pacaud 1989; Mueller 1990)

B. Waste Assay: Because the long-lived radionuclide content is a major factor in determiring the proper disposal means (near-surface or deep geologic) for radioactive wastes, France is continuing to develop improvements in waste assay technology; at Cadarache, both delayed neutron counting and pulsed neutron measurements are being tested; SGN is responsible for converting pilot-scale assay systems to commercial systems (Beroud 1989; Dherbey 1990)

C. Barrier/Backfill Development: clay, either in the form of pressed blocks or a loose form tamped around each waste canister, is being evaluated at Fontenay-aux-Roses for potential application as bariier/backfill material in a HLW repository (Coulon 1987; Baudin 1988; Broc 1989; Schneider et al. 1989) 
10.7 GEOSCIENCES R\&D: extensive geoscience R\&D is underway in France in support of the development of a deep geologic repository for high-level and long-lived wastes; much of this R\&D is being carried out at Fontenay-aux-Roses; geological characterization techniques are being developed for granitic, salt and clay media; the effect of $\mathrm{pH}$, ionic strength and humic concentration on retention of Americium (+3) on silica is being studied; uranium, thorium and rare earth elemert concentrations in granitic rocks are being examined to develop an understanding of the factors cortrolling their mobility and diffusion as an analogue to their presence in radioactive wastes; the Institute of Nuclear Physics at Orsay is developing a method of determining the oxidation state of uranium at concentrations as low as $10^{-10} \mathrm{M}$ (Derlich 1986;

Cathelineau 1989; Hussonnois 1989; Moulin 1989)

10.8 FIELD TESTS: France is conducting underground tests at two research sites to obtain information applicable to deep geologic disposal; it is also cooperating in the underground field tests in Beigium (Mol), Germany (Asse), Sweden (STRIPA) and Switzerland (Grimsel Pass)

A. Fanav-Augéres Mine: ISPN has developed an underground research laboratory in the Fanay-Augéres uranium mine near Limoges to obtain information on the properties of granite and the behavior of fractured granite; two R\&D programs have been completed or are underway:

1) Influence of Scale Effects upon Measured values of Permeability and Dispersion Coefficients: ten boreholes, each $50 \mathrm{~m}$ long, were drilled from a $100-\mathrm{m}$ drift $170 \mathrm{~m}$ below the ground surface; water injection between packers in chambers of different lengths provided permeability information (NEA 1988b)

2) Thermo-Hydro-Mechanical Properties: heat sources of $1 \mathrm{~kW}$ have been placed in 5 horizontal boreholes at $3 \mathrm{~m}$ below the floor of a $10 \mathrm{~m} \times 10 \mathrm{~m}$ excavated room; the room was placed in a $100-\mathrm{m}$-long drift $170 \mathrm{~m}$ below the ground surface; the heating phase was to last $\mathbf{5 0}$ days and the observation phase was to last 6 months; information has been sought on changes in individual fractures, effects upon hydraulic conductivity, rock deformation and rock stresses (NEA 1988b)

B. Amélie Mine: The effects of heat upon crushed salt were studied between 1987 and 1989 in the Amélie Mine in the Alsace region; as in the Fanay-Augéres Mine, the tests were conducted in 5 horizontal boreholes excavated from a gallery at a depth of $550 \mathrm{~m}$ below the surface (NEA 1988b)

C. Testing at Mol: tests and studies have been undertaken by ANDRA in the clay repository site at Mol, Belyium, since 1984; information has been sought on the mechanical behavior of clay for use in designing a disposal facility (NEA 1988b)

D. Testing at Asse: working through the CEC, ANDRA is cooperating in the tests of irradiation fields on salt in the Asse Mine in Germany (NEA 1988b)

E. Testing at STRIPA: France has been a participant in the cooperative research project on nuclear waste storage in crystalline rock conducted by SKB of Sweden since 1977 (SKB 1989)

F. Testing at Grimsel Pass; ANDRA has experimented with a method of detecting fracture zones by electrical resistivity measurements between boreholes in the granitic underground research laboratory operated by Switzerland at Grimsel Pass (NEA 1988b) 
10.9 PERFORMANCE ASSESSMENT: As in the case of near-surface disposal of LLW/LW, France is relying on predictive modeling of release scenarios for its proposed deep geologic repository to demonstrate safety over the long periods of concern; effort has been and is continuing on modeling the source terms, ground hydrology, various release scenarios, migration through the geosphere, distribution in the ecosphere and potential doses to man; probabilities of the events are also being estimated (Chapuis 1986; Foult 1988; Lovera 1988; Lewi 1989; Mangin 1989; Cacas 1990; Izabel 1990; Lewi 1990; Peaudecerf 1990; Robeau 1990)

French experts are also participating in the performance assessment programs sponsored by the CEC, IAEA and NEA (see sections on these multinational agencies for descriptions of their programs)

A. CEC: France's Auriet granitic site served as one of the cases for the extensive performance assessment program, PAGIS, which evaluated the performance of deep geologic repositories at four locations; France is also participating in the CEC underground research programs at Mol, Asse and Grimsel Pass (see Section 10.8) (CEC 1988; NEA 1988b)

B. IAEA: As a member of the IAEA, France has access to and participates in many of the IAEA's activities, which include: development of safety guides on siting, design, construction, operation, and close down of geologic repositories; working groups on the geochemical behavior of long-lived transuranic actinides and fission products; conducting a state-of-the-art review of geologic disposal programs; development of standards and guides for deep geologic repositories, including the performance assessment aspects (IAEA 1988)

C. NEA: France, as a member of the NEA, has access to and participates in the numerous performance assessment programs of the NEA--PAAG, SEDE, PSAC, STRIPA, INTAACOIN, HYDROCOIN, INTAAVAL, Alligator Rivers Analogue Project, Thermochemical Data Base, etc.

10.10 SYSTEMS STUDIES: Studies have been conducted by the CEA to optimize the interim storage period for high-level wastes and the general characteristics of a deep geologic repository; early conclusions reached are: 1) the interim storage period should be a minimum; 2) vertical boreholes in the repository should be deep as possible, and 3) the heat load should be accommodated by placing boreholes as close as possible while maintaining a wide space between access gaileries; to improve control and reporting for the overall waste management operations, the CEA is developing a centralized accounting data system for nuclear materials (Hoorelbeke 1986; Déffes 1989; Dưfer 1990)

\subsection{PROGRAM/FACILITIES COSTS}

A. Work on the geological site investigation, underground research laboratory, disposal layout, etc., being the responsibility of ANDRA, and carried out directly or more often contracted out by ANDRA, is financed by the waste producers through ANDRA, which charges them their share of the cost according to their future delivery forecasts; 300 million FF (\$50 million U.S.) were spent in 1989 (NEA 3/90)

B. Technology R\&D (treatment and conditioning, engineered barriers, etc.) is carried out and funded mainly by the CEA, with some contribution from the CEC and waste producers such as Cogema; the CEA waste R\&D annual budget approximates 345 million FF (\$57 million U.S.) in 1990 (NEA 3/90) 
C. The present site investigation program for a deep geological repository was estimated at 1 billion FF (\$170 million U.S.) in 1990; constructing and operating the underground research laboratory was estimated at 1.5 billion FF ( $\$ 250$ million U.S.) in 1990 (NEA 3/90)

\subsection{MANAGEMENT OF URANIUM MINE AND MILL WASTES}

11.1 WASTE ARISINGS: France has ten uranium and mining and milling sites; four have been shut down; six are presently operating; in 1988, uranium production amounted to $3,920 \mathrm{MTU}$; production of uranium concentrate through 1989 amounted to 60,655 MTU; wastes have been left onsite in basins and/or behind impoundments (Pradel 1982; NEI 1990; NEA 1990a)

11.2 STRATEGY/CRITERIA: Management of wastes from uranium mining and milling is the responsibility of the producer, who must satisty applicable regulations; as is the case with the management of other radioactive wastes, regulations on uranium mine and mill wastes are not contained in any single piece of legislation, but are contained in general legislation on mining, environmental protection, water supply, atmospheric pollution, public health and labor; licenses for mining operations are approved by the Minister for Mining following approval by the General Mining Board and conduct of a public inquiry (NEA 1983)

11.3 MANAGEMENT PRACTICES: Tailings and liquid effluents are retained onsite behind dikes or in basins; water runoft is checked for contamination and may be treated to remove particulate material before discharge to a nearby waterway; sites are being monitored and the radiological effects are being assessed (Descamps 1982; Fourcade 1982; Hugon 1982; Pradel 1982; IAEA 1984)

\subsection{DECOMMISSIONING AND ENVIRONMENTAL RESTORATION}

12.1 STRATEGY/POLICY: France has no specific strategy or policy in regard to decommissioning and environmental restoration; France is relying on the nuclear industry to make decisions based upon economics and applicable regulations; numerous decommissioning projects have been completed or are underway following this policy; because of growing concern by political bodies and the public, the CEA and EDF are accelerating their decommissioning planning, for both major facilities and old civilian waste sites; of particular concern is the recent finding of plutonium that had leaked from a waste storage facility at Saint-Aubin; like most countries, France adheres to the IAEA's three-stage decommissioning pattern in planning its decommissioning projects (IAEA 1986; NEA 1986; NW 11/1/90; NW 11/8/90; NEI 1/91)

12.2 RESEARCH AND DEVELOPMENT: France has done and has considerable R\&D underway on decommissioning; the R\&D is generally related to the numerous D\&D projects underway (NEA 1986)

Specific R\&D reported in recent years includes:

A. An underwater plasma cutting torch is being developed at Cadarache and Saclay for decommissioning programs (Pilot 1990)

B. A methodology for selecting remote-handled tools for decommissioning is being developed at Fontenay-aux-Roses (Clement 1987) 
C. Framatome has undertaken feasibility studies of decommissioning for their PWRs (Dubourg 1987)

D. The CEA has been participating in the CEC's research programme on decommissioning; specific investigations conducted by the CEA include tests on the decontamination of ferritic steel using sulfuric, hydrofluoric and nitric acids, and the development of air-cleaning devices for use where metal cutting is being done (Huber 1987)

E. An instrument with a large detection surface area has been developed for use in segregating contaminated and non-contaminated parts at a decommissioning site (Costes 1989a)

F. The suitability of epoxy resins and epoxy pitches is being investigated as potential embedding agents for the carbon-14 contained in the graphite bricks from dismantled gas-cooled reactors (Costes 1989b)

G. The CEA has evaluated radionuclide exemption limils for materials produced in the dismantling of nuclear facilities (Chapuis 1987)

H. The EDF has produced a guidebook for decontamination at a power plant (Glorennec and Bemer 1988)

12.3 MAJOR PROJECTS: Past, current and planned decommissioning and environmental projects in France include:

A. Reactors: Numerous research and gas-cooled reactors have been shut down and are being decommissioned; all French gas-graphite reactors will be shut down by 1994 for decommissioning; reactor projects underway include (NEA 1985; NUKEM 5/89):

1) Cesar GCR at Cadarache has been decommissioned to Stage 3, i.e., complete dismantlement and removal of radioactive facilities and equipment (NEA 1985)

2) Chinon A1, A2 and A3 GCRs have been shut down; A1 has been decommissioned through Stage 1 (NEA 1985; NEl 1990)

3) EL2, EL3 and Zoe HWRs at Fontenay-aux-Roses have been shut down; EL2 decommissioned to Stage 2 in 1968; El.3 was decommissioned through Stage 3 in 1984; Zoe has been decommissioned through Stage 2 (NEA 1985)

4) The EL4 HWR at Monts d'Arree has been shut down and decommissioning is underway (NW 11/1/90)

5) G1, G2 and G3 GCRs at Marcoule have been shut down; G1 has been decommissioned through Stage 2; G2 decommissioning is underway; G3 decommissioning is planned to be complete by 1993; the G2 project is included in the NEA's Co-Operative Programme on Decommissioning (Bertini 1987; Lourme 1987)

6) Minerve, Nereide and Triton experimental LWRs at Fontenay-aux-Roses are being decommissioned; Minerve and Triton have been decommissioned through stage 3; Nereide decommissioning is underway (NEA 1985) 
7) Pegase and Peggy experimental LWRs, along with the Rapsodie experimental LMFR at Cadarache, have been shut down; Pegase and Peggy have been decommissioned to Stage 3; the Rapsodie project is included in the NEA's Co-Operative programme on decommissioning; decommissioning of Rapsodie is just starting (Bertini 1987)

\section{B. Fuel Reprocessing Facilities:}

1) The AT 1 pilot reprocessing facility at Marcoule for Rapsodie LMFBR fuels has been shut down and decommissioned except for the buildings; the AT 1 project is included in the NEA's Co-Operative programme on decommissioning (Bertini 1987; Montjoie 1987)

2) The Attila pilot facility for dry fuel reprocessing at Fontenay-aux-Roses has been shut down and is being decommissioned through Stage 3 (NEA 1985)

3) The pilot facility for reprocessing of plutonium fuels at Guegnon has been shut down and will be decommissioned (NEA 1985)

4) At the La Hague spent fuel reprocessing plant, 1,085 meters of buried, contaminated pipe has been decommissioned between June 1988 and April 1990; a further 1,315 meters of pipe remain to be decontaminated (Bodin 1991)

\section{Miscellaneous Facilities:}

1) The Bt 18 plutonium metallurgy facility at Fontenay-aux-Roses has been shut down and decommissioned to Stage 3 (NEA 1985)

2) The Elan II A \& B facilities at Saclay and La Hague, respectively, for fabrication of $\mathrm{Cs}$ and $\mathrm{Sr}$ sources have beөn shut down and will be decommissioned to Stage 3 (NEA 1985)

3) The Gulliver pilot vitrification facility at Marcoule has been shut down and decommissioned for reuse (NEA 1985)

12.4 PROGRAM/FACILITIES COSTS: The French CEA, which sponsors much R\&D, includes D\&D ir the annual requests for funds; EDF places $15 \%$ of the capital cost of new reactors in a resene fund for decommissioning; industrial organizations such as Cogema must recover decommissioning costs through charges to customers; estimates of costs for specific programs include:

A. EDF's decommissioning fund contained some 12 billion FF (\$2.4 billion U.S.) at the end of 1988 and 16 billion FF ( $\$ 3.3$ billion U.S.) at the end of 1989; the reserve is expected to rise from 5 biltion FF ( $\$ 0.8$ billion U.S.) for the $900-M W e$ units to 10 billion FF ( $\$ 1.8$ billion U.S.) for the newar 1,300-MWe units (NW 11/1/90)

B. Decommissioning of Chinon A2 GCR to Stage 2 is expected to take 5 years and cost 100 million FF (\$17 million U.S.) (NW 11/1/90)

C. Decommissioning of the G2 and G3 GCRs to Stage 2 at Marcoule is estimated to cost 20 million FF (\$3.3 million U.S.) (NW 11/1/90) 
D. The CEA's budget for decommissioning will be raised substantially above the 106 million FF (\$17 million U.S.) per year programmed in the CEA's most recent 5-year plan (NW $11 / 1 / 90)$

E. Both the CEA and Cogema are developing methodologies to improve the estimates of costs for decommissioning (Barbe 1990; Costes 1990)

13.0 INTERNATIONAL ACTIVITIES: France, as part of its extensive nuclear program, engages in numerous international activities related to its nuclear program; these include participation in international agencies, cooperative technology exchange programs with other countries, and marketing of its nuclear expertise to other countries

13.1 MEMBERSHIPS: France is a member of the CEC, the IAEA and the OECD/NEA

\subsection{COOPERATION WITH MULTINATIONAL ORGANIZATIONS}

A. France participates actively in the programs of the IAEA, including providing "experts," conducting international symposia and workshops on waste management, and preparing technical/safety guides on selected waste management topics

B. France participates actively in the radioactive waste management programs sponsored by the OECD's Nuclear Energy Agency (NEA); this participation includes preparing contributions to summary documents prepared by the NEA, membership in working groups on selected technical topics, and contributing direct support (staff and funds) toward selected projects

C. France participates in the CEC's radioactive waste management programs; many of the shared projects of the CEC are conducted in French facilities; France also participates in the CEC's shared programs conducted in other countries (see Section 10.8)

\subsection{COOPERATION WITH THE UNITED STATES}

A. An agreement between the U.S. Department of Energy (DOE) and the French Atomic Energy Commission (CEA) on exchange of radioactive waste management technology has been in force since 7/26/83; it was renewed in 1988 and expires on 7/26/93; the scope includes preparation and packaging of radioactive wastes, decontamination and decommissioning, surface and subsurface storage, characterization of and disposal in geologic formations, transportation requirements, operational considerations, and environmental and public safety; the last technology exchange planning meeting was held $11 / 7-8 / 88$ in Washington, D.C.; recent exchange activities consist principally of reciprocal visits to nuclear facilities on the topics of HLW vitrification, LWW disposal, TRU waste conditioning, and waste package development for geologic repositories

B. An agreememt between Westinghouse Savannah River Company and Numatec/Cogema was implemented on $7 / 16 / 90$ covering the exchange of technology related to vitrification of high-level radioactive wastes

C. An agreement between the U.S. Nuclear Regulatory Commission (NRC) and the French Atomic Energy Commission (CEA) on exchange of technology related to the safety of radioactive waste management was implemented on 1/10/84 and expired on 1/10/89; a renewal is being negotiated; the scope covers characteristics/long-term performance of 
conditioned high-level and TRU wastes, methods/data for evaluating radionuclide migration from repository to biosphere, methods of classification, treatment and disposal of LLW, and methods for analysis/assessment of operational safety at waste disposal sites

\subsection{TECHNOLOGY EXCHANGE WITH OTHER COUNTRIES}

A. The French CEA has agreements on the exchange of technology on radioactive waste management, similar to the agreement described above for the United States, with Czechoslovakia, Japan, Spain, Switzerland and Sweden (NN 9/86; NEA 1988b; SKB 1989; NW 4/19/90a; NW 5/3/90)

B. France and the USSR have had a research and development agreement in effect since 1967; it was expanded to the industrial domain on January 31, 1989; topics covered under the agreement include reactor development, radwaste, safety, environment and information; on October 5, 1990, the French CEA signed an agreement with the USSR Ministry of Power and Industry for exchange of technology related to decommissioning and public relations; the French IPSN also has an agreement with the USSR, primarily to cover information on safery and accidents (NN 3/89; NE 3-4/89; NW 4/19/90b; NW $10 / 11 / 90)$

C. France has an agreement with Germany and the U.K. to pool their resources on the development of fast-breeder reactor plants; on June 6, 1989, the French and (former West) German governments announced an agreement for bilateral cooperation in nuclear fuel reprocessing (NEI 4/89; NW 6/8/89)

13.5 COMMERCIAL/INDUSTRIAL EXCHANGES WITH OTHER COUNTRIES: France, as part of its government policy, encourages industrial firms to seek and engage in commercial enterprises with firms in other countries; these cooperative activities include:

A. Cogema has signed agreements with nuclear power utilities in several countries and is reprocessing its spent fuel at La Hague

B. The EURODIF enrichment facility at Pierrelatte is owned jointly by Cogema and industrial firms in Belgium, Italy and Spain

C. Transnucieaire, the nuclear transport company, is owned jointly by Cogema and industrial firms in the FRG and the U.K.

D. Cogema provided the design of the AVM-type vitrification facility installed at Sellafield in the U.K.

E. Framatome has entered intc a joint agreement with industrial firms in Bulgaria, Czechoslovakia, Germany, and the USSA to cooperate in reactor dismantling and decommissioning (NW 7/12/90)

F. Framatome and KWU of Germany have signed an agreement on mutual development and selling of PWRs (NW 4/20/89)

G. EDF and Japan's TEPCO signed an agreement on October 17, 1989, to cooperate in the areas of information, environmental protection, quality of service, and training of top-level managers (NW 10/26/89) 
H. The Superphenix, a commercial fast breeder reactor located at Creys-Malville in France, is jointly owned by the EDF and utilities in thały, Germany and Sweden (NEI 1990)

\subsection{REFERENCES}

$-1979$

International Atomic Energy Agency (IAEA). 1979. Handling and Storage of High-level Radioactive Liquid Wastes Requiring Cooling, pp. 43-45, Technical Report Series No. 191, International Atomic Energy Agency, Vienna.

$-1980$

International Atomic Energy Agency (IAEA). 1980. Packaging of Radioactive Wastes for Sea Disposal. Report of an IAEA Technical Committee Meeting on Containers and Packaging for Ocean Dumping. IAEA-TECDOC-240, December 3-7, 1979, Vienna.

CEN. 1980. CEN Cadarache, CEA brochure on the Cadarache site.

Lefevre, J. 1980. "The State of Reprocessing and Its Prospects in France." Proceedings of the International Conference on the Nuclear Fuel Cycle. September 14-17, 1980, Amsterdam, The Netherlands.

$-1982-$

de Carmoy, G. 1982. 'French Energy Policy.' After the Second Energy Crisis, by W. E. Kohl. Lexington Books, Lexington, Massachusetts, pp. 113-135.

Descamps, B., L. Foulquier, Y. Cartier, and Y. Baudin-Jaulent. 1982. "Contribution of Hydrobiological Measurements to the Radioecological Monitoring of a Uranium Mining and Milling Site in France." Proceedings of The IAEA/NEA Symposium on the Management of Wastes from Uranium Mining and Milling, pp. 523-533. May 10-14, 1982, New Mexico. International Atomic Energy Agency, Vienna. (In French).

Fourcade, N., and P. Zettwoog. 1982. "Evaluation of Various Scenarios for the Management of Uranium Mill Tailings." Proceedings of The IAEA/NEA Symposium on the Management of Wastes from Uranium Mining and Milling, pp. 169-196. May 10-14, 1982, Albuquerque, New Mexico. International Atomic Energy Agency, Vienna. (In French).

Goldschmict, B. 1982. The Atomic Complex - A Worldwide Political History of Nuclear Energy. American Nuclear Society, La Grange Park, Illinois, pp. 353-359.

Hoicomb, W. F. 1982. "A History of Ocean Disposal of Packaged Low-Level Radioactive Waste." Nuclear Safety, March-April, 1982 (2):183-187.

Hugon, J., J. Delmas, and J. C. Caries. 1982. 'Evaluation of the Radium Cycle in the Environment on the Basis of In Situ Observations of Its Radiological Impact." Proceedings of The IAEA/NEA Symposium on the Management of Wastes from Uranium Mining and Milling, pp. 535-540, May 10-14, 1982, Albuquerque, New Mexico. International Atomic Energy Agency, Vienna. (In French). 
Pradel, J. 1982. 'Management of Solid Wastes from Uranium Mining and Milling in France.' Proceedings of The IAEANNEA Symposium on the Management of Wastes from Uranium Mining and Milling, pp. 55-68, May 10-14, 1982, Albuquerque, New Mexico. International Atomic Energy Agency, Vienna. (In French).

$-1983-$

Carle, R. 1983. "How France Went Nuclear." New Scientist, January 13, 1983, pp. 84-86.

Cogema. 1983. Radioactive Waste Vitrification in France, brochure published by Cogema, VélizyVillacoublay Cedex, France.

International Atomic Energy Agency (IAEA). 1983. Handling and Storage of Conditioned High-Level Wastes. pp. 35-37, Technical Reports Series No. 229, International Atomic Energy Agency, Vienna.

Nuclear Energy Agency (NEA). 1983. Nuclear Legislation: Analytical Study: Regulatory and Institutional Framework for Nuclear Activities. pp. 67-99, OECD/Nuclear Energy Agency, Paris.

Thiry, H. B., J. P. Laurent, and J. L. Ricaud. 1983. 'French Experience and Projects for the Treatment and Packaging of Radioactive Wastes from Reprocessing Facilities.' Proceedings of The IAEA Conference on Radioactive Waste Management, Vol. 2, pp. 219-238, IAEA-CN43/114, Seattle.

-1984-

Harmon, K. M., and A. B. Johnson, Jr. 1984. Foreign Programs for the Storage of Spent Nuclear Power Plant Fuels, High-Level Waste Canisters and Transuranic Wastes. PNL-5089, Pacific Northwest Laboratory, Richland, Washington.

International Atomic Energy Agency (IAEA). 1984. The Behavior of Radium in Waterways and Aquifers. Final Report of the Co-Ordinated Research Programme on Source, Distribution, Movement and Deposition of Radium in Inland Waterways and Aquifers. IAEA-TECDOC-301, International Atomic Energy Agency, Vienna. op. 248-249.

Mellinger, P. J., K. M. Harmon, and L. T. Lakey. 1984. A Summary of Nuclear Fuel Reprocessing Activities Around the World. PNL-4981, Pacific Northwest Laboratory, Richland, Washington.

Vendryés, G. December 1984. "European Cooperation on Fast Breeder Reactors." Nuclear Europe, Journal of the European Nuclear Society, Berne, Switzerland, pp. 9-10.

$-1985-$

ANDRA. 1985. The Centre de la Manache. Brochure published by the Commissariat a L'Energie Atomique, 31-33 rue de la Federation, 75752, Paris.

Bairiot, H., G. Lebastard, J. F. Marin, and F. Motte. May 1985. 'Recent Advances in Plutonium Fuels in France and Belgium." Nuclear Europe, Journal of the European Nuclear Society, Berne, Switzerland, pp. 25-28.

Barthoux, M. A. 1985. "Disposal of Low-Level Waste." French Industrial Experience in Radioactive Waste Management and Spent Fuel Storage. pp. 172-190, Commissariat a l'Energie Atomique, Paris. 
Fujii, H. 1985. Directory of Nuclear Power Plants in the World. Japanese Nuclear-Energy Information Center, Ltd., Tokyo.

International Atomic Energy Agency (IAEA). 1985. Regulations for the Safe Transport of Radioactive Material, IAEA Safety Series No. 6, international Atomic Energy Agency, Vienna.

Jaouen, C., and A. Boulanger. 1985. "HLW and TRU Design." French Industrial Experience in Radioactive Waste Management and Spent Fuel Storage. pp. 201-211, Commissariat a l'Energie Atomique (CEA), Paris.

Lakey, L. T., K. M. Harmon, and P. Colombo. 1985. Management of Low-Level Radioactive Wastes Around the World. PNL-5173, Pacific Northwest Laboratory, Richland, Washington.

Lenail, B. 1985. "Update of French Experience Shipping Irradiated Fuel." IAEA Bulletin, 27(1):13-15.

Nuclear Energy Agency (NEA). 1985. Compendium on Decommissioning Activities in the NEA Member Countries. pp. 3-6 through 3-27, Report prepared for the Radioactive Waste Management Committee of the NEA, OECD/Nuclear Energy Agency, Paris.

Sombret, C. G. 1985. "The Status of French High-level Nuclear Waste Disposal." Proceedings of The ANS International Topical Meeting on High-Level Nuclear Waste Disposal, pp. 43-52. September 2426, 1985, Pasco, Washington.

$-1986-$

Barthoux, A., and A. Faussat, 1986. "Low and Medium Waste Storage in France." Nuclear Europe, Journal of the European Nuclear Society, Berne, Switzerland, n. 3, p. 7.

Chapuis, A. M., J. Lewi, J. Pradel, D. Queniart, P. Raimbault, and M. Assouline. 1986. "Safety Assessment Methodology for Waste Repositories in Deep Geological Formations." Transactions of The ENS/ANS-Foratom Conference (ENS '86), Vol. 4, pp. 851-856. June 1-6, 1986, Geneva, Switzerland. The European Nuclear Society, Berne, Switzerland.

Cogema. 1986. La Hague Today. Brochure published by Cogema, Cherbourg, France.

Cregut, A., and M. Montjoie. 1986. "Decommissioning of Nuclear Facilities: Choice of Decommissioning Stage: Practical Results." Transactions of The ENS/ANS-Foratom Fourth International Conference (ENC '86), V. 4, pp. 415-426. June 1-6, 1986, Geneva, Switzerland.

Derlich, S. 1986. "Basic Geological Studies for Choice of Storage Environments." Proceedings of The IAEA Symposium on the Siting. Design and Construction of Underground Repositories for Radioactive Wastes, pp. 285-310. March 3-7, 1986, Hannover, Germany. International Atomic Energy Agency, Vienna, (In French).

EDF. September 1986. Nuclear Power Plants: Effluent Releases and the Environment, brochure published by Electricité de France, Engineering and Construction Division, Clamart, France. 
Hoorelbeke, J. M., M. Serrano, L. Chaudon, and M. Cler, 1986. "Design Studies for Storage of Nuclear Wastes in Deep Geological Formations." Proceedings of The IAEA Symposium on the Siting. Design and Construction of Underground Repositories for Radioactive Wastes, pp. 553-571. March 37, 1986, Hannover, Germany. International Atomic Energy Agency, Vienna. (In French).

International Atomic Energy Agency (IAEA). 1986. Methodology and Technology of Decommissioning Nuclear Facilities. Technical Report Series No. 267, International Atomic Energy Agency, Vienna.

Jouan, A., P. Hugony, and J. Maillet. 1986. 'The Vitrification Plants in France,' Proceedings of the ANS International Topical Meeting on Waste Management and Decontamination and Decommissioning, Vol. 1, pp. 699-707. September 14-18, 1986, Niagara Falls, New York.

Leclercq, J. 1986. The Nuclear Age. Published by Le Chéne, Paris, p. 160.

Lefévre, J. J. 1986a. Nuclear Wastes. Published by Eyrolles, Paris. (In French).

Lefévre, J. J. 1986b. "French Experience and Plans." IAEA Bulletin, International Atomic Energy Agency, Vienna. 28(1):45-47.

Nuclear Energy Agency (NEA). 1986. Decommissioning of Nuclear Facilities: Feasibility, Needs and Costs. OECD/Nuclear Energy Agency, Paris, p. 71.

Nuclear News (NN). September 1986. "Waste Management Pact Entered With Spain," pp. 74-75.

Numark, N. J., R. J. Mattson, and J. Gaunt. 1986. "Comparison of National Programs and Regulations for the Management of Spent Fuel and Disposal of High-Level Waste in Seven Countries.' Proceedings of the Symposium on Waste Management (WM '86), Vol. 2, pp. 535-541. March 2-6, 1986, Tucson, Arizona.

Payrus, J. C., J. Porcheron, and J. M. Vinson. 1986. "In Situ Geochemical Measurements for Waste Storage in the Deep Natural Environment.' Transactions of The ENS/ANS-Foratom Fourth International Conference (ENC '86), Vol. 4, pp. 857-860. June 1-6, 1986, Geneva, Switzerland.

RGN. 1986. 'The French Nuclear Power Industry.' Revue Generale Nucleaire: International Edition. Publication of the French Nuclear Society, Paris, pp. 93-154.

$-1987$.

ANDRA. 1987. The Long Term Management of Radioactive Waste. Brochure published by ANDRA, Paris.

Baillif, L., C. Bonnet, M. Domage, and R. Dabat. 1987. "Spent Fuel Unloading and Storage at La Hague." Proceedings of the International Conference on Nuclear Fuel Reprocessing and Waste Management (RECOO 87), Vol. 1, pp, 341-347. August 23-27, 1987, Paris.

Bertini, A, 1987. "International Co-operation on Decommissioning Within the OECD/NEA." Proceedings of The 1987 international Decommissioning Program, Vol. 1, pp. I-1 through I-15. CONF-871018, October 4-8, 1987, Pittsburgh, Pennsylvania. 
Chapuis, A. M., P. Guetat, and H. Garbay. 1987. "Exemption Limits for the Recycling of Materials from the Dismantling of Nuclear Installations." Proceedings of The 1987 International Decommissioning Program, Vol. 1, pp. II-107 to 121. CONF-871018, October 4-8, 1987, Pittsburgh, Pennsylvania.

Chenevier, F., C. Bernard, and J. P. Giraud. 1987. 'Design and Construction of the New Reprocessing Plants at La Hague." Proceedings of the International Conference on Nuclear Fuel Reprocessing and Waste Management (RECOD_87), Vol. 1, pp. 97-102. August 23-27, 1987, Paris.

Clement, G., G. Fraize, P. Antonie, and A. Cregut. 1987. 'Methodology for Selecting Tooling and Telemanipulated Equipments for a Decommissioning Project." Proceedings of The 1987 International Decommissioning Program, Vol. 2, pp. Vl-1 to Vl-13. CONF-871018, October 4-8, 1987, Pittsburgh, Pennsylvania.

Cogema. 1987. Fuel Reprocessing. Brochure published by Cogema, Vélizy-Villacoublay Cedex, France.

Coulon, H., A. Lajudie, P. Debrabant, A. Atabek, M. Jorda, and R. Andre-Jehan. 1987. "Choice of French Clays as Engineered Barrier Components for Waste Disposal." Proceedings of The MRS Symposium on the Scientilic Basis for Nuclear Waste Management X, Vol. 84, pp. 813-824. December 14, 1986, Boston, Massachusetts. Materials Research Society, Pittsburgh, Pennsylvania.

Dubourg, M. 1987. "Experience of Partial Dismantling and Large Component Removal of Light Water Reactors." Proceedings of The 1987 International Decommissioning Program, Vol. 2, pp. VI-121 to Vl136. October 4-8, 1987, Pittsburgh, Pennsyivania.

Ducos, O., G. Delafontaine, J. P. Mistral, and M. Puigredo. 1987. "La Station de Traitement des Effluents Liquides de Marcoule.' Proceedings of the International Conference on Nuclear Fuel Reprocessing and Waste Management (RECOD 87), Vol. 1, pp. 139-145. August 23-27, 1987, Paris. (In Frerich).

Goguel. 1987. Disposal of Radioactive Wastes in Geologic Formations. Report of a group studying the development of selection criteria for a disposal site and chaired by Professor Goguel. Published by the Ministry of Industry, Paris. (In French).

Huber, B. 1987. "Advances in the European Community's Programme of Research on Decommissioning." Proceedings of The 1987 International Decommissioning Program, Vol. 2, pp. 1-30 to I-34, CONF-871018. October 4-8, 1987, Pittsburgh, Pennsylvania.

Jaouen, A., Y. Hery, and A. Boen. 1987. "Packaging of Nuclear Wastes by Melting." Proceedings of The International Conference on Nuclear Fuel Reprocessing and Waste Management (RECOD 87), Vol. 2, pp. 723-729. August 23-27, 1987, Paris, France.

Lebastard, G., and H. Bairiot. 1987. "MOX Fuel Fabrication Industry." Proceedings of International Conference on Nuclear Fuel Reprocessing and Waste Management (RECOD '87), Vol. 2, pp. 841-849. August 23-27, 1987, Paris.

Lenail, B., and H. W. Curtis. 1987. 'The Transport of Irradiated Fuel: An Activity Closely related to Reprocessing.' Proceedings of International Conference on Nuclear Fuel Reprocessing and Waste Management (RECOD '87), Vol, 2, pp. 349-353. August 23-27, 1987, Paris. 
Lourme, P., and J. Richez. 1987. "Management of G2 Decommissioning.' Proceedings of The 1987 International Decommissioning Symposium, Vol. 2, pp. V-34 through III-67, CONF-871018. October 48, 1987, Pittsburgh, Pennsylvania.

LH. 1987. La Hague Today. Brochure published by Establishment de la Hague, Cherbourg, France.

Marque, Y., and B. Vigreux. 1987. "Technology and Experience from the French Comprehensive Waste Disposal Program." Proceedings of The 1987 International Waste Management Conference, pp. 59-63. November 29 - December 5, 1987, Hong Kong.

Montjoie, M., R. Lurie, and J. Roger. 1987. 'Decommissioning Experience of the Reprocessing Facility AT-1." Proceedings of The 1987 International Decommissioning Symposium, Vol. 1, pp. lit-55 through III-67, CONF-871018. October 4-8, 1987, Pittsburgh, Pennsylvania,

Nuclear Engineering International (NEl). October 1987. "EdF Gets Set for Commercial Plutonium Recycle in LWRs," p. 15.

Nuclear Engineering International (NEI). December 1987. "Improving Fuel Pool Design at La Hague." pp. 37-38.

NUKEM Market Report (NUKEM). January 1987. "Reprocessing and Waste Management: Review 1986." NUKEM GmbH, Hanau, Federal Republic of Germany, pp. 10-15.

Patarin, and Le Bouhellec. 1987. "Marcoule Pilot Reprocessing Plant: Construction and Starting Up. Presented at the International Conference on Fast Breeder Reactor Systems: Experience Gained and Path to Economical Power Generation. September 13-17, 1987, Richland, Washington.

Schapira, J. P., and J. C. Zerbib. 1987. 'The 'Castaing Exercise': an Original Contribution to the Technological Evaluation of the Back End of the Fuel Cycle." Proceedings of The International Conference on Nuclear Fuel Reprocessing and Waste Management (RECOD '87), Vol. 3, pp. 1101-1108. August 23-27, 1987, Paris.

Verdier, A., and G. Sert. 1987. "Preliminary Studies of a Transport System for Reprocessing Wastes and Residues.' Proceedings of The International Conference on Nuclear Fuel Reprocessing and Waste Management (RECOD '87), Vol. 2, pp.677-684. August 23-27, 1987, Paris.

\section{$-1988$.}

ANDRA. 1988. ANDRA: A Government Agency for Safe Radioactive Waste Management. Brochure published by ANDRA, Paris.

Baudin, G., R. Atabek, and M. Jorda. 1988. "High Level Waste Disposal Engineered Barriers Objec. tives and Results of the French A\&D Program.' Proceedings of The ANS International Topical Meeting on Nuclear and Hazardous Waste Management (Spectrum '88), pp. 214-216. September 11-15, 1988, Pasco, Washington.

Blomeke, J. O. 1988. A Review and Analysis of European Industrial Experience in Handling LWR Spent Fuel and Vitrified High-Level Waste. ORNL/TM-10696, Oak Ridge National Laboratory, Oak Ridge, Tennesse日. 
Burholt, G. D., and A. Martin. 1988. The Regulatory Framework for Storage and Disposal of Radioactive Waste in the Member States of the European Community. pp. 58-63. Published by Graham and Trotman, Associated Nuclear Services, Epson, United Kingdom, for the Commission of the European Communities.

Carpentier, S., J.-C. Fauré, and P. Saverot. 1988. "Improving Postcombustion for Incineration of Hazardous and/or Radioactive Wastes." Proceedings of The ANS International Topical Meeting on Nuclear and Hazardous Waste Management (Spectrum '88), pp. 556-559. September 11-15, 1988, Pasco, Washington.

CEC. 1988. PAGIS: Performance Assessment of Geological Isolation Systems for Radioactive Waste. EUR 11775 EN, Commission of European Communities, Luxembourg.

French Nuclear Newsletter (FNN). 10/88. 'A Key Nuclear Industry Activity." A quarterly international newsletter published by Alsthom, CEA, Cogema, EDF and Framatome, Paris.

Foult, T. 1988. "Modelling of the Source Term for Repositories for Low- and Intermediate-Level Radioactive Wastes." Proceedings of The NEA Workshop on Near-Field Assessment of Repositories for Low and Medium Level Radioactive Waste, pp. 285-295. November 23-25, 1987, Baden, Switzerland. OECD/Nuclear Energy Agency, Paris. (In French).

Giorennec, C. 1988. 'Multi-Function Tooling for Effluent Treatment at Power Plants." Proceedings of The ANS International Topical Meeting on Nuclear and Hazardous Waste Management (Spectrum '88), pp. 292-294. September 11-15, 1988, Pasco, Washington.

Glorennec, C., and J. P. Bemer. 1988. "EDF Guide Book for Decontamination at Power Plant." Proceedings of The ANS International Topical Meeting on Nuclear and Hazardous Waste Management. (Spectrum '88), pp. 507-510. September 11-15, 1988, Pasco, Washington.

Hoxie, C. L. 1988. 'The French Low-Level Waste Management Program.' Proceedings of The 29th Annual Meeting of the Institute of Nuclear Materials Management, Vol. XVII, pp. 66-72. June 26-29, 1988, Las Vegas, Nevada.

International Atomic Energy Agency (IAEA). 1988a. Design and Operation of OH-Gas Cleaning Systems at High-Level Liquid Waste Conditioning Facilities, Technical Report Series No. 291, International Atornic Energy Agency, Vienna, pp. 48-52.

International Atomic Energy Agency (IAEA). 1988b. The Agency's Programme and Budget for 1989 and 1990. GC $(X \times X \mid 1 / 8.37$, International Atomic Energy Agency, Vienna, pp. 223-224.

Jaouen, C., and B. Vigreux. 1988. 'Cement Solidification of Spent ion Exchange Resins Produced by the Nuclear Industry." Proceedings of The ANS International Topical Meeting on Nuclear and Hazardous Waste Management (Spectrum '88), pp. 105-108. September 11-15, 1988, Pasco, Washington.

Laliement, R., and J. P. Chaudat. 1988. 'Present Reprocessing Situation in France." Presentation made during The 7th Status Reporting on Projects in Reprocessing and Waste Management, Report No. KfK 4476, pp. 13-32. Karlsruhe, FRG.

Lenail, B. 1988. "Future Trends in Reprocessing Mixed Oxide Fuel. Nuclear Technology International. Sterling Publications, Limited, London, pp. 87-88. 
Lovera, P., J. P. Mangin, M. Jorda, and J. Lewi. 1988. " $\alpha$ and Long-Lived $\beta$, Waste Source Term. A First Generation Model for a Deep Cemented Waste Repository." Proceedings of The NEA Workshop on Near-Field Assessment of Repositories for Low and Medium Level Radioactive Waste, pp. 173-184. November 23-25, 1987, Baden, Switzerland. OECD/Nuclear Energy Agency, Paris. (In French).

Lung, M., H. Regnaut, D. Alexandre, and P. Saverot. 1988a. "La Hague Vitrification Plants: A Status Report." Proceedings of the ANS Nuclear and Hazardous Waste Management International Topical Meeting (Spectrum '88), pp. 78-81. September 11-15, 1990, Pasco, Washington.

Lung, M. 1988b. 'Vitrification of Radioactive Wastes: The French Experience.' Nuclear Technology International-1988. Sterlings Publications, Limited, London, pp. 133-138.

Maillet, J., and C. Sombret. 1988. "High-Level Waste Vitrification: The State of the Art in France." Procer lings of The Symposium on Waste Management (WM '88), Vol. 2, pp. 165-179. February 28 Marct 3, 1988, Tucson, Arizona.

Mangin, D., M. Guerin, C. Lattaud, and A. Malfondet. 1988a. "Immobilization into Concrete of Liquid Radwaste." Proceedings of The ANS International Topical Meeting on Nuclear and Hazardous Waste Management (Spectrum '88), pp. 264-267. September 11-15, 1988 Pasco, Washington.

Mangin, D., C. Decobecq, and A. Malfondet. 1988b. "Size Reduction of Large Objects Contaminated with T.R.U.' Proceedings of The ANS International Topical Meeting on Nuclear and Hazardous Waste Management (Spectrum '88), pp. 268-270. September 11-15, 1988, Pasco, Washington.

Marcoule. 1988. The Marcoule Plant Today. Brochure published by The Establishment de Marcoule, Cedex, France.

Marque, Y., and R. Andre-Jehan. 1988. "Industrial Long-term Waste Management in France." Proceedings of The Symposium on Waste Management (WM '88), Vol. 2, pp. 19-27. February 28March 3, 1988, Tucson, Arizona.

Nuclear Engineering International (NEl). 5/88. 'Commissioning the World's First Commercial-Scale FBR at Creys-Malville,' pp. 20-24.

Nuclear Energy Agency (NEA). 1988a. Nuclear Law. OECD/Nuclear Energy Agency, Paris, Bulletin 42, pp. 9-19.

Nuclear Energy Agency (NEA). 1988b. In Situ Research and Investigations in OECD Countries. A status report prepared by the NEA Advisory Group on In Situ Research and Investigations for Geological Disposal (ISAG), pp. 47-54, OECD, Paris.

Nuclear Energy Agency (NEA), 12/88. "Radioactive Waste Management in France." Report prepared for the OECD/Nuclear Energy Agency's Radioactive Waste Management Committee. OECD/NEA, Paris.

Nuclear Fuel (NF). 7/11/88. "Eurodif to Spend 1-Billion Francs to Upgrade SWU Plant's Pertormance." Nuclear Fuel (NF). 11/28/88. "Cogema's UP3 Reprocessing Complex to Begin Initial Operation Next Year," pp. 11-12.

Nucleonics Week (NW), 1/21/88. "France: Framatome Gets Daya Bay Contract," p. 14. 
NUKEM Market Report (NUKEM). 1/88. 'Reprocessing and Waste Management: Review 1987.' NUKEM GmbH, Alzenau, Federal Republic of Germany, pp. 11-15.

NUKEM Market Report (NUKEM). 3/88. "France - Part I: Reprocessing." NUKEM GmbH, Alzenau, Federal Republic of Germany, pp. 15-18.

NUKEM Market Report (NUKEM). 4/88. "France - Part II: Waste Management," NUKEM GmbH, Alzenau, Federal Republic of Germany, pp. 7-9.

NUKEM Market Report (NUKEM). 8/88. "Reprocessing and Waste Management: Review First Half 1988." NUKEM GmbH, Alzenau, Federal Republic of Germany, pp. 12-15.

Rougeau, J. P., and L F. Durret. 1988. "UREP: Gateway to Uranium Recycling.' Nuclear Europe, Journal of the European Nuclear Society, Beme, Switzerland, pp. 19-20.

Schneider, K. J., L. T. Lakey, and D. J. Silviera. 1988. Survey of Waste Package Designs for Disposal of High-Level Waste/Spent fuel in Selected Foreign Countries. PNL-6981, Pacific Northwest Laboratory, Richland, Washington.

$-1989-$

Alexandre, D., J. Maillet, and C. Sombret. 1989a. 'Vitrification of High-Level Waste in France: Over 30 Years of Continuous Development from the Laboratory to Industrial Facilities.' Proceedings of The 1989 Joint International Conference on High Level Radioactive Waste and Spent Fuel Management, Vol. 2, pp. 141-145, October 22-28, 1989, Kyoto, Japan.

Alexandre, D. 1989b. 'The Collection and Treatment in France of Low-Level Waste from Small Producers." Proceedings of An IAEA/CEC Symposium on the Management of Low and Intermediate Level Radioactive Wastes: 1988 , Vol. 1, pp. 417-425. May 16-20, 1988, Stockholm, Sweden. International Atomic Energy Agency, Vienna. (In French)

Barnier, Caminade, Loudenot, Maurel, and Courtois. 1989. "Ultrafiltration Treatment of Laundry Liquid Wastes from a Nuclear Research Center.' Proceedings of The 1989 Joint International Waste Management Conference on Low and intermediate Level Radioactive Waste Management. Vol. 1, pp. 2123. October 22-28, 1989, Kyoto, Japan.

Beroud, Y. 1989. "Measuring Low Fissile Content Concentration in Radioactive Liquid Waste and Solid Waste Packages." Proceedings of the 1989 Joint International Waste Management Conference on Low and Intermediate Level Radioactive Waste Management, Vol. 1, pp. 415-420. October $22-28$, 1989, Kyoto, Japan.

Bonnet, C., and P. L. Chometon. 1989. 'Design of Spent Fuel Unloading and Storage Facilities." Report of the IAEA Technical Committee on Decontamination of Transport Casks and of Spent Fuel Storage Facilities. April 4-7, 1989, Vienna.

Broc, D., F. Plas, and J. C. Robinet. 1989. 'Mechanical Properties of Swelling Clays." Proceedings of The MRS Symposium on the Scientific Basis for Nuclear Waste Management X11, Vol. 127, pp. 669676. October 10-13, 1988, Berlin. Materials Research Society, Pittsburgh, Pennsylvaria. 
Cathelineau, M., and M. Vergneaud. 1989. "U-TH-REE Mobility and Diffusion in Granitic Environments During Alteration of Accessory Minerals and U-Ores: Geochemical Analogue to Radioactive Waste Disposal." Proceedings of The MRS Symposium on the Scientific Basis for Nuclear Waste Management XII, Yol. 127, pp. 941-947. October 10-13, 1988, Berlin. Materials Research Society, Pittsburgh, Pennsylvania.

Celeri, J. J. 1989. "Study of the Processes for Reducing the Volume of Technological Wastes from EDF Nuclear Power Plants.' Proceedings of The CEC/IAEA Symposium on the Management of Low and Intermediate Level Radioactive Wastes 1988, Vol. 1, pp. 313-324, May 16-20, 1988, Stockholm, Sweden. International Atomic Energy Agency, Vienna. (In French).

CEA. 1989a. 1989 Annual Report. French Atomic Energy Commission, Paris.

CEA. 1989b. The CEA-Industrie Group of Companies: 1989 Management Report. French Atomic Energy Commission, Paris.

Cogema. 1989. Annual Report 1989. Cogema, Paris.

Cogema. 6/89. Reprocessing. Cogema, Paris.

Cogema. 10/89. Natural Uranium. Brochure distributed by Cogema, Paris.

Costes, J. R., D. Da Costa, and G. Imbard. 1989a. "Measurement and Sorting Techniques Qualified for Unrestricted Release of Metals from the Nuclear Industry." Proceedings of the 1989 Joint International Waste Management Conference on Low and Intermediate Level Radioactive Waste Management, Vol. 1, pp. 397-400. October 22-28, 1989, Kyoto, Japan.

Costes, J. R., C. de Tassigny, R. Alain, and V. Hugues. 1989b. "Conditioning of Graphite Bricks from Dismantled Gas Cooled Reactors for Disposal." Proceedings of the 1989 Joint International Waste Marnagement Conference on Low and Intermediate Level Radioactive Waste Management, Vol. 1, pp. 497-501. October 22-28, 1989, Kyoto, Japan.

Crovisier, J. L., H. Atassi, V. Daux, J. Honnorez, J. C. Petit, and J. P. Eberhart, 1989a. 'A New Insight into the Nature of Leached Layers Formed on Basaltic Glasses in Relation to the Choice of Constraints for Long Torm Modelling." Proceedings of The MRS Symposium on the Scientific Basis for Nuclear Waste Management XII, Vol, 127, pp. 41-48. October 10-13, 1988, Berlin, Germany. Materials Pesearch Society, Pittsburgh, Pennsylvania.

Crovisier, J. L., T. Advocat, J. C. Petit, and B. Fritz. 1989b. "Alteration of Basaltic Glass in Iceland as a Natural Analogue for Nuclear Waste Glasses: Geochemical Modelling with DISSOL.' Proceedings of The MRS Symposium on the Scientific Basis for Nuclear Waste Management XII. Vol. 127, pp. 57-64. October 10-13, 1988, Berlin, Germany. Materials Research Society, Pittsburgh, Pennsylvania.

Cruickshank, A. February 1989. "France Pushes Ahead with New Repositories," Nuclear Engineering International, 1989, pp. 35-36.

Dabat, R., J. L. Mathien, and M. Lung. 1989. 'Operating Experience with the Spent Fuel Reception and Storage Facilities at the La Hague Reprocessing Plant.' Proceedings of the 1989 Joint internationa! Conference on Low and Intermediate Level Radioactive Waste, Vol. 2, pp. 467-471. October 22 28, 1989, Kyoto, Japan. 
Deffes, A. 1989. "Technical and Economic Optimization Study for HLW Management." Proceedings of the 1989 Joint International Conference on Low and Intermediate Level Radioactive Waste, Vol. 2, pp. 595-599. October 22-28, 1989, Kyoto, Japan.

EDF. 1989. Annual Report 1989. Electricité de France International, Paris.

FNN. 1/89. "The French Nuclear Power Industry." French Nuclear Newsletter. A quarterly international newsletter published by Alsthom, CEA, Cogema, EDF and Framatome.

FNN. 6/89. Transportation of Nuclear Materials," French Nuclear Newsletter. A quarterly international newsletter published by Alsthom, CEA, Cogema, EDF and Framatome.

Gauthey, M.J.C. 1989. 'The Experience of the Thermosetting Polymer Embedding Unit Seth 200.' Proceedings of The Symposium on Waste Management (WM '89), Vol. 2, pp. 481-484. February 26March 2, 1989, Tucson, Arizona.

Geofirey, J. M. Dobremelle, J. C. Fabre, and C. Bonnet. 1989. 'Dry Storage Facility for Spent Fuel or High-Level Wastes." Proceedings of the 1989 Joint International Conference on Low and Intermediate Level Radioactive Waste Management, Vol. 2, pp. 457-462. October 22-28, 1989, Kyoto, Japan.

Gloaguen, A. 1989. "Electricite de France's Experience and Development Programme for Plutonium Recycling in the European industrial Context.' Proceedings of the International Symposium on Good Performance in Nuclear Projects, pp. 530-537. April 17-21, 1989, Tokyo, Japan.

Godon, N., E. Vernaz, J. H. Thomassin, and J. C. Touray. 1989. "Effect of Environmental Materials on Aqueous Corrosion of R7T7 Glass." Proceedings of The MRS Symposium on the Scientific Basis for Nuclear Waste Management Xl1, pp. 97-104. October 10-13, 1988, Berlin, Germany. Materials Research Sociely, Pittsburgh, Pennsylvania.

Gouin, P., E. Mignot, and L. Phan Hoang. 1989. "EDF, a Utility and Its Own Needs in the Field of Transport of Nuclear Materials." Proceedings of The 9th International Symposium on the Packaging and Transportation of Radioactive Materials (PATRAM '89), Vol. 3., pp. 1343-1348, CONF-890631. June 11-16, 1989, Washington, D.C.

Heafield, W., and A. D. Elsden. 1989. "High-Level Waste Management in the United Kingdom." Proceedings of The 1989 Joint International Conference on High Level Radioactive Waste and Spent Fuel Management, Vol. 2, pp. 147-152. October 22-24, 1989, at Kyoto, Japan.

Hussonnois, M., R. Guillaumont, L. Brillard, and M. Fattahi. 1989. 'A Method for Determining the Oxidation State of Uranium at Concentration as Low as $10^{-10} \underline{M}$." Proceedings of The MAS Symposium on the Scientific Basis for Nuclear Waste Management XII, Vol. 127, pp. 979-984. October 10-13, 1988, Berlin, Germany. Materials Research Sociely, Pittsburgh, Pennsylvania.

IAEA. 1989. Treatment of Off-Gas from Radioactive Waste Incinerators. Technical Report Series No. 302, International Atomic Energy Agency, Vienna, pp. 143-152.

Kemp, A. 1989. "Low-Level Radioactive Waste Disposal in Canada: Ontario." Planning and Consultation Procedures for Low-Level Radioactive Waste Disposal: A Comparative Analysis of Overseas Experience, pp. 40-57, Research Report No. 1, Environmental Risk Assessment unit, School of Environmental Sciences, University of East Anglia, Norwich, United Kingdom. 
Kertesz, C., and C. Courtois, 1989. "Conditioning of Incinerator Ash at the CEN, Cadarache." Proceedings of The CEC/IAEA Symposium on the Management of Low and Intermediate Level Radioactive Wastes: 1988, Vol. 1, pp. 341-357. May 16-20, 1988, Stockholm, Sweden, International Atomic Energy Agency, Vienna. (In French).

Lewi, J., M. J. Mejon-Goula, P. Goblet, and A. Cernes. 1989. "Melodie: A Code for Risk Assessment of Waste Repositories in Deep Geological Formations.' Proceedings of The MRS Symposium on the Scientific Basis for Nuclear Waste Management XII, Vol. 127, pp, 605-612. October 10-13, 1988, Berlin, Germany. Materials Research Society, Piitsburgh, Pennsylvania.

Mangin, J. P., E. Mouche, P. Lovera, and H. N. Ngoc. 1989. "Condiment: Source Term for Risk Assessment of French Nuclear Waste Repository.' Proceedings of The MRS Symposium on the Scientific Basis for Nuclear Waste Management XII, Vol. 127, pp. 571-580. October 10-13, 1988, Berlin, Germany. Materials Research Society, Pittsburgh, Pennsylvania.

Moulin, V., and D. Stammose. 1989. "Effect of Humic Substances on Americium (III) Retention onto Silica." Proceedings of The MRS Symposium on the Scientific Basis for Nuclear Waste Management XIll, Vol. 127, pp. 723-727. October 10-13, 1988, Berlin, Germany. Materials Research Society, Pittsburgh, Pennsylvania.

Nomine, J. C., A. Billion, and G. Courtois. 1989, "Leaching Scale Effect for Cement Waste Forms." Proceedings of The MRS Symposium on the Scientific Basis for Nuclear Waste Management XII, Vol. 127, pp. 431-438. October 10-13, 1988, Berlin, Germany. Materials Research Society, Pittsburgh, Pennsylvania.

Nouguier, H., and Y. Marque, 1989. "French Policy for the Management of Low- and IntermediateLevel Radioactive Wastes.' Proceedings of The CEC/IAEA Symposium on the Management of Low and Intermediate Level Radioactive Wastes: 1988, Vol. 1, pp. 3-11. May 16-20, 1989, Stockholm, Sweden, International Atomic Energy Agency, Vienna, Austria. (In French).

Nuciear Energy Agency (NEA). 1989a. Projected Costs of Generating Electricity from Power Stations for Commissioning in the Period 1995-2000, p. 198, OECD/Nuclear Energy Agency, Paris.

Nuclear Energy Agency (NEA). 1989b. Plutonium Fuel: An Assessment. OECD/Nuclear Energy Agency, Paris.

Nuclear Energy Agency (NEA). 1989c. Uranium: Resources, Production and Demand. OECD/Nuclear Energy Agency, Paris.

Nuclear Energy Agency (NEA). 1989d. Nuclear Energy Data, p. 29, OECD/Nuclear Energy Agency, Paris.

Nuclear Engineering International (NEl). 4/89. "Germany, Britain and France Sign Up for the EFR," p. 2.

Nuclear Engineering International (NE). 9/89. "Automating Fuel Production at Pierrelatte," pp. 26-28.

Nuclear Engineering International (NEl). 12/89. 'Eurodif Prepares for the Future," pp. 41-42.

Nuclear Fuel (NF). 10/30/89. "Court Overturns Cogema License to Store Depleted Uranium at Miramas," p. 6. 
Nuclear Europe (NE). 3-4/89. 'France and USSR Agree to Wide Nuclear Cooperation," European Nuclear Society, Berne, Switzerland, p. 51.

Nuclear Fuel (NF). 10/2/89. "Comurhex Licensed to Build New Plant," p. 12.

Nuclear Fuel (NF). 11/13/89. 'FBFC to Open REPU Fuel Pellet Line' and 'Pechiney Hopes Asian Zirconium Sales Make Up for Losses in U.S. Market," pp. 3-4.

Nuclear News (NN). 3/89. "Research Cooperation with France Expanded," p. 91.

Nuclear New (NN). 12/89. 'France's Policy on Nuclear Power Reliance Was Reaffirmed," pp. 107-108.

Nucleonics Week (NW). 2/23/89. "ENEL is Ordered out of Superphenix -- or is It?," p. 7.

Nucleonics Week (NW). 4/20/89. "After Week's Delay, Framatome and KWU Sign PWA Agreement," p. 4.

Nucleonics Week (NW). 6/8/89. "France and Germany Agree on Reprocessing Cooperation," p. 3.

Nucleonics Week (NW). 11/30/89. 'France: Nuclear Budget Down,' p. 15.

NUKEM Special Report (NUKEM). 5/89. "The Nuclear Power Plant Capacities of Individual Countries," NUKEM GmbH, Alzenau, FRG, p. 14.

Numark, N. J., H. W. Paige, and E. F. Wonder. 1989. Public Perception and Acceptance of the Siting of Nuclear Waste Facilities in Seven Countries. Report No. ERCE-R/89-42, ERC Environmental and Energy Services Company, Fairfax, Virginia, pp. I.3-1 to I.3-6.

Pacaud, F., N. Jacquet-Francillon, A. Terki, and C. Fillet. 1989. 'R7T7 Light Water Reference Glass Sensitivity to Variations in Chemical Composition and Operating Parameters." Proceedings of The MAS Symposium on the Scientific Basis for Nuclear Waste Management XII, Vol. 127, pp. 105-112. October 10-13, 1988, Berlin, Germany. Materials Research Society, Pittsburgh, Pennsylvania.

Petit, J. F., and J. Y. Barre. 1989. "Eurodif: An Enrichment Plant for the Present and Beyond the Year 2000." Proceedings of The OECD/NEA International Symposium on Good Performance in Nuclear Projects, pp. 423-427. April 17-21, 1989, Tokyo, Japan. OECD, Paris.

Potier, J. M. 1989. "Disposal Concepts for HLW and TRU Waste in France." Proceedings of The 1989 Joint International Conference on High Level Radioactive Waste and Spent Fuel Management, Vol. 2, pp. 411-416. October 22-24, 1989, Kyoto, Japan.

Quinaux, J-P., M. Delange, J-C. Guais, G. Le Bastard, and L. F. Durret. 1989. "Fuel Cycle." French PWR Technology. Special publication of Nuclear Engineering International magazine, pp. 66-74.

Robinson, E. 1989. "Reprocessing Industry in Europe: Achievement and Current Status." Proceedings of The OECD/NEA International Symposium on Good Performance in Nuclear Projects, pp. 466476. April 17-21, 1989, Tokyo, Japan. OECD, Paris.

Schneider, K. J., L. T. Lakey, and D. J. Silviera. 1989. Survey of Waste Package Designs for Disposal of High-Level Waste/Spent Fuel in Selected Foreign Countries. PNL-6981, Pacific Northwest Laboratory, Richland, Washington. 
Schwartz, J.P., F. Boulet, and M. Coudray. 1989. 'How R\&D Helps.' French PWR Technology. Special publication of Nuclear Engineering International magazine, pp. 12-15.

SKB. 1989. Executive Summary of Phase 2, In Situ Experiments in Granite for the Underground Disposal of Radioactive Wastes, The International STRIPA Project. Report No. 89-01, Swedish Nuclear Fuel and Waste Management Company, Stockholm, Sweden.

$-1980-$

Alexandre, D., C. Bernard, and H. Gegnaut. 1990. "Startup of Commercial High-Level Waste Vitrification Facilities at La Hague." Transactions of the ENS/ANS-Foratom Conference (ENC '90), Vol. 4, pp. 2298-2303. October 23-28, 1990, Lyon, France.

Baillit, L., and P. Guay. 1990. 'Dry Storage Vault for Spent Fuel and Operating Results at the CASCAD Facility." Proceedings of the International Topical Meeting on Nuclear and Hazardous Waste Management (Spectrum '90), pp. 356-359. September 30 - October 4, 1990, Knoxville, Tennessee.

Barbe, A., and R. Pech. 1990. "Cost Estimation of the Decommissioning of Nuclear Fuel Cycle Plants: Application to Reprocessing Plants.' Proceedings of The Symposium on Waste Management (WM '90), Vol. 2, pp. 629-634. February 25- March 1, 1990, Tucson, Arizona.

Bonnet, C., P. Guay, and L. Gilles. 1990. 'The CASCAD Spent Fuel Dry Storage Facility." Transactions of the ENS/ANS-Foratom Conference (ENC '90), Vol. 4, pp. 2124-2132. October 23-28, 1990, Lyon, France,

Cacas, M. C., E. Cordier, A. Coudrain-Ribstein, D. Fargue, P. Goblet, P. Jamet, E. Ledoux, G. de Marsily, and A. Vinsot. 1990. "Modelling Radionuclide Transport in the Geosphere: A Review of the Models Available." Proceedings of The CEC/IAEA/NEA Symposium on Safety Assessment of Radioactive Waste Repositories, pp. 501-512. October 9-13, 1989, Paris. OECD/Nuclear Energy Agency, Paris. (In French).

Cogema. 1990. The Nuclear Fuel Cycle Backend: A Cogema View. Brochure distributed by Cogema, Cedex, France.

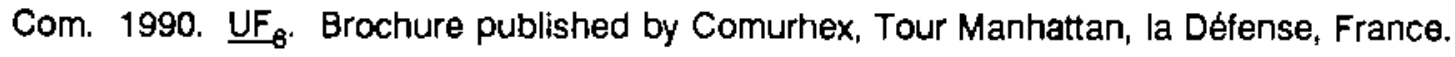

Costes, J. R., and G. Coste. 1990. "Two Financial Criteria For Decommissioning Policy Decisions," in the proceedings of the International Topical Meeting on Nuclear and Hazardous Waste Management (Spectrum '90), pp. 369-372. September 30 - October 4, 1990, Knoxville, Tennessee.

Daily Telegraph (DT). 8/15/90. "Atom Waste Processing Plant Opens," London, United Kingdom.

Dherbey, J. R., G. Bignan, L. M. Deider, and Y. Beroud. 1990. "Active Neutron Interrogation Devices for Gamma Irradiating Solid Alpha Wastes." Proceedings of The Symposium on Waste Management (WM '90), Vol. 2, pp. 807-813. February 25-March 1, 1990, Tucson, Arizona.

Dufer, B., and F. Lecomte. 1990. "Developments in Accounting Data Centralization in France." Proceedings of The 31st Annual Meeting of the Institute of Nuclear Materials Management, Vol. XIX, pp. 512-517. July 15-18, 1990, Los Angeles. Institute of Nuclear Materials Management, Nonhbrook, Illinois. 
EDF. 1990. French Nuclear Power Industry Otters New Technologies to U.S. Market. Brochure distributed by Electricité de France, Calmart, France.

Eurodif. 1990. The Georges Besse Plant. Brochure published by Eurodif S.A., Cedex France.

Gobert, C. 1990. "Fuei Cycle Improvements." Transactions of the ENS/ANS-Foratom Conference (ENC '90), Vol. 1, pp. 70-76. October 23-28, 1990, Lyon, France.

Howles. April 1990. 'Annual Review of Load Factor Trends." Nuclear Engineering International, pp. 12-18.

Izabel, C., and S. Leveel. 1990. "Safely Analysis of the l'Aube Disposal Centre." Proceedings of The CEC/IAEA/NEA Symposium on Safety Assessment of Radioactive Waste Repositories, pp. 117-128. October 9-13, 1989, Paris. OECD/Nuclear Energy Agency, Paris. (In French).

Kertesz, C. J., P. R. Chenavas and G. M. Naud. 1990. The Starting Up of a Pilot Plant for Radioactive Incinerator Ash Conditioning - Results of Two Embedding Campaigns." Proceedings of The Symposium on Waste Management (WM '90), Vol. 1, pp. 703-713. February 25-March 1, 1990, Tucson, Arizona.

Lazarevitch, S. 1990. "Overview of Cogema Transportation System for Present LWR Fuel Operations and Future Prospects Including Transuranic Materials and High-Level Waste." Proceedings of the International Topical Meeting on Nuclear and Hazardous Waste Management (Spectrum '90), pp. 182184. September 30-October 4, 1990, Knoxville, Tennessee.

Lecoy. 1990. "Organization of Radioactive Waste Transportation in France." Presented at The 1990 Summer National Meeting of the AlChE, August 19-22, 1990, San Diego, California.

Leigh, I. W., and S. J. Mitchell. 1990. International Nuclear Fuel Cycle Fact Book. PNL-3594, Rev. 10, Pacific Northwest Laboratory, Richland, Washington.

Lewi, J., M. J. Mejon-Goula, A. Cernes, and C. Brun-Yaba. 1990. "Sensitivity Analyses of Equivalent Dose Calculations for Nuclear Waste Repositories in Deep Geological formations.' Proceedings of The CEC/IAEA/NEA Symposium on Safety Assessment of Radioactive Waste Repositories, pp. 649-661. October 9-13, 1989, Paris. OECD/Nuclear Energy Agency, Paris. (In French).

Madic, C., M. Lecomte, and B. Vigreux. 1990. Treatment of Solid Waste Highly Contaminated with Alpha Emitters: Recent Developments of Leaching Process with Continuous Electrolyte Regeneration." Proceedings of The Symposium on Waste Management (WM '90), Vol, 2, pp. 815-826. February 25. March 1, 1990, Tucson, Arizona.

McCabe, G. H. 1990. 'Lessons Learned from International Siting Experiences of LLW Disposal Facilities." Proceedings of The International Topical Meeting on Nuclear and Hazardous Waste Management (Spectrum '90), pp. 4-6. September 30 - October 4, 1990, Knoxville, Tennessee.

Mollard, P., A. Vielvoye, and P. Courcier, 1990. 'Fabrication and Operation of Reprocessed Uranium Fuels," in the transactions of the ENS/ANS.Foratom Conference (ENC '90), Vol. 4, pp. 2084-2087.

October 23-28, 1990, Lyon, France. 
Mueller, P., and M. Schvoerer. 1990. 'Characterization of Damage Created by Alpha Disintegrations in Radionuclear Waste Glass." Proceedings of The International Topical Meeting on Nuclear and Hazardous Weste Management (Spectrum '90), pp. 317-318. September 30-October 4, 1990, Knoxville, Tennessee.

Nuclear Energy Agency (NEA). 1990a. Uranium: Resources, Production and Demand. A Joint Report of the OECD/NEA and the IAEA. Published by the OECD/Nuclear Energy Agency, Paris, pp. 176-188.

Nuclear Energy Agency (NEA). 1990b. Nuclear Waste Management: France. Brochure published in cooperation with ANDRA. OECD/Nuclear Energy Agency, Paris.

Nuclear Energy Agency (NEA). 1/90. "Recent Developments in the Radioactive Waste Management in France." Handout provided at the meeting of the OECD/NEA's Radioactive Waste Management Committee, January 23-24, 1990, Paris.

Nuclear Energy Agency (NEA). 3/90. 'Radioactive Waste Management in France.' EN/S/632, Prepared by ANDRA for the OECD/Nuclear Energy Agency's Radioactive Waste Management Committee.

Nuclear Energy Agency (NEA). 6/90a. "National Legislative and Regulatory Activities: France." Nuclear Law Bulletin, No. 45. OECD/Nuclear Energy Agency, Paris, pp. 46-48.

Nuclear Energy Agency (NEA). 6/90b. "Investigation of Deep Disposal Sites Stopped." Nuclear Waste Bulletin. OECD/Nuclear Energy Agency, Paris, n. 5, p.15.

Nuciear Engineering International (NEI). 1990. World Nuclear Industry Handbook, Surrey, United Kingdom.

Nuclear Europe (NE). 1-2/90. 'France 74.6\% Nuclear Throughout 1989." Nuclear Europe Worldscan. European Nuclear Society, Berne, Switzerland, p. 90.

Nuclear Europe (NE). 3-4/90. "R\&D Update on SILVA French Laaser Enrichment Process" and "The

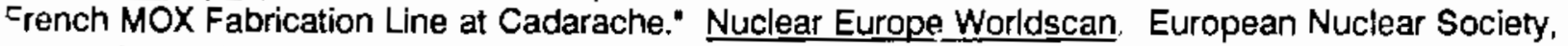
Berne, Switzerland, pp. 11-13 and 59-60.

Nuclear Europe (NE). 5-6/90. "Cogema Aims to Expand U Conversion Facilities," Nuclear Europe Worldscan, publication of the European Nuclear Society, Berne, Switzerland, May June 1990, p. 44.

Nuclear Fuel (NF). 1/22/90. "Gendarmes Injured in Protests at French Candidate Repository Sites," pp. 5-6.

Nuclear Fuel (NF). 3/19/90. "Rouvillois Report Predicts Troubles in Coming Years for French Fuel Sector," pp. 3-4.

Nuclear Fuel (NF). 5/28/90. "Melox S.A. To Be Set Up As MOX Plant Gets French Government Approval,' pp. 5-6.

Nuclear Fuel (NF). 9/3/90. "Cogema Expanding Tails Cleanup Plant," pp. 6-7.

Nuclear Fuel (NF). 10/1/90. "Labor Conflict over Transfer to Cogema Hobbles French Plutonium Plant," p. 13. 
Nuclear News (NN). 1/90. "Vitrification and Pyroprocessing," pp. 88-89.

Nuclear News (NN). 3/90. "France Has Halted Geological studies for HLW Disposal," p. 101.

Nuclear News (NN). 8/90. 'Cogema Profits in 1989 Reported as Highest Ever,' p. 59.

Nuclear News (NN). 10/90. "UP3 Declared Commercial in Early September,' pp. 71-74.

Nucleonics Week (NW). 2/15/90. 'CEA Advised to Adopt New R\&D Goals, Open Up To The World,' pp. 7-9.

Nuclear News (NW). 3/1/90. 'CEA Reorganization Aims to Rejuvenate French R\&D Arm,' pp. 9-11. Nucleonics Week (NW). 3/15/90. "Secret French Government Report Says All Not Rosy in Nuclear," pp. 11-13.

Nucleonics Week (NW). 4/19/90a. "Cooperation Planned with Czechoslovakia," p. 15.

Nucleonics Week (NW). 4/19/90b. "France: Safety Agreement with USSR," pp. 14-15.

Nucleonics Week (NW). 5/3/90. "FRANCE/JAPAN: Nuclear Pact Renewed," p. 15.

Nucleonics Week (NW). 7/12/90. "Framatome and Noell Enter Soviet Decommissioning Market," pp. 2.

Nucleonics Week (NW). 10/11/90. "France and Soviet Union Set Nuclear Cooperation Priorities.'

Nucleonics Week (NW). 11/1/90. 'EDF Ready to Launch 'Serious' Study of Decommissioning," pp. 1314.

Nucleonics Week (NW). 10/11/90. 'France and Soviet Union Set Nuclear Cooperation Priorities," pp. 12-13.

Nucleonics Week (NW). 11/8/90. "French legislators Join Fray Over CEA Waste Site Cleanup," pp. 7 8.

Nucleonics Week (NW). 12/20/90. "French Parliament Wants Reform of HLW Management Office," pp. 1-12.

NUKEM Market Report (NUKEM). 2/90. "Reprocessing and Waste Management: Review 1989." NUKEM GmbH, Alzenau, Federal Republic of Germany, pp. 14-23.

NUKEM Market Report (NUKEM). 4/90. '1989 European Community Electricity Generation and Consumption.' NUKEM GmbH, Alzenau, Federal Republic of Germany, pp, 4-8, 26,27.

NUKEM Market Report (NUKEM). 9/90. 'Reprocessing: France.' NUKEM GmbH, Alzenau, Federal Republic of Germany, p. 5.

NUKEM Market Report (NUKEM). 10/90. 'Peprocessing.' NUKEM GmbH, Alzenau, Federal Republic of Germany, pp. 3-8. 
NUKEM Special Report: Workd Nuclear Power Plant Capacity (NUKEM). 7/90. "Nuclear Power Plant Capacities in Individual Countries.' NUKEM GmbH, Alzenau, Federal Republic of Germany, pp. 14-58.

Peaudecert, P., and P. L Blanc. 1990. "Long Term Evolution of Waste Disposal Sites: Scenario Selection and Methods." Proceedings of The CEC/IAEA/NEA Symposium on Safety Assessment of Radioactive Waste Repositories, pp. 351-362. October 9-13, 1989, Paris. OECD/Nuclear Energy Agency, Paris. (In French).

Pichat, C., and A. M. Jouan. 1990. 'industrial Defluorination Plant: The W Facility.' Transactions of the ENS/ANS-Foratom Conference (ENC '90), Vol. 3, pp. 1882-1884. October 23-28, 1990, Lyon, France.

Pierrelatte. 1990. Pierrelatte Plant. Brochure published by Cogema, Pierrelatte Plant, B.P. 16, Pierrelatte Cedex, France.

Pilot, G., and R. Leautier. 1990. "Underwater Plasma Cutting for Decommissioning Purposes." Proceedings of The International Topical Meeting on Nuclear and Hazardous Waste Management (Spectrum '90), pp. 373-377. September 30-October 4, 1990, Knoxville, Tennessee.

Robeau, D., J. Laporte, and J. M. Pérès. 1990. 'Sensitivity Analysis of the Dose to Biosphere Parameters." Proceedings of The CEC/IAEA/NEA Symposium on Safety Assessment of Radioactive Waste Repositories, pp. 978-986. October 9-13, 1989, Paris. OECD/Nuclear Energy Agency, Paris. (In French).

Schneider, K. J., S. J. Mitchell, L T. Lakey, A. B. Johnson, Jr., R. F. Hazelton, and D. J. Bradley, 1990. Comparison of Selected Foreign Plans and Practices for Spent Fuel and High-Level Waste Management. PNL-7293, Pacitic Northwest Laboratory, Richland, Washington.

Tchemitcheff, E., and Y. Bordas. 1990. "Mobile Concrete Solidification Systems for Power Reactor Waste.' Proceedings of The Symposium on Waste Management (WM '90), Vol. 2, pp. 3-9. February 25-March 1, 1990, Tucson, Arizona.

Technical Review (TR). 1990. Publication of GEC Althsom, Paris, No. 1.

TRI. 1990. The Nuclear Industry at Tricastin. Brochure published by Comurhex, Tour Manhattan.

Vanden Bemden, E. 1990. "Uranium and Plutonium Recycling." Transactions of the ENS/ANSForatom Conference (ENC '90), pp. 387-398. September 23-28, 1990, Lyon, France.

Vincent, F. December 1990. 'Gaining Good Experience with MOX at French Reactors." Nuclear Engineering International, pp. 35-36.

$-1991-$

Bodin, F., J. C. Saublet, and R. Pech. 1991. "Removal of Underground Piping: Decommissioning of Buried, Radiation-Contaminated Pipes." Presented at The Symposium on Waste Management (WM '91). February 24-28, 1991, Tucson, Arizona.

Boudry, J. C., and R. Pech. 1991. 'Development of Metal Fibre Reinforced Concrete Overpacks in France." Presented at The Symposium on Waste Management (WM '91), February 24-28, 1991, Tucson, Arizona. 
Kertesz, C. J. 1991. 'Conditioning of Spent lon Exchange Resins by Embedding in Compound Matrices." Presented at The Symposium on Waste Management (WM '91), February 24-28, 1991, Tucson, Arizona.

Nuclear Enqineering International (NEI). 1/91. "CEA Comes Clean," p. 3.

Singer, B., and B. Vegreux. 1991. "Advanced Waste Technology Developed for Cogema's Spent Fuel Reprocessing Plant at La Hague.' Presented at The Symposium on Waste Management (WM '91), February 24-28, 1991, Tucson, Arizona. 


\section{WEST GERMANY}




\title{
GERMANY (FEDERAL REPUBLIC OF)
}

\author{
CONTENTS
}

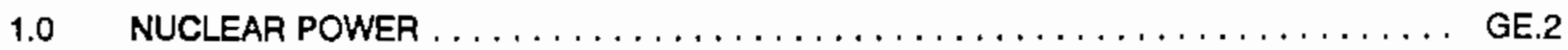

2.0 NUCLEAR FUEL CYCLE AND RADIOACTVE WASTE MANAGEMENT

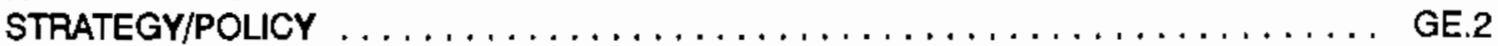

3.0 HIGHLIGHTS AND MAJOR MILESTONES $\ldots \ldots \ldots \ldots \ldots \ldots \ldots \ldots \ldots \ldots, \ldots \ldots \ldots$

4.0 INSTITUTIONAL CONSIDERATIONS/ORGANIZATIONS $\ldots \ldots \ldots \ldots \ldots \ldots \ldots$ GE.5

5.0 NUCLEAR FUEL PRODUCTION $\ldots \ldots \ldots \ldots \ldots \ldots \ldots \ldots \ldots \ldots \ldots \ldots \ldots \ldots \ldots \ldots . .9 \ldots \ldots$

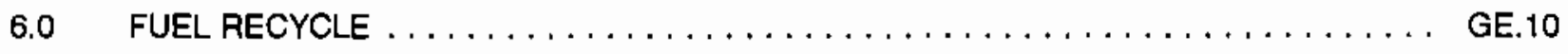

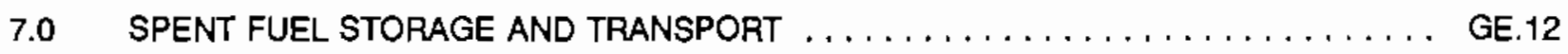

8.0 WASTE CONDITIONING, STORAGE AND TRANSPORT $\ldots \ldots \ldots \ldots \ldots \ldots \ldots$ GE.15

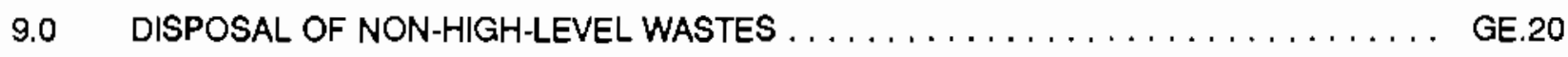

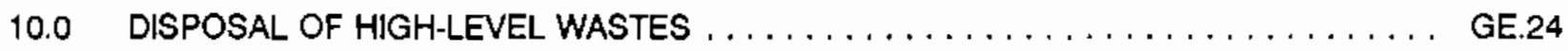

11.0 MANAGEMENT OF URANIUM MINE AND MILL WASTES $\ldots \ldots \ldots \ldots \ldots \ldots \ldots$ GE.31

12.0 DECOMMISSIONING AND ENVIRONMENTAL RESTORATION .............. GE.31

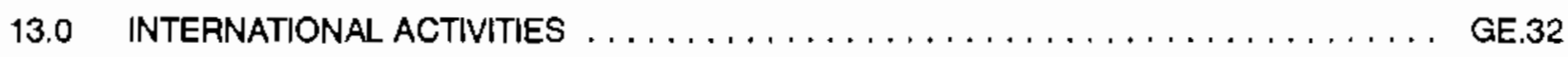

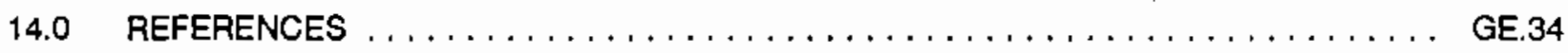

(This section covers only the Federal Republic of Germany before it united with the former German Democratic Repubilc In October 1990,) 


\subsection{NUCLEAR POWER}

1.1 REACTOR MIX: 14 PWRs: 7 BWRs; 1 HTR (296-MWe Demo THTR-300) and 1 LMFBR (295MWe Demo SNR-300) (NUKEM 5/89)

\subsection{ELECTRIC POWER PRODUCTION}

1988--405 TWh NET (34\% Nuclear, 61\% Fossil, 5\% Hydro/Other) (NUKEM 3/89)

\subsection{NUCLEAR POWER CAPACITY PROJECTIONS (NUKEM 2/90a)}

1985--16.1 GWe

1990--22.7 GWe

2000--22.7 GWe

\subsection{NUCLEAR PLANT AVAILABILITY (Howles 1990)}

Year ending $12 / 89-69.1 \%$

Lifetime through $12 / 89-69.9 \%$

1.5 NUCLEAR ENERGY POLICY: Germany supports: 1) use of nuclear energy as an important part of a diversified energy supply; 2) closure of the fuel cycle by recycling plutonium through power reactors; 3 ) continued reactor development in the form of improved PWRs, LMFBRs and HTGRs; and 4) disposal of all radioactive wastes in deep geologic formations; development costs are being shifted to industry (Kramer 1989; NW 10/12/89)

1.6 NUCLEAR R\&D BUDGET: The draft 1990 budget for waste management R\&D is 43 million DM ( $\sim 25$ million U.S.) as against 55 million DM in 1989 (ATW 10/89)

\subsection{ELECTRICITY PRODUCTION COSTS}

A. Costs for generating electricity in 1989 are estimated at 42.2 U.S. mills $/ \mathrm{kWh}$ for nuclear plants and 44.5 U.S. mills/kWh for coal plants (NEA 1989a)

B. German utilities estimate the cost of the nuclear fuel cycle (from natural uranium to spent fuel management) using $1300 \mathrm{MWe}$ plants is $2.47 \mathrm{PI}$ (14.5 U.S. mills) per kWh. Of this cost, $13 \%, 16 \%, 13 \%$, and $58 \%$ are attributed to uranium procurement, enrichment, fuel fabrication and spent fuel management, respectively; reprocessing is responsible for twothirds of the cost of spent fuel management (ATW 1/90)

\subsection{NUCLEAR FUEL CYCLE AND RADIOACTIVE WASTE MANAGEMENT STRATEGY/POLICY}

2.1 OVERALL NUCLEAR FUEL CYCLE POLICY: Germany relies on nuclear power as an important part of a diversified energy supply (Kramer 1989) 


\subsection{POLCY ON THE FRONT END OF THE NUCLEAR FUEL CYCLE}

A. Germany has no domestic production of uranium but explores actively for and mines uranium in other countries (e.g., Canada, Zambia, Zimbabwe, Cameroon, Australia, U.S.) to assure an adequate supply; exploration and mining is done by private companies; a two-year inventory is maintained (NEA 1986a; Hackstein 1987; IAEA 1988)

B. Germany currently buys $\mathrm{UO}_{2}$ to $\mathrm{UF}_{6}$ conversion services (Hackstein 1987)

C. Germany is a partner with Britain and the Netheriands in Urenco, Inc, which operates a 400,000 SWU centrifuge enrichment plant at Gronau in West Germany; in anticipation of using the reprocessed uranium (REPU) returned from foreign reprocessors, Germany has signed long-term enrichment contracts with the U.S. DOE, Cogema/ Eurodif of France and Techsnabexport of the USSR to which the REPU will serve as feed material (Hackstein 1987; IAEA 1988; NF 11/13/89)

D. Germany has the capability for fabricating nuclear fuels for various types of reactors, e.g., PWRs, BWRs, HWRs, and FBRs; fuel assemblies for LWRs are fabricated by RBU at plants in Hanau and Karlstein and by Advanced Nuclear Fuels (ANF) at Lingen; MOX fuel for recycle in LWRs is fabricated by Siemens AG Brennelementewerk Hanau (SBH); specialty fuels for HTRs and material test reactors were fabricated at a NUKEM facility in Hanau, shut down in 1988 (Hackstein 1987; IAEA 1988; NF 3/21/88; NN 9/89)

E. Germany plans to recycle plutonium in breeder reactors, but the German breeder program cannot use all of the plutonium being produced; Germany is expanding use of plutonium in power reactors with reprocessing purchased from other countries; reprocessed uranium will be used as feed material under existing enrichment contracts (NUKEM 12/87; Kramer 1989; NUKEM 2/90b)

F. Programs are under way to increase spent fuel burnup to improve economics, to conserve resources, and to minimize waste volumes (Hackstein 1987)

\subsection{POLICY ON THE BACK END OF THE NUCLEAR FUEL CYCLE}

A. Spent fuel is stored for a minimum of one year (seven years if destined for reprocessing) and up to ten years in reactor pools using compact racks; it may then be transferred to a central, dry interim storage facility, to France for reprocessing, or to a deep repository for direct disposal (Hackstein 1987; Petroll 1987; NUKEM 2/90b)

B. Vitrified high-level waste returned from the foreign reprocessor will be placed in interim dry storage for at least ten years prior to disposal; conditioned cladding and other wastes returned from the reprocessor will be placed in interim storage facilities along with spent fuel not to be reprocessed and the conditioned low- and intermediate-level wastes generated in Germany (Brennecke 1988; NEA 4/88; Weinländer 1988)

C. All radioactive wastes will be disposed in deep geologic structures; this includes the spent fuel for which reprocessing is not economical (NEA 4/88)

\subsection{HIGHLIGHTS AND MAJOR MILESTONES}

1967 Started experimental disposal program in Asse II mine (NUKEM 12/87) 
1971 Began operations at WAK pilot-scale reprocessing plant (NUKEM 12/87)

1975 Started investigation into suitability of Konrad mine for disposal of non-heat-generating radioactive waste (NUKEM 12/87)

1978 Uicense for experimental disposal of radioactive waste at Asse II mine expired (NUKEM $12 / 87)$

1982 Began construction of an AFR interim storage facility for spent fuel at Gorleben (NUKEM $12 / 87)$

1984 Began construction of an AFR interim storage facility for spent fuel at Ahaus (NUKEM 12/87)

1985 Start up of PAMELA pilot plant in Belgium for vitrification of HLLW (Weise 1988)

1985 Started site preparation work of Wackersdor WAW-350 fuel reprocessing plant/interim waste storage facility (NUKEM 12/87)

1986 DWK announced plans for spent fuel conditioning pilot plant to be built near Gorleben site; filed license application 5/86 (NUKEM 12/87)

1986 Started excavation of exploratory shaft at Gorleben (NUKEM 12/87)

1987 Began commercial operation of the THTR-300 HTGR (NUKEM 5/89)

1987 Production of 32 heat and radiation sources completed at Hanford for the FRG (Brouns 1988)

1988 First fuel arrives at AFR dry spent fuel storage facility at Gorleben (NF 9/19/88)

1988 PTB bought Konrad mine from former owners (ATW NEWS 3/88)

1989 Decision made to decommission THTR-300 (NEJ 11/89)

1989 Germany elects foreign reprocessing over completion of Wackersdort reprocessing plant (NUKEM 6/89)

1989 Germany makes joint declarations with France and United Kingdom for cooperation in the peaceful uses of nuclear energy, including reprocessing, fabrication of MOX fuel, enrichment, reactors, and transportation (NEA 12/89)

1989 Lower Saxony approval clears way for construction of a spent fuel conditioning plant for spent fuel destined for direct disposal at Gorleben (NN 2/90)

1990 Sweden transfers its rights to reprocessing 550 MT of spent fuel at Cogema's La Hague plant to eight FRG utilities (NF 2/5/90)

1990 DWK withdraws Wackersdort license application (NEI 2/90)

1990 High-activity testing scheduled to start in Asse II salt mine using waste sources produced in the United States (NUKEM 2/90b) 
1992 Complete vitritication of $800 \mathrm{~m}^{3} \mathrm{HLLW} / \mathrm{HEWC}$ in PAMELA vitrification facility at Mol, Belgium (Wiese 1988; ATW 5/90)

1992 Begin decommissioning of WAK pilot-scale reprocessing plant (NF 1/8/90)

1993 Begin receiving radwaste produced in reprocessing FRG spent fuel at La Hague and Sellafield (Brennecke 1988)

1993 Begin disposal operations at Konrad repository (NUKEM 2/90b)

1994 Begin radioactive operations of PKA pilot spent fuel conditioning plant at Gorieben (Einfeld 1988)

1999 Begin construction of Gorleben repository (NUKEM 2/90b)

2008 Begin disposal operations at Gorleben repository (NUKEM 2/90b)

\subsection{INSTITUTIONAL CONSIDERATIONS/ORGANIZATIONS}

\subsection{LEGAL REQUIREMENTS}

A. Stipulation-type law links licensing of nuclear power plants to an adequate demonstration of spent fuel management (e.g., reprocessing, interim storage); the stipulation condition must be satisfied for six years ahead throughout the life of each reactor (IEAL 1987; Numark 1989)

B. Utilities are responsible for management of spent fuel and wastes through reprocessing, treatment and onsite storage; the federal government is responsible for interim storage and geologic disposal and R\&D support; the states provide interim storage of LLW within their respective boundaries (IEAL 1987)

C. Atomic Energy Act (Law on Peaceful Uses of Nuclear Energy and Protection Against its Hazards, 1959) gives priority to recovery of fissile materials from spent fuel over disposal of spent fuel; cabinet position is that direct disposal of spent fuel is permissible only for fuel for which reprocessing is neither technically feasible nor economically justifiable (NE $1-2 / 87)$

D. Each state (Lânder) has legislative authority and licenses nuclear activities within its boundaries only to the extent the federal government (Bund) has not exercised its authority (NEA 1983; IEAL 1987; Numark 1989)

E. The licensing authority must obtain and consider public and federal reviews prior to granting or revising a license (NEA 1986b; Numark 1989)

F. The control of transportation of radioactive materials is the responsibility of the Federal German Railways (DB) which, in turn, has formed the Nuclear Cargo and Service Company (NCS) to perform that service (NF 10/31/88; Schüler 1989)

\subsection{RADIATION PROTECTION PRINCIPLES (Bloser 1987)}

A. ICRP principles are adhered to, with application of ALARA principle 
B. Doses to occupational workers for normal operations at nuclear facilities must not exceed $5 \mathrm{rem} / \mathrm{yr}$

C. Doses to occupational radioactive waste repository workers must not exceed 500 $\mathrm{mrem} / \mathrm{yr}$ from direct radiation, with no more than $50 \mathrm{mrem} / \mathrm{yr}$ from inhalation

D. Doses to public members from normal operations at nuclear facilities must not exceed 30 $\mathrm{mrem} / \mathrm{yr}$ to the whole body and $90 \mathrm{mrem} / \mathrm{yr}$ to the thyroid; this applies to the operational and post-closure periods of repositories

\subsection{LICENSING (NEA 1983; Paige 1985; Mating 1985; NEA 1986b; NN 2/87)}

A. Federal ministry prescribes all recommendations and limits for radiation protection

B. Repositories must be licensed by both mining and nuclear authorities

C. Licenses for nuclear facilities are issued by state authorities

D. Federal Minister for Environmental Protection and Reactor Safety can direct a state to license a facility

E. Licenses can be revoked by the courts

F. In practice, the final licensing decision is made by state licensing authorities

4.4 PUBLIC INVOLVEMENT (Paige 1985; NEA 1986b; Numark 1989)

A. Extensive public information campaigns, with visitors' centers, are maintained at major waste management sites

B. Media coverage and public hearings are part of licensing process

4.5 WASTE FUND: Nuclear electric power producers pay current costs and accumulate reserves for future decommissioning of nuclear facilities and waste disposal (NEA 4/88)

\subsection{KEY AGENCIES AND FUEL CYCLE CENTERS}

A. BAM (Federal Materials Research/Testing Institute): BAM is a scientific-technological institute under the direction of the Federal Ministry for Economy; it is involved in the testing and evaluation of materials used in nuclear programs (Leigh and Mitchell 1990)

B. BMFT (Federal Ministry for Research and Technology): BMFT is the cognizant federal ministry for fuel cycle/waste management programs (NEA 1983)

1) GSF/IT (Company for Radiation and Environmental Research, Institute for Underground Storage): management of waste disposal R\&D program; operator of Asse II mine facility

2) KfK (Karlsruhe Nuclear Research Center): LWR/LMFBR fuel reprocessing R\&D; waste treatment/packaging R\&D; LWR spent fuel disposal alternatives R\&D; decommissioning R\&D; HLW vitrification R\&D, including PAMELA facility support; operation of KfK waste management facilities 
3) KFA (Jülich Research Center): R\&D on treatment/conditioning of all radioactive wastes; operation of KFA site waste facilities; R\&D on disposal of HTR fuel elements; development/demonstration of waste package quality control

4) HMI (Hahn-Meitner-Institute Berlin $\mathrm{GmbH}$ ): waste form characterization

C. BMT (Federal Ministry of Transport): BMT is responsible for the transport of radioactive materials by rail and by ship within the FRG; in turn, it has charged the Federal German Railways (DB) with control of nuclear materials transport (NF 10/31/88)

1) NCS (Nuclear Cargo and Service Company): a company established for transport of nuclear materials (Schüler 1989)

D. BMU (Federal Ministry for Environmental Protection and Reactor Safety): BMU is responsible for federal standards for nuclear safety and supervision of licensing activities under the Atomic Energy Act

1) RSK (Federal Reactor Safety Commission) and SSK (Radiation Protection Commission): issue licensing requirements on behalf of Ministry of Environment

2) BfS (Federal lnstitute for Radiation Protection): Bfs is responsible for carrying out the administrative duties of the federal government in the field of radiation protection, nuclear safety, transport of nuclear materiais, and management of radioactive waste; the latter activity includes construction and operation of federal facilities for safekeeping and repository storage of radioactive waste; the groups being combined to form the new organization (BfS) include (ATW 12/89):

- the Institute for Radiation Hygiene (formerly part of the Federal Health Office): radiation health effects and risk assessments

- the Division for Final Disposal of Radioactive Waste (formerly part of PTB, the Federal Science and Engineering Agency): responsible for collection, storage and final disposal of radioactive waste

- the Institute for Atmospheric Radioactivity (formerly part of the Federal Office of Civil Protection): monitors background radiation

- $\quad$ selected groups from the Company for Reactor Safety (GRS): expertise in nuclear safety (NEA 1983)

E. BMWI (Federal Ministry for Economics)

1) BGR (Federal Institute for Geosciences and National Resources--equivalent to U.S. Geological Survey): site characterization; geomechanics studies (NEA 1983)

F. DWK (German fuel reprocessing company established and funded by utilities): DWK is responsible for spent fuel management; including reprocessing

1) Operation, with Belgium's Belgoprocess, of PAMELA HLW vitrification pilot plant at Mol, Belgium until completion of current run on HEWC (Wiese 1988)

2) Operation of WAK pilot-scale fuel reprocessing pilot plant at Karlsruhe (NF 12/11/89) 
G. GNS (company for nuclear service): GNS is a German nuclear service company owried by utilities ( $80 \%)$ and Steag Kernenergie $\mathrm{GmbH}$, a nuclear engineering company (20\%) (NF 10/31/88)

1) DBE (German company for the construction and operation of repositories for waste) (Leigh and Mitchell 1990)

- Construction and operation of the Konrad waste repository

- Construction and operation of the Gorleben waste repository

2) BZA (German company for construction and operation of the Ahaus spent fuel storage facility) (NF 12/11/89)

3) BLG (German company for construction and operation of the Gorleben spent fuel storage facility) (NF 12/11/89)

4) Construction of the Pilot Conditioning Plant (PKA) at Gorleben to test conditioning methods for spent fuel to be disposed in the Gorleben repository (NF 12/11/89)

H. Major Industrial Organizations

1) NUKEM: Uranium supply; nuclear technology services for reprocessing: transportation casks, waste packaging and waste treatment; safety analyses (NF 8/7/89)

2) SBH (Siemens AG Brennelementewerk Hanau, formerly Alkem): MOX fuel fabrication and R\&D; TRU waste treatment (NN 9/89, p.54)

4.7 PRINCIPAL RESEARCH, DEVELOPMENT AND DEMONSTRATION FACILITIES/ PROGRAMS: The primary agencies conducting R\&D on the nuclear fuel cycle and waste management have been the Karlsruhe and Jülich nuclear research centers (includes reactor R\&D, molecular laser R\&D, nuclear safety R\&D); Hahn-Meitner-Institute Berlin GmbH, NUKEM, and Alkem; with the recent changes in the FRG's nuclear programs, the nuclear R\&D at Jülich and $\mathrm{HMI}$ has been curtailed; R\&D on TRU waste treatment has been taken over by $\mathrm{SBH}$, a subsidiary of Siemens; and R\&D on spent fuel reprocessing is coming to an end (KfK 1980; NUKEM 1985; Merz 1986b; NEI 11/89; NW 12/21/89; Leigh and Mitchell 1990; NF 1/8/90)

4.8 KEY PERSONNEL (Leigh and Mitchell 1990)
A. Wilhelm Collin: Director, Division of Transport/Storage of Radioactive Materials, BfS
B. Helmut Rơthemeyer: Director, Division of Nuciear Waste Disposal/Transport, BfS
C. Horst Schneider: Director, Division of Waste Disposal Safety, BiS
D. Helmut Venzlaff: Director, Environmental Geology, BGF
E. Michael Langer: Director, Engineering Geology/Geotechniques, BGR
F. Rolf-Peter Randl: Reprocessing/recycling, BMFT 
G. Diethard Lummerzheim: Waste disposal, BMFT

H. Dr. Mayinger: Chairman, Reactor Safety Commission, BMU/RSK

I. A.M. Kellerer: Chairman, Radiation Protection Commission, BMU/SSK

J. Wolfgang Schulz: Manager, Project Gorleben, DBE

K. Rüdiger Putzer: Manager, Project Konrad, DBE

L Hans-Jürgen Engelmann: Manager, Project-Related R\&D, DBE

M. Karl Dieter Kuhn: Head, R\&D/Cooperation Division, DWK

N. Horst Wiese: Plant Manager, PAMELA Project, DWK

O. Henning Baatz: President, GNS

P. Hans-Otto Willax: PKA Project Direction, GNS

Q. Klaus Kühn: Director, GSF/fT

R. Wernt Brewitz: Director, Disposal Safety, GSF/IT

S. Rolf Stippler: Director, Project Management, GSF/IT

T. Klaus Dürr: Director, Asse Mine Operations. GSF/IT

U. Erich R. Merz: Director, Institute of Chemical Technology, KFA

V. Reinhard Kroebel: Manager, Fuel Repro. Waste Management Proj., KfK

W. Klaus-Detlef Closs: Head, Project Group "Entsorgung," KfK

X. Helmut Krause: Director, Inst. for Nuclear Waste Technology, KfK

Y. H. Pirk: Director, NUKEM

Z. Volker Schneider: Chemistry/Waste Management, SBH

\subsection{NUCLEAR FUEL PRODUCTION}

5.1 STRATEGY: Germany relies heavily upon the electric utilities and industry to provide the support required for the front end of the nuclear fuel cycle

5.2 URANIUM RESOURCES: $1987-4800$ MTU reasonably assured; 7300 MTU estimated additional (NEA 1988)

5.3 URANIUM PRODUCTION: Essentially all uranium concentrate is purchased abroad; a 100MTU-capacity processing plant at Ellweiler was closed in 1989 (NN 7/89; Hackstein 1987) 
5.4 URANIUM ENRICHMENT: Germany, along with the United Kingdom and the Netherlands, owns and operates the Urenco enrichment facility located at Gronau, West Germany; capacity at the end of 1986 was $200,000 \mathrm{SWU} / \mathrm{yr}$ with an expansion underway to $400,000 \mathrm{SWU} / \mathrm{yr}$ in 1988. Planned capacity in 1992 is 1,000,000 SWU/yr (Hackstein 1987; IAEA 1988)

- Federal government and private industry are supporting laser enrichment R\&D (NE 1-2/87; AlJ 4/87)

- $\quad$ R\&D on jet nozzle enrichment process was expected to be terminated in 1989 at the same time a pilot enrichment project based upon that technology is expected to be finished in Brazil using that technology; that project is now expected to begin operation in 1990 (NW 3/12/87; NF 9/18/89)

\subsection{URANIUM CONVERSION}

A. Conversion of $\mathrm{UO}_{2}$ to $\mathrm{UF}_{6}$ is purchased from other countries, but the capability to design conversion facilities exists (Hackstein 1987)

B. Reconversion of $\mathrm{UF}_{6}$ to $\mathrm{UO}_{2}$ is performed at two sites; Siemens $\mathrm{AG}$ (SBH) has an 800 MTU/yr capacity for reconversion for LWR fuels at Hackstein and a $300 \mathrm{MTU} / \mathrm{yr}$ capacity at Lingen; SBH also took over NUKEM's plant at Hanau for reconversion of highly enriched uranium for THTR-330 and research reactor fuels (Hackstein 1987; IAEA 1988; NF 1/23/89)

5.6 FUEL FABRICATION: Germany has four facilities for fabricating nuclear fuels, all under the control of Siemens AG (Hackstein 1987; IAEA 1988; NF 1/23/89)

A. Siemens AG operates an 800-MTU/yr facility for PWR/BWR fuels at Karlstein (formerly owned by RBU)

B. Siemens AG operates a 400-MTU/yr facility for PWR/BWR fuels at Hanau (formerly owned by NUKEM/Alkem)

C. Siemens AG operates a 300-MTU/yr facility for PWR/BWR fuels at Lingen (formerly Exxon Nuclear Company)

D. Siemens AG operates a-40 MTU/yr facility for MOX fuels at Hanau (formerly owned by NUKEM/Alkem)

\subsection{PROGRAM/FACILITIES COSTS}

A. Siemens AG paid over 100 million DM (\$55 million U.S.) for the 40-MT/yr fuel fabrication facility (NF 10/5/87)

B. The federal portion of R\&D costs for laser enrichment was about 10 million DM/yr (\$5.5 million U.S./yr) as of 1987 (AlJ 4/87)

6.0 FUEL RECYCLE: Germany's policy is to reprocess spent fuel and recycle plutonium in LWRs and FBRs; in 1989, the government and utilities elected to use foreign reprocessing services and abandoned plans for domestic reprocessing (NUKEM 2/90b; Krämer 1989) 


\subsection{FUEL REPROCESSING}

A. The WAK pilot reprocessing plant at Karlsruhe began operations in 1971 on LWR fuels; the capacity is $175 \mathrm{~kg} / \mathrm{d}$ heavy metal or $35-40 \mathrm{MTU} / \mathrm{yr}$; the first reprocessing of a MOX fuel assembly took place at WAK in 1987 and about 200 MTU of spent fuel, including 3 MTU of MOX fuel have been processed as of 1987; with the government/ utility decision to use foreign reprocessing services, the future of the WAK facility is uncertain; decommissioning is likely after a final campaign in 1991-1992 (Willax 1987; NF 12/14/87; Schmieder 1989; NF 1/8/90)

B. In 1979, German utilities contracted with Cogema in France and BNFL in the United Kingdom for reprocessing service; by late 1988, 1500 MTU had been processed in the French UP2 plant; new contracts written following the 1989 German government decision to abandon domestic reprocessing covers about 3200 MT of service by the year 2005; Cogema and BNFL will share the newly contracted load at a ratio of $2 / 1$, respectively; at the end of 1989, German utilities have about 8,900 tonnes of reprocessing services firmly and optionally contracted with Cogema and BNFL (ATW 2/90; NUKEM 2/90b; NUKEM $12 / 87)$

C. In 1986, construction was started on a 350 MTU reprocessing plant (WAW-350) at Wackersdort in Bavaria; following the decision to abandon domestic reprocessing in 1989, the project has been dropped (NUKEM 6/89)

6.2 PLUTONIUM RECYCLE: Germany plans to recycle plutonium in breeder reactors but the German breeder program cannot use all of the plutonium being produced; until it can, plutonium will be recycled in LWRs; reprocessed uranium will be used as feed material under existing enrichment contracts (NUKEM 12/87)

A. The total amount of plutonium and reprocessed uranium stemming from reprocessing through the year 2000 should be about $40 \mathrm{MT}$ plutonium (fissile) and 5,900 MT reprocessed uranium, respectively (NUKEM i2/87)

B. Through 1987, $48 \mathrm{MOX}$ fuel assemblies had been recycled in four German power reactors; the MOX recycling program plans the insertion of $1,220 \mathrm{MOX}$ fuel elements in ten nuclear power plants between 1988 and 1995 (NF 10/20/86; NUKEM 12/87; NUKEM 1/88)

C. At least $38 \mathrm{MOX}$ assemblies will be reprocessed by the French La Hague facility through 1995 (NF 12/14/87)

6.3 RESEARCH AND DEVELOPMENT: Germany has had extensive R\&D programs under way for years on the spent fuel reprocessing and plutonium recycle

A. Research on spent fuel reprocessing has been heavily concentrated at the Jülich Research Center (KFA) and the Karlsruhe Nuclear Research Center (KfK); at KFA, the research has been concentrated on the HTR fuel cycle (Kaiser 1977) while that at KfK was aimed primarily at the LWR fuel cycle (Schüller 1977); with the decreasing interest within Germany on the HTR reactor system, as evidenced by the closing down of the THTR-300 reactor (NEI 11/89), reprocessing R\&D on the HTR system has essentially stopped (NW 12/21/89); the reprocessing R\&D at KfK led to the construction of the WAK reprocessing plant at Karlsruhe and the initiation of the Wackersdork WAW-350 reprocessing plant at Wackersdorf; but the 1989 decision of the German government and utilities to abandon domestic reprocessing in favor of foreign reprocessing has led to the 
shutdown of the Wackersdort reprocessing project and dimmed prospects for continued R\&D on LWR reprocessing (NF 1/8/90)

B. Along with development of fuel reprocessing, Germany has been developing the use of plutonium in FBRs and LWRS; by 1989, MOX test fuel assemblies had been fabricated for seven LWRs (Hennies 1987; Hackstein 1987; Messer 1987; NEA 1989b)

C. Until the 1989 decision to abandon domestic fuel reprocessing, the Germans have had an active R\&D program under way on fuel reprocessing; the supporting R\&D and associated facilities include (Leigh and Mitchell 1990):

1) MILI hot cell facility for LWR and FBR R\&D at KfK (NF 1/8/90);

2) MINKA hot glove boxes for uranium and plutonium, with pulse columns for solvent extraction R\&D at KfK (ATW 3/86);

3) PUTE hot facility for fuel reprocessing R\&D at KfK on uranium/plutonium separation using pulse columns, electrochemical reduction of plutionium (NF 1/8/90);

4) KRETA facility at KfK for development of low-temperature method for recovering krypton-85 from dissolver off-gas in a reprocessing plant (NE 2/86):

5) PASSAT facility for development and testing of dissolver off-gas filters at KfK; packed fiber mist eliminators, HEPA filters, iodine-removal filters;

6) BEATE facility for R\&D at KfK on aerosol generation and vessel off-gas behavior;

7) LAHDE facility near Hanover for development of remote operations in reprocessing plants (Oeser 1988)

\subsection{PROGRAM/FACIUTIES COSTS}

A. Wackersdort reprocessing costs were projected to be $1.7 \mathrm{Pf}(\$ 0.0091$ U.S.) per $\mathrm{kWh}$; reprocessing by Cogema is estimated to cost 0.5 Pf (\$0.029 U.S.) per kWh (NF 12/25/89)

B. The cost of a completed Wackersdort reprocessing plant is estimated at 7.7 billion DM ( $\$ 3.9$ billion US); by mid-1989 when the project was terminated, the utilities had spent 2.6 billion DM (\$1.3 billion U.S.) (NF 7/10/89)

\subsection{SPENT FUEL STORAGE AND TRANSPORT}

\subsection{SPENT FUEL ARISINGS}

A. In 1976, spent fuel arisings amounted to $400 \mathrm{MTU}$; current spent fuel arisings in Germany are estimated at $500 \mathrm{MTU}$ per year; the arisings rate projected for affer 2000 is $700 \mathrm{MTU}$ per year (NEA 1986c; NUKEM 2/90; NW 4/27/89)

B. The cumulative spent fuel arisings (LWR) through the year 2000 are estimated at (Leigh and Mitchell 1990): 
C. Nuclear power plants in West Germany will produce about 20,000 MT of used fuel elements between now and 2025, according to a study by DWK; 5700MT are under firm contract with Cogema and BNFL with options for reprocessing another 3200 MT; 1000 MT will be treated and disposed st the pilot conditioning plant (PKA) being built at Gorleben (NEI 12/89)

\subsection{FUEL ASSEMBLY CHARACTERISTICS}

A. Most German reactors are either PWRs or BWRs; the PWRs use typical LWR fuel assemblies, ranging in pin arrays from $14 \times 14$ to $18 \times 18$ in each assembly; most of the BWRs use LWR assemblies with an $8 \times 8$ pin array pin; the more recent reactors have pin arrays of $9 \times 9$ (NEI 11/88)

B. The THTR-300 high temperature graphite reactor, referred to as the "pebble-bed" reactor, was filled with 675,000 spherical $\mathrm{UO}_{2} / \mathrm{ThO}_{2}$ elements, each $6 \mathrm{~cm}$ in diameter and clad with graphite; each element contains $0.96 \mathrm{~g}$ of U-235 (93\% enriched) and $10.2 \mathrm{~g}$ of Th232; the coolant is helium (NEI 11/89; Fujii 1985; NW 2/12/87)

C. The SNR-300 fast breeder reactor being built at Kalkar will be fueled with $\mathrm{UO}_{2} / \mathrm{PuO}_{2}$ contained in metal clad rods, 166 rods per assembly; the coolant is sodium (NEl 11/89; Fujii 1985)

7.3 SPENT FUEL STRATEGIES: Germany's policy currently favors reprocessing of spent fuels, but allows for direct disposal of selected spent fuels that are considered to be difficult to reprocess. The utilities make the final decision; both at-reactor water pools and central dry-storage facilities are used for interim storage of spent fuel awaiting reprocessing or direct disposal in deep geologic formations (Weinlănder 1988; Krămer 1989)

7.4 WET STORAGE (Harmon 1984; Petroll 1987)

A. Most German reactor plants have from 3-10 years of storage capacity, with use of compact storage racks; a few with less storage use supplemental at-reactor dry storage

B. LWR spent fuel is normally transferred to reprocessing facilities (at present, these are mostly foreign) within about one year of discharge; at-reactor storage period is five to seven years

C. Spent HTGR fuel from the AVR and THTR reactors is packaged in stainless steel canisters and placed in pool storage for two years; it is then placed in a special Castor cask for transfer to an air-cooled storage facility (Theenhaus 1989)

D. No in-pool consolidation of spent fuel is planned

E. Protection is required against crash of aircraft, earthquakes, shock waves from chemical explosions, floods, and third-party actions (IAEA 1984)

7.5 DRY STORAGE: Germany has emphasized the development of metal casks for storage and transport of spent fuel 
A. Dry storage is used for supplemental interim storage at reactors and at the two 1500 MTU away-from-reactor central storage facilities--Gorleben and Ahaus--in Germany (Peehs 1987; Petroll 1987; Spilker 1986)

B. Air-cooled vault storage has been evaluated for interim storage at reactors (Peehs 1987)

C. Metal casks have been demonstrated at reactors and have been selected for use at the away-from-reactor interim storage centers (Peehs 1987; Petroll 1987)

D. Two suppliers provide the metal storage casks used in Germany--Castor nodular cast iron casks are provided by The Company for Nuclear Service (GNS) and the TN series of ductile cast iron casks are provided by Transnucleaire (Weiser 1989; Pennington 1986)

E. The dry storage facility at Gorleben has been completed but operation has been held up pending resolution of legal appeals by intervenors; the storage facility at Ahaus has been completed and licensed for LWR fuel storage, but has not yet been used (NEA 4/88; NF 9/19/88; NF 4/30/90)

F. Each dry away-from-reactor storage facility will have a capacity of $1500 \mathrm{MTU}$ of spent fuel packaged in 420 casks; the storage hall at Gorleben is constructed of reinforced concrete and is $200 \mathrm{~m}$ long by $38 \mathrm{~m}$ wide by $20 \mathrm{~m}$ high; cooling of one year or more is required at the reactor; the storage casks are stored upright and cooled by natural air circulation (Müller 1986)

G. GNS is developing a cask system (Pollux) at KfK for combined storage and disposal of spent fuel (see Section 10)

7.6 TRANSPORT: Spent fuel has been transported within Germany since the early sixties; in addition, spent LWR fuel has been shipped to reprocessing plants in France and Germany while research reactor fuel has been transported to the United States; most transport is by rail and in the nodular cast iron casks used also for storage (see previous section) (NEA 4/88)

A. Transport casks are approved and licensed by BIS (formerly PTB) working in cooperation with BAM (NEA 4/88)

B. Transport of spent MOX fuel is increasing and planning is under way for the transport of HTGR fuel from the THTR 300 station to an interim storage facility or to a disposal location (Bach 1989; Bromkamp 1986)

7.7 RESEARCH AND DEVELOPMENT: Germany, primarily through the commercial firms GNS and TN, has done extensive R\&D on the development of metal casks for storage and transport of spent fuel (Pennington 1986; Weiser 1989)

\subsection{PROGRAM/FACILITIES COSTS}

A. Cost of the 1500 MTU Ahaus dry storage facility for spent fuel is estimated at 90 million DM (\$50 million U.S.) (NUKEM 2/89)

B. The Gorleben interim storage hall for spent fuel and low-level waste cost 85 million DM (of which spent fuel facility portion cost 30 million DM (\$18 million U.S.) (Lakey 1987)

C. The cost of the proposed PKA pilot facility for conditioning spent nuclear fuel for direct disposal is projected at 400 million DM (\$240 million U.S.); the associated R\&D program 
supported by BMFT over the period 1981 through 1994 is estimated at 150 million DM (\$77 million U.S.) (ATW 2/90b)

\subsection{WASTE CONDITIONING, STORAGE AND TRANSPORT}

8.1 WASTE DEFINITIONS: In the early 1980s, Germany abandoned the simple classifications (lowactive waste, medium-active waste, hlgh-active waste) as they did not provide sufficient information in regard to disposal; In lieu of these, the licensing agency, PTB (now BTS), has categorized radioactive wastes in compliance with disposal requirements; through this categorization system, most of the existing and anticipated waste packages in the FRG, including waste retumed from foreign reprocessors, have been described and registered; by 1985, 300 data sheets had been compiled (Berg 1986)

A. The data compiled for the different weste packages includes the following:

- radionuclide inventory,

- age of the waste,

- number of packages expected,

- origin of waste,

- type of waste,

- immobilization material, and

- packaging

B. A standardization of the various types of packages has been necessary for operations; this standardization led to six types of cylindrical packages and six types of cuboid packages for wastes to be disposed at Konrad

\subsection{WASTE ARISINGS}

A. The amounts of radioactive waste accumulated by the Federal Republic of Germany by source at the end of 1986 are (Brennecke 1988):

\begin{tabular}{lcc} 
& Non-conditioned $\left(\mathrm{m}^{3}\right)$ & Conditioned $\left(\mathrm{m}^{3}\right)$ \\
\cline { 2 - 2 } Reprocessing & 120 & 6741 \\
Reactor operation & 3051 & 10737 \\
Collection depots & 1102 & 1891 \\
Research centers & 1330 & 13297 \\
Fuel cycle industry & 880 & 1121 \\
Others & 102 & 638 \\
Totals & 10593 & 33855
\end{tabular}

B. PTB (now BIS) reported that by the end of 1987, the amounts of non-conditioned and conditioned wastes amount to 8584 and $37920 \mathrm{~m}^{3}$, respectively; during $1987,4271 \mathrm{~m}^{3}$ of conditioned waste was produced of which 807 came from reprocessing, 1288 from nuclear power plants, 182 from collection depots, 1664 from research centers, 322 from fuel cycle industry and 8 from other users; arisings of conditioned waste in 1988 were estimated at $7361 \mathrm{~m}^{3}$ (ATW 8/88)

C. The radioactive waste to be returned from foreign reprocessors under contracts in force during 1987 amounts to 3,200 canisters of vitrified HLW and 35,000 drums of ILW (NUKEM 2/87) 
8.3 STRATEGY: German strategy in regard to conditioning, storage and transport of radioactive wastes is to place responsibility on the producer for conditioning and interim storage until the waste can be transported to a state-operated collection center or a federal disposal facility; transportation must be done by the Nuclear Cargo and Service Company or another federally approved firm; conditioning and packaging must be suitable for disposal in a geologic repository; all costs are to be borne by the producer either through conduct of the work or payment into a fund to support work conducted by the federal governmemt, i.e., repository operation (NUKEM 12/87; NF 10/31/88; NEA 4/88)

8.4 HLW IMMOBILIZATION: Germany has had an active development program under way for many years on the immobilization of high-level liquid wastes; the R\&D efforts have been concentrated at KfK and KFA, with a major demonstration facility being buitt and operated at Mol, Belgium

A. Early work at Karlsruhe $(\mathrm{K} f \mathrm{~K})$ included development of a spray calciner-melter system (NERA); both metal and ceramic melters were tested; the program was discontinued in 1977

B. Early work at Jülich (KFA) included development of a rotary dryer/in-can melter system (FIPS) for application to HTGR and FBR reprocessing wastes, as well as intermediatelevel liquid wastes; the system was tested with radioactive waste in 1976 and shut down in 1977

C. In recent years, development efforts have been concentrated at KfK on the liquid-fed, joule-heated, ceramic metter for application in the PAMELA facility at Mol, Belgium, and the once-proposed Wackersdort reprocessing facility; with the transfer of the PAMELA facility to Belgoprocess in Belgium and the demise of the Wackersdort plant, vitrification $R \& D$ will probably be curtailed; development is under way for transferring the high-level wastes at the WAK reprocessing facility in Karlsruhe to the PAMELA facility for vitrification (Höhlein 1985; Alter 1986; Schmidt 1988; Kuhn 1989; NF 1/8/90)

D. DWK operated a remote maintenance test facility, LAHDE, near Hannover to test remote handling techniques and equipment for the once-proposed Wackersdort reprocessing plant (Oeser 1988)

E. As of 1987 , most work on HLW vitrification development was considered nearly complete (NE 1-2/87)

\subsection{SPENT FUEL CONDITIONING}

A. In 1985, Germany elected to pursue development of direct disposal of spent fuel as a possible alternative to disposal of HLW from spent fuel reprocessing; initial work at KfK led to a proposal to build a pilot conditioning plant (PKA) for spent fuel adjacent to the Gorleben repository site; DWK received a construction license on January 31, 1990, for a 35-MT/yr facility to be erected adjacent to the interim stores for spent fuel and lowlevel wastes at Gorleben; radioactive operation is expected in 1994 (Einfeld 1987; NN $3 / 90)$

B. The test program will include testing of dry rod consolidation of LWR fuels followed by encapsulation in Pollux casks (see Section 10); conditioning may also be required for the THTR fuel (graphite coated 6-cm-diameter $\mathrm{UO}_{2} / \mathrm{ThO}_{2}$ pellets) that will be disposed directly at Gorleben (Einfeld 1987; KfK 1989) 
8.6 LLW/ILW CONDITIONING: Germany has an extensive record of developing and applying conditioning to low- and intermediate-level wastes; this has taken place at the major nuclear research centers as part of both R\&D programs and the research site operations; the utilities and industrial fuel cycle firms, in conjunction with supporting engineering/service firms, also develop and apply conditioning to wastes generated in their operations (Hübenthal 1988; Janberg 1988)

A. At the Karlsruhe Nuclear Research Center, liquid wastes are collected and treated by evaporation and cementation of the concentrate; organic liquids are treated by either incineration or, if suitable, cementation; solid waste conditioning treatments used at KfK includes sorting, hot cell decontamination and disassembly, compaction (including supercompaction), incineration and cementation; bituminization of evaporator concentrates and ion exchange resins was conducted until stopped in 1977 because of concern over the thermal stability of bitumen in interim storage (KJK 1983; KfK 1986; Koster 1986; Lakey 1986; Pfeifer 1988; Pfeiffer 1988)

B. At the Jülich Research Center, liquid wastes are collected, dried and fixed in cement; solid wastes are treated by compaction and incineration (Koster 1986; Laser 1986)

C. At the WAK reprocessing plant adjacent to the Karlsruhe Nuclear Research Center, liquid low- and intermediate-level wastes are transferred to KfK for conditioning; cladding hulls, feed clarification sludge, structural parts, and wear parts from the dissolver operations are cemented and delivered to KfK; other solid wastes are packaged in 200-liter drums (Băhr 1983; Kuhn 1986)

D. About $50 \mathrm{~m}^{3}$ of TRU or alpha-contaminated conditioned waste is generated each year in Germany; most comes from the MOX fuel fabrication plant at Hanau; lesser quantities come from KfK and WAK; conditioning involves washing to recover plutonium followed by cementation; KfK developed an acid digestion system which was installed at Mol, Belgium, and used to treat $1000 \mathrm{~kg}$ of TRU waste; KfK also commissioned an incinerator for TRU wastes in 1989 (Schneider 1986; ATW 6/89)

E. Radioactive waste conditioning at the FRG's nuclear power stations, like that in most developed countries, has constantiy evolved toward improved treatment, driven by economics and regulations; typical conditioning practices include evaporation, filtration and use of ion exchange on liquid wastes and sorting, compaction, and incineration on solid wastes; cement is the most common fixation agent but bitumen and plastic are also used to fix wastes

Treatment is generally performed onsite, often using portable and compactors and cementation units; a commercial radioactive waste incinerator began operation in 1986 at Karlstein (Passig 1983; Brunner 1986; Grăbener 1986; Blinn 1987; Janberg 1988)

Prior to 1988, German nuclear utilities relied heavily upon Transnuclear $\mathrm{GmbH}(\mathrm{TN})$ and the Belgian Nuclear Research Center (CEN/SCK) at Mol for treatment of low-level wastes; because of irregularities in waste accountabilities, German utilities were ordered by the German government to convert to onsite treatment; as a result of the problem, German utilities are developing a national waste accountability system (NW 8/25/88; Strassburg. 1989)

8.7 AIRBORNE WASTES: Treatment of airborne wastes in the FRG involves mainly the use of decay systems and filters at reactors and filters installed in facilities handling radioactive materials, such as WAK (Băhr 1983; Blinn 1987) 
8.8 LLW/ILW STORAGE: At present, all low- and intermediate-level waste in the FRG is being placed in interim storage facilities; the Atomic Energy Act of Germany gives the states (lander) the responsibility for establishing and licensing interim storage facilities within their boundaries; numerous such facilities have been established throughout the $F R G$, including at $K \mathrm{fK}$ and Gorleben (ATW 3/82; NEA 1983; Lakey 1986; Kraemer 1987; Lakey 1987; ATW 2/87).

A. The interim storage halls at $\mathrm{KfK}$ and Gorleben are engineered facilities using heavyreinforced concrete construction; each is provided with shielded fork-litts and cranes to handle the various waste packages being received; waste packages being used include 200-liter steel drum, a 400-liter steel drum, a 200-liter steel drum inside a concrete shieiding cask, a rectangular steel box containing 200-liter steel drums, and a rectangular concrete box containing 200 -liter steel drums surrounded by cement (Kraemer 1987; Lakey 1986; Lakey 1987)

B. Germany has no plans for disposal of radioactive waste in near-surface facilities and has not established a TRU limit for such disposal comparable to that followad in the United States; alpha-bearing or TAU wastes are conditioned and stored together with other $\amalg W / L W$

8.9 HLW STORAGE: In Germany, high-level waste is generated and stored at one location--the WAK pilot-scale reprocessing plant; vitrified high-level waste to be returned from foreign reprocessors will be stored in metal casks at Gorleben or Ahaus prior to disposal

A. The high-level liquid waste originates from the first cycle of the PUREX process used in the WAK facility; it is stored in the acidic form and contains about $15 \mathrm{~g} / \mathrm{l}$ of undissolved solids (Kuhn 1986)

B. The original WAK installation included two stainless-steel tanks, each with a capacity of $65 \mathrm{~m}^{3}$; one tank served as reserve storage; in 1987, a new evaporator and two new stainless steel tanks (LAVA project), each with a capacity of $63 \mathrm{~m}^{3}$, were placed in operation; the HLLW in the original tanks has been moved to the new tanks while the old tanks serve as reserve storage capacity (Kuhn 1986; Fang 1987)

C. Each new tank is located in a concrete hot-cell adjacent to the WAK plant; a stainless steel drip pan under each tank has sufficient capacity to hold the complete contents of the tank; the tanks are equipped with reflux condensers and cooling coils to remove decay heat (Fang 1987)

D. The Pilot Conditioning and Encapsulation Plant being erected at Gorleben for evaluation of the direct disposal of spent fuel will also have the capability of transferring vitrified waste from transport casks into storage casks suitable for interim storage or disposal at Gorleben (Einfeld 1987; Weinlănder 1988)

8.10 TRANSPORT OF WASTES: Until recently, the transport of radioactive waste within Germany was handled largely by Transnuklear, a subsidiary of NUKEM, but following the discovery of irregularities in waste accountabilities, control of transportation has been given to the Federal German Railways (DB), who in turn formed a the Nuclear Cargo and Service Company (NCS) to perform that service (NF 10/31/88; Schüler 1989)

A. Transportation services are used mainly for moving wastes from the generator's site, e.g., power reactor, to a conditioning facility or to a central interim storage facility, e.g., Gorleben; occasionally, they are required in transferring wastes between sites, e.g., 
from the WAK reprocessing plant to the KfK waste treatment center (Ambros 1986; Kuhn 1987)

B. Many different types of packagings have been used for shipments, e.g., Types $A$ and $B$ packaging meeting IAEA recommendations; the most prevalent packages used include casks of nodular cast iron that contain 200-liter or 400-iter steel drums, cylindrical concrete casks, cylindrical cast iron casks, and cuboid-shaped containers made of sheet steel or reinforced normal and heavy concrete (NEA 4/88; Stegmaier 1989)

C. Transport casks have been or are under development for special purposes such as transport of vitrified high-level waste or high-level liquid waste concentrate, (Weiser 1989; Lakey 1986)

8.11 MIXED WASTE CONDITIONING, STORAGE AND TRANSPORT: In Germany, radioactive wastes are governed by the Atomic Energy Act and all radioactive wastes are disposed in deep geologic structures; non-radioactive hazardous wastes are governed by the Waste Disposal Act and are generally disposed by shallow-land burial, atthough one disposal mine is used; the category "Mixed Waste" is not recognized officially and such wastes are handled as radioactive waste (Merz 1988; Nunno 1989)

8.12 RESEARCH AND DEVELOPMENT: As part of tis active program on nuclear power, the Federal Republic of Germany has had and continues a substantial R\&D program on the conditioning, storage and transportation of radioactive waste; Germany's major R\&D activities include:

A. Substantial efforts have gone into R\&D related to fuel reprocessing wastes generated by the pilot-scale WAK plant and expected from the once-proposed Wackersdorf plant; with the recent abandonment of domestic reprocessing in favor of foreign reprocessing, R\&D on reprocessing wastes is being curtailed; such R\&D involved conditioning of dissolver sludges, fuel hulls, airborne radionuclides (iodine-129, krypton-85, carbon14) and spent solvents (Bähr 1983; Bruecher 1986; Frotscher 1988; Krause 1986; Laser 1986)

B. Recent R\&D in the FRG included the investigation of drying and solidifying low-level wastes using microwaves (Best 1989)

C. As part of the decommissioning program for the Niederaichback Nuclear Power Plant, approximately 1.7 MT of carbon and stainless steel will be melted as a means of producing metal suitable for unrestricted release (Loeschhorn 1989)

\subsection{PROGRAM/FACILITIES COSTS}

A. The Mol Pilot Plant for the Production of Storable Waste (PAMELA) was built by DWK at a cost of approximately 150 million DM (\$88 million U.S.), of which $80 \%$ was supplied by BMFT (ATW 5/90)

B. The cost of the proposed PKA pilot facility for conditioning spent nuclear fuel for direct disposal is projected at 400 million DM (\$240 million U.S.); the associated R\&D program supported by BMFT over the period 1981 through 1994 is estimated at 150 million DM (\$77 million U.S.) (ATW 2/90b) 
C. A new incinerator, commissioned at KfK in 1989 for treatment of low-level, alphacontaminated wastes, cost about 33 million DM (\$20 million U.S.) (ATW 6/89)

\subsection{DISPOSAL OF NON-HIGH-LEVEL WASTES}

9.1 STRATEGY: The strategy of the Federal Republic of Germany has, since the early 1960s, been to dispose all radioactive wastes into deep geologic formations; under present planring, nonheat-generating intermediate- and low-ievel radioactive wastes (which amount to about $95 \%$ of the total waste volume) will be dispused in the Konrad repository (an abandoned iron mine); licensing of this repository has been under way since 1982; nonradioactive wastes are generally disposed by shallow-land burial, although one disposal mine is used; the category, 'Mixed Wastes' is not recognized officially and such wastes are handled as radioactive wastes (Merz 1988; NEA 4/88; Nunno 1989; Schmidt-Kuester 1990)

9.2 WASTE DISPOSAL CRITERIA: The basic aspects that must be taken into account for the disposal of radioactive waste are compiled in the "Safety Criteria" recommended by the Reactor Safety Commission in 1982; of these the most important are (Warnecke 1986):

A. The required safety of a repository constructed in a geologic formation must be demonstrated by a site-specific safety analysis which includes the overall geologic situation, the technical concept of the disposal mine and the waste packages;

8. The objectives (need for, personnel protection, etc.) for the operation of a repository are prescribed by the German Atomic Energy Act and the German Radiation Protection Ordinance;

c. In the post-operational phase, the radionuclides which might reach the biosphere via the water path as a result of transport processes not completely excludable must not lead to individual dose rates which exceed the limiting values specified in the German Radiation Protection Ordinance (30 mrem/yr)

9.3 ILW/LLW DISPOSAL (includes transuranic waste): The Federal Republic of Germany does not distinguish among low-level, intermediate-level and transuranic wastes, except by heat content, for choice of disposal location; both the Konrad and Gorleben repositories can accept any radioactive waste except that waste with a heat content above a certain level must be placed in the Gorleben repository; for this reason, the Konrad repository is generally thought of as the ILW/LLW repository, while the Gorleben repository is thought of as the HLW/spent fuel repository; the Asse II sall mine, used at one time for disposal of ILW/LLW, is now used as an underground research laboratory for geologic disposal

A. Description of the Konrad repository for LLW/LW (PTB 10/85; Holtz 1986; Berg 1988; Closs 1988; Stegmaier 1989):

- $\quad$ The mine is located in lower Saxony (10 km southwest of Braunschweig) in workings of a former iron mine (PTB 10/85);

The reference waste is solidified LLW/ILW, including decommissioning wastes; the principal criteria is that the waste is to have only negligible thermal effect (less than $3^{\circ} \mathrm{C}$ temperature rise) on the surrounding host rock (Stegmaier 1989); 
The host rock is clay-marlstone at $850-1100 \mathrm{~m}$ depth; iron mine workings are at depths of $800-1300 \mathrm{~m}$; mine shatts (not to be used for repository) reach depths of about 1000 and $1200 \mathrm{~m}$; the mine is exceptionally dry; overlying strata are primarily argillaceous, hence have good impermeability to water (PTB 1985; Berg 1988);

- $\quad$ Site investigations between 1983 and 1987 included geoscientific investigations, gectechnical measurements, one deep exploratory drilling, and an underground exploration of the planned disposal areas (Berg 1988);

By December 1987, PTB (now BIS) was satisfied the mine will be able to safely dispose of all $\amalg W / L W$ from the nuclear power program through 2008 , based on site evaluations and performance assessment studies (NW 12/17/87);

PTB (now BTS) purchased the Konrad mine from the industrial owner in December 1987 with ownership to become fully effective when a license is obtained (Closs 1988);

- The Konrad repository has an estimated capacity for $650,000 \mathrm{~m}^{3}$ of $\amalg W / \mathrm{WW}$, equivalent to forty years of waste receipts at $20,000 \mathrm{~m}^{3}$ per year (Berg 1988);

- The final radioactivity inventory when the repository is full is estimated at about 30 million curies of beta-gamma and 80,000 curies alpha radioactivity constituted mainly of Co-60, Cs-137 and Pu-242 (Berg 1988);

Reference disposal concept (Ehrlich 1986; Holtz 1986; Engelmann 1987; Berg 1988):

Surface facilities include unloading and transfer building and interim storage (for about three days' receipts);

One 7-m-diameter shaft will be used for waste movements and another 7-m-diameter shaft for ventilation and for all other movements;

Waste containers will be stacked in chambers $40 \mathrm{~m}^{2}$ in cross section and up to $800 \mathrm{~m}$ long, using shielded vehicles; filling factor of $50 \%$ is assumed; after backfill of rooms with crushed rock, $25 \%$ free volume is estimated;

Waste container specifications: maximum weight $20 \mathrm{MT}$; maximum dimensions $3.2 \times 2 \times 2.5 \mathrm{~m}$

B. Major waste criteria are (Brennecke 1987; Berg 1988):

Must be solid, with no free-moving liquids;

No seff-igniting or explosive materials are allowed;

Fissile materials up to $\mathbf{5 0} \mathrm{g} / 100$ liter of waste form are allowed;

Limits are specified for each radionuclide for each type of waste container, based on safety analyses; 
- Waste form may be bitumen or piastic matrix, solid malter, metallic solid matter, compacted waste, cemented waste, or solid and non-particulate concentrates;

External radiation dose rate may be no higher than $10 \mathrm{mrem} / \mathrm{hr}$ at $1 \mathrm{~m}$ distance;

Containers must be leak-tight, stackable to $6 \mathrm{~m}$, corrosion-resistant; inner containers such as 200 - and 400 -liter drums may be used

C. Standard $\amalg W / L W$ waste containers (Brennecke 1987; Berg 1983; Stegmaier 1989):

Waste packagings are Class I (similar to Type A transport packagings, resist temperatures up to $300^{\circ} \mathrm{C}$ ), or Class II (similar to Type B transport packagings, resist temperatures up to $800^{\circ} \mathrm{C}$ );

- $\quad$ Cylindrical concrete containers 1.06 m diameter $\times 1.37$ (wall thickness $\sim 0.15 \mathrm{~m}$ ) or $1.51 \mathrm{~m}$ (wall thickness $\sim 0.086 \mathrm{~m}$ ) high, with gross volume $1.2 \mathrm{or}$ $1.4 \mathrm{~m}^{3}$ (net volume $\sim 0.43$ or $0.75 \mathrm{~m}^{3}$ );

Cylindrical concrete containers (with wall thickness $-0.43 \mathrm{~m}$ ), $1.4 \mathrm{~m}$ outside diameter $\times 2.0 \mathrm{~m}$ high, with grass volume $3.1 \mathrm{~m}^{3}$ (net volume $\sim 0.26 \mathrm{~m}^{3}$ );

Cylindrical cast iron containers with gross volumes of $0.7,1.0$, or $1.3 \mathrm{~m}^{3}$ (wall thickness $\sim 0.12,0.15$, or $0.11 \mathrm{~m}$, respectively);

Five sizes of rectangular concrete, cast iron or steel containers, with gross volumes ranging from 3.8 to $10.9 \mathrm{~m}^{3}$;

Recent trend is toward reducing the waste volume and the use of highintegrity containers in place of concrete containers

D. Waste Emplacement (Ehrlich 1986; Berg 1988; NEA 4/88):

Disposal rooms will be filled by alternate layers of cylindrical and cuboid waste packages; cylindrical containers will be placed horizontally; cuboid containers will set upright;

Cavities and abandoned working areas will be filled with crushed rock;

After emplacement of the waste packages, each waste chamber will be sealed with a closing-off structure to act as a barrier against airborne, volatile radionuclides released from the waste;

Average receiving rate is estimated at $20,000 \mathrm{~m}^{3} / \mathrm{yr}$ for one shift/d operation; peak rate is $40,000 \mathrm{~m}^{3} / \mathrm{yr}$ for two shifts/d

E. Deployment of Konrad repository (Holtz 1986; NUKEM 1/87; Schmidt-Kuester 1990):

1976-1982 Studies of site-related questions--site characteristics, waste handling, safety 
1983-1986 Underground exploration--underground drilling, exploration of new drifts

Sept. 1986 Initial license application submitted

1989 Licensing activities interrupted to consider the effect of Wackersdorf abandonment.

1991 Receive licensing approval and start of construction

1994 Begin emplacement of waste

\subsection{LLW/ILW DISPOSAL R\&D}

A. The Asse salt mine near Braunschweig was used from April 1967 to November 1978 to dispose of about $42,000 \mathrm{~m}^{3}$ of LW and $260 \mathrm{~m}^{3}$ of ILW, mostly in 200-liter drums; these drums were emplaced using different techniques in excavated caverns to evaluate handling practices; all ILW waste drums were 'dropped' remotely into a cavern through a port in the cavern ceiling; the caverns were then backfilled with crushed salt and sealed (GSF 1986; Salander 1990)

B. Technology for in situ immobilization of ILW and UW is being developed at Asse; in a recent large-scale experiment lasting approximately three weeks, simulated radioactive wastes were transported as a fluid cement mixture from above ground through a vertical pipe to an underground cavern where the mixture set up as a concrete monolith (Homann 1985; ATW 3/89)

\subsection{PROGRAM AND FACILITIES COSTS}

A. In 1987, costs of the Konrad repository were estimated at (PTB 11/29/87):
Management and planning
$\sim 160$ million $D M$
Site investigations and mine purchase $\sim 300$ million DM
Licensing
Repository design
Construction/modifications
Total
$\sim 88$ million DM
$\sim 12$ million DM
$\sim 455$ million DM
$\sim 1015$ million DM

B. In 1987, operating costs were expected to be 45-60 million DM (\$27-\$35 million U.S.) (Engelmann 1987)

C. In 1987, the purchase cost of Konrad mine was expected to be 70 million DM (\$38 million U.S.) (NW 12/17/87)

D. In 1988, PTB estimated the total costs of the Konrad repository program to be 1.22 billion DM (\$630 million U.S.); best guesses in early 1990 are currently more than 1.6 billion DM (\$820 million U.S.) (Salander 1990) 


\subsection{DISPOSAL OF HIGH-LEVEL WASTES}

\subsection{SPECIFICATIONS AND CRITERIA}

A. Container integrity is required during operational phase (up to 50 years) (Hamacher 1985; Merz 1986)

B. Container integrity may be required until near-field convergence of salt rock has encapsulated the waste package, possibly up to 200 years (Hamacher 1985; Merz 1986)

C. The maximum allowable temperature is $200^{\circ} \mathrm{C}$ at the salt/canister interface $\left(130^{\circ} \mathrm{C}\right.$ if other minerals are present) (Parker 1984)

D. The maximum allowable dose to the most exposed member of the public is 30 mrem/yr; the maximum allowable dose to workers is $5 \mathrm{rem} / \mathrm{yr}$ equivalent whole body dose (Merz 1986; IEAL 1987)

E. The worst case scenario is water or brine intrusion into the storage area (Merz 1986)

F. Post-closure surveillance will be carried out for a time, limited to ordinary environmental protection requirements (Merz 1986; IEAL 1987)

G. Post-closure retrievability is considered counter-productive in light of overall safety and is not required (IEAL 1987)

\subsection{REPOSITOAY DEPLOYMENT STRATEGY}

A. The repository deployment strategy of the FRG is based on a multi-barrier concept utilizing the waste form, waste package, repository and the geologic environment (Merz 1986)

B. The repository for heat-producing wastes (vitrified HLW, spent fuel as athernative or for spemt fuels not reprocessable) will be located in a salt dome at Gorleben if evaluation proves it to be satisfactory; preliminary characterization of dome, overlying rock and aquifers and surrounding geology has given positive results (PTB 10/85)

C. Underground exploration of dome at proposed repository depth is to answer remaining questions of site suitability; shaft sinking is in progress with Shatt 1 having reached a depth of $262 \mathrm{~m}$ and Shatt 2 a depth of $133 \mathrm{~m}$ in March 1990; if the site is acceptable, the repository could be operating as early as 2008 (NEA 6/90)

D. The FRG is maintaining an awareness of progress in repository development in other countries (NEAPTB 1989)

\subsection{SITE SELECTION AND CHARACTERIZATION}

A. In February 1977, the Gorleben satt dome (100 km northeast of Braunschweig) was nominated by the government of the state of Lower Saxony as a potential site for a future repository for nuclear wastes; the site is situated over one of the largest salt domes in northern Germany and is in a sparsely populated area 
Hydrogeological investigations began on April 17, 1979; deep drilling began on January 4, 1980; in May 1983, PTB preliminarily confirmed the suitability of the salt dome and on July 13,1983, the Federal cabinet approved underground exploration

Sinking of the shafts began on March 17, 1986, but was interrupted in May 1987 by an accident in Shatt 1; shatt sinking was resumed in February 1989 and underground exploration is expected to be completed between 1995 and 1999 (ATW 3/89; Closs 1988; PTB 10/85)

B. Between April 1979 and April 1983, 110 exploration holes, 267 monitoring wells and 9 boreholes were drilled as part of the hydrogeological program covering an area of about $300 \mathrm{~km}^{2}$; in addition, 37 boreholes were drilled extending down to $80 \mathrm{~m}$ into the salt to explore the surface of the salt dome; the first pumping tests were also performed; these tests led to a detailed understanding of the overburden and flow of groundwater (Langer 1989)

C. Between January 1980 and March 1981, four deep boreholes were drilled on the flanks of the salt dome to a depth of about $2,000 \mathrm{~m}$ and cored; two of the holes were backfilled with clay and different special cements; two remain open for further measurements; based upon results of these tests, two locations for shat sinking were selected (Langer 1989)

D. A final decision on the suitability of the Gorleben salt dome rests upon the results of an extensive underground exploration program at the planned repository depth with two main objectives:

to explore where regions of compact rock salt exist, and

to explore if and where anhydrite and carnalite seams occur

The underground program includes some $26 \mathrm{~km}$ of underground drifts and about 100 $\mathrm{km}$ of boreholes (Langer 1989)

\subsection{HLW DISPOSAL CONCEPTS}

A. The reference waste types considered for the repository are:

Stainless steel canisters of vitrified (French borosilicate glass process) HLW, $0.43 \mathrm{~m}$ outside diameter by $1.34 \mathrm{~m}$ high, and containing waste equivalent to 1.15 MTHM (Papp 1989)

Non-standard spent fuel elements, primarily spent fuels from the HTR fuels from the decommissioned AVR and THTR reactors, but could include other spent fuels such as second cycle MOX fuels, LWR fuels with burnup greater than the licensing limit of $50,000 \mathrm{MWd} / \mathrm{MT}$, or LWR fuels over and above fuel reprocessing capacity (Papp 1990)

- Other heat-producing wastes, e.g., dissolver sludges, cladding hulls, structural parts of fuel elements (Closs 1989) 
B. The underground structure planned for the salt dome has the following characteristics:

- The repository will be located in a $300 \mathrm{~km}^{2}$ area in a salt bed with the galleries placed at a depth of 830 to $\mathbf{9 0 0} \mathrm{m}$ and under a gypsum rock cap (Rothmeyer 1979)

Various designs for the repository layout are being evaluated, particularly for their effect on costs; major variables being considered include extended cooling periods, the use of the Pollux disposal cask and development of an advanced ILW treatment, permitting ILW packages to be subjected to higher temperatures (Closs 1989; Papp 1990)

- In the reference concept, canisters of vitrified HLW are to be stacked in boreholes extending vertically downward ( $300 \mathrm{~m}$ deep and 50-60 $\mathrm{m}$ apart) in the gallery floor (Schneider ot al. 1990)

- In an alternative concept, canisters of vitrified HLW will be placed in Polluxtype casks emplaced end-to-end in dritts leading from the access galleries (Closs 1989; Papp 1990)

Cavities are to be backfilled with salt, sealed off from other chambers with clay and concrete dams (Rothemeyer 1979)

10.5 ILW DISPOSAL CONCEPTS: Heat-generating ILW such as reprocessing feed clarification sludge, cladding hulls, and structural parts of fuel assemblies will be embedded in a cement matrix and filled into 400 -liter metal drums which are to be placed into the vertical boreholes in a manner similar to that considered for canisters of high-level waste (see previous section); as an alternative, four of these drums could be placed in the Pollux-type cask and emplaced in a dritt similar to that considered for direct disposal of spent fuel (see following section) (Closs 1989; Papp 1990)

10.6 DIRECT DISPOSAL OF SPENT FUEL: Direct disposal of spent fuel is being considered for those fuels not amenable to reprocessing, e.g., HTR fuels, and as a backup to the disposal of vitrified waste should plans to reprocess be dropped; the studies are being carried out under the Project Group 'Entsorgung' (PTE) at KfK, Karlsruhe (FRG-U.S. Workshop 3/88; KfK 1989; Schneider et al. 1989; Papp 1990; Schneider et al. 1990)

A. The concept being considered for disposal of spent fuel includes:

spent fuel will be disposed in the deep geologic repository in salt planned for high-level wastes, i.e., the Gorleben repository, but likely in a separate section

- two methods of emplacement are under study-either in vertical boreholes or on the floor of the disposal drits; disposal in the vertical boreholes would utilize a metal canister; disposal in the drifts would utilize the Pollux cask; LWR fuel may or may not be consolidated and canistered for disposal

- emplacement will be carried out in a retreating mode as planned for high-level waste

B. The reference waste package concept (Pollux cask) for direct disposal of LWR spent fuel includes (Luckscheiter 1987; Papp 1990): 
consolidated rods from eight PWR assemblies will be placed in a thin-walled canister; the canisters will be loaded into the perimeter of a Pollux-type cask and canisterized, compacted fuel hardware will be loaded into center of cask; the cask will be sealed by welding, coated with a layer of corrosion-resistant Hastelloy-C4, and then inserted into a second shielding overpack cask for transport into the repository

- the empty cask weight is about $58 \mathrm{MT}$; the loaded cask weight is about $65 \mathrm{MT}$

- a package can handle spent fuel three years out-of-reactor with a total heat generation rate of $20 \mathrm{~kW}$

C. An alternative concept for direct disposal of spent fuel is being considered (Luckscheiter 1987; Papp 1990):

disassembled fuel pins from 0.5 PWR fuel assembly are cut into pieces about $1 \mathrm{~m}$ long, and placed in the same type of canister used for vitrified HLW (0.43 $\mathrm{m}$ diameter and $1.33 \mathrm{~m}$ long)

- $\quad$ the shorter canisters of chopped spent fuel rods will be emplaced in boreholes as is planned for HLW canisters

D. The PKA pilot facility for developing/demonstrating spent fuel conditioning for disposal is under design at Gorleben (Einfeld 1987; Closs 1989; Schneider et al. 1989;

Schneider et al. 1990)

- The PKA facility includes a hot cell with capability for rod consolidation, compaction of fuel assembly skeletons, and loading of canisters into a Pollux cask; maximum throughput $35 \mathrm{MTU} / \mathrm{yr}$

The facility will also be capable of transferring vitrified HLW from transport to storage casks, and maintenance of the transport and storage casks

The facility will also demonstrate handling, transport and possibly the simulation of emplacement of canisters at a repository

The first construction permit was received in 1989 and startup is anticipated in 1994 (Einfeld 1988; NN 3/90)

The process building is $59 \times 50 \times 21 \mathrm{~m}$ high and has a $2,000 \mathrm{~m}^{3}$ hot cell

10.7 WASTE PACKAGE R\&D: R\&D is under way on the waste package; the R\&D covers the properties of HLW borosilicate glasses; corrosion and structural considerations of metallic and ceramic materials in brines, and the leaching of spent fuel; limited emphasis is placed on the container as a barrier; supporting packaging R\&D for direct disposal of HTR spent fuel are in progress at Jülich (Parker 1984; Kienzler 1989; Schneider et al. 1990; Theenhaus 1990)

10.8 GEOSCIENCES R\&D: Both laboratory and theoretical studies are under way on the following topics (Warnecke 1988; Schneider et al. 1990):

A. Mechanical and thermal properties of rock salt: stresses; deformation of cavern and borehole walls 
B. Release of liquids and gases from salt

C. Radionuclide migration as result of repository flooding

D. Retention of fission gases by backfill materials (spent fuel disposal)

E. Development of rock mechanical computer codes

10.9 FIELD TESTS: Underground research testing in support of the FRG repository program has been under way or planned at four locations:

A. An extensive array of tests have been conducted and are planned at the Asse salt mine (see ASSE mine section, 10.11)

B. A flooded mine test was conducted at the Hope potash salt mine (Herbert 1985)

C. The FRG has a cooperative program with the Swiss at the Grimsel (Switzerland) facility; the FRG test program addresses discontinuities, stresses, and water flow in the crystalline rock mass; tiltmeter measurements; and ventilation and heater tests (Kühn 1983)

D. Extensive underground exploration and testing will be carried out at the proposed repository location at Gorleben prior to receiving an operating license. (Langer 1989)

E. The Asse salt mine is presently used to test procedures for application in the Gorleben repository; experiments have included investigations on the influence of heat and radiation on the surrounding salt using electrically heated probes and cobalt-60 sources; experiments are planned to evaluate seals/dams and drift emplacement of the Pollux cask (Bechthold 1989; Flasch 1989; Salander 1990)

F. Another experiment, using 30 highly radioactive sources prepared in the United States (canisters of borosilicate glass containing Sr-90 and Cs-137), will be initiated in 1990 in the Asse salt mine (Rothfuchs 1987; Kuhn 1989a; Salander 1990)

G. Emplacement of ILW heat-producing packages (dissolver sludge, cladding hulls, HTGR fuel elements) in boreholes is being considered for testing at Asse (Barnert 1988)

10.10 PERFORMANCE ASSESSMENT: Over the past ten years, five main projects have been carried out to assess the performance of nuclear waste repositories in the Federal Republic of Germany (Storck 1988; Warnecke 1988; NEA 9/89; Schneider et al. 1990)

A. During 1979-1984, the basic deterministic methodology was developed for all types of waste at the Gorleben site

B. During 1982-1987, the extended methodology that takes into account the uncertainty of input data by a Monte Carlo procedure was developed during the CEC project, PAGIS 
C. During 1984-1986, the deterministic methodology was adapted to the situation of the abandoned Konrad mine in a deep iron-ore formation

D. During 1987-1989, the extended methodology developed during the CEC's PAGIS project was applied to the Gorleben site but for a UW/LW repository only

E. During 1987-1989, the available extended methodology was applied to a combined repository for spent fuel, intermediate-level wastes and high-level wastes at Gorleben

\subsection{SYSTEMS STUDIES}

A. A five-year study (1980-1984) of the direct disposal of spent fuel versus reprocessing and disposal of HLW led to the following conclusions (NN 5/85; Karlsruhe 1984):

- $\quad$ Both approaches are technically feasible and can be used with safety; direct disposal has no clear safety advantages over reprocessing

- $\quad$ The application of direct disposal will require further development

B. A systems analysis is in progress on a "dual-purpose" repository that would take both spent fuel and waste (Papp 1990)

C. A seven-year project is in progress to develop and test safety assessment methodology for the back end of the fuel cycle (HMI 1985; Memmert 1986)

10.12 ASSE II SALT MiNE (12 km southeast of Wolfenbüttel)

A. History of the Asse II salt mine programs includes the following (GSF 1987; NUKEM 12/87; Kuhn 1989):

1909-1964 Commercial mining operations were conducted for the extraction of carnallite and rock salt

1967-1978 Test disposal of LLW and ILW and other waste disposal R\&D (125,000 drums of LLW and 1,300 drums of ILW were disposed in this period)

1978

Disposal discontinued when license expired but $A \& D$ continued on disposal of heat-producing wastes in salt formations

1990-1993 Disposal tests under way with 30 fully radioactive canisters (highlyactive waste tests)

B. Past R\&D activities (partially co-sponsored by CEC) at the Asse salt mine have included (Homann 1985; GSF 1987):

test disposal of 125,000 LLW and 1300 ILW drums were performed between 1967 and 1978

- $\quad$ heater and radiation tests to provide thermal, thermomechanical, brine migration and gas generation information in salt

- hydrofracture testing in salt 


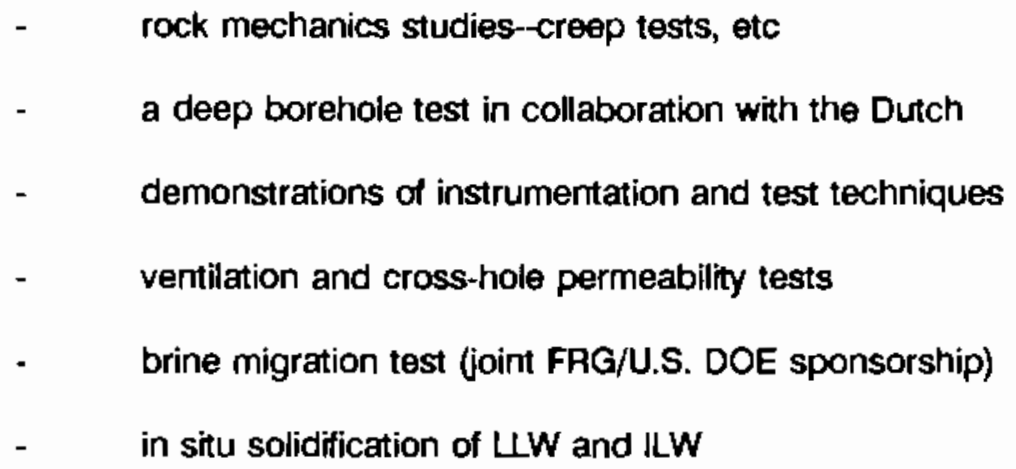

C. Currem and future activities at 750 to $925-\mathrm{m}$ depths will include the following related to the disposal of HLW (NEA 12/88; Kuhn 1989):

- a radioactive demonstration using 30 HAW glass canisters provided by DOE/PNL and emplaced in eight boreholes for five years

- dam/bulkhead development

- backfilling and sealing testing

D. Future activities will also include the following related to the direct disposal of spent fuel (Papp 1986; Engelmann 1986; NEA 12/88):

- $\quad$ above-ground simulation of shaft transport for service loads up to $80 \mathrm{MT}$

- $\quad$ equipment for transport and handling of heavy canisters in repository (aboveground and possibly later at the Asse mine)

- $\quad$ emplacement of electrically-heated heavy canisters (at the Asse mine)

- $\quad$ handling of small canisters loaded with cut-up spent fuel rods (at the Asse mine)

E. The Asse mine is still considered as a potential repository (Ehrlich 1986) space is available in existing cavities for another 100,000 waste drums decision is pending a decision on license application for Konrad mine

10.13 PROGRAM/FACILITIES COSTS: In 1987, costs of the Gorleben repository were estimated at: (PTB 11/29/87)

Management, planning Above-ground site investigations Underground site investigations Licensing

Final repository construction Total $\sim 800$ million DM

-190 million DM

$\sim 1030$ million DM

-140 million DM

- 1200 million DM

-3400 million DM 
11.0 MANAGEMENT OF URANIUM MINE AND MILL WASTES: The Federal Republic of Germany purchases all uranium concentrate from other countries (see Section 5.3)

\subsection{DECOMMISSIONING AND ENVIRONMENTAL RESTORATION}

12.1 STRATEGY/POLICY. As part of the licensing process for nuclear facilities, licensees must show proof that the facility can be decontaminated and decommissioned at the end of its useful life; general D\&D practice in the FRG has been to proceed in three stages as outlined in the IAEA's classitication; considerable effort is going into R\&D on development of D\&D techniques, including waste minimization and recycling of materials; the FRG is a participant in the decommissioning programs of the CEC, NEA and the IAEA (Essmann 1978; IAEA 1983; Petrasch 1986; Bertini 1987; Feraday 1987; Huber 1987)

12.2 MAJOR PROJECTS: The FRG, having a large nuclear program, has undertaken numerous D\&D programs which include:

A. FR-2 research reactor at Karlsruhe: This 44-MWt, tank-type HWR operated between 1961 and 1981; fuel has been removed and non-radioactive structures are being removed (Stage 2); the core structure and bioshield will be dismantled in 30 years (NEA 1985)

B. MZFR research reactor at Karlsruhe: This 58-MW PWR, operated between 1965 and 1984; the facility, except for the fuel storage building, is out of operation and in safe enclosure (NEA 1985; Essmann 1988)

C. WAK pilot scale fuel reprocessing plant at Karlsruhe: This facility (see Section 6.1) is to be shut down in 1992, after which it will be decommissioned; estimated 1984 costs for decommissioning are 300 million DM (NEA 1985; NF 1/8/90)

D. At Karlsruhe, metals are decontaminated (mostly by sand blasting) and melted for reuse when possible; they will be compacted when not decontaminatable (Hempelmann 1987)

E. Niedereichbach nuclear power plant: This heavy-water-moderated, gas-cooled, $100 \mathrm{MWe}$ reactor operated from 1972-1974; D\&D started in 1987 (NEA cooperative program); the site is to be restored to "green-field" condition; the estimated cost for the program is 100 million DM (NEA 1985; NN 1/87; Lóschhorn 1988)

Contaminated steel (about 1700 tons) from the project is to be melted after size reduction in induction-melting furnace installed in the decortaminated and decommissioned building of the FR.2 reactor (facility name 'EIRAM'); the castings produced are $1.5 \mathrm{MTU}, 56 \mathrm{~cm}$ diameter and $81 \mathrm{~cm}$ high; melting began with radioactive materials in 1988 (Korting 1986; Loschhorn 1989)

F. KRB-A power plant at Gundremmingen: This 250-MWe BWR operated from between 1966 and 1977; fuel has been removed and all systems but the biological shield and reactor vessel are expected to be dismantled by 1992 (NEA 1985; Mies 1987)

G. KWL Lingen power plant: This 268-MWe BWA operated between 1968 and 1977; the facility has been placed in safe enclosure (Stage 1); dismantlement will start after 25 years; this project is part of the NEA's cooperative program on decommissioning (NEA 1985; Essmann 1988) 
H. LLW/LW incinerator at Jülich: This unit was dismantled in 1987, producing $51 \mathrm{MT}$ of radioactive wastes, $6 \mathrm{MT}$ reusable metal scrap, $50 \mathrm{MT}$ decomaminated scrap and equipment (Laser 1987)

I. AVR and THTR-300 Reactors: The first stage of decommissioning and dismantling of the THTR-300 high-temperature, gas-cooled reactor will be completed in 1992; the FAG's other HTR, the 15-MW AVR pilot HTR at Jülich, was shut down in 1988 and is awaiting decommissioning licenses from the state regulators; spemt fuel from the two units will be disposed at Gorleben (NW 4/12/90a; Papp 1990)

J. Nuclear Ship "Otto Hahn": This nuclear powered ship, buitt in 1963, was shut down in 1979; all activated and contaminated components were removed and the rooms were decontaminated; the ship is used for non-nuclear purposes; D\&D cost 21.7 million DM (\$11 million U.S.) or about $36 \%$ of its construction costs (NEA 1985)

K. Alkem GmbH Fuel Fabrication Facility: This facility for fabrication of MOX-type fuels operated between 1964 and 1972; equipment was removed to another facility and the building has been released for other uses (NEA 1985)

12.3 A\&D: Active A\&D for D\&D is being conducted by the nuclear power utilities and by the federal government; these include studies on explosive cutting/demolition, chemical and electrochemical decontamination; strippable coatings; cold thermal shock; metal melting; sand blasting decontamination; high-pressure water jet decontamination; flame cleaning; pickling decontamination, cold thermal shock and metal melting; R\&D is being carried out on decommissioning involving nuclear and hazardous wastes under the Project Group 'Entsorgung' (PTE) by KfK at Karlsruhe (Morell 1986; Allen 1987; Engelfried 1987; Freund 1987; Müller 1987; Sappock 1987; Löschhorn 1989)

\subsection{INTERNATIONAL ACTIVITIES}

A. International Organizations: The FAG is a member of the CEC, IAEA and NEA and participates actively in the activities of those organizations

B. Cooperation with U.S. DOE: The U.S. DOE has several technology exchange agreements with the FAG; current emphasis in the U.S./FAG exchanges covers: information exchange in all areas; U.S. observation of PAMELA pilot plant operation and shaft drilling at Gorleben repository site; manufacture of vitrified HLW canisters for FAG; cooperation in cask tests and transportation studies; the agreements in place between the U.S. DOE and FAG are:

DOE/BMFT umbrella agreement on waste management (in the process of being extended)

Term: 1974-1989

Scope: spent fuel and waste storage; waste treatment and disposal; transportation; decommissioning

- $\quad$ DOE/BMFT agreement for ASSE mine studies

Term: $1981-1988$ 
Scope: in situ studies of brine migration; performance of materials; thermal effects; test equipment evaluations

- DOE/BMFT agreement for HLW immobilization studies

Term: 1984-1990

Scope: information exchange of HLW immobilization plant design, construction, operation; fabrication by DOE of vitrified HLW sources for FRG tests at Asse

- DOE/BMFT agreement in the field of remote systems technology

Term: $1987-1992$

Scope: remote connectors; ventilation system and off-gas technology; robotic process samplers; servomanipulator hardware

Other agreements have been in place or are in place on LMFBR, HTGR, and safeguards technology

C. Cooperation with other U.S. Agencies:

NRC/BMI agreement on nuclear safety and regulation

Term: 1981-1986, extended to 1991 (ATW 5/87)

- $\quad$ EPRI/SBK cooperation on small-scale breeder reactors; LMFBR modules, metallic fuels and integrated fuel cycle; 1985--(NE 1-2/87)

D. Cooperation with other countries:

Multinational fuel cycle consortia: The FRG cooperates with other countries through the following commercial entities:

- $\quad$ Nuclear Transport, Limited (France, FRG, U.K.): Spent fuel transport

- United Reprocessors GMBH (France, FRG, U.K): reprocessing

- URENCO (FRG, Netherlands, U.K.): Enrichment

- $\quad$ FRG/Sweden spent fuel exchange: FRG demonstration MOX fuel elements were traded to Sweden for final disposal; in turn, the FRG took responsibility for equivalent amount of Swedish LWR fuel now stored at La Hague for reprocessing (NUKEM 1/86)

- Belgium, France, U.K., and Italy: The FRG has an agreement for R\&D cooperation on fast breeder development (NE 1-2/87)

Negotiations have been conducted with the People's Republic of China; the negotiating parties were Inter Nuclear, an FRG consortium, and the CNEIC (China Nuclear Energy Industry Corporation); subjects of the negotiations include: 
- China proposed to take $150 \mathrm{MTHM}$ of spent fuel on a test basis; if successful, the FRG may buy China's services for 1000 MTHM of spent fuel in return for a Chinese reactor order

- Additional negotiations took place in 1987 where the FRG would participate in technology transfer for the planned $600 \mathrm{MWe}$ Chinese PWRs; China would supply uranium to FRG utilities (NEF 9/87)

- China offered to store sp to $150 \mathrm{MTU}$ of spent fuel in Gobi desert

- A bilateral agreement was signed with the Democratic Republic of Germany for exchange of information relative to radiation protection after a nuclear accident and relative to plans for disposal of radioactive wastes and spent fuel (NW 8/6/87)

- In March of 1990, a working group was established to unify FRG and GDR nuclear laws by 1991 (NW 3/29/90)

- $\quad$ A bilateral agreement was signed with the USSR in April 1987 to exchange information about safety, radioactive waste, nuclear fusion and high energy physics (NE 5/87)

- West Germany industry is exploring the possibilities of building HTA's in the USSA (NW 4/12/90b)

- $\quad$ FRG utilities have signed contracts with Cogema and BNFL for reprocessing spent fuel produced through 2005 (ATW 4/90)

\subsection{REFERENCES}

$-1977$.

Kaiser, G., E. Merz, and E. Zimmer. 1977. "Reprocessing Technology in the HTGR Fuel Cycle." In Proceedings of the IAEA International Conference on Nuclear Power and its Fuel Cycle, Vol. 3, pp. 661-671. May 2-13, 1977, Salzburg, Austria.

Schüller, W. et al. 1977. 'Fuel Reprocessing and Waste Treatment at Karlruhe Nuclear Research Center." in Proceedings of the IAEA International Conference on Nuclear Power and Its Fuel Cycle, Vol. 3, pp. 579-592. May 2-13, 1977, Salzburg, Austria.

$-1978-$

Essmann, J., D. Brosche, G. Thalmann, J. Vollradt, and G. V. P. Watzel. 1978. "Provision for Decommissioning LWR Power Plants by the German Utilities.' In Proceedings of The IAEA/NEA Symposium on Decommissioning of Nuclear Facilities, pp. 41-64. November 13-17, 1978, Vienna, Austria.

$-1979$

Röthemeyer, H. 1979. "Site Investigations and Conceptual Design for the Repository in the Nuclear 'Entsorgungszentrum' of the Federal Republic of Germany.' In Proceedings of the IAEA/NEA Symposium on Underground Disposal of Radioactive Wastes, pp. 297-310. July 2-6, 1979, Otaniemi, Finland. 
$-1980$

KfK 1980. Main Activities: Karlsruhe Nuclear Research Center. Brochure published by Kernforschungszentrum Karlruhe, Karlsruhe, Federal Republic of Germany.

$-1882-$

ATW News (ATW). 3/82. "Expansion of State Collection Centers," p.5.

$-1983-$

Băhr, W. W., G. Hohlein, R. H. Kroebel, and W. Lins. 1983. "Experience and Projects for Treatment and $C_{1}$ rditioning of All Radioactive Wastes in the Federal Republic of Germany.' In Proceedings of the IA A International Conference on Radioactive Waste Management, pp. 239-248. May 16-23, 1983, Seattie, Washington.

International Atomic Energy Agency (IAEA). 1983. Decommissioning of Nuclear Facilities: Decontamination, Disassembly and Waste Management. Technical Report Series No. 230, International Atomic Energy Agency, Vienna.

Kühn, K. 1983. "Pilot Research Projects for Underground Disposal of Radioactive Wastes in the Federal Republic of Germany.' In Proceedings of IAEA International Conference on Radioactive Waste Management, Vol. 3, pp. 351-369. IAEA-CN-43/169, May 16-20, 1983, Seattle.

Nuclear Energy Agency (NEA). 1983. Nuclear Legislation, Vol. I. OECD/Nuclear Energy Agency, Paris, France, pp.101-120.

Passig, E., H. Hepp, T. F. Kienle, and D. Rittscher. 1983. "Improvements in the Treatment, Volume Reduction and Intermediate Storage of Radioactive Wastes from Nuclear Power Plants in the Federal Republic of Germany.' In Proceedings of the IAEA International Conference on Radioactive Waste Management, pp. 129-138. May 16-23, 1983, Seattle, Washington.

$-1984-$

Harmon, K. M., and A. B. Johnson, Jr. 1984. Foreign Programs for the Storage of Spent Nuclear Power Plant Fuels, High-Level Waste Canisters and Transuranic Wastes. PNL-5089, Pacific Northwest Laboratory, Richland, Washington, p. 42.

International Atomic Energy Agency (IAEA). 1984. Guidebook on Spent Fuel Storage. Technical Reports Series No. 240, pp. 42-45, 83, 134-151. International Atomic Energy Agency, Vienna.

Karlsruhe Nuclear Research Center (Karlsruhe). 1984. Systemstudie Andere Entsorgungstechniken: Kurzfassung. Karlsruhe Nuclear Research Center, Karlsruhe, Federal Republic of Germany.

Parker F. L., R. E. Broshems, and P. Janos. 1984. The Disposal of High-Level Radioactive Waste. NAK Rapport II, Swedish National Board for Spent Nuclear Fuel (NAK), Stockholm.

$-1985-$

Fujii, H. 1985. Directory of Nuclear Power Plants in the World. Japan Nuclear Energy Information Center Co., Ltd., Tokyo. 
Hamacher H., E. Merz, and H. Roethemeyer. 1985. "Overview of FRG Waste Disposal R\&D Activities." In Proceedings of the International Seminar on Radioactive Waste Products-Suitability for Final Disposal, pp. 1-16. June 10-13, KFA, Jülich, Federal Republic of Germany.

Herbert H. J., and W. H. Stover. 1985. 'Research Work During and After the Flooding of an Abandoned Potash Mine in Northern Germany." In Proceedings of the ANS topical meeting on High-Level Nuclear Waste Disposal, pp. 499-510. September 24-26, Pasco, Washington.

HMI. 1985. Projekt Sicherheitsstudien Entsorgung: Summarized Final Report. Hahn-Meitner-Institut, Berlin, Federal Republic of Germany.

Hoehlein, G., E. Tittmann, and H. Wiese. 1985. "PAMELA: Advanced Technology for Waste Solidification." Nuclear Europe, February 1985, pp. 18-19.

Homann, H. H., and R. H. Kraemer. 1985. 'Disposal of Low- and Medium-Level Radioactive Wastes by Means of In Situ Solidification.' Waste Management ' 85 , Vol. 3, pp. 441-446. March 24-28, 1985, Tucson, Arizona.

Malting, P., R. Randl, and V. Schneider. 1985. 'Managing Waste in West Germany.' Nuclear Engineering International, March 1985, pp. 16-17.

Nuclear Energy Agency (NEA). 1985. Compendium on Decommissioning Activities in NEA Member Countries. OECD/Nuclear Energy Agency, January 1985, Paris, France.

Nuclear News (NN). 5/85. 'Alternatives for Entsorgung," p. 90.

NUKEM. 1985. NUKEM Annual Report: 1985. NUKEM GmbH, Hanau, Federal Republic of Germany.

Paige, H. W. and N. J. Numark. 1985. Assessmemt of National Systems for Obtaining Local Siting Acceptance of Nuclear Waste Management Facilities. IEAL-R/86-16, International Energy Associates Limited, Washington, D.C., Vol. 1, pp. 6-1 to 6-6 and Vol. 2, pp. 8-1 to 8-7,

PTB. 10/85. PTB Aktuell, Physikalisch-Technische Bundesantalt (PTB), Braunschweig, Federal Republic of Germany, n. 9.

$-1986-$

Alter, U. 1986. "Research and Development Work on Radioactive Material Transport in the Federal Republic of Germany." In Proceedings of the IAEA Symposium on the Packaging and Transportation of Radioactive Materials: PATRAM '86, pp. 317-321. June 16-20, 1986, Davos, Switzerland.

Ambros, R., B. Christ, G. Klessen, and H.-G. Knackstedt. 1986. "Experience with Systems for Collection, Transportation and Storage of Radioactive Wastes.' In Proceedings of the IAEA Symposium on the Packaging and Transportation of Radioactive Materials (PATRAM '86), Pp. 19-12. June 16-20, 1986, Davos, Switzerland.

Arntzen, P. 1986. "Results of Engineering Developments for the Direct Disposal of Spent Fuel." Waste Managemem '86, Vol. 2, pp. 527-530. March 2-6, 1986, Tucson, Arizona.

ATW News. 3/86. "MINKA Reprocessing Test Facility," p. 6. 
Bromkamp, K-H., and D. Methling. 1986. "Handling and Transport System Used for Spert Fuel From the THTR 300MW Nuclear Power Station." In Proceedings of An Imemational Symposium on the Packaging and Transportation of Radioactive Materials, pp. 303-308. June 16-20, 1986, Davos, Switzerland.

Bruecher, P. H. 1986. 'Treatmert and Disposal of Special Radioactive Wastes Comprising Tritium, Carbon-14 and lodine-129.' Radioactive Waste Management and the Nuclear Fuel Cycle. Harwood Academic Publishers, New York, 7(2):195-207.

Brunner, H., B. Christ, and G. Klein. 1986. Volume Reduction and Solidification of Low Level Radwaste." Nuclear Europe, March 1986, p. 21.

Ehrlich, D. 1986. 'Disposal of Radioactive Waste in the Konrad Iron Ore Mine." Waste Management '86, Vol. 3, pp. 185-194, March 2-6, 1986, Tucson, Arizona.

Engelmann, H. J. 1986. "Demonstration of the Spent Fuel Disposal Techniques Test Program in the Federal Republic of Germany.' Waste Management '86, Vol. 2, pp. 531-534. March 2-6, 1986, Tucson, Arizona.

Gräbener, K. H., and A. Kirchenmayer. 1986. "Germany's First Commercial Radwaste Incinerator Starts Up," Nuclear Engineering International, December 1986, pp. 50-52.

Grübler, G. 1986. 'Status of the Mine for the investigation of the Gorleben Salt Dome." Waste Management '86, Vol. 2, pp. 117-120. March 2-6, 1986, Tucson, Arizona.

GSF. 1986. The ASSE Salt Mine: Research for Final Disposal. Publication of Gesellschaft fuer strahien- and Umweltforschung mbH (GSF), Munich, Federal Republic of Germany, $\sim 1986$.

Holtz, G. 1986. 'Technical Design of the Konrad Repository." In Proceedings of IAEA International Symposium on Siting. Design and Construction of Underground Repositories for Radioactive Wastes, pp. 535-542. IAEA-SM-289/45, March 1986, Hanover, Federal Republic of Germany.

KfK 1986. Hauptabteilung Dekontaminationsbetriebe (HBE). Brochure published by Kernforschungszentrum Karlsruhe, Karlsruhe, FRG.

Körting, K. 1986. "Karlsruhe Begins New Facility to Melt Down Reactor Scrap," Nuclear Europe, Journal of the European Nuclear Society, July/August 1986, no. 7/8, p. 43.

Koster, R., and W. Bechtold. 1986. "Conditioning of Low and Intermediate Level Wastes." Radioactive Waste Management and the Nuclear Fuel Cycle. Harwood Academic Publishers, New York, 7(2): 151-164.

Krause, H. 1986. The Treatment and Conditioning of Transuranelement Bearing Wastes in the Federal Republic of Germany." Radioactive Waste Management and the Nuclear Fuel Crcle. Hawwood Academic Publishers, New York, 7(2):139-150.

Kuhn, K. D. 1986. "Waste Management at WAK." In Proceedings of the ANS International Topical Meeting on Waste Management and Decontamination and Decommissioning, pp. 45-54. September 14-18, 1986, Niagara Falls, New York.

Laser, M. 1986. "Volume Reduction of Low Level Solid Radioactive Waste by Incineration and Compaction in the Federal Republic of Germany. Radioactive Waste Management and the Nuclear Fuel Cycle. Harwood Academic Publishers, New York, 7(2):165-180. 
Fang, F., et al. 1987. 'High-Level Waste Concentrate Storage at WAK' In Proceedings of International Conference on Nuclear Fuel Reprocessing and Waste Management, RECOD '87, Vol. 1. August 23-27, 1987, Paris.

Feraday, M. A. 1987. "IAEA. Activities in Decommissioning and Decontamination." In Proceedings of The 1987 Decommissioning Symposium, Vol. 1, pp. 1-16 to I-29. CONF-871018, October 4-8, 1987, Pittsburgh, Pennsylvania.

Freund, H. U., S. Schumann, and K. Müller. 1987. Test Results of Concrete Demolition by Smooth Blasting Inside a Reactor Containment." In Proceedings of The 1987 Decommissioning Symposium, Vol. 2, pp. VI-61 to Vl-79. CONF-871018, October 4-8, 1987, Pittsburgh, Pennsylvania.

GSF. 1987. The Asses Satt Mine: Research for Final Disposal. Brochure published by Gesellschaft für Strahlen- und Umweltforschung mbH, Munich, FRG.

Hackstein, K. G. 1987. 'Front End of the Nuclear Fuel Cycle in Germany.' Nuclear Europe, January/February 1987, pp. 24-25.

Hempelmann, W. 1987. 'Treatment of Waste Metals from Decommissioning.' In Proceedings of The 1987 International Decommissioning Symposium, Vol. 1, pp. Ili-90 to III-99. CONF-871018, October 4-8, 1987, Pittsburgh, Pennsylvania.

Hennies, H. H. 1987. "Nuclear R\&D in Europe." Nuclear Europe, January-February 1987, pp. 21-23.

Hüber, B. 1987. 'Advances in the European Community's Programme of Research on Decommissioning.' In Proceedings of The 1987 Decommissioning Symposium, Vol. 1, pp. I-30 to I-34. CONF-871018, October 4-8, 1987, Pittsburgh, Pennsylvania.

IEAL. 1987. Regulatory Strategies for High-Level Radioactive Waste Management in Nine Countries. IEAL-R/87-93, International Energy Associates, Limited, Fairfax, Virginia.

Kraemer, R., and W. Stegmaier. 1987. "Engineered Storage Facility for Low Level Waste at Karlsruhe, Federal Republic of Germany." In Proceedings of the Ninth Annual DOE Low-Level Waste Management Conference, pp. 121-144. CONF-870859, August 25-27, 1987, Denver, Colorado.

Lakey, L. T. 1987. 'Foreign Travel Report, June 5-13, 1987.' Pacific Northwest Laboratory, Richland, Washington.

Laser, M., et al. 1987. "Incineration of Low-Level Radioactive Waste - Experience with Installation, Operation and Decommissioning of an incineration Plant.' In Proceedings of 1987 International Waste Management Corference. November 29-December 5, 1987, Hong Kong.

Luckscheiter, B. 1987. 'Performance of Solidified High-Level Waste Forms and Engineered Barriers Under Repository Conditions.' International Atomic Energy Agency Coordinated Research Program, Vienna.

Messer, K. P., and H.J. Dibbert. 1987. "Recycling of Plutonium in LWRs in Germany." Nuclear Technology International:1987, London, pp. 129-131.

Mies, H. P., and W. Stang. 1987. "Decommissioning of Nuclear Power Plant Gundremmingen Unit A." In Proceedings of The 1987 International Decommissioning Symposium, Vol. 1, pp. III-31 to III-49. CONF-871018, October 4-8, 1987, Pittsburgh, Pennsylvania. 
Müller, K, and H. U. Freund. 1987. Testing the Demolition of Concrete and Pipes with Explosive Charges within a Nuclear Power Plant.' In Proceedings of The 1987 Decommissioning Symposium, Vol. 2, pp. IV-285 to IV-297. CONF-871018, October 4-8, 1987, Pittsburgh, Pennsylvania.

Nuclear Engineering international (NEI). 9/87. "Germany and China Start Negotiations on Nuclear Cooperation," p. 13.

Nuclear Europe (NE). 1-2/87. "Nuclear R\&D in Germany," p. 21.

Nuclear Europe (NE). 5/87. "F.R. Germany and USSR Seal Nuclear Cooperation Pact," p. 51.

Nuclear Fuel (NF). 12/14/87. 'MOX Fuel Reprocessed Successfully at Karlsruhe's WAK Facility," p. 10.

Nuclear News (NN). 1/87. "Decommissioning License for Gundremmingen A," p. 65.

Nuclear News (NN). 2/87. "A New Radiation Protection Law," p. 52.

Nucleonics Week (NW). 2/12/87. THTR-300 Operator Undaunted by Longer Project Horizons," pp. 11-15.

Nucleonics Week (NW). 8/6/87. 'Two Germanies to Ink Nuclear Pact as East's Waste Site is Questioned;' p. 9.

Nucleonics Week (NW). 12/17/87. "Federal Authorities Prepared to Purchase Konrad Depository Site," p. 7.

NUKEM Market Report on the Nuclear Fuel Cycle (NUKEM). 1/87. "Reprocessing and Waste Management: Review 1986.' NUKEM GmbH, Hanau, Federal Republic of Germany, p. 12.

NUKEM Market Report on the Nuclear Fuel Cycle (NUKEM). 12/87. "Reprocessing and Waste Management Activities: Germany.' NUKEM GmbH, Hanau, Federal Republic of Germany, pp. 8-13. Peehs, M., J. Banck, and R. Bokelmann. 1987. 'Spent Fuel Storage Performance Data and Storage Strategy Assessment." In Proceedings of the IAEA International Conference on Nuclear Power Performance and Safety. IAEA-CN-48/00108, September 28 - October 2, 1987, Vienna.

Petroll, M. 1987. 'Taking the Worry Out of the Back End of the Fuel Cycle.' Nuclear Europe. Berne, Switzerland, January/February 1987, pp. 25-27.

PTB. 11/29/87. Information release from the Physikalisch-Technische (PTB).

Sappock, M. 1987. "Results of Metallic Waste Treatment by Melting." In The 1987 Ünternational Decommissioning Symposium, Vol. 1, pp. III-115 to III-127. October 4-8, 1987, Pittsburgh, Pennsylvania.

Willax, H. O., and M. Weishaupt. 1987. "Reprocessing Plant Karlsruhe (WAK) Plant Experience and Future Tasks." In Proceedings of the international Conference on Nuclear Fuel Reprocessing and Waste Management, pp. 203-209. August 23-27, 1987, Paris.

-1988 .

ATW News (ATW). 3/88. 'PTB Buys Konrad Mine," p. 4.

ATW News (ATW). B/88. "Radioactive Waste Arisings by Late 1987;' p. 6. 
Barnert, E., and H. Bruecher. 1988. "Final Disposal of Intermediate Level Reprocessing Wastes in Boreholes in a Salt Repository.' In Proceedings of An IAEA/CEC Symposium on the Management of Low and Intermediate Level Wastes 1988, pp. 179-186. May 16-20, 1988, Stockholm.

Berg, H. P., P. W. Brennecke, and B. R. Thomauske. 1988. The German KONFAD Repository Project.' Progress in Nuclear Energy, 20, (3):255-307.

Brennecke, P. J. Schumacher, and E. Warnecke. 1988. "Radioactive Waste in Germany." Nuclear Europe, January/February 1988, pp. 34-35.

Brouns, R. A., and J. A. Powell. 1988. Nuclear Waste Treatment Program Annual Report for FY-1987. Pacific Northwest Laboratory, Richland, Washington, pp. 2.1-2.60.

Closs, K D., and R. Papp. 1988. 'Status of 'Entsorgung' in the Federal Republic of Germany." In Proceedings of The Symposium on Waste Management ' 88 , Vol. 2, pp. 267-273. February 28 to March 3, 1988, Tucson, Arizona.

Einfeld, K. 1988. 'The Gorleben Pilot Conditioning Plant.: Nuclear Technology International: 1988. Sterling Publications Limited, London, pp. 92-95.

Essmann, J., and G. Lukacs. 1988. "Experience and Strategy of Decommissioning NPPs in the Federal Republic of Germany.' Nuclear Europe, October 1988, n. 10, pp. 34-36.

FRG-US Workshop. 3/88. Proceedings of the Joint United States/Federal Republic of Germany Technical Exchange Conference on Nuclear Waste. March 8-11, 1988, Albuquerque, New Mexico. U.S. Department of Energy, Washington, D.C.

Frotscher, H., and G. Boehme. 1988. 'Characterization and Conditioning of LWR Hull Wastes at the Kernforschungszentrum Karlsruhe." In Proceedings of the IAEA/CEC Symposium on the Management of Low and Intermediate Level Radioactive Wastes, Vol. 1, pp. 359-369, May 16-20, 1988, Stockholm. Hübenthal, K. 1988. "Policy of the Federal of Germany Concerning Management of Low and Intermediate Level Wastes." In Proceedings of an IAEA/CEC Symposium on the Management of Low and intermediate Level Wastes, pp. 13-16. May 16-20, 1988, Stockholm.

International Atomic Energy Agency (IAEA). 1988. The Nuclear Fuel Cycle Information System: A Directory of Nuclear Fuel Cycle Facilities, International Atomic Energy Agency, Vienna.

Janberg, K. G. 1988. "Waste Management with Special Emphasis on Volume Reduction." In Proceedings of The Symposium on Waste Management (Waste Management '88), pp. 911-912. February 28 - March 3, 1988, Tucson, Arizona.

Löschhorn, U., U. Birkhold, and W. Stasch. 1988. "Decommissioning of Germany's Niederaichbach NPP:" Nuclear Europe, n. 10, October 1988, pp. 32-33.

Merz, E. R., S. Halaszovich, M. Laser, and M. E. Wacks. 1989. 'Management of Mixed Wastes in the Federal Republic of Germany." In Proceedings of the IAEA Symposium on the Management of Low and Intermediate Level Wastes: 1988, pp. 393-404. May 16-20, 1988, Stockholm.

Nuclear Energy Agency (NEA). 4/88. Radioactive Waste Management in the Federal Republic of Germany. (RWM/DOC (88)15), summary prepared for the Radioactive Waste Management Committee of the OECD/Nuclear Energy Agency, Paris. 
Nuclear Energy Agency (NEA). 12/88. "Update on Waste Management Policies and Programmes: Federal Republic of Germany." Nuclear Waste Bulletin. OECD/Nuclear Energy Agency, N. 3.

December 1988, pp. 20-22.

Nuclear Energy Agency (NEA). 1988. Uranium Resources, Production and Demand. OECD/Nuclear Energy Agency, Paris.

Nuclear Fuel (NF). 3/21/88. 'NUKEM to Abandon Production of Research Feactor Fuel,' pp. 6-7.

Nuclear Fuel (NF). 9/19/88. 'West German Otlicials Okay Operation of Spent Fuel Store at Gorleben," pp. 6-7.

Nuclear Fuel (NF). 10/31/88. 'Post-Transnuklear Waste Regime Draws Fire from Industry, Regulators," pp. 3-4.

Nucleonics Week (NW). 8/25/88. "West German Utilities Turning to On-Site Liquid Waste Treatment," pp. 7-8.

Oeser, H.-R. 1988. "Tests and Developments on the German Pemote Maintenance Concept." In Proceedings of the ANS Imternational Topical Meeting on Nuclear and Hazardous Waste Management, SPECTRUM '88, pp. 361-364. September 11-15, 1988, Pasco, Washington.

Pfeifer, W. 1988. "Treatment, Conditioning and Packaging of Low and intermediate Level Radioactive Wastes at the Karlsruhe Nuclear Research Center.' In Proceedings of the 1988 DOE Model Conference on Waste Management, Vol. 1, pp. 255-263. CONF-881054, October 3-7, 1988, Oak Ridge, Tennessee.

Pfeiffer, R. 1988. "Conditioning of Liquid Waste at Karlsruhe Nuclear Research Center." In Proceedings of the ANS International Topical Meeting on Nuclear and Hazardous Waste Management, pp. 289-291. September 11-15, 1988, Pasco, Washington.

Schmidt, D., and B. Racky. 1988. "The Vitrification in the German Reprocessing Plant Wackersdorf: Status of Design, Arrangement and Maintenance Concept." in Proceedings of the ANS International Topical Meeting on Nuclear and Hazardous Waste Management, pp. 88-91. September 11.15, 1988, Pasco, Washington.

Storck, R. 1988. 'Site Specific Performance Assessments for Nuclear Waste Repositories in the FRG," Radiochimica Acta. R. Oldenbourg Verlag, Munich.

Warnecke, E., and W. Hild. 1988. "German Experience in the Field of Radionuclide Migration in the Geosphere." Radioactive Waste Management and the Nuclear Fuel Cycle. Harwood Academic Publishers, Vol. 10(1-3), pp. 115-144.

Weinlander, W. 1988. "Radioactive Waste Management in the Federal Republic of Germany." In Proceedings of the ANS International Topical Meeting on Nuclear and Hazardous Waste Management: Spectrum '88, pp. 450-453. September 11-15, 1988, Pasco, Washington.

Wiese, H., and E. Ewest. 1988. 'Industrial Vitrification of High Level Liquid Waste with the PAMELA Plant in Belgium." In Proceedings of the ANS International Topical Meeting on Nuclear and Hazardous Waste Management: Spectrum '88, pp. 75-77. September 11-15, 1988, Pasco, Washington. 
$-1989-$

ATW News (ATW). 3/89. "Large-Scale Experiment on In Situ Disposal Techniques Completed," p. 7

ATW News (ATW). 6/89. 'KfK: New Incinoration Plant for Radioactive Waste," p. 5.

ATW News (ATW). 10/89. "1990 BMFT Draft Budget," p. 6.

ATW News (ATW). 12/89. "Federal Office for Radiation Protection Inaugurated with Professor Kaul as President," pp. 2-3.

Bach, R. 1989. "Aspects of Spent MOX Fuel Transports." In Proceedings of The 9th international Symposium on the Packaging and Transportation of Radioactive Materials, pp. 1123-1135.

June 11-16, 1989, Washington, D.C.

Bechthold, W., S. Heusermann, C. Schrimpf, and G. E. Gommlich. 1989. "Large-Scale Test on In Situ Backfill Properties and Behavior under Reference Repository Conditions." In Proceedings of an NEA/CEC Workshop on Sealing of Radioactive Waste Repositories, pp. 111-122. May 22-25, 1989, Braunschweig, Federal Republic of Germany. OECD Publications, Paris.

Best, A., and H. Genthner. 1989. "Solidification of Low-Level Radioactive Waste with Microwaves." In Proceedings of the 1989 Joint International Waste Management Conference on Low- and IntermediateLevel Radioactive Waste Management, Vol. 1, pp. 311-316. October 22-28, 1989, Kyoto, Japan.

Closs, K. D., R. Papp, W. Bechtold, H. J. Engelmann, and B. Hartje. 1989. 'Thermal, Operational and Economic Aspects of Repository Design Alternatives." In Proceedings of the 1989 Joint international Waste Management Conference on Low- and Intermediate-Level Radioactive Waste Management, pp. 417-425. October 22-28, 1989, Kyoto, Japan.

Flach, D., and U. Yaramanci. 1989. 'Geophysical Investigations in a Sealing Construction and Test Site in Rock Salt: Seismology, Seismic Topography and Geoelectrics." In Proceedings of a NEA/CEC Workshop on Sealing of Radioactive Waste Repositories, pp. 163-172. May 22-25, 1989, Braunschweig, Federal Republic of Germany. OECD Publications, Paris.

KfK. 1989. "Development Status of Direct Disposal in the Federal Republic of Germany." R+DProgram: Direct Disposal. AE No. 23E, October 1989, p.S-1 to S-3.

Kienzler, B. 1989. "Characterization of the Near-Field of the HLW Form in a Salt Repository." Paper presented at the IAEA's Third Research Coordination Meeting on the Performance of Solidified HighLevel Waste Forms and Engineered Barriers under Repository Conditions. June 5-9, 1989, Winnipeg, Canada.

Krämer, H. 1989. "Nuclear Power in Germany - A Realistic Assessment of Future Direction." In Proceedings of the NEA International Symposium on Good Performance in Nuclear Projects, pp. 704-710. April 17-20, 1989, Tokyo.

Kuhn, K. D., W. Kunz, and W. Grünewald. 1989. "Vitrification of High-Level Waste in the FRG: Development and Operation of the PAMELA Process." In Proceedings of the Joint ASME/JAEA/JSME International Conterence on High Level Radioactive Waste and Spent Fuel Management, pp. 111-117. October 22-28, 1989, Kyoto, Japan.

Kuhn, K., and T. Rothfuchs. 1989. "In Situ Experiments on the Disposal of High-Level Radioactive Waste (HAW) at the Asse Salt Mine Federal Republic of Germany.' In Proceedings of The Symposium on Waste Management (WM '89), Vol. 1, pp. 567-573. February 26 - March 2, 1989, Tucson, Arizona. 
Langer, M., H. Schneider, and K Kuehn. 1989. The Salt Dome of Gorleben: Target Site for the German Repository for Radioactive Waste.' 28th International Geolocical Congress, LBL-27333, July 9-19, 1989, Washington, D.C., pp. 9-10.

Loschhorn, U., U. Birkhold, and W. Stasch. 1989. "Experience on Melting of Contaminated Steel Scrap and Treatment of Large Quantities of Low-Level Contaminated Steel for Unrestricted Release." In Proceedings of the 1989 Joint International Conference on Low- and Intermediate-Level Radioactive Waste Management, Vol. 1, pp. 437439. October 22-28, 1989, Kyoto, Japan.

Nuclear Energy Agency (NEA). 1989a. Projected Costs of Generated Electricity from Power Stations for Commissioning in the Period 1995-2000. OECD/Nuclear Energy Agency, Paris, p. 198.

Nuclear Energy Agency (NEA), 1989b. Plutonium Fuel: An Assessment. OECD/Nuclear Energy Agency, Paris, pp. 106-108.

Nuclear Energy Agency (NEA). 9/89. "GSF Builds Nuclear Waste Repository Pertormance Assessment Expertise." Nuclear Waste Bulletin, No. 4. OECD/NEA, Paris, pp, 10-11.

Nuclear Energy Agency (NEA). 12/89. Nuclear Law. Bulletin 44, OECD/Nuclear Energy Agency, Paris, pp. 60-62.

NEA/PTB. 1989. Nuclear Waste Management: Federal Republic of Germany. Brochure published by the OECD/Nuclear Energy Agency, Paris.

Nuclear Engineering International (NEl). 11/89. Wordd Nuclear Industry Handbook: 1989. Nuclear Engineering International, London.

Nuclear Engineering International (NEI). 12/89. 'DWK Considers Future Waste,' p. 5.

Nuclear Fuel (NF). 1/23/89. West German Fuel Fabricators Alkem, RBU Consolidated Under

Siemens-KWU Division," pp. 1-2.

Nuclear Fuel (NF). 7/10/89. "Abandoning Wackersdorf Will Cost German Utilities Another 1 Billion DM,' pp. 12-13.

Nuclear Fuel (NF). 8/7/89. 'RWE, With Majority Control, Will Direct Future Diversification of NUKEM,' pp. 6-7.

Nuclear Fuel (NF). 9/18/89. 'Brazil Will Develop Domestic Fuel Cycle If lts Nuclear Power Capacity Warrants," pp. 6-7.

Nuclear Fuel (NF). 11/13/89. 'German Utilities Urge Changes to Make Spent Fuel Disposal Viable Option," p. 6.

Nuclear Fuel (NF). 12/11/89. 'DWK to Lose Roles in Waste Management and Reprocessing, German Utilities Say,' pp. 5-6.

Nuclear News (NN). 7/89. "A Uranium Ore Processing Plant in Germany Has Been Closed,' p. 83.

Nuclear News (NN). 9/89. 'Siemens Hopes to Boost Hanau MOX Fuel Output," p. 54. 
Nuclear Engineering International (NEI). 11/89. "Decommissioning to Begin Immediately at THTR-300,' p.11.

Nucleonics Week (NW). 4/27/89. "Franco-German Committee to Study Areas for Nuclear Cooperation," p. 2.

Nucleonics Week (NW). 10/12/89. 'Big Federal Support is Over, West German Official Says,' p. 9.

Nucleonics Week (NW). 12/21/89. "Jülich Center Winding Down Nuclear Research Programs," p. 10.

NUKEM Market Report (NUKEM). 2/89. 'Reprocessing and Waste Management: Review 1988;

Germany," p. 8.

NUKEM Market Report (NUKEM). 3/89. "1988 Electricity Generation," pp. 8-12.

NUKEM. 5/89. 'The Nuclear Power Plant Capacities of Individual Countries.' NUKEM Special Report: The Nuclear Power Plant Capacity of the Western World. pp. 12-48.

NUKEM Market Peport (NUKEM). 6/89. "German Wackersdorf Peprocessing Project Suspended," pp. 7-11.

Numark N. J., H. W. Paige, and E. F. Wonder. 1989. Public Perception and Acceptance of the Siting of Nuclear Waste Facilities in Seven Countries. Report No. ERCE-H/89-42, Environmental and Energy Services Company, Fairfax, Virginia.

Nunno, T., J. Hyman, P. Spawn, J. Healy, C. Spears, and M. Brown. 1989. Assessment of International Technologies for Superfund Applications-- Technology Identification and Selection. EPA/600/2-89/017, U.S. EPA. May 1989, Cincinnati, Ohio, pp. 29-30.

Papp, A., K. D. Closs, W. Bechthold, H. J. Engelmann, and B. Hartje. 1989. Preliminary Results of the Systems Analysis Dual-Purpose Repository." In Proceedings of The Symposium on Waste

Management (WM '89), Vol. 1, pp. 55-61. February 26-March 2, 1989, Tucson, Arizona.

Schmieder, H. 1989. "Status of Reprocessing in the West and Japan," Nuclear Europe. JanuaryFebruary, 1989, pp. 40-41.

Schneider, K. J., L. T. Lakey, and D. J. Silviera. 1989. Survey of Waste Package Designs for Disposal of High-Level Waste/Spent Fuel in Selected Foreign Countries. PNL-6981, Pacific Northwest Laboratory, Richland, Washington.

Schüler, R., and P. Lopatta. 1989. 'The Role of NCS in the New Structure of the German Fuel Cycle Industry." In Proceedings of The 9th International Symposium on the Packaging and Transportation of Radioactive Materials (PATRAM '89), pp. 855-862. June 11-16, 1989, Washington, D.C.

Stegmaier, W., and W. Pfeifer. 1989. Producing Waste Packages in West Germany in Accordance with Waste Acceptance Requirements for Final Disposal." In Proceedings of the 1989 Joint International Waste Management Conference on High Level Radioactive Waste and Spent Fuel Management, pp. 521-526. October 22-28, 1989, Kyoto, Japan.

Strassburg, W., P. Dierkes, and P. Podewils. 1989. 'A System to Supervise Flow of Radwaste and Ensure its Quality for Disposal.' Nuclear Europe, September-October, 1989, pp. 39-40. 
Theenhaus, R., and S. Storch, 1989. IIntermediate Storage Systems and Experience with Spent HTR Fuel Elements.' In Praceedings of The 1989 Joint International Waste Management Conference on High Level Radioactive Waste and Spent Fuel Management, pp. 463-466. October 22-28, 1989, Kyoto, Japan.

Weiser, K. E., D. Aurich, and H. Wüstenberg. 1989. The Status of Ductile Iron Shipping and Storage Containers in the Federal Republic of Germany.' In Proceedings of The 9th International Symposium on the Packaging and Transportation of Radioactive Materials (PATRAM '89), pp. 701-711. June 1116, 1989, Washington, D.C.

$-1990$

ATW News (ATW). 1/90. "Nuclear Fuel Cycle Activities in Germany," p. 7.

ATW News (ATW). 2/90a. 'Contracts for Reprocessing Abroad Ready for Signature,' pp. 2-3.

ATW News (ATW). 2/90b. "Karlsruhe Nuclear Research Center: Status Report on Direct Disposal," p. 7.

ATW News (ATW). 4/90. 'Federal Cabinet Approves Reprocessing Contracts,' pp. 1-2.

ATW Nows (ATW). 5/90. "Production Progress in Pamela," pp, 6-7.

Berg, H. P., P. W. Brennecke, and B. R. Thomauske. 1988. "The German Konrad Repository Project." Progress in Nuclear Energy, 20(3):255-307.

Howles, L. 1990. "Annual Review of Load Factor Trends." Nuclear Engineering International, April 1990, pp. 12-18.

Nuclear Energy Agency (NEA). 6/90. "National Programmes and Policies: Federal Republic of Germany.' Nuclear Waste Bulletin. OECD/Nuclear Energy Agency, Paris, France, pp. 16-17.

Nuclear Engineering International (NEI). 2/90. "Wackersdorf License Formally Halted," p. 12.

Nuclear Fuel (NF). 1/8/90. "Future Uncertain for German Pilot Reprocessing Program," pp. 6-7.

Nuclear Fuel (NF). 2/5/90. "Swedes Transfer Reprocessing Rights to German Utilities,' pp. 13-14.

Nuclear Fuel (NF). 4/30/90. "Spent Fuel May Go To Gorleben, West German Court Rules," p. 9-10.

Nuclear News (NN). 3/90. "A Spent Fuel Conditioning Plant Can Be Built," p. 102.

Nucleonics Week (NW). 3/29/90. "East and West Germany to Write Quickly a Unified Atomic Act," pp. 7-8.

Nucleonics Week (NW). 4/12/90a. "West Germany's HTRs Waiting Decommissioning.' pp. 2-3.

Nucleonics Week (NW). 4/12/90b. "Germans Seek New Soviet Partner for HTR as Contract Plans Stall," pp. 1-2.

NUKEM Market Report (NUKEM). 2/90a, "Nuclear Power Plant Capacity of the Western World," pp. 28-29. 
NUKEM Market Report (NUKEM). 2/90b. "1989 Review: Germany." NUKEM GmbH, Hanau, Federal Republic of Germany, pp. 16-18.

Papp, R., K. D. Closs, W. Bechthold, U. Knapp, H. J. Engelmann, B. Hartje and C. Schrimpt. 1990. 'Results of the System Analysis Dual-Purpose Repository.' In Proceedings of The Symposium on Waste Management (WM '90), Vol. 2, pp. 685-691. February 25 -March 1, 1990, Tucson, Arizona.

Salander, C. 1990. "Radioactive Waste Disposal in the Federal Republic of Germany." Nuclear News, February 1990, pp. 97-100.

Schmict-Kuester, W-J. 1990. 'Disposal of Radwaste in F.R. Germany." Nuclear Europe, n.3/4, MarchApril 1990, p. 42.

Schneider, K. J., A. B. Johnson, S. J. Mitchell, R. F. Hazelton, L T. Lakey, and D. J. Bradley. 1990. Comparison of Selected Foreign Plans and Practices for Spent Fuel and High-Level Waste Management. PNL-7293, Pacific Northwest Laboratory, Richland, Washington.

Theenhaus, R., and S. Storch. 1990. The AVR High-Temperature Reactor - Operating Experience, Storage and Final Disposal of Spent Fuel Elements." In Proceedings of The Symposium on Waste Management (WM '90), Vol. 2, pp. 681-684. February 25 - March 1, 1990, Tucson, Arizona. 
INDIA 
INDIA

\section{INDIA}

\section{CONTENTS}

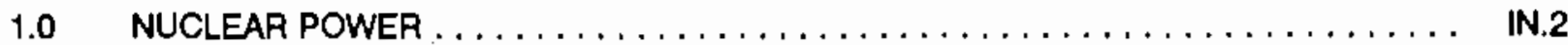

2.0 NUCLEAR FUEL CYCLE AND RADIOACTIVE WASTE MANAGEMENT

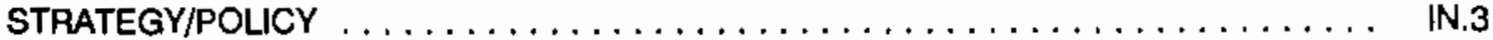

3.0 HIGHLIGHTS AND MAJOR MILESTONES $\ldots \ldots \ldots \ldots \ldots \ldots \ldots \ldots \ldots \ldots \ldots$

$4.0 \quad$ INSTITUTIONAL CONSIDERATIONS/ORGANIZATIONS $\ldots \ldots \ldots \ldots \ldots \ldots \ldots \ldots$

5.0 NUCLEAR FUEL PRODUCTION $\ldots \ldots \ldots \ldots \ldots \ldots \ldots \ldots \ldots \ldots \ldots \ldots$

6.0 FUEL RECYCLE $\ldots \ldots \ldots \ldots \ldots \ldots \ldots \ldots \ldots \ldots \ldots \ldots \ldots \ldots \ldots \ldots \ldots$

7.0 SPENT FUEL STORAGE AND TRANSPORT $\ldots \ldots \ldots \ldots \ldots \ldots \ldots \ldots \ldots \ldots$

8.0 WASTE CONDITIONING, STORAGE AND TRANSPORT $\ldots \ldots \ldots \ldots \ldots \ldots \ldots \ldots$ IN.10

9.0 DISPOSAL OF NON-HIGH-LEVEL WASTES $\ldots \ldots \ldots \ldots \ldots \ldots \ldots \ldots \ldots \ldots \ldots$

10.0 DISPOSAL OF HIGH-LEVEL WASTES $\ldots \ldots \ldots \ldots \ldots \ldots \ldots \ldots \ldots \ldots \ldots \ldots \ldots \ldots$

11.0 MANAGEMENT OF URANIUM MINE AND MILL WASTES $\ldots \ldots \ldots \ldots \ldots \ldots \ldots \ldots$

12.0 DECOMMISSIONING AND ENVIRONMENTAL RESTORATION $\ldots \ldots \ldots \ldots \ldots \ldots \ldots$ IN.16

13.0 INTERNATIONAL ACTIVITIES $\ldots \ldots \ldots \ldots \ldots \ldots \ldots \ldots \ldots \ldots \ldots \ldots \ldots$

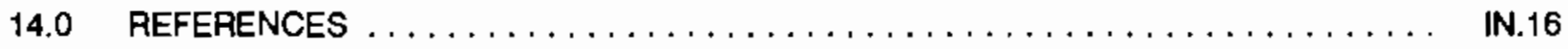




\subsection{NUCLEAR POWER}

1. 7 REACTOR MIX: 5 PHWRs, 2 BWRs, $140-M W e$ FBR Test Reactor

1.2 ELECTRIC POWER PRODUCTION: 166 TWh in 1988 (Leigh and Mitchell 1990); 58\% coat in $1987 ; 33 \%$ hydro in $1987 ; 6 \%$ oil, $3 \%$ nuclear in 1988

Capacity in 1989 was 58,000 MWe (Murthy 1990); capacity in 2000 is projected at $174,000 \mathrm{MWe}$, with nuclear at $5.8 \%$ of this total (Murthy 1990)

\subsection{NUCLEAF POWER CAPACITY PROJECTIONS -}

1989-1.5 GWe

1990-1.7 GWe

1995--2.4 GWe

2000-4.4 GWe (NUKEM 2/90)

--10.0 GWe target with 24 indigenous and 6 foreign reactors (NEI 3/89)

A. India plans to build some 500-MWe breeder reactors early during the 21st century (AIJ 4/87); a prototype FBR 500-MWe power reactor is planned at Kalpakkam, and planned for start-up about the year 2000; the reactor will use mixed plutonium-uranium carbide fuels and will be cooled by sodium (NEI 1/90)

B. The government signed an agreement with the USSR in 1988 to build a nuclear power station of $2000 \mathrm{MWe}$ at Koodankulam with Soviet credit (all equipment and subsystems will come from the USSR); the project will consist of two 1000-MWe PWRs of the Soviet WER type; Finland will provide architect-engineering support services; these reactors, to be completed in the late 1990s, will be in addition to the $10,000 \mathrm{MWe}$ indigenous nuclear program target, using mostly indigenous PHWRs (NEI 2/88; NEI 12/89)

1.4 NUCLEAR PLANT AVAILABILITY: Average in $1988=55.1 \%$ (IAEA 1988) Average lifetime through $1988=47.8 \%$ (IAEA 1988) Average lifetime through $1989=63.1 \%$ (Murthy 1990)

\subsection{NUCLEAR ENERGY POLICY}

A. India is placing heavy dependence on nuclear power to augment its electric power generating capacity; there is a three-phase program--in the first phase, reactors fueled with natural uranium will be used; in the second phase, FBRs fueled with plutonium produced by first-phase reactors will be used; in the third phase, self-sustaining thorium-uranium cycle reactors and fuel cycle system will take advantage of the large thorium resources in India (Murthy 1990)

B. For the period 1987 to about 2002, most nuclear reactors will be a series of 220 or $235 \mathrm{MWe}$ and $500 \mathrm{MWe}$ PHWRs; these are targeted to a goal of about 10,000 MWe nuclear capacity and would account for about $10 \%$ of the total national energy (Sarma 1987); as of 1990, six 500-MWe units have been government approved for construction, and another six are planned (Taylor 1990) 
1.6 NUCLEAR R\&D BUDGET: India's budget for FY 1989-1990 is 19.3 billion rupees (about $\$ 1.28$ billion U.S.), which is a $29 \%$ increase over the prior year; this funding also includes plant operations and design (NW 3/16/89)

\subsection{ELECTRICITY PRODUCTION COSTS}

A. Capital costs of nuclear units to go on-line in about 1993 are about $\$ 1280 / \mathrm{kW}$ installed, compared with about $\$ 1229$ for coal; total unit energy costs for nuclear and coal are $\$ 0.070$ to $\$ 0.082$ per $\mathrm{kWh}$, and $\$ 0.076$ to $\$ 0.099$, respectively (costs are about $15 \%$ lower than these if discounted cash flow is used) (Srinivasan 1987)

B. The planned prototype 500 MWe FBR will cost 10 billion rupees (about $\$ 580$ million U.S.) (NEI 1/90)

\subsection{NUCLEAR FUEL CYCLE AND RADIOACTIVE WASTE MANAGEMENT STRATEGY/POLICY (NEI 1/87)}

2.1 OVERALL NUCLEAR FUEL CYCLE POLICY: India's strategy is to achieve self-sufficiency in total CANDU-type reactors and LWR reactors and the associated fuel cycles: uranium mining, milting and conversion; uranium enrichment; fuel fabrication; heavy water production; reprocessing in small plants adjacent to nuclear power stations; this strategy has been achieved (Murthy 1988); if enriched $\mathrm{UF}_{6}$ supply for India's BWRs is cut off, it may fuel with $\mathrm{UO}_{2}-\mathrm{PuO}_{2}$ (Leigh and Mitchell 1990)

2.2 POLICY ON THE FRONT END OF THE NUCLEAR FUEL CYCLE: The strategy is to be independent in all capabilities on the front end of the fuel cycle; this includes uranium mining, milling and conversion, uranium enrichment, fuel fabrication, and heavy water production (NEI 1/87); India also plans to develop the FBR system, starting with a uranium-plutonium fuel system, then using mixed carbide fuels, and eventually switching to Th/U-233 cycle (Masters 1986; NW 3/5/87)

2.3 POLICY ON THE BACK END OF THE NUCLEAR FUEL CYCLE (Masters 1986)

A. Reprocess spent fuels for recovery and reuse of nuclear materials

B. Store HLLW for a few years in underground, high-integrity stainless steel tanks; then the HLLW will be vitrified and stored for at least 20 years before disposal

C. Dispose of HLW glass and alpha-contaminated materials in a deep geologic repository--granite or gneiss

D. Use extended engineered storage near the surface for LLW and ILW

E. Follow the ALARA principle concerning discharges of radioactivity to the environment

\subsection{HIGHLIGHTS AND MAJOR MILESTONES}


Hot startup of the reprocessing plant at Tarapur

Warm" startup of WIP (Waste Immobilization Plant) HLW vitrification facility at Tarapur

Criticality of 12-MWe fast breeder test reactor (FBTR) at Kalpakkam achieved

Startup of Thal Vaishet heavy water production plant (NW 11/27/86)

Interim storage facility for vitrified HLW commissioned at Tarapur

1987

Electricity generation at the FBTR at Kalpakkam started (NEI 6/87)

1989 Startup, at full radioactivity level, of the HLW immobilization plant at Tarapur

Startup of HLW immobilization plant at BARC, Trombay

Startup of air-cooled dry storage facility for vitrified HLW at Tarapur

1993 Hot startup of Kalpakkam plant for vitrifying HLW from FBR fuel reprocessing

Hot startup of Kalpakkam plant for vitrifying HLW from the FBR fuel reprocessing plant

\subsection{INSTITUTIONAL CONSIDERATIONS/ORGANIZATIONS}

4.1 RADIATION PROTECTION PRINCIPLES: Radioactive releases to the environment should be as low as reasonably achievable (NEJ 8/87)

4.2 KEY AGENCIES AND FUEL CYCLE CENTERS (NEI 5/87; Leigh and Mitchell 1990)

A. DAE (Department of Atomic Energy, cabinet level) is responsible for all aspects of nuclear energy in India

1) DAE's major nuclear fuels complex is at Hyderabad; it has a uranium refining and conversion facility, a fuel fabrication facility, a zirconium fabrication facility, a fuel assembly components production facility, and a fuel assembly facility (IAEA 1987)

2) DAE has a uranium refining and conversion facility at Trombay; it has fuel reprocessing facilities at Kalpakkam, Tarapur and Trombay; it also has a plutonium fuel fabrication facility for FBRs (IAEA 1987)

3) DAE has six heaw water production facilities and more are planned (IAEA 1987)

4) The Atomic Energy Regulatory Board reports to DAE; it formulates regulations and licenses nuclear facilities 
5) The Nuclear Power Corporation reports to DAE; it is responsible for design, construction, and operation/maintenance of nuclear power stations

a. The Tarapur atomic power station: it includes a pilot-scale fuel reprocessing plant and a HLLW vitrification plant

b. The Kalpakkam (Madras) nuclear power station: it includes a pilot-scale fuel reprocessing plant and a future HLLW vitrification plant

B. The Atomic Energy Commission (reports to DAE): it has the BARC research center at Trombay, which includes a pilot-scale fuel reprocessing plant and a HLLW vitrification plant; it also includes a uranium metal plant, a thorium plant, and several waste treatment facilities

C. India has two uranium mines with adjacent mills and others are planned (IAEA 1987)

\subsection{PRINCIPAL RESEARCH, DEVELOPMENT AND DEMONSTRATION FACILITIES/PROGRAMS}

\section{A. Atomic Energy Commission}

1) BARC (Bhabha Atomic Research Center) at Trombay, Bombay, carries out fuel cycle, waste vitrification and disposal R\&D, and R\&D on uranium ore processing (Murthy 1988); BARC also carries out isotope production and processing; it has five test reactors, a number of pilot-scale facilities for fuel reprocessing, isotope production and processing, fuel materials production (heavy water, zirconium, titanium, thorium) and related R\&D; it has facilities for treatment of alpha-emitting wastes (incineration, wet oxidation), immobilization of fuel cladding hulls, and decommissioning R\&D (Leigh and Mitchell 1990); the budget for BARC for FY-1989-90 is 1.8 billion rupees (about $\$ 120$ million U.S.) (NW $3 / 16 / 90)$

2) IGCAR (The Indira Ghandi Centre for Atomic Research) at Kalpakkam carries out fuel cycle R\&D, including FBR fuel reprocessing and waste management; it has an interim storage facility for vitrified $\mathrm{HLW}$; it has a fast breeder test reactor and a thorium-fueled test reactor (Kamini reactor, $30 \mathrm{~kW}$ ); it carries out major R\&D on FBR power reactors (NEI 1/90; Leigh and Mitchell 1990); a nuclear science center was established at the University of Madras in 1989 with linkage to IGCAR; the center will have a cyclotron facility for production of short-lived nuclides, a linear electron accelerator, a laser laboratory, a trace analysis laboratory, a radiation measurement laboratory, and a radiobiology laboratory (NEl 3/89; NEI 5/89; Raj 1989)

3) CAT (Center for Advanced Technologies) was initiated at Indore in 1987; it carries out research on accelerators, lasers and fusion; the CAT budget for FY 1989-1990 is 120 million rupees (about $\$ 8$ million) (NW $3 / 16 / 89)$ 
4.4 KEY PERSONNEL (Leigh and Mitchell 1990)
A. P. K. lyengar, Chairman, Atomic Energy Commission, and Secretary, Department of Atomic Energy
B. N. S. Sunder Rajan, Head, Waste Management Division, BARC
C. R. V. Amalraj, Central Waste Management Facility, Kalpakkam
D. V. Sundaram, Director, IGCAR

\subsection{NUCLEAR FUEL PRODUCTION}

5.1 STRATEGY: To be independent in producing all nuclear fuel within India (Masters 1986)

5.2 URANIUM RESOURCES: $45,000 \mathrm{MTU}$ (all low grade, $0.4-1.0 \mathrm{~kg} \mathrm{U} \mathrm{U}_{3} \mathrm{O}_{8}$ per MT of ore) are reasonably assured (Murthy 1988; NW 2/20/90)

\subsection{THORIUM RESOURCES: $350,000 \mathrm{MT}$ (NW 2/22/90)}

5.4 URANIUM PRODUCTION: All steps in the production of fuel for nuclear reactors are provided in India (Murthy 1988)

A. India's estimated production in 1987 was $170 \mathrm{MTU}$ (NEI 12/87); it plans for 1700 MTU/yr by year 2020 (NEI 5/87)

B. Two mines are operating: one at Jaduguda, including a mill with a capacity of $1,000 \mathrm{MT}$ of ore per day; another is at Bhatin, with a capacity of $250 \mathrm{MT}$ of ore per day; two other mines at Narwa Pahar and Taranidhi are planned; the mine at Jaduguda is 300 to 600 meters deep and will be deepened to 900 meters by 1993; it has a deposit containing about 50,000 MT of uranium ore (NEI 9/88; NFC 1/90)

C. In India, ore is processed by sulfuric acid leaching, ion-exchange concentration and final precipitation as magnesium diuranate (yellowcake) containing $70 \% \mathrm{U}_{3} \mathrm{O}_{8} ; \mathrm{R} \& \mathrm{D}$ and some production of uranium is done by recovery from copper ores and beach sands; trace quantities of copper, nickel and molybdenum are recovered as byproducts from uranium ore processing (Murthy 1988)

\subsection{URANIUM REFINING AND CONVERSION}

A. A facility at Hyderabad converts yellowcake to uranium dioxide, with a capacity in 1984 of $50 \mathrm{MTU} / \mathrm{yr}$; a second facility at Trombay converts yellowcake to uranium (IAEA 1987)

B. A pilot-scale facility has been developed at BARC to convert reprocessed uranyl nitrate to yellowcake by precipitation with ammonia; the capacily of the facility is $10-12 \mathrm{~kg} / \mathrm{hr}$ of uranium (NE 1-2/89)

5.6 URANIUM ENAICHMENT: India has a modest R\&D program on centrifuge and laser enrichment; as of 1987, a large centrifuge facility was reportedly under 
construction in the southern state of Karnataka near Mysore (NW 3/5/87; NEl 6/87); a centrifuge enrichment capability of $28 \mathrm{~kg} / \mathrm{yr}$ of uranium-235 has been reported (NN 2/89)

\subsection{FUEL FABRICATION}

A. The Hyderabad Nuclear Fuel Cycle (NFC) complex, a DAE company, operates a facility for fabrication of all power reactors in India (NEI 12/87); indigenous natural uranium is used for the PHWR, and enriched uranium from France is used for its BWRs (Taylor 1990); the facility also makes zirconium tubes and other fuel parts

1) 1984: $200 \mathrm{MT} / \mathrm{yr}$ capacity (NEI 1/84)

2) 1990: $1000 \mathrm{MT} / \mathrm{yr}$ projected capacity

3) 2002: $1500 \mathrm{MT} / \mathrm{yr}$ projected capacity (NEI 5/87)

B. A small fuel fabrication facility is located at the Bhabha Atomic Research Center, and has the capacity to produce $135 \mathrm{MTU} / \mathrm{yr}$ for PHWR and other fuels, including mixed uranium-plutonium fuels (IAEA 1987)

C. Three new nuclear fuel plants are planned to increase India's fuel production from $65 \mathrm{MT} / \mathrm{yr}$ to $1800 \mathrm{MT} / \mathrm{yr}$ by year 2000; licenses for the plants have been applied for; the three plants will be at Palakayal in Tamil Nadu, in the NFC complex at Hyderabad, and at Turamdih in Bihar, reportedly to be another major nuclear fuel complex ( $10 \mathrm{~km}$ from Jamshedpur and $30 \mathrm{~km}$ from the Jadugora mine) (NEI 9/88; NEI 6/89)

D. Zirconium is produced domestically from beach sand at a facility at Hyderabad (IAEA 1987; Murthy 1988); zircaloy production and fabrication by year 2002 is planned to be $250 \mathrm{MT} / \mathrm{yr}$ (NEI 5/87)

E. The FBTR at Kalpakkam is fueled with plutonium and uranium carbides, fabricated domestically (plutonium fuels at Kalpakkam, fuel pins at BARC, assemblies at the NFC) (Rippon 1985)

F. The enriched fuel for the future two PWRs from the USSR will be supplied by the USSR for the life of the reactors (NUKEM 5/89)

5.8 HEAVY WATER PRODUCTION: Production is in five plants: Thal Vaishet facility (capacity $110 \mathrm{MT} / \mathrm{yr}$ ); Talcher (facility was shutdown by fire in spring 1986; restarted 1987; capacity $63 \mathrm{MT} / \mathrm{yr}$ and expected to be $72 \mathrm{MT} / \mathrm{yr}$ in 1990); Baroda facility (capacity $67 \mathrm{MT} / \mathrm{yr}$ ); Tuticorin facility (capacity $71 \mathrm{MT} / \mathrm{yr}$ ); Kota facility (capacity $100 \mathrm{MT} / \mathrm{yr}$ ); also, the Manuguru facility (capacity $185 \mathrm{MT} / \mathrm{yr}$ and costing 64 billion rupees) is to be started up in 1990, and a mine at Hazira in Gujarat is under development and should start up in 1990 (NW 11/27/86; NF 6/29/87; IAEA 1987; NEI $8 / 87$; NEI 1/89; NEI 8/89)

A. Four new units are planned with an aggregate capacity of $970 \mathrm{MT} / \mathrm{yr}$ (NEI 5/87)

B. India is having operating problems with its heavy water plants and is increasing heavy water imports from the Soviet Union (NW 3/24/88) 
C. A 1972 appraisal anticipated the production of heavy water to outstrip the demand by 1979; however, the four plants at Tuticorin, Talcher, Baroda, and Kota did not reach the production goals (NW 3/10/88)

5.9 PLUTONIUM PRODUCTION: India can produce up to $55 \mathrm{lbs} / \mathrm{yr}$ of weapons-grade plutonium in the Dhruva Research Reactor (100-MW high-flux reactor started up August 1985) (NW 3/5/87)

\subsection{FUEL RECYCLE}

6.1 FUEL REPROCESSING: India has used several small reprocessing plants for several years, each using the PUREX process; however, India is planning to build reprocessing plants of 350-400 MTHM/yr capacity to reach a total capacity of 1000 MTU/yr (MacLachlan 1985; NEI 5/87; Leigh and Mitchell 1990)

A. Trombay pilot reprocessing plant:

1) Original design capacity was $0.1-0.15 \mathrm{MTU} / \mathrm{d}, 30 \mathrm{MTU} / \mathrm{yr}$; facility is contact-maintained

2) The facility reprocesses uranium metal fuel using the PUREX process following chemical decladding; final purification is by ion exchange; in also separates plutonium from the Cyrene and Dhruva test reactors at Trombay; it has a separate pilot-scale facility for separating uranium233 from thorium fuels

3) The operating schedule has been:

1964-1974: operational

1974-1983: modification and expansion

1983-present: operational

B. Tarapur Reprocessing Plant: the plant reprocesses natural and low-enriched uranium dioxide fuels from the Tarapur Nuclear Power Reactors (BWRs) and spent fuel from the Rajasthan Atomic Power Station (NE1 2/89); its design capacity is $0.5 \mathrm{MTHM} / \mathrm{d}$ or $100 \mathrm{MTU} / \mathrm{yr}$; it uses a chop-leach process for dissolution of fuel materials; it uses the PUREX process with uranous nitrate for partitioning uranium and plutonium; it uses contact maintenance; it was completed in 1976 and hot startup was in 1982

C. Kalpakkam Reprocessing Plant: it is located near the Kalpakkam Power plant; its design capacity is $0.5 \mathrm{MTHM} / \mathrm{d}$ for PHWR fuels from the Kalpakkam (Madras) power station; the facility can handie FBTR carbide and PHWR fuels in separate lines; cold operation will start in 1991 (MacLachlan 1985; Mellinger 1984)

D. The spent fuel from the two future Soviet 1000-MWe PWRs will be returned to the USSR for reprocessing (NEI 12/89)

6.2 PLUTONIUM RECYCLE: India may recycle plutonium to its BWRs, but the principal emphasis is on future recycle to breeder system (AIJ 4/87) 


\subsection{RESEARCH AND DEVELOPMENT}

A. R\&D in India is carried out at Kalpakkam on development of process equipment ior the FBR fuel reprocessing plart (Selvaraj 1984)

B. R\&D is being carried out on separation of neptunium, americium, curium and californium for possible reuse in nuclear fuels (NWN 6/15/89)

\subsection{SPENT FUEL STORAGE AND TRANSPORT}

7.1 SPENT FUEL ARISINGS: (Leigh and Mitchell 1990)

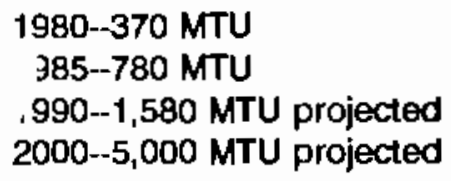

7.2 WET STORAGE: In India, storage of PHWR fuel is in horizomtal racks in relatively shallow pools; it has been demonstrated successfully (Johnson 1986)

A. Storage of PHWR tuels in horizontal racks in relatively shallow pools has been used successfully at the Rajasthan and Madras Atomic Power Stations; at Rajasthan, PHWR fuels are stored horizontally in tray-like racks with fuel assemblies stacked up to 30 high, for a total capacity of 32,200 assemblies as of 1989 (Johnson 1986; Srivastava 1989)

B. A pool-type 'AFR' was built about $0.5 \mathrm{~km}$ from the Tarapur Atomic Power Station; the stainless steel lined AFR pool is $8 \mathrm{~m}$ wide by $13 \mathrm{~m}$ long by $13 \mathrm{~m}$ deep; the pool capacity is 3312 BWR assemblies in $12 \times 12$ assembly racks that will provide space for all the spent fuel discharged for Tarapur over its expected life of 30 years; provisions have also been made to receive and store spent PHWR fuel in the AFR in case of emergency; the AFR can handle the 70 MT casks that are brought in by tractor-trailers (Srivastava 1989)

\subsection{DRY STORAGE}

A. Four dry storage casks, designed and built indigenously, were used at Tarapur starting in 1987; each of the casks holds 37 BWR fuel assemblies; the casks are shielded with $114 \mathrm{~mm}$ of lead, with a 50- $\mathrm{mm}$ stainless steel outer shell and a $12-\mathrm{mm}$ stainless steel inner liner; the cask cavity is $1165 \mathrm{~mm}$ in diameter and $4280 \mathrm{~mm}$ long (Srivastava 1989)

B. A study was completed in 1984 on using dry vault storage to supplement the limited at-reactor in-pool storage; pool storage was selected for increasing the storage capacity because of India's experience with it (Srivastava 1989)

\subsection{TRANSPORT}

A. The Indian policy is to reprocess fuel near power stations to minimize public transpontation, but some public transport is required; casks are designed and built indigenously and are consistert with IAEA transportation safety standards (Prasad 1985; Chandra 1989) 
B. Spent fuel shipping casks weighing from 25 to $70 \mathrm{MT}$ (weight is limited by handling capabilities at the terminals) have been designed and buik indigenously according to the Indian safety code SC/TR-1; the casks use lead shielding with a stainless steel inner cavity and a thick carbon steel outer shell that is usually clad with stainless steel; cask dimensions for BWR fuels are $5.3 \mathrm{~m}$ long by $2 \mathrm{~m}$ wide by $1.5 \mathrm{~m}$ high; dimensions for PHWR fuels are $3.3 \mathrm{~m}$ by $2.5 \mathrm{~m}$ by $2.4 \mathrm{~m}$ high; some have fins and some do not (Prasad 1985; Joshi 1989; Chandra 1989)

C. Spent fuel from the Rajasthan Atomic Power Station (PHWRs) is transported in cube-shaped casks with fins that weigh $70 \mathrm{MT}$ empty and $75 \mathrm{MT}$ full; the overall outer dimensions are $2.2 \mathrm{~m}$ by $1.8 \mathrm{~m}$ by $1.8 \mathrm{~m}$ high, and the inner cavity is $1.6 \mathrm{~m}$ by $1.2 \mathrm{~m}$ by $1.2 \mathrm{~m}$ high; the cask uses $250 \mathrm{~mm}$ lead shielding between a 12-mmthick stainless steel inner liner and 38-mm-thick mild steel outer shell; the cask carries 20 trays that carry 11 fuel bundles each; transport is by a special train that is limited to $30 \mathrm{~km} / \mathrm{hr}$, and includes a radiation monitor; some highway transport of the cask is used, and includes the use of an escort vehicle (Joshi 1989)

\subsection{WASTE CONDITIONING, STORAGE AND TRANSPORT (Rajan 1986; Masters} 1986; Samuel 1987; NW 3/5/87)

\subsection{WASTE ARISINGS (Rajan 1986; NWN 1/15/87)}

A. Arising in 1985: $1850 \mathrm{~m}^{3}$ of primary solid LW wastes; $3000 \mathrm{~m}^{3}$ of LLW concentrates; $800 \mathrm{~m}^{3}$ of ILW; and $450 \mathrm{~m}^{3}$ of $\mathrm{HLW}$

B. Cumulative arisings expected in 2000: $107,000 \mathrm{~m}^{3}$ of primary solid wastes (up to $10,000 \mathrm{rad} / \mathrm{hr}$ ); $77,000 \mathrm{~m}^{3}$ of LW concentrates; $19,900 \mathrm{~m}^{3}$ ILW; $8000 \mathrm{~m}^{3}$ HLLW (volume is to be reduced by a factor of 20 by vitrification) (NEJ 8/87)

\subsection{STRATEGY}

A. HLLW: Store as acid in stainless steel tanks for 3-5 years after reprocessing, then vitrify and store for 25 years (Rajan 1986; NEJ 8/87)

B. Spent fuel cladding hulls: partially decontaminate by various washes; compact and store in 200-liter drums

C. ILW: reduce volume and incorporate into bitumen, cement or polymers; store in engineered, near-surface facilities near source

\subsection{HLW IMMOBILIZATION}

A. HLLW from interim storage is concentrated in an evaporator before vitritication (Raj 1989)

B. The remotely operated and maintained WIP facility Waste Immobilization Plant) at Tarapur is used to convert HUW at Tarapur to borosilicate glass (Nei 8/87; NEI 2/89; Raj 1989; Samuel 1989) 
1) The "pot-glass' process first calcines HLLW (added along with glassmaking additives) at $600^{\circ} \mathrm{C}$ in a metal melter vessel until the melter vessel is about $75 \%$ full; the calcine is then melted at $950-1000^{\circ} \mathrm{C}$ in the same melter vessel; heating is with a three-zone induction furnace; the Inconel-690 metter is $0.325 \mathrm{~m}$ in outside diameter and is $1.8 \mathrm{~m}$ long

2) The melter is drained through a drain pipe (freeze valve) into a stainless steel canister that is insulated to retard cooling; the 304- $\mathrm{L}$ stainless steel canisters are $0.325 \mathrm{~m}$ in outside diameter by $0.775 \mathrm{~m}$ high (wall thickness is $10 \mathrm{~mm}$ ), and contain $125 \mathrm{~kg}$ in 45 liters of glass (27 $w t \%$ waste oxides) in a canister; the heat generation rate in a canister is up to $1.75 \mathrm{~kW}$

3) After sealing the canister by automatic welding of the lid, the canisters are inserted into a carbon steel overpack, the lid is welded on, and the overpack (with two canisters) is taken to the interim storage facility

4) The process capacity is 25 liters/hr (600 liters/d) of HLLW processed combined for the two process lines, producing one canister/day; each of the two calcining/ melting furnaces is rated to produce $4 \mathrm{~kg} / \mathrm{hr}$ of glass; each reference canister will contain about 94,000 curies and will emit an estimated $393 \mathrm{~W}$ of heat initially

5) For quality assurance: the weld joint of the lid to the canister is checked by helium leak detection; waste canisters are selected at random and core drilled

6) Construction was completed in 1981; "warm" commissioning tests were made in 1985-1986; and the facility was expected to start up fully radioactively in late 1989 (Raj 1989)

C. The WIP facility at the IGCAR at Kalpakkam will be used to vitrify HLLW from the Kalpakkam reprocessing plant (spent fuel from the Madras Atomic Power Station, from the FBTR, and the future prototype fast breeder reactor, PFBR), into borosilicate glass (Raj 1989)

1) The process and facility is similar to the one at Tarapur, but of advanced design

2) Radioactive startup is planned for 1993

A. The WIP facility at Trombay will be used to vitrify HLLW from the Trombay reprocessing plant into borosilicate glass (Raj 1989)

1) The process is similar to the one at Tarapur, but of advanced design

2) Radioactive startup is planned for 1990

\subsection{LLW/ILW CONDITIONING}

A. Liquid wastes from reactor and reprocessing operotions (Rajan 1986; NEJ 8/87; Leigh and Mitchell 1990): 
1) Volume reduction is by chemical methods, ion exchange and evaporation; a non-boiling solar evaporation unit is used for $\amalg W$ at Rajasthan

2) Cement and cement composites are used for immobilization of LLW concentrates; at Tarapur, the mixing is done semi-continuously

3) Bitumen matrixes are used for immobilization of ILW; the bituminization plant at Tarapur has a capacity of $120 \mathrm{liter} / \mathrm{hr}$ of wastes; the wastes and bitumen are processed through agitated film evaporators; about 1000 drums/yr are produced at Tarapur

4) Polymer matrixes containing vermiculite fines are used to immobilize reprocessing wastes generating low heat at the Tarapur station; waste content is up to $50 \%$ by volume of the final waste form; lifetime dose to the polymer is $\mathbf{5 0 0}$ million rad; as of 1986, wastes with a total of about 0.8 million curies were solidified with polymer

5) The planned Kaiga nuclear power stations (planned to have six CANDU. type reactors) will have a waste solidification facility and a deep disposal facility (NEI 6/89a)

8.5 LLW/ILW STORAGE: In India, $\amalg W$ and ILW are stored on the respective sites in surface facilities (NEI 12/87)

\subsection{HLW STORAGE}

A. In India, high-level liquid wastes are stored in high-integrity stainless steel tanks in underground vauts for 3-5 years (NEJ 8/87)

B. Vitrified HLW are to be interim stored for $20-25$ years to: 1) cool the vitrified waste so that it cannot met under any foreseeable condition; 2) ensure the integrity of the waste package before disposal; and 3) facilitate safe handling and transportation of the vitrified $H L W$ to the repository (Raj 1989)

C. Vitrified HLW from Tarapur and Trombay reprocessing facilities are to be stored for 20-25 years in engineered facilities with stack-induced (the stack is $100 \mathrm{~m}$ high) natural-draft air cooling; at Tarapur, the Solid Storage Surveillance Facility (SSSF) for these wastes is located at Tarapur; two canisters are stored vertically in a weld-sealed carbon-steel overpack container; the overpack is $0.356 \mathrm{~m}$ in diameter and $2.0 \mathrm{~m}$ long; the newlyfilled and sealed overpack is decontaminated in the vitrification cell and taken to the adjacent SSSF; the facility is to become operational in 19891990; the modular storage facility at Tarapur has two blocks subdivided into three compartments that can contain 332 double-canister storage units each, for a total of about $1700-2000$ overpack units (Rajan 1986; NW 3/5/87; NEI 8/87; Raj 1989; Samuel 1989)

D. Vitrified HLW from Trombay will be interim stored in an interim storage facility (ISF), with the capacity for 2000 overpack units; the facility is similar to that at Tarapur, but it uses vertical convection flow of air in an 
annulus between facility sleeves and the storage overpacks; as of 1989, the facility was under construction (Raj 1989)

E. Vitrified HLW from the Kalpakkam reprocessing facilities will be stored in an ISF onsite (Leigh and Mitchell 1990)

\subsection{RESEARCH AND DEVELOPMENT}

A. R\&D on solidification of HLW has been undertaken at BARC since the early 1960 s; currently, development of a joule-heated metter is underway for use in future higher-capacity needs (Raj 1989)

B. A 10-year program of vitrified waste storage in experimental storage assemblies simulating repository conditions is in progress; samples of wastes are taken periodically for examination and testing; one test canister is in a granite block (Samuel 1987)

C. A major program is being carried out in which detailed characteristics of the vitrified HLW are evaluated (Samuel 1987)

D. A fluidized bed incinerator, operating at $750^{\circ} \mathrm{C}$ for wet polystyrene-type ion exchange resins, has been under development at BARC, with a volume reduction of 20:1 (NEI 12/88)

\subsection{DISPOSAL OF NON-HIGH-LEVEL WASTES}

9.1 STRATEGY. India's strategy is to dispose of short-lived LLW/LW in near-surface formations, and long-lived ILW (such as alpha-bearing wastes) in deep geological formations (Rajan 1986)

9.2 ILW DISPOSAL (Rajan 1986; Godse 1986)

A. Disposal modules for bitumenized ILW at Tarapur are steel-lined concrete tile holes

B. Basalt fiows at Bombay, gneiss at Peninsular, and granite elsewhere are being examined for suitability for long-lived ILW disposal

C. The planned Kaiga Nuclear Power Station (planned to have six CANDU-type reactors) will have a deep disposal facility; an environmental survey laboratory will be set up to monitor the site (NEI 6/89a)

9.3 LLW DISPOSAL (Rajan 1986; Godse 1986)

A. Engineered disposal in near-surface facilities is used; they are buit to site-specific design considerations; most disposal modules for LLW are concrete trenches

B. Disposal sites have ancillary facilities for package decontamination, for waste segregation, and for repacking or overpacking waste containers 
C. Near-surface facilities are located at BARC and at the nuclear power stations at Tarapur, Rajasthan and Madras; technical evaluations have been performed at all selected sites (Sasidhar 1986)

D. Low-level liquid effluents are discharged at coastal locations such as Tarapur and Kalpakkam

\subsection{DISPOSAL OF HIGH-LEVEL WASTES}

10.1 REPOSITORY DEPLOYMENT STRATEGY (Samuel 1987; Godse 1986)
A. India's strategy is to emplace vitrified HLW and solidified alpha-bearing wastes in a deep geologic repository 25 years after reactor discharge
B. India plans to use multiple barriers in the deep geologic disposal concept

\subsection{SITE SELECTION AND CHARACTERIZATION}

A. Preliminary screening of possible repository sites has been completed in India; plutonic granite and granite gneiss are the primary candidates for host rock; basalt and amphibolite are also under consideration; more detailed screening of possible repository sites is underway that will include boreholes 200.750 m deep (Godse 1986; Samuel 1987)

B. A granite pluton at Patna in the southern peninsular granitic shield, $8 \mathrm{~km} \times 4$ $\mathrm{km}$ is under extensive investigation (Samuel 1987)

C. Activities inchude: characterizations and evaluations of host rock media, surrounding geohydrology and waste-rock interactions (Rajan 1986)

\subsection{REFERENCE HLW/SPENT FUEL REPOSITORY CONCEPT}

A. India has not yet developed a reference concept; current considerations are given below

B. Reference wastes

1) Vitrified HLW: borosilicate glass comaining up to $27 \%$ waste oxides; vitrified wastes will be in interim storage about $20-25$ years before disposal; HLW canisters have a diameter of $375 \mathrm{~mm}$ and are $0.375 \mathrm{~m}$ long; each contains about $125 \mathrm{~kg}$ of glass; initial heat output is about $2.5 \mathrm{~kW}$ (Rajan 1983)

2) Alpha-contaminated wastes immobilized in bitumen or polymer

C. Probable host rock: peninsular gneiss, granite or basalt formations

D. Disposal depth: approximately $600 \mathrm{~m}$

E. Bentonite buffer material around the waste canister is being considered 
10.4 WASTE PACKAGE R\&D

A. Materials tests: an extensive program is being carried out at Tarapur to evaluate long-term characteristics of solidified high-level radioactive waste products under extended storage/disposal conditions (Bradley 1985)

1) The tests include engineering-scale waste packages with simulated and actual HLW

a Storage in an experimental storage unit simulating extended storage and repository-related conditions is being carried out in the Solid Storage Surveillance Facility (SSSF) at Tarapur

b. Periodic observation is made of waste package to determine crystallization behavior, chemical durability, mechanical properties and thermal behavior

B. FRG and India are collaborating on dry- and in-pool storage behavior of HLW glass in stainless steel canisters

10.5 FIELD TESTS (Rajan 1986; Samuel 1987; Leigh and Mitchell 1990)

A. Underground experimental stations have been set up starting in 1979 in unused portions of mines in amphibolite rock, located at the Kolar gold fields near Bangalore in Karnataka State (Kolar Waste Disposal Research Station); studies are being carried out to assess the suitability of peninsular gneisses for location of a repository

1) Tunnels at about $1000 \mathrm{~m}$ depth are extended from abandoned sections in the Kolar gold mines (Mysore and Numdydoorg) into a neighboring gneiss formation

2) Experiments have been commissioned for examining thermal, mechanical, hydrologic and chemical behavior of host rock under simulated repository conditions; electrical heaters encased in canisters and other heaters are used; work is to standardize measurement techniques, not to test the rock

B. A 10-year program of vitrified waste storage in experimental storage assemblies in granite blocks ( $1 \mathrm{~m}$ diameter by $1.2 \mathrm{~m}$ high) that simulate repository conditions is in progress at the SSSF at Tarapur; samples of wastes are taken periodically for examination and testing (Samuel 1987)

\subsection{MANAGEMENT OF URANIUM MINE AND MILL WASTES}

11.1 MANAGEMENT PRACTICES: In India, liquid wastes are treated with lime and barytes for precipitation of radium and other uranium daughters, then discharged to tailings ponds; water overflows from tailings ponds are measured (Rajan 1986) 


\subsection{DECOMMISSIONING AND ENVIRONMENTAL RESTORATION}

12.1 MANOR PROJECTS: Trombay reprocessing pilot plant was reconstructed after 10 years of operation; the decommissioning resulted in generation of $300 \mathrm{MT}$ of solid wastes, about 60,000 liters of ILW containing 58,000 beta curies, and 13 million liters of $U W$ with 135 curies; the collective dose equivalent to workers was about 3000 man-rem (Prasad 1985; MacLachlan 1985)

12.2 COSTS: A fee of 0.0125 rupees per $k W h r$ electricity consumed from the Kalpakkam nuclear power station is being levied for future decommissioning; this fee plus an initial fee of 10 million rupees (about $\$ 700,000$ U.S.) set aside during plant construction will provide for dismantling at the end of the 25-year life of the facility (NEI 8/89a)

\subsection{INTERNATIONAL ACTIVITIES}

13.1 MEMBERSHIP: IAEA

\subsection{COOPERATION WITH OTHER COUNTRIES}

A. FRG/India are collaborating on dry- and in-pool storage behavior of HLW glass in stainless steel canisters

B. In November 1988, India signed an agreement with the USSR for design and construction of two PWRs (ELA 1989)

\subsection{REFERENCES}

$-1982-$

Kharbanda, J. L., P. K. Panicker, and K. Balu. 1982. 'A Study on the Development of a Process for Treating Uranium Mill Eftluents." In Proceedings of IAEA symposium on Management of Wastes from Uranjum Mining and Milling, Pp. 325-338. IAEA-SM-262/29, May 1982, Albuquerque, New Mexico.

Markose, P. M. et al. 1982. "Environmental Surveillance Around the Uranium Complex at Jaduguda." In Proceedings of IAEA symposium on Management of Wastes from Uranium Mining and Milling, pp. 541-551. IAEA-SM-262/27, May 1982, Albuquerque, New Mexico.

$-1983-$

Balu, K. et al. 1983. 'Twenty Years' Experience with Shallow Ground Repositories in India." In Proceedings of IAEA conference on Radioactive Waste Management, Vol. 3, pp. 487-502. IAEA-CN-43/135, May 16-20, 1983, Seattle, Washington.

Rajan, N. S. et al. 1983. 'Treatment and Conditioning of Radioactive Wastes from Reprocessing Plants in India." In Proceedings of IAEA conference on Radioactive Waste Management, Vol. 2, pp. 259-278. IAEA-CN-43/134, May 16-20, 1983, Seattle, Washington. 
Mellinger, P. J., K. M. Harmon, and L. T. Lakey. 1984. A Summary of Nuclear Fuel Reprocessing Activities Around the World. PNL-4981, Pacific Northwest Laboratory, Richland, Washington, pp. 34-36.

Nuclear Engineering International (NEI). 1/84. "India Expands Fuel Fabrication Plant," p. 9.

Selvaraj, P. G., M. Venkataraman, and G. R. Balasubramanian. 1984. 'Development of Equipment for Fast Reactor Fuel Reprocessing.' In Proceedings of ANS topical meeting on Fuel Reprocessing and Waste Management, pp. 2-278 to 2-287. August 1984, Jackson, Wyoming.

$-1985$

Bradley, D. J. 1985. Foreign Trip Report. "Report on Travel to India." Pacific Northwest Laboratory, Richland, Washington.

MacLachlan, A. 1985. "India's Kalpakkam Plant Can Reprocess Mixed-Carbide Fuel from FBTR." Nuclear Fuel, June 3, 1985, p. 11.

Prasad, A. N., M. K. Rao, and P. Seetharamiah. 1985 (estimated). 'Spent Fuel Transport and Reprocessing." Journal is Unknown. Bhabba Atomic Research Centre, Bombay, India.

Rippon, S. 1985. "Fast Breeder Reactors: Progress and Prospects." Nuclear News, September 1985, p. 100.

-1986-

Godse, V. B. et al. 1986. "Status of Investigations for Characterization and Evaluation of Geologic Formations to Locate a High-Level Radioactive Waste Repository." In Proceedings of IAEA conference on Siting, Design and Construction of Underground Repositories for Radioactive Wastes. March 3-7, 1986, Hannover, Federal Republic of Germany.

Johnson, A. B. Jr. 1986. Foreign Trip Report. 'Report on Travel to Leningrad for Spent Fuel Meeting at Leningrad.' Pacific Northwest Laboratory, Richland, Washington.

Masters, R. 1986. "World Survey: Still Working through the Backlog." Nuclear Engineering International, June 1986, p. 50.

Nucleonics Week (NW). 11/27/86. The That Vaishet Heavy Water Plant Has Begun Production,' p. 2.

Sasidhar, V. et al. 1986. Techniques for Evaluation and Conditioning of Sites for Shallow Burial of Radioactive Waste.' In Proceedings of IAEA Conference on Siting, Design and Construction of Underground Repositories for Radioactive Wastes. March 3-7, 1986, Hannover, Federal Republic of Germany.

Rajan, N. S. 1986. 'Policy and Practice in India." IAEA Bulletin, Spring 1986, p. 37. 
$-1987$.

Atoms in Japan (AIJ). 4/87. "Japan Atomic Industrial Forum 1987 Annual Conference," p. 10.

International Atomic Energy Agency (IAEA). 1987. The Nuclear Fuel Cycle Information System.' IAEA-TECDOC-408, International Atomic Energy Agency, Vienna.

Nuclear Energy, Journal of the British Nuciear Energy Society (NEJ). 8/87. 'India-Radioactive Waste Management,' p. 197.

Nuclear Engineering International (NEl). 1/87, "India Admits It Can Enrich," p. 8.

Nuclear Engineering International (NEI). 5/87. "Datafile: India," p. 18.

Nuclear Engineering International (NEI). 12/87. 'The World's Nuclear Fuel Cycle Facilities," p. 47.

Nuclear Fuel (NF). 6/29/87. 'DAE Chief Denies Industrial HEU Production at BARC,' p. 6.

Nucleonics Week (NW). 3/5/87. Indian Scientists Exploring U Enrichment, Advanced Technology," p. 9.

Nuclear Waste News (NWiv). 1/15/87. 'India Explores South India Disposal Site; Builds Interim Storage Facility," p. 14.

Samuet, M. T., et al. 1987. "Report of Indian Studies on Performance of Solidified High-Level Waste Glass Forms and Engineered Barriers Under Repository Conditions." IAEA Coordinated Research Program, April 1987.

Sarma, M.S.R., S. P. Singh, P. R. Dastidar, S. K Mehta, A. Kakodkar, V. Venkat Raj, and B. F. Chamany. 1987. The Role of Safety in the Nuclear Power Programme of a Developing Country as Seen From the Indian Perspective." In the Conference Proceedings of Nuclear Power Performance and Safety, Vol. 3, p. 11. IAEA-CN-48/12, September 28 to October 2, 1987, International Atomic Energy Agency, Vienna.

Srinivasan, M. R., and K. V. M. Rao. 1987. "Comparative Investment and Financing Requirements for Nuclear and Coal Based Energy Systems.' In the Conference Proceedings of Nuclear Power Performance and Safety, Vol. 1, p. 251. IAEA-CN-48/26, September 28 to October 2, 1987, International Atomic Energy Agency, Vienna.

$-1988$.

Nucleonics Week (NW). 3/10/88. "India Nuclear Energy Program Lagging and Costly, Says Report," p. 13.

Nucleonics Week (NW). 3/24/88. "Baroda Explosion May Force India to Increase Heavy Water Imports,' p. 5.

Nuclear Engineering International (NEI). 2/88. "India to Go Ahead with Soviet Reactors," p. 6. 
Nuclear Engineering International (NEI). 5/88. "India to Boost Heavy Water Output," p. 11.

Nuclear Engineering International (NEI). 9/88. "India Plans new Fuel Plant," p. 7.

Nuclear Engineering Intemational (NEI). 12/88. 'Fluidized-Bed Waste Incinerator,' $p$. 15.

Murthy, T.K.S. 1988, "Mineral Processing in the Indian Nuclear Programme." Bulletin of Material Science, August 1988, 10(5): 403-410.

Siddiqui, I. A., B. V. Shah, S. H. Tadphale, and S. V. Kumar. 1988. 'A Continuous Process for Precipitation of Ammonium Diuranate from Uranyl Nitrate Solution." Bhabba Atomic Energy Research Centre, Bombay.

$-1989$

Chandra, M., and P. Seetharamiah. 1989. "Experience with Decontamination of Transport Casks and Spent Fuel Storage Facilities." Presented at IAEA's Technical Committee Meeting on Decontamination of Transport Casks and of Spent Fuel Storage Facilities. April 4-7, 1989, International Atomic Energy Agency, Vienna.

Energy Information Agency (EIA). 1989. "Commercial Nuclear Power 1989, Prospects for the United States and the World.' DOE/EIA-0438(89), Energy Information Agency of the U.S. Department of Energy, Washington, D.C., p. 51.

International Atomic Energy Agency (IAEA). 1989. "Operating Experience with Nuclear Power Stations in Member States in 1988." International Atomic Energy Agency, Vienna.

Joshi, K. M. 1989. 'Experience in Decontamination of Spent Fuel Cask at RAPS India.' Presented at the IAEA's Technical Committee Meeting on Decontamination of Transport Casks and of Spent Fuel Storage Facilities. April 4-7, 1989, International Atomic Energy Agency, Vienna.

Nuclear Engineering International (NEl). 1/89. "More Nuclear Fuel From India," p. 3.

Nuclear Engineering International (NEI). 2/89. "indian High Level Waste Plant Expected Soon," p. 14.

Nuclear Engineering International (NEI). 3/89. "Kalpakkam 'Mini" Reactor to Be Commissioned," p. 6.

Nuclear Engineering International (NEl). 5/89. ' Nuclear Center Planned for Madras," p. 5.

Nuclear Engineering International (NEI). 6/89. "More Nuclear Fuel Plants Planned," p. 5. Nuclear Engineering Intemational (NEI). 6/89a. 'Waste Facilities Planned for Kaiga,' p. 5.

Nuclear Engineening Intemational (NEI). 8/89. "Heavy Water Delay," p. 11.

Nuclear Engineering International (NEI). 8/89a. "Levy Covers Costs at Madras," p, 11. 
Nuclear Enqineering International (NEI). 12/89. "Indo-Soviet Working Group Meets," p. 6.

Nuclear Europe (NE). 1-2/89. "India Develops Corversion of Recovered Uranium," p. 56.

Nuclear News (NN). 2/89. "India Has a Secret Centrifuge Enrichment Complex," p. 90.

Nuclear Waste News (NWN). 6/15/89. "Indian Study Says Additional Nuclear Waste Products Can Be Reprocessed," p. 212.

Nucleonics Week (NW). 3/16/89. 'Power Plants, Nuclear R\&D Lead 29\% Indian Nuclear Budget Rise," p. 6.

NUKEM Market Report on the Nuclear Fuel Cycle (NUKEM). 5/89. "NUKEM Special Report: The Nuclear Power Plant Capacity of the Western World.' NUKEM GmbH, Hanau, Federal Republic of Germany, p. 18.

Raj, K., M. T. Samuel, M. S. Kumra, and A. N. Prasad. 1989. "Experiences and Programmes in India - An Update." Presented at IAEA Advisory Group Meeting on Design and Operation of High Level Liquid Waste Vitrification and Storage Facilities. May 22-25, 1989, International Atomic Energy Agency, Vienna.

Samuel, M. T., D. S. Rana, K. Raj, and R. G. Yeotikar. 1989. "Report of Indian Studies." Presented at the Third Coordinated Research Meeting of the IAEA Coordinated Research Program on Performance of Solidified High Level Waste Forms and Engineered Barriers Under Repository Conditions. June 5-9, 1989, International Atomic Energy Agency, Vienna.

Srivastava, N.P. 1989. 'Design and Construction of AFR Spent Fuel Storage Facility and Augmenting Existing Pool Capacities in India." Presented at the IAEA Technical Committee Meeting on Methods for Expanding Spent Fuel Storage Facilities. June 12-15, 1989, Vienna.

$-1990$

Leigh, 1. W., and S. J. Mitchell. January 1990. International Nuclear Fuel Cycle Fact Book. PNL-3594, Rev. 10, Pacific Northwest Laboratory, Richland, Washington.

Murthy, K. S. N., N. P. Srivastava, and B. K. S. Nair. 1990. 'India's Nuclear Program-An Overview." Nuclear News, April 1990, pp. 40-42.

Nucleonics Week (NW). February 22, 1990. "lyengar, Ramanna Appointments Open Bomb Speculation in India,' p. 14.

Nuclear Engineering International (NEI). January 1990. "India Seeks to Scale Up FBR," $p$. 6.

U.S. Department of Energy (DOE). January 1990. "Mining of Uranium in India." Nuclear Fuel Cycle Abstracts, 90(1): 1.

NUKEM Market Report on the Nuclear Fuel Cycle (NUKEM). 2/90. "Nuclear Power Plant Capacity of the Western World." NUKEM GmbH, Hanau, Federal Republic of Germany, pp.2829. 
INDIA

Taylor, G. M. 1990. 'The New Indian Nuclear Plants: Narora and Beyond.' Nuclear News, April 1990, p. 51. 


\section{ITALY}




\section{ITALY}

\section{CONTENTS}

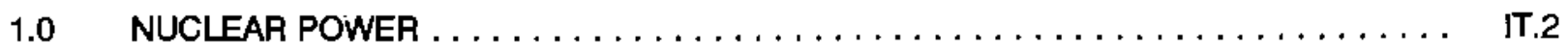

2.0 NUCLEAR FUEL CYCLE AND RADIOACTIVE WASTE MANAGEMENT

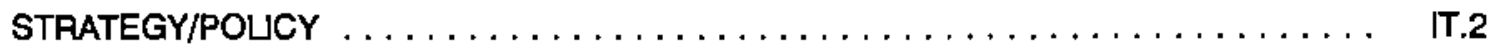

3.0 HIGHUGHTS AND MAJOR MILESTONES $\ldots \ldots \ldots \ldots \ldots \ldots \ldots \ldots \ldots \ldots \ldots \ldots \ldots$ IT.3

4.0 INSTITUTIONAL CONSIDERATIONS/ORGANIZATIONS $\ldots \ldots \ldots \ldots \ldots \ldots \ldots$ IT.4

5.0 NUCLEAR FUEL PRODUCTION $\ldots \ldots \ldots \ldots \ldots \ldots \ldots \ldots \ldots \ldots \ldots \ldots \ldots \ldots \ldots \ldots \ldots$

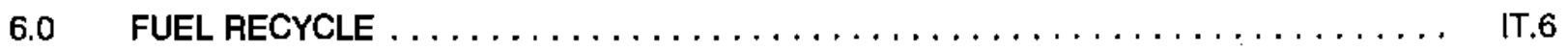

7.0 SPENT FUEL STORAGE AND TRANSPORT $\ldots \ldots \ldots \ldots \ldots \ldots \ldots \ldots \ldots \ldots \ldots \ldots \ldots \ldots$

8.0 WASTE CONDITIONING, STORAGE AND TRANSPORT $\ldots \ldots \ldots \ldots \ldots \ldots \ldots$ IT.8

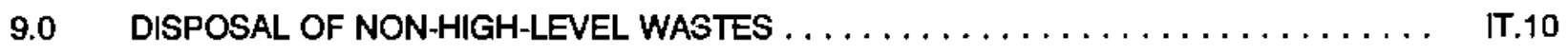

10.0 DISPOSAL OF HIGH-LEVEL WASTES $\ldots \ldots \ldots \ldots \ldots \ldots \ldots \ldots \ldots \ldots \ldots \ldots \ldots \ldots \ldots \ldots$

11.0 MANAGEMENT OF URANIUM MINE AND MILL WASTES $\ldots \ldots \ldots \ldots \ldots \ldots \ldots$

12.0 DECOMMISSIONING AND ENVIRONMENTAL RESTORATION $\ldots \ldots \ldots \ldots \ldots \ldots$ IT.13

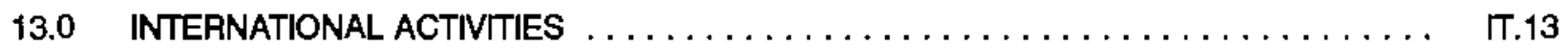

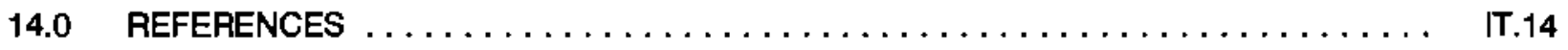




\subsection{NUCLEAR POWER}

1.1 REACTOR MIX: 1 PWR (247 MWe), 1 BWR (840 MWe)

\subsection{ELECTRIC POWER PRODUCTION}

1988--203.6 TWh (44\% oil, $24 \%$ hydro, $1 \%$ other, $17 \%$ coal, $15 \%$ gas); beginning 1988 to date--O\% nuclear (IEA 1990; Leigh and Mitchell 1990)

\subsection{NUCLEAR POWER CAPACITY PROJECTIONS (NUKEM 5/89)}

1986--1.3 GWe

1987-1.1 GWe

1988 to date--1.1 GWe (however, Italy's reactors have been shut down due to referendum)

A. Italy has a one-third share in the French Superphenix breeder reactor

\subsection{NUCLEAR ENERGY POLICY}

A. The Italian government has supported nuclear power growlh, but has been hampered by financial/siting problems and public resistance; the national energy plan of 1981 planned to reduce its dependence on oil and increase coal and nuclear share of power (NUKEM 10/87)

B. In November 1987, a referendum was passed: existing nuclear power plant siting authority for CIPE (Interministerial Planning Committee) and the law that provides for appropriation of funds for municipalities that host nuclear power plants were voted down; a new national energy plan was required; the new National Energy Plan (PEN) of July 1988 calls for abandonment of nuclear power and increased use of coal and natural gas for electricity generation; research into nuclear energy will continue but with a reduced $R \& D$ budget; HLW will be vitrified and stored in an engineered surface facility for 50-60 years; HLW canisters will be emplaced in a geologic repository (clay) (NW 11/12/87; NW 12/24/87; NUKEM 5/89; Leigh and Mitchell 1990)

C. Since February 1989 , Italy has been under a five-year moratorium against operating or constructing nuclear power reactors (NEW 3-4/90)

\subsection{NUCLEAR FUEL CYCLE AND RADIOACTIVE WASTE MANAGEMENT STRATEGY/POLICY (Negroni et al. 1986)}

\subsection{OVERALL NUCLEAR FUEL CYCLE POLICY}

A. When ltaly was using nuclear power, the policy was to develop indigenous fuel cycle and waste treatment capability but purchase all enrichment and conversion services

B. The July 1988 National Energy Plan (PEN) calls for the abandonment of nuclear power and increased use of coal and natural gas for electricity generation; it continues research into nuclear energy but with a reduced R\&D budget; vitrification and storage of HLW in an engineered surface facility for 50-60 years are planned; HLW canisters will be emplaced in a geologic repository (clay) (NUKEM 5/89; Leigh and Mitchell 1990) 
2.2 POUCY ON THE FRONT END OF THE NUCLEAR FUEL CYCLE: Italy plans to maintain its fuel tabrication capability

\subsection{PCUCY ON THE BACK END OF THE NUCLEAR FUEL CYCLE:}

A. Italy plans to store spent fuel and reprocess only if there is a need for plutonium; it will recycle plutonium to a breeder reactor, future reprocessing, if any, is expected to be with foreign projects; an Italian production plant for reprocessing has currently been abandoned, but if decided upon, it will not be needed before about the year 2000 (NEl 12/87); in addition, Italy plans to vitrify $\mathrm{HLW}$ at the reprocessing plant, return it to ltaly and store it for $\mathbf{5 0}$ years or longer before placing it in a geologic repository; Italy will also develop a geologic repository in a clay formation for HLW and TRU wastes

B. In thaly, packaging and conditioning of $\amalg W / L W$ is the responsibility of the waste generator, but they must meet the requirements of federal regulators (ENEA-DISP) (De Crescenzo 1987); the disposal of $\amalg W / L W$ in Italy will be by shallow-land burial (or possibly at sea), when a facility/concept is available; storage will be at the generator site until then

C. A national site for collection and centralized storage of LLW/LW from biomedical/ industrial activities was instituted in 1985

\subsection{HIGHLIGHTS AND MAJOR MILESTONES}

1985 The national site for collection and centralized storage of $\amalg W / L W$ from biomedical/ industrial activities was instituted

1986 The updated National Energy Plan (PEN) was passed by parliament

1987 A referendum was passed abrogating 1) the existing nuclear power plant siting authority for CIPE and 2) the law that provides for appropriation of funds for municipalities that host nuclear power plants

1988 The pilot plant to demonstrate $\amalg W / L W$ optimized cementation started up (NEI 7/87); the new, fully-computerized ICS-42 supercompaction plant at NUCLECO Casaccia Center was completed in late 1988; the commissioned plant was scheduled to start active operations in mid-1989; a new National Energy Plan (PEN) was presented by the Italian Industry Minister (Cao et al. 1989; NUKEM 5/89)

1989 A five-year moratorium against operating or constructing nuclear power reactors began (NEW 3-4/90)

1990 A wet oxidation pilot plant for liquid $\amalg W / \mathrm{LW}$ was started up (Cerretti and Grossi 1987)

2040 Disposal of vitrified HLW in clay repository starts (Chapman et al. 1986)

$\sim 2070$ Disposal of vitrified HLW in clay repository completed (Chapman et al. 1986) 


\subsection{INSTITUTIONAL CONSIDERATIONS/ORGANIZATIONS}

\subsection{LEGAL REQUIREMENTS}

A. No law exists in Italy that links reactor construction with waste management; the local denial of a nuclear facility siting request can be overruled by the appeals court (Paige and Numark 1985)

B. The updated National Energy Plan (PEN) passed by parliament in 1986 assigned specific nuclear responsibilities to various agencies (De Crescenzo 1987)

C. A new National Energy Plan (PEN) was presented by the Italian industry Minister in July 1988 and calls for abandonment of nuclear power and increased use of coal and natural gas for electricity generation (NUKEM 5/89)

D. Italy has been under a five-year moratorium against operating or constructing power reactors since February 1989 (NEW 3-4/90)

4.2 LICENSING: In Italy, site selection of nuclear facilities starts with an interactive process between ENEA, CIPE and local governments; after evaluation, the license is issued by the national government (Paige and Numark 1985)

\subsection{PUBLIC INVOLVEMENT}

A. Public hearings on nuclear facility construction are held at municipal and regional levels in Italy

B. The central government was formerly allowed to provide financial incentives to regions or communities that accepted nuclear power plants (NEI 2/83); however, that law was voted down by referendum in November 1987 (NUKEM 5/89)

4.4 WASTE FUND: Electricity producers in Italy accumulate funds for fuel management and decommissioning; the fee is based on estimated costs and the amount of electricity produced

4.5 KEY AGENCIES AND FUEL CYCLE CENTERS (Crispino 1986; Simen 1986)

A. CIPE (Interministerial Planning Committee): provides nuclear program guidance; designates the regions for location of nuclear plants

B. AGIP (Italian oil company, member of ENI): subsidiaries provide commercial fuel cycle services

1) CETA (Center for Advanced Technologies) near Bologna: produces gel-supported precipitation precursors for use in SYNROC HUW immobilization; fabricates/ characterizes special oxide nuclear fuels

C. ENEA (Italian Commission for Nuclear and Atternative Energy Sources): responsible for energy and the environment; alternative energy sources and renewable energy resources; energy and innovative technology; nuclear power promotion; R\&D; waste treatment and immobilization; waste isolation R\&D; nuclear safety and control; nuclear facility decommissioning; and protection of health and environment 
2) Energy Research Center at Casaccia (near Rome) (NEI 12/87; Cerretti and Grossi 1987; De Crescenzo 1987; Costa and Donato 1987)

a. Solid waste supercompaction facility under construction in $\mathbf{1 9 8 7}$ (10,000 drums/yr in 1500-MT press)

b. National interim storage site for LLW/ILW from biomedical/industrial activities since 1985

D. SNIA TECHINT (Rome) provides architect-engineering services for reprocessing, fuel handling, and HLW conditioning facilities (Leigh and Mitchell 1990)

E. ENI (state-owned group of companies that includes AGIP and FN): handles nuclear fuel supply and fuel cycle operations

F. FN (ENI subsidiary): designs, manufactures, and markets nuclear fuel

G. NUCLECO (60\% AGIP, 40\% ENEA): manages all LLW/ILW treatment, conditioning and disposal

H. ENEL (National Electric Energy Agency): federal government agency responsible for all electric power production

\subsection{PRINCIPAL RESEARCH, DEVELOPMENT AND DEMONSTRATION FACILITIES/PROGRAMS}

A. ENEA's Energy Research Center at Casaccia (near Rome): conducts nuclear fuel cycle and waste disposal R\&D; contains a HLW glass and LLW/LW solid wastes characterization lab; solid waste supercompaction facility under construction in 1987 (10,000 drums/ year in 1500-MT press); experimental optimized cementation pilot plant was scheduled to start up in 1988; ENEA center is used for a national interim storage site for LLW/LW from biomedical/industrial activities (Cerretti and Grossi 1987; Costa and Donato 1987; De Crescenzo 1987; NEI 12/87)

B. ENEA's Energy Research Center at Saluggia (near Vercelli, northern Italy): conducts fabrication (IFEC plant) and reprocessing of fuel elements ( $30 \mathrm{~kg} / \mathrm{d}$ EUREX pilot plant); reprocessing was originally for MTR fuels, then for CANDU fuels (to 1983), currently being modified for MOX fuels; an IVEX plant for HLLW vitrification is planned

C. ENEA's Trisaia Energy Research Center (Matera province, southern italy): develop fuel reprocessing and waste vitritication technology (15 kg/d modular ITREC reprocessing pilot plant for special fuels; startup 1975); a this center are the: 1) IVET-1 nonradioactive HLLW (rising-level pot) vitrification pilot plant (20 liter/hr feed rate; startup July 1980 ); 2) the IVET-2 radioactive HLLW (rising-level pot) vitrification pilot plant (planned startup late 1980s); and 3) a waste cementation plant (under construction in 1987) (Costa and Donato 1987)

D. ENEA's Energy Research Center at Brasimone (between Bologna and Florence): site of fast breeder reactor R\&D, including fuel testing; also present are PEC 120-MWt experimental LMFBR and test loops for LMFBRs 
E. CEC Joint Research Center (ISPRA establishment; CEC laboratory at ISPRA, northern Italy): this center conducts waste management studies for European communities

\subsection{KEY PERSONNEL}
A. S. Cao, President, NUCLECO
B. E. Crispino, Director, Nuclear Fuel Development, AGIP
C. U. Columbo, President, ENEA
D. M. Fiorelii, General Manager, SNIA TECHINT
E. P. Venditti, Director, Fuel Cycle at Casaccia, ENEA
F. F. Pistella, Director General, ENEA
G. F. Pozzi, Director, EUREX Pilot Plant at Saluggia, ENEA
H. T. Candelieri, Director, ITREC Pilot Plant at Trisaia, ENEA
I. T. Marzullo, Manager, Radioactive Waste, ENEL

\subsection{NUCLEAR FUEL PRODUCTION}

5.1 URANIUM RESOURCES: $1987-4800$ MTU reasonably assured; 1300 MTU additional estimated (NEA 1988)

5.2 URANIUM PRODUCTION: Italy plans to establish mining/milling operation, but to purchase all fuel from other countries; however, no new fuel is needed until after 1992 (NUKEM 10/87)

5.3 URANIUM ENRICHMENT: In Italy, enrichment is done through ENEL's $16 \%$ interest in the EURODIF plant in France (NUKEM 10/87)

\subsection{FUEL FABRICATION}

A. Italy's BWR, PWR and GCR fuels have been fabricated in plants at Saluggia, BoscoMarengo and Rotondella; the plant for fabrication of FBR fuels ( $9 \mathrm{MTHM} / \mathrm{yr}$ ) was to be buit at Rotondella (NUKEM 7/82)

B. Italy's total fuel production through September 1985 was 1500 BWR assemblies (280 MTU), 230 PWR assemblies (70 MTU); other fuels include 120 fertile fuel assemblies for Superphenix breeder and 264 fissile fuel assemblies for Superphenix reloads

\subsection{FUEL RECYCLE}

6.1 FUEL REPROCESSING (NUKEM 7/82; Ariemma et al. 1984; Chapman and Gera 1985; Negroni et al. 1986)
A. R\&D continues on reprocessing
B. GCR fuel is sent to the U.K. for reprocessing 
C. There are two pilot plants, both operated by ENEA

1) The EUREX pilot plant at Saluggia: handles $10 \mathrm{MTU} / \mathrm{yr}$ LWR fuel using two-cycle PUREX flowsheet (used tertiary amine 1970-1972) and mixer-settlers; originally designed for MTR fuel, operated 1970-1974 intermittently for MTR tuels; operated from 1980-1983 on CANDU fuels; scheduled shutdown is in 1995 (Alonzo et al. 1984; Pozzi et al. 1987)

2) The ITREC pilot plant at Trisaia center, southern ltaly: designed with a capacity 5 MTU/yr MOX and FBR fuel elements; it is currently testing innovative components for future industrial reprocessing plant (Simen 1986)

D. Italy has considered the construction of an industrial-scale plant; the decision to proceed has been deferred indefinitely (Negroni ot al. 1986)

6.2 PLUTONIUM RECYCLE: Recycling of plutonium in breeder reactors is expected eventually in Italy; plutonium from EUREX plant was to be used for MOX fuel in 1988

\subsection{SPENT FUEL STORAGE AND TRANSPORT}

\subsection{SPENT FUEL ARISINGS}

A. Italy is sending about $40 \mathrm{MTU} / \mathrm{yr}$ GCR fuel to the U.K. for reprocessing

1980-160 MTU cumulative

1985-330 MTU cumulative

1990--520 MTU cumulative

7.2 WET STORAGE (Harmon et al. 1984)

A. Pool storage capacity is available for old reactors until the late 1990s (NEI 12/87); highdensity racks are in use

B. New reactors were fitted out with compact racks, and have capacity for one entire core and ten reloads (NUKEM 7/82)

C. Spent fuel not sent to reprocessing is stored at the reactor sites and in the converted research reactor at Avogadro (NEI 12/87)

D. 1000-MTU AFR storage was planned for startup after 1995 at one time; it could either be pool or dry storage

\subsection{DRY STORAGE}

A. Dry storage concepts for spent fuel and HLW were under study in ltaly but would not be needed until after 1995, even if Italy resumed nuclear power operations (NEI 12/87)

B. A dry storage facility has been designed by ENEA for the Trino Vercellese PWR site; it is a modular concept consisting of a metal container for 12 spent fuel assemblies within a concrete cask; heat removal would be accomplished by natural circulation 


\subsection{TRANSPORT}

A. The AGN- 1 cask, first designed by AGIP and Nuovo Pignone and fabricated by Nuovo Pignone in Italy for LWR fuel, has been used since 1984 for transporting spent fuel to the Avogadro independent spent fuel storage installation (ISFS1); total weight with overweight truck is $140 \mathrm{MT}$; the cask holds seven Garigliano plant BWR fuel assemblies; it has a 14 inch-thick steel body with circumferential fins (Bertoni et al. 1986)

B. ENEL has begun decommissioning its Latina GCR; fuel unloading is expected to take three years (fuel shipments are suspended during the summer); approximately $270 \mathrm{MT}$ of the reactor's fuel will be shipped to the U.K. (NW 7/7/88; NUKEM 8/88)

\subsection{WASTE CONDITIONING, STORAGE AND TRANSPORT}

8.1 WASTE DEFINITIONS: Based on Technical Guide No. 26 of ENEA-DISP (D'Anna et al. 1989)

A Category 1: Wastes generated by bio-medical and research activities, containing shortlived radionuclides whose half-life is less than one year

B. Category 2: Wastes that are primarily generated by nuclear facilities (mainly nuclear power plants); wastes are characterized by initial radioisotopic concentrations requiring a period of a few decades to a few centuries to decay to a final concentration of a few hundred $\mathrm{kBq} / \mathrm{kg}$

C. Category 3: High-level wastes derived from fuel reprocessing and from other research or industrial activities, which also contain alpha and neutron emitters

\subsection{WASTE ARISINGS}

A. From reference 10-GWe nuclear program: 2500 MT (9000 containers) of vitrified HLW; 5200 MT (9000 containers) of packaged cladding hull materials; 27,000 drums of alphacontaminated wastes (Chapman 1985); $75,000 \mathrm{~m}^{3}$ of LLW/LW by the year 2000 with a progressive program (De Crescenzo 1987)

B. Solid LLW/ILW accumulated as of end of 1984: $1215 \mathrm{~m}^{3}$ conditioned (by urea-formaldehyde or bituminization) but needing to be reconditioned; $7760 \mathrm{~m}^{3}$ not conditioned, in 200-fiter stainless steel drums; and $4000 \mathrm{~m}^{3}$ not conditioned, in other-sized drums (Cerretti 1987)

C. HLLW accumulated as of mid-1989 from past reprocessing campaigns carried out at the ENEA pilot facilities EUREX and ITREC: $85 \mathrm{~m}^{3}$ mainly from MTR fuels, $25 \mathrm{~m}^{3}$ from CANDU-type fuels, and about $10 \mathrm{~m}^{3}$ from Elk Fiver thorium fuels; TRU wastes: about 10 $\mathrm{m}^{3}$ of aqueous solutions from the Casaccia plutonium experimental fuel fabrication facility, including $2 \mathrm{~m}^{3}$ of relatively high plutonium content solutions Nenditti 1989)

\subsection{HLW IMMOBILIZATION}

A 'ESTER" in-pot vitrification process: tests processed in non-radioactive pilot plant IVET-1 at Trisaia since 1984 and in hot cell tests at CEC's ISPRA laboratory (Risoluti et al. 1983; Bonner 1985) 
1) 'ESTER' process shut down in 1985 and was replaced by 'PETRA' pot vitrification process (with mini-reprocessing); 'PETRA' is expected to operate from 1987-1991 (Bonner 1985)

B. EUREX has about $100 \mathrm{~m}^{3}$ of assorted HLW; ENEA is considering treatment by separation and cementation of inert ingredients and by vitrification of fission products by pot process

C. A French AVM process has been designed tor EUREX wastes but a decision on its use has not yet been made; estimated plant cost is $\$ 80$ million (U.S.)

\subsection{LLW/ILW CONDITIONING (Negroni et al. 1986)}

A. An industrial promotion program for $U W / L W$ treatment was implemented in 1985; Italy has planned several treatment pilot plants with startup scheduled for 1987-1990 (Cerretti and Grossi 1987)

B. In Italy, solid, non-combustible reactor wastes are compacted where appropriate in 220-liter steel drums (compaction factor 4-5); tuture combustible wastes will be incinerated; other solid wastes are incorporated in a cement matrix (average $40 \%$ waste) in $2-\mathrm{m}^{3}$ rectangular steel drums $(1.4 \times 1.4 \mathrm{~m}$ cross-section); rectangular drums are sometimes lined with concrete shields of varying thicknesses to reduce dose rates (Cerretti and Grossi 1987)

C. Supercompaction of 2,000 DAW drums for haly's Ganigliano BWR by Westinghouse's European Service Center was scheduled to start in March 1988 (NW 1/14/88a)

D. Three ongoing incineration campaigns are being camied out (involving a total of 13,200 drums) at six European research centers since 1985; once qualified, the conditioned product will be returned to haly for its final confinement (D'Anna et al. 1989)

E. The new, fully computerized ICS-42 supercompaction plant at the NUCLECO Casaccia Center was completed in late 1988; the commissioned plant was scheduled to start active operations in mid-1989 (Cao et al. 1989)

F. Operation will start at the beginning of 1990 at a real-scale facility for the treatment of all alpha-contaminated wastes stored at Casaccia (Venditti and Grossi 1989)

8.5 LLW/LW STORAGE (Negroni et al. 1986)

A. Onsite interim storage exists in Italy; a modular storage facility (4000 $\mathrm{m}^{3}$ capacity/module) was developed for new power plants

B. The modules include direct handling of 220 -iter $L W W$ drums and remote handling of $2-\mathrm{m}^{3}$ drums

C. In 1985, ENEA initiated a national service for collection and storage of LLW/LW from biochemical/industrial activities at the Casaccia Center (De Crescenzo 1987)

8.6 HLW STORAGE: Vitrified HLW from the foreign reprocessing plant will be returned to Italy and stored for 50 years or longer before being placed in a geologic repository (Negroni et al. 1986; Leigh and Mitchell 1990) 
8.7 TRANSPORT OF WASTES: In Italy, radioactive wastes are transported by about 150 carriers; transportation is authorized by the Minister of Industry with technical advice from ENEA-DISP; transport requirements conform to those of CEC and IAEA (Orsini 1986)

\subsection{RESEARCH AND DEVELOPMENT}

A. Italy is studying the "declassification" concept: HLLW is treated to remove actinides and radiocesium and radiostrontium for vitrification in IVET or PETRA; the remaining waste stream would be cemented as LLW/LW (Mataloni et al. 1987)

B. Italy is researching TRU waste treatment: partitioning and molten salt combustion of burnable wastes

C. Italian scientists are studying embedding of spent fuel cladding hulls in metallic lead matrix (Chapman 1985)

D. Italy is investigating incineration, wet oxidation of ion-exchange resins using hydrogen peroxide (pilot plant startup 1988), magnetic filtration, and optimized cementation, and evaporation/crystallization of nuclear power plant liquid wastes in an industrial promotion program; formerly, conditioning on urea-formaldehyde was used, but it was discontinued because the product does not conform to 1987 regulations; the liquid reactor wastes are prefiltered and ion-exchanged; the pilot plant at Casaccia Center is imestigating polymerimpregnated cement and polyester resins; startup is scheduled in 1988 (NEl 7/87; NEI 12/87; Cerretti and Grossi 1987)

E. Progress has been reported on a declassification (selective separation) chemical process that was developed and tested to drastically reduce the volume of vitrified product (Venditti and Grossi 1989)

F. Testing campaigns of an advanced LLW incineration process conducted at the pilotplant level by ENEL have resulted in volume reduction factors > 90; thus, the design data for a plant of $100 \mathrm{MT} / \mathrm{y}$ capacity indicate a preliminary estimate of the construction, operating, and maintenance costs of the treatment at about $\$ 6.5 / \mathrm{kg}(1988)$ (Sandrelli et al. 1989)

8.9 PROGRAM/FACILITIES COSTS: An industrial promotion program for treatment of ltaly's LLW/LW is estimated at $\$ 15$ million (U.S.) for pilot plants (includes $\$ 4.5$ million for wet oxidation facility, \$0.8 million for magnetic fittration facility) (Cerretti and Grossi 1987)

\subsection{DISPOSAL OF NON-HIGH-LEVEL WASTES}

9.1 STRATEGY: A disposal concept for LLW/LW is to be selected; Italy has no current national disposal sites, but site selection is in progress; limited shallow-land burial is taking place (Cerretti and Grossi 1987)

\subsection{WASTE DISPOSAL CRITERIA}

A. ENEA has established waste form specifications and quality assurance requirements for LLW/ILW forms (De Crescenzo 1987) 
B. Waste form requirements include compressive strength, thermal cycling, radiation resistance, fire resistance, leaching resistance, absence of free liquids, immersion resistance, and biodegradation resistance (Donato and Ricci 1987; D'Anna et al. 1989)

\subsection{DISPOSAL OF HIGH-LEVEL WASTES}

\subsection{REPOSITORY DEPLOYMENT STRATEGY (Chapman 1985)}

Italian repository studies come under the joint ENEA/CEC program and:

A. Place emphasis on joint ENEACEC program to investigate technical and safety aspects of repository in Italian clay

B. Concentrate program effort on construction and operation of underground research laboratory in clay formation

C. Investigate thalian salt formations

D. Defer site selection for several years

E. Develop geologic repository in clay formation for HLW, TRU wastes (Negroni et al. 1986; Leigh and Mitchell 1990)

10.2 SITE SELECTION AND SITE CHARACTERIZATION (Chapman et al. 1986)

A. A program is underway to delineate the basins likely to have homogeneous clay formations

B. The final site selection will be done after completion of borehole and other extensive studies

10.3 REFERENCE HLW/SPENT FUEL DISPOSAL CONCEPT (Chapman and Gera 1985; Chapman et al. 1986)

A. Reference wastes: vitrified HLW will be cooled for $50-70$ years before disposal; fuel cladding hulls will be embedded in a metal matrix

B. Waste package concept

1) HLW glass in cylindrical containers $1.5 \mathrm{~m}$ in length and $0.3 \mathrm{~m}$ in diameter with thin corrosion-resistant overpack

2) Cladding hulls embedded in metallic lead alloy, also in cylindrical containers $1.6 \mathrm{~m}$ in length and $0.3 \mathrm{~m}$ in diameter

C. Reference concept: deep borehole facility in Italian blue clay (waste package placement from surface with $300 \mathrm{~m}$ overburden, $250-600 \mathrm{~m}$ depth (140 containers stacked in each hole) and holes spaced $\sim 100 \mathrm{~m}$ apart

1) Canisters of HLW and cladding hulis alternated in each hole; 70 canisters of each waste type in each hole 
2) Cavity of lined borehole is $\sim 0.34 \mathrm{~m}$

C. Altemative concept: lined horizontal tunnels at $300-500 \mathrm{~m}$ depth, spaced $20 \mathrm{~m}$ apart; short boreholes (0.7 m diameter, $4 \mathrm{~m}$ depth) in tunnel floors, spaced $2.5 \mathrm{~m}$ apart; each borehole to hold one HLW canister and one fuel cladding canister; an alternative for lined-tunnel concept would be in-tunnel placement of waste packages

E. Backfill and sealing materials: mixture of crushed host clay (possibly with water) and pelletized compact bentonite

10.4 GEOSCIENCES R\&D (Chapman and Gera 1985; Chapman 1985)

A. Measure physical and chemical properties of Italian clays and hole sealants

B. Estimate nuclide migration

C. Estimate thermal effects

D. Perform geotechnical studies and systematic collection of information on faults and fractures in the tunnel (Brondi and Polizzano 1986)

E. Plan for in-clay tests to validate the borehole concept, its sealing, and emplacement concepts (Chapman et al. 1986)

F. Schedule in situ tests: an underground test facility under construction at Pasquasia, Sicily, was scheduled for startup in December 1987 (NEl 12/87)

G. Perform a study of the interaction with the disposal environment (clays) with the Belgian SCK-CEN (Venditti and Grossi 1989)

10.5 PERFORMANCE ASSESSMENT: Studies are continuing on long-term performance and safety (Chapman and Gera 1985; Chapman 1985)

10.6 SYSTEMS STUDIES (Chapman and Gera 1985; Chapman 1985)

A. Cost and feasibility of building repository in Italian clay

B. Evaluation of alternate designs

C. Plans for future demonstration of borehole emplacement concept, with ten non-radioactive packages emplaced 200-300 $\mathrm{m}$ deep in a borehole (Chapman et al. 1986)

10.7 PROGRAM AND FACILITIES COSTS (Chapman et al. 1986; Negroni et al. 1986)

A. Estimated life-cycle cost of a borehole repository for $2500 \mathrm{MT}$ spent fuel (excluding R\&D) is about $\$ 200$ million (U.S.); a tunnel-type repository will cost much more

B. The back-end of the fuel cycle activities will cost about $\$ 600$ million (U.S.); about 600 full-time staff members were expected to be required in 1989

11.0 MANAGEMENT OF URANIUM MINE AND MILL WASTES (no information) 


\subsection{DECOMMISSIONING AND ENVIRONMENTAL RESTORATION}

12.1 STRATEGY/POLICY: Based upon the November 1987 referendum, the current policy calls for Italy's oldest reactor, the 210-MW GCR at Latina, to be decommissioned, and for an indefinite extension of the shutdowns of Italy's other two nuclear power plants (NW 4/6/90)

\subsection{MAJOR PROJECTS}

A. Garigliano nuclear power plant: 160-MWe BWR operated from 1964-1978; nuclear steam supply system to be placed in protective storage for at least 30 years (Negroni et al. 1986)

B. The Avogadro research reactor was decommissioned and its pool converted for spent fuel storage in 1975; the ROSPO research reactor was dismantled; five other research reactors are being decommissioned or have been planned for decommissioning (NEA 1985)

C. The loop in the ESSOR test reactor was being used to test aggressive chemical decontaminants (Conti et al. 1987)

D. ENEL has begun decommissioning its Latina GCR; fuel unloading is expected to take three years (fuel shipments are suspended during summer); possible reuse of the plant's turbines for non-nuclear combined-cycle power generation is under investigation; approximately $270 \mathrm{MT}$ of the reactor's fuel will be shipped to the U.K. for reprocessing (NW 7/7/88; NUKEM 8/88)

12.3 COSTS: Electricity producers in Italy accumulate funds for fuel management and decommissioning; the fee is based on estimated costs and amount of electricity produced

\subsection{INTERNATIONAL ACTIVITIES}

13.1 MEMBERSHIPS: NEA, CEC, IAEA

\subsection{COOPERATION WITH MULTINATIONAL AGENCIES}
A. Italy is the host country for the CEC Joint Research Center at Ispra, north of Milan
B. Italy participated in coordinated research on HLW solidification with IAEA
C. Italian repository studies are under joint ENEACEC program
D. Italy participated in NEA studies on seabed disposal of HLW
E. Italy owns one-third of the French Superphenix breeder reactor
F. ENEL owns $16 \%$ share in EURODIF enrichment plant G. ENEL participates in the advanced reactor concepts working group under World Associa-
tion of Nuclear Operators (NW $1 / 18 / 90)$ 


\subsection{COOPERATION WITH USA}

A. Italy has carried out an information exchange with the U.S. on HLW management under Section 223 of the Nuclear Waste Policy Act of 1982

B. Extensive lab-scale experimental activity has been carried out under a contract with Lowenberg Associates-Battelle PNL to select the proper declassification (selective separation) chemical process for HUW (Venditti and Grossi 1989)

C. ENEL participates financially and concretely under an EPRI program in development of Westinghouse's AP-600 reactor and General Electric's SBWR (NW 1/18/90)

\subsection{COOPERATION WITH OTHER COUNTRIES}

A. A November 1987 referendum passed in Italy that abrogated the law to participate in new nuclear power plants and, with the exception of R\&D, other new projects in foreign countries (NW 11/12/87; NW 1/14/88b)

B. Australia signed an agreement on SYNROC research with Italy's ENEA to evaluate the sol-gel technology (developed in Italy) as a route for precursor powders for SYNROC production (NWN 12/1/88)

C. Brazil's Goias state and the Italian Casegrande group signed a $\$ 35$ million agreement to build a temporany storage facility for the radioactive waste accumulated in the wake of the 1987 Goiania disaster (NWN 3/23/89)

D. A study of interaction with the disposal environment (clays) has been performed in cooperation with the Belgian SCK-CEN (Venditti and Grossi 1989)

E. For nearly a year, ENEL has conducted in-depth studies on Sweden's ASEA Brown Boveri PIUS reactor (NW 1/18/90)

\subsection{REFERENCES}

-1982 -

NUKEM Market Report on the Nuclear Fuel Cycle (NUKEM). 7/82. "NUKEM Special Report: Italy." NUKEM GmbH, Hanau, Federal Republic of Germany.

$-1983-$

Nuclear Engineering International (NEI). 2/83. 'Siting Incentives Approved:"

Risoluti, P., et al. 1983. 'Two Years Experience with Vitrification Inactive Pilot Plant in Italy.' In Proceedings of the IAEA Conference on Radioactive Waste Managernent, Vol. 2, pp. 383-404.

IAEA-CN-43/4, May 16-20, 1983, Seattle, Washington.

$-1984-$

Alonzo, G., et al. 1984. 'Head-end Operations in the Reprocessing of Natural Uranium Fuel." In Proceedings of the ANS Topical Meeting on Fuel Reprocessing and Waste Management, pp. 1.477 to 1-484. August 1990, 1984, Jackson, Wyorning. 
Ariemma, A, et al. 1984. "Italian Reprocessing Activities and Policy." in Proceedings of the ANS Topical Meeting on Fuel Reprocessing and Waste Management, pp. 1-51 to 1-59. August 1990, Jackson, Wyoming.

Harmon, K M., L T. Lakey, and I. W. Leigh. 1984. Summary of National and International Fuel Cycle and Padioactive Waste Management Programs: 1984. PNL-5138, Pacific Northwest Laboratory, Richland, Washington.

$-1985-$

Bonner, W. F. 1985. "Foreign Travel Trip Report." Pacific Northwest Laboratory, Richland, Washington, January 1985.

Chapman, N. A, and F. Gera. 1985. 'Disposal of Radioactive Waste in Italian Clays: Mined Repository or Deep Clays?" Radioactive Waste Management and the Nuclear Fuel Cycle: A Multinational Joumal. Harwood Academic Publishers, New York, Vol. 6, No. 1, p. 51.

Chapman, N. A. 1985. Feasibility Studies for a Radioactive Waste Repository in a Deep Clay Formation. EUR 10061 EN, Commission of the European Communities, Brussels.

Nuclear Energy Agency (NEA). 1985. Compendium on Decommissioning Activities in NEA Member Countries. OECD/Nuclear Energy Agency, Paris.

Paige, H. W. and N. J. Numark. 1985. Assessment of National Systems for Obtaining Local Siting Acceptance of Nuclear Waste Management Facilities. IEAL-R/86-16, International Energy Associates Limited, Washington, D.C., Vol. 1, pp. 9-1 to 9-5, and Vol. 2, pp. 11-1 to 11-4.

$-1886-$

Bertoni, R., et al. 1986. "Quality Assurance Aspects of the Fabrication of the AGN-1 Cask and Its Transport with Spent Fuel." In Proceedings of a Symposium, Packaging and Transportation of Radioactive Materials, PATRAM 1986. June 16-20, 1986, Davos, Switzerland.

Brondi, A., and C. Polizzano. 1986. "Must the Presence of Faults and Fractures Absolutely Exclude a Clay Formation From Consideration as a Potential Radioactive Waste Disposal Site." In Proceedings of the LAEA International Symposium on Siting. Design and Construction of Underground Repositories for Radioactive Wastes, p.361. March 3-7, 1986, Hanover, Federal Republic of Germany.

Chapman, N. A., et al. 1986. 'Disposal of Radioactive Waste in Italian Argillaceous Formations.' In Proceedings of the IAEA international Symposium on Siting, Design and Construction of Underground Repositories for Radioactive Wastes. March 3-7, 1986, Hanover, Federal Republic of Germany.

Crispino, E. 1986. 'Italy's Nuclear Fuel Cycle Industry.' Nuclear Europe. January 1986, p. 23.

Foratom. 1986. Nuclear Power in Western Europe: Status Report 1986. Published by Foratom.

Negroni, A., et al. 1986. 'The Italian Nuclear Energy Program." Nuclear Europe, January 1986, p. 14-34.

Orsini, A. 1986. "Transportation of Small Quantities of Radioactive Materials in Italy." In Proceedings of a Symposium on Packaging and Transportation of Radioactive Materials, PATRAM 1986. June 1620, 1986, Davos, Switzerland. 
Simen, F. 1986. "'taly's Policy on Back End of Fuel Cycle.' Nuclear Europe, January 1986, pp. 24-25.

$-1987-$

Cerretti, P. L., and G. Grossi. 1987. The ENEA Industrial Promotion Program on Management of Radioactive Wastes Produced by the Halian Nuclear Power Plants." In Proceedings of the IAEA International Conference on Nuclear Power Performance and Safety. September 28-October 2, 1987 , Vienna.

Conti, M., et al. 1987. "Chemical Decontamination of the In-Pile Loop for Decommissioning Purposes, Some Evaluation on the Managing Aspects of the Aggressive Solutions in Radioactive Areas.' In Proceedings of the 1987 International Decommissioning Svinposium. October 4-8, 1987, Pittsburgh.

Costa, A., and A. Donato. 1987. "New Trends in the Low-Level Waste Management in Italy." In Proceedings of the 1987 International Waste Management Conference. November 29-December 5, 1987, Hong Kong.

de Crescenzo, V. 1987. "Policy and Progress in Radjoactive Waste Management in thaly: Quality Assurance and Radioactive Waste Processing." In Proceedings of the 1987 International Waste Management Conference. November 29-December 5, 1987, Hong Kong.

Donato, A., and G. Ricci. 1987. "Characterization of Cemented Ashes from the Incineration of UreaFormaldehyde Embedded Radioactive Wastes, According to the Italian Specifications." In Proceedings of the 1987 International Waste Management Conference. November 29-December 5, 1987, Hong Kong.

Mataloni, P. et al. 1987. "Laboratory and Pilot Plant Studies for the Solidification of Aluminum Rich HLW Produced by Eurex Plant." In Proceedings of the International Conference on Nuclear Fuel Reprocessing and Waste Management, RECOD '87, Vol. 1, pp. 297. August 23-27, 1987, Paris.

Nuclear Engineering International (NEI). 7/87. "Italian Waste Innovation," p. 6.

Nucleonics Week (NW). 11/12/87. "Non-Nuclear Future Confronts Italy Following Referendum," p. 1.

Nucleonics Week (NW). 12/24/87. "italian Parliament Approves Policy Lukewarm to Nuclear," p. 2.

NUKEM Market Report on the Nuclear Fuel Cycle (NUKEM). 10/87. "Referendum in Italy." NUKEM $\mathrm{GmbH}_{1}$ Hanau, Federal Republic of Germany, p. 11.

NUKEM Market Report on the Nuclear Fuel Cycle (NUKEM). 12/87. "Nuclear Power Plant Capacity of the Western World." NUKEM GmbH, Hanau, Federal Republic of Germany, p. 20.

Pozzi, F., R. Risoluti, and G. Rolandi. 1987. 'Technical and Commercial Aspects of European MTR Reprocessing." In Proceedings of the International Conference on Nuclear Fuel Reprocessing and Waste Management, RECOD '87, p. 211. August 23-27, 1987, Paris. 
-1988 -

Nuclear Energy Agency (NEA). 1988. Uranium: Resources, Production and Demand. Joint report by OECD/NEA and IAEA. Nuclear Energy Agency, Paris, pp. 104.

Nuclear Waste News (NWN). 12/1/88. 'Synroc May be Superior to Borosilicate Glass for HLW containment, Tests Show," p. 389.

Nucleonics Week (NW). 1/14/88a. "ENEL Orders Europe's First Superçompaction;" p. 12.

Nucleonics Week (NW). 1/14/88b. "ENEL Takes Anti-Nuclear Referendum in Stride," p. 6.

Nucleonics Week (NW). 7/7/88. "ENEL Begins Decommissioning Second Italian Nuclear Plant," p. 2.

NUKEM Market Report on the Nuclear Fuel Cycle (NUKEM), 8/88. "Reprocessing and Waste Management-Review First Half 1988." NUKEM GmbH, Hanau, Federal Republic of Germany, p. 13.

$-1989$.

Cao, S., et al. 1989. "Volume Reduction and Conditioning of ILW and LLW at ENEA Casaccia Center." in Proceedings of the 1989 Joint International Waste Management Conference. October 22-28, 1989, Kyoto, Japan.

D'Anna, C., et al. 1989. 'Experience Achieved on Volume Reduction of Radioactive Waste and On Final Product Qualification.' In Proceedings of the 1989 Joint International Waste Management Conference. October 22-28, 1989, Kyoto, Japan.

Nuclear Waste News (NWN). 3/23/89. "Brazil, Italian Casegrande Group Sign Agreement for Goiania Waste Facility," p. 97.

NUKEM Special Report (NUKEM). 5/89. "Nuclear Power Plant Capacity of the Western World." NUKEM GmbH, Hanau, Federal Republic of Germany, p. 18.

Sandrelli, G., et al. 1989. 'Penformance of a Demonstrative Incineration Plant Designed for Homogenious Waste Processing." In Proceedings of the 1989 Joint International Waste Management Conference. October 22-28, 1989, Kyoto, Japan.

Venditti, P., and G. Grossi. 1989. 'The Italian R\&D Activities in the Field of Treatment and Conditioning of "Third Category (High Level) Liquid Radioactive Wastes." In Proceedings of the 1989 Joint International Waste Management Conference. October 22-28, 1989, Kyoto, Japan.

$-1990-$

International Energy Agency (IEA). 1990. Energy Balances of OECD Countries. Joint report by OECD/IEA, Paris, p. 139.

Leigh, I. W., and S. J. Mitchell. 1990. International Nuclear Fuel Cycle Fact Book. PNL-3594, Rev. 10, Pacific Northwest Laboratory, Richland, Washington.

Nuclear Europe Worldscan (NEW). 34/90. "Halting Nuclear is Costing ltaly Trillions," p. 55. 
Nucleonics Week (NW). 1/18/90. "Hope Springs Eternal as Italy Prepares for Nuclear Future," p. a Nucleonics Week (NW). 4/6/90. "Italian Legislators Ask Rome to Decommission Reactors," p. 2. 


\section{JAPAN}




\section{JAPAN}

\section{CONTENTS}

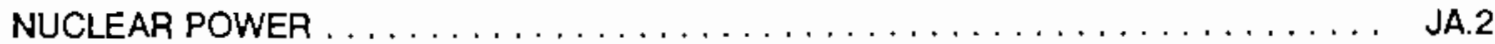

2.0 NUCLEAR FUEL CYCLE AND RADIOACTIVE WASTE MANAGEMENT

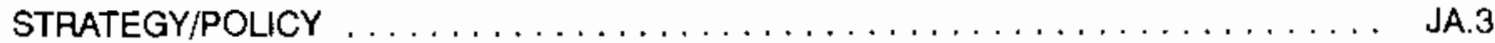

3.0 HIGHLIGHTS AND MAJOR MILESTONES $\ldots \ldots \ldots \ldots \ldots \ldots \ldots \ldots \ldots \ldots$

4.0 INSTITUTIONAL CONSIDERATIONS/ORGANIZATIONS $\ldots \ldots \ldots \ldots \ldots \ldots \ldots \ldots$ JA.5

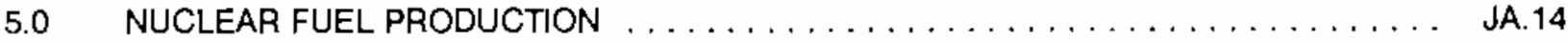

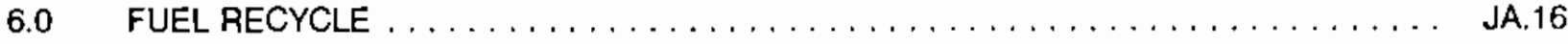

7.0 SPENT FUEL STORAGE AND. TRANSPORT $\ldots \ldots \ldots \ldots \ldots \ldots \ldots \ldots \ldots \ldots \ldots$ JA.17

8.0 WASTE CONDITIONING, STORAGE AND TRANSPORT $\ldots \ldots \ldots \ldots \ldots \ldots \ldots \ldots$ JA.20

9.0 DISPOSAL OF NON-HIGH-LEVEL WASTES $\ldots \ldots \ldots \ldots \ldots \ldots \ldots \ldots \ldots \ldots \ldots \ldots$

10.0 DISPOSAL OF HIGH-LEVEL WASTES $\ldots \ldots \ldots \ldots \ldots \ldots \ldots \ldots \ldots \ldots \ldots \ldots \ldots \ldots \ldots \ldots$

11.0 MANAGEMENT OF URANIUM MINE AND MILL WASTES $\ldots \ldots \ldots \ldots \ldots \ldots \ldots$ JA.30

12.0 DECOMMISSIONING AND ENVIRONMENTAL RESTORATION $\ldots \ldots \ldots \ldots \ldots \ldots \ldots$ JA.31

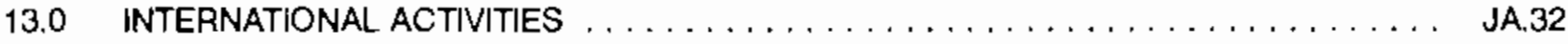

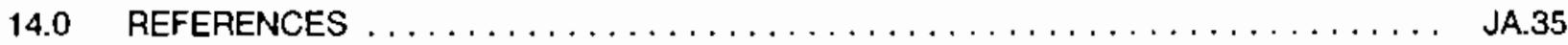




\subsection{NUCLEAR POWER}

1.1 REACTOR MIX: 26 BWRs (21 operable, 5 under construction); 23 PWRs (17 operable, 6 under construction), 1 GCR, 1 ATR, 1 FBR (AlJ 12/90a; WNIH 1991)

\subsection{ELECTRIC POWER PRODUCTION:}

1987 -719 TWh (26\% nuclear) (Leigh and Mitchell 1990)

1988-666 TWh (27\% nuclear) (AlJ 6/90)

1989--668 TWh (25\% nuclear) (NUKEM 7/90)

1.3 NUCLEAR POWER CAPACITY PROJECTIONS (NEI 1990; NUKEM 12/90):

1988-26.9 GWe (NUKEM 12/90)

1990--32.1 GWe (NUKEM 12/90)

1995--38.5 GWe (NUKEM 12/90)

2000-50.8 GWe (NUKEM 12/90)

2005--61.2 GWe (NUKEM 12/90)

2010--72.5 GWe (NEI 1990b)

1.4 NUCLEAR PLANT AVAILABILITY: Japan's nuclear plants had an average capacity factor of $79.2 \%$ in $1987,70.4 \%$ in 1988 , and $72.3 \%$ in 1989 (NN 2/90a)

1.5 NUCLEAR ENERGY POLICY: Japan's long-term nuclear energy policy was reformulated and reisslied by the Japan Atomic Energy Commission (JAEC) in 1987 (Watanabe 1988; Tsuboya 1989; NUKEM 3/90), and updated in 1990 (AlJ 6/90a); the new policy specifies that Japan's long-term goal is to ensure national independence in the supply of nuclear fuel and involves doubling the share of nuclear energy in overall energy production to $16.7 \%$ by 2010 (NEI 7/90); in addition to specifying the importance of nuclear energy in Japan, national policy is directed toward the reduction of oil imports, securing stable supplies, building an active stockpile of fuel, and promoting energy conservation (NEI 1989; AlJ 6/90a)

To achieve these goals, Japan's nuclear power policy specifies that:

- All spent fuel will be reprocessed.

- Utilization of uranium and plutonium from reprocessing of spent fuel shall be promoted

- $\quad$ Plutonium utilization in LWRs and ATRs shall be promoted

- Safe and appropriate radioactive waste treatment and disposal shall be implemented (Tsuboya 1989)

1.6 NUCLEAR R\&D BUDGET: The FY 1990 budget for nuclear-related programs of the Science and Technology Agency (STA) and Ministry of International Trade and Industry (MITI) was 395.5 billion yen ( $\$ 2.7$ billion); about $83 \%$ of the STA nuclear energy budget will go to the Japan Atomic Energy Research Institute (JAERI) and the Power Reactor and Nuclear Fuel Development Corp. (PNC) (AlJ 1/90a)

1.7 ELECTRICITY PRODUCTION COSTS: Based on FY 1989 data, nuclear power is the cheapest source of electricity generation in Japan, costing 9 yen $/ \mathrm{kWh}(\$ 0.06 / \mathrm{kWh})$ compared with 
10 yen $/ \mathrm{kWh}(\$ 0.07 / \mathrm{kWh})$ for coal, 10 to $11 \mathrm{yen} / \mathrm{kWh}(\$ 0.07$ to $\$ 0.08 / \mathrm{kWh})$ for oil and liquefied natural gas, and 13 yen/kWh $(\$ 0.09 / \mathrm{kWh})$ for hydroelectricity (NUKEM 3/90)

\subsection{NUCLEAR FUEL CYCLE AND RADIOACTIVE WASTE MANAGEMENT STRATEGY/POUCY}

(NUKEM 1/87; Tsunoda t987; IEAL 1987; NUKEM 3/88; NEI 1989)

2.1 OVERAL NUCLEAR FUEL CYCLE POLICY: The Japanese are developing domestic commercial capability for all parts of the fuel cycle (excluding uranium conversion), to minimize the risk of over-dependence on foreign technology and production capability; to this end they are developing advanced reactors (ATR and FBR) to improve the elficiency of nuclear fuel utilization; they are in the process of developing commercial enrichment, fuel fabrication and reprocessing capabilities, although currently they are partly dependent on foreign services for enrichment and reprocessing services

\subsection{POLICY ON THE FRONT END OF THE NUCLEAR FUEL CYCLE}

A. Japanese policy is to obtain part or total ownership of selected foreign uranium resources, to develop highly diversified long-term foreign uranium supply contracts, and to participate in overseas prospecting and production; a privately owned company, Overseas Uranium Development Co. (OURD), was established in 1970 to obtain access to foreign uranium reserves (NF 12/90)

B. Domestic enrichment and fuel (including MOX) fabrication facilities are being constructed to fulfill the policy of creating a complete fuel cycle capability in Japan and reducing dependence on other countries (Murata 1987)

2.3 POLICY ON THE BACK END OF THE NUCLEAR FUEL CYCLE (OECD/NEA 1988; Oyama 1989):

A. For spent fuel storage, the Japanese employ at-reactor, in-pool storage in compact racks until the fuel can be reprocessed

B. Reprocessing of spent nuclear fuel is an integral part of the Japanese nuclear fuel cycle, followed by eventual recycle of fissile materials; Japan has been reprocessing in a small plant, with most reprocessing contracted to other countries until larger capacity is available in Japan; careful consideration will be given on whether or not to extend reprocessing consignments with overseas facilities after the year 2000

C. Plutonium will be recycled through breeder reactors about 2020, and to ATRs and LWRs

D. HLW will be converted to borosilicate glass a. d disposed of in geologic formations after an interim (30- to 50-yr) storage period

E. Interim onsite storage of transuranic wastes will be employed pending disposal

F. Japan plans to employ terrestrial storage and central near-surface disposal of LLW from nuclear facilities; the nuclear industry is held responsible for the treatment and disposal of $\amalg W$. Medical and non-nuclear cycle LLW are to be stored and disposed of at small regional centers 
G. Closed nuclear facilities will be mothbailed for 5 to 10 years, followed by dismantling and complete removal of radioactive materials

\subsection{HIGHLIGHTS AND MAJOR MILESTONES}

(NEA 11/86; NUKEM 1/87; Tashiro 1987; Tsunoda 1987; Leigh and Mitchell 1990; NN 3/88; NEI 1989)

1963 The first nuclear power was generated in Japan by the JPDR BWR reactor, which is now being decommissioned

1966 Japan's first commercial nuclear power reactor was commissioned (Tsuboya 1989)

1970 The O-Orai Engineering Center was opened to promote the independent development of FBA and ATA technology in Japan (PNC 8/90)

1977 The "Joyo" experimental FBR attained criticality (PNC 10/90b)

1977 The Tokai reprocessing plant commenced operations

1978 Japan's first (prototype) ATR, Fugen, reached criticality (PNC 4/88b)

1985 The selection of effective geologic formations for a HLW repository was completed

1987 The PNC's treatment facility (PWTF) for transuranic wastes was commissioned

1988 The prototype ATR reactor, Fugen, closed the nuclear fuel cycle when MOX fuel assemblies containing plutonium recovered from spent fuel from the plant were loaded

1988 The prototype LMFBR fuel production line $(5 \mathrm{MTU} / \mathrm{yr}$ ) for the MOX Plutonium Fuel Production Facility (PFPF) was commissioned

1988 Boring of the PNC underground research laboratory was begun (planned to be at Honorobe); it was subsequently canceled in 1989

1989 Construction of the PNC HLW vitrification pilot plant at Tokai was starled

1990 The Tokai Reprocessing Plant completed reprocessing of 500 MT of spent fuel since September 1987 (AlJ 12/90b)

1991 A 40-MTU/yr MOX fuel fabrication line for ATRs will be commissioned

1991 Construction of the commercial-scale fuel reprocessing plant at Rokkasho-mura will begin

1991 The LLW interim storage facility at Rokkasho-mura will be commissioned

1991 The HLW vitrification pilot plant at Tokai will be commissioned

1992 Receipt will begin of plutonium from reprocessed Japanese fuel from French and British reprocessors to fuel the Monja FBR at Fukui (NN 2/90)

1997 A 660-MWe ATR, based on the Fugen model, is scheduled to start operation 
1998 A commercial-scale reprocessing plant, plutonium conversion and product storage facilities, and HLW vitrification/storage facility in the fuel cycle center at Rokkasho-mura are scheduled to start operations

2000 Regulations will be developed for siting a geologic repository for disposal of HLW

2020 Commercial operation of breeder reactors will begin

2030 The $H L W$ repository facility will begin operation

\subsection{INSTITUTIONAL CONSIDERATIONS/ORGANIZATIONS}

\subsection{Legal REQUiREMENTS (Paige 1985; NEA 11/86; IEAL 1987; AlJ 3/88)}

A. Most Japanese laws involving nuclear activities were enacted under the Atomic Energy Basic Law of 1955

B. No stipulation law exists that links reactor licensing to final disposition of radioactive wastes, but the reactor owner must identify a means for reprocessing of spent fuel in Japan or abroad

C. The central government can override a local veto on the siting of nuclear facilities (NEI $7 / 89)$

D. The following have been proposed as changes to Japanese law (AlJ 3/88):

1) The federal government is responsible for the regulation of waste management practices, HLW disposal, and R\&D

2) Generators are accountable for waste treatment, for disposal of LLW and transuranic wastes, and for funding disposal of HLW

3) The regulated exemption dose for shallow-land burial is set at $10 \mathrm{micro}-\mathrm{SV} / \mathrm{yr}$ (1 mrem/yr)

E. In 1989, the Japanese government amended the Law on Compensation for Nuclear Damage, raising compensation rates to triple their original values and extending the term of the Law to the end of 1999 (AlJ 11/89b)

\subsection{RADIATION PAOTECTION PRINCIPLES}

A. Japan has adopted the 'ALARA' principle as its basic nuclear safety and protection principle (Murakami 1987)

B. Radiological protection design objectives for radiation dose (whole-body) exposure limits from nuclear facilities are (Jardine 1989b):

1) Offsite public - normal operations - $2 \mathrm{mrem} / \mathrm{yr}$

2) Onsite workers, normal operations in an unrestricted area - $500 \mathrm{mrem} / \mathrm{yr}$ 
4) Offsite public - accident condition - 5 rem/incident

4.3 LICENSING: In Japan, construction and licensing of radioactive waste facilities closely follows that for nuclear installations and is subject to the following process (except for the requirement for public hearings) (NLB 6/90):

A. The overail licensing procedure for nuclear power installations involves the power ulility, the public, the Electric Power Development Co-ordination Council (EPDCC) of MITI, the Atomic Energy Commission (AEC), and the Nuclear Safety Commission (NSC)

B. After the utility has selected a site and obtained local government and resident approval, a construction plan is submitted to the EPDCC for review and public comment

C. A request for an Installation Permit is submitted to MITI after approval of the construction plan; this is reviewed by the AEC and $\mathrm{NSC}_{1}$ and a second public hearing is hold for comment about plant safety

D. A construction license is then issued by MIT; after construction of several interim testing/inspection reviews by MITI, an operating license is issued

E. The entire process from beginning of construction to starting operation usually takes 50 to 70 months

F. Licensing of underground waste disposal or waste management business is performed directly by the Office of the Prime Minister following review of an operating/safety plan by the Director-General of the Science and Technology Agency (STA) (Yamanouchi 1987)

G. A radioactive waste management licensee is defined by law as anyone handling over 100 curies of radioactive wastes (Yamanouchi 1987)

\subsection{PUBLIC INVOLVEMENT}

A. In Japan, licensing procedures for waste repository construction and operation are similar to the procedures for siting nuclear power plants, except that there is no current requirement for primary public hearings in siting waste repositories; this is expected to change (Numark 1989); formal public hearings similar to those for commercial reactor licensing are expected to be held and, in fact, NSC held such a public hearing voluntarily for the Rokkasho-mura LLW disposal site (AIJ 5/90a)

B. An HLW underground research laboratory was suggested by the site owners (Nippon Steel Corp. subsidiaries) in a copper mine at Kamaishi, $500 \mathrm{~km}$ north of Tokyo, but was eventually rejected as a result of prolonged active public protest (NF. 11/89); thus, atthough public involvement is not required except for comment and opinion, public opposition to nuclear facifities in Japan has actually delayed or prevented site approval

4.5 WASTE FUND: HLW disposal costs will be paid from reserve funds being collected by electricity producers (IEAL 1987; NEI 7/90) 
4.6 KEY AGENCIES AND FUEL CYCLE CENTERS (AlJ 1/88; NEl 2/89; Leigh and Mitcheil 1990)

A. The arrangement of nuclear centers and responsibilities in Japan consists of a mixture of government, quasi-government, and industrial components; the Prime Minister is involved in all stages of the development of nuclear power and is the ultimate authority; two independent oversight bodies (Atomic Energy Commission, AEC; and the Nuclear Safety Commission, NSC) report directly to the Prime Minister's office; government responsibilities for the establishment, operation and inspection of nuclear facilities are shared between the Science and Technology Agency (STA), the Ministry of International Trade and Industry (MITI), and the Ministry of Transport; the various government bodies work closely with Japanese heavy industry companies in all aspects of the nuclear fuel cycle

B. Specific functions of each agency/group are set out below:

1) AEC (Atomic Energy Commission): The function of the AEC, which was formed in 1956, is to perform long-term planning and to make decisions regarding the development and utilization of nuclear energy in Japan; the AEC is also responsible for the formulation of national policy on nuclear energy research, development and utilization, and advises the Prime Minister; the AEC revises the plan for the development of nuclear energy every 5 years; the latest revision was in July 1987

2) NSC (Nuclear Safety Commission): The NSC is responsible for carrying out national policy in regard to safety and security of nuclear energy R\&D and utilization, and is an advisory body to the Prime Minister's office; the NSC has oversight and review authority for nuclear inspections and promulgates safety regulations

3) MITI (Ministry of International Trade and Industry): The MITI is the Japanese government agency responsible for nuclear power development, licensing, fuel cycle and waste management activities; CRIEPI, JNFI, JNFS and RMC are controlled by MITI; MITI has general responsibility for promoting and coordinating industrial activity in nuclear energy and the fuel cycle; the Ministry of Transport is responsible, together with the STA, for formulating policies on the transport of nuclear materials

a. CRIEPI (Central Research Institute of Electric Power Industry): The CRIEPI reports to MITI and provides R\&D suppor for Japanese utilities, including waste management R\&D in the areas of transportation, storage, and disposal of LLW, intermediate and long-term storage of spent fuel, and long-term storage and disposal of HLW

b. JNFI (Japan Nuclear Fuel Industries Company): The JNFI is responsible for commercial uranium enrichment and terminal LLW storage facilities, and reports to MITI

c. JNFS (Japan Nuclear Fuel Service Company): The JNFS is in charge of commercial reprocessing, including solidification and interim storage of reprocessing wastes, and the construction and operation of storage facilities for wastes returned from foreign reprocessors of Japanese spent fuel (COGEMA, France, and BNFL, U.K.) 
d. RMC (Radioactive waste Management Center): The RMC is co-owned by Japanese industry, MITI and STA, and is responsible for the promotion of R\&D to ensure safe and rational $\amalg W$ and HLW disposal

4) STA (Science and Technology Agency): The STA is a government extra-ministerial agency of the Prime Minister's office for comprehensive administration and the promotion of science and technology; the AEB, NIRS, and the NSB are under STA jurisdiction, as are the Power Reactor and Nuclear Fuel Development Corporation (PNC) and the Japan Atomic Energy Research Institute (JAERI), which are mostly governmental agencies/companies; the STA supervises the work of PNC, JAERI, and the Radiation Council (which establishes technical standards for radiation protection); JAERI and PNC share government reservations at the Tokai-mura and Oarai-machi Research Establishments; both PNC and JAERI share funding of some projects with private industry

a. AEB (Atomic Energy Bureau): The AEB develops policy and is responsible for oversight of research and internal affairs and nuclear development; the $\mathrm{AEB}$ also provides technical and advisory support to the Atomic Energy Commission

b. NIRS (National Institute of Radiological Sciences): The NIRS is attached to the STA and is responsible for carrying out studies on radiation hazards, applications for medical use, and the education and training of engineers in these areas

c. NSB (Nuclear Safety Bureau): The NSB provides technical support to the Nuclear Safety Commission in areas of radiation protection, nuclear safely policy, nuclear materials, and safeguards

d. PNC (Power Reactor and Nuclear Fuel Dovelopment Corporation): The PNC was formed in 1967 and is the main channel for the development of advanced reactors and the establishment of the fuel cycle; the PNC reports to the AEB and is a mostly governmental organization responsible for development and demonstration of fuel cycle technology, including uranium enrichment, MOX fuel conversion and fabrication, fuet reprocessing, and technology on HLW and transuranic waste management

2. JAERI (Japan Atomic Energy Research Institute): The JAERI was established in 1956; the JAERI is a semi-governmental research organization implementing national long-term programs in nuclear energy, including joint projects and international cooperation; under STA direction, the JAERI also performs research for safely evaluation, LLW, HLW and transuranic waste management, and advanced waste management R\&D on, e.g., sub-seabed disposal and $\mathrm{HLW}$ partitioning

f. RANDEC (Research Association for Nuclear Facility Decommissioning): The RANDEC was set up in 1988 to be responsible for the research and development on decommissioning of nuclear facilities, related technical information service, training of the specialists, and others; participating members of RANDEC include JAERI, the nine regional utilities, JAPCO, and private industry (NEI 7/89; Oyama 1989) 
5) Specific functions of other key Japanese entities are set out below:

a. FEPCO (Federation of nine private electric utilities and the Japan Atomic Power Company): The FEPCO develops industry policy on energy issues including waste management, and sponsors utility-wide projects; FEPCO played a lead role in establishing the Shimokita site for reprocessing and LLW disposal and in forming JNFS and JNFI

b. GIRIO (Government industrial Research Institute, Osaka): The GIRIO performs R\&D into alternatives for HLW solidification, and waste-form characterization

c. Hitachi, Ltd., is one of five major Japanese companies heavily involved in nuclear power development, including volume-reduction technology development, automation and robotics, fiber optics, and advanced control systems; Hitachi Engineering Co., Ltd., a subsidiary, develops technology to store and reprocess spent LWR fuel, store, fix and dispose of HLW, produce plutonium, and decommission nuclear facilities

d. IHI (Ishikawajima-Harima Heavy Industries Co., Ltd.) is a private company responsible for the development of a nuclear waste management system

e. JAIF (Japan Atomic Industrial Forum): The JAIF is a nonprofit organization with voluntary memberships, whose major purpose is to promote the peaceful use of atomic energy; the Forum represents some 800 organizations, which include the electric power utilities, industrial corporations, construction and financial concerns, R\&D agencies, local authorities, and others involved in atomic energy development in Japan; the JAIF sets up committees and panels for the study of specific nuclear industry problems, and makes recommendations to governmental and other agencies, sponsors general and specific surveys and research on domestic and foreign nuclear matters, promotes international cooperation, and sponsors training of nuclear personnel

f. JGC Corporation is a private corporation responsible for the design and construction of fuel reprocessing and radioactive waste treatment facilities; it performs waste management R\&D, including wet oxidation, incineration, waste forms, ash melting, and selective nuclide removal

g. Kobe Steel, Ltd., is a private company that has activities in spent fuel transportation and storage cask design and production, waste treatment equipment and systems, and LLW/HLW handling and storage

h. MMC (Mitsubishi Metal Corporation) is a private company that performs design and research on facilities for spent fuel storage and reprocessing, waste treatment, and geologic disposal

\subsection{PAINCIPAL RESEAACH, DEVELOPMENT AND DEMONSTRATION FACILITIES/PROGRAMS}

A. STA has announced plans for a Research Association for Nuclear Facility Decommissioning (RANDEC), to include JAERI, the nine regional utilities, JAPCO, and private industry. RANDEC will perform A\&D on equipment and methods for decommissioning (NEI 7/89) 
B. PNC: The purpose of PNC as detined by law [Atomic Energy Basic Law, \#186 of 1955 (PNC 1987)] is to develop the FBR and the ATR, establish domestic production, reprocessing and possession of nuclear fuels, and to exploit, mine, and refine nuclear source materials; several centers, including Tokai, Oarai, and others, have been established to perform and/or support these functions

1) The Chubu Works, located at Toki-shi, Gifu Prefecture, provides technical support to overseas exploration activities by developing new techniques and instruments, training exploration technicians, and carrying out chemical and mineralogical analyses of raw materials

2) PNC has operated a pilot plant at Ningyo-Toge since 1982 to develop a process for the production of reactor-grade $\mathrm{UF}_{4}$ directly from uranium ore and with conversion to $\mathrm{UF}_{6}$ without intermediate formation of yellow-cake

3) The Microwave Heating $(\mathrm{MH})$ direct denitrification process for MOX production was developed by PNC at the Tokai Plutonium Conversion Development Facility; the facility generates $10 \mathrm{~kg} / \mathrm{d}$ of MOX by the MH process; engineering tests using recovered uranium have been performed using $\mathrm{MH}$ at the Continuous Denitration Unit (3 MT UO $2 / \mathrm{yr}$ ), also at Tokai (PNC 10/89C)

4) The Waste Dismantling Facility (WDF) at Oarai Center pertorms R\&D on decommissioning and dismantling, including development of a plasma cutting robot, CO laser cunting, decontamination by ice and dry ice blasting, electropolishing, and the REDOX process

5) PNC is currently designing the Recycle Equipment Test Facility for conducting R\&D on advanced equipment and processes, including a continuous dissolver and centrifugal contactor for FBR spent fuel assembly processing (PNC 4/90c)

6) The Solvent Waste Treatment Demonstration Facility at Tokai Center is engaged in technology development concerning phosphoric acid extraction, separation of tributyl phosphate and dodecane, and solidification of wastes in epoxy and PVC

7) The Krypton Recovery Technology Development Facility at Tokai was designed and built to separate and recover krypton-85 gas released during shearing and dissolution of spent fuel elements during reprocessing; hot testing at this facility began in 1988 (PNC 10/88)

8) The Plutonium Fuel Production Facility (PFPF) at Tokai (see Section 6.0A) was opened in November 1987, has a capacity of $5 \mathrm{MTHM} / \mathrm{yr}$, and will supply fuel elements to the prototype FBR 'Monju' (NUKEM 1/88)

9) Experimental FBR research at PNC (Oarai) includes work with the "Joyo" FBR, which has now operated for over 40,000 hours without serious problems, and plant systems development R\&D aimed at commercialization of FBRs (PNC 1n/90b)

10) The Advanced Thermal Reactor (ATR), based on the "Fugen" prototype, is being designed and studied at PNC (Oarai); work includes plant systems, reactor physics, heat transfer and thermo-hydraulics, components, inspection equipment dovelopment, and safety research (PNC 10/90b) 
11) PNC completed the Tokai Reprocessing Plant (TRP) at the Tokai Works in 1981; in 1988-89 this plant underwent major renovation. The TRP serves as an R\&D center for reprocessing technology as well as a production unit for plutonium recovery from spent fuel to supply the prototype FBR 'Monju' (due to become critical in 1992). The plant has a reprocessing capacity of $0.7 \mathrm{MT} / \mathrm{d}$, but its reprocessing work will be taken over by the proposed Rokkasho-mura reprocessing plant when it is completed, and the TRP will become a strictly R\&D facility (PNC B/90b)

12) Construction of the Plutonium Waste Test Facility (PWTF) at Tokai was completed in 1987; this is an R\&D facility for developing technology for processing solid radioactive wastes from plutonium fuel fabrication, transuranic waste volume reduction, and equipment from obsolete facilities ( $P N C 4 / 88 a)$; it has a capacity of $450 \mathrm{~m}^{3} / \mathrm{yr}$ (2000 to 3000 drums/yr) (NUKEM 1/88)

13) The second High Active Waste Storage Facility for storage of HLW from reprocessing operations was completed in March 1990 at Tokai (PNC 10/90b)

14) Reactor Physics R\&D at PNC (Oarai) includes development of a large, highburnup reactor core, shielding research, MOX fuel properties, transuranic waste incineration, and criticality safety research (PNC 10/90b)

15) Radioactive waste management research is performed at PNC (Oarai) and includes projects on dismantling large-size waste from the Waste Dismantling Facility (WDF), treatment of FBR HLLW, and decommissioning research (PNC 10/90c)

16) Two facilities for bitumenizing wastes are now in operation at Tokai, the second having been certified in 1990 (PNC 1990e); the new facility is capable of storing up to 30,000 asphalt and plastic solidified waste drums

17) The Tokai Vitrification Facility is a pilot plant facility designed to develop technology for conversion of reprocessing waste HLW into glass; a cold trial was scheduled for 1990 and hot operation testing is to begin in 1991 (PNC 10/88a); plant operation at a nominal glass production rate of $9 \mathrm{~kg} / \mathrm{hr}$ is scheduled for 1992 (NUKEM 8/88)

18) A 6-m-diameter, $150-\mathrm{m}$-deep test shaft is being excavated at PNC's Tono mine to determine the effects of excavation on the rock mass, as a preliminary to excavation of a deep geological repository for vitrified HLW (PNC 4/90b)

19) Hydrothermal rock solidification technology is being developed by PNC at Tokai to treat LLW from reprocessing plants; preliminary results indicate that ash, iodine adsorbent and silica gel are converted to rock products with leaching rates of $10^{-5}$ to $10^{-6} \mathrm{~g} / \mathrm{cm}^{3} /$ day, and with other favorable properties for long-term storage (PNC $4 / 88 d)$

20) Research on engineered barrier materials is being performed at PNC (Tokai) with the aim of developing materials suitable for use in HLW repositories (PNC 12/90b); a large-scale, 6-m-diameter concrete block test facility for buffer materials ("Big Ben") is in use to determine the buffer capacity of bentonite clay 
21) PNC is planning to construct a Storage Research Center laboratory facility for HLW studies at Horonobe, Hokkaido (PNC 10/89); the facility will include a vitrified HLW storage plant, hot test facility, $\amalg W$ immobilized waste storage facility, and a deep strata test site (URL); the site survey results were favorable but construction has not yet started, mainly because of local public opposition

C. JAERI pertorms a wide range of nuclear energy research projects at the Tokai and Oarai sites, which it shares with PNC; JAERl's activities cover nuclear safety research, hightemperature gas-cooled reactor R\&D, fusion R\&D, radiation applications, nuclear ships, and fundamental research studies (NE 8/89)

1) JAERI operates the Radioactive waste Management Center (RMC) under MITI and STA funding, together with private sector and electric power company support, to promote $R \& D$ and provide information services on radioactive waste treatment and disposal

2) Safety experiments are pertormed using the Large Scale Test Facility (a PWR) to determine the effects on thermal hydraulic response of small-break, loss-ofcoolant accidents and abnormal transients

3) The Simulation Test Facility for Environmental Radionuclide Migration (STEM) uses migration columns and cells for safety studies on radionuclide migration in soil layers

4) The Nuclear Fuel Cycle Safety Engineering Research Facility (NUCEF) consists of a glove box, hot cells and critical assemblies; it is used for safety evaluation for transuranic waste management, research on partitioning of $\mathrm{HLW}$, criticality safety experiments, and research on advanced reprocessing processes (to be constructed in 1990)

5) The Waste Safety Testing Facility (WASTEF) at Tokai has been operated since 1982 to perform research safety evaluations for the long-term storage and disposal of $\mathrm{HLW}$. The facility includes glove box and hot cells for safety evaluations for HLW management and performs R\&D on simulated and actual wastes, and their vitrification, storage, disposal, stability, and characteristics

6) A High Temperature Test Reactor (HTTR) construction permit application by JAER! for construction within JAERI at Oarai passed STA safety review in December 1989 and is undergoing review by the NSC; the facility will be used to resolve technical problems related to the development of a nuclear heat utilization plant, including hydrogen production from water-splitting, with reactor helium coolant at $950^{\circ} \mathrm{C}$ (AiJ $12 / 89 a)$

7) The Japanese Metal Mining Agency sponsored a research project with an industrial consortium including Mitsubishi Metals Corp. (MMC), three other chemical companies, and MITI, to recover uranium from seawater at the Nio institute in Kagawa Prefecture; a total of $15.4 \mathrm{~kg}$ of yellow-cake was obtained by an adsorption-elution-extraction-purification process using hydrated titania as the specific adsorbent for uranium; the cost of uranium extracted by this method, using an improved adsorbent, was estimated at U.S. \$260/lb (AlJ 3/89) 
8) Laser enrichment technology developed by JAERI has now been passed on to industry for development; a company known as 'Laser $\mathrm{J}$ ' was formed in 1988 to commercialize the technology (NEI 6/88), which uses the Atomic Vapor Laser Isotope Separation (AVLS) technique; Laser-J completed an 8-billion yen ( $\$ 53$ million) test enrichment facility in April 1990 (NF 5/90) as part of a two-year development program which started in July 1990 under JAERI (at Tokai)

9) Fusion research is performed using the JT-60 Tokamak device, at Naka-Machi (lbaraki), which is now being upgraded for additional work to obtain a break-even plasma condition (NE 8/89)

10) Safeguards technology for nuclear materials is being developed to obtain nearreal-time accountability of fissile material for bulk handling facilities (NE 8/89)

11) The OMEGA project is being performed by JAERI/CRIEPI with the intent of developing partitioning and transmutation technology for the separation, conversion and removal of long-lived transuranic elements from nuclear wastes (Hattori 1990); actinide conversion by transmutation was first proposed in December 1984; actinide separation by preprocessing followed by nuclear burnup in a metallicfueled FBR was discussed in 1986

12) Radiation applications include the development of polymer materiais by radiation processing and the radiation sterilization of sludge (NE 8/89)

\subsection{KEY PERSONNEL (Leigh and Mitchell 1990)}

Eizaburo Saito, Chairman (Minister of State for Science and Technology), AEC

Takashi Mukaibo, Acting Chairman, AEC

Hikaru Matsunaga, Minister, MITI

Naomichi Suzuki, Vice-Minister, MITI

Kazumasa Kusaka, Director, Nuclear Energy Industry, MITI

Toru Ishida, Director, International Nuclear Affairs, MITI

Hiroshi Narita, President, CRIEP!

Eizaburo Saito, Minister, Science/Technology, STA

A. Yuki, Director, Nuclear Fuel Division, AEB, STA

Yoshinori Ihara, President, JAERI

Toyojiro Fuketa, Eiichi Tsuji, Vice Presidents, JAERI

Hakubi Sasaki, Executive Director, International, JAERI

Konomu Sanokawa, Director-General, JAERI-Oarai

Takumi Asaoka, Director-General, JAERI-Tokai 
Takao Ishiwatari, President, PNC

Mitsuru Sata, Hiroshi Ohishi, Vice-Presidents, PNC

Yoshikazu Hashimoto, Executive-Director, Waste Management, Storage and Disposal, PNC

Masao Yamamoto, Senior Director, Waste Management, PNC

Takao Tsuboya, Senior Director, Waste Management, PNC

Tadatomo Yamaguchi, International Cooperation, PNC

T. Sasaki, Executive Director, Nuclear Fuel Reprocessing, PNC

Masao Hori, Director, PNC-Oarai

Hidehiko Miyao, Waste Management, PNC-Oarai

Tanehiko Yamanouchi, Director, PNC-Tokai

Makato Toda, Nobukazo Saitoh, Kenichi Matsumoto, Deputy Directors, PNC-Tokai

Kenjiro Ogata, Director General, AEB

Katsuhisa Ida, Deputy Director General, AEB

Sadao Ito, Director, Plant Design-Reprocessing, JNFS

Ryohei Terai, Director, Nuclear Waste Program, GIRIO

Yumi Akimoto, General Manager, Nuclear Energy, MMC

Toshio Fukuda, President, RMC, Tokyo

\subsection{NUCLEAR FUEL PRODUCTION}

5.1 STRATEGY: Japan imports virtually all of its uranium at present, but JAIF recently issued a repon stressing the need for Japan to develop a domestic uranium industry to ensure supply after the year 2000 (AlJ $8 / 90$ ). Private uranium mining in Japan is limited to two production and two exploration projects; JAIF recommended that Japanese industry should be assisted by the government (through PNC) in developing a domestic uranium supply. With minimal domestic economically minable resources of uranium ore, Japan has a strategy of entering into longterm purchase contracts and cooperative agreements for exploration and development of foreign reserves; enrichment services are currently being purchased with the long-term intent of developing a domestic enrichment, nuclear fuel fabrication, and spent fuel recycling capability (PNC 1987; NEI 1989) 


\subsection{URANIUM RESOURCES}

A. Over 100 radioactive deposits have been identified in Japan by the Geological Survey of Japan, the principal ones being at Tono and Ningyo-Toge; the deposits are not large and are widely variable in composition and host rock formations (Okada 1988); Japan has only 10,000 MTU domestically and $230,000 \mathrm{MTU}$ will be required by the year 2000 to supply its nuclear power industry, so the remainder must be imported (PNC 1987)

B. Japan has commitments for $\mathrm{U}_{3} \mathrm{O}_{8}$ purchases of 63,400 MT between 1988 and 2000, from Namibia $(24 \%)$, Central Africa $(19 \%)$, South Africa (4\%), Canada (31\%), Australia $(20 \%)$, and the U.S. (2\%) (NF 2/88).

5.3 URANIUM PRODUCTION: 79 MTU through 1986; 8 MTU in 1987; 0 MTU there after (OECD/IAEA 1989).

PNC has operated a pilot plant at Ningyo-Toge since 1982 to develop a process for the production of reactor-grade $\mathrm{UF}_{4}$ directly from uranium ore and with conversion to $\mathrm{UF}_{6}$ without intermediate formation of yellow-cake (AlJ $8 / 90 a$ )

\subsection{URANIUM ENAICHMENT}

A. Since 1960, PNC has been performing research on uranium enrichment using both gaseous diffusion and centrifuge technologies at the Tokai Works; in 1982, a 7000-unit centrifuge plant went into operation at Ningyo-Toge, with a capacity of 50 MTSWU; a demonstration plant began operation in 1989, with a capacity of $200 \mathrm{MTSWU}$; this plant will enrich uranium to $5 \%$ uranium-235, processing $300 \mathrm{MT}$ of natural uranium into $60 \mathrm{MT}$ of enriched uranium (NEI 6/89; NF 2/89)

B. JNFI is constructing a 1500-MTSWU gas centrifuge enrichment plant at Rokkasho-mura, due for completion in 1991; in April 1990, the first four centrifuge units were installed (AlJ 4/90); the plant is scheduled to reach full capacity by the year 2000

C. Japan is actively developing laser enrichment technology and plans to use this for the next stage of its enrichment program; JAERI announced recently that it had achieved a $5 \%$ uranium enrichment, at $0.01 \mathrm{~g} / \mathrm{hr}$, with an enrichment energy efficiency of 0.004 SWU/KWh (AlJ 9/90b)

5.5 FUEL FABRICATION: Private industy in Japan provides fabrication of LWR fuel; as of December 1986, four commercial LWR fuel fabriaction plants were in operation, each having a capacity in the range of 100 to $640 \mathrm{MTU} / \mathrm{yr}$, with total capacity as of December 1987 of 1,565 MTU/yr (see also items 6.0A and 6.08) (NEI 12/87; NEI 7/89)

\subsection{PROGRAM/FACILITIES COSTS}

A. Costs for the JNFI enrichment plant are budgeted at 160 billion yen ( $\$ 1$ billion); the laser isotope separation process R\&D costs are budgeted at 10 billion yen ( $\$ 65$ million) for 1986-1996

B. The Japanese Metal Mining Agency sponsored a research project with an industrial consortium including MMC, three other chemical companies, and MITI, to recover uranium from seawater at the Nio institute in Kagawa Prefecture; a total of $15.4 \mathrm{~kg}$ of yellow-cake was obtained by an adsorption-elution-extraction-purification process using 
hydrated titania as the specific adsorbent for uranium; the cost of uranium extracted by this method, using an improved adsorbent, was estimated at U.S. \$260/1b (AIJ 3/89; NE $5 / 89$ )

\subsection{FUEL RECYCLE}

The AEC has established an Advisory Committee on Nuclear Fuel Recycling to consider policy on plutonium utilization in LWRs, MOX fuel fabrication, transportation of recovered plutonium from the U.K and France, utilization of recovered uranium, and related fuel recycling matters (AlJ 5/89)

A. Fabrication of MOX fuel began in 1965 for the Fugen and Joyo reactors (NEI 7/89); in October 1989, PNC began production of mixed uranium-plutonium oxide (MOX) fuel for loading the prototype FBR "Monju'; 202 MOX fuel assemblies are to be produced in 30 months; the assemblies are being produced at the Plutonium Fuel Production Facility (PFPF), Tokai Works, which started operation in 1987; the PFPF was constructed to demonstrate mass-production technology (5 MTHM/yr) and economic efficiency in MOX fuel assembly fabrication (AIJ 11/89); a cumulative production of $100 \mathrm{MT}$ of MOX fuel had been produced at the PFPF by March 23, 1989 (PNC 10/89b)

B. Construction of a 40-MT/yr MOX ATR fuel production line began in December 1986 at Tokai, and was to proceed in tandem with construction of the demonstration ATR at Ohma (AlJ 11/89a); operation of the ATR MOX fuel line is scheduled for 1993 (PNC $10 / 89 \mathrm{~b})$, but operation of the 560-MWe demonstration ATR has been postponed until 1998 (NUKEM 5/89)

6.1 FUEL REPROCESSING: While developing its own domestic reprocessing capability, Japan is currently largely dependent on foreign reprocessing of its spent fuel

A. Currently, foreign contracts for 5,900 MTU with BNFL (U.K) and COGEMA (France) exist for the reprocessing of Japanese spent fuel; plutonium derived from this activity will be returned to Japan by sea, beginning in 1992 at the earliest (NF 12/89; NEI 7/89; AlJ 12/89).

B. The small-scale ( $210 \mathrm{MT} / \mathrm{yr}$ ) domestic Tokai reprocessing plant, which began operations in September 1977, had processed 509 MT of spent fuel by the end of 1990 (AlJ 12/90b); PNC is considering converting the Tokai plant to an experimental facility to study FBR fuel reprocessing once the planned Rokkasho reprocessing facility begins operating (NUKEM 2/90)

C. JNFS plans a commercial reprocessing plant with a capacity of $800 \mathrm{MTU} / \mathrm{yr}$ at Rokkashomura (NEI 7/89; Tsuboya 1989), with startup in October 1998 using LWR spent fuel; this plant will use technology developed primarily in France, with input from Japanese, BNFL, and German technology, and will include about $3000 \mathrm{MTU}$ wet storage of spent fuel; the plant will be built on a 390-ha (700-acre) site at a cost of 840 billion yen ( $\$ 6.5$ billion) (AlJ 3/89). Startup was originally planned for 1997, but has recently been delayed for 10 months (NEI 1/91)

6.2 PLUTONIUM RECYCLE: Plutonium and uranium recycle in Japan has been demonstrated in FBRs, and ATRs and experimentally in LWRs; Japan plans to fully utilize all available plutonium and uranium from reprocessing activities in ATRs and breeder reactors, beginning with the use of MOX fuel in commercial LWRs in 1997; eventually, the plutonium supply is expected to be 
sutficient to fuel twelve 100-MWe LWRs (NEl 7/89; NUKEM 9/90); however, in the interim, the supply of plutonium from deliveries from foreign and domestic reprocessing is expected to exceed demand, and the excess will require stockpiling

\subsection{RESEARCH AND DEVELOPMENT}

A. In Japan, R\&D is carried out in the PWTF for developing technology for processing solid radioactive waste from plutonium fuel fabrication, transuranic waste volume reduction, and equipment from obsolete facilities (PNC 4/88a); it has a capacity of $450 \mathrm{~m}^{3} / \mathrm{yr}(2000$ to $3000 \mathrm{drums} / \mathrm{yr}$ ) (NUKEM 1/88)

B. A hot-test facility to be used for the development of FBR reprocessing technology is under construction; the plan is for a $120-\mathrm{kg} / \mathrm{d}$ pilot plant to be built and to begin operation in 1995 (NEI 7/89)

C. The Microwave Heating (MH) direct denitrification process for MOX production was developed by PNC at the Tokai Plutonium Conversion Development Facility; the facility generates $10 \mathrm{~kg} / \mathrm{d}$ of MOX by the MH process; engineering tests using recovered uranium have been performed using $\mathrm{MH}$ at the Continuous Denitration Unit (3 MT $\mathrm{UO}_{2} / \mathrm{yr}$ ), also at Tokai (PNC 10/89c)

D. PNC is currently designing the Recycle Equipment Test Facility for conducting R\&D on advanced equipment and processes, including a continuous dissolver and centrifugal contactor for FBR spent fuel assembly processing (PNC 1990c)

E. PNC is planning to build a Recycle Equipment Test Facility (RETF) to verify advanced equipment and processes for FBR fuel cycle technology; the RETF R\&D work will verify advanced equipment such as the fuel disassembly system, continuous rotary dissolver, centrifugal clarifier, and the centrifugal contactor (PNC 1990)

6.4 PROGRAM/FACILITIES COST: The future commercial-scale JNFS reprocessing facility has a budgeted construction cost of 840 billion yen ( $\$ 6.5$ billion) (Nomura 1987; AlJ 3/89)

\subsection{SPENT FUEL STORAGE AND TRANSPORT}

7.1 SPENT FUEL ARISINGS (Adachi 1987; Nukem 1/87; Watanabe 1988; Tsuboya 1989)

in Japan, a total of 2,100 MTU of spent LWR fuel was stored in AR-pools through 1987. A total of $400 \mathrm{MTU}$ of spent fuel had been transported to the Tokai reprocessing plant by the end of 1987, and 3,600 MTU had been transported to overseas reprocessors (including $950 \mathrm{MT}$ of GCR spent fuel) (Watanabe 1988). Spent fuel arisings in subsequent years were or will be:

$$
\begin{array}{ll}
1987--700 \mathrm{MTU} / \mathrm{yr} & 2000-1,100 \mathrm{MTU} / \mathrm{yr} \\
1990-730 \mathrm{MTU} / \mathrm{yr} & 2030--2,000 \mathrm{MTU} / \mathrm{yr} \\
1995--900 \mathrm{MTU} / \mathrm{yr} &
\end{array}
$$

The cumulative spent fuel total is expected to be 19,600 MTU through the year 2000 , although most will have been reprocessed by that date

7.2 FUEL ASSEMBLY CHARACTERISTICS: Two major types of fuel assemblies are used in commercial reactors in Japan, for BWRs and PWRs, respectively; their typical characteristics are as follows (Adachi 1987): 


$\begin{array}{cc}\text { BWR } & \text { PWR } \\ 8 \times 8 & 17 \times 17 \\ 62 & 264 \\ 4.5 \mathrm{~m} & 4.0 \mathrm{~m} \\ 14 \mathrm{~cm} & 21 \mathrm{~cm} \\ 270 \mathrm{~kg} & 670 \mathrm{~kg} \\ 3 \% & 3.2 \%\end{array}$

7.3 SPENT FUEL STRATEGIES: Japanese strategies for the storage, treatment, and disposal of spent fuel and radioactive wastes were developed in accordance with the "Long Term Program for the Development and Utilization of Nuclear Energy" issued by the AEC on June 22, 1987 (AEC 1987); the waste management program so defined involves:

A. At-reactor storage of spent fuel for a cooling period of 2-3 years

B. Shipment offsite for reprocessing (all spent fuel generated in Japan is to be reprocessed and the uranium and plutonium recovered will be used for power generation); domestic reprocessing technology will be used as soon as it is available (Tsuboya 1989); the implication of this is that spent fuel storage facilities must be in place at both nuclear power plants and reprocessing facilities (Shibato t987)

7.4 WET STORAGE: In Japan, spent fuel is held in at-reactor pool storage at the nuclear power plants until it can be moved to the foreign or domestic reprocessing plants (Shibato 1987; Suyama 1989)

A. BWR spent fuel storage pools are installed on the highest floor of the reactor building adjacent to the reactor well; fuel is transferred from the reactor to the storage racks for minimum of a 2-3 yr cooling period before being transferred into casks at the cask loading pit adjacent to the pool, for transport to the reprocessing facility

B. PWR spent fuel storage pools are in a separate building adjacent to the reactor building; the pools are filled with borated water, and are connected to the reactor cavity by a transfer tube; transfer to casks is similar to that for BWRs

C. All fuel transfers are performed by a fuel handling machine

D. Initial spent fuel pool storage capacity was designed to be $150 \%$ of full-core capacity per reactor, but delays in construction of reprocessing facilities led to expansion of storage capacity at new plants to an average of $300 \%$, and a maximum of $620 \%$ of full-core capacity

E. Storage racks at reactors for BWR spent fuel consist of square tubes in an $8 \times 10$ configuration and a base made of austentitic stainless steel, designed to prevent nuclear criticality even under seismic shock conditions

F. Spent fuel storage at reprocessing plants will be similar in design to the in-pool storage at nuclear power plants; the PNC Tokai reprocessing plant has spent fuel storage pool capacity of 97 MTU and reprocessing capacity of $210 \mathrm{MTU} / \mathrm{yr}$; JNFS's planned Aomori full-scale reprocessing plant will have a storage capacity of 3,000 MTU and a reprocessing capacity of $800 \mathrm{MTU} / \mathrm{yr}$ 
G. The use of super-high density storage racks for spert fuel interim storage in pools is being considered, using boron stainless steel racks, giving a $30 \%$ increase in pool capacity compared to conventional compact racks

\subsection{DRY STORAGE}

A. An evaluation of dry cask storage of spent fuel was pertormed by a governmentindustrial group which considered the technology, regulations, licensing issues and construction cost, and PNC has evaluated the use of dry cask storage for MOX fuel; a trench-type dry storage facility was considered the best alternative from the economics and safety (trom seismic shock) viewpoints (Kaneko 1986)

B. A conceptual design and safety analysis and an economic assessmert of cask and vault spert fuel storage has been pertormed (Saegusa 1989), with the conclusion that for storage of $500 \mathrm{MTU}$ or less, cask storage was preferable, while for 500-3000 MTU, vault storage was preferred; a computer model (FCOM) was applied to the cases for spent fuel storage for 20 years before reprocessing, because of the expected excess plutonium production overutilization in Japan (Nagano 1989); for AR storage of 250-500 MTU, dry cask storage was estimated to be more economical than pool storage, while for larger amounts, vault storage was more economical

C. Various spert fuel storage techniques have been compared on an economic basis. Dry casks, vaults, and in-pool storage of spent fuel in different facilities were evaluated. The report concluded that in in-plant HLW storage facilities, dry casks were most economical, while in independent facilities, vaults were better, depending on the amounts of spert fuel to be stored; in-pool storage was least economical (NFC 12/88)

\subsection{THANSPORT (Adachi 1987)}

A. Nuclear power plants and reprocessing facilities are located on the Japanese coast; spert fuel is transported by sea in dry casks to reprocessors at La Hague (France) and Sellafield (U.K.) under a contract due to expire in 1995 (Harmon 1984); overseas transportation is in one of five ships of Pacific Nuclear Transport Lid., a company coowned by British Nuclear Fuels Ltd. (BNFL) $(60 \%)$, COGEMA (France, 10\%) and Japanese companies (30\%); over 100 voyages have been successfully completed since 1969 with over $4000 \mathrm{MT}$ of spent fuel transported (AlJ 12/89b); the current shipping rate is about $500 \mathrm{MT} / \mathrm{yr}$. Each ship has a carrying capacity of $3000 \mathrm{MT}$; sea transportation around the Japanese coast and between islands is carried out by a single Japanese ship having a carrying capacity of 1,240 MT

B. Land transportation of spent fuel domestically to the Tokai reprocessing plant began in 1978; land transportation of spent fuel within Japan is subject to Japanese regulations that are based on the corresponding 1985 IAEA transport regulations; transport casks are shipped by highway with tractor-trailers with a loaded weight of 115 MT and a speed of $8 \mathrm{~km} / \mathrm{hr}$

C. Transportation of spent fuel to the 800-MT/yr reprocessing plant at Rokkasho-mura will be pertormed by Japan Nuclear Fuel Service

D. Four types of cask are used for spent fuel transportation; the $\mathrm{HZ}$ (Hitachi-Zosen) type developed in Japan is used for spent fuel transportation to the Tokai Reprocessing Plant; the "Excellox" casks (British Nuclear Fuels Limited, BNFL) are used to transport spent fuel to the U.K. for reprocessing; the TN (Transnucleaire, France) casks are used for 
transportation of spent fuel to COGEMA facilities; and the TK-type is used to transport spent GCR fuel from Japan to BNFL (Adachi 1987)

1) The $\mathrm{HZ}$ type is used for domestic land transportation and consists of a body made of stainless-steol inner and outer shells and lead shielding, and ethylene glycol to provide shielding from neutrons; this is a "wet-type" cask

2) BNFL's "Excellox' cask series, with a body of carbon steel and with a lead liner, is filled with water; this is also a wet-type' cask.

3) The TN-type developed by Transnucleaire, France, is used to ship spent fuel in a dry condition without water; the cask is comprised of carbon steel forging for gamma shielding, with a layer of solid organic resin for neutron shielding; internal pressure is kept below atmospheric and the cask is filled with nitrogen

4) The TK-type developed by BNFL is normally used for GCR spent fuel transportation, and is a "wet-type" cask; the body is an alloy-steel forging, filled with fluoridated water

7.7 RESEARCH AND DEVELOPMENT: Spent fuel transport cask safety and reliability testing has been performed by CRIEPI with STA funding since 1977; the first phase of research was completed in 1987 (Nagakura 1989); large (100-MT) casks were subjected to normal and accident conditions, based on IAEA test guidelines:

A. Under 'normal' conditions, casks were subjected to tests which included a water spray; free drop from $0.3 \mathrm{~m}$ height; penetration; and heat transfer test.

B. Under "accident" conditions, the casks were tested by dropping in free fall from 9 meters, striking the bottom of the cask; a horizontal impact of the center of the cask on a steel bar from a free-fall height of $1 \mathrm{~m}$; a fire test $\left(30 \mathrm{~min}\right.$ at $800^{\circ} \mathrm{C}$ in a pre-heated oven); a water pressure test at 20 and then $300 \mathrm{~kg} / \mathrm{cm}^{2}$ for $1 \mathrm{hr}$; a heat transfer measurement at $38^{\circ} \mathrm{C}$; vacuum and helium leakage rate measurement; and radiation shieiding measurements using cobalt-60 and californium-252 sources

\subsection{WASTE CONDITIONING, STORAGE AND TRANSPORT}

The federal government in Japan is responsible for the regulation of waste management practice, disposal, and R\&D. Generators are accountable for waste treatment, disposal of LLW and TRU wastes, and for funding the disposal of HLW (AIJ 3/88)

\subsection{WASTE DEFINITIONS}

A. $\quad H L W$ is loosely defined as spent fuel and fuel reprocessing wastes from the first reprocessing cycle, excluding the ILW and LLW defined below

B. ILW consists of alpha-bearing wastes (from reprocessing plants, plutonium fuel fabrication, and plutonium conversion, etc.) (PNC 2/90); the complete ILW category is not yet defined but ILW arising from reprocessing and MOX fabrication processes will be divided into two categories: LLW (for shallow-land burial) and TRU waste (for disposal in geologic formations) 
C. UW for shallow-land burial may not exceed $300 \mathrm{Ci} / \mathrm{MT}$ for $\mathrm{Co}-60,20 \mathrm{Ci} / \mathrm{MT}$ for $\mathrm{Sr}-90,30$ $\mathrm{Ci} / \mathrm{MT}$ for $\mathrm{Cs}-137$ and $\mathrm{Ni}-63,1.0 \mathrm{Ci} / \mathrm{MT}$ for $\mathrm{C}-14$, and $0.03 \mathrm{Ci} / \mathrm{MT}$ for alpha-emitting nuclides (NEA 1987)

D. LLW is considered to be below regulatory concern and can be buried as non-radioactive if it results in public exposure of $<1 \mathrm{mrem} / \mathrm{yr}$, according to the Radiation Council; this recommendation is reportedly in conformance with the ICRP and IAEA guidelines (NW $2 / 11 / 88)$

E. Uranium-bearing $U W$ from uranium fuel fabrication, mining and enrichment activities is defined as a special class of $U W$, and its disposal has yet to be defined (PNC 2/90)

\subsection{WASTE ARISINGS}

A. Canisters with vitrified HLW (121 MT/Yr) from foreign processors of spent fuel are expected to start arriving in Japan in 1992, comprising 18 casks/yr of 14 canisters/cask, 150 liters of glass/canister (Jardine 1989b)

B. HLW: 40,000110 -liter canisters of HLW vitrified in Japan will have been accumulated by the year 2030 (Kiyose 1989)

C. ILW: $200 \mathrm{~m}^{3}$ of spent tuel cladding hulls and fuel assembly hardware accumulated between 1977 and 1988 (Miyao 1989)

D. LLW Arisings (AEC 1987; AlJ 12/90C):

$1987-712,800$ drums $(200 \mathrm{~L})$

1988--739,500 drums (200 L)

$1989-756,600$ drums $(200 \mathrm{~L})$

$1990-950,000$ drums (200 L)

2000-1,550,000 drums (200 L)

B.3 STRATEGY: Japanese strategy on high-level radioactive waste management is to reprocess spent fuel and vitrify the resulting $H L W$, then to store the waste for 30.50 years in a dry storage facility before ultimate disposal in a deep geological repository (Machida 1989); LLW are currently stored at the generators sites, and are to be reduced in volume, immobilized in bitumen, cement, or resin, and disposed of in a future shallow-land repository planned for Rokkasho-mura; the policy on ILW and TRU waste disposal has not yet been established, and these wastes are stored

\subsection{HLW IMMOBILIZATION}

A. The policy for the ureatment of HLW is to convert it to borosilicate glass, store for $30-50$ years to cool, and then achieve ultimate disposal in a deep geologic repository

B. PNC has performed vitritication research on several glass-making technologies at Tokai for several years. Pilot plant work is due for completion in 1991 (Uematsu 1986; Sasaki 1984; AJJ 9/85; AEB 1986; Tsunoda 1987; NE 2/88; Kiyose 1989). JNFC has selected PNC's liquid-fed ceramic melter (LFCM) technology for use in its proposed Aomori reprocessing plant (Tsunoda 1989).

C. Japan is building a 38-billion yen (\$300-million) demonstration vitrification facility at Tokai (Tokai Vitrification Facility, TVF) capable of vitrifying $0.35 \mathrm{~m}^{3} / \mathrm{d}$ of concentrated HLLW 
(216 kg/d glass production rate) (NW 3/89; Yoshioka 1989); the Tokai Vitrification Facility (TV) is due to begin operation in 1991 (PNC 1990); it will have two stories underground and three above ground, with a floor space of $2,600 \mathrm{~m}^{2}$, to handle waste from the Tokai Reprocessing Plant (the capacity of the TVF is equal to the HLW output of the reprocessing facility); glass-making additives for the TVF will be supplied to the melter in the form of glass fiber cylinders $70 \mathrm{~mm}$ in diameter; canisters of vitrified HLW (110 liters of glass weighing $300 \mathrm{~kg}$ ) will be stored at Tokai during the $30-50$ year cooling period and then disposed of in the proposed geological repository; the Japanese stainless-steel canisters will have a different design but .he same overall dimensions as those to be received from France and the U.K.; but the Japanese canisters will contain 110 liters of glass instead of 150 liters for the French and U.K. canisters; final melter design parameters are (Yoshioka 1989):

- Operating temperature $1100+/-50^{\circ} \mathrm{C}, \max .1250^{\circ} \mathrm{C}$

- Produces $8.8 \mathrm{~kg} / \mathrm{hr}$ of glass from $15 \mathrm{~L} / \mathrm{hr}$ of conditioned HLLW (150 g/L oxide) and $6.6 \mathrm{~kg} / \mathrm{hr}$ glass fiber additive

- Bottom-drain discharge of vitrified HLW every $34 \mathrm{hr}$

- Operating lifetime 5 years

- Dimensions $1.9 \times 1.9 \mathrm{~m} \times 2.3 \mathrm{~m}$ high

- Metting surface area $0.66 \mathrm{~m}^{2}$, maximum glass holdup volume $350 \mathrm{~L}$

The final vitrified waste composition will be $75 \%$ glass additives $(43-47 \%$ silica) with $25 \%$ of HLW in oxide form; HLLW from reprocessing will be concentrated to a composition equivalent to $0.5 \mathrm{~m}^{3} / \mathrm{MTU}$ before transfer to the glass melter, using a continuous feed system with a two-step computer-controlled airlift (Tsuboya 1989)

The joule-heated ceramic melter is based on the glass melter used commercially in the glass industry, but with modifications and improvements added by PNC to make it more suitable for HLLW vitrification; these include changes in glass pool design to prevent the accumulation of electroconductive sludge; use of a glass-fiber additive to reduce particulate entrainment in the off-gas system; improved instrumentation including a glass level detector; remote operation; and design to permit easier dismantling of the highlyradioactive melter after 5 years of operation (Yoshioka 1989)

D. A larger-scale vitritication and storage facility for $H L W$ is planned at the Shimokita site in Aomori prefecture, to treat $H \mathrm{LW}$ from the reprocessing plant to be built there (Tsuboya 1989)

8.5 SPENT FUEL CONDITIONING: In Japan, spent fuel from power reactors is stored on an interim basis with the ultimate objective of reprocessing; thus, spent fuel is not conditioned for its disposal; dissolving spent fuel and storing the zircalloy hulls, end pieces, and grid spacers in stainless steel containers is carried out in the reprocessing plant (Miyao 1989) 


\subsection{LLW/ILW CONDITIONING}

A. Spent fuel element components, including zircalloy hulls, end pieces, and grid spacers will be conditioned before disposal; volume reduction by electroslag re-mehting, chemical treatment, thermochemical treatment, and high-pressure compaction are under study (Miyao 1989)

B. Combustible radioactive wastes, which comprise $60 \%$ of all generated radioactive solid wastes in Japan, are incinerated at the Fugen site in a solid waste incinerator; completed in 1989 , the incinerator has a capacity of $50 \mathrm{~kg} / \mathrm{hr}$ and storage capacity for $250 \mathrm{~m}^{3}$ of waste resins (PNC 4/90a)

At the Tokai site, LLW/LW conditioning is performed by PNC by compaction, incineration, and immobilization in bitumen or thermosetting resins (AlJ 10/85b; Lakey 1985); liquid concentrates and chemical sludges from reprocessing are conditioned by (Miyao 1987):

- Chemical co-precipitation and pH adjustment of wet sludges

- Evaporation of sludge at $200 \mathrm{~L} / \mathrm{hr}$ and incorporation into bitumen in a four-screw extruder evaporator (JGC/Belgonucleaire plant)

- $\quad$ Pouring bitumenized LLW into 200-L steel drums

Recently, PNC has decided not to recommend bituminization of solid LLW because of the dangers of combustibility of the products; however, spent solvent LLW produced at the Tokai reprocessing plant will be bituminized (PNC 2/90)

D. TRU waste conditioning is carried out at the Plutonium Waste Treatment Facility (PWTF); wastes received at the PWTF are sorted, volume-reduced by incineration, compaction, etc., according to the nature of the wastes, and solidified into ceramics or metal ingots (Kiyose 1989; Chapman and Schneider 1989)

E. In some nuclear power plants, LLLW is concentrated by evaporation, dried with a thinfilm evaporator, and formed into pellets with a briquetting machine; the residue is mainly sodium borate or sodium sulfate, which dissolve in normal cement and obstruct setting; a cement called 'cement-glass" is used to solidify these wastes; cement-glass comprises sodium silicate (primary component), silicon phosphate (hardener) and cement in a ratio of 2:2:1 (Horiuchi 1989)

F. JGC has developed an advanced cement solidification process for the treatment and stabilization of radioactive spent ion-exchange resins generated at nuclear power plants; normally, ion-exchange resins swell by absorption of water when mixed with cement; in JGC's process, resins are pretreated by rapid agitation with a highly alkaline cement slurry, thus preventing hydration of the spent resins on mixing with cement (Sauda 1990)

8.7 AIRBORNE WASTES TREATMENT AND IMMOBILIZATION: Off-gases from HLW vitrification are passed through a submerged bed scrubber, venturi scrubber, pertorated plate water scrubber, mist eliminator, and a series of filters to remove volatile and entrained radioisotopes (Tsuboya 1989) 


\subsection{LLW/ILW STORAGE}

A. LLW in Japan is stored at warehouses at PNC's Tokai and Oarai works and at reactor sites (AEC 1987) (Oyama 1989); TRU wastes produced by PNC's MOX fuel fabrication facilities are currently stored in their original forms at the Plutonium-Contaminated Waste Storage Facility and the Low-Active Solid Waste Storage Facility; stabilized wastes will be stored at this facility until a long-term disposal option can be identified (PNC 1987) (Chapman and Schneider 1989)

B. Spent fuel element zircalloy hulls and associated fuel assembly parts are currently stored in storage pools at the Tokai reprocessing plant (Miyao 1989)

C. Bitumenized ILW (including TRU wastes) are stored in drums at the PWTF (Kiyose 1989)

8.9 HLW STORAGE: Current plans for HLW storage in Japan are for the vitrified wastes to be stored in dry, forced-air-cooled storage vaults for $30-50$ years before final placement in a repository (Jardine 1989a; Jardine 1989b); JNFS wastes are to be stored at the Shimokita facility, and PNC wastes are to be stored at the proposed PNC research center at Horonobe; however, the governor of Hokkaido Prefecture has requested reconsideration of PNC's plan to construct the HLW storage center at Horonobe (AlJ 8/90b), following the prefecture government passage of a resolution opposing the center (AIJ 7/90a); there is local concern that the site will become a disposal rather than a storage site for $\mathrm{HLW}$

A. The proposed Horonobe HLW storage facility includes separate areas for shipping cask receiving and handling; cask preparation; cask unloading; canister inspection and handling; canister storage; and support functions (Jardine 1989b); the storage vault is to be a combination steel-frame structure with metal siding and a modular below-grade concrete structure; a 55-MT overhead bridge crane will be used for transporting canisters; the storage vault will be $36.5 \mathrm{ft}$ below grade and will contain five rectangular storage modules (each $21 \times 54 \times 23 \mathrm{ft}$ high): four modules will contain $102(6 \times 17)$ storage sleeves, with each sleeve holding up to five stacked canisters; the fifth module will have space for 84 ( $6 \times 14)$ normal-size canisters and 10 oversize storage sleeves holding up to four stacked, overpacked, oversize canisters; ulfiltered air will be used for cooling and will flow horizontally across the closed sleeves holding the HLW canisters; a total storage capacity of $10,000 \mathrm{HLW}$ canisters is planned

\subsection{TRANSPORT OF WASTES}

A. Vitrified HLW from overseas processors are to be returned by ship about 1992-1995 time frame; the HLW handling and storage facility will receive 18 transport casks/yr; each cask weighs about 120 MT and contains 14 vitrified HLW canisters (Jardine 1989b); the canisters are of stainless steel, with an O.D. of $43 \mathrm{~cm}$ and a height of $1.345 \mathrm{~m}$, and weigh $480 \mathrm{~kg}$

B. LLW currently stored in 200 -liter drums at production sites are to be transported by ship to the planned LLW disposal site at Rokkasho-mura when the site is ready; a ship with a 3,000-MT LLW capacity (3,000 200-liter drums of LLW) has been ordered for exclusive LLW transportation; the drums will be placed in special containers, each to carry eight drums; a total LLW transportation of 25,000 drums/yr in about 10 trips/yr is planned (AlJ 8/88) 


\subsection{RESEARCH AND DEVELOPMENT}

A. R\&D to evaluate technologies for treating the spent fuel cladding hulls and fuel assembly hardware is in progress in Japan; thermomechanical, chemical and metallurgical methods for removing transuranics and fission products deposited on the zircalloy surfaces were examined; all methods had disadvantages such as incomplete decontamination, off-gas production, or a requirement for secondary treatment; the method of choice was the Hot isostatic Pressing method (high-pressure, high-temperature diffusion-bonding), which is now under further development (Chapman and Schneider 1989)

B. Research on several glass-making technologies has been performed (AEB 1986; NEA 11/86; Tsuboya 1989; NEI 7/89).

C. R\&D on the handling and storage of vitrified HLW to be returned to Japan from overseas reprocessing plants is being performed at the Radioactive Waste Management Center; the research includes automated unloading of simulated vitrified HLW casks, automated cask inspection and welding operations, package transfer system and control technology development, and cooling performance tests (Katsunuma 1989)

D. The Tokai Vitrification Facility is a pilot plant facility designed to develop technology for corversion of reprocessing waste HLW into glass; a cold trial was scheduled for 1990 and hot operation testing is to begin in 1991 (PNC 10/88a); plant operation at a nominal glass production rate of $9 \mathrm{~kg} / \mathrm{hr}$ is scheduled for 1992 (NUKEM 8/88)

\subsection{PROGRAM/FACILITIES COSTS}

A. The Plutonium-Contaminated Waste Treatment Facility at PNC-Tokai was designed and constructed at a cost of $\$ 100$ million (Chapman and Schneider 1989)

B. The cost for the Tokai vitrification plant is estimated at 38 billion yen (\$295 million) (NEI 2/89)

C. PNC was allocated 11.8 billion yen ( $\$ 89$ million) in FY 1990 towards development of technology for HLW treatment and storage; a total of 458 million yen (\$3.5 million) was allocated for continuation of the conceptual design work on the vitrified $H L W$ storage plant at Aomori (AlJ 1/90)

\subsection{DISPOSAL OF NON-HIGH-LEVEL WASTES}

9.1 STRATEGY: The Japanese strategy for disposal of non-high-level wastes is to reduce their volumes and convert them to solid form (i.e., immobilize in bitumen, cement, or resins) and store them in drums until the planned LLW shallow-land burial facility at Rokkasho-mura is opened (PNC 2/90); sea disposal of LLW is favored in Japan, but is not being practiced due to international opposition (NE1 7/89); very-low-level waste disposal strategy has not yet been defined; JNSC and the newly-formed RANDEC are to perform R\&D on safe disposal of verylow-level wastes from decommissioning (Oyama 1989); disposal of radioisotope and radioactive medical wastes is under study by JAEC and has not yet been defined (Oyama 1989)

9.2 WASTE DISPOSAL CRITERIA: Criteria for the disposal of LLW are not yet fixed, but a recent recommendation was to base the criteria on upper radionuclide concentration limits and total radioactivity (Ci/MT) of the packages for specific radionuclides, and to use a scaling factor to estimate the concentrations of difficult-to-measure radionuclides (Yagi 1990): 
A. LLW for shallow-land burial may not exceed $300 \mathrm{Ci} / \mathrm{MT}$ for $\mathrm{Co}-60,20 \mathrm{Cl} / \mathrm{MT}$ for $\mathrm{Sr}-90,30$ $\mathrm{Ci} / \mathrm{MT}$ for $\mathrm{Cs}-137$ and $\mathrm{Ni}-63,1.0 \mathrm{Ci} / \mathrm{MT}$ for $\mathrm{C}-14$, and $0.03 \mathrm{Ci} / \mathrm{MT}$ for alpha-emitting nuclides (NEA 1987; Yagi 1990)

B. Waste packages will comprise steel drums (200 L/drum) containing only solid LWW immobilized in bitumen, cement, or resin (Shimoda 1989)

9.3 ILW DISPOSAL: Disposal plans are not yet defined but TRU-containing wastes arising from reprocessing and MOX fabrication processes will be divided into two categories: LLW (for shallow-land burial) and TRU wastes (for disposal in geologic formations)

9.4 LLW DISPOSAL: Japan's official policy on disposal of LLW was formerly to use both land and sea disposal methods; however, Japan is a signatory of the London Dumping Convention and has promised to abide by its ruling to not dump radioactive wastes into the oceans; ocean dumping of $L W$ at a site 560 miles northeast of Tokyo was proposed in 1980 but was strongly opposed by the governments of the Mariana Islands and was never implemented (Gale 1980)

A land facility for LLW disposal has been identified at Rokkasho-mura, on the northern tip of the main island of Japan, Honshu; the site is to provide LLW disposal capacity until 2030; the first phase of construction calls for building facilities to hold $200,000 \mathrm{~m}^{3}$ or 1 million 200 -liter drums of LLW sealed in ferro-concrete cells; the cells are to be covered with a $4 \mathrm{~m}$ depth of soil; eventually, the 310 -hectare site is to hold $600,000 \mathrm{~m}^{3}$ of LLW (>3,000,000 200-liter drums); strong public opposition may delay or prevent operation of the facility (NW.11/90); uranium enrichment, spent fuel reprocessing, HLW storage, and environmental research facilities are also planned for the Rokkasho-mura site (NEI 7/89); JNFI applied for a construction permit at the site in April 1988; the permit was approved by NSC in October 1990 and signed by the Prime Minister in November (NW 11/90; NN 1/91); the permit application specifies an LLW disposal site construction start date of November 30,1990 , and commercial operation beginning in December 1992 (AlJ 9/90a)

The Rokkasho-mura LLW disposal site is situated on a plateau $30-60 \mathrm{~m}$ above sea level; of the 340 -ha area, 290 ha is to be used for LW disposal; the first-stage burial facility is at $45-46 \mathrm{~m}$ elevation, with a north-south descent, facing a stream draining into a marsh; the ground will be open-cut to the stable base, on which reinforced concrete vaults will be built; each vault will contain 5,000 drums of LLW; gaps between drums will be backfilled with mortar grout and then a reinforced concrete cover will be placed over each vault; there will be five vauth in a row, each row being $23 \mathrm{~m}$ long, $120 \mathrm{~m}$ wide, and $5 \mathrm{~m}$ high; eight such rows are planned for the first stage of the facility; monitoring will take place for 300 years atter filling (Shimoda 1989)

\subsection{LWWILW DISPOSAL R\&D}

A. Ancient burial mounds in Saitama Prefecture (1000-1500 years old) have been examined by the Japanese with a view to determining the most appropriate soil type for $\amalg W$ disposal; it was concluded that mounded sand and gravel around the buried wastes with a clay cap to keep moisture away from the buried material should extend the lifetime of buried wastes (Watanabe 1989) 
B. The migration behavior of radionuclides in backfill and concrete material to be used for LLW disposal was examined, to determine effects of waste form leachability; long-term carbonation of concrete did not lead to any significant changes in the diffusion rates of Cs-137, Sr-90, or Co-60 (Shimooka 1989)

9.6 PROGRAM/FACILITIES COSTS: The cost for construction of the LLW disposal facility at Rokkasho-mura is expected to be 100 billion yen ( $\$ 770$ million) (NW 11/90)

\subsection{DISPOSAL OF HIGH LEVEL WASTES}

10.1 SPECIFICATIONS AND CRITERIA: Japan's basic criteria on disposal of HLW is that future generations will not be harmed by radiation as a result of HLW disposal; the NSC had a fiveyear (1986-1990) safety research program to establish safety assurance standards and design criteria for pre- and post-closure time periods, just completed (AlJ 10/85a; Yamamoto 1990)

10.2 AEPOSITORY DEPLOYMENT STRATEGY: The Japanese AEC has set up an R\&D policy for HLW disposal initially in 1987; the plan is to be carried out in four steps (AlJ 1/90b); a report was adopted in December 1989 which established R\&D priorities and a multiple barrier plan for a geologic waste repository for HLW (AIJ 1/90b); the plan specifies that HLW will be vitrified and stored for 30-50 years for heat dissipation, and then disposed of by encapsulation in canisters in a deep geological repository several hundred meters below-ground; the research involves establishing a basic geological disposal system concept, in situ test projects, research facility construction, site characterization techniques development, natural analog studies, database development, and international cooperation (NWB 1987); the program is currently in the second of the four stages; the first stage, selection of acceptable geological formations, was completed in 1984; the second stage (site selection and R\&D) started in 1985, with the emphasis being on generic R\&D at locations that are not to be considered candidate sites, even though originally this stage was to include underground testing at candidate sites; subsequent stages are the five-year demonstration stage to be started at a candidate repository site by 1995 , and the construction, operation and closure stage; the following schedule for the four stages is planned, although the program has suffered some delays due to public opposition (Tsuboya 1989):

- Select potential geologic formations (1976-1985)

- $\quad$ Select candidate disposal sites (1985-), currently in progress

- Demonstrate the technology with simulated and actual wastes at the candidate sites (1995-1999)

- Construct, operate, and seal the disposal facility when full (after about the year 2030)

10.3 SITE SELECTION AND CHAAACTERIZATION (Tsuboya 1989):

The second stage of Japan's four-stage site selection procedure is currently in progress, and will consist of two parts. Objectives of the first part of stage 2 are to:

- Determine the nationwide geological environment

- Develop a waste isolation system based on the geological environment 
- Demonstrate technical feasibility and long-term safety of the geological disposal concept These objectives are to be achieved through:

- Establishment of the basic geological repository concept

- Conceptual design of the repository and associated systems

- In situ experimentation in various geological formations

- Construction of a large-scale research facility (including URL)

- Development of a site analysis technique to permit precise analysis of the underground environment

- Perform natural analog studies, develop a geological disposal database, and obtain other data through intemational cooperation

In the second phase of stage 2, which has been started, experimental work will be performed on:

- natural analogs (at the Tono Uranium Mine)

- research on engineered barriers

- a system design study and performance assessment

- geological investigations

- further international collaboration (e.g., Stripa and Alligator Rivers projects)

10.4 REFERENCE HLW/SPENT FUEL DISPOSAL CONCEPT (Tsuboya 1989): All HLW generated in Japan are to be immobilized in glass (vitrified), and stored for $30-50$ years in an air-cooled vault facility (planned for Aomori) to cool, until they are disposed of in a deep geological repository (several hundred meters below the surface) A. All HLW produced is to be vitrified in joule-heated ceramic melters and placed in 110-
liter stainless-steel canisters
B. Cooled, vitrified HLW in canisters will then be transported to a geological repository
C. The repository host rock is not yet determined and will evolve from the Japanese four- stage R\&D program
D. R\&D on all aspects of the multiple-engineered-barrier concept is in progress, including leaching studies, corrosion tests, systems studies, and a performance assessment

10.5 WASTE PACKAGE R\&D: JAERI and PNC have performed a number of research projects concerned with HLW package safety and management (Nakamura 1986); major topics explored were: 
- The WASTEF hot cell facility has been used to evaluate thermal phenomena, corrosion rates, stability under irradiation, waste form leaching under simulated repository conditions, and hot cell tests on actual HLW glass samples (AEB 1986)

- Heating experiments with a real-size simulated waste canister and migration tests using a non-sorbing tracer have been carried out in a near-surface granite rock mass (Nakamura 1986)

- Long-term behavior of multiple engineered barriers in HLW repository systems is being studied at PNC (Tokai) by evaluation of natural analogs such as natural basaltic glass; sample ages of 280 and 2,800 years were simulated, and leaching rates determined (PNC 8/89)

- Vitrified HLW, and potential overpack and buffer materials are being examined as part of a long-term plan for engineered barrier devleopment; static leach tests were conducted with fully radioactive vitrified HLW; full-scale overpacks of forged carbon steel and porcelain were fabricated and tested; properties of sodium bentonite clay were measured; volcanic glass, smectite-illite deposits, old concrete and old steel pipes were examined as natural analogs to estimate the long-term stability of engineered barrier materials (Sasaki 1990)

- $\quad$ PNC has studies underway to clarify the fundamental behavior of engineered barrier materials under repository conditions; these studies involve glass form leaching tests; candidate overpack corrosion tests; buffer material long-term stability evaluations; radionuclide migration studies; and acquisition of thermodynamic data on radionuclides and minerals (Tsuboya 1989)

Cooperation with other countries on waste forms has been performed (e.g., with Australia on its SYNAOC waste form; and with France on vitrified HLW glass) (Nakashima 1987)

\subsection{GEOSCIENCES R\&D}

A. Sorption tests have been carried out with the candidate overpack materials (sodium bentonite powder and compacted bentonite/quartz sand blocks) to determine hydraulic conductivity, static sorption, and permeabilities under simulated repository conditions (Kanno 1989)

B. Geospheric radionuclide migration is being studied by PNC. Distribution coefficients for several radionuclides (cesium, strontium, transuranic nuclides) were determined using crushed granite and tuff; the effects of particle size, $\mathrm{pH}$, and colloid formation were examined (Uematsu 1987)

C. The mechanisms and kinetics of water-rock interactions and fixation of radionuclides have been studied; groundwater element migration and fixation along fractures in crystalline media (red feldspar from altered granitic rock from Northwest Kyushu, Japan) were measured by scanning electron microscopy (Nakashima 1987)

D. Literature surveys and nationwide geological reconnaissance have been conducted to define the geological environment for HLW disposal; since 1988, permeability test equipment for low-permeability layers and deep groundwater sampling have been developed (Kiyose 1989) 
E. Geological repositories may be used for research on earth sciences, for material synthesis in free fall using the repositories' vertical shat, and for research into precision measurements using a control space free of light, dust, and vibrations (NEI 6/87)

10.7 FIELD TESTS (OECD/NEA 1988; Uematsu 1988; Masuda 1990; OECD/NEA 1990)

A. As part of stage one of Japan's four-stage repository development strategy, rock type inventories accompanied by preliminary investigations were carried out at a number of locations; these tests inciuded heater tests, migration tests, and corrosion tests for engineered barrier materials; sites included:

1) The Akenobe Mine (south-central Japan) - Gabbro rock.

2) The Kasama Quarry (east-central Japan) - Granite rock.

3) The Shimokawa Mine (north-central Hokkaido) - Diabase rock.

4) The Hosokura Mine (north-eastern Japan) - Tuff rock.

These tests were completed in 1984; stage-two investigations are underway for the Tono Uranium Deposit (sedimentary rock, central-Japan) (Seo 1989)

B. PNC plans to build an underground research laboratory at Horonobe in sedimentary rock and has met with strong opposition from local authorities, deadlocking the project since 1985 (PNC 1985); however, the Nuclear Safety Research Association has described an underground research laboratory in Japan as "absolutely necessary" (AlJ 6/90)

C. The behavior of geologic formations to excavations is being studied by PNC in the Shatt Excavation Effect Project; a shatt, $6 \mathrm{~m}$ in diameter and $150 \mathrm{~m}$ deep, is being excavated near the Tono Mine, Chubu Works, to privide information on the effects of excavation on groundwater flow and the surrounding rock; boreholes $180-200 \mathrm{~m}$ deep are being used for groundwater flow measurement and sampling, rock permeability change evaluation, and piezometric changes (PNC 4/90b)

D. PNC has studies underway on repository behavior, including buffer material long-term stability evaluations; radionuclide migration studies; and acquisition of thermodynamic data on radionuclides and minerals (Tsuboya 1989)

10.8 PERFORMANCE ASSESSMENT: Deep geologic repository system performance assessment studies are underway, the first step being to acquire and assess existing computer codes (such as INTRAVAL and PSACOIN); the second stage is to improve on these codes/models and relate them specifically to the Japanese environment (Kiyose 1989; Tsuboya 1989); scenario analysis and consequence assessment studies are underway (Masuda 1990), based on a dynamic probabilistic model; in the first step of the scenario study, 56 events were listed and dependencies between the events were listed on an influence diagram; this information will be used to screen the events and compose the scenarios for further consequence analysis

\subsection{MANAGEMENT OF URANIUM MINE AND MILL WASTES}

Small uranium ore deposits at Ningyo-Toge are conglomerate and sandstone deposits on impermeable granite, and were extracted by heap-leaching with dilute sulfuric acid (Takada 1981), and then solvent-extracted (Takada 1981; PNC 2/90) 


\subsection{WASTE ARISINGS:}

A. Uranium mine wastes: 45,000 MT of dry wastes (1979-1986) as residue from vat leaching operation tests

B. Mill wastes: A total of $29,000 \mathrm{MT}$ of mill tailings and sludges from vat leaching operation tests carried out from $1979-1986$

11.2 REMEDIAL ACTIONS: The original uranium mine and mill residues in Japan were left to stand outside but this has been changed; residues will now be re-buried, covered with compacted shale and revegetated, and monitored for leachate and radon; a scenario for treatment and disposal of uranium wastes is being defined with the goal of establishing disposal technology and locations for shallow-land burial by 1995 (PNC 2/90)

\subsection{DECOMMISSIONING AND ENVIRONMENTAL RESTORATION}

12.1 STRATEGY/POUCY: The Japanese policy on decommissioning of closed nuclear power plants is to mothball them for 5-10 years, and then dismantle them completely so that the land can be reused (NUKEM 1/87; NEI 9/89)

12.2 R\&D

A. The Research Association for Nuclear Facility Decommissioning (RANDEC) will perform R\&D on equipment and methods for decommissioning (NEI 7/89)

B. MITI's Nuclear Engineering Test Center has a test program on laser cutting of core internals

C. The Waste Dismantling Facility (WDF) at Oarai performs R\&D and actual work on decontamination, dismantling, and sectioning of large items; waste sections entering the plant are restricted to no larger than $2 \mathrm{~m}^{3}$ and are separated into (a) remote-handled TRU wastes with a dose rate $>50 \mathrm{mr} / \mathrm{hr}$ and/or alpha contamination $>37 \mathrm{MBq} / 20$ liters, (b) contact-handled TRU with dose values, $>50 \mathrm{mr} / \mathrm{hr}$, and (c) beta/gamma contaminated materials (IAEA 1988); at the WDF, a 70-MT compactor compacts all metal wastes in metal containers about 15 in in diameter; R\&D is being performed on electropolishing, hot isostatic pressing, ice blasting, robot-operated plasma torch cutting, and radiation imagery system technology (Chapman and Schneider 1989)

D. Future dismantling of the joule-heated ceramic melter for vitrification of HLW at the Tokai Vitrification Facility has been studied; the melter is expected to have a life of only 5 years, so a mock-up melter was dismantled to obtain data; the total time required to dismantle the simulated radioactive melter was 361 hours, generating $40-50$ containers or 340 liters volume of waste weighing $600 \mathrm{~kg}$ (Ogata 1989)

E. Radioactive waste management research is performed at PNC (Oarai) and includes projects on dismantling large-size waste from the Waste Dismantling Facility (WDF), treatment of FBR HLLW, and decommissioning research (PNC 10/90c)

12.3 MAJOR PROJECTS: JAERI is at an advanced stage of decommissioning the Japan Power Demonstration Reactor (JPDR); this was a 12.5-MWe BWR at Tokai; dismantling was started in 1986, and site restoration is scheduled to begin in 1992 (JAERI 1985; Masters 1986; NEI 7/89) 
12.4 COSTS: Beginning in 1989, utilities in Japan are required to establish funds to finance reactor decommissioning; current estimates are 30 billion yen ( $\$ 220$ million) for complete dismantling of a 1000-MWe-reactor unit (NEI 7/89)

\subsection{INTERNATIONAL ACTIVITIES}

13.1 MEMBERSHIPS: Japan is a member of the IAEA and the OECD/NEA

\subsection{COOPERATION WITH MULTINATIONAL AGENCIES}

A. Japan participates in most OECD/NEA waste management programs, including the Stripa mine project project (Phase III), Alligator Rivers analogue project (Tsuboya 1989), geochemical data base development (ISIRS), former seabed disposal of HLW investigations, nuclear facility decommissioning (OECD/NEA 1989) and has participated in current and completed modeling projects, including HYDROCOIN, INTRACOIN, and INTRAVAL (NEA 11/86)

B. Japan participates in most IAEA waste management activities, including IAEA's past coordinated research program to evaluate the performance of solidified $\mathrm{HLW}$ forms and engineered barriers (NEA 11/86)

C. Japan (JAERI) and EURATOM have signed a cooperative agreement on R\&D on nuclear safeguards, including analytical methods of the materials accounting system, containment and surveillance measures, and measurement technologies; the 5-year agreement, signed on May 29, 1990, is renewable by mutual agreement (AlJ 6/90d)

D. Japan is a signatory to the IAEA Regional Cooperative Agreement for nuclear power development in southeast Asia, and is also coordinating a separate cooperative program with southeast Asian countries which is to be complementary to the IAEA program (AlJ 3/90a)

E. Japan is a signatory with the EEC, U.S.S.R., and the U.S. to the International Thermonuclear Exporimental Reactor project (AlJ 9/90)

\subsection{COOPERATION WITH USA}

A. DOE/PNC have an umbrella agreement for Cooperation in Radioactive Waste Management; the term is 1986-1996; the scope includes HLW/TRU wastes, waste form development, assay and characterization, waste treatment, packaging and transportation, waste storage and disposal, decontamination, decommissioning, facility operations, environment, safety, and public acceptance

B. DOE/PNC had an agreement for collaborative testing of the Liquid-Fed Ceramic Melter (LFCM) for vitritying HLW; the term is 1985-1990; the scope includes PNC participation in operating the LFCM at the Pacific Northwest Laboratory (PNL)(the fee to be paid by PNC, with the stipulation that DOE can participate in similar PNC activities); recent emphasis has been HLW and TRU waste specialists' workshops; PNC representatives on assignment at PNL; and vitrification hot cell tests

C. DOE/JAERI are negotiating an agreement in the area of nuclear waste management, with emphasis on spent fuel, HLW, and TRU wastes, waste categorization, waste sorting and radiological assay development; waste form characterization and development of new 
waste forms; development of waste treatment processes; container, cask design and handling techniques; transportation of wastes; surface and subsurface systems development for waste storage; geological disposal; decontamination and decommissioning; facility operations; environmental, safety, and public acceptance; the proposed term of the agreement is for 10 years

D. Japan (PNC) signed an agreement in 1989 with DOE's PNL for an assessment of engineered barrier systems for $H L W$, to include corrosion studies and computer model simulations (NW 2/89)

E. Japan's JNFI concluded information exchange agreements on LLW disposal technology with two private U.S. companies, Chem-Nuclear Systems and U.S. Ecology (AIJ 7/90)

F. A U.S./Japan agreement for nuclear cooperation that had been in effect since 1968 was renegotiated in 1988; the agreement covers the areas of fuel enrichment, reprocessing, and transfer of nuclear materials to other nations; the agreement allows Japan to air-lift spent fuel to Europe over the North Pole, including spent fuel under U.S. control, but also requires that the separated plutonium be retumed to Japan by air using the polar route; the agreement was approved by the Japanese Diet on May 25, 1988 (NN 5/88; NN $7 / 88$ ) and came into force on June 17, 1988 (NF 6/88); the agreement has a term of more than 30 years; on October 18, 1988, an amendment was signed which permits sea transportation of reprocessed plutonium in addition to air transport (AlJ 10/88), but requires Japanese coast-guard ships as escort, which is also generating controversy (NN 7/89), as it may violate Japan's constitution

G. DOE/PNC signed a Memorandum of Understanding in September 1988 for cooperation in LMR/FBR R\&D, and set up a U.S. Japan Coordinating Committee to implement the 10year agreement. Activities under the cooperative program include development and testing of a double-walled steam generator and testing the reliability of oxide fuel in FBP-II (PNC 8/89; AlJ 6/90)

H. DOE/PNC reached an agreement in September 1987 for a collaborative study on reliability testing of long-lived oxide fuel materials, including advanced austenitic stainless steel and high-strength ferritic alloys; the agreement is for a period of 8 years (PNC 4/88c)

I. DOE/JAEFI signed an agreement on May 22, 1987, to perform joint A\&D on graphite and metal material properties for HTGRs, to run for 5 years. Emphasis is on irradiationinduced creep; multi-axial strength data and failure criteria; and fracture mechanics data and theory (A|J 5/87)

J. Japan (JNFI) signed a cooperation agreement with Martin Marietta Energy Systems, the DOE contractor at Oak Ridge, TN, for information exchange on gaseous diffusion uranium enrichment topics related to plant safety, environment, health physics, regulations, management, and operation; the information will be used in the construction and operation of the planned enrichment plant at Rokkasho-mura (AlJ 4/89)

K. Japan (CRIEPI) and the U.S. Electric Power Research Institute (EPRI) jointly performed a study from January 1988 to December 1989 on below-regulatory-concem LLW, with EPRI paying $90 \%$ of the U.S. $\$ 2.3$ million cost (NW 2/11/88b)

L. Japan is a signatory with the EEC, U.S.S.R., and the U.S. to the International Thermonuclear Experimental Reactor project (AlJ $9 / 90$ ) 


\subsection{COOPERATION WITH OTHER COUNTRIES}

A. Belgium: PNC signed a 5-year agreement with SCK/CEN of Belgium in 1987 to perform a collaborative research effort into the disposal of long-lived wastes in deep geological clay layers at the Mol underground research laboratory (PNC 1987)

B. Canada: JAERl collaborated with AECL of Canada at the Whiteshell URL facility, and funded a room at the underground research laboratory at the 787-foot level in the Lac du Bonnet borehole; the study, which ended in 1989, was to determine radionuclide percolation rates through granite (NF 1/89)

C. China: Japan (JAIF) and China (China National Nuclear Corporation) agreed in September 1990 to cooperate in the areas of power reactor design, nuclear medicine, environmental protection, and nuclear waste management; exchange visits will take place in 1991 for discussions in these areas (NEI 12/90a)

D. France: The Japanese goveınment formally approved the protocol for Amendment of the Agreement Between the Government of Japan and the Government of the French Republic for Cooperation in the Peaceful Uses of Nuclear Energy (AlJ 6/90); this renewed and extended a 1972 nuclear cooperation agreement to cover the transfer of sensitive information and to bring the agreement into line with the 1977 London Suppliers Group nuclear export guidelines (NW 5/90); the agreement specifies that the information to be transferred to Japan (JNFI) for the new reprocessing plant at Rokkasho-mura will be used for peaceful purposes and will not be transferred to a third country without French consent (AlJ 7/90b); the agreement also sets up the mechanism for transfer to Japan of plutonium from reprocessed Japanese fuel (AIJ 6/90)

Japan (PNC) and COGEMA (France) are developing a common program for research on plutonium air transportation casks which would meet the requirements set out in NUREG0360 (U.S. NRC guidelines) (NF 2/88)

Japan (JNFI) and France (ANDPA) have an agreement to exchange information on LLW disposal; similar agreements also exist between JNFI and U.K. NIREX and Sweden (AIJ 10/89)

E. Indonesia and Japan (JAERI) have agreed to expanded nuclear cooperation in a 5-year agreement on research reactor utilization, radioisotope production and utilization, radioactive waste management, reactor physics, radiation protection, and nuclear safety engineering; the agreement came into force in 1989 and replaces an earlier agreement signed in 1984; the first project will be R\&D on nuclear scattering technology using Indonesia's MPR-30 multi-purpose research reactor (NW 3/88)

F. South Korea: A nuclear cooperation agreement was signed between Japan and South Korea in 1990 to stress nuclear plant safety, radiation protection and monitoring, utilization of radioisotopes and radiation, and related fields (AIJ 5/90; NW 6/90); the agreement also specifies that both countries will act in accordance with the IAEA Conventions on Early Notification and Assistance (NLB 12/90)

G. Sweden: Japan (JNFI) and Sweden have an agreement to exchange information on LLW disposal; similar agreements also exist between JNFI and U.K. NIREX and France (AIJ 10/89) 
H. Switzerland: A technical information exchange program in the area of nuclear waste management between PNC of Japan and NAGRA of Switzerland began in 1988 (AlJ 7/88; Tsuboya 1989); the agreement promotes technical staff exchanges as well as information on geological studies, URLs, seismology, materials, and mathematical models

I. Thailand: Japan (JAERI) and the Thai Ottice of Atomic Energy for Peace agreed in March 1990 to perform joint research on the radiation processing of sludge and its recycling

J. United Kingdom and Japan have the following agreements:

Japan (JNFI) and U.K. NIREX agreed in October 1989 to exchange intormation on LLW disposal; similar agreements also exist between JNFI and Sweden and France (AlJ 10/89)

Japan (JAERI) and the UK Atomic Energy Authority (UKAEA) agreed to exchange information on thermal reactors, covering GCRs and PWRs thermal behavior, circulative radioactivity (including fission product release) and related subjects; the agreement came into effect on March 20,1990, and is valid for 3 years, renewable by mutual agreement (AlJ 3/90)

K. U.S.S.R: Japan and the USSR do not have formal diplomatic relations and do not normally make agreements between their governments; however, in 1990:

- Japan (JAIF) signed an agreement in August 1990 with the Soviet Academy of Sciences for information exchange and joint R\&D in nuclear-grade materials and site-selection methods

- A Memorandum on Cooperation regarding the Chernobyl nuclear accident was signed in September by the respective Foreign Ministers; the agreement is for information exchange on radiation effects, and technical expert exchange visits; Japan's interest is for information on decontamination and immunological research (AlJ 9/90)

- Japan is a signatory with the EEC, U.S.S.R., and the U.S. to the International Thermonuclear Experimental Reactor project (AIJ 9/90)

\subsection{REFERENCES}

$-1980-$

Gale, R. 8/28/80. "Plans for Ocean Dumping of Radwaste Assailed." Energy Daily.

-1981 .

Takada, S. 1981. 'The Development of Uranium Milling and Conversion at Ningyo-Toge Works." Fusen, ol. 28, pp. 153-160. 
Federation of Electric Power Companies (FEPC) 1984. An Outline of Nuclear Fuel Cycle Facility Construction Program. Japan Nuclear Fuel Industries Co. Inc. (JNFl), Tokyo.

Harmon K.M., and A.B. Johnson Jr. 1984. Foreign Programs for the Storage of Spent Nuclear Power Plant Fuels, High-Level Waste Canisters and Transuranic Wastes. PNL-5089, Pacilic Northwest Laboratory, Richland, Washington, p. 54.

Sasaki, N., M. Karino and H. Kashihara. 1984. "Solidification of the High- Level Liquid Waste from the Tokai Reprocessing Plant.' In proceedings of ANS topical meeting on Fuel Reprocessing and Waste Management, August 1984, Vol. 1, pp. 147-60. Jackson, Wyoming.

$-1985-$

Atoms in Japan (AlJ). 9/85. "MITI Studies Strategy for Plutonium Utilization in LWFs," p. 30.

Atoms in Japan (AIJ). 10/85a. "NSC Maps out 5 Year Program for Safety Research on Nuclear Facilities; Scope Expands to ATR and FBR,' pp. 11-14.

Atoms in Japan (AIJ). 10/85b. 'JGC Completes Rad-Waste Volume Reduction Demonstration Plant,' p. 29.

Lakey, L.T., K.M. Harmon, and P. Columbo. 1985. Management of Low-Level Radioactive Wastes Around the World. PNL-5173, Pacific Northwest Laboratory, Richland, Washington, p. 32.

Paige, H.W., and N.J. Numark. 1985. Assessment of National Systems for Obtaining Local Siting Acceptance of Nuclear Waste Management Facilities. IEAL-R/86-16, International Energy Associates Limited, Washington, D.C., Vol. 1, pp. 10-1 to 10-4 and Vol. 2, pp. 12-1 to 12-6.

Power Reactor and Nuclear Fuel Development Corporation (PNC). 1985. "Radioactive Waste Storage Research Center." Paper prepared by Power Reactor and Nuclear Fuel Development Corporation, November 1985, Tokyo.

-1986 -

Atomic Energy Bureau (AEB) 1986. "Radioactive Waste Management Policy in Japan." Atomic Energy Bureau, Science and Technology Agency, May 1986 (presentation by A. Yunki, Senior Officer, Nuclear Energy Policy Planning).

Atoms in Japan (AlJ). 1/86. 'Asahi Chemical to Run Full-Scale Operation of Chemical U-Enrichment Plant," p. 35.

Kaneko, H., Y. Tanaka, and H. Tanuma. 1986. "Cask Storage of MOX Spent Fuels." In proceedings of Third International Spent Fuel Storage Technology Symposium/Workshop. pp.135-136. CONF-860417, April 8-10, Seattle, pp. 135-136.

Nuclear Energy Agency (NEA). 11/86. 'Summary Record of Ad Hoc Meeting of the Directors of Crystalline Rock Projects.' Meeting held November 3-4, 1986, OECD/Nuclear Energy Agency, Paris.

Uematsu, K. 1986. 'Design of the Vitrification Plant for HLLW Generated From the Tokai Reprocessing Plant." Waste Management '86, Vol. 2, pp. 427-434. March 2-6, Tucson, Arizona. 
$-1987$.

Adachi, M. 1987. "Present Status and Prospect of Spent Fuel Transportation." Presented at Japan U.S.S.R. Seminar on Transportation and Storage of Spent Fuel, p.11.1 -11.14. Published Japan Atomic Industrial Forum and USSR State Committee for the Utilization of Atomic Energy, November 1987, Leningrad. USSR.

Atomic Energy Commission (AEC). 6/87. "Long Term Program for the Development and Utilization of Nuclear Energy." Issued by the AEC, Tokyo.

Atoms in Japan (AlJ). 5/87. "JAERI-U.S. DOE Sign Pact for R\&D on Graphite and Metal for HTGR's," p. 26.

International Energy Associates Limited (IEAL) 1987. Requlatory Strategies for High-Level Radioactive Waste Management in Nine Countries. IEAL-R/87-93, International Energy Associates Limited, Fairfax, Virginia.

Murakami, H. 1987. "Main Rules and Licensing Procedures for Transportation and Storage of Spent Fuels in Japan." Presented at Japan - U.S.S.R. Seminar on Transportation and Storage of Spent Fuel, p.2.1 - 2.8. Atomic Industrial Forum and USSR State Committee for the Utilization of Atomic Energy, November 1987, Leningrad.

Murata, H. 1987. "Japan's Nuclear Energy Programme.' Uranium and Nuclear Energy: 1987.' Uranium Institute, published by A.E. Thompson, London, p. 338-358.

Nakashima, S., and H. Nakamura. 1987. "Mechanisms and Quantitative Evaluation of Radionuclide Fixation in Rocks and Sediments." In CEC Radioactive Waste Management Series: Natural Analogues in Radioactive Waste Disposal. Graham \& Trotman, London, pp. 386-393.

Nuclear Energy Agency (NEA). 7/87. "Update on Waste Management Policies and Programmes." Nuclear Waste Bulletin sur les Dechets Nucleaires 1 Published by OECD/NEA. Vol. 1, p. 13. p. 13.

Nomura, M. 1987. "Outline of JNFS Reprocessing Plant Project." In International Conference on Nuclear Fuel Reprocessing and Waste Management "RECOD 87,' Société Française d'Energie Nucléaire, Paris, pp. 89-96.

Nuclear Engineering International (NEI). 6/87. 'Looking for Geotopia," p. 8.

Nuclear Engineering Imternational (NEl). 12/87. The World's Nuclear Fuel Cycle Facilities," p. 47.

Nuclear Fuel (NF) 4/20/87. "New U.S. Japan Agreement Raises Issues About Future Pilutonium Air Shipments."

NUKEM Market Report on the Nuclear Fuel Cycle (NUKEM) 1/87. "NUKEM Special Report: Japan." NUKEM GmbH, Hanau, Federal Republic of Germany, p. 15.

PNC Review. fALL 1987. 'Collaboration Agreement Concerning Geological Disposal Research with SCK/CEN Goes Imto Effect," Fall 1987, p. 11.

Power Reactor and Nuclear Fuel Developmemt Corporation (PNC). 1987. 'PNC Annual Report for 1987." Power Reactor and Nuclear Fuel Development Corporation, Tokyo, p. 6. 
Salmon, A. 1987. 'The Transportation of Radioactive Wastes - A Review.' In Proceedings of the 1987 International Waste Management Conference, P. 359. November 29-December 5, Hong Kong, p. 359.

Shibata, E. 11/87. 'Spent Fuel Storage Facility in Japan.' Presented at Japan -U.S.S.R. Seminar on Transportation and Storage of Spent Fuel, pp. 61-627. Japan Atomic Industrial Forum and USSR State Cornmittee for the Utilization of Atomic Energy, Leningrad.

Tashiro, S., et al. 1987. "Study of the Performance of High-Level Waste Forms and Engineered Barriers Under Repository Conditions at JAERI.' Presented at the IAEA Coordinated Research Meeting, April 6-10, 1987, Sydney, Australia, .

Tsunoda, N. 1987. 'Status of Radioactive Waste Management Program in Japan." Presented at the Symposium of the Bavarian Government on The Back End of the Fuel Cycle. May 21, 1987, Munich, Federal Republic of Germany.

Uematsu, K 1987. "Japanese Approaches to the Assessment of Radionuclide Migration in the Geosphere," Radionuclide Waste Management and the Nuclear Fuel Cycle, Volt. 10, p. 145-158.

Yamanouchi, Y., 1987. 'Japanese Legislation on Radioactive Wastes.' Presented at the Nuclear International 'JURA '87' Symposium. Sept. 1987. International Nuclear Law Association, Brussels, Belgium.

Yamanouchi, T., S. Omachi, and K. Matsumoto. 'Decadal Operational Experience of the Tokai Reprocessing Plant." In International Conference on Nuclear Fuel Reprocessing and Waste Management 'RECOD 87," pp. 195-202. Société Française d'Energie Nucléaire, Paris.

$-1988-$

Atoms in Japan (AlJ). 1/88. "Fiscal 1988 Draft Budget for Nuclear Energy Up $1.9 \%$ to 369 Billion Yen," p. 16.

Atoms in Japan (AlJ). 3/88. 'Ten Micro Sieverts per Year as Exemption Dose,' p. 11.

Atoms in Japan (AlJ). 7/88. "PNC Signs Cooperative Pact with Swiss NAGRA on Rad-Waste Research," p. 28.

Atoms in Japan (AlJ). 8/88. "NFT To Place Ship Order for Exclusive Transportation of LLW," p. 19-20.

Atoms in Japan (AIJ). 10/88. "Japan-U.S. Agreement Amended for Sea Transportation of Plutonium," p. 9.

IAEA. 1988. "Treatment of Alpha-Bearing Wastes," IAEA Technical Report Series No. 287. IAEA, Vienna, p. 52-54.

NFC. $12 / 88$. "Evaluation of Economics of Spent Fuel Storage Techniques," Vol. 88, 6-7.

Nuclear Engineering International (NEI). 2/88. 'US-Japan Deal Rejected by Senate.'

Nuclear Engineering International (NEI). 6/88. "Japan Forms Laser J for AVLIS,' p. 6.

Nuclear Europe (NE). 1-2/88. 'PNC Opens Mox Fuel and Waste Plants,' p. 50.

Nuclear Fuel (NF). 2/22/88. "Japan's U308 Commitments 1988-2000," p. 2. 
Nuclear Fuel (NF), 2/8/88. "French and Japanese Cooperate on Pu Transport Cask Program," p. 5.

Nuclear Fuel (NF). 4/20/88. "PNC Develops New Centrifuge for Uranium and Plutonium Extraction," p. 4.

Nuclear Fuel (NF). 6/27/88. "U.S.-Japan Agreement for Cooperation to Enter Into Force Officially July 17,' p. 4.

Nuclear News (NN). 3/88. "Japan's 1987 Waste Management Activities,' p. 83.

Nuclear News (NN). 4/88, 'Japanese Plant Completed: Operation Due This Month,' p. 58.

Nuclear News (NN). 7/88. 'Japan Diet Approves Pact, Polar Route,' p. 44.

Nuclear Waste News (NWN). 3/24/88. "Bid to Stop Japanese Plutonium Deal Defeated by Senate, 5330," p. 97.

Nuclear Waste News (NWN). 5/26/88. 'Slants and Trends," p.1.

Nucleonics Week (NW). 1/14/88. "Japanese Government's Budget for Nuclear Drops Slightly," p. 11.

Nucleonics Week (NW). 2/11/88. "Japan Set to Deregulate Some Solid Radwastes," p. 6.

Nucleonics Week (NW). 2/11/88. 'Japan: Japan and U.S. to do Joint Waste

Research," p. 16.

Nucleonics Week (NW). 3/24/88. 'Japan and Indonesia Agree on Expanded Nuclear Cooperation," p. 13.

NUKEM Market Report on the Nuclear Fuel Cycle (NUKEM) 1/88. "Japan." NUKEM GmbH, Hanau, Federal Republic of Germany, p. 13.

NUKEM Market Report on the Nuclear Fuel Cycle (NUKEM) 3/88. "NUKEM Special Report,' NUKEM $\mathrm{GmbH}$, Hanau, Federal Republic of Germany, p. 16.

NUKEM Market Report on the Nuclear Fuel Cycle (NUKEM). 8/88. "Japan.' NUKEM GmbH, Hanau, Federal Republic of Germany, p. 13.

OECD/NEA. 1988. "Geological Disposal of Radioactive Waste, In Situ Research and Investigations in OECD Countries." Published by OECD/NEA, Paris, p. 55-57.

Okada, S., Y. Hashimoto, and K. Itoh. "Historical Review of Uranium Exploration in Japan." In Proceedings of a Technical Committee Meeting on Uranium Deposits in Asia and the Pacific: Geology and Exploration, IAEA Panel Proceedings Series. p. 193-206, Published by IAEA, Vienna, Austria.

PNC Review (PNC). 4/88a. "Plutonium Waste Test Facility Completed," p. 4.

PNC Review (PNC). 4/88b. "Fugen: 10 Years Successful Operation Since Criticality," p. 5.

PNC Review (PNC). 4.88c. 'PNC-DOE Coliaboration on Operational Reliability Testing of Long-Lived Oxide Fuels, p. 9. 
PNC Review (PNC). 4/88d. "Development of Hydrothermal Rock Solidification Technology for Low Level Radioactive Waste from Reprocessing Plants,' Spring 1988, p. 24.

PNC Review (PNC). 10/88a. 'Tokai Vitrification Facility Construction Work Begins," p. 5.

PNC Review (PNC). 10/88b. "Hot Test Begins at Krypton Recovery Technology Development Facility," p. 3.

Uematsu, K 1988. "Japanese Approaches to the Assessment of Radionuclide Migration to the Geosphere," Radioactive Waste Management and the Nuclear Fuel Cycle, Vol. 10, p. 145-158.

Watanabe, K., M. Maeda, and J. Shibuya. 1988. "Current Status of Spent Fuel Management in Japan" IAEA-TECDOC-487, Proceedings of an Advisory Group Meeting, p. 113-128. March 15-18, 1988, Vienna

$-1989-$

Atoms in Japan (AlJ). 3/89. "Recovery of Uranium from Seawater to End with Production of $15 \mathrm{Kg}$ $\mathrm{U}_{3} \mathrm{O}_{8}{ }^{\prime}$ p. 12.

Atoms in Japan (AIJ). 3/89. "JNFS Applies for Approval of Reprocessing and Waste Management Businesses," p. 18.

Atoms in Japan (AIJ). 4/89. 'JNFI Concludes Basic Agreement with U.S. MMES for U-Enrichment,' $p$. 37.

Atoms in Japan (AlJ). 5/89. "AEC Establishes Advisory Committee on Nuclear Fuel Recycling,' p. 20.

Atoms in Japan (AIJ). 10/89. 'JNFI and U.K. NIREX Conclude Agreement on LLW Disposal," p. 22.

Atoms in Japan (AlJ). 11/89a. "PNC Starts Fuel Production for First Loading of FBR 'Monju,' p. 21-22.

Atoms in Japan (AlJ). 11/89b. "Amendment to Law on Compensation for Nuclear Damage," p. 25.

Atoms in Japan (AlJ). 12/89a. 'HTTR Permit Procedure Advances to Secondary Examination,' p. 22.

Atoms in Japan (A|J). 12/89b. 'Spent Fuel Transportation Between Japan and Europe Marks 100th Safe Voyage," p. 22.

Chapman, C.C., and K. J. Schneider. 11/22/89. "Foreign Trip Report: Visit to PNC Tokai and O-arai Sites and at Joint International Waste Management Conference in Kyoto, Japan," p.7.

Horiuchi, S., M. Kikuchi, K Chino, T. Baba, H. Yusa, and H. Naitoh. 1989. "Solidification of "CementGlass'," Journal of Nuclear Science and Technology, 26, p. 887-892.

Jardine, L.J., J.L. Hoekwater, N. Machida, Y. Katano, and Y. Kamiya. 1989a. "A Dry Storage Facility for Vitritied High-Level Wastes in Japan,' Nuclear Plant Journal, July-August 1989, pp. 50, 56, 58, 70

Jardine, L.J., J.L. Hoekwater, N. Machida, Y. Katano, and Y. Kamiya, 1989b. "A Passive Air-Cooled Dry Storage Facility for Vitrified High-Level Wastes," In Waste Management 'B9: Vol. 1. High-Level Waste and General interest, Tucson, AZ, Feb. 26 - March 2, 1989, published by Univ. Arizona, p. 457-466. 
Kanno, T., W. Wakamatsu, M. Hatta, and K. Miwa. 1989. "Static and Permeability Sorption Tests of Buffer Materials for Geologic Disposal for High-Level Wastes," In Waste Mạnagement '89: High-Level Waste and General interest, Vol. 1, pp. 647-651. Feb. 26 - March 2, 1989, University of Arizona, Tucson, Arizona.

Katsunuma, Y., S. Murakoshi, T. Yamamoto, and N. Mitsushima. 1989. "Research and Development to Handle Vitrified Waste to be Returned from Overseas Reprocessing Plants." In Proceedings of the 1989 Joint International Waste Management Conference: High Level Radioactive Waste and Spent Fuel Management, Oct. 22-28, 1989, Published by the American Society of Mechanical Engineers, New York, Vol. 2, p. 159-163.

Kiyose, R., and N. Tsunoda. 'Progress in Radioactive Waste Management in Japan.' in Waste Management '89: High-Level Waste and General interest, Vol.1, pp. 25-30. Fob. 26-Mar. 2, University of Arizona, Tucson.

Miyao, H., S. Ikeda, M. Shiotsuki, S. Kawamura, F. Komatsu, H. Tanabe, and T. Kanazawa. 1989. 'Technology for Treatment and Conditioning Spent LWR Fuel Cladding Hulls and Hardware.' In Proceedings of the 1989 Joint International Waste Management Conference: High Level Radioactive Waste and Spent Fuel Management, p. 499-504. Oct. 22-28, 1984, Kyoto, Japan. American Society of Mechanical Engineers, New York.

Nagakura, T., H. Abe, Y. Esashi, S. Shiomi, H. Onuma, and Y. Maki. 1989. "Safety Concerning Transportation of Spent Fuel.' Journal of Nuclear Science and technology, Vol. 26, pp. 105-112.

Nagano, K., and K. Yamaji. 'A Study on the Needs and Economics of Spent Fuel Storage in Japan,' In Proceedings of the 1989 Joint International Waste Management Conference: High Level Radioactive Waste and Spent Fuel Management, Oct. 22-28, 1989, Kyoto, Japan. American Society of Mechanical Engineers, New York, Vol.2, p. 473-482.

Nuclear Energy Agency (NEA). 1989. 'NEA International Co-operative Projects.' OECD INEA, Paris, $p$ 28-37.

Nuclear Energy (NE). 8/89. "JAERI's Research Programme," Vol. 28, p. 205.

Nuclear Engineering International (NEI). 2/89. p. 36.

Nuclear Engineering International (NEl). 6/89. 'World Survey,' p. 25-26.

Nuclear Engineering International (NEI). 7/89. "Datafile: Japan,' p. 56-58.

Nuclear Engineering International (NEI). 1989. "Japan Still Keen on Sea Disposal," p. 54.

Nuclear Europe (NE). 5-6/89. "Japan Completes Uranium Recovery from Seawater," p. 41.

Nuclear Fuel (NF). 1/9/89. 'Completion of AECL Laboratory on Hold Pending Talks on Future Joint Projects," p. 12.

Nuclear Fuel (NF). 2/89. Japan's PNC Begins Operation of Second Half of SWU Plant," p. 9.

Nuclear Fuel (NF). 11/89. "Protests Prompt Official Rejection of Proposed Radwaste Research Site," p. 7. 
Nuclear Fuel (NF). 12/89. "Next Pu Shipment from Europe to Japan to be Done by Sea with Civilian Escort,' p. 13.

Nuclear News (NN). 6/89. 'Japan: Capacity Factor Down for Nuclear Natiowide, p. 76, 78.

Nuclear News (NN). 7/89. "Fuel Briefs," p. 83.

Nuclear Waste News (NW). 2/16/89. JJapan Signs $\$ 10$ Million Contract with PNL for HLW Barrier Study,' p. 54.

Nuclear Waste News (NW). 3/89. "Britain, Japan Plan to Have HLW Vitrification Facilities in Operation by the Early 1990's," p. 81.

NUKEM Market Report on the Nuclear Fuel Cycle (NUKEM) 5/89. 'NUKEM Special Report,' Nukem $\mathrm{GmbH}$, Hanau, Federal Republic of Germany, p. 18.

Numark, N.J., H.W. Paige, and E.F. Wonder. 'Public Perception and Acceptance of the Siting of Nuclear Waste Facilities in Seven Countries', ERCE-R/89-42, ERC Environmental and Energy Services Co., Fairfax, VA; Sept. 1989, p. ES-10.

Ogata, Y., H. Kobayashi, T. Takahashi, and M. Horie. 1989. 'Development of Dismantling Technology for Spent Melter." In Proceedings of the 1989 Joint International Waste Management Conference High Level Radioactive Waste and Spent Fuel Management Vol.2, pp. 261-264. Kyoto, Japan. Oct. 22-28, 1989, American Society of Mechanical Engineers, New York.

Oyama, A. 1989. 'Policy of Japan on Radioactive Waste Management.' In Proceedings of the 1989 Joint International Waste Management Conference High Level Radioactive Waste and Spent Fuel Management. Kyoto, Japan, Oct, 22-28, 1989, American Society of Mechanical Engineers, New York, Vol. 2, 1 p. 11-12.

PNC Review (PNC). 8/89. "Japan-U.S. Memorandums Exchanged on FBR Cooperation," p. 5.

PNC Review (PNC). 8/89. 'Natural Analog Study of Long-Term Behavior of Engineered Barriers in HLW Geological Isolation Systems," p. 6.

PNC Review (PNC). 10/89. "Summary of Plans for the Radioactive Waste Storage Research Center Plan and Affiliated Survey,' p. 4.

PNC Review (PNC). 1989a, "MOX Fuel Production Reaches 100 Tons," Fall 1989, p. 7.

PNC Review (PNC). 1989b. "R\&D Continues on Plutonium Fuel Fabrication," Fall 1989, p. 10.

PNC Review (PNC). 1989c. 'Tokai Vitrification Facility,' Fall 1990, p. 16.

Saegusa, T., C. Ito, and M. Hironaga. 1989. "Overview of Spent Fuel Storage Technologies in Japan Cask and Vault Types." In Proceedings of the 1989 Joint International Waste Management Conference: High Level Radioactive Waste and Spent Fuel Management, Oct. 22-28, 1989, Kyoto, Janpan, American Society of Mechanical Engineers, New York. p. 441-446.

Seo, T., Y. Ochiai, S. Takeda, and N. Nakatsuka. 1989. "Natural Analogue Study on Tono SandstoneType Uranium Deposit in Japan." In Proceedings of the 1989 Joint International Waste Management Conference: High Level Radioactive Waste and Spent Fuel Management, Vol. 2, pp. 353-358. Kyoto, Japan. American Society of Mechanical Engineers, New York 
Shimoda, H. 1989. "Disposal of Low-Level Radioactive Solid Wastes (LLSW) By Burying in Concrete Vault - Plan of Japan Nuclear Fuel Industries Co., Inc.' In Proceedings of the 1989 Joint International Waste Management Conference: Low and Intermediate Level Radioactive Waste Management, Vol. 1 . p. 545-547. Oct. 22-28, 1989, Kyoto, Japan. American Society of Mechanical Engineers, New York.

Shimooka, K, S. Takebe, H.I.F. Hirosue, K Yamada, H. Miyahara, Y. Wadachi, and K. Hirano. 1989. 'Performance Experiment of LRW Disposal Concrete Vault - Migration Behavior of Radionuclides in Backfill and Concrete.' In Proceedings of the 1989 Joint Imternational Waste Management Conference: Low and intermediate Level Radioactive Waste Management, Vol. 1, pp. K581-586. Oct. 22-28, 1989, Kuoto, Sapan. American Society of Mechanical Engineers, New York

Suyama, N., H. Okamoto, and T. Onishi. 'Spent Fuel Storage Activities in the Tokai Reprocessing Plant.' In Proceedings of the 1989 Joint International Waste Management Conference: High Level Radioactive Waste and Spent Fuel Management, Oct. 22-2B, 1989, American Society of Mechanical Engineers, New York. Vol.2, pp. 285-289.

Tsuboya, T, S. Masuda, S. Saito, and Y. Asakura. 1989. 'Overview of High-Level Radioactive Waste Management in Japan." In Proceedings of the 1989 Joint International Waste Management Conference: High Level Radioactive waste and Spent Fuel Management, Oct. 22-28, 1989, Kyoto, Japan. American Society of Mechanical Engineers, New York, 1989 Vol. 2, pp. 105-110.

Watanabe, K 1989. "Archaeological Evidence Supports a Preferred Soil Cap for LLRW Disposal." In Proceedings of the 1989 Joint International Waste Management Conference: Low and Intermediate Level Radioactive Waste Management, Kyoto, Japan. Oct. 22-28, 1989, American Society of Mechanical Engineers, New York, 1989, p. Vol. 1, pp. 567.571.

Yoshioka, M., H. Igarashi, S. Torata, T. Takahashi, and M. Horie. 1989. 'Glass Metter and Process Development for the PNC Toka Vitrification Facility;" In Proceedings of the 1989 Joint International Waste Management Conference: High Level Radioactive waste and Spent Fuel Management, Vol. 2, pp. 13-19. Oct. 22-28, 1989, Kyoto, Japan. American Society of Mechanical Engineers, New York.

$-1990-$

Atoms in Japan (AV). 1/90a. "Fiscal 1990 Dratt Nuclear Budget Up 2.0\% to Y395.5 Bil., p. 22.

Atoms in Japan (AlJ). 1/90. 'Near-Field Research Should be Concentrated on HLW Disposal, AEC Says," p. 26.

Atoms in Japan (AIJ). 3/90. 'Asian Leaders Confirm Common Interests and Tasks for Regional Nuclear Cooperation," p. 12.

Atoms in Japan (AIJ). 3/90. 'JAERI and UKAEA Conclude Agreement on Thermal Reactors,' p. 25.

Atoms in Japan (AIJ). 3/90. 'JAERl and Thai OAEP to Study Radiation Processing of Sludge," p. 26.

Atoms in Japan (AIJ). 4/90. "JNFI Begins Placement of Centrifuges in Commercial U.Enrichment Plant," p. 32.

Atoms in Japan (AIJ). 5/90a. "NSC Holds Public Hearing for LLW Storage Facility," pp. 6-7.

Atoms in Japan (AIJ). 5/90b. Japan and ROK Sign Nuclear Cooperative Arrangement," p. 17. 
Atoms in Japan (AIJ). 6/90a. 'MITI Sets New Energy Policy Concentrated on Conservation and Nuclear Power Development," p. 4.

Atoms In Japan (AIJ). 6/90b. Nuclear Share to be $43 \%$ of kWh with Capacity of 72,500 MW by FY 2010,' p. 10-11.

Atoms in Japan (AlJ). 6/90c. 'New Japan-France Nuclear Pact Approved by the Diet,' p. 28.

Atoms in Japan (AIJ). 6/90d. "JAERI, EURATOM Sign Cooperative Arrangement for R\&D on Safeguards," p. 33.

Atoms in Japan (AlJ). 6/90e. "Japan-U.S. Cooperation in FBR/LMR R\&D Goes Well," p. 33.

Atoms in Japan (AIJ). 6/90t. "NSRA Panel Stresses Need for Underground Research Laboratory for HLW Study," p. 34.

Atoms In Japan (AlJ). 7/90. 'Hokkaido Pret. Assembly Adopts Resolution of Opposition to Honorobe Plan," p. 19.

Atoms in Japan (AIJ). 7/90. "New Japan-France Nuclear Energy Pact Comes Into Effect," p. 17.

Atoms in Japan (AIJ). 7/90. "JNFI Signs Agreements with U.S. Firms on LLW Disposal," p. 23.

Atoms in Japan (AIJ). 8/90. 'JAIF Report Emphasizes Need to Foster Private Uranium Supply industry,' pp.. 4-7.

Atoms In Japan (AIJ). 8/90. "Hokkaido Governor Requests STA to Reconsider the Plan for HLW Storage Center," p. 24.

Atoms in Japan (AlJ). 9/90. 'Construction of LLW Storage Center to be Delayed," p. 21.

Atoms in Japan (AIJ). 9/90. "JAERI Reaches 5\% Uranium Enrichment Through Atomic Vapor Laser Process,' p. 19.

Atoms in Japan (AIJ). 9/90. "Japan and Soviet Governments Ink Cooperation Agreement on Chernobyl," p. 15.

Atoms in Japan (AIJ). 12/90a. 'Operating Records of Nuclear Power Plants In November,' p. 16.

Atoms in Japan (AlJ). 12/90b. Tokai Reprocessing Plant Reprocesses Total of 500 Tons of Spent Fuel," p. 19.

Atoms in Japan (AIJ). 12/90c. "White Paper on Nuclear Safety Features Concept of Risk, Reviewing Probabilistic Safety Assessment," p. 4-6.

Hattori, S., and T. Inoue. 1990. "Status of Research and Development of Partitioning and Transmutation Technology for Long Life Radioactive Nuclides in Japan.' Presentation at American Nuclear Society Meeting, November, 1990, Washington, D.C.

Leigh, 1. W., and S. J. Mitchell. 1990 International Nuclear Cycle Fact Book. PNL-3594, Rev. 10, Pacific Northwest Laboratory, Richland, Washington. 
Masuda, S., H. Umeki, K. Ishiguro, and A. Suzuki. 1990. 'Outline of Performance Assessment Study of Geological Isolation System in Japan.' In High Level Radioactive Waste Management, Vol. 1, p. 339-347.American Nuclear Society/ American Society for Civil Engineers, New York.

Nuclear Enqineering Intemational (NEI). 7/90. 'Report Recommends Doubling Japan's Nuclear Capacity by 2010," p. 2.

Nuclear Enqineering International (NEI). 11-12/90a. Japan to Aid Oinshan Startup," p. 4.

Nuclear Engineering International (NEl). 11-12/90b. "Japan's 39th N-Unit Goes Commercial," p. 54.

Nuclear Fuel. (NF). 5/28/90. 'Japan: Pilot Laser Enrichment Facility Completed,"p. 17.

Nuclear Fuel (NF). 12/24/90, "PNC Transfers Interest in Midwest Lake Project in Canada to Japan's OURD,' p. 4.

Nuclear Law Bulletin (NLB). 6/90. "Japan: Review of Nuclear Legislation (1990)," Vol. 45, pp. 57-62.

Nuclear Law Bulletin (NLB). 12/90. 'Japan-Republic of Korea," Vol. 46, p. 87.

Nuclear News (NN). 2/90a. "Late News in Brief," p. 19.

Nuclear News (NN). 2/90b. "Fuel: Plutonium," p. 40.

Nuclear News (NN). 10/90. JJAlF Signs Research Pact With Soviet Academy," p. 80.

Nuclear Waste Bulletin. (NWB). 7/87. "Update on Waste Management Policies and Programmes: Japan," p. 12.

Nucleonics Week (NW). 5/3/90. "France/Japan Nuclear Pact Renewed," p. 15.

Nucleonics Week (NW). 6/7/90. "South Korea and Japan Sign Nuclear Cooperation Agreement," p. 11.

Nucleonics Woek (NW). 11/29/90. "Rokkasho LLW Site Work to Start on November 30,' p. 11.

Nucleonics Week (NW). 12/20/90. "MITI, Utility Swear Again to Achieve Nuclear Targets," pp. 5-6.

NUKEM Market Report on the Nuclear Fuel Cycle (NUKEM). 2/90. "Japan," NUKEM GmbH, Hanau, Federal Republic of Germany, p. 18.

NUKEM Market Report on the Nuclear Fuel Cycle (NUKEM). 3/90. "Nuclear Fuel Supply and Demand. Update on the Far East," NUKE, GmbH, Hanau, Federal Republic of Germany, p. 23.

NUKEM Market Report on the Nuclear Fuel Cycle (NUKEM). 7/90. "Nuclear Fuel Market Opportunities," NUKEM GmbH, Hanau, Federal Republic of Germany, p. 19.

NUKEM Market Report on the Nuclear Fuel Cycle (NUKEM). 9/90. 'Japan,' NUKEM GmbH, Hanau, Federal Republic of Germany, p. 6.

NUKEM Market Report on the Nuclear Fuel Cycle (NUKEM). 12/90. "World Nuclear Power Plant Capacity..." NUKEM GmbH, Hanau, Federal Republic of Gerriany, pp. 21-22. 
NUKEM Special Report (NUKEM). 7/90. "World Nuclear Power Plant Capacity..." NUKEM GmbH, Hanau, Federal Republic of Germany, p. 8.

OECD/AAEA. 1990. "Uranium. Resources, Production and Demand." Joint Report by the OECD Nuclear Energy Agency and the International Atomic Energy Agency, Published by OECD, Paris, $p$. 215.

PNC Review (PNC). 2/90. "Waste Management RD\&D Program for Low-Level TRU-Bearing Waste.' PNC SN4020 87-001. May 1987. Translated 2/9C by PNC for DOE.

PNC Review (PNC). 1990. "New Radioactive Waste Treatment Facility Completed at Fugen." Spring 1990 , p. 8.

PNC Review (PNC). 1990. "Preliminary Investigations Begin for Shaft Excavation Effect Test." Spring 1990, p. 9.

PNC Review (PNC). 4/90a. "RETF Design Work Makes Progress." Spring 1990, p. 11.

PNC Review (PNC). 4/90b. "Shaft Excavation Effect Project." Spring 1990, p. 16.

PNC Review (PNC). 8/90a, 'O-Orai Engineering Center Marks 20th Anniversary." Summer 1990, pp. 4.6.

PNC Review (PNC). 8/90b. 'Tokai Reprocessing Plant.' Summer 1990, pp. 16-18.

PNC Review (PNC). 10/90a. "Roll-in Rack Designed for Recycle Equipment Test Facility." Fall 1990, p. 8.

PNC Review (PNC). 10/90b. 'Second High Active Solid Waste Facility Completed." Fall 1990, p. 7.

PNC Review (PNC). 10/90b. "Research and Development of the Fast Breeder Reactor." Fall 1990. pp. $12-15$.

PNC Review (PNC). 10/90c. "Research and Development on Radioactive Waste Management." Fall 1990, p. 15.

PNC Review (PNC). 12/90a. 'Second Bituminized Waste Storage Facility Passes Inspection." Winter 1990, p. 4.

PNC Review (PNC). 12/90b. "Research on Engineered Barrier Materials." Winter 1990, p. 8-9.

Sasaki, N., H. Ishikawa, K. Miyahara, K. Yamada, and Y. Yusa. 1990. 'Development of the Engineered Barriers for the Deep Geological Disposal of High-Level Radioactive Waste.' In High Level Radioactive Waste Management. Proceedings of the International Topical Meeting, Vol. 1, pp. 675-682. April 8-12, 1990, Las Vegas. American Nuclear Society, La Grange Park, lilinois.

Sauda, K, T. Nakashima, T. Kagawa, and H. Kuribayashi. 1990. "Advanced Cement Soliditication Process for Spent Ion-Exchange Resins.' In Waste Management '90: Waste Processing Transportation, Storage and Disposal, Technical Programs and Public Education, Vol. 2, pp. 299-303, February 25 - March 1, 1990, University of Arizona, Tucson.

Yagi, T., H. Yamazaki, A. Yokota, and H. Kuribayashi. 1990. "Advanced LLW Classification System." in Waste Management '90: Waste Processing. Transportation, Storage and Disposal, Technical 
Programs and Public Education, Vol. 2, pp. 221-227. February 25 - March 1, 1990, University of Arizona, Tucson.

Yamamoto, M. "Status of Waste Management Technology in PNC, Japan." 1990. In Waste Management '90: Overview and General Waste Management, Vol. 1, pp. 291-293. February 25 - March 1, 1990, University of Arizona, Tucson.

$$
-1991 .
$$

Nuclear Enqineering International (NEI). 1/91. "JNFS Postponements," p. 7.

Nuclear News (NN). 1/91. 'Japan's STA Okays Start of Work at Rokkasho-mura,' p. 91.

World , vuclear Industry Handbook (WNIH). 1991. 'Country-by-Country Reactor Status," p. 32. 

SOUTH KOREA 


\section{KOREA (SOUTH)}

\section{CONTENTS}

NUCLEAR POWER

$\mathrm{KS} .2$

2.0 NUCLEAR FUEL CYCLE AND RADIOACTIVE WASTE MANAGEMENT

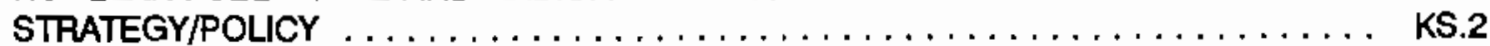

3.0 HIGHLIGHTS AND MAJOR MILESTONES $\ldots \ldots \ldots \ldots \ldots \ldots \ldots \ldots \ldots \ldots \ldots$

4.0 INSTITUTIONAL CONSIDERATIONS/ORGANIZATIONS $\ldots \ldots \ldots \ldots \ldots \ldots \ldots \ldots \ldots$

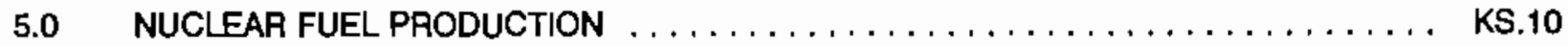

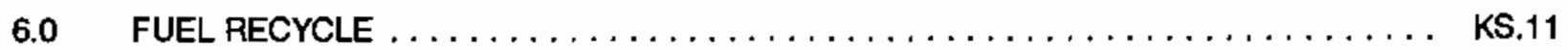

7.0 SPENT FUEL STORAGE AND TRANSPORT $\ldots \ldots \ldots \ldots \ldots \ldots \ldots \ldots \ldots \ldots$ KS.11

8.0 WASTE CONDITIONING, STORAGE AND TRANSPORT $\ldots \ldots \ldots \ldots \ldots \ldots \ldots \ldots$

9.0 DISPOSAL OF NON-HIGH-LEVEL WASTES $\ldots \ldots \ldots \ldots \ldots \ldots \ldots \ldots \ldots \ldots$

10.0 DISPOSAL OF HIGH-LEVEL WASTES $\ldots \ldots \ldots \ldots \ldots \ldots \ldots \ldots \ldots \ldots \ldots \ldots \ldots$

11.0 MANAGEMENT OF URANIUM MINE AND MILL WASTES $\ldots \ldots \ldots \ldots \ldots \ldots \ldots$

12.0 DECOMMISSIONING AND ENVIRONMENTAL RESTORATION $\ldots \ldots \ldots \ldots \ldots \ldots \ldots$ KS.16

13.0 INTERNATIONAL ACTIVITIES $\ldots \ldots \ldots \ldots \ldots \ldots \ldots \ldots \ldots \ldots \ldots \ldots \ldots \ldots$

14.0 REFERENCES $\ldots \ldots \ldots \ldots \ldots \ldots \ldots \ldots \ldots \ldots \ldots \ldots \ldots \ldots \ldots \ldots \ldots \ldots \ldots$ 


\subsection{NUCLEAR POWER}

1.1 REACTOR MIX: 8 PWRs, 1 PHWR (CANDU) (NN 8/90; NUKEM 7/90)

1.2 ELECTRIC POWEA PAODUCTION (NUKEM 12/87; Park 1990)

1986--64.7 TWh total (43.8\% nuclear) (NUKEM 12/87; Park 1990)

1987--74.0 TWh total (53.1\% nuclear)

1988-85.5 TWh total (46.9\% nuclear, 48.9\% thermal, $4.2 \%$ hydro) (Leigh and Mitchell 1990; NEI 9/89; Park 1990)

1989--94.5 TWh total (50.1\% nuclear, $45.1 \%$ thermal, 4.8\% hydro) (KAIF 1990; Park 1990)

1.3 NUCLEAR POWER CAPACITY PROJECTIONS (NN 8/90; NUKEM 7/90)

1990-7.2 GWe

1997-8.1 GWe

$1998-9.1 \mathrm{GWe}$

1999-11.6 GWe net with 12 LWRs, 2 PHWRs (Juhn 1990)

2000-10.7 GWe

2031-50 new plants (Juhn 1989)

1.4 NUCLEAA PLANT AVAILABILITY: The power system in South Korea is going to extendedexposure fuel to increase capacity factors (NN 4/89; KAIF 1990)

\begin{tabular}{lll} 
Year & $\begin{array}{l}\text { Capacity } \\
\text { Factor }(\%)\end{array}$ & $\begin{array}{l}\text { Availability } \\
\text { Factor }(\%)\end{array}$ \\
\hline 1983 & 66.6 & 75.4 \\
1985 & 78.7 & 82.1 \\
1988 & 73.0 & 74.6 \\
1989 & 76.2 & 77.5 (Park 1990)
\end{tabular}

1.5 NUCLEAR ENERGY POLICY (Leigh and Mitchell 1990)

South Korea's policy is to continue the expansion of electric power capacity as required, and to reduce the dependence on foreign oil (and coal) by maintaining a strong nuclear power program, with indigenous manufacturing, construction, operating and servicing capability; a long-term goal is the development of fast breeder reactor (FBR) capability with fuel recycle; increasing attention is being paid to ameliorating rising public concern about nuclear energy (Han 1989); Korea's long-range strategy is to acquire, as nearly as possible, technological and manufacturing capabilities in all phases of the nuclear fuel cycle (Park 1986; Han and Köster 1989; Juhn 1990; KAIF 1990); KAERI has been selected as the managing agency for the waste management program (Han and Park 1989)

\subsection{NUCLEAR FUEL CYCLE AND RADIOACTIVE WASTE MANAGEMENT STRATEGY/POLICY (Leigh and Mitchell 1990; Park 1990; KAIF 1990).}

\subsection{OVERALL FUEL CYCLE POUCY}

Korean policy entails the development of long-term contracts for fuel supplies and needed services, combined with Korean holdings of foreign uranium resources; conversion and fabrication of uranium fuel for CANDU (PHWR) and PWR plants; a "wait and see" approach toward reprocessing of spent fuel and recycle of plutonium in FBR, CANDU and PWR plants; 
Korea is proceeding with cooperative studies analyzing alternate fuel cycle options, including reprocessing, recycling and direct disposal of spent fuel (Whang et al. 1989)

\subsection{POLICY ON FRONT END OF NUCLEAR FUEL CYCLE}

Korean policy is to attain ownership of foreign uranium resources and to participate in uranium exploration in other countries, coupled with uranium purchases on long-term contracts; it will rely on foreign sources (currently France and U.S.) for enrichment services; plans for purchase of enriched uranium from the Soviet Union were announced in 1990; consideration is being given to possible imvestment in an overseas enrichment plant; conversion and reconversion services have been purchased in the past; Korea now has capability for uranium reconversion and fuel fabrication for both PWR and PHWR reactors to meet its own foreseen near-term demands

\subsection{POLCY ON BACK END OF NUCLEAR FUEL CYCLE}

Korean policy on spent fuel is to store it at nuclear power plant sites until a central interim storage facility is constructed (expected at the end of 1997); fuel will be held until a decision is made on the means of final disposition, and on whether to reprocess fuel prior to disposal

Low-level and intermediate-level wastes will be disposed of in an underground 'engineered rock cave,' a multiple-tunnel facility, with surface facilities for waste receipt and packaging; the LLWILW site will be away from other nuclear facility sites, probably near the sea coast; until the disposal facility is available, LLW and ILW generated at power plants or fuel cycle facilities will be stored at the originating sites; other wastes, principally wastes from industrial and medical isotope use, are being stored at KAERI

\subsection{HIGHLIGHTS AND MAJOR MILESTONES}

1985 Non-radioactive testing in post-irradiation examination facility completed

1986 Construction of PWR fuel fabrication plant started

1987 KAERI $\mathrm{U}_{3} \mathrm{O}_{\mathrm{B}}-\mathrm{UO}_{2}$ conversion plant for CANDU fuel began operation (KAERI 1990)

1987 CANDU fuel fabrication plant (expanded from pilot facility) began operation (NEI 12/87)

1989 PWR fuel fabrication plant (Taejon) began operations (KAlF 1990)

1989 A preliminary safety and performance assessment was completed for the LLWILW disposal facility; selection of an underground, horizontal-tunnel concept resulted (Han and Park 1989)

$1990 \quad \mathrm{~A} \mathrm{UF}_{6}-\mathrm{UO}_{2}$ reconversion facility started commercial operation at the KNFC Taejon PWR fuel fabrication plant (KAIF 1990; FCR 1990)

1990 Site selection for the LLW-ILW repository (public concern may result in delays)

1992 First criticality attained for the Multi-Purpose Research Reactor (MRR) at KAERIDaeduk (KAERI 1990) 

1989) 1990)

\subsection{INSTITUTIONAL CONSIDERATIONS/ORGANIZATIONS}

\subsection{LEGAL REOUIREMENTS (Leigh and Mitchell 1990; KAIF 1990; KINS 1990)}

A. The basic legal authority governing Korean nuclear activities rests in the Atomic Energy Law; development of policies under this law is assigned to the Atomic Energy Bureau (AEB) of the Ministry of Science and Technology (MOST); policies and related activities are promulgated after consultation and agreement among the AEB, the Electric Power Bureau (EPB) of the Ministry of Energy and Resources (MER), and the Korean Institute of Nuclear Safety (KINS), and after approval by the Atomic Energy Commission (AEC)

B. Nuclear plant licensing procedures are multi-stage; site approvals and limited work permits are utilized to limit delays in starting projects; a construction permit is required prior to start of major construction, and following construction the issuance of an operating license is required prior to start of operations; licenses are also issued to nuclear plant operators, nuclear fuel handlers, and radioisotope handlers

C. Facility operations are subject to AEB technical standards and procedures, and to inspections and audits carried out by KINS and enforced by AEB

\subsection{RADIATION PROTECTION PRINCIPLES}

A. Radiation protection standards and plant safety regulations are promulgated by the AEB based on reviews by the Korea Institute of Nuclear Safety (KINS)

B. Principles of radiation protection in Korea are modeled after, and in general in conformance with, IAEA and U.S. principles (Leigh and Mitchell 1990; KINS 1990); the maximum worker exposure allowed is $5 \mathrm{rem} / \mathrm{yr}$, conforming to ICAP (before November 1990); ALARA principles are applied; in 1989 the average annual worker exposure was 0.178 rem (Park 1990)

\subsection{LICENSING}

A. All nuclear-related licenses are issued by the Atomic Energy Bureau of MOST; plant construction permits and operating licenses are awarded after evaluation and recommendation of KINS, with AEC approval; operators' licenses are issued following evaluation and recommendation by KINS (KAIF 1990; KINS 1990); nuclear regulatory procedures are a "mixing (of) those of the U.S. and Japan" (KAIF 1990)

B. For either construction permits or operating licenses, the operating agency (KEPCO for power plants, KNFC for fuel fabrication facilities, and KAERI for other fuel cycle facilities) subrnits an application, accompanied by a PSAR and an environmental report, to KINS. who reviews it for safety aspects and forwards a safety assessment to MOST-AEB; the $A E B$ then reviews it, obtains other reviews as needed, and submits it to $A E C ; A E C$ makes 
the final decision, and approves (or denies) the request; following approval, AEB issues the permit or license; abbreviated versions of these procedures are used for site approvals and limited work permits

4.4 PUBUC INVOLVEMENT: In Korea, recent increases in public concern regarding nuclear power have resulted in efforts to develop comprehensive programs for understanding and dealing with these concerns; KAIF has taken the lead in improving public acceptance of nuclear power production; KAERl is developing a public acceptance program for radioactive waste disposal (Han 1989; Han and Park 1989)

In November 1990, about ten-thousand rioters seized government offices and burned a police station on Anmyondo (Anmyon Island), about 85 miles southwest of Seoul, protesting against the planned construction of a nuclear waste disposal facility (NWN 11/15/90)

Beginning in August 1989, a fee consisting of $0.3 \%$ of the revenue from total electricity sales has been collected for community support programs for residents living near nuclear power plants (this is separate from the waste management fee described in 4.5 below); the fee will be used for building public facilities, construction of local manufacturing facilities for income augmentation, and for educational programs; expenditure levels are projected at 15 billion won (\$2 million) annually for communities with power stations under construction, and 5 to 10 billion won annually for communities hosting operating nuclear power plants (Park 1990; KAIF 1990)

4.5 WASTE FUND: A waste management fee assessed against nuclear power plants, amounting to a surcharge of $\$ 0.002 / \mathrm{kWh}$ electricity generated, was established in 1987 to cover disposal costs of reactor-generated spent fuel, HLW, ILW, and LLW; other LLW-ILW waste generators will be assessed fees according to the volume and category of the wastes to be disposed and based on recovery of costs (NE 3/4/87; Leigh and Mitchell 1990; Han and Park 1989); Juhn (1990) reports the waste management fee as $\$ 0.003 / \mathrm{kWh}$.

The waste fund is designed to cover the estimated total cost of the radioactive waste disposal program, including:

- Transport and disposal of radioactive wastes generated from:

- power reactor operations

- fuel cycle facilities

- decommissioning of nuclear reactors

- Disposal of radioactive wastes from other producers (i.e., radioisotope users)

- Packaging, transport, AFR storage, treatment and disposal of spent fuel from power reactors

- R\&D and related services required in radjoactive waste management development and operations (Han and Park 1989)

4.6 KEY AGENCIES AND FUEL CYCLE CENTERS (Leigh and Mitchell 1990; KAIF 1990)

The Korean nuclear infrastructure has many component organizations; the key centers are listed below; a more comprehensive listing of agencies and supporting industry is found in KAIF (1990) 
A. MER (Ministry of Energy and Resources): MER is the lead government agency in power development and resource utilization; KEPCO, as well as several resource- and energyintensive "public" companies, is administratively under MER (KAIF 1990)

- EPB (Electric Power Bureau): the EPB is a bureau of the MER; it establishes plans and policies on energy and resources, in coordination with MOST and the AEB; the EPB also provides "owner supervision of construction and operations of nuclear power plants, enforces safety regulations, and manages nuclear fue! acquisition

- KEPCO (The Korea Electric Power Company): KEPCO operates all nuclear (and conventional) power plants in Korea, coordinates generation from all sources, and operates transmission networks; it is a "public" (government-owned) corporation, located administratively under the Vice Minister of NIER; KEPCO has several subsidiaries covering the nuclear power industry; these include KNFC, KOPEC, $\mathrm{KEPOS}$, and $\mathrm{KHIC}_{\mathrm{i}}$ as Korea's only electrical utility, KEPCO is responsible for construction, operation, and decommissioning of generating plants, and for onsite treatment of the radioactive waste generated at the plants

- KEPOS (Korea Electric Power Operating Service Co.): KEPOS, a subsidiary of $\mathrm{KEPCO}$, is a service company specializing in power plant maintenance and repair, serving all Korean power plants, nuclear and conventional

- KOPEC (Korea Power Engineering Company): KOPEC, which is $94 \%$ KEPCO owned, provides architect-engineering services (design, engineering, construction management, and plant startup) for nuclear and conventional power facilities; it is a subsidiary of KEPCO

- KNFC (Korea Nuclear Fuel Corporation): KNFC was recently 'spun off" from KAERl; it is currently concentrating on PWR fuel manufacture; KNFC is owned $90 \%$ by KEPCO and $10 \%$ by KAERI, and is operated as a subsidiary of KEPCO

- KHIC (Korea Heavy Industries and Construction Co.): KHIC is a worldwide contractor for construction of industrial plants and power plants; the Korean government has assigned KHIC as the sole construction manager and major equipment fabricator for future Korean power plants; KHIC is a subsidiary of KEPCO

B. AEB (Atomic Energy Bureau): the AEB is a bureau of the Ministry of Science and Technology; it is responsible for amendments to the basic Atomic Energy Law (subject to the National Assembly), authorization and licensing of nuclear power plants, fuel cycle facilities and related facilities; issuance of operators' licenses, control over nuclear materials, development of technical codes and standards, and oversight and support of the entire nuclear complex

The AEB is composed of four divisions:

- The Nuclear Policy Division, which is responsible for policy development, management of the nuclear waste fund and of other nuclear-related funds established by law, and management of systems for promotion and regulation of nuclear power 
KOREA (SOUTH)

- The Nuclear Energy Research and Development Division, which plans, sponsors and directs Korean R\&D efforts in the nuclear field

- The Nuclear Reactor Division, which is responsible for issuing permits and licenses for the construction and operation of nuclear reactors and fuel cycle facilities, licensing of reactor operators, establishment and enforcement of QA programs, compliance reviews, inspections and entorcement, and establishment of codes, standards, and technical criteria for nuclear facilities and activities

- The Radiation Safety Division, which is responsible for licensing of radioisotope use and industrial x-ray equipment, for safety regulation of transport, handling, storage, and disposal of spent fuel and radioactive wastes, and for environmental regulations for nuclear facility sites

C. MOST (Ministry of Science and Technology): MOST has authority over virtually all scientific and technological efforts in Korea; its main operating arms relating to nuclear activities are the Atomic Energy Bureau and the Nuclear Safety and Cooperation Office; ten major technological institutes (including KAERI, KAIST, and KINS) are attached administratively to MOST

- NSCO (Nuclear Safety and Cooperation Office): This office is a major component of MOST, reporting directly to the MOST vice-minister; this is the major Korean center for policy development and implementation, safety regulation, and enforcement for matters conceming nuclear safety; representatives of this office serve as resident officers at all nuclear sites and report directly to the DirectorGeneral of the office

- The Nuclear Safety and Cooperation office has two divisions: the Nuclear Safety Division, concerned with nuclear safety regulation, physical protection of nuclear facilities, and emergency preparedness; and the Nuclear Cooperation Division, charged with implementation and management of activities required by multilateral or bilateral agreements, and with management of overseas training in nuclear fields

D. AEC (Atomic Energy Commission): The Atomic Energy Commission reports directly to the Prime Minister of Korea and serves as a decision-making body on nuclear energy policies and activities; the Deputy Prime Minister is AEC chairman; members include the ministers of MOST and MER and the president of the Korea Electric Power Co. (KEPCO); other members are appointed by the President of Korea upon recommendation by the Deputy Prime Minister; it provides policy coordination, financial control, and regulatory and safety enforcement over a wide range of nuclear-related activities; the AEC is described as an 'advisory organization for determining and executing nuclear policy"; however, its close connection to the Prime Minister gives it power which is considerably more than advisory (Han and Park 1989)

E. KAERI (Korea Atomic Energy Research Institute): This institute is responsible for development of reactor engineering technology and nuclear fuel cycle technology (from uranium ore processing to radioactive waste treatment and disposal); it conducts R\&D on these areas including environmental research, and assists MOST in developing national nuclear policy; its major research areas are nuclear R\&D, design of fuels and nuclear steam supply systems (NSSS) for Korean reactors, fabrication of CANDU fuel, and nuclear waste management; its name was changed from Korea Advanced Energy Research Institute in December 1989 (KAEFI 1990) 
F. KIER (Korea Institute of Energy and Resources): KIER performs geological investigations within Korea and offshore, technical research for exploration, mining and processing of mineral resources, and research into atternate energy sources; KIER has been engaged in uranium ore investigations and in site evaluations for nuclear power plant and waste disposal facilities

G. KINS (Korea Institute of Nuclear Safety): KINS was established under MOST on February 15, 1990 (KAIF 1990); it was formerly the Nuclear Safety Center of KAERI; it conducts safety reviews and evaluations for licensing activities; it carries out safety inspection of nuclear facilities, technical assessments of environmental safety of radiation-associated facilities, and technical standards development; KINS performs licensing examinations; the KINS Radiation and Environment Division provides safety reviews, technical standards development, inspection, and environmental surveys; KiNS is organized similar to the U.S. Nuclear Regulatory Commission, and has generally similar responsibilities (except that facility licensing is through AEB with KINS evaluation and recommendation)

H. KAIST (Korea Advanced Institute of Science and Technology): KAIST is a broad-based post-graduate educational and research institute founded in 1965 as the Korea Institute of Science and Technology (KIST) (Chiton 1968); it has a strong nuclear engineering department, founded in 1980; the institute plays a major role in research and training associated with the Korean riuclear complex (KAIF 1990)

1. KAIF (Korea Atomic Industrial Forum): KAIF is a blanket organization of organizations active in the nuclear industry; it lists 78 organizations and 104 individuals as members (KAIF 1990)

\subsection{PRINCIPAL RESEARCH, DEVELOPMENT AND DEMONSTRATION FACILITIES/PROGRAMS}

The majority of Korean nuclear-related research and development activities and facilities are centered at KAERI or KINS (KAIF 1990)

\section{A. KAERI R\&D Programs:}

KAERI R\&D programs cover the entire nuclear fuel cycle, stressing technical support for operations, process and equipment development, and design of facilities and fuel

R\&D facilities at KAERI include:

1) The Korea Multipurpose Research Reactor (KMRR), now under construction, which is scheduled to attain criticality in late 1992 (KAIF 1990)

2) Two smail TRIGA research reactors, a 250-kW Mark II and a 2-MW Mark III (Han 1988; KAIF 1990)

3) The Radioactive Waste Treatment Facility (RWTF) at the KAERI Radioactive waste Management Center, Daeduk (Han 1987)

4) A pilot plant for uranium milling and $\mathrm{U}_{3} \mathrm{O}_{8}$ beneficiation and recovery (Han 1988; Leigh and Mitchell 1990)

5) A post-irradiation examination (PIE) facility which has been in service at KAERI since 1984; this facility contains water pools for cask loading/unloading, fuel 
storage, assembly inspection and disassembly, respectively; it has six hot cells, including four concrete-shielded cells for fuel rod examination, dissection, and sample preparation, and two lead-shielded metallurgical cells for sample examination and gamma scanning

6) Chemical engineering and ceramics facilities used in development of uranium reconversion, fuel pelieting, and sintering processes (KAERI 1990)

A former pilot plant for $\mathrm{U}_{3} \mathrm{O}_{8}-\mathrm{UO}_{2}$ direct conversion and Candu fuel fabrication was upgraded to commercial scale to supply fuel for Korean Candu power plants (KAERI 1990)

B. KINS R\&D programs are concerned primarily with nuclear safety, licensing and regulation, standards development, site assessment, and environmental analysis (KINS 1990)

4.8 KEY PERSONNEL (Leigh and Mitchell 1990; KAIF 1990)

Soon Cho, Deputy Prime Minister, Atomic Energy Commission (AEC)

Hee-II Lee, Minister, Ministry of Energy and Resources (MER)

Se-Jong Kim, Director-General, Nuclear Power, Electric Power Bureau (MER-EPB) (Leigh and Mitchell 1990)

Sook Huh, General Manager, Korea Electric Power Co. (KEPCO) (Huh 1990)

Jae-Hee Kim, Manager, Nuclear Engineering Department, Korea Electric Power Operating Service Co. (KEPOS) (Trivelpiece 1990)

Chun-Hak Ahn, President, Korea Heavy Industries and Construction Co. (KHIC)

Pil-Soon Han, President, Korea Nuclear Fuel Co. (KNFC)

Ki-Jo Shin, President, Korea Power Engineering Co. (KOPEC)

Chin Hyun Kim, Minister, Ministry of Science and Technology (MOST) (KAIF 1990)

Poong-Eli Juhn, Director-General, Atomic Energy Bureau (MOST-AEB) (Juhn 1990)

Uk-Jong Yu, Director, R\&D Division, Atomic Energy Bureau (MOST-AEB)

Sang-Hoon Choi, Director, Nuclear Policy Division, Atomic Energy Bureau (MOST-AEB)

Tae-Sik Min, Director, Nuclear Cooperation Division, Nuclear Safety and Cooperation Office (MOST-NSCO)

Haz-Ke Chong, President, Korea Advanced Institute of Science and Technology (KAIST)

Chang Saeng Rim, President, Korea Atomic Energy Research Institute (KAERI)

Kwang-Jae Lee, Sr. Vice President, Nuclear, Korea Atomic Energy Research Institute (KAERI) 
Dr. In-Suk Suh, Vice President, Radwaste Management Projects, Korea Atomic Energy Research Institute (KAERI)

Hun-Hwee Park, Director, Radioactive Waste Management, Korea Atomic Energy Research Institute (KAERI)

Dr. Kyong-Won Han, Head, Radwaste Disposal Department, Korea Atomic Energy Research Institute (KAERI)

Dr. Joon-Hyung Kim, Head, Radwaste Treatment Technology Department, Korea Atomic Energy Research Institute (KAERI)

Hyun-Soo Park, Director, Spent Fuel Management, Korea Atomic Energy Research Institute (KAERI)

Dae-Jong Kim, President, Korea Institute of Energy Resources (KIER)

Sang-Hoon Lee, President, Korea Institute of Nuclear Safety (KINS)

\subsection{NUCLEAR FUEL PRODUCTION}

Korea, lacking commercial uranium resources, has attained production capability in all phases of nuclear fuel production except uranium enrichment, starting with the purchase of refined yellowcake or of enriched $\mathrm{UF}_{6}$

\subsection{URANIUM RESOURCES}

A. Korea has no economically extractable natural uranium reserves; low-grade ore with a uranium content of 24,000 MTU (uranium content is $0.035 \%$ ) has been found, but this is of no imterest to the nuclear industry (NUKEM 12/87); Korea also has about one million tons of monazite ore reserves, from which $45,000 \mathrm{MT}$ of $\mathrm{ThO}_{2}$ could be extracted (KAIST 1982)

B. Korea participates in exploration projects for foreign uranium in Gabon, in Canada and in the U.S; it and buys uranium from Canada, Australia, France and the U.S. (NUKEM $12 / 87)$

\subsection{URANIUM PRODUCTION}

Korea has no domestic uranium mining industry or significant reserves, and has produced only pilot plant quantities of native $\mathrm{U}_{3} \mathrm{O}_{8}$ (NUKEM 12/87); a pilot plant capable of milling three metric tons of ore per day is situated at the KAERI Daeduk site (Leigh and Mitchell 1990; Trivelpiece 1989)

The annual uranium demand for reactor fuel, $1100 \mathrm{MTU}$ in 1988 , is projected to increase to 1300 MTU in 1997 (NUKEM 12/87)

\subsection{URANIUM CONVERSION}

A. Korea buys conversion services from Cariada and the U.S. 
B. A KAERI plant with a capacity of $100 \mathrm{MTU} / \mathrm{yr}$ converting yellowcake to uranium dioxide for CANDU fuel is located in Taejon (150 km south of Seoul); it started up in 1987 (KAERI 1990; NEI 10/89)

C. Reconversion of uranium hexafluoride to uranium dioxide at the KNFC Taejon fuel fabrication facility began in 1990 with an initial capacity of $200 \mathrm{MTU} / \mathrm{yr}$ (KAlF 1990; FCF 1990)

5.4 URANIUM ENRICHMENT: Korea buys enrichment services from France and the U.S. (NUKEM 12/87); the Korean government has approved a KEPCO plan to import $40 \mathrm{MT}$ per year of $3.5 \%$ enriched uranium from the Soviet Union over a ten-year period starting in 1990; this material will be stockpiled for power plants constructed after 1995 (NF 3/19/90)

\subsection{FUEL FABRICATION}

A. A PWR fuel fabrication plant with initial capacity of $200 \mathrm{MTU} / \mathrm{yr}$ in Taejon, owned by KNFC and designed by KWU (FRG), was completed in 1988 (NEI 2/87; NUKEM 12/87); the plant delivered its first fuel (to Ko-Ri 2) in July 1989 and added a $\mathrm{UF}_{6}-\mathrm{UO}_{2}$ conversion facility in early 1990 (KA.IF 1990; FCR 1990; KNFC 1988)

1) The plant initially started with imported uranium dioxide powder and imported fuel assembly parts

a. Operation began in early 1989

b. The facility will have capacity to fabricate fuels for all Korea's nuclear needs

2) The plart is capable of converting uranium hexafluoride to uranium dioxide (200 MTU/yr) (see 5.3 above)

3) The plant (fabrication and reconversion facilities) is expandable to $400 \mathrm{MTU} / \mathrm{yr}$

B. A 100-MT/yr CANDU fuel fabrication plant is located at KAERI-Taejon; this plant was upgraded from a pilot-scale facility (KAERI 1988)

\subsection{FUEL RECYCLE}

6.1 FUEL REPROCESSING: No firm decision has been made concerning reprocessing and recycling of fuel materials (NUKEM 12/87); studies in support of a reprocessing decision are underway (Han and Koster 1989)

Korea is developing an interest in co-processing of spent fuel, resulting in a mixed U-Pu product; this product would be recycled in Korea's CANDU reactors (NF 1989; Head 1989)

\subsection{SPENT FUEL STORAGE AND TRANSPORT}

7.1 SPENT FUEL ARISINGS (Park 1986; NUKEM 12/87; Suh 04/89)

1986-450 MTU cumulative .

1988--910 MTU cumulative

2000-3,800 MTU cumulative 
2010-7,000 MTU cumulative 2025-19,000 MTU cumulative

7.2 SPENT FUEL STRATEGY: The Korean strategy is to store spent fuel at reactors by reracking until a central AFR storage facility is available, and to store at the AFR facility until a decision is made on final disposition of spent fuel (NUKEM 12/87; Suh 1989; Whang et al. 1989); a wet fuel storage facility will be constructed by December 1997 (Suh 1989); transportation of the fuel will be by specially designed "roll on-roll off' ships (all Korean reactors have access to sea transport) (Hahn 1989)

\subsection{WET STORAGE (KAERI 1984; NUKEM 12/87)}

A. At-reactor onsite storage: power stations have wet storage capacity in their spent fuel pools to last into the to early 1990s, using reracking with compact racks; the multireactor PWR sites are expected to reach their storage limits from 1995 to 2000; the Wolsung CANDU reactor will need additional storage capacity by 1991 (Suh 1989)

B. With at-reactor rod consolidation under consideration, and transshipment of some spent fuels between reactor pools, storage capacity could be increased to handle storage load to around the year 2000 (Newman 1985)

C. A central wet storage facility for spent fuel, with a planned capacity of $3,000 \mathrm{MTU}$, will be constructed at one of three potential sites on or near the coast by December 1997 (Suh 1989)

7.4 DAY STORAGE: No decision has been made for a dry AFA storage facility: however, KAERI is planning the construction of a central AFR wet storage facility by 1997, and is studying the need for additional dry storage (Suh 1989); KEPCO has contracted with Atomic Energy of Canada, Ld. (AECL) for equipment and technical services for an at-reactor dry storage facility for CANDU (PHWR) spent fuel at the Wolsung-2 plant, utilizing concrete canisters (casks) (NWN 1990)

7.5 TRANSPORT: KAERI is designing a metallic-lead, shielded, stainless-steel cask for transport of 1 PWR assembly per load to a post-irradiation examination facility (Newman 1985); larger-scale transport of spent fuel and nuclear wastes planned for the future will utilize primarily ocean transport for spent fuel, and combinations of truck and ship transport for ILW-LLW, using 'roll on-roll oft' ship designs (Suh 1989)

\subsection{R\&D (NUKEM 12/87)}

KAER|'S R\&D program for spent fuel management consists of:

A. Development of a standard canister design for spent fuel storage; conceptual studies are currently underway (Whang et al. 1989)

B. Development of remote handling and rod consolidation technologies

C. Studies on long-term integrity of spent fuel

D. Safety analyses of AFRs

E. Construction of a wet AFR facility for storage of PWR and CANDU fuels); continued study of a dry AFR facility (Suh 1989) 
F. Performance of alternative scenario studies, with supporting R\&D, to compare scenarios with and without reprocessing in support of an eventual reprocessing decision (Whang et al. 1989)

\subsection{WASTE CONDITIONING, STORAGE AND TRANSPORT (NUKEM 12/87)}

\subsection{WASTE DEFINITIONS}

Nuclear wastes are classified as high-level (HLW), intermediate-level (ILW), and low-level (LLW); four categories of wastes are used in Korean radioactive waste management programs (Suh 1989; Han 1987):
A. Spent nuclear fuel ( $\mathrm{HLW})$
B. Wastes from nuclear power plant operations (LLW-ILW)
C. Wastes from nuclear research and fuel cycie facilities (LLW-ILW)
D. Wastes generated by users of radioisotopes (ILW-LLW); in 1988, there were 594 licensed users of radioisotopes in Korea (Han and Park 1989)

A fifth category, that of wastes from reprocessing of spent fuel $H L W$, is under study in Korea but will not be of interest unless a decision is made to reprocess

\subsection{WASTE ARISINGS}

1986--465 (55 gal) drums cumulative by radioisotope users

1988--20,503 (55 gal) drums cumulative LLW/LW from power plants and radioisotope operations

2000-198,000 drums cumulative

2010-445,000 drums cumulative

2025--1,038,500 drums cumulative (Hahn 1989)

\subsection{LLW/ILW WASTE CONDITIONING}

A. Light water reactor (LWR) wastes are mainly stabilized by bitumenization and cementation (including polymer-reinforced cements) in carbon steel, 200-liter drums (NUKEM 12/87)

1) A pilot-scale liquid waste treatment facility for bitumenization process performance testing started up in 1987

2) A test facility for incineration of combustible LLW-ILW wastes is in operation at KAERI-Taejon (Han and Park 1989)

3) Gaseous wastes are collected into decay tanks, held 45 days, and released to the atmosphere

4) Low-level solid wastes are packaged and stored at each plant awaiting disposal

5) Very low-level liquid wastes are discharged into the ocean 
B. For PHWR wastes, investigations of bitumenization, polymerization and cementation are underway

\subsection{LLW/ILW STORAGE}

A. LWR wastes are stored at the reactor site in concrete buildings with 10-year current capacity

B. PHWR wastes are stored at the reactor site

C. Wastes from research facilities and radioisotope users are treated and stored in the KAERI Radioactive Waste Treatment Facility (RWTF) (Han 1987)

\subsection{DISPOSAL OF NON-HIGH-LEVEL WASTES}

\subsection{WASTE DISPOSAL STRATEGY (NUKEM 12/87)}

A. Wastes are to be disposed of into the terrestrial environment; disposal into the ocean may be considered later

B. Disposal will be at a central site and away from existing power plant sites

\subsection{WASTE DISPOSAL CRITERIA}

Twenty-five general criteria have been developed for waste acceptance; these criteria cover attribules desired in a radioactive waste package, including:

- chemical, biological, mechanical, thermal and radiation stability

- compatibility with the disposal medium and its environment

- low surface area combined with low leaching rates

- restriction to solid form, with low dispersivity

- minimization of the content of non-degradable, toxic materials

- prohibition of combustible materials, except when packaged in an approved manner

- packaging must provide durability combined with easy handling and transporting (Park 1986; Han and Koster 1989);

\subsection{LLW/ILW DISPOSAL}

A. Surveys of country land areas have been carried out for siting a potential disposal facility for $\amalg W / L W$ (NUKEM 12/87)

B. Site pre-characterization for three candidate sites was underway during 1990; the final site selection was to be made in 1990 (Suh 1989); public opposition to sites is increasing (Han 1989; Han and Park 1989); this opposition may cause slippage of the selection date 
C. The safety of shallow-land burial, engineering-trench burial, and disposal in a mined cavity in granite were evaluated based on comparative performance analyses for the different concepts (Park 1986); the concept analyses were completed in 1989 and an underground "engineered cave" concept (an array of horizontal tunnels excavated into a granite hillside) was selected (Han and Park 1989); engineered barriers will be used to minimize waste migration (Suh 1989; Han 1989)

D. Site selection is being based on the following major criteria (Han and Park 1989)

- Site location is to be in an area providing suitable geological and hydrological conditions to ensure adequate isolation of the wastes while they are radiologically hazardous

- Sites to be avoided are industrial and military sites, historic sites, and sites planned for other, non-compatible land development

- Sites must have ready access to transportation (roads and shipping access) and reasonable distances to waste generation and storage sites

- Site topography should provide reasonable construction and access costs

E. Three potential sites in mountainous areas near the sea coast are being evaluated; the coastal sites have the advantages of lower population density and greater dispersion of any migrating radionuclides by dilution in sea water (Suh 1989; Han and Park 1989); these candidate sites were selected from an initial list of 25 potential sites (Hahn 1989)

F. Preliminary studies have begun to establish a site on an uninhabited island off the Korean coast, if required to circumvent public opposition (NUKEM 5/90)

G. The LLW-ILW disposal facility will have an initial capacity for 500,000 drums of wastes; a first phase will provide 250,000 drums capacity; final capacity will be at least one-million drums (Lee 1989)

H. The construction of the disposal facility is planned to be complete in 1995; startup is scheduled for January 1996 (Suh 1989)

\subsection{DISPOSAL OF HIGH-LEVEL WASTES}

10.1 REPOSITORY DEPLOYMENT STRATEGY: Development of a site for geologic disposal of HLW in Korea is pending a decision on whether spent fuel will be reprocessed or disposed of directly as fuel assemblies; scenario studies, conceptual designs, and technical evaluations of disposal atternatives are underway (Whang ot al. 1989)

10.2 REFERENCE HLW DISPOSAL CONCEPT: The probable choice for HLW disposal will be deep geologic disposal in a granite rock cavern; scenario studies assuming alternative disposal of intact spent fuel or reprocessing wastes are underway in support of future decisions on reprocessing by the Korean government (Whang et al. 1989)

10.3 PROGRAM/FACILITIES COSTS: Preliminary costs of HLW/spent fuel disposal are being developed in the scenario studies described above; estimates of the disposal costs themselves are still being developed; preliminary estimates for pre-disposal costs (at-reactor storage, interim storage at a central facility, and encapsulation in disposal canisters) for an assumed fuel 
inventory of 23,000 PWR assemblies and 150,000 CANDU bundles approximate \$2.6 billion U.S. for intact assemblies, or $\$ 3$ billion if fuel is consolidated (Whang et al. 1989)

11.0 MANAGEMENT OF URANIUM MINE AND MILL WASTES: No information

12.0 DECOMMISSIONING AND ENVIRONMENTAL RESTORATION: No information

\subsection{INTERNATIONAL ACTIVITIES}

13.1 MEMBERSHIPS: Korea joined the IAEA in 1957, and ratified the non-proliferation treaty in 1975 (KAIF 1990)

\subsection{COOFERATION WITH USA}

Korea-U.S. cooperation in energy-related and nuclear-related activities dates back to the 1960 s and beyond (Chilton 1968); Korea and the U.S. signed a bilateral agreement on peaceful uses of nuclear energy in 1956; currently this agreement is implemented under the Korea-U.S. Standing Committee on Nuclear and Other Energy Technologies (JSCNOET); it includes a broad range of fields including assistance and joint studies relating to energy technology development, agreements, and implementation methods for export controls of nuclear and other materials and technologies, assistance on specific projects, and training assignments of Korean individuals in the U.S.; the JSCNOET is under the aegis of the Nuclear Technology and Safeguards Office, U.S. Department of State, and the Nuclear Safety and Cooperation Office, Korean Ministry of Science and Technology (Wilkinson 1987)

Korea Heavy Industries and Construction Co. (KHIC) is currently engaged in a technologytransfer venture with Combustion Engineering, which is intended to provide $\mathrm{KHIC}$ with capability for the design, engineering and fabrication of NSSS components and systems

\subsection{COOPERATION WITH OTHER COUNTRIES}

A. Korea is cooperating with the Federal Republic of Germany (FRG) on fuel fabrication and fuel cycle studies (Han and KOster 1989)

B. Korea participates in uranium exploration projects in Gabon, Canada, and the U.S. (NUKEM 12/87)

C. Korea signed a nuclear cooperation agreement with Japan on nuclear power plant safety improvement on May 25, 1990 (NW 06/90)

D. Korea has signed bilateral agreements concerning nuclear programs with Australia, Belgium, Canada, France, and Spain in addition to those listed above (KAIF 1990); the planned Korean central wet storage facility for spent fuel was designed in a joint study with Sweden (Suh 1989)

\subsection{REFERENCES}

$-1968$.

Chilton, C. H., J. B.. Burnham, J. F. Fletcher, J. W. Mullen, D. A. Gardner, S. R. Simon, H. W. Nelson, and W. T. Reid. 1968. "Survey of Energy Supply and Demand in the Republic of Korea, 1966-1981." Research Report, Battelle Memorial Institute, Columbus, Ohio. 
KOREA (SOUTH)

$-1982-$

KAIST and KEPCO. 1982. "Overview of Korean Spent Fuel Management Program." Korea Advanced Institute of Science and Technology and Korea Electric Power Company, June, 1982.

-1984-

Korea Advanced Energy Research Institute (KAERI). 1984. Republic of Korea/United States Joint Study on Spent Fuel Management. KAER//RR-411-1/83, Korea Advanced Energy Research Institute, Seoul, Korea.

Ro, S.-G., K-S. Lee, and E.-K. Kim. 1984. 'Post Irradiation Examination Facility of KAERI." KAERI/GP60/84, Korea Advanced Energy Research Institute, Daejon, Korea.

$-1985$

Newman, D. F. 1985. 'Foreign Trip Report from April 7-23, 1985.' Pacific Northwest Laboratory, Richland, Washington.

$-1986-$

Park, H. H., K W. Han, I. S. Suh, and W. L Lenneman. 1986. The Status of Radioactive Waste Management and Its Policy in the Republic of Korea' Waste Management '86, Vol, 1, pp. 475-480. March 2-6, 1986, Tucson, Arizona.

$-1987-$

Han, K W., J. H. Kim, H. H. Park, and I. S. Suh. 1987. "Characteristics of Waste from a Country with Nuclear Power." Korea Advanced Energy Research Institute, Daeduk, Korea.

Nuclear Europe (NE). 3-4/87. "Korea Plans to Build Radwaste Repository by 1995," p. 57.

Nuclear Engineering Imtemational (NEI). 2/87. "Korea Buys Fuel Technology From FR Germany," p. 16.

Nuclear Engineering International (NEl). 6/87. Korea, A Win for Technology Transter," p. 37.

Nuclear Engineering Imternational (NEI). 12/87. 'The World's Nuclear Fuel Cycle Facilities,' pp. 47-48.

NUKEM Market Report on the Nuclear Fuel Cycle (NUKEM). 12/87. NUKEM Special Report: Republic of Korea. NUKEM Gmbh, Alzenau, Federal Republic of Germany.

Nuclear News (NN). 12/87. "South Korea: Planning for Self-Reliance,' pp. 59-63.

Wilkinson, T., and U.J. Yu. 1987. 'Summary Record of the Preparatory Meeting of the 11th KoreaU.S. Joint Standing Committee on Nuclear and Other Energy Technologies." May 6-7, 1987, U.S. Department of State/Korean Ministry of Science and Technology, Seoul, Korea.

-1988-

Leigh, I. W. 1988. Imternational Nuclear Fuel Cycle Fact Book. PNL-3594, Rev. 8, Pacific Northwest Laboratory, Richland, Washington. 
NUKEM Market Report on the Nuclear Fuel Cycle (NUKEM). 4/88. NUKEM GmbH, Alzenau, Federal Fepublic of Germany, p. 16.

KNFC. 1988. KNFC. A brochure published by the Korea Nuclear Fuel Company, Daejeon, Korea.

$-1989-$

Hahn, P.S. 1989. "Current Status of Low- and Intermediate-Level Radwaste Management in Korea." In Proceedings of the International Seminar on Radwaste and Spent Fuel Management. April 24-27, 1989, Korea Advanced Energy Research institute, Daeduk, Korea.

Han, K. W. 1989. "Public Acceptance Program in Korea.' In Proceedings of the International Seminar on Radwaste and Spent Fuel Management. Korea Advanced Energy Research Institute (KAERI), April 24-27, 1989, Daeduk, Korea.

Han, K W., and R. Koster. 1989. "Radwaste Disposal Planning in a Developing Nation with Nuclear Power: Korea.' In Proceedings of the 1989 Joint International Waste Management Conference, Vol. 1, pp. 647-648. October 22-28, 1989, Kyoto, Japan.

Han, K. W., and H. H. Park. 1989. 'Status of Low- and Intermediate-Level Radwaste Management in Korea." In Proceedings of the 1989 Joint International Waste Management Conference, Vol. 1, pp. 121-125. October 22-28, 1989, Kyoto, Japan.

Head, C. R. 1989, "Report of a Trip to the April 1989 KAERI Radwaste and Spent Fuel Management Seminar and to the U.S./Taiwan JSCNOET Meeting.' Memorandum, U.S. Department of Energy, Office of Civilian Radioactive Waste Management.

Juhn, P.-E. 1989. Highlights of Nuclear_Programs in Korea, Korea Advanced Energy Research Institute, Daeduk, Korea.

Kim, C. L., K. S. Choi, C. H. Cho, J. Kim, and.I. S. Suh. 1989. "Source-Term Models Based on Mass Transfer Analysis and Measurement-Based Source-Term Models for a Geologic Radioactive Waste Repository.' In Proceedings of the 1989 Joint international Waste Management Conference, Vol. 1, pp. 383-388. October 22-28, 1989, Kyoto, Japan.

Lee, S. Y. 1989. "Report of Foreign Travel of S. Y. Lee, Research Associate, Environmental Sciences Division." Oak Ridge National Laboratory, Oak Ridge, Tennessee.

Nuclear Engineering Intemational (NEI). 4/89. "Datafile: Korea," pp. 67-72.

Nuclear Fuel (NF). 7/10/89. 'KOREA: KNFC Begins Operating Fuel Plant,' p. 14.

Nuclear Fuel (NF). 10/2/89. "North Korea Begins Negotiations with IAEA; South Korea Interested in Coprocessing,' pp. 11-12.

NUKEM Market Report on the Nuclear Fuel Cycle (NUKEM). 5/89. NUKEM Special Report: The Nuclear Power Plant Capacity of the Westem World. NUKEM Gmbh, Alzenau, Federal Republic of Germany.

NUKEM Market Report on the Nuclear Fuel Cycle (NUKEM). 8/89. "Reprocessing and Waste Management Review, First Seven Months of 1989." NUKEM Gmbh, Alzenau, Federal Republic of Germany, p. 8. 
Shupe, M. W. 1989. "Foreign Travel Report for the International Seminar on Radwaste and Spent Fuel Management at the Korea Advanced Energy Research Institute, April 21-29, 1989." Idaho Operations Office, U.S. Department of Energy, Idaho Falls, Idaho.

Suh, I. S. 1989. 'General Overview of Radioactive Waste and Spent Fuel Management in Korea." International Seminar on Radwaste and Spent Fuel Management. April 24-27, 1989, Korea Advanced Energy Research Institute, Daeduk, Korea.

Trivelpiece, A. W. 1989. Peport on Foreign Travel of Earl W. McDaniel, Manager, Waste Management Program Development, Chemical Technology Division." Oak Ridge National Laboratory, Oak Ridge, Tennessee.

Whang, J. H., H. S. Park, and R. Papp. 1989. "Scenario Study on the Direct Disposal of Spent Nuclear Fuels.' In Proceedings of the 1989 Joint International Conference Waste Management Conference, Vol. 2, pp. 513-517. October 22-28, 1989, Kyoto, Japan.

$-1990-$

Fuel Cycle Review 1990 (FCR). 1990. Special publication by Nuclear Engineering International. Surrey, England.

Huh, S. 1990. 'Technology Self-Reliance for the Construction of Nuclear Power Plant." ENC '90: ENS/ANS-Foratom Conference Transactions, Vol. 2, pp. 676-682. September 23-28, 1990, Lyon, France.

Juhn, P. E. 1990. 'Nuclear Power Technology Development in Korea.' ENC '90: ENS/ANS-Foratom Conference Transactions, Vol. 2, pp. 638-647. September 23-28, 1990, Lyon, France.

KAERI. 1990. KAERI. Brochure, Korea Atomic Energy Research Institute, Daeduk, Korea.

KAIF. 1990. Nuclear Industry in the Republic of Korea. Brochure, Korea Atomic Industrial Forum, Seoul, Korea.

KINS. 1990. KINS. Brocture, Korea Institute of Nuclear Safety, Korea.

Kwon, J. K. 1990. "Progress in Domestic Participation in Nuclear Component Technology." ENC '90: ENS/ANS-Foratom Conference Transactions, Vol. 2, pp. 683-691. September 23-28, 1990, Lyon, France.

Leigh, I. W., and S. J. Mitchell. 1990. International Fuel Cycle Fact Book. PNL-3594, Rev.10, Pacitic Northwest Laboratory, Rictland, Washington.

Nuclear Fuel (NF). 3/19/90. 'KEPCO to Buy About 40 Metric Tons/yr of Enriched Uranium From the Soviet Union,' p. 5.

Nuclear News (NN). 8/90. World List of Nuclear power Plants as of June 30, 1990,' pp. 63-82.

Nuclear Waste News (NWN). 3/22/90. 'Korean Electric Power Company Contracts for Canadian Dry Storage Technology,' p. 113.

Nuclear Waste News (NWN). 11/15/90. "South Koreans Protest Construction of Nuclear Waste Storage Facility," p. 445. 
Nucleonics Week (NW). 6/7/90. 'South Korea and Japan Sign Nuclear Cooperation Agreeniemt," p. 11.

NUKEM Market Report on the Nuclear Fuel Cycle (NUKEM). 2/90. "Reprocessing and Waste Management Review, 1989." NUKEM Gmbh, Alzenau, Federal Republic of Germany, p. 19.

NUKEM Market Report on the Nuclear Fuel Cycle (NUKEM). 7/90. Special Report: World Nuclear Power Plant Capacity. NUKEM Gmbh, Alzenau, Federal Republic of Germany, p. 44.

Park, S. K 1990. "Overview of Operational Experience of Nuclear Power Plants in Korea." ENC '90: ENS/ANS-Foratom Conference Transactions, Vol. 2, pp. 646-658. September 23-28, 1990, Lyon, France. 


\section{MEXICO}




\section{MEXICO}

\section{CONTENTS}

$1.0 \quad$ NUCLEAR POWER $\ldots \ldots \ldots \ldots \ldots \ldots \ldots \ldots \ldots \ldots \ldots \ldots \ldots \ldots \ldots \ldots$

2.0 NUCLEAR FUEL CYCLE AND RADIOACTIVE WASTE MANAGEMENT

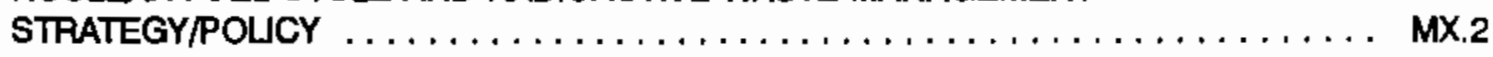

3.0 HIGHLGHTS AND MAJOR MILESTONES $\ldots \ldots \ldots \ldots \ldots \ldots \ldots \ldots \ldots \ldots \ldots .2$

4.0 INSTITUTONAL CONSIDERATIONS/ORGANIZATIONS $\ldots \ldots \ldots \ldots \ldots \ldots \ldots$

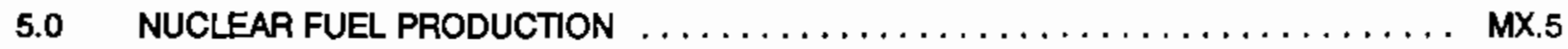

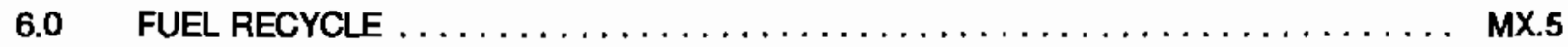

7.0 SPENT FUEL STORAGE AND TRANSPORT $\ldots \ldots \ldots \ldots \ldots \ldots \ldots \ldots \ldots \ldots$

8.0 WASTE CONDTIONING, STORAGE AND TRANSPORT $\ldots \ldots \ldots \ldots \ldots \ldots \ldots$

9.0 DISPOSAL OF NONHIGH-LEVEL WASTES $\ldots \ldots \ldots \ldots \ldots \ldots \ldots \ldots \ldots$

10.0 DISPOSAL OF HIGH-LEVEL WAStES $\ldots \ldots \ldots \ldots \ldots \ldots \ldots \ldots \ldots \ldots$

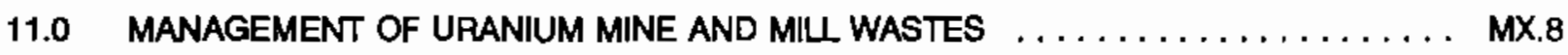

12.0 DECOMMISSIONING AND ENVIRONMENTAL RESTORATION $\ldots \ldots \ldots \ldots \ldots \ldots$ MX.8

13.0 INTERNATIONAL ACTIVITIES $\ldots \ldots \ldots \ldots \ldots \ldots \ldots \ldots \ldots \ldots \ldots$

14.0 REFERENCES $\ldots \ldots \ldots \ldots \ldots \ldots \ldots \ldots \ldots \ldots \ldots \ldots \ldots \ldots \ldots \ldots \ldots \ldots \ldots$ 


\subsection{NUCLEAR POWER}

1.1 REACTOR MIX: One 654-GWe BWR (GE), startup 1989 (NN 8/89); second to start up in 1993 (N!IKEM 5/89a)

\subsection{ELECTRIC POWER PRODUCTION}

1987-90.96 TWh (O\% nuclear) (The World Fact Book 1988)

\subsection{NUCLEAR POWER CAPACITY PROJECTIONS (NUKEM 5/89b)}

1989--0.7 GWe

1995-1.3 GWe

2000-1.3 GWe

1.4 NUCLEAR PLANT AVAILAgILITY: No information

\subsection{NUCLEAR ENERGY POLICY (NUKEM 8/88)}

A. Mexico's plans for nuclear plant construction were originally drawn in the early 1970 s when Mexico was not yet aware of its giant resources of petroleum; as a result, the 1980 national energy program included plans for an installed nuclear capacity of $20 \mathrm{GWe}$ by the year 2000

B. After Mexico failed to realize the anticipated annual electricity growth rate, the 1984 national energy program scaled nuclear plans back to completion of the Laguna Verde-1 and -2 units and for feasibility studies of new units

C. The Chernobyl accident in the USSR and growing public concem on environmental issues make future nuclear growth in Mexico questionable

\subsection{NUCLEAR R\&D BUDGET: No information}

\subsection{ELECTRICITY PRODUCTION COSTS: No information}

\subsection{NUCLEAR FUEL CYCLE AND RADIOACTIVE WASTE MANAGEMENT}

STRATEGY/POLICY: Mexico's strategy is to pursue development of nuclear fuel cycle cautiously; the present course is to develop uranium mining, fuel fabrication and waste management capabilities sufficiently to support the Laguna Verde station and institutional/industrial uses of radioactive isotopes; further development will depend upon the need for and public acceptance of nuclear power (NUKEM 8/88)

\subsection{HIGHLIGHTS AND MAJOR MILESTONES}

1955 Creation of the National Nuclear Energy Commission (NNEC) (IAEA 1986)

$1965 \quad$ Nuclear center of Mexico opened (IAEA 1986)

1966 Decision made to build two 650-MWe reactors (IAEA 1986)

1972 NNEC replaced by the National Institute of Nuclear Energy (NINE) (IAEA 1986) 
1978 The 1978 statutory law on nuclear energy replaced nine with three entities: 1) the National Institute of Nuclear Research (ININ); 2) the National Nuclear Commission for Safeguards and Safety (CNSNS); and 3) Uranium of Mexico (URAMEX) (Uranium 1986)

1980

The national energy program was launched, calling for a total installed nuclear capacily of 20,000 MWe by the year 2000 (NUKEM 8/88)

1984 A new national energy plan was released, calling for completion of the Laguna Verde units 1 and 2 and for feasibility studies of new units (NUKEM 8/88)

1985

Uramex was dissolved and its functions were assumed by the Commission on Mining Development (CFM) and the Council of Mineral Resources (CRM) (Uranium 1988)

1989

The Laguna Verde-1 nuclear power reactor achieved criticality (NN 8/89)

1993

The Laguna Verde-2 nuclear power reactor is to begin operation (NUKEM 5/89b)

\subsection{INSTITUTIONAL CONSIDERATIONS/ORGANIZATIONS}

4.1 LEGAL REQUIREMENTS: There is a single Mexican nuclear energy law, adopted in January 1979, which govems all nuclear activities in Mexico; licensing of nuclear power stations is not linked to the availability of waste disposal means; there is no land use veto power exercised by local authorities or national referendum system, and the regulatory process has not included public hearings; for these reasons, regulatory power is highly centralized in the federal government (Paige 1985)

\subsection{RADIATION PROTECTION PRINCIPLES (NEA 12/86; Zorilla 1986)}

A. Exposure to ionizing radiation will be reduced to the lowest reasonable level; taking account of economic, technological, and social factors is the underlying basis for Mexico's regulations

B. The annual effective dose equivalent levels for workers (uniform exposure to the entire body) and members of the public are the same as those set in the IAEA radiation protection standards (5 rem and 0.5 rem, respectively)

4.3 LICENSING: The licensing system in Mexico is defined in the 1988 general radiological safety regulations published November 22, 1988; the competent licensing authority is the national nuclear safety and safeguards commission, under control of the ministry of energy, mines and industry (Bello 1981; NEA 6/89)

4.4 PUBLIC INVOLVEMENT: Through 1985, the Mexican nuclear regulatory process has not included public hearings and such hearings are not contemplated for the future (Paige 1985)

4.5 WASTE FUND: No information

4.6 OTHER KEY SUBUECTS: None 
4.7 KEY AGENCIES AND FUEL CYCLE CENTERS: Nuclear activities in Mexico are managed by six organizations which report to the Ministry of Energy, Mines and Industry (IAEA 1986; IAEA 6/10/88); nuclear activities are concentrated at three locations (IAEA 6/10/88)

A. The Federal Commission of Electricity (CFE) is responsible for design, construction and operation of nuclear power plants

8. The National Commission of Nuclear Safety and Sadeguards (CNSNS) is responsible for ficensing and regulation of nuclear activities

C. The National Institute of Nuclear Research (ININ) is responsible for R\&D in the nuclear and radiological fields

D. The Council of Mineral Resources (CRN) is responsible for uranium exploration

E. The Commission of Mining Development (CFM) is responsible for exploitation of uranium resources

F. The Commission of Nuclear Industry (CNIN) is entrusted with all the operational phases of the nuclear fuel cycle

G. The Nuclear Center of Mexico, operated by ININ, is located at Mexico City; besides nuclear R\&D (see Section 4.8), operations underway at the center include the conversion of $\mathrm{UF}_{6}$ to $\mathrm{UNH} / \mathrm{NO}_{2}$, the production of $\mathrm{MO}-99$, and a waste collection center for low-level wastes from sources other than the Laguna Verde power station; after packaging, the wastes are transported to the Maquixco site for disposal; conditioning equipment is available at the center, including a baler and a bitumenization unit

H. The Center for the Collection, Treatment and Storage of Low-Level Radioactive Waste (CRTADRBN) is located near the town of Maquixco, $42 \mathrm{~km}$ northeast of Mexico City; the site was developed in 1972 and is operated by ININ for the disposal of medical, biological, pharmaceutical and R\&D wastes; disposal is by burial in trenches

I. The Laguna Verde Nuclear Power Station Site is located $70 \mathrm{~km}$ north of Veracruz on Mexico's gulf coast; waste management facilities are provided at this site for packaging, bitumenization, and storage of wastes; the site also has an environmental laboratory

4.8 PRINCIPAL RESEARCH, DEVELOPMENT AND DEMONSTRATION FACILITIES/PROGRAMS: The Nuclear Center of Mexico at Mexico City is the focal point for nuclear R\&D in Mexico; the programs at the Center include operation of a Triga Mark III research reactor, a tandem particle accelerator, and a nuclear information center; there appear to be no major R\&D efforts underway on waste management (IAEA 6/10/90)

\subsection{KEY PERSONNEL (IAEA 6/10/88)}
A. Juan Eibenschutz, Deputy Director General, CFE
B. Carlos Velez, Director General, ININ
C. Maguel Medina Vailerd, Director General, CNSNS
D. Rafael Fernandez Garza, Head, Laguna Verde Project 
E. Cesar Bascia Gassia, Engineering Manager, Laguna Verde Project

F. Lu Alicia Fucuguachi, Head, Applied Research Unit, ININ

\subsection{NUCLEAR FUEL PRODUCTION}

5.1 STRATEGY: Mexico appears to be in a "holding pattern' on further development of nuclear power, including production of nuclear fuel, but is still planning to complete the Laguna Verde-2 nuclear station (NUKEM 8/88)

5.2 URANIUM RESOURCES: Proven uranium resources in Mexico are estimated at 10,600 MT following geological surveys covering $15 \%$ of the country (NEI 6/89)

5.3 URANIUM PRODUCTION: Mexico has no present plans for uranium production; the uranium production company, URAMCO, was dissolved in 1983 (Uranium 1988; NW 7/3/83)

5.4 URANIUM CONVERSION: ININ has operated a 2-MT/yr facility at the nuclear center at Salazar since 1987 for conversion of yellowcake to uranium dioxide (IAEA 1988)

5.5 Uranlum enrichment: No information

5.6 FUEL FABRICATION: ININ has operated a 2-MT/yr pilot plant at the nuclear center at Salazar since 1980, developing technology applicable to PWRs and BWRs (IAES 1988); Mexico contacted Argentina in 1987 about obtaining technology for fabrication of nuclear fuel, in an effort to cut costs and reduce reliance on U.S. technology (NW 6/25/87)

5.7 HEAVY WATER PRODUCTION: No information

5.8 PROGRAM/FACILITIES COSTS: No information

6.0 FUEL RECYCLE: Mexico's earlier plans for reprocessing spent fuel have been dropped (IAEA 6/10/88)

\subsection{SPENT FUEL STORAGE AND TRANSPORT}

\subsection{SPENT FUEL ARISINGS}

2015 - 1,050 MT (IAEA 5/20/88)

7.2 FUEL ASSEMBLY CHARACTERISTICS: Typical $8 \times 8$ BWR assemblies; $13.9 \mathrm{~cm} \times 13.9 \mathrm{~cm} \times$ $44.7 \mathrm{~cm}$ long; 62 rods per assembly; $\mathrm{UO}_{2}$ pellets; $2.8 \%$ enrichment (for reloads); zircaloy 2 cladding (Hill 1982; NEI 11/89)

7.3 SPENT FUEL STRATEGIES: Mexico plans to place spent fuel in interim storage through periodic expansions, using wet or dry storage, for indefinite period (Newman 1985; IAEA $6 / 10 / 88)$

7.4 WET STORAGE: Laguna Verde-1 has water pool capacity for storage of spent fuel from five years of reactor operation; evaluations of alternative means (wet and dry) of providing additional storage are underway (IAEA 6/10/88) 
High-density compact racks have been designed but have not been licensed for use in Mexico; these racks would increase pool storage capacity from 528 to 1100 assemblies (Newman 1985); in 1988, CFE planned to add another five-years of pool storage at the Laguna Verde station (IAEA 6/10/88)

7.5 DRY STORAGE: See previous item

7.6 TRANSPORT: No information

7.7 RESEARCH AND DEVELOPMENT: No information

7.8 PROGRAM/FACILITIES COSTS: No information

\subsection{WASTE CONDITIONING, STORAGE AND TRANSPORT}

8.1 WASTE DEFINITIONS: Mexico characterizes its low- and intermediate-level wastes in accordance with IAEA recommendations (Orozco 1986)

\subsection{WASTE ARISINGS}

$2015-16,500 \mathrm{~m}^{3}$ of ILW/LW (IAEA 5/20/88)

8.3 STRATEGY: Mexico plans to develop a second disposal site for low- and intermediate-level wastes at or near the Laguna Verde nuclear station (IAEA 6/10/88)

8.4 HLW IMMOBILZATION: No information

8.5 SPENT FUEL CONDITIONING: Mexico has not yet developed plans for conditioning spent fuel for disposal (IAEA 6/10/88)

8.6 LLW/ILW CONDITIONING: Limited conditioning of radioactive waste is performed at the Laguna Verde nuclear power station, at ININ's nuclear research center and the Maquixco disposal site:

A. The Laguna Verde station includes fitters, evaporators, and demineralizers for treating cortaminated liquid waste arisings; most of the concentrates from these operations are fixed in bitumen; those not compatible with bitumen are fixed in cement (IAEA 6/10/88)

B. At ININ's nuclear research center, some wastes are fixed in bitumen (IAEA 6/10/88)

C. At the Maquixco disposal site, radioactive wastes received from the ININ nuclear research center are sorted, treated (as required) and disposed of; liquid wastes are evaporated in open pans; the resulting sludge is mixed with clay and placed in 200-liter mild steel containers, covered with more clay, and sealed for disposal (IAEA 6/10/88)

\subsection{AIRBORNE WASTES: No information}

8.8 LLW/ILW STORAGE: Interim storage areas exist at the Laguna Verde nuclear power station, at the ININ nuclear research center, and at the Maquixco disposal site: 
A. At the Laguna Verde nuclear station, storage for 1 year's production of bitumenized wastes in drums has been provided in the waste treatment building; a waste storage building capable of accommodating 5-year's production of waste, and expansion for an additional 5 years is planned/under construction (IAEA 6/10/88)

B. At the ININ nuclear research center, radioactive wastes from sources other than the Laguna Verde nuclear station are collected, treated, and stored temporarily prior to transport to the Maquixco disposal site; no information is available on the storage system (IAEA 6/10/88)

C. At the Maquixco disposal site, there are two temporary storage facilities for storing wastes prior to disposal; no information is available on the storage facilities (IAEA 6/10/88)

8.9 HLW STORAGE: Mexico generates spent nuclear fuel but no high-level waste

8.10 TRANSPORT OF WASTES: No information available

8.11 MDED WASTE CONDITIONING, STORAGE AND TRANSPORT: No intormation available

8.12 RESEARCH AND DEVELOPMENT: No information available

8.13 PROGRAM/FACILITIES COSTS: No information available

\subsection{DISPOSAL OF NON-HIGH-LEVEL WASTES}

9.1 STRATEGY: Mexico's non-high-level radioactive wastes are and will continue to be disposed in near-surface facilities (IAEA 6/10/88)

\subsection{Waste dlsposal criteria}

A. In the 1960 s, various regions in the vicinity of Mexico City were studied with a view to finding suitable sites for the installation of a burial ground for radioactive wastes; each region was assessed from the viewpoints of communication, rainfall, proximity to population centers, prevailing wind and their velocity, liability to earthquakes, sub-soil structure, fertility, and in general all factors which might make it desirable or undesirable for habitation in the future

Other important factors studied were the possibility of acquiring sites, their size and proximity to common land which might be considered as affected, and certain legal aspects which might affect the land in the planning stage, such as rights of way, restrictions on use, and possible expressway connection; these studies led to the recom. mendation of four possible sites in the $150-\mathrm{km}$-long by $40-\mathrm{km}$-wide corridor northeast of Mexico City (Barete 1967)

B. The design of the Maquixco disposal site is based upon three general criteria (Zorilla 1986):

1) Safety: Allowable doses to occupationally exposed persons and to the general public are expressed as fractions of the natural radiation dose and the need for delay of dispersion or migration of the radioactive material to the biosphere, or controlled dispersion of such material 


\section{2) Storage capacity}

3) Economics: The design should be simple and use the site characteristics rationally; elimination of all equipment, instruments and works is not absolutely required

C. Criteria for new disposal sites, e.g., Laguna verde reactor site, are under development (IAEA 6/10/88)

9.3 ILW DISPOSAL: Generation of ILW is just beginning in Mexico with operation of the nuclear Verde nuclear power station; no information was found on disposal plans

9.4 LLW DISPOSAL: LLW is disposed in trenches at the Maquixco site; the trenches used, $180 \mathrm{~m}$ long by $1.5 \mathrm{~m}$ wide by $3 \mathrm{~m}$ deep, have a slight downward slope and a gravel base so that any rainwater which infiltrates will run off to a final collection basin (Zorilla 1986)

9.5 LLW/ILW DISPOSAL R\&D: No information

9.6 PROGRAM/FACILITIES COSTS: No information

10.0 DISPOSAL OF HIGH-LEVEL WASTES: Mexico generates spent fuel as high-level waste; only preliminary investigations for siting of a high-level waste repository have been conducted (IAEA 6/10/88)

11.0 MANAGEMENT OF URANIUM MINING AND MILLING WASTES: Uranium mining and milling in Mexico has been discontinued; two 200-MT/yr uranium ore processing plants have been shut down or are in standby status (NEI 11/89); no information was found on management of mining and milling wastes

12.0 DECOMMISSIONING AND ENVIRONMENTAL RESTORATION: No information

\subsection{INTERNATIONAL ACTIVITIES}

\subsection{MEMBERSHIPS: IAEA}

\subsection{COOPERATION WITH MULTINATIONAL AGENCIES}

A. Mexico is a signatory of the treaty on the non-proliferation of nuclear weapons (IAEA 1986)

B. Through 1985 , the IAEA had provided $\$ 1,400,000$ for completed technical assistance projects related to nuclear energy in Mexico; of these funds, the U.S. contribution was $19.4 \%$; as of 1986 , additional projects worth $\$ 2,200,000$ were underway (Rundo 1987)

\subsection{COOPERATION WITH USA}

A. United States and Mexican representatives met 9/21/87 to brief Mexican authorities on plans for a low-level waste disposal site in Texas (US DOE 1987) 
B. On December 4-5, 1984, a delegation from Mexico visited Pacific Northwest Laboratory at Richland, Washington, in response to the U.S. DOE's previous offer of cooperation and assistance under Section 223 of the Nuclear Waste Policy Act of 1982; there was no subsequent followup by either party atter this meeting (Newman 1985)

\subsection{COOPERATION WITH OTHER COUNTRIES}

A. ININ's Nuclear Irformation and Documentation Center (CIDN), through special bilateral agreements, has offered information services to Chile, Cuba, Ecuador, Guatemala, and Uruguay (IAEA 1986)

B. In 1987, the Mexican government and nuclear officials discreetly queried Argentina about obtaining fuel fabrication technology (NW 6/25/87)

\subsection{REFERENCES}

$-1967$.

Barete, M. V., and E. B. Suarez. 1967. "Evaluation of the Different Factors Concerning the Establishment of a Disposal Site for Radioactive Wastes in Mexico." In Proceedings of the IAEA/ENEA. Symposium on the Disposal of Radioactive Wastes into the Ground, pp. 367-382. May 29 to June 2, 1967, Vienna

$-1981-$

Bello, R. 1981. The Nuclear Option in Mexico: Established Goals and Regulatory Aspects." Transactions of the American Nuclear Society, Vol. 39, p. 708.

-1982 -

Hill, O. F., A. M. Platt, and J. V. Robinson. 1982. Nuclear Fact Book. PNL-4239, Pacific Northwest Laboratory, Richland, Washington, p. 7.1.

$-1983-$

Nucleonics Week (NW). 7/3/83. "Mexico Shuts Down Fuel Cycle Company."

$-1985-$

Newman, D. F. 1985. "Foreign Visitor Report: Delegation from Mexico." Letter to P. A. Craig, DOE/RL. Pacific Northwest Laboratory, Richland, Washington, January 2, 1985.

Paige, H. W., and N. J. Numark.' 1985. Assessment of National Systems for Obtaining Local Siting Acceptance of Nuclear Waste Management Facilities. International Energy Associates Limited, Washington, D.C., IEAL-R/86-16.

$-1986-$

International Atomic Energy Agency (IAEA). 1986. "Report from Mexico: INIS and lts Impact on Nuclear Power Development." IAEA Bulletin, Winter 1986, pp. 14-15. 
Nuclear Energy Agency (NEA). 1986. Nuclear Law. Bulletin 38, December 1986, OECD Nuclear Energy Agency, Paris, pp. 26-29.

Orozco, L A. O. 1986. 'Management of Low-Level Wastes in Mexico.' IAEA Seminar on Management Options for Low- and Intermediate-Level Wastes in Latin America. October 13-17, 1986, Rio de Janeiro, IAEA-SR-110/10.

Zorilla, S. 1986. "Design and Operational Experience of the Centre for Collection, Treatment and Storage of Low-Level Radjoactive Wastes.' IAEA Seminar on Management Options for Low- and Intermediate-Level Wastes in Latin America. October 13-17, 1986, Rio de Janeiro, IAEA-SR-110/11.

$-1987-$

Nucleonics Week (NW). 6/25/87. Mexico Quietly Seeking Fuel Cycle Technology from Argentina," pp. 23.

Rundo, J. 1987. Technical Assistance to Mexico, International Nuclear Technology Liaison Office, Argonne National Laboratory, Argonne, Illinois, September 1987.

U.S. Department of Energy (DOE). 1987. U.S. DOE Meeting Summary, 10/7/87.

$-1988-$

International Atomic Energy Agency (IAEA). 1988. The Nuclear Fuel Cycle Information System: A Directory of Nuclear Fuel Crcle Facilities. Vienna, p.77.

International Atomic Energy Agency (IAEA). 5/20/88. "World Overview: Radioactive Waste Management." IAEA News Features, pp.8-9.

International Atomic Energy Agency (IAEA). 6/10/88. 'Travel Report: Report of WAMAP Mission to Mexico, 9-13 May 1988, INT/9/081: Vienna.

NUKEM Market Report (NUKEM). 8/88. "The Day's of Mexico's Nuclear Program Possibly Numbered." NUKEM GmbH, Hanau, Federal Republic of Germany, pp. 4-5.

The World Fact Book. 1988. Superintendent of Documents, U.S. Government Printing Office, Washington, D.C.

Uranium and Nuclear Energy. 1988. Proceedings of the Thirteenth International Symposium held by the Uranium Institute, London, September 1988, p. 399.

$-1989-$

Nuclear Energy Agency (NEA). 6/89. Nuclear Law, Bulletin 43, June 1989, OECD Nuclear Energy Agency, Paris, pp. 74-75.

Nuclear Engineering International (NEI). 6/89. "Mexico: Startup at Last," p. 26.

Nuclear Engineering International (NEI). 11/89. "World Nuclear Industry Handbook: 1990.'

Nuclear News (NN). 5/89. 'Startup at CFE's Laguna Verde-1,' pp. 46-48. 
NUKEM Special Report (NUKEM). 5/89a. The Nuclear Power Plant Capacities of Individual Countries." NUKEM GmbH, Hanau, Federal Republic of Germany, p. 19.

NUKEM Special Report (NUKEM). 5/89b. "Nuclear Power Plant Capacity of the Western World," NUKEM GmbH, Hanau, Federal Republic of Germany, pp. 24-25. 

THE NETHERLANDS 
NETHERLANDS

\section{THE NETHERLANDS}

\section{CONTENTS}

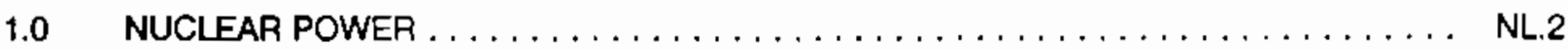

2.0 NUCLEAR FUEL CYCLE AND RADIOACTIVE WASTE MANAGEMENT

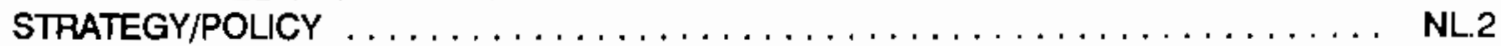

3.0 HIGHUGHTS AND MAJOR MILESTONES $\ldots \ldots \ldots \ldots \ldots \ldots \ldots \ldots \ldots \ldots$

4.0 INSTITUTIONAL CONSIDERATIONS/ORGANIZATIONS $\ldots \ldots \ldots \ldots \ldots \ldots \ldots \ldots$

$5.0 \quad$ NUCLEAR FUEL PRODUCTION $\ldots \ldots \ldots \ldots \ldots \ldots \ldots \ldots \ldots \ldots \ldots \ldots$

6.0 FUEL RECYCLE $\ldots \ldots \ldots \ldots \ldots \ldots \ldots \ldots \ldots \ldots \ldots \ldots \ldots \ldots \ldots \ldots \ldots \ldots$

$7.0 \quad$ SPENT FUEL STORAGE AND TRANSPORT $\ldots \ldots \ldots \ldots \ldots \ldots \ldots \ldots$

8.0 WASTE CONDITIONING, STORAGE AND TRANSPORT $\ldots \ldots \ldots \ldots \ldots \ldots \ldots$

9.0 DISPOSAL OF NON-HIGH-LEVEL WASTES $\ldots \ldots \ldots \ldots \ldots \ldots \ldots \ldots \ldots \ldots \ldots$

10.0 DISPOSAL OF HIGH-LEVEL WASTES $\ldots \ldots \ldots \ldots \ldots \ldots \ldots \ldots \ldots \ldots \ldots \ldots \ldots \ldots$

11.0 MANAGEMENT OF URANIUM MINE AND MILL WASTES $\ldots \ldots \ldots \ldots \ldots \ldots \ldots$

12.0 DECOMMISSIONING AND ENVIRONMENTAL RESTORATON $\ldots \ldots \ldots \ldots \ldots \ldots \ldots$ NL.14

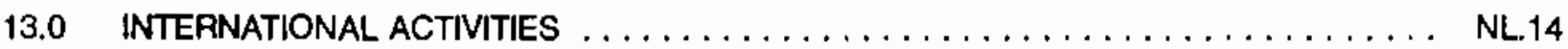

14.0 REFERENCES $\ldots \ldots \ldots \ldots \ldots \ldots \ldots \ldots \ldots \ldots \ldots \ldots \ldots \ldots \ldots \ldots \ldots \ldots \ldots$ 


\title{
1.0 NUCLEAR POWER
}

1.1 REACTOR MIX: 1 BWR (58 MWe), 1 PWR (480 MWe)

\subsection{ELECTRIC POWER PRODUCTION}

1989--61 TWh (6.3\% Nuclear) (NEI 3/90)

1998--85 TWh (NUKEM 8/89)

\subsection{NUCLEAR POWER CAPACITY PROJECTIONS}

\author{
1988-0.5 GWe \\ 1995-0.5 GWe \\ 2000-0.4 GWe (NUKEM 5/90)
}

1.4 NUCLEAR PLANT AVAILABILITY: $82.4 \%$ cumulative through 1987 (IAEA 1988)

1.5 NUCLEAR ENERGY POLICY: In 1985, the Dutch government agreed in principle to the possible future construction of additional nuclear power plants; however, because of the public's concern about nuclear energy since the Chernobyl accident in 1986, the Netherlands has deferred any possible new construction of nuclear power plants; its current energy plan for 1989-1998 has no definite provisions for new nuclear energy (NUKEM 8/89)

\subsection{NUCLEAR FUEL CYCLE AND RADIOACTIVE WASTE MANAGEMENT STRATEGY/POLICY (Ministry 1984; Paige 1985)}

2.1 OVERALL NUCLEAR FUEL CYCLE POLICY: The Netherlands generally prefers to use foreign services for nuclear fuel cycle needs (Leigh and Mitchell 1990)

2.2 POLICY ON THE FRONT END OF THE NUCLEAR FUEL CYCLE: The Netherlands uses foreign front-end fuel cycle services, and has not developed front-end capabilities in the nuclear fuel cycle except for partnership with the FRG and the U.K. in a large uranium enrichment facility in the Netherlands (Leigh and Mitchell 1990)

\subsection{POLICY ON THE BACK END OF THE NUCLEAR FUEL CYCLE}

A. The Netherlands is to provide for interim storage of spent fuel and all radioactive wastes, including vitrified HLW and other reprocessing wastes returned from foreign reprocessors, until disposal can be accomplished; extended storage of the wastes for 50.100 years is planned in a central engineered facility, and such storage and subsequent disposal is managed by the government; central storage should be implemented by 1994 at the latest (Codee 1989)

B. The Netherlands is encouraging international cooperation in disposal of HLW, but continues with the domestic program to site and develop technology for a geologic repository in Dutch salt formation

C. The Netherlands will use existing foreign contracts for reprocessing of spent fuel; for fong term, the decision on further reprocessing is deferred, but the Netherlands is leaning toward the once-through fuel cycle 
D. In 1985, the Netherlands initiated an Integrated National Research Programme (ILONA) to study storage and disposal of LLW, ILW, and HLW in deep geological formations in the Netherlands, disposal in the sub-seabed sediments (supervised by the Deep-Sea Research Programme on Radioactive Waste, DORA Committee), and disposal in a multinational repository in another country; of these, the main studies are in the Onshore Disposal Programme (OPLA), which is investigating geologic disposal within the Netherlands in three phases; subsequent activities, it any, depend on the results of the preceding program phases (OPLA 1989)

E. In the Netherlands, the producers of radioactive waste must pay for its extended storage and disposal (Codee 1987)

F. The Netherlands practiced sea disposal of LLW into the North Atlantic from 1965 until the London Dumping Convention moratorium in 1982; it would like to resume it the moratorium is lifted; it participated in the Nuclear Energy Agency (NEA)-sponsored study on disposal of HLW in the seabed, and is still interested in the concept (Leigh and Mitchell 1990)

\subsection{HIGHUGHTS AND MAJOR MILESTONES (Lakey 1985)}

1965- Disposed of UW by sea dumping into the North Atlantic (Vrijen 1980) 1982

1969 Started up first nuclear power reactor (BWR) at Dodewaard (Codee 1988)

1982 Founded the governmental nuclear waste management organization, COVRA

1995 Approved construction of additional nuclear power plant(s), with final decisions deferred

1985 Initiated the Integrated National Research Programme, Nuclear Waste (ILONA) (OPLA 1989)

1987 Completed site selection process for interim storage center for spent fuel and radioactive wastes

1990 Begin construction of the interim storage center for all wastes (Codee 1989)

1992 Receive first LLW from foreign reprocessors (Codee 1989)

1992 Commission the central storage facility for all wastes (Codee 1989)

1996 Receive first HLW from foreign reprocessors (Codee 1989)

\subsection{INSTITUTIONAL CONSIDERATIONS/ORGANIZATIONS}

\subsection{LEGAL PEQUIREMENTS}

A. The Ministries of Economic Affairs; Housing, Physical Planning and Environment; and Social Affairs exercise overall control of nuclear matters with Parliamentary approval of their decisions (Leigh and Mitchell 1990)

B. A stipulation law exists: a definitive plan for waste management must be submitted by govemment before construction permit for new nuclear plant can be approved (Paige 1985)

C. Land use veto by town council can be overridden by provincial government (Paige 1985) 
D. The current policy for radioactive waste management is based on a 1982 federal government decree that the policy for treatment, storage and disposal of all kinds of waste is also applicable to radioactive waste management (Vrijen 1988)

E. The requirements for management of radioactive waste were established in a federal Lower Parliament House enactment, "Memorandum on Radioactive Waste," in 1985, which set basic radiation protection standards (OPLA 1989)

4.2 RADIATION PROTECTION PRINCIPLES: Basic radiation protection principles for radioactive waste management were set in 1985 by the federal Lower Parliament House in the "Memorandum on Radioactive Waste"; among other things, the requirements are: each radiation exposure must be restricted as much as is reasonably possible; the sum of the received and expected doses for persons may not exceed the defined limit doses; and radioactive wastes must be managed so that these principles are permanently satistied (OPLA 1989)

\subsection{LICENSING}

A. Construction and operating licenses are issued by joint action of three ministries of the federal government, following consultation with experts, other ministries, and local government; the three ministries are: Ministries of Economic Affairs; Housing, Physical Planning and Environment; and Social Affairs (NW 5/4/89)

B. The waste management organization, COVRA (owned partly by private enterprise and partly by the federal government), is licensed by the federal government (Codee 1987)

C. The use of radioactivity requires a license under the Nuclear Energy Act (Codee 1987)

4.4 PUBLIC INVOLVEMENT: Local officials and the public are invited to review applications; public hearings are held; the public and local officials can have a significant influence on nuclear waste policy: town councils can invoke a veto on land uses, but this veto can be overridden by the provincial government (Paige 1985)

4.5 WASTE FUND: COVRA collects funds for all wastes it receives; a reserve fund is set up for the costs of future storage and disposal of wastes; electricity producers accumulate reserve fiunds for decommissioning and interim storage/disposal of $\mathrm{HLW}$; fees are based on generic cost considerations (Codee 1987)

4.6 KEY AGENCIES AND FUEL CYCLE CENTERS (Leigh and Mitchell 1990)

A. The COVRA (Central Organization for Radioactive Waste), founded in 1982, is the only organization authorized to collect, treat, transport and store (and dispose of) LLW/LW in the Netherlands; it operates the interim facility for LLW/ILW storage at Petten; the company is owned $10 \%$ by the federal government (the government's favorable vote is required for all major decisions), $60 \%$ by the nuclear utilities, and $30 \%$ by the Petten Research Center, ECN (Codee 1987)

B. The Ministries of Economic Affairs; Housing, Physical Planning and Ervironment; and Social Affairs must approve licensing (NW 5/4/89)

C. The ILONA (Integrated National Research Programme, Nuclear Waste) Policy Committee advises the Minister of Economic Affairs and the Minister of Housing, Physical Planning and the Environment regarding the ILONA program, carried out under the three study committees; the ILONA Pollcy Committee is made up of representatives from a number of federal Ministries and other experts; the three committees supervised by the ILONA Policy Committee are (OPLA 1989): 
1) The OPLA (On-shore Disposal Programme) Research Committee supervises and carries out the studies on geologic disposal in the Netherlands;

2) The DORA (Deep-Sea Research Programme on Radioactive Waste) Committee supervises and carries out studies on disposal in the deep sea sediments;

3) The MINSK (Interim Storage Programme) Committee supervises and carries out studies on interim storage of radioactive wastes in the Nethellands (work was completed in 1984)

D. The Geological Survey of the Netherlands carries out geological studies on waste disposal

E. The National Institute of Public Health and Environmental Protection (RIVM) carries out studies on safety assessment of waste disposal facilities

F. The Ministry of Economic Affairs is responsible for nuclear energy and radioactive waste planning

G. The Ministry of Housing, Physical Planning and Environment is responsible for protection of the environment from radiation and other hazardous materials; the agency within the ministry for hazardous waste management is the Directorate-General for Environmental Protection (Beecher 1990)

\subsection{PRINCIPAL RESEARCH, DEVELOPMENT AND DEMONSTRATION FACILITIES/PROGRAMS}

A. The ECN (Petten Research Center of The Netherlands Energy Research Foundation) carries out energy studies, radioactive waste treatment and disposal studies, decontamination studies, and other nuclear research; ECN is partly government-funded (Leigh and Mitchell 1990)

1) The Hot Cell Laboratory $(\mathrm{HCL})$ is the only facility in the country for investigation of large, highly-radioactive materials; the HCL serves mainly as a post-irradiation examination facility, mostly for materlals exposed in the European Community's HighFux Reactor on the ECN site (NE 1-2/89)

2) The Center includes the CEC's High-Flux Reactor (HFR) for irradiation tests for fuels and other materials (NE 1-2/90)

B. The KEMA (Research and Testing Electrochemical Materials Company) at Arnhem carries out research and engineering services for utilities, including R\&D on volume-reduction and storage of reactor station wastes (Leigh and Mitchell 1990)

4.8 KEY PERSONNEL (Leigh and Mitchell 1990)

W. J. K. Brugman, Director, Radiatlon Protection, Ministry of Housing, Physical Planning and Environment

R. de Korte, Minister of Economic Affairs

H. F. G. Geyzers, Deputy Director for Electricity and Nuclear Energy, Ministry of Economic Affairs

R. M. Korthof, Radioactive Waste, Ministry of Economic Affairs

A. Comelissen, Radioactive Waste, Ministry of Housing, Physical Planning and Environment 
J. Versteeg, Nuclear Safety, Ministry of Social Affairs

J. Vrljen, Managing Director, COVRA

H. D. K Codee, Radiation Protection, COVRA

U. Bakema, Waste Storage/Transportation, COVRA

H. H. Kroonenberg, Managing Director, Research, ECN

A. M. Versteegh, Nuclear Energy Research, ECN

L H. Vons, Nuclear Waste/Geologic Disposal, ECN

K. A. Duijves, Experimental Underground Disposal Program, ECN

J. Pru, Safety Assessment, ECN

A. Van Dalen, Radionuclide Migration, ECN

H. M. van Monttrans, Deep Subsurface Department, GSN

P. Glasbergen, Safety Assessment of Underground Disposal Studies, RIVM

H. Boekschoten, Nuclear Waste Research, KEMA

J. Matteman, Acid Digestion/Incineration, KEMA

\subsection{NUCLEAR FUEL PRODUCTION}

\subsection{URANIUM RESOURCES: None identified}

5.2 URANIUM ENAICHMENT: The Netherlands is partner with FRG and U.K. interests in the URENCO (Uranium Enrichment Consortium); URENCO owns and operates a 1,500,000-SWU/yr centrifuge enrichment plant at Almelo, the Netherlands

\subsection{FUEL RECYCLE (NF 5/4/87)}

6.1 FUEL REPROCESSING: Reprocessing of $120 \mathrm{MTU}$ of spent fuel has been contracted with France, and $45 \mathrm{MT}$ with the U.K.; long-term reprocessing plans are uncertain; resulting wastes will be retumed to the Netherlands (IAEA 1989)

\subsection{SPENT FUEL STORAGE AND TRANSPORT}

7.1 SPENT FUEL ARISINGS: (Leigh and Mitchell 1990)

1980103 MTU cumulative

1985190 MTU cumulative

1990270 MTU cumulative

2000420 MTU cumulative

\subsection{SPENT FUEL STRATEGY (Codee 1989)}

A. Spent fuel will be stored temporarily in storage pools at reactors until transfer to foreign reprocessors or to the Netherlands' extended interim storage facility 
B. A facility will be constructed for extended interlm storage of spent fuel (50-100 years) and all other radioactive wastes

C. The Netherlands continues to explore possible foreign or international disposal facilities for radicactive waste, and disposal in deep ocean sediments (van Montfrans 1989)

D. The Netherlands is proceeding with a research program on geologic disposal in the Netherlands

7.3 WET STORAGE: At-reactor pool storage plus foreign reprocessing will handle spent fuel discharges from operating reactors through the early $1990 \mathrm{~s}$ in the Netherlands; wet storage pools were considered as a potential concept for storage of spent fuel and vitrified $\mathrm{HLW}$ in the central interim storage facility, but dry storage was favored (Codee 1987; Codee 1989)

7.4 DRY STORAGE: Away-from-reactor spent fuel storage, if any, will be in a central storage facility for all radioactive wastes (Codee 1989)

A. A site next to the Borssele nuclear power plant was selected by COVRA; after most licensing procedures had been completed, opposition by a local community $1 \mathrm{~km}$ from the site forced COVRA to abandon the site; currently, another nearby coastal site that is $2 \mathrm{~km}$ from the community has been selected, and a license application was submitted in 1989 (Codee 1989)

B. The facility is being designed to last up to 100 years and to handle all categories of radioactive wastes with capacity sufficient for at least $\mathbf{4 0}$ years (Codee 1989)

C. The planned spent fuel and high-level waste portion of the facility will be in a separate vault with 2-m-thick walls built in 500-MTU modules with total capacity of 4000 MTU (Codee 1989)

1) Fuel reception capacity will be $200 \mathrm{MTU} / \mathrm{yr}$ (Codee 1987)

2) Dry vault storage that has a passive air cooling system will be used; it is designed to accept 5-year-old spent fuel or vitrified high-level wastes

3) Individual fuel assemblies will be placed in a set of double stainless steel overpack containers at the facility, each filled with helium to reduce corrosion and to allow for continual monitoring for possible leakage with pressure gages

4) No rod consolidation is planned (Codee 1987)

7.5 TRANSPORT: in the Netherlands, spent fuel is transported by truck or train (Codee 1989)

7.6 PROGRAM/FACILITIES COSTS: The cost of a HLW/spent fuel storage facility is about $\$ 400 / \mathrm{kgU}$ for $500 \mathrm{MTU}$ capacity and about $\$ 100 / \mathrm{kgU}$ for a system with 4000 MTU capacity (Gevers 1988)

8.0 WASTE CONDITIONING, STORAGE AND TRANSPORT (Codee 1986, 1987)

B.1 WASTE ARISINGS (Vrijen 1988; Codee 1989)

A. Total arisings of LLW are about $700 \mathrm{~m}^{3} / \mathrm{yr}$, with the volume about $400 \mathrm{~m}^{3} / \mathrm{yr}$ after treatment and packaging (about half of this is from the nuclear power stations, and the other half from research, hospitals, and industrial facilitios); an additional $450 \mathrm{~m}^{3} / \mathrm{yr}$ consist of cemented evaporator sludges, filter sludges and ion exchange resins from the nuclear 
power stations; the total annual waste volume contains about 1400 curies, of which about $50 \%$ is tritium and $30 \%$ is cobalt -60

B. Cumulative arisings of all radioactive wastes in the next 100 years are estimated at about $63,000 \mathrm{~m}^{3}$ with no expansion of nuclear power, or about $113,000 \mathrm{~m}^{3}$ with an additional $2000 \mathrm{MWe}$ of nuclear power

C. Approximately $70 \mathrm{~m}^{3} / \mathrm{yr}$ of conditioned LLW-ILW (or a cumulative total of about $2000 \mathrm{~m}^{3}$ ) will be returned from French and U.K. reprocessing of Dutch fuel starting in 1994

D. Total arisings of HLW from French and U.K. reprocessing of Dutch fuel will be approximately $20 \mathrm{~m}^{3} / \mathrm{yr}$ of vitrified HLW (or a cumulative total of about $45 \mathrm{~m}^{3}$ ), and a total of about $500 \mathrm{~m}^{3}$ of non-heat-generating $\mathrm{HLW}$

\subsection{STRATEGY}

A. The Dutch plan to provide a temporary capability for interim storage of LLW/ILW at COVRA's Petten facility

B. They also plan to construct an above-ground central facility for extended interim storage (50-100 years) for spent fuel and all wastes until a permanent disposal facility is available; in this time period, technology and realization of a final disposal method should be developed (Codee 1987)

8.3 HLW IMMOBILIZATION: HLW from spent fuel reprocessed in France and the U. K. will be vitrified into borosilicate glass at the reprocessing facilities and returned to the Netherlands for final disposition starting in 1994 (Codee 1989)

\subsection{LLW/ILW CONDITIONING}

A. Conditioning at the existing interim central facility at the Energy Research Foundation at Petten is carried out for wastes from non-fuel cycle facilities, and includes (Codee 1987; Codee 1989):

1) Solid wastes in 100-liter drums are compacted in a 1500-MT press, then embedded in concrete in 200-liter drums; about 10,000 drums/year of dry low-level wastes are compacted in this facility

2) Inorganic liquid wastes are precipitated, and embedded in concrete in standard 200-liter drums

3) Organic wastes are currently stored, awaiting incineration at a future incinerator

B. Conditioning at the nuclear power plants involves treatment and incorporation into cernent (Codee 1987); a portable, remotely operated cement solidification system will be installed at the Borssele PWR in late 1990 to solidity spent ion exchange resins, sludge and concentrate into 200-liter drums (NW 10/26/89)

C. The planned new central facility near Borssele nuclear power plant will have a reception bay and lag storage of wastes awaiting treatment; treatment and conditioning will include (Codee 1989):

1) A $1500-M T$ supercompactor that compacts wastes and 100-liter drums

2) Three incinerators (one for liquid organic wastes, one for biological wastes, and a third for other solid wastes) 
3) An organic-inorganic liquid separator

4) Shearing and cutting installations

5) Decontamination facilities

6) Decay storage for short-lived wastes

7) A cementation station; the supercompacted drums will be placed in 200-liter drums with cement; precipitates from inorganic liquid treatment, used radiation sources, small solid waste pieces, and ashes from the incinerators will also be cemented in 200-liter drums

8) A waste water and liquid waste treatment system; inorganic liquids will be treated by coagulation/precipitation; purified water is discharged into the bay

9) Standard package sizes are 200-liter drums and 600-, 1000-, and 1500-liter packages

\subsection{LLW/ILW STORAGE}

A. Current temporary central storage is in an above-ground building at Petten, licensed for about 10 years, and must be shut down by about 1994 (Codee 1987; Vons 1987)

1) 200- and 400-liter drums, and 800- and 1500-liter packages are used; 200-liter drums are stored horizontally in units of three on a pallet, and stacked nine high; other sizes of containers are placed where convenient

2) The capacity will be $5,000 \mathrm{~m}^{3}$ (enough for five years), expandable to 10 years' capacity

3) The allowable dose rate at the site fence is $15 \mathrm{mrem} / \mathrm{yr}$

B. Future storage for 50-100 years of all radioactive wastes will be in the planned central facility about $2 \mathrm{~km}$ from the town of Borssele and about $1 \mathrm{~km}$ from the Borssele nuclear power station (Codee 1989)

1) The site measures 30 hectares

2) A new treatment and storage facility for LLW/ILW will include: a waste receiving facility and buffer storage for untreated wastes, a super compactor, an incinerator for biological wastes, an organic-inorganic liquid separator, a waste-water treatment system, an incinerator for organic liquids (the two incinerators share the same offgas treatment equipment), a shearing and cutting installation, and a cementing station; in the future, additional options may include decontamination facilities, an incinerator for solid wastes, and decay storage for short-lived wastes

3) Four modular storage units with $5,000 \mathrm{~m}^{3}$ each will provide for storage and radionuclide decay

a) One unit will be for JLW with remote handling

b) Other units will be for LLW for contact handling

4) A license was granted for the facility in 1989 but is being contested by some local public; construction is planned to start in 1990; storage of LLW is planned to start 
in 1992; storage of heat-generating HLW is planned to start in 1996, and non-heatgenerating HLW in 1998

8.6 HLW STORAGE: The centra! storage facility, about one $\mathrm{km}$ from the Borssele nuclear power plant, will provide for handling and storage of spent fuel or vitrified HLW and some non-heat-generating high-level wastes; the facility will have an initial capacity of approximately 4000 MTU (or HLW equivalent) in a modular design, with capability for future expansion; construction is expected to start in 1990; the facility for storage of heat-generating wastes is expected to start up in 1996, and for non-heat-generating high-level wastes in 1998; the facility will have (Codee 1989):

A. A receiving and unloading bay for truck and rail casks

B. An area for cleaning transportation equipment

C. Hot cells for inspection, decontamination (if necessary) and overpacking of three HLW containers stacked vertically in a sealed stainless steel storage container; these containers will be back-filled with helium and monitored for leakage with pressure gages

D. A transfer area where wastes will be brought in a storage-loading machine

E. Storage hot cells with natural convection air cooling for spent fuel and vitrified, heat-generating high-level wastes

F. Provisions for handling and storage of non-heat-generating high-level-wastes from reprocessing; this facility, which is expected to start up in 1998 for $\mathrm{HLW}$, will have shielding concrete walls of 1.6-meter thickness and includes:

1) A remote unloading area

2) Storage area modules with a capacity of $2400 \mathrm{~m}^{3}$ each

G. See also Section 7.3

8.7 PROGRAM/FACILITIES COSTS: In the Netherlands, costs for storage of wastes will be collected at the time of receipt of the wastes (Codee 1989)

\subsection{DISPOSAL OF NON-HIGH-LEVEL WASTES (Codee 1987)}

\subsection{STRATEGY Nrijen 1988)}

A. The Netherlands is planning eventual geologic disposal of non-high-level wastes, to be determined in the next 50-100 years; the geologic disposal facility for LLW/ILW will likely be near the HLW disposal facility (OPLA 1989)

B. Non-HLW will be stored for 50-100 years in a central surface facility until a disposal facility is available

C. The R\&D program for disposal of all types of radioactive wastes in the Nethertands is the integrated OPLA (Onshore Disposal Study) program (See also Section 10)

9.2 WASTE DISPOSAL CRITEBIA: Criteria for underground disposal have not yet been completed; work to date has been based on general radioactive risk criteria set out in the Indicative MultiYear Programme for Environmental Management (IMPM) 1986-1990 (OPLA 1989)

\subsection{LLW DISPOSAL}


A The Netherlands practiced sea dumping of $\amalg W$ at 4,000-meter depth into the North Atlantic from 1965-1982 (Vrijen 1988)

B. Disposal of LLW and ILW in a Dutch deep geological formation is currently planned in conjunction with disposal of $\mathrm{HLW}$, after a storage period of 50 to 100 years at a central storage facility on the surface; the stage 1 safety studies for geological disposal (see Section 10.2) concluded that safe dlsposal of $\amalg W$ and ILW would be comparable to the conventional mine concept or the deep borehole concept (van Montfrans 1989; OPLA 1989)

C. The reference $\amalg W / I L W$ disposal concepts in the OPLA stage 1 study involved disposal tacilities in the same geologic salt formation and area as the HLW disposal facility; they were: 1) disposal in mined-out rooms in salt, with the LLW/ILW disposal area above or beside the HLW disposal area; and 2) disposal in a cavity at the bottom of a shaft accessible only at the surface, near the HLW disposal area using deep boreholes; multiple barriers including the waste form (primarily concreted and bitumenized waste); the container and other engineered barriers would be utilized for disposal (OPLA 1989)

9.4 UW/LW DISPOSAL R\&D: Feasibility R\&D of disposal of LLW/ILW in deep geological formations has been carried out by the Dutch, primarily as part of the OPLA program (OPLA 1989)

\subsection{DISPOSAL OF HIGH-LEVEL WASTES}

10.1 SPECIFICATIONS AND CRITERIA: Criteria for underground disposal have not yet been completed by the Dutch; work to date has been based on general radioactive risk criteria set forth in the IMPM 1986-1990 (OPLA 1989)

10.2 REPOSITORY DEPLOYMENT STRATEGY: The strategy is to dispose of HLW/spent fuel in a geologic formation, preferably in a foreign repository, but to plan for a Dutch repository in 50-100 years; in the interim, perform research and siting studies in a three-stage R\&D program (OPLA program carried out through the Onshore Disposal Study Committee) that was partly sponsored by the CEC; retrievability of disposed wastes was considered, but is secondary to the long-term need for waste isolation (Codee 1987; Vons 1987; van Montfrans 1989; OPLA 1989)

A. Stage 1: Carry out an inventory and comparison of potential disposal concepts, host rocks and sites, and acquire knowledge and understanding about the possibility of final and safe disposal using currently available mining techniques in rock salt formations that probably occur in the Netherlands; a total of 26 studies were completed in 1989 by a number of Dutch institutes to constitute the stage 1 activities, with the central theme throughout being waste isolation safety (OPLA 1989)

1) Probable host rock: rock salt formation (can be in salt domes, in salt pillows, or in bedded salt); a formation in the northem part of country is preferred; clay is a possible second choice; metamorphic cambrian rock is also a possibility

2) The primary repository concepts under consideration: conventional mine with waste canisters in holes in floors of tunnels; waste canisters lowered into boreholes drilled from surface; other concepts have also been considered

3) Research activities: further the development of preliminary designs; carry out preliminary geologic, hydrologic and safety studies; develop safety criteria for geological disposal; participate in geologic disposal R\&D with other countries and the CEC and the NEA

4) Stage 1 studies included studies on: safety and dose consequences, mostly deterministic, on numerous scenarios of occurrences both natural and man-caused, for 
repositories in salt domes, salt pillows, and bedded salt; behavior of rock salt under repository temperature and pressure conditions; the effect of radiation on rock salt; the role of nonhomogeneities in rock salt formations; the development of models of groundwater flows and transport of radionuclides; the feasibiiity of using available mining techniques; sealing technologies; leakage along the outside of borehole linings; the feasibility of retrieving wastes after emplacement

5) The general conclusion from the stage 1 studies is that safe disposal is possible in either salt or clay, and no insurmountable engineering problems for disposal are anticipated; more specific conclusions from stage 1 are: 1) construction and operation of a disposal facility in Dutch rocksalt is technically feasible for the concepts of using existing cavems or conventionally constructed mine and deep boreholes drilled from the surface; 2) safe disposal of waste in Dutch rocksalt is possible; and 3 ) isolation of HLW in the conventional mine concept is better than in deep boreholes (van Montfrans 1989; OPLA 1989)

6) The results from stage 1 will lead to selection of a general reference concept and host rock

B. Stage 2: Carry out geologic and hydrologic comparisons of several sites, foltowed by preliminary surveys at two sites that include 1) further development of preliminary designs, 2) performance of a concurrent safety study; 3) three-dimensional seismic exploration, and 4) construction of medium-depth boreholes (up to $500 \mathrm{~m}$ ) (stage 2 remains to be authorized by Parliament)

C. Stage 3: Definitive surface and subsurface exploration of the final candidate site chosen for evaluation; activities will include about 100 geohydrological borings into the overlying rocks, and possibly around the disposal formation considered, seismic surveys, and exploratory borings into the salt

10.3 SITE SELECTION AND CHARACTERIZATION: Only general identification of potential sites has been carried out to date as part of the OPLA program (See Section 10.1) (OPLA 1989)

\subsection{REFERENCE HLW/SPENT FUEL DISPOSAL CONCEPT}

A. Five disposal concepts have been under consideration in the Netherlands: 1) HLW placed in boreholes in floors of tunnels (up to $1500 \mathrm{~m}$ deep), and LLW/ILW in rooms; 2) all wastes placed in deep caverns made by drilling (this concept was found to be not feasible); 3 ) all wastes placed in caverns (up to $2000 \mathrm{~m}$ deep) made by solution mining (emplacement can be while brine is in the cavern or after cavern areas are dried; 4) phased construction of concept 2); and 5) all wastes placed in deep boreholes (2000 to $2500 \mathrm{~m}$ deep) from the surface; safety, feasibility and cost comparison evaluations of the various concepts in salt were completed in 1987 Nons 1987; van Montfrans 1989; OPLA 1989)

B. The stage 1 repository studies in the OPLA program have concluded that the conventional mined facility or the deep borehole facility would provide suitable safety for HLW disposal (van Montfrans 1989; OPLA 1989)

C. The reference HLW disposal concepts in the OPLA stage 1 study involved disposal in the same geologic salt formation and area as the LLW/ILW disposal facility; they were: 1) disposal in boreholes in the floors of mined-out rooms in salt, with the HLW disposal area below or beside the $\amalg W / L W$ disposal area; and 2) disposal in deep boreholes accessible only from the surface in an area near the $L \mathrm{~W} / \mathrm{ILW}$ disposal area (that would have a cavity at the bottom of a shaft accessible only from the surface) (OPLA 1989) 
D. Disposal concepts will use a multi-barrier system that includes the waste form, various engineered barriers, the host rocksalt, and the surrounding and overlying strata (van Montfrans 1989; OPLA 1989)

\subsection{GEOSCIENCES R\&D (de Boer 1987; Vons 1987)}

A. The Dutch place heavy dependence on access to results of salt repository research in other countries

B. Mapability, mapping, and geological evaluations of the Netherlands' salt structures have been carried out by the Dutch

C. Stress effects around excavations in salt formation are being studied (Delft technical University)

D. The influence of liquid-rock interactions on rheology of salt is under investigation (University of Utrecht)

D. The influence of heterogeneity in soil on dispersion of radionuclides in the soil and groundwater system is being studied (Delft Technical University)

E. Recommendations from the OPLA research committee, based on the results of the OPLA stage 1 study, are that future R\&D will be based on the conventional mining concept (OPLA 1989)

\subsection{FIELD TESTS}

A. In the Asse salt mine in Germany, tests are being carried out by ECN on deep-drilling techniques, rock mechanics and creep behavior of rock salt at different temperatures, effects of radiation on salt, and pressure buildup around stored waste containers (De Boer 1987)

B. Field tests in the Netherlands have not yet been started; however, the foilowing preparatory studies for field reconnaissance have been made (van Montfrans 1989):

1) Geophysical techniques capable of mapping salt structures

2) The extent to which currently available hydrogeological exploration methods are capable of describing subsurface features

10.7 PERFORMANCE ASSESSMENT (Glasbergen 1987; Codee 1987; Vons 1987; OPLA 1989)

A. General safety studies and studies specific to some geologies in the Netherlands are being carried out by ECN

B. A finite-element migration model is being developed (METROPOL model) using Asse salt mine data for assessing the effects of intrusion of water into a disposal mine and migration of radionuclides into the biosphere, considered to be the primary accident scenario; major efforts are being placed on model validation

C. The safety studies have concluded that salt $o r$ clay should be acceptable host rocks

D. The results of the stage 1 OPLA studies identified the need for further validation of computer models for performance assessment

11.0 MANAGEMENT OF URANIUM MINE AND MILL WASTES (no information) 


\subsection{DECOMMISSIONING AND ENVIRONMENTAL RESTORATION}

A. The Netherlands has had effective major programs for cleanup of facilities and areas of past contamination with hazardous materials for 10 to 20 years; the industries generally work as partners with government in deciding on action, but industry is generally responsible for the action (Beecher 1990)

B. No information was found on decommissioning and environmental restoration for radioactive materials

\subsection{INTERNATIONAL ACTIVITIES}

13.1 MEMBERSHIPS: CEC, IAEA, NEA

\subsection{COOPERATION WITH MULTINATIONAL AGENCIES}

A. The Netherlands participates in the CEC program on radioactive waste disposal, including some studies partly funded by the CEC; in 1989, it requested and received a review of the Dutch radioactive waste management program by NEA- and CEC-selected national experts

B. The Netherlands participates in most IAEA activities in radioactive waste management

C. The Netherlands participates in many NEA activities in radioactive waste management; in 1989 , it requested and received a review of the Dutch radioactive waste management program by NEA- and CEC-selected national experts

\subsection{COOPERATION WITH USA}

A. U.S./Netherlands exchange - a proposed DOE/Ministry of Economic Affairs umbrella Memorandum of Understanding:

1) Term: To be determined ( 5 years from date of signature)

2) Scope: Treatment, packaging and storage of spent fuel and radioactive waste; decommissioning; transportation; geologic disposal in salt

B. The U.S. and the Netherlands have carried out information exchanges on spent fuel storage, transportation and disposal under Section 223 of the U.S. Nuclear Waste Policy Act of 1982

\subsection{COOPERATION WITH OTHER COUNTRIES}

A. The Netherlands cooperates with the F.R.G. on Asse mine investigations

B. The Netherlands is a partner with the F.R.G. and the U.K. in URENCO uranium enrichment venture in the Netherlands

\subsection{REFERENCES}

$-1984-$

Harmon, K. M., and A. B. Johnson, Jr. 1984. Foreign Programs for the Storage of Spent Nuclear Power Plant Fuels, Hiah-Level Waste Canisters and Transuranic Wastes. PNL-5089, Pacitic Northwest Laboratory, Richland, Washington, p. 58. 
Minlstry of Housing, Physical Planning and Environment (Ministry). 1984. Radloactlve Waste Policy in the Netherlands. Pamphlet issued by Ministry of Housing, Physical Planning and Environment, The Hague, Netherlands.

Nuclear Europe (NE). 12/84. "Dutch Final Waste Disposal Needs Further Investigation," p. 38.

Onshore Disposal Committee (ODC). 1984. Proposal for a Research Programme on Geological Disposal of Radioactive Waste in The Netherlands. Issued by the Ministry of Economic Affairs, The Hague, Netherlands.

$-1985-$

Lakey, L. T. 1985. "Foreign Travel Trip Report to France and The Netherlands." Pacific Northwest Laboratory, Richland, Washington.

Paige, H. W., and N. J. Numark. 1985. Assessment of National Systems for Obtaining Local Siting Acceptance of Nuclear Waste Management Facilities. IEAL-R/86-16, International Energy Associates Limited, Washington, D.C., Vol. 1, pp. 12-1 to 12-4 and Vol. 2, pp. 14-1 to 14-4.

$-1986-$

Codee, H. D. K. 1986. "Netherlands Low and Medium Waste Management." Nuclear Europe, March 1986, p. 18.

Nuclear Europe (NE). 7-8/86. "Dutch Pick Borssele as Waste Storage Site," p. 42.

Nuclear Europe (NE). 11/86. "Dutch Set 1988 for New Decision on Nuclear," p. 35.

-1987-

Codee, H. D. K., and J. Vrigen. 1987. "Radwaste in The Netherlands." Waste Management 'B7, p. 97. March 1-5, 1987, Tucson, Arizona.

de Boer, T. C., and B. Vriesema. 1987. "Engineering Safety Aspects of the High Active Waste (HAW) Test Disposal Project in the Asse Salt Mine." Waste Management 'B7. March 1-5, 1987, Tucson, Arizona.

Glasbergen, P., 1. Nijhoff-Pan, and F. Sauter. 1987. "Comparative Site-Specific Calculation of the Migration of Radionuclides Released from a Repository in Rock Salt." Waste Management '87. March 1-5, 1987, Tucson, Arizona.

Nuclear Fuel (NF). 5/4/87. "Dutch Utilities Still Plan to Reprocess Despite Doubts by Some in Government," p. 3.

NUKEM Market Report on the Nuclear Fuel Cycle (NUKEM). 1/87. NUKEM GmbH, Hanau, Federal Republic of Germany, p. 13.

Vons, L. H. 1987. "The OPLA Research Program on the Final Disposal of Radioactive Waste in Geological Formations (Salt) in the Netherlands." In proceedings of Waste Management '87, Vol. 1, p. 673. March 1-5, 1987, Tucson, Arizona.

$-1988-$

Codee, H. D. K. 1988. "Licensing of a Central Treatment and Long-Term Storage Facility." Proceedings of Spectrum 'B8, Nuclear and Hazardous Waste Management International Topical Meeting, p. 457. September 11-15, 1988, Pasco, Washington. 
Gevers, F. 1988. "The Dutch Monitored Retrievable Storage Plans." In Proceedings of Spectrum 'B8. Nuclear and Hazardous Waste Management International Topical Meeting, p. 142. September 11-15, 1988, Pasco, Washington.

International Atomic Energy Agency (IAEA). 1988. Operating Experience with Nuclear Power Stations in Member States in 1987, Vienna.

NUKEM Market Report on the Nuclear Fuel Cycle (NUKEM). 3/88. NUKEM GmbH, Hanau, Federal Republic of Germany, p. 12.

NUKEM Market Report on the Nuclear Fuel Cycle (NUKEM). 4/88. NUKEM GmbH, Hanau, Federal Republic of Germany, p. 16.

Vrijen, J., and R. M. Van Kleef. 1988. "The Dutch Waste Management System." Proceedings of Spectrum '68, Nuciear and Hazardous Waste Management International Topical Meeting, p. 454. September 11-15, 1988, Pasco, Washington.

-1989 .

Codee, H. D. K., and I. J. Vrijen. 1989. "The Dutch Treatment and Long-Term Storage Facility for Radioactive Wastes." In Proceedings of the 1989 Joint International Waste Management Conference, Vol. 1, p. 115. October 22-28, 1989, Kyoto, Japan.

International Atomic Energy Agency (IAEA). 1989. IAEA Yearbook 1989. Vienna.

Nuclear Europe (NE). 1-2, 1989. "PIE of LWR Fuel Rods at ECN, Netherlands," p. 18.

Nucleonics Week (NW). 5/4/89. "Dutch Decision on More Nuclear Plants Delayed to 1991, at Least," p. 5.

Nucleonics Week (NW). 10/26/89. "Netherlands: ABB to Deliver Waste System," p. 17.

NUKEM Market Report on the Nuclear Fuel Cycle (NUKEM). 8/89. "Nuclear Policy, Continued Nuclear Uncertainty in the Netherlands." NUKEM GmbH, Hanau, Federal Republic of Germany, p. 4.

Onshore Disposal Committee (OPLA). 1989. Research Programme on Geological Disposal of Radioactive Waste in the Netherlands. Final Report on Phase 1, Parts 1-3. Onshore Disposal Committee, Ministry of Economic Affairs, The Hague, Netherlands.

van Montfrans, H. M. 1989. "Research Programme on Geological Disposal of Radioactive Waste in the Netherfands." Proceedings of the 28th International Geological Congress. July 9-19, 1989,

Washington, D.C.

$-1990-$

Beecher, N., and A. Rappaport. 1990. "Hazardous Waste Management Policies Overseas." Chemical Engineering Progress, May 1990, p. 30.

Leigh, I. W, and S. J. Mitchell. 1990. International Nuclear Fuel Cycle Fact Book. PNL-3594, Rev. 10, Pacific Northwest Laboratory, Richland, Washington.

Nuclear Engineering International (NEI). 3/90. "Nine New Plants in 1989," p. 12.

NUKEM Market Report on the Nuclear Fuel Cycle (NUKEM). 5/90. "Nuclear Power Plant Capacity of the Western World (GWe Net)." NUKEM GmbH, Hanau, Federal Republic of Germany, p. 22. 
PAKISTAN 
PAKISTAN

\section{PAKISTAN}

\section{CONTENTS}

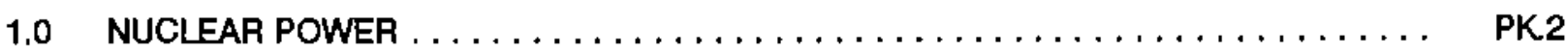

2.0 NUCLEAR FUEL CYCLE AND RADIOACTIVE WASTE MANAGEMENT

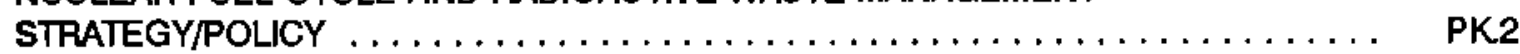

3.0 HIGHUGHTS AND MAJOR MILESTONES $\ldots \ldots \ldots \ldots \ldots \ldots \ldots \ldots \ldots \ldots$

4.0 INSTITUTIONAL CONSIDERATIONS/ORGANIZATIONS $\ldots \ldots \ldots \ldots \ldots \ldots \ldots \ldots$ PK3

5.0 NUCLEAR FUEL PRODUCTION $\ldots \ldots \ldots \ldots \ldots \ldots \ldots \ldots \ldots \ldots \ldots \ldots \ldots \ldots$

6.0 FUEL RECYCLE $\ldots \ldots \ldots \ldots \ldots \ldots \ldots \ldots \ldots \ldots \ldots \ldots \ldots \ldots \ldots \ldots \ldots \ldots \ldots \ldots$

7.0 SPENT FUEL STORAGE AND TRANSPORT $\ldots \ldots \ldots \ldots \ldots \ldots \ldots \ldots \ldots \ldots \ldots$

8.0 WASTE CONDITIONING, STORAGE AND TRANSPORT $\ldots \ldots \ldots \ldots \ldots \ldots \ldots \ldots$ PK.5

9.0 DISPOSAL OF NON-HIGH-LEVEL WASTES $\ldots \ldots \ldots \ldots \ldots \ldots \ldots \ldots \ldots$

10.0 DISPOSAL OF HIGH LEVEL WASTES $\ldots \ldots \ldots \ldots \ldots \ldots \ldots \ldots \ldots \ldots \ldots$

11.0 MANAGEMENT OF URANIUM MINE AND MILL WASTES $\ldots \ldots \ldots \ldots \ldots \ldots$

12.0 DECOMMISSIONING AND ENVIRONMENTAL RESTORATION $\ldots \ldots \ldots \ldots \ldots \ldots$ PK6

13.0 INTERNATIONAL ACTIVITIES $\ldots \ldots \ldots \ldots \ldots \ldots \ldots \ldots \ldots \ldots \ldots \ldots$

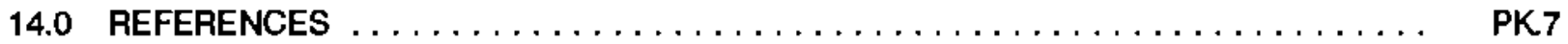




\subsection{NUCLEAR POWER}

1.1 REACTOR MIX: 1 137 MWE PHWR (CANDU) near Karachi

1300 MWe PWR from China planned for startup in 1996 (NN 1/90)

1.2 ELECTRIC POWER PRODUCTION: Total 1988: 33.0 TWh (Leigh and Mitchell 1990) Nuclear 1989: 0.07 TWh (NN 1/90)

Pakistan's total electricity production capacity in June 1988 was $6,720 \mathrm{MWe}$, and is expected to be $13,800 \mathrm{MWe}$ by year 2000 , with hydropower (the current primary power source) to be no more than 9,000 MWe (Kahn 1989)

\subsection{NUCLEAR POWER CAPACITY PROJECTIONS}

1986-0.1 GWe

1995-0.1 GWe

2000-1.1 GWe (NUKEM 1/90)

1.4 NUCLEAR PLANT AVAILABILITY: $1987-25.1 \%$ (IAEA 1988)

1.5 NUCLEAR ENERGY POLICY: Pakistan plans to expand electric power capacity with nuclear energy to be one of the major components in energy supply; Pakistan will cooperate with advanced countries in building LWRs or HWRs (Khan 1984; AlJ 4/89)

A. In 1989, Pakistan drew up a 20-year plan to develop nuclear power through reactors produced domestically via co-manufacturing arrangements with foreign companies (NEJ 8/89); Pakistan is attempting to negotiate with a number of European countries for importing PWRs (NEJ 6/B7)

B. Work has been initiated on an indigenous reactor using enriched uranium and plutonium (NEI 6/87)

C. As of 1984, Pakistan was planning to build at least five reactors of $900 \mathrm{MWe}$ each by the year 2000 (NE1 10/87)

1.6 ELECTRICITY PRODUCTION COSTS: Projected costs for electricity in 1993 are estimated as follows (Kahn 1989):

Nuclear: U.S. $\$ 1,823 / \mathrm{kW}$ capital; $\$ 0.041 / \mathrm{kW}$ operating

Oil: $\quad$ U.S. $\$ 848 / \mathrm{kW}$ capital; $\$ 0.050 / \mathrm{kW}$ operating

Coal: $\quad$ U.S. $\$ 1,220 / \mathrm{kW}$ capital; $\$ 0.047 / \mathrm{kW}$ operating

\subsection{NUCLEAR FUEL CYCLE AND RADIOACTIVE WASTE MANAGEMENT STRATEGY/POLICY}

2.1 OVERALL NUCLEAR FUEL CYCLE POLICY: As far as possible, Pakistan plans to develop indigenous fuel cycle capability; this includes uranium mining, milling, conversion, enrichment, fuel fabrication, and spent fuel reprocessing (Leigh and Mitchell 1990; AlJ 1989) 
2.2 POLICY ON THE BACK END OF THE NUCLEAR FUEL CYCLE: Store waste at the generator sites until disposal capability is available (NW 11/23/89)

\subsection{HIGHLIGHTS AND MAJOR MILESTONES}

1972 Commissioned Karachi nuclear power plant (Kannup, 137-MWe CANDU)

1980 Commissioned Chashma fuel fabrication plant

1980 Started manufacture of test fuel for Kanupp reactor (NF 8/16/82)

1984 Partial startup of Kahuta enrichment plant

1985 Installed first indigenously-fabricated fuel in Kanupp reactor

1989 Started up the second research reactor, builh indigenously with collaboration with China (NW 12/14/89)

\subsection{INSTITUTIONAL CONSIDERATIONS/ORGANIZATIONS}

\subsection{KEY AGENCIES AND FUEL CYCLE CENTERS}

A. The PAEC (Pakistan Atomic Energy Commission) is the federal commission responsible for all aspects of operation and development of Pakistan's nuclear program; its 1984-85 project budget was \$35 million U.S. (Katz 1982; NW 7/5/84)

B. The Directorate of Nuclear Safety and Radiation, established in 1984, regulates waste management facilities and operations (Orphi 1988)

C. The National Science Council, the Pakistan Science Foundation, and the Academy of Sciences all provide review and advice on nuclear programs (Katz 1982)

\subsection{PRINCIPAL RESEARCH, DEVELOPMENT AND DEMONSTRATION FACILITIES/PROGRAMS}

A. The PINSTECH (Pakistan Institute of Nuclear Science and Technology) at Islamabad, with some satellite centers: carries out research on fuel cycle, analytical chemistry, nuclear materials, metallurgy, fuel development, digital electronics, control instrumentation, computational physics, and industrial uses of radionuclides; it has a research reactor and laboratory-scale reprocessing facility (Katz 1982; Kahn 1989; Leigh and Mitchell 1990)

B. The Abdul Qadeer Khan Research Laboratory (at Kahuta near Rawalpindi): provides development of centrifuge enrichment technology and nuclear traning (NW 12/8/88)

\subsection{KEY PERSONNEL}
A. Munir Ahmad Khan, Chairman, PAEC
B. I. H. Qureshi, Director, PINSTECH 

C. Abdul Qadeer Khan, Head of Enrichment Project
D. Shahid Zafar, Minister of State for Production

\subsection{NUCLEAR FUEL PRODUCTION}

5.1 STRATEGY: Pakistan plans to develop full capability for the front end of the fuel cycle (enrichment and fuel fabrication, achieved in 1984) (NF 3/25/85)

5.2 URANIUM RESOURCES: Reserves in Punjab are reportedly sulficient to supply Kahuta enrichment plant (NF 3/25/85; Spector 1985; NW 11/13/86)

\subsection{URANIUM PRODUCTION}

A. Pakistan's mine/mill operation for uranium is to be established for the second nuclear power plant project

B. Uranium mining/milling is in operation at Lahore at Bagalchur; Dera Ghazi Khan ore processing facility (capacity $30 \mathrm{MT} /$ year) is operational; Issa Khel ore processing facility was planned as of 1987 (Spector 1985; IAEA 1987; Khan 1989)

C. Zirconium mining and processing has been in progress at Karachi since about 1979 (AlJ 4/89)

5.4 URANIUM CONVERSION: Dera Ghazi Khan uranium conversion plant, with a capacity of $198 \mathrm{MT} / \mathrm{yr}$ for uranium hexafluoride, started up in 1980; the facility is not under international safeguards (Spector 1985)

\subsection{URANIUM ENRICHMENT}

A. A centrifuge enrichment plant is located at Kahuta, near Rawalpindi, 20 miles southeast of Islamabad; an estimated 1000 centrifuges were operational at startup in 1984, with potential future 2000-3000 units; the facility is not under international safeguards (NW 2/9/84; Spector 1985; NF 6/30/86; Financial Times 12/11/87)

B. A second centrifuge facility was reportedly under construction at Golra, six miles west of islamabad as of 1987 (Financial Times 12/11/87)

C. A research and development program is under way to support the enrichment program for Pakistan's future LWR fuels (AlJ 4/89)

5.6 FUEL FABRICATION: A fuel fabrication plant (at Kundian) near the Chashma Dam over the Indus river; it has sufficient capacity for the Kanupp reactor needs; startup was in 1980; as of early 1989, the facility had made several thousand fuel bundles for the Kannup reactor; the facility is not under international safeguards (NF 8/16/82; Spector 1985; Kahn 1989) 
5.7 HEAVY WATER PRODUCTION: Pakistan has a distillation system for upgrading about $15 \mathrm{MT} / \mathrm{yr}$ of heavy water; some sources think Pakistan may have an indigenous heavy water manufacturing capability (NF 5/29/89)

\subsection{FUEL RECYCLE}

\subsection{FUEL REPROCESSING}

A. In 1974, SGN (France) accepted a PAEC order to build a 50-100 MTU/yr spent fuel reprocessing plant for installation at the Chashma site; SGN delivered the design, then cancelled the project in 1977 after completing most of the design drawings; PAEC may be proceeding with construction, but as of January 1990, PAEC is still suing SGN for not supplying the facility (NF 11/18/85; Spector 1985; NW 5/14/87; NF 1/22/90)

B. A laboratory-scale reprocessing plant is located at Rawalpindi; non-radioactive startup was in 1982; as of 1985, it was not known if the plant was operating (Spector 1985)

\subsection{SPENT FUEL STORAGE AND TRANSPORT}

7.1 SPENT FUEL ARISINGS: (Leigh and Mitchell 1990)

Through 1985-cumulative $110 \mathrm{MTU}$

Through 1990--cumulative $170 \mathrm{MTU}$, projected

Through 2000-cumulative $440 \mathrm{MTU}$, projected

7.2 SPENT FUEL STRATEGY: Spent fuel at Pakistan's only power reactor is stored onsite (NW 11/23/89)

\subsection{WASTE CONDITIONING, STORAGE AND TRANSPORT}

8.1 WASTE ARISINGS: At PINSTECH, $50-55 \mathrm{~m}^{3} / \mathrm{yr}$ of solid LLW, about $3,000 \mathrm{~m}^{3} / \mathrm{yr}$ LLLW (containing about $1200 \mathrm{mCl}$ ), about 50 liters of ILLW, and about $5 \mathrm{~m}^{3} / \mathrm{yr}$ of solid ILW are generated (Orphi 1988)

\subsection{LLW/LW CONDITIONING}

A. At PINSTECH, solid ILW from the research reactor are immobilized in cement in campaigns every 2-3 years (Orphi 1988)

B. At PINSTECH, liquid ILW are mixed with cement, sand and concrete in the ratio of 1:1.5:3, poured into a shielded mild steel container, and covered with $15 \mathrm{~cm}$ of cementsand-concrete mix; the quantity of waste is controlled to maintain a surface dose rate on the canister of no more than $200 \mathrm{mr} / \mathrm{hr}$ (Orphi 1988)

C. At PINSTECH, solid LLW are placed in double polyethylene bags for interim storage and disposal; future treatment will include a waste compactor and incinerator (Orphi 1988) 


\subsection{DISPOSAL OF NON-HIGH-LEVEL WASTES}

9.1 ILW DISPOSAL: At PINSTECH, the small quantities of cemented solid and liquid ILW are disposed of by burial in trenches (Orphi 1988)

\subsection{LLW DISPOSAL}

A. At PINSTECH, solid LLW are disposed of by burial in a trench and covered with 2 meters of soil (Orphi 1988)

B. At PINSTECH, ILLW are disposed of by pumping seepage into seepage pits in the ground onsite; the pits are $32 \mathrm{~m}$ long by $10 \mathrm{~m}$ wide by $1.6 \mathrm{~m}$ deep, with a bottom layer of gravel (Orphi 1988)

9.3 LLW/ILW DISPOSAL R\&D: R\&D was carried out at PINSTECH in collaboration with the IAEA on the adsorption of the subsolls around the PINSTECH facility (Orphi 1988)

10.0 DISPOSAL OF HIGH-LEVEL WASTES: (No intormation)

11.0 MANAGEMENT OF URANIUM MINE AND MILL WASTES: (No information)

12.0 DECOMMISSIONING AND ENVIRONMENTAL RESTORATION: (No information)

\subsection{INTERNATIONAL ACTIVITIES}

\subsection{MEMBERSHIPS: IAEA, WANO}

\subsection{COOPERATION WITH OTHER COUNTRIES}

A. Pakistan signed an agreement with China on peaceful uses of atomic energy; it included collaboration on the second research reactor (NEI 11/86; NW 12/14/89); an agreement in principle was signed with China to sell Pakistan a 300-MWe PWR of Chinese design (NF $1 / 22 / 90$ )

B. A 1974-1977 agreement was signed between Pakistan and SGN (France) to supply a small reprocessing plant but SGN cancelled the project (Spector 1985)

C. Pakistan has approached a number of countries for agreements to receive and cooperate in foreign nuclear equipment and facilities for Pakistan (AlJ 4/89)

13.3 COOPERATION WITH U.S.: The U.S. provides economic and military aid to Pakistan, but as of late 1989, a controversy has arisen because the U.S. foreign assistance act requires annual certification that the assisted country does not possess a nuclear explosive device; certification by the U.S. has been questioned; Pakistan has not signed the nuclear non-proliferation treaty (NF 11/27/89) 


\subsection{REFERENCES}

$-1982$.

Katz, J. E., and O. S. Marwah. 1982. Nuclear Power in Developing Countries. Lexington Books, D.C. Heath and Company, Lexington, Massachusetts, pp. 257-272.

Nuclear Fuel (NF). 8/16/82. "Pakistan Hopes SWR Fuel Supply Capability Will Stem from 'R\&D-Size' Enrichment Plant," p. 7.

$-1984-$

Khan, M. A. 1984. 'Nuclear Energy in Pakistan.' Nuclear Europe, July-August 1984, p. 33-34.

Nuclear Fuel (NF). 3/26/84. 'Belgians Awaiting Government Approval to Complete Pakistani Reprocessing Lab," p. 9.

Nucleonics Week (NW). 2/9/84. "Pakistan Calls for Nuclear Cooperation with India," p. 10.

Nucleonics Week (NW). 7/5/84. "Pakistan's Budget for 1984-85 Provides \$35 Million,"

$-1985-$

Nuclear Fuel (NF). 11/18/85. "ICC Ruling Said to Favor Pakistan in Reprocessing Plant Dispute," p. 1. Spector, L. S. 1985. 'Pakistan.' In The New Nuclear Nations, A Carnegie Endowment Book, Vintage Books, New York, pp. 113-130.

\section{$-1986-$}

Nuclear Engineering International (NEI). 11/86. "Pakistan Signs Pact With China," p. 9.

Nucleonics Week (NW). 11/13/86. 'Zia Orders Pakistan AEC to Design Indigenous Nuclear Reactor,' p. 3.

$$
\text { -1987- }
$$

Financial Times. 12/11/87. 'Pakistan Builds Second Plant to Enrich Uranium," p. 5.

International Atomic Energy Agency (IAEA). 1987. The Nuclear Fuel Oycle Information System. IAEATECDOC-408, International Atomic Energy Agency, Vienna, p. 76.

Nuclear Engineering International (NEI). 6/87. "Pakistan: Going it Alone?" p. 37.

Nuclear Engineering International (NEI). 10/87. "Five More for Pakistan," p. 10.

Nucleonics Week (NW). 5/14/87. "France Offers Pakistan Nuclear Plant in Reprocessing Dispute Talks," p. 1. 
$-1988$.

International Atomic Energy Agency (IAEA). 1988. Operating Experience with Nuclear Power Stations in Member States in 1987. International Atomic Energy Agency, Vienna, p. 399.

Nucleonics Week (NW). 12/8/88. "Benazir Bhutto Commits Pakistan to Peaceful Nuclear Program," p. 4.

Orphi, S. D., S. Ahmed, M. Javed, M. A. Mubarak, and M. Jamil. 1988. "Low-Level Radioactive Waste Management Practices at PINSTECH." Paper IAEA-SM-303/12P, at IAEA and CEC Symposium on Management of Low and Intermediate Level Radioactive Wastes 1988. Volume 2, May 16-20, 1988, Stockholm.

$-1989-$

Atoms in Japan (AJJ). April 1989. "JAIF Annual Conference: Nuclear Energy in Modern History: Missions and Issues," p. 9.

Kahn, M. A. 1989. 'Nuclear Energy Developments in Pakistan - Policy Prospects and Problems,' Preserted at The 22nd Annual JAIF Conference. April 12-14, 1989, Japan Atomic Industrial Forum, Tokyo.

Nuclear Engineering International (NEI). 8/89. "Pakistan Looks to Co-Manufacture," p. 12.

Nuclear Fuel (NF). 5/29/89. "Incident in Pakistan Raises Questions About Source of Heavy Water Supply," p. 8.

Nuclear Fuel (NF). 11/27/89. 'Glenn Calls For Cutback in Pakistan Aid Unless U.S. Gets Safeguards Assurances," p. 5.

Nucleonics Week. 11/23/89. "China Agrees to Supply 300-MW PWR to Pakistan;" p. 1.

Nucleonics Week. 12/14/89. "Pakistan: Research Reactor Inaugurated," p. 15.

$-1990$.

Leigh, I. W., and S. J. Mitchell. 1990. International Nuclear Fuel Cycle Fact Book. PNL-3594, Rev. 10, Pacitic Northwest Laboratory, Richland, Washington, p. PK-t.

Nuclear Fuel. 1/22/1990. "France, Pakistan May Soon Settle Dispute Over Reprocessing Plant," p. 4.

Nuclear News. January 1990. "China to Supply PWA in 300 MWe Range," p. 73.

NUKEM Market Report on the Nuclear Fuel Cycle (NUKEM). 1/90. NUKEM GmbH, Hanau, Federal Republic of Germany, p. 20.

Nucleonics Week (NW). 2/8/90. 'Nuclear Electricity Generation for December 1989,' p. 17. 


\section{SOUTH AFRICA}




\section{SOUTH AFRICA}

\section{CONIENTS}

1.0 NUCLEAR POWER $\ldots \ldots \ldots \ldots \ldots \ldots \ldots \ldots \ldots \ldots \ldots \ldots \ldots \ldots \ldots \ldots$

2.0 NUCLEAR FUEL CYCLE AND RADIOACTIVE WASTE MANAGEMENT

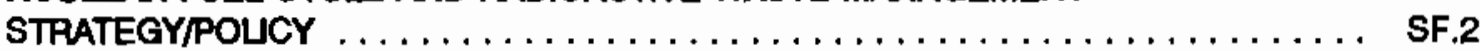

3.0 HIGHUGHTS AND MAJOR MILESTONES $\ldots \ldots \ldots \ldots \ldots \ldots \ldots \ldots \ldots$

4.0 INSTITUTIONAL CONSIDERATIONS/ORGANIZATIONS $\ldots \ldots \ldots \ldots \ldots \ldots \ldots \ldots$ SF.4

5.0 NUCLEAR FUEL PRODUCTION $\ldots \ldots \ldots \ldots \ldots \ldots \ldots \ldots \ldots \ldots \ldots \ldots \ldots$

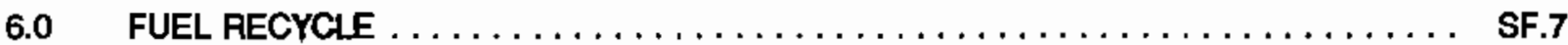

7.0 SPENT FUEL STORAGE AND TRANSPORT $\ldots \ldots \ldots \ldots \ldots \ldots \ldots \ldots \ldots \ldots$ SF.7

8.0 WASTE CONDIIONING, STORAGE AND TRANSPORT $\ldots \ldots \ldots \ldots \ldots \ldots \ldots \ldots$ SF.8

9.0 DISPOSAL OF NON-HIGH-LEVEL WASTES $\ldots \ldots \ldots \ldots \ldots \ldots \ldots \ldots \ldots \ldots \ldots$

10.0 DISPOSAL OF HIGH-LEVEL WASTES $\ldots \ldots \ldots \ldots \ldots \ldots \ldots \ldots \ldots \ldots \ldots \ldots \ldots \ldots$

11.0 MANAGEMENT OF URANIUM MINE AND MILL WASTES $\ldots \ldots \ldots \ldots \ldots \ldots \ldots$ SF.10

12.0 DECOMMISSIONING AND ENVIRONMENTAL RESTORATION $\ldots \ldots \ldots \ldots \ldots \ldots$ SF.10

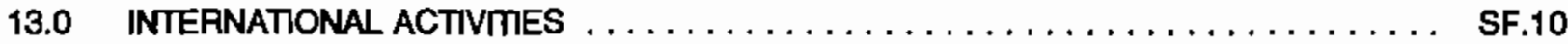

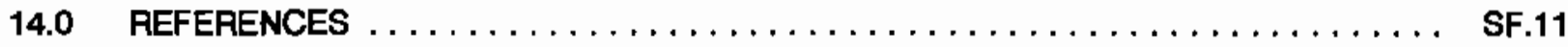




\subsection{NUCLEAR POWER}

1.1 REACTOR MIX: 2 PWRs (French supplied) (NEI 1989)

\subsection{ELECTRIC POWER PRODUCTION}

1986--126.8 TWh (7\% nuclear) (Leigh and Mitchell 1989)

\subsection{NUCLEAR POWER CAPACITY PROJECTIONS (NUKEM 2/90)}

1989--1.8 GWe

$1995 \sim 1.8 \mathrm{GWe}$

2000--1.8 GWe

\subsection{NUCLEAR PLANT AVAILABILITY (NEI 4/90)}

$1989-47.6 \%$ for Koeberg 1; lifetime through 12/89

$-59.2 \%$ for Koeberg 2; lifetime through $12 / 89$

\subsection{NUCLEAR ENERGY POLICY (Leigh and Mitchell 1989; NUKEM 5/89a)}

South Africa intends to expand electric power production capacity to match market demand chiefly through coal-burning plants in the near future; it will develop and maintain its domestic capability for electricity production by nuclear power to eventually replace the coal-burning facilities in the 2050 time frame

1.6 NUCLEAR R\&D BUDGET: No information

\subsection{ELECTRICITY PRODUCTION COSTS}

$1987--5.18$ cents/kWh sold (ESKOM 1988)

\subsection{NUCLEAR FUEL CYCLE AND RADIOACTIVE WASTE MANAGEMENT STRATEGY/POLICY}

\subsection{OVERALL NUCLEAR FUEL CYCLE POLICY}

South Africa intends to develop the domestic capability to produce electricity by nuclear power based upon the once-through fuel cycle (no reprocessing or recycle of fissile material); radioactive wastes are to be managed using the conventional techniques of volume reduction, packaging, interim storage transportation and disposal in both near-surface and deep geologic facilities (de Villiers 1986; Spencer 1988)

\subsection{POLICY ON THE FRONT END OF THE NUCLEAR FUEL CYCLE}

The Republic of South Africa is self-sufficient in uranium and has developed the conversion, enrichment, and fuel fabrication capabilities sufficient for its needs until new reactors are constructed (de Villiers 1986) 


\subsection{POLICY ON THE BACK END OF THE NUCLEAR FUEL CYCLE}

The Republic of South Africa has established waste collection centers for low- and intermediatelevel wastes at its Pelindaba R\&D center and the Vaalputs disposal site; wastes are treated and packaged for near-surface disposal at Pelindaba and the Vaalputs arid site in the northeast part of the country (van der Westhuizen 1986)

Spent fuel discharged from the Koeberg reactors is presently stored in water pools at the reactors; eventually, the spent fuel will be moved to a dry, near-surface interim storage facility to be located adjacent to the present disposal facility for low- and intermediate-level wastes at Vaalputs; interim storage of 30 to 40 years is contemplated (NF 3/24/86; NWS 10/20/88; Spencer 1988)

The suitability of Vaalputs for the disposal of spent fuel or high-level wastes is being pursued; it is low priority since such a disposal facility will not be needed in the near future (van der Westhuizen 1986)

3.0 HIGHLIGHTS AND MAJOR MILESTONES (de Villiers 1986; Brynard 1988; NF 7/25/88; FOCUS $5 / 89$ )

1948 The Atomic Energy Act was promulgated and the Atomic Energy Board (AEB) was established

1961 Construction started on Pelindaba Nuclear Research Center about $20 \mathrm{~km}$ west of Pretoria

1965

Safari-1 research reactor goes critical at Pelindaba

1965 The nuclear fuels corporation of South Africa (NUFCOR) was established to negotiate uranium sales contracts on behalf of the Chamber of Mines

1967 The feasibility of a domestically developed vortex-tube enrichment process was demonstrated

1970

The uranium enrichment corporation of SF Ltd (UCOR) was created at Pelindaba, adjacent to Pelindaba site

1976 Site work was started for two Koeberg power stations near Capetown

1979 The search for a radioactive waste disposal site started

1981 The Safari-1 research reactor was loaded with domestically produced fuel elements

1982 All nuclear activities were combined under control of the Atomic Energy Corporation of SF Ltd (AEC) with UCOR and the AEB, renamed the Nuclear Development Corporation of SF Ltd (NUCOR), as subsidiaries

1982 The Council for Nuclear Safety (CNS) was established to provide independent oversight of nuclear activities and final approval for licenses 
1984-85 The Koeberg 1 \& 2 reactors began producing commercial power

1985 UCOR and NUCOR were brought under the AEC as the Nuclear Fuels Department and the Nuclear Research and Development Department, respectively, along with a new Corporate Services Department

1986 Disposal of low- and intermediate-level wastes began at Vaalputs

1988 The semi-commercial enrichmont plant began operation in 8/88 (NF 10/30/89)

1988 The Council for Nuclear Safety (CNS) was empowered as the independent regulatory agency.

1989 Domestically produced reload fuel was provided for the Koeberg reactors (NF 10/30/89)

1994 Startup of dry spent fuel storage facility at Vaalputs

\subsection{INSTITUTIONAL CONSIDERATIONS/ORGANIZATIONS}

\subsection{LEGAL REQUIREMENTS}

A. The Nuclear Energy Act No. 92 of 1982 requires that any activity involving use of nuclear materials in South Africa must be licensed (Simpson 1986)

B. The Nuclear Energy Amendment Act No. 56 of 1988 empowered the CNS to act as the independent regulatory agency for nuclear installations

\subsection{RADIATION PROTECTION PRINCIPLES (Simpson 1986)}

A. The risks presented by a nuclear plant must not increase significantly the total population risk

B. The nuclear risks must compare favorably with those associated with other major industrial enterprises

C. Allowances must be made for a possible increase in the standards of safety demanded by society over the period - usually several decades - represented by the working life of the plant; this point has particular relevance to radwaste disposal facilities in South Africa

\subsection{LICENSING (Simpson 1986)}

A. Under the Nuclear Energy Act No. 92 of 1982 the Atomic Energy Corporation of South Africa, Ltd (AEC) was granted the responsibility for issuing licenses for nuclear activities; at that time, no license could be issued without approval of the independent CNS

B. The Nuclear Energy Amendment Act of 1988 transferred the responsibility for licensing from the AEC to the CNS (NEA 1989)

4.4 PUBLIC INVOLVEMENT: No information 
SOUTH AFRICA

\subsection{WASTE MANAGEMENT FUNDING}

A. In South Africa, the costs of providing facilities for disposal of radioactive wastes and offsite storage of spent fuel must be bome by the user (van der Westhuizen 1986)

\subsection{KEY AGENCIES AND FUEL CYCLE CENTERS}

A. Control and regulation of all nuclear materials and activities financed by the South African govemment is the responsibility of the AEC, a government organization reporting to the Ministry of Mineral and Energy Affairs (de Villiers 1986)

1) The AEC performs nuclear R\&D and operates nuclear facilities at Pelindaba, 18 miles west of Pretoria; facilities include a technical center, Safari-1 research reactor, isotope production line, waste treatment and disposal facility for low-level wastes, and a food irtadiation facility

2) The AEC performs R\&D on and operetes uranium enrichment facilities at Pelindaba adjacent to the Pelindaba site

3) The AEC performs site characterization and environmental studies and operates disposal facilities for low- and intermediate-level wastes at the Vaalputs arid site 375 miles north of Capetown

4) The AEC is building a new R\&D center (Gouriqua) on the Indian Ocean coast, 45 kilometers west of Mossel Bay; informed sources say an indigenously designed research reactor will likely be built there (NW 2/27/86)

B. Control and regulation of fabricated isotopes used outside of nuclear installations is the responsibility of the Department of National Health and Community Development (de Villiers 1986; van der Westhuizen 1986)

C. The CNS is an independent body advising the Minister of Mineral and Energy Affairs on nuclear safety matters (de Villiers 1986)

D. Reactor plant procurement and operation is the responsibility of the Electricity Supply Commission of South Africa (ESCOM)

1) ESCOM operates the two 922-MWe PWRs of French design at Koeberg near Capetown

2) ESCOM recently acquired a new power station site at Cape St. Francis, west of Port Elizabeth on the Cape east coast (NW 5/11/89; NEI 12/89)

E. The Nuclear Fuels Corporation of South Africa Ltd. has the responsibility for negotiating production and refining uranium ore with domestic mining firms and negotiating sales contracts

\subsection{PRINCIPAL RESEARCH, DEVELOPMENT AND DEMONSTRATION FACILITIES/PROGRAMS}

A. The Nuclear Research and Development Department of the AEC conducts numerous activities at the National Nuclear Research Center located at Pelindaba; the facilities located at Pelindaba include a technical center with R\&D laboratories, the Safari-1 research and materials testing reactor, a computing center, and facilities for fuel 
fabrication, isotope production, food irradiation, waste treatment and disposal; the R\&D conducted covers uranium recovery, fuel fabrication techniques, isotope applications, and basic studies in the numerous technical areas (NUCOR 1985)

B. The Nuclear Fuels Department of the AEC conducts development and demonstration programs on uranium enrichment at the Valindaba site adjacent to the Nuclear Research and Development Center at Pelindaba; the major facility at this site is the 300,000-SWU/yr enrichment facility buitt on the Helikon centrifuge design; this facility began operation on a semi-commercial basis in late 1989 (NF 10/2/89); a pilot plant enrichment facility, commissioned in 1978 to provide $45 \%$ enriched fuel for the Safari-1 research reactor, was shut down in 1990 (NF 5/14/90); a UF $_{6}$ conversion pilot plant has been expanded to provide feedstock for the enrichment facility (NF 7/25/88)

C. The Nuclear Research and Development Department of the AEC conducts R\&D programs at the National Radioactive Waste Disposal Facility (Naalputs), located 375 miles north of Capetown; detailed geotechnical and environmental studies were conducted to characterize the site which began operation in November 1986; these studies continue to monitor disposal operations and evaluate the site for storage and disposal of high-level waste (van der Westhuizen 1986)

4.8 KEY PERSONNEL (Leigh and Mitchell 1990; NEI 11/89)

A. Dr. W. E. Stumpf, Chief Executive Officer, Atomic Energy Corporation (AEC)

B. Dr. J. J. Wannenburg, Senjor General Manager, Nuclear Fuel Production, AEC

C. Dr. D. M. Kemp, Senior General Manager, Research and Development, AEC

D. L S. Snyder, Senior General Manager, Engineering, AEC

E. H. J. van der Westhuizen, Manager, Nuclear Waste Technology, AEC

F. J. Maree, Chairman, Electricity Council, ESKOM

G. I. C. Mcrae, Chief Executive, ESKOM

H. J. M. van Riet Lowe, General Manager, NUFCOR

I. Prof. J. B. Martin, Chairman, Council for Nuclear Safety

J. J. O. Tattersall, Executive Officer/General Manager, Licensing, Council for Nuclear Safety

\subsection{NUCLEAR FUEL PRODUCTION}

5.1 STRATEGY: South Africa plans to develop self-sufficiency in the nuclear fuel cycle and market uranium and enrichment services (Brynard 1988)

5.2 URANIUM RESOURCES: 1987--536,500 MTU reasonably assured (Brynard 1988) 


\subsection{URANIUM PRODUCTION}

A. South Atrica has 17 uranium ore processing facilities with a total capacity of $7,900 \mathrm{MT} / \mathrm{yr}$; of these, 9 representing a capacity of $4,450 \mathrm{MT} / \mathrm{yr}$ were operational in 1989 (NEI 11/89)

B. South Africa's uranium production amounted to 3,000 MT/yr in 1990 (NUKEM 3/90)

C. Sanctions against the South African govemment have had a direct impact on the country's uranium mining industry; output from the NUFCOR calcining plant has dropped from about 4,500 MT/yr in 1987 to just under 2,900 MT/yr in 1989; currently six mines are supplying slurry for processing, down from ten mines in 1986 (NUKEM 2/90)

5.4 URANIUM CONVERSION: 1988-700 MTU/yr at Valindaba (NEI 11/89)

5.5 URANIUM ENRICHMENT: 1989-300,000 SWU/yr at Valindaba (NF 10/2/89; NEl 11/89)

\subsection{FUEL FABRICATION}

1981-Safari-1 was fueled with locally manufactured fuel (Brynard 1988)

1988-fueled Koeberg reactors were fueled with locally manufactured fuel (FOCUS 1989)

5.7 HEAVY WATER PRODUCTION: No information

5.8 PROGRAM/FACILJTES COSTS: No information

\subsection{FUEL RECYCLE}

6.1 FUEL REPROCESSING: No plans (de Villiers 1986; NWS 10/20/88)

6.2 PLUTONIUM RECYCLE: No information

6.3 RESEARCH AND DEVELOPMENT: No information

6.4 PROGRAM/FACILITES COSTS: No information

\subsection{SPENT FUEL STORAGE AND TRANSPORT}

7.1 SPENT FUEL ARISINGS: $200 \mathrm{MTU}$ through 1989 (estimated)

7.2 FUEL ASSEMBLY CHARACTERISTICS: $21.4 \mathrm{~cm} \times 21.4 \mathrm{~cm} \times 42.5 \mathrm{~cm}$ long; 264 rods per assembly; $\mathrm{UO}_{2}$ pellets; $3.25 \%$ enrichment; zircalloy 4 cladding (ESCOM 1982; NEI 11/89)

7.3 SPENT FUEL STRATEGIES: High-density interim storage for 10-14 years will be in water pools at Koeberg reactors followed by interim storage of consolidated spent fuel in dry casks at the Vaalputs site (FOCUS 5/89; Spencer 1986; van der Westhuizen 1986; Spencer 1988)

7.4 WET STORAGE: Spent fuel pools at Koeberg reactor site can store 1100 fuel assemblies (500 MTU) with present compact rack design; design is near the criteria limit for a Safe Shutdown Earthquake, eliminating potential for storing consolidated spent fuel in pools (Spencer 1986) 
7.5 DRY STORAGE: South Africa is negotiating with suppliers of metal casks (GNS Castor $V$ cask each capable of holding 21 PWR fuel assemblies) for interim storage at Vaalputs (NF $3 / 24 / 86$ )

7.6 TRANSPORT: No information

7.7 RESEARCH AND DEVELOPMENT: No information

7.8 PROGRAM/FACILITIES COSTS: No information

\subsection{WASTE CONDITIONING, STORAGE AND TRANSPORT}

8.1 WASTE DEFINITIONS: No information

\subsection{WASTE ARISINGS}

A. Pelindaba disposes of wastes arising from operations at Pelindaba and institutional sources; by $1986,9,500 \mathrm{~m}^{3}$ containing $600 \mathrm{GBq}$ (about $16 \mathrm{Ci}$ ) of waste, mostly uranium, had been buried (van der Westhuizen 1986)

B. Vaalputs disposes of wastes from Koeberg, Valindaba and institutional sources close to that site; $1470 \mathrm{M}^{3}$ is disposed of per year (van der Westhuizen 1986)

8.3 WASTE MANAGEMENT STRATEGY: Otfsite storage and disposal of radioactive waste is the responsibility of the state but the waste generator covers the cost of management; shallow-land burial is used for disposal of low- and intermediate-level wastes; a decision has not been reached on disposal of spent fuel or high-level wastes; all sites must be licensed and have an environmental monitoring and measuring program (Simpson 1986; van der Westhuizen 1986)

8.4 HLW IMMOBILIZATION: Not perfomed (van der Westhuizen 1986)

6.5 SPENT FUEL CONDITIONING: Spent fuel is to be consolidated for interim storage in dry casks at Vaalputs (Spencer 1986)

\subsection{LLW/ILW CONDITIONING:}

A. Conditioning of wastes at Pelindaba includes the following processes (van der Westhiuzen 1986; Barbour 1966a; Barbour 1966b):

1) Low-level liquid wastes are treated in a $100 \mathrm{~m}^{3} / 8 \mathrm{hr}$ shift chemical plant by means of $\mathrm{Al}(\mathrm{OH})_{3}$ and $\mathrm{Fe}(\mathrm{OH})_{3}$ coprecipitation, and on average a $90 \%$ removal of radioactivity and metal contaminants is achieved; the sludge is drummed as low-level waste

2) Intermediate-level liquid wastes are processed through one of two evaporators; high-volume, low-salt wastes are evaporated in a vapor-recompression forcedcirculation evaporator with a capacity of $10 \mathrm{~m}^{3} / 8 \mathrm{hr}$ shitt; small volumes of higher salt-content waste generated mainly by the ion-exchange columns of the Safari reactor cleanup systems are evaporated in a steam-heated convection-circulated evaporator with a capacity of $2.5 \mathrm{~m}^{3} / 8 \mathrm{hr}$ shitt; small quantities of intermediatelevel liquid wastes are solidified directly in a mixture of cement and vermiculite; the evaporator concentrates are batched and solidified by a vacuum-intrusion process 
3) Compressible solid waste is compacted by means of a 6-ton baling press into 100 -iter motal drums

4) Sealed sources of short-half-life isotopes are sealed in stainless steel canisters and disposed of in a pipe disposal facility embedded in concrete

5) $\mathrm{CaF}_{2}$ sludge contaminated with uranium is disposed of in concrete-lined pits in the disposal facility

B. At the Koeberg site, low- and intemediate-level wastes arise from the liquid cleanup systems and maintenance activities at the site; conditioning includes (Spencer 1986):

1) Liquid concentrates from the evaporators and ion exchange systems immobilized in concrete and packaged in metal ( $0.59 \mathrm{~m}$ diameter by $0.88 \mathrm{~m}$ high) or concrete (1.1 to $1.4 \mathrm{~m}$ diameter by $1.3 \mathrm{~m}$ high) drums

2) Solid wastes packaged in wooden boxes $(0.5 \mathrm{~m}$ by $0.5 \mathrm{~m}$ by $1.0 \mathrm{~m}$ high; $0.85 \mathrm{~m}$ by $0.85 \mathrm{~m}$ by $0.180 \mathrm{~m}$. high; $2.0 \mathrm{~m}$ by $2.0 \mathrm{~m}$ by $2.0 \mathrm{~m}$ high) or metal (same as above) drums; some are compacted into a metal drum

C. At Vaalputs, liquid wastes from decomtamination of incoming waste packages will be immobilized in cement and vermiculite, as it is at Pelindaba (van der Westhuizen 1986)

\subsection{AIRBORNE WASTES TREATMENT AND IMMOBILZATION: No information}

\subsection{LLW/LW STORAGE}

A. No information is available on waste storage at Pelindaba

B. The storage building at Koeberg reactors can accommodate five years of waste production-3000 concrete orums and 7500 metal drums; the building includes a six-ton crane and capability for remote handling of waste packages (Spencer 1986)

C. The waste receiving building at Vaalputs includes two areas (estimated at $5,000 \mathrm{ft}^{2}$ ), one shielded, for temporary storage of waste packages (van der Westhuizen 1986)

\subsection{HLW STORACE; Not applicable}

\subsection{TRANSPORT OF WASTES}

A. No information on transport of wastes to Pelindaba is available

B. ESCOM has procured a special-purpose semi-trailer truck for transporting low- and intermediate-level wastes from Koeberg to Vaalputs; payload is 4 concrete orums and 16 metal drums; the unit is $12.25 \mathrm{~m}$ long by $2.44 \mathrm{~m}$ wide by $2.8 \mathrm{~m}$ high; a trip takes 8-9 hours and 3 trips are made each week; two drivers are provided (Spencer 1986)

8.11 MIXED WASTE CONDMONING,STORAGE AND TRANSPORTATION: No information

8.12 RESEARCH AND DEVELOPMENT: No information 
8.13 PROGRAM/FACILTEES COSTS: No intormation

\subsection{DISPOSAL OF NON-HIGH-LEVEL WASTES}

9.1 STRATEGY: South Africa plans to dispose of low- and intermediate-level wastes by shallowland burial at Pelindaba and Vaalputs (van der Westhuizen 1986)

9.2 WASTE DISPOSAL CRITERIA: The disposal site must be licensed, requiring site characterization, risk studies by both the licensee and the licensing agency, and monitoring of construction and operation (Simpson 1986); the license for Vaalputs has a limit on total inventory but not on radionuclides, except for transuranics (van der Westhuizen 1986)

9.3 ILW DISPOSAL: Intermediate-level wastes are solidified in concrete and packaged in concrete casks for disposal in the shallow-land site at Vaalputs (van der Westhuizen 1986)

9.4 LLW DISPOSAL (van der Westhuizen 1986)

A. Low-level wastes are disposed of by shallow-land burial at Pelindaba; sludges and solid wastes are buried in drums or boxes; low-level liquid wastes are solidified in vermiculite/ cement and packaged in metal drums for disposal

B. The disposal facility at Pelindaba is on a high ridge, called Radiation Hill, where the possibility of flooding is eliminated; trenches are $5 \mathrm{~m}$ deep and the water table is at a depth of $\mathbf{4 0}$ to $45 \mathrm{~m}$

9.5 UW/LW DISPOSAL R\&D: Four experimental trenches have been evaluated at Vaaiputs to obtain data for selecting excavation techniques, methods of backfilling, trench cap design, and rehabilitation methods (Hambleton-Jones 1986)

9.6 PROGRAM/FACIUTIES COSTS: The cost of the waste-receiving facility at Vaalputs is quoted at $\$ 1,500,000$ U.S. (Lakey 1986)

10.0 DISPOSAL OF HIGH-LEVEL WASTES: No information

11.0 MANAGEMENT OF URANIUM MINE AND MILL WASTES: No information

12.0 DECOMMISSIONING AND ENVIRONMENTAL RESTORATION: No information

\subsection{INTERNATIONAL ACTIVITIES}

\subsection{MEMBERSHIPS: IAEA}

13.2 COOPERATION WITH MULTNATIONAL AGENCIES: Safari-1 research reactor and Koeberg reactors are under IAEA safeguards, but the Valindaba enrichment plant is not (NF 6/29/87; NF 10/2/89)

13.3 COOPERATION WITH USA: The USA imposed economic sanctions against South Africa on 12/31/86, which ended cooperation on nuclear materials and technical data (NUKEM 10/86)

13.4 COOPERATION WITH OTHER COUNTAIES: No information 


\subsection{REFERENCES}

$-1966-$

Barbour, R. A. 1966a. "Review of New Developments in the Field of Low and Intermediate Radioactive Waste Disposal in the Republic of South Africa.' In Proceedings of the IAEAJENEA Symposium on Practices in the Treatment of Low- and Intermediate-Level Radioactive Wastes, pp. 911-919. December 6-10, 1965, Vienna.

Barbour, R. A., and D. J. Ayre. 1966b. The Treatment of Radioactive Waste at the South African National Research Centre, Pelindaba" In Proceedings of the IAEAEENEA Symposium on Practices in the Treatment of Low- and Imtermediate-Level Radioactive Wastes, pp. 127-146. December 6-10, 1965, Vienna.

$-1982$.

ESCOM. 1982. Koeberg Nuclear Power Station. Brochure published by the Public Relations Division of ESCOM, Johannesburg, South Africa.

$-1985-$

NUCOR. 1985. Brochure compiled, designed and printed by the Public Relations Division of the Nuclear Research and Development Department of the Atomic Energy Corporation of South Africa, Pretoria, South Africa.

$-1986-$

de Villiers, J. W. L 1986. "South Africa's Research and Development Program." In Proceedings of the Conference on the Treatment and Comtainment of Radioactive Waste and Its Disposal in Arid Environments: RADWASTE '86, pp. 13-23. September 7-12, 1986, Capetown, South Africa.

Hambleton-Jones, B. B., and P. E. Moore. 1986. 'Design Criteria for Experimental Radioactive Waste Disposal Trenches at the Vaalputs Radioactive Waste Disposal Facility." In Proceedings of the Conference on the Treatment and Containment of Radioactive Waste and lts Disposal in Arid Environments: RADWASTE ' 86 , pp. 436-460. September 7-12, 1986, Capetown, South Africa.

Lakey, L T. 1986. "Foreign Travel Report, August 29-September 17, 1986." Pacific Northwest Laboratory, Fichland, Washington.

Nuclear Energy Agency (NEA). 1986. Uraniuin Resources, Production and Demand. OECD/Nuclear Energy Agency, Paris.

Nuclear Fuel (NF). 3/24/86. "South Africa's Aim is 'Selt-Sufficiency' as AEC Studies Casks and Reprocessing,' pp. 1-2.

Nucleonics Week (NW). 2/27/86. "South Africa Will Offer SWU on the World Market in 1988," pp. 1-2.

Simpson, D. M., and E. L Langford. 1986. "Safety and Licensing Requirements in the Republic of South Africa.' In Proceedings of the Conference on the Treatment and Containment of Radioactive Waste and lts Disposal in Arid Emvironments: RADWASTE '86, pp. 809-824. September 7-12, 1986, Capetown, South Africa, 
Spencer, P. H., H. F. Rohm, and M. I. J. Harris. 1986. "Radioactive Waste Disposal: Solutions Pursued in South Africa by ESCOM." In Proceedings of the Conference on the treatment and Containment of Radioactive waste and its Disposal in Arid Environments: RADWASTE '86, pp. 851-878. September 7-12, 1986, Capetown, South Africa.

van der Westhuizen, H. J., and P. E. Moore. 1986. "Radioactive Waste Disposal in South Africa." In Proceedings of the Conference on the Treatment and Containment of Radioactive Waste and lts Disposal in Arid Environments: RADWASTE '86, pp. 963-982. September 7-12, 1986, Capetown, South Africa.

$-1987$.

Nuclear Fuel (NF). 6/29/87. 'IAEA, South Africa Have Different Views on Who Broke Off Safeguards Negotiations," p. 5.

$-1988-$

Brynard, H. J., L. C. Ainslie, and P. J. van der Merve. 1988. URANIUM IN SOUTH AFRICA: 1987. ISBN 0-86960-857-6, June 1988, The Atomic Energy Corporation of South Africa, Pretoria, South Africa.

ESKOM. 1988. ESKOM's 1987 Statistical Yearbook. ESCOM, Johannesburg, South Africa.

Nuclear Fuel (NF). 7/25/88. "Govemment Reports 13.9\% Decline in South African U Production in 1987,' p. 9.

Nuclear Waste News (NWS). 10/20/88. "South Africa Opts for Once-Through Nuclear Cycle with 30to 40-Year Storage,' p. 338.

Spencer, P., and H. Rohm. 1988. "Interim Storage - the Precursor to Disposal of Spent Fuel." In Proceedings of the Thirteenth International Symposium, Uranium and Nuclear Energy: 1988, pp. 193198. September 7-9, 1988, Uranium Institute, London.

$-1989-$

FOCUS. 5/89. "NUCLEAR ENERGY: SA Nuclear Plant Exceptional." Focus on South Africa. South African Department of Foreign Affairs, Pretoria, Republic of South Africa.

Nuclear Energy Agency (NEA). June 1989. Nuclear Law. OECD/Nuclear Energy Agency, Paris, pp. 75-76.

Nuclear Engineering International (NEI). 11/89. "World Nuclear Industry Handbook; 1990," supplement to monthly issue.

Nuclear Engineering International (NEl). 12/89. "Eskom Considers New Nuclear Sites," p. 6.

Nuclear Fuel (NF). 10/2/89. "Soviets Say They Have Got Assurances That South Africa Will Adhere to NPT," p. 5.

NUKEM Special Report (NUKEM). 5/89a. "The Nuclear Power Plant Capacities of Individual Countries." NUKEM GmbH, Hanau, Federal Republic of Germany, p. 20. 
SOUTH AFRICA

Nucieonics Week (NW). 5/11/89. South Africa's ESCOM Expects No Nuclear Power Order Before $1994, "$ p. 9.

\section{$-1890-$}

Leigh, I. W., and S. J. Mitchell. 1990. Intemational Nuclear Fuel Cycle Fact Book. PNL-3594, Rev. 10, Pacific Northwest Laboratory, Richtand, Washington.

Nuclear Engineering Internationat (NEI). 4/90. 'Annual Review of Load Factor Trends,' pp. 12-18.

Nuclear Fuel (NF). 5/14/90. 'Clasing of Pilot Enrichment Facility Seen as Sign that South Africa Will Sign NPT'" pp. 1, 14.

NUKEM Market Report on the Nuctear Fuel Cycle (NUKEM). 2/90. "Nuclear Power Plant Capacity of the Western World." NUKEM GmbH, Hanau, Federal Republic of Germany, pp. 28-29.

NUKEM Market Report on the Nuclear Fuel Cycle (NUKEM). 3/90. "Uranium Production of the Western World." .NUKEM GmbH, Hanau, Federal Republic of Germany, pp. 3,5. 

SPAIN 


\section{SPAIN}

\section{CONTENTS}

$1.0 \quad$ NUCLEAR POWER $\ldots \ldots \ldots \ldots \ldots \ldots \ldots \ldots \ldots \ldots \ldots \ldots \ldots \ldots \ldots \ldots$

2.0 NUCLEAR FUEL CYCLE AND RADIOACTIVE WASTE MANAGEMENT

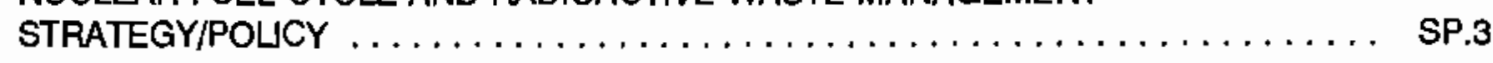

3.0 HIGHUGHTS AND MAJOR MILESTONES $\ldots \ldots \ldots \ldots \ldots \ldots \ldots \ldots \ldots \ldots$

4.G INSTITUTIONAL CONSIDERATIONS/ORGANIZATIONS $\ldots \ldots \ldots \ldots \ldots \ldots \ldots \ldots$ SP.4

5.0 NUCLEAR FUEL PRODUCTION $\ldots \ldots \ldots \ldots \ldots \ldots \ldots \ldots \ldots \ldots \ldots \ldots$

6.0 FUEL RECYCLE $\ldots \ldots \ldots \ldots \ldots \ldots \ldots \ldots \ldots \ldots \ldots \ldots \ldots \ldots \ldots \ldots$

7.0 SPENT FUEL STORAGE AND TRANSPORT $\ldots \ldots \ldots \ldots \ldots \ldots \ldots \ldots \ldots \ldots$

8.0 WASTE CONDITIONING, STORAGE AND TRANSPORT $\ldots \ldots \ldots \ldots \ldots \ldots \ldots$ SP.10

9.0 DISPOSAL OF NON-HIGH-LEVEL WASTES $\ldots \ldots \ldots \ldots \ldots \ldots \ldots \ldots \ldots \ldots$

10.0 DISPOSAL OF HIGH-LEVEL WASTES $\ldots \ldots \ldots \ldots \ldots \ldots \ldots \ldots \ldots \ldots \ldots \ldots$ SP.12

11.0 MANAGEMENT OF URANIUM MINE AND MILL WASTES $\ldots \ldots \ldots \ldots \ldots \ldots \ldots$ SP.14

12.0 DECOMMISSIONING AND ENVIRONMENTAL RESTORATION $\ldots \ldots \ldots \ldots \ldots \ldots \ldots$ SP.14

13.0 INTERNATIONAL ACTIVTIES $\ldots \ldots \ldots \ldots \ldots \ldots \ldots \ldots \ldots \ldots \ldots \ldots \ldots \ldots$ SP.15

14.0 REFERENCES $\ldots \ldots \ldots \ldots \ldots \ldots \ldots \ldots \ldots \ldots \ldots \ldots \ldots \ldots \ldots \ldots \ldots \ldots \ldots$ 


\subsection{NUCLEAR POWER}

\subsection{REACTOR MIX}

2 BWRs, 7 PWRs (two new reactors in 1988)(NN 8/90)

The GCR, Vandellos 1, was closed in October 1989 because of a severe fire (NN 7/90); in early 1990 , it was officially closed permanently and is to be decommissioned (NUKEM 7/90)

\subsection{ELECTRIC POWER PRODUCTION}

1987--133,100 GWh (31\% nuclear, $42 \%$ coal, 21\% hydro/geoth, $6 \%$ oil/gas) (Leigh and Mitchell 1990)

$1988-133,800$ GWh (36\% nuclear) (NUKEM 7/90)

1989m-139,800 GWh (38\% nuclear) (NUKEM 7/90)

A. The country's utilities want the electricity-supply industry to be restructured; ENDESA, the state-operated utility which sells wholesale power to the private utilities, is seen by some of them to have an unfair advantage; in 1989 the government announced it would prepare a study on how to restructure the industry, with indications in 1990 that it will be reduced to three utilities in total (NUKEM 7/90)

B. The latest expert opinion in Spain forecasts that the present rate of growth in energy demand will lead to shortages in domestic electricity by 1994, 2 years ahead of official estimates; Spanish utilities are signing electricity supply contracts with France to minimize the risks of shortages (NN 7/90); REDESA (Red Electra Espanola), which controls the Spanish national grid, signed a $\$ 4$ billion contract with Electricite de France (EdF) to supply electricity to Spain; EdF will make available up to 1,000 MWe of capacity to supply the Spanish system starting in the mid-1990s; the contract has raised speculation that purchases from France may be used to forestall the need to lift the 1984 halt on construction of Spanish nuclear projects (NN $3 / 90)$

\subsection{NUCLEAR POWER CAPACITY PROJECTIONS (NUKEM 7/90)}

1988-- 7.5 GWe

1995-- $7.0 \mathrm{GWe}$

2000-- 8.8 GWe

2005--10.7 GWe

1.4 NUCLEAR ENERGY POLICY: Spain plans to continue to operate existing nuclear power plants; the loss of generating capacity from the permanent closure of Vandellos 1 nuclear plant should support arguments to restart construction at three of the five Spanish nuclear plants that has been stopped since 1984; a further point supporting a revival of Spain's nuclear program is the fact that Spain has already developed the industrial and technological capacity to allow it to be largely independent in nuclear power plant construction (NUKEM 4/89); however, Spain's lack of a clearly defined nuclear policy since 1983 has contributed to the development of unfavorable public opinion toward nuclear power (Rodriguez 1990); as part of the National Energy Plan (PEN 1983-1992) currently in force, the policy concerning the moratorium against nuclear power is to be reviewed officially by parliament in late 1990 (NUKEM 7/90) 


\subsection{ELECTRICITY PRODUCTION COSTS}

Nuclear- $\$ 0.036 / \mathrm{kWh}(4.654$ pesetas $/ \mathrm{kWh})$

Coal- $\$ 0.051 / \mathrm{kWh}(6.566$ pesetas $/ \mathrm{kWh})$ (Foratom 1986)

\subsection{NUCLEAR FUEL CYCLE AND RADIOACTIVE WASTE MANAGEMENT STRATEGY/POLICY (NEA 12/89; Leigh and Mitchell 1990)}

2.1 OVERAU NUCLEAR FUEL CYCLE POUCY: Spain will continue to use the once-through fuel cycle for LWRs, with no domestic reprocessing planned and no further contracts for foreign reprocessing, except for Vandellos 1 GCR tuel, which is reprocessed in France (NEA 12/89; Leigh and Mitchell 1990)

2.2 POLICY ON THE FRONT END OF THE NUCLEAR FUEL CYCLE: Spain's goal is to become self-sufficient for nuclear fuel supplies by 1992 (NN 1/87); ENUSA, Spain's state-owned nuclear fuel company, will build a new uranium ore processing plant at Saelices el Chico in the province of Salamanca for operation in 1992 (NN 10/90)

2.3 POLICY ON THE BACK END OF THE NUCLEAR FUEL CYCLE: Spain plans to employ atreactor storage of spent fuel for about 10 years, followed by central wet and/or dry AFR dry cask storage for up to 40 years or more (Leigh and Mitchell 1990)

A. ENRESA National Waste Management Company developed the first back-end plan (approved by the federal government in October 1987; the plan requires updating and approval each year) that included (NUKEM 1/88; NE 11-12/87):

1) Construction of LLW/LW interim storage facilities

2) Eventual construction of a final disposal facility for LLW/LW

3) Construction of a spent fuel interim storage facility

4) Selection of potential sites for HLW/spent fuel disposal

5) Research into final disposal of $\mathrm{HLW}$

6) Decommissioning of nuclear plants

B. Spain's reference option is the direct disposal of spent fuel, but it will also develop waste disposal technology that can accommodate spent fuel or HLW (Melches 1987)

C. Spain strongly opposes sea dumping; it disposes of LLW/LW in near-surface, shallowland burial facilities

\subsection{HIGHLIGHTS AND MAJOR MILESTONES (NEA 11/86; NUKEM 4/89; NEA 12/89)}

1975 The first National Energy Plan (PEN) is announced as a consequence of the 1973-74 oil crisis

1977-78 Updating the PEN reduces Spain's ambitious nuclear program to more manageable levels 
1980 The current nuclear regulatory agency, CSN, was created by law in 1980

1983 The government issues a new PEN for the 1983-1992 period; the projected annual electricity demand growth rates are reduced from $4.7 \%$ to $3.3 \%$

1984 ENRESA was created by law in 1984 to manage radioactive wastes in Spain (treatment, transportation, storage, and disposal)

1986-1994 Carry out R\&D for a HLW/spent fuel repository, preferably in granite or salt formations

1989 The Spanish government approved ENRESA's second national waste managemert plan (the first plan was approved in 1987)

1990 Regional authorities approved ENRESA's plan to construct a shallow-land burial facility for $\amalg W$ and ILW at EL Cabril; construction of the installation is in progress and expected to be completed by the end of 199-l (NUKEM 8/89; NEA 12/89)

1990 Start of operation of the Spanish LLW and ILW disposal facility is expected (NUKEM 8/89)

$1993 \quad$ ENUSA's new uranium ore processing plant will start production (NN 10/90a)

1994 Commission an AFR facility for spent fuel storage

1995 Complete development of criteria for evaluation and characterization of potential repository sites for spent fuel

$2000 \quad$ Propose three to five candidate sites for a spent fuel repository to federal authorities (NF 4/18/88)

2020 Commission a deep geological disposal site for spent fuel (NEJ 8/89)

\subsection{INSTITUTIONAL CONSIDERATIONS/ORGANIZATIONS (Paige 1985;}

Kindelan 1986; NEA 11/86)

4.1 LEGAL REQUIREMENTS: Spain's Plan General de Residuos (General Waste Plan, or PGR) is the formal document containing the main guidelines on the different aspects of waste management in the country; the PGR has to be approved every year by the federal government on the basis of proposals made by ENRESA and reports from the different organizations that have responsibilities in the nuclear field; parliament is to be informed about the PGR (NE 3-4/87); in January 1989, the Spanish government approved the second General Radioactive Waste Plan (GRWP), including revised estimates of radioactive waste arisings (NUKEM 2/90)

A. Spain has no stipulation law that links reactor construction to waste disposition; the central government can preempt a local veto on the siting of a nuclear facility

B. The current nuclear regulatory agency, CSN, was created by law in 1980

C. ENRESA was created by law in 1984 to manage radioactive waste in Spain (treatment, transportation, storage, and disposal) 
4.2 LICENSING: Licenses for nuclear facilities in Spain are issued by the Minister of Industry and Energy, after consultation with local authorities and the Nuclear Safety Council; decisions may be challenged in court; interim storage of LLW/LW and spent fuel at nuclear power plants is subject to the general terms and/or specific provisions stated in the operating license of each plant (NEA 12/89)

4.3 PUBLIC INVOLVEMENT: In Spain, public hearings are held to impart information and solicit local opinion during the first phase of the authorization process; local councils in areas where nuclear power plants are located will receive grants from the Spanish government for acceptance of wastes that are temporarily stored at the power station sites (NN 3/90)

\subsection{WASTE FUND}

A. ENRESA collects and manages a waste fund fee per $\mathrm{kWh}$, based on estimated costs, for decommissioning and all spent fuel and waste management operations outside power stations; also included is a fee for other radioactive waste generators, which are costs per unit volume according to radioactivity level; the fees are adjusted annually (ENRESA 1986; NEA 11/86; Melches 1987)

1) The 1988 fee for power stations was $1.4 \%$ of electric power revenues and an arrangement for compensation between utilities so that each pays only the cost of its own waste (NEI 3/88)

2) The 1989 fee applied to electricity rates was $1.2 \%$ (NEA 12/89)

3) It was estimated that ENRESA would receive about $\$ 175$ million in waste management fees in 1989 from Spanish utilities (NF 5/15/89); by May 1989, ENRESA had raised funds totaling 104 billion pesetas (\$800 million U.S.) (NEI 8/89)

B. The Spanish government has decided that local councils in areas where nuclear power plants are located will receive grants for acceptance of waste that is temporarily stored at the power station sites; a total sum of 13 billion pesetas ( $\$ 104$ million U.S.) has been set aside for these grants through 1996; the money, derived from the levy on units of nuclear electricity production, will be distributed by ENRESA on the basis of 250 million pesetas (\$2 million U.S.) per council, plus 3 million pesetas $(\$ 24,000$ U.S.) per MT of waste stored within the administrative area (NN 3/90)

4.5 KEY AGENCIES AND FUEL CYCLE CENTERS (ENRESA 1986; NEA 12/89; Leigh and Mitchell 1990)

A. CSN (Consejo de Seguridad Nuclear, or Council of Nuclear Safety); this is the national nuclear regulatory agency; it evaluates license applications, recommends government action, and establishes research programs in nuclear safety and radiological protection; in addition, it conducts onsite inspections; it is an independent body reporting directly to the parliament

B. MIE (Ministry of Industry and Energy): the ministry oversees energy production and development, controls ENRESA and sets the waste management fee; in addition, the ministry is responsible for the authorization procedure for nuclear power stations (three steps: preliminary site authorization, construction license, and operating license) and issues the ficenses on the basis of reports from the CSN (NEI 3/88) 
C. ENRESA (National Waste Management Company, created in 1985): ENRESA provides services of preparation, transport, treatment, interim storage, and permanent storage of spent fuel and radioactive wastes; it oversees decommissioning of surplus facilities, and promotes R\&D on waste management; the company, out of its Madrid offices, defines, directs and controls all the activities of the back-end of the fuel cycle through engineering and service companies (NEI 3/88)

1) ENRESA is federally-owned, and is controlled by the Ministry of Industry and Energy and the Ministry of Economy

2) Current funding is $80 \%$ by CIEMAT and $20 \%$ by the National Institute of Industry

3) ENRESA operates the LLW surface storage facility at El Cabril, Cordoba (NN 4/86)

D. ENUSA (National Fuel Cycle Company): ENUSA provides the majority of front-end fuel cycle services; ENUSA has a LWR fuel fabrication plant at Juzbado, $200 \mathrm{MTU} / \mathrm{yr}$, expandable to $500 \mathrm{MTU} / \mathrm{yr}$ (NN 8/87)

E. ENDESA is the state-operated utility which sells wholesale power to the private utilities

F. REDESA (Red Electra Espanola): REDESA controls the Spanish national electricity grid; it signed a $\$ 4$ billion contract with Electricite de France (EdF) to supply electricity to Spain (NN 9/90)

\subsection{PRINCIPAL RESEARCH, DEVELOPMENT AND DEMONSTRA $A_{i}$ TION FACILITIES/PROGRAMS}

A. CIEMAT (Center for Environmental, Energy and Technological Research): this center carries out R\&D in the field of energy and environmental protection as well as in some fields of fundamental research and fuel cycle and waste management $R \& D$; there are four main research institutes at the center (NE 10/87):

1) The institute of Nuclear Technology works in three main areas: materials research, safety analysis, and nuclear fuel cycle (front end and back end); the Institute collaborates closely with the CSN, with the nuclear fuel cycle industries ( $40 \%$ share with ENUSA and $80 \%$ share with ENRESA), and with the utilities; in addition, it participates in international projects such as the reactor Loss of Fluid Test, TRANSRAMP, NEA's Stripa underground re:search laboratory, and in late1987 signed its participation in LACE, and has plans to join PHEBUS, IPIRG, and the Severe Accident project (NE 10/87)

2) The Institute of Fundamental Research works in four main areas: fusion by magnetic confinement, particle physics, radiation metrology, and laser physics

3) The Institute of Radiological Protection and Environment's main thrust is carrying out R\&D on all matters related to the impact on the environment of energy generated through nuclear and coal combustion; in addition, it collaborates with universities, Consejo de Seguridad Nuclear, IAEA, NEA, CEC, and DOE and universities in the USA,

4) The institute of Renewable Energies works in the areas of solar-thermal, solarphotovoltaic, wind, and biomass areas; it collaborates with universities, industrial companies, CEC, and AIE 
5) The Juan Vigon National Nuclear Energy Center, located at Madrid, has been the major nuclear R\&D center of CIEMAT, including waste treatment and waste disposal; however, in recent years the activities of this center have been substantially reduced; the center's first research reactor, which was closed down in 1984, and a reprocessing center are scheduled to be dismantled (NEI 3/88)

4.7 KEY PERSONNEL (Leigh and Mitchell 1990)
A. Donato Fuejo Lago, President, CSN
B. Claudio Aranzadi, Minister, MIE
C. Ramon Perez Simarro, Director General of Energy, MIE
D. Juan Manuel Kindelan, President, ENRESA
E. Alberto Lopez, Director General, ENRESA
F. Aurelia M. Ulibarri, Director, Engineering, ENRESA
G. Victor Perez Pita, President, CIEMAT
H. Jose Angel Azuara Solis, General Director, CIEMAT
I. Manuel Montes, Director, Nuclear Technology, CIEMAT
J. Armando Uriarte, Waste Management, CIEMAT
K. Jose Manuel Jimenez Arana, President, ENUSA

\subsection{NUCLEAR FUEL PRODUCTION}

5.1 STRATEGY: Spain plans to reduce dependence from foreign control of nuclear fuel sources through domestic capability or part ownership of a foreign plant by 1992 (NN 1/87); the strategy for long-term uranium procurements is to substantially increase the portion covered by national uranium production (NEA 1989)

5.2 URANIUM RESOURCES: 35,000 MTU are reasonably assured; 9000 MTU are estimated as additional resources; no new exploration is under way (NEA 1989)

\subsection{URANIUM PRODUCTION}

A. 1984--196 MTU

1987-223 MTU

1989-216 MTU (estimated) (NEA 1989); Spain plans to expand to 1,000 MTU/yr by 1991 (NEI 3/88)

B. Two uranium mines are located in Salamanca province (Blansfield 1987); one mine can produce about $200 \mathrm{MTU} / \mathrm{yr}$; the second can produce about $30 \mathrm{MTU} / \mathrm{yr}$; both mines are open pit mines; the mill for the larger mine uses heap leaching and the smaller mill uses acid leaching plus heap leaching (NEA 1988) 
C. Because of good results in uranium exploration, a 950-MTU/yr uranium ore processing plant is planned for startup in 1993 in the area of Saelices el Chico in the province of Salamanca (NEA 1989; NN 10/90a)

5.4 URANIUM ENRICHMENT: Spain has no domestic enrichment capability; enrichment services are contracted by ENUSA with the U.S. DOE and with Technsnabexport (USSR); Spain has an $11.1 \%$ share in the EURODIF enrichment facility (NEI 3/88)

\subsection{FUEL FABRICATION}

A. The Juzbado LWR fuel fabrication plant, located $25 \mathrm{~km}$ from Salamanca, was commissioned in late 1985; the plant receives uranium dioxide and zirconium tubes, and constructs final assemblies; actual output in 1986 was 150 MTU; there are two production lines for PWR pellets and one for BWR pellets; the plant's capacity is $200 \mathrm{MT} / \mathrm{yr}$, with provision for an increase to $500 \mathrm{MTU} / \mathrm{yr}$ when more capacity is needed, which would make Spain seff-sufficient in 1992 (NE 3-4/87; NN 12/85; NN 1/87)

B. In early 1987 , a contract valued at 9 billion pesetas ( $\$ 43$ million) for the two 930-MWe PWRs at Almaraz was awarded to Fragema, the French fuel fabrication company (NN 8/87)

\subsection{FUEL RECYCLE}

\subsection{FUEL REPROCESSING (NEA 12/89)}

A. The spent fuel from the Vandellos GCR--closed October 1989 (NN 8/90)--is reprocessed by COGEMA in France; earlier, limited LWR fuel reprocessing contracts were placed with BNFL

B. CIEMAT had planned for domestic reprocessing capability, but the R\&D program has been terminated; the current government position is against reprocessing

6.2 PROGRAM/FACILITIES COSTS: The government has estimated the cost of reprocessing the fuel from the shutdown Vandellos-I reactor at 25 billion pesetas; (about $\$ 244$ million U.S.) (NW 6/7/90)

\subsection{SPENT FUEL STORAGE AND TRANSPORT}

7.1 SPENT FUEL AfISINGS (Leigh and Mitchell 1990)

1985--202 MTU cumulative

1990-950 MTU cumulative

1995--1800 MTU cumulative

2000--2800 MTU cumulative

Spain's nuclear program is expected to generate a total of 5,500 MTHM (NF 1/23/89), for a total volume of $9,700 \mathrm{~m}^{3}$ (NUKEM 2/90) 


\subsection{SPENT FUEL STRATEGIES}

A. Spain's reference option is the direct disposal of spent tuel, but it will develop waste disposal technology that can accommodate spent fuel or HLW (Melches 1987)

B. Spain plans to store spent fuel in reactor pools for about $\mathbf{1 0}$ years, then store the fuel in dry storage casks at a central facility away from reactors until a waste repository is available (NUKEM 1/88)

C. A site-independent design for an interim spent fuel storage facility, contemplating different alternatives, was completed in 1988 (NEA 12/89)

D. In 1989, ENRESA presented a draft plan for interim storage of high-level waste (i.e., spent fuel) to the Ministry of Industry for review; the plan would be financed by ENRESA out of the waste fund it receives from utilities, based on a percentage charge on electricity rates; ENRESA's draft plan suggests adopting a mixed approach using both dry cask and pool storage (NF 5/15/89)

E. Disposal in deep geological formations will be provided for spent fuel and vitrified waste resulting from reprocessing the spent fuel from the Vandellos 1 GCR nuclear power plant, which will be returned from France (NEA 12/89)

\subsection{WET STORAGE}

A. Spanish reactors have an average of 10 years' onsite spent fuel storage capacity; architect/engineers Initec (public sector) and Empresarios Agrupados (private sector) are jointly designing a pool type of central spent fuel storage facility with a nominal capacity of 2,500 MTU, or roughly half of the estimated total spent fuel production of 5,500 MTU (NW 4/14/88)

B. See Section 7.4 for Spain's current plans for expanded wet storage

7.4 DRY STORAGE: Additional storage capacity is planned to be provided with dry storage, at-reactor, or away-from-reactor, using metal casks manufactured in Spain (ENRESA 1986)

A. ENRESA has drawn up a draft plan for an interim away-from-reactor storage facility (combining both dry and wet storage technologies) to store 6,000 MTU of Spanish spent fuel until 2020, when a planned final repository is to be ready (NF 5/15/89); the pian calls for installation in two stages of 3,000 MTU each, with a first-phase combination of 2,500 MTU capacity in modular pools and $500 \mathrm{MTU}$ in dry metal casks (NF 5/15/89); construction of an interim spent fuel storage facility was approved by the federal government in 1987 (NUKEM 1/88)

B. CIEMAT developed to half-scale a nodular cast iron transport-storage cask of its own called Centauro; however, ENRESA planned on another design and in early 1988 a Spanish nuclear component manufacturer (ENSA) entered into agreements with the major international cask designers (NF 4/18/88)

C. ENRESA chose the U.S. Nuclear Assurance Corp. (NAC) and German Gesellschaft für Nuklear-Service $\mathrm{mbH}$ (GNS) companies to negotiate the first phase of its spent fuel storage-transfer $(S / T)$ cask program; the design/development contract would last 2 years, to 1991; ENRESA plans to have NAC develop its S/T cask into a cask licensed in Spain 
for both storage and transport (and also certified by the U.S. NRC) by 1992-93; the NAC design would be manufactured by ENSA in Spain; no details were available on the GNS proposal (NF 1/23/89)

1) NAC plans to deliver its first U.S. NRC-certified storage/transport cask, designated NAC-STC, to ENRESA by the end of 1990 , and the second cask sometime in 1991 (NF 3/6/89)

2) The capacity of the NAC-STC cask is 28 PWR assemblies for storage and transport or, with a different basket configuration, 37 PWR assemblies for storage only (RE 10/20/89)

\subsection{TRANSPORT (NEA 12/89)}

A. ENRESA is responsible for the transport of all types of radioactive wastes from the moment of receiving the wastes; transportation services are normally subcontracted to specialized companies

B. The Nuclear Safety Council is responsible for monitoring and entorcing safety and radiation protection requirements in the field of transportation of radioactive materials

7.6 PROGRAMS/FACILITIES COSTS: The 1989 ENRESA draft plan estimates the cost for interim storage of spent fuel at about $\$ 610$ million (NF 5/15/89)

\subsection{WASTE CONDITIONING, STORAGE AND TRANSPORT}

\subsection{WASTE DEFINITIONS (MIE 10/87)}

A. Radioactive wastes in Spain are generally classified as:

1) Low- and intermediate-level wastes (LLW/LW); the main characteristics of these wastes are: low specific activity; bearing beta-gamma emitters with half-lives shorter than 30 years; limited content of long-lived alpha emitters (half-lives of several thousand years)

2) High-level wastes (HLW); the main characteristics of these wastes are: high specific activity of short-lived emitters; significant concentration of long-lived emitters; considerable heat generation

B. A separate category is the wastes arising from uranium mining and milling; although the specific activity of this waste category is very low, its huge volume requires special management

8.2 WASTE ARISINGS: In addition to the nuclear power reactors, there are about 900 other installations producing radioactive wastes in Spain, including medical facilities, diverse industry and research centers, 200 of which are regular radioactive waste producers (NE 3-4/1987)

A. As of early 1988, there were 6,355 canisters (drums) of LLW/LW stored in above-ground modules at El Cabril-(NW 3/24/88)

B. Through 1990--30-35,000 $\mathrm{m}^{3}$ LLW (NF 12/15/86) 
C. Through $2000-58,000 \mathrm{~m}^{3}$ (NN 2/90)

D. Through $2020-100,000 \mathrm{~m}^{3}$ LLW and ILW (5-10\% of this is ILW) (NF 12/15/86)

E. Through $2037-275,600 \mathrm{~m}^{3}$ of LLW/LW (includes $130,000 \mathrm{~m}^{3}$ of decommissioning wastes (Melches 1987; NW 3/24/88)

F. Through $2037-5,370 \mathrm{~m}^{3}$ of $\mathrm{HLW}\left(5,280 \mathrm{~m}^{3}\right.$ spent fuel and $90 \mathrm{~m}^{3}$ vitrified $\mathrm{HLW}$ from reprocessing of Vandellos spent fuel in France) (Melches 1987; NW 3/24/88; NW 4/18/88)

G. Spain's second General Radioactive Waste Plan (GRWP) shows an estimated total of $243,500 \mathrm{~m}^{3}$ of LLW and ILW, while spent fuel and HLW totals $9,700 \mathrm{~m}^{3}$; these figures are based on the total installed nuclear capacity foreseen in the National Energy Plan (PEN) of 1983 and on nuclear power plant lifetimes of 30 years (NUKEM 2/90)

8.3 STRATEGY: A national plan for radioactive waste management covering storage, transportation, control and surveillance has been developed by Spain; the first plan was approved by the federal government in October 1987; the plan includes construction of interim storage facilities for LLW/LW, and spent fuel, and research into final disposal of HLW and decommissioning of nuclear plants (NUKEM 1/88); the second plan, approved in 1989, provided revised estimates of radioactive quantities (see Section 8.2 ) (NUKEM 2/90)

8.4 LLW/ILW CONDITIONING (Lakey 1985; Melches 1987)

A. Most small producers have LLW/LW conditioned at the CIEMAT facility; nuclear power plants and other major producers condition their own wastes according to ENAESA specifications

B. Solid wastes are sorted, compacted, and incinerated; liquid wastes are chemically treated

C. Most LLW is incorporated in cement; the use of urea-formaldehyde was being phased out as of 1987

D. The waste containers are 200-liter steel drums

8.5 LLW/ILW STORAGE (NW 3/24/88)

A. Initial interim storage of LLW/LW is at the site of the producers; subsequent interim storage is in the only operating centralized storage facility at El Cabril (Melches 1987; NN 2/90)

B. Wastes are stored in storage bays in above-ground modules; there is space for 15,000 canisters or $5,000 \mathrm{~m}^{3}$; expansion to $48,000 \mathrm{~m}^{3}$ is awaiting government approval (NW 3/24/88)

C. LLW/LW, once stored in an old uranium mine (EI Cabril) in Sierra Albarrana in Cordoba province, have been removed after partial reconditioning and placed in the aboveground storage modules 


\subsection{PROGRAM/FACILITES COSTS}

A. The expansion (and transformation from existing surface storage modules to shallowland burial) of the El Cabril storage facility to $60,000 \mathrm{~m}^{3}$ for LLW/LW will cost an estimated 12 billion pesetas, or about $\$ 130$ million U.S. (NUKEM $2 / 90$ )

B. In Spain, the costs of waste disposal are born by the producers, and the different arrangements are approved each year in the General Waste Plan (PGR); in 1988, there was a surcharge of $1.4 \%$ on electricity tariffs and an arrangement for compensation between utilities so that each pays only the cost of its own waste ( $\mathrm{NEl} \mathrm{3/88)}$

\subsection{DISPOSAL OF NON-HIGH-LEVEL WASTES}

\subsection{LLW DISPOSAL}

A. In 1986, a search by ENRESA was undertaken for a site for a LLW disposal facility (EI Cabril II); the new facility would have a capacity of about $35,000 \mathrm{~m}^{3}$ (ENRESA 1986; NF 12/15/86)

B. Regional authorities have approved ENRESA's plan to construct a disposal facility for $\mathrm{LLW}$ and ILW at EL Cabril; construction of the installation is in progress and expected to be completed by the end of 1991 (NUKEM 8/89; NEA 12/89)

\subsection{WASTE DISPOSAL CRITERIA (NEA 12/89)}

A. ENRESA establishes acceptance criteria for receiving waste packages on a contractual basis, with the producers of the waste

B. Only solid form wastes conforming to the safety specifications will be accepted and only solid form waste packages will be accepted for disposal at the El Cabril center

9.3 PROGRAM/FACILITIES COSTS: ENRESA collects and manages the fees for non-high-level radioactive waste generators, which are costs per unit volume according to activity; the fees are adjusted annually

\subsection{DISPOSAL OF HIGH-LEVEL WASTES}

10.1 SPECIFICATIONS AND CRITERIA: In Spain, the general ba:ses for the selection of waste disposal sites are (NEA 11/86, NEA 12/89):
A. Easy access at depths of $700 \mathrm{~m}$
B. Low tectonic activity
C. Good characterization of the site
D. Use of multiple barriers (NEA 11/86)
E. In 1989, the Nuclear Safety Council issued the technical criteria for repository site selec- tion in Spain and stated the following two criteria concerning dose limitation and waste acceptance (NEA 12/89):


1) An individual risk limit of $10^{-6}$ per year must be considered as an objective

2) Waste acceptance criteria will be contemplated specifically on a project basis

\subsection{REPOSITORY DEPLOYMENT STRATEGY}

Spain's repository deployment strategy is:

A. Spain's reference option is the direct disposal of spent fuel, but it will develop waste disposal technology that can accommodate spent fuel or HLW (Melches 1987)

B. Carry out the generic research, including that in an underground research laboratory

C. Prepare a national inventory of favorable geologic formations

D. Screen through several stages for the final potential site

E. Evaluate the final potential site in detail, and obtain official approvals

F. Operate the repository

\subsection{SITE SELECTION AND CHARACTERIZATION (NEA 12/89)}
A. Geologic and hydrologic studies are in progress for a deep geological repository
B. A national inventory of favorable formations was performed in 1986-1987
C. Screening in several stages to select the potential final site in the year 2000

\subsection{REFERENCE HLW/SPENT FUEL DISPOSAL CONCEPT (NEA 12/89)}

A. Spain's reference waste form is spent fuel, with a small amount of $\mathrm{HLW}$ borosilicate glass from $\mathrm{HLW}$ from foreign reprocessing of GCR fuel

B. Spain prefers encapsulation of spent fuel at a repository site

C. Granite, salt, and clay are being considered by the Spanish as potential host rock formations for final disposal and site prospection studies are underway

10.5 GEOSCIENCES R\&D

A. Salt and granite formations have been under study in Spain as have thermal responses of materials in a repository

B. Collaborative projects in the framework of the CEC R\&D program are being undertaken, such as Spain's participation in the Federal Republic of Germany's high-activity waste project in the Asse salt mine (NEA 12/89)

10.6 FIELD TESTS: In 1988, a tentative site for a potential Underground Research Laboratory (URL) in granite was selected at Aldeadavila de Ribera in Salmanca province (near the Portugese border), but deferred (and later canceled altogether) because of local and Portugese protest; a 
2-km-long tunnel at 700-m depth had been planned for the facility for spent fuel disposal tests (NW 3/24/88); ENRESA has abandoned altogether the attempt to build such a laboratory, and will now participate in similar experiments in other European countries (NW 4/14/88)

\subsection{PROGRAM/FACIUTIES COSTS (ENRESA 1986; NEA 11/86)}

A. The 1988 waste management budget for all radioactive wastes (low-, medium-, and highactivity) was 3 billion pesetas ( $\$ 33$ million U.S.); this financial burden was shouldered by the waste generators themselves, with utilities contributing a percentage of sales income (1.4\% in 1987) and small producers paying fees for services rendered (NF 11/2/87)

B. Costs for the once-planned underground research laboratory in Salmanca province were estimated at $\$ 16$ million

C. In 1986, the projected total cost of radioactive waste management in Spain was 753 billion pesetas (about $\$ 7$ billion U.S. calculated at April 1988 exchange rates) (NF 4/18/88); distribution of costs were:

Intermediate storage of spent fuel and $\mathrm{HLW} \ldots \quad \ldots \quad 12 \%$ Final disposal of spent fuel and $\mathrm{HLW} \ldots \ldots \ldots, \mathbf{3} \% \%$ Reprocessing of spent GCR fuel ....... 11\% Final disposal of $\amalg W / L W \ldots \ldots \ldots \ldots \ldots$ Dismamtling of installations . . . . . . . . . $24 \%$ Transportation . . . . . . . . $3 \%$

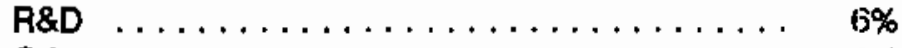
Other costs $\ldots \ldots \ldots \ldots \ldots \ldots \ldots \ldots \ldots \ldots \ldots$

D. In 1989, estimates of the overall repository program costs up to the year 2042 result in the range of 797 to 878 million pesetas (\$8.8 to $\$ 9.7$ billion U.S.) (NEA 12/89)

\subsection{MANAGEMENT OF URANIUM MINE AND MILL WASTES}

11.1 WASTE ARISINGS: Through 1992- $320,000,000 \mathrm{~m}^{3}$ of mine tailings are expected, and $50,000,000 \mathrm{~m}^{3}$ of mill tailings are expected (Melches 1987); a current uranium mining waste inventory is being established

11.2 REMEDIAL ACTIONS: As of 1987, a 1.2-million-MT pile of mill tailings from the Andujar uranium concentrate plant was to be conditioned and stabilized (Melches 1987)

11.3 COSTS: Production of yellowcake at the Andujar mill was stopped in 1981 and the facility has been in a technical shutdown situation since; ENRESA plans to spend about $\$ 22$ million on dismantling the obsolete uranium mill; dismantling of the mill was scheduted to start in September 1989 and was estimated to take 20 months (NW 12/15/88)

\subsection{DECOMMISSIONING AND ENVIRONMENTAL RESTORATION}

12.1 WASTE ARISINGS: The Spanish expect $130,000 \mathrm{~m}^{3}$ of decommissioning wastes through the year 2034 (Melches 1987)

12.2 STRATEGY/POLICY: It has been assumed for calculation and planning purposes that once the useful life of Spain's nuclear power plants (estimated at 30 years) comes to an end and after a "cooling" period of about 5 years, total dismantling would begin, lasting approximately another 
5 years, leaving the site ready for other unrestricted uses (MIE 10/87); Spain's main efforts and expenditures on decommissioning of nuclear facilities are predicted to be in 2000-2025 (NEI $8 / 89$ ); in principal, no dismantling of the $\amalg W / L W$ temporary storage facility is contemplated (NEA 12/89)

12.3 R\&D: Spain does not deem it advisable to undertake specific R\&D projects on decommissioning; rather, it plans to follow the R\&D programs in other countries, especially those in the European Community; it may undertake direct collaboration/participation in some foreign projects (MIE 10/87)

12.4 MAJOR PROJECTS: The 20-year-old Jen-1, a 3-kW experimental reactor, and the reprocessing R\&D center at Madrid are being dismantled (NW 2/26/87; NEI 3/88); the shutdown GCR, Vandellos 1, is to be decommissioned (NUKEM 7/90)

\subsection{COSTS}

A. The Spanish government has estimated the cost of dismantling the Vandellos-1 GCR at 15 billion pesetas (about $\$ 146$ million U.S.) (NW 6/7/90)

B. ENRESA's General Radioactive Waste Plan, approved in January 1989, projects the total cost of nuclear plant decommissioning in Spain at 205 billion pesetas (about $\$ 2.0$ billion U.S.) (NW 6/7/90)

\subsection{INTERNATIONAL ACTIVITIES}

13.1 MEMBERSHIPS: Spain is a member of the CEC, IAEA, and NEA

13.2 COOPERATION WITH MULTINATIONAL AGENCIES (NE 10/87; NEA 12/89)

A. Spain's Institute of Radiological Protection and Environment collaborates on various projects with IAEA, NEA, and CEC

B. As of 1987, Spain was an active participant in cooperative projects with CEC on conditioning and disposal of radioactive wastes and in renewable energy concepts

C. Spain has participated in NEA's Stripa underground research laboratory, the former Magnetic Confinement and Reactor Loss of Fluid Test projects

D. The Institute of Nuclear Technology participates in international projects such as TRANSRAMP, and in late-1987 signed its participation in LACE, and has plans to join PHEBUS, IPIAG, and the Severe Accident project (NE 10/87)

\subsection{COOPERATION WITH USA}

A. Spain's CIEMAT and U.S. DOE have a Memorandum of Understanding for cooperation in energy research and development

1) Term: 1986 to 1991 
2) Scope: Exchange of experience and results of theoretical, experimental, and conceptual design problems; agreed R\&D projects; areas covered are: renewable energy, including biomass; coal/gas technologies; environmental impact of energy technologies; energy conservation; high energy physics and nuclear energy, including nuclear safety technology; radioactive waste management

B. Spain's Institute of Radiological Protection and Environment collaborates on projects with the U.S. DOE and the Massachusetts Institute of Technology (NE 10/87)

\subsection{COOPERATION WITH OTHER COUNTRIES}

A. Spain has an agreement with CEA (France) on management of LLW/LW, which includes waste characterization and specifications developmert (NE 3-4/87)

B. ENUSA imports about $200 \mathrm{MTU} / \mathrm{yr}$ of $\mathrm{U}_{3} \mathrm{O}_{8}$ from Cominak, Niger (where it has a $10 \%$ share in a mining activity) to ensure a supply of concentrates (NEI 3/88)

C. ENRESA signed an accord in early 1988 for cooperation with German organizations running the Asse salt mine waste experiments (NF 4/18/88)

D. On April 5, 1989, Spain signed the same Treaty on the Non-Proliferation of Nuclear Weapons (NPT) as the other nine non-nuclear-weapcn states in the European Atomic Energy Community (IAEA 1990)

E. In June 1990, Canadian specialists held a training session in Spain to teach scientists from ENRESA how to use the SYNVAC3 computer code--a systems variability analysis code developed to assess the Canadian concept for spent nuclear fuel disposal (NWN 7/5/90)

\subsection{REFERENCES}

-1985-

Lakey, L. T., K M. Harmon, and P. Colombo. 1985. Management of Low- Level Radioactive Wastes Around the World. PNL-5173, Pacific Northwest Laboratory, Richland, Washington.

Nuclear News (NN). 12/85. "Spain: Technology: Transferred and Waiting," p. 74.

Paige, H. W., and N. J. Numark. 1985. Assessment of National Systems for Obtaining Local Siting Acceptance of Nuclear Waste Management Activities. IEAL-R/86-16, International Energy Associates Limited, Washington, D.C., Vol. 1, pp. 13-1 to 13-5 and Vol. 2, pp. 15-1,2.

$-1986-$

Empresa Nacional de Residuos Radiactivos, S.A. (ENRESA). 1986. Memoria. Empresa Nacional de Pesiduos Radiactivos, S. A., Madrid.

Foratom. 1986. Nuclear Power in Western Europe: Status Report 1986. Pubished by Foratom.

Kindelan, J. M. 1986. 'Editorial." Nuclear_Europe, March, 1986, p. 5. 
Nuclear Energy Agency (NEA). 11/86. "Record of Ad Hoc Meeting of Directors of Crystalline Rock Projects." Meeting held November 3-4, 1986, Paris.

Nuclear Fuel (NF). 12/15/86. 'Spain Moving on Nuclear Waste Disposal," p. 8.

Nuclear News (NN). 4/86. 'Spain: Investing in Uranium and Waste Management," p. 86.

$-1987-$

Blansfield, J. 1987. 'ENRESA Plan for Spent Fuel Disposal Lab Sparks Spanish Protests.' Nucleonics Week, April 30, 1987, p. 11.

Ministry of Industry and Energy (MIE), 10/87. First General Radioactive Waste Plan (Brochure)

Melches, C., and J. M. Espejo-Hernandez. 1987. "Management of Nuclear Waste in Spain." in proceedings of IAEA symposium, Back End of the Nuclear Fuel Cycle: Strategies and Options, p. 41. May 1-5, International Atomic Energy Agency, Vienna.

Nuclear Engineering International (NEI). 12/87. "Spain Plans a Granite Laboratory," p. 54.

Nuclear Europe (NE). 3-4/87. 'Waste Management in Spain,' p. 42; and 'Nuclear Fuel Capabilities in Spain," p. 11.

Nuclear Europe (NE). 10/87. "Nuclear R\&D in Spain," p. 48.

Nuclear Europe (NE). 11-12/87. 'Spanish Government Approves Long-Term Radwaste Program," p. 51.

Nuclear Fuel (NF). 11/2/87. "Spain Drops Plans for Waste Project," p. 16.

Nuclear News (NN). 1/87. "Spanish Nuclear Society Holds 21st Year Reunion," pp. 65-67.

Nuclear News (NN). 8/87. 'Spain's Almaraz Will Get Three Fuel Reloads from France," pp. 167-168.

Nucleonics Week (NW). 2/26/87. "Spain to Relocate Nuclear Waste Found Stored in Central Madrid," p. 5.

$-1988-$

Nuclear Engineering International (NEI). 3/88. "Datafile: Spain," pp. 50-53.

Nuclear Fuel (NF). 4/18/88. "Rumored Plans for Spanish Spent Fuel Storage at Trillo Spark Protests," pp. 9-10.

Nuclear News (NN). 2/88. "Energy Plan Postponed at Least to Late 1988," p. 54.

Nucleonics Week (NW). 2/4/88. "Nuclear Electricity Generation for December 1987," p. 19.

Nucleonics Week (NW). 3/24/88. 'Local Official Trying to Close Spain's El Cabril Waste Site," p. 8.

Nucleonics Week (NW). 4/14/88. "Rumor of Interim Waste Facility Brings Violent Protests in Spain," p. 4. 
Nucleonics Week (NW). 12/15/88. 'Spain's ENRESA Plans Spending for Waste Site Addition, Cleanup," p. 10.

NUKEM Market Report on the Nuclear Fuel Cycle (NUKEM). 1/88. '1987 Review--Spain.' NUKEM GmbH, Hanau, Federal Republic of Gemany, p. 13.

-1989 -

Nuclear Energy Agency (NEA). 1989. Uranium: Resources, Production and Demand. Joint report by OECD/NEA and IAEA, Nuclear Energy Agency, Paris, pp. 261-270.

Nuclear Energy Agency (NEA). 12/89. "Radioactive Waste Management in Spain." Prepared for Radioactive Waste Management Committee of the OECD Nuclear Energy Agency.

Nuclear Engineering International. (NEI) 8/89. 'ENFESA Takes 1.2. Per Cent Levy,' p. 4.

Nuclear Fuel (NF). 1/23/89. 'Spain Picks NAC, GNS to Negotiate First Phase of its Cask Program," pp. 6-7.

Nuclear Fuel (NF). 3/6/89. "Virginia Power, EPRI Might Participate in Spanish Waste Program," pp. 15-16.

Nuclear Fuel (NF). 5/15/89. "ENAESA Proposes Central Interim Spent Fuel Store," p. 16.

NUKEM Market Report (NUKEM). 4/89. "Nuclear Policy - Review of Spain's Nuclear Moratorium in Sight,' NUKEM GmbH, Hanaw, Federal Republic of Germany, pp. 3-6.

NUKEM Market Report (NUKEM). 8/89. 'Spain." NUKEM GmbH, Hanau, Federal Republic of Germany, p. 8.

The Radioactive Exchange (RE). 10/20/89. 'In the Industry,' p. 11.

$-1990$.

IAEA Information Circular/193/Add. 4. May 1989. Accession of Spain. International Atomic Energy Agency, Vienna.

Leigh, 1. W., and S. J. Mitchell. 1990. International Nuclear Fuel Cvcle Fact Book. PNL-3594 Rev. 10, Pacific Northwest Laboratory, Fichland, Washington.

Nuclear News (NN). 2/90. "Waste Management: Spain" p. 95.

Nuclear News (NN). 3/2/90. "Vandellos Ruling Stalled; Waste Grants Expanded" p. 59.

Nuclear News (NN). 7/90. "Spain's Socialist Leaders Split on Nuclear Issue," pp. 63-64.

Nuclear News (NN). 7/90. 'Vandellos-1 to Be Closed; 1989 Incident Analyzed,' pp. 62-63.

Nuclear News (NN). 8/90. "World. List of Nuclear Power Plants," p. 75.

Nuclear News (NN). 9/90. "Grid Owner to Buy Up to 1000 MWe from France," p. 78.

Nuclear News (NN). 10/90a. 'Selt-Sulficiency Sought in Uranium Supply,' p. 82. 
Nuclear News (NN). 10/90b. 'Trillo-1 to Continue to Use German Fuel,' pp. 82-83.

Nuclear Waste News (NWN). 7/5/90. "Business and Technology News," p. 268.

Nucleonics Week (NW). 6/7/90. 'Vandellos-1 to be Shut for 'Economic Reasons'," pp. 8-10.

NUKEM Market Report (NUKEM). 2/90. "Spain." NUKEM GmbH, Hanau, Federal Republic of Germany, pp. 19-20.

NUKEM Special Report (NUKEM). 7/90. "World Nuclear Power Plant Capacity." NUKEM GmbH, Hanau, Federal Republic of Germany, pp. 21-27.

Rodriguez, A. G. 1990. The Role of Good Management in Nuclear Power Plant Construction and Operation.' In proceedings of the 3rd Joint Conference of the ENS/ANS-Foratom Conference Transactions, Volume I, pp. 102-108, September 23-28, Lyon, France. 


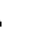



• 
SWEDEN 


\section{SWEDEN}

\section{CONTENTS}

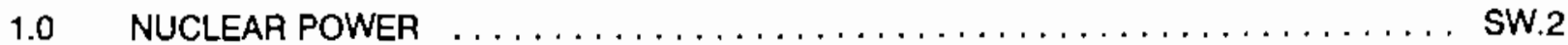

2.0 NUCLEAR FUEL CYCLE AND RADIOACTIVE WASTE MANAGEMENT

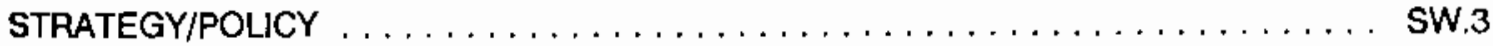

3.0 HIGHLIGHTS AND MAJOR MILESTONES $\ldots \ldots \ldots \ldots \ldots \ldots \ldots \ldots \ldots$ SW.5

4.0 INSTITUTIONAL CONSIDERATIONS/ORGANIZATIONS $\ldots \ldots \ldots \ldots \ldots \ldots \ldots$

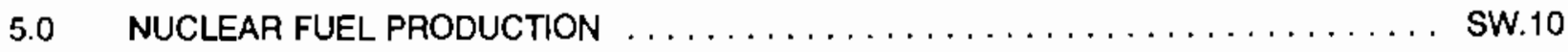

6.0 FUEL RECYCLE $\ldots \ldots \ldots \ldots \ldots \ldots \ldots \ldots \ldots \ldots \ldots \ldots \ldots \ldots \ldots \ldots \ldots \ldots \ldots$

7.0 SPENT FUEL STORAGE AND TRANSPORT $\ldots \ldots \ldots \ldots \ldots \ldots \ldots \ldots \ldots \ldots$ SW.12

8.0 WASTE CONDITIONING, STORAGE, AND TRANSPORT $\ldots \ldots \ldots \ldots \ldots \ldots \ldots$ SW.14

9.0 DISPOSAL OF NON-HIGH-LEVEL WASTES $\ldots \ldots \ldots \ldots \ldots \ldots \ldots \ldots \ldots \ldots \ldots \ldots$

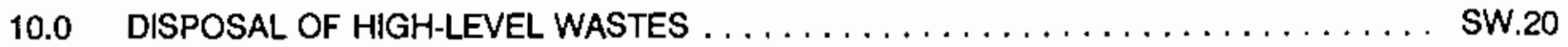

11.0 MANAGEMENT OF URANIUM MINE AND MILL WASTES $\ldots \ldots \ldots \ldots \ldots \ldots \ldots$ SW.28

12.0 DECOMMISSIONING AND ENVIRONMENTAL RESTORATION $\ldots \ldots \ldots \ldots \ldots \ldots$ SW.28

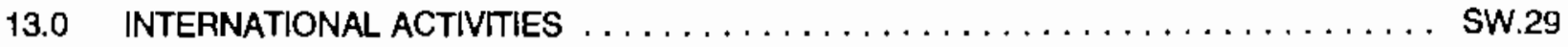

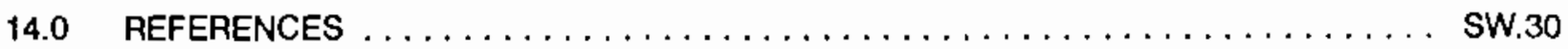




\subsection{NUCLEAR POWER}

\subsection{REACTOR MIX}

9 BWRs (442 to $1155 \mathrm{MWe}$ ) and 3 PWRs (800 to $915 \mathrm{MWe}$ ); four sites; three utility companies

\subsection{ELECTRIC POWER PRODUCTION}

1989-139 TWh (63 TWh, or $45 \%$ nuclear (oNN 1/90)

\subsection{NUCLEAR POWER CAPACITY PROJECTIONS}

$1980-4.6$ GWe net

1989-9.8 GWe net (NEI 10/90)

\subsection{NUCLEAR PLANT AVAILABILITY (NW 2/8/90)}
A. Capacity factor for 1989 was $\mathbf{7 4 . 3 \%}$
B. Cumulative lifetime capacity factor is $68.3 \%$

\subsection{NUCLEAR ENERGY POLICY}

A. Sweden uses existing nuclear power capacity, but plans to phase-out all nuclear plants by the year 2010 at the latest; a parliamentary decision would be required to change this policy; based on the federal government's March 1988 energy bill, phase-out will start with the shutdown of one BWR at Barsback and one PWR at Ringhals in 1995 and 1996, respectively (NN 4/88); however, Sweden's Minister for Industry, R. Molin, says he will not accept a start of the phasing out before it is shown that it will not harm employment (SNN 1/90)

B. Sweden's present capacity is sufficient until 1995; no new plants are under construction, but plans are ready to build combined-cycle gas-fired plants to meet the increasing demand and eventually to replace retired nuclear capacity (NEI 10/90)

C. Swedish energy options are: 1) relax $\mathrm{CO}_{2}$ limits permitting construction of fossil-fired plants and shutdown of two nuclear units in 1995 and 1996; 2) build more hydro power stations on four Swedish rivers now without hydro plants (currently forbidden by Parliament); 3) delay shutdown of nuclear plants in 1995 and 1996; or 4) limit industrial production dependent on electric power; a vote on energy policy is expected in Parliament in March 1991 (NW 4/26/90)

D. Key dates in the formation of a revised energy policy are (NEI 10/90):

1. September 1990 - Annual congress of Social Democratic party

2. November 1990 - Government presents new Energy Bill which includes a proposal for new law covering nuclear phase-out

3. March 1991 - Parliament decides on new energy policy 
4. September 1991 - General election; if there is no consensus between some of the main parties, energy could be a main issue

\subsection{NUCLEAR R\&D BUDGET}

Total cost for radioactive waste management in Sweden, including all types of wastes and decommissioning of 12 nuclear plants is, 45 billion SEK (U.S $\$ 6.2$ billion) or 0.019 SEK/kWh (about U.S. \$0.0026/kWh) (NEA 11/86; SSB 1987)

\subsection{ELECTRICITY PRODUCTION COSTS}

\section{A. Electricity costs:}

1. In 1988 , the average cost for electricity in Sweden was 160 SEK/MWh (U.S. \$22/MWh); new coal or natural gas will cost at least 300 SEK/MWh (U.S. $\$ 48 / \mathrm{MWh}$ ) (Lemmel 1990)

2. In 1988, the total production cost from nuclear power for Swedish once-through fuel cycle was 170 SEK/MWh (U.S. \$23/MWh); this was made up of the following costs (SEK/MWh): capital, 80; fuel, 30; waste disposal and decommissioning, 20; other, 40 (SNN 1/90)

3. In 1990, the average cost of power from Sweden's 12 operating nuclear reactors, including fees for waste disposal and decommissioning, is about $100 \mathrm{SEK} / \mathrm{MWh}$ (U.S \$0.016/kWh) (NN 10/90)

B. Estimated future electricity costs from new plants are (NN 10/90):

1. Hydro from a large river: 200 SEKMMWh (U.S. \$32/MWh)

2. Combined-cycle gas turbine: 250 SEK/MWh (U.S. \$40/MWh)

3. Nuclear: $250 \mathrm{SEK} / \mathrm{MWh}$ (U.S. \$40/MWh)

4. Coal: 300 SEK/MWh (U.S. \$48/MWh)

5. Large-scale wind or biomass: 400 to 600 SEK/MWh (U.S. $\$ 65$ to $\$ 97 / M W h$ )

C. Based on plant lifetime of $\mathbf{4 0}$ years, the cost of phasing out all nuclear power in Sweden to year of 2010 will be 200 billion SEK (U.S. $\$ 32$ billion) (Lemmel 1990)

\subsection{NUCLEAR FUEL CYCLE AND RADIOACTIVE WASTE MANAGEMENT STRATEGY/POLICY (SSB 1987)}

\subsection{OVERALL NUCLEAR FUEL CYCLE POLICY}

A. Sweden bases all fuel cycle planning on the assumption that nuclear power will be phased out by 2010 as required by current law (Act on Nuclear Activities and Ordinance on Nuclear Activities)

B. Sweden's present policy is based on the following decisions by the Parliament (Lemmet 1990) 
1. Nuclear power shall be phased out completely by 2010

2. Phase-out shall start with two nuclear plants in 1995 and 1996

3. No more hydro power can be built

4. Emission of $\mathrm{CO}_{2}$ in the future shall not exceed 1988 emissions

C. Sweden has developed internal capabilities for fuel fabrication and nuclear power plant design, fabrication, and installation; Swedish utilities purchase uranium fuel material from other countries; Sweden plans to manage all radioactive wastes of Swedish origin in Sweden; it provides its own transportation of fuel cycle materials; all other fuel cycle services and fuel materials will be purchased from other countries

\subsection{POLICY ON THE FRONT END OF THE NUCLEAR FUEL. CYCLE}

Sweden has developed capabilities within Sweden (for domestic use and for expon) for fuel fabrication and nuclear power plant design, fabrication, and installation; Sweden purchases uranium fuel material from other countries; it provides its own transportation of fuel cycle materials

\subsection{POLICY ON THE BACK END OF THE NUCLEAR FUEL CYCLE}

A. Sweden plans to:

1. dispose of spent fuel, HLW, and long-lived ILW in a deep geological repository

2. dispose of short-lived LLW/LW in an underground cavern repository

3. dispose of limited amounts of "very low-level wastes" in a limited number of shallow ground burial facilities

B. Sweden plans to manage all radioactive wastes of Swedish origin in Sweden

C. Spent fuel will be disposed of directly without reprocessing; no plutonium recycle is planned; the Swedish Nuclear Fuel and Waste Management Company (SKB) had contracted for foreign reprocessing of over 800 MTU spent fuel, but has sold contracts or traded HLW from reprocessing for other spent fuel to be disposed of in Sweden (NF 2/5/90)

D. Sweden plans to use available technology for waste management; it will impose no waste management burdens on future generations; Sweden plans to maintain independence from foreign countries in waste management; in addition, Sweden plans to employ very high safety requirements, have high redundancy for radioactive waste disposal, and require major public and technical review

E. Sweden plans to store spent fuel in a pool-type away-from-reactor (AFR) facility for 30-40 years; encapsulate the spent fuel after storage in highly corrosion-resistant packages; emplace them in a crystalline rock repository in Sweden

F. Sweden conditions reactor wastes at reactor sites; it isolates them with other non-HLW in Sweden in a repository mined out of bedrock 
G. Sweden transports spent fuel and wastes primarily by sea

\subsection{HIGHLIGHTS AND MAJOR MILESTONES (SKB 1986b)}

1977 Started site investigations for spent fuel/HLW repository

1977 Passed the Conditions Act (to allow changing fuel to nuclear reactors)

1977 Initiated joint U.S./Swedish test program at Stripa Mine

1977 Issued KBS I report (to satisfy disposal feasibility requirements of stipulation act)

1978 Issued KBS II report (to satisfy disposal feasibility requirements of stipulation act)

1980 Approved the applications for waste repository activities based on KBS I and KBS II reports

1980 Initiated multinational Stripa Project under NEA sponsorship

1980 Voted to recommend phaseout of nuclear power in a national referendum

1980 Decided in parliament to phase out nuclear power by 2010

1982 Started shipping spent fuel in transport ship, M. S. Sigyn

1983 Issued KBS III report (to satisfy the feasibility of disposal of spent fuel)

1984 Passed Act on Nuclear Activities, replacing the 1977 Conditions Act and the 1956 Atomic Energy Act

1984 Approved applications for waste repository activities based on KBS IIf report

1985 Commissioned CLAB (AFR spent-fuel storage facility)

1988 Commissioned SFR (disposal repository for short-lived reactor wastes)

1990 Started construction of a new underground Hard Rock Laboratory (HRL) (SKB 1990c)

1991 Complete a new safety assessment, "SDB 91", for a design closely related to KBS-3 (SKB 1990c)

1992 Start pre-investigation of three candidate repository sites for spent fuel (SKB 1990C)

1994 Start up underground Hard Rock Laboratory (SKB 1990C)

1996 Start detailed characterization of two candidate sites for spent fuel repository (SKB 1990c)

1995 Shut down first nuclear power reactor as part of nuclear power phase-out

2003 Select repository site for spent fuel and submit licence application for site (SKB 1990C) 
2003 Submit license application

2006 Start spent-fuel repository design (SKB 1990C)

2010 Terminate operation of remaining operating nuclear power plants; initiate immediate dismantling

2010 Start spent-fuel repository construction (SKB 1990c); start up encapsulation plant for spent fuel (BSAB)

2015 Shut down and decommission SFR repository for short-lived reactor wastes

2020 Commission repository for spent fuel and long-lived wastes (SFL)

2050-60 Conclude operational phase and complete decommissioning of spent-fuel repository

4.0 INSTITUTIONAL CONSIDERATIONS/ORGANIZATIONS (Paige 1985; SSB 1987; Soderberg 1987)

\subsection{LEGAL REQUIREMENTS}

A. The "Radiation Protection Act," as amended in 1988, regulates the handling of radioactive substances in Sweden; it requires that licenses be obtained for all activities involving ionizing radiation (Norrby 1988)

B. The "Conditions Act" of 1977 requires proving the feasibility of radioactive waste management before nuclear reactors can charge new fuel (SKB 1977)

C. The "Act on Nuclear Activities" of 1984 replaced the 1977 Stipulation Act; it requires owners of nuclear power reactors in Sweden to have primary responsibility for all aspects of radioactive waste management, including R\&D and decommissioning; ultimate and long-term responsibility for disposal is with federal government; the act also supports and amends the 1977 Conditions Act in tying startup of new reactors to having a satisfactory waste management plan (NEi 10/90)

D. The "Act on Financing of Future Expenses for Spent Nuclear Fuel" puts responsibility of financing spent-fuel management on Swedish reactor owners (NEI 10/90)

E. The "Act on Natural Resources" and "Planning and Building Act" gives Swedish municipal councils (equivalent to U.S. county government) veto rights on land-use proposals (NEI 10/90)

F. The "Environmental Protection Act" covers the non-radiological aspects of waste disposal in Sweden; this, and 16 other laws, must be considered before nuclear wastes can be disposed of in a repository (Norrby 1988)

G. In 1980, the Swedish Parliament voted to build no more reactors and to shut down 12 existing ones by 2010 . 
SWEDEN

\subsection{RADIATION PROTECTION PRINCIPLES}

A. Sweden's fundamental radiation protection requirements are based on 1CRP Publication 26, including the principle of ALARA (IEAL 1987)

1. Occupational doses at any nuclear facilities, including waste management, shall not exceed $5 \mathrm{rem} / \mathrm{yr}$ (however, see change in item B below)

2. Public doses, due to nuclear power plants, shall be no more than $10 \mathrm{mrem} / \mathrm{yr}$ to individual members of the maximally exposed group

3. Shallow-land burial sites for "very low-level wastes" have been licensed (at Studsvik Center, Oskarshamn and Forsmark) to limit calculated consequences to less than $1 \mathrm{mrem} / \mathrm{yr}$

4. The time period considered for intermediate-depth repository for short-lived reactor wastes (SFR) is 10,000 years

5. Doses for the spent-fuel repository are believed to be unusable as basic acceptance criteria in the long term because of uncertainties beyond 100-1000 years; specific criteria will be given on times of closures for the LLW/LW and spent-fuel repositories

B. A 1989 ordinance in Sweden changed the dose limits to $50 \mathrm{mSv} / \mathrm{yr}$ (5 rem/yr) for radiation workers and $1 \mathrm{mSv} / \mathrm{yr}(100 \mathrm{mrem} / \mathrm{yr})$ for the general public; accumulated dose limits for radiation workers must be less than $180 \mathrm{mSv}$ (18 rem) at age 30 and less than $700 \mathrm{mSv}$ (70 rem) for a lifetime; in effect, this limits the average yearly dose to less that $15 \mathrm{mSv} / \mathrm{yr}$ (1.5 rem) (NLB 6/90)

C. The safety of the final repository for spent fuel should not rely on post-closure monitoring, but monitoring may be valuable for other reasons (IEAL 1987)

D. Retrievability of spent fuel is not required in Sweden, but it is not ruled out (IEAL 1987)

\subsection{LICENSING}

A. in Sweden, the applicant is required to secure:

1. a site permit from the municipal administration

2. a permit from the federal government under the Nuclear Activities Act, after favorable recommendations from the Nuclear Power Inspectorate (SKI) and the National Institute of Radiation Protection (SSI)

3. a permit from the federal government for environmental protection including administrative authorities and the municipal council board

4. a building permit from the municipal employment board

B. SKI has found that an active regulatory role requires an independent R\&D program with performance assessmemt as a driving force; SKI intends to develop step-by-step guidelines on the spent-fuel repository system, the scientific basis for performance assessment models, and the assessment itself (Andersson 1990) 


\subsection{PUBUC INVOLVEMENT}

A. The local municipal council, as well as the federal government, must approve the licensing of a facility

B. An extensive public communication program has been launched in Sweden, consisting of public-opinion polls, public-affairs work, business-world contacts, mobile exhibitions, open houses, printed material, seminars, and study tours (Ungermark 1989)

C. SKN has responsibility for providing the public with information (Soderberg 1989)

1. The scope of information includes work and planning on disposal of spent fuel, radwaste from spent fuel, and decommissioning and dismantling of reactors

2. SKN's information activities have included: management and disposal of spent fuel; social policies on nuclear waste; Swedish and international developments within the field; SKN's functions, results, and supervision; costs and financing of high-level waste management in Sweden

D. A public opinion poll shows $54 \%$ of the Swedish population favor keeping nuclear power beyond 2010; this compares with $30 \%$ for a similar poll just after the Chernobyl accident (NN 5/90)

\subsection{WASTE FUND (Ahlstroem 1987a; Söderberg 1987)}

A. A Swedish waste fund was established in 1982; the fund is based on estimated costs of spent fuel and other waste management and decommissioning; it is administered by the National Board for Spent Nuclear Fuel (SKN); it is financed by a national bank; loans are made from the fund to nuclear companies

B. The fee averages about 0.019 SEK/kWh (about U.S. $\$ 0.0026 / \mathrm{kWh}$ U.S.) but varies for each utility by waste mix; the fee is reviewed and can be adjusted annually if necessary; operating costs for immediate management of nuclear power wastes is an additional $0.001 \mathrm{SEK} / \mathrm{kWh}$ (U.S. $\$ 0.00014 / \mathrm{kWh}$ )

4.6 KEY AGENCIES AND FUEL CYCLE CENTERS (Ahlstroem 1985; SSB 1987; Leigh and Mitchell 1990)

A. SKB (Nuclear Fuel and Waste Management Company): SKB is a private company composed of representatives from the nuclear utilities; it is responsible for nuclear fuel supply; it manages and funds waste management R\&D for nuclear utilities; it plans, builds, designs and operates facilities for storage and disposal of nuclear wastes; it demonstrates that spent fuel and radioactive wastes can be disposed of safely and permanently; it provides transportation and handling of spent nuclear fuel outside reactor sites; it obtained foreign reprocessing services in the past; major facilities are:

1. CLAB: An AFR spent-fuel storage facility (underground pools) at Simpevarp, adjacent to the Oskarshamn Power Station; CLAD started up in 1985; initial capacity is 3,000 MTU

2. SFR: The Subseabed Forsmark Repository, is a central repository for short-lived $\mathrm{LLW}$ and $\mathrm{ILW}$; the repository is located in rock $50 \mathrm{~m}$ below the seabed, $1 \mathrm{~km}$ 
outside Forsmark Harbor on the Gulf of Bothnia; the facility started receiving wastes in 1988; the initial capacity is $90,000 \mathrm{~m}^{3}$ of conditioned waste; it is expandable to more than $200,000 \mathrm{~m}^{3}$

3. Stripa Mine: The Stripa mine is near Kopparberg, $15 \mathrm{~km}$ north of Lindesberg and about $250 \mathrm{~km}$ west of Stockholm; it is an Underground Research Laboratory in granite, about $350-400 \mathrm{~m}$ below grade; it is near the Stripa iron mine

B. SKI (Nuclear Power Inspectorate): SKI licenses, supervises and controls the safety of design, construction and operation of nuclear facilities; it reviews and subcontracts R\&D on nuclear safety issues; SKI reports to the Ministry of Environment and Energy

C. SKN (National Board for Spent Nuclear Fuel): SKN evaluates and supervises planning, research and development for management of spent fuel and for D\&D of nuclear facilities; it administers funding for waste management; reports to the Ministry of Environment and Energy

D. KASAM (Swedish Consultative Committee for Nuclear Waste Management): KASAM is a government expert committee for advice on nuclear waste and D\&D of nuclear facilities; it reports to the Ministry of Environment and Energy

E. SSI (National Institute of Radiation Protection): SSI sets and enforces basic radiation protection standards; it supervises radiation protection measures and reports to Ministry of Environment and Energy

F. Studsvik (Energy Technology Company, government owned): Studsvik has provided interim LLW and ILW storage in a rock cavity (since 1985) from its operations and from institutions

\subsection{PRINCIPAL RESEARCH, DEVELOPMENT AND DEMONSTRATION FACILITIES/PROGRAMS (Leigh and Mitchell 1990)}

A. Stripa Mine: Stripa is a multi-nationally-used Underground Research Laboratory (URL) at $350-400 \mathrm{~m}$ below surface in granite, near Kopparberg, $15 \mathrm{~km}$ north of Lindesberg, and about $250 \mathrm{~km}$ west of Stockholm; the mine provides for research in a realistic crystalline rock environment; activities include development of investigation methods and instruments, measurements of radionuclide migration, and supporting studies

B. Studsvik (Energy Technology Company, research center at Nykoping): Studsvik is owned by the Ministry of Industry and carries out contract nuclear and waste management R\&D to support energy programs R\&D on LLW/LW treatment, incinerator development, decommissioning, leaching from waste and spent fuel, and biosphere migration

1. Waste treatment plant (upgraded in the "AMOS" project), since 1986; it has treated much of LLW/ILW from nuclear power plants, including treatment of combustibies by incineration from German nuclear power plants until 1988; it treats LLW/LW from hospitals and laboratories; it assumes long-term management of the wastes for a fee; the "AMOS" project, built at a cost of $\$ 26$ million (U.S.), went operational in 1988; it will serve as a model for future facility construction and take care of waste from industry, medicine and research (CEN 12/88) 
2. Studsvik carried out HLW glass leach experiments in the Japan-SwedenSwitzerland (JSS) project on evaluation/modeling of HLW glass performance; the project was completed in 1988

C. Chalmers (Technical University in Goteberg): Chalmers performs waste management R\&D, studies on radionuclide transport by groundwater and sorption of radionuclides on natural clays and rock materials

D. KTH (Royal Institute of Technology in Stockholm): KTH conducts near- and far-field migration modeling, rock-matrix diffusion experiments, actinide chemistry studies, solubility calculations, groundwater sampling, and characterization of waste forms and rocks

E. SGAB (Swedish Geologic Company in Uppsala): SGAB evaluates rock formations for waste disposal

4.8 KEY PERSONNEL (Leigh and Mitchell 1990)

A. R. Molin, Minister for Industry (with responsibility for energy) (SNN 1/90)

B. S. Bjurstroem, Presidert, SKB

C. P.-E. Ahlstroem, Director, Research \& Development, SKB

D. H. Forsstroem, Director of Systems and Facilities, SKB

D. T. Eng, International Relations, SKB

E. C. E. Nyquist, Director General, Swedish State Power Board, and Chairman of the Board, SKB

F. S. Norrby, Manager, Waste Management, SKI

G. N. Rydell, Chief Engineer, SKN

H. R. Boge, Radioactive Waste Group, SSI

I. S. Bergstroem, Director, Nuclear Technology, Studsvik

J. J-O Liljenzin, Head, Nuclear Chemistry, Chalmers University

K I. Neretnieks, Head, Chemical Engineering, KTH

L K. Ahlbom, Geology and Site Investigations, SGAB

\subsection{NUCLEAR FUEL PRODUCTION}

\subsection{STRATEGY}

Sweden's strategy is to purchase fuel materials and enrichment services from other countries and provide fuel fabrication for Swedish reactors and some for export 


\subsection{URANIUM RESOURCES}

A. $37,000 \mathrm{MTU}$ are reasonably assured, but expensive to recover; $45,300 \mathrm{MTU}$ are estimated additional reserves (NEA 1986)

B. No local exploration is currently active (formenty carried out by SKB); no exploration is conducted in foreign courtries (NEA 1988)

\subsection{URANIUM PRODUCTION}

No mining activity is planned; a small production (about 300 MT yellowcake) took place at Ranstad in southern Sweden between 1965 and 1969, then the plant was shut down; in late 1970s, mining at Pleutajokk in northern Sweden was initiated, then abandoned; both mining ites used sulfuric acid leaching

\subsection{URANIUM CONVERSION}

Sweden has no conversion capability; Sweden utilizes conversion services from Canada, U.S., U.K. and France (SKB 1986d)

\subsection{URANIUM ENRICHMENT}

Sweden has no enrichment capability; Swedish utilities utilize conversion services from Eurodif, Urenco, USSR, and U.S. (SKB 1986d)

\subsection{FUEL FABRICATION}

A. Sweden's utilities purchase nuclear fuel fabrication services with the objective of lowest fuel cycle cost (SKB 1986d)

B. Sweden has commercial BWR and PWR fuel fabrication capability, $400 \mathrm{MTU} / \mathrm{yr}$, in facility at Vasteras; in an adjacent facility, BWR control rods are fabricated, including control rods for export (NEI 12/87)

\subsection{FUEL RECYCLE}

\subsection{FUEL REPROCESSING}

A. Sweden has no plans for domestic reprocessing

B. In 1984 Sweden approved a method for direct disposal of spent fuel, making it unnecessary to reprocess the fuel; in January 1990 SKB sold the rest (730 MTU) of the 1978 reprocessing contract with Cogema to eight West German utilities (SNN 1/90)

C. 140 MTU were contracted for reprocessing in U.K.; the waste will not be returned to Sweden

D. 217 spent MOX fuel assemblies from demonstrations in Germany are being received for storage/disposal in Sweden in exchange for the plutonium and wastes from some Swedish spent fuel sent to France for reprocessing (ATW 2/88) 


\subsection{SPENT FUEL STORAGE AND TRANSPORT}

\subsection{SPENT FUEL ARISINGS (Leigh and Mitchell 1990)}

Through 1985--cumulative $1330 \mathrm{MTU}$

Through 1990-cumulative $2360 \mathrm{MTU}$

Through 2010--cumulative $7800 \mathrm{MTU}$ (end of nuclear power program)

\subsection{SPENT FUEL STRATEGY}

Sweden's strategy is to store spent fuel in reactor pools for 1-5 years; it then plans to store spent fuel in the central AFR storage facility for $30-40$ years until a repository is available

\subsection{WET STORAGE}

A. Interim long-term wet storage of spent fuel has been implemented in Sweden at the central storage facility (CLAB) to allow for flexibility and planning time, and await transport to the planned geologic repository (Gustatsson 1986; Gustafsson 1987; SSB 1987)

1. The CLAB is adjacent to the Oskarshamn Nuclear Power Station

2. The fuel-receipt capacity is $300 \mathrm{MTU} / \mathrm{yr}\left(16 \mathrm{hr}_{i} \mathrm{~d}, 5 \mathrm{~d} / \mathrm{wk}\right.$ ); fuel loading started 1985

3. By mid-1990, i500 MTU of spent fuel were being stored at CLAB (Bjurstróm 1990)

4. Assemblies are stored in open canisters/racks in water pools; rod consolidation is not practiced

5. The storage section at the CLAB facility consists of free-standing, stainless steel-lined, reinforced concrete pools in an underground rock cavern (canyontype facility) whose roof is $25-30 \mathrm{~m}$ below surface

6. The normal CLAB water temperature is $25-30^{\circ} \mathrm{C}$; maximum cooling capacity is $6.5 \mathrm{Mw}$

7. The current capacity at CLAB is $3000 \mathrm{MTU}$, in four pools; the capacity can be increased to $9000 \mathrm{MTU}$ by construction of addditional caverns and pools; the planned ultimate capacity is $8,000 \mathrm{MTU}$ in mid 1990 s (SKB 1986b; ED 3/1/88)

8. The CLAB facility will be filled with $3000 \mathrm{MTU}$ in 1996; altematives for expansion are under study; expansion from 3000 to 5000 MTU is estimated to cost 600 million SEK (\$U.S. 97 million) (Johnson 1989)

9. Many operations are carried out by remote control to reduce radiation exposure

10. Most cask handling is done remotely

a. Casks are received by heavy-haul truck, tilted to vertical, lifted then lowered into a cooling hot cell where it is fitted with protective metal skirt

b. Pre-cooling of spent fuel that is up to $300^{\circ} \mathrm{C}$ is done by water injection into and external water onto the cask 
c. After cooling the cask, it is lifted by crane out of the cooling cell and lowered onto a transport wagon at boltom of the CLAB pool

d. After spent fuel is transported to the unloading pool, cask lids are removed remotely and fuel assemblies are lifted individually and placed in a fuel storage canister

e. Each fuel canister is lowered into the underground storage pool through a water lock, where it is lifted and moved to storage location by overhead crane

11. Receiving facilities, including cask maintenance and remote maintenance facilities, are on the surlace; normally one cask is being maintained in the facility at one time

\subsection{TRANSPORT}

A. The nuclear power stations, CLAB and the candidate repository sites are on the coast; spent fuel is loaded onto a special, one-piece overweight truck at the reactor for transport to the port (Gustafsson 1986)

B. Spent fuel and wastes have been transported between sites in a specially-built ship, M. S. Sigyn, since 1983; the ship is $90 \mathrm{~m}$ long, $18 \mathrm{~m}$ wide, gross weight $2000 \mathrm{MT}$, payload capacity $1200 \mathrm{MT}$; it has a loaded draft of $4 \mathrm{~m}$, and cruising speed of 11.5 knots; ship capacity is 10 casks, or about $30 \mathrm{MTU}$ in one main hold $57 \mathrm{~m}$ long, $10 \mathrm{~m}$ wide, $5.6 \mathrm{~m}$ high; its main hold also has two 25 - $\mathrm{m}$-long hatchways for top entry; a tophinged, water-tight stern door for roll-on entry is provided; on the ship, trailer wheeis are lowered and the transport frame and cask are lowered onto the ship's hold floor and fastened; normally roll-on/roll-off loading is used, but lift-on/litt-off loading can also be used (Gustafsson 1986)

C. The Integrated Sea Transportation System (ISTS) is now in routine operation with about 30 trips with $M$. S. Sigyn; fifteen trips are with spent fuel to the CLAB facility and 15 with ILW containers to SFR; a total of $1500 \mathrm{MT}$ of spent fuel has been shipped to CLAB and about $2500 \mathrm{~m}^{3}$ of reactor waste to SFR; this corresponds to 300 casks and $150 \mathrm{ILW}$ transport container movements; typical one-way ship travel time is about 24 hours; $8-12$ days are required at the reactor to load a typical shipment of five casks; transport and handling of spent-fuel casks have proven to be very safe and reliable; previously experienced low dose commitment to the ship crew has only increased slightly even with the transport of higher burn-up fuel (Gustaisson 1989)

D. During an average year, about $250 \mathrm{MT}$ of spent fuel and 3000 to $4000 \mathrm{~m}^{3}$ of reactor waste are transported to CLAB and SFR, respectively, corresponding to about 30 sea voyages; the $M$. S. Sigyn has sailed about $195,000 \mathrm{~km}$ with an average of $50,000 \mathrm{~km}$ per year; doses to the crew have not exceeded background; the permissible maximum annual dose rate per individual is $5 \mathrm{mSv}(500 \mathrm{mrem}$ ) (Dybeck 1990)

E. Transnucleaire casks (TN17/Mk2, nitrogen-filed at $0.5 \mathrm{~atm}$ ) hold 17 BWR or seven PWR assemblies (about 32 MTU); 10 spent-fuel casks are available; each cask weighs 76 MT when empty and $80 \mathrm{MT}$ when full; the heat capacity of each is $43.5 \mathrm{~kW}$; casks have removable impact limiters and external copper fins (Gustafsson 1986) 
F. Two casks similar to TN17/Mk2 (TN17/CC), without cooling fins and neutron shield, are used for shipping non-fuel-bearing hardware, boron neutron absorbers, and control rods (Gustafsson 1986)

G. In-service inspection and maintenance of transportation casks are performed at the CLAB facility following the "Green Book" principles; from start of operation in 1985, about 30 casks had been processed through the 8-10 cycle inspection and maintenance, and 3 casks had been processed through the 30-40 cycle irispection and maintenance; experience has shown that most damage occurs on trunnions and tightness surfaces on the cask and secondary lid (Dybeck 1989)

H. MOX fuel assemblies from the VAX reactor at Kahl, West Germany, were shipped to the CLAB facility in the Swedish transport ship, M. S. Sigyn (NN 1/89)

7.5 PROGRAM/FACILITIES COSTS (SSB 1987; Cooley 1987; Gustafsson 1987)

A. The CLAB initial construction cost was 1.7 billion SEK or about $\$ 300$ million (U.S.) (ED $3 / 1 / 88)$

1. Underground costs were about $20 \%$ of total construction costs; the remaining costs were in surface receiving facilities

2. Operating cost is about 70 million SEK/yr, or about $\$ 12$ million/yr (U.S.) (ED 3/1/88)

3. Total cost is about $\$ 0.5 \mathrm{mil} / \mathrm{kWh}$ (U.S.)

B. The transportation of $300 \mathrm{MTU} / \mathrm{yr}$ of spent fuel to CLAB costs about $\$ 1.2 \mathrm{million} / \mathrm{yr}$ (U.S.)

C. The total cost of transportation equipment (ship, 10 casks, vehicles, cradles, etc.) was 200 million SEK ( $\$ 28$ million U.S.), of which about half was for 10 cask systems (Hilley 1986)

D. See also Section 10.11

\subsection{WASTE CONDITIONING, STORAGE, AND TRANSPORT}

\subsection{WASTE DEFINITIONS (IEAL 1987)}

A. In Sweden, no activity levels are used to distinguish between LLW, ILW, and HLW; IAEA descriptions are generally used:

1. LLW can be handled and stored in simple packages without special protective measures

2. ILW must be radiation-shielded

3. HLW must be shielded and cooled for a certain period

4. Short-lived wastes contain radionuclides with half-lives generally less than 30 years

5. Long-lived wastes remain radioactive for thousands of years or more 
B. The Swedish Consultative Committee for Nuclear Waste management has concluded that chemical, as well as radiological toxic effects, should be considered in determining the potential health risks from future geologic repositories for radioactive wastes (NWN $1 / 19 / 89)$

8.2 WASTE ARISINGS (to the end of the planned Swedish nuclear power program in 2010) (Ahlstroem 1987a; SKB 1990c):

Spent fuel (7800 MTU)

Reactor wastes (LLW/LW)

Reactor core components (ILW)

Alpha wastes

D\&D wastes (LLW/ILW)

\author{
$12,600 \mathrm{~m}^{3}$ (5,600 canisters) \\ $95,000 \mathrm{~m}^{3}(270,000$ curies maximum) \\ $19,000 \mathrm{~m}^{3}$ \\ $6,000 \mathrm{~m}^{3}$ \\ $113,000 \mathrm{~m}^{3}$
}

\subsection{LLW/ILW CONDITIONING}

A. The waste-treatment plant at Studsvik has treated much of LLW/LW from nuclear power plants (including treatment of combustibles by incineration from German nuclear power plants until 1988); it treats LLW/LW from Swedish hospitals and laboratories; it assumes long-term management of the wastes for a fee (Leigh and Mitchell 1990)

B. Processing for volume reduction is done at Studsvik Nuclear, Nykoping (Menon 1990)

1. Incineration - Over $4000 \mathrm{MT}$ of bumable wastes have been treated in the past 12 years in a controlled-air incinerator; the $250-\mathrm{kg} / \mathrm{h}$ plant was recently renovated; the volume reduction factor is about 115; a similar plant with a capacity of $500 \mathrm{~kg} / \mathrm{h}$ recently started operation by Scientific Ecology Growp in the U.S.

2. Melting - The facility includes a preparation/segmentation area and inductionmetting furnace with capacity of $3 \mathrm{MT}$ per charge; during the 6-month test period 93 melts were performed on carbon and stainless steel; Cs-137 was removed and collected in the ventilation filters, leaving Co-60 as the dominant radionuclide in the melt; of $1000 \mathrm{MT}$ of metallic scrap melted so far, $120 \mathrm{MT}$ of carbon steel and 20 MT of stainless steel were fit for unrestricted use

3. Decontamination - Two processes, Ozone Decontamination Process (ODP) and Arvesen Scrap DEcontamination Process (ASDEP), have been developed; the ASDEP process will be demonstrated at the pilot scale in 1991

4. Supercompaction - In late 1989 , a 1200-MT supercompactor was tested on 5000 200-liter barrels; volume was reduced by 3 to 4 times

C. Low-level wastes in Sweden are incorporated in cement (at Ringhais and Oskarsharnn Power Stations) or bitumen matrixes (at Barsback and Forsmark Power Stations)

D. Concrete boxes, $1.2 \mathrm{~m}$ on a side (typically for concreted waste), or 200-liter drums, $0.6 \mathrm{~m}$ diameter by $0.9 \mathrm{~m}$ high (typically for bitumenized waste), are the most frequently used containers; also, some concrete tanks $3.3 \times 1.3 \times 2.3 \mathrm{~m}$ are used for dewatered resins and filter material (Lakey 1985; Gustafsson 1987) 
E. As of 1987 , studies were in progress on wet oxidation (WOX) of organic ion exchange resins using hydrogen peroxide in sulfuric acid medium, with separation of the solid phase, followed by cementation of final residue; final treated waste is $2.3 \mathrm{~kg}$ resin residue per $\mathrm{m}^{3}$ final waste, or a volume reduction of about $15: 1$, compared with direct cementation of resins (Petersson 1987)

\subsection{LLW/ILW STORAGE}

In Sweden, interim storage of reactor wastes is at reactors in either concrete cells or a concrete building at the surface at three of the nuclear power stations; interim storage is in a belowground cavern in bedrock for ILW and long-lived wastes at the Oskarshamn Reactor Station and at thie Studsvik Center (Larsson 1986)

\subsection{SPENT FUEL CONDITIONING}

A. Spent fuel will be encapsulated in a canister; copper is the reference material, but other materials may also be considered (SKB 1990C)

B. Waste from testing of spent fuel generated since 1960 at the Studsvik research facility is being encapsulated in stainless steel canisters, loaded into a transport box containing 12 canisters and shipped to the CLAB interim storage facility; all of the older accumulated waste, about $2200 \mathrm{~kg}$, will be encapsulated and transferred to CLAB by the end of 1992 (Holmer 1990)

C. An encapsulation plant is planned adjacent to the future repository, although an alternative site at CLAB will be considered; construction of the encapsulation plant will not begin until about 2010 (SKB 1990C)

\section{See also Section 10.4}

\subsection{TRANSPORT}

A. Transport to the SFR repository is by the ship M. S. Sigyn in one of three types of transport containers that meet IAEA transportation standards and weigh about $100 \mathrm{MT}$ each; type 1 holds 12 concrete moulds or 72 drums; type 2 holds 16 concrete moulds or 96 drums; type 3 holds three concrete tanks with resiris

B. Sweden also has two casks similar to TN17/Mk2 casks for spent fuel (called TN17/CC), without cooling fins and neutron shield, that will be used for shipping non-fuel-bearing hardware, boron neutron absorbers, and control rods; loaded casks weigh about 120 MT

C. The Integrated Sea Transportation System (ISTS) is now in routine operation with about 30 trips with M. S. Sigyn; fifteen of these trips were with LIW/LW containers to SFR; a total of about $2500 \mathrm{~m}^{3}$ of reactor waste has been shipped to SFR; this corresponds to 150 ILW transport container movernents; up to 10 casks of LLW/LW can be carried in each shipment; ice conditions at Forsmark generally will not allow use of that port between December and April (SKB 1986b; Gustafsson 1987; Gustafsson 1989)

D. A special overweight truck vehicle is used for waste transport at the SFR and between the harbor, the SFR, and the Forsmark Nuclear Power Station; the vehicle has seven axles and 28 wheels; it is diesel powered above ground and remotely powered by electricity in tunnels 
E. ILW is transported in large IP-2 steel containers (ATB) to the SFR disposal facility; the containers are of different types depending on shielding requirements and size of waste units; LLW is transported in standard ISO containers (Dybeck 1990)

\subsection{MIXED WASTE CONDITIONING, STORAGE AND TRANSPORT (Bengtsson 1989)}

A. In Sweden, non-radioactive and mixed (i.e., radioactive and other hazardous) wastes have some common characteristics and some greatly different characteristics

1. Compared with radioactive wastes, the compositions of non-radioactive and mixed wastes are much more complex and are generated in much larger quantities; policies and procedures for treatment and disposal are not consistent or well developed

2. Highly radioactive wastes can be more dangerous even at a distance; the risks are often perceived to be greater by the public

3. Both types of waste may have long-term impact on health and environment

B. The same general principles should be applied for management of radioactive and non-radioactive wastes

C. International cooperation is needed in R\&D; development of protection policies; evaluation of costs, risks, and benefits of proposed disposal practices

\subsection{PROGRAM/FACILITIES COSTS}

Costs to Swedish utilities for immediate management of their operating wastes is about 0.001 SEK/kWh (\$0.00014/kWh U.S.) (Ahlstroem 1987a)

\subsection{DISPOSAL OF NON-HIGH-LEVEL WASTES}

\subsection{STRATEGY}

A. Sweden's strategy is to build a single national repository (SFR) for reactor and other short-lived LLW and ILW and decommissioning wastes near the Forsmark nuclear power station; long-lived ILW will be disposed of in a deep geologic repository (see Section 10)

B. A limited amount of "very low-level wastes" may be disposed of in shallow-ground repositories at some waste-generating sites (two are in operation)

\subsection{WASTE DISPOSAL CRITERIA}

A. The Swedes will provide long-life containment for the waste packages

B. The SFR repository in Sweden will be situated in bedrock under the Baltic Sea, where any leakage would be into the sea rather than into the groundwater

C. The safety analysis of the Swedish disposal system must consider the entire system, but analysis of performance of specific subsystems must be performed (IEAL 1987) 


\section{Safety analyses should play a major role in defining R\&D}

2. Deterministic and probabilistic models should be used and should be complementary

D. The safety of the final repository should not rely on post-closure monitoring, but monitoring may be valuable for other reasons

E. No wastes from other countries will be accepted for disposal in Sweden

\subsection{LLW/ILW DISPOSAL}

A. Sweden plans to emplace most short-lived LLW/ILW in the SFR facility (an intermediatedepth geologic repository for reactor wastes) (SKB 1986c; SKB 1987)

1. The SFR facility includes a surface receiving and handling facility that consolidates small waste packages into fewer larger ones ( $\mathrm{NEI} 2 / 88$ )

2. The facility can handle $\mathbf{2 0 0}$ transport containers of waste packages each year

B. The SFR facility is situated in rock caverns excavated in crystalline rock beneath the seabed, $1000 \mathrm{~m}$ from Forsmark Harbor; the top of the repository is $50 \mathrm{~m}$ beneath the seabed; access is by a 1-km-long tunnel ( $8.5 \mathrm{~m}$ wide and $7.5 \mathrm{~m}$ high) from the harbor area; the access tunnel will be plugged with concrete upon closure; the initial waste capacity is $100,000 \mathrm{~m}^{3}$, expandable to $230,000 \mathrm{~m}^{3}$ (Hedman 1984; Lakey 1985; SKB 1990a)

1. Transport of waste from the shore facilities through an access tunnel is on special trailers towed by a large truck/forklift; the maximum gross payload capacity of vehicle is $120 \mathrm{MT}$, and its total weight is $155 \mathrm{MT}$

2. The trailers are moved with a vehicle with a specially ventilated, pressurized, shielded cab (7-cm thick) and shielding windows; the towing system can be operated by diesel engines (above grade) or by electric motors (below grade); television viewing is provided (NE1 2/88)

C. The first phase of the SFR facility was placed in service in 1988; the second phase will start operating in the late 1990s; the final phase is for decommissioning wastes when reactors are decommissioned after 2010 (SKB 1986b)

D. The operating license was issued by $S K I$ in $3 / 88$; the requirements are: to keep characterization data on each package; maintain a surveillance program during repository operation; carry out periodic safety analyses; each type of waste package must be approved by SKI and SSI; no part of the repository may be sealed off without an SKI permit; the total maximum content is 270,000 curies (only a small fraction of which can be long-lived) (NW 4/14/88)

E. Four repository types exist at the SFR facility (SKB 1986c; SKB 1987; Hanson 1990)

1. Concrete silos surrounded by bentonite clay barriers for ILW with highest radioactivity levels (SKB 1986C; SKB 1987) 
a. The cylindrical cavities in the rock are $70 \mathrm{~m}$ high and $30 \mathrm{~m}$ in diameter; each has concrete silo $50 \mathrm{~m}$ high and $25 \mathrm{~m}$ in diameter, resting on a bed of clay and sand; clay is placed between the concrete silo wall (nearty $1 \mathrm{~m}$ thick) and cavity; the top of the silo will be backfilied with the same material when a silo is full

b. Each silo is divided intemally by concrete walls into cells with 2.5- by 2.5-mm cross-section; after each cell is filled with waste to pre-selected levels, it is backfilled with concrete; the process is repeated until the cells are filled to the top of the silo

c. All operations are remote; waste emplacement is automated using an overhead rail-mounted crane and a cart that are in the tunnel extending over two silos; four concrete moulds or 16 drums can be emplaced in one sequence in about two hours

2. Two types of tunnel rooms are used for LLW and some ILW, depending on canister type, spaced $15 \mathrm{~m}$ apart

a. One type of tunnel is for $\amalg W$ packages that are emplaced using forklifts

b. The second type of tunnel (for ILW packages) is fitted with concrete-walled hot cells; waste packages are emplaced remotely using an overhead track-mounted crane; after filling a cell with waste, backfill around waste packages is done with concrete grout

3. Future metal drums of bitumenized LLW/LW resins may be placed in caissons made of concrete constructed in a large tunnel; the tops of the caissons are to be sealed with concrete; all operations will be by remotely operated overhead crane; a thick concrete slab will then be poured over all filled caissons; other spaces will be backfilled with a bentonite clay and sand mixture

F. Disposal containers for the SFR facility are: Concrete moulds, 200-liter drums, or concrete tanks with ion exchange resins; see also Section 8.3 (SKB 1987); concrete mouids, used for disposal of core components, have dimensions of $5.5 \times 1.25 \times 1.25 \mathrm{~m}$; they are designed to be stacked in tunnels, and have adequate shielding to permit access to the tunnel; the total number of moulds is about 2,300 (SKB 1986c)

G. Plugs of all SFR tunnel entrances will be made of concrete (SKB 1987)

H. Safety and performance tests will be performed throughout construction and operating phases of all parts of the SFR repository (SKB 1987)

I. The safety assessment factors considered for the SFA facility are (Carlsson 1989):

1. Repository design and operation

2. Method and time of sealing the repository

3. Hydraulic flow

4. Expected geologic changes 
5. Long-term properties of engineered and natural barriers; the major barrier is considered to be the hast rock

6. QA program during operation

J. Factors intluencing public acceptance of the siting process for the SFR facility are (McCabe 1990):

1. High dependence on nuclear power (47\%)

2. People generally trust the government

3. SKB (the site developer) had institutional credibility

4. Details of the plan were not presented until the search centered on Forsmak, Vatenfall

5. Few public meetings were held and only four meetings were conducted with environmental groups (which had no legal forum for intervention)

6. An advisory council of citizens from six surrounding communities, representing all seven political parties, was established; the council voted 30 in favor of the facility and 19 opposed

K. Shallow-land burial sites (at Studsvik Center, Oskarshamn and Forsmark) have been licensed for "very low-level wastes" to limit calculated consequences to less than $1 \mathrm{mrem} / \mathrm{yr}$ (IEAL 1987)

9.4 PROGRAM/FACILITIES COSTS (SKB 1986a,C; SKB 1987)

A. SFR construction cost is about $\$ 150$ million (U.S.) (1.25 billion SEK)

B. SFR operations cost is about $\$ 25$ million/yr (U.S.) (240 million SEK/yr)

C. SFR sealing, at end of program, will cost about $\$ 6$ million (U.S.) (60 million SEK)

D. SFR total life-cycle will cost about $\$ 250$ million (U.S.), or about U.S. $\$ 0.0015 / \mathrm{kWh}$

E. In 1989, the cost of total reactor waste management (power-plant wastes to final disposal) for the four Ringhals reactors was 2.18 million SEK, or $\$ 0.35$ million (U.S.) (Hanson 1990)

\subsection{DISPOSAL OF HIGH-LEVEL WASTES}

\subsection{SPECIFICATIONS AND CRITERIA}
A. Dispose of spent fuel in long-lived (up to 1 million years) waste packages
B. Use multiple barriers and available technology 
C. Impose no burdens on future generations

D. Require no surveillance and make waste difficult or impossible to retrieve (SKB 1990c)

E. Maintain the greatest possible independence of foreign countries in waste management

F. Radiation doses are believed to be not usable as basic acceptance criteria in the long term for the spent-fuel repository because of uncertainties beyond $100-1000$ years (IEAL 1987)

1. SKI does not generally develop detailed safety criteria in advance of license application

2. Specific criteria will be specified, if necessary, about the time of closure of spentfuel repository

G. Safety analysis of the disposal system must consider the entire system, but analysis of performance of specific subsystems must be carried out (IEAL 1987)

1. Safety analyses should play a major role in defining R\&D

2. Deterministic and probabilistic models should be used and should be complementary

H. The safety of the final repository should not rely on post-closure monitoring, but monitoring may be valuable for other reasons (IEAL 1987)

I. $\quad 100 \mathrm{~m}$ is required between spent fuel and a potential channel for migration of radionuclides (i.e., a major fracture zone with potential for increased water flow)

J. A special "Project 90 " is under way by SKI (Andersson 1990; Norrby 1990)

1. The purpose is to develop regulatory guidance during the $1990 \mathrm{~s}$, including guidance for R\&D and development of performance assessment models

2. Regulatory issues are: research needs (i.e., prediction of fuel dissolution and groundwater movement); site characterization; and repository characteristics

3. Performance assessment model development emphasizes deterministic analysis; deterministic and probabilistic methods are used to estimate uncertainties

4. Performance measures will be presented in terms of radiation doses to individuals in certain reference biospheres

5. Final reports will be published in the beginning of 1991

\subsection{REPOSITORY DEPLOYMENT STRATEGY}

A. Sweden plans to proceed with siting and construction of a deep geologic repository for spent fuel and long-lived wastes and any reprocessing wastes (including vitrified $\mathrm{HLW}$ returned by foreign reprocessor) for any reprocessed spent fuel; long-lived ILW will be disposed of in a nearby but separate deep geologic repository 
B. Pertorm major field R\&D in a realistic Hard Rock Laboratory (HRL)

C. Store spent fuel and HLW canisters in the AFR wet storage facility until the repository is ready; aging simplifies the repository design, making it possible to have a repository of smalier volume, and allowing time to re-evaluate a decision concerning direct disposal of spert tuel

\subsection{SITE SELECTION AND CHARACTERIZATION}

A. Site selection

1. In 1985, imvestigations were started at 15 sites in Sweden and were completed at eight (SKB 1986b)

2. A "standard" program was employed for site-screening investigations (Nilsson 1984, 1985; Ahlstroem 1984; Carlsson 1987)

a. Preliminary reconnaissance involved mapping, field reconnaissance, and reconnaissance drilling

b. Surface investigations employed geologic mapping and geophysical surface measurements to identify main geologic and tectonic features; evaluations of investigations followed

c. Subsurface investigations

1) Borehole investigations were conducted to $1000 \mathrm{~m}$ depth to measure hydraulic conductivity and piezometric pressures as a function of depth; boreholes were also used to make geophysical and geochemical measurements and to study the chemistry of groundwater

2) Percussion drilling was used to determine fracture zones and groundwater locations

d. Evaluation of results was used to set up a descriptive model of the sites

3. The final site selection and license application is expected to be submitted by about the year 2000; the government decision on the license application is expected to be one to two years later

B. Site characterization (NWN 1/22/90)

1. In 1992, three possible sites will be named

2. Characterization will start on three sites in 1993

3. In 1996, two sites will be studied in detail, leading to a license application in 2003

C. Major R\&D study areas are: fracture-zone studies, bedrock stability, groundwater movement, and radionuclide migration 


\subsection{REFERENCE HLW/SPENT FUEL DISPOSAL CONCEPT (NEI 12/85)}

A. The reference waste form in Sweden is spent fuel cooled 40 years after reactor discharge; if necessary, vitrified HLW from foreign reprocessors could be received

B. Sweden's reference waste package concept is (Ahlstroem 1984):

1. The spent fuel will be a long-lived package; the fuel rods will be embedded in metallic lead or copper, in thick-wall copper canister that provides shielding as well as corrosion resistance; the canister wall is about $10 \mathrm{~cm}$ thick, $0.8 \mathrm{~m}$ diameter, $4.5 \mathrm{~m}$ long, and weighs about $22 \mathrm{MT}$ (includes about 10.5 MT metallic lead and 9.5 MT copper); each package contains about 1.4 MTU (typically eight BWR assemblies or two BWA and two PWR assemblies)

a. An equivalent reference concept involves filling a canister with 9 BWA assemblies with powdered copper followed by hot isostatic pressing into a solid body of copper

b. BWA fuel channels and PWR poison rods, removed before encapsulation of spent-fuel rods, are placed in rectangular concrete boxes $(1.25 \mathrm{~m}$ square $\mathrm{x}$ $5.3 \mathrm{~m}$ long) that are backfilled with concrete

2. The temperature limit at the surface of waste package is about $80^{\circ} \mathrm{C}$

3. An alternate waste package concept includes ceramic materials for waste canisters (SKN 1987)

4. Vitrified HLW, if received from foreign reprocessors, includes a waste canister encapsulated in metallic lead with an outer shell of titanium

5. The engineered barrier around waste package will be compacted bentonite 'donuts' about 0.35 m thick

6. Backfill of tunnels is planned to be a $90 \%$ sand - $10 \%$ bentonite mixture; the temperature limit of the backfill is about $80^{\circ} \mathrm{C}$ (NEI 12/85)

7. Final sealing of shafts will be with $90 \%$ sand - $10 \%$ bentonite and plugs of compacted bentonite

C. Sweden's reference facility and waste package concepts were developed to show that safe waste disposal is feasible; these and alternatives are under continuing evaluation; final concepts may differ from current reference concepts

1. Spent fuel is to be shipped by water to nearest port, then by rail, if necessary, to the repository where there will be two receiving lines

2. The spent-fuel encapsulation station will be located at the repository site; construction of the encapsulation station will begin about 2010 (SKB 1986b)

3. Waste disposal will be in galleries mined from crystalline rock (granite or gneiss); the disposal tunnels will be located at a depth typically of $500 \mathrm{~m}$ 
4. Spent-fuel packages will be placed in individual holes (1.5 $\mathrm{m}$ in diameter and $7.5 \mathrm{~m}$ deep, $6 \mathrm{~m}$ apart) in the floors of horizontal drifts (in an array with a total length of tunnels about $38 \mathrm{~km}$ )

5. A disposal tunnel for long-lived ILW (i.e., non-fuel-bearing hardware from spent fuel) will be located at $300 \mathrm{~m}$ depth; ILW waste packages will be stacked in a tunnel and backfilled with shotcrete; the ILW repository will be separate but near the spent-fuel repository

6. Repository site construction will start in 2010 and will be completed in 2020 (NWN 1/22/90)

D. A new method of encapsulating spent fuel is being investigated by SKB and the Finnish utility TVO, which uses thick steel containers covered with a thin layer of copper for corrosion protection; substartial savings are expected from new storage and containersealing techniques that would enable the use of containers about three times larger than the KBS-3 type (NF 11/12/90)

\subsection{WASTE PACKAGE R\&D}

A. Waste-package R\&D in Sweden involves primarily materials tests on: properties, dissolution and leaching tests of spent fuel; properties of the French HLW glass (in a cooperative study with Japan and Switzerland in the JSS project, completed 1988); fabrication techniques for copper canisters; corrosion measurements on copper and titanium; alternatives to copper canisters; and physical and chemical long-term stability of bertonite under repository conditions (SKB 1985; Nilsson 1984)

\subsection{GEOSCIENCES R\&D}

A. Geologic research has included: measurement of fracture palterns; measurement of characteristics of single fractures and larger fracture zones; measurement of seismic and tectonic condition; drilling and measurements in boreholes; crosshole radar measurements (Nilsson 1984; SKB 1986b)

B. Geohydrologic research has included prediction of groundwater movement in Swedish bedrock, and development of improved experimental techniques and 3-dimensional models of flow in fractured crystalline rock (Nilsson 1984; SKB 1986b)

C. Rock mechanics research has been carried out on the effects of stress releases at potential repository sites

D. Geochemical research has included: chemical composition and age of groundwater; methods for in situ-sampling and measurement of different chemical parameters of groundwater; mobile field laboratory analyses of groundwater; actinide and fission-product chemistry in groundwater; in situ radionuclide migration experiments; development of near-field and far-field transport models; and natural analog studies (Nilsson 1984; SKB 1985)

E. Emphasis of future research will be on: characterizing gneiss and granite rocks; evaluation and intercomparison of possible alternative concepts to the KBS-III approaches; groundwater flow in jointed rock masses; flow and nuclide migration in fracture zones in crystalline rock; development of improved models for safety assessment 
(with emphasis on international cooperation); natural analog systems; and measures for treatment of lower quality zones in repository rock masses (Burstroem 1985; SKB 1986b)

\subsection{FIELD TESTS}

A. Stripa URL Project

1. The test station is in a depleted iron mine near Lindesberg; the experimental area is excavated in granite adjacent to the mine, at depth of about $350 \mathrm{~m}$

2. From 1977 to 1980 , U.S./LBL - Sweden/KBS cooperative tests were carried out; studies included: thermomechanical response measurements of rock to local heating; large-scale hydraulic conductivity measurements; and measurements of the geochemistry of groundwater

3. From 1980 to 1985 , the NEA Stripa Project Phase I studies included: coordinated tests with logging systems for borehole hydrogeological measurements; measurements of the geochemistry of groundwaters at great depths; measurements of migration of various chemical elements in fractures; and behavior and utility of backfilling materials in real geologic environment (in a bulfer mass test)

4. From 1983 to 1987 , the NEA Stripa Project Phase il studies inciuded: development of crosshole techniques for detecting and characterizing fracture zones in the vicinity of the repository; a 3-dimensional tracer experiment to measure migration; investigations of groundwater fracture flow and associated nuclide transport; and borehole and shaft sealing tests

5. From 1986 to 1991, the NEA-coordinated Stripa Project Phase III studies will include: coupling of tests to full-scale repository demonstrations; groundwaterflow measurements in unexplored rock volume, including fractures; and evaluation of sealing materials (SKB 1990c)

B. A Hard Rock Laboratory (HRL) is planned for operation in 1994 (NEA 12/88; SKB 1990C)

1. The site will be on the island of Āspö, about $20 \mathrm{~km}$ north of Oskarshamn

2. Construction will begin in 1990 and be completed in 1994; tests will be carried out for about 15 years; a number of tests will be conducted in parallel with construction; the tunnel will be excavated to the $500 \mathrm{~m}$ level in stages

3. The primary objectives of studies in the HRL are to: demonstrate that the factors controlling safety of the final repository for spent fuel are understood and can be quantified; validate pertormance assessment models and assumptions included in safety analyses; and develop methods for construction and QA of final repository

4. Tests planned for the operational phase starting in 1994 include: large-scale tracer tests, block-scale tracer tests, block-scale redox tests, methodology for repository construction, and pilot-scale tests on repository systems; planned study activities until 2010 are: to conduct detailed investigation of the natural barrier, i.e., the host rock; to study the performance interaction between engineered and 
natural barriers; to develop methods for implementation and QA of repository construction; and to demonstrate the waste management system, its technology and $Q A$

C. The Poços de Caldas (natural analog) project has been carried out in Brazil in which Sweden cooperates with Switzerland, U.K, and U.S. (SKB 1990c)

1. The goals of the project are: to validate equilibrium migration models for different water/mineral systems; to characterize and determine the concentration of natural colloids and organic complexes in the groundwater; and to measure and evaluate the distribution of analog elements over a hydrothermal contact zone in the rock

2. The project was started in 1986 and field work was completed in 1989; currently, analyses are being supplemented, results are being evaluated, and processes are being modeled

\subsection{PERFORMANCE ASSESSMENT}

A. Swedish work in performance assessment includes: detailed analyses of the consequences of canister corrosion, nuclide release from fuel dissolution, geosphere and biosphere transport, and dose to man; natural analog studies; development and use of transport codes; emphasis has been on worst-case scenarios; future studies will be aimed at optimizing the system

B. SKI leads the international code comparison and validation efforts: INTRACOIN, INTRAVAL, and HYDROCOIN (Eng 1989)

1. The HYDROCOIN (Hydrologic Code Intercomparison) was initiated in 1984 by SKI; the objective is to model groundwater flow for performance assessment of radioactive repositories; the project addresses code verification, model validation, and sensitivity/uncertainty analysis (Grundfelt 1989)

a. No completely satisfactory independent data sets were found to validate the models used

b. The five data sets considered to be the most suitable and representing a variety of temporal and spatial scales were studied

c. Work has increased confidence in applying existing codes to different flow situations and has also provided insight into the validation process

2. INTRAVAL is an international project managed by SKl; it began in October 1987, and is based on experience with the INTRACOIN and HYDROCOIN projects; its purpose is to understand how geophysical, hydrogeologic and geochemical processes related to radionuclide transport can be described by numerical models (Andersson 1989)

a. More than a dozen flow and transport phenomena are being studied; selection criteria for Phase I test cases have been developed; 17 test cases have been identified; laboratory experiments are being performed; several field experiments are underway; two natural analogues are included 
b. Phase ! of INTRAVAL is to be completed by October 1991; an optional Phase II would require an additional three years

c. In 1990, a second set of test cases will be selected for further model validation studies if Phase $\mathrm{I}$ is conducted

C. A start has been made in the development of scenarios for performance assessment of a Swedish repository (Andersson and Eng 1989)

1. Scenarios are based on the KBS-III repository concept for disposal of spent fuel

2. An extensive list of features, events, and processes (FEPs) has been developed and sorted into different groups; the FEPs represent key external events and processes that could be of critical importance for a radioactive waste repository

3. It has not been possible to continue the evaluation by combining the FEPs into scenarios because the specifications of the FEPs are too general

D. The relative importance of various release and transport mechanisms for Swedish repository designs are described (Neretnieks 1989)

1. Uptake into the rock matrix by diffusion has been by far the most important retardation mechanism for sorbing nuclide species; nuclides most strongly influenced are the actinides $(\mathrm{U}, \mathrm{Pu}, \mathrm{Np}, \mathrm{Am}, \mathrm{Pa})$ and certain fission products (Cs, $\mathrm{Sr}, \mathrm{Aa}, \mathrm{Tc}$, and several other metals)

2. Data needs and availability for continued work have been evaluated

E. Performance assessment is being used by SKl as a regulatory tool; regulatory guidance, performance assessment, and supporting research are integrated into a prograrn called "Project-90"; this project will be finalized in 1991 and will be followed by guidelines to SKB (Andersson 1989)

F. A new safety assessment called "SKB 91" is planned for 1991 (SKB 1990C)

\subsection{ENVIRONMENTAL RESEARCH}

Environmental research in Sweden has included: collection of biosphere and surface water data from site investigation areas; measurements of the influence of organic complexants on ion mobilities; and transport of nuclides in sediments (SKB 1985; SKB 1986b)

\subsection{SYSTEMS STUDIES}

A. In Sweden, studies of different alternative repository systems will gradually be focused; alternatives with the highest priority will continue to be studied; special studies will be conducted on certain basic designs based on: 1) radiological safety, 2) feasibility based on existing technology, 3) development potential, 4) cost, 5) uncertainties in data and models, and 6) confidence in the quality of the assessment (SKB 1990)

B. A cut-off of the time-period of evaluations in the quantitative safety assessment of radioactive wastes may be justified because (Johansson 1989): 
1. The potential risk from radioactive waste is not unique; non-radioactive wastes pose similar risks

2. Limited resources exist for waste disposal systems

3. Evaluation of long-term performance of disposal systems involves very large uncertainties

10.11 PROGRAM/FACILITIES COSTS (SKB 1986b,c; SSB 1987; Ahlstroem 1987a)

A. The total lifetime costs for backend of the fuel cycle program including decommissioning of facilities have been estimated at 46 billion SEK (U.S. $\$ 6.3$ billion)

1. This total cost is about $\$ 0.003 / \mathrm{kWh}$ (U.S.), or about $7 \%$ of the cost of nuclear electricity in Sweden (ED 3/1/88)

2. The total expenses for all waste fund activities were about 800 million SEK (U.S. $\$ 110$ million) in 1987 (Soderterg 1987)

3. Spent-fuel management is estimated to cost an average of 4,300 SEK/kgU (U.S. $\$ 790 / \mathrm{kgU}$ ) for the $7,600 \mathrm{MTU}$ of spent fuel expected to accumulate over the 30year lifetime of the Swedish reactors; this cost is made up of the following: R\&D $10 \%$, transportation $7 \%, 40$-year interim storage $27 \%$, encapsulation $30 \%$, and final disposal $26 \%$ (NF 11/12/90)

B. The R\&D the for $1987-92$ program costs will be 600 million SEK (U.S. $\$ 83$ million) plus foreign participation in the Stripa Project (SKB 1986b)

1. 175 million SEK (U.S. \$24 million) of this is for the future URL

2. The 1984-85 annual payments from U.S. to Sweden for Stripa Phase II were $\$ 420,000 / y r$ (U.S.)

3. The cost of Stripa Phase III is 120 million SĖK (U.S. \$17 million); costs to the U.S. for Stripa Phase III are U.S. \$24 million

\subsection{MANAGEMENT OF URANIUM MINE AND MILL WASTES}

\subsection{STRATEGY/POUCY}

Tailings at two mining sites from a small amount of early mining activity have been covered with $1.3 \mathrm{~m}$ of till and top soil; no mining and milling have been carried out in Sweden for many years

\subsection{DECOMMISSIONING AND ENVIRONMENTAL RESTORATION}

\subsection{STRATEGY/POLICY}

In Sweden, decommissioning of radioactive facilities must be done by dismantling to unrestricted use 


\subsection{R\&D}

As of 1986 Sweden was not doing decommissioning research; development of special equipment and techniques will be started a few years before decommissioning is to start (SKB 1986d)

\section{2,3 costs}

A. Costs for future decommissioning of about 8 billion SEK (U.S. $\$ 1.1$ billion) are included in the 46 billion SEK (U.S. $\$ 6.3$ billion) for the total back-end of fuel cycle program; this is about 20\% of the estimated total back-end costs (see Section 10.11) (SKB 1986d)

B. A recent estimate of decommissioning costs for two nuclear reactor power units currently planned for shutdown in 1995 has increased to 4 billion SEK (about U.S. $\$ 650$ million); this is a five-fold increase from the 1985 estimate (NW 2/15/90)

\subsection{INTERNATIONAL ACTIVITIES (NEA 11/86)}

\subsection{MEMBERSHIP}

IAEA, OECD/NEA

\subsection{COOPERATION WITH MULTINATIONAL AGENCIES}

A. Sweden is the host country for the NEA-coordinated Stripa Project

B. Sweden participates in most of NEA's waste management activities, including NEA's INTRACOIN, HYDFOCOIN, and INTRAVAL projects (Andersson 1990)

C. Sweden participates in most of IAEA's waste management activities

D. Sweden (SKB) has a bilateral agreement with the CEC (the term is 1986-1990)

E. See also Section 13.4

\subsection{COOPERATION WITH USA}

A. DOE/SKB Bilateral Agreement

1. Term of the agreement was originally 1977-1990; in 1990 this was extended to 9/9/95 (Strahl 1990)

2. Scope of the agreement includes conditioning, packaging, storage, and disposal of radioactive wastes; field and laboratory testing; operations; safety and environment; public relations

3. Emphasis is on collaboration in Stripa Project, through NEA coordination; performance assessment computer model and code intercomparison coordinated by SK]; exchange of technical staff for extended time periods 
4. The 1990 amendment to the agreement added technical activities at the HRL (Strahl 1990)

5. Following the U.S. decision to focus on the Yucca Mountain site in 1987, DOE discontinued two crystalline rock activities with SKB on long-term bedrock stability and effects of extreme cold and thawing

\subsection{COOPERATION WITH OTHER COUNTRIES}

A. Sweden has active formal and informal information exchanges with several countries (Eng 1989)

1. Bilateral information-exchange agreements are in place with the following countries and organizations: DOE - U.S.; JAECL - Canada; NAGRA - Switzerland; TVO and IVO - Finland; CEA - France; SCUAE - Soviet Union; and EURATOM - CEC

2. Informal exchange of information also occurs with organizations in the Federal Republic of Germany, Belgium, Great Britain, Japan, and Nordic countries

3. Information is exchanged in the areas of radionuclide transport and hydrogeological modeling; natural analogues; scenario analysis; probabilistic safety assessment codes; and integrated safety assessments

B. Sweden participated in the Japan-Sweden-Switzerland (JSS) project, on HLW glass leaching and glass leaching modeling; the project was carried out 1981.1987 through five phases

C. Sweden participates in the Poços de Caldas Natural Analog Project in Brazil, with Brazil, Switzerland, and the United Kingdom; natural analog studies started in 1986

D. Sweden participates bilaterally with Canada in the Canadian URL Project

E. Sweden cooperates bilaterally through agreements/projects with Finland, France, Switzerland

F. Sweden participates with Australia, Japan, the United Kingdom, and U.S. (NRC) on the Alligator Rivers Natural Analog Study in Australia

G. Sweden cooperates with Switzerland, the United Kingdom, and the Nordic Countries on development of criteria for HLW disposal

\subsection{REFERENCES}

$-1977-$

Svensk Kärnbränslehantering $A B(S K B)$. 1977. Handling of Spent Nuclear Fuel and Final Storage of Vitrified High Level Reprocessing Waste. Svensk Kärnbränslehantering AB, Stockholm. 
$-1984$

Ahlstroem, P. E., and C. Thegerström. 1984. 'A Possible Strategy Based on Direct Disposal of Unreprocessed Spent Nuclear Fuel - The Swedish KBS-III Concept." In Proceedings of ANS Topical Meeting on Fuel Reprocessing and Waste Management, Vol. 1, pp. 1-276-1-289. August 1984, Jackson, Wyoming.

Hedman, T., and H. Forsström. 1984. The Swedish Final Repository for Low and Medium Level Reactor Waste." Waste Management 'B4, Vol. 1, pp. 85-91. March 1984, Tucson, Arizona.

Nilsson, L. B., and C. Thegerstrom. 1984. TThe Swedish KBS-1H Concept and Program for Continued R\&D Work." Waste Management '84, Vol. 1, pp. 77-84, March 1984, Tucson, Arizona

$-1985-$

Ahlstroem, P. E, 1985. 'Current Status of the Swedish Waste Disposal Program." In Proceedings of ANS Topical Meeting on High-Level Nuclear Waste Disposal, pp. 81-90. September 1985, Pasco, Washington.

Burstrom, S., and T. Papp. 1985. 'Swedish Nuclear High-Level Waste Program--Key Research Areas." In Proceedings of Materials Research Society symposium on Scientific Basis for Nuclear Waste Management IX, pp. 9-15. September 1985, Stockholm.

Lakey, L. T., K. M. Harmon, and P. Colombo. 1985. Management of Low-Level Radioactive Wastes Around the World. PNL-5173, Pacific Northwest Laboratory, Richland, Washington, pp. 39-42.

Larsson, A., and S. Wingefors. 1985. 'Aspects on the Licensing of a Final Repository for Reactor Wastes." In Proceedings of the International Seminar on Radioactive Waste Products-Suitability for Final Disposal, pp. 601-613. June 1985, KFA, Julich, Federal Republic of Germany.

Nuclear Engineering International (NEl). 12/85. "Disposing of Spent Fuel Underground," pp. 31-37.

Paige, H. W., and N. J. Numark. 1985. Assessment of National Systems for Obtaining Local Siting Acceptance of Nuclear Waste Management Facilities. International Energy Associates Limited, Washington, D.C., IEAL-R/86-16, Vol. I, pp. 14-1 to 14-4 and Vol. If, pp. 16-1 to 16-7.

Svensk Kărnbrănslehantering AB (SKB). 1985. Annual Research and Development Report 1984. SKB 85-01, Svensk Kămbrănslehantering AB, Stockholm.

$-1986-$

Gustafsson, B., and A. Ekendahl. 1986. 'Operation of the Swedish Sea Transportation System for Spent Fuel." IAEA International Symposium on the Packaging and Transport of Radioactive Materials (PATRAM 1986), June 16-20, 1986, Davos, Switzerland.

Hilley, J. R. 1986. 'Travel Report on IAEA PATRAM and Fuel Transportation Handling Experience in France, Federal Republic of Germany, and Sweden.' U.S. Department of Energy, Washington, D.C.

Larsson, A., K. Andersson, and S. Wingefors. 1986. "Sweden: Policy and Licensing." IAEA Bulletin, Spring 1986, p. 41. 
Nuclear Energy Agency (NEA). 11/86. 'Summary Record of Ad Hoc Meeting of the Directors of Crystalline Rock Projects.' Meeting held November 3-4, 1986, Paris.

Numark, N. J., R. J. Mattson, and J. Gaunt. 1986. 'Comparison of National Programs and Regulations for the Management of Spent Fuel and Disposal of High-Level Waste in Seven Countries." Waste Management '86, Vol. 2, pp. 535-541, March 1986, Tucson, Arizona.

Svensk Kărnbrănslehantering AB (SKB). 1986a. Final Repository for Reactor Waste_SFR. Svensk Kärnbrănslehantering $A B$, Stockholm.

Svensk Karnbränslehantering AB (SKB). 1986b. Handling and Final Disposal of Nuclear Waste, Programme for Research, Development, and Other Measures, SKB R\&D Programme 86. Svensk Karnbränslehantering $\mathrm{AB}$, Stockholm.

Svensk Kärnbränslehantering AB (SKB). 1986c. Plan 86 Costs for Management of Radioactive Waste From Nuclear Power Production. SKB 86-12, Svensk Kärnbränslehantering AB, Stockholm.

Svensk Kärnbrănslehantering AB (SKB). 1986d. SKB Annual Report 1986, Including Summaries of Technical Reports Issued in 1986. SKB 86-31, Svensk Karnbränslehantering AB, Stockholm.

-1987-

Ahlströem, P. E., and S. Ungermark. 1987a. "Radwaste Managernent in Sweden." Nuclear Europe, November-December 1987, p. 16.

Ahlstrठem, P. E. 1987b. "Current Once-Through Fue! Cycle and Future Trends.' In proceedings of IAEA symposium on Back End of the Nuclear Fuel Cycle: Strategies and Options, p. 95. May 11-15, 1987, Vienna.

Carlsson, H.S. 1987. Foreign Trip Report by G. Green, Golder Associates, Redmond, Washington. 'Progress of the Swedish Radioactive Waste Management Program." Second International Symposium on Field Measurements in Geomechanics, April 6-9, 1987, Kobe, Japan.

Cooley, C. R. 1987. 'Travel Report on Visits to Sweden, Switzerland, France, and OECD/NEA," U.S. Department of Energy, Washington, D.C.

Gustafsson, B. 1987. 'A Sea Transportation System Integrated with a Nuclear Waste Management Programme." In Proceedings of the 1987 International Waste Marlagement Conference, p. 393. November 29-December 5, 1987, Hong Kong.

International Energy Associates Limited (IEAL). 1987. Regulatory Strategies for High-Level Radioactive Waste Management in Nine Countries, Chapter 6, IAEL-R/87-93, Fairfax, Virginia.

Nuclear Engineering International (NEI). 12/87. 'The World's Nuclear Fuel Cycle Facilities," p. 47.

Nuclear Energy Agency (NEA). 1987. 'Sweden, Project-90 Established by SKI." Nuclear Waste Bulletin, p. $\{4$.

Petersson, S., and G. Hedin. 1987. The WoX Process - New Volume Reduction Technology. Waste Management ' 87 , Vol. 3, p. 665. March 1-5, 1987, University of Arizona, Tucson, Arizona. 
Soderberg, O. 1987. 'Organizing Nuclear Waste Management - The Swedish Approach.' The Bavarian Symposium on the Back End of the Nuclear Fuel Cycle, May 18-21, 1987, Munich, Federal Republic of Germany.

Statens Käarnbrănslenämnd (SKN), 1987. Management and Disposal of Spent Nuclear Fuel; Review of a Programme for Research, Development and Other Measures. Swedish National Board for Spent Nuclear Fuel, Stockholm.

Statens Vattensfallswerk (SSB). 1987. Nyquist, C. E., and S. Bjurström. "Briefings on Swedish State Power Board," presentation to U.S. Congress.

Svensk Kămbrănslehantering AB (SKB). 1987. SKB, Final Repository for Reactor Waste - SFR. Svensk Kämbränslehantering AB, Stockholm.

$-1988-$

ATW News (ATW), 2/88. 'Spent MOX Fuel Elements to Sweden,' p. 5.

Canadian Energy News (CEN). 12/88. "Complete System for Handling Low and Medium Level Nuclear Waste." p. 253.

Energy Daily (ED). 3/1/88. "Beneath the Waves: How Sweden is Handling Its Nuclear Waste," p. 3.

Norrby, S., K. Andersson, S. Wingefors, and C. Bergman. 1988. "Licensing of the Swedish Final Repository for Reactor Waste." In Proceedings of the Symposium on Management of Low and Imtermediate Level Radioactive Wastes, 1988, Vol. 1, p. 129. May 16-20, 1988, Stockholm.

Nuclear Energy Agency Bulletin (NEA). 12/88. "Swedish Hard Rock Laboratory (HRL)," p. 30.

Nuclear Energy Agency (NEA). 1988. Uranium Production, Resources and Demand. Joint report by OECD/NEA and the IAEA, p. 147.

Nuclear Engineering International (NEl). 2/88. "Kalmar Supplies Forklift for Waste Repository," p. 9.

Nuclear News (NN). 4/88. "Closure of Two Units Seen for 1995, 1996," p. 70.

Nucleonics Week (NW). 3/24/88. "First Commercial LLW Incinerator in U.S. to be Built by Studsvik," p. 7.

Nucleonics Week (NW). 4/14/88. 'Swedish LLW/MLW Repository Gets Operating License," p. 3.

$-1989-$

Andersson, J. 1989. "Performance Assessment as a Regulatory Tool - An Integrated Approach". In Proceedings of the Symposium on Safety Assessment of Radioactive Waste Repositories, p. 786. October 9-13, 1989, Paris.

Andersson, J., and T. Eng. 1989. "The Joint SKI/SKB Scenario Development Project". In Proceedings of the Symposium on Safety Assessment of Radioactive Waste Repositories, p. 397. October 9-13, 1989, Paris. 
Andersson, $\mathrm{K}$, et al. 1989. INTRAVAL as an integrated International Effort for Geosphere Model Validation - A Status Report." In Proceedings of the Symposium on Safety Assessment of Radioactive Waste Repositories, p. 725 . October 9-13, 1989, Paris.

Bengtsson, G. 1989. "Can the Same Principles Be Used for the Management of Radioactive and Non-Radioactive Waste?" In Proceedings of the Symposium on Safety Assessment of Radioactive Waste Repositories, p. 59. October 9-13, 1989, Paris.

Carisson, J. 1989. The Swedish Final Repository for Radioactive Waste (SRF) Safety Assessment and Quality Assurance.' In Proceedings of the Symposium on Waste Management, Vol. 1, p. 691. February 26-March 2, 1989, Tucson, Arizona.

Dybeck, P., B. Gustafsson, and S. Frykman. 1989. 'Inservice Inspection and Maintenance of Transport Casks at the CLAB Facility in Sweden." In Proceedings of the 9th International Symposium on the Packaging and Transportation of Radioactive Materials, V'ol. 3, p. 1334.

Eng, T., and P. Ahlstrom. 1989. The Role of International Cooperation Regarding Safety Assessment Development in the SKB Research Program." In Proceedings of the Symposium on Waste Management, Vol. 1, p. 69. February 26-March 2, 1989, Tucsori, Arizona.

Grundfelt, B., B. Lindbom, and K. Andersson. 1989. "HYDROCOIN - Findings from Level 2: Model Validation." In Proceedings of the Symposium on Safety Assessment of Radioactive Wasie Repositories, p. 717. October 9-13, 1989, Paris.

Gustafsson, B., P. Dybeck, and S. Petersson 1989. "Development, Implementation and Experiences of the Swedish Spent Fuel and Waste Sea Transportation System." In Proceedings of the 9th International Symposium on the Packaging and Transportation of Radioactive Materials, Vol. 2, p. 1115.

Johansson, G., and C. Haegg. 1989. The Disposal of High Level Radioactive Waste and the Need for Assessing the Future Radiological Impact.' In Proceedings of the Symposium on Safety Assessment of Radioactive Waste Repositories, p. 309. October 9-13, 1989, Paris.

Johnson, E. R. 1989. Trip Report -- Attendance at IAEA Techrical Committee Meeting on Methods for Expanding Spent Fuel Storage Facilities. JA1-326, Martin Marietta Energy Systems, Inc.

IAEA. 1989. Operating Experience with Nuclear Power Stations in Member States in 1988. International Atomic Energy Agency, Vienna.

Neretnieks, I. 1989. 'Release and Transport Modelling: Some Experiences from the Swedish Program." In Proceedings of the Symposium on Satety Assessment of Radioactive Waste Repositories, p. 533. October 9-13, 1989, Paris.

Nuclear Engineering International (NEI). 12/89. "Swedish Waste Plans Take Shape," p. 4.

Nuclear News (NN). 1/89. "VAK Spent Fuel Shipped to Sweden at Last," p. 68.

Nuclear Waste News (NWN). 1/19/89. "Swedish Panel Urges Evaluation of Chemical Risks from Radioactive Waste Repositories," p. 23.

NUKEM Market Report (NUKEM). 8/89. "Sweden," NUKEM GrnbH, Alzenau, Federal Republic of Germany, P. 8. 
Soderberg, O. 1989. "Information Strategies in Sweden Concerning the Disposal of Nuclear Waste." Advisory Group Meeting on Public Understanding of Radioactive Waste Management Issues, June 5-9, 1989, Vienna.

Ungermark, S. 1989. 'Informing the Swedish Public about Nuclear Waste.' Advisory Group Meeting on Public Understanding of Radioactive Waste Management Issues, June 5-9, 1989, Vienna.

-1990 -

Andersson, K., and S. Norrby. 1990. The SKI Regulatory Strategy and Pertormance Assessment Program in Relation to Final Disposal of Spent Nuclear Fuel and High Level Radioactive Waste.' In Proceedings of the International Topical Meeting on High Level Radioactive Waste Management, Vol. 1, p. 325.

Bjurströ, S. 1990. "Advancements in Radioactive Waste Management." ENC'90: ENS/ANS-Foratom Conference Transactions, Vol. I, p. 86.

Dybeck, P., and B. Gustafsson. 1990. 'Transporting Spent Fuel and Reactor Waste in Sweden. Experience from 5 Years of Operation.' In Proceedings of the International Topical Meeting on Nuclear and Hazardous Waste Management - Spectrum '90, p. 179.

Hanson, T., and S. Pettersson. 1990. "Ringhals Nuclear Power Plant - Reactor Waste Management 50 Reactor Years of Operating Experiences and Future Program." In Proceedings of the Symposium on Waste Management, Vol. 1, p. 279. February 25 - March 1, 1990, Tucson, Arizona.

Holmer, A., S. Hammar, and P. Dybeck. 1990. "Management of Fuel Waste from Fuel Testing Programs and Postirradiation Examination in Sweden.' In Proceedings of the Symposium on Waste Management, Vol. 2, p. 541. February 25 - March 1, 1990, Tucson, Arizona.

Leigh, I. W., and S. J. Mitchell. 1990. International Nuclear Fuel Cycle Fact Book. PNL-3594 Rev. 10, Pacific Northwest Laboratory, Richland, Washington.

Lemmel, M. 1990. 'Sweden as a National Example - The Impact on Swedish Industry." ENC'90: ENS/ANS-Foratom Conference Transactions, Vol. I, p. 26.

McCabe, G. H. 1990. "Lessons Learned from International Siting Experiences of LLW Disposal Facilities." In Proceedings of the International Topical Meeting on Nuclear and Hazardous Waste Management - Spectrum_90, 1990, p. 4.

Menon, S., and J. Bjerler. 1990. "Processing of Low Level Waste for Volume Reduction." ENC'90: ENS/ANS-Foratom Conference Transactions, Vol. IV, p. 2234.

Norrby, S., and K Andersson. 1990. "Developments in the Regulatory Process for the Safety Assessment of a Spent Fuel Repository in Sweden." In Proceedings of the Symposium on Waste Management, Vol. 1, p. 585. February 25 - March 1, 1990, Tucson, Arizona.

Nuclear Engineering International (NEI). 3/90. "Power Reactors in Operation and Under Construction at 31 December, 1989," p. 12.

Nuclear Engineering international (NEI). 10/90. "Datafile: Sweden," p. 131. 
Nuclear Europe (NE). 3-4/90. "State Board Warns Swedes That Non-Nuclear = Steep Price Rise," p. 51.

Nuclear Europe Worldscan (NEW). 5-6/90. 'Sweden Increases Its Nuclear Power by 550 MW,' p. 42.

Nuclear Europe Worldscan (NEW). 1-2/90. 'Sweden's Planned Phase-out Loses Public Credibility,' p. 90.

Nuclear Fuel (NF). 11/12/90. 'TVO Submits Cheaper Spent Fuel Plan Thanks to New SwedishFinnish Concept," p. 11.

Nuclear Fuel (NF). 2/5/90. "Swedes Transfer Reprocessing Rights to German Utilities," p. 13.

Nuclear Law Bulletin 89 (NLB). 6/90. "Ordinance on Maximum Limits for Exposure to Radiation (1989)," p. 65.

Nuclear News (NN). 5/90. "Poll Says Majority Wants Nuclear Power after 2020," p. 70.

Nuclear News (NN). 10/90. 'Review for Closures in Mid-'90s Postponed," p. 77.

Nuclear Waste News (NWN). 2/22/90. "SKB Proposes Swedish Repository Schedule," p. 74.

Nucleonics Week (NW). 2/8/90. "Nuclear Waste Generation for December 1989," p. 17.

Nucleonics Week (NW). 4/26/90. "Swedish Nuclear Phase-out Dlepends on $\mathrm{CO}_{2}$ Emissions, Premier Says," p. 6.

Nucleonics Week (NW). 2/15/90. "Swedish Nuclear Phase-out Cost Five Times Higher Than Thought," p. 3.

Persson, L. 1990. "Ethical Aspects on Nuclear Waste." In Proceedings of the Symposium on Waste Management, Vol. 2, p. 635. February 25 - March 1, 1990, Tucson, Arizona.

Strahl, J. F., et al. 1990. Trip Report on the Participation in Meetings with Switzerland (DOE Bilateral Agreement with NAGRA) and Sweden (DOE Bilateral Agreement with SKB), 1990.

Svensk Kărnbränslehantering AB (SKB). 1990a. Swedish Final Repository for Reactor Waste-.SFR. Svensk Kärnbränslehantering $A B$, Stockholm.

Svensk Kämbränslehantering AB (SKB). 1990b. Transporting Radioactive Waste-.SFR, Svensk Kärnbränslehantering $\mathrm{AB}$, Stockholm.

Svensk Kärnbränslehantering AB (SKB). 1990c. R\&D Programme 89 - Handling and Final Disposal of Nuclear Waste, Svensk Kärnbrănslehantering AB, Stockholm.

Swedish Nuclear News (SNN). 1/90. "Swedish Nuclear Politics at a Turning Point?" p. 1. 
SWITZERLAND 
SWITZERLAND

\section{SWITZERLAND}

\section{CONTENTS}

$1.0 \quad$ NUCLEAR POWER $\ldots \ldots \ldots \ldots \ldots \ldots \ldots \ldots \ldots \ldots \ldots \ldots \ldots \ldots \ldots \ldots$

NUCLEAR FUEL CYCLE AND RADIOACTIVE WASTE MANAGEMENT
STRATEGY/POLICY $\ldots \ldots \ldots \ldots \ldots \ldots \ldots \ldots \ldots \ldots \ldots \ldots \ldots \ldots \ldots \ldots \ldots \ldots \ldots \ldots$

3.0 HIGHUGHTS AND MAJOR MILESTONES $\ldots \ldots \ldots \ldots \ldots \ldots \ldots \ldots \ldots \ldots \ldots$

4.0 INSTIUUTIONAL CONSIDERATIONS/ORGANIZATIONS $\ldots \ldots \ldots \ldots \ldots \ldots \ldots \ldots$ SZ.3

$5.0 \quad$ NUCLEAR FUEL PRODUCTION $\ldots \ldots \ldots \ldots \ldots \ldots \ldots \ldots \ldots \ldots \ldots \ldots \ldots$

6.0 FUEL RECYCLE $\ldots \ldots \ldots \ldots \ldots \ldots \ldots \ldots \ldots \ldots \ldots \ldots \ldots \ldots \ldots$

7.0 SPENT FUEL STORAGE AND TRANSPORT $\ldots \ldots \ldots \ldots \ldots \ldots \ldots \ldots \ldots$

8.0 WASTE CONDITIONING, STORAGE AND TRANSPORT $\ldots \ldots \ldots \ldots \ldots \ldots \ldots \ldots$ sZ.7

9.0 DISPOSAL OF NON-HIGH-LEVEL WASTES $\ldots \ldots \ldots \ldots \ldots \ldots \ldots \ldots \ldots \ldots$

10.0 DISPOSAL OF HIGH-LEVEL WASTES $\ldots \ldots \ldots \ldots \ldots \ldots \ldots \ldots \ldots \ldots \ldots \ldots \ldots \ldots$

11.0 MANAGEMENT OF URANIUM MINE AND MIU WASTES $\ldots \ldots \ldots \ldots \ldots \ldots \ldots$

12.0 DECOMMISSIONING AND ENVIRONMENTAL RESTORATION $\ldots \ldots \ldots \ldots \ldots \ldots$ SZ.16

13.0 INTERNATIONAL ACTIVITIES $\ldots \ldots \ldots \ldots \ldots \ldots \ldots \ldots \ldots \ldots \ldots \ldots \ldots \ldots \ldots$

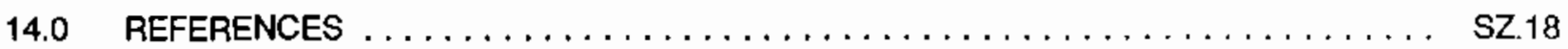




\subsection{NUCLEAR POWER}

\subsection{REACTOR MIX: 2 BWRs, 3 PWRs}

\subsection{ELECTRIC POWER PRODUCTION}

1986--54,400 GWh (39.2\% nuclear) (IAEA 1987)

1987--22,900 GWh gross nuclear (NW 2/4/88)

\subsection{NUCLEAR POWER CAPACITY PROJECTIONS}

1990--2.9 GWe

2000-3.8 GWe (NUKEM 3/88)

1.4 NUCLEAR ENERGY POLICY: The federal government is in favor of nuclear power but local opposition exists and has delayed its expansion

A. Some nuclear district heating was under construction in Switzerland in 1987 but has been abandoned (NW 2/5/87; NEI 6/90)

\subsection{NUCLEAR FUEL CYCLE AND RADIOACTIVE WASTE MANAGEMENT STRATEGY/POLICY}

2.1 OVERALL NUCLEAR FUEL CYCLE POLICY: The overalt fuel cycle policy in Switzerland is to purchase fresh LWR fuel assemblies from foreign suppliers, purchase foreign reprocessing services for spent fuel, and recycle plutonium to either LWRs or FBRs

\subsection{POLICY ON THE BACK END OF THE NUCLEAR FUEL CYCLLE}

A. The policy on the back end of the nuclear fuel cycle in Switzerland is to purchase foreign reprocessing services for spent fuel and recycle plutonium to either LWRs or FBRs; the option is open for direct disposal of spent fuel; the policy is to store vitrified HLW and spent fuel that is not reprocessed in a central AFR facility (in dry casks) until it is reprocessed or disposed of (not before 2020); plans are to store LLW and ILW in separate halls at the same storage site until a disposal facility is available

B. The Swiss policy is to dispose of all radioactive wastes in underground facilities; $H L W$ and alpha wastes are to be disposed in a deep crystalline rock repository; the preferred option is to dispose of HLW and alpha wastes in other countries; LLW/LW is planned to be disposed in a horizontally accessed rock cavern repository in a mountain

C. Development of a disposal facility for LLW/LW is a top priority (Kowaiski et al. 1988)

\subsection{HIGHLIGHTS AND MAJOR MILESTONES (NEA 11/88)}

1985 Submitted warranty report to parliament (Project Gewahr, a demonstration of feasibility for waste disposal in Switzerland)

1988 Decided by government that safety and feasibility of final disposal had been demonstrated in Project Gewahr (NEA 12/88)

1992 Start operation of AFR facility for dry cask storage of spent fuel 
1993 Select LLW/LW repository site from candidate sites where work has been completed

1993 Select one site for HLW repository for site characterization

1993 Start receiving vitrified HLW from reprocessing of Swiss spent fuel in France and the U.K. (Leigh and Mitchell 1990)

1998 Commission repository for LLW/LW (Kowalski et al. 1989)

2005 Make decision on final development of Swiss HLW repository or participation in a foreign repository

2010 Submit license application for HLW repository

2025 Commission repository for HLW or spent fuel and alpha waste

\subsection{INSTITUTIONAL CONSIDERATIONS/ORGANIZATIONS}

4.1 LEGAL REQUIREMENTS (Paige and Numark 1985; NEA 11/86; IEAL 1987)

A. In Switzerland, producers of radioactive wastes are responsible for their safe disposal

B. Proof of safe disposal of radioactive wastes must be shown in applying for new reactor licenses; Swiss utilities were required to 'guarantee' safety and feasibility of final disposat of nuclear wastes as a prerequisite to extension of nuclear plant operating licenses beyond 1985; this was accomplished by Project Gewahr

C. The federal government has the right of expropriation and can transter this right to the implementor (i.e., utilities); conflicts between federal and local governments may be settled by a federal tribunal

D. The federal government assumes responsibility for waste repositories after they are closed

4.2 LICENSING (Paige and Numark 1985; NUKEM 4/89)

A. In Switzerland, all nuclear installations need a general license that is granted by the Federal Council (based on advice from HSK and KSA) and approved by Parliament

B. Once the general license is issued, construction and operating licenses may be granted by the federal government

C. Test drillings must be licensed by the federal government

4.3 PUBLIC INVOLVEMENT (Paige and Numark 1985)

A. In Switzerland, local officials and the public are brought into the project review process from the beginning; public hearings are sometimes held as part of the facility siting process 
B. National referenda have been used without success by nuclear opponents trying to fimit or cripple the Swiss nuclear program

c. Public relations activities include quarterly reports to news media, open guided tours of drilling on candidate sites for waste facilities, and a regularly scheduled news bulletin on waste management

\subsection{WASTE FUND}

A. Swiss electricity tariffs include costs of NAGRA's work, future repository construction, and nuclear power plant decommissioning

B. Electricity and other waste producers accumulate reserves for disposal costs; NAGRA handles R\&D funds; decommissioning funds are handled by the federal government (NEA 11/86)

4.5 KEY AGENCIES AND FUEL CYCLE CENTERS (IEAL 1987; Leigh and Mitchell 1990;

A. EDI (Federal Department of Interior): develops rules to implement radiation protection standards; collects and stores radioactive wastes from facilities other than nuclear power plants and fuel reprocessing plants

B. HSK (Nuclear Safety Division of the Federal Energy Office $\{B E W\}$ of the Federal Department of Transport, Communication and Energy (EVED\}, Würenlingen): performs federal licensing and inspection of nuclear installations; has regulatory responsibility shared with KSA; sets criteria for waste management practices, including geologic disposal

C. KSA (Commission for the Safety of Atomic Installations): provides regulatory safety review and advice for nuclear facilities

D. NAGRA/CEDRA (National Cooperative for the Disposal of Radioactive Waste) in Baden: a private organization that was formed by utilities/federal government to provide facilities for the disposal of radioactive waste

1) NAGRA has responsibility for siting, design, and operation of waste management facilities; it also carries out waste management R\&D

2) NAGRA has operated an underground research laboratory (URL) in crystalline rock at Grimsel Pass since 1984

3) Utilities will provide central storage for vitrified HLW, other reprocessing wastes, and spent fues

E. PSI (Paul Sherrer Institute): federal institute formed in 1987 through a merger of the former Federal Institute for Reactor Research (EIR) and the Swiss Institute for Nuclear Research (SIN); PSI is part of the Department of Interior and is located at Wurenlingen

F. Federal interagency Working Group on Nuclear Waste Management (AGNEB) supports decisions of the federal government on waste management topics; it is an interdepartmental group with representatives of all federal agenisies directly interested in waste management (NEA 1988) 
G. Commission on Nuclear Waste Management: established in 1989 as a subgroup of the Federal Geology Commission; it advises administration and regulators on matters of waste disposal geology and will review major NAGRA projects (NEA 1/90)

\subsection{PRINCIPAL RESEARCH, DEVELOPMENT AND DEMONSTRATION FACILITIES/PROGRAMS}

A. R\&D facilities at PSI include the following:

1) Hot cells, active laboratories, incinerator

2) Acid Digestion Pilot Plant for Alpha Wastes (ADA); nonradioactive operation in 1981, radioactive operation in 1988

B. Primary waste R\&D at PSI includes (NEA Bull. 9/89):

1) Characterization of waste matrixes (glass, concrete, bitumen)

2) Repository performance

3) Radionuclide transport in the geosphere and biosphere

\subsection{KEY PERSONNEL}
A. U. Niederer, Waste Management, Federal Energy Office
B. Hans Issler, President, NAGRA
c. Charles McCombie, Director of Science/Technology Division, NAGRA
D. E. Kowalski, Director of Repository Projects, NAGRA
E. Anton Menth, Director, PSI

\subsection{NUCLEAR FUEL PRODUCTION}

5.1 STRATEGY: The Swiss purchase LWR fuel assemblies from foreign suppliers

5.2 URANIUM RESOURCES: No significant resources have been found, but some low-quality (Up to 8000 parts per million uranium) ores have been found in the Swiss Alps; prospecting has been discontinued (NF 3/9/87)

5.3 URANIUM ENRICHMENT: The Swiss have held discussions with China for supply and enrichment of about $200 \mathrm{MTU}$ (NF 10/5/87)

5.4 FUEL FABRICATION: PSI performs development of uranium-plutonium sphere-pac, nitride fuels in cooperation with the French 


\subsection{FUEL RECYCLE}

\subsection{FUEL REPROCESSING}

A. Swiss strategy is to purchase reprocessing from foreign countries; the option is maintained to not reprocess fuels discharged after 1993 (Rometsch and Issler 1986)

B. All Swiss nuclear fuel to be discharged up through 1993 is contracted to be reprocessed in France and the U.K. (Rometsch and Issler 1986)

C. Reprocessing of 165 MTU spent fuel has been contracted to BNFL and 599 MTU to COGEMA; contracts were signed before 1980 with COGEMA that include COGEMA keeping the wastes; discussions have been held with China to reprocess some Swiss spent fuel and to keep the wastes (NF 10/5/87)

\subsection{PLUTONIUM RECYCLE}

A. Swiss utilities have agreed on a general plan to use plutonium in their nuclear power plants; plutonium from recycling will be pooled initially for future use in MOX fuel in all Swiss reactors (NF 9/21/87; NUKEM 1/88)

B. Plutonium in spent fuel from two Beznau PWRs (reprocessed by COGEMA) has been recycled in those reactors since 1978; reprocessed fuel from the Mühleberg BWR has been used in the French breeder program (NF 9/21/87)

\subsection{SPENT FUEL STORAGE AND TRANSPORT}

7.1 SPENT FUEL ARISINGS (NAGRA 1985; NUKEM 4/89; Leigh and Mitchell 1990)
A. 1985650 MTU cumulative
1988945 MTU cumulative
19901090 MTU cumblative
20001835 MTU cumulative

B. $7860 \mathrm{MTU}$ were expected to arise from a reference power production program of 240 GWe over 40 years (6-GWe/yr production); 1988 planning is based on 160 GWe total

7.2 WET STORAGE: In Switzerland, reactor pools are equipped with dense storage racks; they will provide adequate AR storage capacity until the mid-1990s

\subsection{DRY STORAGE}

A. PSI made an evaluation of possible alternates to pool storage for the DIORIT (research reactor) spent fuel; the West German Castor cask system was selected, tested and licensed for transport and storage (Ospina 1986)

B. A project for a central facility (called ZWILAG) was initiated for interim storage of spent fuel and reprocessed wastes; it will use a dry cask system; completion of licensing is expected in 1994; the facility is to be located adjacent to the Paul Scherrer Institute at Wurenlingen 
1) The facility will have a capacity for $1555 \mathrm{MTU}$ of spent fuel or $550 \mathrm{~m}^{3}$ of vitrified HLW from reprocessing of 4968 MTU of spent fuel in 184 casks

a. This initial capacity is sufficient for $15-20$ years accumulation; future capacity is planned for $30-50$ years accumulation

2) The facility will also provide separate storage halls for LLW and ILW

C. The owners of the two Beznau power plants applied for an interim onsite storage facility for spent fuel, vitrified wastes, and other wastes; depending on progress of the central storage facility (see 7.3 B.), only part of the Beznau storage facility may have to be constructed (NEA 1/90)

\subsection{TRANSPORT (Dommann 1986)}

A. Swiss transport regulations are consistent with IAEA standards

B. Transport of spent fuel to La Hague (France) and Sellafield (U.K.) has been done since the early 1970s (462 MTU through 1985), using different casks weighing up to $120 \mathrm{MT}$; spent fuel has been transported in both wet and dry systems

C. Four of five existing power reactors have rail access and ship by rail

\subsection{RESEARCH AND DEVELOPMENT}

A. In Switzerland, R\&D was formerly done on the MODREX storage concept; it is presently not active (IAEA 1984)

1) Spent fuel assembties were to be placed in dry storage canisters at the reactor plant

2) The sealed canisters were to be transported to the fuel storage facility in standard casks

3) Canisters were to be stored in a concrete silo; cooling was by natural circulation inside the silo, heat removal from the silo was done by heat pipes

4) This concept lent itself to a modular approach; addition of storage capacity could be done as needed

\subsection{WASTE CONDITIONING, STORAGE AND TRANSPORT}

\subsection{WASTE DEFINITIONS (NAGRA 1985; IEAL 1987)}

A. HLW: the wastes remaining after reprocessing to remove plutonium and uranium; they contains $99 \%$ of all original radioactivity

B. LLW: all other wastes with surface dose rates less than $200 \mathrm{mrem} / \mathrm{hr}$

C. ILW: all other wastes with surface dose rates greater than $200 \mathrm{mrem} / \mathrm{hr}$

1) LLW plus ILW contain about $1 \%$ of all original activity in the spent fuel 
D. Alpha wastes: similar to LLW or ILW but containing alpha-emitting radionuclides

\subsection{WASTE ARISINGS}

A. Reference 240 GWe total scenario--200,000 $\mathrm{m}^{3}$ LLW/LW; $1200 \mathrm{~m}^{3}$ glass (6000 canisters) or $3700 \mathrm{~m}^{3}$ spent fuel (7860 MT) (NAGRA 1985)

B. 1988 planning is based on $160 \mathrm{GWe}$ total

C. The current estimates of total waste arising from the reprocessing contracts abroad are: $240 \mathrm{~m}^{3} \mathrm{HLW}, 4500 \mathrm{~m}^{3}$ alpha waste, and $30,000 \mathrm{~m}^{3}$ LLW/LW (Ospina 1988)

\subsection{LLW/ILW WASTE CONDITIONING}
A. Combustible low-level and alpha wastes are incinerated (PSI)
B. Wastes (LLW/LW) are immobilized in cement (primarily) or bitumen
C. Conditioning of wastes by incineration and/or cementation is planned at the central storage facility in Wurenlingen (NEA 1/90)

\subsection{LLW/ILW STORAGE (MacLachlan 1985; IEAL 1987)}

A. Warehouse storage of cemented and bituminized LLW packages is used

B. The central facility for HLW and spent fuel also will include separate halls for storage of LLW (capacity $4000 \mathrm{~m}^{3}$ ) and ILW (capacity $1000 \mathrm{~m}^{3}$ )

1) Construction of storage halls for LLW and ILW was approved by the Swiss National Council in 1987

2) The central interim storage facility at PSI was approved by Wurenlingen voters; its cost is estimated to be $\$ 4.8$ million (U.S.), and construction will take 2 years (NW $11 / 30 / 90$ ); licensing is expected to take 4 years (Veya $3 / 4 / 90$ )

\subsection{HLW STORAGE (MacLachlan 1985)}

A. In Switzerland, no specific minimum or maximum time period is required, but storage is planned for about 40 years

B. A central facility was initiated for interim storage of Swiss HLW and spent fuel that cannot be reprocessed (and other wastes); it will use a West German Castor cask system (IAEA 1984; MacLachlan 1985; Ospina 1986; IEAL 1987)

1) The facility will have a capacity for 1555 MTU of spent fuel or $550 \mathrm{~m}^{3}$ of vitrified HLW from reprocessing of $4968 \mathrm{MTU}$ of spent fuel in 184 casks

2) It will have sufficient capacity for $30-50$ years' accumulation of spent fuel

3) The municipality of Wurenlingen will receive compensation payments from Swiss nuclear utilities for 25 years (NUKEM 2/90) 


\subsection{RESEARCH AND DEVELOPMENT (Leigh and Mitchell 1990)}

In Switzerland, research and development have been conducted in the following areas:
A. Melting of metallic scrap from reactors
B. Leaching studies on LLW/LW forms
C. Corrosion tests on waste package materials

\subsection{TRANSPORT (Dommann 1986)}
A. Swiss transport regulations are consistent with IAEA standards
B. Prototype tests are carried out by PSI to ensure the compliance of transportation packagings with regulations (Stalder 1986)

8.8 PROGRAM/FACILITIES COSTS: LLW and ILW storage facilities are estimated to cost 7.95 million Swiss francs (NW 10/1/87)

9.0 DISPOSAL OF NON-HIGH-LEVEL WASTES (Rometsch and Issler 1985; Issler and McCombie 1985; NAGFA 1985; Rometsch 1989; Kowalski et al. 1989)

\subsection{STRATEGY}

A. The Swiss plan to dispose of conditioned $\amalg W / \mathrm{LW}$ in an intermediate-depth repository (type B) as proposed in NAGRA 1985 (alpha wastes are planned to be disposed in the deep geological repository for HLW)

1) The federal government has accepted the NAGRA plans for LLW/LW disposal, providing no alpha wastes are included (NF 2/8/88)

2) Shallow-land disposal of LLW is not foreseen (Kowalski et al. 1988)

3) Long-lived ILW (alpha wastes) are planned to be disposed together with HLW; an option for disposal of long-lived ILW in a special cavern at the site for short-lived LLW/LW will be kept open (Nagra 2/89)

B. Retrievability is not required

C. Development of the disposal facility for LLW/LW is a top priority (Kowalski et al. 1988)

D. Sea-dumping of LLW was practiced during 1969-1982 (Dommann 1986)

\subsection{WASTE DISPOSAL CRITERIA}

A. In Switzerland, general criteria are the same as for HLW/spent fuel (see Sections 10.1.A 10.1.C)

1) Maximum permissible concentrations have been established for the $L L W / L W$ repository 

B. Toxicity of wastes must be at least 100 -fold lower than in the HLW repository
C. Post-closure controls are not required

9.3 LLW/ILW DISPOSAL (Issler and MCCombie 1985; NAGRA 1985; Rometsch 1986)

A. The Swiss reference disposal system is based primarily on the Project Gewahr study

1) The repository will be at an intermediate depth (several hundred meters)

2) The repository reception area is in an excavated cavern and includes facilities for placing incoming waste canisters in disposal containers and for lag storage

3) Waste packages are to be remotely emplaced in a concrete-lined horizontal tunnel system excavated in a marl (reference host rock) formation several hundred meters below the summit of a mountain

4) Disposal tunnels are to be accessible by vehicle via a horizontal tunnel from the entrance

5) Disposal containers are to be stacked in tunnels and backfilled with a special fluid cement

6) Disposal tunnels are to be lined with concrete and backfilled with a special cement mixture

7) The operations mode is to use successive waste placement and backfilling in a given tunnel

8) The design capacity will be $100,000 \mathrm{~m}^{3}$, corresponding to 40 years operation of present nuclear power plants (NN 2/90)

B. The Swiss reference waste package description follows (Knecht and Van Dorp 1989):

1) A cement (primarily) or asphalt waste form in metal containers is to be used

2) Small packages are to be emplaced in standard repository containers and immobilized with cement within containers; large packages are to be emplaced directly in repository tunnels

3) The concept for reactor decommissioning wastes uses standardized, large concrete containers $(2.18 \mathrm{~m} \times 2.08 \mathrm{~m} \times 4.78 \mathrm{rn})$, with $10-\mathrm{cm}$ wall thickness and $17.1 \mathrm{~m}^{3}$ inner volume; internal metal shielding will be used where required, and containers will be filled with fluid concrete; tentative heat load limits are $6 \mathrm{~W} / \mathrm{m}^{3}$ at disposal time and $30 \mathrm{~W} / \mathrm{m}^{3}$ for storage in air (Alder 1987)

4) Backfill materials may be cement/pumice mortars; a hydraulic barrier may be needed between the backfill and host rock (Knecht and Van Dorp 1989)

5) Final sealing of access tunnels will be by either concrete or bentonite plugs (NEA $11 / 88)$ 
C. Site selection in Switzerland is being undertaken as follows:

1) NAGRA reduced the initial list of 100 conceivable sites to three in two stages; site characterization (geologic, geophysical and geohydrologic exploration) has been started at those three: Bois de la Glaivaz (anhydrite), Oberbauenstock (marl), and Piz Pian Grand (alpine gneiss); in addition, a fourth site at Wellenberg (marl) will be investigated for LLW/LW (horizontal access) and alpha wastes (vertical access at $300 \mathrm{~m}$ depth, option presently deferred) (Kowalski et al. 1988)

2) An exploratory tunnel (with a small URL) will be drilled in at least one of the sites where no unforeseen problems are found

3) No licensed work has been done at Bois de la Glaive due to severe political obstruction at this site (Kowalski et al. 1989)

4) The first site to be evaluated in detail will be at Wellenberg; the Federal Council approved test drillings and construction of an access tunnel (2000 $\mathrm{m}$ long); drilling work will start in 1990 (NEA Bulletin 9/89); the investigations at Wellenberg will be presently confined to short-lived wastes (NAGRA 2/89)

D. The schedule for the repository is: site selection until 1992; start construction in 19931994; start disposal in 1998 (Lakey 1987; Kowalski et al. 1989)

E. Performance assessment has been conducted and the results are as follows:

1) A preliminary evaluation of the proposed disposal system was based on data for a marl formation in a mountain (Oberbauenstock) near Lake Lucerne, using available data and two- and three- dimensional hydrologic modeling

2) Complete isolation by the tunnel lining is assumed for the first 500 years; after 10,000 years, all cement is assumed to have disintegrated

F. Sea dumping of LLW was discontinued in 1982 (Leigh and Mitchell 1990)

\subsection{PROGRAM/FACILITIES COSTS}

A. The LLW/LW repository cost is estimated at 320 million Swiss francs, or $\$ 207$ million U.S. (NAGRA 1985)

B. Almost $60 \%$ of the NAGRA budget for FY 1987, 60 million Swiss francs, was for work on UW/ILW (NF 2/8/88)

\subsection{DISPOSAL OF HIGH-LEVEL WASTES}

10.1 SPECIFICATIONS AND CRITERIA (Issler and McCombie 1985; NAGRA 1985; Rometsch 1986)

A. The Swiss repository will be designed so that it may be closed at any time within several years and so that after closure there will be no requirement for safety and supervision measures; post-closure surveillance may be optional but cannot be required to meet safety requirements; retrievability is neither required nor ruled out 
B. Radionuclides from the sealed repository, which reach the biosphere as a result of realistically conceivable processes and events, may at no time lead to individual doses which exceed $10 \mathrm{mrem} / \mathrm{yr}$

C. No more specific criteria are to be developed by the Swiss government; it is the responsibility of waste producers to show that the atove criteria are met

D. Safety analyses are based on a 1000-year waste package; emphasis is placed on the overall system performance rather than on standards for each barrier

\subsection{REPOSITORY DEPLOYMENT STAATEGY (issler and McCombie 1985; NAGRA 1985)}

A. To satisly the legal requirement for a convincing illustration of the technical feasibility and long-term safety of radioactive waste disposal in Swizerland, generic safety analyses and construction project studies (Project Gewahr) have been performed, based on the reference design concept and geologic, hydrologic and geochemical field data that are representative of conceivable repository locations

1) Experts at the federal level have not yet accepted or rejected NAGRA's plans for HLW disposal because they are concerned that Switzerland does not have an adequate site in crystalline rock with sutficienl capacity for Swiss HLW (NF 2/8/88)

B. In parallel, preliminary site investigations will be conducted, including deep drilling, in northern Switzerland, to provide a basis for future site selection

C. Successive, independent and multiple barriers will be used for long-term protection

D. The design is to provide complete containment from the biosphere for 1000 years

E. In situ tests are performed in the URL at Grimsel Pass

\subsection{SITE SELECTION AND CHARACTERIZATION (Thury 198!5; NEA 1986)}

A. Past activities have focused on crystalline basement rock under a $1000 \mathrm{~km}^{2}$ area in northern Switzerland; it is granitic formation with extensive small-scale fracturing that has been sealed by deposition of minerals; the rock is covered by a few hundred meters of sediments; drilling has identified a large permocarboniferous deposit (coal-bearing) at $2000 \mathrm{~m}$ that limits the area available for the crystalline repository to a $15-20 \mathrm{~km}$ area along the Rhine River; site selection activity was expanded to include sedimentary layers elsewhere

B. Opalinus clay and lower freshwater molasse (sedimentary rocks) were selected for consideration as potential host rocks; after selecting the most promising option, application for field investigations is planned for 1990 (Kowalski et al. 1989)

C. By 1993 , synthesis of knowledge of crystalline bedrock and sedimentary rocks will be concluded, and one site will be selected for detailed characterization (Kowalski et al. 1988; NUKEM 2/90)

D. The Swiss expect to have an underground repository laboratory at the final repository site for detailed investigations 
E. The schedule for the Swiss repository follows (Lakey 1987; Kowalski et al. 1988;

NEA 11/88):

1980-1985 Geologic investigations and site selections

1985-1993 Investigations at one to four sites

1993 Selection of one site for detailed studies

1998 Application for an underground research laboratory at the repository site

2005 Decision on development of Swiss repository or participation in a foreign repository

2010-2025 Construction of the HLW repository

2025 Start operation of the HLW repository

10.4 REFERENCE HLW/SPENT FUEL DISPOSAL CONCEPT (based primarily on the Project Gewahr study) (NAGRA 1985; Nold and Gassner 1985)

A. The reference waste is:

1) HLW in borosilicate glass cooled 40 years after reactor discharge; it contains about $10 \mathrm{wt} \%$ actinide and fission-product oxides

2) Alpha wastes are to be incorporated into cement or bitumen in a steel drum

B. The reference waste package concept is (NAGRA 1985; Knecht and Van Dorp 1989):

1) HLW borosilicate glass in a stainless steel canister with a thick, sealed cast steel disposal container overpack, wall thickness $25 \mathrm{~cm}$; total length is $2.0 \mathrm{~m}$; outside diameter is $0.94 \mathrm{~m}$; design life is 1000 years; total weight of filled and sealed canister is 8.5 MT (Knecht and McCombie 1985; NEA 11/88)

a. Maximum temperature of the emplaced HLW glass is about $195^{\circ} \mathrm{C}$ and the disposal container is about $150^{\circ} \mathrm{C}$

2) Alpha wastes, embedded in cement or bitumen, are emplaced in a cylindrical concrete silo and surrounded by special concrete (NEA 11/88)

3) Packing/buffer and seal materials are:

a. Compacted bentonite ( $>1 \mathrm{~m}$ thick) is emplaced around HLW packages to fill tunnels; bentonite is expected to retain radionuclides for about 100,000 years; the temperature limit for bentonite is $90^{\circ} \mathrm{C}$; expected total pressure on disposal container is less than $30 \mathrm{MPa}$

b. Bentonite granulate would be placed between alpha waste silos and cavern walls; empty spaces in silos are to be filled with cement 
c. Sealing of key zones is to be done with bentonite; remaining spaces are to be filled with bentonite/sand mixture or other materials like concrete (NEA 11/88)

C. The surface reception area at the Swiss repository site will seal HLW waste canisters into cast steel disposal containers

D. The repository concept for HLW wastes (type $\mathrm{C}$ ) is a mined facility in the middle of a tectonically stable block of crystalline bedrock at $1200 \mathrm{~m}$ depth; HLW packages are placed horizontally, $5 \mathrm{~m}$ apart, in 3.7-m-diameter parallel tunnels

E. Alpha waste drums are to be placed in vertical concrete silos in caverns $10 \mathrm{~m}$ diameter and $55 \mathrm{~m}$ depth; construction of parts of the repository would be simultaneous with operations in other parts

F. The reference repository is sized to handle 6000 cylinders of $\mathrm{HLW}$ borosilicate glass from 7860 MT spent fuel, plus alpha wastes from reprocessing; overall underground repository dimensions are about $1600 \mathrm{~m} \times 1200 \mathrm{~m}$ (NEA 11/88)

G. For closure and post-closure monitoring, long-term surveillance is not to be required

\subsection{WASTE PACKAGE R\&D}

A. Joint Swiss-Swedish-Japanese leaching tests have been performed on French and British glass samples

B. Theoretical and laboratory evaluation of many overpack concepts was being done (Knecht and McCombie 1985)

C. Results of corrosion tests performed on container and overpack materials have narrowed the choice to cast steel as the reference material (Knecht and McCombie 1985; Simpson and Knecht 1985)

D. Mechanical and chemical behavior of bentonite materials are being investigated in the laboratory

\subsection{GEOSCIENCES R\&D}

A. In Switzerland, geologic research is composed of comparison of observations of bore cores with data from sonic, seismic and television logging in a network of deep boreholes

B. Geohydrologic research comprises:

1) Measurements of hydraulic conductivities, water age dating, and movement of injected tracers in deep borehole tests

2) Development of improved fluid logging methods

3) Studies of surface waters

4) Development of a regional flow model, calibrated by borehole data 
C. In the area of rock mechanics, measurements of mechanical, thermal and petrographic properties of different rock types are being performed by the Swiss

D. Swiss geochemical research includes the following:

1) The Swiss granite site at the proposed repository depth has reducing conditions, mildly alkaline $\mathrm{pH}$, and fractures filled with radionuclide-sorbing aluminosilicate alteration minerals

2) PSI studies comprised: experimental studies and modeling of transport of various radionuclides; measurements of actinide sorption on sections of rock from borehole cores; and validation of performance assessment models by natural and archeological analogs

\subsection{FIELD TESTS}

A. A URL has been used for field tests at Grimsel Pass, a Swiss cooperative effort with two FRG research institutes (BGR and GSF); a joint project with the U.S. is also being conducted at the Grimsel Test Site, operational since 1984 (NEA 11/88; Lieb 1989;)

1) The objectives of investigations at Grimsel Pass facility are to (IEAL 1987; Lieb 1989):

a. Confirm applicability of foreign research results to geologic conditions in Switzerland

b. Conduct experiments necessary for NAGRA's HLW and alpha waste disposal concepts

c. Acquire knowledge in implementing and interpreting underground tests in different experimental areas

d. Acquire practical experience in developing, testing, and using experimental apparati and measurement methods

2) The Grimsel Pass URL consists of a central area and tunnels accessed from pumping-station tunnels; it is located in a saturated granodiorite body at an elevation of $1730 \mathrm{~m}$ above sea level; the test area is 3000 feet in from a portal via access drift, with $450 \mathrm{~m}$ of overlying rock; the facility contains about 2800 feet of excavations; main test drifts are about $11.5 \mathrm{ft}$ in diameter (Montgomery 1987); the tunnels branch into three different rock areas where measurements can be made in dry impermeable rock, damp zones, and water-bearing fissures (NN 2/90)

3) Major experiments include underground seismics, rock stress tests, fracture flow tests, geochemistry tests, migration experiments, gas and its effects on transport, heat tests, ventilation tests, electromagnetic high frequency measurements, excavation tests, tilt measurements, and borehole sealing tests (no radioactivity planned to be used)

4) The Grimsel Pass URL is not being considered as a final repository site

B. A deep borehole project is being conducted in northern Switzerland (Tsang 1988) 
1) Six boreholes have been drilled up to $2500 \mathrm{~m}$ deep, and a seventh was drilled at Siblingen (NEA 1/90)

2) The tests include rock characterization, hydrology, and fracture hydrology

C. The Swiss participate with Sweden, Brazil, and the U.S. in the Pocos de Caldas natural analog project in Brazil (Shea 1987)

1) Studies use boreholes to study rock-water interactions, geochemical processes, characterization of behavior of plutonium and technetium, hydrothermal mobilization of radioelements, and assessment of microbial activity

10.8 PERFORMANCE ASSESSMENT (McCombie 1985; Leigh and Mitchell 1990)

Performance assessment in Switzerland efforts have included:
A. Scenario and deterministic consequence analysis
B. Modeling of radionuclide migration in porous and fractured and heterogeneous media
C. Estimation of potential radionuclide migration and release to biosphere
D. Chemical behavior of radionuclides during migration
E. Sorption data of radionuclides in different media

\subsection{PROGRAM/FACILITIES COSTS}

A. NAGRA costs through 1988 have totaled about 350 million Swiss francs (NEA 11/88)

1) The NAGRA budget for FY 1986 included 38.4 million Swiss francs (\$25 million U.S.)

2) The NAGRA budget for FY 1987 included 60 million Swiss francs; almost $60 \%$ of this was for work on LLW/LW (NF 2/8/88)

B. The HLW repository construction costs are estimated to be about 600 million Swiss francs (NAGRA 1985)

C. Total costs through HLW repository construction are estimated at about 1.5 billion Swiss francs; operational costs will be about equal to these (NEA 11/86)

\subsection{MANAGEMENT OF URANIUM MINE AND MILL WASTES}

A. Swizzerland does not mine uranium, and therefore does not have wastes in this category

\subsection{DECOMMISSIONING AND ENVIRONMENTAL RESTORATION}

A. Detailed decommissioning plans have been prepared for all Swiss nuclear power plants

B. Dismantling is expected to be done between 2 and 30 years after the nuclear power plant is shut down (Alder 1987, 1989) 
1) Reactor decommissioning wastes will be put into standardized, large concrete containers $(2.18 \mathrm{~m} \times 2.08 \mathrm{~m} \times 4.78 \mathrm{~m})$, with $10 \mathrm{-cm}$ wall thickness and $17.1 \mathrm{~m}^{3}$ inner volume; internal metal shielding will be used where required, and containers will be filled with fluid concrete; tentative heat load limits are $6 \mathrm{~W} / \mathrm{m}^{3}$ at disposal time and $30 \mathrm{~W} / \mathrm{m}^{3}$ for storage in air; the container weight when filled is limited to 60 tons (Alder 1989)

2) Decommissioning wastes are to be disposed in the type B repository for LLW and ILW; a volume of $97,000 \mathrm{~m}^{3}$ of decommissioning wastes is assumed for the Project Gewahr reference case (240 GWe) (Alder 1989)

C. Electricity and other waste producers accumulate reserves for decommissioning; decommissioning funds are handled by the federal government (NEA 11/86)

D. Decommissioning of the experimental nuclear power plant of Lucens is planned to be accomplished by backfilling of the rock caverns in which the plant was located (NEA $1 / 90)$

\subsection{INTERNATIONAL ACTIVITIES}

\subsection{MEMBERSHIPS: IAEA, OECD/NEA}

13.2 COOPERATION WITH MULTINATIONAL AGENCIES: CEC/NAGRA have an agreement on radioactive waste management studies (term: June 1984-1988)

\subsection{COOPERATION WITH USA}

A. DOE has an exchange agreement with NAGRA (umbrella agreement)

1) The term of the agreement is $1985-1990$

2) The scope includes conditioning, packaging, storage, and disposal of wastes; transportation; environment and safety; and public acceptance

3) The current emphasis is an exchange of crystalline rock information and interchanges concerning Grimsel Pass URL activities

B. NRC has an exchange agreement with NAGRA

1) The term of the agreement is 1986-1991

2) The scope includes cooperation and information exchange on radioactive waste management safety research, data, analyses, and computer codes, including the possibility of proprietary information

3) The current activities include hydrologic, package performance, and migration tests at Grimsel Pass; site characterization techniques, source terms, shaft sealing, backfill techniques and performance, and migration analysis 


\subsection{COOPERATION WITH OTHER COUNTRIES}

A. NAGRA has an agreement with FRG's BMFT for joint research at the Grimsel Pass URL, extended through 1990; several countries (U.S., France, Sweden) have participated in research work at the Grimsel Pass site (NEA 11/88)

B. The Swiss have cooperative agreements with Sweden (SKB), France (CEA/ANDRA), Finland (TVO and IVO), Japan (PNC), the FRG (BMFT, BGR, GSF), Belgium (ONDRAF), and the U.K. (NRPB, BGS, BNFI) on radioactive waste management (PNC Review Fa!l 1988; NEA 11/88)

C. Joint Swiss-Swedish-Japanese leaching tests were conducted on French AVM glass samples

D. The Swiss participate with Sweden, the U.S. and Brazil on the Pocos de Caldas natura! analog project in Brazil

E. The Swiss have an agreement with the CEA, France, on cooperative R\&D on advanced uranium nitride or uranium/plutonium nitride fuels for FBRs

F. The Swiss have signed bilateral peaceful nuclear cooperation agreements (exchange of technology, materials, and equipment) with China in 1986 and Australia in 1987

1) The Swiss PSI is actively participating in a district nuclear heating demonstration project in Beijing, China (NE 11-12/87)

G. The Swiss signed an agreement for peaceful nuclear cooperation (limited to nuclear materials) with the Soviet Union in 1990 (NF 4/90)

H. The Swiss Parliament ratified a nuclear cooperation agreement with Canada in 1989 which allows Swiss utitfities to resume normal uranium trade with Canada; a previous agreement was suspended by Canada in 1977 (NF 4/89)

I. The Swiss participate in the Stripa rock laboratory project (an NEA project located in Sweden)

\subsection{REFERENCES}

\section{$-1984-$}

International Atomic Energy Agency (IAEA). 1984. Guidebook on Spent Fuel Storage. Technical Reports Series No. 240, pp. 37, 152-157, Vienna.

$-1985-$

Issler, H., and C. McCombie. 1985. "Demonstration of the Feasibility of Safe Disposal of Radioactive Wastes: the Swiss Approach." Waste Management '85, Vol. 1, pp. 55-62. March 1985, Tucson, Arizona.

Knecht, B., and C. McCombie. 1985. "High-Level Waste Overpack for Finat Storage in the Swiss Granitic Bedrock: Material Selection, Design and Characteristics." In Proceedings of ANS Topical Meeting on High-Level Nuclear Waste Disposal, pp. 533-544. September 1985, Pasco, Washington. 
MacLachlan, A. 1985. 'Swiss Utilities Choose Cask System for Interim Storage of Spent Fuel." Nuclear Fuel, June 18, 1985, p. 7.

McCombie, C. 1985. "Predicting the Safety of a HLW Repository." In Proceedings of ANS Topical Meeting on High-Level Nuclear Waste Disposal, pp. 617-627. September 1985, Pasco, Washington.

NAGRA. 1985. "Project Gewahr 1985." Feasibility and Safety Studies for Final Disposal of Radioactive Wastes in Switzerland. NAGRA, Baden, Switzerland.

Nold, A. L., and R. Gassner. 1985. "The High-Level Waste Repository Concept for the 1985 Gewaehr Project in Switzerland." In Proceedings of ANS Topical Meeting on High-Level Nuclear Waste Disposal, pp. 411-420. September 1985, Pasco, Washington.

Paige, H. W. and N. J. Numark. 1985. Assessment of National Systems for Obtaining Local Siting Acceptance of Nuclear Waste Management Facilities. IEAL-R/86-16, International Energy Associates Limited, Washington, D.C., Vol. 1, pp. 15-1 to 15-6 and Vol. 2, pp. 17-1 to 17-7.

Rometsch, R., and H. Issler. 1985. "Status of the High-Level Nuclear Waste Disposal Program in Switzerland.' In' Proceedings of ANS Topical Meeting on High-Level Nuclear Waste Disposal, pp. 24-26. September 1985, Pasco, Washington.

Simpson, J., and B. Knecht. 1985. "Corrosion Behavior of Unalloyed Steel and Cast Iron in Groundwaters of the Bedrock of Northern Switzerland." In Proceedings of the international Seminar on Radioactive Waste Products - Suitability for Final Disposal, pp. 445-454. June 1985, KFA, Juelich, Federal Republic of Germany.

Thury, M. 1985, "The Swiss Site-Selection Program for High-Level Radioactive Waste Disposal." In Proceedings of ANS Topical Meeting on High-Level Waste Disposal, pp. 223.232. September 1985, Pasco, Washington.

-1986 -

Dommann, F. 1986. 'Transport of Nuclear Wastes and Spent Fuel in Switzerland.' In Proceedings of IAEA symposium on Packaging and Transportation of Radioactive Materials PATRAM 1986, Vol. 1 , p. 7. June 16-20, 1986, Davos, Swilzerland.

Nuclear Energy Agency (NEA). 11/86. "Summary Record of the Ad Hoc Meeting of the Directors of Crystalline Rock Projects." Meeting held November 3-4, 1986, Paris.

Ospina, C. 1986. 'Dry Storage Cask - Diorit - Swiss Experience.' In Proceedings of the Third International Spent Fuel Storage Technology Symposium/Workshop, p. P-128. CONF-860417, April 1986, Seattie, Washington.

Rometsch, R. 1986. "Swiss Projects for Geological Disposal of $\amalg W / L W$ in Mined Caverns." Waste Management ' 86 , Vol. 1, pp. 47-54. March 1986, Tucson, Arizona.

Rometsch, R., and H. Issler. 1986. 'Geologic Disposal of Low- and Intermediate-Level Radioactive Waste." International Symposium on Alternative Low-Level Waste Technologies, p. 59. February 28March 1, 1986, Illinois Department of Safety. 
Stalder. 1986. "Quality Assurance Concept in the Field of Low and Intermediate Radioactive Waste Packaging." In Proceedings of IAEA Symposium on Packaging and Transportation of Radioactive Materials, PATRAM 1986, Vol. 1. p. 55. June 16-20, 1986, Davos, Switzerland.

$-1987$.

Alder, J. C. 1987. "Waste Packages from Decommissioning: Characterization, Constraints and Disposal Risks." In Proceedings of 1987 International Decommissioning Symposium, p. IV-368. October 4-8, 1987, Pittsburgh, Pennsylvania.

International Atomic Energy Agency (IAEA). 1987. "Nuclear Share of Electricity Production." Nuclear Safety Review for 1986, p. 23. August 1987, Vienna.

International Energy Associates Limited (IEAL). 1987. Regulatory Strategies for High-Level Radioactive Waste Management in Nine Countries. IEAL-R/87-93, Cecember 1987, Fairiax, Virginia.

Lakey, L T. 1987. 'Foreign Trip Report - Travel to Switzerland, Frarce and Federal Republic of Germany for Technology Exchange Discussions and Attendance at the OECD/NEA RWMC Meeting in Paris, June 5-13, 1987.' Pacific Northwest Laboratory, Richland, Weshington.

Montgomery, J. E. 1987. 'Foreign Trip Report - Shalt Sinking by Freezing Method in West Germany, September 11-15, 1987." R.F. Weston, Inc., Washington, D.C.

Nuclear Europe (NE). 11-12/87. 'Swiss-Chinese Cooperation in Developing a Small Integrai Heating Reactor System," p. 28.

Nuclear Fuel (NF). 3/9/87. 'Swiss Government Halts Uranium Prospecting Alter 18 Years," p. 8.

Nuclear Fuel (NF). 9/21/87. 'Swiss Mull Pooling Plutonium for Recycle," p. 3.

Nuclear Fuel (NF). 10/5/87. "Swiss Foresee Deal Within Two Years to Ship Spent Fuel to China," p. 7.

Nucleonics Week (NW). 2/5/87. 'Swiss Nuclear District Heating Plans Got Another Boost," p. 5.

Nucleonics Week (NW). 10/1/87. "SWITZERLAND: Waste Storage Area Gets OK," p. 16.

Shea, M. E. 1987. 'Foreign Trip Report for Travel to Baden, Switzerland, November 12 to 15, 1987." Battelle Memorial Institute, Willowbrook, Illinois.

$-1988-$

Kowalski, E., et. al. 1988. "Status of Swiss Disposal Projects." Waste Management '88. Tucson, Arizona.

NEA Nuclear Waste Bulletin. 12/88. "Government Approves Project Gewahr,"

Nuclear Energy Agency (NEA). 1988. "Switzerland, Nuclear Waste Management."

Nuclear Energy Agency (NEA). 11/88. 'Radioactive Waste Management in Switzerland," Paper prepared for Radioactive Waste Management Committee of the OECD Nuclear Energy Agency, November 1988. 
Nuclear Fuel (NF). 2/8/88. "NAGRA Wants Swiss Government Support of Plans for High-Level Waste Disposal," p. 5.

Nucleonics Week (NW). 2/4/88. 'Nuclear Electricity Generation for December 1987," p. 18.

NUKEM Market Report on the Nuclear Fuel Cycle (NUKEM). 1/88. "1987 Review - Switzerland." NUKEM GmbH, Hanau, Federal Republic of Germany, p. 14.

NUKEM Market Report on the Nuclear Fuel Cycle (NUKEM). 3/88. "Nuclear Power Plant Capacity of the Western World.' NUKEM GmbH, Hanau, Federal Republic of Germany, p. 22.

Ospina, C. 1988. 'Spent Fuel Management in Switzerland.' In Proceedings of Spent Fuel Manas, ment: Current Status and Prospects. Advisory Group Meeting for the IAEA, March 15-18, 1988, fienna.

PNC Review. Fall 1988. "PNC Starts Collaborative Research Program with the National Cooperative for the Storage of Fadioactive Waste of Switzerland (NAGRA).'

Tsang, C. F. 1988. "Foreign Trip Report, Baden, Switzerland, December 13, 1987." Lawrence Berkeley Laboratory, Berkeley, California.

$-1989-$

Alder, J. C. 1989. "Preliminary Studies of Packaging and Disposal of Decommissioning Waste in Switzerland.' Nuclear Technology, Vol. 86. August 1989.

Knecht, B., and F. Van Dorp. 8/89. "Concept and Design of Engineered Barriers in Swiss Repository Projects:" Nuclear Engineering and Design, 116(1):33-36.

Kowalski, E., C. McCombie, and H. Issler. 1989. "Swiss Projects for Radioactive Waste Disposal Move into a New Phase." Waste Management ' 89 , Vol. 1, p. 73-76. Kyoto, Japan.

Lieb, R. W. 8/89. "Presentation of the Grimsel Test Site." Nuclear Engineering and Design, $116(1): 7-8$.

Nagra Informiert. 2/89. "Arbeitskonzept der Nagra fur die Neunziger Jahre," p. 9.

NEA Nuclear Waste Bulietin. 9/89. "Switzerland: Recent Developments in HLW Disposal Programme, LLW Disposal Programme, and at Paul Scherrer Institute," No. 4, p. 26-28.

Nuclear Fuel (NF). 4/17/89. "Switzerland: Pact with Canada Ratified." p. 11.

NUKEM Market Repor. (NUKEM). 4/89. 'Reprocessing and Waste Management, Country: Switzerland.' NUKEM GmbH, Hanau, Federal Republic of Germany, p. 7-12.

$-1990-$

Leigh, I. W., and S. J. Mitchell. 1990. International Nuclear Fuel Cycle Fact Book. PNL-3594, Rev. 10. Pacific Northwest Laboratory, Richland, Washington.

Nuclear Engineering International (NEI). 6/90. "World Survey," pp. 20-28. 
TAIWAN 


\section{TAIWAN}

\section{CONTENTS}

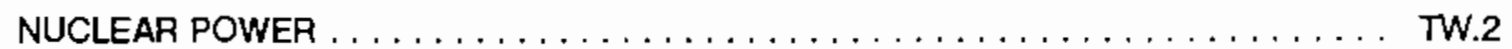

2.0 NUCLEAR FUEL CYCLE AND RADIOACTIVE WASTE MANAGEMENT

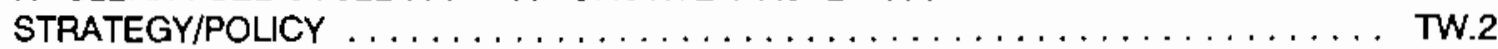

3.0 HIGHLIGHTS AND MAJOR MLLESTONES $\ldots \ldots \ldots \ldots \ldots \ldots \ldots \ldots, \ldots \ldots$ TW. 3

4.0 INSTITUTIONAL CONSIDERATIONS/ORGANIZATIONS $\ldots \ldots \ldots \ldots \ldots \ldots \ldots$ TW.3

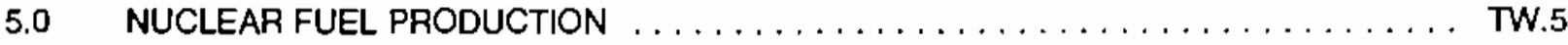

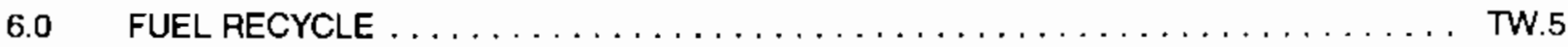

7.0 SPENT FUEL STORAGE AND TRANSPORT $\ldots \ldots \ldots \ldots \ldots \ldots \ldots \ldots \ldots \ldots \ldots \ldots$

8.0 WASTE CONDITIONING, STORAGE AND TRANSPORT $\ldots \ldots \ldots \ldots \ldots \ldots$ TW.7

9.0 DISPOSAL OF NON-HIGH LEVEL WASTES $\ldots \ldots \ldots \ldots \ldots \ldots \ldots \ldots \ldots \ldots \ldots$

10.0 DISPOSAL OF HIGH LEVEL WASTES $\ldots \ldots \ldots \ldots \ldots \ldots \ldots \ldots \ldots \ldots \ldots \ldots \ldots \ldots \ldots$

11.0 MANAGEMENT OF URANIUM MINE AND MILL WASTES $\ldots \ldots \ldots \ldots \ldots \ldots$ TW.9

12.0 DECOMMISSIONING AND ENVIRONMENTAL RESTORATION $\ldots \ldots \ldots \ldots \ldots \ldots$ TW.9

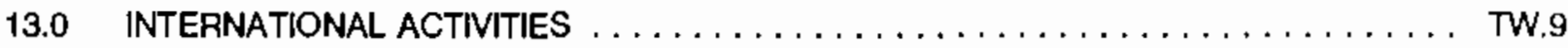

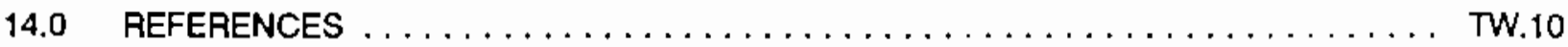




\subsection{NUCLEAR POWER}

\subsection{REACTOR MIX}

4 BWRs, 2 PWRs (Soong 1989; Yeh 1990)

\subsection{ELECTRIC POWER PRODUCTION}

1986-59.0 TWh, 44\% nuclear (Leigh and Mitchell 1990) $1988-41 \%$ nuclear

$1989-36.4 \%$ nuclear (Yeh 1990)

\subsection{NUCLEAR POWER CAPACITY PROJECTIONS}

1989-4.9 GWe

1997-4.9 GWe

1998--5.8 GWe

1999--6.7 GWe

2000-6.9 GWe (Leigh and Mitchell 1990)

\subsection{NUCLEAR PLANT AVAILABILITY}

Availability factors (\%) (Yeh 1990):

$\begin{array}{llll} & \underline{1986} & \underline{1987} & 1988 \\ \text { Range } & 24-95 & 64-90 & 69-82 \\ \text { Average } & 70 & 81 & 75\end{array}$

\subsection{NUCLEAR ENERGY POUCY}

Taiwan's energy policy is to diversity, with about one-third being nuclear; plans for a fourth nuclear power project with two 1000-MWe LWR units were shelved in 1982 due to stagnating demand and public opposition, but are now being reconsidered (Yeh 1990)

1.6 ELECTRICITY PRODUCTION COSTS: \$0.032/kWh (U.S.) by nuclear (AlJ 1987)

\subsection{NUCLEAR FUEL CYCLE AND RADIOACTIVE WASTE MANAGEMENT} STRATEGY/POLICY (RWA 1983; Payne 1985; Shapiro 1986)

\subsection{OVERALL NUCLEAR FUEL CYCLE POLICY}

Taiwan will purchase fuel from foreign suppliers until indigenous fuel production and fabrication capability can be developed for $\mathrm{UF}_{6}$ conversion to $\mathrm{UO}_{2}$ pellets (Leigh and Mitchell 1990); plans for a fuel fabrication plant have been postponed until additional' nuclear power plants at Yenliao have been approved (NEI 1987)

\subsection{POLICY ON THE FRONT END OF THE NUCLEAR FUEL CYCLE}

There are no current plans to enrich uranium in Taiwan 


\subsection{POLICY ON THE BACK END OF THE NUCLEAR FUEL CYCLE (Wang 1990)}

A. Costs of waste disposal are borne by the generator, Taiwan Power Company (Taipower), - under the "polluter pays" principle, and disposal is under the supervision of the AEC/Radwaste Administration

B. Taiwan plans to cortinue at-reactor storage of spent fuel until pools are full, and until facilities can be developed for 50-year storage in dry casks (at or away from reactors)

C. Major milestones for radioactive waste management policy (HLW) in Tawan are to expand and improve temporary storage facilities for spent fuel, focusing on onsite storage and implementing as soon as possible; and to continue planning of final disposal alternatives for $\mathrm{HLW}$

\subsection{HIGHLIGHTS AND MANOR MILESTONES}

1961 First operation of experimental reactor at National Tsing Hua University (Yang and Lo 1989)

1968 Atomic Energy Law passed (Tsai and Chou 1989)

1978 Commercial operation of first nuclear power plant started (Yeh 1990)

1981 Radioactive Waste (RadWaste) Administration created (Tsai and Chou 1989)

1982 LLW storage was started on Lan Yu (Orchid) Island (Yang and Lo 1989)

1989 Taipower resubmitted its proposal to build two new nuclear power stations, which had been initiated and then stalled since 1982 (NUKEM 1989)

1990 Radwaste Administration is to become a regulatory body only and is to tum over operation of Lan-Yu facility to TaiPower (Tsai and Chou 1989).

1996 Decision due on concept for LLW disposal (Chang 1989)

1999 Implementation of HLW interim storage facility (Soong 1989)

\subsection{INSTITUTIONAL CONSIDERATIONS/ORGANIZATIONS}

\subsection{LEGAL REQUIREMENTS}

A. The Atomic Energy Council (AEC) oversees all non-military uses of atomic energy, subject to control of the government (Chung 1990)

B. The AEC established the Radwaste Administration to supervise, conduct, and regulate all issues relating to nuclear waste (Chung 1990)

C. The Radwaste Management Decree of 1981 detines the radioactive waste policy, packaging, and disposal to be pursued in Tawan; milestones set out in the Radwaste Management decree are (Tsai and Chou 1989; Wang 1990):

- $\quad$ expand and improve temporary onsite spent fuel storage facilities 
- complete safety analysis and environmental impact assessment of an interim storage facility and commence operation of this facility before the year 2000

- continue planning for final disposal altematives for HLW

- implement all aspects of $\amalg W$ licensing, treatment, conditioning, transportation, storage, and final disposal in regulations to be legislated by 1991

4.2 RADIATION PROTECTION PRINCIPLES: Taiwan uses the ALARA principle for protecting against radiation exposure, both for individual and collective radiation doses (INER 1986)

4.3 LICENSING: Taiwan has a two-step licensing process similar to that in the U.S. for most nuclear facilities; a full-power license is not granted until the licensing authority has observed full-power operation of the new facility (Payne 1985)

4.4 PUBLC INVOLVEMENT: Public hearings are not required in the licensing process, but Taipower has found it necessary to set up an extensive public education program, including a power generation exhibit, informational TV programs, etc. (Chung 1990); extensive public ignorance and negative perceptions were found regarding nuclear power and nuclear waste management activities; the 2,800 residents of Lan-Yu are reported totally opposed to the LLW storage facility (NN 1990; NW 1988)

4.5 WASTE FUND: Costs of radioactive waste disposal in Taiwan are borne by the generator, and disposal is under supervision of the AEC/Radwaste Administration; Taipower collects funds for waste management from the waste producers (INER, hospitals, etc.) (Wang 1990)

\subsection{KEY AGENCIES AND FUEL CYCLE CENTERS (Leigh 1990)}

A. The Atomic Energy Council (AEC) is the national nuclear power agency; the AEC oversees all non-military uses of atomic energy, subject to control of the government (Chung 1990)

B. The Radioactive Waste Administration (Radwaste Administration) is an AEC component and is the national radioactive waste management agency; the AEC established the Radwaste Administration to supervise, conduct, and regulate all issues relating to nuclear waste (Chung 1990)

C. The institute of Nuclear Energy Research (INER) at Lung-Tan is the national laboratory for nuclear energy R\&D (and also an AEC component); INER performs research on nuclear fuel development, safety analysis, and waste management studies

D. The Taiwan Electric Power Company (Taipower) is the only electric utility in Taiwan and is fully owned by the federal government; Taipower is responsible for construction and operation of nuclear power plants, carries out fuel cycle activities, and in 1990 is scheduled to take over management of the national Lan-Yu LLW waste repository from the Radwaste Administration (Tsai and Chou 1989)

\subsection{PRINCIPAL RESEARCH, DEVELOPMENT AND DEMONSTRATION FACILITIES/PROGRAMS}

A. INER is responsible for (INER 1986):

- undertaking nuclear safety-related research 
- developing advanced technology in LWR systems

- developing the capability for design, fabrication, examination and testing of LWR fuels

- developing radioactive waste treatment technology to best suit Taiwan's national environment

- exploration of nuclear raw materials and technical development for Taiwan's applications

- production of high quality radioisotopes and promotion of the application of radioisotopes and radiation in Taiwan

- undertaking advanced fundamental research related to nuclear energy

B. Examples of projects supported include probabilistic risk assessments, nuclear power plant safety analyses, seismic safety research, radiation shielding and protection, transportation, accident analyses, nuclear materials chemistry and performance, LWR fuel design, radwaste treatment and disposal, radioisotope production, chemistry, and applications

4.8 KEY PERSONNEL (Leigh and Mitchell 1990)

A. Yu Hao Lee, Secretary General, AEC

B. Yi-Ching Yang, Director, Radiation Protection Division, AEC

C. Chao-Ming Tsai, Director, Radwaste Administration, AEC

D. Sen-I Chang, Sung-Ling Ho, Deputy Directors, INER

E. Chia-Pao Tung, Head of Radioactive Waste Management Division, INER

F. Tise-Sheng Chou, Head of Radioactive Waste Management Technical Program, INER

G. S. M. Chang, President, Taipower

H. Eng Lin, Director of Nuclear Engineering, Taipower

\subsection{NUCLEAR FUEL PRODUCTION (NEI 1987)}

5.1 URANIUM RESOURCES: No domestic uranium resources have been identified

5.2 URANIUM ENRICHMENT: Taiwan has no enrichment capability, and is not developing a capability

5.3 FUEL FABRICATION: INER has an R\&D facility for fuel fabrication; Taipower has studied the feasibility of a domestic fuel fabrication plant

\subsection{FUEL RECYCLE (Payne 1985)}




\subsection{FUEL REPROCESSING}
A. Early attempts were made to secure toreign technology and equipment
B. Foreign reprocessing has been considered
C. Taiwan has no current plans for reprocessing (NF 1988)

\subsection{SPENT FUEL STORAGE AND TRANSPORT}

7.1 SPENT FUEL ARISINGS (Leigh and Mitchelf 1990)

1980-70 MTU cumulative
1985-430 MTU cumulative
1990-1140 MTU cumulative
$2000-2600$ MTU cumulative

\subsection{SPENT FUEL STRATEGIES}

Spent fuel/HLW storage options are currently being evaluated in a four-year study; the first part (repository requirements analysis) was completed in 1988 (Soong 1989); a second part to determine final disposition of spent fuel was begun in late 1988; long-term spent fuel management strategy is to be determined; Taiwan's policy is to complete a safety analysis and environmental impact assessment of an interim storage facility and begin facility use by the year 2000; however, Taiwan is evaluating the option to reprocess spent fuel in other countries (Leigh and Mitchell 1990); over 90\% of Taiwan's HLW comes from six Taipower nuclear plants, and expanded onsite storage capacity (from repacking) will be exhausted in 10-26 years (Wang 1990); Taiwan's spent fuel strategy is currently as follows:

A. Wet storage of spent fuel will be continued onsite for the foreseeable future, with reracking and consolidation to maximize use of storage volume (Wang 1990)

B. On a long-term basis, interim dry storage options have been considered, followed by final disposal if reprocessing is eventually found to be infeasible (Lee 1987)

7.3 WET STORAGE: The first four operating reactors, with high-density racks, had the capacity to store fuel until about 1989; pool capacity has been expanded by reracking to last until the year 2000 (Harmon 1984; Shapiro 1986; Lee 1987)

7.4 DRY STORAGE: At-reactor (AR) or away-from-reactor (AFR) dry storage of spent fuel is under investigation (Shapiro 1986; Lee 1987)

A. A decision on dry storage of spent fuel is to be deferred for as long as possible, to take advantage of foreign technology developments in the meantime (Lee 1987)

B. The management plan on spent fuel interim storage has been under development since 1987

7.5 TRANSPORT: Taiwan's six.reactors are all located close to the coast and have port access; water transport (ship) is preferred for inter-site movement but detailed evaluations have yet to be done; truck transport is also used 
7.6 RESEARCH AND DEVELOPMENT: All spent tuel R\&D is performed in Taiwan by INER in areas related to safety, risk assessment, and spent fuel storage; it is directly related to national needs (INER 1986)

7.7 PROGRAM/FACIUTIES COSTS: Taiwan's radwaste management guidelines (Tsai and Chou 1989) specify that all backend storage and disposal costs are to be borne by a levy on the producers (Lee 1987); Taipower produces $90 \%$ of the HLW and $95 \%$ of the $\amalg W$ in Taiwan (Wang 1990; Tsai and Chou 1989); in July 1986 Taipower started collecting 0.14 now Taiwan dollars (U.S. $\$ 0.004) / \mathrm{kWh}$ of nuclear electricity produced for future payment of all costs related to radioactive waste disposal including decommissioning costs (Lee 1987); the plan is for this unit cost to be adjusted yearly, and the total back-end cost estimate to be reviewed every five years by an ad-hoc committee from Taipower; all financing and expenditures related to nuclear power back-end management are to be fully accountable to the public

\subsection{WASTE CONDITIONING, STORAGE AND TRANSPORT}

8.1 WASTE DEFINITIONS: Waste categories are spent fuel (HLW), operating, and decommissioning wastes (ILW/LLW), and LLW (Lee 1987); currently all HLW are stored at reactor sites and are not transported; for ILW and LLW transportation purposes, surface dose rates on containers are used to define ILW as $<0.2 \mathrm{mrem} / \mathrm{hr}$, and LLW as $>5 \times 10^{-6}$ and $0.2 \mathrm{mrem} / \mathrm{hr}$, and low LLW as $<5 \times 10^{-3} \mathrm{mrem} / \mathrm{hr}$ (EPRI 1987)

\subsection{WASTE ARISINGS}

A. $\quad W W$ produced through 1985: 54,000 200-liter drums (Lu 1987)

B. LLW production rate through 1986: 13,000 200-liter drums/yr (Tsai et al. 1987)

8.3 STRATEGY: Taiwan's policy is to store spent fuel at the waste generator's site until long-term disposal or storage options can be identified and a final repository opened, sometime after the year 2000 (Wang 1990); utimately, deep geological disposal is considered the best option (Lu 1989)

8.4 HLW IMMOBILIZATION: Currently and for the foreseeable future all HLW (spent fuel) is stored onsite and is not subjected to reprocessing or other treatment (Wang 1990)

8.5 LLW/ILW WASTE CONDITIONING: (Lakey 1985; Liu 1987; NW 1985)

A. LLW wastes are conditioned at the generation site except for institutional wastes, which are treated at INER; only solid wastes immobilized in cement or asphalt in 220-liter steel drums are allowed for disposal (Tsai and Chou 1989)

B. Methods used for chemical treatment of LLW liquids include ionexchange, incineration, and incorporation in cement or bitumen matrices; following concern about the LLW waste volumes, Taiwan purchased an incineration plant for $\amalg W$ from nuclear power plants from NUKEM Gmbh, which was delivered to INER in January 1990; the plant has a throughput capacity of $100 \mathrm{~kg} / \mathrm{hr}$ (ATW News 1990) 
8.6 LLW/LW STORAGE: (RWA 1983, 1987; Payne 1985; Lakey 1985; Tsai et al. 1987)

A. The national retrievable waste storage facility is on Lan-Yu (Orchid) Island located $75 \mathrm{~km}$ southeast of the southern tip of Taiwan; the facility began operation in 1982 (Yang and Lo 1989); by November 1988, 58,452 drums of LW were stored at Lan Yu; a five-stage master plan exists for LLW storage facility development; stage one consists of 23 concrete-lined, capped trenches and associated facilities and is at or near its design capacity; an automatic drum inspection/handling system was completed in 1988

- Storage is in concrete-lined ( $35 \mathrm{~cm}$ thick) trenches, $3 \mathrm{~m}$ below-grade plus $1.5 \mathrm{~m}$ above-grade, $5.4 \mathrm{~m}$ wide, and about $90 \mathrm{~m}$ long

- Drums are stacked vertically, 3 high

- Filled trenches are covered with concrete slabs and sealed with asphalt

- Storage capacity is 100 years for all solid LLW arisings

8.7 TRANSPORT OF WASTES: In Taiwan, LLW is first transported by land on trucks that hold one cask (metal shipping container) with 48 drums; LLW is then transported to Lan-Yu storage site on Lan-Yu (Orchid) Island by a ship that holds 6 casks; one-way trip requires 24-26 hours for the $350-\mathrm{km}$ water trip and is subject to formal rules on weather conditions; the cask surface radiation levels for transportation are required to be $<200 \mathrm{mR} / \mathrm{hr}$, and $<10 \mathrm{mR} / \mathrm{hr}$ at $2 \mathrm{~m}$ distance (Liu 1987)

\subsection{DISPOSAL OF NON-HIGH LEVEL WASTES}

\subsection{LLW DISPOSAL}

A. The final disposal concept is to be determined by 1996 (Tsai and Chou 1989)

B. Ocean disposal of ILW/LLW is favored in Taiwan but has been postponed indefinitely because of the international decision to ban ocean disposal in 1983; three possible disposal sites within the 200-mile economic exclusion zone of Taiwan have been identified and are still under consideration if the international ban is lifted; the sites meet the following criteria (Tsai and Chou 1989):

- The site must be within 200 miles of shore

- It must have a vertical circulation cycle above the target area $>800$ years

- The bottom at the target area should be covered with soft, fine-grained sediment, with a high sedimentation rate

- The sea floor should be stable and free from active faults and turbidity currents

- The ocean bottom density should be less than the waste package bulk density of 1.4

- The sea floor depth must be $>5,000 \mathrm{~m}$, and be free of strong currents above the target areas 
- The site must be free from undersea cables and outside shipping routes

c. In the interim period, improved shailow-land burial in Lan-Yu Island is being investigated as a backup to ocean disposal

\subsection{DISPOSAL OF HIGH LEVEL WASTES}

Taiwan favors final disposal of wastes in the Penghu Islands in the Taiwan Strait (Tsai and Chou 1989; Chen 1990) or in deep borehole emplacement in southern Taiwan mudstone formation (Wang 1990); currently, all HLW and spent fuel is stored in ponds at reactor sites; Taiwan's policy is to begin operation of interim spent fuel monitored retrievable storage facilities in 1999 (Soong 1989)

10.1 SPECIFICATIONS AND CRITERIA (Soong 1989)

A. Deep geological disposal and multibarrier concepts will be adopted

B. Granite, shale, and mudstones are the only available host rocks

C. After a 60 -year interim storage, Taiwan will require a $1.4 \mathrm{~km}^{2}$ underground HLW repository area in shale rock, or $0.7 \mathrm{~km}^{2}$ in granite after $30 \mathrm{yr}$ interim storage

D. Long-range planning for the overall HLW disposal program was due to be completed in November 1990; geological screening studies for potential repository sites are being performed

\subsection{MANAGEMENT OF URANIUM MINE AND MILL WASTES}

There is no mining or milling of uranium in Taiwan (Payne 1985; NEI 1987)

\subsection{DECOMMISSIONING AND ENVIRONMENTAL RESTORATION (Lee 1987)}

\subsection{STRATEGY/POLICY}

A. Taiwan's nuclear power plants will be mothballed or salely stored for an undefined period of time after final shutdown, and then be dismantled to release the land for other possible uses (Lee 1987; NEI 1987)

B. It is expected that improved and advanced technologies for plant decontamination and dismantling will be available for plant decommissioning projects, which are expected to take place after the year 2010; Taiwan intends to study decommissioning and environmental restoration experience in other countries before defining its own policy

\subsection{INTERNATIONAL ACTIVITIES}

\subsection{COOPERATION WITH U.S. (NEI 1987)}

A. Agreements: The U.S. Coordination Council for North American Affairs Exchange Agreement with the American Institute in Taiwan (term expired 10/3/90); the scope of the agreement was for information exchange on spent fuel handling and waste management, health physics, severe nuclear accidents, technical safety support, and exchange of staff for agreed periods 
B. DOE has provided technical assistance to Taiwan under Section 223 of the Nuclear Waste Policy Act of 1982

C. EPRI has participated in technical exchanges on nuclear power plants and their safety

\subsection{REFERENCES}

$-1983-$

Racdwaste Administration (RWA). 1983. Radioactive Waste Management in Taiwan. Brochure by Radwaste Administration, Atomic Energy Council, Republic of China.

$-1984-$

Harmon, K M., and A. B. Johnson, Jr. 1984. Foreign Programs for the Storage of Spent Nuclear Power Plant Fuels, High-Level Waste Canisters and Transuranic Wastes. PNL-5089, Pacific Northwest Laboratory, Richland, Washington, p. 64.

$-1985-$

Lakey, L T., K. M. Harmon, and P. Colombo. 1985. Management of Low-Level Radioactive Wastes Around the World. PNL-5173, Pacific Northwest Laboratory, Richland, Washington.

Nucleonics Week (NW). 2/14/85. The Taiwan Power Company is Planning to Carry Out a Low-Level Radwaste Volume Reduction Project,' p. 12.

Payne, J. 1985. 'Taiwan Counting on Nuclear Energy." Nuclear News, September 1985, pp. 75-78.

$-1986-$

Institute of Nuclear Energy Research (INER). 2/86. "Institute of Nuclear Energy Research: Research and Development Program Plan.' INER 08-01, Institute of Nuclear Energy Research, Luag-Tan, Taiwan.

Shapiro, D. 1986. 'Taipower Plans to Store Spent Fuel in Casks until Sometime after 2050." Nuclear Fuel, February 10, 1986, p. 3.

$-1987$.

Atoms in Japan (AlJ). 4/87. "Role of Nuclear Energy Toward the 21st Century," pp. 12-13.

Electric Power Research Council (EPRI). 1987. "Onsite Storage of Low-Level Radioactive Waste at Power Reactors: An International Scoping Study.' EPRI NP-6163s, Electric Power Research Council, Palo Alto, California, pp. 4.7-4.8.

Lee, R. C. S. 1987. 'Taipower's Nuclear Backend Management." In Proceedings of the 1987 International Waste Management Conference, p.443-446. November 29-December 5, 1987, Hong Kong.

Liu, D. S., R. T. Lee, and C. M. Tsai. 1987. 'Transportation of Low-Level Radioactive Waste in Taiwan, Republic of China." Waste Management '87, Vol 3, p. 427. March 1-5, 1987, Tucson, Arizona. 
Nuclear Engineering International (NEI). 12/87. .'Datafile Taiwan," pp. 18-20.

Tsai, C. M., D. P. Chou, and C. S. Yeh. 1987. "Low-Level Radwaste Storage and Disposal in Taiwan, R.O.C.' In Proceedings of the 1987 International Waste Management Conference, pp. 427-430. November 29-December 5, 1987, Hong Kong.

$-1988-$

Nuclear Fuel (NF). 4/4/88. "U.S. Pleased Taiwan is Shutting Down Reactor Producing Good Quality Pu," p. 12.

NUKEM Market Report on the Nuclear Fuel Cycle (NUKEM). 3/88. NUKEM GmbH, Hanau, Federal Republic of Germany, p. 26.

$-1989$

Chang, F. D., C. T. Liou, M. F. Su, and S. C. Tsai. 1989. 'Derivation of Upper Bound Concentration of LLW for Land Disposal in Taiwan." In Proceedings of the 1989 Joint International Waste Management Conference, Vol. 2, p. 539-544. October 22-28, Kyoto, Japan,

Liu, S.J., and K. L Soong. 1989. 'Risk Assessment for the Final Disposal of Spent Fuel in Taiwan.' In Proceedings of the 1989 Joint International Waste Management Conference, Vol. 2, p. 581-588.

October 22-28, 1989, Kyoto, Japan.

NUKEM Market Report on the Nuclear Fuel Cycle (NUKEM). 12/89. NUKEM GmbH, Hanau, Federal Republic of Germany, p. 3.

Soong, K.-L, and S. J. Liu, 1989. "Current Status of Spent Fuel Disposal Program in Taiwan, Republic of China.' Waste Management '89; Proceedings of the Symposium on Waste Management, pp. 77 -

82. February 26-March 2, 1989, Tucson, Arizona.

Tsai, C. M., and D. P. Chou. 1989. 'Radwaste Management in Taiwan, China." In Proceedings of the 1989 Joint International Waste Management Conference, Vol. 1, pp. 133-135. October 22-28, 1989, Kyoto, Japan.

Yang, C. T., and L. F. Lo. 1989. 'The Automated Inspection and Handling System in Lan-Yu Radwaste Storage Site." In Proceedings of the 1989 Joint Imternational Waste Management Conference, Vol. 1, p. 389-392. October 22-28, 1989, Kyoto, Japan.

$-1990$

ATW News. March 1990. "NUKEM Delivered Incineration Plant for Nuclear Power Plant Waste," p.7.

Chen, D.-B., and Z. H. Chen. 1990. "Study of an Altemative for Repository of Radioactive Waste -

Taiwan Case." Proceedings of International Topical Meeting on High Level Radioactive Waste

Management, Vol. 2, p. 1214-1221. April 8-12, 1990, Las Vegas, Nevada.

Chung, C., and C. C. Hu. 1990. "Public Concern of Nuclear Waste Issues in Taiwan." In Proceedings of International Topical Meeting on High Level Radioactive Waste Management, Vol. 1, p. 251-255. April 8-12, 1990, Las Vegas, Nevada.

Leigh, I. W., and S. J. Mitchell. 1990. Intemational Nuclear Fuel Cycle Fact Book. PNL-3594, Rev. 10 , Pacific Northwest Laboratory, Richland, Washington. 
TAIWAN

Nuclear News (NN). January 1990. "1989 ANS Winter Meeting: Planning for the 90s -and Beyond," 33(1):90.

Nucleonics Week (NW). 4/14/88. Taiwan Could Change LLW Center if New National Site Can Be Found," 29(15):4.

Wang, J. H. C. 1990. "Management of High Level Wastes in the Republic of China." In Proceedings of International Topical Meeting on High Level Radioactive Waste Management, Vol. 1, p. 188-192. April 8-12, 1990, Las Vegas, Nevada.

Yeh. Y. S. 7/8/90. "Overview of Taiwan Power Company's Nuclear Program." Nuclear Europe Worldscan. 


\section{USSR}




\section{UNION OF SOVIET SOCIALIST REPUBLCS}

\section{CONTENTS}

1.0 NUCLEAR POWER $\ldots \ldots \ldots \ldots \ldots \ldots \ldots \ldots \ldots \ldots \ldots \ldots \ldots \ldots \ldots$ UR.2

2.0 NUCLEAR FUEL CYCLE AND RADIOACTIVE WASTE MANAGEMENT

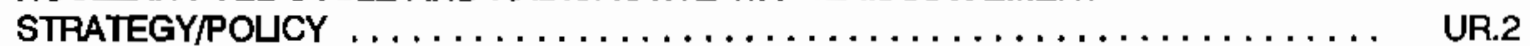

3.0 HIGHUGHTS AND MAJOR MILESTONES $\ldots \ldots \ldots \ldots \ldots \ldots \ldots \ldots \ldots \ldots$ UR.3

4.0 INSTITUTIONAL CONSIDERATIONSIORGANIZATIONS $\ldots \ldots \ldots \ldots \ldots \ldots \ldots \ldots$ UR.4

5.0 NUCLEAR FUEL PRODUCTION $\ldots \ldots \ldots \ldots \ldots \ldots \ldots \ldots \ldots \ldots \ldots \ldots \ldots \ldots$ UR.7

6.0 FUEL RECYCLE $\ldots \ldots \ldots \ldots \ldots \ldots \ldots \ldots \ldots \ldots \ldots \ldots \ldots \ldots \ldots \ldots \ldots \ldots \ldots$ UR.8

7.0 SPENT FUEL STORAGE AND TRANSPORT $\ldots \ldots \ldots \ldots \ldots \ldots \ldots \ldots \ldots \ldots$ UR.8

8.0 WASTE CONDITONING, STORAGE, AND TRANSPORT $\ldots \ldots \ldots \ldots \ldots \ldots \ldots$ UR.10

9.0 DISPOSAL OF NON-HIGH-LEVEL WASTES $\ldots \ldots \ldots \ldots \ldots \ldots \ldots \ldots \ldots \ldots \ldots$ UR.15

10.0 DISPOSAL OF HIGH-LEVEL WASTES $\ldots \ldots \ldots \ldots \ldots \ldots \ldots \ldots \ldots \ldots \ldots \ldots \ldots \ldots \ldots$

11.0 MANAGEMENT OF URANIUM MINE AND MIL WASTES $\ldots \ldots \ldots \ldots \ldots \ldots \ldots$ UR.18

12.0 DECOMMISSIONING AND ENVIRONMENTAL RESTORATON $\ldots \ldots \ldots \ldots \ldots \ldots$ UR.19

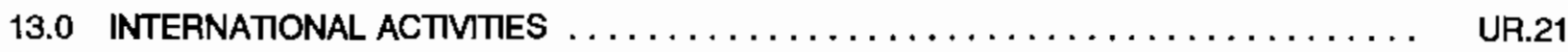

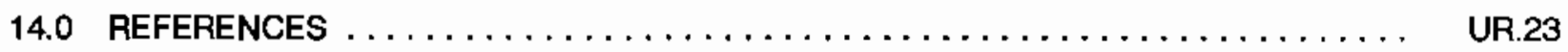




\subsection{NUCLEAR POWER}

\subsection{REACTOR MIX: 2 BWRS}

21 RBMKs (light-water cooled, graphite moderated)

25 WERs (PWRs)

2 FBRs (Bradley and Schneider 1990)

\subsection{ELECTRIC POWER PRODUCTION}

19841712 TWh (12.6\% nuclear) (Leigh and Mitchell 1990)

19891800 TWh (Bradley and Schneider 1990)

1991 (21\% nuclear) (Leigh and Mitchell 1990)

\subsection{NUCLEAR POWER CAPACITY PROJECTIONS}
1960
$0.6 \mathrm{GWe}$
1970
$1.5 \mathrm{GWe}$
1980
12.5 GWe
1985
$26.3 \mathrm{GWe}$
1988
1990
33.9 GWe (Leigh and Mitchell 1990)
1995
38.0 GWe
$68.0 \mathrm{GWe}$
2000
100.0 GWe (Bradley and Schneider 1990)

The increase in future Soviet nuclear power is predicated on the use of the WER-1000-type reactor

\subsection{NUCLEAR PLANT AVAILABILITY}

The nuclear plant availabilities for Soviet power reactors for 1989 and for the plant lifetime were (IAEA 1990):

\section{Plant Lifetime}

$\begin{array}{lll}\text { PWR, } \% & 74.1 & 65.5 \\ \text { LWGR, } \% & 76.8 & 73.6\end{array}$

\subsection{NUCLEAR FUEL CYCLE AND RADIOACTIVE WASTE MANAGEMENT STRATEGY/POLICY (Bradley and Schneider 1990)}

\subsection{OVERALL NUCLEAR FUEL CYCLE POLICY}

The overall policy in the Soviet Union is to provide and maintain all capabilities for the nuclear fuel cycle, provide fuel, reactors, and take back spent nuclear fuel from reactors supplied to the CMEA (Council for Mutual Economic Assistance) countries; the USSA is an aggressive marketer of uranium enrichment services 


\subsection{POLICY ON THE FRONT END OF THE NUCLEAR FUEL CYCLE}

Extensive uranium mining operations are found in the CMEA countries and in the Soviet Union, with processing centers in the Soviet Union; the USSR maintains a high capacity for uranium enrichment and aggressively markets enrichment services to other countries

\subsection{POUCY ON THE BACK END OF THE NUCLEAR FUEL CYCLE}

A. The Soviet's policy on spent fuel is to store it for 3-5 years, then to reprocess and recycle the fuel materials; plans to reprocess RBMK fuel have been postponed indefinitely; spent fuel is stored in water basins at the reactor and then transferred to independent spent fuel storage installations located at major nuclear power stations

B. Low- and intermediate-level liquid wastes in the Soviet Union are volume-reduced, then incorporated into bitumen or cement and disposed of by shallow-land burial at reactor sites; some solid wastes in these calegories are incinerated, others are placed in shallow-land burial at reactor sites; non-reactor wastes are taken to central treatment/storage/disposal (shallow land) facilities

C. Soviet high-level wastes are to be vitrified, stored in canisters for $30-50$ years, then placed in a deep geologic repository; R\&D on repositories is ongoing, and a candidate site may be named in the early 1990 s

D. Intermediate-level wastes in the Soviet Union may be vitrified in the future or possibly combined with high-level wastes and placed in a deep geologic repository

\subsection{HIGHLIGHTS AND MAJOR MILESTONES (Bradley and Schneider 1990)}

1949 The reprocessing facility at Kyshtym was commissioned

1949 The first gaseous-diffusion plant for enrichment became operational

1950s The research on solidification and vitrification techniques for HLW were initiated

1952 The first pilot-scale gas centrifuge was buitt for enrichment of uranium

1955 Construction was started on the BR-1 experimental fast-fuel reactor at Obninsk

1957 Explosion of a high-level waste storage tank occurred at Kyshtym

1959 The first industrial gas centrifuge became operational for uranium enrichment

1959 The world's first nuclear-powered icebreaker, Lenin, was commissioned

1964 Operation of the first WVER (PWR) reactor, the 210-MWe Unit 1 at Novovoronezh, began

1969 Construction was started on the BOR-60 fast test reactor at Dimitrovgrad

1971 Operation of the first WVER-440 MWe reactor, Unit 3 at Novovoronezh, began 
1973 The first operation of nuclear reactors for district heating began at Bilibino, north of the Arctic Circle

1973 Operation of the first industrial fast reactor, BN-350 (350 MWe), began at Shevchenko

1973 Operation of the first RBMK reactor, the $1000 \mathrm{MWe}$ Unit 1 at Leningrad, began

1974 Operation of non-radioactive HLW vitrification pilot plant(s) was initiated

1978 Operation of reprocessing plant was initiated at Kyshtym for commercial VVER-440 reactor fuel

1980 The BN-600 (600 MWe) fast reactor at Beloyarsk was commissioned

1981 The first WER-1000 MWe reactor, Unit 5 at Novovoronezh, was commissioned

1986 Reactor accident occurred at Chernobyl's Unit 4 RBMK-1000 reactor (NN 10/86)

1986 The first commercial bituminization facility for reactor low- and intermediate-level wastes became operational at the Leningrad site

1987-1988 A fully radioactive waste vitrification facility at Kyshtym became operational, then was shut down in 1988

1989 Construction of a large (1500 MTU/yr) reprocessing plant near Krasnoyarsk was postponed indefinitely

1990 A candidate site for deep geologic storage of HLW may be selected

1991 A modified, fully radioactive waste vitrification facility is to become operational

\subsection{INSTITUTIONAL CONSIDERATIONS/ORGANIZATIONS}

\subsection{KEY AGENCIES AND FUEL CYCLE CENTERS}

A. The Ministry of Atomic Power and Industry (Minatomenergoprom or MAPI, the combination of the Ministry of Medium Machine Building and the Ministry of Nuclear Power) is responsible for the civilian and defense nuclear fuel cycle, reprocessing, and waste-management operations

B. The State Committee for the Utilization of Atomic Energy (GKAE) had overall responsibility for nuclear development until April 1990, when it was superseded by the Ministry of Atomic Power and Industry

C. The State Committee for the Supervision of Safe Working Practices in Industry and the Nuclear Power industry (GOSPROMATOMNADZOR) is the Soviet Union's nuclear regulatory and safety monitoring body 
D. The State Committee for Ervironmental Protection (formerly the State Committee for Sanitary Inspection) is responsible for ensuring environmental protection throughout the USSR; it outlines policies for state programs in ecology and environmental protection; it develops regulations and requirements; it inspects all industries that cause pollution; it issues permits for waste disposal; and it helps develop waste-free industries

E. The Ecology Committee of the USSR Council of Ministers is the primary legislative/regulatory body responsible for environmental issues (Lesperance 1990)

F. The State Atomic Inspection Committee was set up in 1986 following the Chernobyl accident; it incorporates the former State Sanitary Inspectorate of the Ministry of Health; the committee monitors and develops documents on standards for radiation safety and nuclear power-plarit-operation (Parker 1990)

\subsection{PRINCIPAL RESEARCH, DEVELOPMENT AND DEMONSTRATION FACILITIES/PROGRAMS}

A. The Institute of Physical Chemistry is part of the USSR Academy of Sciences and is located in Moscow; athough it focuses on corrosion and electrochemistry, it is also involved in waste management R\&D; activities include studies of radionuclide migration and sorption in soils and the chemistry of technetium

B. The Institute of Development of Atomic Energetics is located in Moscow and is a part of the USSR Academy of Sciences; this institute provides technical assistance to the newly established nuckear regulatory organization

C. The All Union Scientific Research Institute for Inorganic Materials in Moscow is responsible for the management and permanent disposal of HLW and for setting standards for disposal; the following are specific areas of activities related to nuclear technology (Parker 1990):

1. Management of HLW trom power plants and military installations

2. Cleanup processes for liquid LIW from nuclear plants and from other research institutes

3. Metallurgical processing technology for metals used in reactors, particularly zirconium, titanium, and beryllium

D. The Chemical Plant Research Institute in Sverdlovsk carries out R\&D on HLW vitrification

E. The Scientific Research Institute of Atomic Reactors at Dimitrovgrad carries out R\&D on nuclear reactors and on low- and intermediate-level waste disposal

F. The I. V. Kurchatov Institute of Atomic Energy in Moscow is the primary nuclear power research institute; it carries out R\&D on low- and intermediate-level wastes; it is responsible for work at Chemobyl No. 4

G. The V. G. Khlopin Radium Institute, located in Leningrad, does R\&D on radioactive wastes and geologic disposal; specific activities include (Falci 1990):

1. R\&D on reprocessing reactor fuels 
2. Partitioning of HLW streams into cesium, strontium, and transplutonium elements

3. Development of technologies for trapping iodine, tritium, gases containing carbon14 , and other gases from radiochemical plants

4. Separation of organics from radioactive waste

5. Production of radiation sources using cesiurn (in phosphate glass) and strontium (in borosilicate glass) (Parker 1990)

$\mathrm{H}$. The Research and Development institute of Power Engineering in Moscow conducts R\&D on improvements in power reactors

I. The Science and Technology Center (location not specified) provides technical support to the Soviet regulatory agency (NEI 3/89)

J. The Zniitmash Materials Development Laboratory (location not specified) is involved in nuclear component manufacturing (Rippon 1984)

K. The Radon facility was established in 1964 and is located near Zagorsk (about $100 \mathrm{~km}$ east of Moscow); it is one of 34 (or 35) such facilities that store solids and solidified liquid wastes in shallow-land burial; the facility also conducts feasibility and demonstration studies on the vitrification of low- and intermediate-ievel radioactive wastes (Parker 1990)

L. The Leonid Bolshov Nuclear Safety Institute was established in Moscow following the Chernobyl accident to provide an independent assessment of problems related to nuclear-power generation; activities include radiological field measurements, nuclear fuel cycle R\&D, training of power-plant operators, modeling of severe accidents, health effects, ecology, and global impacts (Parker 1990)

4.3 KEY PERSONNEL (Bradley and Schneider 1990)

A. Vitaly Fedorovich Konovalov, Minister, Atomic Power and Industry (MAPI) (NW 4/19/90)

B. Viktor Sidorenko, First Deputy Minister, MAPI, responsible for nuclear power (NW 4/19/90)

C. Boris V. Nikipelov, First Deputy Minister, MAPI, responsible for the nuclear fuel cycle (NW $4 / 19 / 90)$

D. Yevgeniy Y. Mikerin, Head, Nuclear Fuel Cycle Department, MAPI

E. Nikolaye N. Egorov, Deputy Head, Nuclear Fuel Cycle Department, MAPI

F. Sergee N. Babayev, Head, Department of Science and Technology, MAPI

G. Leonido O. Kedrovskiy, Director, Scientific Research and Design, Institute of Industrial Technology (IT)

H. Yurye 1. Shitsits, Head, Division of Scientific Research and Design, IIT

I. Alexander S. Nikiforov, Director, All Union Scientific Research Institute for Inorganic Materials, Moscow 
J. Yuriy M. Polukarov, Director, Institute of Physical Chemistry

K Alexander I. Karelin, Director, Khlopin Radium Institute

L. L. N. Lazarev, Chief Scientist, Khlopin Radium Institute

M. Konstantino K. Dashutin, Scientific Industrial Center "Pripyat"

N. E. P. Velikhov, President, USSR Nuclear Society

o. Vadim Malyshev, Chairman of the State Committee for the Supervision of Safe Working Practices in Industry and the Nuclear Power Industry

P. Yuri K. Semenov, Minister, Power and Electrification

Q. Lev Ryabev, Deputy Chairman, USSR Council of Ministers

\subsection{NUCLEAR FUEL PRODUCTION}

\subsection{STRATEGY}

The Soviets intend to maintain facilities for the complete nuclear fuel cycle, as well as supplying fuel, reactors, and enrichment services through various marketing organizations; the USSR markets uranium processing and conversion and fuel-fabrication services, and takes back all spent fuel from Soviet-supplied reactors to other countries

\subsection{URANIUM RESOURCES}

Significant mining operations are carried out in the Soviet Union and in CMEA countries (Economist 5/10/86); uranium resources in the Soviet Union are extensive; the Soviets also have extensive mining operations in several of the eastem European countries

\subsection{URANIUM PRODUCTION}

In the Soviet Union, the estimated production of uranium (as $\mathrm{U}_{3} \mathrm{O}_{2}$ ) in 1980 was about $2500 \mathrm{MT}$ (Bradley and Schneider 1990); in 1986, the uranium stockpile was reported to be as large as 200,000 MT (Economist 5/10/86)

\subsection{URANIUM ENRICHMENT}

A. The Soviet's first enrichment facility using gaseous diffusion started operation in 1949; five gaseous diffusion plants were mentioned and one may still be operating as of 1989; a series of modular gas-centrifuge plants (about $1 \mathrm{MSWU} / \mathrm{yr}$ per plant), believed to be located at three or more sites, have an estimated combined capacity of $10 \mathrm{MSWU} / \mathrm{yr}$ (NF 10/2/89)

B. The current annual Soviet enrichment sales to other countries are about 2 MSWU (EIA 1989); the Soviets may have 5-6 MSWU for sale to western countries due to delays in their reactor programs and slowdown in their defense programs (NF 6/89) 


\subsection{FUEL RECYCLE}

\subsection{FUEL REPROCESSING}

A. The Soviet policy on fuel reprocessing has been to recover and recycle uranium and plutonium (NE 1-2/88); however, reprocessing of RBMK fuel has not yet been started, and no decision has been made on its utimate disposition (Bradley and Schneider 1990)

B. Reprocessing of defense reactor fuel began in 1949 at the Kyshtym site with a process involving sodium uranyl acetate precipitation from nitric acid solution; the current method uses the PUREX process (Drozhko 1989)

C. Reprocessing of commercial reactor fuel is reported to have started in 1978 at Kyshtym on WER-440 and on naval reactor fuel; over the plant's 10 years of reprocessing, about 2000 MTU of civilian reactor fuel were processed (Briadley and Schneider 1990)

D. A large reprocessing facility near Krosnoyarsk was 30\% complete by July 1989; construction of this plant was indefinitely postponed in the summer of 1989 (NF 10/16/89); this facility was to have been built in increments with a capacity of $1500 \mathrm{MTU} / \mathrm{yr}$ each (NE 1-2/88)

\subsection{PLUTONIUM RECYCLE}

A. A slowdown in the Soviet's fast-reactor program and reprocessing has delayed major plutonium recycle (Bradley and Schneider 1990)

B. Manutacture of mixed-oxide (MOX) fuel for recycle of plutonium has now been deferred at least until early in the next century (NF 10/16/89)

C. About $20 \mathrm{MT}$ of plutonium are reported to have been recovered since 1978 from WER reactor fuel in the reprocessing facility at Kyshtym (NF 10/16/89)

\subsection{RESEARCH AND DEVELOPMENT}

R\&D on dry reprocessing has been carried out at Dimitrovgrad; a mini pilot plant called

Fregate 1 was operational; a larger unit, Fregate 2, was uncler construction as of 1984 (NF 6/84)

\subsection{SPENT FUEL STORAGE AND TRANSPORT}

\subsection{SPENT FUEL ARISINGS}

As of 1990 in the Soviet Union, about 11,000 MT of spent fuel will have been discharged from all WER (including those in other CMEA countries) and RBMK reactors; an estimated 30,000 MT of spent fuel will be discharged by the year 2000 (Bradley and Schneider 1990)

\subsection{SPENT FUEL STRATEGIES (Bradley and Schneider 1990)}

A. The Soviet policy calls for storage of spent fuels for 3-5 years prior to reprocessing; however, due to delays in reactor construction and reprocessing, the trend is for storage of more spent fuel and for longer storage times (10 years or more); RBMK fuel is being stored until a decision is made on its disposition 
B. The Soviet Union has always taken back spent fuel from Soviet reactors in other countries, but it is requiring longer storage times than originally planned; fuel is stored in at-reactor pools (possibly up to 10 years) and then transferred to long-term central storage facilities at multiple-reactor sites (for $25-50$ years)

C. Recent decisions by the president of the Russian Soviet Federated Socialist Republic (SFSR) may have a major impact on spent fuel from some CMEA countries; it was announced in June 1990 that "foreign wastes would no longer be welcome in Russia" after January 1, 1991; this is expected to cause severe problems for Bulgaria, Czechoslovakia, Hungary, and the former German Democratic Republic (NW 7/12/90)

D. In 1990 the Soviet Union substantially raised the price charged for return of CMEA-country spent fuel; effective July 1,1990 , the Soviets cancelled existing spent fuel arrangements and required payment in western currency at the rate of $\$ 1,200-\$ 1,300$ per kilogram of uranium for spent fuel returned to the Soviet Union; Czechoslovakia is now considering construction of a final repository for disposal of spent fuel in their country (NF 7/9/90)

\subsection{WET STORAGE (Bradley and Schneider 1990)}

\section{A. At-Reactor Storage in the Soviet Union}

1. Spent fuel is stored in at-reactor pools for all types of reactors; in the case of the WER-440 reactors, storage times are reported as 8 years; the standard at-reactor storage capacity for WER-440 reactors is $84 \mathrm{MT}$, which represents a 3-year capacity with a reserve space allowed for one full reactor core; spent fuel from WER reactors is discharged when the reactor is shut down

2. Spent fuel is discharged from RBMK reactors while on-line; it is stored in pools having a volume of $700 \mathrm{~m}^{3}$

3. Spent fuel is discharged from fast reactors during periods of routine maintenance; it is stored in sodium for about $\mathbf{1 8 0}$ days, stored in sodium-filled drums for an additional 90 days; it is then washed, placed in cans, and transferred to longerterm storage

B. Independent Spent Fuel Storage Installations (ISFSI) in the Soviet Union

1. Large central spent fuel storage basins have been buit at multiple-reactor sites for long-term wet storage of spent fuel

2. The ISFSIs built to date for WER reactors are nearly identical and have a capacity of $600 \mathrm{MT}$, while those for RBMK reactors have a capacity of $1800 \mathrm{MT}$; ISFSIs have a design life of 25-30 years, and are built using layers of carbon and stainless steel (Bradley and Schneider 1990)

3. The ISFSIs in the Soviet Union are at the following nuclear power stations: at Novovoronezh, 600 MT capacity, started operation in 1986; at Leningrad, 1800 MT capacity, started operation in 1986; at Chernobyl, 1800 MT capacity, under construction in 1986; and at Kursk, 1800 MT capacity, under construction in 1986 


\subsection{DAY STORAGE}

Tests on dry storage of spent fuel in a Castor V cask, designed for storing 12 WER-1000 fuel assemblies, were started in 1984; a GNS $V$ transportation and storage cask was purchased in 1989 (Bradley and Schneider 1990)

\subsection{TRANSPORT (Bradley and Schneider 1990)}

A. The primary method of spent fuel transportation in the Soviet Union is by railroad car; however, in some cases, such as for Kozloduy, Bulgaria, barge or truck transport may be used

B. Transport of spent fuel is carried out under regulations consistent with those of the IAEA

C. WER-440 fuel is transported vertically, while WER-1000 and RBMK fuel is transported horizontally

D. Spent fuel is shipped dry, using a nitrogen gas coolant; if the fuel exposure is greater than 24,000 MWd/MT, neutron shielding is used; shielding may be a water jacket and/or the cask may be filled with water; characteristics of some USSR transportation casks are:

1. For WER-440 fuel, TK-6 cask type weighing 90 MT; capacity is 30 assemblies or 3.8 MT

2. For WER-1000 fuel, TK-10 cask type weighing $103 \mathrm{MT}$; capacity is 6 assemblies or $2.9 \mathrm{MT}$

3. For RBMK-1000 fuel, TK-11 cask type, weighing 86.5 MT; capacity is 102 half-assemblies or $5 \mathrm{MT}$

E. Transportation of BN-600 reactor spent fuel assemblies is by the Soviet TK- $\uparrow 1$ railroad container car; it is designed for maximum permissible fuel burnup with a 3-year cooling (Ogordov 1987)

F. Cask decontamination methods that have been developed include chemical and electrochemical techniques and strippable polymeric coatings

\subsection{WASTE CONDITIONING, STORAGE, AND TRANSPORT}

\subsection{WASTE DEFINITIONS}

A. Classifications of liquid radioactive wastes in the USSR are (Sedov 1983):

1. Low-level wastes, less than $1 \times 10^{-5} \mathrm{Ci} / \mathrm{L}$

2. Intermediate-level wastes, from $1 \times 10^{-5}$ to $1 \mathrm{Ci} / \mathrm{L}$

3. High-level wastes, greater than $1 \mathrm{Ci} / \mathrm{L}$

B. Classifications of solid radioactive wastes in the USSA (excluding solidified high-level wastes) are (Sedov 1983): 


\begin{tabular}{|c|c|c|c|}
\hline Category & $\begin{array}{l}\text { Gamma Dose Rate } \\
10 \mathrm{~cm} \text { from Surface } \\
\text { of Waste, mrem/h/ }\end{array}$ & $\begin{array}{c}\text { Specific } \\
\text { Beta Activity, Ci/kg }\end{array}$ & $\begin{array}{c}\text { Specific } \\
\text { Alpha Activity, } \mathrm{Ci} / \mathrm{kg}\end{array}$ \\
\hline $\begin{array}{l}\text { Group I } \\
\text { Group II } \\
\text { Group III }\end{array}$ & $\begin{array}{l}\text { Less than } 30 \\
\text { From } 30 \text { to } 1000 \\
\text { Greater than } 1000\end{array}$ & $\begin{array}{l}\text { From } 2 \times 10^{-6} \text { to } 1 \times 10^{-4} \\
\text { From } 1 \times 10^{-4} \text { to } 1 \times 10^{-1} \\
\text { Greater than } 1 \times 10^{-1}\end{array}$ & $\begin{array}{l}\text { From } 2 \times 10^{-7} \text { to } 1 \times 10^{-5} \\
\text { From } 1 \times 10^{-5} \text { to } 1 \times 10^{-2} \\
\text { Greater than } 1 \times 10^{-2}\end{array}$ \\
\hline
\end{tabular}

\section{B.2 WASTE ARISINGS}

A. Wastes from Soviet reactor operations (Bradley and Schneider 1990):

1. The WER-1000 reactors produce between 10,000 and $15,000 \mathrm{~m}^{3}$ of liquid radioactive wastes (LLW and ILW) per year, which results in about 50 MT of salts after treatment

2. The RBMK-1000 reactors produce about $10,000 \mathrm{~m}^{3}$ of liquid radioactive wastes per year, which results in about $100 \mathrm{MT}$ of salts after treatment

3. The cumulative waste volume produced through 1989 is estimated to be 3.4 million $\mathrm{m}^{3}$ of liquid LLW and ILW; this would yield about 13,700 MT of salts after treatment

B. Reprocessing wastes: the quantities of wastes generated by reprocessing $1 \mathrm{MT}$ of spent fuel are: 0.7 to $1.0 \mathrm{~m}^{3}$ high-level liquids; 3 to $5 \mathrm{~m}^{3}$ intermediate-level liquids; and 50 to $100 \mathrm{~m}^{3}$ low-level liquids (GKAE 1978)

\subsection{STRATEGY (Sedov 1983, 1988)}

The general Soviet plan for handling all levels of liquid radioactive wastes consists of the following six steps: 1) collection and primary concentration; 2) temporary storage of concentrates in stainless-steel tanks; 3) solidification of the concentrates formed during the processing of low-, intermediate- and high-level wastes; 4) temporary storage of solidified wastes in above-ground storage facilities; 5) transport of solidified wastes to centralized or regional storage sites in special containers; 6) and final disposal at centralized or regional disposal sites

\subsection{HLW IMMOBILIZATION}

A. In the Soviet Union, liquid wastes are stored in stainless-steel tanks for 3-5 years, then vitritied into a final volume of 100-150 LMMU; three canisters, each containing $200 \mathrm{~L}$ of glass, are placed in a larger container and kept in air storage for 30-50 years (Bradley and Schneider 1990)

B. Several pilot-scale vitrification plants using non-radioactive simulated wastes and/or using radioactive wastes as feed materials have operated, including one capable of processing $100 \mathrm{~L} / \mathrm{h}$ of glass that had operated for 10 years as of 1987 (Bradley and Schneider 1990)

C. A fuly radioactive single-stage solidification process using a ceramic melter operated at Kyshtym from 1987 to 1988 and produced about $160 \mathrm{MT}$ of phosphate glass containing $3.9 \times 10^{6} \mathrm{Ci}$ (Bradley and Schneider); after 13 months of producing HLW phosphate glass, the furnace was decommissioned because of "loss of tightness" (corrosion) of the 
system used to cool the leads to the melter electrodes; in 1989 the design of a new two-stage melter system was completed; it is expected to be operational at the beginning of 1991 (see also Section 8.10) (Falci 1990)

\subsection{SPENT FUEL CONDITIONING}

Soviet policy calls for a closed fuel cycle; RBMK spent fuel is being stored indefinitely, pending a decision on its ultimate disposition; VVER spent fuel is interim stored and then reprocessed

8.6 LLW/ILW CONDITIONING (Bradley and Schneider 1990)

A. LLW/ILW waste streams are treated to reduce volume by evaporation, ion exchange, compaction, and incineration

B. Some metallic wastes are decontaminated then reused

C. Conditioned liquid wastes from reactors and ashes from incinerated wastes are incorporated into bitumen or cement and are placed in containers for disposal

1. In the past, the Soviets preferred bitumenization to cementation because of the low water resistance and waste content of their cement-based waste forms; however, recent work has improved the leach resistance, ductility, and strength of cement materials (Nikipelov 1990a)

2. Liquid LLW from reactor operations at Novovoronezh is evaporated to a concentration of 900 to 950 grams of solids per liter (a volume reduction of 20) and mixed with bitumen (Parker 1990)

3. Two types of bitumenization plants are used; for RBMK-1000 reactors the plant has a capacity of $500 \mathrm{~L} / \mathrm{h}$; for VVER-1000 reastors the plant capacity is $200 \mathrm{~L} / \mathrm{h}$

4. The first bitumenization facility started operation in 1984 at the Leningrad reactor station; a second plant began operation in 1987 at Ignalina (Nikipelov 1990a)

D. Feasibility and demonstration studies on the vitrification of intermediate-level wastes have been conducted at the Radon facility near Moscow (Parker 1990)

E. Transuranic wastes and other wastes streams, such as those containing cesium and strontium, may be vitrified and incorporated into ceramics or metal-matrix waste forms (Bradley and Schneider 1990)

F. New regulations do not permit the co-location of organic-containing wastes with radioactive wastes

\subsection{AIRBORNE WASTES TREATMENT AND IMMOBILIZATION}

The removal of various radioactive gases from reprocessing and vitrification operations (particularly iodine, krypton, tritium, and carbon-14) has been studied for a variety of methods; these include chemical methods such as scrubbing by mercuric nitrate, liquid silicones and caustic (to remove jodine), and cryogenic distillation for removal of krypton (Nikiforov 1981); the extent to which these treatment methods are being used is not known 


\subsection{LLW/ILW STORAGE}

The Radon facility is one of 34 (or 35) regional $\amalg W$ and ILW shallow-land storage and disposal facilities; some wastes are disposed of and some are stored in canisters in above-ground vaults inside a storage building; a storage life of 500 years is planned (also see Section 4.2) (Parker 1990)

\subsection{HLW STORAGE}

High-level liquid wastes are concentrated and stored at the reprocessing site in stainless-steel tanks equipped with cooling coils, air purges for hydrogen gas removal, and outlets for emergency waste discharge; storage tank capacities are from several hundred to $1200 \mathrm{~m}^{3}$ each and are located in groups that hold a total of about $7500 \mathrm{~m}^{3}$ of wastes; the tanks are located a minimum of $4 \mathrm{~m}$ above the groundwater level, operate at $50-60^{\circ} \mathrm{C}$, and have an expected lifetime of 20-25 years (Nikiforov 1988, 1989)

\subsection{RESEARCH AND DEVELOPMENT}

A. Solidification research on high-level wastes started in the 1950s; phosphate and borosilicate glasses, "vitromet" and metal matrix, and ceramics (including "synthetic minerals") were or are being studied (Bradley and Schneider 1990)

B. Calcination procasses such as fluidized bed, spray calciners, and rotary evaporators have been studied; induction-heated batch and continuous ceramic melters have also been studied; HLW glasses have been produced in a single-stage ceramic melter; crystalline HLW forms have been produced using a calciner and an induction-heated melter (Kedrovskiy 1987; Nikiforov 1988)

c. Significant R\&D on partitioning of HLW streams into various fractions has been conducted (Parker 1990)

1. A pilot plant has separated about $300,000 \mathrm{Ci}$ each of cesium and strontium (Aloy 1989)

2. Research is being conducted on separation or partitioning of element fractions from $\mathrm{HLW}$ W using cobalt dicarboly anion in strong $\mathrm{HNO}_{3}$; this reagent is especially effective for large ions; the process separates strontium, cesium, rare earths, and transuranic elements with elficiencies up to $99 \%$

3. The waste products are vitrified into glass blocks or glass-metal composites

D. The use of transmutation for treatment of certain radioactive element fractions is also being studied (Parker 1990)

1. After separation into fractions containing actinides, fission products, and/or isotopes of long half-life, the fractions would be fabricated into targets and irradiated in a high flux of thermal neutrons, protons, or lasers

2. In the case of neutron irradiation, a mixture of lithium and waste (approximate composition of: $35 \% \mathrm{~Np}-237,27 \% \mathrm{Am}-243$, and $44 \% \mathrm{Cm}$ ) would be irradiated in a heavy water reactor 


\section{Approximately 500 to $1000 \mathrm{~kg}$ of actinides would be transmuted}

E. The removal of various radioactive gases from reprocessing and vitrification operations (particularty iodine, krypton, tritium, and carbon-14) has been studied using a variety of methods; these include chemical methods such as scrubbing with mercuric nitrate, liquid silicones, and caustic (to remove iodine), and cryogenic distillation for removal of krypton (Nikiforov 1981)

F. A two-stage vitrification process is being developed (Nikiforov 1990)

1. The process is based on a method to dry the liquid waste and then melt the waste in a second stage using a high-frequency induction melter

2. A "cold-wall" or cold-crucible" design helps to contain the mett and decrease corrosion of the melter materials

3. The design capacity is $100 \mathrm{~L} / \mathrm{h}$ of feed solution and $25-35 \mathrm{~kg} / \mathrm{h}$ of solidified product

G. Pilot processes, including both ceramic and induction melters were initiated at the Radon facility in mid-1989 for vitrification of ILW; production rates were $100 \mathrm{~kg} / \mathrm{h}$ of glass with a liquid-waste feed rate of $300 \mathrm{~L} / \mathrm{h}$; a plasma-jet fuel burner based on an electric-arc plasmatron was also identified as a promising method (Parker 1990)

H. Relatively high temperatures $\left(1500^{\circ} \mathrm{C}\right)$ are used duririg LLW/LW processing to obtain highly stable mineral slag; high temperatures also make it possible to incinerate unsorted wastes and wastes with up to $30 \%$ metal and $10 \%$ concrete (Parker 1990)

I. The Soviets are studying specialized waste forms for the immobilization of iodine-129, carbon-14, and tritium wastes (Kalinin 1988)

1. For iodine-129, the waste forms studied are: cement and bituminous compounds, glasses, epoxides, and dense polycrystalline and "chemically modified" materials based on slightly soluble iodates; it appears that $\mathrm{Pbl}_{2}$ or $\mathrm{Cul}$ waste forms are preferred, since they have prepared a flow diagram for producing these waste forms for storage and burial

2. For carbon-14, slightly soluble carbonates forrned in a 'double alkaline process' seem to be the most convenient final waste form, but for storage or "burial conditions" cement may be the preferred form; compounds of Portland cement and calcium, strontium, and barium carbonates have been studied

3. The solidification of aqueous tritium wastes has been studied; a dry powder of tritiated calcium hydroxide is produced by treating the waste with calcium oxide; this is incorporated into bitumen or other binders such as epoxide resin, paraffin, ceresin, and polystyrene; the epoxide resin waste is reported to have the lowest tritium leach rate, but other matrix materials are being sought

\subsection{PROGRAM/FACILITIES COSTS}

The Soviets have stated the costs of solidification of HLLW to be $40-60 \%$ of the cost of treatment, solidification, and subsequent interim storage of $\mathrm{HLW}$; the capital costs for these three 
stages (excluding geologic disposal) amounts to $2-3 \%$ of the total capital costs of the entire nuclear fuel cycle (Nikiforov 1988)

\subsection{DISPOSAL OF NON-HIGH-LEVEL WASTES}

\subsection{STRATEGY}

A. The current Soviet policy calls for disposal of low- and intermediate-level wastes by shallow burial at reactor sites; the shallow burial sites are concrete-lined trenches with concrete covers (Bradley and Schneider 1990)

\subsection{LLW/ILW DISPOSAL}

A. In the past in the Soviet Union, large quantities of low- and intermediate-level liquid wastes were disposed of by well-injection; some gaseous wastes were also disposed of by well injection (Bradley and Schneider 1990); recently it was stated that this practice is not acceptable for safety reasons and would most likely be discontinued (Nikipelov 1990c)

B. In addition to the above waste disposal practices for wastes from reactor operations, 34 (or 35) regional stations are available for disposal of research, medical, and industrial radioactive wastes, including sealed sources; although few details are known, the wastes are placed in underground chambers isolated by metal and concrete, as well as by earth and/or clay barriers; the Radon Decontamination Station near Moscow and one near Riga, Latvia, are examples of these regional facilities (Bradley and Schneider 1990)

C. For wastes comtaining short half-life radionuclides, engineered barriers function as the main isolation barrier

\subsection{DISPOSAL OF HIGH-LEVEL WASTES}

\subsection{SPECIFICATIONS AND CRITERIA}

A. The Soviet considerations for geologic disposal of HLW are (Kedrovskiy 1990):

1. Geological and geohydrological conditions are the main isolation barriers for HLW

2. The waste form (whose mechanical, physical and chemical properties can be changed by treatment processes) constitutes the second most important barrier

3. Engineered barriers provide additional isolation, mainly in the pre-closure period

\subsection{REPOSITORY DEPLOYMENT STRATEGY}

A. The Soviet policy is that high-level wastes will be disposed of in deep geologic repositories; some intermediate-level wastes may also be disposed of with the high-level wastes; space disposal is also being investigated for selected elements such as iodinet29 (NW 10/5/89) 
B. There is no set schedule for operation of a high-level waste repository; candidate sites are being sought; one candidate site is in Chelyabinsk (Kyshtym site); a decision may be made on the first site in 1990 (NW 10/5/89)

c. There is no nationally organized program that integrates repository design, geoscience, waste-package research, and performance assessments

D. It was announced in June 1990 that the Russian SFSR would not allow the construction of new nuclear facilities on its territory after January 1, 1991, pending adoption of a program for dealing with radioactive waste and spent nuclear materials and their utilization and burial in the USSR" (SR 6/28/90)

\subsection{SITE SELECTION AND CHARACTERIZATION}

A. The overall criteria for selection of the region for a geological waste repository in the Soviet Union are (Kedrovskiy 1989):

1. The region must be within a large "tectonic" area on a continent

2. The region must be in a seismically inactive area (no higher than 5 on a 12-unit scale)

3. The host geologic formation should have a sufficient thickness and areal extent, with no tectonic disturbances or faults (believed to be within 2-3 km) of break zones; micro-fissures are allowed

4. The strata of the host rock formation must be close to horizontal and should be highly impermeable

5. The separation of the host rock formation from groundwaters must be by impermeable formations at least $150-200 \mathrm{~m}$ thick

6. No mineral resources should be present in the host geologic formation

7. A minimum of groundwater networks should exist, with no productive groundwaters on the site

8. No extraneous boreholes or underground construction can be present on the site; all boreholes are to be mapped and sealed

9. The topography must have low relief for surface construction and access

10. There must be no zones of possible flooding, natural, or man-made calamities

11. The geologic formation must be the main protective barrier, although waste packages are required

12. The Soviets believe the greatest risk is from waste transportation; transportation risks may affect the repository site location (Lehman 1989) 


\subsection{REFERENCE HLW/SPENT FUEL DISPOSAL CONCEPT}

No reference disposal concept has been developed by the Soviets, but several basic concepts have been considered, as follows (Kedrovskiy 1979, 1989):

A. Disposal in mining shafts: a mining shaft, $4-6 \mathrm{~m}$ in diameter, would be constructed to a depth of $400-800 \mathrm{~m}$; the canned wastes would be packed in layers in the shaft and covered or mixed with quartz sand; once the shatt is filled to a mark 150-250 m below the earth's surface, the repository would be dried by heating to a temperature exceeding $100^{\circ} \mathrm{C}$

B. Disposal of wastes in drill holes: two general concepts have been stated:

1. A number of holes would be drilled from the surface into a series of low-permeability rocks; the canisters with the wastes, depending on the amount of the heat evolution, would be placed either one above the other, or alternated with plugs; the holes would then be filled with canisters to a depth that ensures the isolation of the wastes from the water-exchange level; the remaining free part of the hole would be filled with cement

2. If a site can be located in a thinly populated area, a repository can be constructed at a shallow depth; in this case, the canisters with the wastes are placed in drill holes bored in a series of thick clay deposits to a maximum depth of $40 \mathrm{~m}$

C. Disposal of wastes in underground chambers: the wastes would be placed in an underground chamber through a mining shaft or a drill hole that is provided with corresponding locking devices; once the chamber has been filled with a planned amount of wastes, the hole or shaft would be filled completely with cement; the heat produced by a large mass of wastes would melt the surrounding rock

D. Disposal of wastes in underground excavations: one of the methods would be to emplace canisters of wastes in mine excavations

E. The Soviets recently noted that the following types of repositories would be necessary (Kedrovskiy 1990):

1. Municipal storage facilities for disposal of non-industrial wastes

2. Final disposal storage facilities for spent fuel and wastes from nuclear plant decommissioning

3. Repositories for HLW containing long-lived radionuclides

\subsection{GEOSCIENCES R\&D}

A. Past Soviet site investigations for a deep geological repository have consisted of general survey work on salt, granite, clay, gneiss, and other formations (Bradley and Schneider 1990) 
B. Granite may now be considered unfavorable relative to salt and clay, due to "circulating water problems;' the main siting areas now appear to be the lowlands surrounding the Caspian Sea for salt domes and bedded salt and a Cambrian clay not far from Leningrad (Bradley and Schneider 1990)

C. The Soviets recently reported that the Khlopin Institute has been studying geological disposal for 20 years in three principal areas: the role of barriers; the stability of wastes; and the characterization of regional and central disposal sites (Parker 1990)

D. It was recently reported that the following concepts of geologic disposal have been (or are being) evaluated (Kedrovskiy 1990):

1. Deep boreholes in salt and hard rock formations

2. Special underground facilities in salt formations, where wastes are emplaced in mine workings or into relatively short holes bored from these mine workings

3. Specially mined salt and potassium mines

4. Underground cavities mined in salt formations

5. Specially mined openings in hard rocks

\subsection{MANAGEMENT OF URANIUM MINE AND MILL WASTES}

\subsection{WASTE ARISINGS}

A. The USSR has about $5 \times 10^{9} \mathrm{MT}$ of mill tailings from uranium mining operations; an additional 6 to $7 \times 10^{6} \mathrm{MT} / \mathrm{yr}$ of tailings are produced from current operations (Falci 1990)

B. The quantities of liquid wastes from mining and millir.g uranium ore vary from $0.5 \mathrm{~m}^{3} / \mathrm{MT}$ to $5,0 \mathrm{~m}^{3} / \mathrm{MT}$ of ore

\subsection{MANAGEMENT PRACTICES}

A. Soviet plans for management of mine and mill wastes are (Falci 1990):

1. The tailings will be "temporarily stored" until they are permanently covered

2. By the year 2000 the tailings will be covered, probably by $1.5-\mathrm{m}$ of clay and grass

3. The cover will reduce the release of radioactivity from the tailings by a factor of 300 and will return about 166,000 acres to berieficial use

B. Uranium mining soils are treated by covering them with an overburden to prevent wind dispersion and water leaching and by planting a ground cover

C. Water from mill tailings is treated and reused (Bradley and Schneider 1990) 
D. An important trend in the USSR is the introduction of low-waste underground ore mining; the mined area is backfilled with dead rocks, tailings from enrichment (presumed to be from purification of ore materials) and hydrometallurgy, and ashes from thermoelectric plants (Nikiforov 1989)

E. It is expected that uranium mill tailings and mining sites will receive more attention in the Soviet Union due to public concern (Bradley and Schneider 1990)

\subsection{DECOMMISSIONING AND ENVIRONMENTAL RESTORATION}

\subsection{MANOR PROJECTS}

A. Several nuclear power reactors have been shut down for decommissioning in the Soviet Union, but information on the details of decommissioning facilities is not well known; shutdown reactors include (Bradley and Schneider 1990):

1. Chernobyl Unit No. 4, destroyed in an accident, April 26, 1986

2. AMB-1 at Beloyarsk, a 100-MWe BWR, in 1987

3. Novovoronezh Unit 1, a 210-MWe WER, in 1988

4. Armenian Units 1 and 2, WER-440 MWe reactors, in 1989

B. A number of nuclear facilities and sites at Chelyabinsk-40 are being decommissioned and/or restored; the Production Association Mayak has carried out military and industrial nuclear activities since 1948 at the Chelyabinsk-40 site; this site is located $70 \mathrm{~km}$ north of the city of Chelyabinsk, and, in the past, has been commonly referred to as the Kyshtym or Mayak site (Nikipelov 1990b; NW 7/26/90)

C. Environmental restoration activities have been concentrated primarily at the two sites (Mayak and Chernobyl) where past practices or accidents have caused large releases of radioactivity; monitoring and restoration activities are continuing at both sites as follows (Nikipelov 1990b):

1. At the Mayak site (also called Kyshtym), the upper regions of the Techa River were severely contaminated from the discharge of HLW effluents; the discharges were stopped in the summer of 1951:

a. Extensive environmental restoration work has been underway for many years; this includes: withdrawing the Techa River from economic use; evacuating some settlements; supplying water from other sources; building reservoirs to contain the contamination; and isolating the radioactivity deposited in the floodlands

b. At present, the effects of shutting down the five plutonium production reactors at Mayak and the consequent steadily increasing water levels in the reservoirs are being evaluated 
2. At the Mayak site, a tank containing liquid HLW exploded in September 1957, expelling approximately 2 million curies into the atmosphere and surrounding environment (McNeece 1990; Falci 1990)

a. Approximately $23,000 \mathrm{~km}^{2}$ were contaminated; 10,000 people living in the area were relocated, many received large doses of radiation (ETE 1/90; Nikipelov 1990d; DOE 1990)

b. Various mitigation and cleanup activities have been carried out since the accident; these include: restricting access to contaminated areas, destroying contaminated crops grown in the area, deep plowing, and burial of contaminated soil

c. The long-term (15-year) waste management program at the Mayak site has four main objectives: provide safe processing and storage of all waste streams; restore/recover contaminated areas and 'localize' the contamination sources; decommission the facilities; and carry out R\&D to support the above activities

3. At the Chernobyl site where the nuclear power plant Chemobyl No. 4 was destroyed in April 1986, efforts to contain and clean up the contaminated facilities and surrounding area are continuing as follows:

a. A number of options are being studied to provide a more permanent and tighter continement system over the Chernobyl-4 sarcophagus (NW 5/17/90; Falci 1990)

b. An Industrial Association was organized in 1986 to remediate the Chernobyl site; their work is to: monitor and predict migration of radionuclides; assess medical and biological consequences of the accident; decontaminate and manage the radioactive areas; study and predict the radionuclide situation in the control zone; and monitor the radioecology of the control zone

4. The IAEA has organized a major project to reassess the conflicting findings on the causes, health and environmental effects, and precautions against a repetition of the Chernobyl-4 accident; a report on the study is scheduled by the end of 1990 (NW 5/10/90)

a. As of November 1990, over 100 experts had gathered exlensive data on radiological conditions in the republics of Byelorussia, Russia, and the Ukraine; data is being analyzed independently in France and at the IAEA laboratory at Seibersdort, Austria (NWN 11/22/90)

b. Field work included 2,000 measurements of gamma dose rates at indoor and outdoor locations; collection of more than 1,000 samples of soil, grass and milk; and environmental monitoring for radioactive hot spots in a 500 $\mathrm{km}^{2}$ area; individual radiation exposure studies included distribution of nearly 8,000 dosimeters and measurements of intemal cesium levels of t0,000 people (NWN 11/22/90) 
c. By December 1990 all field work had been completed; a few activities remained, including a radioecology meeting scheduled for January 1991 and a technology-transfer project for safe crop cultivation and animal husbandry in some contaminated areas (NW 12/6/90)

5. The Soviets have set up an intemational research center at the site of the 1986 Chernobyl reactor accident and are defining a series of collaborative projects on the aftereffects of the accident (NWN 11/22/90)

a. The Chernobyl Center was established under an agreement signed September 21, 1990, at the IAEA headquarters in Vienna

b. The agreement defines the facilfities and services to be provided by the USSR, Byelorussian SSR, and the Ukrainian SSR, and defines the IAEA's role in the development and coordination of research and dissemination of the results

c. Projects under negotiation include: development of decontamination techniques suitable for large areas; the movement of radionuclides, their uptake in vegetation, and effects on plant biology; and consolidation of a shared database on the health of populations living and working in the area

D. A new organization that is studying nuclear power plant decommissioning methods is located in the town of New Voronezh; the Soviets are using a decontamination method involving chelating agents at reactor stations; the process has a low corrosivity, is reusable, and is competitive with "phosphorous' (Parker 1990)

\section{2 costs}

A Soviet study has concluded that the cost of cleaning up the Chemobyl accident may be about 20 times higher than previously estimated; by the year 2000 , the accident may cost 170 to 215 bilion rubles (U.S. $\$ 315$ to $\$ 400$ billion) in direct and indirect costs (WS J 3/29/90); another source reported that the accident so far has cost 9 billion rubles (U.S. $\$ 17$ billion) and was projected to cost between 100 and 200 billion rubles (U.S. $\$ 185$ and $\$ 370$ billion) by 1995 and 2000 , respectively (Times $4 / 26 / 90$ )

\subsection{INTERNATIONAL ACTIVITIES}

13.1 MEMBERSHIPS: IAEA, CMEA

\subsection{COOPERATION WITH MULTINATIONAL AGENCIES}

A. The Soviet Union is an active member of the IAEA; it provides technical experts, participates in IAEA waste-management projects, and sends representatives to committee meetings and symposia

B. The Soviet Union is cooperating with the IAEA on a major project to reassess the conflicting findings on the causes, health and emvironmental effects, and precautions against a repetition of the Chernobyl-4 accident; a report on the study is scheduled by the end of 1990 (NW 5/10/90) 
C. The Soviets and the IAEA have set up an international research center at the site of the 1986 Chemobyl reactor accident on the aftereffects of the accident (see Section 12.1) (NWN 11/22/90)

D. The IAEA has organized a major project to reassess the conflicting findings on the causes, health and environmental effects, and precautions against a repetition of the Chemobyl-4 accident (see Section 12.1) (NW 5/10/90)

E. As of August 1990, discussions were underway between the Soviet Union and the Commission of the European Communities (CEC) regarding agreements on nuclear safety, exchange of fissile material and nuclear-fusion research (NW 8/23/90)

\subsection{COOPERATION WITH USA}

A. General agreememts covering technical exchanges have been in place for some time between the U.S. and the USSR; however, the U.S. DOE is pursuing new agreements, including one on waste management and environmental restoration (see Section 12.1); the NRC has an agreement in the area of nuclear safety and regulation (Bradley and Schneider 1990)

B. The U.S. DOE entered into an agreement with the U.S. Institute of Nuclear Power Operations (INPO) under which INPO will run a new bilateral program aimed at improving the operation and management of civilian reactors in the Soviet Union (NW 3/29/90)

1. The agreement focused on the use of operating instructions in both normal and emergency situations, personnel training, and managemem and operational control

2. A joint plan to improve the operational safety of Soviet nuclear plants was completed by U.S. and Soviet officials; U.S. utility experts associated with the INPO worked jointly with their Soviet counterparts in developing the plan (NN 1/91)

C. The Ninth Atomic Energy Agreement between the U.S. and the USSR was signed on May 25, 1990; the 5-year agreement provides for cooperation on environmental restoration and waste management (NWN 5/31/90)

\subsection{COOPERATION WITH OTHER COUNTRIES}

A. The Soviet Union has had long-standing agreements with the other CMEA countries for providing uranium enrichment services and supplying nuclear fuel, nuclear reactors, and receipt of spent fuel from these countries

B. General agreements between the USSR and technical exchanges with other countries have existed for some time; however, in the last 5 years the scope and number of technical exchange agreements have increased in the areas of safety, reactor design, reactor engineering, regulations, and waste-management-specific agreements (Bradley and Schneider 1990) 


\subsection{REFERENCES}

$-1978-$

GKAE (State Committee on Utilization of Atomic Energy). 1978. The Main Methods of Solving the Problem of Radioactive Waste Management from Nuclear Power Stations and Spent Fuel Reprocessing Plants in the USSA.' Papers presented at the International Nuclear Fuel Cycle Evaluation Meeting, Moscow, USSR.

$-1979-$

Kedrovskiy, O. L, Y. A. Leonov, N. M. Romadin, and I. Y. Shishchits. 1979. "Program of Imestigation Studies Concerning the Permanent Disposal of High-Level Radioactive Wastes in Deep Low Permeability Geological Formations." Paper presented at Symposium on the Underground Disposal of Radioactive Wastes, July 2-6, 1979, Helsinki, Finland.

- 1981-

Nikiforov, A. S., M. I. Zhikharev, V. I. Zemlyanukhin, V. V. Kulichenko, I. E. Nakhutin, A. S. Polyakov, and N. A. Rakov. 1981. "Handling Radioactive Wastes from Nuclear Power Plants and Reprocessing Spent Nuclear Fuel," UDC 621.039.71. Translated from Atomnaya Energiva, 50(2):128-136. February 1981, Plenum Publishing Corporation, p. 116.

- 1983-

Sedov, V. M. A. S. Nikiforov, M. V. Strakhov, V. T. Sorokin, E. A. Shashukov, M. I. Zavadskii, and A. F. Nechaev. 1983. "Effect of Waste Reprocessing on the Cost of Nuclear Energy." Paper CN-43/432 presented at the International Waste Management Conference, May 16-20, 1983, Seattle.

- 1984-

Nuclear Fuel (NF). 6/4/84. 'France and USSR Consider Experimental Dry Reprocessing for Breeder Fuel," p. 14.

Rippon, S. 1984. "Nuclear Power Growth in the Soviet Union." Nuclear News, February 1984, p. 62.

$-1986-$

Economist. 5/10/86. "Uranium; Too Much of a Bad Thing?" U.S. Edition, p. 70.

Nuclear News (NN). 10/86. "Chernobyl: The Soviet Report," p. 59.

$-1987-$

Kedrovskiy, O. L, et al. 1987. Main Directions to Solve the Problem of Reliable isolation of Radioactive Waste in the USSR." Paper IAEA-CN-48/259, presented at the International Conference on Nuclear Power Performance and Safety, September 28 - October 2, 1987, Vienna 
Ogorodov, A. N., and E. L Rozenbaum. 1987. Test of TK-11 Container-Car During the BN-600 Reactor Spent Fuel Dispatch." USSR presentation at the USSR-Japan Seminar on "Transportation and Storage of Spent Fuel." USSR SCUA-JAIF Scientific-Technical Cooperation, November 1987, Leningrad.

$-1988-$

Kalinin, N. N., A. A. Bochkov, V. N. Shchebetkovskii, Yu. V. Kuznetsov, and I. I. Starygin. 'Production of Solid Waste Forms Containing lodine-129, Carbon-14 and Tritium.' V. G. Khlopin Radium Institute, March 1988, Leningrad, USSR.

Nikiforov, A. S., A. S. Aloy, V. V. Dolgov, Yu. V. Kuznetsov, V. V. Kusichenko, B. V. Nikipelov, V. I. Osnovin, A. S. Polyakov, V. M. Sedov, V. T. Sorokin, and S. N. Filippov. 1988. "Dealing with Highly Active Wastes Formed in Nuclear-Fuel Regeneration." 0038-531X/87/6305-0818, Plenum Publishing Corporation. Translated from Atomnava Energiya, November 1987, 63(5):319-323. .

Nuclear Europe (NE). 1-2/88. 'USSR Relies on Reprocessing to Close Its Fuel Cycle,' p. 49.

Sedov, V. M., et al. 1988. "Technical and Economic Aspects of Nanagement of Radioactive Wastes on the Back-End of the Nuclear Fuel Cycles.' Paper 64h presented at the American Institute of Chemical Engineers 1988 Summer National Meeting, August 21-24, 1988, Denver.

- 1989-

Aloy, A. S., B. Y. Galkin, B. S. Kuznetsov, R. I. Lyubtsev, and V. M. Esimantovskii. 1989. "Fractionation of Liquid Highly Radioactive Wastes and Incorporation of Long-Lived Radionuclides into Ceramics and Vitromet Compositions.' Paper 8 (Session XXII) presented at Waste Management '89, February 26-March 2, 1989, Tucson, Ajizona.

Drozhko, E. G., B. V. Nikipelov, A. S. Nikiforov, A. P. Suslov and A. F. Tsarenko. 1989. "Experience in Radioactive Waste Management at the Soviet Radiochemical Plant and the Main Approaches to Waste Reliable Confinement Development." Paper presented at the International Symposium on the Safety Assessment of Radioactive Waste Repositories, October 9-12, 1989, Paris.

Energy Information Administration (EIA). 1989. 'Commercial Nuclear Power 1989 - Prospects for the United States and the World." DOE/EIA-0438(89), U.S. Departmenl of Energy/Energy Information Administration, Washington, D.C.

Kedrovskiy, O. L., E. A. Leonov, and I. Y. Sheeshiz. 1989. "Principles and Requirements for Siting of Underground Repositories for Solidified Radioactive Waste in Geological Emvironments." Paper 6-27 presented at Waste Management '89, February 26-March 2, 1989, Tucson, Arizona.

Lehman, L. L 1989. "Nuclear Waste Management and Nuclear Related Accidents in the Soviet Union," Briefing for the National Academy of Sciences, Washington, D.C., L. Lehman and Associates, Burnsville, Minnesota, December 1, 1989.

Natural Resources Defense Council (NRDC). 1989. "NRDC Technical Team Releases New Information on Unprecedented Nuclear Warhead Monitoring and Visits to Secret Military Facilities in Soviet Union." News Release from the NRDC, July 12, 1989, Washington, D.C. 
Nikitorov, A. S., B. V. Nikipelov, and V. V. Kulichenko. 1989. 'Policy and Principles of Radjoactive Waste Management in USSR.' In Low and Imtermediate Level Radioactive Waste Management, Proceedirigs of the 1989 Joint International Waste Manaqement Conference. October 22-28, 1989, Kyoto, Japan. American Society of Mechanical Engineers, New York.

Nikipelov, B. V. 1989. "Experience in Managing the Radiological and Radioecological Consequences of the Accidental Release of Radioactivity Which Occurred in the Southem Urals in 1957." Paper presented at the IAEA International Symposium on Recovery Operations in the Event of a Nuclear Power Plant Accident, November 6-10, 1989, Vienna, Austria.

Nuclear Engineering International (NEl). 3/89. "Improving Safety Practices in the Soviet Union," p. 15.

Nuclear Fuel (NF). 6/26/89. "Soviet Centrituge Capacity Said to Free More Low-Cost SWU for Western Markets,' June 26, 1989, p. 1.

Nuclear Fuel (NF). 10/2/89. "Soviet Otficial Says Centrifuge Process Allows TSE Flexibility for SWU Sales," p. 6.

Nuclear Fuel (NF). 10/16/89. 'Soviet Union Postpones Completion of Siberian Reprocessing Plant,' October 16, 1989, pp. 1-2.

Nucleonics Week (NW). 10/5/89. 'Chernobyl Study Center Proposal Gets Cautious Reception in Vienna," p. 1.

$-1990$

Bradley, D. J., and K J. Schneider. March 1990. Radioactive Waste Management in the USSR: A Review of Unclassified Sources, 1963-1990. PNL-7182, Pacific Northwest Laboratory, Richland, Washington.

EKONOMIKA, TEKHNIKA, EKOLOGIYA (ETE). 1/90. (In Russian) Moscow, pp. 51-55.

Falci, F. P. 1990. 'Travel to USSR for Fact-Finding Discussions on Environmental Restoration and Waste Management, June 15-28, 1990," Foreign Travel Report. Doe Office of Technology Development, July 27, 1990.

International Atomic Energy Agency (IAEA). 1990. Operating Experience with Nuclear Power Stations in Member States in 1989. Vienna.

Leigh, I. W., and S. J. Mitchell. 1990. International Nuclear Fuel Cycle Fact Book. PNL-3594, Rev. 10, Pacific Northwest Laboratory, Richland, Washington.

Kedrovskiy, O. L., I. Y. Shishchits, V. N. Morosov, and A. I. Ribalchenko. 1990. "Principal Results of Research Works Carried Out in the USSR on Geological Repository Construction for Safe Radioactive Waste Disposal.' Presented on 3/26/90 during a visit to the U.S.

Lesperance, A. M. 1990. "Foreign Travel Trip Report from Environmental Technology Delegation Visit to the Soviet Union." January 29 - February 12, 1990, Pacific Northwest Laboratory, Richland, Washington.

McNeece, J. P. 1990. "Foreign Travel Report," August 1990, Pacific Northwest Laboratory, Richland, Washington. 
Nikiforov, A. S., V. E. Vlasov, V. V. Kushnikov, N. K. Krilova, T. S. Smelova, and R. N. Salamatina. 1990. 'Development of a Two-Stage Process for Consolidation of Highly-Active Wastes.' All Union Institute of Inorganic Materials of Academician - A. A. Bochvar. Ministry of Atomic Power and Industry. Paper given during the U.S. Department of Energy visit to the Soviet Union, June 15-29, 1990.

Nikipelov, B. V., Ye. I. Mikerin, A. S. Nikiforov, A. S. Nikiforov, A. S. Poliakov, V. G. Shatsillo, V. A. Kurnosov, M. V. Strakhov, A. P. Suslov, V. I. Legedev, V. G. Shatsillo, V. A. Kurnosov, M. V. Strakhov, A. P. Suslov, V. I. Lebedev, and Y. V. Kuznetsov. 1990a. "Main Trends and the Results of Works Made in the USSR on Solidification of High- and Medium-Level Liquid Wastes." State Committee of the USSR for Utilization of Atomic Energy. Presented on 3/26/90 during a visit to the U.S.

Nikipelov, B. V., A. S. Nikiforov, O. L. Kedrovskiy, M. V. Strakhov, and E. G. Drozhko. 1990b. 'Practical Rehabilitation of Territories Contaminated as a Result of Implementation of Nuclear Material Production Defense Programs." Presented on $3 / 26 / 90$ during a visit to the U.S.

Nikipelov, B. V., A. P. Suslov, and A. F. Tsarenko. 1990c. "Perspective," Presented Waste Management '90, February 25 - March 1, 1990, Tucson, Arizona.

Nikipelov, B. V., G. N. Romanov, L. A. Buldakov, N. S. Babev, Y. B. Kholina, and E. I. Mikerin. 1990 d. A Radiation Accident in the Southern Urals in 1957. Original article submitted July 14, 1989, Plenum Publishing Co.

Nuclear Waste News (NWN). 5/31/90. "Slants and Trends," p. 211.

Nuclear Waste News (NWN). 11/22/90. "USSR Sets Up Chernobyl Research Center; IAEA Completes Radiological Study," p. 455.

Nucleonics Week (NW). 4/19/90. 'USSR Again Reorganizes Nuclear Power Bureaucracy,' p. 12.

Nucleonics Week (NW). 5/17/90. 'USSR Official Sees 'No Real Health Hazard' from Chernobyl \#4 Aerosols," p. 12.

Nucleonics Week (NW). 3/29/90. "INPO to Run U.S.-USSR Initiative to Improve Soviet Reactor Safety," p. 1.

Nucleonics Week (NW). 8/23/90. "EC and USSR Plan to Develop Nuclear R\&D Cooperation Plants," p. 14.

Nucleonics Week (NW). 5/10/90. "International Team Will Reassess Data on Chernobyl Health Effects," p. 3.

Nucleonics Week (NW). 7/12/90. "Soviet Chief Attorney Says USSR Should Honor Fuel Accord," p. 11.

Nucleonics Week (NW). 7/26/90. "Letter from Chilyabinsk,' p. 11.

Nucleonics Week (NW). 12/6/90. 'IAEA Nears Conclusions on Chernobyl Radiation Effects,' p. 9.

Parker, F. L. 1990. "Draft Working Papers on Trip to Soviet Union, February 12-23, 1990 by the Radioactive Waste Board of the National Academy of Sciences." Vanderbilt University, TN. 
Sovetskaya Rossiya (SR). 6/28/90. "Resolution on Nuclear Waste State Program Viewed,' 2nd Ed., p. 1.

Times. 3/8/90. "Iran Nuclear Power," London.

Times. 4/26/90. '300 Death Toll Admitted on Grim Chernobyl Day,' London.

U.S. Department of Energy (DOE). 1990. Information presented to U.S. DOE delegation visiting the Soviet Union, June 15-28, 1990.

Wall Street Journal (WSJ). 3/29/90. "Cost of Chernobyl Disaster Soars in Study," p. 10.

$$
-1991 \text {. }
$$

Nuclear News (NN). 1/91. 'INPO Assists Soviets in Procedure Development," p. 26. 



\section{UNITED KINGDOM}




\section{UNITED KINGDOM}

\section{CONTENTS}

1.0 NUCLEAR POWER $\ldots \ldots \ldots \ldots \ldots \ldots \ldots \ldots \ldots \ldots \ldots \ldots \ldots \ldots \ldots$

2.0 NUCLEAR FUEL CYCLE AND RADIOACTIVE WASTE MANAGEMENT

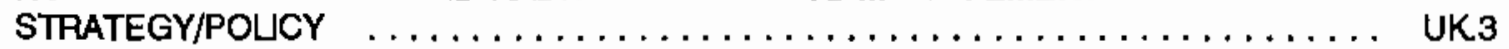

3.0 HIGHLIGHTS AND MAJOR MILESTONES $\ldots \ldots \ldots \ldots \ldots \ldots \ldots \ldots \ldots \ldots$ UK4

4.0 INSTITUTIONAL CONSIDERATIONS/ORGANIZATIONS $\ldots \ldots \ldots \ldots \ldots \ldots \ldots \ldots$ UK.5

$5.0 \quad$ NUCLEAR FUEL PRODUCTION $\ldots \ldots \ldots \ldots \ldots \ldots \ldots \ldots \ldots \ldots \ldots \ldots \ldots$

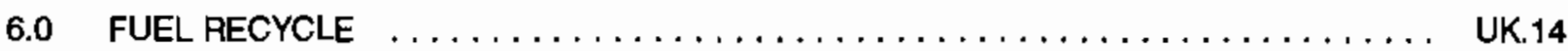

7.0 SPENT FUEL STORAGE AND TRANSPORT $\ldots \ldots \ldots \ldots \ldots \ldots \ldots \ldots \ldots \ldots$

8.0 WASTE CONDITIONING, STORAGE AND TRANSPORT $\ldots \ldots \ldots \ldots \ldots \ldots \ldots \ldots$ UK.19

9.0 DISPOSAL OF NON-HIGH-LEVEL WASTES $\ldots \ldots \ldots \ldots \ldots \ldots \ldots \ldots \ldots \ldots \ldots \ldots$

10.0 DISPOSAL OF HIGH-LEVEL WASTES $\ldots \ldots \ldots \ldots \ldots \ldots \ldots \ldots \ldots \ldots \ldots \ldots \ldots$

11.0 MANAGEMENT OF URANIUM MINE AND MILL WASTES $\ldots \ldots \ldots \ldots \ldots \ldots \ldots$ UK.33

12.0 DECOMMISSIONING AND ENVIRONMENTAL RESTORATION $\ldots \ldots \ldots \ldots \ldots$ UK.33

13.0 INTERNATIONAL ACTIVITES $\ldots \ldots \ldots \ldots \ldots \ldots \ldots \ldots \ldots \ldots \ldots \ldots \ldots \ldots \ldots$

14.0 REFERENCES $\ldots \ldots \ldots \ldots \ldots \ldots \ldots \ldots \ldots \ldots \ldots \ldots \ldots \ldots \ldots \ldots \ldots$ UK.38 
UNITED KINGDOM

\subsection{NUCLEAR POWER}

\subsection{REACTOR MIX}

24 GCR, 14 AGR, 1 HWR; 1 LMFBR; ordered 1 PWR (1.1 GWe) in 1987 (NEI 1990)

\subsection{ELECTRIC POWER PRODUCTION}

1989--292.1 TWh (21.7\% Nuclear) (NUKEM 4/90a)

\subsection{NUCLEAR POWER CAPACITY PROJECTIONS}

1990--12.0 Net GWe

1995--11.6 Net GWe

2000-12.8 Net GWe (NUKEM 3/90)

\subsection{NUCLEAR PLANT AVAILABIUTY (Howles 1990)}

Year ending $12 / 89-53.5 \%$

Lifetime through $12 / 89-52.1 \%$

1.5 NUCLEAR ENERGY POLICY: The United Kingdom follows a strong nuclear policy. Key features are (Feates 1988; Miller 1989; Numark 1989; NW 7/13/89; Leigh and Mitchell 1990; NEA 1990; NEI 1/90):

A. The U.K. relies on nuclear energy for a significant portion of its electricity needs; although the Magnox/AGR reactor system used in the U.K. results in nuclear generation costs higher than those of fossil fuel generation, recent privatization plans for the electricity-generating industry call for at least $20 \%$ of the power to be generated by nuclear plants

B. U.K.'s nuclear power policy is flexible, allowing adjusıment for new technologies and public input; examples include: 1) the U.K. trend away from the initial gas-cooled reactors to advanced gas-cooled reactors and possibly pressurized water reactors, followed by advanced breeder reactors; 2) implementation of new waste treatment methods; and 3) improvements in efiluent control and waste disposal as a result of public pressure

C. The U.K. distributes management of nuclear programs among government, utility and industrial entities; the responsibility for safety and costs of radioactive waste management belong to the generator

D. The U.K. permits and promotes extensive cooperation with international organizations and foreign entities on nuclear matters

E. R\&D on nuclear matters is being carried out primarily by the federal government; however, the federal government is attempting to shift some of the R\&D burden to private industry by breaking the UKAEA into "profit-oriented" entities

F. A firm policy has not yet been defined relative to decommissioning of nuclear facilities 
1.6 NUCLEAR R\&D BUDGET: In 1988/89, the U.K.'s total expenditure on waste management R\&D, including that carried out by industry, was estimated at $\$ 41$ million (U.S. $\$ 70,000,000)$; there is political pressure to transfer nuclear R\&D from the government to industry (NEA 3/88; NWN 2/23/89; NEA 1990)

1.7 ELECTRICITY PRODUCTION COSTS: Costs for generating electricity in the U.K are estimated at U.S. $\$ 0.077$ to $\$ 0.094 / \mathrm{kWh}$ for nuclear stations (NEI 12/90)

\subsection{NUCLEAR FUEL CYCLE AND RADIOACTIVE WASTE MANAGEMENT STRATEGY/POLICY}

2.1 OVERALL NUCLEAR FUEL CYCLE POLICY: The U.K. follows a policy on the nuclear fuel cycle that:

A. Has developed domestic capabilities for all phases of the nuclear fuel cycle except uranium production (IAEA 1988; Leigh and Mitchell 1990)

B. Uses reprocessing of spent nuclear fuel to recover unused fissile materials for both defense programs and electricity generation (NEA 1989b; Denny 1990)

C. Calls for disposal of radioactive wastes in both near-surface structures and deep geologic formations; though not pursuing disposal in the sea, the U.K. is keeping the option open (NEA 1990; NW 3/15/90)

D. Allows the responsible organizations, e.g., UKAEA, BNFL, utilities, to arrange for transportation of radioactive materials using their own subsidiaries or industrial firms established for that purpose (ACSTRM 1988; Kovan 1988; Pecover 1989; NEA 1990)

2.2 POLICY ON THE FRONT END OF THE NUCLEAR FUEL CYCLE: The U.K. follows a policy on the front end of the nuclear fuel cycle that (Wilkinson 1989):

A. Obtains its uranium supply from diversified foreign sources, including those in which the U.K. participates in exploration for uranium (NEA 1989c)

B. Provides domestic uranium comversion, uranium enrichment and fuel fabrication (IAEA 1988)

2.3 POLICY ON THE BACK END OF THE NUCLEAR FUEL CYCLE: The U.K follows a policy on the back end of the nuclear fuel cycle that (Bush 1987; Wilkinson 1989):

A. Employs interim storage of spent fuel at reactors, in central stores, and at reprocessing plants; both wet and dry storage systems are used (Wilkirıson 1987; Sills 1989)

B. Has led to the development of major fuel reprocessing facilities at Sellafield for gasreactor and light-water reactor fuels and a small facility for reprocessing materials testing reactor and breeder reactor fuels at Dounreay (NEA 1990; NUKEM 2/90)

C. Includes vitrification of high-level liquid wastes from reprocessing followed by dry interim storage for an extended period (50 to 100 years) at which time the wastes would be considered and disposed as intermediate-level wastes (NEA 1/90; NUKEM 2/90) 
D. Promotes a continuing development program on the treatment, storage and disposal of radioactive wastes to ensure that each type of waste is disposed of in the most appropriate way (Flowers 1989; NEA 1990)

E. Has led to a change in the method of disposing of low-level wastes in the near-term from trench burial to placement in engineered surface facilities (NE 3-4/89; NEA 1990; NUKEM 2/90)

F. Has led to a decision to eventually use deep geologic formations for disposal of low- and intermediate-level (alpha) wastes (NEA 1990; NUKEM 2/90)

\subsection{HIGHLIGHTS AND MAJOR MILESTONES}

1988 Plans were announced for a new dry storage facility at Heysham for advanced AGR spent fuels (NW 9/22/88)

1989 Sellafield and Dounreay were nominated by NIREX as candidate sites for the proposed deep LLW/LW repository site (NEI 5/89)

1989 Operation of a new concrete disposal vault for _LW began at Drigg (NUKEM 2/90)

1989 Privatization of the U.K's electricity industry was instituted with breakup of CEGB into several companies (NN 1/90; NUKEM 4/90b)

1989 Construction of a European Fast Reactor Reprocessing Plant at Dounreay was approved by Scottish authorities (NWN 11/2/89a and 11/2/89b)

1989 The UKAEA formed AEA Technology as a major international contracting organization offering nuclear services worldwide (NEl 1/90)

1990 Operation of the Waste Vitrification Plant (WV) on $\mathrm{HLW}$ from reprocessing Magnox fuels began at Sellafield (NEA 1990; NUKEM 2/90)

1990 Encapsulation of Magnox fuel cladding in cement at Sellatield will begin (NEA 1990)

1990 The encapsulation plant for ILW from THORP reprocessing plant is to be commissioned (NUKEM 2/90)

1992 Operation of the new, large THORP reprocessing plant on AGR fuels will begin (NEA 1990; NUKEM 2/90)

1992 Operation of the Enhanced Actinide Removal Plant (EARP) to lower alpha activity in liquid effluents from Sellafield will begin (NEA 1990)

1993 Construction of a demonstration mixed-oxide fuel fabrication plant is to be completed (NF 4/16/90; NN 5/90)

1995 Operation of the BNFL New Oxide Fuel Complex at Springfields is to begin for fabricating AGR and PWR fuels (NF 4/2/90) 
2005 New deep geological repository for LLW/LW is to open (NEA 1990)

2040 Selection of the disposal system for HLW (NEA 1990)

4.0 INSTITUTIONAL CONSIDERATIONS/ORGANIZATIONS: No single authority has overall authority for nuclear energy in the U.K; while the Secretaries of State for Energy and for the Environment are competent authorities for development and health/safety aspects, respectively, they share those powers with other ministers when the issue under consideration falls within the competence of the other ministry; many of the functions carried out by the ministers in England are exercised by the corresponding ministers in Wales, Scotland, and Northem Ireland (NEA 1984)

\subsection{LEGAL REQUIREMENTS}

A. Storage, release or disposal of radioactive materials in the U.K requires approval of the appropriate federal governing agency (IEAL 1987; NEA 1990)

B. All nuclear installations in the U.K. must be licensed (IEAL 1987)

C. No stipulation law exists that links reactor construction or operation to waste management plans (Paige 1985)

D. Organizations that produce radioactive wastes must carry the burden of responsibility for safe and effective management of the wastes, e.g., in the U.K, spent fuel and HLW management are the responsibility of utilities and reprocessors (NEA 1990)

E. The central govemment has legal authority to overide local siting vetoes (Paige 1985)

F. Costs of radioactive waste management must be met by the producers and reflected in their accounting practices; most producers are govemment-owned organizations and provisions are made in their budgets to meet waste management costs; no independent waste management fund has been established in the U.K. (IEAL 1987)

\subsection{RADIATION PROTECTION PRINCIPLES}

A. In the U.K., all practices giving rise to radioactive wastes must be justified (IEAL 1987)

B. Radiation exposure of individuals and the collective dose to the population shall be reduced to levels which are as low as reasonably achievable (ALARA), economic and social factors being taken into account (IEAL 1987)

C. The average effective dose equivalent from all sources, excluding natural background radiation and medical procedures, to representative members of the public shall not exceed $5 \mathrm{mSv}$ (500 mrem) in any one year (IEAL 1987)

D. For radiation workers, the current limit is $50 \mathrm{mSv} / \mathrm{yr}$ (5 rem/yr); in November 1987, the U.K. National Radiation Protection Board (NRPB) recommended that the worker limits be lowered to $15 \mathrm{mSv} / \mathrm{yr}(1500 \mathrm{mrem} / \mathrm{yr})$ in anticipation that the ICRP would lower its guidance limits in 1990; the ICRP did lower its recommendations to $20 \mathrm{mSv} / \mathrm{yr}$ in November 1990 (NW 3/17/88; NW 11/9/89; NN 12/90) 


\subsection{LICENSING (NEA 1984; NEA 1990; Billington 1990)}

A. The use of radioactive materials anywhere in the U.K. must be authorized by the appropriate federal government department; these departments are: the Department of the Environment (DOE), the Ministry of Agriculture, Fisheries and Food (MAFF), the Welsh Office (WO), the Scottish Office (SO), and the Department of the Environment for Northern Ireland (DOENI)

B. Licenses are actually granted by the Health and Safety Executive (HSE) through its Nuclear Installations Inspectorate (NII) after receiving approval from all appropriate agencies

C. The Nil's approach to licensing includes:

1) preparation of a Preliminary Safety Report (PSR) and a Pre-Construction Safety Report (PCSR) by the applicant

2) a decision on proceeding with licensing based upon review and approval by the authorizing departments mentioned above

3) conduct of a Public Inquiry by the NII

4) approval of construction following revision of the PCSR by the applicant to incorporate information/decisions developed in the review process

5) preparation of a Pre-Operational Safety Report by the applicant reflecting the knowledge gained during the construction period

6) approval of operation followed by continuing inspection and regulation during the lifetime of the project

4.4 PUBLIC INVOLVEMENT: Prior to 1980, public awareness and involvement in nuclear decisions was minor; since that time, public involvement has increased markedly; it is evident in the public hearings on radiation releases from Sellafield, the selection of disposal sites for radioactive wastes, and the inclusion of PWRs in the U.K.'s inventory of power reactors (Numark 1989; NEA 1990; Curd 1990)

A. In the U.K, any proposal to extend an existing nuclear site or create a new one must be sent to the relevant local planning authority (borough or county) under the Town and Country Planning Acts

B. The proposal is reviewed by the local planning authority, made up of locally elected representatives, who will consider public comments submitted in writing

C. If the local planning authority refuses to approve the proposal, the applicant may appeal to the Secretary of State who can set up a public, local inquiry to help him in determining the case; the Secretary of State can overrule the local authority after the public hearing

D. Since 1980 and particularly since the Chernobyl accident, U.K nuclear agencies, e.g., NIREX, BNFL, have expanded their public relations activities substantially to include: 
a round-the-clock information service for the press and broadcast media

2)

provision of speakers for technical meetings and public debates around the country

3) encouragement of the inclusion of information on radiation in school science curricula and sponsorship of teachers to work in the nuclear industry for one year

4) participation in conferences and exhibitions, including sponsorship of a mobile exhibition

5) initiation of the Sellafield Visitors' Center which hosts about 150,000 visitors per year

4.5 KEY AGENCIES AND FUEL CYCLE CENTERS: The nuclear industry in the U.K. has been highly nationalized, with responsibilities assigned to various government-supported agencies and corporations reporting to different government ministries or departments; recently, changes have been made in an effort to make the industry more seff-supporting, e.g., formation of AEA Technology and privatization of the electric utility industry; lead responsibilities for the fuel cycle and waste management are exercised as follows:

A. AEA Technology, a government agency under the Department of Energy and formerly the United Kingdom Atomic Energy Authority, is responsible for nuclear research, which is now performed through nine discrete business divisions representing the fields of (UKAEA 1986; NEN 10/89; NEI 1/90):

1) fast reactors

2) fusion technology

3) nuclear fuel cycle technology

4) thermal reactor technology

5) decommissioning and radioactive waste management technology

6) environmental protection services

$7 \quad$ oil and gas

8) risk management technology

9) contract research and development and emerging businesses

AEA Technology conducts its research at numerous sites--Harwell (reactor development, materials research, reprocessing, waste management), Risley (engineering and materials), Dounreay (FBR fuel cycle development), Springfield (reactor fuels development and advanced waste treatment processes), Sellafield (Pu fuels development, AGR studies and waste treatment) and Winfrith (reactor development, safety studies and decontamination)

B. British Nuclear Fuels plc (BNFL), a government-owned corporation under the Department of Environment, provides commercial fuel cycle services for domestic and foreign customers; activities include design and development of nuclear processing plants, 
procurement and processing of uraniurn, uranium enrichment, fuel element fabrication, and transport and reprocessing of spent fuel; BNFL holds a one-third interest in each of the three international consortia: Urenco (uranium enrichment by gas centrifuge), United Reprocessors GmbH (reprocessing), and Nuclear Transport Limited (spent fuel transportation); BNFL also has the lead responsibility for management of high-level wastes from reprocessing and operates the low-level waste disposal site at Drigg (BNFL 1988; Johnson 1990)

Its major facilities are located at Capenhurst (enrichment), Springfield (fuel fabrication), Sellafield (reprocessing, reactor operation and low-level waste disposal), Chapelcross (reactor operation) and Risley (management center)

C. The Nuclear Energy Radioactive Waste Executive (U.K. NIREX, Ltd.) was set up in 1985 to implement the government's strategy for the dispossal of most low-and intermediatelevel radioactive wastes produced in the U.K.; it is a government-owned corporation under the Department of Energy with shares held by the Department of Energy, BNFL, the Central Electricity Generating Board (CEGB), and the South of Scotland Electricity Board (SSEB); the activities of U.K. NIREX Ltd. consist primarily of coordinating the work of other groups (NIREX 1988a; NEA 1990)

D. The Nuclear Electricity Authorities are government-owned utilities under the Department of Energy that produce and distribute electricity from nuclear power; they include the CEGB and the SSEB; in 1988, the U.K government announced plans to privatize the electric utility industry with the authorities being broken up into companies whose shares would be sold in the stock market; in 1989, the government modified its plans to privatize only the distribution and non-nuclear generating systems; the new private companies, listed below, are expected to be sold on the market in 1991 (Marshall 1989; NN 1/90; NE! 1/90; NUKEM 4/90b)

1) National Grid: a new company for distribution of electricity in the U.K.

2) National Power and Power Gen: two new companies operating the non-nuclear stations of the CEGB

3) Scottish Hydro Electric Power and Scottish Power: two new companies operating the non-nuclear stations of the South of Scotland Electricity Board

The nuclear stations of the generating boards will be operated by two new governmentowned corporations, Nuclear Electric and Scottish Nuclear; Nuclear Electric will have the responsibility for completion of the Sizewell B PWR

E. The Department of the Environment (DOE) assumed the responsibility for management of radioactive wastes from the Department of Energy/UKAEA in 1977; this responsibility includes development of a national waste disposal strategy and the performance of related research; implementation of the strategy is the responsibility of the generators, e.g., CEGB, BNFL, working through NIREX; within DOE, the development of strategy is performed through Her Majesty's Inspectorate of Pollution (HMIP) (Dotchin 1988; Ponsford 1989; NEA 1990)

The R\&D which DOE funds is performed by several organizations--DOE's Building Research Establishment (BRE), the British Geologic Survey (BGS), the Institute of Oceanographic Sciences (IOS), and the UKAEA at Harwell 
F. The National Radiation Protection Board (NRPB), located at Harwell, was established under the Radiological Protection Act of 1970 to provide an authoritative reference point on radiological protection in the U.K; the NRPB, under the Department of Health/Social services, is responsible for all radiological protection services and related R\&D, training, and information dissemination (NRPB 1989)

G. The Health and Safety Executive (HSE), an independent federal government department has the authority to enforce statutory requirements on health and safety and is responsible for granting licenses for nuclear installations; the HSE obtains advice from the Radioactive Waste Management Advisory Committee (RWMAC), which reports to the Department of the Environment; the HSE performs licensing through its subsidiary organization, the Nuclear Installations Inspectorate (NII) (Dotchin 1988; NEA 1990)

H. The Department of Agriculture, Food, and Fisheries (MAFF), together with the Scottish Development Department, is responsible jointly with the Department of the Environment for authorizations for routine releases of radioactive material to the environment (land, sea or air) (NEA 1/90)

I. The Atomic Weapons Research Establishment (AWRE) at Aldermaston carries out research directed towards defense aspects of nuclear energy for the Department of Defense; the AWRE also carries out research and development work of a non-defense nature, including radioactive waste management

4.6 PRINCIPAL RESEARCH, DEVELOPMENT AND DEMONSTRATION FACILITIES/PROGRAMS: The U.K. has an extensive array of R\&D activities underway in support of its nuclear programs; they cover all parts of the nuclear fuel cycle except uranium mining and ore processing; the UKAEA has been the principal nuclear research and development organization in the U.K.; the headquarters is at Harwell, but it conducts R\&D at various sites; with the breakup of the UKAEA into nine business areas, R\&D at each site may be the responsibility of one or more of the business entities; BNFL and Nuclear Electric, formerly CEGB, also conduct R\&D; the principal R\&D locations and their programs include the following:

A. The Harwell Atomic Energy Research Establishment, located about $90 \mathrm{~km}$ west of London, is the center of the U.K.'s nuclear research, embracing all aspects of the nuclear fuel cycle--nuclear fuels performance, reactor materials, safety, reprocessing, isotope recovery and production, fuel preparation and radioactive waste management; besides the development laboratories, facilities at Harwell include three research reactors (two recently shut down), hot cells used for radiochemical research, radioisotope production, and treatment and storage facilities for low-level wastes produced on the site; the nearby Culham Laboratory, site of FBR and fusion research, is being combined with Harwell in the new AEA Technology organization (Harwell 1986; UKAEA 1986; NEA 3/88; NEl 1/90; NEN 4/90)

B. The Winfrith Atomic Energy Establishment, located near the English Channel in South Dorset, was established in the late 1950 s for reactor development; major facilities at Winfrith include the 100-MWe SGHWR, four research reactors, fabrication capability for research reactor fuels, hot cells used for post-irradiation examination of fuels, facilities for conducting safety tests, and storage/treatment services for radioactive wastes generated onsite; Wirfrith, formerly part of UKAEA, is now an autonomous site (UKAEA 1986; NEI 1/90; Lloyd 1990)

C. The Sellafield Site, located on the west coast approximately 400 kilometers from London, is the center of BNFL's reprocessing and waste management operations; BNFL maintains 
an R\&D department onsite that supports five areas-chemistry, the Magnox reactors, waste management, reprocessing, and physical sciences; the UKAEA maintained a research laboratory on the Sellafield site for many years, but it is being phased out as part of the UKAEA reorganization; major programs underway at the site include operation of the four Calder Hall Magnox reactors, operation of the reprocessing plant for Magnox fuels, construction of a new (THORP) reprocessing plant for oxide fuels together with a spent fuel storage facility, oparation of a vitrification facility for high-level wastes, decommissioning of the Windscale Advanced Gas-Cooled Reactor and decommissioning of the BNFL Co-Precipitation Plant for fabrication of mixed-oxide fuels (BNFL 1988; NEA 3/88; NEN 6/89a; NEA 10/89)

D. The Dounreay Nuclear Power Development Establishment, formerly part of the UKAEA and located in northern Scotland, is now an autonomous site; Dounreay is the center of the U.K's fast reactor development, including reprocessing of fast reactor fuels; major programs underway at the site include operation of the Prototype Fast Reactor (PFR) and associated reprocessing plant, fuel fabrication for and reprocessing of fuel from materials testing reactors, post-irradiation examination of fast-reactor fuels, and safety testing involving sodium coolant; the British government has given permission for a plutonium reprocessing plant to be built at Dounreay as part of the European fast breeder program and NIREX has selected Dounreay to be evaluated as a site for deep geologic disposal of low- and intermediate-level wastes; AEA Technology is soliciting MTR-fuel reprocessing business for Dounreay from foreign agencies (UKAEA 1986; NWN 11/2/89b; NEA 1990; NF 5/14/90)

E. The Springfields Nuclear Power Development Laboratories, located about 55 kilometers northwest of Manchester, is being discontinued as part of the UKAEA reorganization; started 40 years ago on development of reactor fuels, emphasis has shifted recently to the back end of the fuel cycle; BNFL operates a uranium conversion plant and a fuel fabrication facility for Magnox fuels and is now building a fuel fabrication plant for AGR and PWR fuels near Springfield; BNFL also has established a technical department there to support its operations (UKAEA 1986; BNFL 1988; NN 9/89; NEI 1/90)

F. The Risley Nuclear Power Establishment, located about 30 kilometers from Manchester, was part of the UKAEA and is being discontinued as part of the UKAEA reorganization; research programs that were conducted at Risley emphasized reactor component and material development for fast breeders; Risley is also the location of the headquarters for BNFL (UKAEA 1986; BNFL 1988; NEl 1/90)

G. Capenhurst, located near Chester, is the site of Urenco's centrifuge enrichment facility; Urenco is owned by the Netherlands, FRG and BNFL; Urenco conducts R\&D on advanced centrifuges and BNFL, along with the Harwell Atomic Energy Research Establishment, is conducting research on laser enrichment (UKAEA 1986; BNFL 1988)

H. U.K. NIREX, Ltd., headquartered at Harwell, is responsible for disposal of low- and intermediate-level wastes, including conduct of the related R\&D; the company subcontracts its R\&D out to other organizations; R\&D programs are underway on site evaluations, environmental assessments, repository designs, performance assessment and safety, waste inventories, characterization, transpiort, waste characterization, inventories, packaging, and public relations; NIREX also sponsors research the STRIPA Project in Sweden and the URL at Mol, Belgium (NEA 1988a; NIREX 1988a; NEA 1990; Curd 1990) 
I. The NRPB, headquartered at Harwell, sponsors research at numerous institutions on standards development, radiation monitoring and training, background radiation (including radon exposure), emergency planning, epidemiology, leukemia clusters, and effects of exposure to both ionizing and non-ionizing radiation (NEA 1988a; NRPB 1989)

J. Other R\&D related to the nuclear fuel cycle is conducted by the AWRE, BGS, BAE, CEGB, MAFF, and the IOS (all defined below)

1) The Atomic Weapons Research Establishment (AWRE), located at Aidermaston near Reading, conducts A\&D on defense-related programs, including radioactive waste management (Leigh and Mitchell 1990)

2) The British Geologic Survey (BGS), working at Harwell, supports the NIREX effort to locate waste disposal sites (NEA 1988a; Beale 1990)

3) The Building Research Establishment (BGE), located about 20 miles northeast of London, supports NIREX emplacement engineering and rock mechanics studies (Leigh and Mitchell 1990)

4) Nuclear Electric, formerly CEGB (see Section 4.5D), performs R\&D on waste storage, conditioning, and transportation for its operating stations; this is done at three main research centers (Berkeley Nuclear Laboratories, Central Electricity Research Laboratories, and Marshwood Engineering Laboratories) and five technical service laboratories (NE 3/4/87a; NEA 1988a; NE 1/2/89; Wilkinson 1989)

5) The Ministry of Agriculture, Fisheries and Food (MAFF) operates the Fisheries Radiobiological Laboratory at Lowestoft and the Agricultural Research Letcomb Laboratory near Oxford (NEA 1988a; NEA 1990)

6) The Institute of Oceanographic Sciences (IOS), located about 30 kilometers southwest of London, models radionuclide transport in the oceans for DOE (Leigh and Mitchell 1990)

4.7 KEY PERSONNEL (Leigh and Mitchell 1990)

A. AEA Technology (NW 4/6/90; NW 5/17/90):

1) John Mattby, Chairman, AEA Technology

2) Ron H. Flowers, Chief Technologist, Nuciear Technology

3) Mel H. Wood, Chief Executive, AEA Decommissioning and Radioactive Waste

4) J. Rae, Chief Executive, AEA Environmental Services

5) Owen Pugh, Chief Executive, AEA Nuclear Fuel Cycle Technology

6) A.R. Taig, Chief Executive, AEA Risk Management Technology

B. AWRE: D. Hunter, Waste Management

C. BGS: G.I. Lumsden, Director 
D. BNFL (NF 5/28/90):

1) Christopher G.F. Harding, Chairman, Risley

2) Derek May, General Manager, International Nuclear Fuels, Limited, Risley

3) W.A. MacLaughlin, Director, Transport Division, Risley

4) Grahame K Smith, Director, Reprocessing and Reactors (Magnox reprocessing, THORP, waste management decommissioning and reactors, Sellafield

5) Ken G. Jackson, Director, THORP Division, Sellafield

6) Stuart Don, Director, Waste Management and Decommissioning Division, Sellafield

7) Alan Dobson, Manager, Vitrification Plant, Sellaf eld

E. Building Research Establishment:

1) J.B. Menzies, Assistant Director, Geotechnical and Structural Engineering

2) T. Freeman, Seabed Disposal

3) C.M. Cooling, Continental Disposal

F. Department of the Environment:

1) Frank S. Feates, Director, Her Majesty's Inspectorate of Pollution

2) Steven Brown, Research, Her Majesty's Inspectorate of Pollution

G. Institute of Oceanographic Sciences:

1) Colin Summershayes, Director

2) R.B. Whitmarsh, Nuclear Waste

H. Ministry of Agriculture, Fisheries and Food:

1) D.J. Garrod, Director, Fisheries Research

I. Nuclear Electric:

1) John G. Collier, Chairman

J. Nuclear Installations inspectorate:

1) E.A. Ryder, Chief Inspector, Nuclear Installations

2) J.S. MacLoud, Overseas Liaison

K. U.K. Nirex, Limited: 
1) P. Tom McInemey, Managing Director

2) Maurice E. Ginniff, Technical Program

L National Radiation Protection Board:

1) Roger H. Clark, Director

2) B. Holliday, Assistant Director, Environmental Sciences

M. Scottish Nuclear Limited:

1) James Hann, Chairman

\subsection{NUCLEAR FUEL PRODUCTION}

5.1 STRATEGY: The U.K actively supports all aspects of nuclear fuel production for its nuclear power and defense programs, using both government and industrial agencies (IAEA 1988)

5.2 URANIUM RESOURCES: No significant uranium resources have been found in the U.K (NEA 1989C)

5.3 URANIUM PRODUCTION: The U.K procurement strategy is to diversity its uranium supply sources among the major producing countries and, where practicable, among suppliers within those countries; its policy is to maintain a stockpile equivalent to 2 years forward uranium requirements; the estimated reactor-related requirements are (NEA 1989c):

1990-1900 MTU

1995-1700 MTU

2000-1700 MTU

\subsection{URANIUM CONVERSION}

A. The U.K has several uranium corversion facilities (IAEA 1988):

1) BNFL/Springfields $-10,000 \mathrm{MT} / \mathrm{y} \mathrm{UO}_{2}$ from yellowcake

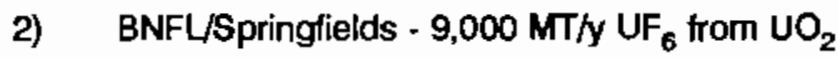

3) BNFU/Springfields - 1,000 MT/y UF $\mathrm{N}_{6}$ from recycled $\mathrm{UO}_{3}$ (startup in 1993)

4) BNFL/Springfields - 2,000 MT/y U matal from $\mathrm{UO}_{2} / \mathrm{UF}_{4}$ for Magnox fuels

B. BNFL is using the Integrated Dry Route (IDR) process for manufacture of $\mathrm{UO}_{2}$ from enriched $\mathrm{UF}_{6}$ and is marketing the process worldwide; the process converts uranium hexafluoride directly to ceramic-grade uranium dioxide in a single rotary kiln unit operating at $600-800^{\circ} \mathrm{C}$ (NE 3-4/87b; BNFL 1988; NUKEM 7/90)

5.5 URANIUM ENRICHMENT: BNFL operated a gaseous diffusion plant at Capenhurst until 1982; this has been replaced by a URENCO gas centrifuge plant, also at Capenhurst; the capacity of the URENCO plant, owned jointly by the U.K, the Netherlands and the FRG, is $800 \mathrm{kSWU} / \mathrm{y}$; expansion will add $700 \mathrm{kSWU} / \mathrm{y}$ in 1991 (IAEA 1988; NF 7/9/90) 
UNITED KINGDOM

\subsection{FUEL FABRICATION}

A. BNFL produces all of the nuclear fuel required in the U.K; two fabrication facilities are operating at Springfields, a 1300-MT/y plant for Magnox fuels and a 300-MT/y plant for AGR fuels (IAEA 1988)

B. BNFL is also building a new fabrication plant at the Springfields site for AGR fuels (230 MT/y) and for PWR fuels (70 MT/y); operation of the new tacility is planned for 1995 (NN 9/89)

C. BNFL also operates a small facility (6 MT/Y) for fabrication of FBR fuels and is planning, with the UKAEA, a demonstration facility for fabrication of LWR/MOX fuels (5 MT/Y) at Sellafield; the LWA/MOX facility will be expanded to $50-100 \mathrm{MT} / \mathrm{y}$ by the late 1990 S (IAEA 1988; NWN 11/2/89)

\subsection{FUEL RECYCLE}

6.1 FUEL REPROCESSING: BNFL reprocesses Magnox fuels (uranium metal clad in magnesium alloy) at Sellafield and is constructing a reprocessing plant (THORP) for AGR and PWR fuels at Sellafield; the UKAEA operates reprocessing facilities for materials testing and fast reactor fuels at Dounreay in northern Scotland; both sites service domestic and foreign customers

A. Metal fuel reprocessing at Sellafield: the first reprocessing in the U.K. began in 1952 at Sellafield (then Windscale) on metal fuels for the weapons program; a second facility was commissioned in 1964 to reprocess Magnox fuel from the U.K civilian nuclear power reactor program; by $1989,30,000 \mathrm{MTU}$ of spent Magnox fuel had been reprocessed (Mellinger 1984; Heafield 1987; IAEA 1988; Robinson 1989; Sills 1989)

B. Oxide fuel reprocessing at Sellafield: in the late 1960s and early 1970s, a head-end was added to each of the metal fuel reprocessing facilities for stainless steel (AGR) and zircaloy-clad (LWP) oxide fuels; about 70 MTU of oxide fuel was reprocessed between 1969 and 1973; a new reprocessing facility (THORP) is under construction at Sellafield with a planned startup date of 1992 (Mellinger 1984; Heafield 1987; Robinson 1989; NF $5 / 28 / 90)$

C. Metal fuel reprocessing at Dounreay: a small facility was commissioned at Dounreay in 1959 for uranium fuel from the Dounreay Fast Reactor (DFP); it was used to reprocess materials test reactor fuels from foreign sources during 1962 to 1973 and is now being offered for additional reprocessing of foreign fuels; contracts have been signed with reactor operators in the FRG, the Netherlands, and Spain (Mellinger 1984; IAEA 19B8; NN $6 / 90 ;$ NWN 9/20/90)

D. Oxide fuel reprocessing at Dounreay: a mechanical head-end was added to the small reprocessing facility at Dounreay in 1980 to permit reprocessing of the plutonium-containing fuel from the Prototype Fast Reactor (PFF); the facility is still operational; the British government recently approved Dounreay as the site for the $80 \mathrm{MT} / \mathrm{y}$ European Demonstration Reprocessing Plant (EDRP), part of the joint European fast breeder program (Mellinger 1984; Bailey 1987; IAEA 1988; NWN 11/2/89) 
6.2 PLUTONIUM/URANIUM RECYCLE: The U.K has recycled plutonium in its fast reactor, the PFR, and is recycling uranium recovered from AGR fuels (IAEA 1988; NEA 1989b; NN 5/90; NUKEM 7/90)

A. The Prototype Fast Reactor (PFR) at Dounreay has been operating on mixed oxide fuel produced at Sellafield and Cadarache in France and some PFR fuel has been reprocessed and the plutonium has been retabricated and re-irradiated in the PFR

B. Though the U.K has not recycled plutonium in its thermal reactors, BNFL has produced up to 3 MT of fuel at up to $7 \%$ plutonium for use in other European reactors in the 1960s; BNFL and AEA Technology are cooperating on a $5 \mathrm{MT} / \mathrm{y}$ PWR MOX demonstration facility at Sellafield to be operational in 1993

C. Over 15,000 MT of depleted uranium has been recovered by reprocessing Magnox fuel, converting it to $\mathrm{UF}_{6}$ at Springfields, enniching it at Capenhurst and refabricating it into fuel at Springfields

D. By March 31, 1988, BNFL held 48.5 MT of recovered plutonium under imternational safeguards; of this amount, 31 MT were owned by CEGB and SSEB, 2 MT by the UKAEA and 15.5 MT by BNFL and its foreign customers (NF 3/20/89a)

6.3 RESEARCH AND DEVELOPMENT: The U.K is involved in nuclear fuel reprocessing with recycle of the recovered plutonium and uranium and conducts R\&D to support those efforts; the R\&D is conducted primarily by AEA Technology and BNFL in support of reprocessing of Magnox, AGR and PWR fuels at Sellatield, reprocessing of materials testing reactor and fast reactor fuels at Dounreay, and fabrication of MOX and fast reactor fuels at Sellafield, Springfields and Dounreay (Dounreay 1985; UKAEA 1986; Harwell 1987; BNFL 1988; NEN 6/89; NEN 10/89; Jenkins 1989; Shaw 1989)

\subsection{PROGRAM/FACILITIES COSTS}

A. BNFL's investment in its reprocessing and waste treatment facilities at Sellafield through the year 2000 is expected to total 5.5 billion pounds (U.S. $\$ 9.35$ billion); of this, about 1.7 billion pounds (U.S. $\$ 2.9$ billion) are being channeled into waste management facilities (NN 3/90)

B. BNFL's new oxide fuel fabrication complex, NOFC, which is being built near Springfields, is expected to cost 125 million pounds (U.S. $\$ 200$ million) (NF 4/2/90)

C. The proposed European Demonstration Fast Reactor Reprocessing Plant (EDRP) approved for Dounreay will cost an estimated 350 million pounds (U.S. $\$ 560$ million) (NF $10 / 30 / 89)$

D. The BNFL/AEA Technology pilot plamt for MOX fueis that is being built at Sellafield will cost an estimated 15 million pounds (U.S. \$25 million); expansion of the facility from a capacity of $5 \mathrm{MT} / \mathrm{y}$ to $50 \mathrm{MT} / \mathrm{y}$ in the late 1990 s will cost an estimated 150 million pounds (U.S. $\$ 250$ million) (NF 4/16/90)

\subsection{SPENT FUEL STORAGE AND TRANSPORT}

7.1 SPENT FUEL ARISINGS: The U.K has been reprocessing spemt fuel since the early 1950s; thus, the amount of spent fuel in storage represents the unreprocessed backlog in reactor 
storage basins and away-from-reactor storage facilities; the IAEA estimates that the U.K. would produce 39,750 MTU of spent fuel in 30 years of operation of its present nuclear plants (IAEA $5 / 20 / 88)$

7.2 FUEL ASSEMBLY CHARACTERISTICS: The U.K operates six generic types of reactors producing spent fuel: 1) the Magnox reactors; 2) the AGAs; 3) the future PWR LWR, Sizewell B; 4) the SGHWR at Winfrith; 5) the PFR at Dounreay; and 6) the materials test reactors (MTRS)

A. The $24 \mathrm{CO}_{2}$-cooled, graphite-moderated Magnox reactors vary in size from $60 \mathrm{MWe}$ to $655 \mathrm{MWe}$ each; a fuel assembly, or pin, consists of natural uranium metal clad in a magnesium alloy (Magnox) and varies in length from 74 to $110 \mathrm{~cm}$ and in diameter from 2.9 to $5.0 \mathrm{~cm}$; the burnup of the fuel ranges from less than 4000 to $5400 \mathrm{MWd} / \mathrm{MTU}$ (NEI 11/90)

B. The $14 \mathrm{CO}_{2}$-cooled, graphite-moderated Advanced Gas Reactors (AGR) are of one size-$660 \mathrm{MWe}$ each; fuel assemblies contain 36 pins each, fabricated of $\mathrm{UO}_{2}$ clad in stainless steel; the length is about $100 \mathrm{~cm}$; enrichments vary from 2.11 to $2.77 \%$; the fuel is irradiated to 1800 to $21,000 \mathrm{MWd} / \mathrm{MT}$ (NEl 11/90)

C. The one PWR under construction, Sizewell B, is a 1258-MWe unit; it contains 193 fuel assemblies; each assembly contains 264 rods on a $17 \times 17$ pitch and is cooled with water; the fuel is $\mathrm{UO}_{2}$ enriched to $3.1 \%$ and clad in zirconium; the rod length is $385 \mathrm{~cm}$ and the outside diameter is $0.95 \mathrm{~cm}$ (NEl 11/90)

D. The Steam Generating Heaw Water Reactor (SGHWR) at Winfrith has a capacity of $100 \mathrm{MWe}$; the core has a tube design containing 104 fuel assemblies that use water as a coolant and heavy water as a moderator; each assembly contains 57 rods on a $17 \times 17$ pitch; the rods are $380.5 \mathrm{~cm}$ long and have a diameter of $1.22 \mathrm{~cm}$; the fuel is $\mathrm{UO}_{2}$ enriched to 2.8-3.9\%; cladding is zirconium (NEI 11/90)

E. The 270-MWe Prototype Fast Reactor (PFR) at Dounreay uses a $\mathrm{UO}_{2} / \mathrm{PuO}_{2}$ fuel clad in stainless steel and cooled with liquid sodium; plutonium content varies from 24 to $30 \%$; the reactor contains 78 assemblies, each containing 325 fuel pins (NEI 11/90)

F. The U.K. has built four Materials Testing Reactors (MTRs): two at Sellafield, one at Dounreay and one at Aldermaston; all have been shut down; these reactors use assemblies fabricated in various designs of highly enriched uranium alloyed with aluminum and clad with aluminum (Fellingham 1988a; NEN 4/90)

7.3 SPENT FUEL STRATEGIES: U.K.'s strategy for spent fuel management revolves heavily around fuel reprocessing; because of fuel cladding corrosion in water storage, Magnox fuels must be reprocessed soon after irradiation (within 6 to 12 months) or moved into dry storage, which allows a longer storage period (i.e., several years); a dry storage facility has been built at Wylfa for Magnox fuels; AGR fuel cladding, while more durable than that of Magnox fuels, also suffers from corrosion in water, and wet storage is limited to about 3 years; dry storage of AGR spent fuel is also being considered to provide more flexibility in planning reprocessing campaigns; the capacity of the water basin at the one PWR I.WR under construction is sufficient for 18 years of operation (Wilkinson 1987; Sills 1989)

7.4 WET STORAGE: Except for one dry facility adjacent to the Wylfa reactor station, all interim storage of spent fuel in the U.K. is done in water basins; both at-reactor (AR) and away-fromreactor storage (AFR) are used, with the AFR storage being located at Sellafield 
A. The major AFR storage basins in the U.K (all at Seltafield) have storage capacity for $3300 \mathrm{MTU}$ of Magnox fuels and $3850 \mathrm{MTU}$ of AGR/LWR fuels; the new THORP reprocessing plant will add another $3200 \mathrm{MTU}$ of capacity for AGR/LWR fuels (IAEA 1988)

B. Magnox fuels are stored in water at the reactor for only a short period before being transported to Sellafield; the B30 facility for Magnox fuels at Sellafield was put into operation in 1962 with a capacity of $1500 \mathrm{MTU}$; a new storage and decanning facility, the Fuel Handling Plant (FHP), was placed in operation in 1986, increasing the storage capacity by another 2550 MTU if used only for Magnox fuels; because of corrosion, storage of Magnox fuel in water is limited to about one year (NEA 1986; IAEA 1988)

C. AGR fuels are stored in water at the reactor for only a short period before being transported to Sellafield; a water basin, Pond 4, was put into operation at Sellafield in 1981 to provide storage capacity for 550 MTU of AGR huets; the Fuel Handling Plant, installed in 1986, offers an additional $1680 \mathrm{MTU}$ of capacity if used only for AGR assemblies; the Receiving and Storage Facility that is being constructed with THORP will add another 3200 MTU of capacity; it is currently considered prudent not to store AGR fuel in water for more than a decade (BNFL 1985; NEA 1986; LAEA 1988; Robinson 1989)

D. Storage of foreign spent fuels (MTR, Magnox) is done in the water basins at Sellafield with some MTR fuel being stored in water at Dounzeay; the B27 pool at Sellafield has a capacity of 2300 MTU of LWR fuels and the 3200 MTU THORP Receipt and Storage Facility will be used for both AGR and LWR fuets (Fellingham 1988a; IAEA 1988)

E. The spent fuel from the SGHWR is currently stored 2-5 years in the reactor water basin at Winfrith; the fuel is transported to Sellafield and stored in one of the water basins for eventual reprocessing in THORP (Fellingham 1988b)

F. Spent fuel from the PFR at Dounreay is stored briefly in sodium, then cleaned of sodium and transferred to the Irradiated Fuel Store Buffer Pond (IFBS) to await transfer to the Dounreay Fast Reactor Reprocessing Plant; the facility consists of a $13 \times 17$ array (247 channels) of stainless steel storage tubes set in porous concrete; canned fuel is placed in the tubes which are filled with water to a level $1.37 \mathrm{~m}$ above the top of the open tubes (Bates 1987)

7.5 DRY STORAGE: Because of corrosion problems with Magnox and AGR fuels stored in water, the U.K. has built a dry storage facility for Magnox fuets and is building a dry storage facility for AGR fuels

A. Design of a dry storage system for Magnox fuets was initiated in the 1960 s and the first three dry storage vaults, using $\mathrm{CO}_{2}$ as a cookant, were completed in 1976 at the Wylfa power station; two additional vaults, using air cooling, were commissioned in 1979, resulting in a storage capacity of $700 \mathrm{MT}$; some spent fuel has been in storage at Wylfa for as long as 14 years (Maxwell 1982; NEA 1986)

B. Consideration of dry storage of AGR fuets has been underway in the U.K. for several years to increase storage periods and provide additional flexibility in planning reprocessing schedules; in 1989, work began on an 840-MT air-cooled facility located at the Heysham power station (NEA 1986; NW 9/22/88; NWN 7/13/89)

7.6 TRANSPORT: The U.K. has been involved in the transport of spent fuel since the start of its nuclear program; the nuclear ejectric utilities are responsible for transport of spent fuel arising in their power stations while BNFL handles spent fuel arising in the BNFL-operated Calder Hall 


\section{UNITED KINGDOM}

and Chapelcross stations; BNFL also transports spert fuel within Europe and between other countries and the U.K; transport is primarily between the power station and the Sellafield reprocessing plant but includes transport from power stations to the Wylia interim dry storage facility

A. After cooling at the reactor, Magnox fuel is loaded into transport casks for road and rail transport to BNFL's reprocessing plant at Sellafield; the cask for Magnox fuel is designed to transport about 3 MT of fuel in a wet condition; each package weighs about 50 MT loaded and is capable of heat loadings to about $6 \mathrm{~kW}$ (Mummery 1989; Sills 1989; Gowing 1990; Mummery 1990)

B. AGR fuel is transported by truck and rail to Sellafield in casks similar to the Magnox fuel casks (Mummery 1989; Sills 1989; Gowing 1990; Mummery 1990)

C. Magnox and LWR spent fuel shipped to Sellafield from foreign reactors is transported in a wet condition by Pacific Nuclear Transport Limited (PNTL) using 150 BNFL-designed "Excellox" casks, Transnucleaire-designed casks, and flasks derived from a CEGB-design for Magnox fuels; PNTL, a subsidiary of BNFL, operates a fleet of six ocean-going ships for this purpose (Salmon 1987; Kovan 1988; Gowing 1989; Coulthart 1990; Gowing 1990; Boyer 1990)

D. New transport casks are being developed for spent fuels with increased burnup, for spent mixed oxide fuels, and for vitrified high-level wastes being returned from Sellafield to the country of origin (BNFL. 1989a; NEl 9/89; Gowing 1990)

E. BNFL operates two cask maintenance facilities at Sellafield: one for Magnox fuel casks and one for LWR fuel casks (BNFL 1989a; Coulthart 1990)

F. BNFL operates a cask decontamination facility at Sellafield (BNFL 1989a)

\subsection{RESEARCH AND DEVELOPMENT}

A. Wet Storage: Because of the relatively high corrosivity of Magnox and AGR fuel cladding in water, the U.K. is performing R\&D disected at lengthening the storage period of these fuels by control of water chemistry in the storage basins and fuel canning; this R\&D is concentrated mainly at Sellafield (BNFL) and the nuclear power stations (BNFL 1985; Addison 1987; Conboy 1990)

B. Dry Storage: The U.K is now considering greater use of dry storage to extend the allowable storage period of Magnox and AGR fuels; R\&D in support of this is being performed mainly by Nuclear Electric, formerly CEGB, and directed at the dry store planned at Heysham for AGR fuels (NEA 1986; NWN $7 / 13 / 89$ )

C. Transportation: Transportation of spent fuel by the U.K. is a relatively mature industry; R\&D is directed primarily at optimizing the transportation casks and systems and accommodating anticipated changes in spent fuel characteristics (higher burnup, MOX fuels, and breeder reactor fuels); the R\&D is performed by BNFL, Nuclear Electric and the numerous contractors employed by those firms (BNFL 1989; Holt 1989; Wood 1989) 
D. Testing: A cask development center has been established at Winfrith where there are laboratory facilities for conducting a range of cask testing, including fire and decontamination tests (UKAEA 1986; Kovan 1988; IAEA 1989)

\subsection{PROGRAM/FACILITIES COSTS}

A. In 1989 , the cost of interim storage of spent fuel was estimated at $\$ 85,000$ to $\$ 250,000$ (U.S.) per MT of uranium depending upon the quantity of fuel and timing of delivery (NEA 1990)

B. The cost of the 840 MTU dry storage facility being built at Heysham for spent AGR fuels is estimated at $\$ 390$ million (U.S.) (NW 9/22/88; NWN 7/13/89)

C. The cost of Pond 5 at Sellafield (Central Spent Fuel Handling Plant for Magnox and AGR Fuels) with a capacity of $1680 \mathrm{MT}$ of AGR fuels was $\$ 560$ million (U.S.) (BNFL 1985; NEI 8/86)

D. In 1987, the purchasing costs for a cask (24 PWR or 60 BWR fuel elements of 21 canisters of vitrified $\mathrm{HLW}$ ) for sea transport was estimated at $\$ 2$ million (U.S.); the cost of an ocean-going transport ship at $\$ 18$ million (U.S.); and the cost of the port terminal at $\$ 15$ million (U.S.) (Salmon 1987)

8.0 WASTE CONDITIONING, STORAGE AND TRANSPORT: The major sources of radioactive wastes in the U.K. are Nuclear Electric (formerly CEGB), Scottish Electric (formerly SSEB), AEA Technology, BNFL, AWRE and Amersham International (irradiation sources); these wastes may be treated and most are stored on the generator's site except for low-level wastes which are transported to Drigg or Dounreay for disposal in near-surface disposal facilities

\subsection{WASTE DEFINITIONS (Nirex 1986; Dotchin 1988; Johnson 1990)}

A. $\quad$ HLW: High-level wastes are those wastes in which the temperature may rise sufficiently as a result of radioactivity that it must be taken into account in designing storage or disposal facilities; deep geologic disposal is required

B. LLW: Low-level wastes are those wastes active with sufficient radioactivity to be subject to control but do not exceed $4 \mathrm{GBq}(120 \mathrm{mCi}) / \mathrm{MT}$ alpha or $12 \mathrm{GBq}(360 \mathrm{mCi}) / \mathrm{MT}$ beta-gamma activity

C. LLW: Intermediate-level wastes are those wastes in between HLW and LLW

D. Very LLW: Very low-level wastes are those wastes containing less than $0.0004 \mathrm{GBq}$ $(10 \mu \mathrm{Ci}) / \mathrm{MT}$ alpha or $0.02 \mathrm{GBq}(540 \mu \mathrm{Ci}) / \mathrm{MT}$ beta-gamma activity; such wastes can be disposed with ordinary domestic waste

8.2 WASTE ARISINGS: the accumulations and estimated future arisings of conditioned radioactive wastes in the U.K. are shown below (Flowers 1989): 


Waste Type
NLW
Medicine, Power Industry
Medustry \& Research

$\underline{\text { LW }}$

\begin{tabular}{|c|c|c|}
\hline \multicolumn{3}{|c|}{$\begin{array}{c}\text { Cumulative } \\
\text { Arisings }\left(1000 \mathrm{~m}^{3}\right)\end{array}$} \\
\hline $1 / 1 / 86$ & 2000 & $\underline{2030}$ \\
\hline 1.6 & 380.0 & 690.0 \\
\hline 0.83 & 110.0 & 290.0 \\
\hline
\end{tabular}

$\begin{array}{rrr}50.0 & 85.0 & 110.0 \\ 6.3 & 13.0 & 40.0\end{array}$

\section{HLW}

Nuclear Power Industry

$\begin{array}{lll}0.43 & 0.89 & 1.4 \\ 0.006 & 0.025 & 0.25\end{array}$

8.3 STRATEGY: Responsibility for the development of a national strategy for the management of radioactive wastes in the U.K. lies with the Secretary of State for the Environment, acting in conjunction with his ministerial colleagues; the current national strategy involves the use and development of a range of treatment/conditioning, storage and disposal facilities and a continuing program of research and assessment to ensure that each type of waste is disposed in the most appropriate way (Dotchin 1988; Flowers 1989; NEA 1990)

A. High-level liquid wastes resulting from reprocessing activities are stored in stainless steel tanks contained in concrete vaults until they can be fed to the vitrification facilities that recently became operational; the vitrified wastes will be stored in air-cooled vaults for an undefined period (e.g., 50 years), sufficient for the high-level wastes to decay to the intermediate-level, at which time they can be disposed as ILW

B. Intermediate-level wastes are treated and conditionec by bitumenization, cementation, or compaction and placed in an interim storage facility until a deep geologic repository for ILW/LLW becomes available, expected to be in 2005

C. Low-level wastes are treated and conditioned by bitumenization, cementation, compaction, or incineration, and either disposed in near-surface engineered structures at Drigg in Cumbria or stored onsite until the deep geologic repository for ILW/LLW becomes available

8.4 HLW IMMOBILIZATION: Processes for the vitrification of licquid high-level wastes have been studied since the U.K.'s nuclear program began; the original FINGAL work (in-canister batch melting and conversion to glass) was completed in the 1960); development resumed in 1972 with the intention to implement the vitrification at Sellafield based upon the newer pot-type HARVEST process; a comparison of the HARVEST process and the French AVM process in 1979-80 led to a decision by BNFL to adopt the AVM process based upon its advanced development and higher throughput; construction of the Windscale Vitrification Plant (WP) was completed and commissioning started in 1989; radioactive operation began in 1990 on Magnox waste, and it is expected to begin processing LWR wastes fom THORP in 1992 (Heafield 1989; NEN 6/89; NUKEM 2/90; NEI 3/90; DT 8/15/90)

A. The French AVM process adopted for use at Sellafield employs a continuous rotary inclined-tube calciner and an elliptical cross-section metallic melter; two lines have been 
installed that are capable of vitritying the high-level wastes from 2500 MT of Magnox fuel per year and producing 600 canisters per year, each containing 150 liters of glass (Heafield 1989; NEN 6/89)

B. The product canisters are $430 \mathrm{~mm}$ in diameter by $1340 \mathrm{~mm}$ high and are fabricated of Type 309 stainless steel; each canister contains 150 liters of borosilicate glass (20 wt\% waste oxides) and weighs $470 \mathrm{~kg}$; the maximum heat output is $2.5 \mathrm{~kW}$ (Heafield 1989)

8.5 LLW/ILW CONDITIONING: As is the case with high-level wastes, the U.K has been developing and implementing LLW/ILW conditioning processes since the start of its nuclear program; a variety of processes such as evaporation, ion exchange, precipitation, compaction, incineration, and cementation are employed following the U.K. strategy of seeking the conditioning processes most suitable for a given application; in recent years, the emphasis placed upon environmental protection has resulted in several major conditioning facilities being constructed

A. Sellafield: At Sellafield, low- and intermediate-level radioactive wastes arise mainly from activities related to spent fuel storage (Magnox sludge) and reprocessing; the HLW Waste Vitrification Plant that began operation in 1990 will create additional LLW/LW; major improvements are being implemented to reduce the radioactivity in the liquid effluents discharged to the North Sea, to reduce the plutonium content of waste materials, and to immobilize several types of wastes (Chamberlain 1988; Electrowatt 1988; Mogg 1988)

1) SIXEP: The Site lon Exchange Effluent Plant (SIXEP) is the most recent of several improvements made to reduce the radioactivity of the water in fuel storage basin water; this radioactivity is a major contributor to that in the liquid effluent discharged from the Sellafield complex to the North Sea; filtration and ion exchange are used to clean the basin water with the filter residue and spent ion exchange resin being placed in storage pending addition of cementation capability; the facility began operation in 1985 (BNFL 1985; Howden 1987; Mogg 1987)

2) EARP: The Enhanced Actinide Removal Plant (EARP) is being installed to reduce the alpha content of the intermediate-level liquid wastes from reprocessing operations; the process uses floc precipitation and ultra filtration; the concentrated floc and filter residue are fixed in cement for storage and disposal; startup of the plant is expected in 1992 (Howden 1987; Mogg 1988; Conboy 1990)

3) EP-1: The Magnox Swarf Encapsulation Plant (EP-1) is being constructed to fix into cement the cladding residues from Magnox fuel decanning operations; these residues are presently stored under water in silos; operation is expected to begin in 1990 (Howarth 1988; Mogg 1988)

4) EP-2: The Thorp Waste Encapsulation Plant (EP-2) is being constructed to fix intermediate-level wastes from the reprocessing operations in the Thorp facility; similar in concept to EP-1, operation is expected to coincide with the startup of the Thorp plant in 1992 (Howarth 1988; Mogg 1988)

5) WTC: The Waste Treatment Complex (WTC) is under construction at Sellafield to treat plutonium-contaminated solid wastes; capabilities for sorting, compaction, cementation and, eventually large-scale volume reduction, are to be provided; startup is anticipated in the early 1990s (Chamberlain 1988) 
6) New Compaction Facility: BNFL has recently decided to build a new compaction facility for low-level wastes at either Sellafield or the Drigg site; such a facility is expected to extend the operating life of the Drigg disposal facility for several decades (Johnson 1990; NW 9/27/90; NWN 10/4/90)

B. Dounreay: As in the case of Seliafield, low- and intermediate-level wastes arise mainly from operations involving spent fuel handling/storage and reprocessing; Dounreay is also involved in the development of breeder reactor fuels, which produces plutonium-contaminated waste; liquid radioactive wastes are conditioned by a flocculation treatment with the liquid effluent being discharged to the sea and the concentrated residue being stored onsite; alpha-contaminated solid wastes are stored onsite while low-level solid wastes, some after incineration, are disposed to an onsite burial ground; a cementation plant began operations in 1988 on ILW liquid wastes from reprocessing operations and the Residues Recovery Plant is being built to process wastes from MOX fuel fabrication (Dounreay 1985; UKAEA 1986; Bailey 1987; NE 5/88; Electrowatt 1988; Patrick 1988)

C. Winfrith: The activities at the AEA Technology's Winfrith Technology Center include operation of the 100-MWe SGHWR, four research reactors, fuel examination, reactor safety studies, cask development and R\&D; all nuclear operations produce low-level radioactive wastes; reactor operations and the fuel examination programs produce intermediate-level wastes; the general practice for managing liquid wastes has been to use settling basins, storing the resulting sludges and discharging the effluerit to the sea; solid wastes are packaged and either stored or are transported to Drigg for disposal; three improvements in waste management are underway (UKAEA 1986; Electrowatt 1988; Barents 1990; Lloyd 1990):

1) Stratos: The Sludge Homogenization Plant (Stratos) will recover and treat the accumulated sludge for fixation in the RTP

2) RTP: The Radwaste Treatment Plant (RTP) will provide the capability for cementing both sludges and solid wastes and packaging them in 500-liter stainless steel drums

3) TRS: The Treated Radwaste Store (TRS) will provide interim storage for the cemented wastes

D. AWRE: The Atomic Weapons Research Establishment (AWRE) at Aldermaston produces low beta-gamma, alpha-contaminated wastes; conditioning operations include sorting, shredding, washing and incineration; improvements underway include a new liquid waste treatment plant, a new solid waste treatment (sorting, shredding, washing, concreting) plant, and a new size-reduction facility for large contaminated plant and equipment items (DOE-JIO 1986; NEI 3/87)

E. Harwell: The Harwell Laboratory is the largest R\&D center for AEA Technology (formerly the UKAEA) and produces intermediate- and low-level wastes from programs involving research reactor operation, accelerators, radioisotope production, post-jrradiation fuel and sample analyses, and radiochemicai research; conditioning operations for solid wastes include collection, sorting, washing, compaction, and incineration; liquids are stored or, if sufficiently low in radioactivity content, roleased to the nearest waterway; Harwell is also a collection station for industrial and institutional wastes which are eventually transported to Drigg (UKAEA 1986; Electrowatt 1988) 
F. Nuclear Utilities: The nuclear electricity-generating stations operated by Nuclear Electric, Scottish Nuclear and BNFL produce low- and intermediate-level radioactive wastes in the forms of liquids, combustible and non-combustible trash, sludges, spent ion exchange resins, and fuel hardware; conditioning of the liquid wastes involves a variety of treatments: collection, filtration, evaporation, and ion exchange, with the residues being packaged for storage or immobilized as solid wastes; conditioning of the solid wastes involves collecting, sorting, shredding, compacting, incinerating and packaging; improvements underway or being contemplated include cementation of sludges and ion exchange resins, use of mobile compactors, use of supercompactors and the reduction of the volume of sludges collected at these power stations over an extended period (Curry 1987; Haigh 1987; Electrowatt 1988; NWN 3/23/89a; NEI 7/89; Fincher 1990; ATW $6 / 90))$

G. Other Sites: Lesser amounts of low- and intermediate-level radioactive wastes are produced at National Electric's Berkeley and Bradwell Laboratories and at BNFL's Capenhurst, Springfields and Risley installations; some wastes also originate at the bases for nuclear-powered navy vessels; the Royal Navy is building a storage facility for those wastes at Fife, Scotland; management of these wastes is similar to that at other installations (Electrowatt 1988; NWN 6/2/88)

8.6 AIRBORNE WASTES TREATMENT AND IMMOBILIZATION: The principal method of treating gaseous effluents from nuclear operations is filtration; filters, when loaded, are removed and disposed as low-level wastes if the radioactivity is beta-gamma and as intermediate-level wastes if the radioactivity is atpha; after removal, the filters may be compacted or incinerated depending on the installation; scrubbing is employed in selected cases with the scrubbing solutions being treated and disposed with other liquid wastes; selected gaseous radionuclides such as iodine129 and carbon-14 from reprocessing operations are recovered on adsorbents which are treated as solid wastes; electrostatic precipitators are also employed in selected cases (Haigh 1987; NEI 8/87; Electrowatt 1988; NEI 3/90b)

8.7 LLW/ILW STORAGE: Low-level wastes are stored on the generator's site briefly until transported to the near-surface disposal site at Drigg; intermediate-level wastes not suitabie for shailow-land disposal are held in interim storage pending access to a LLW/LW geologic repository now under development; long-term interim stores for ILW are being built at several sites, many in connection with the conditioning processes that are being installed

A. Sellafieid: BNFL is building interim stores at Sellafield for the cemented cladding from Magnox, AGR and LWR fuels; for the graphite removed from AGR fuels; for the stainless steel hardware from AGR fuels; for the cemented residues from the EARP (all ILW); the facility will also store miscellaneous beta-gamma wastes and low beta-gamma, alphacontaminated wastes (Wilson 1990)

1) Encapsulated Product Store: Cemented magnox, stainless-steel, and zirconium cladding cemented in standard Nirex 500 -liter drums are placed in a seismicresistant engineered structure equipped with a ventilation system to remove decay heat and radiolytic gases; the store has a capacity of 12,544 drums

2) Graphite Store: Graphite moderator material removed from AGR fuels is placed in drums and stored in an open structure to which access is provided through roof slabs; because of the low-radioactivity levels of the waste material, the store is not designed to be seismic-resistant and no ventilation is provided; the store has a capacity of 4,880 drums stacked five high in 16 storage bays 
3) Stainless Steel Store: Fuel assembly hardware from dismantling AGR fuels is drummed and placed in an engineered storage structure in which the drums are placed five high, in separate concrete tubes, in a hexagonal array set in a concrete monolith; each tube is capped with a concrete plug; the store has a capacity of 680 drums; forced-air ventilation is used

4) Waste Packaging and Encapsulation Plant Store: Drums of encapsulated ferric oxide floc from the EARP facility and maintenance waste solids from liquid effluent treatment plants are placed in a store similar to the Stainless Steel Store but larger; drums are stacked 15 high in the channels formed by a matrix of concrete columns; each channel is capped with a concrete plug; the store is not designed to be seismic-resistant, and it is ventilated by a forced air system

5) Miscellaneous Beta/Gamma Waste Store: Miscellaneous solid wastes packaged in $3.5 \mathrm{~m}^{3}$-concrete-lined steel boxes are stored in an engineered vault; the vault has a capacity of 1,734 boxes arranged in a series of aisles; boxes are moved in the aisles on a rail system and are stacked three high without support; each of the 18 aisles will accommodate 34 stacks of boxes; humidity-controlled ventilation is provided to minimize corrosion of the boxes; a stack of 3 boxes witl not topple in a Design Basis Earthquake

6) Engineered Drum Store: Alpha-contaminated wastes packaged in 200-400-, or $500-$ liter steel drums will be placed in a new engineered store at Sellafield; drums are handled manually with a shielded fork-lift truck; it is planned to inspect and assay $1 \%$ of the drums annually

B. Dounreay: interim stores are in place at Dounreay for high alpha-beta-gamma wastes, for high beta-gamma wastes, and for high alpha wastes; the cementation plant built at Dounreay for ILW from reprocessing operations includes an $800-\mathrm{m}^{3}$ store for the drummed wastes; the stores are concrete vaults designed for retrieval of the wastes which are packaged in 200 -liter drums; the drums are stacked vertically in the vaults, and access is provided from above with shielding blocks provided over the high alpha-betagamma wastes (Bailey 1987; Electrowatt 1988)

c. Winfrith: The Atomic Energy Establishment at Winfrith has interim storage capability for low-and intermediate-level wastes not suitable for disposal at Drigg; it is also building an interim store for unshielded 500-liter drums of cemiented intermediate-level waste from the Waste Treatment Center under construction; the store is an engineered, aboveground, shielded facility in which unshielded 500-liter drums are stacked in an array of spun concrete tubes; void space in the tubes is filled with sand and access is provided from the top; the store has sufficient capacity to hold wastes generated until 2005, when the proposed ILW repository is scheduled to becorne operational (Electrowatt 1988; Lloyd 1988)

D. Harwell: The Atomic Energy Research Establishment at Harwell has several stores for low- and intermediate-level wastes; these stores include water basin storage (for radiation sources), tank storage for liquids, shielded storage for high beta-gamma wastes, and unshielded storage for low beta-gamma wastes; wastes destined for sea disposal in 1982 remain in storage at Harwell (Electrowatt 1988) 
E. FIFE, SCOTLAND: The Royal Navy is constructing an interim store for ILW from nuclearpowered submarines at its Rosyth dockyard at Fife, Scotland; the facility will be ready in 1991 and will have sufficient capacity to hold wastes expected through 2010; before 1983 , these wastes were disposed at sea (NWN 6/2/88)

8.8 HLW STORAGE: High-level wastes are stored at Sellafield and Dounreay adjacent to the reprocessing facilities where they are generated

A. Sellafield: BNFL has operated a storage system for high-level liquid wastes at the Sellafield site for over 30 years; these wastes, which originate from the first cycle of solvent extraction during fuel reprocessing, are concentrated and placed in doublewalled, staintess steel tanks equipped with water cooling coils to remove decay heat; about $1300 \mathrm{~m}^{3}$ of waste are stored in this manner and every fourth tank is used as standby storage

BNFL has also built an air-cooled dry storage facility for storage of the vitrified high-level wastes being produced in the Windscale Vitrification Plant (WWP); the storage facility for the vitrified wastes, located adjacent to the WVP, contains four vaults, each having 200 carbon steel thimble tubes for holding the waste containers; each thimble tube holds 10 canisters; heat is removed by natural convection air flow around the thimbles; the maximum heat load is $20 \mathrm{~kW}$ for a thimble and $3.5 \mathrm{MW}$ for the entire store; storage for at least 50 years is anticipated (Wilkinson 1985; BNFL 1989b; NEl 3/90)

B. Dounreay: High-level liquid wastes produced in reprocessing operations at Dounreay are collected in four $80 \cdot \mathrm{m}^{3}$ tanks located in a concrete vault adjacent to the reprocessing facilities (Bailey 1987)

8.9 TRANSPORT OF WASTES: The transport of radioactive wastes other than spent fuel in the U.K. involves mainly the shipment of low-level wastes from the generator to the Drigg disposal site; in the future, high-level and other wastes from reprocessing spent fuel of foreign origin are expected to be returned to the source; shipments of low- and intermediate-level wastes from their present interim store to the geologic repository will begin atter 2005 (ACSTRM 1988)

A. Low-Level Wastes from Sellafield: The Drigg disposal site in Cumbria is the main disposal site in the U.K. for low-level wastes; a small amount of low-level wastes is disposed onsite at Dounreay; Sellafield, which accounts for over half of the waste sent to Drigg, transports the wastes by train for the 6-km trip; wastes are picked up by the train at various collection points within Sellafield and placed in metal boxes called 'skips"; light waste materials are contained in paper or fiber sacks; heavy materials are enclosed in PVC plastic; rubble and loose earth are not packaged (ACSTRM 1988; Gowing 1990)

B. Low-Level Wastes from Other Sources: Low-level wastes from sources other than Sellafield are transported by truck; most wastes are packaged in plastic sacks and placed in steel drums; after monitoring, the drums are placed in a reusable shipping container, the most common being a strong rigid metal box with a door in the rear; wastes have also been carried in standard commercial ISO containers, either with solid sides and top or in some cases with camvas tops or sides on a steel frame; bulk transport of earth and rubble has been done in similar containers without the drums; large items have on Qccasion been wrapped in PVC plastic and transported on a flatbed truck (ACSTRM 1988)

c. Vitrified High-Level Wastes: With the Windscale Vitrification Plant beginning operation in 1990, a cask is needed to transport canisters of vitrified wastes to the reprocessing 
customers in Japan and Europe; BNFL has been designing a cask for this purpose; similar in design to a spent fuel transport cask, the HLW cask will hold 21 waste canisters and weigh about $110 \mathrm{MT}$; it will be designed for both rail and ship transport; sea shipments are expected to begin in 1994 (NEI 9/89; Gowing 1990; DT 8/15/90)

D. ILW Destined for a Geologic Repository: U.K. Nirex, l_td., working with the waste generators, has developed a standard range of waste packagings for low- and intermediatelevel wastes to be used in transporting wastes to the planned geologic repository; for low-level wastes, these include a 200-liter steel drum (operational wastes), a $3 \cdot \mathrm{m}^{3}$ metal box (wastes unsuitable for drums), and a $12-\mathrm{m}^{3}$ concrete box for large items); for intermediate-level wastes, these include a 500-liter urshielded metal drum (operational wastes), a $3-m^{3}$ unshielded metal box (wastes unsuitiable for the drum), and a $12-m^{3}$ selfshielded concrete box (decommissioning wastes): a 500 -liter drum meeting these criteria has been designed at Winfrith for the new Winfrith Reidwaste Treatment Plant; the lowlevel waste drums will be transported in commercial ISO containers; transport packagings are being designed for the other waste packages (NIREX 1988a; Leeks 1989; Gowing 1990)

8.10 RESEARCH AND DEVELOPMENT: The U.K., as part of its long history of nuclear activities, has conducted an extensive amount of R\&D on waste conditioning, storage and transport; R\&D currently underway emphasizes the reduction of contaminarts in liquid effluents discharged from operating facilities, the characterization of wastes, the reduction of waste volumes, and the fixation of wastes

A. Reduction of Contaminants in Liquid Effluents: Each of the major U.K. nuclear sites has been engaged in a program of lowering the contaminant levels in liquid effluents that are discharged to the sea or a nearby waterway; at Sellatield, R\&D efforts have led to construction of facilities for lowering the radioactivity in storage basins for Magnox fuels (SIXEP) and for reducing the actinide content of reprocessing liquid wastes (EARP) (see Section 8.6); ultrafiltration has been evaluated at Dounreay and AWRE has selected and installed a new liquid waste treatment facility; AEA Technology is investigating precipitation processes, ion exchange, ultralikration, microfiltration and electrical processes for treating liquid wastes (Bailey 1987; NEI 3/87; Chamberlain 1988; Turner 1988; Cross 1989; NEI 8/89; Hooper 1990; Tyson 1990)

B. Characterization of Wastes: Characterization of wastes, particularly low-and intermediate-level wastes, has increased in recent years because of the number of waste treatment improvements being implemented, the increasing costs of disposal at Drigg, and the planning underway by U.K. Nirex, Ltd., for a L.LW/LW geologic repository; this R\&D also covers the assay of waste packages (Davies 1988; Electrowatt 1988; Barlow 1989; Lee 1989; Armitage 1990; Green 1990)

C. Reduction of Waste Volumes: Recent emphasis on the reduction of waste volumes has centered on dissolution of the debris removed from Magnox spent fuel elements and the use of supercompactors to reduce the volume of low-level solid wastes (Haigh 1987; NEI 3/90b)

D. Fixation of Wastes: Considerable R\&D is being expended upon waste fixation, particularly upon high-level waste vitrification, solidification of fuel storage pool and waste collection tank sludges, and alpha-contaminated wastes; R\&D on $\mathrm{HLW}$ vitrification is directed mainly at optimization of the French AVM-type processes being installed at 
Sellalield (see Section 8.4); R\&D on sludge fixation has led to construction of facilities at Sellafield (SIXEP), Winfrith (Radwaste Treatment Plant), and Dounreay (cementation plant) (see Section 8.6)

\subsection{PROGRAM/FACILITIES COSTS}

A. The HLW vitrification plant and product store at Sellafield, patterned after the French AVM system, is costing $£ 250$ million ( $\$ 425$ million U.S.) (NEN 6/89)

B. The two Medium Active Solid Waste Encapsulation Plants being erected at Sellafield will cost $\$ 600$ million ( $\$ 1$ billion U.S.); the first plant, the Magnox Swarf Encapsulation Plant (EP1), was completed at Sellafield in 1990 at a cost of £262 million (\$445 million U.S.) (Heafield 1987; Chamberlain 1988; NEl 12/88)

C. The Site lon Exchange Effluent Plant (SIXEP), which began operation at Sellafield in 1985 to reduce the radioactivity levels in Magnox fuel storage basins, cost \$126 million (\$215 million U.S.) (Howden 1987)

D. The Enhanced Actinide Removal Plant (EARP) recently completed at Sellafield cost 乏140 million (\$237 million U.S.) (BNFL 1989b)

E. The Waste Treatment Complex (WTC) under construction at Sellatield to treat plutoniumcontaminated solid wastes is estimated to cost $\$ 80$ million (\$136 million U.S.)

(Chamberlain 1988)

F. The plant built at the Dungeness nuclear power station for dissolving Magnox spent fuel debris cost 4 million ( $\$ 6.8$ million U.S.) (NE 1-2/89)

G. The capital cost for treating ILW from submarines at Fife is estimated at $£ 4.5$ million (\$7.5 million U.S.) (NWN 6/2/88)

\subsection{DISPOSAL OF NON-HIGH-LEVEL WASTES}

9.1 STRATEGY: At present, the U.K. stores high-, intermediate-, and low-level wastes on nuclear sites and disposes of most low-level wastes at Drigg, near the Sellalield site; some disposal of low- and intermediate-level wastes to the sea bed was done between 1949 and 1982; this practice has been discontinued because of international pressure, though the British government maintains the practice is both sale and practical; in 1983, U.K. Nirex, Ltd. named two locations as the sites for a near-surface repository and for a deep geologic repository; in 1986, the government, following the advice of a legislative committee, stipulated that a near-surface repository could not be used for intermediate-level wastes; at the same time, the U.K. Department of Environment concluded that indefinite storage of waste was unacceptable; these decisions, coupled with a reduction in thisuthorization levels for the Drigg repository, led to a site evaluation program that selected the Sellafield and Dounreay areas as the first locations to be evaluated for construction of deep geologic repositories for low- and intermediate-level wastes; high-level wastes are to be allowed to decay at least $\mathbf{5 0}$ years to the intermediate-level category before a decision is made on their disposal (Electrowatt 1988; Billington 1989; Flowers 1989; Ginniff 1989; NEA 1990) 


\subsection{WASTE DISPOSAL CRITERIA}

A. Disposal at Drigg: The following conditions and limitations apply to waste disposal at Drigg (DOE 1988):

1) The only waste acceptable at Drigg is "relevant waste," which is defined by the Radioactive Substances Act of 1960 as "solid radioactive waste which has been treated or packaged in such a way as to render it so far as is reasonably practicable insoluble in water and not readily flammable'

2) The wastes shall contain less than $4 \mathrm{GBq}(12 \mathrm{C} \mathrm{mCi}) / \mathrm{MT}$ alpha-emitting radionuclides and less than $12 \mathrm{GBq}(360 \mathrm{mCi}) / \mathrm{MT}$ of other radionuclides

3) Annual disposals of the following materials shall not exceed:

Uranium

Radium-226 plus Thorium-232

Other alpha-emitting nuclides

Carbon-14

lodine-129

Tritium

Others (of which the cobalt-60

content shall not exceed $2 \mathrm{TBq}$

or $54 \mathrm{Ci}$ )

$$
\begin{aligned}
& 0.6 \mathrm{TBq}(16.2 \mathrm{Ci}) \\
& 0.03 \mathrm{TBq}(0.8 \mathrm{Ci}) \\
& 0.3 \mathrm{TBq}(8.1 \mathrm{Ci}) \\
& 0.05 \mathrm{TBq}(1.35 \mathrm{Ci}) \\
& 0.05 \mathrm{TBq}(-1.35 \mathrm{Ci}) \\
& 10 \quad \mathrm{TBq}(270 \quad \mathrm{Ci}) \\
& 15 \mathrm{TBC}(405 \mathrm{Ci})
\end{aligned}
$$

4) Disposed wastes shall be covered with at least 1.5 meters of soil or other inert material

5) The concentrations of radionuclides in the leachate collected from the site and released to the environment shall not exceed:

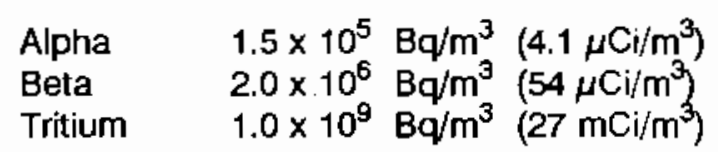

6) Wastes shall be compacted by the best practicable means

B. Disposal in Proposed Deep Geologic Repository: The principles to be applied by the authorizing departments in considering an application for a new disposal facility are (Nirex 1988b):

1) The site should be chosen and the facility should be designed so that the risk or probability of fatal cancer to any memberet the public, from any movement of radioactivity from the facility is not greater than 1 in a million in any one year

2) Future movement of radioactivity from a facility should not lead to a significant increase in the radioactivity naturally occurring in the general location of the facility

3) A site must be selected where it is unlikely that future development of natural resources or of the site will disturb the facility 
4) There must be adequate provision for environmental monitoring, including the determination of background levels, in order to provide a baseline for the assessment of future performance

5) There must be adequate provision for detailed records of the wastes and their location within the facility

6) There must be evidence that, using established technology, the facility can be closed and surface installations removed, and there must be adequate funding for these operations available

7) The necessary arrangements must be made for post-closure institutional control, including the preservation of details of the facility and records of the location and type of waste

9.3 ILW DISPOSAL: From over 500 potential locations, U.K. Nirex, Ltd. has selected candidate sites near Sellafield and Dounreay for development of a deep geologic repository for low- and intermediate-level wastes; preliminary investigations of these sites, both situated in hard, fractured basement rocks, are just starting (Flowers 1989; Beale 1990; Ginniff 1990)

A. The repositories are likely to be at depths between 500 and 1000 meters (Chapman 1989)

B. The conceptual design is an array of 26 horizontal drifts covering an area of $1025 \mathrm{~m} \mathrm{x}$ $610 \mathrm{~m}$; each drift would be $25 \mathrm{~m}$ wide, $35 \mathrm{~m}$ high, and $250 \mathrm{~m}$ long; the drifts would be serviced by two tunnels, one above the other; the upper tunnel would handle the waste loading and backfilling; the lower tunnel would serve for removal of excavated material (Chapman 1989; Beale 1990; Myall 1990a)

C. The combined effects of radioactive decay, chemical reactions and the geothermal gradient may lead to temperatures up to $80^{\circ} \mathrm{C}$ (Chapman 1989)

D. Wastes will be disposed in mild steel containers which will be vented to permit the release of gases generated by the degradation of organic materials in the wastes, and by anaerobic corrosion of metals in the wastes and containers (Chapman 1989)

E. The proposed design of the repository will make use of considerable volumes of cementitious material both as grout in and around the containers, and as bulk backlill (Chapman 1989)

9.4 LLW DISPOSAL: in the U.K., most disposal of low-level radioactive wastes is being done at Drigg, a shallow-land disposal site 4 miles southeast of Sellafield; a small amount is disposed onsite at Dounreay; disposal operations at Drigg began in 1959; the site, now owned and operated by BNFL under terms of an authorization granted by DOE and MAFF, was opened originally to receive low-level wastes from the Sellafield operations; over the years, since it was the only authorized site in England, an increasing amount of low-level wastes from non-Sellafield sources has been accepted by BNFL for disposal at Drigg; beginning in 1987, major improvements have been made that changed the disposal concept from trench burial to engineered structures, with an accompanying increase in disposal costs (Larkin 1988; Bindon 1989; Higson 1989; NW 2/16/89; Johnsoh 1990)

Use of the Drigg facility for disposal of low-level wastes was expected to continue until the geologic repository under development (see Section 9.3) became available; however, BNFL has 
UNITED KINGDOM

recently decided to install a compaction facility for low-level wastes at either Sellafield or Drigg; with compaction, the Drigg facility can accommodate all the low-level waste expected to be generated in Britain over the next 60 years (NW 9/27/90; NWN 10/4/90)

A. The Drigg site has a total area of 270 acres and runs parallel to the coast, about one kilometer from the sea; the geology at Drigg consists of a complex heterogeneous sequence of glacial sediments overlying an irregular surface of red sandstone bedrock; the glacial deposits range from compacted clays through sitts to coarse sand and gravels; only 88 acres are presently authorized for use; within this area there is an essentially continuous clay layer at about 5-8 meters depth (Johnson 1990)

B. Past disposal operations have involved the direct disposal in unlined trenches cut so that the clay layer forms a graded, low-permeability base; infiltrating rain and groundwater was thus directed to the southern end of the trenches, where it was collected by a series of drains and discharged in to the Irish Sea via the Drigg Stream and the River Irt. Wastes were dumped into the trench and covered with at least 1.5 meters of soil and aggregate to restore the site to its original level (Johnson 1990)

C. In recent years, the average rate of arisings from Sellafield (prior to treatment or packaging) has been about $25,000 \mathrm{~m}^{3} / \mathrm{yr}$; this rate is expected to rise to about $40,000 \mathrm{~m}^{3} / \mathrm{yr}$ as new plants come on line; arisings from other sources have in the past amounted to about $13,000 \mathrm{~m}^{3} / \mathrm{yr}$ (prior to treatment or packaging) but recent estimates suggest these sources will drop to about $6,000 \mathrm{~m}^{3} / \mathrm{yr}$ as a result of more careful segregation at the source (Johnson 1990)

D. While maintaining that risk assessments showed that trench disposal at Drigg was radiologically acceptable, BNFL announced in 1987 that a major program of improvements would be implemented; these improvements include (Johnson 1990):

1) capping and provision of groundwater cut-off walls to limit rainwater infiltration and lateral migration of groundwater;

2) the refurbishment of the leachate drainage system;

3) containerization of wastes with compaction where appropriate;

4) provision of below-grade concrete vaults for future disposals

E. A temporary cap of an earthen mound with a slope of 1:25 incorporating an impermeable low-density polyethylene membrane has been constructed over the old, filled trenches; this will be replaced later by a permanent cap incorporating a thick band of clay; a groundwater cut-off wall has been installed around the ncrtheast corner of the site to control the known pathway for leachate migration and to control groundwater outflows and inflows (Johnson 1990)

F. The trench drainage system has been refurbished and flow proportional sampling equipment has been installed; refurbishment of an existing marine outfall line will permit discharge of leachate directly to the sea during high water (Johnson 1990)

G. Waste containerization is being introduced on a phased basis; wastes from nonSellafield consignors are now routinely dispatched to Drigg in 200-liter drums placed inside either full- or hatf-full ISO freight containers, which are placed directly in a new 
concrete vault; Sellafield wastes, packaged in paper, fiber or PVC, continue to be dumped into trenches on a temporary basis (NW 2/16/89; Johnson 1990)

H. Construction of the first engineered storage vault (Vault 8) was completed in late 1988; the vaut, with a capacity of $195,000 \mathrm{~m}^{3}$, includes an engineered clay base and sampling/ instrumentation to monitor performance; two additional vaults are planned for installation in the 1990s (NE 3/4/89)

9.5 LLW/ILW DISPOSAL R\&D: In the U.K, research and development on disposal of low- and intermediate-level wastes is concentrated on improvements at the Drigg site for low-level waste disposal and development of a deep geologic repository for mostly ILW disposal at Sellafield or Dounreay.

A. Improvements in Near-Surface Disposal at Drigg: Due to the relatively short timescale over which the recent program of improvements has been implemented, it was recognized that measures introduced to date may only be interim and that there may still be further improvements; development is continuing on waste compaction and packaging, on the vault capping, on the monitoring system, and on performance assessment

1) Users of the Drigg disposal site are having to develop a new standardized family of steel transportation/disposal containers for placement directly in the Drigg vaults; Sellafield, which packages low-level wastes in paper, fiber or plastic, is upgrading to disposable metal containers as are other waste generators; a one- $\mathrm{m}^{3}$ metal box is being developed to replace drums to reduce the voidage in the ISO containers. BNFL and other major waste generators have or are planning the further use of compaction (NW 2/16/89; Johnson 1990)

2) An alternate permanent capping system involving the use of ridges rather than a single mound is being considered; multiple caps would reduce the volume of fill required and present a more aesthetic appearance (Johnson 1990)

3) Deeper vaults and vertical drains that would route leachate directly to an underground aquifer which discharges to the sea are being considered (Johnson)

4) Both near-and far-field studies are underway to improve the understanding of the site's geology and hydrogeology and to develop migration models and the supporting databases with the overall aim of creating a site-specific risk assessment methodology (Hoimes 1990; Johnson 1990)

B. Development of a Deep Geologic Pepository at Sellafield or Dounreay: Nirex has an extensive R\&D program underway covering all aspects of its plans to locate a deep, underground repository at Dounreay or Sellafield; the program covers characterization of the wastes destined for disposal, development of standardized packaging, characterization of sites, development of repository designs, and performance assessment studies

1) The U.K. is emphasizing cement-based systems for immobilization of ILW destined for a deep geologic repository; characterization of the solidified ILW streams from each facility is underway; assay systems are also being developed, and gas production/migration is being examined (Barlow 1989; DOE 1989; Glasser 1989; Lee 1989; MacDonald 1989; Armitage 1990; Ginniff 1990) 
2) Nirex is developing a standardized range of packages for low- and intermediatelevel wastes for use by waste producers; three containers, a 500 -liter drum, a $3-\mathrm{m}^{3}$ box and a $12-\mathrm{m}^{3}$ concrete box, are envisioned for ILW; the influence of waste treatment on packaging for disposal, the structural integrity of packaging in the repository and methods of retrieval of packages from the repository are also being examined (Nirex 1988a; Keer 1990; Tutton 1990; Myall 1990b)

3) Current proposals for the investigations at Dounreay and Sellafield envision a twostage program of work at each site; the first stage includes geophysical surveying, supported by the drilling of two boreholes (800-1000 $\mathrm{m}$ deep) at each site; safety assessments will be underway simultaneously with the first stage; during the second stage, additional data will be sought, possibly requiring more drilling, to answer questions raised in the safety assessments; following an anticipated public inquiry in favor of proceeding at one of the sites, sinking of an underground shaft will begin leading to underground exploration (Chapman 1989; Ginniff 1990)

4) Simultaneously with site characterization, Nirex has initiated studies leading to the selection of a repository concept (see Section 9.3); concrete and steel are being examined for their value as barriers to radionuclide transport (Atkinson 1989; Beale 1990; Myall 1990a)

5) The performance assessments being made by Nirex take into account the four main pathways by which radionuclides could conceivably enter the environment: groundwater transport, intrusion by people, gaseous transport, and natural disruptive events; the assessments are carried out in two complementary phases; first, deterministic models are used to represent processes in considerable detaif; second, the effects of data uncertainty are examined using a probabilistic approach; these assessments will be continually updated as new data become available (Nirex 1988b; Nirex 1988c; Monckton 1989; Beale 1990; Billington 1990; Longworth 1990)

\subsection{PROGRAM/FACILITIES COSTS}

A. Nirex's developmental costs for 1988 were reported to be about $\Sigma 8.9$ million ( $\$ 15$ million U.S.) (Nirex 1988a)

B. As part of conceptual design studies, Nirex has estimated costs for several options for disposal of low- and intermediate-level wastes; these costs are summarized in the following table (NEA 1990):

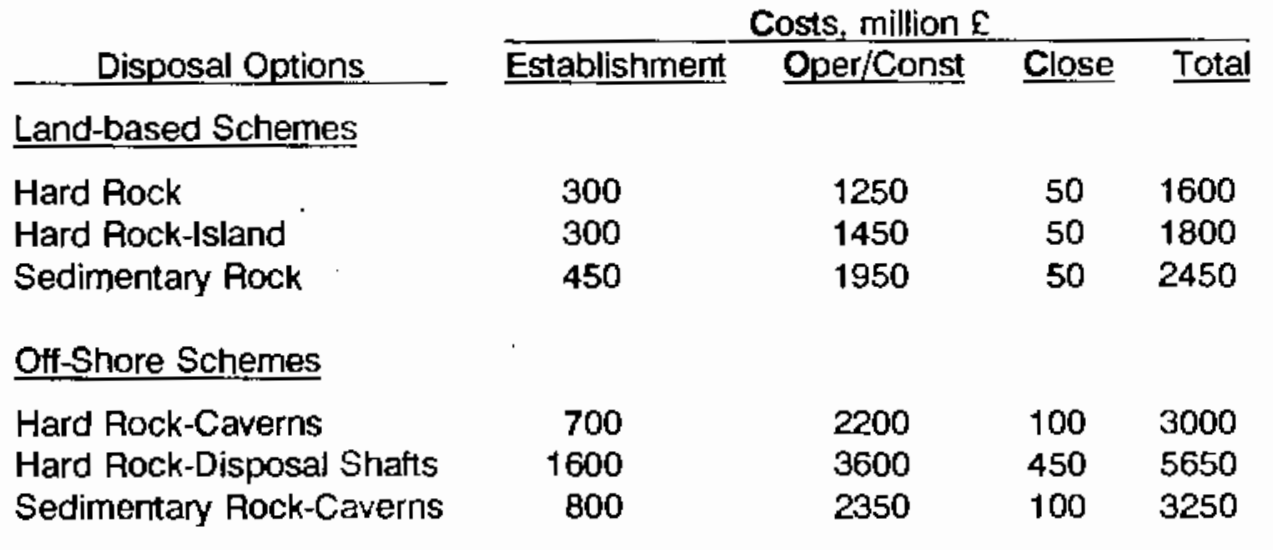


C. The $195,000-\mathrm{m}^{3}$ vault recently installed at Drigg cost an estimated $\mathrm{\varepsilon} 8.6$ million (\$14 miljion U.S.); the cost of retrieval from the vault, if necessary, was estimated at $\Sigma 10$ million (\$16 million U.S.) to $\$ 130$ million (\$215 million U.S.) depending upon the condition of the wastes and the required supporting facilities (Larkins 1988; NE 3/4/89)

D. The recent improvements being implemented at the Drigg disposal site for low-level wastes have increased disposal costs seventeen-fold; from about $\mathrm{\varepsilon 30} / \mathrm{m}^{3}$ in 1985 , costs

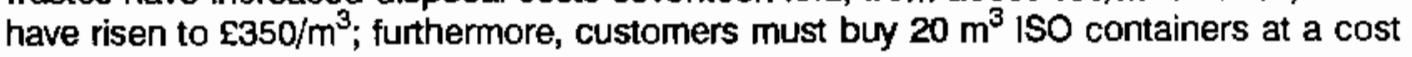
of $£ 3,000$ each (NWN 8/24/89; NEI 2/90)

E. BNFL estimates the R\&D support program for the Drigg improvements will cost about E3 million (\$5 million U.S.) for the 1988-1990 period (Larkins 1988)

F. Costs for disposal of low-level radioactive wastes are recovered by charges to the waste generator based upon waste volume and radioactivity; additional charges for waste transportation and handling are based upon miles transported and number of containers handled (Bindon 1990)

10.0 DISPOSAL OF HIGH-LEVEL WASTES: U.K.'s high-level wastes, consisting mainly of the canisters of vitrified products produced at Sellafield, will be stored at least 50 years; at that time a decision will be made as to their disposal; the 50 -year period will start with the commissioning of the THORP reprocessing plant, expected in 1992 (NEA 1990)

11.0 MANAGEMENT OF URANIUM MINE AND MILL WASTES: The U.K. has no domestic mining and milling industry; all uranium is imported (see Section 5.3)

12.0 DECOMMISSIONING AND ENVIRONMENTAL RESTORATION: The U.K., with its long-time and substantial nuclear program, has had extensive experience in decontamination and decommissioning nuclear facilities; based upon this experience and the considerable R\&D underway on decommissioning, AEA Technology and BNFL are collaborating in offering R\&D services worldwide on a commercial basis (AEA/BNFL 1990)

12.1 WASTE ARISINGS: A 1987 inventory of existing and projected radioactive wastes commissioned by the DOE and Nirex includes decommissioning wastes; the volumes of ILW and LLW arising from decommissioning through the year 2030 are shown below (Electrowatt 1988):

\begin{tabular}{|c|c|}
\hline Waste Category & $\begin{array}{l}\text { Volume }\left(\mathrm{m}^{3}\right) \text { from } \\
\text { Decommissioning }\end{array}$ \\
\hline \multicolumn{2}{|l|}{ ILW } \\
\hline $\begin{array}{l}\text { Sellafield } \\
\text { Other Nuclear Industry } \\
\text { Research, Medical, Industry }\end{array}$ & $\begin{array}{r}47,000 \\
960 \\
17,000\end{array}$ \\
\hline \multicolumn{2}{|l|}{ LLWW } \\
\hline $\begin{array}{l}\text { Sellafield } \\
\text { Other Nuclear Industry } \\
\text { Research, Medical, Industry }\end{array}$ & $\begin{array}{r}50,000 \\
162,000 \\
37,500\end{array}$ \\
\hline
\end{tabular}




\subsection{STRATEGY/POLICY}

A. The nuclear utilities and BNFL follow a policy of charging customers a fee sufficient to recover all costs, including decommissioning; as a tuture development, the government plans to introduce a charging scheme for recovery of costs from licensees seeking to store and dispose of radioactive wastes (NEA 1990)

B. The U.K's plans for R\&D of nuclear power reactors covers three phases: 1) removing spent fuel and bulk wastes; 2) dismantling and removing the non-radioactive equipment/ facilities around the reactor; and 3) removing the radioactive portions of the reactor after a 100-year delay to allow decay of the radioactivity; BNFL's plans for decommissioning of process plants are similar but with a shorter decay period (50 years) (Regan 1988; NEI 2/89)

12.3 RESEARCH AND DEVELOPMENT: TO support its large nuclear program and its large number of decontamination/decommissioning programs (see Section 12.4), the U.K has and continues to conduct R\&D on decontamination and decommissioning; these R\&D programs include the following:

A. The AEA Technology laboratory at Hanwell has developed a new industrial robot for decommissioning and waste management (NWN 3/8/90)

B. BNFL has developed plutonium assay equipment and applied it during decommissioning of the mixed-oxide fuel manufacturing plant at Sellafield (Buck 1990)

C. AEA Technology has conducted studies on the characterization of concretes from aging facilities to obtain information for planning future decommissioning projects; techniques for removing radioactive concrete have also been evaluated (Davies 1987; Angus 1990)

D. As part of the Windscale Advanced Gas-Cooled Reactor (WAGR) decommissioning program, remote cutting and handling machines were developed; a package was also developed for transport and disposal of the ILW formed by irradiation of reactor materials (Collins 1987; Thomas 1987)

E. At the Winfrith Technology Center, the washing of non-combustible alpha-contaminated wastes with aqueous and non-aqueous media to reduce the alpha content is being evaluated; wet abrasive particle impact cleaning is also being evaluated as a decontamination technique (Gugan 1990; Smith 1990)

F. AEA Technology is developing a destruction process using silver for the troublesome organic (TBP) accumulated as waste during reprocessing operations (Batey 1990)

12.4 MAJOR PROJECTS: Past and planned decommissioning/environmental restoration projects in the U.K include:

A. Four nuclear power stations, the Dounreay DFR, the Berkeley Magnox units 1 and 2, and the prototype Windscale AGR, have been shut down; decommissioning of the Berkeley units is just starting with Stage 2 decommissioning expected to be complete in about 10 years; phase 1 decommissioning of the DFR has been completed with no plans for further work, while phase 3 decommissioning of the WAGR is expected to be completed in the mid/late-1990s; decommissioning of the WAGR was included in the OECD/NEA Co-operative Program on Decornmissioning (NEA 1985; NEA 1988; Brown 1989) 
Recent studies indicate substantial savings can be realized by "mounding over" obsolete Magnox reactors instead of completely decommissioning them (NEI 9/90)

B. Decommissioning of the Windscale Piles, shut down after a serious fire in 1957, is just beginning (Jones 1990; NEI 6/90)

C. Decontamination and decommissioning of the half-mile long diffusion enrichment plant at Capenhurst is underway with completion planned for 1993 (BNFL 1989c)

D. Several facilities at the Springfields fuel manufacturing plant, including a fluidized-bed corversion process, have been decontaminated and decommissioned (BNFL 1989c)

E. Decontamination and decommissioning of a mixed oxide fuel manufacturing facility at Sellafield started in 1986 (BNFL 1989c; Sheil 1990)

F. Decommissioning work is undenway at Sellafield on the first spent fuel storage pond, erected in 1952 (BNFL 1989c; Sheil 1990)

G. Sellafield's first reprocessing plant, operated from 1952 to 1964, was decontaminated and refurbished for continuing operation on oxide fuels until the late 1960s (BNFL 1989c; Sheil 1990)

H. Sellafield's second reprocessing plant was commissioned in 1964 with two dissolver cells; in 1978, the operating dissolver cell was withdrawn from service and the second cell was placed in service; to provide additional capacity on Magnox fuels, the first cell is being decontaminated and refurbished for operation (Watkinson 1990)

I. Since 1975 , five beta-gamma laboratories at Sellafield have been decontaminated and dismantled; two more are currently being dismantled (BNFL 1989c)

J. A decontamination center was operated at Sellafield between 1952 and 1982; this facility has been decontaminated and dismantled (BNFL 1989C)

K. The radioactive working area of the Royal Navy Dockyard at Chatham was decommissioned in 1985, allowing the area to be retumed to unrestricted use (Warren 1997)

L. The Hermes experimental electromagnetic separation facility was decommissioned in 1987 (NEI B/87)

M. Rehabilitation of 13 hectares of land in East London, where the soils have been contaminated with thorium and radium through 90 years of industrial use, is underway (Harris 1990)

\section{5 costs}

A. The cost of decommissioning the U.K's outdated Magnax power stations and reprocessing their wastes was estimated at $\$ 2.4$ billion U.S. as reported in the $1988 / 89$ annual report of the CEGB; the total for CEGB was estimated at $\$ 18.5$ billion U.S. (13 Magnox reactors) and at $\$ 2.9$ billion U.S. for the SSEB (three Magnox reactors) (NWN 1/4/90) 


\section{UNITED KINGDOM}

B. BNFL estimates its total decommissioning costs (reactors and chemical plants) to be £4.6 billion (\$7.9 billion U.S.) at 1988 prices; the funds are being accrued through charges to customers (NF $3 / 20 / 89 b)$

13.0 INTERNATIONAL ACTIVITIES: The U.K., with its long-time and extensive nuclear program, has actively participated with other countries through international organizations and technology exchange programs; the U.K is also a participant in several international firms providing nuclear services

\subsection{PARTICIPATION IN INTERNATIONAL ORGANIZATIONS}

A. The U.K is a member of the International Atomic Energy Agency (IAEA) and participates actively in its programs, including providing "experts," conducting international symposia and workshops on waste management, and preparing technical documents on selected waste management topics

B. The U.K is a member of the OECD and participates actively in the radioactive waste management programs sponsored by the Nuclear Eriergy Agency (NEA); this participation includes preparing contributions to summary documents prepared by the NEA, participating in working groups on selected technical topics, and contributing direct support toward selected projects; R. Flowers of the U.K. is the present Chairman of the NEA's Radioactive Waste Management Committee

C. The U.K. is a member of the Commission of Europeain Communities (CEC) and participates in its radioactive waste management programs

D. The nuclear utilities in the U.K belong to the World Association of Nuclear Plant Operators (WANO), an international organization patterned after the Institute of Nuclear Power Operations (INPO) in the U.S.; all but two nuclear plant operators, one in the People's Republic of China and one in Romania, belong to this organization which has the objective of maximizing safety and reliability of nuclear power plants through information exchange (Goring 1990)

\subsection{COOPERATION WITH THE U.S.A.}

A. In June 1990, the 1984 "Memorandum of Understanding (MOU) Between the Department of Energy of the United States and the Department of Energy of Great Britain and Northern Ireland on Collaboration in Energy Researchi and Development" was extended for another ten years; the new agreement includes, but is not limited to, waste management and the environment, renewable and fossil energies, end-use technologies, and exchange of energy-related information; collaboration under the agreement can include: exchanges of scientific and technical information and research results; exchanges of personnel; exchanges of samples, materials, instruments and components; joint meetings; use of research facilities; and cooperative projects (NWN 6/21/90)

B. An agreement in the field of Radioactive Waste Management Technology between the U.S. DOE and the UKAEA was signed on October 30, 1976, and continues to October 30,1991; the scope of the agreement includiss preparation and packaging of radioactive wastes, surface and subsurface storage, transportation requirements, characterization of and disposal in geologic formations, design and operational issues, performance assessment, field and laboratory testing, LLW/LW/TRU waste treatment and disposal technologies, decommissioning waste treatment and disposal technology, 
environmental and safety issues, and public acceptance issues; a separate agreement on decommissioning was signed on March 1, 1985, and expired on March 1, 1989.

C. Prior to 1986, technical exchanges in the area of radioactive waste management were conducted under the USDOE/UKAEA agreement in the field of Liquid Metal-Cooled Fast Breeder Reactors; that agreement is still in force as well as several sub-agreements related to breeder reactors.

\subsection{COOPERATION WITH OTHER COUNTRIES}

A. The U.K is, along with France, West Germany, Belgium and the Netherlands, a participant in the European Fast Breeder Program, initiated in 1984; in 1989, the U.K government gave permission for an $80-M T / y$ plutonium reprocessing plant to be built at Dounreay as part of the program (NWN 11/2/89)

B. The U.K, along with Canada, Finland, Japan, Sweden, Switzerland, and the U.S., is participating in the NEA-coordinated (STRIPA) cooperative research program conducted by the Swedish Nuclear Fuel and Waste Management Company (SKB) at a former iron mine in central Sweden (NEA 6/90)

C. The U.K, along with Australia, Japan, Sweden, and the U.S. NRC, finances the International Alligator Rivers Project (APAP); the purpose of this project is to increase the understanding of the long-term chemical and physical processes likely to influence the transport of radionuclides through the geosphere using studies of uranium ore deposits in the Alligator Rivers region of Australia; the project is managed by the Australian Nuclear Science and Technology Organization (ANSTO) and sponsored by the NEA (NEA 6/90)

D. The U.K Department of Environment and the U.K Nirex participate in the INTRAVAL Project organized by the Swedish Nuclear Power Inspectorate (SKI) and designed to help test geological pathway models against laboratory or field observations; the U.K has also participated in similar Swedish-initiated code intercomparison projects such as BIOMOVS, PSACOIN and HYDAOCOIN (NEA 1/90; NEA 6/90)

E. The UKAEA has an agreement with JAERI in Japan on exchange of information related to decontamination and decommissioning (NUKEM 7/87)

F. On July 25, 1989, the governments of the U.K and the FRG signed a joint declaration recording the intentions of both governments to increase their existing cooperation in the peaceful uses of nuclear energy; the aim of the accord was to remove obstacles to the shipment of spent nuckear fuel from the FAG to the U.K for reprocessing, and the return of reprocessing wastes to the FRG (NEA 12/89)

G. On April 10, 1990, the governments of the U.K and the Soviet Union signed an agreement calling for prompt notification of nuclear accidents and exchange of information on nuclear facilities (NWN 4/22/90)

H. The U.K, through various government agencies and private companies, actively cooperates in commercial activities involving other countries

1) Exploration for uranium is carried out by the British Civil Uranium Procurement Organization (BCUPO) on behalf of civil users of uranium such as CEGB (NEA 1989c) 
2) Urenco Limited was incorporated in 1971 for the purpose of marketing uranium enrichment by the centrifuge process; BNFL holds one-third of the shares; the remainder are held by Netherlands and German organizations; Urenco operates the centrifuge enrichment plant at Capenhurst (BNFL 1988)

3) United Reprocessors GmbH was incorporated in 1971 for the purpose of providing services for reprocessing irradiated fuels from nuclear power stations using uranium oxide fuel; BNFL holds one-third of the shares; the remainder are held by French and German organizations (BNFL 1986)

4) Pacific Nuclear Transport Limited was incorporated in 1975 to transport irradiated fuel from Japan to Europe for reprocessing; BNFL holds $62.5 \%$ of the shares; the remainder are held by Japanese and French crganizations (BNFL 1988)

5) NTL Nukleare Transportleistungen $\mathrm{GmbH}$ was incorporated in 1979 for the purpose of providing transport of irradiated fuel elements from oxide-fueled power reactors to a reprocessing plant; BNFL holds one-third of the shares; the remainder are held by French and German organizations (BNFL 1988)

\subsection{REFERENCES}

$-1982-$

Maxwell, E.O., and D. Deacon. 1982. "Operating Experience of Vault Type Dry Storage and Its Relevance to Future Storage Needs.' Drv Storage of Spent Fuel Elements, pp. 190-217. Proceedings of an NEA Specialist Workshop, May 11-13, 1982, Madrid, Spain on OECD/Nuclear Energy Agency, Paris.

$-1984-$

Mellinger, P.J., K.M. Harmon, and LT. Lakey. 1984. A Summary of Nuclear Fuel Reprocessing Activjties Around the World. PNL-4981, Pacific Northwest Laboratory, Richland, Washington.

Nuclear Energy Agency (NEA). 1984. "United Kingdom.' Nuclear Legislation. OECD/Nuclear Energy Agency, Paris, v. II, pp. 133-157.

$-1985-$

British Nuclear Fuels plc (BNFL). 1985. Fuel Handling Plant and Site lon Exchange Effluent Plant. Brochure published by British Nuclear Fuels plc, Risley, Warrington, WA3 6AS, United Kingdom.

Dounreay. 1985. PFR Reprocessing: Dounreay. Brochure published by Dounreay Nuclear Power Development Establishment, Thurso, UKAEA.

Nuclear Energy Agency (NEA). 1985. Compendium on Decommissioning Activities in NEA Member Countries. OECD Nuclear Energy Agency, Paris, pp. 3-81 to 3-85.

Paige, H.W., and N.J. Numark. 1985. Assessment of National Systems for Obtaining Local Siting Acceptance of Nuclear Waste Management Facilities. IEAL-R/86-16, International Energy Associates Limited, Washington D.C., Vol. 1:16-1 to 16-4 and Vol. 2:18-1 to 18-6. 
Wilkinson, W.L. February 1985. "High-Level Waste Management in the U.K" Nuclear Europe, pp. 9-11.

$-1986-$

Harwell. 1986. Chemistry at Harwell: Research and Development in the Nuclear Industry. Brochure distributed by the Harwell Laboratory, Oxfordshire OX11 ORA, United Kingdom, 1988.

NIREX. 1986. United Kingdom Nirex Limited Annual Report: 1985/1986. U.K Nirex, Ltd., Curie Avenue, Harwell, Didcot, Oxfordshire, United Kingdom.

Nuclear Energy Agency (NEA). 1986. Nuclear Spent Fuel Management: Experience and Options, OECD/Nuclear Energy Agency, Paris, pp.98-105.

Nuclear Engineering international (NEI). August 1986. "Sellafield Fuel Handling Plant Starts Up." 31(385):27-28.

UKAEA. 1986. United Kingdom Atomic Energy Authority Annual Report 1985-1986, UKAEA Information Services Branch, London.

U.S. Department of Energy (DOE). 1986. Proceedings of the US DOE/UK AEA Workshop on Facility Design. DOE-JiO-018, October 27-29, 1986, Albuquerque, New Mexico, November 1986.

$-1987-$

Addison, C.W.E. 1987. "Spent Fuel Surveillance at BNFL, Sellafield Nuclear Fuel Reprocessing Plant." In the proceedings of an IAEA Technical Committee Meeting on Spent Fuel Surveillance and Monitoring Methods, pp. 51-71. IAEA-TECDOC-461, October 27-30, 1987, Vienna, Austria.

Bailey, G. 1987. "Radioactive Waste Management at Dounreay." Radioactive Waste Management and the Nuclear Fuel Cycle. 9:27-50.

Bates, P.M. 1987. 'The Construction and Operating Experience of the PFR Irradiated Fuel Buffer Store." In the proceedings of an IAEA Technical Committee Meeting on Spent Fuel Surveillance and Monitoring Methods, pp. 25-38. IAEA-TECDOC-461, October 27-30, 1987, Vienna, Austria.

Bush, R.P., R.H. Flowers, and R.K. Webster. 1987. "Selection of Strategies for the Back End of the Nuclear Fuel Cycle in the United Kingdom.' In the proceedings of The IAEA/NEA International Symposium on the Back End of the Nuclear Fuel Cycle: Strategies and Options, pp. 183-197. IAEA-SM-2S4/46, May 11-15, 1987, Vienna, Austria.

Collins, N.W. March 1987. "Developing Machines to Dismantle the Windscale Prototype AGR." Nuclear Engineering International, pp. 39-41.

Curry, A., and A.P. Haighton. 1987. "CEGB Development of Waste Immobilization Processes." Nuclear Europe, Journal of the European Nuclear Society, n. 3/4, p. 41.

Davies, I.L., C.C. Fleischer, and A.A. Patton. March 1987. "Developing Techniques for Removing Activated Concrete." Nuclear Engineering International, pp. 45-47. 


\section{UNITED KINGDOM}

Haigh, C.P. and J.A. Luke. 1987. "Recent Developments in Power Station Management Procedures." Radioactive Waste Management and the Nuclear Fuel Cycle. Hanwood Academic Publishers, London, $9(1-3): 71-84$.

Harwell. 1987. Chemistry at Harwell: Research and Development for the Nuclear Industry. Brochure published by Harwell Laboratory, Oxfordshire, United Kingdom.

Heafield, W. 1987. 'Encapsulation of Intermediate Level Wastes Arising from Reprocessing Operations at BNFL, Sellafield." In Radioactive Waste Management and the Nuclear Fuel Cycle, $9(1-3): 19-25$.

Howden, M., and T.L.J. Moulding. 1987. "Progress in the Reduction of Liquid Radioactive Discharges from the Sellafield Site." In the proceedings of The International Conference on Nuclear Fuel; Reprocessing and Waste Management (RECOD '87), pp. 1045-1054. August 23-27, 1987, Paris, v. 3.

International Energy Associates Limited (IEAL). 1987. Regulatory Strategies for High-Level Radioactive Waste Management in Nine Countries. IEAL-R/87-93, International Energy Associates Limited, Fairfax, Virginia.

Mogg, C.S., and W. Heafield. 1987. 'BNFL's Objectives and Achievements in the Reduction of Radioactive Discharges from Reprocessing Plants." In the proceedings of The 1987 International Waste Management Conference, pp. 349-358. November 29 - December 5, 1987, Hong Kong.

Nuclear Europe (NE). 3/4/87. "Fuel Fabrication for Thermal Reactors by the IDR Process." European Nuclear Society, Berne, Switzerland, p. 15.

Nuclear Engineering International (NEI). March 1987. "Commissioning at AWRE," 32(392):20.

Nuclear Engineering International (NEI). August 1987. "Cleaning Up Hermes, an Alpha-Contaminated Facility' and 'Thorp takes BNFL into the 21st Century," pp. 26-27 and 32-36.

NUKEM. July 1987. "Reprocessing and Waste Management: Review First Half 1987." NUKEM Market Report on the Nuclear Fuel Cycle. NUKEM GmbH, Hanau, Federal Republic of Germany, p. 15.

Salmon, A. 1987. "The Transportation of Radioactive Waste: A Review." In the proceedings of The 1987 ASME International Waste Management Conference, pp. 359-368. November 29 - December 1987, Hong Kong. American Society of Mechanical Engineers, New York.

Thomas, P.J., and J.R. Wakefield. 1987. The Development of a Large Container for WAGR Decommissioning Waste." In the proceedings of the 1987 International Decommissioning Symposium, v.1, pp. III-128-147. CONF-871018, October 4-8, 1987, Pittsburgh, Pennsylvania.

Warren, G.A. 1987. "Decommissioning of Redundant Radioactive Working Area at HM Dockyard, Chatham, Kent." In the proceedings of the 1987 International Decommissioning Symposium, v.1, pp. III-254 to III-268. CONF-871018, October 4-8, 1987, Pittsburgh, Pennsylvania.

Wilkinson, W.L., P.M. Billam, and M. Townsend. 1987. "Spent Fuel Management Strategy in the United Kingdom." In the proceedings of The IAEA/NEA Intemational Svmposium on the Backend of the Nuclear Fuel Cycle: Strategies and Options, Pp. 33-39. IAEA.SM-294/69, May 11-15, 1987, Vienna, Austria. 
ACSTRM. 1988. The U.K. Regulation of the Transport of Radioactive Materials, pp. 6-8. A publication of the Advisory Committee on the Safe Transport of Radioactive Materials, Her Majesty's Stationary Office, London.

British Nuclear Fuels plc (BNFL). 1988. British Nuclear Fuels PLC Annual Report and Accounts: 1987-1988, BNFL, Risley Warrington, WA3 6AS, United Kingdom.

Chamberlain, LN. 1988. 'Sellafield in the 1990s,' Nuclear Europe, n. 5, May 1988, pp. 22-23. A publication of the European Nuclear Society, Beme, Switzerland.

Davies, I.L, T.V. Molesworth, D.J.S. Findlay, and T.H. Green. 1988. 'Assay of Radioactive Waste Packages in a Quality Programme." In the proceedings of The CEC/lAEA Symposium on the Management of Low and Imtermediate Level Wastes: 1988, v. 1, pp. 259-277. May 16-20, 1988, Stockholm, Sweden.

U.K. Department of the Environment (DOE). 1988. Drigg: Certificate of Authorization (in conjunction with Conditions for Acceptance by BNFL), London.

Dotchin, N., and S. Carlyle. 1988. 'Strategies for Management of Low and Intermediate Level Radioactive Wastes in the United Kingdom." In the proceedings of The CEC/IAEA Symposium on the Management of low and Intermediate Level Radioactive Wastes, pp. 53-68. IAEA, Vienna, May 16-20, 1988, Stockholm, Sweden.

Electrowatt. October 1988. The 1987 United Kingdom Radioactive Waste Inventory. U.K. Nirex Report No. 54, DOE/RW/88.061, Electrowatt Engineering Services Ltd, West Sussex, England.

Feates, F. 1988. "U.K. Policy on Radioactive Waste Management." Nuclear Technology International. Sterling Publications, Limited, London, pp. 116-119.

Fellingham, LR. 1988a. The Management of Spent Fuel from Materials Testing Reactors in the United Kingdom." In the proceedings of an IAEA Technical Meeting on Management of Spent Fuel from Research and Prototype Power Reactors and Residues from Post-Irradiation Examination of Fuel, pp. 15-28. IAEA-TECDOC-513, November 28 - December 1, 1988, Vienna, Austria.

Fellingham, LR. 1988b. The Management of Spent Fuel and Post-Irradiation Examination Fuel Samples from Experimental, Research and Prototype Reactors in the United Kingdom.' In the proceedings of an IAEA Technical Meeting on Management of Spent Fuel from Research and Prototype Power Reactors and Residues from Post-Irradiation Examination of Fuel, pp. 73-91. IAEA-TECDOC-513, November 28 - December 1, 1988, Vienna, Austria.

Howarth, G. December 1988. "BNFL's First Encapsulation Plant Enters the Testing Phase." Nuclear Engineering International, pp. 52-56.

International Atomic Energy Agency (IAEA). 1988. The Nuclear Fuel Cycle Information System. Vienna, Austria.

International Atomic Emergy Agency (IAEA). 5/20/88. World Overview: Radioactive Waste Management.' IAEA News Features, IAEA, Vienna, Austria.

Kovan, D. August 1988. 'Transportation in the Nuclear Industry." ATOM. London, England, pp. 13-18. 
Larkins, W.S. 1988. "Solid Low Level Waste Disposal." In The 1988 DOE Model Conference Proceedings, v. 1, pp. 230-239. CONF-881054, October 3-7, 1988, Oak Ridge, Tennessee.

Lloyd, A.I., G. Robinson, and M.S.T. Price. 1988. 'Development of a Store Design for Packaged Intermediate Level Wastes.' In the proceedings of The IAEA Symposium on the Management of Low and Intermediate Level Radioactive Wastes, pp. 182-185. May 16-20, 1988, Stockholm, Sweden.

Mogg, C.S. 1988. 'An Overview of Radioactive Waste Management at Sellafield,' in the proceedings of The Symposium on Waste Management (Tucson '88), v. 2, pp. 281-287. February 28 -March 3, 1988, Tucson, Arizona.

Nirex. 1988a. United Kingdom Nirex Limited Annual Report for 1987-1988. U.K. NIREX Limited, Harwell, Didcot, Oxfordshire, United Kingdom.

Nirex. 1988b. The Way Forward: A Discussion Document on the Development of a Repository for the Disposal of Low and Intermediate Level Radioactive Waste. U.K. NIREX Limited, Harwell, Didcot, Oxtordshire, United Kingdom.

Nirex. 1988c. Presentation of the Nirex Disposal Safety Research Programme. NSS/G108, November 1, 1988, Nirex Limited, Harwell, Didcot, Oxfordshire, United Kingdom.

Nuclear Energy Agency (NEA). March 1988. "U.K. Research Prog'ammes on Radioactive Waste Management." Handout from the March 29-31, 1988 meeting of the OECD/NEA's Radioactive Waste Management Committee, Paris.

Nuclear Energy Agency (NEA). 1988. 'Third Annual report of Programme Activities to the Radioactive Waste Management Committee for the period January - December 1988." Handout from the January 23-24, 1990 meeting of the OECD/NEA's Radioactive Waste Management Committee, Paris.

Nuclear Energy (NE). June 1989. "Vitrification Plant Commissionirg Starts." British Nuclear Energy Society, London, 28(3):133.

Nuclear Engineering International (NEI). December 1988. "BNFL's First Encapsulation Plant Enters the Testing Phase, pp. 52-56.

Nuclear Europe (NE). 1-2/89. "New Magnox Dissolution Plant's Discharge Liquid is Fit to Drink." European Nuclear Society, Berne, Swilzerland, n. 1-2, 1989, p.50.

Nuclear Europe (NE). May 1988. "Dounreay Radwaste Plant Nears Commissioning." European Nuclear Society, Berne, Switzerland, n. 5, p.20.

Nucleonics Week (NW). 3/17/88. "NRPB Move To Slash Worker Doses Could Force Global Reassessment," pp. 1,8-9.

Nucleonics Week (NW). 9/2/88. 'British Utilities to Go Ahead with Dry Storage for Spent Fuel," PP. 8-9.

Nuclear Waste News (NWN). 6/2/88. "Britain Plans Storage Facility for ILW From Operational Subs," p.176. 
Patrick, B.H. 1988. "The Development of Near Real Time Materials Accountancy within the U.K. Safeguards Programme." In the proceedings of The 29th Annual INMM Meeting on Nuclear Materials Management, v. XVII, pp. 871-877. June 26-29, 1988, Las Vegas, Nevada.

Regan, J.D. October 1988. 'Decommissioning of Nuclear Power Stations.' Nuclear Europe. Journal of the European Nuclear Society, Berne, Switzerland, p. 39.

Turner, A.D., A.R. Junkison, and N.J. Bridger. 1988. 'Electrical Processes for Liquid Waste Treatment.' In the proceedings of The CEC/IAEA Symposium on The Management of Low and Intermediate Level Radioactive Wastes: 1988, v. 2, pp. 75-87. May 16-20, 1988, Stockholm, Sweden.

1989

Atkinson, A., and G.P. Marsh. 1989. "Performance of Engineered Barriers for Intermediate and Low Level Waste Disposal." in the proceedings of The Symposium on Waste Management (WM '89), v. 2, pp. 185-190. February 26 - March 2, 1989, Tucson, Arizona.

Barlow, P., D.M. Beaumont, and G.A. Fairhall. 1989. 'Characterization of Raw and Encapsulated Reprocessing Wastes in the U.K." In the proceedings of The Symposium on Waste Management $(W M$ '89), v. 1, pp. 269-272. February 26 - March 2, 1989, Tucson, Arizona.

Billington, D.E., and R.H. Flowers, 1989. "Past, Present and Future Technical Basis of Radioactive Waste Disposal in the U.K.' In the proceedings of The Symposium on Waste Management (WM '89), v. 2, pp. 167-172. February 26 - March 2, 1989, Tucson, Arizona.

Bindon, F.J.L. 1989. "Drigg: Land Burial of Low Activity Waste." Nuclear Engineer. Institute of Nuclear Engineers, 30(5):144-148.

British Nuclear Fuels plc (BNFL). 1989a. Transport of Radioactive Materials. Risley, Warrington, Cheshire, England.

British Nuclear Fuels plc (BNFL). 1989b. Waste Management and Storage. Risley, Warrington, Cheshire, England.

British Nuclear Fuels plc (BNFL). 1989c. Decommissioning of Nuclear Plants. Risley, Warrington, Cheshire, England.

Brown, G.A. July 1989. 'Starting to Dismantle Berkeley." Nuclear Engineering International, pp. 23-24.

Chapman, N.A., and T.J. McEwen. 1989. 'Geological Aspects of the British Programme for Deep Disposal of Nuclear Wastes." Presented at the 28th International Geological Congress. LBL-27333, July 9-19, 1989, Washington, D.C.

Cross, J.E., and E.W. Hooper. 1989. "Recent Studies on Advanced Methods for Decontamination of Low and Intermediate Level Wastes." in the proceedings of The 1989 Joint International Waste Management Conference on Low and Intermediate Level Radioactive Waste Management, v. 1, Pp. 45-52. October 22-28, 1989, Kyoto, Japan.

Flowers, R.H. 1989. "Radioactive Waste Management in the United Kingdom." In the proceedings of The 1989 Joint International Conference on Low and intermediate Level Waste Management, v. 1, pp. 107-114. October 22-28, 1989, Kyoto, Japan. 


\section{UNITED KINGDOM}

Ginniff, M.E. 1989. "Disposal of Radioactive Wastes by U.K. Nirex Lid." In the proceedings of The Symposium on Waste Management (WM '89), v. 1, pp. 83-91. February 26 - March 2, 1989, Tucson, Arizona.

Glasser, F.P. et al. 1989. "The Performance of Cement-Based Systems." In the Progress Report for the Period 1st January 1989 - 30th June 1989 on the Joint CEC/U $\{$ DOE Research Programme on Medium Waste Form Characterization. Commission of European Communities, Brussels, Belgium.

Gowing, R. 1989. "Experience in Wet Transport of Irradiated LWF Fuels." In the proceedings of The Sth International Symposium on the Packaging and Transportation of Radioactive Materials (PATRAM '89), v. 2, pp. 1143-1150. CONF-890631, June 11-16, 1989, Washington, D.C.

Heafield, W., and A.D. Elsden. 1989. "High Level Waste Managenent in the United Kingdom." In the proceedings of The 1989 Joint international Conference on High Level Radioactive Waste and Spent Fuel Management, v. 2, pp.147-152. October 22-28, 1989, Kyoto, Japan.

Higson, S.G. 1989. 'Development of an Integrated Strategy for the Disposal of Solid Low Level Waste at BNFL's Drigg." Presented at the Eleventh Annual DOE Low-Level Waste Management Conference. CONF-890854, August 22-24, 1989, Pittsburg, Pennsylvania.

Holt, P.J., and T.P.T. Soanes. 1989. The Use of Glass-Reinforced Plastic as a Flask Energy Absorbing Material." In the proceedings of The 9th International Symposium on the Packaging and Transportation of Radioactive Materials (PATRAM'89), v. 1, pp. 71-78. CONF-890631, June 11-16, 1989, Washington, D.C.

International Atomic Energy Agency (IAEA). 1989. "Development of Decontamination Techniques for Fuel Transport Flasks at the Winfrith Atomic Energy Establishment.' Presented at the IAEA Technical Committee Meeting on Decontamination of Transport Casks and S Jent Fuel Storage Facilities. April 4-7, 1989, Vienna, Austria.

Jenkins, J.A., D.H. Logsdail, E. Lysall, P.E. Myers, B.A. Partridge, and P. Mistry. 1989. "Developments in Liquid-Liquid Extraction for Fuel Reprocessing Reduce Waste Management Problems." In the proceedings of The 1989 Joint International Conference on Low and Intermediate Level Waste Management, v. 2, pp. 193-196. October 22-28, 1989, Kyoto, Japan.

Lee, D.J., C.G. Howard, and C.R. Wilding. 1989. "Cement Wastefcrm Properties." In the proceedings of The 1989 Joint International Conference on Low and Intermediate Level Waste Management,

v. 1, pp. 261-268. October 22-28, 1989 in Kyoto, Japan.

Leeks, C.W.E., A.I. Lloyd, M.S.T. Price, and G.P. Marsh. 1989. "The Development of a 500 Liter Drum Package for Processing, Storage and Disposal of Intermediate Level Radioactive Waste." In the proceedings of The Symposium on Waste Management (WM '89), 'v. 2, pp. 781-786. February 26March 2, 1989, Tucson, Arizona.

MacDonald, C.A. 1989. "Gas Production from the Biodegradation of Organic Components of LowLevel Radioactive Waste." In the proceedings of The 1989 Joint International Conference on Low and Intermediate Level Waste Management, v. 1, pp. 301-309. October 22-28, 1989, Kyoto, Japan.

Marshall, L. 1989. "Privatization and its Impact on the Future of the Nuclear Programme in the United Kingdom." In the proceedings of The OECD/NEA International Symposium on Good Performance in Nuclear Projects, pp. 699-703. April 17-20, 1989, Tokyo. 
Miller, D.J. April 1989. "Nuclear Power and the Private Sector." Nuclear Energy, Journal of the British Nuclear Energy Society, London, 28(2):73-80.

Monckton, N. 1989. "Ensuring the Safety of Deep Repositories." Nuclear Engineering international, February 1989, pp. 30-33.

Mummery, G.B., and R.F. Pannett. 1989. Ten Thousand Movements of Irradiated Fuel from CEGB Power Stations--Review of Recent Experience." In the proceedings of The 9th international Symposium on the Packaging and Transportation of Radioactive Materials, v. 2, pp. 1109-1114. CONF-896031, June 11-16, 1989, Washington, D.C.

National Radiation Protection Board (NRPB). 1989. NRPB Report 1987-1989. Chilton, Didcot, Oxon, United Kingdom.

Nuclear Energy Agency (NEA). 10/89. Third Annual Report of Programme Activities to the Radioactive Waste Management Committee. CPD/DOC(89)4, Paris.

Nuclear Energy Agency (NEA). 12/89. 'Joint Declaration on Co-Operation in the Peaceful Uses of Nuclear Energy." Nuclear Law. Bulletin 44, Paris, pp. 61-62.

Nuclear Energy Agency (NEA). 1989b. Plutonium Fuel: An Assessment. Paris, pp. 114-116.

Nuclear Energy Agency (NEA). 1989c. URANIUM: Resources, Production and Demand. Paris, pp. 287-293.

Nuclear Engineering International (NEI). 2/89. "BNFL Into Line on Decommissioning," p. 7.

Nuclear Engineering International (NEI). 5/89. "NIREX Names Candidates for Repository Sites," p. 11.

Nuclear Engineering International (NEI). 7/89. "Supercompaction Planned in the U.K.," p. 14.

Nuclear Engineering International (NEI). 8/89. "Crossflow Microfiltration at AEA Technology," pp. 53-54.

Nuclear Engineering international (NEI). 9/89. 'Developing a Flask for Vitrified Waste,' pp. 38-40.

Nuclear Energy (NEN). 6/89. Vitrification Plant Commissioning Starts," and "Research and Development at Sellafield.' British Nuclear Energy Society, London, 28(3):133-134.

Nuclear Energy (NEN). 10/89. "UKAEA Restructuring." British Nuclear Energy Society, London, 28(5):287.

Nuclear Europe (NE). 1-2/89. "CEGB Begins Fitting Labs into Plans for 1990 Privatization." European Nuclear Society, Berne, Switzerland, p.50-51.

Nuclear Europe (NE). 3-4/89. "U.K. Begins Disposing of tts Low Active Radwaste in Special Vault." European Nuclear Society, Berne, Switzerland, p.54.

Nuclear Fuel (NF). 3/20/89a. "U.K.'s Stockpile of Civilian Pu to be Transierred to Private Firm," p. 6. 
UNITED KINC DOM

Nuclear Fuel (NF). 3/20/89b. "BNFL Revises Decommissioning Policy, Increases Cost Estimate TenFold," p. 11.

Nuclear News (NN). 10/30/89. "U.K. Gives Permission to Plan of Fast Reactor Reprocessing Plant," pp. 13-14.

Nuclear News (NN). 9/89. 'BNFL Has Started Building a New Oxide Fuels Complex, or NOFC," p. 103.

Nucieonics Week (NW). 2/16/89. 'Study Finds Higher Costs Follow Upgrades of U.K LLW Disposal,' p. 10.

Nucleonics Week (NW). 11/9/89. 'Recommended Radiation Dose I.imit Exceeded by 443 BNFL Workers in 1988," p. 8.

Nuclear Waste News (NWN), 2/23/89. "Slants and Trends," 9(8):59.

Nuclear Waste News (NWN). 3/23/89a. 'Nuclear Power Said Firmly Part of U.K's Privatized Future,' pp. 9-10.

Nuclear Waste News (NWN). 3/23/89b. "Dungeness Nuclear Station, U.K, To Build LLW Treatment Plant,' p. 99.

Nuclear Waste News (NWN). 7/13/89. "Work Starts on U.K. Dry Store for Fuel Rods as Alternative to Sellafield,' p. 252.

Nuclear Waste News (NWN). 8/24/89. "Upgrading BNF Repository at Drigg Boosted Waste Disposal Costs 10-Fold," p. 313.

Nuclear Waste News (NWN). 11/2/89a. 'British Nuclear Fuels to Build \$16 Million MOX Fuel Plant," p. 404.

Nuclear Waste News (NWN). 11/2/89b. "British Government Approves European Demonstration Reprocessing Plant, ${ }^{\circ}$ p. 405.

Numark, N.J., H.W. Paige, and E.F. Wonder, 1989. Public Perception and Acceptance of the Siting of Nuclear Waste Facilities in Seven Countries. Environmental and Energy Services Company (ERC), Fairfax, Virginia, pp. 7-1 to 7-18.

Pecover, C.J., and B.C. Ross. 1989. 'Compliance Assurance and Regulatory Agency's Co-Operation in the U.K. Proceedings of The 9th International Symposium on the Packaging and Transportation of Radioactive Materials, vol. I, pp. 483-489. CONF-890631, June 11-16, 1989, Washington, D.C.

Ponsford, B. 1989. "Department of the Environment Proof of Evidence." Testimony given at the public inquiry held in October 1989 on the CEGB application to construct Hinckley Point C PWR.

Robinson, E. 1989. "Reprocessing Industry in Europe Achievement and Current Status." In the proceedings of the NEALCEC International Symposium on Good Periormance in Nuclear Projects, pp. 466-476. April 17-20, 1989, Tokyo, Japan.

Shaw, H.M. 1989. "Application of Power Fluidics in British Nuclear Reprocessing Plants." In the proceedings of The 1989 Joint International waste Management Corference on Low and Intermediate Level Waste Management, v. 2, pp. 39-46. October 22-28, 1989, Kycto, Japan. 
Sills, R.J. 1989. "Spent Fuel Storage and Management in the United Kingdom," Journal of the Institute of Nuclear Materials Management, XVII(3):17-19.

U.S. Department of Energy (DOE). 1989. Objectives and Scope of the Joint Funded BNFL/DOE Product Evaluation Development Programme. DOE/RW/89/050, March 1989, Washington, D.C.

Wilkinson, W.L. 1989. 'The Nuclear Scene in the U.K.' In the proceedings of the Symposium on Waste Management (WM '89), v.1, pp. 35-39. February 26 - March 2, 1989, Tucson, Arizona.

Wood, I.A., and M. Blackbourn, 1989. "Design Features of the MK A2 Flask." In the proceedings of The 9th International Symposium on the Packaging and Transportation of Radioactive Materials (PATRAM '89), v. 2, pp. 662-669. CONF-890631, June 11-16, 1989, Washington, D.C.

1990

AEA/BNFL. 1990. A Major Force in Decommissioning. Brochure distributed by AEA Decommissioning \& Radwaste (Division of AEA Technology) and BNFL at the ENS/ANS-Foratom Conference held September 23-28, 1990, Lyon, France.

Angus, M.J., S.R. Hunter, and J. Ketchen. 1990. 'Classification of Contaminated and NeutronActivated Concretes from Nuclear Facilities Prior to Their Decontamination or Decommissioning." In the proceedings of the Symposium of Waste Management (WM '90), v. 2, pp. 229-237.

February 25 - March 1, 1990, Tucson, Arizona.

Armitage, B.H., K.P. Lambert, and M.T. Swinhoe. 1990. "Development of Non-Destructive Actinide Assay Methods for Radioactive Waste." In the proceedings of The Symposium on Waste Management (WM '90), v. 2, pp. 239-245. February 25 - March 1, 1990, Tucson, Arizona.

ATW News (ATW). 6/90. 'HPA: Waste Conditioning in the U.K' Atomwirtschaft-Atomtechnic, Dusseldorf, FRG, p. 7.

Barents, M.S. 1990. "Quality Assurance of Radioactive Waste Disposal at the Winfrith Technology Center." In the proceedings of The Symposium on Waste Management (WM '90), v. 1, pp. 681-685. February 25 - March 1, 1990, Tucson, Arizona.

Batey, W. 1990. "The Dounreay Silver Destruction Process for Difficult Organic Wastes." In the proceedings of the Nuclear and Hazardous Waste Management International Topical Meeting (Spectrum '90), pp. 237-239. September 30 - October 4, 1990, Knoxville, Tennessee.

Beale, H. 1990. 'The Selection and Assessment of Potentially Suitable Sites for Deep Repository Development." In the proceedings of The Symposium on Waste Management (WM '90), v. 1, pp. 265-271. February 25 - March 1, 1990, Tucson, Arizona.

Billington, D.E., D.A. Lever, and S.J. Wisbey. 1990. "U.K Regulations and the Safety Assessment of Radioactive Waste Repositories." In the proceedings of the Symposium on Waste Management (WM '90), v. 1, pp. 569-576. February 25 -March 1, 1990, Tucson, Arizona.

Boyer, D., and J. Fletcher. 1990. 'The Continuing Evolution of a Radioactive Material Transport System.' In the transactions of The ENS/ANS-Foratom Conference (ENC '90), v. IV, pp. 2105-2118. September 23-28, 1990, Lyon, France. 
Buck, S., J.P. Ronaldson, and A. Colquhoun 1990. "Plutonium Inventory Measurements During Decommissioning Operations." In the proceedings of the Symposilum on Waste Management (WM '90), v. 2, pp. 797-805. February 25 - March 1, 1990 at Tucson, Arizona.

Conboy, T.M., D.M.C. Horsely, and C.S. Hogg. 1990. "A Design Approach to Low-Leve! Liquid Waste Treatment at Sellafield:" In the proceedings of The Symposium on Waste Management (WM '90), v. 1, pp. 577-583. February 25 - March 1, 1990, Tucson, Arizona.

Coulthart, D.R., and J. Emmison. 1990. "BNFL Wet Spent Fuel Handling Experience." In the proceedings of The Symposium on Waste Management (WM '90), v. 2, pp. 659-661. February 25 March 1, 1990, Tucson, Arizona.

Curd, P.J. 1990. 'Technical Excellence or Political Acceptability: The Waste Disposal Dilemma.' In the proceedings of the Symposium on Waste Management (WM '90), v. 1, pp. 621-627. February 25 March 1, 1990, Tucson, Arizona.

Denny, A. March-April 1990. 'The Confident Case for Reprocessing." Nuclear Europe. European Nuclear Society, Berne, Switzerland, pp. 22-23.

Daily Telegraph (DT). 8/15/90. 'Atom Waste Reprocessing Plant Opens."

Fincher, C.E., M.S.T. Price, and L.R.K. Rickard. March 1990. "U.K. Finds Supercompaction Promising." Nuclear Engineering International, pp. 47-48.

Ginniff, M.E. 1990. "U.K. NIREX Commences Deep Site Investigations." In the proceedings of The Symposium on Waste Management (WM '89), v. 1, pp. 257-263. February 25 - March 1, 1990,

Tucson, Arizona.

Goring, Lord Marshall of. 1990. "International Collaboration for the Safe Operation of Nuclear Power Stations.' Paper presented at the ENS/ANS-Foratom Corference (ENC '90), October 23-28, 1990, Lyon, France.

Gowing, R. 1990. "U.K. Transportation of Spent Fuel and Radioactive Waste." Presentation at the 1990 Summer Meeting of the American Institute of Chemical Engineers, August 19-23, 1990, San

Diego, California.

Green, T.H., et al. 1990. 'U.K. Department of Environment Quality Checking Facility.' In the proceedings of the Symposium on Waste Management (WM '90), v. 1, pp. 673-679. February 25 March 1, 1990.

Gugan, M.A., M.J. Sanders, and K.F. Collett. 1990. "Wet Abrasive Particle Impact Cleaning as a Nuclear Decontamination Technique." in the proceedings of the Nuclear and Hazardous Waste Management International Topical Meeting (Spectrum '90), pp. 269-271. September 30 - October 4, 1990, Knoxville, Tennessee.

Harris, M.R.R., T.V. Kirby, and C.G. Rawlins. 1990. The Removal of Thorium and Radium Contaminated Soils from an Urban Site." In the transactions of the ENS/ANS-Foratom Conference (ENC '90), v. 4, pp. 2465-2467. October 23-28, 1990, Lyon, France.

Holmes, R.G.G. 1990. Technical Programme to Characterize the Near Field of a Low Level Waste Repository.' In the proceedings of the Nuclear and Hazardous Waste Management intemational Topical Meeting, pp. 400-404. September 30 -October 4, 1990, Knoxville, Tennessee. 


\section{UNITED KINGDOM}

Hooper, E.W. and J.E. Cross. 1990. "Recent Studies on Advanced Methods for the Decontamination of Aqueous Effluents." in the proceedings of the Nuclear and Hazardous Waste Management International Topical Meeting, pp. 471-480. September 30 - October 4, 1990, Knoxville, Tennessee.

Howles, L April 1990. "Annual Review of Load Factor Trends," Nuclear Engineering International, 35(429):12-18.

Johnson, L.F. 1990. 'Soiid Low Level Radioactive Waste Management within British Nuclear Fuels plc." In the proceedings of Symposium on Waste Management (WM '90), v. 2, pp. 413-417, February 25 - March 1, 1990, Tucson, Arizona.

Jones, J.M., and P.W. Worthington. 1990. The Windscale Piles Complex Preparatory Work Prior to Decommissioning," presented at the 1990 Summer Meeting of the American Institute of Chemical Engineers, held August 20-22, 1990, San Diego, Califomia

Keer, T.J., N.J. Martindale, and B. Haijtink. 1990. The Structural Integrity of High Level Waste Containers for Deep Disposal." In the proceedings of The Symposium on Waste Management (WM '90), v. 2, pp. 839-846. February 25 - March 1, 1990, Tucson, Arizona.

Leigh, I.W., and S.J. Mitchell. 1990. International Nuclear Fuel Cycle Fact Book. PNL-3594, Rev. 10, Pacific Northwest Laboratory, Richland, Washington.

Lloyd, A.I., M.S.T. Price, and A.T. Staples. 1990. "Facilities for Processing, Packaging and Storage of Intermediate Level Radioactive Waste at the Winfrith Technology Center." In the proceedings of the Symposium on Waste Management (WM '90), v. 2, pp. 91-97. February 25- March 1, 1990, Tucson, Arizona.

Longworth, G., and M. Ivanovich. 1990. "A Review of Some Geocolloid Transport Studies in the Farfield Relevant to Radioactive Waste Disposal." In the proceedings of The Symposium on Waste Management (WM '90), v. 2, pp. 571-575. February 25 - March 1, 1990, Tucson, Arizona.

Mummery, G.B., and R.F. Pannett. October 1990. 'CEGB's Operational Experience in the Transport of Radioactive Waste Packages." Nuclear Energy. British Nuclear Energy Society, 29(5):351-357.

Myall, M.G., and R. Beardmore. 1990a. "Radwaste Handling Systems for Deep Land Based Repositories.' In the proceedings of The Symposium on Waste Management (WM '90), v. 2, pp. 139151. February 25 - March 1, 1990, Tucson, Arizona.

Myall, M.G. 1990b. "Retrieval of Nuclear Waste from a Land Based Deep Repository." In the proceedings of The Symposium on Waste Management (WM '90), v. 2, pp. 139-151. February 25 March 1, 1990, Tucson, Arizona.

Nuclear Energy Agency (NEA). 1990. Status Report on U.K. Radioactive Waste Disposal Programmes: 2nd Edition. Paper presented at the January 23-24, 1990 meeting of the OECD/Nuclear Energy Agency's Radioactive Waste Management Committee held in Paris.

Nuclear Energy Agency (NEA) 6/90. "Other International Activities," Nuclear Waste Builetin. OECD/ Nuclear Energy Agency, pp. 62-66.

Nuclear Engineering International (NEI). 1/90. 'AEA Technology: The Rebirth of a Nuclear Institution," pp. 14-16. 
Nuclear Engineering international (NEI). 2/90. "Rolls-Royce Disposal Costs More," p. 16.

Nuclear Engineering International (NEI). 3/90a. "Assessing Sellafield's Vitrification Technology," pp. 43-46.

Nuclear Engineering International (NEI). 3/90b. 'U.K. Finds Supercompaction Promising,' pp. 47-48.

Nuclear Engineering International (NEI). 6/90. "After the Fire: Preparing the Windscale Piles for Decommissioning,' p. 48-49.

Nuclear Engineering Intemational (NEI). 9/90. "Radical Approaches Could Reduce the Liability for U.K. Decommissioning.' pp. 25-26.

Nuclear Engineering International (NEI). 1990. "Country-by-Country Reactor Status." World Nuclear Industry Handbook, p. 35.

Nuclear Engineering International (NEI). 11/90. World Nuclear Industry Handbook," pp. 116-123.

Nuclear Engineering International (NEI). 12/90. "Datafile U.K," pp. 48-54.

Nuclear Energy (NEN). 4/90. "Pluto and Dido Shut Down." British Nuclear Energy Society, London, 29(2):82.

Nuclear Fuel (NF). 4/2/90. "U.K: Fuel Plant Contract Let," p. 16.

Nuclear Fuel (NF). 4/16/90. "Demonstration MOX Plant to be Built in U.K. by BNFL, AEA Technology," pp. 15-16.

Nuclear Fuel (NF). 5/28/90. "U.K.: BNFL Announces Personnel Changes," p. 17.

Nuclear News (NN). 1/90. "Marshall Explains Why Nuclear Will Not Be Privatized," pp. 71-73.

Nuclear News (NN). 3/90. 'Waste Management,' pp. 82-83.

Nuclear News (NN). 5/90. 'BNFL, AEA Technology to Build MOX Plant," p. 58.

Nuclear News (NN). 6/90. "Research Reactor Fuel to be Sent to Dounreay.' pp. 67-68.

Nuclear News (NN). 12/90. 'The ICRP Has Recommended Lower Occupational Dose Limits," $33(15): 19$.

Nuiclear Waste News (NWN). 1/4/90. "British Electricity Board Doubles Decommissioning Cost Estimates,' p. 7.

Nuclear Waste News (NWN). 3/8/90. 'News Briefs," p. 98.

Nuclear Waste News (NWN), 4/22/90. "Slants and Trends," p. 141.

Nuclear Waste News (NWN). 6/21/90. "U.S./U.K. Energy Agreement Covers Waste Managernent, Environmental R\&D," p. 247.

Nuclear Waste News (NWN). 9/20/90. "Dounreay to Begin Reprocessing Foreign Research Reactor Fuel," p. 364. 
Nuclear Waste News (NWN). 10/4/90. "British Nuclear Fuels Changes its Policy on Low-Level Waste Disposal," p. 384.

Nucleonics Week (NW). 3/15/90. "U.K.: Britain Maintains Sea Disposal Right," p. 17.

Nucleonics Week (NW). 4/6/90. "Inheritors of British Nuclear Plants Begin Official Business," pp. 7-8.

Nucleonics Week (NW). 5/17/90. 'Maltby, Eyre to Head U.K. Atomic Energy Authority,' p. 14.

Nucleonics Week (NW). 9/27/90. "BNFL Says LLW Compaction Plant Would Ease U.K. Waste Concerns,' p. 6.

NUKEM Market Report (NUKEM). 2/90. "Reprocessing and Waste Management: Review 1989." NUKEM GmbH, Alzenau, FRG, pp. 21-22.

NUKEM Market Report (NUKEM). 3/90. 'Nuclear Power Plant Capacity of the Western World." NUKEM, Inc., Alzenau FRG, pp. 30-31.

NUKEM Market Report (NUKEM). 4/90a. "Electricity Generation." NUKEM, Inc., Alzenau, FRG, pp. 4-8.

NUKEM Market Report (NUKEM). 4/90b. "National Update: United Kingdom." NUKEM GmbH, Alzenau, FRG, pp. 3-4.

NUKEM Market Report (NUKEM). 7/90. 'Processor Profile: British Nuclear Fuels plc." NUKEM GmbH, Alzenau, FRG, pp. 12-15.

Sheil, A.E., and A.P. Colquhoun. 1990. "Environmental Protection Considerations During Decommissioning.' In the proceedings of the Symposium on Waste Management (WM '90), v. 2, pp. 497-501. February 25 - March 1, 1990, Tucson, Arizona.

Smith, D.I., and S.P. Burke. 1990. "Washing of Non-Combustible Transuranic (TRU) waste in Aqueous and Non-Aqueous Media." In the proceedings of the Nuclear and Hazardous Waste Management International Topical Meeting (Spectrum '90), pp. 164-169. September 30-October 4, 1990, Knoxville, Tennessee,

Tulton, E.P.S., H.G. Whipp, and D. Vande Putte. 1990. The Influence of Waste Treatment, Conditioning and Packaging on Design for Disposal." in the proceedings of The Symposium on Waste Management (WM '90), v. 2, pp. 353-357. February 25 - March 1, 1990, Tucson, Arizona.

Tyson, A. 1990. "Caesium - Leaching from Clinoptilolite/Cement Wasteforms." In the proceedings of the Nuclear and Hazardous Waste Management International Topical Meeting (Spectrum '90), pp. 322-325. September 30 - October 4, 1990, Knoxville, Tennessee.

Watkinson, A.B. 1990. 'Sellatield Primary Separation Plant: Interim Summary Project Report.' In the proceedings of the Nuclear and Hazardous Waste Management International Topical Meeting (Spectrum '90), pp. 272-275. September 30 - October 4, 1990, Knoxville, Tennessee.

Wilson, G.K., and A. Elsden. 1990. "Monitored Retrievable Storage at Sellafield." In the proceedings of the Symposium on Waste Management (WM '90), v. 2, pp. 765-769. February 25 - March 1, 1990, Tucson, Arizona. 

UNITED STATES 


\section{UNITED STATES}

\section{CONTENTS}

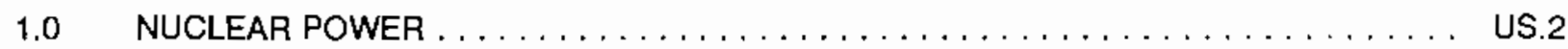

2.0 NUCLEAR FUEL CYCLE AND RADIOACTIVE WASTE MANAGEMENT

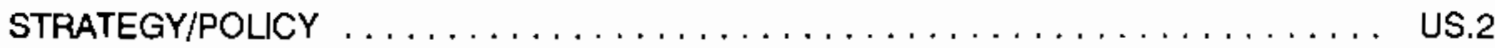

3.0 HIGHLIGHTS AND MAJOR MILESTONES $\ldots \ldots \ldots \ldots \ldots \ldots \ldots \ldots \ldots \ldots \ldots$

4.0 INSTITUTIONAL CONSIDERATIONS/ORGANIZATIONS $\ldots \ldots \ldots \ldots \ldots \ldots \ldots \ldots$ US.9

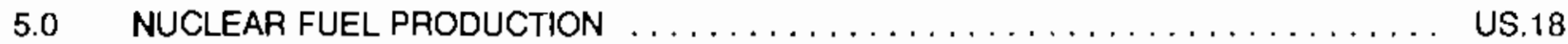

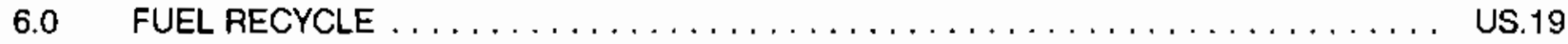

7.0 SPENT FUEL STORAGE AND TRANSPORT $\ldots \ldots \ldots \ldots \ldots \ldots \ldots \ldots \ldots \ldots$ US.20

8.0 WASTE CONDITIONING, STORAGE AND TRANSPORT $\ldots \ldots \ldots \ldots \ldots \ldots \ldots$ US.24

9.0 DISPOSAL OF NON-HIGH-LEVEL WASTES $\ldots \ldots \ldots \ldots \ldots \ldots \ldots \ldots \ldots \ldots$

10.0 DisPOSAL OF HIGH-LEVEL WAStES $\ldots \ldots \ldots \ldots \ldots \ldots \ldots \ldots \ldots \ldots \ldots \ldots \ldots$

11.0 MANAGEMENT OF URANIUM MINE AND MILL WASTES $\ldots \ldots \ldots \ldots \ldots \ldots$ US.42

12.0 DECOMMISSIONING AND ENVIRONMENTAL RESTORATION $\ldots \ldots \ldots \ldots \ldots$ US.43

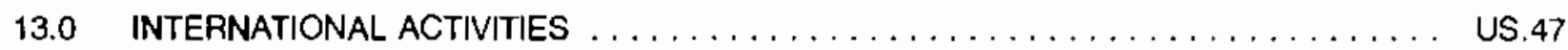

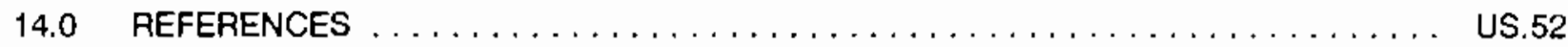


UNITED STATES

\subsection{NUCLEAR POWER}

1.t REACTOR MIX: 38 BWRs, 73 PWRs, and 1 FBR (NEI 6/90);

the U.S.'s only high-temperature, helium gas-cooled reactor (HTGR), Fort St. Vrain, was closed for decommissioning in August 1989 (NWN 2/14/91a)

1.2 ELECTRIC POWER PRODUCTION (NEA 1990):

1989--2,932 TWh (17.8\% nuclear) (actual data)

$1990--2,974$ TWh (18.0\% nuclear)

1.3 NUCLEAR POWER CAPACITY PROJECTIONS: The following projections, beyond the actual data shown for 1989 , are based on the case of no new future orders of nuclear power (NEA 1990; EIA 10/26/90)

1988-95.0 GWe (actual data)

1989-98.0 GWe (actual data)

1990-100.0 GWe

1995--103.0 GWe

2000-104.0 GWe

2005--104.0 GWe

2010--100.0 GWe

2015-69.0 GWe

2020-54.0 GWe

During 1990, three new U.S. units started commercial operation and none was permanently taken out of service; no U.S. nuclear plants are expected to begin commercial operation in 1991; only one U.S. unit in 1992 and one in 1993 are projected to come on line, rellecting the lack of U.S. orders in recent years (NN 2/91)

1.4 NUClear Plant AVAlLABIUTY: 62.3\% capacity factor in 1989 (EIA 9/28/90)

1.5 NUCLEAR ENERGY POLICY: The U.S. government fully supports the development of nuclear power; it has carried out the majority of development work since its inception; the industrial development and implementation is the responsibility of private enterprise; however, no new orders for nuclear power plants have been placed since 1978 primarily because of economics, public resistance to nuclear power, and increasingly more restrictive regulations

1.6 NUCLEAR R\&D BUDGET: Nuclear energy R\&D programs at the U.S. Department of Energy (DOE) are funded at $\$ 306.5$ million for fiscal year 1991 (NN 12/90)

1.7 ELECTRICITY PRODUCTION COSTS: The cost for electricity generation in the U.S. using nuclear power is about 3.6 cents per $\mathrm{kWh}(\mathrm{NW} 2 / 8 / 90)$; the cost for generating electricity by a new nuclear plant ( $1200 \mathrm{MWe})$ is estimated at 4.3 cents per $\mathrm{kWh}$, competitive with coal-fired electricity ( 4.8 cents per $k W h)$, less than gas-fired electricity ( 6.1 cents per $k W h)$, and less than oil-fired electricity (8.1 cents per kWh) (NEI 3/91)

\subsection{NUCLEAR FUEL CYCLE AND RADIOACTIVE WASTE MANAGEMENT STRATEGY/POLICY}

2.1 OVERALL NUCLEAR FUEL CYCLE POLICY: The U.S. has developed and maintains all aspects of the nuclear fuel cycle, except reprocessing by private industry; private industry 
provides all nuclear fuel cycle services, except enrichment and disposal of spent nuclear fuel and HLW, including its transportation and AFR storage prior to disposal (the latter activities are federal activities); spent fuel and HLW in solid form are planned to be disposed in licensed deep, stable geologic structures; the federal government operates a complete nuclear fuel cycle for the national defense production system, including LLW waste disposal; defense TRU wastes are planned to be disposed of in the Waste Isolation Pilot Plant salt repository in New Mexico if it is confirmed as suitable; defense HLW will be disposed together with civilian HLW and spent fuel (EIA 10/26/90)

2.2 POLICY ON THE FRONT END OF THE NUCLEAR FUEL CYCLE: The U.S. plans to remain independent in uranium mining, milling, conversion, enrichment, and fuel fabrication; these activities are carried out by private industry except for enrichment, which is carried out by the federal government; the U.S. uses the gaseous diffusion process for uranium enrichment; the laser separation enrichment technology is currently under development (EIA 10/26/90)

\subsection{POLICY ON THE BACK END OF THE NUCLEAR FUEL CYCLE:}

A. The U.S. policy allows for reprocessing of spent fuel from nuclear power; however, private industry decided not to reprocess spent nuclear fuel (primarily due to economics) after the only commercial operating reprocessing plant (at West Valley, New York) shut down in 1972; except for the small amount of commercial HLW generated at West Valtey, it is planned to dispose of spent nuclear fuel directly in deep geological repositories; extended interim storage of spent fuel and HLW awaiting disposal will be the responsibility of the federal government alter its acceptance by the U.S. Department of Energy (DOE)

B. U.S. policy is to facilitate establishment of a reliable civilian LLW management system; each state is responsible for providing facilities for disposal of LLW generated within its borders, either by itself or in cooperation with other states (compacts); however, the disposal of civilian greater-than-class-C low-level wastes is the responsiblity of the federal government

C. The federal government is responsible for treatment, storage, transportation, and disposal of all defense wastes (LLW, TRU, HLW); the DOE plans to demonstrate the geologic disposal of defense TRU wastes at the Waste lsolation Pilot Plant (WIPP) in New Mexico (salt formation); defense HLW (in solid form) will be disposed together with commercial spent fuel and HLW in a deep geologic repository

D. The U.S. plans to immobilize HLW from the shutdown West Valley reprocessing plant and defense-related activities by constructing and operating plants for the vitrification of HLW in the West Valley demonstration project and for defense HLW in the Defense Waste Processing Facility (DWPF) at Savannah River, the future Hanford Waste Vitrification Plant (HWVP), and a future waste processing facility at ldaho Falls

E. The U.S. cooperates with the OECD/NEA, IAEA, CEC, and with other nations in developing and demonstrating fuel cycle and waste management technology

F. The U.S. will apply appropriate remedial actions to surplus defense nuclear facilities, including mine/mill tailings sites, in accordance with established priorities and as rapidly as funding constraints allow 
G. The federal government plans to demonstrate decontamination and decommissioning technologies for nuclear power reactors and other nuclear fuel cycle facilities; D\&D of commercial facilities will be the responsibility of the owners

\subsection{HIGHLIGHTS AND MAJOR MILESTONES}

3.1 THE DEPARTMENT OF ENERGY'S OFFICE OF CIVILIAN RADIOACTIVE WASTE MANAGEMENT (OCRWM) MILESTONES FOR CIVILIAN SPENT FUEL AND HLW (DOE/RW-0067 1986; OCRWM Bulletin 12/86; DOE/RW-0035 1987; DOE/RW-0123 1987; DOE/RW-0187 1988; DOE/RW-0247 1989; DOE/RW-0217P 1990; Smith 1991)

January 1983 The Nuclear Waste Policy Act (NWPA), Public Law 97-425, was signed by the President; it established the Office of Civilian Radioactive Waste. Management (OCRWM)

February 1983 Nine sites in six states were identified as potentially acceptable for the first repository for spent fuel and high-level wastes

April 1983 The $\$ 0.001 / \mathrm{kWh}$ fee for nuclear-generated electricity was implemented; also, the one-time payment fee structure for prior nuclear electricity was implemented

January 1984 The first deployment plan for federal interim storage (FIS) was submitted to Congress

August 1984 The Comprehensive Nuclear Waste Fund Management Plan was issued

October $1984 \quad$ NRC concurrence was received on the siting guidelines by DOE for recommendation of spent fuel repositon' sites (issued later in 10 CFR 960)

December 1984 The Draft environmental assessments for each of the nine potentially acceptable spent fuel/HLW repository sites were published

April 1985

The President approved DOE's recommendation that a combined repository for both defense HLW and civilian radioactive waste be implemented

April 1985 A preliminary report was published on the need for and the feasibility of a Monitored Retrievable Storage (MRS) facility

June 1985

The first Mission Plan for a civilian HLW and spent fuel management program was issued and submitted to Congress (DOE/RW-0005 1985)

September 1985 The final regional geologic and environmental characterization reports were issued, based on crystalline repository project studies

January 1986 The Draft Area Recommendation Report for the second repository was issued

The Transportation Business Plan (DOE/RW-0046 1986) was issued 
May 1986

July 1986

August 1986

March 1987

June 1987

December 1987

January 1988

June 1988

December 1988

1992

1992

1994

1996

1996

1998

1999

2001
The final environmental assessments for the candidate sites for the first repository were issued; three sites were recommended for detailed site characterization

The decision was made to postpone indefinitely all site-specific work related to a second repository; planning was initiated for a broad-based technology development program for the second repository

A license was issued by the NRC for the first independent dry spent fuel storage facility (Carolina Power and Light Co.)

The Transportation Institutional Plan was issued (DOE/RW-0094 1986)

The proposal to implement an MRS facility for the civilian radioactive waste system was submitted to Congress (DOE/RW-0035 1987)

The Dratt Mission Plan Amendment was submitted to Congress, proposing delay of initial operations at the first spent fuel repository until 2003 (DOE/RW-0128 1987)

The Nuclear Waste Policy Amendments Act (NWPAA), Public Law 100-203, was enacted; the NWPAA established the Office of the Nuclear Waste Negotiator (an independent establishment in the executive branch) and the Monitored Retrievable Storage Commission

The Consultation Draft of the Site Characterization Plan (SCP) for the candidate repository site (in tuff) at Yucca Mountain was issued

The Dratt 1988 Mission Plan Amendment for the Civilian HLW and Spent Fuel Management Program was issued and submitted to Congress (DOE/RW-0187 1988)

The Site Characterization Plan for the HLW/Spent Fuel Repository Site at Yucca Mountain was issued (DOE/RW-0199 1988)

Construction of the exploratory shatts at the Yucca Mountain site is scheduled to begin

The site for the MRS facility is planned to be selected

The MRS license application is planned to be submitted to the NRC

The MRS facility license is planned to be received from the NRC

The construction of the MRS facility is planned to begin

Waste acceptance is planned to begin at the MRS simple receiving facility

Waste acceptance is planned to begin at the MRS spent fuel handling building

The Final Environmental Impact Statement for the candidate Yucca Mountain repository site is planned to be issued 
The site recommendation repon on the candidate Yucca Mountain site is planned to be submitted to the President

2001

The license application for the HLW/spent fuel repository at Yucca Mountain is planned to be submited to the NRC, assuming DOE judges the site to be acceptable

2004

Construction of the repository at Yucca Mountain is planned to begin, assuming NRC approval

2008

An updated license application to receive and possess HLW at the Yucca Mountain repository is planned to be submitted to the NRC

2010

Waste emplacement is planned to be started at the Yucca Mountain repository, assuming NRC approval

$2007-2010$

The DOE is required by the INWPAA to report to Congress on the need for a second spent fuel repository

-2075 Final closure of the spent fuel repository at Yucca Mountain is anticipated

\subsection{THE DEPARTMENT OF. ENERGY'S OFFICE OF ENVIRONMENTAL RESTORATION AND WASTE MANAGEMENT MILESTONES FOR DEFENSE WASTES:}

1944

1974

1978

1978

1979

1981

1989

1989

1989

1990
The first disposal facilities for defense LLW became operational

The Formerly Utilized Sites Remedial Action Program (FUSRAP) was established

The Uranium Mill Tailings Remedial Action Program (UMTRAP) was established

The Surplus Facilities Management Program (SFMP) was established

Disposal of defense LLW was discontinued at commercial LLW disposal facilities (some defense LLW was disposed at these facilities since the 1960s)

The Carlsbad, New Mexico, site was selected as the final candidate site for disposal of defense TRU wastes

The DOE Office of Environmental Restoration and Waste Management was established

The first Environmental Restoration and Waste Management Five-Year Plan was issued, which initiated environmental cleanup of all DOE sites (DOE/S0070 1989)

The Shippingport nuclear power station was decommissioned

The first update of the Environmental Restoration and Waste Management

Five-Year Plan was issued (DOE/S-D078P 1990) 
1991

1991

1992

1994

1994

1996

1996-1998

1998

1999

2001

2004

2012

2019

An administrative land withdrawal order was signed by the Department of Interior giving the DOE use of the land at the Waste Isolation Pilot Plant (WIPP) in Carlsbad, New Mexico, until June 29, 1997 (Radioactive Exchange $1 / 31 / 91 a)$

The start of the five-to-seven-year test phase at the WIPP is planned, with acceptance and demonstration emplacement of contact-handled defense TRU wastes (Radioactive Exchange 1/31/91b)

Radioactive operation is scheduled to commence at the Defense Waste Processing Facility (DWPF) for vitrification of defense HLW at Savannah River

The Uranium Mill Tailings Remedial Action Program (UMTRAP) activities are scheduled for completion

A final waste form for HLW calcine at the Idaho Nuclear Engineering Laboratory is to be selected

Vitrification of the West Valley HLW is scheduled to be started

The demonstration period is scheduled for completion at the WIPP; site confirmation is expected to allow for beginning of permanent emplacement of defense TRU wastes

Vitrification of the West Valley $\mathrm{HLW}$ is scheduled to be completed

Radioactive operation is scheduled to commence at the Hanford Waste Vitrification Plant (HWW) for defense wastes

Activities under the Formerly Utilized Sites Remedial Action Program (FUSRAP) are scheduled to be completed

Activities under the Surplus Facilities Management Program (SFMP) are scheduled to be completed

Activities under the Decontamination and Decommissioning program for inactive DOE facilities are scheduled to be completed

Scheduled goal for completing environmental cleanup of DOE sites within 30 years

\subsection{CIVILIAN LOW-LEVEL WASTE MILESTONES:}

1962

1971

$1975-1978$

1980
The first commercial LLW disposal facility opened at Beatty, Nevada

Six commercial LLW disposal facilities were operational

Three commercial LLW disposal facilities closed, leaving three operational

The Low-Level Radioactive Waste Policy Act, Public Law 95-573, was enacted by Congress 
The Low-Level Radioactive Waste Policy Amendments Act, Public Law 94240, was enacted by Congress

Host states for future LLW disposal facilities were to have been identified

1993

All states must have civilian LLW disposal capability, either by themselves or together with other states formed into compacts, or otherwise be able to manage their own LLW; the existing disposal sites can restrict assess to LLW from outside their respective compacts after this date

1996

All states not having LLW disposal capability must take titfe to all LLW produced within the state

\subsection{REPROCESSING MILESTONES (OTA 1985):}

1944

1952

1953

1954

1956

1963

1966

1971

1972

1973

1977

1981

1990
Startup of two bismuth phosphate deferise reprocessing facilities at Hanford site

Startup of REDOX defense reprocessing plant at Hanford site

Reprocessing of Naval and research materials started at Idaho site

Reprocessing (modified PUREX process) of defense materials started at Savannah River site

Startup of PUREX defense reprocessing plant at Hanford site

Waste calcination facility started operations at Idaho site

Startup of civilian reprocessing at West Valley site

First double-shell tanks used for HLLW storage at Hanford site

Shutdown of civilian reprocessing at West Valley site

Waste encapsulation and storage facility started operations of packaging cesium and strontium capsules at Hanford site

President Jimmy Carter's nuclear policy statement banned commercial reprocessing in the U.S.

President Ronald Reagan's nuclear policy statement reversed the ban on commercial reprocessing in the U.S.

Shutdown of defense reprocessing at the PUREX plant at Hanford; a decision on possible future PUREX operations has not been made 
UNITED STATES

\subsection{INSTITUTIONAL CONSIDERATIONS/ORGANIZATIONS}

\subsection{LEGAL REQUIREMENTS}

A. The Atomic Energy Act of 1954 specifies conditions for activities using atomic energy and radioactive materials for civilian and for national defense purposes

B. The U.S. does not have a federal stipulation law that requires a waste management solution to allow nuclear power

C. The Nuclear Waste Policy Act (NWPA) of 1982 and its Amendments Act of 1987 designate that the federal government is responsible for long-term management/disposal of civilian spent fuel and high-level wastes, and specify the conditions and the schedule for implementing the waste management system; they establish that DOE is responsibile for development and operation of a geologic repository for civilan spent fuel/ $\mathrm{HLW}$, a transportation system, and an MRS facility (if needed); they also establish a waste fund for the program by imposing a levy on nuclear electricity producers; the 1987 Amendments Act also authorized DOE to study subseabed disposal of spent fuel and HLW as an altemative to deep geologic disposal (DOE/RW-0216 1989)

D. Federal nuclear operating and R\&D activities, and regulatory activities must be the responsiblity of separate agencies

E. The Low-Level Radioactive Waste Policy Act, enacted by Congress in 1980, placed responsiblitiy for disposal of civilian LLW on the individual states; it encouraged states to enter into compacts (agreements) with neighboring states to establish regional disposal sites; states would also be able to restrict access to disposal sites to wastes generated solely within the compact region after 1986; the Low-Level Radioactive Waste Policy Amendments Act of 1985 revised the schedule to enable continued access, on a limited basis, to the three existing sites until January 1, 1993; the federal government is responsible for disposal of greater-than-class-C low-level wastes

\subsection{LICENSING (U.S. Congress 1983,1987 )}

A. Civilian nuclear installations and federal repositories for spent fuel and HLW must be licensed by the NRC and must meet requirements by the U.S. Environmental Protection Agency (EPA)

B. Transportation packagings for civilian wastes must be certified by the NRC and must meet licensing requirements of the U.S. Department of Transportation (DOT)

C. A two-step procedure is followed for licensing of civilian nuclear reactors and fuel cycle facilities: 1) a construction permit is required before the start of construction; and 2) an operating license is required prior to fuel loading and subsequent operation

D. A one-step procedure is established for licensing an MRS facility and away-from-reactor storage facilities (AFRs) and at-reactor extended storage facilities (ARs): one license is required before both.construction and operation are permitted. 
E. Federal detense and research facilities are exempt from NRC licensing but must meet federal safety and environmental standards; the Waste Isolation Pilot Plant (WIPP) must meet requirements by the DOE and the EPA

F. Commercial low-level waste disposal facilities are licensed by the NRC or by states with delegated authority from the NAC (i.e., agreement states)

\subsection{PUBLIC INVOLVEMENT}

A. Public hearing(s) are required before issuance of a construction permit; hearings may also be held, if requested, prior to issuance of an operating permit for licensing of civilian reactors and most other civilian nuclear fuel cycle facilities

B. The NWPA and its Amendments Act require close interaction between the federal government and the host state for the spent fuel and HLW repository and affected indian tribes, both of which have the right to disapprove siting decisions for repositories and MRS facilities, as legislated in the NWPA; such disapproval can be overridden by congressional veto; DOE grants are provided to affected states and Indian tribes for overview and participation in activities associated with repository or MRS programs

C. Extensive public information activities and public participation in the siting process have been used to increase public knowledge regarding new low-level waste disposal facilities

\subsection{WASTE FUND}

A. A nuclear waste fund for disposal of spent fuel and high-level wastes was established by the Nuclear Waste Policy Act; a fee is assessed to owners and generators of spent nuclear fuel and HLW to provide full recovery of disposal program costs

B. The U.S. Treasury Department accumulates the fund for disposal of spent fuel and HLW; the current fee is 1 mill/kWh net electricity sold $(\$ 0.001 / \mathrm{kWh}) ;$ the unaudited nuclear waste fund balance for 1990 is $\$ 2.6$ billion (DOE/RW-0301P 1991)

C. DOE is required to pay its proportionate share of costs for management of its HLW in the civilian waste management system

D. Through fiscal year 1989 , approximately $\$ 4.0$ billion has been paid by the utilities into the Nuclear Waste Fund (NWF); the NWF earned $\$ 609$ million of interest on investments in government securities through fiscal year 1989

E. The appropriation for fiscal year 1991 for the total OCRWM program was \$242.8 million; the DOE requested $\$ 305.1$ million from the NWF for OCRWM program activities in fiscal year 1992 (DOE/RW-0305P 1991; NWN 2/7/91)

4.5 KEY AGENCIES AND FUEL CYCLE CENTERS (Leigh and Mitchell 1990)

A. Department of Energy (DOE): The DOE is responsible for planning and development of national energy strategies and activities, including planning and implementing programs for the safe handling of radioactive wastes generated by federal activities, and for disposal of all high-level wastes, spent fuel, transuranic wastes, and greater-than-class-C low-level wastes; DOE is also responsible for ensuring availability of adequate technology 
for safe and efficiem management of nuclear wastes from both civilian and federal activities; the main DOE offices involved in nuclear fuel cycle and waste management activities and in international exchange activities are identified below:

1) Otfice of Civilian Radioactive Waste Management (OCRWM): OCRWM manages all aspects of transportation, extended interim federal storage, and disposal of civilian spent fuel and HLW and disposal of defense HLW; OCRWM is developing an MAS facility

2) Office of Environmental Restoration and Waste Management (EM): EM manages all aspects of treatment, storage, and disposal of wastes at DOE sites. Wastes include HLW, TRU wastes, LLW, hazardous chemical wastes, mixed hazardous and radioactive wastes, and sanitary wastes. EM responsibilities include operation of site waste management facilities, cleanup of inactive hazardous and radioactive waste sites at all DOE facilities, assistance to states on commercial LLW, D\&D programs, UMTRAP, and FUSRAP; EM is also responsible for providing new and more effective technologies to meet DOE's goal of regulatory compliance and cleanup.

3) Office of Energy Research (ER): ER carries out research on basic energy sciences, high energy and nuclear physics, and fusion energy; ER is also responsible for research, development, and demonstration of the possible alternative of subseabed disposal for $\mathrm{HLW}$ and spent nuclear fuel

4) Office of Nuclear Energy (NE): NE is responsible for development and demonstration of technology for all federal non-defense nuclear power and fuel cycle activities (except the waste management activities under DOE/EM and DOE/OCRWM)

5) Othice of Defense Programs (DP): DP is responsible for management and operation of defense activities and facilities (except waste management activities under DOE/EM and DOE/OCRWM)

6) Office of International Aftairs and Energy Emergencies (IE): IE coordinates international energy technology exchanges and emergency energy plans and activities

B. Department of interior $(\mathrm{DOI})$

1) U.S. Geologic Survey (USGS): USGS conducts laboratory and field investigations in support of DOE waste disposal programs

2) Bureau of Land Management (BLM): BLM manages federally owned land; it reviews proposals to place waste disposal facilities on federal lands

C. Department of Transportation (DOT): DOT develops, issues, and enforces safety standards that govern the transport of all materials, including radioactive and other hazardous materials

D. Environmental Protection Agency (EPA): EPA sets overall federal standards for protection of the environment and public health; the EPA, together with the NRC, regulates management of hazardous wastes and mixed radioactive and hazardous wastes 
E. Nuclear Regulatory Commission (NRC): NRC, in compliance with general standards developed by the EPA, regulates and licenses civilian nuclear facilities and federally operated facilities used primarily for receipt, transportation, storage, and disposal of civilian HLW and spent fuel; it regulates and certifies civilian nuclear materials transportation packagings; the NRC performs R\&D related to safety and licensing; together with the EPA, it regulates management of mixed wastes

F. DOE Operations (or field) offices: DOE operates its fiacilities through regional DOE field offices; these field offices are identified below:

1) Albuquerque Operations (AL): manages work by contractors of WIPP, Rocky Flats Plant, Mound Laboratory, Los Alamos and Sandia National Laboratories; AL's waste management activities include development support of transportation systems, TRU waste management R\&D, and carrying out the uranium mill tailings restoration program

2) Chicago Operations $(\mathrm{CH})$ : manages work by contractors of Argonne and Brookhaven National Laboratories; its waste management activities include IFR fuel cycle development and TRUEX process development, including waste partitioning development

3) Idaho Operations (ID): manages work by contractors of the Idaho National Engineering Laboratory (INEL), Idaho Chemical Processing Plant (ICPP), West Valley vitrification facility and site cleanup, and Three-Mile-island (TMi) reactor cleanup projects; its waste management activities include development of the transportation cask fleet for civilian spent fuel, demonstration of spent fuel rod consolidation and resultant waste treatment, reorocessing of special fuels, and treatment of low-level and TRU wastes

4) Nevada Operations (NV): manages work by contractors of Nevada Test Site operations

5) Oak Ridge Operations (OR): manages work by contractors of the Oak Ridge National Laboratory (ORNL); its waste managernent activities include civilian waste characterization, civilian and defense waste management $R \& D$, and civilian transportation system operations R\&D

6) Richland Operations (RL): manages work by contractors of the Hanford Operations, the Fast Flux Test Facility (FFTF) demonstration fast breeder reactor, the Pacific Northwest Laboratory (PNL), and formerly the Shippingport Decommissioning project (decommissioning completed in October 1989); RL's waste management activities include research and development, demonstration and application of spent fuel storage, waste treatment and waste isolation technology, and cleanup/restoration of the Hanford site

7) San Francisco Operations (SAN): manages work by contractors of Lawrence Berkeley and Lawrence Livermore Laboratories; its waste management activities include civilian spent fuel and HLW packaging R\&D activities; it also manages work on nuclear physics, safeguards development, and advanced reactor concepts 
8) Savannah River Operations (SA): manages work by contractors of Savannah River Laboratory (SRL) and Savannah River Plant (SPP) operations (which include defense materials production and separation, waste management); SR also manages work on the Defense Waste Processing Facility (DWPF) and supponting R\&D for the Savannah River site

G. DOE national laboratories and nuclear research centers; the following discussions identity nuclear fuel cycle and waste management $A \& D$ activities at the DOE national laboratories:

1) Argonne National Laboratory (ANL) near Chicago, Illinois: ANL operates the materials integration office for waste materials characterization; it conducts development of pyrochemical and aqueous fuel reprocessing technology, including TRUEX processes; ANL carries out R\&D on remedial actions for formerlyused federal radioactive sites and for the surplus facilities management program

a. Facilities include hot cells at ANL East (near Chicago) and ANL West (near INEL in (daho), a large gamma radiation facility, the Experimental Breeder Reactor-2 (EBR-II), the Zero-Power Plutonium Reactor (ZPPA), the Hot Fuel Examination Facility (HFEF), the Transient Reactor Test Facility (TREAT), a radioactive scrap and waste facility, the Sodium Process Demonstration (SPD) facility, and the Radioactive Liquid Waste Treatment Facility (RLWTF)

2) Brookhaven National Laboratory (BNL) on Long Island, New York: BNL conducts R\&D on waste treatment, $\amalg W$ waste form evaluation, and nuclear physics

a. Facilities include radioactive and nonradioactive development laboratories

3) Idaho National Engineering Laboratory (INEL) near Idaho Falls, Idaho: INEL coordinates development of national LLW treatment and disposal technology; it develops and carries out waste examination technology, TRU waste volume reduction and conditioning, reprocessing of federal research fuels, decommissioning of onsite research reactors, and dry technology demonstration of consolidation of spent fuel rods

a. Facilities include the transuranic waste Processing Experimental Pilot Plant (PREPP), the Waste Environmental Reduction Facility (WERF), the Stored Waste Examination Pilot Plant (SWEPP), the Test Area North (TAN) spent fuel storage area, a chemical plant for reprocessing research and naval spent fuels, and research reactors

4) Lawrence Livermore National Laboratory (LLNL) 30 miles east of Berkeley, California: LLNL conducts development of geologic repository waste package design criteria, monitoring techniques for geologic repositories, and performance assessment for geologic repositories; it also develops particulate filters and performs laser fusion research

a. Facilities include the CLIMAX spent fuel test facility at the Nevada Test Site (now shut down)

5) Los Alamos National Laboratory (LANL) at Los Alamos, New Mexico: LANL performs TRU waste management R\&D, geologic repository support technology 
R\&D, fundamental studies of waste materials, and studies on migration from LLW sites; it carries out decommissioning of various onsite facilities

a. Facilities include a controlled air incinerator demonstration facility, a glove box reduction facility, and TAU waste assay systems

6) Mound Laboratory at Miamisburg, Ohio: Mound conducts research on solid waste volume reduction with a glass melter, developinent of TRU waste records systems, and R\&D on TAU waste treatment technologies including incineration; it also carries out tritium recovery from wastes and decommissioning of unused onsite facilities

a. Facilities include a glass melter for waste treatment, an incinerator, a waste treatment facility, the Combined Electrolysis Catalytic Exchange system (CECE), the Tritium Effluent Recovery System (ERS), and the Hydrogen Isotope (cryogenic distillation) Separation System (HISS)

7) Oak Ridge National Laboratory (ORNL) near Oak Ridge, Tennessee: ORNL conducts A\&D on fuel reprocessing technologr. TRU waste and LLW technologies, hazardous waste remedial actions, and HLW system characterization technology; it performs operations studies for the civilian spent fuel/HLW system; it maintains a remedial action information center and a decommissioning data base

a. Facilities include the integrated remote equipment test facility, test facilities for spent fuel shearing and decladding studies, a spent fuel dissolving test facility, a tower shielding facility for transportation cask drop tests, and a tumulus LLW disposal facility

8) Pacific Northwest Laboratory (PNL) at the Hanford site near Richland, Washington: PNL conducts R\&D on all aspects of radioactive and hazardous waste management technology; it maintains the Materials Characterization Center for waste forms and the International Program Supsport Office (for international waste management and fuel cycle activities); it performs environmental studies of all types, geologic repository support studies, perormance assessment scientific support (PASS) studies, studies of byproduct ricovery and use technology, and waste systems studies; it also conducts work cn advanced reactor systems

a. Facilities include radioactive and nonradioactive development laboratories, large hot celis for development and pilot-scale programs and spent fuel characterization

9) Sandia National Laboratories (SNL) in Albuquerque, New Mexico: SNL performs $R \& D$ on transportation technology and support $A \& D$ for geologic repositories (in tuff rock) for spent fuel/HLW and WIPP (in salt rock) for defense TRU wastes; it also conducts safety assessments for NRC

a. Facilities include research reactors and rlumerous test facilities

10) Savannah River Laboratory (SAL) near Aiken, South Carolina: SRL provides R\&D support to defense fuel reprocessing; it performs defense $\mathrm{HLW}$ form development and characterization, defense TRU waste technology development, defense LLW technology development, and defense HLW technology development 
a. Facilities include a HLW vitrification pilot plant, a liquid HLW storage tank mocklip, and HLW caves for process development

11) Savannah River Plant (SRP) near Aiken, South Carolina: The SRP is operated by the Westinghouse Savannah River Company (WSRC); it performs defense fuel reprocessing and associated spent fuel storage and HLLW tank storage; it has constructed and will operate the Defense Waste Processing Facility (DWPF) for vitrification of $\mathrm{HLW}$; it operates LLW disposal facilities, including saltstone vaults

a. Facilities include two reprocessing plants, the HLW tank farm, the DWPF, an incinerator facility, and LLW disposal facilities, including saltstone vaults

12) Westinghouse Hanford Company (WHC), at the Hanford site near Richland, Washington: WHC conducts operations related to its waste cleanup mission; it carries out HLW tank storage, D\&D of Hanford reactors and fuel cycle facilities, and grout solidification of LLW

a. Facilities include the Fast Flux Test Facility (FFTF, test LMFBR) and the transportable grout facility for defense LLW

13) Waste Isolation Pilot Plant (MIPP) 35 miles from Carlsbad, New Mexico: Westinghouse Electric Corp. provides operation of and technical support for WIPP

a. Facilities include the WIPP repository for demonstrating geologic disposal of defense TRU wastes

14) TRW Environmental Satety Systems, Inc.: In 1991, TRW signed a 10-year management and operating contract (which includes an option to renew for up to an additional five years) for DOE's spent fuel and high-level radioactive waste management program; the contract will give DOE-OCRWM its main tool for consolidating and integrating the complex repository site characterization efforts and supporting systems and R\&D studies (NWN 2/14/91b)

\subsection{KEY PERSONNEL}

A. James D. Watkins: Secretary of Department of Energy (DOE)

1) John W. Bartlett: Director, Office of Civilian Radioactive Waste Management (OCAWM)

a. Franklin G. Peters: Deputy Director, OCRWM

b. Donald G. Horton: Acting Director, Office of Quality Assurance

c. Thomas $H$. Isaacs: Acting Director, Office of Strategic Planning and International Programs

1) William J. Danker: International Activities Coordinator

2) Renee M. Jackson: International Activities Coordinator

d. Jerome D. Saltzman: Acting Director, Office of External Relations 


\section{UNITED STATES}

e. Samuel Rousso: Associate Director, Dttice of Program and Resources Management

f. Carl P. Gertz: Acting Associate Director, Office of Geologic Disposal

g. Dwight D. Sheior: Acting Associate Director, Office of Systems and Compliance

h. Ronald A. Milner: Acting Associate D rector, Otfice of Storage and Transportation

i. Franklin G. Peters: Acting Associate Director, Office of Contract Business Management

2) Leo P. Duffy: Director, Office of Environmential Restoration and Waste Management (EM)

a. Paul D, Grimm: Deputy Director, EM

b. James E. Dieckhoner: Acting Associate Director, OHlice of Planning and Resource Management

c. Randal Scott: Associate Director, Office of Environmental Quality Assurance and Ouality Control

d. Jill E. Lytle: Associate Director, Office of Waste Operations

e. R. P. (Pat) Whitfield: Associate Directcr, Office of Environmental Restoration

f. Clyde W. Frank: Associate Director, OHice of Technology Development

1) Lawrence H. Harmon: Director, Program Support Division

2) Donald H. Alexander: Manager, International Technology Exchange

3) John J. Easton, Jr.: Assistant Secretary for International Affairs and Energy Emergencies (IE)

a. Arlen l. Erdahl: Principal Deputy Assistant Secretary, IE

1) Harold Jaffe: Director of International Research and Development Policy

4) Bruce G. Twining: Manager, Albuquerque Operations (AL)

a. James Bickel: Assistant Manager for Ënergy and Special Programs

b. Arlen Hunt: Project Manager of Waste Isolation Pilot Plant Project

5) Dr. David T. Goldman: Acting Manager, Chicago Operations (CH)

a. Richard C. Baker: Senior Program Manager of Repository Technology Program 


\section{UNITED STATES}

b. Jeffrey B. Roberts: Senior Program Manager of Transportation Program Office

6) A. A. Pitrolo: Manager, ldaho Operations (ID)

a. James E. Solecki: Assistant Manager for Environmental Restoration and Waste Management

1) Scott $T$. Hinschberger: Manager, Waste Management

2) Thomas J. Roland: Director, West Valley Project Office

7) Nick C. Aquilina: Manager, Nevada Operations (NV)

8) Joe La Grone: Manager, Oak Ridge Operations (OR)

9) John D. Wagoner: Manager, Richland Operations (RL)

a. W. W. Bixby: Deputy Manager for Environmental Management

1) Leo E. Little: Assistant Manager for Environmental Management

2) John H. Anttonen: Assistant Manager for Projects

a) Robert W. Brown: Project Manager, Vitrification Project Office

3) Joseph J, Sutey: Director, Research and Development

b. J. Phil Hamric: Deputy Manager of Operations

1) John R. Hunter: Assistant Manager of Operations

a) Kenneth W. Bracken: Director, Waste Management Division

b) J. E. Mecca: Director, Operations Division

c) R. E. Gerton: Director, Tank Farm Project Office

10) Donald Pearman: Manager, San Francisco Operations (SAN)

11) P. W. (Bill) Kaspar: Manager, Savannah River Operations (SR)

a. A. Lee Watkins: Director, Defense Waste Processing Facility

B. William K. Reilly: Administrator, Environmental Protection Agency (EPA)

1) Alan Hecht: Deputy Administrator, International Activities

2) Timothy B. Atkeson: Assistant Administrator, International Activities

3) Richard Guimond: Director, Radiation Programs 
UNITED STATES

a. Floyd L. Galpin: Chief, Waste Management Standards Branch

C. Kenneth M. Carr: Chairman, Nuclear Regulatory Commission (NRC)

1) James R. Shea: Director, International Prograrns

2) Robert M. Bernero: Director, Nuclear Material Safety and Safeguards

a. Billy J. Youngblood: Director, High-Level Waste Management

b. Richard L Bangart: Director, Low-Level 'Naste Management and Decommissioning

3) Eric S. Beckjord: Director, Nuclear Regulatory Research

D. David Leroy: Office of the Nuclear Waste Negotiator

E. Don U. Deere: Chairman of the Board, Nuclear Waste Technical Review Board (NWTRB)

1) William D. Barnard: Executive Director, NWTRB

\subsection{NUCLEAR FUEL PRODUCTION}

5.1 STRATEGY: In the U.S., private industry provides for all uralium resource exploration and production and fuel production of civilian nuclear fuels; all enrichment services and defense fuel production are performed by DOE; industry markets uranium and nuclear fuels to foreign entities, subject to federal restrictions; a federal license is required for export of natural or enriched uranium materials; there are no restrictions on import of natural uranium except from selected countries

5.2 URANIUM RESOURCES: January 1989--377,500 MTU reas.onably assured; 903,800 MTU estimated additional (NEA 1989)

5.3 URANIUM PRODUCTION: In 1989-5,300 MTU (NEA 1990)

At the end of 1988, three conventional mills were operating, one in each of the states of Utah, Texas, and New Mexico; in addition, there were six solution rining plants and five copper leach and phosphate by-product operations (NEA 1989); some of the uranium is exported to foreign countries

5,4 URANIUM CONVERSION: Allied Chemical Corporation at Nietropolis, Illinois $(12,700 \mathrm{MTU} / \mathrm{yr}$ capacity) uses the dry fluoride volatility process; Sequoya Fuels Corporation in Gore, Oklahoma (9,090 MTU/yr capacity) uses the wet chemical process (EIA 10/26/90; NEI 1991)

\subsection{URANIUM ENRICHMENT:}

A. The U.S. has extensive government-operated industrial-scale capability $(19,200,000$ SWU/ yr) for enrichment by gaseous diffusion in two facilities: the Paducah Gaseous Diffusion Plant in Paducah, Kentucky, has capacity for 11,300,000 SWU/yr and the Portsmouth Gaseous Diffusion Plant in Portsmouth, Ohio, has capacity for $7,900,000 \mathrm{SWU} / \mathrm{yr}$; enrichment services are also marketed to foreign entities; the atomic vapor laser isotope 
separation (AVLIS) enrichment technology is currently under development (EIA 10/26/90; NEI 1991)

B. Louisiana Energy Services, a private-sector uranium enrichment consortium (involving three U.S. electric utilities, Fluor Daniel Inc., and Urenco Inc.), will build a $\$ 750$ million plant in Claiborne Parish in northwest Louisiana with a capacity of 1.5 million SWU/yr; construction is planned to start in 1992 with operations in 1996 (ED 6/12/89)

5.6 FUEL FABRICATION: The U.S. has commercial capability (capacity up to $3,750 \mathrm{MTHM} / \mathrm{yr}$ ) in five facilities for fabrication of LWR fuels at (NEI 1991)

Westinghouse facility in Columbia, South Carolina (1250 MTHM/yr capacity) Babcock \& Wilcox facility in Lynchburg, Virginia (400 MTHM/yr capacity) Advanced Nuclear Fuels facility in Richland, Washington (700 MTHM/yr capacity) General Electric facility in Wilmington, Delaware (1100 MTHM/yr capacity) ABB Combustion Engineering facility in Windsor, Connecticut (300 MTHM/yr capacity)

\subsection{PROGRAM/FACILITIES COSTS:}

A. The cost for enrichment in the DOE fiscal year 1991 budget is $\$ 1.34$ billion (NN 3/91)

B. The DOE's budget for fiscal year 1991 included a request for $\$ 154.5$ million for development of the atomic vapor laser isotope separation (AVUS) process (NEI 6/90)

C. The Louisiana Energy Services private-sector uranium enrichment plant is expected to cost $\$ 750$ million (ED 6/12/89)

\subsection{FUEL RECYCLE}

\subsection{FUEL REPROCESSING}

A. Industrial organizations have decided not to reprocess commercial spent fuel at the current time, primarily because reprocessing and fuel recycle are not currently costeffective in the U.S.

B. Commercial reprocessing was conducted from 1966 to 1972 at the West Valley Plant, now being decommissioned; construction of the Morris, Illinois, and Barnwell, South Carolina, commercial reprocessing plants was completed but the plants never operated

C. Peprocessing of defense fuels is carried out at Savannah River, South Carolina, and also formerly at Hanford, Washington; reprocessing of nuclear submarine and test reactor fuels is carried out at a site near ldaho Falls, Idaho; all current reprocessing plants use the PUREX solvent extraction process (see Section 3.4 for dates of operation)

D. In 1977 President Jimmy Carter issued a nuclear policy statement which banned commercial reprocessing in the U.S.; President Reagan's nuclear policy statement, issued in 1981, reversed the ban on reprocessing (NW 4/7/77; NW 10/15/81)

6.2 PLUTONIUM RECYCLE: Technology has been under development for reprocessing of breeder fuels and plutonium recycle to breeders; recycle is not currently planned, but application is contingent upon possible future U.S. move to a breeder fuel system (Feldman and Hammel 
UNITED STATES

1984); fuels and materials are tested in the Fast Fiux Test Facility, a demonstration/test LMFBR near Richland, Washington

6.3 RESEARCH AND DEVELOPMENT: The U.S. has carried ott major R\&D on reprocessing, starting with defense activities in the early 1940s; the federa R\&D has developed the bismuth phosphate, REDOX, and PUREX processes to routine production scale; federal R\&D continues to support and improve the existing defense reprocessing facilities and to develop new processes, such as the TRUEX process for improved removial of actinides from wastes; private industry also carried out signiticant R\&D in support of their private reprocessing ventures in the 1960 s and 1970s

\subsection{SPENT FUEL STORAGE AND TRANSPORT}

7.1 SPENT FUEL ARISINGS (assuming no new orders for nuclear power reactors in the U.S.)

198614,100 MTU cumulative for commercial spent fuel (DCE/RW-0006 1990)

1989 19,600 MTU cumulative for commercial spent fuel (DCE/RW-0006 1990)

199021,800 MTU cumulative projected (EIA 10/26/90)

200040,400 MTU cumulative projected (EIA 10/26/90)

202074,800 MTU cumulative projected (EIA 10/26/90)

204084,100 MTU cumulative projected (EIA 10/26/90)

7.2 FUEL ASSEMBLY CHARACTERISTICS: Almost all civilian riuclear spent fueis are from PWRs and BWRs; spent fuel characteristics vary with reactor and with fuel manufacturer; a typical PWR fuel assembly has 284 fuel rods $(-0.95 \mathrm{~cm}$ diameter), is $\sim 4.5 \mathrm{~m}$ long and $-21.4 \mathrm{~cm}$ on a side of the square cross section, and contains $0.46 \mathrm{MTU} / \mathrm{ass}$ embly; a typical BWR fuet assembly has 63 fuel rods $(-1.25 \mathrm{~cm}$ diameter), is $\sim 4.1 \mathrm{~m}$ long and $\sim 13.9 \mathrm{~cm}$ on a side of the square cross section, and contains $0.18 \mathrm{MTU} /$ assembly (DOE/RW-0006 1990)

7.3 SPENT FUEL STRATEGY: Electrical utilities with nuclear power are responsible for storing their spent fuel until the DOE accepts it for extended interim storage or geologic disposal; these utilities presently store civilian spent fuel in compact racks in reactor pools; the DOE is developing a Monitored Retrievable Storage (MRS) facility for acceptance of civilian spent fuel by the federal government prior to disposal in a deep geologic repository; DOE will provide a transportation system for civilian spent fuel to an MRS facility and to the geologic repository; industry is and has been responsible for transporting the small amounts of spent fuel between nuclear power stations to an existing private AFR storage facility at Morris, Illinois, and previously to the shut-down West Valley reprocessing plant; $n$ 1989, NRC proposed revisions to its 1984 waste confidence decision: NRC expects that an HLN repository will be available within the first quarter of the twenty-first century, and it views that sjent fuel storage is acceptable for up to 30 years after the end of a reactor's licensed operatior (including a license renewal period) (NRC 1984; NN 11/90)

\subsection{WET STORAGE (Harmon and Johnson 1984)}

A. In the U.S., the general practice for storage of comme'cial spent fuel is in-pool storage in metal racks at reactor sites; capacity is increased in rrany cases by installation of high-densily racks with integral neutron poisons

B. Some commercial spent fuel may be disassembled in the reactor pool and the fuel rods consolidated into canisters which are then stored in the pool; fuel rod consolidation ratios 
of 2:1 have been demonstrated (although not at high throughput rates); compaction ratios of 10:1 have been demonstrated for the non-fuel-bearing components (NFBCs) (Smith 1991)

C. Away-from-reactor (AFR) spent fuel storage capacity of $750 \mathrm{MTHM}$ exists at the Morris, Illinois, reprocessing facility (the reprocessing facility was never operated); it is a pool storage facility (NEl 1991)

D. Defense spent fuel is stored in pools at the reactors before transport to the onsite defense reprocessing

\subsection{DRY STORAGE (Harmon and Johnson 1984; DOE/RW-0144 1987)}

A. Some commercial nuclear power stations are implementing additional spent fuel storage in dry storage casks (metal and concrete) and in modular concrete vaults; the concrete systems are generally less expensive (NWN 1/25/90)

1) Metal casks for dry spent fuel storage (some metal casks also provide transport capabilities) are described below:

a) The NAC-STC (Nuclear Assurance Corporation) cask is a dual-purpose cask for both spent fuel storage and transport; it utilizes a multiwall concept made up of a 304 stainless steel inner shell (1.5 in. thick), a lead layer for gamma shielding ( 3.7 in. thick), and an outer shell of 304 stainless steel (2.7 in. thick), surrounded by a BISCO layer for neutron shielding (5.5 in. thick); the cask has the capacity for 26 intact PWR assemblies and weighs about 125 tons when loaded; it is 175-in. long and 94-in. in diameter (Stuart 1991)

b) The Castor-V/21 [Gesellschaft fur Nuklear Service (GNS)] PWR spent fuel storage cask consists of a nodular cast-iron body; it has the capacity for 21 intact PWR assemblies and weighs about 100 tons when loaded; the cask

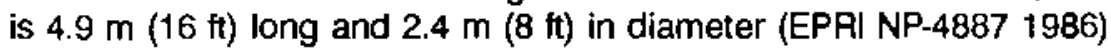

c) The TN-24P (Transnuclear, Inc.) PWR spent fuel storage cask consists of a forged steel body, surrounded by a resin layer for neutron shielding, and contained in a steel outer shell; it has the capacity for 24 PWR intact assemblies and weighs about 100 tons when loaded; the cask is $5.0 \mathrm{~m}$ (16 ft) long and $2.3 \mathrm{~m}(7.5 \mathrm{t})$ in diameter (EPRI NP-5128 1987)

d) The MC-10 (Westinghouse) PWR spent fuel storage cask consists of a lowalloy forged steel body and a layer of BISCO around the outside of the cask for neutron shielding; it has the capacity for 24 intact PWR assemblies and weighs approximately 110 tons when loaded; the cask is $4.8 \mathrm{~m}(15.7 \mathrm{ft})$ long and $2.7 \mathrm{~m}(8.9 \mathrm{t})$ in diameter (EPRI NP.5268 1987)

e) The REA 2023 (Ridihalgh, Eggers \& Associates) [MSF IV (Mitsubishi)] BWR spent fuel storage cask consists of a stainless steel outer skin, a lead/stainless steel gamma shield, and a water/glycol neutron shield; it has the capacity for 52 intact BWR assemblies and weighs about 100 tons when loaded; the cask is $5 \mathrm{~m}(16.4 \mathrm{ft})$ tall and $2.25 \mathrm{~m}(7.4 \mathrm{tt}$ ) in diameter (PNL5777 1986) 
Concrete casks for dry spent fuel storage are described below:

a) Pacific Sierra Nuclear (PSN) has desigried a ventilated storage cask (VSC) system; the PSN design is a vertically-criented, concrete storage cask; the cask design can be sized to store 4 to 24 intact PWR assemblies or 9 to 56 intact BWR assemblies (Creer and Collantes 1990)

b) The Babcock \& Wilcox (B\&W) CONSTAR (concrete storage at reactor/repository) spe rt fuel storage cask is constructed of steel-fiber reinforced concrete; it is unventilated, using heat pipes attached to an inner steel liner which transfer heat to an external radiator; it is about $3.4 \mathrm{~m}(11 \mathrm{ft})$ in diameter, $6.1 \mathrm{~m} \mathrm{(20} \mathrm{ft)} \mathrm{tall,} \mathrm{and} \mathrm{weighs} 165$ tons when loaded (Creer and Collantes 1990)

3) Modular concrete vaults for spent fuel storage: the NUHOMS system consists of horizontal storage modules; the fuel assemblies are confined in a helium atmosphere within a stainless steel canister; the canister, which has lead-shielded ends, is protected and shielded by the reinforced concrete storage module; passive ventilation heat removal is employed; the modules can be designed to hold as many as 24 intact PWR assemblies (NEJ 9/89; EPRI NP-6940 1990)

B. DOE implemented (1983-1990) a government/industny cooperative storage and fuel management program with the following objectives:

1) Make dry storage and rod consolidation technology available to commercial utilities for licensing

2) Participate in cooperative demonstrations with sommercial utilities

3) Provide information to utilities to facilitate their licensing of dry storage and rod consolidation technologies

C. In March 1987, a Monitored Retrievable Storage (MRSi) facility was proposed at a specific site by DOE to Congress; in December 1987, Congress revoked the DOE proposal but authorized the MRS facility in the NWPAA, subject to satisfactory outcome of certain restrictions and evaluations (U.S. Congress 1987; DOE/RW-0187 1988; DOE/RW-0247 1989)

1) Currently, the reference MRS facility would only be designed to provide temporary storage for spent fuel priur to shipment to the repository

2) The maximum storage capacity is limited by the NWPAA to no more than $10,000 \mathrm{MTU}$ until the repository begins to accejt waste and to $15,000 \mathrm{MTU}$ thereafter

3) The current reference storage concept is dry sealed storage casks (concrete) that would contain multiple intact spent fuel assemblies and multiple failed (canisterized at reactor) spent fuel assemblies; the ventilated concrete storage casks are cylindrical, reinforced-concrete structures with a stepped, carbon-steellined cavity; an air annulus between the liner and concrete will provide heat removal capability; the cask cavity will be inerted before sealing; the casks are 22 ft high with a 12 ft outside diameter and 6 ft interior diameter (PNL-7400 1990) 
4) The waste acceptance design-rate will be approximately 3,000 MTU/yr spent fuel

5) Schedule linkages between repository and MRS siting and construction presently exist in the NWPA and the NWPAA: an MAS site cannot be selected until a repository site has been recommended to the President, and the construction of an MRS facility cannot begin until an NRC license has been issued for construction of a repository

6) An independent MRS Review Commission reported to Congress on the need for an MRS facility; it concluded that building an MRS would be justified if: 1) there were no linkages between the MRS and the repository, 2) the MRS could be constructed at an early date, and 3) opening of the repository was delayed considerably

7) A negotiated (volunteer) site selection process began in 1990 after the appoirtment of the Nuclear Waste Negotiator to try to find offers of an acceptable site by a state or Indian tribe, with the final site to be selected in 1992 (Smith 1991)

8) The current operating schedule for the MAS facility is for limited acceptance of spent fuel in 1998, and the design-rate waste acceptance in 2000

\subsection{TRANSPORT (DOE/RW-0187 1988)}

A. To date, modest amounts of commercial spent fuel have been transported between reactor sites and to former fuel reprocessing plants; conventional truck and rail casks have been provided and operated by industry

B. Development of a DOE system for commercial spent fuel transport is underway

C. Conceptual designs (both legal-weight truck and rail) have been developed and detailed designs are well along, with final designs expected to be completed in 1992, for the initial DOE cask fleet for transport of civilian spent fuel from reactors to the MAS facility or to the repository (Smith 1991)

1) The truck casks are expected to have capacities of 4 intact PWA assemblies or 5 intact BWA assemblies; the casks are designed with a stainless steel inner liner, a depleted uranium gamma shield layer, a stainless steel body, a polyethylene neutron shield layer, and a stainless steel outer skin; the casks are to be transported on legal-weight trucks

2) The rail/barge casks are expected to have capacities of 21 intact PWR or 40 intact BWR assemblies; the casks are designed with an inner stainless steel shell, a lead gamma shield layer, a neutron/thermal shield layer, and an outer stainless steel shell; the casks will each weigh about 100 tons when loaded

D. A DOE cask fleet for transport of civilian spent fuel from the MRS facility and HLW from its sources to the repository will be developed later; this transport is planned to be by rail only

E. Dual-purpose casks, i.e., for both transport and storage, are not currently planned in the federal system, but some utilities are considering their use 
F. Defense spent fuels have been transported to the resjective onsite fuel reprocessing plants by rail since the 1940 s

\subsection{RESEARCH AND DEVELOPMENT}

A. DOE completed an R\&D program in 1990 to develop :nformation for industry and government to provide safe, licensed dry storage of spent fuel; the program included government/industry cooperative storage and fuel management studies; the program

. included the following activities (DOE/RW-0144 1987):

1) Characterizing spent fuel

2) Determining effects on spent fuel of wet and dry storage under various conditions

3) Evaluating dry storage concepts, confirming design and performance models, and demonstrating dry storage

4) Providing licensing support to utilities for dry storage

5) Developing dry consolidation of spent fuel (still underway)

B. Some commercial utilities are investigating in-pool spent fuel rod consolidation (see 7.4B)

C. DOE is continuing to suppor R\&D on spent fuel transportation subjects, including institutional issues, operational concerns, and burnup credit in casks

7.8 PROGRAM/FACILITIES COSTS (DOE/RW-0047 1987; PNL-6770 1988; DOE/RW-0220 1989; DOE/RW-0291P 1990)

A. Costs of reracking to high-density racks for in-pool stirage of civilian spent fuel are $\$ 5,000$ to $\$ 10,000$ per MTU

B. The concrete casks for intact spent fuel storage in the proposed MRS facility are estimated to cost about $\$ 14,000$ per MTU

C. The metal casks for intact spent fuel storage are estirnated to cost about $\$ 100,000$ per MTU

D. Total ife-cycle costs of the basic MRS facility and its operations as proposed in 1990 are estimated at $\$ 1.9$ billion

E. Total life-cycle costs of the transportation system for civilian spent fuel and HLW are estimated at $\$ 2.8$ billion

\subsection{WASTE CONDITIONING, STORAGE AND TRANSPORT}

\subsection{WASTE DEFINITIONS:}

A. High-Level Waste (HLW) in the U.S. is defined by the NRC $(10$ CFR 60) as: 1) irradiated reactor fuel, 2) liquid wastes resulting from the operation of the first cycle solvent extraction system, or equivalent, and the concentrated wastes from subsequent 
extraction cycles, or equivalent, in a facility for reprocessing irradiated reactor fuel, and 3) solids into which such liquid wastes have been converted (CFR 1989)

B. Transuranic (TRU) waste in the U.S. is defined by the EPA (40 CFR 191) as: waste contaminated with alpha-emitting radionuclides with half-lives greater than 20 years and concentrations greater than 100 nanocuries per gram

C. Low-Level Waste (LLW) in the U.S. is defined by the NRC (10 CFR 61) as: all wastes that are not classified as spent nuclear fuel, HLW, TRU waste or by-product material (i.e., uranium or thorium mill tailings); LLW may contain long-lived alpha emitters in concentrations up to 100 nanocuries per gram of waste (CFR 1989)

1) The NAC has subdivided LLW into three categories in 10 CFR 61 (Class A, Class $B$, and Class $C$ ), based on the concentration of long-lived radionuclides and the length of time they could cause exposures, and on the concentrations of shorter-lived radionuclides; Class A wastes are the least toxic, and Class $\mathrm{C}$ wastes are the most toxic for longer time periods and require additional intrusion resistance at the disposal facility

2) Class A low-level wastes have a maximum concentration limit for total nuclides with half-lives less than five years of 700 curies per cubic meter; low-level wastes must not contain greater than 100 nanocuries per gram of transuranic radionuclides (alpha emitters with hall-lives greater than five years); radionuclides of major concern in LLW include the short-lived radionuclides cesium-137, strontium-90, tritium, nickel-63, and cobalt-60; long-lived radionuclides of concern include carbon-14, nickel-59, niobium-94, technetium-99, iodine-129, plutonium-241, and curium-242; maximum concentration limits for these radionuclides for the different classes of LLW are given in the 10 CFA 61 regulations (CFR 1989)

3) Greater-than-Class-C (GTCC) LLW have radionuclide content between Class C LLW and HLW, and require different management practices from Class C LLW; in 1989 , the NRC amendments to 10 CFR 61 effectively treat GTCC for disposal purposes as if it were high-level waste (DOE will dispose of HLW in a deep geologic repository); a waste is considered to be GTCC if it meets any of the following criteria (CFA 1989; NN 7/89):

a. Carbon-14 content of more than 8 curies per cubic meter, or more than 80 $\mathrm{Ci} / \mathrm{m}^{3}$ in activated metal

b. Nickel-59 content of more than $220 \mathrm{ci} / \mathrm{m}^{3}$ in activated metal

c. Nickel-63 content of more than $700 \mathrm{Ci} / \mathrm{m}^{3}$, or more than $7,000 \mathrm{Ci} / \mathrm{m}^{3}$ in activated metal

d. Strontium-90 content of more than $7,000 \mathrm{Ci} / \mathrm{m}^{3}$

e. Niobium-94 content of more than $0.2 \mathrm{Ci} / \mathrm{m}^{3}$ in activated metal

f. Technețium-99 content of more than $3 \mathrm{Ci} / \mathrm{m}^{3}$

g. lodine-129 content of more than $0.08 \mathrm{Ci} / \mathrm{m}^{3}$

h. Cesium-137 content of more than $4,600 \mathrm{Ci} / \mathrm{m}^{3}$ 
i. Transuranics nuclides as follows: plutonium-241 content of more than $3,500 \mathrm{nCi} / \mathrm{gram}$; curium-242 content of more than $20,000 \mathrm{nCi} / \mathrm{g}$; and for any other species with a half-life of more than five years, content of more than $100 \mathrm{nCi} / \mathrm{g}$

D. By-product material in the U.S. is defined as: 1) any radioactive material (except special nuclear material) yielded in or made radioactive by exposure to the radiation incident to the process of producing or utilizing special nuclear inaterial, and 2) the tailings or wastes produced by the extraction or concentration of uranium or thorium from any ore processed primarily for its source material content (Moghissi et al. 1986)

E. Naturally Occurring and Accelerator Produced Radioactive Materials (NORM and NARM) in the U.S, are defined as any radioactive materials that can be considered naturally occurring and are not source, special nuclear, or byproduct materials or those materials produced in a charged particle accelerator

\subsection{WASTE ARISINGS (Cumulative to year 2020) (DOE/RW-00C16 1990)}

A. Commercial wastes (assumes no future reprocessing): $3,080,000 \mathrm{~m}^{3} \mathrm{LLW}$ including 605,000 from decommissioning; $120,100,000 \mathrm{~m}^{3}$ mill tailings (in year 2000 ); 74,800 MTU spent fuel; $210 \mathrm{~m}^{3}$ vitrified HLW

B. Defense wastes: $358,000 \mathrm{~m}^{3} \mathrm{HLLW}\left(-3,300 \mathrm{~m}^{3}\right.$ as class from Savannah River); 299,000 $\mathrm{m}^{3}$ TRU wastes (in year 2010); $8,142,000 \mathrm{~m}^{3} \mathrm{LLW} ; 3 \approx, 700,000 \mathrm{~m}^{3}$ mill tailings

8.3 STRATEGY: In the U.S., waste generators are responsible "or treating and packaging their wastes and for providing interim onsite storage until the wa:stes are transported to their ultimate disposal site; the wastes are typically treated and packagecl at the source location to minimize volume and total management costs and to meet transportation and disposal requirements

\subsection{HLW IMMOBILIZATION}

A. Civilian and most defense high-level liquid wastes (H_LW) in the U.S. are to be converted to borosilicate glass by the liquid-fed ceramic meher process

1) Vitrification plants are under construction at the Savannah River Plant (construction completed, defense wastes) and West Valley (civilian wastes and a small amount of defense wastes, see Section 12.4), and are planned for Hanford, Washington and Idaho (defense wastes)

2) HLLW (both defense and civilian) will be converted to borosilicate glass with about $28 \%$ wastes oxides at processing temperatures of about $1150^{\circ} \mathrm{C}$

3) The commercial HI.W glass will be poured intc stainless steel canisters; the canisters have a glass fill neck and connecting flange; the canisters are 24-in. (61 $\mathrm{cm}$ ) in diameter, 118-in. $(3 \mathrm{~m})$ long, and have a 0.375 -in. $(0.95 \mathrm{~cm})$ thick wall; each canister will hold vitrified HLW from about 2 MTU of commercial spent fuel

4) Defense HLW glass will be poured into stainless steel canisters that are similar to those for commercial HLW glass; each canister will hold vitrified HLW from about $0.51 \mathrm{MTU}$ of defense spent fuel 
B. HLLW at INEL have been converted to a granular calcine, as a waste form for interim storage, in a fluidized-bed calciner since 1963; several options are still under consideration for the final waste form for disposal, including borosilicate glass and ceramic waste forms; conversion of the wastes to the final form will be started in the early 2000 s

C. At Hanford, Washington, much of the Cs-137 and Sr-90 has been chemically separated from the HLLW and converted to solid cesium chloride and strontium fluoride and placed in double-walled metal capsules for pool storage

8.5 SPENT FUEL CONDITIONING: At present in the U.S., civilian spent fuel from power reactors is planned to be stored intact at the MRS facility for an interim period, with any failed fuel to be canistered at the reactors before shipment to the MAS; some spent fuel consolidation demonstrations are under way at civilian power reactors, but no decision has been made yet as to large-scale consolidation of spent fuel (see Sections 7.4 and 7.5)

\subsection{LLW/ILW CONDITIONING:}

A. Standard practices, used worldwide (i.e., compaction of solids, evaporation of liquids, ion exchange and precipitation of liquid wastes, incineration of combustibles, incorporation into bitumen, cement, and plastic matrices), are employed in the U.S. to reduce volumes and solidify wastes; canisterizing is done to meet transportation and disposal requirements; conditioning is done either in an onsite facility or by a mobile facility or central facility that is contracted by the waste generator; for some Class C LLW where the waste form does not meet disposal requirements, a high-integrity container (typically cement or plastic) with life expectancy of at least 300 years can be used in place of meeting all waste form requirements (Lakey et al. 1985)

B. Volume reduction, both at the source (waste minimization) and by treatment, has been emphasized due to rapidly increasing disposal costs and volume surcharges and quotas for certain wastes

C. Solidification of LLW liquids prior to disposal is mandatory; disposal of any container with more than one percent of free liquid by volume is prohibited

D. Technology for acid digestion was developed for transuranic waste conditioning but not used; incineration, waste-sorting and volume-reduction processes have been developed, and immobilization in cement matrices is utilized (Lakey et al. 1983)

8.7 AIRBORNE WASTES TREATMENT AND IMMOBILIZATION: Standard practices are used to treat airborne wastes, particularly filtration of aerosols; fitters loaded with wastes are then managed as solid wastes

\subsection{LLW/ILW STORAGE:}

A. LLW/LW are typically stored onsite, usually in covered areas; they are most frequently stored after treatment and conditioning in their final waste containers, such as sieel drums, until transport to a disposal facility; storage is usually for relatively short times of no more than a few months

B. Most small quantity generators of radioactive wastes such as research institutes, universities, and hospitals are served by brokers, who contract to pick up the LLW and transport it to a licensed regional storage warehouse; wastes from numerous small 
UNITED STATES

volume waste producers are stored at the regional warehouses until a full truckioad has accumulated for transport to the disposal facility

C. Storage to allow for radioactive decay is widely practiced by hospitals and universities

D. Interim storage of LLW may be necessary in certain states/compacts atter January 1993 and until disposal facilities have been constructed

\subsection{HLW STORAGE}

A. The only civilian HLW is at the shutdown West Valley reprocessing piant; acid HLLW is stured in a stainless steel underground tank, and alkaline HLLW is stored in a mild steel underground tank; the wastes have been kept below about $60^{\circ} \mathrm{C}$ by water cooling of the tanks through internal cooling coils; after vitrification in 1996-1998, the canisters of vitrified HLW will be stored onsite in an air-cooled hot cell until shipment to the geologic repository (DOE/AW-0006 1990)

B. Defense HLLW is stored at Savannah River and Hanford, Washington, as alkaline wastes in large double-shell mild steel tanks in below ground concrete vaults (some older HLLW at Hanford is stored in single-shell tanks with mild steel "saucers" below for detection and collection of potential leakage), and at INEL as acid waste in double-shell stainless steel tanks; alkaline wastes are cooled by internal water cooling coils and by evaporation at the boiling point of the wastes followed by return of the condensate from evaporation; acid wastes are typicaliy cooled to below about $60^{\circ} \mathrm{C}$; granular $\mathrm{HLW}$ caicine at INEL has been stored in underground, air-cooled stainless steel bins since 1963

C. Capsules of solid cesium-137 chloride and strontium-so fluoride separated from HLLW at Hanford are stored in a water pool

\subsection{TRANSPORT OF WASTES}

A. Transportation of wastes is carried out under regulations by the Department of Transportation (DOT) using packagings certified by the: NAC; the regulatory requirements are consistent with IAEA transportation standards

B. HLW: No vitrified high-level wastes have been transpcrted yet except for R\&D quantities; plans are to transport the vitrified civilian and defense HLW to the repository in their canisters in casks similar to those for civilian spent fuel; transport is planned to be in large rail casks after the year 2010 (see Section 7.6)

C. LLWILW: These wastes are transported primarily by truck but some by rail, in certified transport packagings and using shielded packagings where required; civilian wastes are transported by commercial carriers; defense wastes are transported by government carriers or by commercial carriers and transport packagings under contract to the federal government

D. Civilian TAU wastes; A small amount of civilian TAU wastes have been transported because of the small quantities generated; those transported have been in commercial, certified Type B transport packagings; transport has typically been by truck

E. Defense TRU wastes have been transported between [OOE sites by truck and rail, using DOE-certified transport packagings; contact-handled TIZU wastes will be transported to the Waste Isolation Pilot Plant in TRUPACT-II transport packagings by truck; TRUPACT-II 
is an NRC-licensed, double-contained, unvented, cylindrical-shaped packaging; the packagings, with overall dimensions of $8 \mathrm{ft}$ diameter by $10 \mathrm{ft}$ tall, have a flat bottom and domed removable top, and will hold two layers of seven 55-gallon drums arranged in a circle; the space between the double walls is filled with polyurethane foam to serve as a thermal insulator and shock absorber; three TRUPACT-II packagings can be carried on a truck trailer; each packaging weighs $11,600 \mathrm{lbs}$ empty and has a payload capacity of $7,000 \mathrm{lbs}$

\subsection{RESEARCH AND DEVELOPMENT}

A. Vitrification process (liquid-fed ceramic melter) development and demonstration programs have been carried out at PNL and SRL for many years

B. In situ vitrification (ISV) of low-level, transuranic, and mixed hazardous and radioactive wastes is being developed by the Pacific Northwest Laboratory; the ISV process involves the insertion of electrodes into the soil around the wastes and application of electrical current to melt the wastes and soil into a vitreous block

C. The Catalized Electrochemical Plutonium Oxide Dissolution (CEPOD) process is being developed for recovery of plutonium from scrap and wastes in order to minimize the generation of transuranic wastes; the process has applicability to removal of plutonium from contaminated solls and incinerator ash

D. The TRUEX solvent extraction process is being developed for highly efficient recovery of transuranic elements from high-level wastes, to reduce the long-term hazards associated with HLW disposal.

\subsection{PROGRAM/FACILITIES COSTS:}

A. West Valley estimated costs for reprocessing plant decontamination, and installation and operation of the HLW vitrification facility, and interim storage of HLW canisters is approximately $\$ 1.4$ billion

B. Construction of the Defense Waste Processing Facility for vitrification of HLLW at Savannah River cost $\$ 930$ million

\subsection{DISPOSAL OF NON-HIGH-LEVEL WASTES}

\subsection{STRATEGY}

A. Civilian LLW disposal is the responsibility of states or groups of states (compacts) in regional facilities as prescribed in the Low-Level Radioactive Waste Policy Act of 1980 and as amended in 1985; disposal of civilian LLW is currently in licensed shallow-land burial facilities at three sites--Barnwell (South Carolina), Beatty Flats (Nevada), and Hanford (Washington); by January 1993, all states/compacts must have licensed disposal facilities within their own state/compact, or the states/compacts must be able to otherwise manage their own wastes (e.g., provide interim storage or make a cooperative agreement with another state/compact); the Low-Level Radioactive Waste Policy Amendments Act of 1985 encourages volume reduction by setting surcharges based on waste volume and by setting volume quotas for waste generators (Kemp 1989) 


\section{UNITED STATES}

B. Defense LLW management is the responsibility of the respective federal agencies that generate the wastes; disposal is typically done at the respective waste generation sites, but wastes may be shipped to other government facilities for treatment and/or disposal

C. Disposal of greater-than-class-C (GTCC) LLW is the risponsibility of the federal government (DOE); GTCC wastes are to be disposed of in a deep geological repository or other NAC-approved facility; the strategy for GTCC: disposal is under development

D. Defense transuranic (alpha-contaminated) wastes are to be disposed of by deep geologic disposal; demonstration of the concept and confirmation of repository performance will be carried out at the Waste Isolation Pilot Plant (WIPP), near Carlsbad in New Mexico; the decision on the use of WIPP for the final repository and for full.scale operation will be made after a five-year demonstration period with radioactive wastes

\subsection{WASTE DISPOSAL CRITERIA (CFR 1989; DOE/LLW-103 1990)}

A. Disposal of Class A LLW must provide isolation for at least 100 years; disposai of Classes $B$ and C LLW must provide isolation for at least 300 y aars; disposal of Class $C$ wastes must include additional intruder protection to divert intruders for up to 500 years

B. Sites for LLW disposal must have characteristics whic 7 maximize long-term stability and isolation of wastes, and ensure that performance objectives are met; site characteristics and performance must be evaluated for at least a 500 -year period

C. The LLW disposal facility must be designed to provide for long-term isolation of the wastes while minimizing the need for active maintenarice after the site is closed; a 100 year period of institutional control is required following facility closure

D. To reduce subsidence or cracking of the caps or barriers covering the LLW, all LLW must be placed in the disposal units in a way that maintains the integrity of the waste packages and permits voids to be filled

E. Greater-than-Class C LLW and transuranic wastes must be disposed in a deep geologic repository or other NRC-approved facility

\subsection{LLW DISPOSAL}

A. Civilian LLW has been disposed of for many years in commercial facilities, licensed by the NAC or respective agreement states in which the disposal facilities are located (DOE/LLW-103 1990)

1) Commercial disposal sites have been operating at Beatty, Nevada (since 1962), Richland, Washington (since 1965) and Barnwell, South Carolina (since 1971); these three disposal facilities are continuing to coperate successfully for disposal of all the commercial LLW currently generated in the U.S.; existing LLW disposal facilities use the shallow-land burial method of disposal which consists of emplacement of wastes in unlined near-surface :renches that are backfilled with soil; at the humid Barnwell site the trenches are covered with a multi-layered earthen and clay cap designed to minimize water infiltration

2) Commercial disposal sites were previously operated at Maxey Flats, Kentucky (1963-1977), West Valley, New York (1963-1975), and Sheffield, llinois (19671978); these shaliow-land burial facilities (all in wet climates with near-surface 
groundwater) consisted of unlined trenches and were closed generally because of water infikration and leaching and migration of radioisotopes contained in the wastes; the lessons learned from operation of these facilities were reflected in the subsequent 10 CFR 61 regulations

3) Future commercial disposal facilities for LLW are currently being developed by eight compacts (the Northwest compact will continue to use the existing Richland disposal facility) and four unaligned states; these plans are subject to further change, and it is not likely that all twelve of the currently planned new sites will be developed; most of the new sites are planning to use engineered disposal concepts; a number of states have passed legislation declaring shallow-land burial (consisting of unlined trenches) to be inadequate; a new site being developed at Needles, California, will use "enhanced" shallow-land burial (i.e., deeper overburden); earth-mounded concrete bunkers are planned to be used at several of the new sites

B. Defense LLW has been disposed of in DOE-approved shallow-land burial facilities (unlined trenches) for many years at sites of federal nuclear activities; requirements for disposal are approaching those for civilian LLW that are licensed by the NRC or delegated states (agreement states); the trend for government $\amalg W$ disposal facilities is for additional engineered facilities

C. Grout injection into deep underlying geologic strata by the hydrofracture process was used for about 15 years for disposal of defense liquid low-level wastes at ORNL; this practice was discontinued in the mid-1980s (DOE/DP/48010-T1 1985)

D. Liquid defense LLW is incorporated into concrete grout and emplaced in shallow concrete vaults at Hanford, Washington, and Savannah River, South Carolina; the dimensions of the vaults at the Hanford site are $125 \mathrm{ft}$ long by $50 \mathrm{ft}$ wide by $34 \mathrm{ft}$ deep (Mitchell et al. 1989)

\subsection{TRANSURANIC WASTE DiSPOSAL (DOE 1988; DOE/EIS-0026-FS 1990)}

A. Repository deployment strategy: Defense transuranic (alpha-contaminated) wastes are to be disposed of by deep geologic disposal; the concept will be demonstrated, with the hope to confirm repository performance, at the Waste Isolation Pilot Plant (WIPP), near Carlsbad in New Mexico, on a 10,240-acre site, where the surface is 3,600 feet above sea level; the decision on the use of WIPP for a final repository and for full-scale operation will be made after the five-to-seven-year demonstration period is concluded about 1998, with contact-handled TRU wastes that will be retrievable; the demonstration will involve about $0.5 \%$ of the total waste quantity planned for ultimate disposal at WIPP; the demonstration will include performance assessment and operations demonstrations

B. Reference waste: Contact-handled defense transuranic wastes $(97 \%$ of the wastes to be received at the repository, with the dose rate $<200 \mathrm{mr} / \mathrm{hr}$ at any package surface) and remote-handled defense transuranic wastes $(3 \%$ of the waste to be received, with the dose rate $>200 \mathrm{mr} / \mathrm{hr}$ at any package surface); the waste form consists of miscellaneous solid materials containing transuranic radionuclides; the wastes cannot contain free liquids, dispersible solids, or pyrophoric materials; the wastes must be in fire-proof canisters; about $60 \%$ of the waste is estimated to be classified as mixed waste; the capacity of the WIPP facility is 6.2 million $\mathrm{ft}^{3}$ of contact-handled transuranic wastes and 0.25 million $\mathrm{tt}^{3}$ of remote-handled transuranic wastes (over a 25 -year operational time) 
C. Reference repository concept (Hunt et al. 1986; Halverson and Cole 1986; DOE-EIS U026-FS 1990)

1) A waste handling facility and waste package repair/packaging facility are at the surface; waste canisters are received by truck, unloaded, checked, and transported to the disposal horizon in an elevator

2) The demonstration repository is near the center of the Permian salt basin in south. eastern New Mexico; the disposal horizon is at 2150 feet below grade in a bedded salt formation that extends from 1000-2900 feet below grade

3) The demonstration repository has four large shafts (air intake, air exhaust, salt handling, and waste emplacement) and a serie!s of tunnels and disposal drifts in c. rectangular array; it has a total of 48 rooms, 6 rooms in each of 8 panels; a typical disposal room is $300 \mathrm{ft}$ long, $33 \mathrm{ft}$ wide, and $17 \mathrm{fthigh}$; the area underground for waste disposal is 100 acres in size

4) Contact-handled wastes are to be stacked on the floors of disposal drifts; remotehandled wastes are to be emplaced in steel-lined horizontal holes in walls of separate emplacement dritts

5) Backfill is under study, but is expected to be a mixture of crushed salt and bentonite

D. Waste package concept

1) The primary canister for contact-handled wastes is a 55-gallon mild steel drum; other cylindrical canisters may vary from 30 galions to 500 gallons in size and may be made of steel, concrete, or fiberglass-plastic; the repository can accept packages up to $12 \times 8 \times 8.5 \mathrm{ft}$ and weighing up to $21,000 \mathrm{lbs}$; the waste container design life is 20 years

2) The primary canister for remote-handled waste will be a stainless steel, sealwelded cylindrical container, $0.66 \mathrm{~m}$ diameter $\times 3.0 \mathrm{~m}$ long; other containers may also be used, with maximum dimensions the same as the reference canister and weighing up to $10,000 \mathrm{lbs}$; the maximum heat loading for a remote-handled waste package will be $300 \mathrm{~W}$, and the maximum transuranic waste activity will be 23 curies per liter

E. Site characterization (Stein and Krumhansi 1986; Nowak 1986; Sandia National Laboratories 1987)

1) The principal site characterization effort was carried out during 1975-1983; the decision to proceed with development of the demonstration repository (made in 1981) and site confirmation was based on results of surface-based studies; site and preliminary design validation was carried oint during 1981-1983

2) Studies carried out include: geologic mapping, exploration geophysics, exploratory drilling and borehole tests, hydrologic testing, and seismic monitoring

3) Key contentious issues that have been resolved: salt dissolution; deformation of the salt beds; presence of brine reservoirs; definition of the hydrologic regime; potential conflict with natural resources; future geologic stability 
F. Field tests (Stein and Krumhansi 1986; Nowak 1986; Stormont 1986; Sandia National Laboratories 1987)

1) Two shafts and several thousand feet of underground dritts were constructed in the first phase of the project and were used for a wide variety of insitu tests that included: thermal/structural interactions; behavior/performance of waste packages, waste forms, and seal materials; near-field effects; and brine properties

2) Field tests will be performed with actual TRU waste packages during the five-toseven year demonstration period

G. Performance Assessment:

1) The performance assessment program to be conducted during the five-to-sevenyear test phase at WIPP will consist of a large number of activities including data collection, modeling, and calculations leading to a performance assessment; the performance assessment process will evaluate the long-term performance of the waste disposal system and compare the results to the EPA standard, 40 CFR 191, subpart $B$, to determine whether the WIPP will meet these requirements

2) The performance assessment process will be using data collected from four study areas: 1) the interaction of the salt storage room environment with waste containers and backfill material, including evaluation of the amount of gas generated by the decomposition of the waste and the corrosion of waste drums; 2) the method for sealing different areas in the underground; 3) the rate at which the salt creeps to surround the waste containers and the rate of brine movement; and 4) scientific studies of the Rustler formation located approximately 1,100 feet above the underground facility; the first test will include evaluation of the amount of gas generated by decomposition of the wastes and corrosion of the drums

H. Environmental studies: Extensive surveillance of baseline environmental conditions has been carried out since 1985; environmental monitoring will continue through the operational period; post-operational environmental monitoring will proceed upon facility decommissioning

\subsection{LLW/ILW DISPOSAL R\&D}

A. Demonstration of the French tumulus concept for defense LLW disposal is being performed at the Oak Ridge Nationai Laboratory

B. In situ vitrification (ISV) of low-level, transuranic, and mixed hazardous and radioactive wastes is being developed by the Pacific Northwest Laboratory; the ISV process involves the insertion of electrodes into the soil around the wastes and application of electrical current to melt the wastes and soil into a vitreous block

\subsection{PROGRAM/FACILITIES COSTS}

A. Disposal costs for commercial LLW increased from about $\$ 10$ per cubic foot in 1980 to about \$45 per cubic foot in 1990; the smaller capacity and engineered technology of the new facilities could raise disposal costs from the present costs to about $\$ 120$ to $\$ 500$ per cubic foot (NWN 11/8/90; NEI 10/90) 
B. WIPP program and facilities costs (DOE-JIO-023 1987)

1) The estimated total life-cycle costs for the WIPF' facility for disposal of federal transuranic wastes are:

$\$ 900$ million for facility development through 1990 (NWN 2/7/91)

$\$ 180$ million for capital equipment through 2010

$\$ 2,124$ million for operating costs through 2017 (including decommissioning)

$\$ 270$ million for total transportation costs

$\$ 3,474$ million total life-cycle costs (excluding costs for onsite waste treatment, storage, or long-term surveillance)

\subsection{DISPOSAL OF HIGH-LEVEL WASTES}

A. In the geologic repository for spent fuel/HLW, spent fuel will be the dominant waste form because industry has elected not to reprocess spent luel, but the repository will receive solidified civilian HLW from the West Valley demonstration project and solidified defense wastes from the DOE program; the flexibility to accept civilian HLW will be provided should reprocessing be adopted by U.S. nuclear industry

B. The U.S. plans on implementing provisions of the Nuclear Waste Policy Act of 1982 (NWPA) and its 1987 Nuclear Waste Policy Amendments Act (NWPAA) with an integrated national civilian radioactive waste management program to (U.S. Congress 1983; U.S. Congress 1987; DOE/RW-0187 1988):

1) Site, license, construct and operate a geologic repository for spent fuel and HLW (and other wastes that will be determined to require geologic disposal) by 2010 (OOE/RW-0291P 11/90); the 1987 Amendments Act mandated the Yucca Mountain site in Nevada as the only site to currently undergo detailed site characterization to determine its suitability for a potential repositiony

2) Report to the President and Congress between 2007 and 2010 on the need for a second repository

3) Site, construct, and operate a licensed federal rnonitored retrievable storage (MRS) facility for temporary storage of civilian spent fuel, subject to demonstrating its need and certain other conditions specified in the Amendments Act

4) Develop and implement a federal system to transport spent nuclear fuel (and solidified HLW) from reactors (and the MRS facility as authorized by Congress, if need is demonstrated) to the repository, with maximum use of the commercial transportation industry

5) Cooperate with U.S. industry in developing and demonstrating technology and systems for dry storage of spent fuels until the foderal waste management system can accept waste, including fuel rod consolidation and packaging of the non-fuelbearing components of spent fuel assemblies

6) Maintain the Nuclear Waste Fund from the fee assessed to owners and generators of waste to provide full recovery of program costs

7) Develop consultation and coordination with affected states and Indian tribes 
8) Provide limited amount, if needed and requested by industry, of federal interim storage capacity for spent fuels from civilian power reactors

9) Provide technical assistance to nonnuclear weapons countries, when requested by a country, on spent fuel storage and disposal

\subsection{SPECIFICATIONS AND CRITERIA}

A. The basic requirements by EPA ( 40 CFR 191) are summarized below (Meyers 1985) TThe 1985 regulations were remanded by the U.S. Court in 1987; EPA is revising the basic rule, so some of these requirements will be revised in the future (Radwaste News 8/3/87)]:

1) Disposal systems shall not depend on active institutional controls for more than 100 years after disposal

2) Long-term disposal system pertormance shall be monitored for a reasonable time as a supplement to other types of protection

3) Disposal systems shall be marked and their locations recorded in all appropriate government records

4) Disposal systems shall be designed with several different types of barriers, both natural and engineered

5) Sites shall not be located where scarce or easily accessible resources are located

6) Wastes shall be recoverable for a reasonable time after disposal

7) Radionuclide releases from a repository shall not exceed in 10,000 years the numerical quantities specified [the numerical quantities are based on less than 1000 deaths in 10,000 years $(0.1$ deaths/yr) for each 100,000 MTHM equivalent of waste disposed]; a probabilistic approach is used to assess the releases to which the containment requirements apply: there should be less than one chance in ten of releasing quantities exceeding the values specified and less than one chance in 1000 of exceeding ten times the quantities specified

8) Individual protection requirements limit exposures to members of the public in the accessible environment from the disposal system to $25 \mathrm{mrem}$ to the whole body and 75 mrem to any organ, from undisturbed performance of the disposal system for 1000 years after disposal

9) Groundwater protection requirements limit the concentrations of radioactivity in waters withdrawn from most Class I sources of groundwater near a disposal system to specified quantities (dose less than $4 \mathrm{mrem} / \mathrm{yr}$ ) for 1000 years after disposal

B. The basic requirements by the NRC are given in 10 CFR 60 and summarized below (note that these requirements may need to be changed after the more fundamental EPA requirements are revised) (CFR 1/1/89) 
1) The waste package [i.e., the waste form, the canister, the disposal container (if any), and any buffer material around the waste container] shall provide substantially complete containment of the waste for $300-1000$ years

2) The rate of release of each significant radionuclide from the engineered-barrier system shall not exceed one part in $100,000 / y r$ of the inventory of that radionuclide at 1000 years after permanent ciosure of the repository

3) The pre-waste-emplacement groundwater travel times trom the "disturbed zone" around the repository to the accessible environment shall exceed 1000 years

4) The repository operations area must be desigried to preserve the option of waste retrieval starting at any time up to 50 years after waste emplacement begins

\subsection{REPOSITORY DEPLOYMENT STRATEGY (U.S. Congress 1983; U.S. Congress 1987)}

A. As specified in the Nuclear Waste Policy Act of 1982 and the 1987 Amendments Act, commercial spent fuel and all solidified HLW are to be disposed of by deep geologic disposal; the Yucca Mountain (tuff) site in Nevada is t te only candidate site for the first repository, and its suitability is being determined through site characterization; if the Yucca Mountain site is found to be unsuitable, characterization of other sites will be carried out until a suitable site is found; siting and project work on a possible second repository is to be deferred until after 2007-2010 when the need is to be demonstrated through a study by DOE

B. Commercial greater-than-class-C wastes will be dispo:sed of in a federal deep geological repository or other NRC-approved facility, but its specific disposition has not yet been developed (see Section 9)

C. Defense transuranic (aipha-contaminated) wastes are to be disposed of by deep geologic disposal (this subject is covered in Section 9)

\subsection{SITE SELECTION AND CHARACTERIZATION}

A. Site selection

1) The overall site selection and evaluation process for a spent fuel and HLW repository was mandated by the 1982 Nuclear Waste Policy Act (NWPA) and modified by the 1987 Nuclear Waste Policy Amendments Act (NWPAA); the NWPA directed that site selection be conducted through a screening process to the final selection of three candidate sites to be charactirized; the site selection process was reviewed by the National Academy of Sciences; screening was performed and the NWPAA designated the Yucca Mountain site in Nevada as the only site to be characterized at this time

a. Draft Environmental Assessments (EAs) were published in 1984 for nine candidate sites in six states: Louisiana (salt), Mississippi (salt), Nevada (tuff), Texas (salt), Utah (salt), Washington (basalt); public hearings were held, and the draft EAs were revised to respond to comments; final EAs were published for the nine sites; five sites were nominated in 1986 as suitable for site characterization, based on the EAs and surface-based evaluations 
b. Three sites were recommended for characterization in 1986: Deaf Smith, Texas (salt); Yucca Mountain, Nevada (tuff); Hanford, Washington (basalt)

c. The Yucca Mountain Site was selected by Congress in the NWPAA as the only site to undergo site characterization

B. Site characterization (DOE/RW-0144 1987; DOE/RW-0160 1988; DOE/RW-0199 1988)

1) Site characterization consists of surface-based investigations, boreholes, laboratory tests, and underground tests; these will provide information for performance assessments to evaluate the expected safety performance of the repository

a. The underground tests will be carried out in an underground exploratory study facility at repository depth; they will include two exploratory shatts and a connecting tunnel and other tunnels and rooms

b. Exploratory study tests are to be carried out in two phases:

1) Construction testing phase, with tests on construction and rock response to shaft and underground construction activities

2) In situ testing phase, after completion of underground construction and its testing; testing will include rock characterization, stress, permeability, thermomechanical properties, geologic parameters, geochemical properties, geomechanics, hydrologic parameters, performance parameters, heat dissipation, etc.

\subsection{REFERENCE HLW/SPENT FUEL DISPOSAL CONCEPT (MacDougail et al. 1987)}

A. Reference wastes:

1) The reference waste form will consist of intact spent fuel assemblies (SFAs) and canistered wastes from the civilian reactors (PWRs and BWRs); the spent fuel wastes will consist of intact SFAs, failed SFAs in canisters, fuel rods, SFA hardware, and miscellaneous wastes; there currently are three reference packages for spent fuel; the first reference package consists of a disposal container that contains three intact PWR and four intact BWR assembiies; the second reference package consists of four PWR assemblies, and the third contains $10 \mathrm{BWR}$ assemblies; if consolidation of the spent fuel rods is employed, the current reference disposal container will hold rods from eight PWR assemblies or 20 BWR assemblies that are in 9.1-in. $(23.1 \mathrm{~cm})$ and 6.0 -in. $(15.2 \mathrm{~cm})$ square stainiess steel canisters; an additional container of five 55-gallon drums with compacted spent fuel hardware would also be required if consolidation were employed; handling will be done using the pintle on one end of the disposal container; the current reference disposal container is stainless steel and is 28 -in. $(71.1 \mathrm{~cm})$ in outside diameter by 187.5 -in. $(4.76 \mathrm{~m})$ long and 0.375 -in. $(0.952 \mathrm{~cm})$ thick and will use different internal spiders for selected wastes (FR 4/18/83; DOE/RW-0235 1989; DOE/RW-0236 1989)

2) Because the current basic MRS concept is plarned to be a pass-through facility used for storage only, wastes from the MRS facility will be the same as those received from the nuclear power stations; the current reference system involves 


\section{UNITED STATES}

canisterizing and placement of spent fuel in disposal containers at the repository handling facility

3) Existing commercial HLW (converted to borosilicate glass with $28 \%$ waste oxides) from the West Valley demonstration project will be poured into stainless steel canisters that are 24-in. $(61 \mathrm{~cm})$ in diameter and 118-in. $(3 \mathrm{~m})$ long; the canisters have a glass fill neck and connecting flange, and a 0.375 -in. $(0.95 \mathrm{~cm})$ thick wall; each canister will hold HLW from about 2 MTU; a disposal container of stainless steel that has a 26-in. $(66 \mathrm{~cm})$ outside diameter and 130-in. $(3.3 \mathrm{~m})$ length will be used as an overpack for each canister; HLW will be canisterized at the waste generator site and placed in the disposal contiainer at the repository

4) Defense HLW (converted to borosilicate glass 'with $28 \%$ waste oxides) will be poured into stainless steel canisters that are similar to those for commercial $\mathrm{HLW}$ glass; each canister will hold vitrified HLW from about $0.5 \mathrm{MTU}$; a similar stainless steel disposal container as used for the HLW from West Valley will be used as an overpack for the canister

B. Reference repository concept (DOE/RW-0199 1988)

1) Assuming the site is found suitable (which could change significantly in subsequent development work), surface facilities for the current conceptual design at the Yucca Mountain site will provide waste handling and packaging; access to the repository will be through a downward sloping tunnel into the host rock in the base of Yucca Mountain; boreholes will be exciavated in the floors of tunnels; no backfill is planned to be used around the disposal container

2) The disposal depth will be about $350 \mathrm{~m}$ below the top of Yucca Mountain in welded tuff; the disposal horizon is $200-400 \mathrm{~m}$ above the water table

3) Disposal will be from a series of emplacement drifts in a rectangular array; the emplacement concept involves use of stainless steel-lined boreholes, with one disposal container per borehole; the disposal container is covered with a shieid plug, and the top of the hole is filled with crushed tuff backfill

4) The reference concept involves commingling containers with spent fuel and $\mathrm{HLW}$ in alternate disposal holes

5) Disposed waste must be kept retrievable for at least 50 years from start of emplacement; during filling and after the repository is full, repository performance confirmation will be carried out; upon satisfactory outcome of performance confirmation, a license application will be submitted to NRC to decommission the repository; upon receipt of the license to decommission, all excavations will be backfilled with crushed tuff and sealed, and surface facilities will be decommissioned

6) See Section 3.1 for the geologic repository schedule

C. Second repository

1) The NWPAA mandated discontinuing work on a second repository, and requires DOE to evaluate and report to Congress between 2007 and 2010 on the need for 
a second repository; the decision on a second repository will be made after that time (U.S. Congress 1987)

2) Before enactment of the NWPAA, work that was carried out on a second repository included:

a. Crystalline rock was to be included in potential host rocks for a second repository, along with potential host rocks considered for a first repository (i.e., saht, basalt, tuff)

b. The draft area recommendation report, issued in January 1986, identitied 12 crystalline rock areas in seven states for preliminary field investigations

c. In May 1986, the recommendation was made to postpone site-specitic studies; the generic technology program continued until January 1988 with the following objectives:

1) Identify and evaluate major geologic structures such as exposed crystalline rock, buried plutons, sedimentary rock sequences

2) Develop and improve geologic, geophysical and hydrologic characterization techniques for field studies and for computer modeling

3) Develop approaches to demonstrate achievement of regulatory requirements

4) Identity non-site-specific geologic concepts; integrate engineering compatibility and performance with regulatory requirements

5) Develop strategies for the second repository siling process

6) Develop technology in cooperation with other countries and multinational organizations on crystalline rock

\subsection{FIELD TESTS}

A. The first underground tests using spent fuel were carried out in a salt mine near Lyons, Kansas, from 1965-1968; those tests included effects of radiation and heat on salt

B. Underground testing began at the Nevada Test Site in 1977; experiments were conducted on rock mechanics and on radionuclide migration in tuff and granite; in the early 1980s, 11 canisters of spent fuel were placed in a granite test facility 1400 feet below grade to evaluate granite

C. Field tests will be carried out at the Yucca Mountain site as part of site characterization; an underground research facility, the exploratory study facility (ESF), will be constructed and consist of two exploratory shafts, a tunnel that connects the shafts, other tunnels and underground rooms for testing, and associated surface facilities; the development of the underground workings will start as soon as the first shaft is sunk to full depth and is sufticiently equipped (DOE/RW-0199 1988)

D. Underground research during site characterization at the Yucca Mountain site will be conducted in two phases; the first phase, construction testing, is defined as the tests and 
investigation starting with shaft construction and continuing until underground connection of the shafts is completed; the second phase, in situ lesting, will start at the completion of construction testing and continue until sullicient data have been collected; these tests will concentrate on characterizing the rock mass and will assess in situ stress, permeability, thermomechanical parameters, geochenical properties, thermal properties, and heat dissipation; some tests will be used to verify design assumptions and the suitability of repository construction methods; some tests will be used to confirm the stability of the site during repository operations and the long-term waste isolation aller closure; the tests must provide information required tis support the siting guidelines, the license application to NRC, and the Environmental Impact Statement (DOE/RW-0199 1988)

10.6 PERFORMANCE ASSESSMENT: DOE has carried out major development ellons in performance assessment for about 15 years and will continue these eHorts at an increasing pace as characterization of the proposed Yucca Mountain repository site is implemented (DOE/RW-0199 1988)

A. The DOE strategy on performance assessment for the? spent fuel and $\mathrm{HLW}$ geologic repository is directed towards compliance with the EFA standard (40 CFR 191) and the NRC regulations (10 CFR 60 )

1) The EPA standard is a probabilistic standard and requires scenario development and consequence modeling; scenarios are prozesses and events resulting in releases to the accessible environment, including disruptive and intrusive events

2) The NRC regulations require the deterministic modeling of the performance of specific subsystems under expected conditions;

B. Three types of performance assessment activities are conducted under the DOE geologic repository program:

1) Probabilistic and deterministic modeling methouds and approaches to analyzing container and engineered barrier performance are being developed and will be improved

2) Performance assessments of the site will be done to evaluate the Yucca Mountain site characterization activities, to guide additional characterization, to interpret and synthesize field and laboratory data, and to determine when characterization appears sufficient to close out performance issıes; performance assessments during the early stages of site characterization will be done to support the early approach to identify any site disqualifying features

3) Confidence in the predictions of performance assessments will be improved by validation of performance assessment models

C. Activities are being conducted to enhance computer code capabilities in the areas of 1) waste package performance, 2) rock and groundwater behavior in the repository where heat effects are important, 3) rock and groundwater behavior in the far field of the repository where heat effects are negligible, and 4) tolal system behavior using models with probabilistic capabilities; several computerized models are being developed in each category to allow code intercomparisons as part of the verification process and for sensitivity analyses; a performance assessment effort that is unique to the Yucca 
UNITED STATES

Mountain site is the modeling of the unsaturated zone above groundwater where the repository horizon is planned

D. DOE cooperates in the following international performance assessment activities:

1) DOE participates in the OECD Nuclear Energy Agency's Performance Assessment Advisory Group (PAAG) and the Probabilistic Systern Assessment Code (PSAC) user group, which are exploring scenario analysis and total system performance issues

2) DOE participates in the international INTRAVAL study, which is being conducted to validate geosphere transport models

10.7 ENVIRONMENTAL RESEARCH: Ervironmental research has been carried out at the Nevada Test Site for many years; extensive environmental monitoring and research will be carried out at the Yucca Mountain site during site characterization

10.8 SYSTEMS STUDIES: Extensive systems studies have been carned out since 1983; systems studies investigate effects of atternatives in any part of the waste management system (i.e., spent fuel management at nuclear power reactors, interim storage, transportation and related handling, storage and handling at federal facilities, conditioning and packaging of wastes, emplacement of wastes in a repository, repository design and operational concepts, and repository decommissioning and post-closure activities) on the total system, with emphasis on safety, costs, and system effectiveness; the systems studies have played a significant role in the current system concepts and plans

\subsection{PROGRAM AND FACILITIES COSTS}

A. The cost estimate values that follow are for a single-repository system for intact spent fuel, and include a Monitored Retrievable Storage (MRS) facility for interim storage only; the estimated costs are in constant 1988 dollars (DOE/RW-0291P 1990)

$\$ 11.5$ billion for development and evaluations

$\$ 0.7$ billion for socioeconomic impact mitigation

$\$ 1.2$ billion for construction

$\$ 7.0$ billion for operation

\$2.8 billion for total transportation costs

\$0.5 billion for closure and decommissioning

$\$ 1.9$ billion for basic MRS facility

$\$ 25.6$ billion for total system life-cycle costs

B. If a two-repository system is assumed, the total system life-cycle costs are estimated to increase by about $\$ 8$ billion

C. The total defense-waste share of the total-system costs for the single- and two-repository systems are estimated at $\$ 3.6$ billion and $\$ 5.8$ billion, respectively

D. Through fiscal year 1989 , approximately $\$ 4.0$ billion has been paid by the utilities into the Nuclear Waste Fund. (NWF); the NWF earned $\$ 609$ million on interest on investments in government securities through 1989; at the end of 1989, the NWF had a balance of $\$ 2.2$ billion; the unaudited NWF balance for 1990 is $\$ 2.6$ billion 
E. The appropriation for fiscal year 1991 for the total OCAWM program was \$242.8 million; the DOE requested $\$ 305.1$ milion from the NWF for OCRWM program activities in fiscal year 1992 (DOE/AW-0305P 1991; NWN 2/7/91)

\subsection{MANAGEMENT OF URANIUM MINE AND MILL WASTES}

\subsection{WASTE ARISINGS (DOE/RW-0006 1990)}

A. The historical and projected volumes for all U.S. sites are:

$198094,400,000 \mathrm{~m}^{3}$ cumulative

$1985114,600,000 \mathrm{~m}^{3}$ cumulative

$1989 \quad 117,600,000 \mathrm{~m}^{3}$ cumulative

$2000120,100,000 \mathrm{~m}^{3}$ projected cumulative

B. The volume for currently active sites is:

$198917,900,000 \mathrm{~m}^{3}$ cumulative

C. The volumes for currently inactive sites are:

$198999,700,000 \mathrm{~m}^{3}$ cumulative, including $5,800,000 \mathrm{~m}^{3}$ of :subordinate wastes (soils contaminated by windblown tailings, ore in storage areas, material underlying tailings piles, and contaminated soils from vicinity properties)

11.2 CAITERIA: The criteria used in the Uranium Miil Tailings Remedial Action Program (UMTAAP) site cleanup and waste disposal work, a major area of the DOE Environmental Restoration and Waste Management Program, are based on EPA standards contained in 40 CFR 192

A. The EPA 40 CFR 192 standards require that radiation levels and emissions be reduced:

1) To the extent reasonably achievable, for up to '000 years, and for at least 200 years

2) To provide reasonable assurance that releases of An-222 from residual radioactive material will not exceed an average release rate of $20 \mathrm{pCi} / \mathrm{m}^{2} \mathrm{~s}$ or increase the annual average concentration of Rn-222 in air at any location outside the disposal site by more than $0.5 \mathrm{pCi} / \mathrm{L}$

8. The purpose of the EPA 40 CFR 192 standards is to frovide for long-term stabilization of mill tailings, discourage the future misuse of tailings, control releases of radon, and protect water resources; the standards are intended tis guide remedial actions for offsite levels of radioactive materials including the use of taitings in landfill or construction; appropriate remedial measures include the use of sealants, filtration, and ventilation, as well as removal of the material

11.3 STRATEGY/POLICY: The U.S. plans to control the potential for long-term detrimental effects on the environment to acceptable levels, to implement remedial actions on shutdown facilities, and to implement preventive actions on existing and new facilities; (DOE/RW-0006 1990)

A. The cleanup of uranium mill tailings sites is authorized by the "Uranium Mill Tailings Radiation Control Act of 1978" (Public Law 95-604); the Act separates the responsibility 
for the cleanup of Title I (inactive) and Title II (active) sites; the UMTRAP activities are scheduled for completion by September 1994

1) Titie I sites produced uranium primarily for the former Atomic Energy Commission [AEC, the predecessor of the current Department of Energy (DOE)] for defense activities; most of these sites ceased operation during the 1980s; DOE was given the responsibility, in cooperation with affected states and Indian tribes, to clean up these sites

2) Title II sites are those currently licensed by the NRC or by agreement states (whether or not they are currently in production); owners and licensees have the responsibility for the cleanup of these sites; most of these siles have produced uranium for commercial sales

B. An August 1986 EPA rule requires mill owners to phase out (in six years) the use of large existing tailings piles; now tailings piles may be contained in small impoundments or disposed of continuously by dewatering and burial

C. A December 1987 rule by the NRC requires licensees and license applicants to install liners under new portions of impoundments with liquid wastes, to meet certain concentration limits of radioactive and hazardous wastes in groundwater, and to establish detection programs to ensure meeting the groundwater requirements

11.4 REMEDIAL ACTIONS: DOE is proceeding with corrective measures at 24 inactive uranium processing sites and associated vicinity properties; at the end of 1989 , over 6.5 million $\mathrm{m}^{3}$ of mill tailings and other (subordinate) wastes had been stabilized at eight sites where site processing activities were completed; in addition, 2.2 million $\mathrm{m}^{3}$ of similar wastes had been stabilized at two sites where processing activities are still under way; depending on specific site characteristics, tailings may be stabilized onsite or removed to other locations and stabilized (DOE/RW-0006 1990)

11.5 R\&D: The U.S. research program on management of mill tailings wastes was completed in 1984, including research on radon barrier materials, prevention of groundwater contamination, ground covers to mitigate erosion, and liners under impoundments to retain radionuclides

\subsection{DECOMMISSIONING AND ENVIRONMENTAL RESTORATION}

\subsection{WASTE ARISINGS (DOE/AW-0006 1990)}

A. The estimated total volumes of LLW from decommissioning a typical commercial light water reactor are estimated to be $12,960 \mathrm{~m}^{3}$ to $18,520 \mathrm{~m}^{3}$, with the larger volumes associated with BWRs (EIA 10/26/90)

B. The total estimated volumes of radioactive wastes expected to arise from complete decommissioning of commercial light-water reactors in the U.S. shut down during 19902020:
1) BWRs:
LLW Classes A, B, \& C LLW Greater-than-Class C
$287,800 \mathrm{~m}^{3}$ projected cumulative
2) PWRs:
LLW Classes A, B, \& C
LLW Greater-than-Class $C$
$547,500 \mathrm{~m}^{3}$ projected cumulative
$4,000 \mathrm{~m}^{3}$ projected cumulative 
C. The total estimated remaining inventories from the four major areas (UMTRAP, FUSRAP, D\&D, and SFMP) in the DOE Environmental Restoration Program are $3,000 \mathrm{~m}^{3}$ of TRU waste, about $2,340,000 \mathrm{~m}^{3}$ of LLW, $18,100,000 \mathrm{~m}^{3}$ of mill tailings, and about $5,790,000$ $\mathrm{m}^{3}$ of other wastes (all contaminated material outside the immediate tailings piles) (DOE/RW-0006 1990)

\subsection{STRATEGY/POLICY:}

A. At the end of their useful lives, commercial nuclear facilities will be shut down and decommissioned; eventually, the facilities/sites must be decommissioned to levels allowing unrestricted use, but interim decommissioning status may be allowed; similarly, defense facilities must be decommissioned to acceptable levels at the end of their useful lives

B. Past operations connected with DOE and other federal agency [e.g., Department of Defense (DOD)] programs have resulted in contamination of a large number of sites and facilities with quantities of radioactive, hazardous, and mixed hazardous and radioactive wastes; environmental restoration is concerned with assessment and cleanup of such sites and facilities to meet prescribed standards derived from federal and state laws

C. The owners of the facilities and sites are responsible for the decommissioning and environmental restoration of their facilities and sites; the decommissioning and environmental restoration of facilities and sites owned by DOE and other federal agencies are the responsibility of the respective federal agencies; the DOE has also taken responsibility for decommissioning and remediation of certain civilian facilities and sites previously used to support DOE programs (see section 12.4 for information on UMTRAP, FUSRAP, SFMP, etc.)

D. Regulatory authority for the decommissioning of civilian nuclear facilities is the responsibility of the NRC and agreement states having delegated regulatory responsibility from the NRC; the EPA is responsibie for setting overall standards for the protection of the environment, including environmental standards for decommissioning and environmental restoration

E. DOE's Office of Environmental Restoration and Waste Management (EM) carries out DOE's program for decommissioning and environmental restoration; the EM program is responsible for the management of all aspects of treatment, storage, and disposal of wastes - HLW, TRU wastes, LLW, hazardous chemical wastes, mixed hazardous and radioactive wastes, and sanitary wastes - at DOE sites; EM's responsibilities include operation of DOE's waste management facilities, clear up of inactive hazardous and radioactive waste sites at all DOE facilities, assistance to states on commercial LLW, decommissioning programs, UMTRAP, and FUSRAP, and responsibility for providing new and more effective technologies to meet DOE's goal of regulatory compliance and cleanup; DOE is committed to full compliance with environmental regulations and to a goal of completing environmental restoration by the year 2119 (DOE/S-0070 1989; DOE/RW-0006 1990; DOE/S-0078P 1990; FR 10/22/90; NWN 2/7/91)

F. Corrective activities are those activities needed to bring active and standby DOE facilities currently out of compliance with applicable local, state, and federal requirements and internal DOE requirements into compliance in an expeditious manner; corrective activities are not managed as a separate DOE program by EM, but rather, they are managed by the DOE program offices having responsibility for the activity [e.g., Defense Programs 
(DP), EM, Nuclear Energy (NE), and Energy Research (ER)]; EM will have responsibility for many corrective activities, primarily because of the large number of waste operational facilities under its jurisdiction (DOE/S-0078P 1990)

\subsection{R\&D:}

A. DOE has sponsored development of decommissioning technology for tens of years; currently, technology is considered to be developed in general, and DOE's support of such technology is reduced; DOE and industry are generally carrying out decommissioning R\&D to reduce the resulting waste volumes and to reduce costs and radiation exposures to decommissioning workers; industry is applying the technology with developments of its capabilities; DOE has been sponsoring some large decommissioning projects to demonstrate the availability of technology

B. The EM Ottice of Technology Development has responsibility for DOE's program to provide new and more effective technologies for meeting the DOE 30-year goal for compliance and cleanup of its facilities; included are research and development of new technologies and demonstration, testing, and evaluation of technologies; for environmental restoration, technology needs have been identified in the areas of cleanup of groundwater, soil, and buried objects; integrated demonstrations will be used as a means to rapidly develop, demonstrate, and transfer needed technology to the environmental restoration and waste management efforts; an integrated demonstration is a cost-effective mechanism that evaluates the performance of multiple related technologies at a single site, that are applicable to many DOE sites, as part of a complete system in correcting waste management and environmental problems from "cradle-to-grave" (DOE/S-0078P 1990)

\subsection{MAJOR PROJECTS (DOE/RW-0006 1990; DOE/S-0078P 1990)}

A. DOE-EM has responsiblity for the program to clean up inactive hazardous and radioactive waste sites at all DOE installations and some non-DOE sites for which DOE has responsibility; included are the remedial actions and decontamination and decommissioning programs; the remedial actions program is primarily concerned with all aspects of the assessment and cleanup of inactive potential release sites; the decontamination and decommissioning program is primarily concerned with the safe caretaking of surplus nuclear facilities until they are decontaminated for reuse or they are completely removed; the DOE programs emphasize reuse of facilities, use of state-of-theart techniques, waste disposal according to established priorities, and transfer of technology to U.S. industry

1) The Uranium Mill Tailings Remedial Action Program (UMTRAP) is proceeding with corrective measures at 24 inactive uranium processing sites and associated vicinity properties; at the end of 1989 , over 6.5 million $\mathrm{m}^{3}$ of mill tailings and other (subordinate) wastes had been stabilized at eight sites where site processing activities were completed; in addition, about 2.2 million $\mathrm{m}^{3}$ of similar wastes had been stabilized at two sites where processing activities are still under way; the UMTRAP activities are scheduled for completion by September 1994

2) The Formerly Utilized Sites Remedial Action Program (FUSRAP) is remediating 30 sites (mostly private facilities); most of the FUSRAP sites were formerly used to support the nuclear activities of DOE's predecessor agencies, the Manhattan Engineer District (MED) and the Atomic Energy Commission (AEC); sites of concern were used primarily for research, processing, and storage of uranium and 
thorium ores, concentrates, and residues; when these sites were no longer needed, they were decommissioned in accordance with the health and safety guidelines that were applicable at that time; those guidelines do not necessarily meet today's more stringent criteria; FUSRAP was established in 1974 to identify and remediate such sites; as of late 1990 initial remediation activities have been completed at 10 sites and partially completed at 8 additional sites; a total of about $1,452,000 \mathrm{~m}^{3}$ of LLW are expected from FUSRAP; the FUSRAP activities are scheduled for completion after 2001

3) The Decontamination and Decommissioning Program's objective is to decontaminate and decommission inactive, surplus DOE facilities formerly associated with the U.S. government's defense efforts; approximately 220 radioactively contaminated, DOE-owned facilities, concentrated in seven locations throughout the U.S. have boen identified for decommissioning; the predominant wastes to be generated by decommissioning of these facilities are LLW (about $110,000 \mathrm{~m}^{3}$ ) (most from the Grand Junction site in Colorado and the Mound Plant in Ohio) and mill tailings (about $84,100 \mathrm{~m}^{3}$ ) (most from the Grand Junction site in Colorado); about $555 \mathrm{~m}^{3}$ of TRU wastes (most from the Hanford site in Washington) will also be generated; the decommissioning activities for these government facilities are scheduled for completion in 2012

4) The Surplus Facilities Management Program (SFMP), whose objective is to decontaminate and decommission inactive, surplus DOE facilities formerly associated with civilian projects, has identified 30 DOE facilities that have been declared surplus to government needs; the SFIMP was established in 1978; about $968,400 \mathrm{~m}^{3}$ of LLW are expected (most from the Weldon Spring site in Missouri), about $2,400 \mathrm{~m}^{3}$ of TRU waste are expected (most from the Battelle Columbus Laboratory in Ohio), and about $1,529,000 \mathrm{~m}^{3}$ of mill tailings (from the Monticello site in Utah) are expected from SFMP; the SFMP activities are scheduled for completion in 2004

B. The Grand Junction Remedial Action Project (GJRAP) was initiated by DOE and the state of Colorado in 1973 to oversee the remediation/reconstruction of private facilities that were contaminated by tailings from a nearby uranium mill; the GJRAP was completed in 1988

C. West Valley Demonstration Project: The West Valley facility was the first and only commercial fuel reprocessing plant which was operated (from 1966-1972) in the U.S.; the decommissioning project was undertaken by DOE as a demonstration project under a Congressional Act in 1980; a major part of the project is vitrification of about 600,000 gallons (about $2000 \mathrm{~m}^{3}$ ) of liquid $\mathrm{HLW}\left(1,796 \mathrm{~m}^{3}\right.$ of alkaline waste and $50 \mathrm{~m}^{3}$ of acidic waste) and $31 \mathrm{~m}^{3}$ of inorganic ion-exchange material, using new vitrification equipment installed in existing hot cells that are decontaminated; vitrification will be started in 1996 and completed in 1998; total decommissioning of the facility will be completed later after in-cell, air-cooled, interim stored, vitrified HLW canisters (about 300 of them) can be sent to the HLW repository; projected wastes upon completion of the project are $210 \mathrm{~m}^{3} \mathrm{HLW}$ glass; $300 \mathrm{~m}^{3}$ TRU wastes; $15,000 \mathrm{~m}^{3} \amalg W$; and $4,300 \mathrm{~m}^{3}$ wastes from post-HLWsolidification decommissioning 
D. Shippingport Reactor Decommissioning Project: The Shippingport nuclear reactor, located in Shippingport, Pennsylvania, was the first U.S. commercial nuclear power reactor; the 72-MWe PWR operated from 1957 to 1982; physical decommissioning started in 1985, including dismantlement of the nonradioactive structures; DOE removed the spent fuel and sent it to the Idaho National Engineering Laboratory, and disposed of about $6,117 \mathrm{~m}^{3}$ of low-level radioactive waste at the DOE Hanford, Washington, facility; DOE removed the reactor pressure vessel intact and shipped it by barge to Hanford for disposal; the site was certified as radiologically safe in October 1989, with release for unrestricted use (GAO 9/90, NEI 9/90)

E. The first DOE-EM integrated demonstration (ID) began in October 1989; this ID is comparing technologies for remediation of volatile organics (e.g, trichloroethylene, perchloroethylene) in soils and groundwater at nonarid sites; the ID is being conducted at the Savannah River site in South Carolina; similar technologies will then be evaluated for remediation of arid sites around the U.S.

\subsection{INTERNATIONAL COOPERATION ON DECOMMISSIONING:}

The U.S. has participated in the OECD/NEA cooperative program on decommissioning of large nuclear facilities (Shippingport and West Valley Projects were U.S. contributions), and in OECD/NEA and IAEA technical studies; bilateral agreements with Canada, Federal Republic of Germany, France, Japan, and the U.K. include decommissioning

\subsection{COSTS}

A. The DOE's environmental restoration and waste management costs for 1991 total $\$ 2.8$ billion (NWN 2/7/91):

$\$ 145.4$ million for corrective activities

$\$ 764.1$ million for waste operations

$\$ 1,570.7$ million for environmental restoration

$\$ 200.3$ million for technology development (R\&D)

$\$ 5.6$ million for program direction

$\$ 59.9$ million for transportation and site management

B. The estimated costs for the West Valley project through vitrification and storage of vitrified HLW are approximately $\$ 1.4$ billion

C. The Shippingport project total cost was $\$ 91.3$ million (NWN 10/18/90; NEI 9/90)

D. A report by TLG Engineering estimates that decommissioning of each BWR will cost more than $\$ 200$ million (in 1987 dollars); PNL had earlier estimated the cost at $\$ 138$ million (in 1987 dollars) (NW 10/25/90)

\subsection{INTERNATIONAL ACTIVITIES}

13.1 MEMBERSHIPS: The United States is a member of the IAEA and OECD/NEA

\subsection{COOPERATION WITH MULTINATIONAL AGENCIES}

A. International Atomic Energy Agency (IAEA): DOE, NAC and EPA contribute to IAEA waste management studies by providing technical experts and by participating in 
committee meetings, workshops, and study projects; the U.S. also participates in IAEA symposia and seminars

B. The Nuclear Energy Agency of the Organization for Economic Cooperation and Development (OECD/NEA): DOE sponsors participation in the NEA Radioactive Waste Management Committee (RWMC) which guides and reviews the NEA work in waste management; DOE also participates in specialist workshops, coordinating groups, multinational projects coordinated by NEA (e.g., the Stripa Project in Sweden, cooperative program on decommissioning)

C. Commission of the European Communities (CEC): The U.S. DOE and the CEC have a bilateral agreement: 'Agreement for Exchange of Information Concerning a Cooperative Program in the Field of Management of Radioactive Wastes'; the term is 10/6/82 to $10 / 6 / 92$; the scope includes characterization of waste forms, disposal in geologic formations and seabed (including performance assessments and related modeling), geologic repository site characterization and facility design, radionuclide migration and modeling, underground research, backfill and seal batriers, risk analysis; the DOE also has agreements with the CEC on safeguards, health and environmental effects of radiation, and several agreements on thermonuclear fusion

\subsection{COOPERATION WITH OTHER COUNTRIES}

A. Cooperative agreements on waste management and related activities (Leigh and Mitchell 1990)

1) DOE, NAC, and EPA find it beneficial to cooperate with other nations in radioactive waste management technology; cooperative activities include: exchange of technical personnel and test data; collaboration (including mutual funding) in tests and joint projects; exchange of materials, samples, equipment, and documents; joint testing and evaluation of computer codes; short visits of teams or individuals to facilities of the other party

2) Bilateral agreements are in place with the following countries:

a. Belgium: DOE has an umbrella agreement with the Belgian Centre d'Etude de l'Energie Nucleaire/Studiecentrum vcor Kernenergie (CEN/SCK): "Agreement in the Field of Radioactive Waste Management"; the term is $1 / 19 / 81$ to $1 / 19 / 94$; the scope includes geologic disposal, retrievable storage, waste processing, airborne waste management, and environmental effects

b. Canada: DOE has an umbrella agreement with Atomic Energy of Canada, Ltd. (AECL) on "Cooperation in Radioactive Waste Management"; the term is 1976 to $8 / 25 / 92$; the scope includes waste preparation and packaging, surface/subsurface storage, characterization of and disposal in geologic formations, transportation requirements, decontamination and decommissioning, environment and safety, and public acceptance

1) A former "Subsidiary Agreement for a Radioactive Waste Management Technical Cooperation Program' is being renegotiated; the former scope included cooperation in an experimental program in the Canadian underground research laboratory in granite at Whiteshell and performance asse:ssment studies 
c. France: DOE has an umbrella agreement with the French Atomic Energy Commission (CEA): 'Agreement in the Field of Radioactive Waste Management; the term is $7 / 26 / 83$ to $7 / 26 / 93$; the scope includes waste preparation/packaging, decontamination and decommissioning, surface and subsurface storage, geologic disposal, transportation requirements, environmental and public safoty

1) DOE and the French CEA have a 'Statement of Intent for Cooperation on the West Valley Demonstration Project"

2) DOE and the French CEA have a 'Statement of Intent for Cooperation in the Field of Low-Level Radioactive Waste'

3) DOE also has agreements with France on remote systems technology, nuclear criticality safety, safeguards, and several agreements on reactor technology

4) NRC has an umbrella agreement with the French CEA on 'Technical Exchange and Cooperation Arrangement in the Field of Safety of Radioactive Waste Management"; the scope includes characteristics and long-term performance of conditioned HLW and TRU wastes, methods/data for evaluating radionuclide migration, methods of classification/treatment and disposal of LLW, and methods for analysis of operational safety

d. Germany: DOE has an umbrella agreement with the German Federal Ministry for Research and Technology (BMFT): 'Technical Exchange and Cooperative Arrangement in the Field of Management of Radioactive Wastes"; the term is $12 / 20 / 74$ to $12 / 31 / 89$ (the agreement is being renegotiated); the scope includes preparation of waste forms, decontamination and decommissioning, surface storage, characterization of and disposal in geologic formations, transportation requirements, environmental and safety considerations, and public acceptance issues

1) DOE and Germany previousiy had a "Project Agreement on Experiments at the Asse Salt Mine"

2) DOE and Germany previously had a 'Project Agreement on Methods of Treatment for Immobilization of High-Level Radioactive Wastes"; this agreement included the U.S. fabrication of isotopic heat sources

3) DOE also has agreements with Germany on reactors, safeguards, and remote systems technology

e. Japan: DOE has an umbrella agreement with the Japanese Power Reactor and Nuclear Fuel Development Corporation (PNC): "Agreement in the Area of Radioactive Waste Management"; the teim is $12 / 3 / 86$ to $12 / 3 / 96$; the scope includes waste treatment, waste form characterization, packaging, storage, transportation, disposal, decontamination and decommissioning, facility operations, environment and safety, and public acceptance 
DOE previously had a subsidiary agreement for "Collaborative Testing of Liquid-Fed Ceramic Mether for Radioactive Waste Vitrification'

2) DOE also previously had agreements with Japan on nuclear criticality, Three-Mile-Island reseal'ch, and several agreements on breeder reactors

3) NAC has an agreement with the Japan Atomic Energy Research Institute (JAERI) on "Cooperation in Radioactive Waste Management Satety Research"; the term is $11 / 7 / 84$ to $11 / 7 / 89$ (negotiations are in progress for an extension); the scope includes radionuclide migration through soils, source terms of radionuclides, safety performance of LLW disposal, materials/engineening, characterization of natural barriers, and performance assessiment for HLW disposal

f. People's Republic of China: The U.S. and China have an umbrella "Agreement for Cooperation Concerning| Peaceful Uses of Nuclear Energy"; the term is $7 / 23 / 85$ to $7 / 23 / 2015$; the scope includes nuclear fuel cycle R\&D, industrial nuclear applications, nuclear fuel supply, and waste management techniques

g. Spain: DOE has a Memorandum of Understanding (MOU) with the Spanish Energy Research Center (CIEMAT) for "Dooperation in Energy Research and Development," including radioactive waste management; the term is $6 / 6 / 86$ to $6 / 6 / 91$

h. Sweden: DOE has an umbrella agreement with the Swedish Nuclear Fuel and Waste Management Company (SKE): Agreement Concerning a Cooperative Program in the Field of Management of Radioactive Wastes"; the term is 1977 to $9 / 9 / 95$; the scope includes waste preparation/packaging, surface and subsurface storage, characterization and disposal in geologic formations, field and laboratory testing, environmental and safety considerations, institutional and public relationships

i. Switzerland: DOE has an umbrella agreement with the National Cooperative for the Disposal of Radioactive Waste [Nationale Genossenschatt fur die Lagerung Radioaktiver Abfalle (NAGRA)]: 'Agreement in the Field of Radioactive Waste Management'; the term is $4 / 19 / 85$ to $4 / 19 / 95$; the scope includes characterization of geologic formations, field and laboratory testing, waste preparation and packaging, surface and subsurface storage, disposal in geologic formations, performance assessment, public acceptance, transportation requirements, environment and safety

1) DOE and Switzerland also have a "Project Agreement in the Field of Flow and Transport of Radionuclides in Fractured Media"

2) DOE also has agreements with Switzerland on GCR technology and carbide fuel development

3) The NRC and Switzerland (NAGRA) have an 'Agreement on Cooperation in Radioactive Waste Management Safety Research"; 
the term is $9 / 26 / 86$ to $9 / 25 / 91$; the scope includes hydrologic tests in the Swiss underground research laboratory, performance tests of waste package, repository backfill, repository host rock, radionuclide migration, field tests and site characterization techniques, radionuclide source term data, thermohydrologic interactions, and shaft sealing

j. Union of Soviet Socialist Republics: DOE has a "Memorandum of Cooperation in the Fields of Environmental Restoration and Waste Management Between the United States of America and the Union of Soviet Socialist Republics"; the term is 9/18/90 to 9/18/95; the scope includes environmental restoration, waste management, decontamination and decommissioning, safety and public acceptability, waste partitioning, and geologic disposal

k. United Kingdom: DOE has an 'Agreement in the Field of Radioactive Waste Management" with the United Kingdom Atomic Energy Authority (UKAEA); the term is 10/30/86 to 10/30/91; the scope includes waste preparation and packaging, surface and subsurface storage, transportation requirements, characterization of and disposal in geologic formations, repository design and performance assessment, field and laboratory testing, LLW/ILW/TRU waste treatment and disposal technology, environment and safety, public acceptance, and decommissioning waste treatment

1) The DOE and the UKAEA also previously had a separate agreement on decommissioning projects

2) The DOE and the UKAEA also previously had an umbrella agreement and several subsidiary agreements on LMFBRs

B. Assistance to Non-nuclear Weapons States:

The Nuclear Waste Policy Act (Section 223) required DOE and NRC to offer technical assistance to non-nuclear weapons states in the area of spent fuel storage and disposal for five years (assistance was carried out from 1984-1988); inquiries were received from fifteen countries; briefings and/or technical documents or other type of tochnical assistance were transferred to Argentina, Botswana, Brazil, Colombia, Egypt, Indonesia, Italy, South Korea, Madagascar, Mexico, Netherlands, Norway, Philippines, Spain, and Taiwan

C. Cooperation in the Field of Nuclear Safety:

The U.S. NRC has cooperative agreements with many countries in the field of nuclear safety inciuding: Belgium, Brazil, Canada, Chi, ia, Denmark, Egypt, Finland, France, Germany, Greece, Israel, Italy, Japan, Republic of Korea, Mexico, Netherlands, Phillipines, Spain, Sweden, Switzerland, USSR, United Kingdom, and Yugoslavia (IAEA 1990) 
UNITED STATES

\subsection{REFERENCES}

$-1977$.

Nucleonics Week (NW), 4/7/77. 'U.S. No Reprocessing Anywhere Policy Denounced at German Meeting,' pp. 5-8.

$-1981-$

Nucleonics Week (NW), 10/15/81. Pronuclear Forces Find Things to Cheer in Reagan Policy Statement," pp. 4-6.

$-1983-$

Federal Register (FR). 4/18/83. 10 CFR 961 Standard Contract for Disposal of Spent Nuclear Fuel and/or High-Level Radioactive Waste, Vol. 48, No. 75, p. 16600.

Lakey, L. T. ot al. 1983. "Management of Transuranic Wastes Throughout the World.' Nuclear and Chemical Waste Management, Vol. 4, pp. 35-46.

U.S. Congress. 1983. Nuclear Waste Policy Act of 1982. Public Law 97-425, 97th Congress,

U.S. Government Printing Office, Washington, D.C., January 7, 1983.

-1984 -

Feldman, M. J., and W. R. Hammel. 1984. 'The Advancement of Femote Systems Technology: Past Perspectives and Future Plans.' In proceedings of ANS International Topical Meeting on Fuel Reprocessing and Waste Management, Jackson, Wyoming, August 1984, Vol. 2, pp. 494-505.

Harmon, K. M., and A. B. Johnson, Jr. 1984. Foreign Programs for the Storage of Spent Nuclear Power Plant Fuels, High-Level Waste Canisters and Transuranic Wastes. PNL-5089, Pacific Northwest Laboratory, Richland, Washington.

U.S. Nuclear Regulatory Commission (NRC). 1984. "Waste Confidence Decision," Federal Register, Vol. 49, No. 171, pp. 34 and 658, 10 CFR Parts 50 and 51, August 31, 1984.

$-1985-$

DOE/DP/48010-T1. 1985. The Management of Radioactive Waste at the Oak Ridge National Laboratory: A Technical Review, National Research Council, Washington, D.C.

DOE/RW-0005. 1985. Mission Plan for the Civilian Radioactive Waste Management Program, U.S. Department of Energy, Washington, D.C., June 1985.

Lakey, L. T., K. M. Harmon, and P. Colombo. 1985. Management of Low-Level Radioactive Wastes Around the World. PNL-5173, Pacific Northwest Laboratory, Richland, Washington.

Meyers, S. 1985. "EPA's HLW Standards and Waste Package Performance." In proceedings of the international seminar on Radioactive Waste Products-Suitability for Final Disposal, June 10-13, KFA, Jülich, Federal Republic of Germany, pp. 492-496. 
Office of Technology Assessment (OTA). 1985. Managing the Nation's Commercial High-Level Radioactive Waste, U.S. Congress, Office of Technology Assessment, OTA-O-171, Washington, D.C., March 1985.

$-1986-$

DOE/RW-0046. 1986. Transportation Business Plan, U.S. Department of Energy, Office of Civilian Radioactive Waste Management, Washington, D.C.

DOE/RW-0067. 1986. Radioactive Waste Management System: Project Decision Schedule, U.S. Department of Energy, Office of Civilian Radioactive Waste Management, Washington, D.C.

DOE/RW-0094. 1986. Transportation Institutional Plan, U.S. Department of Energy, Office of Civilian Radioactive Waste Management, Washington, D.C.

EPRI NP-4887. 1986. The Castor-V/21 PWR Spent-Fuel Storage Cask: Testing and Analyses, Electric Power Research Institute, Palo Alto, California.

Halverson, T. W., and L. T. Cole. 1986. 'Optimization of Waste Operations at WIPP.' Waste Management ' 86 , March 2-6, Tucson, Arizona, Vol. 2, pp. 135-138.

Hunt, A. E., W. R. Chiquelin, and T. W. Halverson. 1986. "The Operational Status of WIPP." Waste Management '86, March 2-6, Tucson, Arizona, Vol. 2, pp. 121-123.

Moghissi, A.A., H.W. Godbee, and S.A. Hobart. 1986. Radioactive Waste Technology, the American Society of Mechanical Engineers, New York, N.Y.

Nowak, E. J. 1986. "Brine Migration Studies in the Waste Isolation Pilot Plant (WIPP)." Waste Management '86, March 2-6, Tucson, Arizona, Vol. 2, pp. 153-158.

OCAWM Backgrounder. 4/86. U.S. Department of Energy, Washington, D.C.

OCRWM Bulletin. 12/86. U.S. Department of Energy, Washington, D.C.

PNL-5777. 1986. Cask Handling Experience and Decay Heat, Heat Transfer, and Shielding Data, Pacific Northwest Laboratory, Richland, Washington.

Stein, C. L., and J. L. Krumhansl. 1986. "Geochemical Overview of the Waste Isolation Pilot Plant Near Carlsbad, New Mexico.' Waste Management '86, March 2-6, Tucson, Arizona, Vol. 2, pp. 141-144.

Stormont, J. C. 1986. "In Situ Seal Tests at the Waste Isolation Pilot Plant (WIPP)." Waste Management '86, March 2-6, Tucson, Arizona, Vol. 2, pp. 167-176.

$-1987-$

DOE-JIO-023. 1987. Long-Pange Master Plan for Defense Transuranic Waste Program. U.S. Department of Energy (Joint Integration Office), Albuquerque, New Mexico.

DOE/RW-0035. 1987. Monitored Betrievable Storage Submission to Congress, Rev. 1 (3 Vols.), U.S. Department of Energy, Washington, D.C.

DOE/RW-0128. 1987. Draft Mission Plan Amendment, U.S. Department of Energy, Washington, D.C. 
DOE/RW-0144. 1987. Fiscal Year 1986 Annual Report to Congress: OCRWM, U.S. Department of Energy, Washington, D.C.

EPRI NP-5128. 1987. The TN-24P PWR Spent-Fuel Storage Cask: Testing and Analyses, Electric Power Research Institute, Palo Alto, California.

EPRI NP-5268. 1987. The MC-10 PWR Spent-Fuel Storage Cask: Testing and Analyses, Electric Power Research Institute, Palo Alto, California.

MacDougall, H. R., L. W. Scully, and J. R. Tillerson. 1987. Nevada Nuclear Waste Storage Investigations Project, Site Characterization Plan Conceptual Design Report. SNL-84-2641 (6 Vols.), Sandia National Laboratories, Albuquerque, New Mexico.

Sandia National Laboratories (SNL). 1987. The Scientific Program at the Waste Isolation Pilot Plant. SAND85-1699, Sandia National Laboratories, Carlsbad, New Mexico.

U.S. Congress, 1987. Nuclear Waste Policy Amendments Act of 1987. 42 U.S.C. 10101, Fublic Law 100-203, December 21, U.S. Government Printing Office, Washington, D.C.

$-1988-$

DOE/RW-0160. 1988. Consultation Draft Site Characterization Plan, Yucca Mountain Site, Nevada Research and Development Area, Nevada, Department of Energy, Washington, D.C. (7 Vols), January 1988.

DOE/RW-0187. 1988. Dratt 1988 Mission Plan Amendment, Department of Energy, June 1988.

DOE/RW-0199. 1988. Site Characterization Plan: Yucca Mountain Site, Nevada Research and Development Area, Nevada (8 Volumes), Department of Energy, Office of Civilian Radioactive Waste Management, Washington, D.C., December 1988.

Nuclear Waste News (NWN). 7/28/88. "DOE is Not Authorized to Tap Waste Fund for On-Site Dry Cask Storage, DOE Finds ," p. 242.

PNL-6770. 1988. MRS Action Plan Task B Report - Analysis of Alternate Designs and Operating Approaches for a Monitored Retrievable Storage Facility. U.S. Department of Energy Report by Ralph $M$. Parsons Company of Delaware, Pasadena, California, and by Pacific Northwest Laboratory, Richland, Washington.

U.S. Department of Energy (DOE). 1988. Waste Isolation Pilot Plant--WIPP (Brochure), Department of Energy, Washington, D.C.

\section{9 -}

Code of Federal Regulations (CFR). 1989. Title 10, Parts 51 to 199, Energy, January 1, 1989.

DOE/RW-0216. 1989. Annual Report to Congress, U.S. Department of Energy, Office of Civilian Radioactive Waste Management, Washington, D.C.

DOE/AW-0220. 1989. Final Version Dry Cask Storage Study, U.S. Department of Energy, Office of Civilian Radioactive Waste Management, Washington, D.C. 
DOE/RW-0235. 1989. MRS System Study Summary Report, U.S. Department of Energy, Office of Civilian Radioactive Waste Management, Washington, D.C.

DOE/RW-0236. 1989. Analysis of the Total System Life Cycle Cost for the Civilian Radioacive Waste Management Program, U.S. Department of Energy, Office of Civilian Radioactive Waste Management, Washington, D.C.

DOE/RW-0247. 1989. Report to Congress on Reassessment of the Civilian Radioactive Waste Management Program, U.S. Department of Energy, Office of Civilian Radioactive Waste Management, Washington, D.C.

DOE/S-0070. 1989. Environmental Restoration and Waste Management, Five-Year Plan, U.S. Department of Energy, Washington, D.C.

The Energy Daily (ED). 6/12/89. "New U.S. Private-Sector Uranium Enrichment Venture Set For Louisiana," Vol. 17, No. 110, pp. 1-2.

Kemp, R. 1989. Planning and Consultation Procedures for Low-Level Radioactive Waste Disposal: A Comparative Analysis of Overseas Experience, University of East Anglia, Nonwich, United Kingdom.

Mitchell, D.H., G.W. MCNair, and J.M. Allison. 1989. "Performance Assessment on Grouted DoubleShell Tank Waste at Hanford,' CONF-890854, Proceedings of the Eleventh Annual DOE Low-Level Waste Management Conference, August 22-24, 1989, Pittsburgh, Pennsylvania, pp. PA61-PA72.

Nuclear Energy Agency (NEA). 1989. Uranium: Resources, Production and Demand. Joint report by OECD/NEA and IAEA, Nuclear Energy Agency, Paris, pp. 294-304.

Nuclear Engineering International (NEI). 9/89. "Success for the NUHOMS Dry Store," pp. 29-30.

Nuclear News (NN). 7/89. 'Greater-Than-Class-C Included by NRC Rule,' p. 84.

-1990 -

Creer, J.M., and C.E. Collantes. May 1990. "Selected Concrete Spent Fuel Storage Cask Concepts and the DOE/PSN Cooperative Cask Testing Program," Journal of Nuclear Materials Management, pp. $10-17$.

DOE/EIS-0026-FS. 1990. Final Supplement Environmental Impact Statement, Waste Isolation Pilot Plant, Vol. 1, U.S. Department of Energy, Washington, D.C.

DOE/LLW-103. 1990. Directions in Low-Level Radioactive Waste Management: A Brief History of Commercial Low-Level Radioactive Waste Disposal, National Low-Level Waste Management Program (NLLWMP), U.S. Department of Energy, Idaho Falls, Idaho.

DOE/RW-0006. 1990. Integrated Data Base for 1990: U.S. Spent Fuel and Radioactive Waste Inventories, Projections, and Characteristics, Rev. 6, Department of Energy, Washington, D.C.

DOE/RW-0217P. 1990. Progress Report on the Scientific Investigation Program for the Nevada Yucca Mountain Site, U.S. Department of Energy, Office of Civilian Radioactive Waste Management, Washington, D.C.

DOE/RW-0291P. 1990. Nuclear Waste Fund Fee Adequacy: An Assessment, U.S. Department of Energy, Washington, D.C. 
DOE/S-0078P. 1990. Environmental Restoration and Waste Management, Five-Year Plan Fiscal Years 1992-1996, U.S. Department of Energy, Washington, D.C.

Energy Information Administration (EIA). 9/28/90. Commercial Nuclear Power 1990 - Prospects for the United States and the World, DOE/EIA-0438(90). Report prepared by the Energy Information Administration, Washington, D.C., pp. 3-4.

Energy Information Administration (ElA). 10/26/90. World Nuclear Fuel Cycle Requirements 1990, DOE/ElA-0436(90). Report prepared by the Energy Information Adiministration, Washington, D.C., pp. 3-49.

EPRI NP-6940. 1990. NUHOMS Modular Spent-Fuel Storage System: Design, Licensing, and Construction, Electric Power Research Institute, Palo Alto, California.

Federal Register (FR). 10/22/90. Intent to Prepare a Programmatic Environmental Impact Statement on the Department of Energy's Proposed Integrated Environmental Restoration and Waste Management Program, and To Conduct, Public Scoping Hearings, vol. 55, No. 204, pp. 42633-42638.

International Atomic Energy Agency (IAEA). 1990. Bilateral, Regicnal and Multilateral Agreements Relating to Co-operation in the Field of Nuclear Safety. Legal Series No. 15.

International Energy Agency (IEA). 1990. Energy Balances of OECD Countries 1987-1988. Joint report by OECD/IEA, Nuclear Energy Agency, Paris, France, p. 189.

Leigh, I.W., and S.J. Mitchell. 1990. International Nuclear Fuel Cycle Fact Book, PNL-3594, Rev. 10, Pacific Northwest Laboratory, Richland, Washington.

Nuclear Energy Agency (NEA). 1990. "Nuclear Energy Data," Paris, France.

Nuclear Engineering International (NEl). 1990, "World Nuclear Industry Handbook."

Nuclear Engineering International (NEI). 6/90. "World Survey," pp. 27-28.

Nuclear Engineering International (NEI). 9/90. "Cost Lessons Learned from Decommissioning Shippingport,' pp. 20-22.

Nuclear Engineering International (NEI). 10/90. "U.S. Utility UW Volume Drops Sharply," p. 16.

Nuclear News (NN). 11/90. "NRC expects longer fuel storage, repository delay," pp. 116-117.

Nuclear News (NN). 12/90. "Clean Air, Budget, Other Laws Finally Passed," pp. 72-75.

Nuclear Waste News (NWN). 1/25/90. "Utilities Look to Dry Systerns to Meet Near-term Spent Fuel Storage Needs,' pp. 35-36.

Nuclear Waste News (NWN). 10/18/90. 'Shippingport Decommissioning Met Cost, Schedule Goals, GAO Finds," p. 406.

Nuclear Waste News (NWN). 11/8/90. "Future Radwaste Disposal Facilities to be Safer, Smaller, More Expensive," p. 435. 
Nucleonics Week (NW), 2/8/90. 'Coal and Capital Prices Found Key to Nuclear Competitiveness,' pp. 1 and 6-9.

Nucleonics Week (NW). 10/25/90. "Price Tag for BWR Decommissioning Soars in TLG Engineering Analysis," p. 5-6.

NUKEM Special Report (NUKEM). 7/90. 'World Nuclear Power Plant Capacity.' Nukem GmbH, Hanau, Federal Republic of Germany, pp. 21-27.

PNL-7400. 1990. Preconceptual Design for an MRS Transfer Facility, Pacific Northwest Laboratory, Richland, Washington.

United States General Accounting Office (GAO). 9/90. Nuclear Research and Development: Shippingpon Decommissioning - How Applicable Are the Lessons Learned? GAO/RCED-90-208, U.S. Government Accounting Office Report to Congressional Requesters.

- 1991 .

DOE/RW-0310P. 1991. "DOE Issues Assessment of Nuclear Waste Fund Fee Adequacy," OCRWM Bulletin. Department of Energy, Washington, D.C., December 1990/January 1991.

DOE/RW-0305P. 1991. 'OCRWM Fiscal Year 1992 Budget Request,' OCRWM Bulletin. Department of Energy, Washington, D.C., February/March 1991.

Nuclear Engineering International (NEl). 1991. "World Nuclear Industry Handbook."

Nuclear Engineering International (NEI). 3/91. 'Nuclear Competitive with Fossil Fuel: USCEA,' p. 11.

Nuclear News (NN). 2/91. 'Late News In Brief: 1990 Ended with 413 Nuclear Plants Worldwide,' p. 20.

Nuclear News (NN). 3/91. "DOE Seeks Steep Hike for Advanced LWR Work," p. 28

Nuclear Waste News (NWN). 2/7/91. "Nuclear Waste Fund Request Up 26 Percent over '91,' p. 53.

Nuclear Waste News (NWN). 2/14/91a. "Idaho Governor Forbids Radwaste to Enter DOE Weapons Facility," p. 64.

Nuclear Waste News (NWNb). 2/14/91b. 'Repository Program 'Supergorilla' Contract Signed,' p. 62.

Radioactive Exchange. 1/31/91a. "DOE Issues WIPP Administrative Land Withdrawl Order," Vol. 10, No. 2, p. 1 .

Radioactive Exchange. 1/31/91b. "DOE New Decision Timetable has WIPP Opening in July '91," Vol. 10, No. 2, pp. 9-10.

Smith, R.I. 1991. 'Status of U.S. Program for Disposal of Spent Nuclear Fuel," paper presented at The Management of Spent Nuclear Fuel, London, United Kingdom, April 29-30, 1991.

Stuart, I.F. 1991. 'The Development of the Transportable Storage Cask,' Presented at The Institute of Nuclear Materials Management Spent Fuel Management Seminar, Washington, D.C., January 16-18, 1991. 


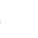




\section{CEC}


CEC

\section{COMMISSION OF THE EUROPEAN COMMUNITIES (CEC)}

\section{CONTENTS}

1.0 INSTITUTIONAL CONSIDERATIONSIORGANIZATIONS $\ldots \ldots \ldots \ldots \ldots \ldots \ldots \ldots$ CEC.2

2.0 WAStE MANAGEMENT ACTIVITIES $\ldots \ldots \ldots \ldots \ldots \ldots \ldots \ldots \ldots \ldots \ldots \ldots \ldots$

$3.0 \quad$ U.S. PARTICIPATION $\ldots \ldots \ldots \ldots \ldots \ldots \ldots \ldots \ldots \ldots \ldots \ldots \ldots \ldots \ldots \ldots \ldots$ CEC.7

4.0 REFERENCES $\ldots \ldots \ldots \ldots \ldots \ldots \ldots \ldots \ldots \ldots \ldots \ldots \ldots \ldots \ldots \ldots$ 


\subsection{INSTITUTIONAL CONSIDERATIONS/ORGANIZATIONS}

\subsection{MEMBER STATES}

The Commission of the European Communities (CEC) has 12 Member States; they are Belgium, Denmark, France, Federal Republic of Germany (FRG), Greece, Ireland, Italy, Luxembourg, Netherlands, Portugal, Spain, and the United Kingdom (U.K.)

\subsection{BASIC CHARTER/PURPOSE}

A. The purpose of the CEC is to put an end to national prejudice, discrimination, and armed conflict; to open up economic frontiers which could divide Western Europe; to improve the quality of life in Western Europe; to make the community a single economic area; to provide world influence beyond that of Western Europe's individual nations; to become a strong force for peace; to provide aid to the world's poorer nations; to contribute to world stability and contribute to international law and order

B. The purpose of the waste management program is to develop and demonstrate systems for managing the radioactive wastes produced by the nuclear industry, ensuring, at various stages, the best possible protection of man and the environment

C. The CEC plan of action in the field of radioactive waste for the period 1980-1992 is to (CEC 1987):

1. Provide continuous analysis of the waste-management situation in the Member States with a view to adopting necessary solutions

2. Encourage technical cooperation between the European Community (EC) Member States to promote optimum solutions for disposal of wastés

3. Consult regularly at the EC level concerning national practices of waste management and possible harmonization

4. Continue EC research

5. Provide information to the public on a regular basis

D. Recently, the CEC has placed greater emphasis on protection of the global environment (Schneider 1990)

\subsection{HISTORY}

A. The CEC was established in 1967 as the single administrative body for the three European Communities: the European Coal and Steel Community (created in 1951), the Economic Community (created in 1957), and EURATOM (created in 1957)

B. The EC has set the end of 1992 as the date for removing remaining national barriers to the free movement of goods, services, capital, and people within the EC countries (CEC 1990c; Hieronymi 1989) 


\subsection{ORGANIZATION}

A. The administrative body of the Commission (CEC-Brussels) is composed of members from each member state; the Commission proposes and supervises the execution of laws within the EC countries

B. The Council of Ministers, one from each member state, is the main decisionmaking body, and approves programs; the Council enacts laws and programs based on Commission proposals

C. The European Parliament, primarily a consultative body, passes on most of the Commission's legislation, but has censure powers over the Commission

D. Other CEC bodies are: the Court of Justice, the Economic and Social Committee, the European Imvestment Bank, and the Court of Auditors (CEC 1989b)

E. The 'direct action' R\&D in the CEC is carried out at the four operating establishments of the Joint Research Center (JRC) located at Ispra (Italy), Karlsruhe (FRG), Petten (the Netherlands), and Geel (Belgium)

F. Most of the CEC's "direct action" nuclear waste management R\&D is carried out within the Ispra and Karisruhe establishments

G. Joint Research Center (JRC) - Ispra Establishment (ECF 4/89)

1. The Ispra Establishment is located in Northern Italy, about $50 \mathrm{~km}$ from Milan

2. The Ispra R\&D programs on treatment, storage, and disposal of radioactive wastes are: volume reduction and actinide separation of TRU wastes; waste-disposal risk analysis; nuclide migration; and waste-form properties

3. A hot-cell facility known as PETRA (Project for Evaluation of Treatments in Radioactive Waste in Adeco) was expected to begin operation in 1989 at the Ispra Establishment (NWN 4/27/89)

a. The PETRA facility is equipped to study reprocessing and waste-treatment flowsheets at the pre-industrial scale (6-kg batches of LWR spent fuel (Dworschak 1989); in the fall of 1990, the hardware had been installed and the facility was undergoing functional testing (Dworschak 1990)

b. The facility will test techniques to minimize radioactive wastes from spent nuclear fuel reprocessing

c. A process-control and information system incorporating an expert system was recently installed in the facility (Magni 1990)

d. Following non-radioactive testing, the facility will be operated in the standard PUREX mode, with the goal of obtaining $3 \mathrm{~kg}$ glass blocks for characterization studies

e. In the second phase, beginning in 1991, alternative waste-treatment procedures will be studied 
H. Joint Research Center - Karlsruhe Establishment (European Institute for Transuranium Elements) (ECF 4/89)

1. The Karlsruhe Establishment is located at Karlsruhe, FRG

2. The Karlsruhe Establishment conducts basic research in the transuranium elements, especially plutonium and reactor fuels development; specific work includes:
a. Plutonium conversion and plutonium fuels
b. Characterization of waste forms, notably spent fuel when considered as a waste

\subsection{KEY PERSONNEL}

A. Filippo N. Pandolfi, Vice President, Industrial Affairs, Information Technologies, Research/Science and the JRCs

B. L. J. Brinkhorst, Director General, Environment, Nuclear Safety and Civil Protection

C. Jean-Pierre Contzen, Director General, JRCs

D. Paolo Fasella, Director General, Science/R\&D

E. Sergio Finzi, Director, Nuclear Safety R\&D, CEC-Brussels

F. Serge Orlowski, Head, Nuclear Fuel Cycle Division, CEC-Brussels

G. Emilio L. Menchero, Head, Nuclear Plant Safety, JRC-Ispra

H. Georg Gerber, Head, Radiological Protection

i. Jacobus Van Geel, Director, Karlsruhe Establishment (European Institute for Transuranium Elements), JRC-Karlsruhe

J. Francesco Girardi, Waste Management Programs, CEC-Ispra

\subsection{FUNDING FOR CEC FUEL CYCLE PROGRAMS}

Expenditures are covered by Member States through levies; funding for the waste management R\&D programs is as follows:

A. The "direct-action" programs are fully funded by the CEC and are carried out by the Joint Research Centers at Ispra (Italy) and Karlsruhe (FRG)

B. The "shared-cost" actions are jointly funded by the CEC and by the countries carrying out the work under cost-sharing contracts (usually about 50-50) (ECF 3/90;

Schneider 1990)

1. The work is conducted by Member States and their research centers, universities, and industries; the work is coordinated by the Nuciear Fuel Cycle Division in Brussels 
2. Most of the CEC's radioactive waste management R\&D program is funded by the shared-cost actions

3. The CEC's cost of the five-year shared-action program was: 19.2 million ECUs (European Currency Units) for the $1975-1979$ period, 43 million ECUs for the 1980-1984 period, and 62 million ECUs for the 1985-1989 period (in $19901 \mathrm{ECU} \approx$ $1.2 \$)$

4. For the $1990-1994$ period the budget is 80 million ECUs (\$96 million U.S.) (EC 1/22/90)

5. The decommissioning part of the shared-cost R\&D budget for the period 1989-1993 is 31.5 million ECUs (\$35 miltion U.S.) (NN 5/89); this is double the amount spent on the 1984-1989 program (NN 4/89)

C. By 1994, the costs for CEC's radioactive waste management programs since its inception in 1975 will total about 650 million ECUs (about $\$ 780$ million U.S.), including the costs shared by the Member States (Orlowski 1990)

\subsection{WASTE MANAGEMENT ACTIVITIES}

\subsection{SHARED-COST WASTE MANAGEMENT ACTIVITIES (CEC 1990a,b; Schneider 1990)}

A. The research areas during the $1985-1989$ program were:

1. System studies (feasibility, costs, impacts)

2. Improvement of radioactive waste treatment and conditioning technologies

3. Evaluation of conditioned waste and qualification of engineered barriers

4. Research in support of the development of disposal facilities; shallow burial and geological disposal studies

5. Safety of geological disposal

6. Joint elaboration of radioactive waste management policies

B. The construction and operation of the following underground experimental facilities have been supponed

1. Salt: Asse salt mine (FRG and Netherlands) (Kuehn 1985)

2. Clay: Mol boom clay (Belgium, France, Italy and U.K.)

3. Granite: Underground laboratory at Fanay Augeres, France

C. Major projects coordinated by the CEC are: COSA (Comparison of Rock Mechanics Computer Codes for Salt): MIRAGE (Migration of Radionuclides in the Geosphere) project (Come 1988); COCO (Colloids and Complexes); CHEMVAL (Geochemical Codes Evaluation); NAWG (International Natural Analogues Working Group) (Come and Chapman 1987) 
D. The performance assessment studies that have been conducted are PAGiS (Performance Assessment of Geological isolation Systems) (Cadelli 1986) and PACOMA (Performance Assessment of Confinement for Medium-Level and Alpha Wastes)

1. The conclusion of the PAGIS study is that, during the many thousands of years of simulated operation of a vitrified HLW in several repository geologies, no radioactivity is expected to reach the biosphere (Cadelli 1988, 1990)

2. Similar results were obtained for the PACOMA study (deep geological disposal of medium-level and alpha-bearing waste); the results of the PACOMA study were scheduled to be published in late 1990 (Cadelli 1990)

\subsection{DIRECT-ACTION WASTE MANAGEMENT R\&D PROGRAM}

A. Hecent $\mathrm{CEC}$ activities have emphasized advanced technologies for improving waste treatment, improved waste forms, and reduced releases to the environment; future work will be expanded to include radionuclide partitioning and destruction by transmutation, studies on mixed wastes, and a major effort on decommissioning (Schneider 1990; Orlowski 1990)

B. A new series of CEC topical reports on radioactive waste management, called the EURAOWASTE series, has been initiated (Schneider 1990); as of late 1990, three reports had been published and one more was in process:

- $\quad$ Objectives, Standards and Criteria for Radioactive Waste Disposal in the European Community.' EUA 12570 E (EUAADWASTE Report), Office for Official EC Publications, Luxembourg.

- $\quad$ "Radioactive Waste Equivalence." EUR 12879 E (EURADWASTE Report), Office for Official EC Publications, Luxembourg.

- $\quad$ "Evaluation of Storage and Disposal Costs for Conditioned Radioactive Waste in Several European Countries.' EUR 12871 E (EURADWASTE Report), Office for Official EC Publications, Luxembourg.

- "Quality Assurance in the Management of Radioactive Waste in the European Community." (EURADWASTE Report), Office for Official EC Publications, Luxembourg. (to be published)

\subsection{SHARED-COST DECOMMISSIONING ACTIVITIES}

A. The CEC's decommissioning program has three components (NWN 4/13/89):

1. Laboratory research and assessment of the long-term integrity of buildings and systems; decontamination for decommissioning; dismantling techniques; treatment of waste materials; development of remote-controlled systems; and estimation of the amount of radioactive materials resulting from decommissioning

2. The identification of guiding principles in the design and operation of nuclear instaflations that would simplify decommissioning and keep occupational radiation exposures as low as reasonably achievable (ALARA)

3. Testing of new techniques through actual decommissioning of the following projects: Windscale AGR at Seliafield, U.K.; the Gundremmingen BWR (KRB-A) in 
Germany; the BR-3 PWR in Mol, Belgium; and the AT-1 fuel reprocessing plant in La Hague, France

B. The CEC budget for decommissioning R\&D for the period 1989-1993 is 31.5 million ECUs (\$35 million U.S.) (NN 5/89)

C. The CEC's Energy, Research and Technology Committee has concluded that decommissioning of nuclear plants is neither urgently necessary nor desirable at this time; the nuclear-plant sites will be maintained and used for radioactive waste storage until decommissioning technology has been better developed (NN 4/89)

\subsection{RADIOACTIVE WASTE DISPOSAL}

A. The EC has adopted the following recommendations concerning the application of Article 37 of the EURATOM Treaty (AE 1991):

1. Each Member State is required to provide general data relating to any plan for the disposal of radioactive waste (this recommendation revises a 1982 version by stating more clearly the information required from Member States before disposal may be authorized)

2. The "general data" that must accompany any plan for radioactive waste disposal are identified

3. The meaning of "disposal of radioactive waste" is defined and the categories of activities covered by the obligations are enumerated

4. The disposal of radioactive waste, within the meaning of Article 37 of the treaty, covers any form of disposal, planned or accidental, of radioactive substances from three categories of operations

B. A detailed report has been issued on the objectives, standards and criteria for radioactive waste disposal in the EC; the general principles cover the fields of radiation protection, ethical and sociological questions, protection of the environment and natural resources, and nuclear safeguards (ECF 3/90; CEC 1989a)

\subsection{COOPERATION WITH OTHER AGENCIES}

A. The CEC cooperates with the OECD/NEA and the IAEA

B. The CEC has bilateral agreements with the non-CEC countries of Canada, Finland, Sweden, Switzerland, and the United States (Schneider 1990)

\subsection{U.S. PARTICIPATION}

3.1 DOE/CEC UMBRELLA AGREEMENT FOR WASTE-MANAGEMENT EXCHANGE (Leigh 1990)
A. Term: October 6, 1982 to October 6, 1992
B. Scope: Characterization of waste forms; disposal in geologic formations
C. Emphasis: R\&D 


\subsection{OTHERS}

A. The CEC and DOE have other agreements on safeguards, health and environmental effects of radiation, and several agreements on thermonuclear fusion

\subsection{REFERENCES}

$-1985-$

Huber, B. 1985. "The European Community's Research Programme-Next Phase." IAEA Bulletin, Winter 1985, p. 9.

Kuehn, K, and B. Verkerk. 1985. "in-Situ Investigations in Salt Formations." In Proceedings of the Second European Community Conference on Radioactive Waste Management and Disposal 1985, Cambridge University Press, London, pp. 410-424.

\section{$-1986-$}

Cadelli, N., F. Girardi, and S. Orlowski. 1986. "PAGIS, Common European Methodology for Repository Performance Analysis.' In Radioactive Waste Management and Disposal, EUR10163, ed. R. Simon, University Press, Cambridge, pp. 628-638.

$-1987$.

Come, B., and N.A. Chapman. 1987. Natural Analogues in Radioactive Waste Disposal. EUR 11037, Graham \& Trotman, London.

Commission of the European Communities (CEC) 1987. Analysis of the Present Situation and Prospects in the Field of Radioactive Waste Management in the European Community - Second Report, $\operatorname{COM}(87) 312$, Communication from the Commission, Brussels.

$-1988-$

Cadelli, N., G. Cottone, S. Orlowski, G. Bertozzi, F. Girardi, and A. Saltelli, 1988. PAGIS - Performance Assessment of Geological Isolation Systems for Radioactive Waste (Five Volumes). EUR $11775 \mathrm{EN}$, Office for Official EC Publications, Luxembourg.

Come, B. 1988. 'An Overview of the CEC Project MIRAGE (Migration of Radionuclides in the Geosphere)." In Radioactive Waste Management and the Nuclear Fuel Cycle, Volume 10 (1-2), pp. 41-49.

\section{$-1989-$}

Commission of the European Communities (CEC) 1989a. Objectives, Standards and Criteria for Radioactive Waste Disposal in the European Community. EUR-12570, Office for Official EC Publications, Luxembourg.

Commission of the European Communities (CEC) 1989b. 1989 Directory of EEC Information Sources. Office for Otficial EC Publications, Luxembourg.

EC Focus (ECF). 4/89. "The 1989-1991 Programme of the Joint Research Centre on Radioactive Waste," April 10, 1989, p. 1. 
Dworschak, H., and F. Girardi. 1989. "Construction and Commissioning of the PETRA Pilot Plant Facility for Waste Management Studies," in Proceeding of the 1989 Joint International Waste Conference of High Level Radioactive Waste and Spent Fuel Management, October 22-28, Kyoto, Japan, Vol. 2, p. 559.

Nuclear News (NN). 4/89. "EEC Panel Advises Delay for Bulk Decommissioning," p. 83.

Nuclear News (NN). 5/89. "Decommissioning Research Budget Approved by EEC,' p. 76.

Nuclear Waste News (NWN). 4/13/89. "European Council Approves Five-Year, \$35 Million Decommissioning Program," p. 124.

Nuclear Waste News (NWN). 4/27/89. "European Facility Will Test Ways to Minimize Reprocessing Wastes," p. 145.

-1990 -

Announcement from the CEC Director General's Office, "Développements Récents en Materièr de Déchets Radioactifs," January 22, 1990, Brussels, Belgium.

Cadelli, N., and G. Cottone. 1990. 'PAGIS \& PACOMA : Performance Evaluations of Deep Geological Disposal. Results and Conclusions." in Proceedings of the International Topical Meeting on High Level Radioactive Waste Management, Vol. 1, April 8-12, 1990, Las Vegas, Nevada, p. 332.

Commission of the European Communities (CEC). 1990a. The Community's R\&D Programme on Decommissioning of Nuclear Installations - Annual Progress Report 1989 (Volume 1). EUR 12761/1, Office for Official EC Publications, Luxembourg.

Commission of the European Communities (CEC). 1990b. The Community's R\&D Programme on Decommissioning of Nuclear Installations - Annual Progress Report 1989 Nolume 2). EUR 12761/2, OHice for Officia! EC Publications, Luxembourg.

Commission of the European Communities (CEC). 1990c. Deadline 1992 - Putting Europe to Work. Office for OHicial EC Publications, Luxembourg.

Dworschak, H., 8. A. Hunt, S. Bertelli, L. Bondar, G. Girardi, H. Bokelund, and R. Nannicini. 1990. 'Overview of the JRC's Research in the Field of Waste Management and the Fuel Cycle.' In Book of Abstracts of the Third European Community Conference on Radioactive Waste Management and Disposal, September 17-21, 1990, Luxembourg, 1990.

EC Focus (ECF). 3/90. "The 1990-1994 European Community Programme on Management and Storage of Radioactive Waste," March 12, 1990, p. 1.

Hieronymi, O., and G. Stacey. 1990. 'Technology and the Challenge of the European Internal Market of 1992," Battelie Today, No. 61, December 1989.

Leigh, I. W., and S. J. Mitchell. 1990. International Nuclear Fuel Cycle Fact Book, PNL-3594, Rev. 10, Pacific Northwest Laboratory, Richland, Washington.

Magni, G., B. A. Hunt, S. Bertelli, H. Dworschak, and R. Nannicini. 1990. "Process Control and Information System in the PETRA Nuclear Plant Installation," ENC '90 ENS/ANS - Foratom Conference Transactions, Vol. III, p. 1743. 
Orlowski, S., and F. Girardi 1990. "European Community R\&D in the Field of Radioactive Waste: A 20 Year Programme." In Book of Abstracts of the Third European Community Conference on Radioactive Waste Management and Disposal, September 17-21, 1990, Luxembourg, 1990.

Schneider, K. J. 1990. "Foreign Travel Trip Report -- Participation in the CEC's Third European Community Conference on Radioactive Waste Management and Disposal in Luxembourg, September 17-21, 1990," Pacific Northwest Laboratory, Richland, Washington.

$-1991-$

American Embassy (AE). 1991. "EC Recommendation on Radioactive Waste Disposal", Telex to the U.S. State Department from the American Embassy in Brussels, January 1991. 


\section{IAEA}




\title{
INTERNATIONAL ATOMIC ENERGY AGENCY (IAEA)
}

\begin{abstract}
CONTENTS
1.0 INSTITUTIONAL CONSIDERATIONS/ORGANIZATIONS $\ldots \ldots \ldots \ldots \ldots \ldots \ldots \ldots$ IAEA.2

2.0 WASte ManAgemEnt ACtivitiES $\ldots \ldots \ldots \ldots \ldots \ldots \ldots \ldots \ldots \ldots \ldots \ldots$ IAEA.3

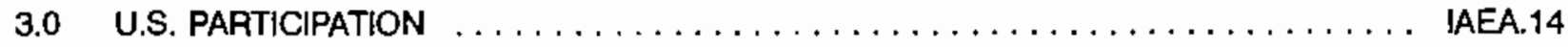

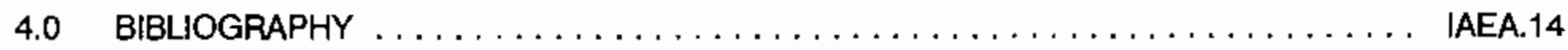

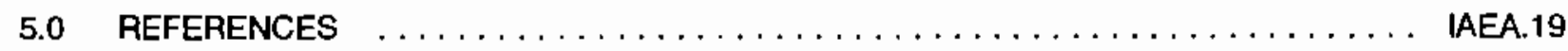




\subsection{INSTITUTIONAL CONSIDERATIONS/ORGANIZATIONS}

\subsection{NiSMBER STATES}

The IAEA is composed of 113 nations, including 80 that are classified as developing countries

\subsection{BASIC CHARTER/PURPOSE}

A. The IAEA seeks to accelerate and enlarge the contribution of atomic energy to peace, health and prosperity throughout the world; to accomplish this, the Agency:

t. Fosters and encourages, guides, and advises the development of peaceful uses of atomic energy throughout the world

2. Organizes meetings and conferences, publishes books, establishes safety standards for all types of nuclear activities, prepares feasibility and market studies, operates three laboratories (the International Laboratory of Marine Radioactivity at Monaco; the Seibersdorf Laboratory in Seibersdorf, Austria; and the International Center for Theoretical Physics at Trieste, Italy), and applies safeguards to nuclear materials to ensure that they are used only for their intended peaceful purposes

3. Advises governments on atomic energy programs, awards fellowships for advanced study, arranges equipment loans, finances research, and acts as an intermediary in arranging supply of nuclear materials

4. Advises Member States on the physical protection of nuclear materials

5. Provides technical assistance of varying kinds to developing countries in the peaceful uses of atomic energy

6. Maintains international data bases and libraries on various aspects of use of nuclear energy

B. In radioactive waste management, the overall objective of the IAEA is to assist its Member States in protecting man and his ervironment from hazards arising from radioactive wastes and effluents; the three main elements of the IAEA waste management program are to (Lakey 1990):

1. Provide technical assistance to developing Member States, primarily through the Radioactive Waste Management Advisory Programme (WAMAP)

2. Coordinate common-interest activities with developed Member States

3. Transfer information from developed to developing Member States

\subsection{ORGANIZATION}

A. Spent fuel and waste management programs are handled by the agency's Nuclear Fuel Cycle Division, with the help of technical specialists loaned by panticipating countries 
B. A committee, known as the International Radioactive Waste Management Advisory Committee (INWAC), was formed in 1989 to assist the Agency in planning its waste management program (Lakey 1990)

1. The function of INWAC is to advise the Director General on all matters related to the management and disposal of radioactive wastes

2. The INWAC is composed of experts from 18 Member States representing both developed and developing countries

3. At the first meeting of INWAC in April 1989, one of the major recommendations was that the IAEA estabish a new document series dedicated to the safety aspects of radioactive waste management

\subsection{KEY PERSONNEL}
A. Hans Blix, Director General
B. Boris Semenov, Deputy Director General, Nuclear Energy \& Safety
C. Maurizio Zifferero, Deputy Director General, Research \& Isotopes
D. Jia-Luo Zhu, Director, Nuclear Fuel Cycle and Waste Management Division
E. Donald E. Saire (U.S.), Head, Waste Management Section

1. V. S. Tsyplenkov (USSR), Handling, Treatment, Conditioning and Storage of Radioactive Wastes

2. G. S. Linsley (U.K.), Radiological and Environmental Effects of Waste Disposal

3. M. J. Bell (U.S.), Underground Disposal of Radioactive Wastes

4. D.J. Squires (U.S.), Underground Disposal of Radioactive Wastes

5. P. De (CA), Decontamination and Decommissioning of Nuclear Facilities

6. K. T. Thomas (IN), WAMAP

7. W. Baehr (FRG), Technical Assistance

F. N. Oi, Head, Nuclear Materials and Fuel Cycle Technology Section

1. F. Sokolov (USSR), Spent Fuel Management

\subsection{WASTE MANAGEMENT ACTIVITIES}

\subsection{BUDGET}

A. The IAEA's 1991 budget was U.S. $\$ 178.9$ million (at the exchange rate of 12.7 Austrian schillings to U.S. \$1) (IAEA 9/21/90) 
B. The 1991 budget for radioactive waste management is U.S. $\$ 4.397$ million and for spent fuel management is U.S. $\$ 982,000$ (at the exchange rate of 12.7 Austrian schillings to 1 U.S. dollar) (IAEA 7/90)

\subsection{MAJOR ACTIVITIES}

A. The IAEA sponsors international conferences, symposia, and seminars

B. The IAEA collects and publishes data on the nuclear fuel cycle through its International Nuclear Information System (INIS) and its waste management data base (IAEA 1988); the following information from the IAEA is of particular interest for radioactive waste management

1. The total volume $\left(\mathrm{m}^{3}\right)$ of fuel-cycle wastes arising from the OECD, CMEA, and other states is as follows (IAEA 1989)

\begin{tabular}{lrrr} 
& $\frac{1988}{15,100}$ & 1990 & $\underline{1995}$ \\
Spent Fuel & 17,400 & 19,300 \\
ILW & 3,200 & 3,400 & 3,840 \\
LLW & 23,900 & 26,200 & 28,900 \\
Total & $\underline{328,000}$ & $\underline{366,000}$ & $\underline{404,000}$ \\
\hline 370,200 & 413,000 & 456,040
\end{tabular}

2. At the beginning of 1989 , there were about 430 nuclear power reactors in operation in 26 countries around the world; they produced more than $16 \%$ of the world's electrical energy (Blix 1989)

3. At the beginning of 1989 approximately $61,000 \mathrm{MT}$ of spent fuel (as heavy metals) had been discharged from water-cooled nuclear power reactors worldwide; only about 2,100-2,300 MT were reprocessed and no spent fuel or HLW had been permanently disposed of (Nechaev 1989)

C. The IAEA prepares international safety standards on transportation of nuclear materials

D. The IAEA's radioactive waste management program is composed of five major component areas (IAEA 7/90):

1. Handling, treatment, conditioning and storage of radioactive wastes

2. Radioactive waste disposal

3. Decontamination and decommissioning of nuclear installations

4. Radiological and environnental aspects of waste management

5. Waste management planning and infrastructure

In addition, IAEA has a separate sub-program of sperit fuel management, technology and safely, and other sub-program activities in all parts of the nuclear fuel cycle 
E. The IAEA prepares standards, criteria, codes of practice, guides, and technical reports on all aspects of the use radioactive materials, including a significant effort on radioactive waste management

1. A tist of formal publications on waste management since 1982 is given in Section 4.0

2. In September 1990, the IAEA General Conference adopted a Code of Practice for international transactions involving radioactive wastes (IAEA 9/21/90)

a. The purpose of the code is to establist a set of principles to protect developing countries from unauthorized dumping of radioactive materials (NEI 10/90)

b. The code will serve as the criteria for trans-boundary movement of radioactive wastes (NWB 6/90)

c. The IAEA reported that, as of 1989, no case of radioactive waste dumping had been found (IAEA 1989)

F. The IAEA conducts coordinated research programs (CRPs), which typically last about five years; following are the current CRPs in radioactive waste and spent fuel management

1. Performance of HLW forms and packages under repository conditions (through 1995)

2. Migration and biological transfer of radionuclides from shallow-land burial

3. Decontamination and decommissioning technology (1989-1993)

4. Influence of radiation on structural materials in the back end of the nuclear fuel cycle (1990-1994)

5. Use of inorganic sorbents for liquid radioactive waste treatment and backfill for underground repositories (through 1992)

6. Treatment technologies for low-and intermediate-level wastes generated from nuclear applications (1991-1995)

7. Validation of models of radionuclide transfer in terrestrial, urban and aquatic environments NAMP - Validation of Model Prediction, jointly with CEC) (through 1992)

8. Behavior of spent fuel and storage-facility components during long-term storage (BEFAST-II, 1987-1991)

9. The performance of engineered barrier materials in shallow-ground disposat systems (1991-1995)

10. Safety assessment of near-surface radioactive waste repositories (1990-1993) 
11. Sources of radioactivity in the marine environment and their relative contributions to overall dose assessment from marine radioactivity (1990-1992)

G. The IAEA has formalized its peer-review process on radioactive waste management programs; the program is known as the Waste Management Assessment and Technical Review Program (WATRP) (NWN 11/23/89)

1. Member States can request international peer reviews on technical, safety, operational, or performance aspects of their programs from the WATRP

2. Member States can also request international evaluations of national waste management policies, concepts, or program activities

3. Two to three reviews are expected to be carried out annually to requesting Member States (IAEA 7/90)

$\mathrm{H}$. The IAEA is continuing its work on the implementation of the 1988 international consensus on Exemption Principles developed jointly by the IAEA and the Nuclear Energy Agency (NEA) (Lakey 1990)

1. Current projects include application of the Exemption Principles to the recycle of slightly contaminated materials and to the waste arisings from the use of radioisotopes in hospitals and research establishments (Linsley 1989)

2. Future work will define exempt quantities for the marine environment, i.e., what level of radioactive waste may be considered non-radioactive for sea-dumping purposes

I. A Waste Management Database is being developed (Lakey 1990)

1. When completed, the database will give a waste management profile of each Member State; as of the end of 1989, 41 questionnaires had been returned, and letters expressing interest in participating had been received from many other Member States

2. The database will contain information on inventories of wastes, processing of wastes, spent sealed sources, spent fuel designated as the final waste form, and waste arisings from decommissioning activities

3. The first product from the database program, scheduled for early 1991 , will be a document on the status and trends of waste management

J. A spent fuel database is being developed; the database will include spent fuel inventories, projections, and characteristics (completed in 1992), and periodic publication of selected data, with the first issue in 1993 (IAEA 7/90)

K. In 1991, the IAEA is starting development of a new group of safety-series standards documents solely on radioactive waste management; the series is entitled RADioactive WAste Safety Standards (RADWASS); the documents are expected to (NWB 6/90):

1. Achieve greater visibility and status for safety-related documents on radioactive waste management 
2. Provide the opportunity for a coherent and well-defined structure for waste management safety documents

3. Increase international cooperation in approaches to radioactive waste management

L. As part of the IAEA's nuclear spent fuel sub-program, it started preparing a series of international safety standards for the long-term storage of spent fuel in 1991 (IAEA 7/90)

M. The IAEA provides technical assistance to developing countries as follows (IAEA 7/90):

1. Technical, material, and financial assistance to qualifying waste management research and demonstration projects of developing countries (Zhu 1989)

2. The Waste Management Advisory Program (WAMAP); started in 1987, this program provides assistance from technical experts in formulating waste management concepts and programs

a. The WAMAP is developing four technical manuals for waste treatment and conditioning for small users of radioactive materials, to be completed in 1991 and 1992; and for handling, conditioning, and disposal of spent radiation sources

b. The WAMAP is developing a guidebook on legislation for the management of medical, research and industrial radioactive wastes

c. The WAMAP will prepare a training course for senior national officials with responsibility for waste management, and another course for senior national . regulatory personnel in waste management

d. During 1989 seven WAMAP missions were undertaken to developing Member States in the regions of Africa, Asia, the Middle East, Latin America, and Europe; these missions pointed out the need for developing Member States to improve their waste management infrastructures, processing, and disposal of radioactive wastes (Lakey 1990); as of July 1990 five to six missions are planned annualiy

3. The IAEA coordinates one to two advisory missions per year on safety assessment methodologies for radioactive waste management

4. The IAEA carries out analytical radiological quality assurance service to Member States worldwide (60 to 100 laboratories per year)

5. The IAEA provides in-service training (2 to 3 trainees per year) in radionuclide measurements and radiotracer experiments

6. The IAEA provides sediment transport training (through 2 to 3 fellowships per year) in States with regional cooperative agreements 
N. The IAEA continues to develop its definition and recommendation on marine disposal of radioactive wastes. This includes also the following activities on a continuing basis:

1. Assessment of radionuclide transfer through marine food chains

2. Participation in international cooperative programs on marine cycling and fate of radionuclides

3. Participation in international working group reports on marine pollution, in cooperation with UN-GESAMP (United Nations Joint Group of Experts on the Scientific Aspects of Marine Pollution)

O. The IAEA established an office at Gomel, in Byelorussia (about $100 \mathrm{~km}$ northeast of Chernobyl), to coordinate an international project to assess outlying contamination from the April 1986 Chernobyl nuclear power reactor accident (NN 6/90)

P. The IAEA organized a major project to reassess the conflicting findings on the causes, health and environmental effects, and precautions against a repetition of the Chernobyl accident (NW 5/10/90)

Q. In a cooperative program, the USSR and the IAEA have established an international research center at the site of the 1986 Chernobyl accident; a series of collaborative projects on the altereffects of the accident is being defined (NWN 11/22/90)

1. The Chernobyl Center was established under an agreement signed September 21, 1990 , at the IAEA headquarters in Vienna

2. The agreement defines the facilities and services to be provided by the USSR, Byelorussian SSR, and the Ukrainian SSR, and defines the IAEA's role in the development and coordination of research and dissemination of the results

3. Projects under negotiation include development of decontamination techniques suitable for large areas; the movement of radionuclides, their uptake in vegetation, and effects on plant biology; and consolidation of a shared database on the health of populations living and working in the Chernobyl area

R. A new IAEA service is planned to assist developing Member States with the handing, processing, and storage of low- and intermediate-fevel radioactive wastes; a reference design package of a centralized Waste Processing and Storage Facility (WPSF) is planned to be available by the end of 1990 (NWB 6/90)

\subsection{FORMAL REPORTS AND DOCUMENTS PLANNED FOR FUTURE PUBLICATION (includes} some less formal documents in the "Tec-Doc" series)

A. RADioactive WAste Safety Standards (RADWASS) reports planned to be issued through 1995 (IAEA 1990; IAEA 7/90)

1. Safety Fundamentals

a. Principles for Radioactive Waste Management (1994) 


\section{Safety Standards and Guides}

a. Standard No. 1, Establishing a National Radioactive Waste Management System (1995)

b. Guide No. 1.1, Classification of Radioactive Wastes (1995)

c. Standard No. 2, Pre-disposal Management of Radioactive Waste (1995)

d. Guide No. 2.1, Collection and Treatment of Low- and Intermediate Level Waste at Nuclear Facilities (1995)

e. Standard No. 3, Near-Surface Disposal of Radioactive Waste (1994)

f. Guide No. 3.1, Siting of Near-Surface Disposal Facilities (1993)

g. Standard No. 4, Geologic Disposal of Radioactive Wastes (post-1994)

h. Guide No. 4.1, Siting of Geological Disposal Facilities (1993)

i. Standard No. 5, Management of Wastes from Mining and Milling of Ores Containing Uranium and Thorium (post-1994)

j. Standard No. 6, Decommissioning of Facilities (1995)

B. General informational reports on radioactive waste management (IAEA 7/90)

1. Development, testing and evaluation of a waste management database (1991)

2. Development of database of waste management safety assessment computer codes (1993)

3. Waste management glossary (1991 updated version of glossary issued in 1988)

4. Waste management status report (updated annually)

5. Waste management research abstracts (1992)

6. Classifying radioactive wastes (1992)

7. Assessment and comparison of waste management system costs for nuclear and other energy systems (1992)

C. Handling, treatment and conditioning of radioactive wastes (IAEA 7/90)

1. Technical reports and documents

a. Volume-reduction technologies for solid radioactive wastes (1992)

b. Chemical treatment of low- and intermediate-level radioactive wastes (1990) 
c. Containers and packages for low- and intermediate-level radioactive waste (t991)

d. Handling and retention of airborne radionuclides at nuclear power plants during abnormal operations (1990)

e. Technical concepts for conditioning of spent fuel for final waste disposal (1991)

f. Retention, conditioning and disposal of carbon-14 (1992)

g. Onsite treatment of large volumes of liquid wastes generated at nuclear facilities as a result of major accidents (1991)

h. Technical and procedural options for minimization of radioactive wastes generated in the nuclear fuel cycle (1992)

i. Administrative prevention and control methods for minimization of radicactive wastes generated in the nuclear fuel cycle (1993)

k. Guidebook on quality control, waste acceptance criteria and compliance requirements for production of high-fevel waste packages (1994)

I. Advanced technologies for the treatment of low- and intermediate-level radioactive wastes (1994)

m. In-situ solidification of low- and intermediate-fevel radioactive wastes (1993)

n. Guidebook on acceptance testing requirements for high-level waste forms and packages (1992)

o. Status of mixed oxide (MOX) fuel utilization and plutonium arisings (1992)

2. Safety-series reports (other than RADWASS reponts)

a. Handling of radioactive waste generated during unplanned events or accident situations (1991)

D. Radioactive waste disposal

1. Technical reports and documents

a. In-situ experiments for the disposal of radioactive waste in deep geological formations (future)

b. Considerations for disposing of chemically hazardous radioactive wastes (1990)

c. Guidelines and recommendations relating to the safety assessment of the environmental impact of radioactive and mixed wastes from the nuclear fuel cycle (1991) 
d. Assessment of the radiological impact of the disposal of wastes from radioisotope use in medicine, research and industry (1991)

e. The comparative assessment of available options for low-level radioactive waste disposal (1992)

f. Manual on the siting of low-level radioactive waste disposal facilities (1993)

g. Manual on the design of low-level radioactive waste disposal facilities (1994)

h. Consideration of the technical, economic and safety factors in evaluating conditioned spent fuels as a final waste form (1990)

i. Quality assurance requirements for siting, design, construction and operation of radioactive waste disposal facilities (1994)

j. Adequacy of transport regulations for radioactive waste disposal (1993)

k. The methodology for selecting, siting and characterizing a deep geological repository for disposal of high-level radioactive waste (1993)

I. Criteria for outlining the hydrogeological data required to determine site suitability of a deep geological repository for high-level radioactive wastes (1994)

m. Perlormance of engineered barriers in deep geołogical repositories (1992)

n. The scientific basis of the time period to be considered in waste repository safety assessment (1992)

o. Improved safety criteria for waste repositories (1993)

2. Safety-series reports (other then RADWASS reports)

a. Four reports on codes of practice and guides on regulation of underground disposal, including shallow ground, rock cavities, and deep geological formations (1990-1993)

E. Decommissioning of nuclear facilities

1. Technical reports and documents

a. Guidebook on policy, regulation and planning for decommissioning large nuclear facilities (1992)

b. Development of decontamination technology (1991)

c. Rernote-system technology in decommissioning and rehabilitation of nuclear facilities (1990)

d. Equipment and techniques to comply with criteria for decommissioning termination surveys (1992) 
e. Guidebook on project planning and management for the decommissioning for small and large nuclear facilities (1992)

f. Safe transpon, disposal, and stabilization of very large volumes of contaminated material from the cleanup of large areas after a nuclear accident (1991)

g. Assessing the rehabilitation, decommissioning, and disposal alternatives for a nuclear reactor after a serious accident (1992)

2. Safety-series report (other than RADWASS reports)

a. Safety guide on criteria for unrestricted releases of materials, facilities or sites from decommissioning (1992)

b. Three reports: near-field effects on post-accident entombment for damaged nuclear facilities, safety and performance assessment, and optimization of post-accident sealing technology (1991)

F. Management of mining and milling wastes and sites

1. Technical reports and documents

a. Developments in modeling and assessment of new tailings technologies (1991)

b. Review of factors relevant to the decommissioning of mine and mill facilities, mines, and sites, and managing of wastes from such operations (1992)

G. Spent-fuel management

1. Technical reports and documents

a. Improvement of storage capacities taking into account fuel with extended burnup and burnable poisons (1993)

b. Remote technology in the back end of the nuclear fuel cycle: status and prospects (1992)

c. Handbook on design, technology and operational experience of spent fuel storage facilities (1993)

d. Impact of extended burnup on back-end activities: storage, transport, treatment (1993)

e. Spent fuel management: current status and prospects (biennial 1992)

f. Strategies, options and trends in spent fuet management, with emphasis on safety, economics and environmental impact (1993) 
g. Establishment of database on spent fuel inventories, projections and characteristics (1992) and periodic publication of selected data (first issue 1993)

h. World survey of spent fuel treatment and plutonium utilization and emerging problems in this area (1992)

i. Economics of $U$ and PU recycling (1993)

j. Economics of the back end of the nuclear fuel cycle (1993)

2. Safety-series reports (other than RADWASS reports)

a. Development of a set of safety-series documents for safe long-term storage of spent fuel (spent fuel storage safety series, 1994)

H. Environmental evaluations related to radioactive waste management

1. Technical reports and documents

a. Generic exempt quantities for application to terrestrial waste disposal and recycle (1993)

b. Acceptance levels for soil following decontamination operations (1994)

c. Principles for exclusion of radiation sources from regulatory control (1993)

d. Derivation of exempt quantities for marine disposal (1992)

e. Revision of Agency's Definition and Recommendations on Marine Disposal (1992)

f. Development of database on inputs of radionuclides to the marine environment - technical document (1992)

g. The evaluation of source upper bounds for marine disposal (1993)

h. Role of the Agency in the control of discharges to freshwater and coastal marine environments (1992)

i. A series of 4 to 6 technical documents (resulting from VAMP CRP) on modeling in the terrestrial and aquatic environment and on multiple pathways (jointly with CEC) (1991-1992)

j. Technical report on radionuclide transfer data in tropical and semitropical environments (jointly with International Union of Radioecologists) ( $\$ 993$ )

k. Environmental safety aspects of the storage and transportation of extracted fissile materials (1990) 
2. Safety-series reports (other than RADWASS reports)

a. Assessment methods for use in deriving exempt quantities of radioactive waste for disposal in the marine environment (1989)

b. Technical procedures for compliance with radiation-protection regulations for control of radionuclide discharges to fresh-water systems and coastal waters (1992)

3. Review of IAEA'S definition and recommendations on radioactive matters in connection with the London Dumping Convention (1990)

\subsection{COOPERATION WITH OTHER AGENCIES}
A. The IAEA cooperates with all other United Nations organizations
B. The IAEA has cooperative agreements with OECD/NEA, EURATOM, and CMEA

\subsection{U.S. PARTICIPATION}

The U.S. cooperates with the IAEA and provides support to all aspects of the waste management program by:
A. Participating in advisory and technical committees, conferences, symposia, and seminars
B. Providing.consultants for special studies and preparation of documents
C. Providing technical assistance to developing countries
D. Providing U.S. technical staff on temporary and long-term assignments with the IAEA

\subsection{BIBLIOGRAPHY}

The foliowing is a list of formal IAEA publications on waste management since 1982. Further information on the following reports can be obtained from D.E. Saire, Waste Management Section, Division of Nuclear Fuel Cycle, International Atomic Energy Agency, P.O. Box 100, A-1400 Vienna, Austria [Tel. 43 (1) 2360 2674; Tlx: 112645; Fax 43 (1) 234 564].

$-1982-$

Technical Report Series No. 218, Storage of Water Reactor Spent Fuel in Water Pools: Survey of World Experience, International Atomic Energy Agency, Vienna.

Technical Report Series No. 220, Control of Semi-volatile Radionuclides in Gaseous Effluents at Nuclear Facilities, International Atomic Energy Agency, Vienna. 
-1983-

Safety Series No. 58, Concepts and Examples of Safety Analyses for Radioactive Waste Repositories in Continental Geologic Formations, International Atomic Energy Agency, Vienna.

Safety Series No. 59, Disposal of Low- and Intermediate-Level Solid Radioactive Wastes in Rock Cavities: A Guidebook, International Atomic Energy Agency, Vienna.

Safety Series No. 60, Criteria for Underground Disposal of Solid Radioactive Wastes, International Atomic Energy Agency, Vienna.

Safety Series No. 61, Control of Radioactive Waste Disposal into the Marine Environment, International Atomic Energy Agency, Vienna.

Technical Report Series No. 222, Conditioning of Low and Intermediate-Level Radioactive Wastes, international Atomic Energy Agency, Vienna.

Technical Report Series No. 223, Treatment of Low- and Intermediate-Level Solid Radioactive Wastes, international Atomic Energy Agency, Vienna.

Technical Feport Series No. 229, Handling and Storage of Conditioned High-Level Wastes, international Atornic Energy Agency, Vienna.

Technical Feport Series No. 230, Decommissioning of Nuclear Facilities: Decontarnination, Disassembly and Waste Management, International Atornic Energy Agency, Vienna.

Technical Feport Series No. 232, Disposal of Radioactive Grouts into Hydraulically Fractured Shale, Internationa! Atornic Energy Agency, Vienna.

$-1984-$

Safety Series No. 62, Site Investigations, Design, Constiuction, Operation, Shut-Down and Surveillance of Repositories for Fadioactive Waste in Rock Cavities, International Atomic Energy Agency, Vienna.

Safety Series No. 63, Design, Construction, Operation, Shut-Down and Surveillance of Repositories for Solid Fadioactive Waste in Shallow Ground, International Atomic Energy Agency, Vienna

Safety Series No. 64, Safety Analysis Methodology for Radioactive Waste Repositories in Shallow Ground, International Atomic Energy Agency, Vienna.

Safety Series No. 65, Environmental Assessment Methodologies for Sea Dumping of Radioactive Wastes, international Atomic Energy Agency, Vienna.

Safety Series No. 66, Oceanographic and Radiological Basis for the Definition of High-Level Wastes Unsuitable for Dumping at Sea, International Atomic Energy Agency, Vienna.

Technical Report Series No. 234, Management of Tritium at Nuclear Facilities, International Atomic Energy Agency, Vienna.

Technical Report Series No. 236, Treatment of Low-and Intermediate-Level Liquid Radioactive Wastes, International Atornic Energy Agency, Vienna. 
Technical Feport Series No. 240, Guidebook on Spent Fuel Storage, International Atomic Energy Agency, Vienna.

Technical Report Series No. 243, Testing and Monitoring of Off-Gas Clean-Up Systems at Nuclear Facilities, International Atomic Energy Agency, Vienna.

$-1985-$

Safety Series No. 6, Regulations for the Safe Transport of Radioactive Material, 1985 Edition, International Atomic Energy Agency, Vienna.

Safety Series No. 68, Performance Assessment for Underground Radioactive Waste Disposat Systems, International Atomic Energy Agency, Vienna.

Safety Series No, 69, Management of Radioactive Waste from Nuclear Power Plants - Code of Practice, International Atomic Energy Agency, Vienna.

Safety Series No. 70, Management of Radioactive Wastes Produced by Users of Radioactive Materials, International Atomic Energy Agency, Vienna.

Safety Series No. 71, Acceptance Criteria for Disposal of Radioactive Wastes in Shallow Ground and Rock Cavities, International Atomic Energy Agency, Vienna.

Technical Report No. 247, Sediment Ko's and Concentration Factors for Radionuclides in the Marine Environment, international Atomic Energy Agency, Vienna.

Technical Report Series No. 249, Modification or Plant Decommissioning, Decontamination of Nuclear Facilitics to Permit Operation, Inspection, Maintenance, International Atomic Energy Agency, Vienna.

Technical Report No. 250. The Radiological Impact of Radionuclides Dispersed on a Regional and Global Scale: Methods for Assessment and their Applicetion, International Atomic Energy Agency, Vienna.

Technical Repon Series No. 251, Deep Underground Disposal of Radioactive Waste: Near Fieid Effects, International Atomic Energy Agency, Vienna.

Technical Report Series No. 253, Operational Experience in Shallow Ground Disposal of Radioactive Wastes, International Atomic Energy Agency, Vienna.

Technical Report Series No. 254, Treatment of Spent ton-Exchange Resins for Storage and Disposal. International Atomic Energy Agency, Vienna.

Technical Report Series No. 256, Techniques for Site Investigation tor Underground Disposal of Radioactive Wastes, International Atomic Energy Agency, Vienna.

Technical Report Series No. 257, Chemical Durability and Related Properlies of Solidified High-Leve! Waste Forms, International Atomic Energy Agency, Vienna.

Technical Report Series No. 258, Management of Cladding Hulls and Fuel Hardware, International Atomic Energy Agency, Vienna. 
$-1986-$

Safety Series No. 6. Regulations for the Safe Transport of Radioactive Material, 1985 Edition, Supplement 1986, International Atomic Energy Agency, Vienna.

Safety Report Series No. 74, IAEA Safety Guides, Safety in Decommissioning of Research Reactors, International Atomic Energy Agency, Vienna.

Safety Series Report No. 77, Principles for Limiting Releases of Radioactive Effluents into the Environment, IAEA Safety Guides, International Atomic Energy Agency, Vienna.

Safety Report Series No. 78, Definition and Recommendations for the Convention on the Dumping of Wastes and Other Matter, 1972, IAEA Safety Standards, 1986 Edition, international Atomic Energy Agency, Vienna.

Safety Report Series No. 79, Design of Radioactive Waste Management Systems at Nuclear Power Plants, IAEA Safety Guides, International Atomic Energy Agency, Vienna.

Safety Report Series No. 80, Schedule of Requirements for the Transport of Specified Types of Radioactive Material Consignments, IAEA Safety Guides, (Companion Document to Safety Series No. 6), International Atomic Energy Agency, Vienna.

Technical Report Series No. 263, An Oceanographic Model for the Dispersion of Wastes Disposed of in the Deep Sea, International Atomic Energy Agency, Vienna.

Technical Report Series No. 267, Methodology and Technology of Decommissioning Nuclear Facilities, International Atomic Energy Agency, Vienna.

$-1987-$

Safety Report Series No. 85, Code of Practice and Guide to the Code, Safe Management of Wastes from the Mining and Milling of Uranium and Thorium Ores, International Atomic Energy Agency, Vienna.

Technical Report Series No. 272, Techniques and Practices for Pretreatment of Low and Intermediate Level Solid and Liquid Radioactive Wastes, International Atomic Energy Agency, Vienna.

Technical Report Series No. 276, Conditioning and Disposal of lodine-129 Treatment, International Atomic Energy Agency, Vienna.

$-1988-$

Technical Report Series No. 286, Decontamination and Demolition of Concrete and Metal Structures During the Decommissioning of Nuclear Facilities, International Atomic Energy Agency, Vienna.

Technical Report Series No. 287, Treatment of Alpha Bearing Wastes, International Atomic Energy Agency, Vienna.

Technical Report Series No. 288, Accessing the Impact of Deep Sea Disposal of Low Level Radioactive Waste on Living Marine Resources, International Atomic Energy Agency, Vienna. 
Technical Report Series No. 289, Immobilization of Low and Intermediate Level Radioactive Wastes with Polymers, international Atomic Energy Agency, Vienna.

Technical Report Series No. 290, Survey of Experience with Dry Srorage of Spent Nuclear Fuel and Update of Wet Storage Experience, International Atomic Energy Agency, Vienna.

Technical Report Series No. 291, Design and Operation of Off-Gas: Clearing Systems at High Level Liquid Waste Conditioning Facility, International Atomic Energy Agency, Vienna.

Technical Report Series No, 292, Design and Operation of Off-Gas Cleaning and Ventilation Systems in Facilities Handling Low and Intermediate Level Radioactive Material, International Atomic Energy Agency, Vienna.

$-1989-$

Legal Report Series No. 15, Bilateral, Regional, and Multilateral Agreements Relating to Cooperation in the Field of Nuclear Safety, International Atomic Energy Agency, Vienna.

Safety Report Series No. 89, Principles for the Exemption of Radiation Sources and Practices from Regulatory Control, International Atomic Energy Agency, Vienna.

Safety Report Series No. 92, Principles for the Establishment of Upper Bounds to Doses to Individuals from Global and Regional Sources, International Atomic Energy Agency, Vienna,

Safety Report Series No. 96, Guidance for Regulation of Underground Repositories for Disposal of Radioactive Wastes, International Atomic Energy Agency, Vienna.

Safety Report Series No. 99, Safery Principles and Technical Criteria for the Uniderground Disposal of High-Level Radioactive Wastes, International Atomic Energy Agency, Vienna.

Safety Report Series No. 100, Evaluating the Reliability of Predictions Made Using Environmental Transfer Models, International Atomic Energy Agency, Vienna.

Technical Report Series No. 294, Options for the Treatment and Solidification of Organic Radioactive Wastes, International Atomic Energy Agency, Vienna.

Technical Report Series No. 300, Cleanup of Large Areas Contaminated As a Result of a Nuclear Accident, International Atomic Energy Agency, Vienna.

Technical Report Series No. 302, Treatment of Off-Gas from Radioactive Waste Incinerators, International Atomic Energy Agency, Vienna.

Technical Report Series No. 304, Natural Analogues in Performance Assessments for the Disposal of Long-Lived Radioactive Wastes, International Atomic Energy Agency, Vienna.

Technical Report Series No. 307, Management of Abnormal Radioactive Wastes at Nuclear Power Plants, International Atomic Energy Agency, Vienna.

Technical Report Series No. 308, Feasibility of Separation and Utilization of Ruthenium, Rhodium, and Pailadium from High-Level Wastes, International Atomic Energy Agency, Vienna. 
Proceedings Report Series, Management of Low-and Intermediate-Level Radioactive Wastes, (IAEA-CEC Symposium, Stockholm, 1988), International Atomic Energy Agency, Vienna.

\section{Planned - 1990 and later}

RADWASS Safety Guide, The Regulatory Process in the Decommissioning of Nuclear Facilities, International Atomic Energy Agency, Vienna, Austria, 1991.

RADWASS Safety Guide, Design and Operation of Radioactive Waste Incineration Facilities, International Atomic Energy Agency, Vienna, Austria, 1991.

RADWASS Safety Guide, Operation, Shutdown, and Closing of Deep Geological Repositories, International Atomic Energy Agency, Vienna, Austria, 1992.

RADWASS Safety Guide, Performance and Safety Assessment of Radioactive Waste Repositories, International Atomic Energy Agency, Vienna, Austria, 1992.

RADWASS Safety Guide, Criteria for Unrestricted Release of Materials, Facility or Site from Decommissioning, International Atomic Energy Agency, Vienna, Austria, 1992.

RADWASS Safety Guide, Siting, Design, and Construction of a Deep Geological Repository for Disposal of High-Level and Alpha-Bearing Wastes, International Atomic Energy Agency, Vienna, Austria, 1991.

RADWASS Safety Practices, Application of Exemption Principles to the Recycle and Reuse of Materials from the Nuclear Fuel Cycle, International Atomic Energy Agency, Vienna, Austria, 1991.

RADWASS Safety Practices, Application of Exemption Principles to Wastes Arising from Radioisotope Uses in Hospitals and Research Establisthments, International Atomic Energy Agency, Vienna, Austria, 1991.

RADWASS Safety Practices, Application of Exemption Principles to the Marine Disposal of Radioactive Wastes, International Atomic Energy Agency, Vienna, Austria, 1993.

\subsection{REFERENCES}

$-1989-$

Blix, H., 1989. 'Nuclear Power in the World: Results and Current Issues." in Good Performance in Nuclear Projects, Proceedings of an International Symposium, Tokyo, Japan, Aprit 1989.

IAEA Yearbook 1989 (IAEA). 1989. International Atomic Energy Agency, Vienna, Austria.

Linsley, G. S. 1989. International Principles for Exemption from Regulatory Control and Their Application to Waste Management.' Presented at Waste Management '89, February 26-March 2, 1989, Tucson, Arizona.

Nechaev, A. F. and J. L. Rojas. 1989. "Comparative Statistics of Spent Fuel Storage Options," in Proceedings of the 1989 Joint International Waste Conference on High Level Radioactive Waste and Spent Fuel Management, October 22-28, 1989, Kyoto, Japan, Vol. 2, p. 433. 
Nuclear Waste News (NWN). 11/23/89. "News Briefs - International Peer Reviews," p. 435.

Zhu, J. L., D. E. Saire, and K. T. Thomas. 1989. "IAEA Technical Assistance to Developing Countries with Particular Reference to Radioactive Waste Management," in Proceedings of the 1989 Joint International Waste Conference on High Level Radioactive Waste and Spent Fuel Management, October 22-28, 1989, Kyoto, Japan, Vol. 1, p. 649.

$-1990-$

The Agency's Programme and Budget for 1991 and 1992 (IAEA). July 1990, International Atomic Energy Agency, Vienna, Austria.

Lakey, L. T. 1990. Presentation by IAEA Representative. Foreign Trip Report, "Travel to Paris, France and Attendance at the OECD/Nuclear Energy Agency's Radioactive Waste Management Committee (RWMC) Meeting," Pacific Northwest Laboratory, January 1990.

Nuclear Engineering International (NEI). 10/90. "Draft Code Aims to Prevent Dumping," p. 6.

International Atomic Energy Agency (IAEA). 1990. The Radioactive Waste Safety Standards (RADWASS) Programme. August 23, 1990.

IAEA Bulletin (IAEA). 1/90. "Waste Management Advisory Missions," p. 62.

IAEA Press Release (IAEA). September 21, 1990. "IAEA Budget and Extrabudgetary Resources for 1991." P. 2.

Nuclear News (NN), 6/90. "The IAEA Will Establish an Office near Chernobyl." p. ${ }^{1} 57$.

Nuclear Waste Bulletin (NWB). 6/90. OECD Nuclear Energy Agency, Paris, France.

Nuclear Waste News (NWN). 11/22/90. "USSR Sets Up Chernobyl Research Center; IAEA Completes Radiological Study," p. 455.

Nucleonics Week (NW). 5/10/90. "International Team Will Reassess Data on Chernoby! Health Effects,' p. 3. 

NEA 


\section{OECD NUCLEAR ENERGY AGENCY (NEA)}

\begin{tabular}{|c|c|c|}
\hline \multicolumn{3}{|c|}{ CONTENTS } \\
\hline 1.0 & INSTIUTIONAL CONSIDERATIONS/ORGANIZATIONS & NEA.2 \\
\hline 2,0 & WASTE MANAGEMENT ACTIVITIES & NEA.4 \\
\hline 3.0 & U.S. PARTICIPATION & NEA.8 \\
\hline 4.0 & BIBUOGRAPHY & NEA.9 \\
\hline 5.0 & REFERENCES & NEA.11 \\
\hline
\end{tabular}




\subsection{INSTITUTIONAL CONSIDERATIONS/ORGANIZATIONS}

\subsection{MEMBER STATES (Leigh and Mitchell 1990)}

A. The following countries are members of the Nuclear Energy Agency (NEA): Australia, Austria, Belgium, Canada, Denmark, Finland, France, Germany, Greece, Iceland, Ireland, Italy, Japan, Luxembourg, Netherlands, Norway, Portugal, Spain, Sweden, Switzeriand, Turkey, United Kingdom, United States

B. The political opening of the Eastern European countries and the continued rapid economic expansion of the Southeast Asian area have led to increasing contacts with these countries; it is possible that these developments will lead to applications for membership in OECD/NEA (NWB 6/90)

\subsection{BASIC CHARTER/PURPOSE}

A. The overall objectives of the OECD (Organization for Economic Cooperation and Development) are:

1. To achieve highest economic growth and employment and to contribute to development of the world economy

2. To contribute to sound economic expansion in OECD and developing countries

3. To contribute to expansion of world trade

B. The overall objectives of the NEA, which is a directorate in the OECD, are:

1. To encourage harmonization of governments' regulatory policies and practices, particularly on nuclear safety, radiation protection, waste management, and third-party liability and insurance in the nuclear field

2. To keep under review the nuclear power development, demand, and supply in the nuclear fuel cycle

3. To develop information exchanges on the NEf,'s topics of interest (in items $\mathbf{1}$ and 2, above)

4. To set up international $\mathrm{R} \& \mathrm{D}$ programs in topics of interest (in items 1 and 2, above)

\subsection{HISTORY}

A. The European Nuclear Energy Agency (ENEA) was established in 1958 by the Organization for European Economic Cooperation (OEEC); its objectives were to: establish joint projects in nuclear energy, solve specific legal problems on nuclear energy, and provide a forum for exchange of nuclear-energy information

1. Early ENEA activities included joint projects, such as the Eurochemic Fuel Reprocessing Plant at Mol, Belgium

2. The OEEC evolved into the OECD in 1960 

B. The ENEA was renamed the Nuclear Energy Agency (NEA) in 1972
C. The United States joined the OECD in 1960 and the NEA in 1976

\subsection{ORGANIZATION}

A. The OECD council is the primary authority for all its directorates; for the NEA:

1. General guidance is provided by an OECD steering committee for nuclear energy made up of representatives from each member state, the CEC, and the IAEA

2. The OECD steering committee is assisted by subordinate committees and working groups of specialists appointed by member states

3. Work is coordinated by a small NEA secretariat

B. Radioactive waste management activities are handled primarily through the Nuclear Safety Division and the Radiation Protection and Waste Management Division (six pro. fessionals) under the guidance of several standing committees (Leigh and Mitchell 1990)

\section{Radioactive Waste Management Committee (RWMC)}

1. The RWMC is composed of senior national government experts and responsible administrators

2. The RWMC meets once or twice each year to review developments in member states and to plan and adjust its programs

3. The RWMC has several advisory groups reflecting its program priorities:

a. The Performance Assessment Advisory Group (PAAG) was formed in 1985 to provide a broad forum for discussion of performance-assessment technologies for radioactive waste disposal facilities, and to advise the RWMC on technical aspects of system-performance assessments

b. The Coordinating Group on Site Evaluation and Design of Experiments for Radioactive Waste Disposal (SEDE)

1) The SEDE was established in 1990 after disbanding the Advisory Group on In Situ Research and Investigations for Geological Disposal (ISAG)

2) SEDE's purpose is to place more emphasis on international cooperation on site evaluation and design of experiments (NWB 6/90)

c. The Probabilistic System Assessment Code (PSAC) user group was taken over by the NEA from Canada in 1985; it provides a broad forum for discussion and development of probabilistic system-assessment codes; it reports to the RWMC on the technical aspects of such codes

d. The Joint Technical Committee of the Stripa Project provides oversight of the NEA-coordinated in situ investigations in fractured hard rock at the Stripa Mine in Sweden 
e. The Liaison Committee for Cooperative Program on Decommissioning is concerned with the exchange of scientific and technical information on nuclear decommissioning projects

t. The Joint Technical Committee of the Alligator Pivers Analogue Project oversees research on natural analogues in the Australian uranium ore bodies for the long-term prediction of radionuclide transport

D. The Committee on Radiation Protection and Public Health (CRPPH) oversees the Coordinated Pesearch and Environmental Surveillance Progyram (CRESP); beginning in 1985, the former LLW sea dumping area in the North Atlantic has been monitored every 5 years (see Section 2.2)

E. The Committee for Technical/Economic Studies on Nidclear Energy Development and Fuel Cycle (NDC and FCC) assesses, reviews and evaluates technical and economic implications related to the nuclear fuel cycle (Leigh and Mitchell 1990)

1.5 KEY PERSONNEL (Leigh and Mitchell 1990; NWB 6/90)
A. K. Uematsu, Director General, NEA
B. P. Strohl, Deputy Director General, NEA
C. K. Stadie, Deputy Director, Safety and Regulation, NEA
D. J. -P. Olivier, Head, Division of Padiation Protection ard Waste Management, NEA
E. O. Ilari, Deputy Head, Division of Padiation Protection and Waste Management, NEA (NWB 6/90)
F. J. Rosen, Deputy Director, Science and Information Processing, NEA
G. R. Flowers (U.K.), Chairman of Radioactive Waste Ma agement Committee

\subsection{WASTE MANAGEMENT ACTIVITIES}

\subsection{WASTE MANAGEMENT OBJECTIVES}

The overall NEA objectives in the field of radioactive waste management are to:
A. Promote studies to improve the database available in support of national programs, particularly in the field of waste disposal and long-term safety assessment

B. Support research and development through coordination of national activities and promotion of international projects

C. Improve the general level of understanding of waste-rnanagement issues and options

\subsection{WASTE MANAGEMENT ACTIVITIES ON RADIOLOGICAL ACCEPTABILITY AND PERFORM- ANCE ASSESSMENT OF WASTE DISPOSAL PRACTICES}
A. Past activities were: 
1. Definition of long-term radiation protection objectives and concepts of collective radiation dose

2. Study of long-term management of uranium mill tailings

3. Assessment of radiological suitability of the Northeast Atlantic Site for disposal of LLW according to the London Dumping Convention

4. Shallow-land disposal of radioactive waste; reference levels for the acceptance of long-lived radionuclides

B. Conceptual and mathematical models for radionuclide and groundwater transport in the geosphere and biosphere have been evaluated through several international cooperative projects

1. INTRACOIN dealt with code verification, model validation, and uncertainty analysis for radionuclide transport models (1981-1984)

2. HYDROCOIN dealt with the veritication and validation of codes and models for groundwater movement (1984-1987)

3. INTAAVAL deals with the development and testing of mathematical models of nuclide transport from a repository to the biosphere (1987-continuing) (NEA 1990)

a. The managing participant is the Swedish Nuclear Power Inspectorate (SKI)

b. Data from laboratory experiments, field experiments, and natural analogue studies are input to mathernatical models to validate the underlying conceptual models

c. Phase 1 of the project is about complete; the seventeen test cases studied to date will be documented in 1991

d. Continuation of the project (Phase 2, 1991-1993) is being discussed with participants; emphasis will be on validation based on field studies and natural analogues

C. Geochemical Data Bases (NEA 1989)

1. The Thermochemical Data Base (TDB) was established in 1983 to critically review and publish chemical data for uranium, plutonium, and other key elements in the disposal of nuclear wastes; the status of reports in preparation on $U, T c, N p, P u$, and Am was recently documented (NEA 1989)

2. The Sorption Data Base (SDB) is a system for storing and handling information on transfer of radionuclides from groundwater to geologic materials; the database was modified for use on a microcomputer (NEA 1989)

3. A Geochemical Modeling and Data group was established in 1987 to coordinate and advise on the activities of SDB and TDB

D. Coordinated Research and Environmental Surveillance Program (CRESP) 
1. Term: 1981-1995

2. Purpose: coordinate national efforts to monitor and evaluate the results of sea dumping of LLW in the North Atlantic

3. No sea dumping of LLW has occurred since 1982

4. Starting in 1985 the sea-dump area has been nonitored every 5 years; the 1990 tests showed no significant change from 1985; the area will be sampled again in 1995

E. Coordinated research and development program on sub-seabed disposal (NEA 1988a, NEA 1989)

1. Term: $1977-1987$

2. Purpose: assess safety and feasibility of sub-seabed disposal of long-lived and high-level waste

3. The assessment of technical feasibility and long-term safety of the seabed disposal concept was completed with the publication of an eight-volume series documenting results of the program (NWB 9/89); conclusions on the feasibility of seabed disposal were (NEA 1988a):

a. Sites in both the North Atlantic and North Pacific appear suitable for sub-seabed disposal

b. Both penetrator and drilled emplacemert technologies are technically and economically feasible

c. Disposal of $H L W$ on the ocean floor wolid not be internationally acceptable at this time (NWN 4/20/89)

4. Conclusions from safely assessments of seabed disposal are:

a. The waste packages would survive for a few hundred to a few thousand years after burial; wastes would be slowly released over the next few thousand years

b. The primary sediment barrier would contain most of the radionuclides for thousands of years

c. Radionuclides that escape the sediment into the ocean would give the maximum dose to humans about 100,000 years after burial; the dose would be very small relative to natural background

d. There would be insignificant risk to the deep-sea environment from seabed disposal

e. Further research is needed to reduce uricertainties on a number of engineering aspects and on the migration of radionuclides in the sediments 
F. International STRIPA project (NEA 1989)

1. Term: 1980-1991 (Phase 2 concluded in 1986; Phase 3 is in the concluding phase)

2. Purpose: conduct in situ tests in a fractured granite environment (STRIPA mine in Sweden)

3. Results of Phases 1 and 2 showed that bentonite is a suitable buffer material for use around waste canisters and for backfilling the sealed repository

4. Phase 3 , which began in 1987 , is investigating how groundwater flows in granite

G. Cooperative program for exchange of scientific and technical information concerning nuclear-installation decommissioning projects

1. Term: 1985-1989; this program was recently extended for a second term to 1989-1993 (NWB 6/90)

2. Purpose: share information and experience relating to decommissioning and dismantling of large nuclear facilities

3. $\quad 17$ projects and participants have been proposed for the second 5-year program; 7 projects and 10 participants were included in the first program

4. Projects added in the second 5-year program will include the assessment of new decommissioning techniques for the BR-3 reactor (Belgium), the WAGR reactor (U.K), the KBR reactor at Gundremmingen (FRG), and the AT1 facility at La Hague (France) (NWB 6/90)

5. The 13th edition of the uranium "Red Book", published by the IAEA and NEA, concludes that uranium production should be sufficient to supply the non-Communist world until the year 2005; thereafter increasing amounts of uranium from yet-unknown deposits would be needed (NF 8/6/90)

H. Alligator Rivers Analogue Project (NWN 6/21/90)

1. Term: $1987-1992$

2. Purpose: joint experimental program to study geochemical and hydrogeological processes of interest in performance assessment at the Alligator Rivers Site, Australia

3. Progress to date includes: existing experimental data have been reviewed; data have been assembled for a test to validate the migration model; field work has added new data on hydrology, geochemistry, radioisotope disequilibria, and fission product and plutonium distributions (NEA 1989)

4. Results to date indicate that radionuclides have migrated about $80 \mathrm{~m}$ in the last million years; this is less than predicted 
5. The second phase of the project (1990-1992) work will focus on the hydrogeology of the ore deposit, the movement and chemistry of the groundwater, and interaction between water and rock

\subsection{STATE-OF-THE-ART REVIEWS ON WASTE MANAGEMENT (BROAD POLICY ISSUES)}

A. Overviews of the current status of understanding and development on geologic disposal of radioactive waste have been carried out; these have been:

1. In situ studies on the development of methods and instrumentation for specific sites and the validation of process and performance-assessment models

2. An overview of the purpose and scope of in situ research by OECD member countries was completed in 1988 (NEA 1988bi

B. The legal, administrative, and financial aspects of long-term management of radioactive waste are studied and documented

C. The decommissioning activities in member states are summarized and reported

\subsection{U.S. PARTICIPATION}

\subsection{ACTIVITIES IN WHICH DOE/NRC/EPA PARTICIPATE}

A. Radioactive Waste Management Committee (RWMC)

B. Committee on Radiation Protection and Public Health (CRPPH)

C. Cooperative program on decommissioning

D. Performance assessment studies

1. Performance Assessment Advisory Group (PAAG)

2. HYYROCOIN, project for studying groundwater hydrology modeling

3. INTRAVAL, project for studying validation of geosphere performance assessment modeling

4. Probabilistic Systems Analysis Codes Users Group (PSAC)

5. Altigator Rivers Natural Analogues Project

E. STRIPA project

F. Thermochemical Data Base

G. Coordinated Research and Environmental Surveillance Program for sea disposal (CRESP)

1. The U.S. does not participate but is interested in the data coming from this program 
2. The U.S. believes that an intensive sampling program should be carried out at 5-year intervals

3. The U.S. is interested in participating in a validation exercise of the CRESP models at some time in the future

\subsection{BIBLIOGRAPHY}

The following documents have been published by the OECD Nuclear Energy Agency, Paris.

$-1982-$

Disposal of Radioactive Waste: An Overview of the Principles Involved.

Geological Disposal of Radioactive Waste: Research in the OECD Area.

$-1983-$

Interim Oceanographic Description of the North-east Atlantic Site for the Disposal of Low-level Radioactive Waste.

The International Stripa Project: Background and Research Results.

The Long-term Management of High-level Radioactive Waste: The Meaning of A Demonstration.

$-1984-$

Geological Disposal of Radioactive Waste: An Overview of the Current Status of Understanding and Development. (Joint study of NEA and CEC)

Long-term Management of Radioactive Waste: Legal, Administrative and Financial Aspects.

Long-term Radiation Protection Objectives for Radioactive Waste Disposal.

Long-term Radiological Aspects of Management of Wastes From Uranium Mining and Milling.

Seabed Disposal of High-level Radioactive Waste: A Status Report On the NEA Coordinated Research Programme.

Technical Appraisal of the Situation in the Field of Radioactive Waste Management: a Collective Opinion by the RWMC.

$-1985-$

Compendium on Decommissioning Activities in NEA Member Countries.

Concepts of Collective Dose in Radiological Protection.

The Management of High-Level Radioactive Waste: A Survev of Demonstration Activities. 
Radioactive Waste Disposal - In Situ Experiments In Granite. (Proceedings of NEA/Stripa Project Symposium)

Review of the Continued Suitability of the Dumping Site for Radioaztive Waste in the North-east Atlantic.

-1986 .

Coordinated Research and Environmental Surveillance Programme Related to Sea Disposal of Radioactive Waste. (CRESP Activity Report)

$-1987-$

The International HYDROCOIN Project. Background and Results.

PSACOIN Level O Intercomparison. PSAC User Group.

Shallow Land Disposal of Radioactive Waste, Reference Levels for the Acceptance of Long-lived Radionuclides.

Uncertainty Analysis for Performance Assessments of Radioactive Waste Disposal Svstems.

(Proceedings of the Seattle Workshop)

-1988 .

Geological Disposal of Radioactive Waste. In Situ Research and Investigations In the OECD Countries. Near-field Assessment of Repositories for Low- and Medium-Level Wasie. (Proceedings of the Baden Workshop)

The International HYDROCOIN Project. Level 1 Code Verification.

HYDROCOIN Level 1: Benchmarking and Verification Test Results with CFEST Code.

Feasibility of Disposal of High-Level Radioactive Waste into the Sea.bed, Vols. 1-8.

Excavation Response in Geological Repositories for Radioactive Waste. (Proceedings of an NEA Workshop)

$-1989-$

Safety Assessment of Radioactive Waste Repositories. (Proceedings of an international symposium organized by NEA, IAEA and CEC)

Radioactive Waste Disposal: In Situ Experiments. (Proceedings of the 3rd NEA/SKB Symposium on the International Stripa Project, Stockholm)

Risks Associated with Human Intrusion at Radioactive Waste Disposal Sites. (Proceedings of an NEA Workshop)

Sealing of Radioactive Waste Repositories. (Proceedings of an NEA/CEC Workshop, Braunschweig, F.R. of Germany) 
PSACOIN Level E Imtercomparison.

Excavation Response in Geological Repositories for Radioactive Waste. (Proceedings of an NEA workshop)

Nuclear Energy Data.

Nuclear Energy in Perspective.

Projected Costs of Generating Electricity from Power Stations for Commissioning in the Period 1995-2000.

$-1990-$

Alligator Rivers Analogue Project. First Annual Report 1988-89.

The International INTRAVAL Project. Background and Results.

Nuclear Energy Agency Publications.

\subsection{REFERENCES}

$-1988-$

OECD/Nuclear Energy Agency (NEA). 1988a. Feasibility of Disposal of High-Level Radioactive Waste into the Seabed, Vols. 1-8. OECD Nuclear Energy Agency, Paris, France.

OECD/Nuclear Energy Agency (NEA). 1988b. Geological Disposal of Radioactive Waste. In Situ Research and Investigations in OECD Countries. OECD Nuclear Energy Agency, Paris, France.

$-1989-$

OECD/Nuclear Energy Agency (NEA). 1989. Expert Group on Geochemical Modelling and Data. Summary Record of the Second Meeting 1 18th-19th April 1989. OECD Nuclear Energy Agency, Paris, France, May 31, 1989.

OECD Nuclear Energy Agency (NEA). 1989. "NEA International Cooperative Projects." OECD Nuclear Energy Agency, Paris, France.

Nuclear Waste Bulletin (NWB). September 1989, OECD Nuclear Energy Agency, Paris, France.

Nuclear Waste News (NWN). April 20, 1989. "Seabed Disposal is Safe and Feasible, But Not Internationally Acceptable," p. 137.

$-1990$.

Leigh, I. W., and S. J. Mitchell. 1990. International Nuclear Fuel Cycle Fact Book. PNL-3594 Rev. 10, Pacific Northwest Laboratory, Richland, Washington.

OECD/Nuclear Energy Agency (NEA). 1990. 'The International INTRAVAL Project,' OECD Nuclear Energy Agency, Paris, France. 
Nuclear Waste Bulletin (NWB). June 1990. OECD Nuclear Enercy Agency, Paris, France.

Nuclear Waste News (NWN). June 21, 1990. "Work Extended on Australian Radionuclide Migration Study," p. 248.

Nuclear Fuel (NF) August 6, 1990. 'New Red Book-Says Uraniur Production Sufficient to Cover Demand to $2005, '$ p. 7. 
GLOSSARY 


\section{GLOSSARY}

\section{ORGANIZATIONS AND FACILITIES}

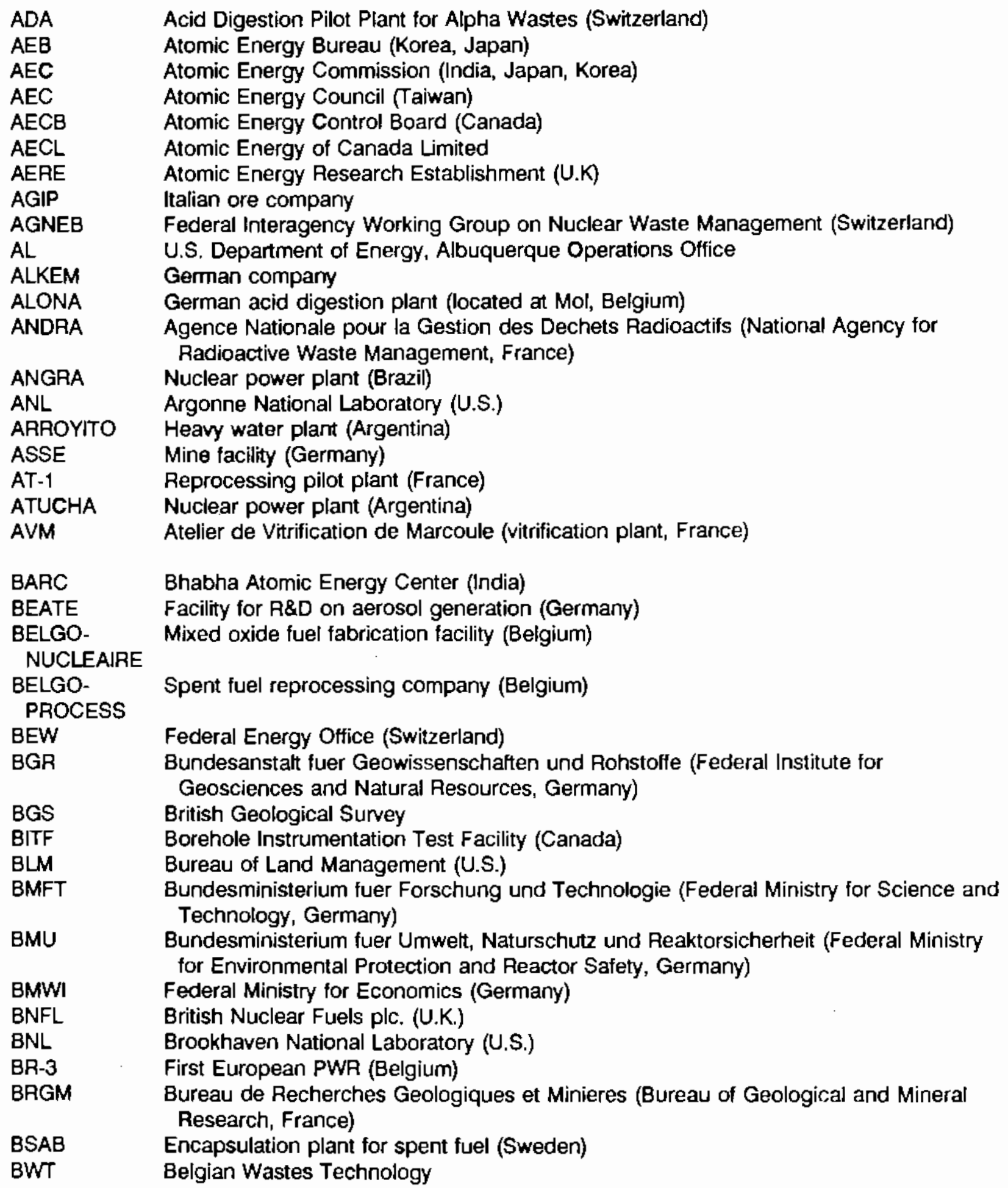




\begin{tabular}{|c|c|}
\hline $\begin{array}{l}\text { CANADA } \\
\text { G-E }\end{array}$ & General Electric Company of Canada \\
\hline CANDU & Canadian Deuterium Uranium Reactor \\
\hline CAT & Center for Advanced Technologies (India) \\
\hline CDTN & $\begin{array}{l}\text { Centro de Desenvolvimento de Technologia Nuclear de Nuclebras (Center for the } \\
\text { Develcpment of Nuclear Technology, Brazil) }\end{array}$ \\
\hline CEA & Commissariat a l'Energie Atomique (Atomic Energy Commission, France) \\
\hline CEA-CEN-M & $\begin{array}{l}\text { CEA-Centre d'Etudes Nucleaires de la Vallee du Rhone (Marcoule Nuclear Research } \\
\text { Center, France) }\end{array}$ \\
\hline CEC & Commission of the European Communities \\
\hline CEDRA & $\begin{array}{l}\text { Societe Cooperative Nationale pour l'Entreposage de Dechets Radioactifs (National } \\
\text { Cooperative for the Disposal of Radioactive Waste, Switzerland) }\end{array}$ \\
\hline CEGB & Central Electricity Generating Board (U.K.) \\
\hline CEN/SCK & $\begin{array}{l}\text { Centre d'Etudes de l'Energie Nucleaire/ Studiecentr.dm voor Kernenerqie (Nuclear } \\
\text { Energy Research Center, Belgium) }\end{array}$ \\
\hline CEN-CA & Centre d'Etudes Nucleaires de Cadarache (France) \\
\hline CETA & Center for Advanced Technologies (Italy) \\
\hline $\mathrm{CH}$ & U.S. Department of Energy, Chicago Operations Office \\
\hline CHASMA & Fuel Fabrication Plant (Pakistan) \\
\hline CIEMAT & $\begin{array}{l}\text { Centro de Investigaciones Energeticas, Medio Ambientales y Tecnologicas (Energy } \\
\text { Research Center, Spain) }\end{array}$ \\
\hline CIPE & International Planning Council (Italy) \\
\hline CLAB & Central Spent Fuel Storage Facility (Sweden) \\
\hline CMEA & Council for Mutual Economic Assistance \\
\hline CNEA & $\begin{array}{l}\text { Comision Nacional de Energia Atomica (National Atomic Energy Commission, } \\
\text { Argentina) }\end{array}$ \\
\hline CNEIC & China Nuclear Energy Industry Corporation \\
\hline CNEN & Commissao Nacional de Energia Nuclear (Nuciear Energy Commission, Brazil) \\
\hline Cogema & $\begin{array}{l}\text { Compagnie Generale des Matieres Nucleaires (commercial fuel cycle arm of the } \\
\text { French CEA) }\end{array}$ \\
\hline COVRA & Central Organization for Radiological Waste (Netherlands) \\
\hline CRIEPI & Central Research Institute of Electric Power industry (Japan) \\
\hline CAISLA & Chemical Reaction by isotope Laser Activation \\
\hline CRNL & Chalk River National Laboratory (Canada) \\
\hline CRPPH & Committee on Radiation Protection and Public Health (NEA) \\
\hline CSN & Consejo de Seguridad Nuclear (Council of Nuclear Safety, Spain) \\
\hline DAE & Department of Atomic Energy (India) \\
\hline DAM & Direction Des Applications Militaires (Directorate of Military Applications, France) \\
\hline DBE & $\begin{array}{l}\text { Deutsche Gesellschaft zum Bau und Betrieb von Endlagern fuer Abfallstoffe mbH } \\
\text { (Company for Construction and Operation of Waste Disposal Facilities, Germany) }\end{array}$ \\
\hline DFR & Dounreay Fast Reactor (U.K.) \\
\hline DHSS & Department of Health and Social Security (U.K.) \\
\hline DISP & Nuclear Regulatory Commission (ttaly) \\
\hline DoE & U.K. Department of the Environment \\
\hline DOE & U.S. Department of Energy \\
\hline DORA & Deep sea research program on radioactive waste (Netherlands) \\
\hline DOT & U.S. Department of Transponation \\
\hline DP & U.S. Department of Energy, Office of Defense Programs \\
\hline DSPEH & Department of Safety, Protection, Environment, and Health (China) \\
\hline DWK & $\begin{array}{l}\text { Deutsche Gesellschaft fuer Wiederaufarbeitung vcn Kernbrennstoffen mbH (German } \\
\text { Fuel Reprocessing Company) }\end{array}$ \\
\hline DWPF & Defense Waste Processing Facility (U.S.) \\
\hline
\end{tabular}




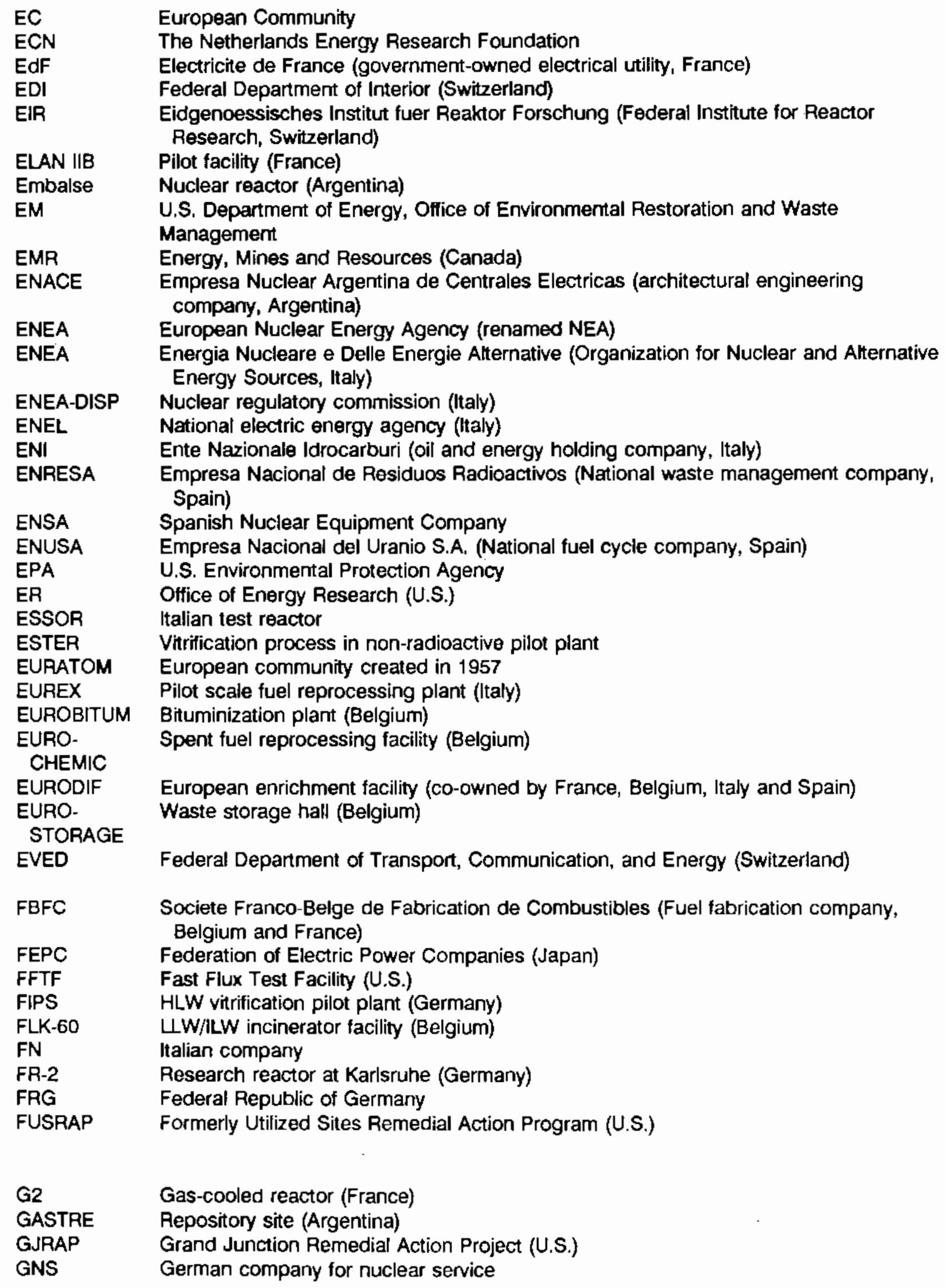


GSF/IT Company for Radiation and Environmental Research/Institute for Underground Storage (Germany)

HADES

HFEF

HISS

$\mathrm{HMl}$

HSK

HTF

HWR-1

HWP

IAE

IAEA

ICRP

ID

IE

IEN

IFEC

IFTF

IGCAR

ILONA

INEL

INEA

IPEN

IPES

IPSN

IRD

IRUS

ISAG

ISVL

ITREC

IVEX

IVO

JAERI

JAIF

JNFI

JNFS

JPDR

JRC

JSS

High Activity Disposal Experimental Site (Belgium)

Hot Fuel Examination Facility (U.S.)

Hydrogen isotope Separation System (U.S.)

Hahn-Meitner Institute (Germany)

Nuclear Safety Division (Switzerland)

Hydrostatic Test Facility (Canada)

First commissioned reactor (China)

Hanford Defense Waste Vitrification Facility (U.S.)

Institute of Atomic Energy (China)

International Atomic Energy Agency

International Commission on Radiological Protection

U.S. Department of Energy, Idaho Operations Office:

U.S. Department of Energy, Office of International Affairs and Energy Emergencies

Nuclear Engineering Institute (Brazil)

Fabrication plant (Italy)

Immobilized Fuel Test Facility (Canada)

Indira Ghandi Center for Atomic Research (India)

Integrated National Research Program, Nuclear Waste (Netherlands)

Idaho National Engineering Laboratory (U.S.)

Institute of Nuclear Energy Research (Taiwan)

Instituto de Pesquisas Energeticas e Nucleares (Energy and Nuclear Research institute, Brazil)

Underground research laboratory concept (Spain)

Institut de Protection et de Surete Nucleaire (institute for Nuclear Safety, CEA, France)

Health, Physics \& Dosimetry institute (Brazil)

Disposal concept for LLW (Canada)

Advisory Group In Situ Research and Investigations; for Geological Disposal (NEA program)

In Situ Validation Laboratory (France)

Pilot scale reprocessing plant (Italy)

Vitrification pilot plant for high-level waste (italy)

Imatra Power Company (Finland)

KAEC Korea Atomic Energy Commission

KAERI Korea Advanced Energy Research Institute

KAHUTA Enrichment plant (Pakistan)

KAJ

KANUPP

KBS

KEMA

KEPCO

Japan Atomic Energy Research Institute

Japan Atomic Industrial Forum

Japan Nuclear Fuel industries Co., Inc.

Japan Nuclear Fuel Service Co., Ltd.

Japan Power Demonstration Reactor

Joint Research Center (of the CEC, one in Germany, one in Italy)

Japan-Sweden-Switzerland Project

KFA

Finnish storage facility for ILW

CANDU Nuclear Power Plant (Pakistan)

Study project on management of radioactive wastes (Sweden)

Research and Testing Electrochemical Materials $\mathrm{Co}$. (Netherlands)

Korea Electric Power Corporation

Kernforschungsanlage Jülich GmbH (Jülich Nuclear Research Center, Germany) 


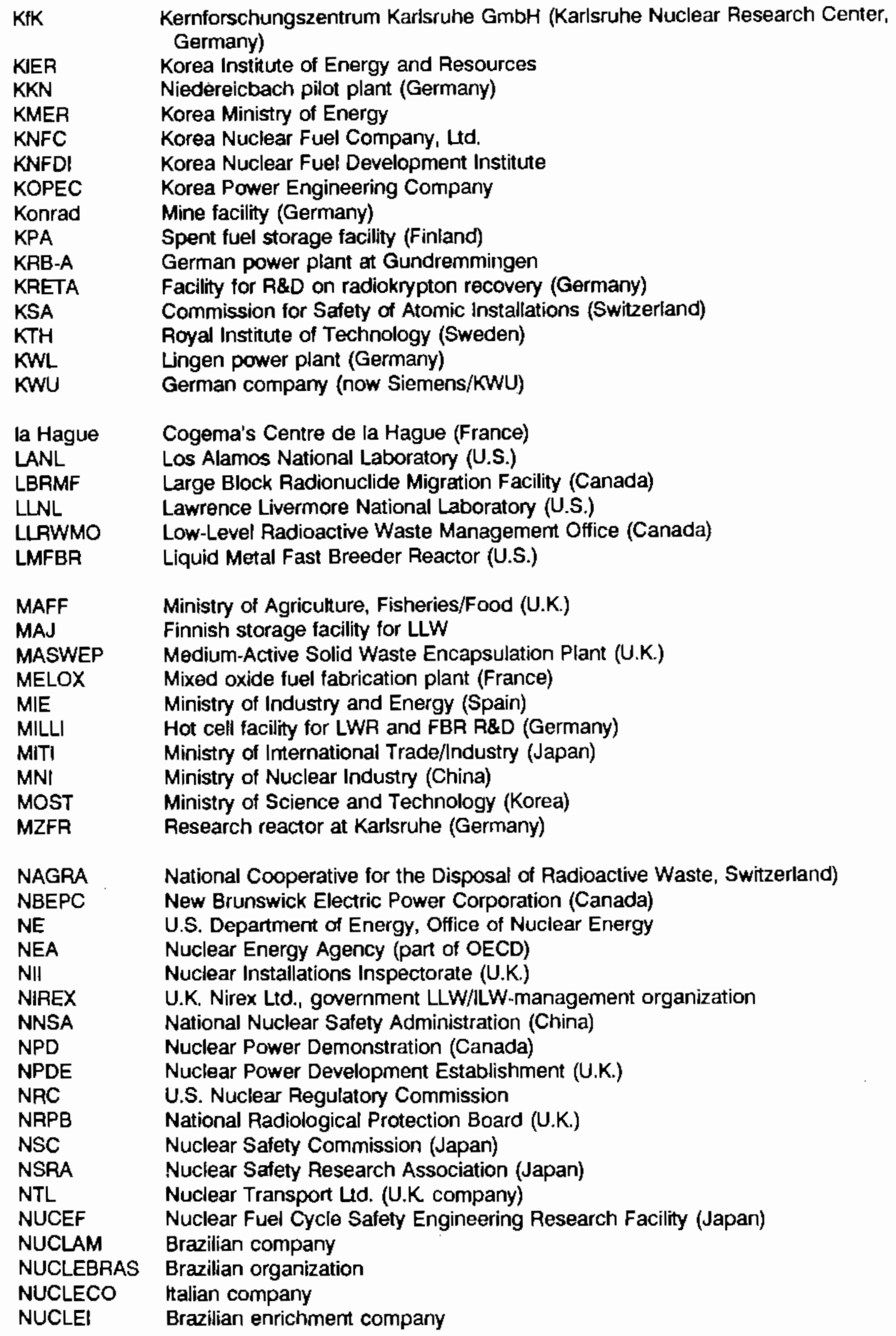




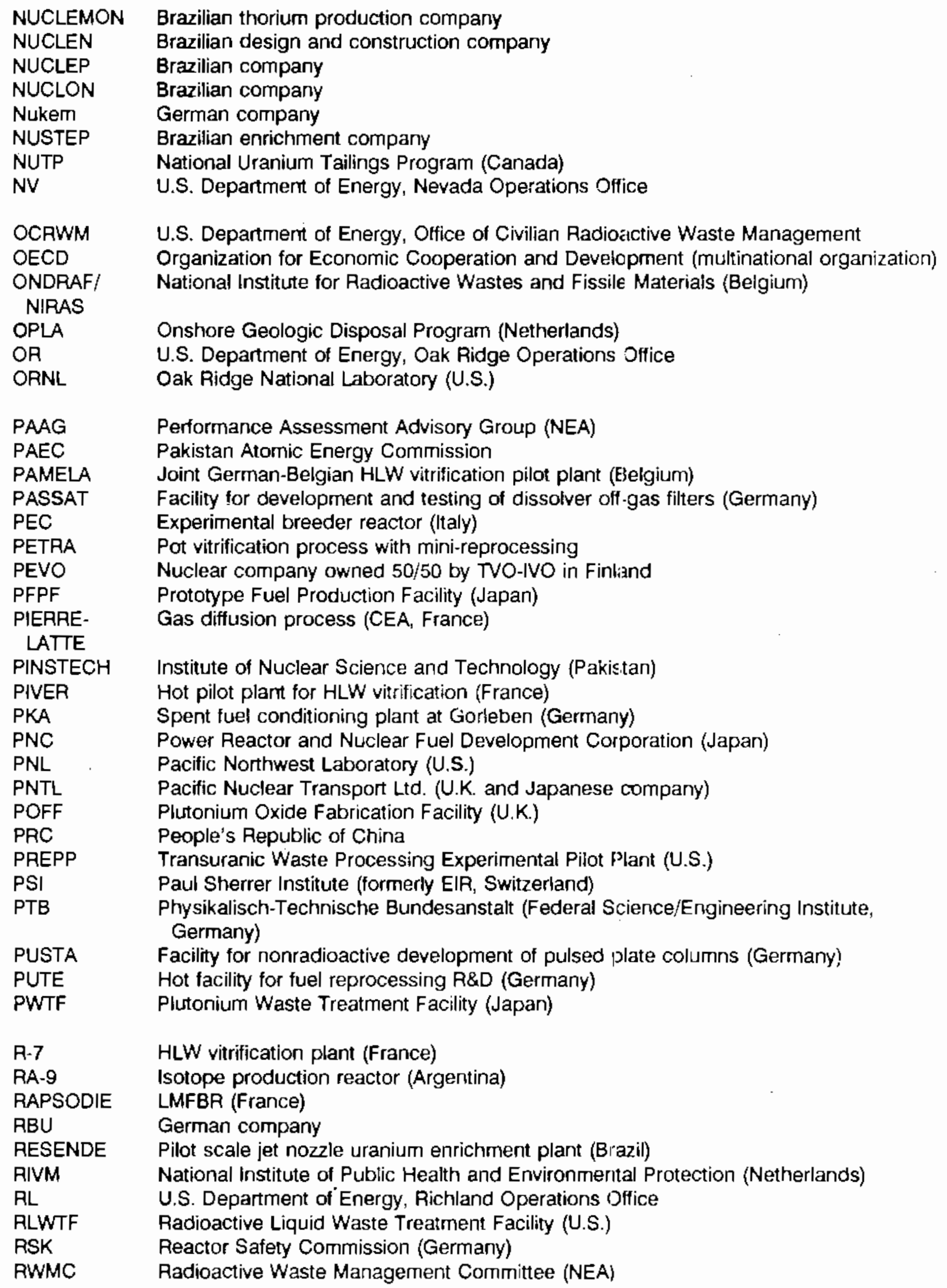




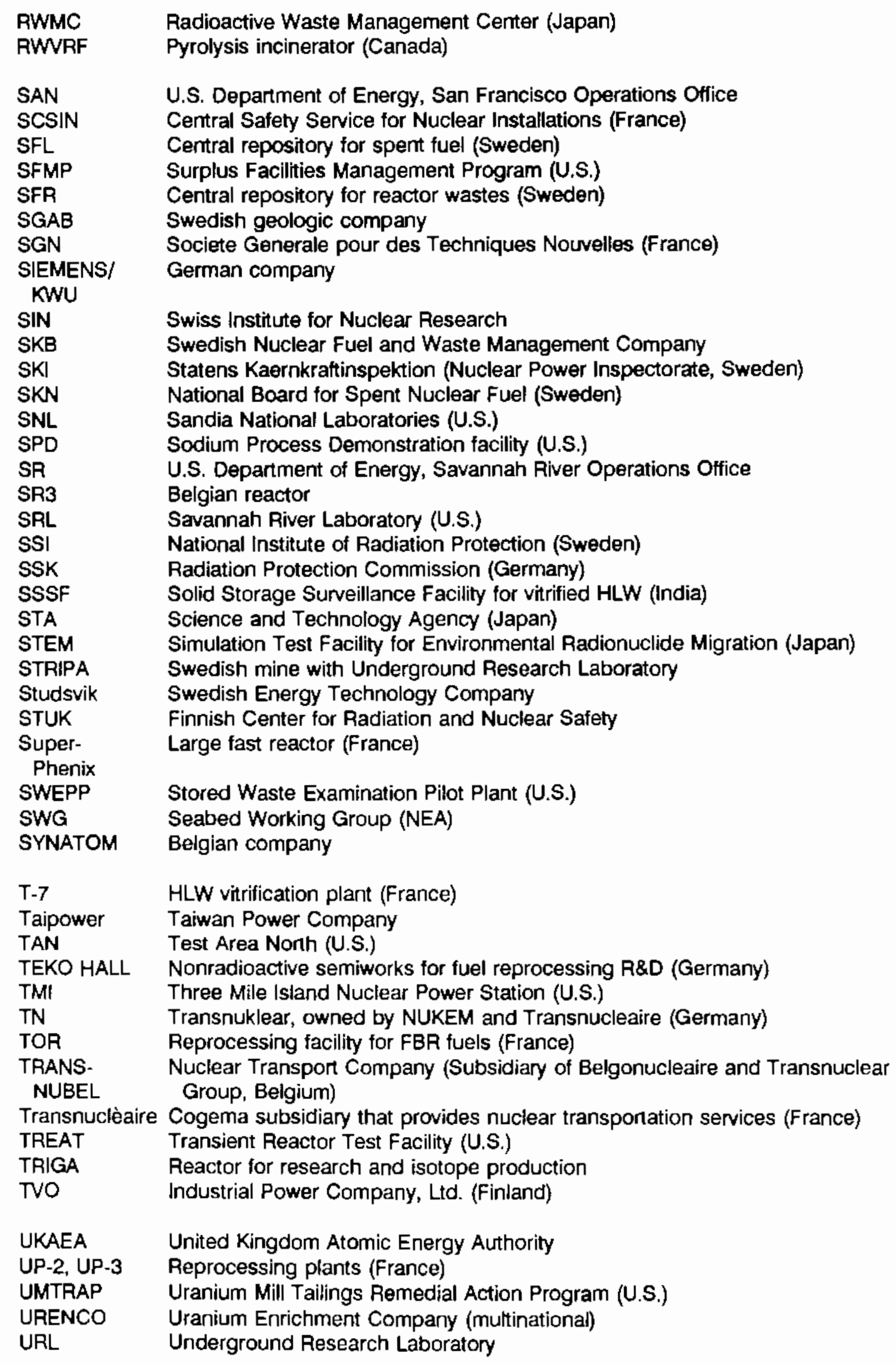




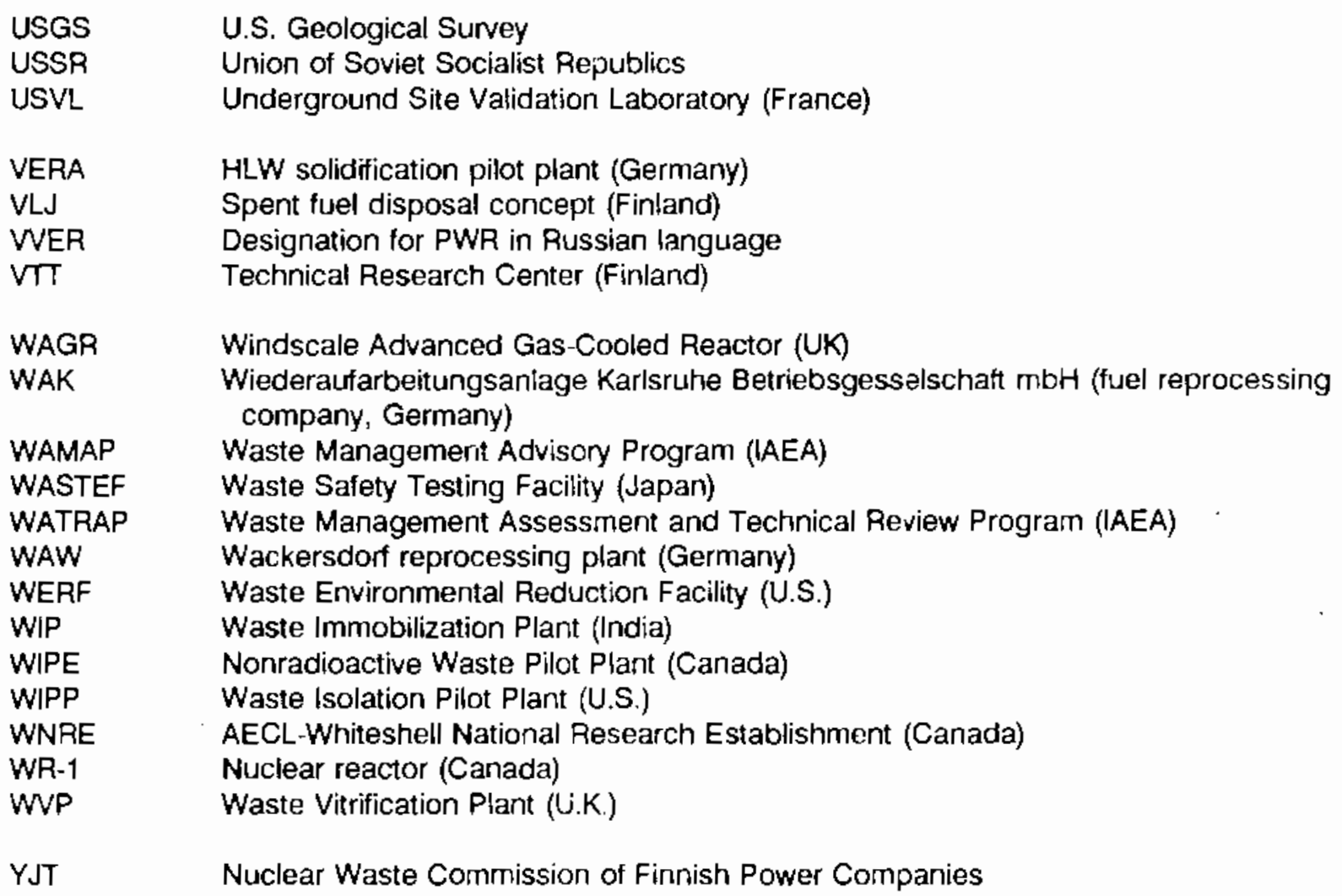

\section{ADDITIONAL ACRONYMS AND OTHER ABBREVIATIONS}

$\begin{array}{ll}\text { AFR } & \text { Away-From-Reactor (spent fuel storage facility) } \\ \text { AGR } & \text { Advanced Gas-Cooled Reactor (UO }{ }_{2} \text { fuel) } \\ \text { ALARA } & \text { As Low as Reasonably Achievable } \\ \text { AR } & \text { At-Reactor (used for spent fuel storage) } \\ \text { ATR } & \text { Advanced Thermal Reactor } \\ \text { BF } & \text { Belgian Francs } \\ \text { BWR } & \text { Boiling Water Reactor } \\ \text { CAN- } & \text { Dilute chemical decontamination process for reactor } \\ \text { DECON } & \text { piping systems developed by AECL and Ontario Hydro (Canada) } \\ \text { CECE } & \text { Combined Electrolysis Catalytic Exchange System (U.S.) } \\ \text { CENTIMES } & \text { French monetary unit } \\ \text { CHEMEX } & \text { Chemical Exchange process (France) } \\ \text { COCO } & \text { Colloids and Complexes } \\ \text { COMVAL } & \text { Geochemical codes evaluation } \\ \text { COSA } & \text { Comparison of rock mechanics computer codes } \\ \text { CRESP } & \text { Coordinated Research and Environmental Surveillance Program (NEA) } \\ & \\ \text { Demo } & \text { Demonstration } \\ \text { D\&D } & \text { Decontamination and Decommissioning } \\ \text { DM } & \text { Deutsche Mark (German monetary unit) } \\ & \\ \text { EA } & \text { Environmental Assessment (U.S.) } \\ \text { ECOSYS } & \text { Performance assessment computer code (Germainy) } \\ \text { EMOS } & \text { Performance assessment computer code (Germainy) }\end{array}$




\begin{tabular}{|c|c|}
\hline $\begin{array}{l}\text { ERS } \\
\text { ESTER }\end{array}$ & $\begin{array}{l}\text { Tritium effluent recovery system (U.S.) } \\
\text { Multistage pot calcination-vitrification process for HLW (Italy) }\end{array}$ \\
\hline $\begin{array}{l}\text { FBR } \\
\text { FBTR } \\
\text { FIS } \\
\text { FY }\end{array}$ & $\begin{array}{l}\text { Fast Breeder Reactor } \\
\text { Fast Breeder Test Reactor } \\
\text { Federal Interim Storage } \\
\text { Fiscal Year }\end{array}$ \\
\hline $\begin{array}{l}\text { GCR } \\
\text { GCHWR } \\
\text { GGR } \\
\text { GS }\end{array}$ & $\begin{array}{l}\text { Gas-Cooled, graphite-moderated Reactor } \\
\text { Gas-Cooled, Heav-Water Reactor } \\
\text { Gas-Graphite Reactor } \\
\text { Water-hydrogen sulfide exchange process technology }\end{array}$ \\
\hline $\begin{array}{l}\text { HAO } \\
\text { HAW } \\
\text { HCL } \\
\text { HEPA } \\
\text { HEU } \\
\text { HEWC } \\
\text { HF } \\
\text { HFR } \\
\text { HLLW } \\
\text { HLW } \\
\text { HM } \\
\text { HTGR } \\
\text { HTR } \\
\text { HWR } \\
\text { HYDROCOIN }\end{array}$ & $\begin{array}{l}\text { Chop-leach head end (France) } \\
\text { High-Activity Wastes } \\
\text { Hot Cell Laboratory } \\
\text { High-Efficiency Particulate Air (filter) } \\
\text { High-Enriched Uranium } \\
\text { High-Enriched Waste Concentrate } \\
\text { High Frequency } \\
\text { High Flux Reactor } \\
\text { High-Level Liquid Wastes } \\
\text { High-Level Wastes } \\
\text { Heaw Metal } \\
\text { High-Temperature, Gas-cooled Reactor } \\
\text { High-Temperature Reactor } \\
\text { Heaw Water Reactor } \\
\text { Project for comparing groundwater hydrology models (NEA) }\end{array}$ \\
\hline $\begin{array}{l}\text { ILW } \\
\text { ILLW } \\
\text { IMPM } \\
\text { INTRACOIN } \\
\text { ISF } \\
\text { ISFSI } \\
\text { ISIRS }\end{array}$ & $\begin{array}{l}\text { Intermediate-Level Wastes } \\
\text { Intermediate-Level Liquid Wastes } \\
\text { Indicative Multiyear Program for Environmental Management } \\
\text { Project for comparing models for radionuclide transport in geologic media (NEA) } \\
\text { Interim Storage Facility } \\
\text { Independent Spent Fuel Storage Installation } \\
\text { International Sorption Information Retrieval System (NEA program) }\end{array}$ \\
\hline $\begin{array}{l}\text { LEWC } \\
\text { LFCM } \\
\text { LGR } \\
\text { LLW } \\
\text { LLLW } \\
\text { LLWPAA } \\
\text { LMFBR } \\
\text { LWR }\end{array}$ & $\begin{array}{l}\text { Low-Enriched Waste Concentrate } \\
\text { Liquid-Fed Ceramic Melter } \\
\text { Light-water-cooled, Graphite-moderated Reactor } \\
\text { Low-Level Wastes } \\
\text { Low-Level Liquid Wastes } \\
\text { Low-Level Waste Policy Amendment Act (U.S.) } \\
\text { Liquid Metal Fast Breeder Reactor } \\
\text { Light Water Reactor }\end{array}$ \\
\hline $\begin{array}{l}\text { MICOF } \\
\text { MINKA } \\
\text { MIRAGE } \\
\text { MTR } \\
\text { MOWA } \\
\text { MOX } \\
\text { MRS }\end{array}$ & $\begin{array}{l}\text { Computer model for radionuclide transport in clay (Belgium) } \\
\text { Hot glove boxes for uranium and plutonium extraction studies (Germany) } \\
\text { Migration of radionuclides in the environment (CEC Project) } \\
\text { Materials Test Reactor } \\
\text { Mobile waste concrete solidification, compaction and packing machine (Belgium) } \\
\text { Mixed (plutonium/uranium) Oxide } \\
\text { Monitored Retrievable Storage }\end{array}$ \\
\hline
\end{tabular}




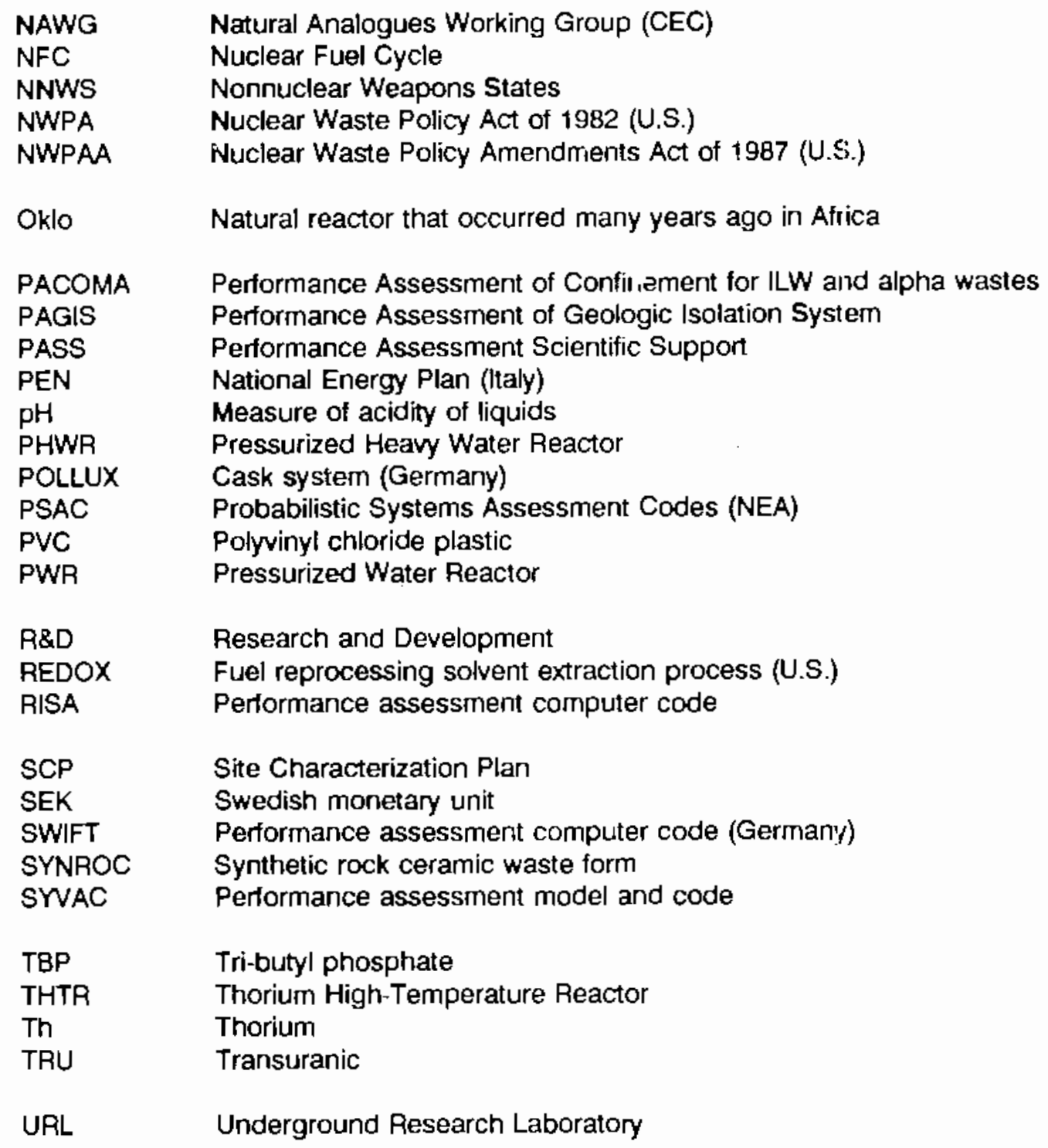

$1 E-5$

$1 E-9$

$3.2 \mathrm{E}+8$

$\mathrm{cm} \quad$ centimeter

d day

fl feet

g gram

GBq GigaBequerel (1 billion Bequerels)

GWd GigaWatt-day

GWe GigaWatts, or 1 billion watts of electricity (1000 MWe)

GWh GigaWatt-hour 


\begin{tabular}{|c|c|}
\hline $\mathrm{hr}$ & hour \\
\hline k & kilo \\
\hline kg & kilogram \\
\hline $\mathrm{kgu}$ & kilograms of Uranium \\
\hline km & kilometer \\
\hline kWh & kilowatt hour \\
\hline $\mathrm{lb}$ & pounds \\
\hline $\mathbf{M}$ & mega (million) or metric, depending on usage \\
\hline m & meter or milli, depending on usage \\
\hline MPA & Mega Pascals \\
\hline mR & milliRoentgen \\
\hline mreni & millirem \\
\hline MT & Metric tons (equal to $1,000 \mathrm{~kg}$ or $2205 \mathrm{lb}$ ) \\
\hline MTHM & Metric Tons of Heavy Metal \\
\hline MTSWU & Metric Tons of Separative Work Units (unit of enrichment energy) \\
\hline MTU & Metric Tons of Uranium \\
\hline MW & MegaWatt \\
\hline MWd & MegaWatt-day \\
\hline MWe & MegaWatts electric \\
\hline MWt & MegaWatts thermal \\
\hline REM & Roentgen Equivalent Man (absorbed radiation dose unit) \\
\hline $\begin{array}{l}\text { Sv } \\
\text { SWU }\end{array}$ & $\begin{array}{l}\text { Sievert (equal to } 100 \text { rem) } \\
\text { Separative Work Units }\end{array}$ \\
\hline $\mathbf{T}$ & Tera (millions of millions) or tons, depending on usage \\
\hline TBq & TeraBequerels ( 1 million million radiation particles or photons/second) \\
\hline TSWU & Tera (1 million million) Separate Work Units \\
\hline TWh & TeraWatt-hour (million megawatt hours) \\
\hline $\begin{array}{l}\mathrm{UO}_{2} \\
\mathrm{UO}_{3} \\
\mathrm{UF}_{6}\end{array}$ & $\begin{array}{l}\text { Uranium dioxide } \\
\text { Uranium trioxide } \\
\text { Uranium hexafluoride }\end{array}$ \\
\hline W & Watt \\
\hline Wi\% & Weight percent \\
\hline & \\
\hline
\end{tabular}





\section{DISTRIBUTION}

No. of

Copies

\section{OFFSITE}

12

Office of Scientific and Technical Information
U.S. Department of Energy 12800 Middlebrook Rd. TREV \| Germantown, MD 20585
D. H. Alexander, EM-53
J. E. Baublitz, EM-50
J. A. Coleman, EM-32
C. R. Cooley, EM-55
S. P. Cowan, EM-30
J. E. Dieckhoner, EM-10
L. P. Duffy, EM-1
J. J. Fiore, EM-40
C. W. Frank, EM-50
L. H. Harmon, EM-32
J. Lytle, EM-30
T. W. McIntosh, EM-343
W. E. Murphie, EM-423
S. M. Prestwich, EM-52
H. F. Walter, EM-343
R. P. Whitfield, EM-40

23 U.S. Department of Energy FORS

1000 Independence Ave., SW

Washington, DC 20585

J. W. Bartlett, RW-1

J. C. Bresee, RW-10

S. J. Brocoum, RW-22

C. E. Brooks, RW-322

J. H. Carlson, RW-43

B. A. Cerny, RW-12

W. J. Danker, RW-4

G. DeLaTorre, IE-12

L J. Desell, RW-331
No. of

Copies

U.S. Department of Energy

FORS (contd)

J. J. Easton, Jr., IE-1

C. P. Gertz, RW-20

H. J. Hale, RW-32

T. H. Isaacs, AW-4

P. M. Jackson, RW-4

H. Jaffe, IE-12

G. P. King, AW-5.1

W. A. Lemeschewsky, RW-321

A. A. Milner, RW-40

F. G. Peters, RW-2

J. D. Saltzman, RW-5

D. D. Shelor, RW-30

R. A. Terrell, RW-5.2

B. $H$. Thomas, IE-13

3

Yucca Mountain Site Characterization Project Office

U.S. Department of Energy

Phase 2, Suite 200

101 Convention Center Drive

Las Vegas, NV 89109

M. Blanchard

R. Dyer

R. A. Levich

M. Eaton

U.S. Department of Energy

U.S. Embassy - Tokyo

APO San Francisco 96503

P. P. Jodin

U.S. OECD Mission

19 rue Franqueville

75016 Paris

FRANCE 
No. of

Copies

4 Albuquerque Operations Office

U.S. Department of Energy

P.O. Box 5400

Albuquerque, NM 87115

D. Bandy

J. Bickel

A. E. Hunt

P. A. Saxman

3 Chicago Operations Office U.S. Department of Energy 9800 S. Cass Avenue

Argonne, IL 60439

R. C. Baker

J. C. Haugen

S. Webster

2 Idaho Operations Office

U.S. Department of Energy

785 DOE Place

Idaho Falls, ID 83402

L. Shikashio

M. W. Shupe

2 Nevada Operations Office

U.S. Department of Energy

P.O. Box 98518

Las Vegas, NV $89193-8518$

R. Boland

J. Hall

2 Oak Ridge Operations Office

U.S. Department of Energy

P.O. Box 2001

Oak Ridge, TN 37831-8600

L. W. Clark

J. Moore

2 DOE Rocky Flats Office

Rocky Flats Plant

P.O. Box 464

Golden, CO 80402-0464

R. Schassburger

R. Tyler
No. of

Copies

2 Laboratory Operations Division

U.S. Department of Energy

San Francisco Operations Office

1333 Broadway

Oakland, CA 94612

B. Holman

D. Nakahara

2 Savannah River Operations Office

U.S. Department of Energy

P.O. Box A

Aiken, SC 29802

H. H. Brandt

S. King

T. Roland

West: Valley Project Office

U.S. Department of Energy

P.O. Box 191

West Valley, NY 14171-0191

2 Argonne National Laboratory

9700 S. Cass Avenue

Argonne, IL 60439

J. E. Holt

M. J. Steindler

2 Brookhaven National Laboratory

Bldg. 703

Upton, NY 11973

P. Colombo

P. Soo

6 Idato National Engineering Laboratory

EG\&G Idaho, Inc.

1580 Sawtelle

P.O. Box 1625

Idaho Falls, ID 83415

W. Carlson

J. Ferguson

K. H. Henry

L. P. Leach

B. Morrealle

C. B. Ozaki 
No. of

\section{Copies}

2 Los Alamos National Laboratory

P.O. Box 1663

Los Alamos, NM 87545

R. J. Herbst

D. T. Oakley

J. C. S. Long

Lawrence Berkeley Laboratory

Earth Science Division

1 Cyclotron Road, 50E

Berkeley, CA 94720

3 Lawrence Livermore National

Laboratory

University of Calitornia

P.O. Box 808, L209

Livermore, CA 94550

L. Jardine

L. D. Ramspott

J. L. Youl

4 EG\&G Mound Applied Technologies

P.O. Box 3000

Miamisburg, OH 45343

R. K. Blauveh

R. R. Jaeger

T. K. Mills

W. H. Smith

S. P. Viani

Nuclear Remediation Technologies

P.O. Box 85608

3550 General Atomics Court

San Diego, CA 92138

4 Oak Ridge National Laboratory

Martin Marietta Energy Systems, Inc.

P.O. Box 2008

Oak Ridge, TN 37831-7155
A. G. Crott
P. T. Owen
R. R. Rawl
T. H. Row

No. of

Copies

2 EG\&G Rocky Flats, Inc.

Rocky Flats Plant

P.O. Box 464

Golden, CO 80402-0464
A. C. Ficklin
E. R. Naimon

5 Sandia National Laboratories

P.O. Box 5800

Albuquerque, NM 87185

T. O. Hunter

R. W. Lynch

T. L. Sanders

J. E. Stiegler

W. D. Weart

L Papouchado

Westinghouse Savannah Fiver Site

P.O. Box 616

Aiken, SC 29802

2 Westinghouse Savannah River

Laboratory

P.O. Box 616

Aiken, SC 29808

B. D. Helton

B. G. Kitchen

B. R. Wheeler

Westinghouse Idaho Nuclear Co., Inc.

P.O. Box 4000

Idaho Falls, ID 83403

A. L. Trego

WIPP Project

Westinghouse Electric Corporation

Advanced Energy Systems Division

P.O. Box 2078

Carlsbad, NM 88221

J. L. Knabenshuh

West Valley Nuclear Services Inc.

P.O. Box 191

West Valley, NY 14171-0191 
No. of

Copies

2

Battelle

Columbus Operations

505 King Ave.

Columbus, $\mathrm{OH}$ 43201-2693

R. A. Nathan

W. E. Newcomb

R. Grenier

General Atomics

P.O. Box 85608

3550 General Atomics Court

San Diego, CA 92138

N. J. Numark

ERC Environmental \& Energy

Service Co.

3211 Jermantown Road

Fairfax, VA 22030

E. R. Johnson

E. R. Johnson Associates, Inc.

10461 White Granite Drive

Suite 204

Oakton, VA 22124

2 Science Applications International Corporation

101 Convention Center Drive \#407

Las Vegas, NV 89109-2005

E. Hardin

J. H. Nelson

S. L. Marcum

Science Applications International Corporation

12850 Middlebrook Road

Suite 200

Germantown, MD 20874

D. W. Geiser

Science Applications Int'I Corp.

10 rue de Conseiller, Collignon

75016 Paris

FRANCE
No. of

Copies

2 R. F. Weston, Inc.

955 L_Enfant Plaza

8th Floor

Washington, DC 20024

K. S. Czyscinski

R. Jackson

2 U.S. Envirenmental Protection Agency Office of Radiation Programs

401 M Street, SW

Washington, DC 20460

F. L. Galpin

A. Hecht

7 U.S. Nuclear Regulatory Commission Washington, DC 20555

R. L. Bangart

R. M. Bernero

R. E. Browning

S. Coplan

R. D. Hauber

C. A. Peabody

H. B. Schechtor

W. Barnard

U.S. Nuclear Waste Tech.

Review Board

1100 Wilson Blvd., NW

Suite 910

Arlington, VA 72209

D. E. Saire

International Atomic Energy Agency

P.O. Box 200

1400 Vienna

AUSTRIA

D. L.eRoy

U.S. Nuclear Waste Negotiator

Boise, ID 83777 
PNL-6241, Rev. 2

UC 810

No. of

Copies

\author{
W. Murphy \\ Center for Nuclear Waste Regulatory \\ Analysis \\ 6220 Culebra Road \\ San Antonio, TX 78228-0510 \\ M. Katz \\ U.S. Mission to Int'। \\ Organizations to Vienna (UNVIE) \\ Obersteinergasse 11-1 \\ 1190 Vienna \\ AUSTRIA \\ 2 U.S. Geological Survey \\ 410 National Ctr \\ 12201 Sunrise Valley Drive \\ Reston, VA 22092 \\ L. R. Hayes \\ P. R. Stevens \\ R. F. Williams \\ Electric Power Research Institute \\ P.O. Box 10412 \\ 3412 Hillview Avenue \\ Palo Alto, CA 94303 \\ M. E. Wacks \\ University of Arizona \\ Department of Nuclear \& Energy \\ Engineering \\ Tucson, AZ 85721
}

\section{ONSITE}

6 DOE Richland Operations Office

E. A. Bracken, A5-19

J. M. Hennig, A5-21

D. K. Jones, A5-90

D. C. Langstaff, A5-90

S. Moy, A5-21

R. P. Saget, A5-52
No. of

Copies

5 Westinghouse Hanford Company

R. L Miller, HO-34

J. A. Rawlins, HO-36

J. E. Tarcza, B2-20

E. T. Weber, G6-08

D. D. Wodrich, R2.23

28 Pacific Northwest Laboratory

C. R. Allen, P7-43

D. J. Bradley, K6-47

H. C. Burkholder, P7-41

L R. Dodd, K6-48

T. R. Fox, P7-35

A. B. Johnson, Jr., P8-10

A. K. Johnson, BWO

J. F. Keller, K1-51

M. R. Kreiter, K6-35

L. T. Lakey, K6-24

1. W. Leigh, K6-24

J. L McElroy, P7-46

G. W. McNair, K6-25

S. J. Mitchell, K6-24

P. M. Motton, K6-24

Y. Onishi, K6-88

D. R. Payson, K6-35

J. T. A. Roberts, K1-73

K. J. Schneider, K6-24

S. C. Slate, K6-27

J. F. Strahl, BWO

A. E. Van Luik, K6-24

Publishing Coordination

Technical Report Files (5) 
